Prepared in cooperation with the Water Replenishment District of Southern California

\title{
Development of a Groundwater-Simulation Model in the Los Angeles Coastal Plain, Los Angeles County, California
}

Scientific Investigations Report 2021-5088 
Cover: Complex aquifer system simulated in the Los Angeles Coastal Plain, California. 


\section{Development of a Groundwater-Simulation Model in the Los Angeles Coastal Plain, Los Angeles County, California}

Edited by Scott Paulinski

Prepared in cooperation with the Water Replenishment District of Southern California

Scientific Investigations Report 2021-5088 


\section{U.S. Geological Survey, Reston, Virginia: 2021}

For more information on the USGS - the Federal source for science about the Earth, its natural and living resources, natural hazards, and the environment—visit https://www.usgs.gov or call 1-888-ASK-USGS.

For an overview of USGS information products, including maps, imagery, and publications, visit https://store.usgs.gov/.

Any use of trade, firm, or product names is for descriptive purposes only and does not imply endorsement by the U.S. Government.

Although this information product, for the most part, is in the public domain, it also may contain copyrighted materials as noted in the text. Permission to reproduce copyrighted items must be secured from the copyright owner.

Suggested citation:

Paulinski, S., ed., 2021, Development of a groundwater-simulation model in the Los Angeles Coastal Plain, Los Angeles County, California: U.S. Geological Survey Scientific Investigations Report 2021-5088, 489 p., https://doi.org/10.3133/sir20215088.

Associated data for this publication:

Paulinski, S.R., Martin, P., Martin, D.J., Johnson, T.A., Faunt, C.C., 2021, MODFLOW-USG model used to evaluate water management issues in the Los Angeles Coastal Plain, California: U.S. Geological Survey data release, https://doi.org/10.5066/P9H15ZAX.

ISSN 2328-0328 (online) 


\section{Contents}

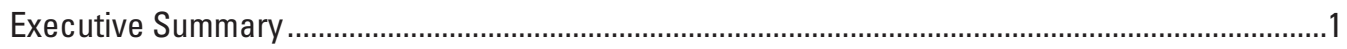

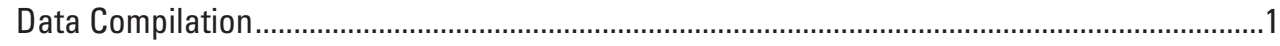

Chronostratigraphic Hydrogeologic-Framework Model .......................................................2

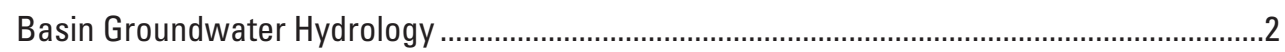

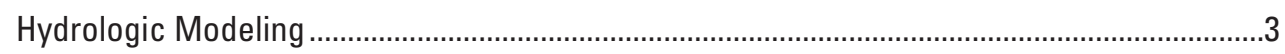

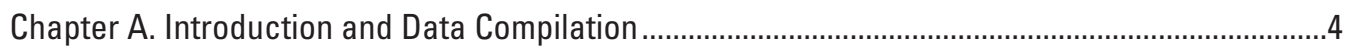

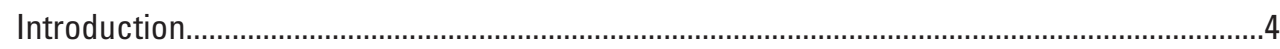

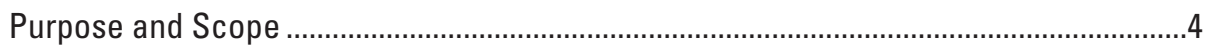

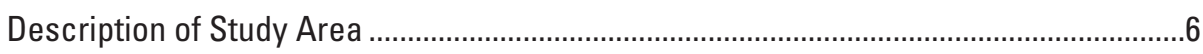

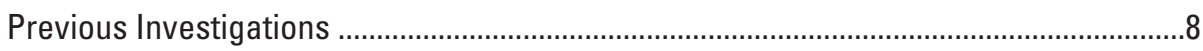

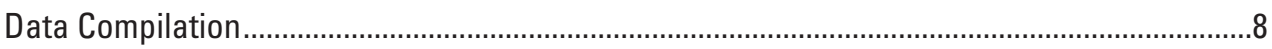

Well-Construction Data ................................................................................................

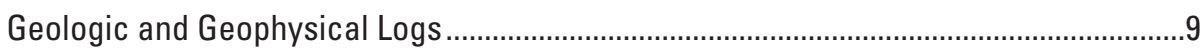

Groundwater Recharge and Discharge Data ..................................................................

Water-Level Measurements .........................................................................................11

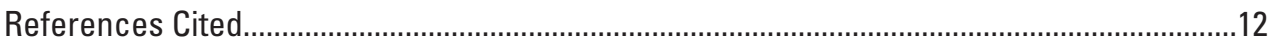

Chapter B. Development of a Chronostratigraphic Hydrogeologic Framework Model..................14

Previous Work and Formal Stratigraphic Nomenclature ....................................................15

Identification of Chronostratigraphic Unit Boundaries ......................................................18

Analysis of Lithologic and Geophysical Logs.......................................................

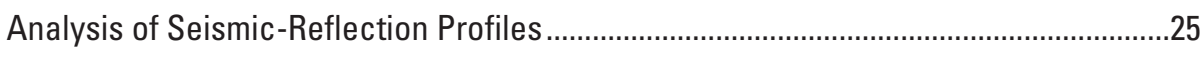

Analysis of Surficial Geology ..............................................................................25

Analysis of Water-Level and Water-Quality Data to Refine Chronostratigraphic

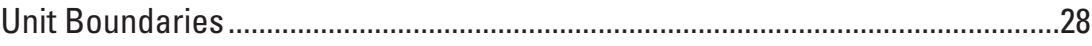

Chronostratigraphic Model Construction .........................................................................28

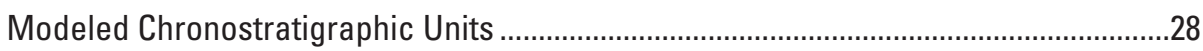

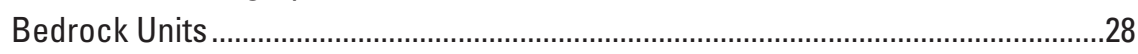

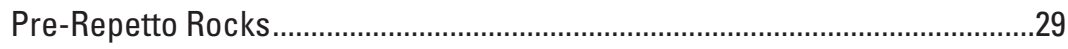

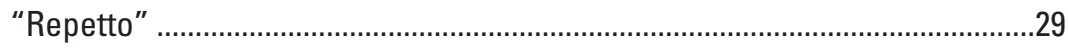

Late Pliocene and Quaternary Chronostratigraphic Units......................................29

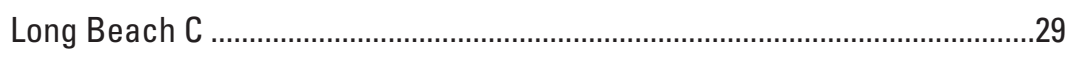

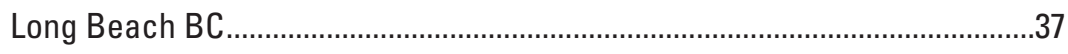

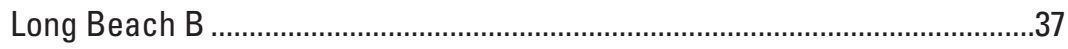

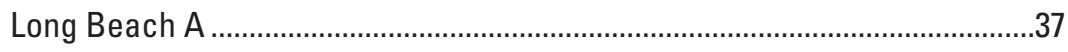

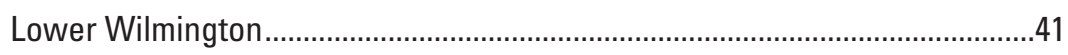

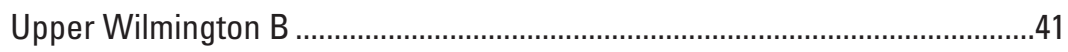

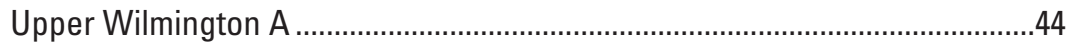

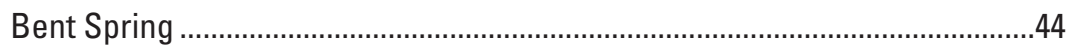

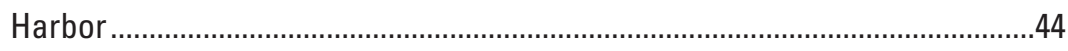

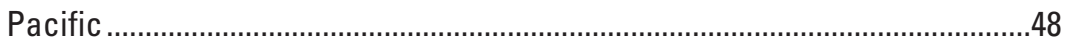

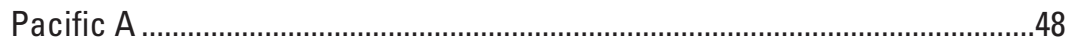

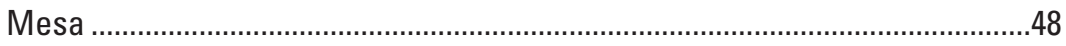

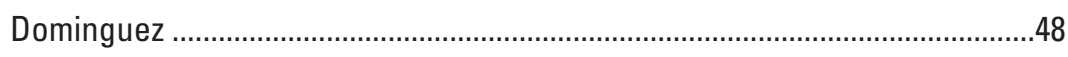


Comparison of the Chronostratigraphic Framework to Previous Hydrogeologic Units and Aquifer Nomenclature .............................................................................53

Geological Structures ..........................................................................................

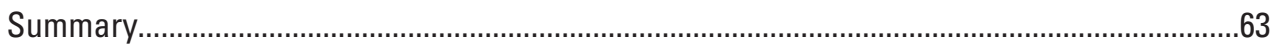

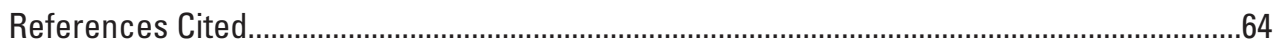

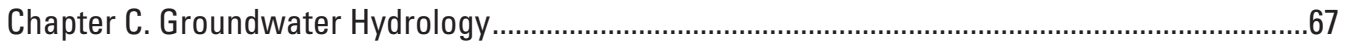

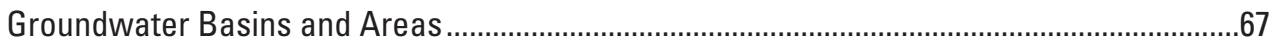

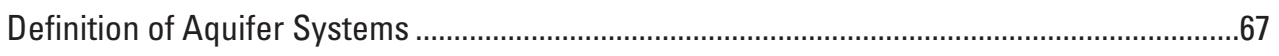

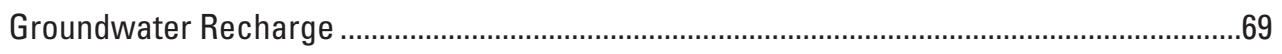

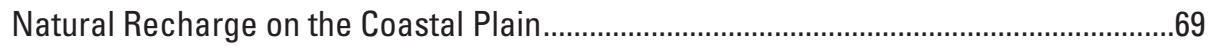

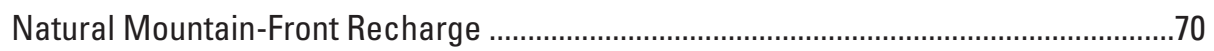

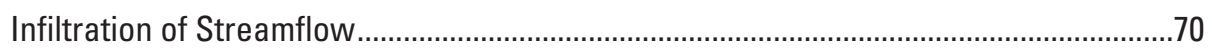

Return Flow from Urban Landscape Irrigation ................................................................

Return Flow from Leakage of Water and Sewer Lines.................................................71

Underflow from Adjacent Groundwater Basins ...........................................................71

Managed Aquifer Recharge from Spreading Grounds ................................................71

Managed Aquifer Recharge Through Injection Wells at Seawater Barriers..................73

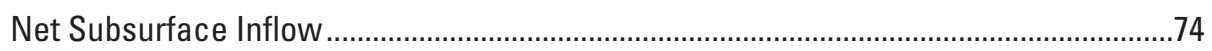

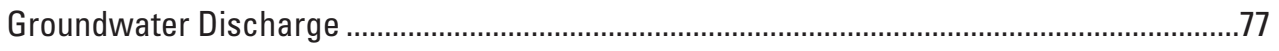

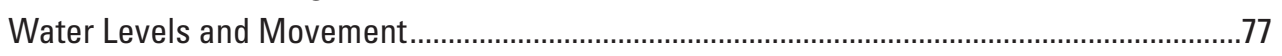

Pre- or Early Development Water Levels..................................................................

Post-Development Water Levels.................................................................................77

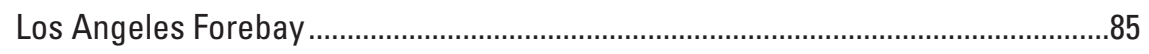

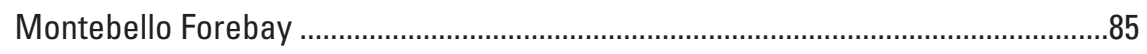

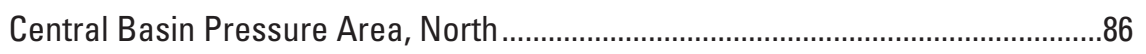

Central Basin Pressure Area, Central ....................................................................8

Central Basin Pressure Area, South..........................................................................

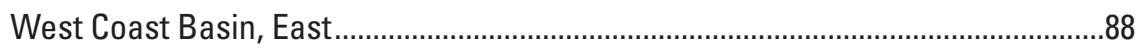

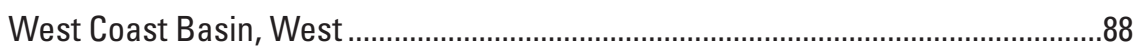

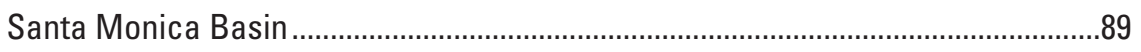

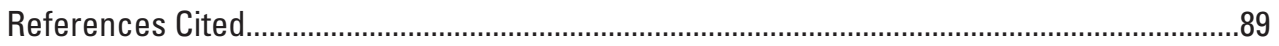

Chapter D. Development of a Groundwater-Simulation Model and Future

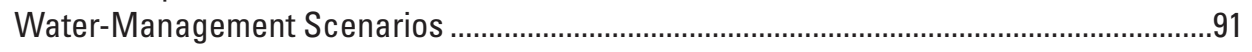

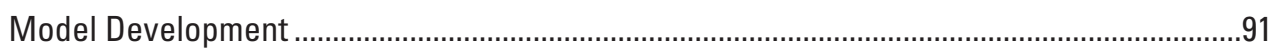

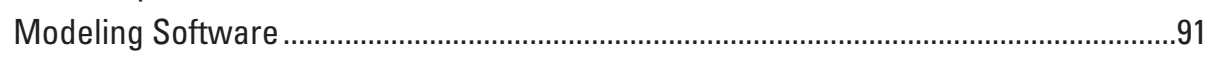

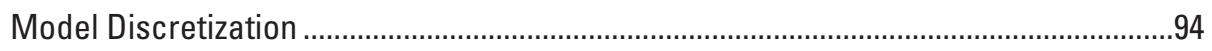

Spatial Discretization and Layering .....................................................................94

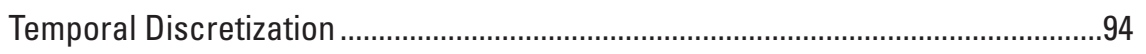

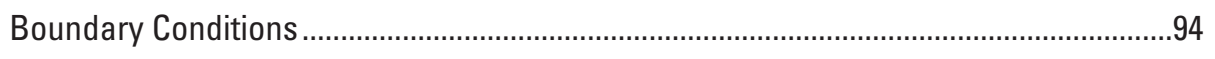

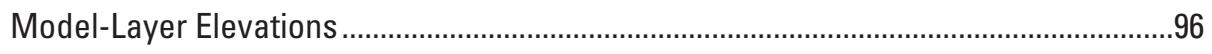

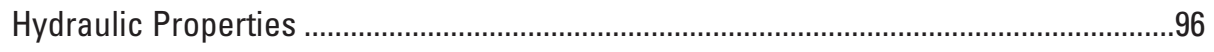

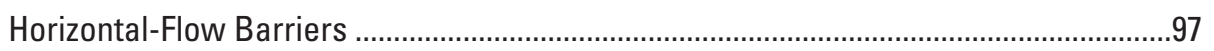

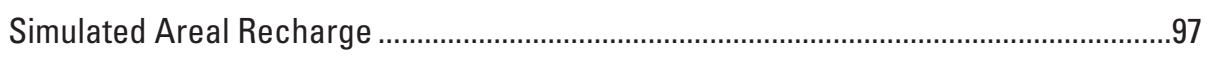

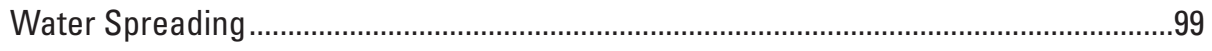

Water-Supply and Injection Wells .........................................................................100

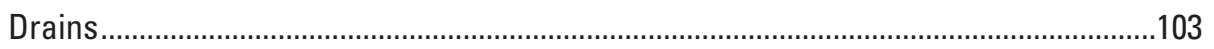




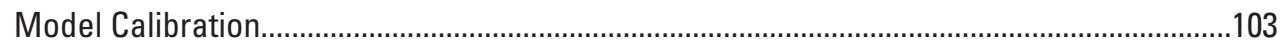

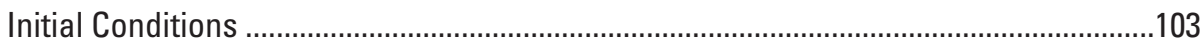

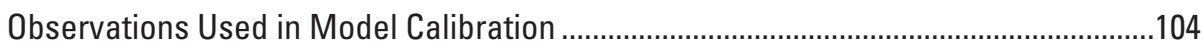

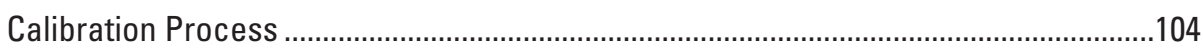

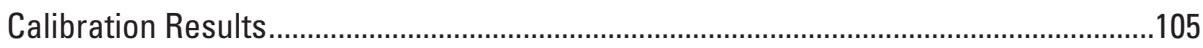

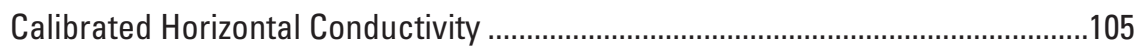

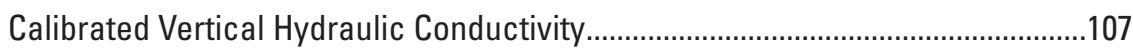

Calibrated Groundwater-Flow Barrier Hydraulic-Characteristic Values ...............107

Calibrated Specific Storage and Specific Yield ....................................................107

Hydrographs Comparing Simulated Head and Measured Water Levels ..............134

Los Angeles Forebay ......................................................................................134

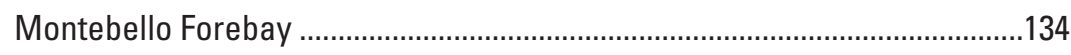

Central Basin Pressure Area, North ...........................................................139

Central Basin Pressure Area, Central ...........................................................139

Central Basin Pressure Area, South.............................................................. 140

West Coast Basin, East...............................................................................140

West Coast Basin, West ............................................................................ 140

Santa Monica Basin ......................................................................................141

Simulated Hydraulic Heads for Fall 2013 and Spring 2006 ..................................141

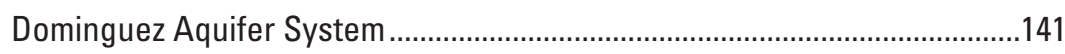

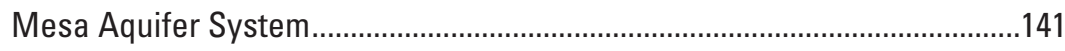

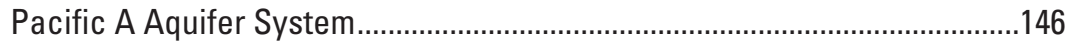

Pacific Aquifer System ................................................................................146

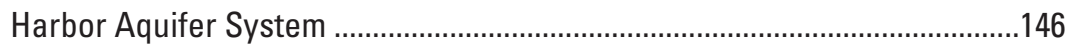

Bent Spring Aquifer System.....................................................................147

Upper Wilmington A Aquifer System............................................................147

Upper Wilmington B Aquifer System...........................................................148

Lower Wilmington Aquifer System ............................................................148

Long Beach A Aquifer System...................................................................149

Long Beach B Aquifer System.....................................................................149

Long Beach C Aquifer System ......................................................................149

Model-Parameter Sensitivity ....................................................................................... 149

Simulated Regional Groundwater Budget and Flow Between Subareas .....................150

Simulated Average Groundwater Budget, 1971 to 2015 ...............................................171

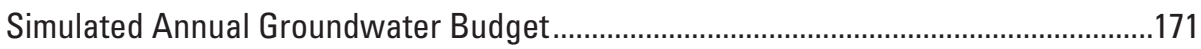

Simulated Flow between Subareas and Layers ..........................................................172

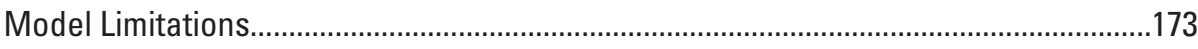

Simulation of Future Water-Management Scenarios ......................................................175

Description of Future Water-Management Scenarios ...................................................175

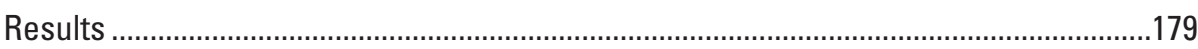

Base-Case Scenario with Wet Conditions …………….......................................179

Base-Case Scenario with Dry Conditions ………………….............................179

Increased-Pumpage Scenario with Wet Conditions ............................................179

Increased-Pumpage Scenario with Dry Conditions ..............................................197

Comparison of Scenarios ................................................................................197 
Simulation-Optimization Analysis ...............................................................................198

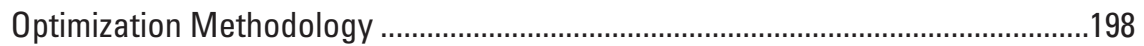

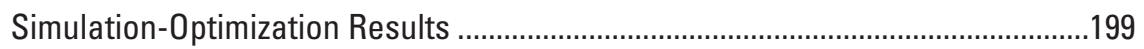

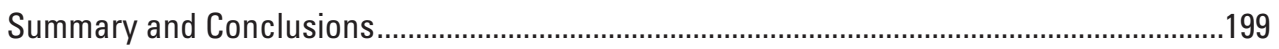

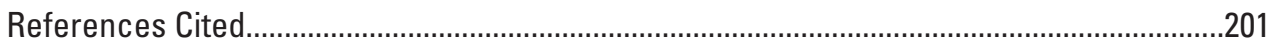

Appendix 1. The Use of Water-Quality Data to Help Identify Chronostratigraphic Unit

Boundaries, Sediment Sources, Sediment Facies, Water Sources, and Model Zones ...202

Appendix 2. Utilization of Downhole Geophysical Logs to Determine Sediment Grain Size .....364

Appendix 3. Los Angeles Coastal Plain Groundwater-flow Model Setup Including Wells

Used to Constrain Boundary Conditions .............................................................................378

Appendix 4. Results for Los Angeles Coastal Plain Groundwater-flow Model and

Management Scenario Simulations .............................................................................383

Appendix 5. Rainfall-Recharge Analysis .................................................................................48

\section{Figures}

A1. Map showing groundwater basins in the Los Angeles Coastal Plain including the Central, West Coast, Hollywood, and Santa Monica Basins and part of Orange County Basin, Los Angeles and Orange Counties, California ..

A2. Map showing land use in the Los Angeles Coastal Plain, Los Angeles and Orange Counties, California ..............................................................

A3. Map showing monitoring wells used in this study, Los Angeles County, California .......10

B1. Map showing Los Angeles Coastal Plain area and cross-section locations and surficial chronostratigraphic units inferred from geologic mapping by Saucedo and others (2003), Morton and Miller (2006), and Campbell and others (2014)

B2. Map showing surface geologic units and faults, Los Angeles Coastal Plain, California

B3. Map showing location of control wells and seismic-reflection profiles used for the location of chronostratigraphic unit boundaries, Los Angeles Coastal Plain, California

B4. Stratigraphic and structural cross-section A-A' showing modeled chronostratigraphic unit boundaries.

B5. Stratigraphic and structural cross-section B-B' showing modeled chronostratigraphic unit boundaries.

B6. Chair-cut view through the three-dimensional structure model of the study area ..........32

B7. Map showing inferred facies distribution of the Long Beach $C$ chronostratigraphic unit with dominant lithologies from control wells and source drainages derived from available strontium-isotope data

B8. Map showing inferred facies distribution of the Long Beach BC chronostratigraphic unit with dominant lithologies from control wells and source drainages derived from available strontium-isotope data

B9. Map showing inferred facies distribution of the Long Beach B chronostratigraphic unit with dominant lithologies from control wells and source drainages derived from available strontium-isotope data

B10. Map showing inferred facies distribution of the Long Beach A chronostratigraphic unit with dominant lithologies from control wells and source drainages derived from available strontium-isotope data 
B11. Map showing inferred facies distribution of the Lower Wilmington chronostratigraphic unit with dominant lithologies from control wells and source drainages derived from available strontium-isotope data....

B12. Map showing inferred facies distribution of the Upper Wilmington $B$ chronostratigraphic unit with dominant lithologies from control wells and source drainages derived from available strontium-isotope data...

B13. Map showing inferred facies distribution of the Upper Wilmington A chronostratigraphic unit with dominant lithologies from control wells and source drainages derived from available strontium-isotope data

B14. Map showing inferred facies distribution of the Bent Spring chronostratigraphic unit with dominant lithologies from control wells and source drainages derived from available strontium-isotope data.....

B15. Map showing inferred facies distribution of the Harbor chronostratigraphic unit, Los Angeles Coastal Plain, California, with dominant lithologies from control wells and source drainages derived from available strontium-isotope data .....47

B16. Map showing inferred facies distribution of the Pacific chronostratigraphic unit with dominant lithologies from control wells and source drainages derived from available strontium-isotope data

B17. Map showing inferred facies distribution of the Pacific A chronostratigraphic unit with dominant lithologies from control wells and source drainages derived from available strontium-isotope data

B18. Map showing inferred facies distribution of the Mesa chronostratigraphic unit with dominant lithologies from control wells and source drainages derived from available strontium-isotope data

B19. Map showing inferred facies distribution of the Dominguez chronostratigraphic unit with grain-size distribution from key wells and available strontium-isotope data

B20. Stratigraphic and structural cross-section C-C' comparing modeled chronostratigraphic unit boundaries, this study, to lithostratigraphic formations (colored shading; queried where uncertain) and aquifers of the California Department of Water Resources

B21. Stratigraphic and structural cross-section D-D' comparing modeled chronostratigraphic unit boundaries, this study, to lithostratigraphic formations (colored shading; queried where uncertain) and aquifers of California Department of Water Resources.

B22. Stratigraphic and structural cross-section E-E' comparing modeled chronostratigraphic unit boundaries, this study, to lithostratigraphic formations (colored shading; queried where uncertain) and aquifers of California Department of Water Resources

B23. Map showing depth from land surface to the base of water-bearing units .....................61

B24. Map showing depth from land surface to the base of the Pacific chronostratigraphic unit

C1. Map showing groundwater basins and subareas of the Los Angeles Coastal Plain, California

C2. Cumulative departure from the mean for precipitation measured at the University of Southern California campus (Los Angeles Almanac, 2018), Los Angeles County, California.

C3. Graph showing annual recharge at Rio Hondo spreading grounds, San Gabriel River spreading grounds, and Whittier Narrows Dam for calendar years 1971 to 2015, Los Angeles County, California 
C4. Graph showing annual injection during calendar years 1971-2015 at West Coast Basin barrier project, Dominguez Gap barrier project, and Alamitos barrier project, Los Angeles County, California. Injection data provided by Water Replenishment District of Southern California

C5. Map showing average injections and pumpage for 1971 to 1979 and 2010 to 2015 in Los Angeles County, California. Injection and pumpage data provided by Water Replenishment District of Southern California

C6. Map showing top of perforation depths and bottom of perforation depths of active production and injection wells during 1971 to 2015, Los Angeles County, California

C7. Graph showing annual pumpage by calendar year in the Los Angeles Coastal Plain as provided by reporting agency, Los Angeles County, California

C8. Map showing locations of selected long-screened basin-monitoring wells and paired multiple-well monitoring sites in the Los Angeles Coastal Plain, Los Angeles County, California

C9. Graphs showing long-term hydrographs of observed heads for selected long-screened, basin-monitoring wells and (generally) paired multiple-well monitoring sites in the Los Angeles Forebay, Montebello Forebay, Central Basin Pressure Area (North), Central Basin Pressure Area (Central), Central Pressure Area (South), West Coast Basin (East), West Coast Basin (West), and Santa Monica Basin, Los Angeles County, California.

D1. Model domain and grid showing pumping, drain, and boundary condition cells in the Los Angeles Coastal Plain Groundwater-flow Model as a composite of all model layers, Los Angeles and Orange Counties, California ...

D2. Maps showing areal recharge as zones and multipliers, and as simulated average areal recharge rates 1971 to 2015 of the Los Angeles Coastal Plain Groundwater-flow Model, Los Angeles and Orange Counties, California

D3. Graph showing areal recharge applied to the Los Angeles Coastal Plain Groundwater-flow Model quarterly estimates from 1971 to 2015, Los Angeles and Orange Counties, California

D4. Map showing uppermost model layer in the Los Angeles Coastal Plain Groundwater-flow Model, Los Angeles and Orange Counties, California.. 101

D5. Maps showing cells with injection or spreading for layers 2-13 of the Los Angeles Coastal Plain Groundwater-flow Model, Los Angeles and Orange Counties, California

D6. Plot of simulated versus measured water levels of the Los Angeles Coastal Plain Groundwater-flow Model for 1971 through 2015, and histogram of simulated versus measured water-level residuals of the Los Angeles Coastal Plain Groundwater-flow Model for 1971 through 2015

D7. Maps showing calibrated horizontal hydraulic conductivities and grain-size distribution in well bores for model layers in Los Angeles and Orange Counties, California

D8. Maps showing calibrated vertical hydraulic conductivities, specific yield, and flow-barrier hydraulic characteristic values for layers 2 to 13 in select areas, Los Angeles and Orange Counties, California

D9. Graphs showing measured and simulated hydraulic heads for selected long-screened basin-monitoring wells and paired multiple-well monitoring sites in select areas, Los Angeles and Orange Counties, California

D10. Maps showing simulated head for Fall of 2013 and Spring of 2006 for layers 2 to 13 of the Los Angeles Coastal Plain Groundwater-flow Model. 
D11. Graphs showing top 30 parameters with high observation sensitivity values, Los Angeles Coastal Plain Groundwater-flow Model, Los Angeles and Orange Counties, California

D12. Graph showing composite scaled sensitivity values for all simulated values, hydraulic heads only, changes in hydraulic head only, and vertical differences in hydraulic head only, Los Angeles Coastal Plain Groundwater-flow Model, Los Angeles and Orange Counties, California .

D13. Graph showing simulated annual groundwater-flow budget for the Los Angeles Coastal Plain, 1971 to 2015, Los Angeles and Orange Counties, California

D14. Map showing simulated average annual groundwater flow between subareas in Los Angeles Coastal Plain, 1971 to 2015, Los Angeles and Orange Counties, California

D15. Graph showing simulated cumulative change in storage 1971-2015, Los

Angeles Coastal Plain Groundwater-flow Model, Los Angeles and Orange Counties, California

D16. Map showing GRIP injection wells, existing production wells whose pumping rates were increased during the management scenarios, and production wells that were added to the management scenarios, Los Angeles and Orange Counties, California

D17. Graphs showing simulated annual water budgets, Los Angeles Coastal Groundwater-flow Model

D18. Graph showing cumulative change in storage for future water-management scenarios, Los Angeles Coastal Plain Groundwater-flow Model.

D19. Maps showing simulated maximum relative difference in drawdown of hydraulic head in the Pacific and Bent Spring aquifer systems, Los Angeles Coastal Plain Groundwater-flow Model.

D20. Graphs showing simulated hydrographs for the Pacific and Bent Spring aquifer systems at selected calibration wells for future water-management scenarios, Los Angeles Coastal Plain Groundwater-flow Model.

\section{Tables}

B1. Control wells used for identification of chronostratigraphic unit boundaries .................20

B2. Modeled chronostratigraphic units, Los Angeles Coastal Plain ......................................33

C1. Estimated underflow in acre-ft from the San Gabriel Valley into the LACP provided by SGRWM, Los Angeles County, California, 1962 to 2015.

C2. Estimated annual flow budget in acre-ft of saturated zone 1971 to 2015, Los Angeles groundwater study area, California

D1. MODFLOW-USG Version 1.3 packages and processes used with the LACPGM, California

D2. LACPGM layer average and maximum thickness ..........................................................96

D3. Key multiple-well monitoring sites used during Los Angeles Coastal Plain Groundwater-flow Model calibration

D4. Parameter type and upper and lower bound for parameters in the Los Angeles Coastal Plain Groundwater-flow Model.

D5. Parameter code explanation for the Los Angeles Coastal Plain 
D6. Simulated average 45-year water budget (acre-ft/yr) by model layer and subarea of the Los Angeles Coastal Plain Groundwater-flow Model, 1971 to 2015, Los Angeles County, California.

D7. Simulated average 10-year water budget (acre-ft/yr) by model layer and subarea of the Los Angeles Coastal Plain Groundwater-flow Model, 2006 to 2015, Los Angeles County, California..

D8. Summary of inputs in acre-ft/yr for future water-management scenarios

D9. Planned new pumping wells and simulated pumping rates for future water-management scenarios, Los Angeles Coastal Plain Groundwater-flow Model

D10. Projected increased pumping rates for existing wells for future water-management scenarios, Los Angeles Coastal Plain Groundwater-flow Model

\section{Conversion Factors}

U.S. customary units to International System of Units

\begin{tabular}{|c|c|c|}
\hline Multiply & By & To obtain \\
\hline \multicolumn{3}{|c|}{ Length } \\
\hline inch (in.) & 2.54 & centimeter $(\mathrm{cm})$ \\
\hline inch (in.) & 25.4 & millimeter (mm) \\
\hline foot $(\mathrm{ft})$ & 0.3048 & meter $(\mathrm{m})$ \\
\hline mile (mi) & 1.609 & kilometer $(\mathrm{km})$ \\
\hline \multicolumn{3}{|c|}{ Area } \\
\hline acre & 4,047 & square meter $\left(\mathrm{m}^{2}\right)$ \\
\hline acre & 0.4047 & hectare (ha) \\
\hline acre & 0.4047 & square hectometer $\left(\mathrm{hm}^{2}\right)$ \\
\hline acre & 0.004047 & square kilometer $\left(\mathrm{km}^{2}\right)$ \\
\hline square mile $\left(\mathrm{mi}^{2}\right)$ & 259.0 & hectare (ha) \\
\hline square mile $\left(\mathrm{mi}^{2}\right)$ & 2.590 & square kilometer $\left(\mathrm{km}^{2}\right)$ \\
\hline \multicolumn{3}{|c|}{ Volume } \\
\hline acre-foot (acre-ft) & 1,233 & cubic meter $\left(\mathrm{m}^{3}\right)$ \\
\hline acre-foot (acre-ft) & 0.001233 & cubic hectometer $\left(\mathrm{hm}^{3}\right)$ \\
\hline \multicolumn{3}{|c|}{ Flow rate } \\
\hline acre-foot per year (acre-ft/yr) & 1,233 & cubic meter per year $\left(\mathrm{m}^{3} / \mathrm{yr}\right)$ \\
\hline acre-foot per year (acre-ft/yr) & 0.001233 & cubic hectometer per year $\left(\mathrm{hm}^{3} / \mathrm{yr}\right)$ \\
\hline
\end{tabular}

Temperature in degrees Celsius $\left({ }^{\circ} \mathrm{C}\right)$ may be converted to degrees Fahrenheit $\left({ }^{\circ} \mathrm{F}\right)$ as follows:

$$
{ }^{\circ} \mathrm{F}=\left(1.8 \times{ }^{\circ} \mathrm{C}\right)+32 .
$$




\section{Datum}

Vertical coordinate information is referenced to the North American Vertical Datum of 1988 (NAVD 88).

Horizontal coordinate information is referenced to the North American Datum of 1983 (NAD 83).

Altitude, as used in this report, refers to distance above the vertical datum.

\section{Supplemental Information}

Concentrations of chemical constituents in water are given in either milligrams per liter (mg/L) or micrograms per liter $(\mu \mathrm{g} / \mathrm{L})$.

\section{Well-Numbering System}

Wells are identified and numbered according to their location in the rectangular system for the subdivision of public lands. Identification consists of the township number, north or south; the range number, east or west; and the section number. Each section is divided into sixteen 40 -acre tracts lettered consecutively (except I and 0 ), beginning with " $\mathrm{A}$ " in the northeast corner of the section and progressing in a sinusoidal manner to "R" in the southeast corner. Within the 40 -acre tract, wells are sequentially numbered in the order they are inventoried. The final letter refers to the base line and meridian. In California, there are three base lines and meridians; Humboldt $(\mathrm{H})$, Mount Diablo (M), and San Bernardino (S). All wells in the study area are referenced to the San Bernardino base line and meridian (S). Well numbers consist of 15 characters and follow the format $004 \mathrm{~S} 012 \mathrm{~W} 05 \mathrm{H} 005 \mathrm{~S}$. In this report, well numbers are abbreviated and written $4 \mathrm{~S} / 12 \mathrm{~W}-5 \mathrm{H} 5$. Wells in the same township and range are referred to only by their section designation, $5 \mathrm{H} 5$. The following diagram shows how the number for well $4 \mathrm{~S} / 12 \mathrm{~W}-5 \mathrm{H} 5$ is derived.

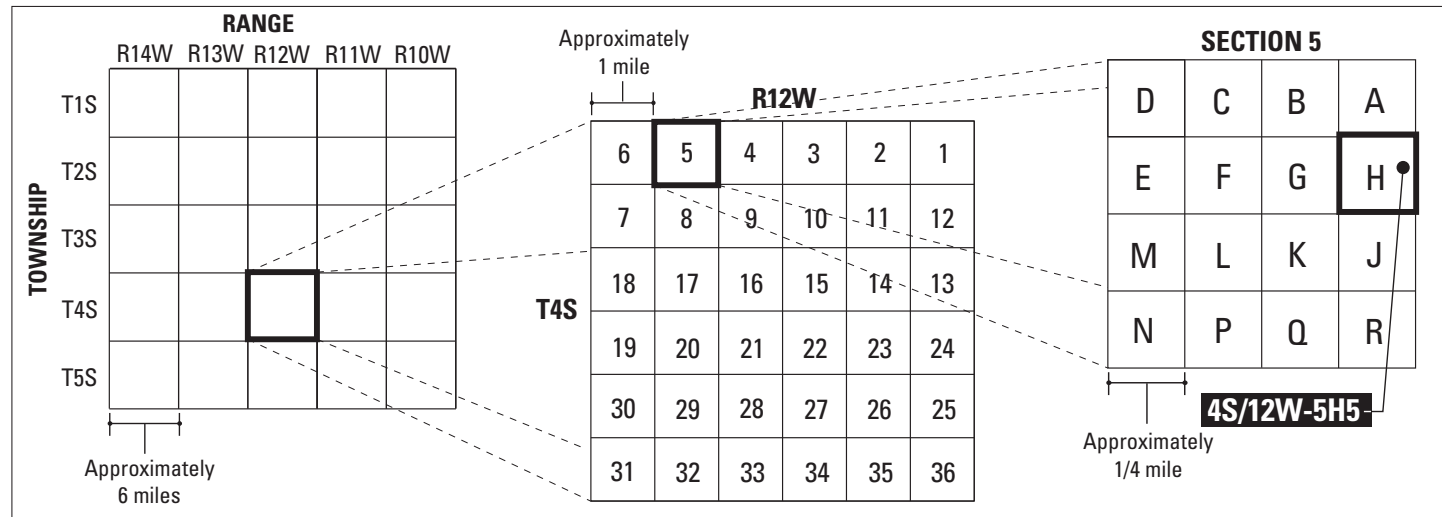

Well-numbering diagram (Note: maps in this report use abbreviated well numbers such as "5H5") 


\section{Abbreviations}

$\begin{array}{ll}\text { ABP } & \text { Alamitos Barrier Project } \\ \text { AIT } & \text { array induction 2-foot resistivity } \\ \text { bls } & \text { below land surface } \\ \text { CalGEM } & \text { California Geologic Energy Management Division } \\ \text { CDWR } & \text { California Department of Water Resources } \\ \text { CHD } & \text { time-variant specified head } \\ \text { CLN } & \text { connected linear network } \\ \text { CSS } & \text { composite scale sensitivity } \\ \text { DGBP } & \text { Dominguez Gap Barrier Project } \\ \text { DRN } & \text { drain package } \\ \text { EMF } & \text { East Montebello fault } \\ \text { GAMA } & \text { Groundwater Ambient Monitoring and Assessment } \\ \text { GHB } & \text { general-head boundary } \\ \text { GIS } & \text { geographic information system } \\ \text { GRIP } & \text { Groundwater Reliability Improvement Project } \\ \text { HFB } & \text { horizontal-flow barrier } \\ \text { HK } & \text { horizontal hydraulic conductivity } \\ \text { ka } & \text { thousand years } \\ \text { LA } & \text { Los Angeles } \\ \text { LACDPW } & \text { Los Angeles County Department of Public Works } \\ \text { LACFCD } & \text { Los Angeles County Flood Control District } \\ \text { RACP } & \text { Los Angeles Coastal Plain } \\ \text { LACPGM } & \text { Los Angeles Coastal Plain groundwater model } \\ \text { LADWP } & \text { Los Angeles Department of Water and Power } \\ \text { Ma } & \text { million years } \\ \text { NMR } & \text { nuclear magnetic resonance } \\ \text { NWIS } & \text { USGS National Water Information System } \\ \text { OCWD } & \text { Orange County Water District } \\ \text { PSL } & \text { optically stimulated luminescence } \\ \text { Pacific Coast Highway } \\ \text { recharge package } \\ \text { RE }\end{array}$


SGRSG San Gabriel River spreading grounds

SGRWM San Gabriel River Water Master

SS specific storage

SY specific yield

TDS total dissolved solids

TL thermoluminescence

TU tritium unit

USC University of Southern California

USGS U.S. Geological Survey

UTM Universal Transverse Mercator

VK vertical hydraulic conductivity

WCBBP West Coast Basin Barrier Project

WEL well package

WND Whittier Narrows Dam

WRD Water Replenishment District of Southern California 



\title{
Development of a Groundwater-Simulation Model in the Los Angeles Coastal Plain, Los Angeles County, California
}

\author{
Edited by Scott Paulinski
}

\section{Executive Summary}

The Los Angeles Coastal Plain (LACP) covers about 580 square miles and is the largest coastal plain of semiarid southern California. The LACP is heavily developed with mostly residential, commercial, and industrial land uses that rely heavily on groundwater for water supply. In 2010, the LACP was home to about 14 percent of California's population, or about 5.4 million residents. The LACP is also a major commercial and industrial hub with industries including manufacturing, aerospace, entertainment, and tourism.

There has been a heavy reliance on groundwater from the LACP for many years. An average of 305,000 acre-feet per year (acre-ft/yr) of groundwater was used annually from the LACP from 1971 to 2015. The need to replenish the groundwater basins within the LACP was recognized as far back as the 1930s, when spreading grounds were first used to replenish groundwater basins and store water underground during times of water surplus to meet demands in times of shortage. Seawater intrusion resulting from freshwater pumping was first observed in the 1940s. As a result, injection of imported water through wells at what is now the West Coast Basin Barrier Project began on an experimental basis in 1951. Managed aquifer recharge from the spreading grounds and barrier wells is now a substantial component of the LACP's groundwater supply. The average annual recharge from water spreading from 1971 to 2015 was about 120,000 acre-ft/yr, and the average annual injection into the barrier wells was about 33,000 acre-ft/yr. Other inflows include areal recharge, underflow from San Gabriel and San Fernando Valleys, and onshore flow from the ocean. The average annual recharge from these sources was 100,000 acre-feet (acre-ft) from 1971 to 2015. Additionally, cross-boundary flow from Orange County into the western Orange County subareas of the LACP was simulated as 48,000 acre-ft from 1971 to 2015.
This study, conducted in cooperation with the Water Replenishment District of Southern California (WRD), involved an assessment of the historical and present status of groundwater resources in the LACP and the development of tools to better understand the groundwater system. These efforts were built upon results from previous studies and incorporate new information and developments in modeling capabilities to provide a more detailed analysis of the aquifer systems.

This study includes a comprehensive compilation of geologic and hydrologic data (Chapter A), development of a chronostratigraphic model that provides a detailed description of the LACP aquifer systems (Chapter B), characterization of the groundwater hydrology of the LACP, including a down-hole analysis of grain size using lithologic and geophysical logs (Chapter C), and development and application of the Los Angeles Coastal Plain Groundwater-flow Model (LACPGM) to simulate past groundwater conditions, estimate groundwater-budget components and flow paths, and approximate future groundwater conditions under different scenarios (Chapter D).

\section{Data Compilation}

A geographic information system (GIS) was used to store, analyze, and visualize model input and output data. Data were compiled from multiple sources for the construction of the chronostratigraphic and groundwater-flow models including: (1) water levels in wells; (2) well-construction information; (3) volumes of pumping, injection, and water spreading; (4) information on areal recharge (Chapter C), water-chemistry data (appendix 1), geophysical logs (appendix 2), seismic cross sections (Chapter B), and data related to land subsidence. Various inputs to the LACPGM, including chronostratigraphic layer boundaries, fault locations, hydraulic heads, hydraulic properties, and water-budget calculations, were also incorporated into the GIS. 


\section{Chronostratigraphic Hydrogeologic-Framework Model}

The stratigraphy and structure of the LACP was reevaluated for this study utilizing the concepts of sequence stratigraphy to develop a chronostratigraphic (time-based) hydrogeologic-framework model for the water-bearing sediments of the LACP. Sequence stratigraphy subdivides and links sedimentary deposits into unconformity-bound chronostratigraphic units (sequences) that represent cycles of deposition that are controlled by variations in base level (elevations relative to the North American Vertical Datum of 1988 [NAVD 88]), sediment supply, and accommodation space. Sequence-bounding unconformities separate sediments that are deposited within discrete time intervals. Within each sequence, the depositional processes result in layers of heterogeneous sediments. In general, the sediments are anisotropic, with the horizontal hydraulic conductivity of the sediments being greater than the vertical hydraulic conductivity. Because of the anisotropy in the layered sediments, groundwater preferentially flows within the sequence, limiting flow to overlying or underlying sequences. However, flow between sequences may not be as limited if vertical hydraulic gradients are high, or where coarse-grained deposits are juxtaposed across a sequence boundary or laterally because of incision, onlap, or faulting.

The chronostratigraphic hydrogeologic framework model developed for this study extended a study completed by Ponti and others (2007) in the Long Beach area to the entire LACP through compilation and analysis of 193 detailed geologic and geophysical logs, including logs from 57 WRD and U.S. Geological Survey (USGS) multiple-well monitoring sites, 183 seismic-reflection profiles, and surficial geology. The resulting chronostratigraphic-hydrogeologic framework model consists of 15 units, 13 of which compose the groundwater basin. The 13 chronostratigraphic units identified in the groundwater basin range in age from late Pliocene through Holocene (approximately 3 million years ago [Ma] to present). Chronostratigraphic unit boundaries were refined using water-level and water-quality data (appendix 1).

The chronostratigraphic units identified in this study often do not correlate with aquifers defined in previous investigations that used lithostratigraphic techniques to subdivide the sedimentary deposits based on their physical properties. The lithostratigraphically defined formations and aquifers contain sediments that were deposited at considerably different times from the basin margin to the basin center. This variability in deposition implies that many of the aquifers defined lithostratigraphically are composed of multiple depositional units and likely are not areally connected. For example, the lithostratigraphically defined older aquifers generally are associated with older chronostratigraphic units along the eastern and western margins of the Central Basin, whereas they are associated with younger chronostratigraphic units in the middle of the Central Basin. Seismic reflection data compiled and interpreted for this study demonstrated that the lower (older) chronostratigraphic units dip more deeply into the Central Basin than the lithostratigraphically defined aquifers and become much thicker toward the center of the basin. The improved understanding of the hydrodeological framework of the LACP was used to more accurately simulate groundwater flow in the LACP (Chapter D).

\section{Basin Groundwater Hydrology}

The LACP receives natural recharge primarily from the downward percolation of precipitation, underflow, and mountain-front recharge. Percolation of precipitation occurs where land uses and land-surface characteristics are conducive to infiltration. Underflow into the LACP occurs from the San Fernando Valley through the Los Angeles Narrows into the northwestern Central Basin, and from the San Gabriel Valley through the Whittier Narrows into the northern Central Basin. Mountain-front recharge occurs primarily along the base of mountains and hills bordering the north, northeast, and southwest boundaries of the LACP. The San Gabriel River, Rio Hondo, and Los Angeles River drain the San Gabriel and San Fernando Valleys and enter the LACP through the Whittier and Los Angeles Narrows. Under pre-development conditions, infiltration from streamflow was the main source of groundwater recharge to the LACP; however, these rivers have been channelized and lined in the LACP, limiting their contribution to recharge.

As the LACP became more urbanized and populous, the anthropogenic influences on the groundwater system greatly increased. Groundwater pumping increased from the early 1900s until the early 1960s, resulting in large water-level declines throughout most of the LACP. More than $100 \mathrm{ft}$ of water-level decline were measured in parts of the Central Basin, and water levels declined more than $60 \mathrm{ft}$ below NAVD 88 in parts of the West Coast and Santa Monica Basins. By the mid-1960s, the Central and West Coast Basins were adjudicated to address long-term issues associated with sustainability of the groundwater supply, including overdraft and seawater intrusion.

The complex chronographic stratigraphy, grain-size distribution, and geologic structure affects vertical and horizontal groundwater flow rates through the LACP. Sediment grain size varies in the LACP from coarse gravels to fine clays. The distribution of various sediments penetrated by numerous boreholes associated with multiple-well monitoring sites was determined based on an analysis of downhole geophysical logs and lithologic samples collected during the installation of these sites (appendix 2). These results, along with other data, were used to help estimate the hydraulic properties of each chronostratigraphic unit geographically throughout the study area. 
An annual average of 305,000 acre-ft/yr of groundwater was pumped from the LACP from 1971 to 2015, with much of the pumping occurring in the Central and West Coast Basins (appendix 4). From 1971 to 2015, spreading grounds in northern Central Basin south of Whittier Narrows recharged about 123,000 acre-ft/yr and injection wells at the seawater barriers recharged about 33,000 acre-ft/yr to coastal areas of the West Coast and Central Basins.

Water levels measured from 1970 to 2015 varied by chronostratigraphic layer and location within the LACP. Long-term data from long-screened wells, paired with more recent data from multiple-well monitoring sites, were interpolated to approximate the spatial distribution of water levels in the LACP.

\section{Hydrologic Modeling}

The LACPGM represents a major update of a previous groundwater-flow model developed by Reichard and others (2003), incorporating new data, analyses, and modeling tools (Chapter D and appendix 3, 4). The LACPGM uses the USGS model code MODFLOW-USG, which enables the use of an unstructured finite-difference grid; this grid for the LACPGM contains nodes one-eighth mile (mi; $660 \mathrm{ft}$ ) in length and width. The LACPGM incorporates 12 layers for the 13 chronostratigraphic units, with the two bottom units modeled as a single layer. MODFLOW-USG was selected for its ability to effectively represent the discontinuous and faulted chronostratigraphic layers using an unstructured grid. The LACPGM simulates groundwater flow in the LACP using quarterly stress periods from 1971 to 2015.

The LACPGM incorporates no-flow, time-variant specified-head and general-head boundary conditions. A specified-head boundary simulates underflow from the San Fernando Valley through the Los Angeles Narrows using the constant head (CHD) package. General-head (GHD) boundaries in the GHD package simulate underflow from the San Gabriel Valley through the Whittier Narrows, flow between the eastern edge of the model and Orange County, underflow from the Palos Verdes Hills into the southwestern model area, and flow between the western and southern model area and the Santa Monica and San Pedro Bays. No-flow boundaries were simulated along the remaining edges of the model. The LACPGM simulates faults and folds believed to restrict groundwater flow as horizontal-flow barriers (HFB package). Pumping and injection were simulated using the connected linear network (CLN) package and the well (WEL) package. Spreading grounds were simulated using the well package, and areal recharge was simulated using the recharge ( $\mathrm{RCH})$ package.

The LACPGM was calibrated using PEST (parameter-estimation) software. Horizontal and vertical hydraulic conductivity, specific storage, and specific yield were parameterized using zones defined for each model layer. Areal recharge was parameterized using zones. General-head boundaries and horizontal-flow barriers were segmented; the conductance of each segment was parameterized. The LACPGM was calibrated to 27,860 water-level measurements from 464 wells and to yearly underflow estimates through Whittier Narrows.

The LACPGM simulation results included groundwater-flow direction and amount throughout the LACP (Chapter D and appendix 4). Groundwater in the LACP generally flowed from the northern regions of the model, including the Santa Monica and Hollywood Basins, the northern Los Angeles and Montebello Forebays, and the Whittier area toward the central and southern parts of the model (including the southern Los Angeles Forebay, the Central Basin Pressure Area, West Coast Basin, and parts of Orange County). The model simulated lateral flows between subareas, vertical flows between model layers, and underflow from adjacent groundwater basins.

The LACPGM was used to simulate water levels under future water-management scenarios, base case wet and dry scenarios, increased pumpage wet and dry scenarios, and optimized replenishment wet and dry scenarios. Scenarios included projected future pumping rates and estimated the increases in water spreading and injection that would be needed to maintain water levels. Scenarios also simulated expected future pumping rates and estimated needed increases in water spreading and injection in order to maintain water levels. Results of these scenarios showed that adding water at spreading grounds and seawater barrier injection wells reduced drawdowns in some areas but had limited effects on water levels in some wells in the eastern and northeastern Central Basin and the eastern West Coast Basin, leading to large drawdowns in these areas. The large drawdowns generally occurred in the lower aquifer systems in the West Coast Basin and in the upper and lower aquifer systems in the Central Basin, with more drawdown in the lower aquifer systems. 


\title{
Chapter A. Introduction and Data Compilation
}

\author{
By Scott Paulinski, Claudia Faunt, Michael Land, Tracy Nishikawa, and Peter Martin
}

\section{Introduction}

The study area, referred to as the Los Angeles Coastal Plain (LACP) in this report, includes most of the Coastal Plain of Los Angeles County, which subdivided the LACP into four groundwater basins: Central, West Coast, Hollywood, and Santa Monica Basins (fig. A1; California Department of Water Resources, 1961). The LACP, the largest coastal plain of semiarid southern California, historically has relied on local groundwater supplies for a substantial portion of its water supply (fig. A1). In 2010 there were approximately 5.4 million residents, or about 14 percent of California's population, living in the LACP (U.S. Census Bureau, 2010). Groundwater development over the first half of the 20th century caused large groundwater declines throughout the LACP and subsequent seawater intrusion along the coastline. In the early 1950s, water-supply wells along the coast began to be abandoned because of seawater intrusion (Nishikawa and others, 2009). In 1959, the Water Replenishment District of Southern California (WRD) was formed for the purpose of protecting the groundwater resources of the Central and West Coast Basins (fig. A1). The WRD has supplemented natural recharge to the groundwater basins through the spreading of imported and recycled waters at spreading grounds and at seawater barrier injection wells along the coastline. In 2016-17, groundwater met over 40 percent (Water Replenishment District of Southern California, 2018) of the water demand for approximately 4 million people living in the Central and West Coast Basins.

To further enable the effective management of the groundwater resources of the LACP, the U.S. Geological Survey (USGS) and WRD have worked cooperatively to better understand the complex hydrogeology of the Central and West Coast Basins and to develop numerical models to help evaluate the relative effectiveness of different management alternatives. Since the early 1990s, the USGS has worked with the WRD and other agencies to develop a better understanding of the geology, hydrogeology, and geochemistry of the area. Although numerous studies have been completed on specific groundwater issues in the Central and West Coast Basins, there had been no regional studies using sequence stratigraphy to develop a better understanding of the hydrogeology of the groundwater basins. The sequence stratigraphy approach (time-based or chronostratigraphy) is a useful alternative to the lithostratigraphic approach utilized by previous investigations because the sequence stratigraphic approach can produce a more realistic representation of geologic structure, the distribution of lithologic facies, and aquifer architecture. This more realistic representation improves our understanding of and ability to predict the lateral distribution of coarse-grained aquifers and their fine-grained confining aquitards. Chronostratigraphic layering can better model anisotropic groundwater flow in areas with folding since the chronostratigraphic layering can better reflect the direction of anisotropy within that fold.

\section{Purpose and Scope}

The primary purpose of this report is to provide increased scientific understanding of the hydrogeologic system of the Los Angeles Coastal Plain that can be utilized to improve groundwater management. To achieve this objective, this report utilizes results of the study and the extensive literature on the Los Angeles Coastal Plain. The main tasks of the study involved (1) compiling hydrogeologic data to help characterize and conceptualize the hydrogeologic system, (2) developing a hydrogeologic-framework model using a sequence-stratigraphy approach, (3) developing a rainfall-runoff-infiltration model for the estimation of recharge in response to precipitation and irrigation, (4) developing a conceptual model and water budget, and (5) developing a regional three-dimensional groundwater-flow model to characterize the groundwater system and evaluate groundwater-management issues in the LACP. This study was completed by the USGS in cooperation with WRD.

The rainfall-runoff-infiltration model developed for this study (Task 3) was previously described in Hevesi and Johnson (2016). The remaining tasks are described in detail in four chapters of this report: Chapter A contains the introduction and a section on data compilation, Chapter B presents an overview of the geologic framework, Chapter $\mathrm{C}$ describes the groundwater hydrology of the study area and presents a conceptual model of the hydrologic cycle and a groundwater budget, and Chapter D describes the groundwater-flow model and simulations of future water-management scenarios. 


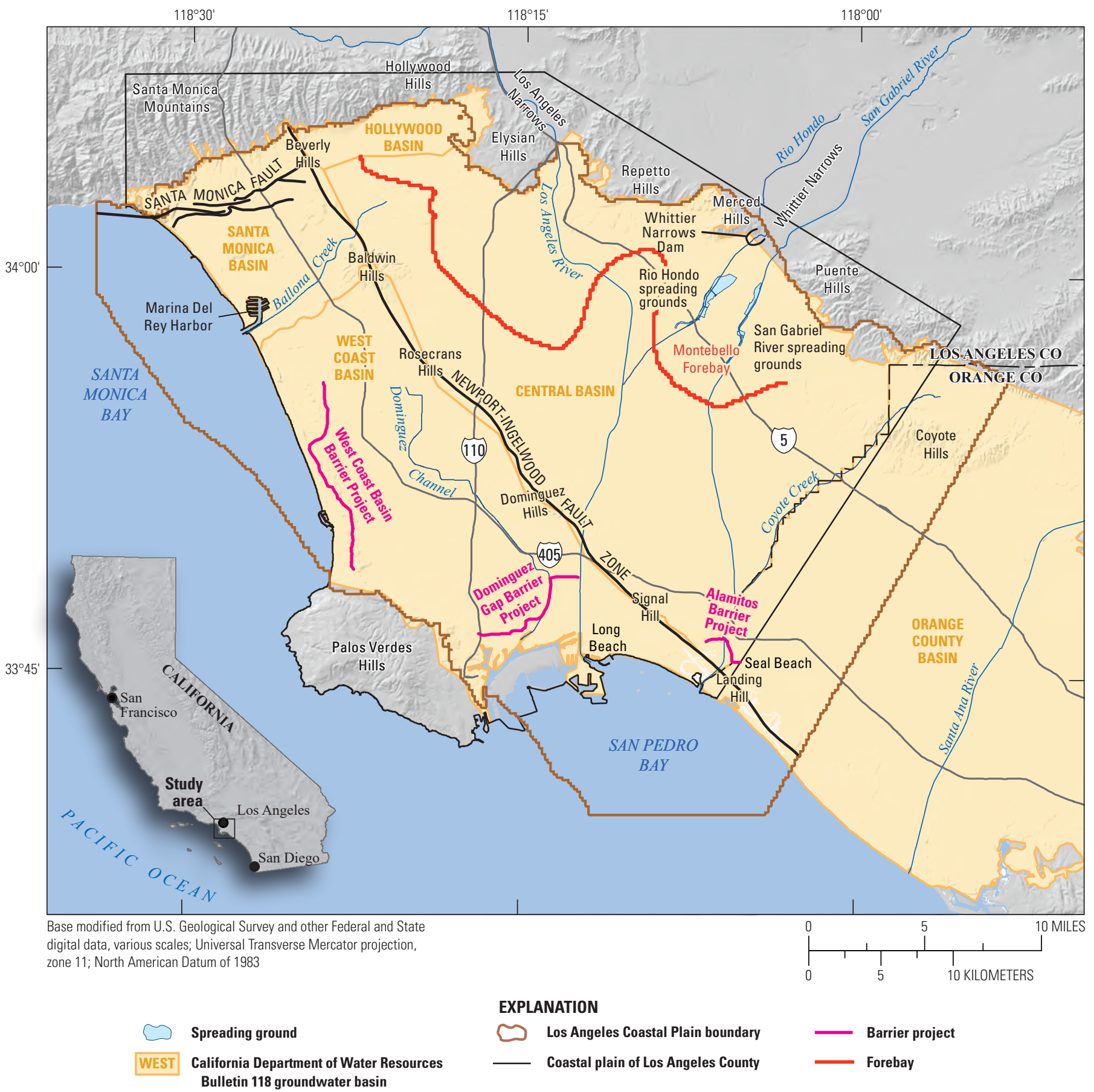

Figure A1. Groundwater basins in the Los Angeles Coastal Plain including the Central, West Coast, Hollywood, and Santa Monica Basins and part of Orange County Basin, Los Angeles and Orange Counties, California. 
This report contains five appendixes, which contain additional supporting information including water-quality data, a grain-size analysis, and an explanation of a rainfall-recharge analysis. Appendix 1 provides background information for water-quality data used in the construction of a chronostratigraphic model (Chapter B) and in the construction and calibration of a groundwater flow model (Chapter D). Appendix 2 presents a grain-size analysis of geophysical logs from WRD/USGS multiple-well monitoring sites. This grain-size analysis was used as a guide when initially defining and calibrating the groundwater-flow model's hydraulic properties (Chapter D). Appendix 3 contains supporting figures and tables that describe how the groundwater flow model was set up (Chapter D). Appendix 4 contains detailed results of the groundwater flow model (Chapter D) including hydrographs, calibrated values, and water budgets. Appendix 5 contains a rainfall-recharge analysis, which can be used to approximate areal recharge for the groundwater flow model (Chapter D) based on rainfall data. The rainfall-recharge analysis is intended to be used in future updates to the groundwater flow model.

\section{Description of Study Area}

The study area, referred to in this report as the LACP (fig. A1), encompasses the coastal parts of the Los Angeles metropolitan area and parts of Orange County. It is bounded by the Santa Monica Mountains and Hollywood Hills to the north; the Elysian, Repetto, Merced, and Puente Hills to the northeast; and the Palos Verdes Hills to the west and southwest. The mountains and hills to the north, as well as the Palos Verdes Hills to the southwest are believed to act as flow barriers as layers fold steeply upward. The LACP covers about 580 square miles $\left(\mathrm{mi}^{2}\right)$, and extends up to 5 miles (mi) into the Santa Monica Bay to the west and the San Pedro Bay to the south, and approximately $5 \mathrm{mi}$ into Orange County to the east (fig. A1) to better simulate flow to and from the Pacific Ocean and Orange County, respectively. The California Department of Water Resources (1961) subdivided the LACP into four groundwater basins: Central, West Coast, Hollywood, and Santa Monica Basins (fig. A1). The Central Basin is separated from the West Coast and Santa Monica Basins by the Newport-Inglewood fault zone (fig. A1). The Hollywood Basin is separated from the Central Basin by the Santa Monica fault (fig. A1) and from the Santa Monica Basin by the Newport-Inglewood fault zone. The West Coast and Santa Monica Basins are separated by the Baldwin Hills and an uplift to the south of Baldwin Hills. Land-surface elevation ranges from approximately 800 feet $(\mathrm{ft})$ in the surrounding hills to sea level at the coast. Several low hills lie within the study area, including the Coyote Hills near the Orange County boundary and the Baldwin Hills, Rosecrans Hills, Dominguez Hills, Signal Hill, and Landing Hill which lie between the Central and West Coast Basins (fig. A1).

The LACP is heavily developed with mostly residential, commercial, and industrial land uses (fig. A2). Residential and commercial land use is scattered throughout the study area. Industrial land use is concentrated southeast of the city of Los Angeles and in and around the cities of Commerce, Norwalk, Carson, Wilmington, and Torrance (fig. A2). The land use and landscape have changed with development of the LACP leading to less open space over time.

Six river systems drain the study area: the Los Angeles and San Gabriel Rivers, Rio Hondo, the Dominguez Channel, and the Ballona and Coyote Creeks (fig. A1). The Los Angeles River flows from Simi Hills (not shown), Santa Monica and Santa Susana Mountains (not shown) south through the Los Angeles Narrows into the study area, where it flows south into the San Pedro Bay near Long Beach. The San Gabriel River and Rio Hondo flow from the San Gabriel Mountains (not shown) south and enter the study area at the Whittier Narrows. The Rio Hondo flows from Whitter Narrows southwest to its confluence with the Los Angeles River, while the San Gabriel River flows south from Whittier Narrows to the San Pedro Bay near Seal Beach. Ballona Creek drains the Santa Monica and Hollywood Basins in the northern part of the study area to the Santa Monica Bay. The Dominguez Channel is a small, local stream which drains most of the West Coast Basin to the San Pedro Bay. Coyote Creek, which drains the northeastern part of the study area, flows south from the Coyote Hills to its confluence with the San Gabriel River. Many of the rivers in the study area have been channelized and concrete-lined to reduce flood and erosion risk.

The study area is characterized by a Mediterranean climate with warm summers, cool winters, and marked precipitation seasonality. Most rain falls from late autumn to early spring; and almost no precipitation falls during the summer. The average annual precipitation on the coastal plain is about 15 inches (in.). Precipitation is highest in the surrounding hills and highlands and decreases progressively toward the ocean. Long-term average annual precipitation ranges from 18 in. in the foothills of the Santa Monica Mountains to $11 \mathrm{in}$. near the coast at the southern corner of the study area (Hevesi and Johnson, 2016). Potential evapotranspiration in the area exceeds precipitation on an annual basis (Hevesi and Johnson, 2016). 


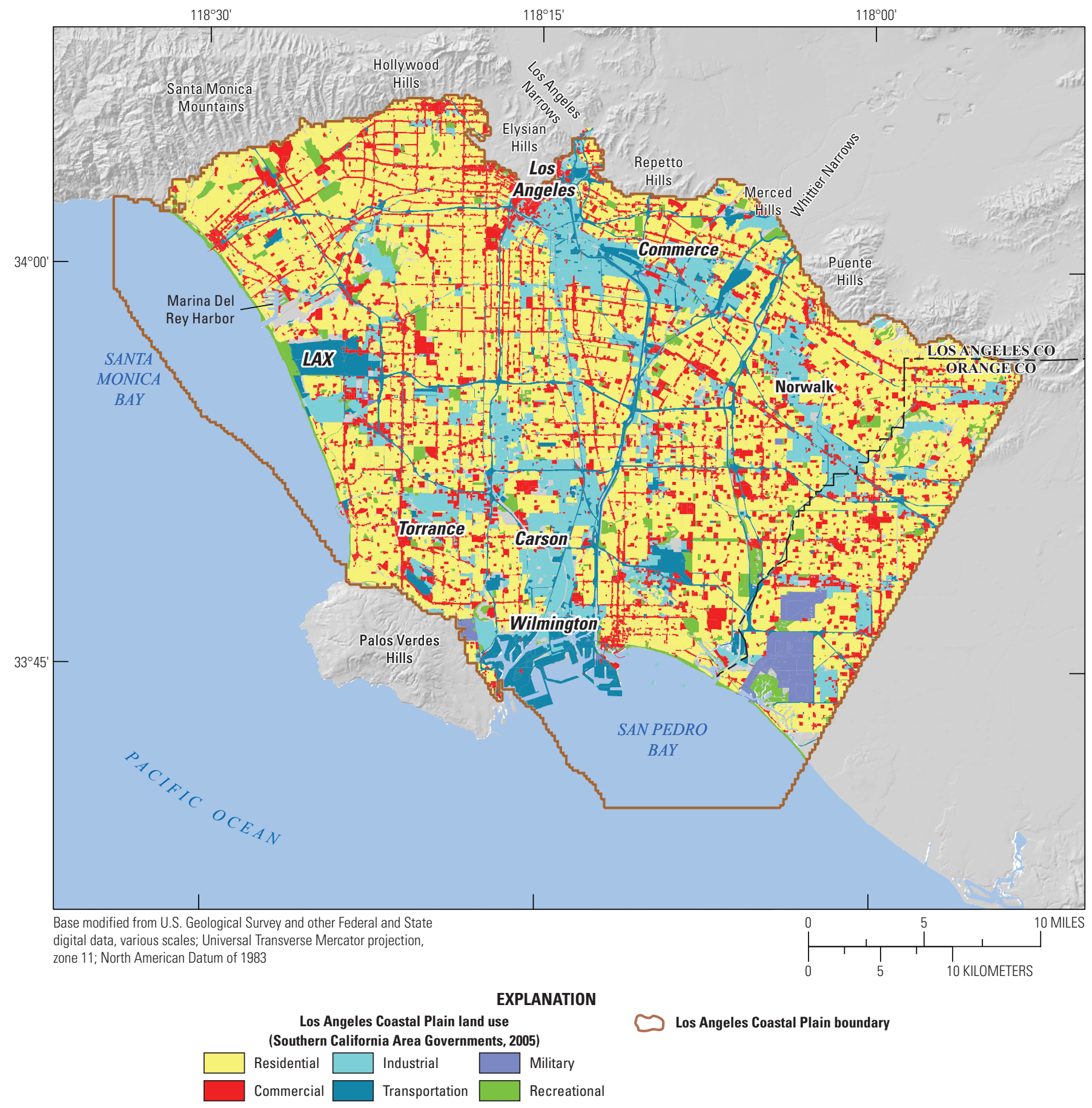

Figure A2. Land use in the Los Angeles Coastal Plain, Los Angeles and Orange Counties, California. 


\section{Previous Investigations}

Over the last century, a substantial number of studies have been completed describing the geology, hydrology, and water chemistry of the LACP, including regional-scale, comprehensive studies as well as local studies of focused interests. Comprehensive regional-scale studies (Mendenhall, 1905a, 1905b, 1905c; Poland and Piper, 1956; Poland and others, 1959; California Department of Water Resources, 1961, 1962, 1966; Reichard and others, 2003) formed the foundation of the hydrogeological framework of the LACP and provided a regional context for local-scale groundwater studies. Mendenhall (1905a, 1905b, 1905c) provided the first regional assessment of groundwater conditions in the area. A detailed description of the geology, hydrogeology, and geochemistry was later provided by Piper and Garrett (1953), Poland and Piper (1956), and Poland and others (1959). The California Department of Water Resources (1961, 1962, 1966) built on these previous studies and further analyzed the regional hydrogeology. The tectonic history and geology of the Los Angeles Basin are described in Yerkes and others (1965) and Wright (1991).

In recent years, sequence stratigraphy has been used by investigators to better understand and describe the hydrogeologic framework of the Los Angeles Basin. Ponti and others (2007) used sequence stratigraphy to develop a chronostratigraphic framework for the Long Beach area. Ehman and others (2014) constructed a series of cross sections from seismic-reflection lines and well logs to expand the sequences first described by Ponti and others (2007) from the Long Beach area into the Central Basin. The chronostratigraphic framework developed for the Long Beach area was utilized by Ponti and others (2014) to characterize potential transport pathways and implications for groundwater management near Santa Fe Springs (not shown) in the Central Basin.

Several studies utilizing groundwater-simulation models to help evaluate regional management strategies have been completed by the USGS in cooperation with WRD. A regional assessment of the hydrogeology and geochemistry, and the development of a groundwater-flow model of the Central and West Coast Basins, was provided by Reichard and others (2003). This regional groundwater-flow model was used by Reichard and Johnson (2005) to assess regional management strategies in the LACP. Nishikawa and others (2009) developed a cross-sectional solute-transport model to evaluate the stratigraphic controls on seawater intrusion in the Long Beach area. Reichard and others (2010) used the regional groundwater-flow model (Reichard and others, 2003) to evaluate the emergency use of groundwater as a backup supply.

In addition to groundwater-flow modeling reports completed by the USGS, multiple modeling studies have been completed by consultants for WRD and other agencies in the LACP. Kennedy/Jenks/Todd, LLC and Lawrence Berkeley National Laboratory (2008) completed a study in the Montebello Forebay to evaluate the fate and transport of recycled water from water reclamation plants in the Whittier Narrows (fig. A1). AMEC Geomatrix (2009) described the development of a groundwater-flow and chemical-transport model for the West Coast Basin Barrier Project. Intera developed a groundwater-flow and transport model for the Dominguez Gap Barrier Project (Intera, 2011) and the Alamitos Barrier Project (Intera, 2010).

Other studies that were joint efforts of Federal, State and local water agencies include a report compiling geologic, hydrologic, and water-quality data in the Central and West Coast Basins (Land and others, 2002), a water augmentation study on storm-water infiltration in the greater Los Angeles area (Los Angeles and San Gabriel Rivers Watershed Council, 2010), and USGS reports assessing the status of groundwater quality of the coastal Los Angeles Basin (Mathany and others, 2008; Goldrath and others, 2012) as part of the Groundwater Ambient Monitoring and Assessment (GAMA) program.

\section{Data Compilation}

A major component of this study was the compilation of hydrogeologic data collected by multiple agencies in the LACP into a geographic information system (GIS). The GIS is a spatially relational database that serves as a tool for combining data and geographic features from a variety of sources. The GIS used for this study was originally developed by Reichard and others (2003). The major sources of data compiled in the GIS are the USGS, WRD, Orange County Water District (OCWD), Los Angeles Department of Water and Power (LADWP), City of Santa Monica, City of Beverly Hills, Los Angeles County Department of Public Works (LACDPW), Los Angeles County Flood Control District (LACFCD), San Gabriel River Water Master (SGRWM), California Department of Water Resources (CDWR), and California Geologic Energy Management Division (CalGEM). Data compiled in the GIS can be categorized into the following groups: (1) well-construction data, (2) geologic and geophysical logs, (3) groundwater recharge and discharge data, and (4) water-level measurements. Data compiled for this study are primarily from the period 1971 to 2015 . 
Most of the data compiled in the GIS are from production wells with long-screened intervals. To provide depth-dependent hydrogeologic data, the USGS, in cooperation with WRD, constructed 57 multiple-well monitoring sites comprising a total of 311 wells in the Central and West Coast Basins (fig. A3). These sites consist of monitoring wells installed at different depths in the same drill hole. The monitoring wells are screened over a small interval (usually 20-40 ft) and are isolated from one another by low-permeability bentonite grout. A detailed description of a typical multiple-well monitoring site is presented in Land and others (2002). Detailed hydrologic and water-quality data have been collected from wells composing these sites. Water-quality data collected for this study can be retrieved from the USGS National Water Information System (NWIS; U.S. Geological Survey, 2016). An important aspect of the drilling in recent years has been application of continuous coring techniques. Cores provided a direct observation of lithology and stratigraphy and were used to interpret the geophysical logs. Data collected from multiple-well monitoring sites constructed by the OCWD along the eastern edge of the LACP have also been incorporated into the GIS (fig. A3). Data collected from the multiple-well monitoring sites were used to help develop the hydrogeologic-framework model for this study, as described in Chapter B of this report. Water-level and water-quality data collected from these sites were used to construct and calibrate the groundwater-flow model described in Chapter D of this report.

\section{Well-Construction Data}

Well-construction data are basic information required to assign water-level, pumping, and other data collected from wells to specific areas and aquifers in the LACP groundwater basins. Information gathered includes well identification, common name, owner, spatial coordinates, depth and perforation interval, well use, and status (whether the well is active, abandoned, destroyed, and so forth). These data were downloaded from the USGS NWIS and other data repositories or archives of five local agencies-WRD, OCWD, Los Angeles County, City of Santa Monica, and City of Beverly Hills - and then imported and merged into the project GIS. The updated GIS includes about 9,250 wells; however, only 1,940 of the wells stored in the database were used in this study after reviewing the location, active period, and the quality of well data (1,466 pumping wells, 301 injection wells, and 173 monitoring sites). The monitoring sites are wells with water-level observation data. Most wells that were inactive during the entire model period (1971-2015) or lacked construction information were excluded from the project GIS.

\section{Geologic and Geophysical Logs}

Geologic and geophysical logs from the WRD/USGS multiple-well monitoring sites were used to determine the grain size of the formations penetrated at each site (appendix 2). Grain size was used to estimate the hydraulic conductivity, as described in Chapter C. Geophysical logs used to estimate formation grain size include nuclear magnetic resonance (NMR), resistivity, induction, and gamma ray. Nuclear magnetic resonance tools provide porosity estimates, which correlate with grain size (Coates and others, 1999). Resistivity and induction tools were used to provide estimates of the electrical properties of the formation and formation fluid. For the saturated deposits in the LACP, a high resistivity on the logs was interpreted as coarse-grained deposits that contain water with low concentrations of dissolved solids; low resistivity was interpreted as either groundwater of high salinity or fine-grained deposits, or both. Gamma-ray tools provide information about the mineralogy of the formation (Schlumberger Limited, 1972). Gamma-ray emissions are typically higher in clays than gravels but can also be high in feldspar-rich sand and gravel.

\section{Groundwater Recharge and Discharge Data}

Groundwater recharge and discharge data were used to estimate the hydrologic budget of groundwater basin(s) or subarea(s). Data gathered for this report include injection into and pumpage from wells and managed aquifer recharge in spreading grounds. Estimated groundwater underflows from or to the neighboring groundwater basins and offshore areas were also obtained.

Pumpage records were collected and compiled for all pumping wells that produced groundwater from 1971 through 2015. Pumping data for wells within the WRD boundary were downloaded from the WRD database. Pre-2007 pumping data for wells in the Santa Monica Basin and the Orange County Basin were obtained directly from the City of Santa Monica and OCWD, respectively; 2007 through 2015 pumping data from the City of Santa Monica and OCWD were obtained through the WRD. Pumping data for wells in the Hollywood Basin were obtained from the City of Beverly Hills through the WRD.

Injection data were available as estimated flow rates per injection well and as monthly totals per injection barrier. The LACFCD measures the injection rate of each well periodically, and WRD records the total amount of injection water being delivered to each of the three barrier projects (fig. A1) monthly. Injection data for the West Coast Basin Barrier Project (WCBBP), Dominguez Gap Barrier Project (DGBP), and Alamitos Barrier Project (ABP) were acquired from LACFCD through WRD. Surface-recharge data for spreading facilities (fig. A1) at the San Gabriel River spreading grounds (SGRSG), Rio Hondo spreading grounds (RHSG), and Whittier Narrows Dam (WND) were also acquired from LACFCD through the WRD. 


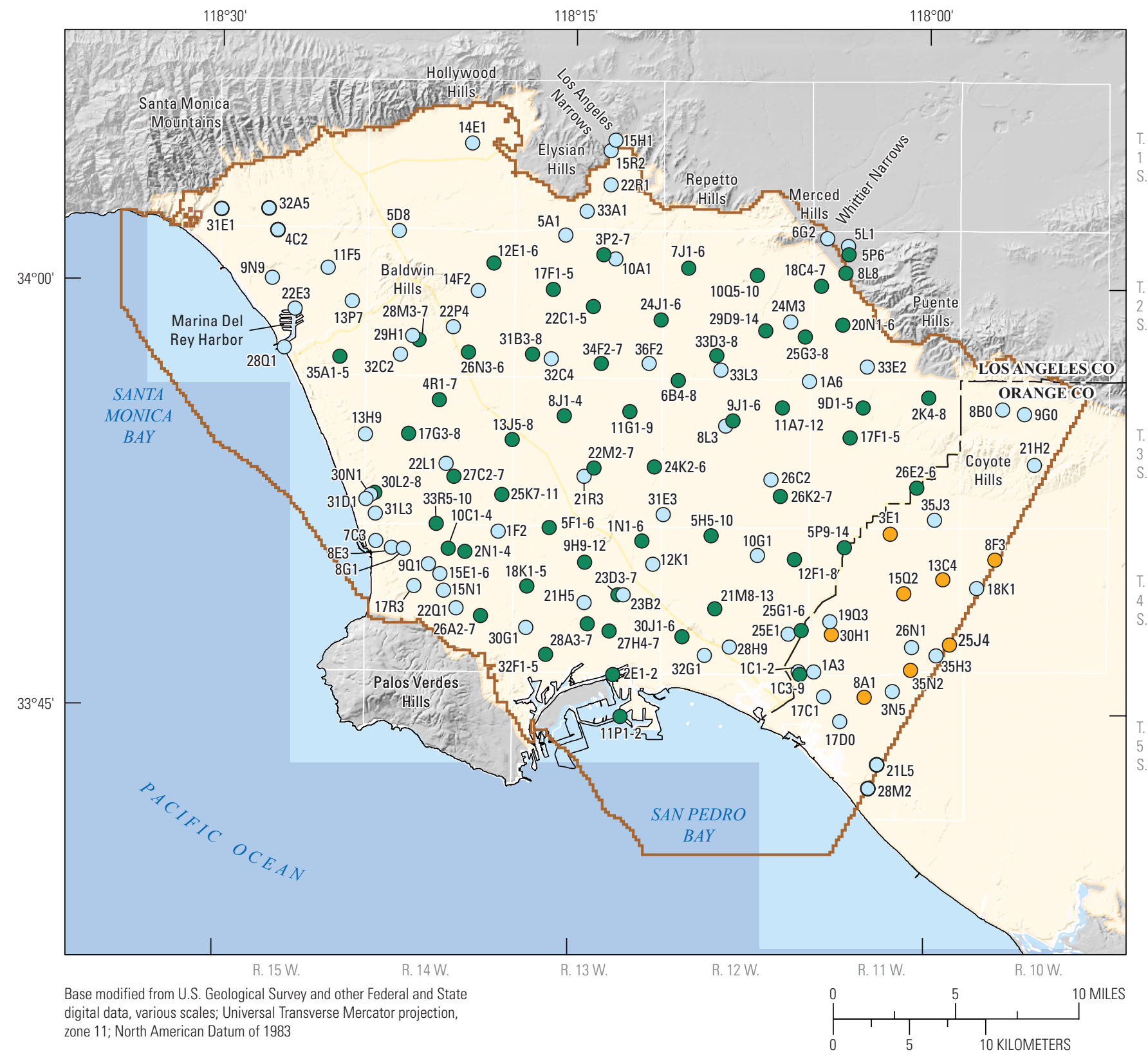

EXPLANATION

California Department of Water Resources Bulletin 118 groundwater basin

Los Angeles Coastal Plain boundary
Well type

$8 \mathrm{~A} 1 \bigcirc$ Orange County Water District multiple-completion well monitoring site and identifier

1C3-9 Water Replenishment District and U.S. Geological Survey multiple-completion well and identifier

$28 \mathrm{H} 9 \bigcirc$ Long-screened monitoring well and identifier

Figure A3. Monitoring wells in Los Angeles and Orange Counties, California, used to develop a groundwater-simulation model in the Los Angeles Coastal Plain. 
Underflow estimates were collected and compiled from different sources. Seasonal underflow across Whittier Narrows from the San Gabriel Valley was estimated using water levels from the SGRWM. These estimates were also acquired through the WRD. Field data to estimate underflow across the Los Angeles Narrows from the San Fernando Valley were not available; modeling estimates of average underflow were obtained from the previous regional groundwater-flow model (Reichard and others, 2003). Estimates of onshore or offshore flows, as well as potential flows across the Orange County boundary, were also obtained from the groundwater-flow model by Reichard and others (2003).

\section{Water-Level Measurements}

Water levels are key indicators of groundwater conditions, including groundwater basin storage. Three types of water-level data were compiled and collected for this study: water-level contour maps; high-frequency measurements from short-screened wells composing multiple-well monitoring sites; and periodic measurements from long-screened observation or production wells (fig. A3).
Historical water-level contour maps of the Los Angeles Basin were digitized from available paper copies of the maps. More recent water-level contours were constructed using water levels from composite aquifers that were acquired from WRD and OCWD. Water-level measurements from multiple-well monitoring sites were provided by WRD and OCWD. Multiple-well monitoring sites provide depth-dependent or aquifer-dependent data that are the cornerstone of this study. Water-level data collected from long-screened monitoring and production wells were used to augment the data collected in areas where multiple-well monitoring sites are not present (Santa Monica and Hollywood Basins) and for the time period prior to the construction of the multiple-well monitoring sites.

Time-series of water-level data from long-screened observation or production wells were acquired from the Cities of Santa Monica and Beverly Hills in addition to the WRD and OCWD (fig. A3). Water-level data for wells within the WRD boundary and at the north end of the Central Basin were downloaded from the WRD database (Water Replenishment District of Southern California, 2018). Pre-2007 water-level data for wells in the Santa Monica Basin and the Orange County Basin were obtained directly from the City of Santa Monica and OCWD, respectively; 2007 through 2015 water-level data were obtained from the City of Santa Monica and OCWD through WRD. 


\section{References Cited}

AMEC Geomatrix, 2009, Groundwater flow and transport model development: Los Angeles, Calif., West Coast Basin Barrier Project, 15 p.

California Department of Water Resources, 1961, Planned utilization of the ground water basins of the coastal plain of Los Angeles County, Appendix A, Ground water geology: California Department of Water Resources Bulletin 104, 191 p., http://wdl.water.ca.gov/waterdatalibrary/docs/ historic/Bulletins/Bulletin_104/Bulletin_104-A_1961.pdf.

California Department of Water Resources, 1962, Planned utilization of the ground water basins of the coastal plain of Los Angeles County, Appendix B, Safe yield determinations: California Department of Water Resources Bulletin 104, 129 p.

California Department of Water Resources, 1966, Planned utilization of ground water basins of the coastal plain of Los Angeles County: State of California Bulletin 104-2, 25 p.

California Department of Water Resources, 1975, California's ground water: California Department of Water Resources Bulletin 118, 135 p., https://water.ca.gov/LegacyFiles/pubs/ groundwater/bulletin_118/california's_ground_water bulletin_118-75/b118-1975.pdf.

Coates, G.R., Xiao, L., and Prammer, M.G., 1999, NMR logging principles and applications: Halliburton Energy Services, accessed May 21, 2018, at https://www.halliburton.com/public/lp/contents/Books and_Catalogs/web/NMR-Logging-Principles-andApplications.pdf.

Ehman, K.D., Edwards, B.D., and Ponti, D.J., 2014, Sequence stratigraphic framework of upper Pliocene to Holocene sediments of the Los Angeles Basin, CaliforniaImplications for aquifer architecture: Pacific Section, SEPM, Society for Sedimentary Geology, 49 p.

Goldrath, D.A., Fram, M.S., Land, M., and Belitz, K., 2012, Status of groundwater quality in the Coastal Los Angeles Basin, 2006-California GAMA Priority Basin Project: U.S. Geological Survey Scientific Investigations Report 2012-5048, 64 p., https://doi.org/10.3133/sir20125048.

Hevesi, J.A., and Johnson, T.D., 2016, Estimating spatially and temporally varying recharge and runoff from precipitation and urban irrigation in the Los Angeles Basin, California: U.S. Geological Survey Scientific Investigations Report 2016-5068, 192 p., https://doi.org/10.3133/sir20165068.

Intera, 2010, Alamitos Barrier Model, Task 7 Final Draft Report: Albuquerque, N. Mex. 146 p.
Intera, 2011, Technical memorandum, Dominguez Gap Barrier Model Calibration Updates: Albuquerque, N. Mex., 78 p.

Kennedy/Jenks/Todd, LLC, and Lawrence Berkeley National Laboratory (LBNL), 2008, Final Project Report, Montebello Forebay attenuation and dilution studies: Whittier, Calif., County Sanitation Districts of Los Angeles County, 43 p.

Land, M., Everett, R.R., and Crawford, S.M., 2002, Geologic, hydrologic, and water-quality data from multiple-well monitoring sites in the Central and West Coast Basins, Los Angeles County, California, 1995-2000: U.S. Geological Survey Open-File Report 2001-277, 178 p., https://doi.org/10.3133/ofr01277.

Los Angeles and San Gabriel Rivers Watershed Council, 2010, Water augmentation study - Research, strategy, and implementation report: Pasadena, California, Los Angeles and San Gabriel Rivers Watershed Council, 75 p.

Mathany, T.M., Land, M., and Belitz, K., 2008, Ground-water quality data in the coastal Los Angeles Basin Study Unit, 2006-Results from the California GAMA Program: U.S. Geological Survey Data Series 387, 98 p., https://doi.org/10.3133/ds387.

Mendenhall, W.C., 1905a, Development of underground waters in the eastern coastal-plain region of Southern California: U.S. Geological Survey Water-Supply Paper 137, 140 p., https://doi.org/10.3133/wsp137.

Mendenhall, W.C., 1905b, Development of underground waters in the central coastal-plain region of Southern California: U.S. Geological Survey Water-Supply Paper 138, 162 p., https://doi.org/10.3133/wsp138.

Mendenhall, W.C., 1905c, Development of underground waters in the western coastal-plain region of Southern California: U.S. Geological Survey Water-Supply Paper 139, 105 p., https://doi.org/10.3133/wsp139.

Nishikawa, T., Siade, A.J., Reichard, E.G., Ponti, D.J., Canales, A.G., and Johnson, T.A., 2009, Stratigraphic controls on seawater intrusion and implications for groundwater management, Dominguez Gap area of Los Angeles, California, USA: Hydrogeology Journal, v. 17, no. 7, p. 1699-1725, https://doi.org/10.1007/s10040-009-0481-8.

Piper, A.M., and Garrett, A.A., 1953, Native and contaminated ground waters in the Long Beach-Santa Ana area, California: U.S. Geological Survey Water Supply Paper 1136, 320 p., https://doi.org/10.3133/wsp1136.

Poland, J.F., Garrett, A.A., and Sinnott, A., 1959, Geology, hydrology, and chemical character of ground waters in the Torrance-Santa Monica area, California: U.S. Geological Survey Water- Supply Paper 1461, 425 p., https://doi.org/10.3133/wsp1461. 
Poland, J.F., and Piper, A.M., 1956, Ground-water geology of the coastal zone, Long Beach-Santa Ana area, California: U.S. Geological Survey Water-Supply Paper 1109, 162 p., https://doi.org/10.3133/wsp1109.

Ponti, D.J., Ehman, K.D., Edwards, B.D., Tinsley, J.C., III, Hildenbrand, T., Hillhouse, J.W., Hanson, R.T., McDougall, K., Powell, C.L., II, Wan, E., Land, M., Mahan, S., and Sarna-Wojcicki, A.M., 2007, A 3-dimensional model of water-bearing sequences in the Dominguez Gap region, Long Beach, California: U.S. Geological Survey Open-File Report 2007-1013, 34 p., https://doi.org/10.3133/ofr20071013.

Ponti, D.J., Wagner, B.J., Land, M., and Landon, M.K., 2014, Characterization of potential transport pathways and implications for groundwater management near an anticline in the Central Basin area, Los Angeles County, California: U.S. Geological Survey Open-File Report 2014-1087, 75 p., https://doi.org/10.3133/ofr20141087.

Reichard, E.G., and Johnson, T.A., 2005, Assessment of regional management strategies for controlling seawater intrusion: Journal of Water Resources Planning and Management, v. 131, no. 4, p. 280-291, https://doi.org/ 10.1061/(ASCE)0733-9496(2005)131:4(280).

Reichard, E.G., Land, M., Crawford, S.M., Johnson, T.D., Everett, R.R., Kulshan, T.V., Ponti, D.J., Halford, K.L., Johnson, T.A., Paybins, K.S., and Nishikawa, T., 2003, Geohydrology, geochemistry, and ground-water simulation-optimization of the Central and West Coast Basins, Los Angeles County, California: U.S. Geological Survey Water-Resources Investigations Report 2003-4065, 196 p., https://doi.org/10.3133/wri034065.

Reichard, E.G., Li, Z., and Hermans, C., 2010, Emergency use of groundwater as backup supply - Quantifying hydraulic impacts and economic benefits: Water Resources Research, v. 46, no. 9, https://doi.org/10.1029/2009WR008208.
Schlumberger Limited, 1972, Log interpretation, volume IPrinciples: New York, Schlumberger, 113 p.

Southern California Area of Governments, 2005, Los Angeles County land use. Digital polygon set.

U.S. Census Bureau, 2010, TIGER/Line with Selected Demographic and Economic Data: U.S. Census Bureau digital data, accessed on June 2018 at https:/www.census.gov/geographies/mapping-files/2010/ geo/tiger-data.html.

U.S. Geological Survey, 2016, National Water Information System data available on the World Wide Web (USGS Water Data for the Nation), accessed 2016, at URL [http://waterdata.usgs.gov/nwis/], https://doi.org/10.5066/F7P55KJN.

Water Replenishment District of Southern California, 2018, Regional groundwater monitoring report water year 2016-2017, Central and West Coast Basins: Los Angeles County, Calif., Water Replenishment District of Southern California 210 p., https://www.wrd.org/sites/pr/files/ 2017\%20RGWMR\%20Final\%20for\%20Web.pdf.

Wright, T.L., 1991, Structural geology and tectonic evolution of the Los Angeles Basin, California, chap. 3 of Biddle, K.T., ed., Active margin basins: American Association of Petroleum Geologists Memoir 52, p. 35-79, https://doi.org/10.1306/M52531C3.

Yerkes, R.F., McCulloh, T.H., Schoellhamer, J.E., and Vedder, J.G., 1965, Geology of the Los Angeles Basin, California-An introduction: U.S. Geological Survey Professional Paper 420-A, 57 p., https://doi.org/10.3133/pp420A. 


\title{
Chapter B. Development of a Chronostratigraphic Hydrogeologic Framework Model
}

\author{
By Daniel Ponti and Peter Martin
}

Reevaluation of the stratigraphy and geologic structure of the Los Angeles Coastal Plain (LACP) to better understand and refine its hydrogeologic framework was a large component of this study (fig. B1). This reevaluation involved applying the concepts of sequence stratigraphy to interpret available surface and subsurface information and develop a chronostratigraphic (time-based) framework model for the water-bearing sediments of the LACP. Previous investigators (Poland and Piper, 1956; Poland and others, 1959; California Department of Water Resources, 1961) utilized the lithostratigraphic approach, subdividing sedimentary deposits based on their physical characteristics. The sequence-stratigraphic approach used in this study is a useful alternative to the lithostratigraphic approach because the sequence-stratigraphic approach can produce a more realistic representation of geologic structure, distribution of lithologic facies, and aquifer architecture.

Sequence stratigraphy subdivides and links sedimentary deposits into unconformity-bound chronostratigraphic units that represent cycles of deposition that are controlled by variations in base level (sea level), sediment supply, and available accommodation space (Van Wagoner and others, 1990; Catuneanu, 2006). Within depositional sequences, facies and lithologic properties can change both laterally and vertically. These changes result from depositional processes that are mappable and predictable, thus the lateral distribution of coarse-grained aquifers and their fine-grained confining aquitards can be more readily understood and predicted. Sequences are defined by their bounding discontinuities. Within the LACP, the identified sequences are bounded on top and on the bottom by regionally unconformable surfaces, upon which there appears to be evidence for erosion or a depositional hiatus. While the sequence-bounding unconformities are not strictly surfaces of the same age (isochronous surfaces), they are important because sediment deposited above an unconformity is younger than sediment that underlies that unconformity. Thus, sequence-bounding unconformities separate sediments that are deposited within discrete time intervals.

In the LACP, the geologic sequences of Quaternary age generally formed in response to sea-level changes resulting from worldwide glaciation cycles (Imbrie and others, 1984). Most sediment accumulation likely occurred during interglacial periods when sea levels rose and coastlines prograded across the shelf. During glacial periods when sea levels were low, erosion on the exposed shelf occurred and thus produced the bounding unconformities. The sequences and their boundaries can be identified by characteristic cycles of coarsening- or fining-upward bed sets that reflect sediment progradation and retrogradation, respectively. These cycles are often recognized and correlated as characteristic vertical patterns in geophysical and lithologic logs. Evidence for bed truncation and onlap at sequence boundaries also can be observed in seismic-reflection profiles. In this study, a combination of borehole logs and seismic data were used for sequence identification and correlation. Water-level hydrographs and water-quality data collected from monitoring wells composing multiple-well monitoring sites were used to help constrain the identification of sequences.

The sequence-stratigraphy approach used in this study provides a robust framework for defining geologic structure, hydraulic properties, and aquifer connectivity. For example, within a given sequence, coarse-grained deposits that may serve as productive aquifers might transition toward the coastline from river channel sands and gravels, to coastal dunes and tidal-channel sands, and then to intertidal and neritic-marine sands. Within each sequence, the depositional processes result in layers of heterogeneous sediments. In general, the sediments are anisotropic, with the horizontal hydraulic conductivity of the sediments being greater than the vertical hydraulic conductivity. The primary cause of anisotropy on a small scale is the orientation of clay minerals in the sediments (Freeze and Cherry, 1979). The horizontal to vertical anisotropy in core samples of clays and shales seldom are greater than 10:1 and are usually less than $3: 1$ (Freeze and Cherry, 1979). However, on a larger field scale, it is not uncommon for layered heterogeneity to lead to regional anisotropy values on the order of 100:1 or larger (Freeze and Cherry, 1979). Because of the anisotropy in the layered sediments, groundwater preferentially flows within the sequence, limiting flow to overlying or underlying sequences. However, flow between sequences may not be as limited if vertical hydraulic gradients are high, or where coarse-grained deposits are juxtaposed across a sequence boundary or laterally because of incision, onlap, or faulting. 


\section{Previous Work and Formal Stratigraphic Nomenclature}

Sediments that record the evolution of the LACP have been extensively mapped and studied since the late 1800 s, culminating in a formal lithostratigraphic framework in the mid-20th century. The formal stratigraphic nomenclature for Pleistocene-age deposits (which contain most of the producing aquifers) was developed from work on the Palos Verdes Hills (fig. B2) by Woodring and others (1946), who recognized three formations of marine origin (the Lomita Marl, Timms Point Silt, and San Pedro Sand), unconformably overlain by a series of marine-terrace deposits, the youngest of which was named the Palos Verdes Sand. The angular unconformity separating the marine and non-marine units in the Palos Verdes Hills was attributed to a mid-Pleistocene orogenic event (Pasadenian orogeny $^{1}$ ), and the marine and non-marine units were assigned by the authors to the lower and upper Pleistocene subepochs, respectively. This framework and nomenclature were first extended into the subsurface of the western coastal plain area in two groundwater geology investigations by Poland and Piper (1956) and Poland and others (1959). The various Pleistocene marine formations recognized on the Palos Verdes Hills could not be readily distinguished in the subsurface. Therefore, the Lomita Marl, Timms Point Silt, and San Pedro Sand of Woodring and others (1946) were combined into the marine San Pedro Formation. In addition, the upper Pleistocene marine-terrace deposits and the Palos Verdes Sand were included with paralic deposits (interfingered marine and continental deposits) and non-marine deposits identified in the subsurface and called the "upper Pleistocene." This subsurface framework was then extended into the Central Basin (fig. B2) by the California Department of Water Resources (1961). The California Department of Water Resources retained the term "San Pedro Formation" to represent the shallow marine deposits of Pleistocene age, but reassigned the unnamed upper Pleistocene of Poland and Piper (1956) and Poland and others (1959) to the informally named Lakewood Formation.

In the Puente Hills and Coyote Hills area (fig. B2), Durham and Yerkes (1964) and Yerkes (1972) defined three Pleistocene-age formations separated by unconformities. In succession from youngest to oldest, these formations are (1) the early Pleistocene San Pedro Formation of shallow-water marine origin, which was correlated to the subsurface San Pedro Formation of Poland and Piper (1956) and Poland and others (1959); (2) the early late-Pleistocene Coyote Hills Formation, consisting of intertidal and non-marine sediment, correlated to the lower part of the

\footnotetext{
${ }^{1}$ Although classically defined as mid-Pleistocene diastrophism (American Geological Institute, 1957), the term Pasadenian orogeny has subsequently been understood to be deformation and uplift within southern California resulting from north-south shortening that began in the early Pleistocene and continues to the present day (Nagle and Parker, 1971; Yeats, 1983; Namson, 1987). Our work shows that the unconformity separating marine and nonmarine deposits within the LACP varies in age depending on location.
}

unnamed upper Pleistocene of Poland and Piper (1956) and Poland and others (1959); and (3) the late-Pleistocene La Habra Formation, a non-marine unit correlated to the upper part of the unnamed upper Pleistocene and the marine-terrace deposits on the Palos Verdes Hills.

More recent paleontological work in the Coyote Hills (fig. B2) by Powell and Stevens (2000) indicated that the San Pedro Formation in the Coyote Hills is substantial older than the San Pedro Sand in the Palos Verdes Peninsula (and by analogy, much of the subsurface San Pedro Formation). Ponti and others (2014) used seismic-reflection data to infer that the La Habra and Coyote Hills Formations are likely older than most of the upper Pleistocene deposits in the subsurface (unnamed upper Pleistocene or Lakewood Formation) as well.

In the Puente Hills area (fig. B2), Durham and Yerkes (1964) and Yerkes (1972) mapped younger alluvial fan deposits that overlie the La Habra and older Pleistocene formations. These are informally named old (Pleistocene) and young (Holocene) alluvium. More recent surficial mapping (Saucedo and others, 2003; Morton and Miller, 2006; Campbell and others, 2014) has further subdivided the surficial deposits of the LACP by relative age (based on topographic position, degree of dissection, and soil formation), depositional environment (alluvial fan, flood basin, channel, or eolian deposits), and average grain size, but still retained informal names. These deposits comprise the surface of nearly the entire LACP and are derived from the San Gabriel, Rio Hondo, Los Angeles, and Santa Ana River drainages, as well as from local drainages that have their headwaters in the Puente Hills, Santa Monica Mountains, Palos Verdes Hills, and the low hills along the Newport-Inglewood fault zone (fig. B2).

The hydrostratigraphic subsurface framework developed for the area of the LACP by California Department of Water Resources (1961) gives names to zones of sands and gravels, embedded within the lithostratigraphic formations, that serve as producing aquifers. Sand- and gravel-filled river channels near the base of the young Holocene deposits are primarily derived from the San Gabriel, Los Angeles, and Santa Ana Rivers, and constitute the Gaspur, Ballona, and Talbert aquifers, respectively. Pleistocene alluvial and intertidal deposits that constitute the Lakewood Formation of the California Department of Water Resources (1961) contain the Exposition, Artesia, Gardena, and Gage aquifers; permeable zones composing these aquifers probably represent coarser-grained fluvial and tidal-channel facies. The marine San Pedro Formation is inferred by the California Department of Water Resources (1961) to extend to a depth of greater than 1,000 feet (ft) and contains the Hollydale, Jefferson, Lynwood, Silverado, and Sunnyside aquifers. These aquifers likely include coastal beach, dune, nearshore-sand, and deltaic-channel deposits that tend to be more laterally homogeneous than non-marine sediment. Therefore, the Hollydale, Jefferson, Lynwood, Silverado, and Sunnyside aquifers are the aquifers most extensively exploited for public water supply. 


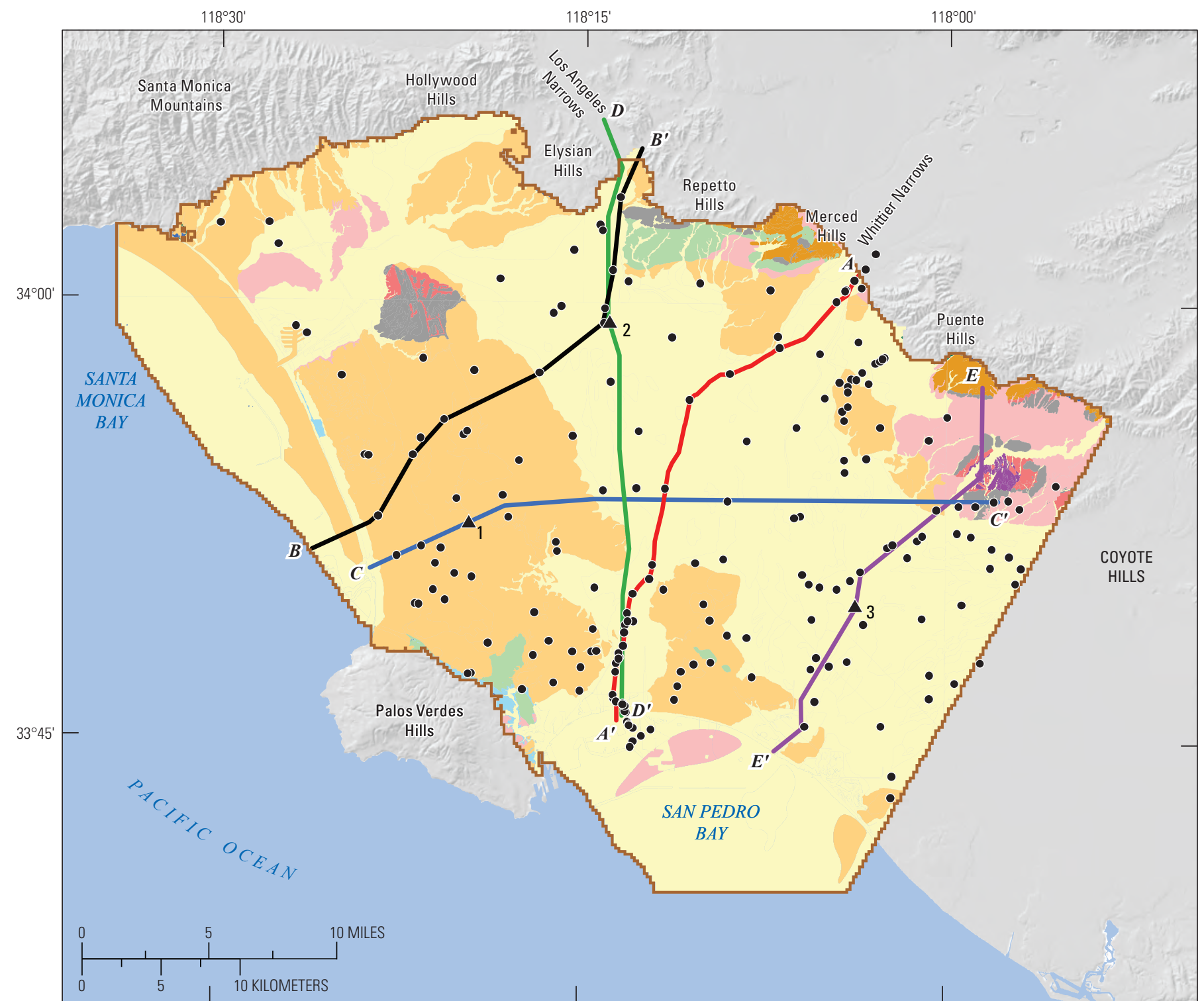

Based modified from U.S. Geological Survey and other Federal and State digital data, various scales; Universal Transverse Mercator projection, zone 11; North American Datum of 1983

Surficial chronostratigraphic units inferred from geologic mapping by Campbell and others, (2004), Morton and Miller (2006), and Saucedo and others (2003)

\section{EXPLANATION}

Chronostratigraphic units

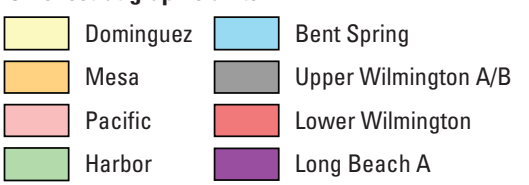

Section Lines

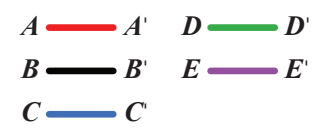

- Control well

3ـ Comparison site and identifier

$\simeq$ Los Angeles Coastal Plain boundary

Figure B1. Los Angeles Coastal Plain area and cross-section locations and surficial chronostratigraphic units inferred from geologic mapping by Saucedo and others (2003), Morton and Miller (2006), and Campbell and others (2014). Numbered triangles are comparison sites described in table B2. 


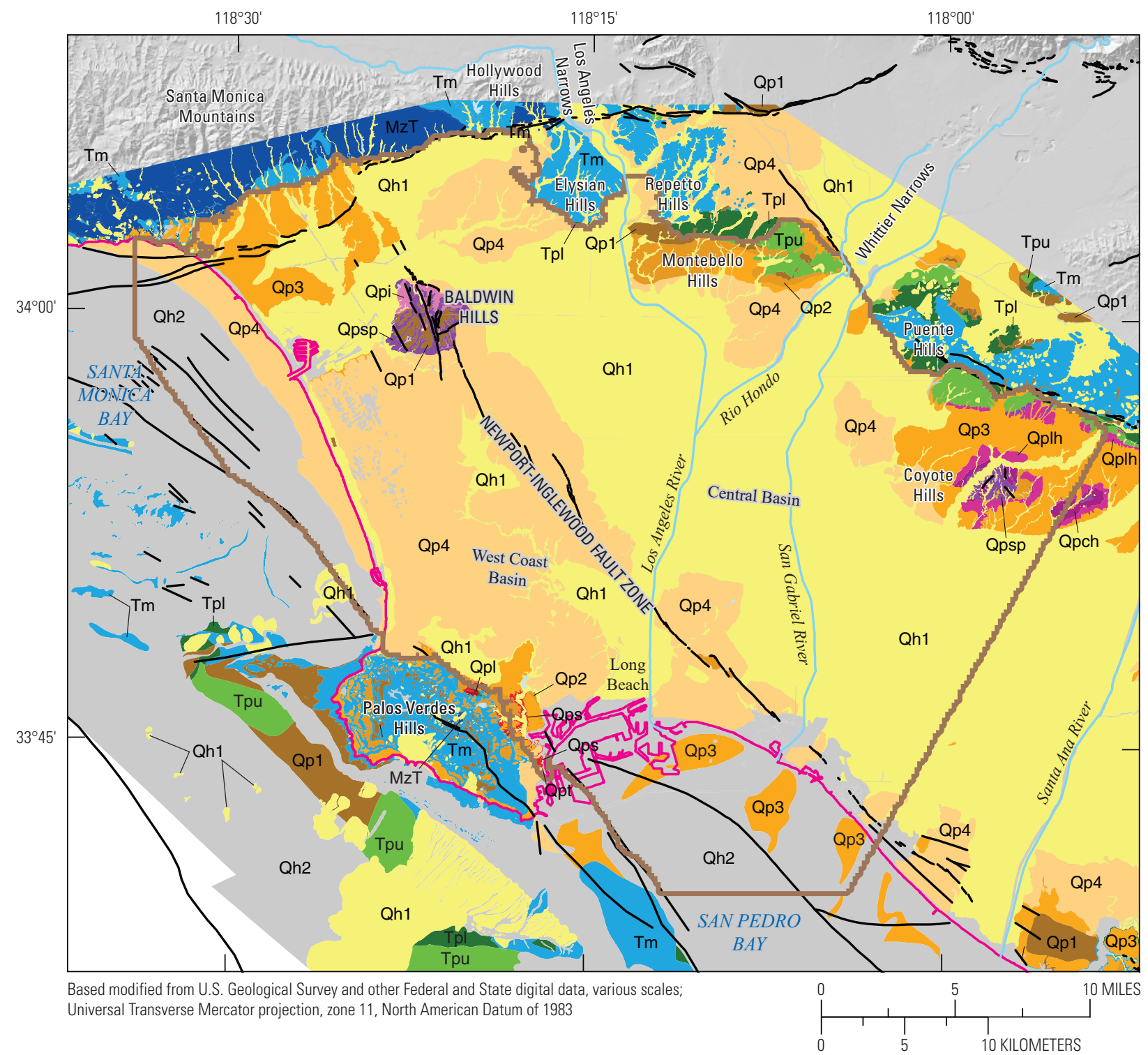

EXPLANATION
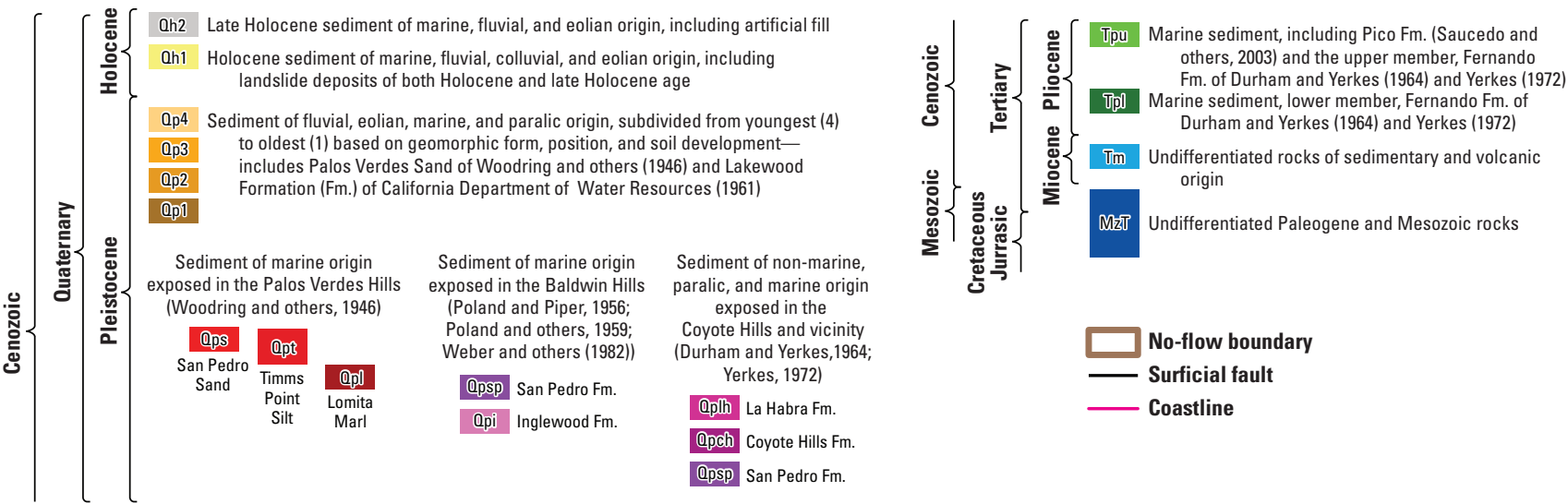

Figure B2. Surface geologic units and faults, Los Angeles Coastal Plain, California. Geology modified from compilations by Saucedo and others (2003), Morton and Miller (2006), U.S. Geological Survey and California Geological Survey (2006), and Campbell and others (2014). 


\section{Identification of Chronostratigraphic Unit Boundaries}

The chronostratigraphic framework model developed for the LACP relied on a study completed by Ponti and others (2007) in the Long Beach area (fig. B2). The Long Beach study involved detailed analyses and age dating of continuously cored boreholes to identify key unconformities that bound 10 sequences spanning the Holocene through latest Pliocene epochs (Ponti and others, 2007). Through analysis of available well and seismic data, the authors constructed a digital three-dimensional chronostratigraphic framework model of the Long Beach area.

The current study extends the Long Beach chronostratigraphic framework model to the entire LACP through compilation and analysis of (1) geologic and geophysical logs from Water Replenishment District of Southern California (WRD) and U.S. Geological Survey (USGS) multiple-well monitoring sites; (2) oil- and water-well logs from various sources; (3) medium- to high-resolution seismic-reflection data collected by the USGS (offshore); and (4) the oil industry (onshore), and surficial geology (fig. B3). This model developed for this report incorporates the 10 sequences identified in the Long Beach model, plus 3 additional chronostratigraphic units that were recognized when the model was extended through the entire LACP. These new units may simply be conformable subdivisions within the sequences originally identified in Long Beach that have distinctive hydrologic characteristics, at least at local scales. Therefore, for this report we use the term chronostratigraphic unit to represent both the 10 previously defined sequences and the 3 additional chronostratigraphic units identified for this study. The LACP model also extends to greater depth than that in the Long Beach area (approximately $-20,000 \mathrm{ft}$ elevation versus $-3,000 \mathrm{ft}$ elevation for Long Beach) to capture the base of the oldest water-bearing units within the Central Basin.

\section{Analysis of Lithologic and Geophysical Logs}

High-quality lithologic and geophysical logs from the WRD/USGS multiple-well monitoring sites were the primary data used for identifying chronostratigraphic unit boundaries within the LACP. These data were supplemented by a second set of data composed of logs from previously drilled water, geotechnical, geoenvironmental, and oil wells and boreholes. Logs from non-USGS water wells are of varying quality; drillers' logs from wells constructed using rotary-wash and cable-tool methods tend to be quite general in nature and are therefore of limited value for sequence-stratigraphic analysis. Although rare, some of these wells have accompanying geophysical logs, which are valuable for identifying finingor coarsening-upward sediment packages and bounding unconformities. A number of these wells were selected for areas where other data were lacking.
Logs derived from geotechnical and geoenvironmental wells and boreholes are of much higher quality, but they are fewer in number and more limited in depth (generally less than $200 \mathrm{ft}$ ) than water-well drillers' logs. Most logs derived from geotechnical and geoenvironmental wells and boreholes were made by geologists or engineers and were derived from examination of core samples either collected continuously or at regularly spaced intervals of $10 \mathrm{ft}$ or less. However, a few descriptions came from drill cuttings supplemented by interpretation of geophysical logs. With few exceptions, lithologies from geoenvironmental and geotechnical boreholes were classified in the field using the Unified Soil Classification System (American Society for Testing and Materials, 1985), which provides consistency when comparing data from multiple boreholes and different investigations. Many of these logs also contain constituent information (for example, color, mineralogical components, and fossils) that can be useful for identifying potential unconformities. Some of these wells and boreholes also have geophysical logs.

The third type of well logs used were from oil wells filed with the California Geologic Energy Management Division (California Department of Conservation, 2017). These wells extend to great depths (thousands of feet), but they often lack recorded data in the upper few hundred feet, and only a few logs contain data recorded in the upper 1,000 ft. Oil wells typically only have electrical resistivity and spontaneous potential logs. These geophysical logs are valuable for determining stacking patterns and general lithologic character, but geologic descriptions of the sediment are rarely available.

Several thousand logs were collected and evaluated to develop the LACP chronostratigraphic framework model. A total of 193 logs were selected from these as primary controls for the model, including logs for $57 \mathrm{WRD} / \mathrm{USGS}$ multiple-well monitoring sites (fig. B3; table B1). Nearly 500 additional well logs were checked to ensure that the shape of modeled stratigraphic surfaces were appropriately constrained, but these logs were not used to specifically identify chronostratigraphic boundaries.

Existing descriptive lithologic logs were reclassified, and a median grain size for each described geologic layer was estimated from the descriptions to facilitate interpretation and identification of key boundaries and fining- or coarsening-upward sediment packages. For lithologic logs with Unified Soil Classification System assignments, the classifications were kept as assigned and median grain sizes were estimated from the Unified Soil Classification System group and other descriptive information, as available. For water-well and other logs where lithologic descriptions were more generic and did not use a prescriptive classification system, described geologic layers were classified into a simple five-level lithologic classification scheme consisting of gravelly sediment, coarse sands, medium to fine sands, silty and clayey sands, and silts/clays. Graphic logs were then constructed to display these lithologic data along with any accompanying electric logs. 


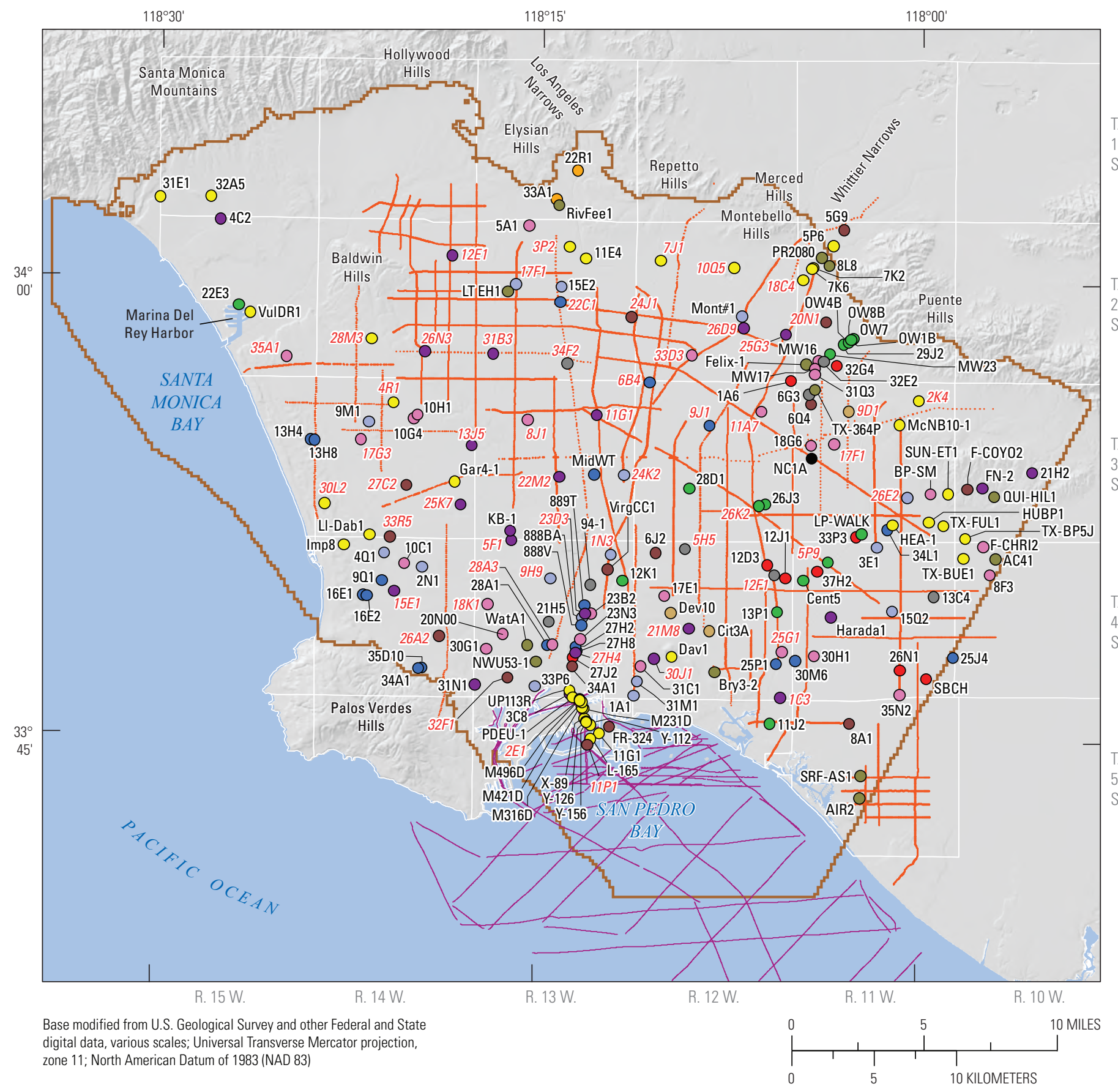

\section{EXPLANATION}

Control well and identifier-Deepest chronostratigraphic unit identified; Red label denotes a Water Replenishment District/U.S. Geological Survey multiple-well monitoring site

\begin{tabular}{|c|c|c|c|c|}
\hline $22 \mathrm{R} 1 \mathrm{O}$ & Mesa & $31 \mathrm{M} 1 \mathrm{O}$ & Upper Wilmington B & Dav1 $\bigcirc$ Long Beach C \\
\hline $37 \mathrm{H} 2 \mathrm{O}$ & Pacific & $35 \mathrm{~N} 2 \mathrm{O}$ & Lower Wilmington & AIR2 $\bigcirc$ “Repetto” \\
\hline $11 \mathrm{~J} 2 \mathrm{O}$ & Harbor & $31 \mathrm{~N} 1 \mathrm{C}$ & Long Beach A & NC1A Pre-Repetto \\
\hline 25P1 & Bent Spring & $8 \mathrm{~A} 10$ & Long Beach B & \\
\hline$x-1$ & Upper Wilmington A & Cit3A O & Long Beach BC & \\
\hline
\end{tabular}

Seismic-reflection lines and data source

- U.S. Geological Survey offshore seismic

Oil industry onshore seismic

Los Angeles Coastal Plain boundary

Oil industry shot-point

Figure B3. Location of control wells and seismic-reflection profiles used for the location of chronostratigraphic unit boundaries, Los Angeles Coastal Plain, California. Labels are well abbreviations described in table B1. Red labels are Water Replenishment District of Southern California and U.S. Geological Survey multiple-well monitoring sites. 
Table B1. Control wells used for identification of chronostratigraphic unit boundaries, Los Angeles Coastal Plain, California.

[ID, identification; NAD 83, North American Datum of 1983; UTM, Universal Transverse Mercator; NAVD 88, North American Vertical Datum of 1988; N/A, not assigned]

\begin{tabular}{|c|c|c|c|c|c|c|c|}
\hline $\begin{array}{c}\text { State well } \\
\text { number }\end{array}$ & $\begin{array}{c}\text { Well } \\
\text { abbreviation } \\
\text { (fig. B3) }\end{array}$ & Well ID & $\begin{array}{l}\text { Easting, } \\
\text { NAD 83, UTM } \\
\text { zone 11N } \\
\text { (meters) }\end{array}$ & $\begin{array}{l}\text { Northing, } \\
\text { NAD 83, UTM } \\
\text { zone 11N } \\
\text { (meters) }\end{array}$ & $\begin{array}{l}\text { Land surface } \\
\text { elevation, } \\
\text { NAVD } 88 \\
\text { (feet) }\end{array}$ & $\begin{array}{l}\text { Well depth } \\
\text { below land } \\
\text { surface } \\
\text { (feet) }\end{array}$ & $\begin{array}{c}\text { Oldest } \\
\text { chronostratigraphic } \\
\text { unit penetrated/ } \\
\text { identified }\end{array}$ \\
\hline 1S/13W-22R1 & $22 \mathrm{R} 1$ & 2773 & $386,898.95$ & $3,769,486.21$ & 278.8 & 99 & Mesa \\
\hline $1 \mathrm{~S} / 13 \mathrm{~W}-33 \mathrm{~A} 1$ & $33 \mathrm{~A} 1$ & 2765 & $385,587.97$ & $3,767,750.60$ & 260.1 & 254 & Mesa \\
\hline $1 \mathrm{~S} / 15 \mathrm{~W}-31 \mathrm{E} 1$ & $31 \mathrm{E} 1$ & 2505 & $361,567.87$ & $3,767,944.29$ & 311.9 & 283 & Long Beach C \\
\hline $1 \mathrm{~S} / 15 \mathrm{~W}-32 \mathrm{~A} 5$ & $32 \mathrm{~A} 5$ & $2535 \mathrm{~J}$ & $364,640.75$ & $3,767,965.83$ & 241.3 & 236 & Long Beach C \\
\hline $2 \mathrm{~S} / 11 \mathrm{~W}-18 \mathrm{C} 4$ & $18 \mathrm{C} 4$ & Pico Rivera1 & $400,577.65$ & $3,762,839.18$ & 182.8 & 930 & Long Beach C \\
\hline $2 \mathrm{~S} / 11 \mathrm{~W}-20 \mathrm{~N} 1$ & $20 \mathrm{~N} 1$ & Whittier2 & $401,951.21$ & $3,760,286.49$ & 168.4 & 1,402 & Long Beach B \\
\hline $2 \mathrm{~S} / 11 \mathrm{~W}-29 \mathrm{~J} 2$ & $29 J 2$ & MW24 & $402,993.50$ & $3,758,908.73$ & 162.4 & 200 & Harbor \\
\hline 2S/11W-31Q3 & 31Q3 & MW26 & $401,270.06$ & $3,757,125.16$ & 156.0 & 250 & Lower Wilmington \\
\hline 2S/11W-32E2 & $32 \mathrm{E} 2$ & MW25 & $401,814.58$ & $3,757,890.60$ & 148.3 & 230 & Upper Wilmington A \\
\hline $2 \mathrm{~S} / 11 \mathrm{~W}-32 \mathrm{G} 4$ & $32 \mathrm{G} 4$ & MW18 & $402,590.55$ & $3,757,631.05$ & 144.3 & 166 & Pacific \\
\hline 2S/11W-5G9 & $5 \mathrm{G} 9$ & $2947 \mathrm{NN}$ & $403,036.20$ & $3,765,873.27$ & 212.3 & 878 & Long Beach B \\
\hline 2S/11W-5P6 & $5 \mathrm{P} 6$ & Whittier Narrows1 & $402,382.71$ & $3,764,902.54$ & 202.2 & 860 & Long Beach C \\
\hline $2 \mathrm{~S} / 11 \mathrm{~W}-7 \mathrm{~K} 2$ & $7 \mathrm{~K} 2$ & Pico Rivera3 & $401,184.93$ & $3,763,584.07$ & 191.3 & 820 & Long Beach C \\
\hline 2S/11W-7K6 & $7 \mathrm{~K} 6$ & Pico Rivera4 & $401,101.18$ & $3,763,519.89$ & 191.8 & 900 & Long Beach C \\
\hline $2 \mathrm{~S} / 11 \mathrm{~W}-8 \mathrm{~L} 8$ & $8 \mathrm{~L} 8$ & Whittier Narrows2 & $402,151.88$ & $3,763,690.61$ & 210.9 & 760 & "Repetto" \\
\hline 2S/12W-10Q5 & 10Q5 & Montebello1 & $396,384.34$ & $3,763,596.67$ & 191.9 & 1,003 & Long Beach C \\
\hline $2 \mathrm{~S} / 12 \mathrm{~W}-25 \mathrm{G} 3$ & $25 \mathrm{G} 3$ & Pico Rivera2 & $399,536.11$ & $3,759,546.50$ & 152.4 & 1,203 & Long Beach A \\
\hline 2S/12W-26D9 & 26D9 & Rio Hondo1 & $396,958.96$ & $3,759,924.89$ & 162.6 & 1,160 & Long Beach A \\
\hline $2 \mathrm{~S} / 12 \mathrm{~W}-33 \mathrm{D} 3$ & 33D3 & Bell Gardens1 & $393,781.14$ & $3,758,284.83$ & 120.0 & 1,823 & Lower Wilmington \\
\hline 2S/12W-7J1 & $7 \mathrm{~J} 1$ & Commerce1 & $391,933.00$ & $3,764,029.98$ & 163.3 & 1,401 & Long Beach C \\
\hline 2S/13W-11E4 & $11 \mathrm{E} 4$ & $2788 \mathrm{~J}$ & $387,389.12$ & $3,764,178.00$ & 205.2 & 2,445 & Long Beach C \\
\hline $2 \mathrm{~S} / 13 \mathrm{~W}-15 \mathrm{E} 2$ & $15 \mathrm{E} 2$ & $1460 X$ & $385,898.56$ & $3,762,458.79$ & 191.4 & 1,443 & Upper Wilmington B \\
\hline 2S/13W-17F1 & $17 \mathrm{~F} 1$ & Los Angeles 1 & $383,115.85$ & $3,762,626.70$ & 176.5 & 1,389 & Upper Wilmington B \\
\hline $2 \mathrm{~S} / 13 \mathrm{~W}-22 \mathrm{C} 1$ & $22 \mathrm{C} 1$ & Huntington Park1 & $385,828.52$ & $3,761,513.98$ & 179.4 & 1,020 & Bent Spring \\
\hline $2 \mathrm{~S} / 13 \mathrm{~W}-24 \mathrm{~J} 1$ & 24J1 & Bell1 & $390,128.83$ & $3,760,612.23$ & 148.4 & 1,804 & Long Beach B \\
\hline 2S/13W-31B3 & 31B3 & Los Angeles4 & $381,752.26$ & $3,758,381.27$ & 140.7 & 1,825 & Long Beach A \\
\hline 2S/13W-34F2 & $34 \mathrm{~F} 2$ & South Gate2 & $386,239.99$ & $3,757,790.00$ & 122.0 & 2,020 & Upper Wilmington A \\
\hline $2 \mathrm{~S} / 13 \mathrm{~W}-3 \mathrm{P} 2$ & $3 \mathrm{P} 2$ & Los Angeles2 & $386,408.36$ & $3,764,888.65$ & 222.6 & 1,400 & Long Beach C \\
\hline $2 \mathrm{~S} / 13 \mathrm{~W}-5 \mathrm{~A} 1$ & $5 \mathrm{~A} 1$ & $2747 \mathrm{~A}$ & $383,936.91$ & $3,766,181.69$ & 228.3 & 462 & Lower Wilmington \\
\hline 2S/14W-12E1 & $12 \mathrm{E} 1$ & Los Angeles3 & $379,258.46$ & $3,764,352.54$ & 145.7 & 1,609 & Long Beach A \\
\hline $2 \mathrm{~S} / 14 \mathrm{~W}-26 \mathrm{~N} 3$ & $26 \mathrm{~N} 3$ & Inglewood2 & $377,617.44$ & $3,758,537.68$ & 219.5 & 882 & Long Beach A \\
\hline $2 \mathrm{~S} / 14 \mathrm{~W}-28 \mathrm{M} 3$ & $28 \mathrm{M} 3$ & Inglewood1 & $374,384.48$ & $3,759,325.81$ & 117.4 & 1,420 & Long Beach C \\
\hline $2 \mathrm{~S} / 15 \mathrm{~W}-22 \mathrm{E} 3$ & 22E3 & $1251 \mathrm{~T}$ & $366,336.77$ & $3,761,394.29$ & 12.4 & 330 & Harbor \\
\hline $2 \mathrm{~S} / 15 \mathrm{~W}-35 \mathrm{~A} 1$ & $35 \mathrm{~A} 1$ & Westchester 1 & $369,225.60$ & $3,758,249.28$ & 129.0 & 898 & Lower Wilmington \\
\hline $2 \mathrm{~S} / 15 \mathrm{~W}-4 \mathrm{C} 2$ & $4 \mathrm{C} 2$ & $2546 \mathrm{~K}$ & $365,215.84$ & $3,766,566.71$ & 155.4 & 598 & Long Beach A \\
\hline $3 \mathrm{~S} / 11 \mathrm{~W}-17 \mathrm{~F} 1$ & $17 \mathrm{~F} 1$ & Norwalk1 & $402,432.54$ & $3,752,895.55$ & 97.4 & 1,433 & Lower Wilmington \\
\hline 3S/11W-18G6 & $18 \mathrm{G} 6$ & 003S011W18G006S & $401,052.91$ & $3,752,802.00$ & 102.0 & 1,560 & Lower Wilmington \\
\hline 3S/11W-26E2 & $26 \mathrm{E} 2$ & La Mirada1 & $406,867.30$ & $3,749,634.17$ & 83.9 & 1,257 & Upper Wilmington B \\
\hline $3 \mathrm{~S} / 11 \mathrm{~W}-2 \mathrm{~K} 4$ & $2 \mathrm{~K} 4$ & Whittier1 & $407,565.05$ & $3,755,510.53$ & 215.3 & 1,298 & Long Beach C \\
\hline 3S/11W-30M6 & 30M6 & 004S011W30M006S & $400,072.17$ & $3,739,755.47$ & 14.4 & 800 & Bent Spring \\
\hline $3 \mathrm{~S} / 11 \mathrm{~W}-33 \mathrm{P} 3$ & 33P3 & $1063 \mathrm{~K}$ & $403,759.69$ & $3,747,238.59$ & 29.3 & 753 & Pacific \\
\hline
\end{tabular}


Table B1. Control wells used for identification of chronostratigraphic unit boundaries, Los Angeles Coastal Plain, California.Continued

[ID, identification; NAD 83, North American Datum of 1983; UTM, Universal Transverse Mercator; NAVD 88, North American Vertical Datum of 1988; N/A, not assigned]

\begin{tabular}{|c|c|c|c|c|c|c|c|}
\hline $\begin{array}{l}\text { State well } \\
\text { number }\end{array}$ & $\begin{array}{c}\text { Well } \\
\text { abbreviation } \\
\text { (fig. B3) }\end{array}$ & Well ID & $\begin{array}{c}\text { Easting, } \\
\text { NAD 83, UTM } \\
\text { zone 11N } \\
\text { (meters) } \\
\end{array}$ & $\begin{array}{l}\text { Northing, } \\
\text { NAD 83, UTM } \\
\text { zone 11N } \\
\text { (meters) } \\
\end{array}$ & $\begin{array}{l}\text { Land surface } \\
\text { elevation, } \\
\text { NAVD } 88 \\
\text { (feet) }\end{array}$ & $\begin{array}{l}\text { Well depth } \\
\text { below land } \\
\text { surface } \\
\text { (feet) }\end{array}$ & $\begin{array}{c}\text { Oldest } \\
\text { chronostratigraphic } \\
\text { unit penetrated/ } \\
\text { identified }\end{array}$ \\
\hline 3S/11W-34L1 & $34 \mathrm{~L} 1$ & 003S011W34L001S & $405,631.49$ & $3,747,664.38$ & 58.4 & 1,430 & Bent Spring \\
\hline 3S/11W-6G3 & $6 \mathrm{G} 3$ & MW27 & $400,902.97$ & $3,755,901.78$ & 139.5 & 225 & Upper Wilmington A \\
\hline 3S/11W-6Q4 & $6 \mathrm{Q} 4$ & 003S011W06Q004S & $401,060.19$ & $3,755,307.19$ & 135.4 & 1,000 & Long Beach B \\
\hline 3S/11W-9D2 & 9D1 & Santa Fe Springs 1 & $403,298.23$ & $3,754,855.09$ & 169.4 & 1,420 & Long Beach BC \\
\hline $3 \mathrm{~S} / 12 \mathrm{~W}-11 \mathrm{~A} 7$ & $11 \mathrm{~A} 7$ & Norwalk2 & $398,041.80$ & $3,754,862.06$ & 117.4 & 1,502 & Lower Wilmington \\
\hline $3 \mathrm{~S} / 12 \mathrm{~W}-1 \mathrm{~A} 6$ & $1 \mathrm{~A} 6$ & $1615 \mathrm{P}$ & $399,814.61$ & $3,756,730.70$ & 133.4 & 216 & Pacific \\
\hline $3 \mathrm{~S} / 12 \mathrm{~W}-26 \mathrm{~J} 3$ & $26 \mathrm{~J} 3$ & Cerritos C-4 & $398,250.26$ & $3,749,223.73$ & 69.4 & 1,030 & Harbor \\
\hline $3 \mathrm{~S} / 12 \mathrm{~W}-26 \mathrm{~K} 2$ & $26 \mathrm{~K} 2$ & Cerritos 2 & $397,875.24$ & $3,749,146.92$ & 63.4 & 1,504 & Harbor \\
\hline 3S/12W-28D1 & 28D1 & $951 \mathrm{~J}$ & $393,652.80$ & $3,750,217.16$ & 68.4 & 1,150 & Harbor \\
\hline $3 \mathrm{~S} / 12 \mathrm{~W}-6 \mathrm{~B} 4$ & $6 \mathrm{~B} 4$ & South Gate1 & $391,244.46$ & $3,756,669.78$ & 103.4 & 1,493 & Bent Spring \\
\hline $3 \mathrm{~S} / 12 \mathrm{~W}-9 \mathrm{~J} 1$ & $9 \mathrm{~J} 1$ & Downey1 & $394,893.75$ & $3,754,010.90$ & 100.4 & 1,200 & Bent Spring \\
\hline 3S/13W-11G1 & 11G1 & Lynwood1 & $388,042.82$ & $3,754,652.88$ & 87.4 & 3,023 & Long Beach A \\
\hline 3S/13W-22M2 & $22 \mathrm{M} 2$ & Compton2 & $385,779.41$ & $3,750,931.72$ & 77.4 & 1,500 & Long Beach A \\
\hline $3 \mathrm{~S} / 13 \mathrm{~W}-24 \mathrm{~K} 2$ & $24 \mathrm{~K} 2$ & Compton 1 & $389,696.02$ & $3,751,020.32$ & 68.4 & 1,435 & Upper Wilmington B \\
\hline $3 \mathrm{~S} / 13 \mathrm{~W}-8 \mathrm{~J} 1$ & $8 \mathrm{~J} 1$ & Willowbrook1 & $383,849.91$ & $3,754,373.97$ & 100.4 & 1,000 & Lower Wilmington \\
\hline 3S/14W-10G4 & 10G4 & $1367 \mathrm{G}$ & $376,940.03$ & $3,754,503.08$ & 53.1 & 812 & Lower Wilmington \\
\hline $3 \mathrm{~S} / 14 \mathrm{~W}-10 \mathrm{H} 1$ & $10 \mathrm{H} 1$ & $1367 \mathrm{H}$ & $377,188.03$ & $3,754,698.29$ & 61.0 & 811 & Lower Wilmington \\
\hline $3 \mathrm{~S} / 14 \mathrm{~W}-13 \mathrm{~J} 5$ & $13 \mathrm{~J} 5$ & Gardenal & $380,457.79$ & $3,752,816.04$ & 85.0 & 1,020 & Long Beach A \\
\hline 3S/14W-17G3 & $17 \mathrm{G} 3$ & Hawthorne1 & $373,701.58$ & $3,753,211.86$ & 87.5 & 1,001 & Lower Wilmington \\
\hline $3 \mathrm{~S} / 14 \mathrm{~W}-25 \mathrm{~K} 7$ & $25 \mathrm{~K} 7$ & Gardena2 & $379,776.69$ & $3,749,225.41$ & 28.5 & 1,399 & Long Beach A \\
\hline 3S/14W-27C2 & $27 \mathrm{C} 2$ & Lawndale1 & $376,504.55$ & $3,750,417.10$ & 33.5 & 1,460 & Long Beach B \\
\hline 3S/14W-30L2 & $30 \mathrm{~L} 2$ & Manhattan Beach1 & $371,511.22$ & $3,749,352.16$ & 135.2 & 2,000 & Long Beach C \\
\hline 3S/14W-33R5 & $33 \mathrm{R} 5$ & Torrance 1 & $375,494.57$ & $3,747,319.36$ & 80.5 & 1,509 & Long Beach B \\
\hline 3S/14W-4R1 & $4 \mathrm{R} 1$ & Inglewood3 & $375,732.47$ & $3,755,421.06$ & 72.5 & 1,980 & Long Beach C \\
\hline 3S/14W-9M1 & 9M1 & $1337 \mathrm{~F}$ & $374,242.56$ & $3,754,287.94$ & 82.5 & 600 & Upper Wilmington B \\
\hline $3 \mathrm{~S} / 15 \mathrm{~W}-13 \mathrm{H} 4$ & $13 \mathrm{H} 4$ & $1308 \mathrm{H}$ & $370,682.03$ & $3,753,214.52$ & 103.5 & 555 & Bent Spring \\
\hline 3S/15W-13H8 & $13 \mathrm{H} 8$ & $1308 \mathrm{~S}$ & $370,912.28$ & $3,753,163.62$ & 102.4 & 526 & Bent Spring \\
\hline $4 \mathrm{~S} / 11 \mathrm{~W}-37 \mathrm{H} 2$ & $37 \mathrm{H} 2$ & $1035 \mathrm{H}$ & $401,407.93$ & $3,745,162.40$ & 38.4 & 822 & Pacific \\
\hline $4 \mathrm{~S} / 11 \mathrm{~W}-5 \mathrm{P} 9$ & $5 \mathrm{P} 9$ & Cerritos 1 & $402,050.21$ & $3,745,724.59$ & 42.4 & 1,221 & Harbor \\
\hline $4 \mathrm{~S} / 12 \mathrm{~W}-12 \mathrm{D} 3$ & $12 \mathrm{D} 3$ & $1005 \mathrm{D}$ & $398,379.49$ & $3,745,550.72$ & 38.4 & 626 & Pacific \\
\hline $4 \mathrm{~S} / 12 \mathrm{~W}-12 \mathrm{~F} 1$ & $12 \mathrm{~F} 1$ & Lakewood2 & $398,816.89$ & $3,744,941.75$ & 38.4 & 2,151 & Upper Wilmington A \\
\hline 4S/12W-12J1 & $12 \mathrm{~J} 1$ & $1016 \mathrm{~N}$ & $399,470.78$ & $3,744,775.73$ & 35.6 & 885 & Pacific \\
\hline 4S/12W-13P1 & $13 \mathrm{P} 1$ & $1008 \mathrm{~L}$ & $398,975.60$ & $3,742,690.33$ & 22.9 & 810 & Harbor \\
\hline $4 \mathrm{~S} / 12 \mathrm{~W}-17 \mathrm{E} 1$ & $17 \mathrm{E} 1$ & $937 \mathrm{~A}$ & $392,134.58$ & $3,743,687.69$ & 68.5 & 1,030 & Lower Wilmington \\
\hline $4 \mathrm{~S} / 12 \mathrm{~W}-21 \mathrm{M} 8$ & $21 \mathrm{M} 8$ & Long Beach6 & $393,640.60$ & $3,741,731.59$ & 36.5 & 1,550 & Long Beach A \\
\hline 4S/12W-25G1 & $25 \mathrm{G} 1$ & Long Beach1 & $399,249.81$ & $3,740,291.52$ & 11.7 & 1,498 & Lower Wilmington \\
\hline $4 \mathrm{~S} / 12 \mathrm{~W}-25 \mathrm{P} 1$ & $25 \mathrm{P} 1$ & $500 \mathrm{E}$ & $398,897.68$ & $3,739,571.19$ & 10.0 & 645 & Bent Spring \\
\hline $4 \mathrm{~S} / 12 \mathrm{~W}-30 \mathrm{~J} 1$ & $30 \mathrm{~J} 1$ & Long Beach8 & $391,479.43$ & $3,739,900.30$ & 18.5 & 1,515 & Long Beach A \\
\hline $4 \mathrm{~S} / 12 \mathrm{~W}-31 \mathrm{C} 1$ & $31 \mathrm{C} 1$ & 411 & $390,697.05$ & $3,739,409.65$ & 27.0 & 1,005 & Lower Wilmington \\
\hline 4S/12W-31M1 & $31 \mathrm{M} 1$ & $411 \mathrm{~A}$ & $390,477.15$ & $3,738,498.55$ & 36.5 & 810 & Upper Wilmington B \\
\hline
\end{tabular}


Table B1. Control wells used for identification of chronostratigraphic unit boundaries, Los Angeles Coastal Plain, California.Continued

[ID, identification; NAD 83, North American Datum of 1983; UTM, Universal Transverse Mercator; NAVD 88, North American Vertical Datum of 1988; N/A, not assigned]

\begin{tabular}{|c|c|c|c|c|c|c|c|}
\hline $\begin{array}{c}\text { State well } \\
\text { number }\end{array}$ & $\begin{array}{c}\text { Well } \\
\text { abbreviation } \\
\text { (fig. B3) }\end{array}$ & Well ID & $\begin{array}{c}\text { Easting, } \\
\text { NAD 83, UTM } \\
\text { zone 11N } \\
\text { (meters) } \\
\end{array}$ & $\begin{array}{c}\text { Northing, } \\
\text { NAD 83, UTM } \\
\text { zone 11N } \\
\text { (meters) } \\
\end{array}$ & $\begin{array}{c}\text { Land surface } \\
\text { elevation, } \\
\text { NAVD } 88 \\
\text { (feet) }\end{array}$ & $\begin{array}{l}\text { Well depth } \\
\text { below land } \\
\text { surface } \\
\text { (feet) }\end{array}$ & $\begin{array}{c}\text { Oldest } \\
\text { chronostratigraphic } \\
\text { unit penetrated/ } \\
\text { identified }\end{array}$ \\
\hline $4 \mathrm{~S} / 12 \mathrm{~W}-5 \mathrm{H} 5$ & $5 \mathrm{H} 5$ & Lakewood1 & $393,407.55$ & $3,746,519.06$ & 50.9 & 1,020 & Upper Wilmington A \\
\hline $4 \mathrm{~S} / 12 \mathrm{~W}-6 \mathrm{~J} 2$ & $6 \mathrm{~J} 2$ & $924 \mathrm{G}$ & $391,582.37$ & $3,746,296.07$ & 45.7 & 2,017 & Long Beach B \\
\hline $4 \mathrm{~S} / 13 \mathrm{~W}-12 \mathrm{~K} 1$ & $12 \mathrm{~K} 1$ & $906 \mathrm{D}$ & $389,604.89$ & $3,744,643.35$ & 90.0 & 1,285 & Harbor \\
\hline $4 \mathrm{~S} / 13 \mathrm{~W}-18 \mathrm{~K} 1$ & $18 \mathrm{~K} 1$ & Carson2 & $381,404.68$ & $3,743,223.28$ & 41.5 & 1,309 & Lower Wilmington \\
\hline $4 \mathrm{~S} / 13 \mathrm{~W}-1 \mathrm{~N} 3$ & $1 \mathrm{~N} 3$ & Long Beach2 & $388,884.05$ & $3,746,183.57$ & 40.4 & 1,118 & Upper Wilmington B \\
\hline $4 \mathrm{~S} / 13 \mathrm{~W}-21 \mathrm{H} 5$ & $21 \mathrm{H} 5$ & $868 \mathrm{H}$ & $385,116.16$ & $3,742,116.60$ & 23.5 & 721 & Upper Wilmington A \\
\hline 4S/13W-23B2 & $23 \mathrm{~B} 2$ & $888 \mathrm{~F}$ & $387,677.60$ & $3,742,646.71$ & 30.5 & 1,074 & Lower Wilmington \\
\hline 4S/13W-23D3 & 23D3 & Long Beach3 & $387,313.84$ & $3,742,640.47$ & 26.5 & 1,404 & Long Beach A \\
\hline $4 \mathrm{~S} / 13 \mathrm{~W}-23 \mathrm{~N} 3$ & $23 \mathrm{~N} 3$ & 889P & $387,035.20$ & $3,741,094.87$ & 18.5 & 1,125 & Lower Wilmington \\
\hline $4 \mathrm{~S} / 13 \mathrm{~W}-27 \mathrm{H} 2$ & $27 \mathrm{H} 2$ & $370 Z$ & $386,767.56$ & $3,740,603.31$ & 18.0 & 343 & Bent Spring \\
\hline $4 \mathrm{~S} / 13 \mathrm{~W}-27 \mathrm{H} 4$ & $27 \mathrm{H} 4$ & Long Beach7 & $386,760.65$ & $3,740,255.17$ & 17.5 & 1,412 & Long Beach A \\
\hline $4 \mathrm{~S} / 13 \mathrm{~W}-27 \mathrm{H} 8$ & $27 \mathrm{H} 8$ & $370 \mathrm{AJ}$ & $386,789.66$ & $3,740,359.07$ & 17.5 & 415 & Bent Spring \\
\hline $4 \mathrm{~S} / 13 \mathrm{~W}-27 \mathrm{~J} 2$ & $27 \mathrm{~J} 2$ & $370 \mathrm{~W}$ & $386,581.23$ & $3,739,961.20$ & 17.5 & 199 & Pacific \\
\hline $4 \mathrm{~S} / 13 \mathrm{~W}-28 \mathrm{~A} 1$ & $28 \mathrm{~A} 1$ & $859 \mathrm{C}$ & $385,028.11$ & $3,740,699.55$ & 31.0 & 445 & Bent Spring \\
\hline $4 \mathrm{~S} / 13 \mathrm{~W}-28 \mathrm{~A} 3$ & $28 \mathrm{~A} 3$ & Wilmington 1 & $385,319.61$ & $3,740,733.55$ & 41.8 & 1,038 & Lower Wilmington \\
\hline 4S/13W-30G1 & 30G1 & $310 \mathrm{C}$ & $381,341.57$ & $3,740,496.30$ & 39.4 & 682 & Lower Wilmington \\
\hline $4 \mathrm{~S} / 13 \mathrm{~W}-31 \mathrm{~N} 1$ & $31 \mathrm{~N} 1$ & $302 \mathrm{~B}$ & $380,609.23$ & $3,738,343.02$ & 44.7 & 1,050 & Long Beach A \\
\hline $4 \mathrm{~S} / 13 \mathrm{~W}-32 \mathrm{~F} 1$ & $32 \mathrm{~F} 1$ & Wilmington2 & $382,632.29$ & $3,738,743.67$ & 31.5 & 1,040 & Long Beach B \\
\hline 4S/13W-33P6 & $33 \mathrm{P} 6$ & $352 \mathrm{~F}$ & $384,275.86$ & $3,738,220.04$ & 13.8 & 453 & Upper Wilmington B \\
\hline $4 \mathrm{~S} / 13 \mathrm{~W}-34 \mathrm{~A} 1$ & $34 \mathrm{~A} 1$ & $371 \mathrm{D}$ & $386,548.81$ & $3,739,424.21$ & 14.5 & 1,050 & Long Beach B \\
\hline $4 \mathrm{~S} / 13 \mathrm{~W}-5 \mathrm{~F} 1$ & $5 \mathrm{~F} 1$ & Carson3 & $382,858.04$ & $3,747,055.63$ & 22.5 & 1,820 & Long Beach A \\
\hline 4S/13W-9H9 & $9 \mathrm{H} 9$ & Carson1 & $385,245.80$ & $3,744,781.40$ & 25.5 & 1,200 & Upper Wilmington B \\
\hline $4 \mathrm{~S} / 14 \mathrm{~W}-15 \mathrm{E} 1$ & $15 \mathrm{E} 1$ & Torrance 2 & $375,755.61$ & $3,744,020.36$ & 80.5 & 1,260 & Long Beach A \\
\hline $4 \mathrm{~S} / 14 \mathrm{~W}-16 \mathrm{E} 1$ & $16 \mathrm{E} 1$ & Sepulveda 1 & $373,852.48$ & $3,743,796.66$ & 93.4 & 702 & Upper Wilmington A \\
\hline $4 \mathrm{~S} / 14 \mathrm{~W}-16 \mathrm{E} 2$ & $16 \mathrm{E} 2$ & Sepulveda2 & $374,091.26$ & $3,743,761.23$ & 93.5 & 620 & Bent Spring \\
\hline $4 \mathrm{~S} / 14 \mathrm{~W}-26 \mathrm{~A} 2$ & $26 \mathrm{~A} 2$ & Lomita1 & $378,457.08$ & $3,741,270.15$ & 79.5 & 1,340 & Long Beach B \\
\hline $4 \mathrm{~S} / 14 \mathrm{~W}-2 \mathrm{~N} 1$ & $2 \mathrm{~N} 1$ & Madrid & $377,453.13$ & $3,745,487.40$ & 74.5 & 812 & Upper Wilmington B \\
\hline 4S/14W-34A1 & $34 \mathrm{~A} 1$ & Chandler-4 & $377,192.50$ & $3,739,314.46$ & 161.4 & 205 & Bent Spring \\
\hline $4 \mathrm{~S} / 14 \mathrm{~W}-35 \mathrm{D} 10$ & $35 \mathrm{D} 10$ & Chandler-3 & $377,421.76$ & $3,739,356.22$ & 153.4 & 402 & Bent Spring \\
\hline 4S/14W-4Q1 & 4Q1 & Mariner & $375,137.13$ & $3,746,316.71$ & 106.5 & 811 & Upper Wilmington B \\
\hline 4S/14W-9Q1 & 9Q1 & 746 & $374,999.89$ & $3,744,662.55$ & 102.5 & 557 & Bent Spring \\
\hline $4 \mathrm{~S} 13 \mathrm{~W}-10 \mathrm{C} 1$ & $10 \mathrm{C} 1$ & Columbia & $376,366.30$ & $3,745,672.25$ & 81.5 & 793 & Lower Wilmington \\
\hline $5 \mathrm{~S} / 12 \mathrm{~W}-11 \mathrm{~J} 2$ & $11 \mathrm{~J} 2$ & $504 \mathrm{~F}$ & $398,513.18$ & $3,735,919.79$ & 11.3 & 705 & Harbor \\
\hline $5 \mathrm{~S} / 12 \mathrm{~W}-1 \mathrm{C} 3$ & $1 \mathrm{C} 3$ & Seal Beach1 & $399,154.18$ & $3,737,509.73$ & 11.4 & 1,505 & Long Beach A \\
\hline $5 \mathrm{~S} / 13 \mathrm{~W}-11 \mathrm{G} 1$ & $11 \mathrm{G} 1$ & $394 \mathrm{G}$ & $388,173.71$ & $3,735,370.04$ & 13.0 & 1,882 & Long Beach C \\
\hline $5 \mathrm{~S} / 13 \mathrm{~W}-11 \mathrm{P} 1$ & $11 \mathrm{P} 1$ & Long Beach5 & $387,471.75$ & $3,734,680.73$ & 17.5 & 1,203 & Long Beach B \\
\hline $5 \mathrm{~S} / 13 \mathrm{~W}-1 \mathrm{~A} 1$ & $1 \mathrm{~A} 1$ & $412 \mathrm{~A}$ & $390,261.25$ & $3,737,646.05$ & 38.5 & 810 & Upper Wilmington B \\
\hline $5 \mathrm{~S} / 13 \mathrm{~W}-2 \mathrm{E} 1$ & $2 \mathrm{E} 1$ & Long Beach4 & $386,982.71$ & $3,737,429.04$ & 3.5 & 1,401 & Long Beach B \\
\hline $5 \mathrm{~S} / 13 \mathrm{~W}-3 \mathrm{C} 8$ & $3 \mathrm{C} 8$ & $372 \mathrm{~F}$ & $386,429.93$ & $3,737,751.66$ & -1.5 & 1,005 & Long Beach A \\
\hline N/A & $20 \mathrm{~N} 00$ & 004S013W20N000S & $382,309.55$ & $3,741,376.02$ & 42.5 & 1,005 & Lower Wilmington \\
\hline
\end{tabular}


Table B1. Control wells used for identification of chronostratigraphic unit boundaries, Los Angeles Coastal Plain, California.Continued

[ID, identification; NAD 83, North American Datum of 1983; UTM, Universal Transverse Mercator; NAVD 88, North American Vertical Datum of 1988; N/A, not assigned]

\begin{tabular}{|c|c|c|c|c|c|c|c|}
\hline $\begin{array}{l}\text { State well } \\
\text { number }\end{array}$ & $\begin{array}{c}\text { Well } \\
\text { abbreviation } \\
\text { (fig. B3) }\end{array}$ & Well ID & $\begin{array}{l}\text { Easting, } \\
\text { NAD 83, UTM } \\
\text { zone 11N } \\
\text { (meters) }\end{array}$ & $\begin{array}{l}\text { Northing, } \\
\text { NAD 83, UTM } \\
\text { zone 11N } \\
\text { (meters) }\end{array}$ & $\begin{array}{l}\text { Land surface } \\
\text { elevation, } \\
\text { NAVD } 88 \\
\text { (feet) }\end{array}$ & $\begin{array}{l}\text { Well depth } \\
\text { below land } \\
\text { surface } \\
\text { (feet) }\end{array}$ & $\begin{array}{c}\text { Oldest } \\
\text { chronostratigraphic } \\
\text { unit penetrated/ } \\
\text { identified }\end{array}$ \\
\hline N/A & $888 \mathrm{~V}$ & $888 \mathrm{~V}$ & $387,098.73$ & $3,741,925.33$ & 22.5 & 480 & Bent Spring \\
\hline N/A & 888BA & 888BA & $387,174.80$ & $3,742,390.62$ & 25.5 & 1,025 & Upper Wilmington B \\
\hline N/A & $889 \mathrm{~T}$ & $889 \mathrm{~T}$ & $387,305.93$ & $3,743,139.62$ & 27.5 & 617 & Bent Spring \\
\hline N/A & $94-1$ & Dom. Water94-1 & $387,626.82$ & $3,744,375.75$ & 39.5 & 1,013 & Upper Wilmington A \\
\hline $\mathrm{N} / \mathrm{A}$ & $\mathrm{AC} 41$ & CONT-AC41 & $412,229.34$ & $3,745,905.06$ & 125.5 & 10,539 & "Repetto" \\
\hline $\mathrm{N} / \mathrm{A}$ & AIR2 & HOC-AIR2 & $403,939.68$ & $3,731,418.52$ & 27.1 & 8,508 & "Repetto" \\
\hline N/A & AMD-8 & AMD-8 & $408,464.24$ & $3,743,618.96$ & 79.2 & 2,080 & Upper Wilmington A \\
\hline $\mathrm{N} / \mathrm{A}$ & BPM-1 & BPM-1 & $405,048.48$ & $3,746,616.75$ & 58.4 & 2,210 & Upper Wilmington B \\
\hline N/A & BPM-2 & BPM-2 & $405,943.53$ & $3,742,722.02$ & 58.4 & 2,227 & Upper Wilmington B \\
\hline $\mathrm{N} / \mathrm{A}$ & BP-SM & BP-SM & $408,282.27$ & $3,749,841.10$ & 113.6 & 1,038 & Lower Wilmington \\
\hline N/A & Bry3-2 & CalRes Bryant32 & $395,175.91$ & $3,739,067.24$ & 30.9 & 9,922 & "Repetto" \\
\hline N/A & CB-1 & CB-1 & $411,869.83$ & $3,744,926.66$ & 114.4 & 1,543 & Lower Wilmington \\
\hline N/A & Cent5 & SCW Centralia5 & $400,564.45$ & $3,744,640.71$ & 33.4 & 1,215 & Harbor \\
\hline N/A & Cit3A & Citizens $3 \mathrm{~A}$ & $394,851.66$ & $3,741,559.05$ & 21.5 & 2,360 & Long Beach BC \\
\hline N/A & Dav1 & COLV-DAV1 & $392,581.84$ & $3,739,998.78$ & 178.1 & 3,690 & Long Beach C \\
\hline $\mathrm{N} / \mathrm{A}$ & Dev10 & LB Dev 10 & $392,516.41$ & $3,742,665.49$ & 51.5 & 2,185 & Long Beach BC \\
\hline $\mathrm{N} / \mathrm{A}$ & F-CHRI2 & F-CHRI2 & $411,470.16$ & $3,746,677.18$ & 115.2 & 1,504 & Lower Wilmington \\
\hline $\mathrm{N} / \mathrm{A}$ & F-COYO2 & F-COYO2 & $410,513.77$ & $3,750,157.45$ & 273.7 & 1,517 & Long Beach B \\
\hline N/A & Felix-1 & Conoco Felix 1 & $400,736.56$ & $3,757,721.06$ & 160.9 & 11,109 & "Repetto" \\
\hline $\mathrm{N} / \mathrm{A}$ & FM-6 & FM-6 & $414,437.16$ & $3,751,123.36$ & 254.9 & 405 & Long Beach A \\
\hline $\mathrm{N} / \mathrm{A}$ & FN-2 & CHEV-FN2 & $411,450.34$ & $3,750,218.15$ & 258.9 & 743 & Long Beach A \\
\hline $\mathrm{N} / \mathrm{A}$ & FR-324 & FR-324 & $388,776.44$ & $3,735,762.03$ & 17.0 & 6,486 & Long Beach B \\
\hline $\mathrm{N} / \mathrm{A}$ & Gar4-1 & Gardena4-1 & $379,423.06$ & $3,750,619.90$ & 49.5 & 10,288 & Long Beach C \\
\hline N/A & GG-22 & GG-22 & $406,419.86$ & $3,739,181.92$ & 46.4 & 1,040 & Pacific \\
\hline $\mathrm{N} / \mathrm{A}$ & GGM-2 & GGM-2 & $406,384.37$ & $3,737,695.22$ & 45.3 & 2,057 & Lower Wilmington \\
\hline $4 \mathrm{~S} / 11 \mathrm{~W}-25 \mathrm{~J} 4$ & GGM-3 & GGM-3 & $409,651.26$ & $3,739,920.27$ & 78.1 & 2,025 & Bent Spring \\
\hline N/A & Harada1 & Vaughn Harada 1 & $402,216.09$ & $3,742,385.32$ & 40.4 & 4,823 & Long Beach A \\
\hline $\mathrm{N} / \mathrm{A}$ & HEA-1 & MOBL-HEA1 & $405,994.21$ & $3,747,973.64$ & 61.4 & 6,689 & Long Beach C \\
\hline N/A & HUBP1 & HUMB-BP1 & $408,199.05$ & $3,748,140.19$ & 80.2 & 9,564 & Long Beach C \\
\hline N/A & Imp8 & Improv.8 & $372,695.60$ & $3,746,845.14$ & 109.2 & 3,629 & Long Beach C \\
\hline N/A & KB-1 & Kim-Bell 1 & $382,788.95$ & $3,747,652.61$ & 26.5 & 8,090 & Long Beach A \\
\hline $\mathrm{N} / \mathrm{A}$ & L-165 & L-165 & $387,636.55$ & $3,735,004.66$ & 17.3 & 3,620 & Long Beach C \\
\hline $\mathrm{N} / \mathrm{A}$ & LAM-1 & LAM-1 & $401,204.52$ & $3,740,038.64$ & 22.4 & 2,211 & Lower Wilmington \\
\hline $\mathrm{N} / \mathrm{A}$ & L1-Dab1 & Lloyd-Dabney 1 & $374,261.23$ & $3,747,442.18$ & 102.5 & 6,263 & Long Beach C \\
\hline $\mathrm{N} / \mathrm{A}$ & LP-WALK & LP-WALK & $404,079.79$ & $3,747,455.52$ & 48.2 & 1,020 & Harbor \\
\hline $\mathrm{N} / \mathrm{A}$ & LT EH1 & La Tijera E.H. 1 & $382,646.80$ & $3,762,183.31$ & 181.9 & 9,763 & "Repetto" \\
\hline $\mathrm{N} / \mathrm{A}$ & M231D & M231D & $387,239.61$ & $3,736,876.29$ & 13.5 & 3,895 & Long Beach C \\
\hline N/A & M316D & M316D & $387,130.88$ & $3,736,963.19$ & 9.8 & 4,065 & Long Beach C \\
\hline $\mathrm{N} / \mathrm{A}$ & M421D & M421D & $387,120.64$ & $3,737,240.66$ & 7.5 & 6,060 & Long Beach C \\
\hline N/A & M496D & M496D & $386,976.87$ & $3,737,356.81$ & -0.8 & 2,952 & Long Beach C \\
\hline
\end{tabular}


Table B1. Control wells used for identification of chronostratigraphic unit boundaries, Los Angeles Coastal Plain, California.Continued

[ID, identification; NAD 83, North American Datum of 1983; UTM, Universal Transverse Mercator; NAVD 88, North American Vertical Datum of 1988; N/A, not assigned]

\begin{tabular}{|c|c|c|c|c|c|c|c|}
\hline $\begin{array}{l}\text { State well } \\
\text { number }\end{array}$ & $\begin{array}{c}\text { Well } \\
\text { abbreviation } \\
\text { (fig. B3) }\end{array}$ & Well ID & $\begin{array}{l}\text { Easting, } \\
\text { NAD 83, UTM } \\
\text { zone 11N } \\
\text { (meters) }\end{array}$ & $\begin{array}{l}\text { Northing, } \\
\text { NAD 83, UTM } \\
\text { zone 11N } \\
\text { (meters) }\end{array}$ & $\begin{array}{l}\text { Land surface } \\
\text { elevation, } \\
\text { NAVD } 88 \\
\text { (feet) }\end{array}$ & $\begin{array}{l}\text { Well depth } \\
\text { below land } \\
\text { surface } \\
\text { (feet) }\end{array}$ & $\begin{array}{c}\text { Oldest } \\
\text { chronostratigraphic } \\
\text { unit penetrated/ } \\
\text { identified }\end{array}$ \\
\hline $\mathrm{N} / \mathrm{A}$ & McNB10-1 & McNally B 10-1 & $406,389.37$ & $3,754,035.52$ & 212.5 & 10,000 & Long Beach C \\
\hline N/A & MidWT & Midland Water Trust & $387,876.63$ & $3,751,072.36$ & 67.4 & 875 & Bent Spring \\
\hline N/A & Mont\#1 & Montebello \#1 & $396,846.70$ & $3,760,665.88$ & 168.4 & 660 & Upper Wilmington B \\
\hline $\mathrm{N} / \mathrm{A}$ & MW16 & MW16 & $401,492.78$ & $3,757,951.13$ & 153.5 & 182 & Lower Wilmington \\
\hline N/A & MW17 & MW17 & $401,264.18$ & $3,757,463.42$ & 159.4 & 192 & Lower Wilmington \\
\hline N/A & MW23 & MW23 & $402,203.78$ & $3,758,349.18$ & 149.4 & 192 & Harbor \\
\hline N/A & $\mathrm{NC} 1 \mathrm{~A}$ & CSOC-NC1A & $401,092.75$ & $3,752,028.98$ & 93.9 & 14,971 & Pre-Repetto Rocks \\
\hline N/A & NWU53-1 & NWU53-1 & $384,362.53$ & $3,739,725.68$ & 37.1 & 3,884 & "Repetto" \\
\hline $\mathrm{N} / \mathrm{A}$ & OW1B & OW1B & $403,542.85$ & $3,759,236.76$ & 207.4 & 132 & Harbor \\
\hline $\mathrm{N} / \mathrm{A}$ & OW4B & OW4B & $403,317.04$ & $3,759,072.35$ & 185.0 & 132 & Harbor \\
\hline N/A & OW7 & OW7 & $403,600.40$ & $3,759,301.60$ & 217.9 & 92 & Harbor \\
\hline N/A & OW8B & OW8B & $403,480.04$ & $3,759,212.79$ & 201.4 & 143 & Harbor \\
\hline N/A & PDEU-1 & UP PD-EU-1 & $386,585.52$ & $3,737,556.86$ & 9.5 & 5,575 & Long Beach C \\
\hline N/A & PR2080 & Pico Rivera2080 & $401,698.39$ & $3,764,214.26$ & 192.3 & 1,030 & "Repetto" \\
\hline $\mathrm{N} / \mathrm{A}$ & QUI-HIL1 & QUIN-HIL1 & $412,148.03$ & $3,749,693.63$ & 172.0 & 12,048 & "Repetto" \\
\hline $\mathrm{N} / \mathrm{A}$ & RivFee1 & LA River Fee 1 & $385,760.12$ & $3,767,387.46$ & 266.7 & 4,618 & "Repetto" \\
\hline $\mathrm{N} / \mathrm{A}$ & $\mathrm{SBCH}$ & SCWC-SBCH & $408,016.93$ & $3,738,641.52$ & 54.2 & 600 & Pacific \\
\hline N/A & SBM-1 & SBM-1 & $403,361.92$ & $3,735,933.99$ & 18.4 & 2,023 & Long Beach B \\
\hline N/A & SRF-AS1 & SURF-AS1 & $404,008.55$ & $3,732,793.48$ & 12.3 & 8,033 & "Repetto" \\
\hline $\mathrm{N} / \mathrm{A}$ & SUN-ET1 & SUN-ET1 & $409,326.60$ & $3,749,853.50$ & 191.0 & 10,671 & Long Beach C \\
\hline N/A & TX-364P & Texaco364P & $401,282.64$ & $3,756,174.36$ & 158.4 & 7,820 & "Repetto" \\
\hline $\mathrm{N} / \mathrm{A}$ & TX-BP5J & TEX-BP5J & $410,402.80$ & $3,747,143.32$ & 102.2 & 9,577 & Long Beach C \\
\hline N/A & TX-BUE1 & TEX-BUE1 & $410,280.36$ & $3,745,970.51$ & 105.2 & 9,020 & Long Beach C \\
\hline N/A & TX-FUL1 & TEX-FUL1 & $409,076.44$ & $3,747,930.18$ & 87.2 & 10,010 & Long Beach C \\
\hline $\mathrm{N} / \mathrm{A}$ & UP113R & 3U5C UP113R & $386,367.11$ & $3,737,976.43$ & -0.5 & 3,629 & Long Beach C \\
\hline N/A & VirgCC1 & Chevron Virg. CC 1 & $388,678.44$ & $3,745,301.35$ & 39.5 & 12,047 & Long Beach B \\
\hline $\mathrm{N} / \mathrm{A}$ & VulDR1 & Vulcan Del Rey 1 & $367,027.68$ & $3,760,935.10$ & 13.1 & 7,363 & Long Beach C \\
\hline $\mathrm{N} / \mathrm{A}$ & WatA1 & Watson A 1 & $383,810.27$ & $3,740,698.32$ & 54.5 & 4,501 & "Repetto" \\
\hline N/A & $\mathrm{X}-89$ & $\mathrm{X}-89$ & $387,311.86$ & $3,736,270.93$ & 12.5 & 2,695 & Long Beach C \\
\hline N/A & $\mathrm{Y}-112$ & Y-112 & $387,646.38$ & $3,735,880.07$ & 12.5 & 3,951 & Long Beach C \\
\hline N/A & Y-126 & Y-126 & $387,384.93$ & $3,736,104.83$ & 12.5 & 3,632 & Long Beach C \\
\hline N/A & Y-156 & Y-156 & $387,385.92$ & $3,736,016.97$ & 24.0 & 3,135 & Long Beach C \\
\hline
\end{tabular}


Chronostratigraphic unit boundaries were inferred from the logs using stacking patterns identified from the graphic and electric logs, and then tied to nearby mapped unconformities identified in the seismic-reflection profiles. Characteristics used to identify chronostratigraphic unit boundaries from lithologic and geophysical logs include (1) abrupt changes in lithologic character, often a coarse sand or gravel overlying a silt/clay; (2) changes in stacking pattern character, such as change from coarsening-upward cycles to fining- upward cycles; (3) changes in sediment color, typically reddening suggestive of soil rubification or oxidation; (4) the presence of organic material, carbonate, or both, or other cementation; (5) changes in described density, stiffness, or shear-wave velocity (where such data were available); (6) abrupt changes in drilling rate; and (7) changes in the character and trend with depth of spontaneous potential curves, all of which are possible indicators of buried soils, substantial changes in consolidation that likely would signify an unconformable boundary, or changes in water chemistry.

\section{Analysis of Seismic-Reflection Profiles}

In addition to the well and borehole data, 183 seismic-reflection profiles collected by the USGS and the oil industry were used to help identify chronostratigraphic unit boundaries (fig. B3). The oil-industry profiles were either obtained by the Southern California Earthquake Center (SCEC) and made available for this study or were licensed and provided to the USGS by the WRD. These oil-industry profiles, however obtained, are proprietary and cannot be released without written permission from the owner.

Unconformities can be observed in the seismic data, based on the occurrence of onlap, downlap, toplap, and truncation of seismic reflectors (fig. B4). Unconformities and seismic reflectors correlative with these surfaces were identified and digitized using Landmark ${ }^{\circledR}$ seismic interpretation software (Halliburton Landmark in Houston Texas) in the time-domain, and then converted to elevations using the SCEC Community Velocity Model - Harvard (CVM-H) velocity model (Süss and Shaw, 2003; Plesch and others, 2007). Some uncertainties are inherent in the time-to-depth conversions of the seismic data, and in some instances, computed seismic horizon depths do not agree precisely with the chronostratigraphic unit boundary depths identified from boreholes. However, the depth discrepancies are less than 10 percent in most cases. Where borehole control exists near the seismic lines, chronostratigraphic boundaries defined from the seismic data were locally adjusted to conform with the borehole depths.

\section{Analysis of Surficial Geology}

Another purpose of identifying chronostratigraphic boundaries was to correlate mapped surficial geologic units with the chronostratigraphic units identified from subsurface data (figs. B1, B2). For the mapped young, old, and very old alluvial fans and eolian deposits, this correlation process is relatively straightforward because the original depositional surfaces of these deposits are preserved, and geologists have subdivided the deposits by relative stratigraphic position, not by lithologic character. Therefore, these map units are chronostratigraphic units, and the exposed depositional surfaces of these fans are unconformities that can be projected with some confidence into the subsurface.

For older map units that were defined lithostratigraphically, the associations with the chronostratigraphic units identified in the subsurface are less clear. For the older Pleistocene and Pliocene deposits exposed along the eastern margin of the LACP, Durham and Yerkes (1964) and Yerkes (1972) reported that they are unconformably bounded where exposed. Therefore, the ages of the mapped La Habra, Coyote Hills, and San Pedro Formations, and upper Fernando Formation deposits likely do not overlap, and while their original depositional surfaces are no longer entirely preserved, these formations can be reasonably projected to subsurface chronostratigraphic units by estimating the likely location of the original depositional tops using dip and thickness data. Correlation of mapped surficial deposits to the subsurface chronostratigraphic units in the southwestern part of the LACP was constrained by amino-acid dating and other chronostratigraphic controls (Ponti, 1989; Ponti and others, 2007; McDougall and others, 2012). 


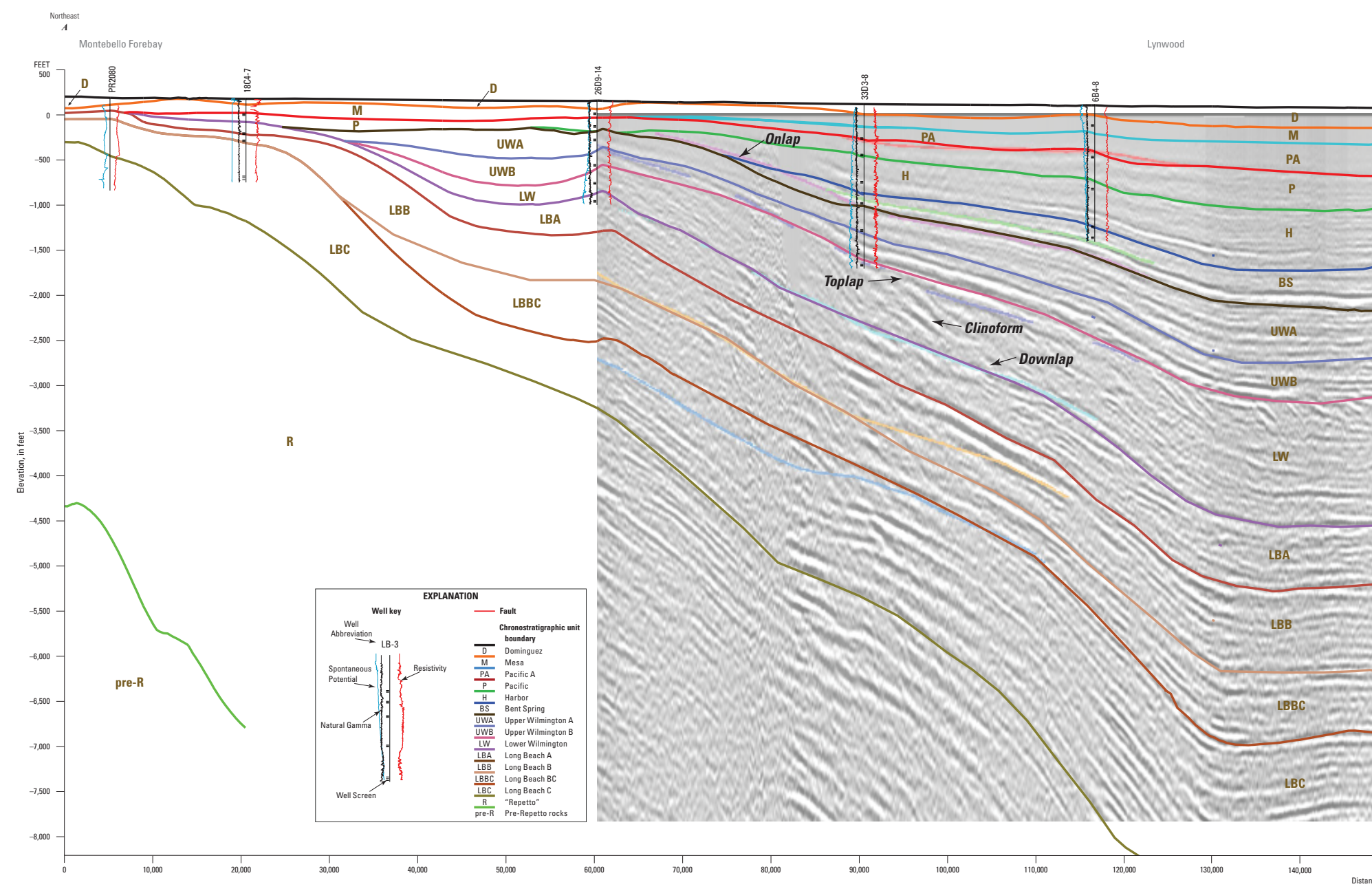

Figure B4. Chronostratigraphic unit boundaries on seismic profile along cross-section A-A', Los Angeles Coastal Plain, California. (Trace of section is shown in fig. B1; colored lines mark the top of each unit; unit identifier codes: D, Dominguez; M, Mesa; PA, Pacific A; P, Pacific; H, Harbor; BS, Bent Spring; UWA, Upper Wilmington A; UWB, Upper Wilmington B; LW, Lower Wilmington; LBA, Long Beach $A$; LBB, Long Beach B; LBBC, Long Beach BC; LBC, Long Beach C; R, “Repetto"; pre-R, pre-Repetto rocks). Examples of unconformable contacts shown with arrows. Seismic images (Texaco lines 8582-13 and 8582-14) courtesy of Southern California Earthquake Center and closely parallel section. See fig. B1 for section location; table B1 for more information on control wells. Vertical exaggeration 4:1. 


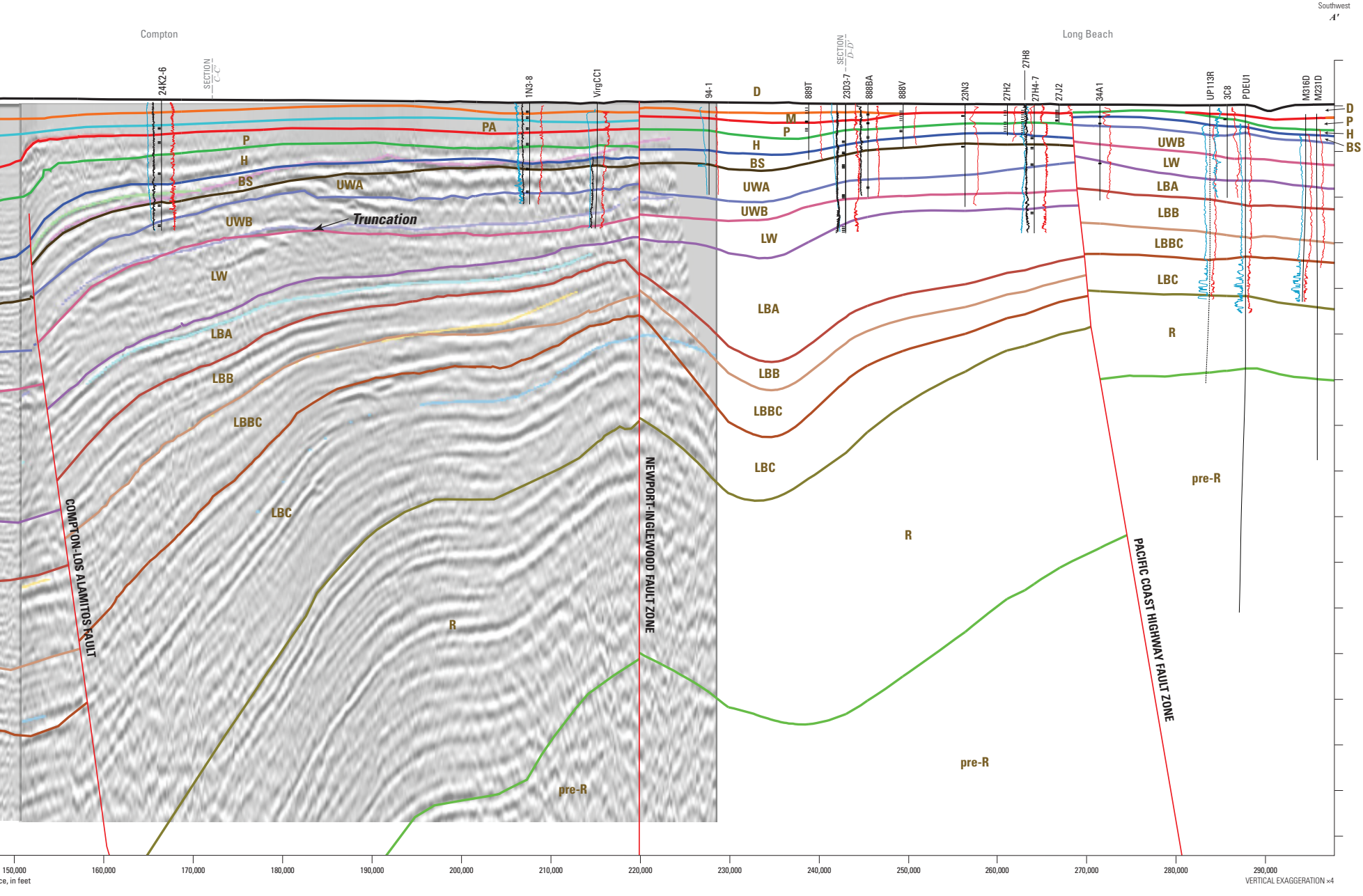




\section{Analysis of Water-Level and Water-Quality Data to Refine Chronostratigraphic Unit Boundaries}

Following the initial identification of chronostratigraphic unit boundaries, their locations were refined using water-level hydrographs and water-quality data (appendix 1, fig. 1.2) collected from WRD/USGS multiple-well monitoring sites. Water-level hydrographs and water-quality data (dissolved-solids concentration, general chemical character, and isotopic composition) from nearby wells screened in the same chronostratigraphic unit were compared to check if they were similar. Wells in adjacent chronostratigraphic units could have similar water-level hydrographs and water-quality characteristics, but where nearby wells inferred to be in the same unit displayed different water-level hydrographs or water-quality characteristics, we assumed that there was a problem with the correlation, and adjusted boundaries accordingly. In most cases, only minor adjustments to boundary locations were needed to be consistent with the water-level and water-quality data while remaining consistent with structural constraints from the seismic data. However, in a few cases, chronostratigraphic unit boundary locations could not be adjusted without violating structural constraints. This usually occurred in areas near fold crests, where thinning and pinching out of reflectors in seismic profiles were commonly observed. As a result, these folds likely act as barriers to groundwater flow even though no fault is present. These potential barriers were noted so that they could be properly simulated in the groundwater-flow model developed as part of this study (see Chapter D).

\section{Chronostratigraphic Model Construction}

Modeled surfaces that represent the tops of the chronostratigraphic units, known as horizons, were constructed as grids using EarthVision ${ }^{\circledR}$ software (Dynamic Graphics, Alameda, California). The grids have a cell size of 492 by $656 \mathrm{ft}$ ( 150 by 200 meters) and are rotated 42 degrees counter-clockwise from true north; this orientation was chosen in order to best reflect the structural grain of the northwest-trending faults and folds. Horizon gridding is the process used to produce these grids and was performed using EarthVision's minimum-tension gridding algorithm, which calculates a smooth surface that closely fits the input data values using a bicubic spline technique. Fault surfaces derived from the Southern California Earthquake Center Community Fault Model (Plesch and others, 2007), or identified as part of this study, were also gridded using minimum tension, and the resulting fault grids were used to divide the model space into fault blocks to control horizon gridding within each block. In addition to control points from boreholes, seismic-reflection profiles, and surficial outcrops, additional control points were added to the model as necessary to constrain interpolation and extrapolation of horizons in areas where data were sparse. Horizon gridding was an iterative process, where horizons were alternately calculated and then used as reference surfaces to constrain the gridding of adjacent horizons in order to preserve fold trends and to prevent inadvertent horizon pinchouts. Once the horizon grids within each fault block were constructed, the grids were intersected and assembled to produce a solid framework model that reveals the complexity of the underlying LACP's structure.

\section{Modeled Chronostratigraphic Units}

The chronostratigraphic framework model developed for this study includes 13 chronostratigraphic units of late Pliocene to Quaternary age and 2 units consisting of consolidated rocks of mid-Pliocene and older age, herein referred to as "bedrock units" (figs. B4-B6; table B2). The age of each unit, inferred depositional environments, and local correlations to lithostratigraphic units and previously published aquifer units are presented in table B2. Because the chronostratigraphic framework generally is described differently than the geologic formations and aquifer framework of the California Department of Water Resources (1961) that were defined lithostratigraphically, we use a different set of informal names for the Pliocene and Pleistocene chronostratigraphic units, following the nomenclature introduced in Ponti and others (2007) for the Long Beach area. We then correlate the Pleistocene units to the paleomagnetic and marine oxygen isotope records based on age estimates reported in Ponti and others (2007) and McDougall and others (2012).

\section{Bedrock Units}

The pre-Repetto Rocks and the "Repetto," the lowermost two units in the chronostratigraphic framework model, are consolidated rocks of mid-Pliocene and older age. They are included in the model to provide structural context and constraints for the overlying units that are the primary focus of this study. Data used to define these units come primarily from published sources (Wright, 1991; Saucedo and others, 2003; Morton and Miller, 2006), except where noted. 


\section{Pre-Repetto Rocks}

The pre-Repetto Rocks unit serves as the base of the regional chronostratigraphic framework model. Its upper surface is derived from structure contours and cross-sections on the "Base of Repetto" of Wright (1991). This boundary is thought to be at about 4.5 million years (Ma) old (Wright, 1991). Below this surface, we do not subdivide the underlying rocks, so the volume of the pre-Repetto Rocks unit incorporates several Miocene formations, as well as Paleogene sediment and Mesozoic crystalline rocks that crop out along the margins of the LACP. The top of the pre-Repetto Rocks unit reaches a minimum elevation of greater than $18,000 \mathrm{ft}$ below NAVD 88 in the Central Basin (Wright, 1991).

\section{"Repetto"}

The term "Repetto" has been used commonly since the 1930s to describe generally deep-water marine sediment of Pliocene age encountered in the subsurface of the Los Angeles area (Reed, 1933; Kew, 1937) and is defined on the basis of microfaunal zones (Natland, 1953; Natland and Rothwell, 1954; Blake, 1991). Therefore, as defined by these authors, the "Repetto" is a biostratigraphic unit and, because of the time-transgressive nature of the microfaunal zones, it is not a chronostratigraphic unit. Durham and Yerkes (1964) have argued for the term "lower Fernando Formation" to describe these rocks in outcrop. We use the term "Repetto" in this study to define rocks that lie between the "pre-Repetto" surface, and a horizon defined by an apparent unconformity identified in seismic reflection profiles in the Central Basin. Near the basin margins, this horizon appears correlative with the top of exposed lower Fernando Formation and with the top of the "Repetto," as represented in cross-sections by Wright (1991), but lies above (is younger than) Wright's top of the "Repetto" in the center of the Central Basin. The age of the "Repetto" unit generally is constrained to be between approximately 3 and 4.5 Ma. The top of the Repetto Rocks unit reaches a minimum elevation of more than $8,000 \mathrm{ft}$ below NAVD 88 in the Central Basin (fig. B4; Wright, 1991).

\section{Late Pliocene and Quaternary Chronostratigraphic Units}

Thirteen chronostratigraphic units have been identified that overlie the bedrock units and range in age from latest Pliocene through Holocene (table B2). Chronostratigraphic units contain the water-bearing sediment within the LACP. Descriptions of the 13 units are based on work by Ponti and others (2007), McDougall and others (2012), Ponti and others (2014), and Ehman and others (2014). Descriptions of the units were refined as appropriate for this study based on geophysical and other data collected as part of USGS studies in the LACP. Overall, the distribution of various facies within the units reflects the shoaling of the Los Angeles Basin over time, which largely controls the distribution of coarse-grained deposits that form the aquifers. For each unit, we created facies maps showing the inferred distribution of various depositional environments (for example, non-marine, shallow marine and paralic, and deep marine slope and basin deposits), along with the likely location of coarse-grained sandy fan, delta and axial channel deposits that would likely comprise the more productive aquifers. Facies maps were constructed using grain-size descriptions from available geologic logs, geophysical log signatures, and microfossil data, along with selected water-quality data (for example, chloride-to-boron ratios and strontium isotope data; appendix 1, figs. 1.5, 1.6). Facies assignments for each unit were made at control wells based on the dominant lithology and geophysical log signature that was present over the entire thickness of the unit. Boundary locations were estimated from the control well locations supplemented by the strontium-isotope data, which were used to determine likely source drainages (appendix 1). Estimates of boundary locations were qualitative interpretations based on sparse data in many of the units and were not directly used in the groundwater-flow model (Chapter D).

\section{Long Beach C}

The Long Beach $\mathrm{C}$ chronostratigraphic unit was identified in the Long Beach area and characterized by a thin, fining-upward sand at its base, overlain by sediment that generally coarsens upward (Ponti and others, 2007). The Long Beach $\mathrm{C}$ unit is inferred to be of late Pliocene age (greater than $2.6 \mathrm{Ma}$ ) based on microfossil and paleomagnetic constraints from the younger Long Beach B unit in the Long Beach area (McDougall and others, 2012; table B2). The Long Beach C unit is present over nearly the entire LACP, except along a portion of the LACP's northern margin, where the unit was presumably uplifted and subsequently eroded (fig. B7). In the Puente Hills area, Long Beach C is believed to be correlative with the upper Fernando Formation and is inferred to have been deposited in the neritic zone (marine waters from the low tide level to a depth of approximately $650 \mathrm{ft}$; Yerkes, 1972). However, over most of the LACP, based on very limited borehole data, Long Beach $\mathrm{C}$ appears to consist of bathyal deposits (sediments deposited within a deep marine basin, from depths of 600 to $13,500 \mathrm{ft}$ below the ocean surface). Overall, the unit is fine-grained and consistently dominated by hemipelagic (marine sediments deposited on continental shelves and rises) silts and clays (fig. B7). Although data are sparse, the sandy nature of the unit in the West Coast Basin and Whittier Narrows area suggests the presence of one or more narrow northeast-southwest trending zones of coarse-grained deposits, likely within canyon channel systems of submarine fans that sourced from near the Whittier Narrows area and flowed toward present-day Santa Monica Bay. 


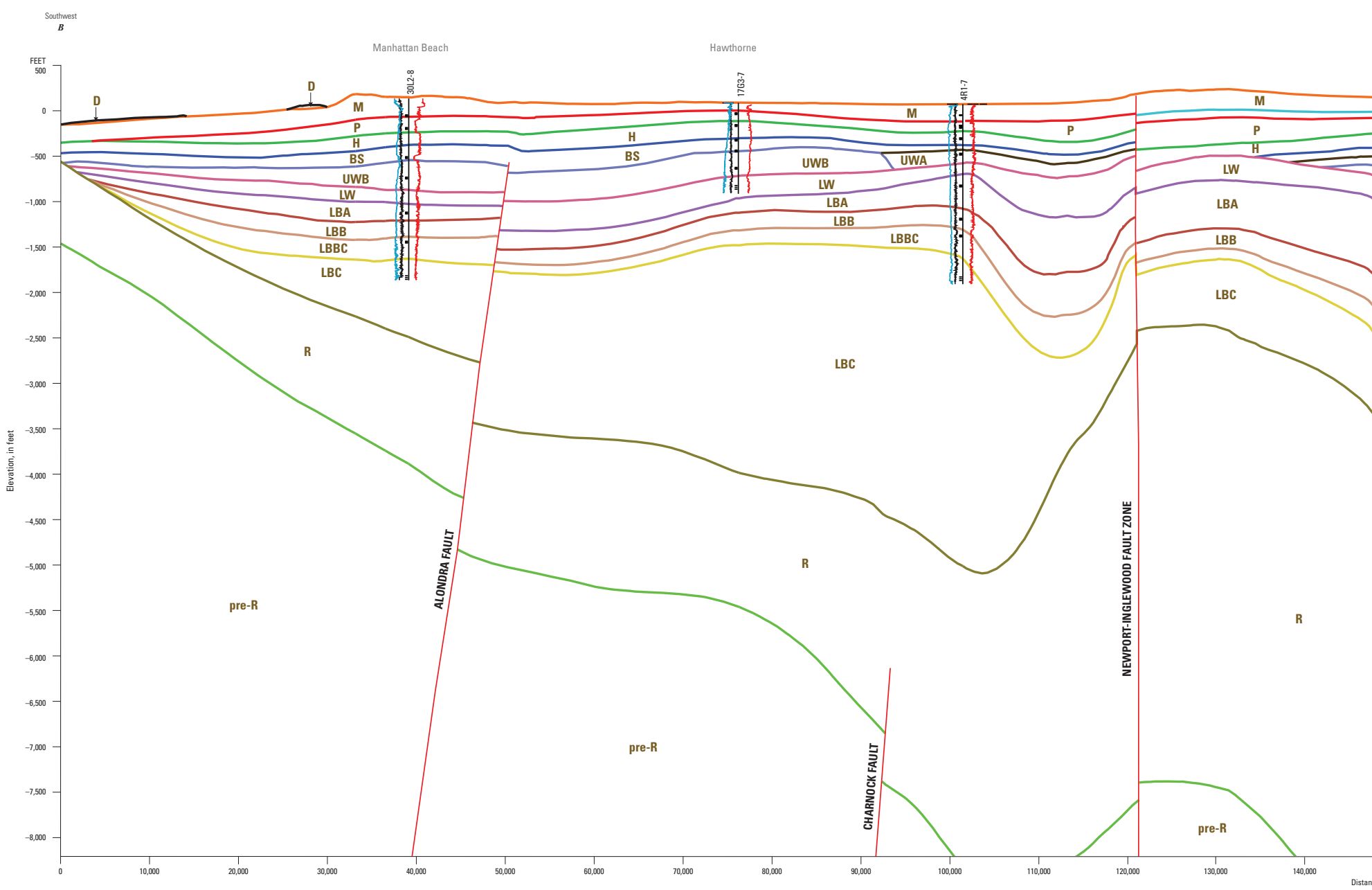

Figure B5. Modeled chronostratigraphic unit boundaries along cross-section B-B', Los Angeles Coastal Plain, California. (Trace of section is shown in fig. B1; colored lines mark the top of each unit; unit identifier codes: D, Dominguez; M, Mesa; PA, Pacific $A ; P$, Pacific; H, Harbor; BS, Bent Spring; UWA, Upper Wilmington A; UWB, Upper Wilmington B; LW, Lower Wilmington; LBA, Long Beach A; LBB, Long Beach B; LBBC, Long Beach BC; LBC, Long Beach C; R, "Repetto"; pre-R, pre-Repetto Rocks.) Vertical exaggeration 4:1. 


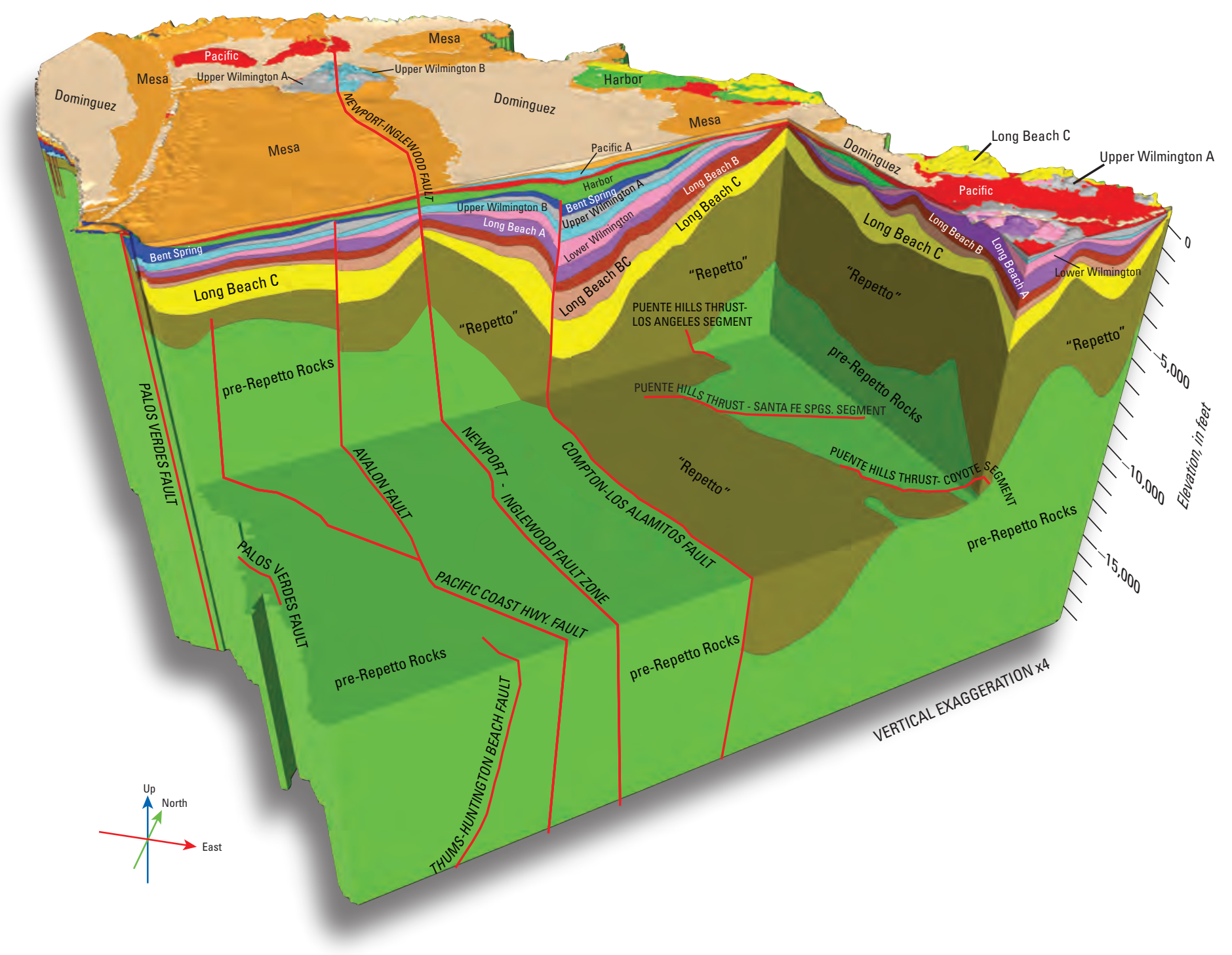

Figure B6. Three-dimensional structure model of the Los Angeles Coastal Plain study area, California. 
Table B2. Modeled chronostratigraphic units, Los Angeles Coastal Plain (LACP), California.

[Unit names and age estimates derive from Ponti and others (2007) and McDougall and others (2012). Long Beach A, B, and C units are renamed here from original Pliocene A, B, and C (Ponti and others, 2007) as a result of recent redefinition in the age of the Pliocene-Pleistocene boundary (Gibbard and others, 2010). Abbreviations: $<$, less than; $\leq$, less than or equal to; $>$, greater than; , approximate; AAR, amino acid racemerization/epimerization; Fm., formation; ka, thousand years; Ma, million years; OSL, optically stimulated luminescence; TL, thermoluminescence; —, no data]

\begin{tabular}{|c|c|c|c|c|c|}
\hline Unit & $\begin{array}{l}\text { Estimated age } \\
\text { range }\end{array}$ & Epoch & Age controls & Subsurface constraints & $\begin{array}{c}\text { Probable correlative surficial map units (after } \\
\text { Saucedo and others, 2003; Morton and Miller, 2006; } \\
\text { Campbell and others, 2014) }\end{array}$ \\
\hline Dominguez & $<18 \mathrm{ka}$ & $\begin{array}{l}\text { Holocene/ } \\
\text { latest } \\
\text { Pleisto- } \\
\text { cene }\end{array}$ & - & $\begin{array}{l}\text { Very good; contains basal sand or } \\
\text { gravel in many areas. }\end{array}$ & $\begin{array}{l}\text { Young alluvial fan and valley deposits; alluvial } \\
\text { wash deposits, active channel and wash deposits. }\end{array}$ \\
\hline Mesa & $\sim 20-80 \mathrm{ka}$ & $\begin{array}{l}\text { late Pleisto- } \\
\text { cene }\end{array}$ & $\begin{array}{l}\text { OSL, possible Laschamp magnetic polarity } \\
\text { event ( } \sim 40 \mathrm{ka}) \text { present; AAR on marine- } \\
\text { terrace outcrops. }\end{array}$ & $\begin{array}{l}\text { Good; top surface usually marked } \\
\text { by basal gravel of overlying } \\
\text { Dominguez sequence. }\end{array}$ & $\begin{array}{l}\text { Old alluvial fan and valley deposits (also mapped } \\
\text { as Lakewood Fm. by California Department of } \\
\text { Water Resources, 1961). }\end{array}$ \\
\hline Pacific A & $\leq 80 \mathrm{ka}$ & $\begin{array}{l}\text { late Pleisto- } \\
\text { cene }\end{array}$ & $\begin{array}{l}\text { Lower subdivision of Mesa sequence in } \\
\text { Central Basin to account for variations in } \\
\text { hydraulic character within the sequence. }\end{array}$ & $\begin{array}{l}\text { Fair to poor; upper boundary } \\
\text { arbitrary in some areas. }\end{array}$ & No known exposures. \\
\hline Pacific & $\sim 97-133 \mathrm{ka}$ & $\begin{array}{l}\text { late Pleisto- } \\
\text { cene }\end{array}$ & $\begin{array}{l}\text { OSL, Blake magnetic polarity event }(\sim 115 \\
\text { ka); AAR estimates on marine-terrace } \\
\text { outcrops. }\end{array}$ & $\begin{array}{l}\text { Fair, top surface seen in seis- } \\
\text { mic reflection data, but often } \\
\text { difficult to pick due to poor } \\
\text { resolution at depths where this } \\
\text { horizon typically occurs. }\end{array}$ & $\begin{array}{l}\text { Very old, old alluvial fan and terrace deposits (also } \\
\text { mapped as Lakewood Fm. of California Depart- } \\
\text { ment of Water Resources, 1961). }\end{array}$ \\
\hline Harbor & $\sim 186-248 \mathrm{ka}$ & $\begin{array}{l}\text { middle Pleis- } \\
\text { tocene }\end{array}$ & $\begin{array}{l}\text { AAR estimates from shallow boreholes; } \\
\text { macrofossils, TL; possible Pringle Falls } \\
\text { magnetic polarity event ( } 200 \mathrm{ka}) \text {. }\end{array}$ & $\begin{array}{l}\text { No clear seismic reflector; unit } \\
\text { often is marked by coarse- } \\
\text { grained base and top with in- } \\
\text { tervening fine-grained interval. }\end{array}$ & $\begin{array}{l}\text { Very old, old alluvial fan and terrace deposits (also } \\
\text { mapped as Lakewood Fm. of California Depart- } \\
\text { ment of Water Resources, 1961). }\end{array}$ \\
\hline Bent Spring & $\sim 295-340 \mathrm{ka}$ & $\begin{array}{l}\text { middle Pleis- } \\
\text { tocene }\end{array}$ & $\begin{array}{l}\text { TL; AAR estimates on terrace outcrops; } \\
\text { Possible Pringle Falls magnetic polarity } \\
\text { event ( } 200 \mathrm{ka}) \text { south of Pacific Coast } \\
\text { Highway fault; otherwise unit appears to } \\
\text { be older than } \sim 300 \mathrm{ka} \text {. }\end{array}$ & $\begin{array}{l}\text { Good, clear seismic reflector at } \\
\text { top of unit in most areas. }\end{array}$ & San Pedro Sand of Palos Verdes Hills. \\
\hline $\begin{array}{l}\text { Upper Wilm- } \\
\text { ington A }\end{array}$ & $\sim 340-434 \mathrm{ka}$ & $\begin{array}{l}\text { middle Pleis- } \\
\text { tocene }\end{array}$ & $\begin{array}{l}\text { Correlated to marine oxygen isotope record } \\
\text { and constrained by bounding units. }\end{array}$ & $\begin{array}{l}\text { Good, clear seismic reflector at } \\
\text { top of unit in most areas. }\end{array}$ & $\begin{array}{l}\text { San Pedro Formation in Baldwin Hills; La Habra } \\
\text { Formation in Puente Hills area. }\end{array}$ \\
\hline $\begin{array}{l}\text { Upper Wilm- } \\
\text { ington B }\end{array}$ & $\sim 434-536 \mathrm{ka}$ & $\begin{array}{l}\text { middle Pleis- } \\
\text { tocene }\end{array}$ & $\begin{array}{l}\text { Questionable Big Lost magnetic polarity } \\
\text { event in Long Beach }(\sim 525-550 \mathrm{ka}) \text {; cor- } \\
\text { related to marine oxygen isotope record } \\
\text { and constrained by bounding units. }\end{array}$ & - & Inglewood Formation in Baldwin Hills. \\
\hline $\begin{array}{l}\text { Lower Wilm- } \\
\quad \text { ington }\end{array}$ & $\begin{array}{l}625-780 \\
\text { ka (Long } \\
\text { Beach); prob- } \\
\text { ably }<1.0 \mathrm{Ma} \\
\text { elsewhere }\end{array}$ & $\begin{array}{l}\text { middle/early } \\
\text { Pleisto- } \\
\text { cene }\end{array}$ & $\begin{array}{l}\text { Contains Lava Creek "B" ash }(\sim 0.64 \mathrm{Ma}) \\
\text { in Long Beach area; Bishop ash }(\sim 0.76 \\
\text { Ma) and magnetically reversed sediment } \\
(>0.78 \mathrm{Ma}) \text { in a northern portion of the } \\
\text { Central Basin is inferred to belong to this } \\
\text { unit (Quinn and others, } 2000) \text {. }\end{array}$ & $\begin{array}{l}\text { Top surface is marked by a clear } \\
\text { seismic reflector in most areas. } \\
\text { Poorly defined lower boundary } \\
\text { is likely older in Central Basin. }\end{array}$ & Coyote Hills Formation in Coyote Hills. \\
\hline
\end{tabular}


[Unit names and age estimates derive from Ponti and others (2007) and McDougall and others (2012). Long Beach A, B, and C units are renamed here from original Pliocene A, B, and C (Ponti and others, 2007) as a result of recent redefinition in the age of the Pliocene-Pleistocene boundary (Gibbard and others, 2010). Abbreviations: <, less than; $\leq$, less than or equal to; >, greater than; $\sim$, approximate; AAR, amino acid racemerization/epimerization; Fm., formation; ka, thousand years; Ma, million years; OSL, optically stimulated luminescence; TL, thermoluminescence; —, no data]

\begin{tabular}{|c|c|c|c|c|c|}
\hline Unit & $\begin{array}{l}\text { Estimated age } \\
\text { range }\end{array}$ & Epoch & Age controls & Subsurface constraints & $\begin{array}{c}\text { Probable correlative surficial map units (after } \\
\text { Saucedo and others, 2003; Morton and Miller, 2006; } \\
\text { Campbell and others, 2014) }\end{array}$ \\
\hline $\begin{array}{l}\text { Long Beach } \\
\qquad \mathrm{A}^{1}\end{array}$ & $\begin{array}{l}\sim 0.9-1.2 \mathrm{Ma} \\
\text { possibly as } \\
\text { old as } \sim 1.9 \\
\mathrm{Ma}\end{array}$ & $\begin{array}{l}\text { early Pleisto- } \\
\text { cene (?) }\end{array}$ & $\begin{array}{l}\text { Apparent lower Pleistocene planktic fauna; } \\
\text { but normal polarity indicates deposition } \\
\text { during the Santa Rosa, Jaramillo, or Cobb } \\
\text { Mountain chrons }(0.92-1.18 \mathrm{Ma}) \text { or the } \\
\text { Olduvai chron (1.77-1.95 Ma). }\end{array}$ & $\begin{array}{l}\text { Poorly defined-not often distin- } \\
\text { guishable from Long Beach } \\
\text { B or Lower Wilmington in } \\
\text { seismic profiles. }\end{array}$ & San Pedro Formation in Coyote Hills. \\
\hline $\begin{array}{l}\text { Long Beach } \\
\qquad \mathrm{B}^{2}\end{array}$ & $\begin{array}{l}\sim 2.0 \mathrm{Ma} \text { or } \\
\text { possibly }>2.6 \\
\text { Ma }\end{array}$ & $\begin{array}{l}\text { early Pleis- } \\
\text { tocene to } \\
\text { late Plio- } \\
\text { cene (?) }\end{array}$ & $\begin{array}{l}\text { Apparent lower Pleistocene planktic fauna } \\
\text { in Long Beach, but normal polarity paleo- } \\
\text { magnetic signature could place the unit } \\
\text { within the Olduvai chron (1.77-1.95 Ma). }\end{array}$ & $\begin{array}{l}\text { Fair, generally marked by thick } \\
\text { sands in electric logs, top } \\
\text { marked by clear seismic reflec- } \\
\text { tor. }\end{array}$ & No known exposures. \\
\hline $\begin{array}{l}\text { Long Beach } \\
\text { BC }\end{array}$ & $\begin{array}{l}\sim 2.0 \mathrm{Ma} \text { or } \\
\text { possibly }>2.6 \\
\text { Ma }\end{array}$ & $\begin{array}{l}\text { early Pleis- } \\
\text { tocene to } \\
\text { late Plio- } \\
\text { cene (?) }\end{array}$ & $\begin{array}{l}\text { Stratigraphically located between Long } \\
\text { Beach B and Long Beach C. May be } \\
\text { basal portion of Long Beach B and there- } \\
\text { fore closer to it in age. }\end{array}$ & $\begin{array}{l}\text { Fair to poor. Upper boundary } \\
\text { not clearly unconformable in } \\
\text { seismic imaging. }\end{array}$ & No known exposures. \\
\hline $\begin{array}{l}\text { Long Beach } \\
\qquad C^{3}\end{array}$ & $>2.6 \mathrm{Ma}$ & late Pliocene & $\begin{array}{l}\text { Probable Pliocene age based on microfossil } \\
\text { and paleomagnetic constraints in overly- } \\
\text { ing Long Beach B unit in Long Beach } \\
\text { area. Normal polarity indicates unit is } \\
\text { within the Gauss chron }(>2.58 \mathrm{Ma}) \text {. }\end{array}$ & $\begin{array}{l}\text { Good, clear seismic reflector } \\
\text { marks top of unit in most } \\
\text { areas. }\end{array}$ & Fernando Formation, upper member. \\
\hline "Repetto" & $\sim 3-4.5 \mathrm{Ma}$ & Pliocene & Benthic fauna. & $\begin{array}{l}\text { Based on cross-sections in } \\
\text { Wright (1991) and clear } \\
\text { seismic horizon in Central } \\
\text { Basin; seismic horizon appears } \\
\text { correlative with biostratigraph- } \\
\text { ically-defined Repetto near } \\
\text { margins of the basin, but may } \\
\text { be younger elsewhere. }\end{array}$ & $\begin{array}{l}\text { Not exposed within, but forms part of the boundary } \\
\text { of the LACP within the Elysian, Repetto, and } \\
\text { Puente Hills. Bounding surficial units include } \\
\text { lower member of the Fernando Fm. and Repetto } \\
\text { Fm. of Wright (1991) }\end{array}$ \\
\hline $\begin{array}{l}\text { Pre-Repetto } \\
\text { Rocks }\end{array}$ & $>4.5 \mathrm{Ma}$ & $\begin{array}{l}\text { Miocene and } \\
\text { possibly } \\
\text { older }\end{array}$ & Benthic fauna. & $\begin{array}{l}\text { Based on sections and structure } \\
\text { contours in Wright (1991). }\end{array}$ & $\begin{array}{l}\text { Not exposed within, but forms part of the bound- } \\
\text { ary of the LACP within the Santa Monica } \\
\text { Mountains, Elysian, Repetto, Puente, and Palos } \\
\text { Verdes Hills. Bounding surficial units include } \\
\text { Mesozoic crystalline and metamorphic rocks, } \\
\text { and Calabasas, Topanga, Modelo, Monterey, and } \\
\text { Puente Formations. }\end{array}$ \\
\hline
\end{tabular}


Table B2. Modeled chronostratigraphic units, Los Angeles Coastal Plain (LACP), California.—Continued

[Unit names and age estimates derive from Ponti and others (2007) and McDougall and others (2012). Long Beach A, B, and C units are renamed here from original Pliocene A, B, and C (Ponti and others, 2007) as a result of recent redefinition in the age of the Pliocene-Pleistocene boundary (Gibbard and others, 2010). Abbreviations: $<$, less than; $<$, less than or equal to; $>$, greater than; , approximate; AAR, amino acid racemerization/epimerization; Fm., formation; ka, thousand years; Ma, million years; OSL, optically stimulated luminescence; TL, thermoluminescence; —, no data]

\begin{tabular}{|c|c|c|c|c|c|c|c|c|c|}
\hline \multirow[b]{2}{*}{ Unit } & \multicolumn{3}{|c|}{ Comparison Site 1 (figs. B1 and B20) } & \multicolumn{3}{|c|}{ Comparison Site 2 (figs. B1 and B21) } & \multicolumn{3}{|c|}{ Comparison Site 3 (figs. B1 and B22) } \\
\hline & $\begin{array}{c}\text { Inferred } \\
\text { depositional } \\
\text { environments }\end{array}$ & $\begin{array}{l}\text { Lithostratigraphic } \\
\text { unit from California } \\
\text { Department of } \\
\text { Water Resources } \\
\text { (1961) }\end{array}$ & $\begin{array}{l}\text { Aquifer(s) } \\
\text { from } \\
\text { California } \\
\text { Department } \\
\text { of Water } \\
\text { Resources } \\
\text { (1961) }\end{array}$ & $\begin{array}{c}\text { Inferred } \\
\text { depositional } \\
\text { environments }\end{array}$ & $\begin{array}{c}\text { Lithostratigraphic } \\
\text { unit from } \\
\text { California } \\
\text { Department of } \\
\text { Water Resources } \\
\text { (1961) }\end{array}$ & $\begin{array}{l}\text { Aquifer(s) } \\
\text { from } \\
\text { California } \\
\text { Department } \\
\text { of Water } \\
\text { Resources } \\
\text { (1961) }\end{array}$ & $\begin{array}{c}\text { Inferred } \\
\text { depositional } \\
\text { environments }\end{array}$ & $\begin{array}{c}\text { Lithostratigraphic } \\
\text { unit from } \\
\text { California } \\
\text { Department of } \\
\text { Water Resources } \\
\text { (1961) }\end{array}$ & $\begin{array}{l}\text { Aquifer(s) } \\
\text { from } \\
\text { California } \\
\text { Department } \\
\text { of Water } \\
\text { Resources } \\
\text { (1961) }\end{array}$ \\
\hline Dominguez & not present & - & - & $\begin{array}{l}\text { Alluvial fan and } \\
\text { stream channel }\end{array}$ & Recent alluvium & Gaspur & $\begin{array}{l}\text { Alluvial fan/ } \\
\text { flood basin }\end{array}$ & $\begin{array}{l}\text { Recent alluvium/ } \\
\text { Lakewood Fm. }\end{array}$ & Artesia \\
\hline Mesa & $\begin{array}{l}\text { Alluvial fan/ } \\
\text { flood basin }\end{array}$ & Lakewood Fm. & $\begin{array}{l}\text { perched } \\
\text { water }\end{array}$ & Alluvial fan & Lakewood Fm. & Exposition & $\begin{array}{l}\text { Alluvial fan/ } \\
\text { flood basin }\end{array}$ & Lakewood Fm. & $\begin{array}{l}\text { Artesia/ } \\
\text { Gage }\end{array}$ \\
\hline Pacific A & not present & - & - & $\begin{array}{l}\text { Paralic/inner } \\
\text { neritic }\end{array}$ & $\begin{array}{l}\text { Lakewood Fm./ } \\
\text { San Pedro Fm. }\end{array}$ & Gage & Paralic & San Pedro Fm. & Hollydale \\
\hline Pacific & $\begin{array}{l}\text { Alluvial fan/ } \\
\text { flood basin }\end{array}$ & San Pedro Fm. & Gardena & $\begin{array}{l}\text { Paralic/inner } \\
\text { neritic }\end{array}$ & San Pedro Fm. & Hollydale & $\begin{array}{l}\text { Inner neritic/ } \\
\text { paralic }\end{array}$ & San Pedro Fm. & $\begin{array}{l}\text { Lynwood/ } \\
\text { Silverado }\end{array}$ \\
\hline Harbor & $\begin{array}{c}\text { Paralic/inner } \\
\text { neritic }\end{array}$ & San Pedro Fm. & Lynwood & $\begin{array}{l}\text { Paralic/inner } \\
\text { neritic }\end{array}$ & San Pedro Fm. & $\begin{array}{l}\text { Lynwood/ } \\
\text { Silverado }\end{array}$ & Neritic & $\begin{array}{l}\text { San Pedro Fm./ } \\
\text { Pico Fm. }\end{array}$ & Sunnyside \\
\hline Bent Spring & Inner neritic & San Pedro Fm. & Silverado & Inner neritic & San Pedro Fm. & Silverado & Neritic & - & - \\
\hline Upper Wilmington A & not present & & & Inner neritic & San Pedro Fm. & Sunnyside & Neritic & Pico Fm. & - \\
\hline Upper Wilmington B & Outer neritic & San Pedro Fm. & Silverado & Inner neritic & Pico Fm. & - & $\begin{array}{l}\text { Bathyl marine } \\
\text { (slope facies) }\end{array}$ & Pico Fm. & - \\
\hline Lower Wilmington & $\begin{array}{l}\text { Bathyl marine } \\
\text { (slope facies) }\end{array}$ & San Pedro Fm. & $\begin{array}{l}\text { Sunnyside } \\
\text { (nearby) }\end{array}$ & Neritic & Pico Fm. & - & $\begin{array}{l}\text { Bathyl marine } \\
\quad \text { (slope facies) }\end{array}$ & Pico Fm. & - \\
\hline Long Beach $\mathrm{A}^{1}$ & Bathyl marine & $\begin{array}{l}\text { Pico Fm./San Pedro } \\
\text { Fm. }\end{array}$ & - & $\begin{array}{l}\text { Outer neritic/ } \\
\text { upper slope }\end{array}$ & Pico Fm. & - & Bathyl marine & Pico Fm. & - \\
\hline Long Beach B ${ }^{2}$ & Bathyl marine & Pico Fm. & - & $\begin{array}{l}\text { Bathyl marine } \\
\text { (slope facies) }\end{array}$ & Pico Fm. & - & Bathyl marine & Pico Fm. & - \\
\hline Long Beach BC & Bathyl marine & Pico Fm. & - & $\begin{array}{l}\text { Bathyl marine } \\
\text { (slope facies) }\end{array}$ & Pico Fm. & - & Bathyl marine & Pico Fm. & - \\
\hline Long Beach $\mathrm{C}^{3}$ & Bathyl marine & Pico Fm. & - & Bathyl marine & Pico Fm. & - & Bathyl marine & Pico Fm. & - \\
\hline "Repetto" & Bathyl marine & Pliocene formations & - & Bathyl marine & $\begin{array}{l}\text { Pliocene } \\
\text { formations }\end{array}$ & - & Bathyl marine & $\begin{array}{l}\text { Pliocene } \\
\text { formations }\end{array}$ & - \\
\hline Pre-Repetto Rocks & Marine & $\begin{array}{l}\text { Miocene } \\
\text { formations }\end{array}$ & - & Marine & $\begin{array}{l}\text { Miocene } \\
\text { formations }\end{array}$ & - & Marine & $\begin{array}{l}\text { Miocene } \\
\text { formations }\end{array}$ & - \\
\hline
\end{tabular}

${ }^{1}$ Upper-, ${ }^{2}$ Middle-, and ${ }^{3}$ Lower-Long Beach of McDougall and others (2012). 


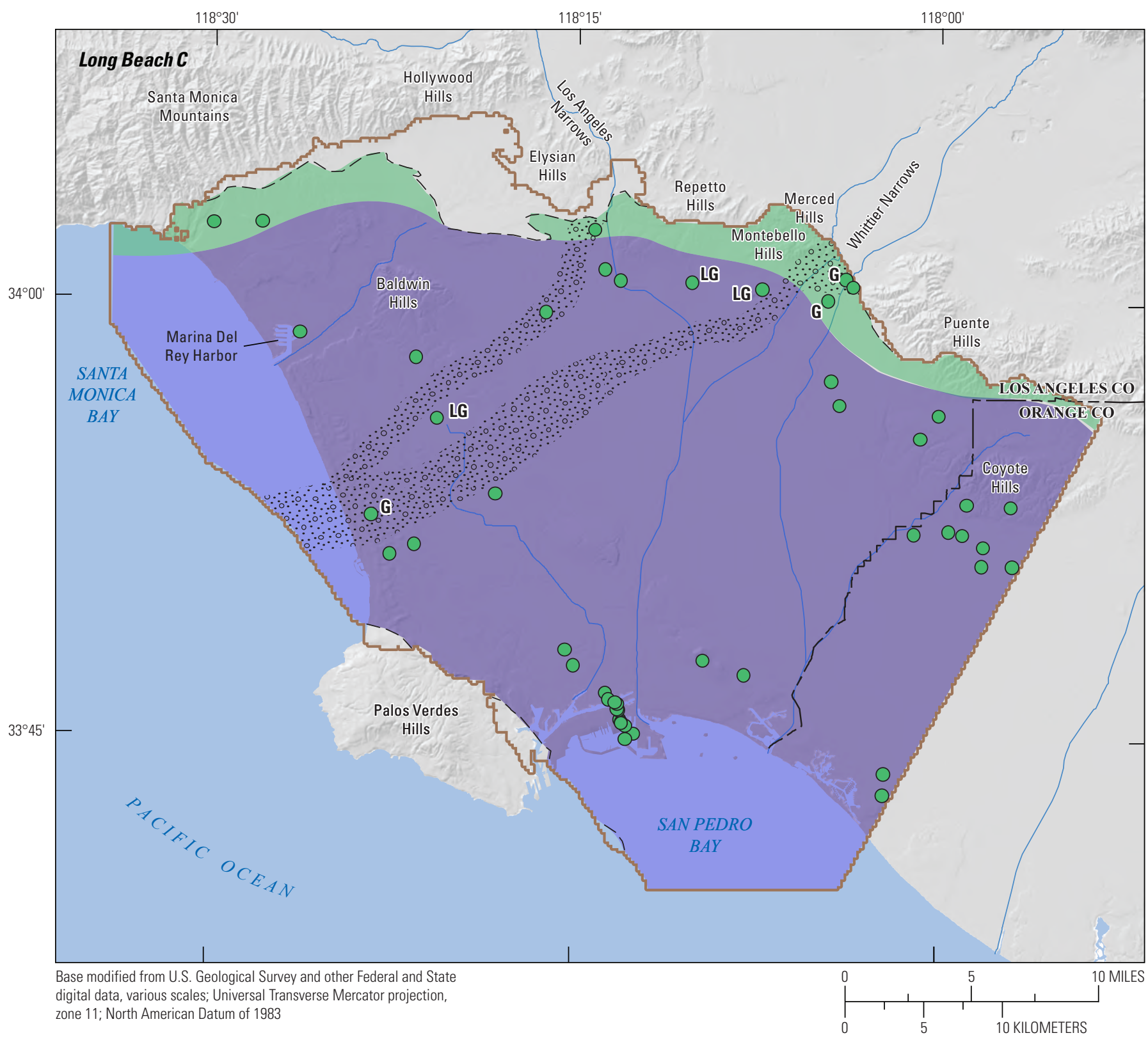

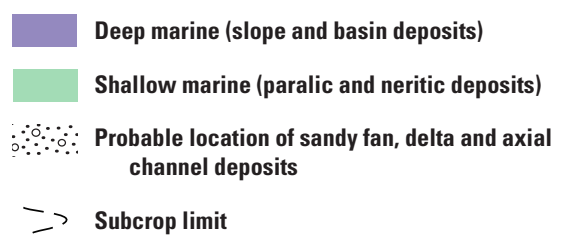

$\Longrightarrow$ Subcrop limit

\section{EXPLANATION}

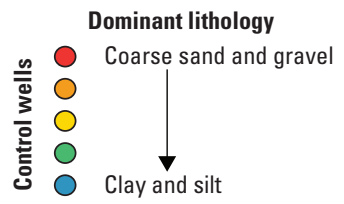

\begin{abstract}
Predominant source drainage derived from ${ }^{87} \mathrm{Sr} /{ }^{86} \mathrm{Sr}$ ratio

L_Los Angeles River (0.7081-0.7088)

LG-Mixed Los Angeles and San Gabriel Rivers (0.7089-0.7096)

G-San Gabriel River (0.7097-0.7104)

GA-Mixed San Gabriel and Santa Ana Rivers (greater than 0.7104)
\end{abstract}

Figure B7. Inferred facies distribution of the Long Beach C chronostratigraphic unit, Los Angeles Coastal Plain, California, with dominant lithologies from control wells and source drainages derived from available strontium-isotope data. Abbreviation: ${ }^{87} \mathrm{Sr} /{ }^{86} \mathrm{Sr}$, strontium [Sr] isotope ratio, dimensionless values; $\mathrm{Sr}$ has two stable isotopes (strontium-87 [87 $\mathrm{Sr}$ ] and strontium-86 [ ${ }^{86} \mathrm{Sr}$ ]). 


\section{Long Beach BC}

The Long Beach BC chronostratigraphic unit is dominantly composed of deep-marine deposits and was distinguished from Long Beach $\mathrm{C}$ using hydrographs from wells screened in Long Beach BC in the West Coast Basin. For example, 3S/14W-4R1 to 4R7 (4R1-7; fig. A3) and 3S/14W-30L2 to 30L8 (30L2-8; fig. A3) show the water levels in the Long Beach BC unit were consistently lower than in the underlying Long Beach $\mathrm{C}$ unit (by approximately $13 \mathrm{ft}$ in 4R1-7) and consistently higher than in the overlying Long Beach B unit (by approximately $18 \mathrm{ft}$ in 4R1-7). Evidence for erosion, onlap, or toplap at the top of the unit cannot be discerned from seismic reflection data, so we cannot determine if the Long Beach BC unit is bounded by unconformities or is just a conformal unit that comprises the lowermost part of the Long Beach B unit; therefore the ages of the Long Beach $\mathrm{BC}$ and Long Beach B units are comparable. The combined thickness of the Long Beach $\mathrm{C}$ and Long Beach $\mathrm{BC}$ units exceeds 2,500 ft in the Central Basin (fig. B6). The extents and inferred distributions of sedimentary facies and source areas of the Long Beach BC unit are likely similar to the Long Beach $\mathrm{C}$ unit (fig. B8), but our interpretation is limited because there are only a few data points available.

\section{Long Beach B}

The Long Beach B chronostratigraphic unit in the Long Beach area was described by Ponti and others (2007) as a generally fining-upward unit, possibly reflective of a marine transgression, with a sandy base eventually grading up into silts. In the northeastern part of the Central Basin, the unit is characterized by a basal fining-upward section overlain by a generally coarsening-upward package indicative of high-stand progradation. This coarsening-upward section of the unit is more than $150 \mathrm{ft}$ thick, and, several production wells in the northeastern LACP are screened in this unit.

Microfossil and paleomagnetic data from two core holes in the Long Beach area indicate an early Pleistocene to late Pliocene age for the Long Beach B unit. Planktic foraminifera suggest correlation with a Northern Hemisphere glaciation from approximately 2.75 to $2.0 \mathrm{Ma}$ and an early Pleistocene warm period at about $2 \mathrm{Ma}$. However, paleomagnetic analysis likely correlates the Long Beach B unit with the Olduvai Normal Polarity Subchron (1.95-1.77 Ma); this age range corresponds with the ages predicted by the planktic foraminifera, but substantially restricts the age range of this unit (McDougall and others, 2012). While the Long Beach B unit possibly could be of late Pliocene age (greater than $2.6 \mathrm{Ma}$ ) based on the microfossils, fossil reworking is probable, and the younger age for the unit (approximately $2 \mathrm{Ma}$ ) may be more likely.

The top of Long Beach B is marked by a well-defined seismic reflector that locally exhibits evidence of truncation. The unit reaches a maximum thickness of approximately $650 \mathrm{ft}$ in the Central Basin (fig. B4). Based on the character of electric logs, compared with the Long Beach $\mathrm{C}$ and Long Beach BC units, there is evidence for a broader shelf of neritic deposits extending westward from the northeast margin of the LACP. Sandy sediment appears to have been transported dominantly from the Whittier Narrows area and likely flowed southward via submarine fan channels to San Pedro Bay based on the presence of coarse-grained turbidite sands in the Long Beach harbor area, (fig. B9).

\section{Long Beach A}

The Long Beach A chronostratigraphic unit was identified in the Long Beach area based on a distinctive electric-log signature and strong, regionally extensive reflector offshore in San Pedro Bay (Ponti and others, 2007). However, in the Central Basin, the top of the Long Beach A unit is difficult to discern in oil industry seismic-reflection data, and no clear unconformable seismic horizon corresponding to the top of this unit is recognized.

Microfossil and paleomagnetic data from the Long Beach A unit in the Long Beach area indicate an age similar to that of the Long Beach B unit (for example, approximately 2.0 Ma; McDougall and others, 2012). In Long Beach, the top of the Long Beach A unit represents a major hiatal surface and there is a substantial section missing above this horizon (Ponti and others, 2007). A substantial increase in clay stiffness below Long Beach A at multiple-well monitoring site 2E1-2 (5S/13W-2E1 to 2E2) suggests Long Beach A may be substantially younger than Long Beach B and was perhaps in part deposited during an interval of normal magnetic polarity between about 0.92 and 1.18 Ma (McDougall and others, 2012). In the Central Basin and the southern part of the study area where basin subsidence was greater and more of the section is presumably preserved, the Long Beach A unit likely is younger than in the Long Beach area, where this unit is probably representative of only the older part of the unit.

We tentatively infer the subsurface Long Beach A unit to be roughly correlative with exposures of the San Pedro Formation in the Coyote Hills, where analysis of macrofossils and a strontium-isotope age determination of 1.4 plus or minus ( \pm ) 0.4 Ma from a bivalve, Patinopecten caurinus (Gould, 1850), collected from the upper part of the San Pedro Formation indicates a lower Pleistocene age (Powell and Stevens, 2000). If this correlation is valid, the Long Beach A unit reflects an inner neritic environment in the Coyote Hills.

The presumed shelf/slope boundary during deposition of the Long Beach A unit, approximated as the boundary between inferred shallow marine (neritic) and deep marine (bathyal) deposits, appears similar to that of the Long Beach B unit (fig. B10). The main source of deposits is from the Whittier Narrows area, and overall, the unit is predominantly fine-grained (fig. B10). Available well data suggest that several linear zones of predominantly sandy deposits (likely submarine fan axial channel deposits) extend from the Whittier Narrows area to the south and southeast (fig. B10). 


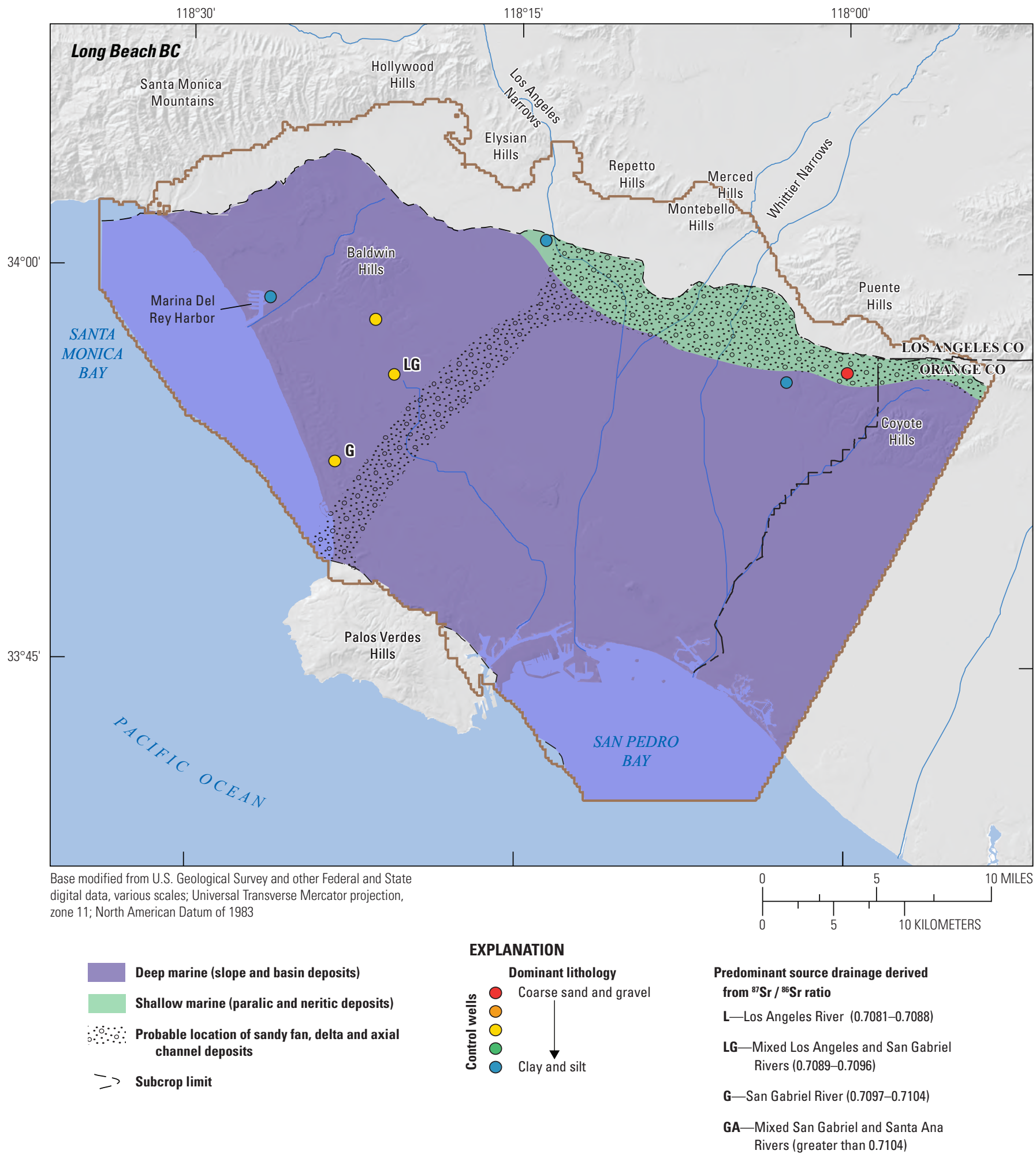

Figure B8. Inferred facies distribution of the Long Beach BC chronostratigraphic unit, Los Angeles Coastal Plain, California, with dominant lithologies from control wells and source drainages derived from available strontium-isotope data. Abbreviation: ${ }^{87} \mathrm{Sr} /{ }^{86} \mathrm{Sr}$, strontium [Sr] isotope ratio, dimensionless values; $\mathrm{Sr}$ has two stable isotopes (strontium-87 [ $\left.{ }^{87} \mathrm{Sr}\right]$ and strontium-86 [86 $\left.\mathrm{Sr}\right]$ ). 


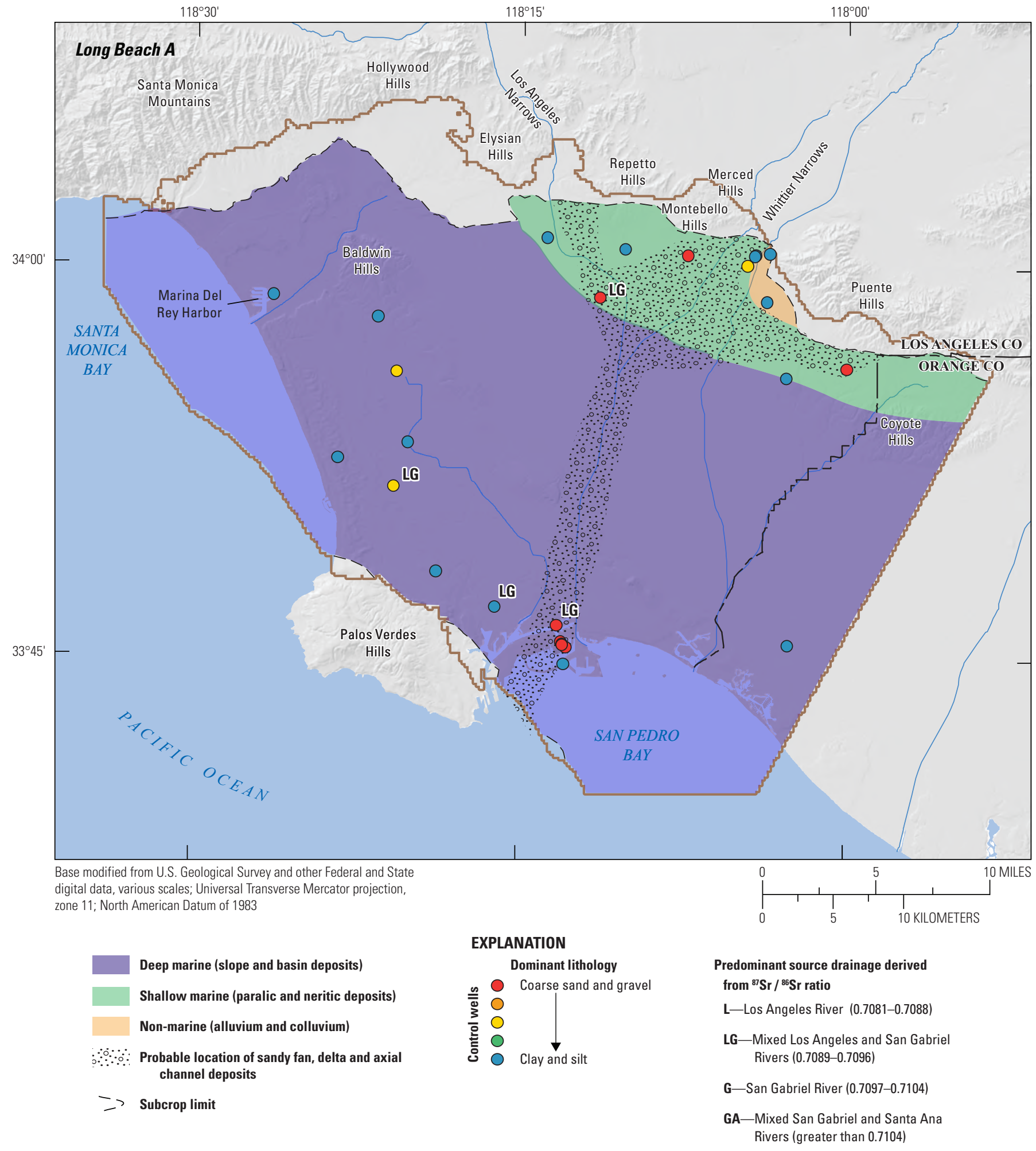

Figure B9. Inferred facies distribution of the Long Beach B chronostratigraphic unit, Los Angeles Coastal Plain, California, with dominant lithologies from control wells and source drainages derived from available strontium-isotope data. Abbreviation: ${ }^{87} \mathrm{Sr} /{ }^{86} \mathrm{Sr}$, strontium [Sr] isotope ratio, dimensionless values; $\mathrm{Sr}$ has two stable isotopes (strontium-87 [ ${ }^{87 \mathrm{Sr}}$ ] and strontium-86 [ $\left.{ }^{86} \mathrm{Sr}\right]$ ). 


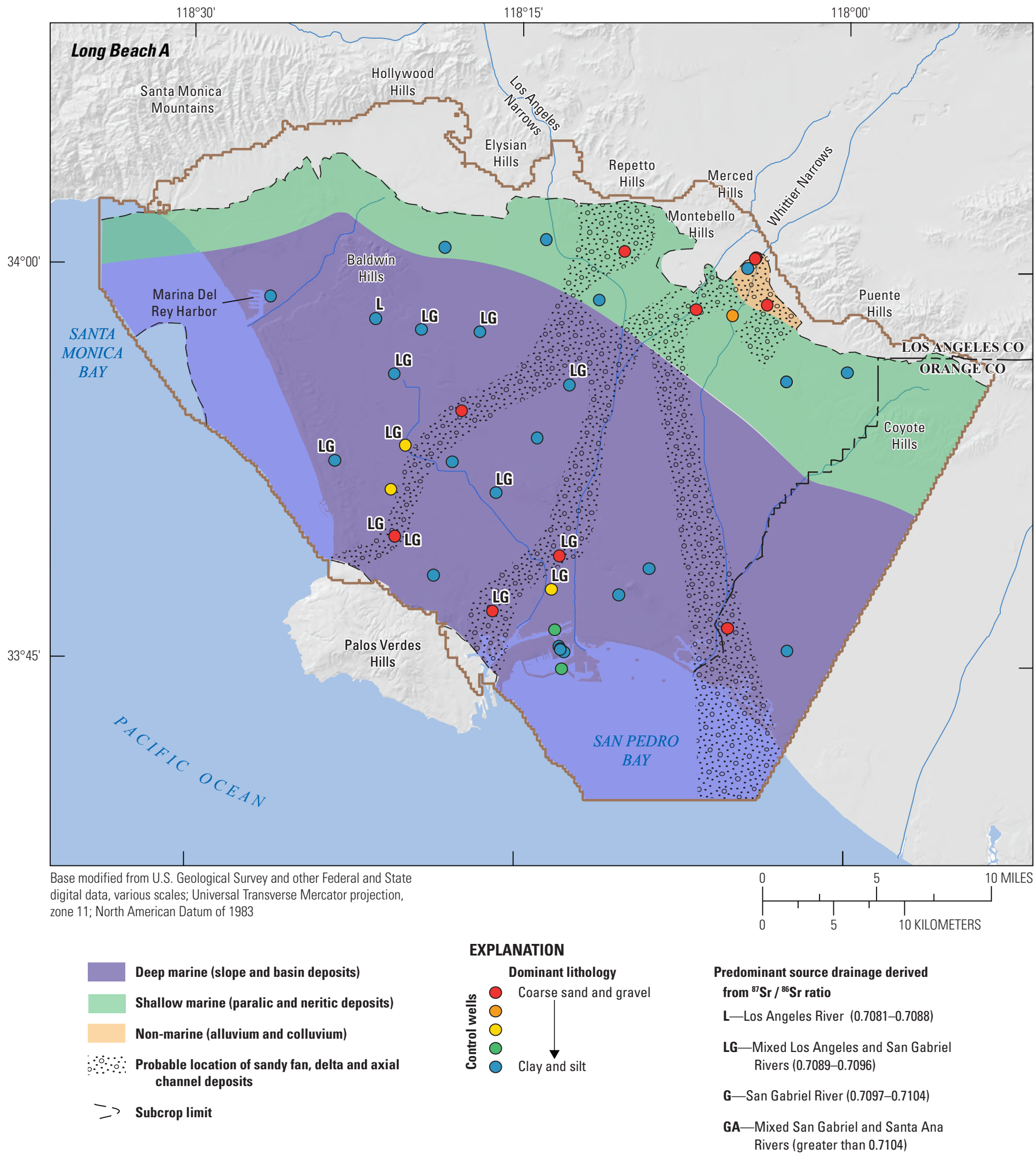

Figure B10. Inferred facies distribution of the Long Beach A chronostratigraphic unit, Los Angeles Coastal Plain, California, with dominant lithologies from control wells and source drainages derived from available strontium-isotope data. Abbreviation: ${ }^{87} \mathrm{Sr} /{ }^{86} \mathrm{Sr}$, strontium [Sr] isotope ratio, dimensionless values; Sr has two stable isotopes (strontium-87 [ $\left.{ }^{87} \mathrm{Sr}\right]$ and strontium-86 [ $\left.{ }^{86} \mathrm{Sr}\right]$ ). 


\section{Lower Wilmington}

The Lower Wilmington chronostratigraphic unit was described in the Long Beach area as consisting of basal blocky sands capped by thick muds with an overall coarsening-upward character (Ponti and others, 2007). In seismic-reflection profiles, the top of the unit is marked by a clear seismic reflector, and the sequence shows internal clinoform structure indicative of a prograding delta complex in the Central Basin (fig. B4). The ages and paleoecologic interpretations from cores in the Long Beach area indicate deposition in both warm- and cool-water intervals (McDougall and others, 2012). Paleomagnetic data from cores in the Long Beach area place this unit in the Brunhes Normal Polarity chron, which would restrict the age to $0.78 \mathrm{Ma}$ or younger (McDougall and others, 2012). The Lava Creek B ash ( $639 \pm 2$ thousand years; $\mathrm{ka}$ ) occurs at 1,240 ft measured depth below land surface in the lower part of the Lower Wilmington unit in multiple-well monitoring site Long Beach-8 (4S/12W-30J1-6; 30J1 on fig. B3), and biostratigraphic data suggest an age of greater than $0.6 \mathrm{Ma}$ (McDougall and others, 2012). Marine deposits of similar character that contain the Bishop ash (approximately $0.76 \mathrm{Ma}$ ) and sediment with reversed magnetic polarity in the northern Los Angeles Basin (Quinn and others, 2000) suggest that the base of the Lower Wilmington unit may extend into the lower Pleistocene in the Central Basin (less than or equal to approximately 1.0 Ma). We correlate the subsurface Lower Wilmington unit with outcrops of the Coyote Hills Formation in the Coyote Hills (Durham and Yerkes, 1964; Yerkes, 1972; table B2), where the formation is of paralic and non-marine origin.

Inferred facies distribution of the Lower Wilmington sequence (fig. B11) indicates that the unit likely is of non-marine origin near the northeastern margin of the LACP south of Whittier Narrows. Shallow marine (neritic) deposits encompass the northern half of the LACP, with a fairly extensive coarse-grained zone of likely deltaic channel deposits that extends westward from the Whittier Narrows area (fig. B11).

\section{Upper Wilmington B}

The Upper Wilmington B chronostratigraphic unit corresponds to the lower portion of the Upper Wilmington sequence as defined by Ponti and others (2007) in the Long Beach area. Subsequent analysis of borehole and seismic data elsewhere in the LACP reveals evidence of erosion and incision that warrants subdividing the original Upper Wilmington unit of Ponti and others (2007) into the Upper Wilmington B and Upper Wilmington A chronostratigraphic units. The Upper Wilmington B unit can be correlated to exposures of the Inglewood Formation in the Baldwin Hills (Weber and others, 1982; Saucedo and others, 2003) and appears to be of shallow marine origin.

Based on age constraints on the underlying Lower Wilmington unit and analysis of microfossils in the Long Beach area, the ages of both the Upper Wilmington B and A units are likely constrained to less than $600 \mathrm{ka}$ old and greater than $340 \mathrm{ka}$ old. Best estimate for the age of the Upper Wilmington B unit from correlation to marine oxygen isotope stages (Bassinot and others, 1994) is between 434 and $536 \mathrm{ka}$ (table B2).

By Upper Wilmington B time, the LACP had sufficiently shoaled such that most of the Upper Wilmington B unit is of shallow marine or non-marine origin. Only in the southeastern part of the Central Basin is there evidence suggestive of deep marine deposition (bathyal depths; fig. B12). Coarse-grained zones indicative of delta progradation appear to source from both the Whittier Narrows and Los Angeles Narrows areas, with the Whittier Narrows area extending to the south and into the southern West Coast Basin, and the Los Angeles Narrows area extending to the west-southwest toward the present Baldwin Hills and the northern West Coast Basin into Santa Monica Bay. These coarse-grained axial channel deposits and shallow marine sands are relatively permeable compared to the underlying units, and these coarse-grained deposits are extensively pumped, especially in the Long Beach area. Uplift along the Newport-Inglewood fault zone southeast of Baldwin Hills likely caused Upper Wilmington B deposits to be eroded prior to deposition of the Upper Wilmington A unit. The Upper Wilmington B deposits in the central part of the West Coast Basin are dominantly fine-grained and likely of slightly deeper marine origin (fig. B12). 


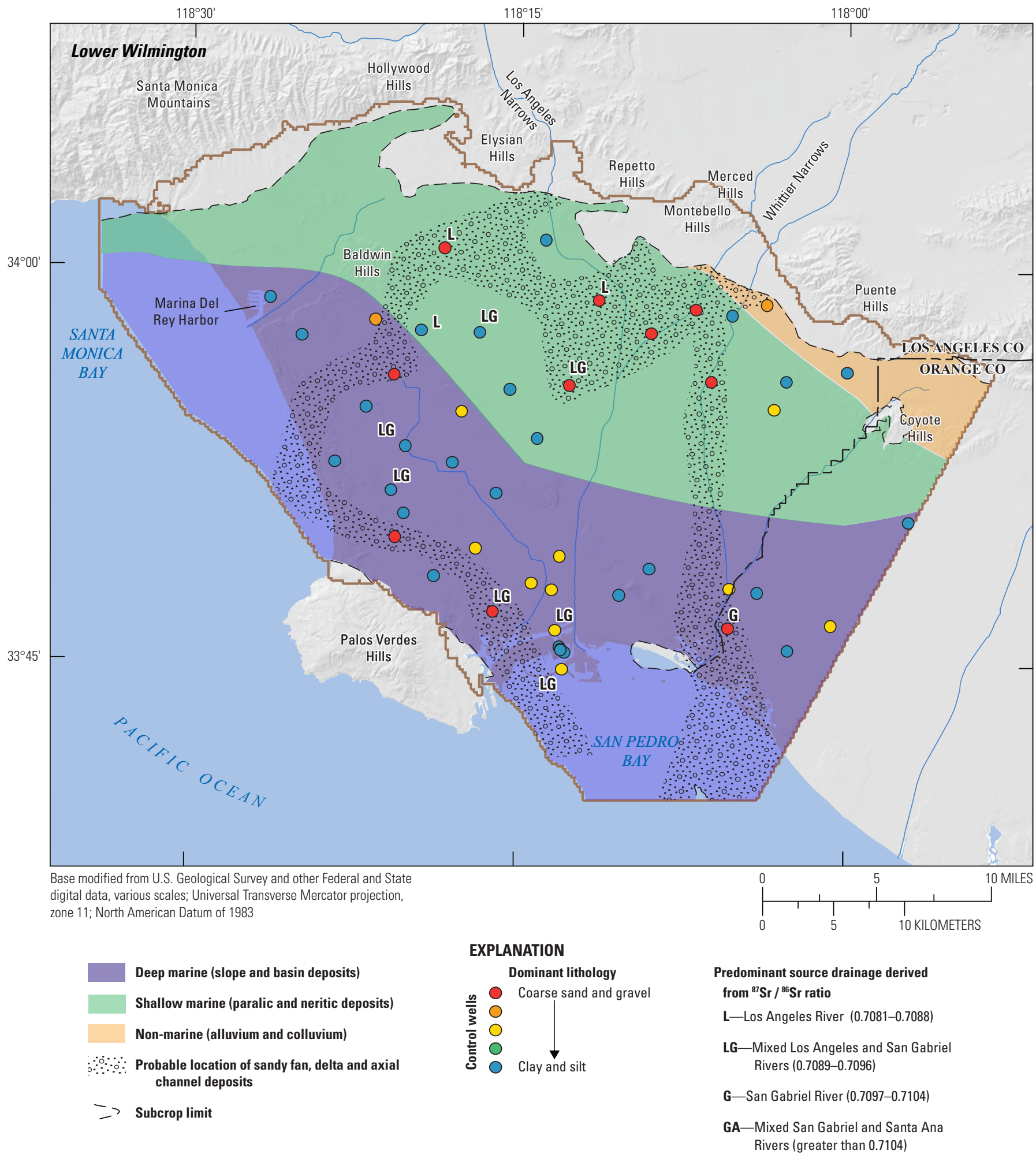

Figure B11. Inferred facies distribution of the Lower Wilmington chronostratigraphic unit, Los Angeles Coastal Plain, California, with dominant lithologies from control wells and source drainages derived from available strontium-isotope data. Abbreviation: ${ }^{87} \mathrm{Sr} /{ }^{86} \mathrm{Sr}$, strontium [Sr] isotope ratio, dimensionless values; Sr has two stable isotopes (strontium-87 [ $\left.{ }^{87} \mathrm{Sr}\right]$ and strontium-86 [ $\left.{ }^{86} \mathrm{Sr}\right]$ ). 


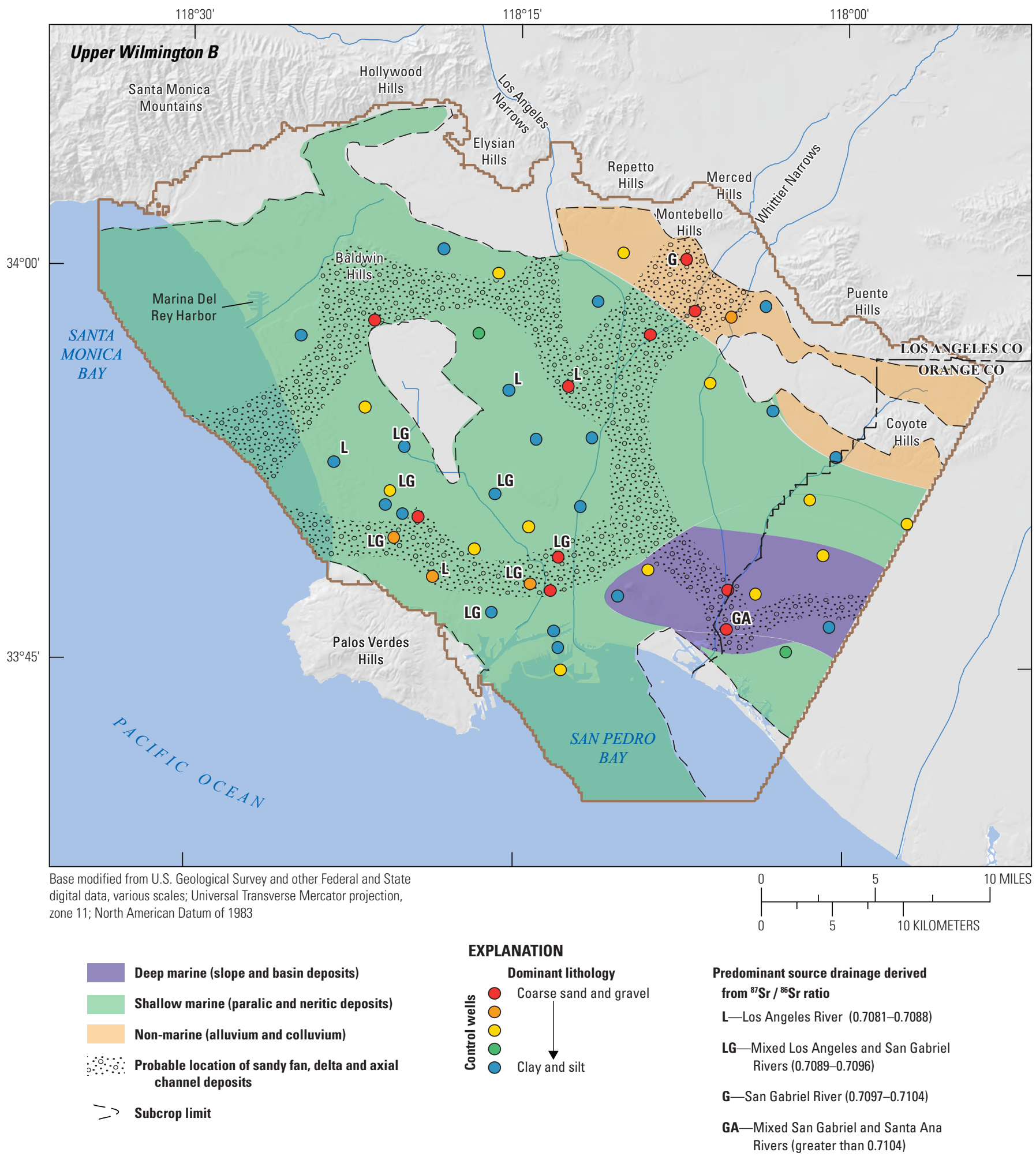

Figure B12. Inferred facies distribution of the Upper Wilmington B chronostratigraphic unit, Los Angeles Coastal Plain, California, with dominant lithologies from control wells and source drainages derived from available strontium-isotope data. Abbreviation: ${ }^{87} \mathrm{Sr} /{ }^{86} \mathrm{Sr}$, strontium [Sr] isotope ratio, dimensionless values; Sr has two stable isotopes (strontium-87 [ $\left.{ }^{87} \mathrm{Sr}\right]$ and strontium-86 [ $\left.{ }^{86} \mathrm{Sr}\right]$ ). 


\section{Upper Wilmington A}

The Upper Wilmington A chronostratigraphic unit comprises the uppermost part of Ponti and others' (2007) Upper Wilmington unit. The best estimate for the age of the Upper Wilmington A unit is between 340 and $434 \mathrm{ka}$ (table B2) based on correlation to marine oxygen isotope stages (Bassinot and others, 1994).

In the Long Beach area and western Central Basin, the Upper Wilmington A unit contains the Silverado aquifer, which is a major producing aquifer (Reichard and others, 2003). As with the Upper Wilmington B unit, electric-log signatures and well logs from across the LACP indicate that the Upper Wilmington A unit was primarily deposited in shallow marine waters (inner to outer neritic). An episode of substantial delta progradation occurred southward across the shelf from the Whittier Narrows area toward San Pedro Bay before turning westward across Long Beach and north of the Palos Verdes Hills into Santa Monica Bay (fig. B13). There is also indication of another series of likely deltaic channel deposits that source from the Los Angeles Narrows and extend west across the Newport-Inglewood fault zone and then southward toward Long Beach (fig. B13). Seismic-reflection data indicate that in the eastern part of the West Coast Basin the Upper Wilmington A unit is incised into the underlying, generally finer-grained, Upper Wilmington B unit. The Upper Wilmington A unit locally completely erodes the Upper Wilmington B unit in this area. The Upper Wilmington A channel that laterally juxtaposes the coarse-grained Upper Wilmington A deposits from the generally finer-grained Upper Wilmington B unit at similar depths may explain water-level differences in wells that have previously been attributed to the inferred Charnock fault (a northwest-trending structure that has been mapped approximately coincident with the Upper Wilmington A channel's western margin; California Department of Water Resources, 1961). However, this study and previous studies (Wright, 1991; Legg Geophysical, Inc., 2016) have failed to find evidence of faulting within the Pleistocene section that could form such a hydrologic barrier.

\section{Bent Spring}

In the San Pedro area, the Bent Spring chronostratigraphic unit is correlated by Ponti and others (2007) to San Pedro Sand, Timms Point Silt, and Lomita Marl of Woodring and others (1946), where the Bent Spring unit represents a thick, prograding shallow marine delta that was deposited into a subsiding northwest-southeast trending basin along the north side of the Palos Verdes Hills. Over much of the Central Basin, however, the unit is quite thin (less than $350 \mathrm{ft}$ ), as evidenced in seismic-reflection profiles. Data from the Long Beach area provide an age estimate of between 200 and $500 \mathrm{ka}$ for the Bent Spring chronostratigraphic unit (McDougall and others, 2012). Bounding constraints from the underlying Upper Wilmington A chronostratigraphic unit and thermoluminescence (TL) ages suggest that the age of Bent Spring is most likely between 295 and $340 \mathrm{ka}$ (Bassinot and others, 1994; McDougall and others, 2012; table B2).

Strontium-isotope data suggest that the thick deltaic sands of the Bent Spring unit found near the Palos Verdes Hills were sourced from the Whittier Narrows and Los Angeles Narrows areas. Coarse-grained zones within the Bent Spring unit are also noted in the southern Central Basin (fig. B14). The Bent Spring unit is missing locally along the Newport-Inglewood fault zone of deformation-likely the result of subsequent uplift and erosion along this trend.

\section{Harbor}

In the Long Beach area, the Harbor chronostratigraphic unit is an areally extensive series of deposits that record a coastal progradation and encompass a number of sedimentary environments ranging from fluvial channels, fans, and floodplains to coastal beach and paralic environments like tidal flats and lagoons. In the Central Basin, electric-log signatures and well-log descriptions indicate that the Harbor unit probably is of shallow, open marine origin (fig. B15). The top of the Harbor unit is not clearly distinguishable as an unconformity in seismic-reflection profiles.

The age of the Harbor chronostratigraphic unit, based on macrofossils and TL (Aitken, 1985) dates from the Long Beach area (McDougall and others, 2012) is constrained between 100 and $275 \mathrm{ka}$, with a best estimate inferred from ages of underlying and overlying sequences of between approximately 186-248 ka (table B2). The Harbor unit reaches a thickness of more than $650 \mathrm{ft}$ in the Central Basin and appears to mark an acceleration in the rate of basin subsidence in the Central Basin that continued through deposition of the Pacific A chronostratigraphic unit. 


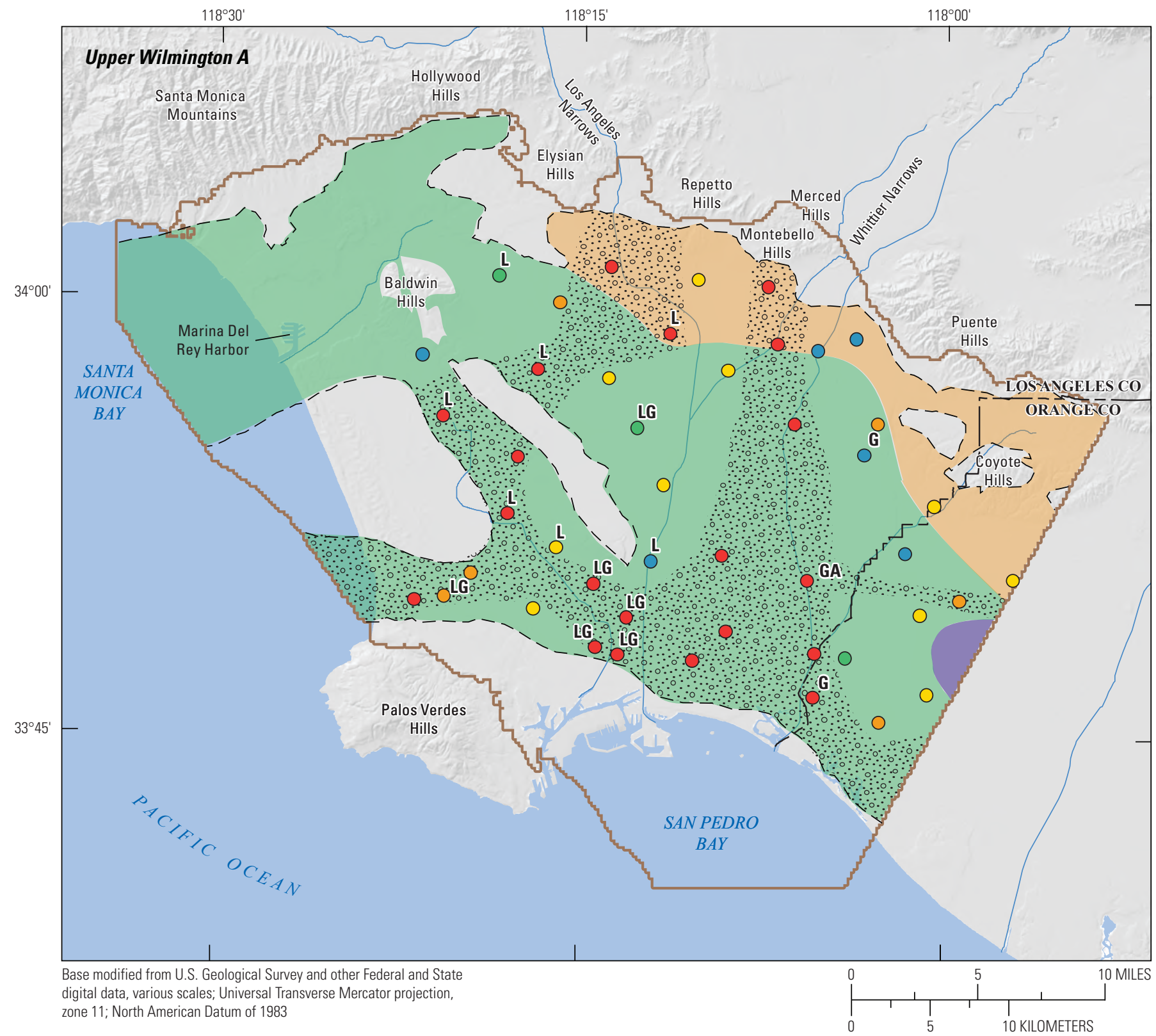

\section{zone 11; North American Datum of 1983}

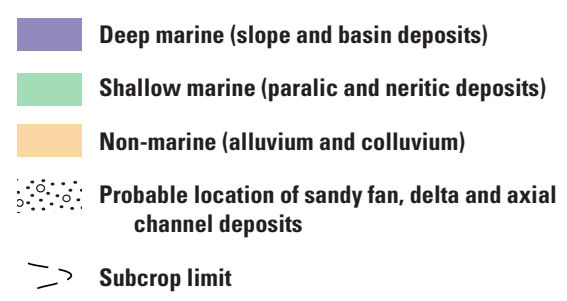

\section{EXPLANATION}

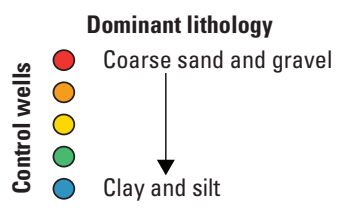

\begin{abstract}
Predominant source drainage derived from ${ }^{87} \mathrm{Sr} /{ }^{86} \mathrm{Sr}$ ratio

L-Los Angeles River (0.7081-0.7088)

LG-Mixed Los Angeles and San Gabriel Rivers (0.7089-0.7096)

G-San Gabriel River (0.7097-0.7104)

GA-Mixed San Gabriel and Santa Ana Rivers (greater than 0.7104)
\end{abstract}

Figure B13. Inferred facies distribution of the Upper Wilmington A chronostratigraphic unit, Los Angeles Coastal Plain, California, with dominant lithologies from control wells and source drainages derived from available strontium-isotope data. Abbreviation: ${ }^{87} \mathrm{Sr} /{ }^{86} \mathrm{Sr}$, strontium [Sr] isotope ratio, dimensionless values; Sr has two stable isotopes (strontium-87 [ $\left.{ }^{87} \mathrm{Sr}\right]$ and strontium-86 [86 $\left.{ }^{86}\right]$ ). 


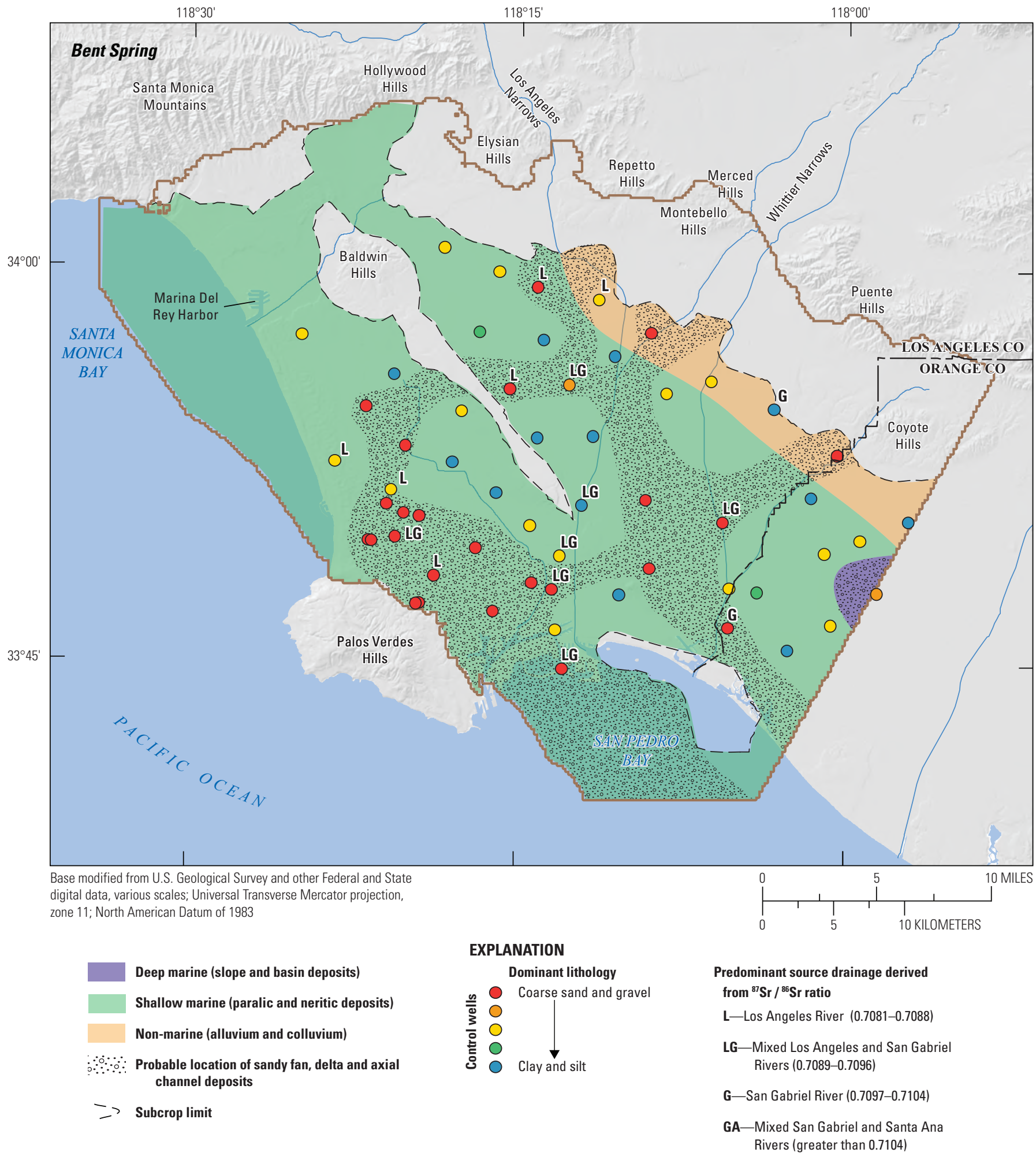

Figure B14. Inferred facies distribution of the Bent Spring chronostratigraphic unit, Los Angeles Coastal Plain, California, with dominant lithologies from control wells and source drainages derived from available strontium-isotope data. Abbreviation: ${ }^{87} \mathrm{Sr} /{ }^{86} \mathrm{Sr}$, strontium [Sr] isotope ratio, dimensionless values; Sr has two stable isotopes (strontium-87 [ $\left.{ }^{87} \mathrm{Sr}\right]$ and strontium-86 [86 Sr]). 


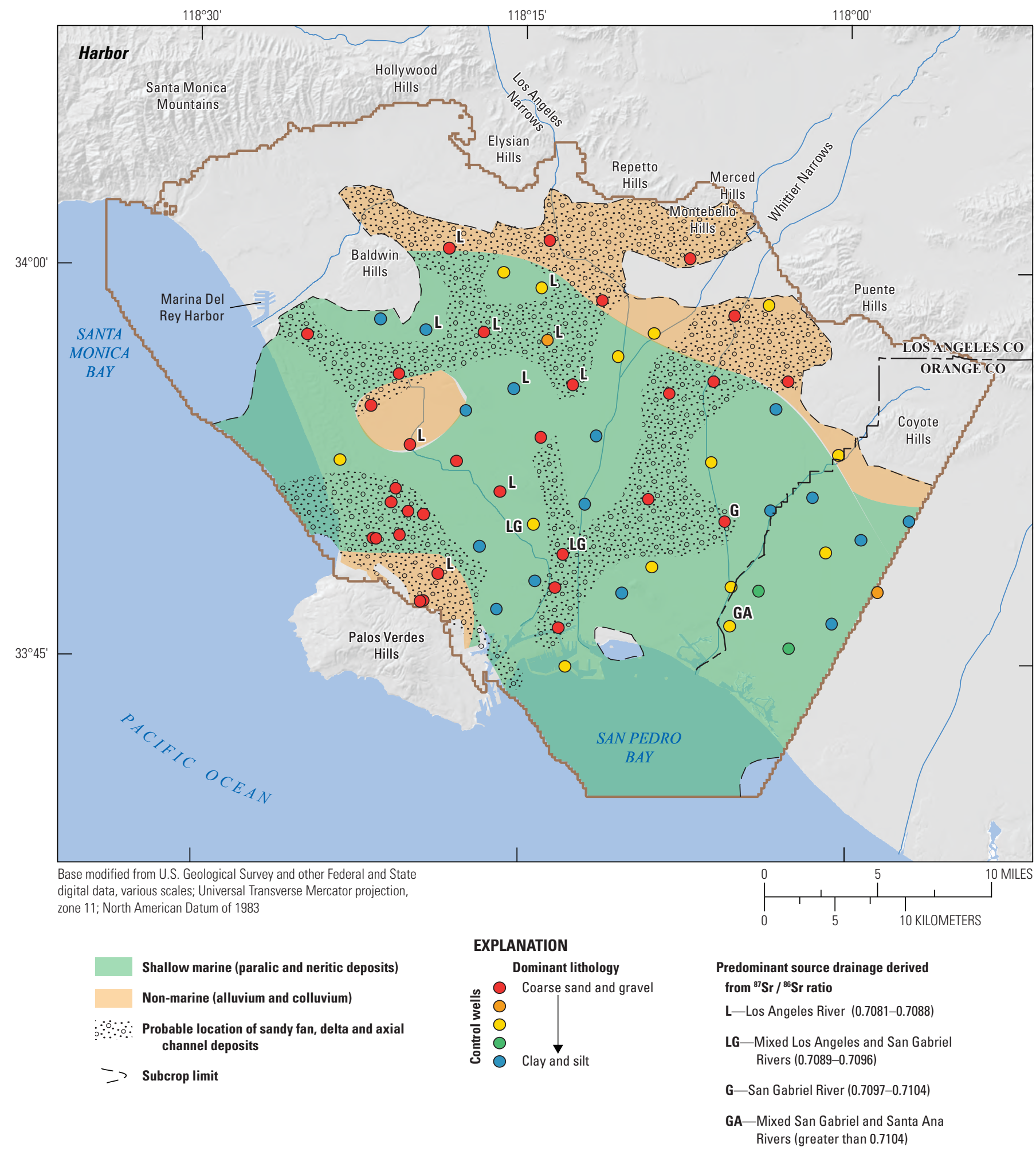

Figure B15. Inferred facies distribution of the Harbor chronostratigraphic unit with dominant lithologies from control wells and source drainages derived from available strontium-isotope data. Abbreviation: ${ }^{87} \mathrm{Sr} /{ }^{86} \mathrm{Sr}$, strontium [Sr] isotope ratio, dimensionless values; $\mathrm{Sr}$ has two stable isotopes (strontium-87 [ $\left.{ }^{87} \mathrm{Sr}\right]$ and strontium-86 [ $\left.{ }^{86} \mathrm{Sr}\right]$ ). 


\section{Pacific}

In the Long Beach area, the Pacific chronostratigraphic unit is believed to have resulted from marine high-stand progradation during early $\delta^{18} \mathrm{O}$ stage 5 , (approximately 97-133 ka; Bassinot and others, 1994; $\delta^{18} \mathrm{O}$ is a measure of the ratio of stable isotopes oxygen-18 $\left[{ }^{18} \mathrm{O}\right]$ and oxygen-16 $\left[{ }^{16} \mathrm{O}\right]$, see appendix 1), based on thermoluminescence ages, macrofossil data, amino-acid racemization ages on marine terrace deposits, and the presence of the Blake paleomagnetic event (McDougall and others, 2012). McDougall and others (2012) reported optically stimulated luminescence (OSL; Aitken, 1998) ages from the same unit that are as young as 28-33 ka, but these ages appear to be too young as they are contradicted by the weight of other evidence. The Pacific unit appears to correlate with exposed old alluvial fans that crop out near the Coyote Hills and Santa Monica Mountains, as well as marine terrace deposits in San Pedro and the Pacific Palisades area.

The top of the Pacific chronostratigraphic unit is defined by a distinctive seismic reflector in the Central Basin, but this reflector is often difficult to correlate on many seismic lines where the horizon reaches shallow depths. In much of the West Coast Basin, and along the northeast margin of the LACP, the unit expresses a fining-upward character indicative of a non-marine origin, typically with a basal sand that grades up to a silt or silty clay that caps the unit. However, in the Central Basin where the Pacific unit reaches a thickness of more than $500 \mathrm{ft}$, the Pacific unit appears to be of shallow maring origin (paralic or neritic; fig. B16).

\section{Pacific A}

The Pacific A chronostratigraphic unit was established to accommodate observed variations of water levels and hydrograph character in wells open to sediment bounded by the underlying Pacific and overlying Mesa units. The Pacific A unit is recognized in the Central Basin only and may represent the lowermost portion of the overlying Mesa chronostratigraphic unit where the Mesa unit thickens substantially into the Central Basin (figs. B4, B5). The top of Pacific A usually is identified at the base of a fining-upward package that is often observed within the Mesa unit, but in some cases, the top of the Pacific $\mathrm{A}$ is somewhat ambiguous in borehole or electric logs. As with the Long Beach $\mathrm{BC}$ unit, we cannot determine whether the top of the Pacific A represents an unconformity-bound sequence or just conformably underlies the Mesa unit where the boundary represents an upward transition from deposits of shallow marine origin (paralic or neritic) to deposits of non-marine origin typical of the overlying Mesa chronostratigraphic unit.

Based on age estimates for the Mesa chronostratigraphic unit, the Pacific A unit is late Pleistocene in age, most likely less than $80 \mathrm{ka}$, and may be coeval with paralic deposits of the Mesa sequence in the West Coast Basin. Most of the Pacific A unit appears to be of shallow marine origin (paralic), with some likely non-marine deposits located along the eastern and western margins of the unit's extent (fig. B17).
Mesa

The Mesa chronostratigraphic unit is the youngest of the Pleistocene units in the Los Angeles Basin. Onshore, the unit is primarily of non-marine origin (alluvial-fan and flood-basin deposits), except for deposits of dune sands in the western portion of the West Coast Basin (fig. B18). The offshore portions of the Mesa unit that lie beneath San Pedro and Santa Monica Bays, and along the southern margin of the West Coast and Central Basins, are of shallow marine origin. Borehole and electric logs indicate that the Mesa unit typically has a sandy base inferred to be deposited within fluvial channels, and grades finer up-section, culminating in probable overbank or flood-basin silts and clays that typically cap the unit. The surface of the Mesa unit is exposed along the margins of the Central Basin and in the West Coast Basin (figs. B1, B18). In the Long Beach area, the Mesa unit comprises young marine terrace deposits that are inferred to be approximately $80 \mathrm{ka}$ old based on amino-acid racemization data (Ponti and others, 2007), but OSL, TL, and radiocarbon dates on fluvial deposits, and the occurrence of the Laschamp paleomagnetic event, indicate that much of the unit regionally is as young as 20-40 ka (table B2). In the subsurface, the top of the Mesa unit is readily picked at the base of a coarse sand or gravel deposit that generally marks the beginning of the Holocene progradation. The Mesa unit reaches a maximum thickness of about $300 \mathrm{ft}$ in the Central Basin.

\section{Dominguez}

The Dominguez chronostratigraphic unit is the result of deposition that occurred in response to worldwide climate change that initiated the Holocene epoch. As the Pleistocene climate ameliorated, sea level began to rise, and vegetation assemblages in the mountains ringing the Los Angeles Basin shifted from conifer-dominated to the oak-grassland-chaparra 1-dominated sclerophyllous vegetation common on today's hillslopes in central and southern California (Bull, 1991). Consequently, the thick mantle of weathered rock and soil materials that accumulated on the hillslopes under coniferous forest conditions became unstable as the conifers died out and were replaced by oaks. Wildland fires also became more frequent, further serving to destabilize the landscape and expose the soil mantle to erosional processes. Resultant erosion caused mountain streams to aggrade rapidly and push sediment out onto the coastal plain, ultimately filling the eroded channels and blanketing the coastal plain with flood deposits. In offshore areas and just inland of the current coastline, sediments of the Dominguez chronostratigraphic unit are of shallow-marine origin (fig. B19).

The Dominguez chronostratigraphic unit reaches a thickness of more than $200 \mathrm{ft}$ in the Central Basin. The Dominguez unit typically comprises a sandy or gravelly basal unit that grades up into silt, although in some areas, the basal unit is composed of fine sand or silty sand. OSL, TL, and radiocarbon dates, as well as macrofossil evidence from the Long Beach area, indicate that the Dominguez unit is younger than $18 \mathrm{ka}$ (McDougall and others, 2012; table B2). 


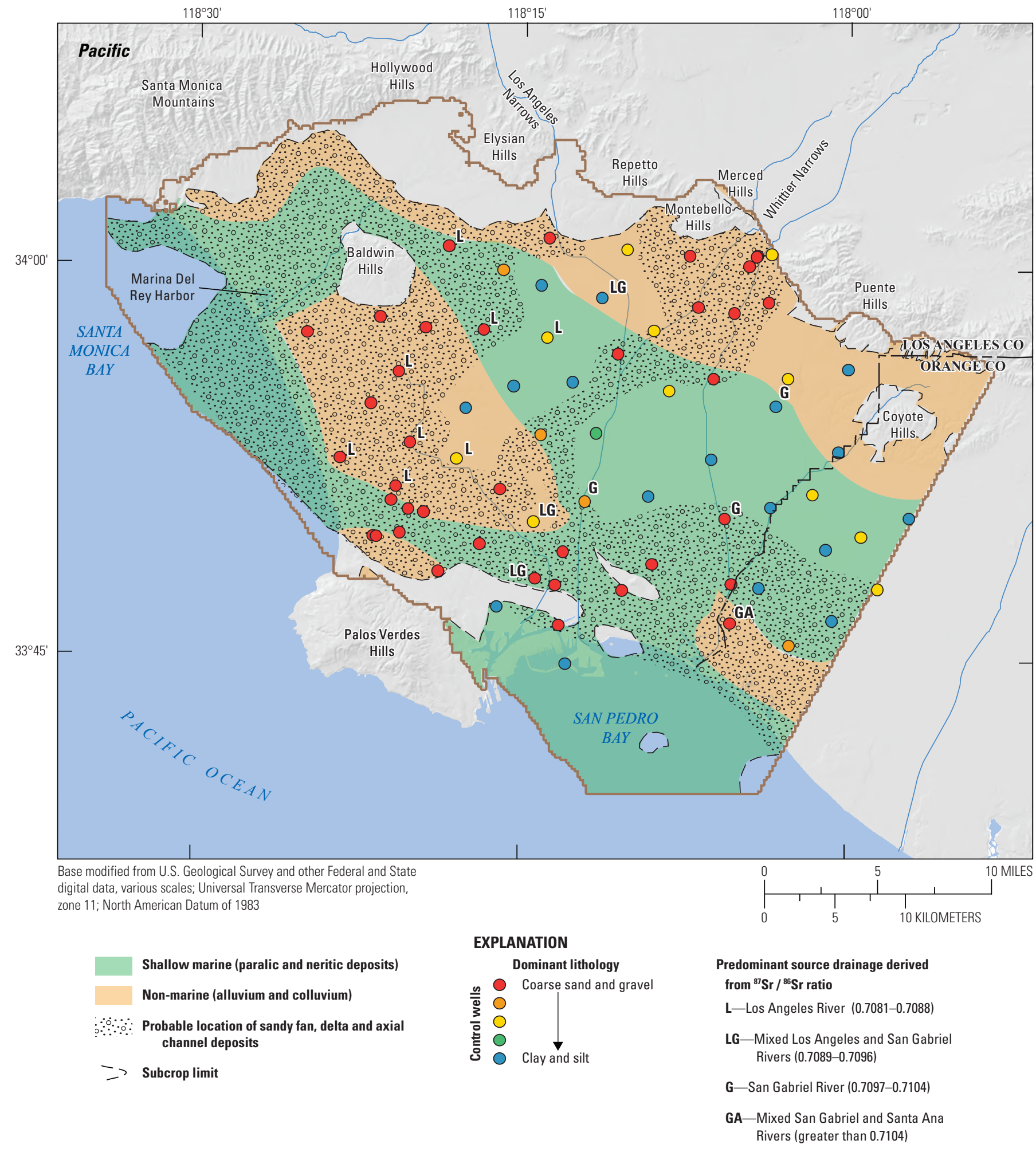

Figure B16. Inferred facies distribution of the Pacific chronostratigraphic unit, Los Angeles Coastal Plain, California, with dominant lithologies from control wells and source drainages derived from available strontium-isotope data. Abbreviation: ${ }^{87} \mathrm{Sr} /{ }^{86} \mathrm{Sr}$, strontium $[\mathrm{Sr}]$ isotope ratio, dimensionless values; $\mathrm{Sr}$ has two stable isotopes (strontium-87 [ $\left.{ }^{87} \mathrm{Sr}\right]$ and strontium-86 [ $\left.{ }^{86} \mathrm{Sr}\right]$ ). 


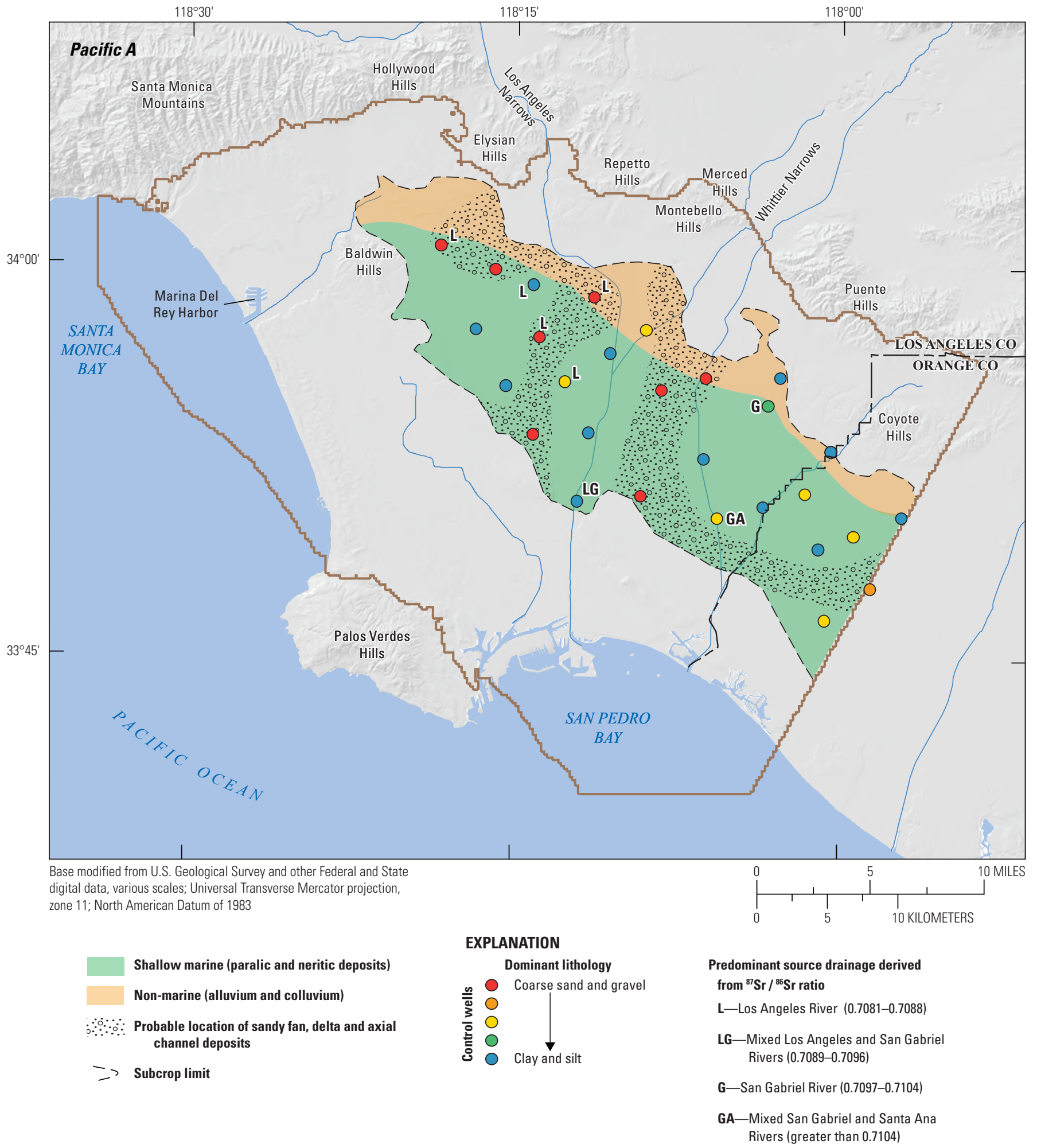

Figure B17. Inferred facies distribution of the Pacific A chronostratigraphic unit, Los Angeles Coastal Plain, California, with dominant lithologies from control wells and source drainages derived from available strontium-isotope data. Abbreviation: ${ }^{87} \mathrm{Sr} /{ }^{86} \mathrm{Sr}$, strontium [Sr] isotope ratio, dimensionless values; $\mathrm{Sr}$ has two stable isotopes (strontium-87 [ $\left.{ }^{87} \mathrm{Sr}\right]$ and strontium-86 [ $\left.{ }^{86} \mathrm{Sr}\right]$ ). 


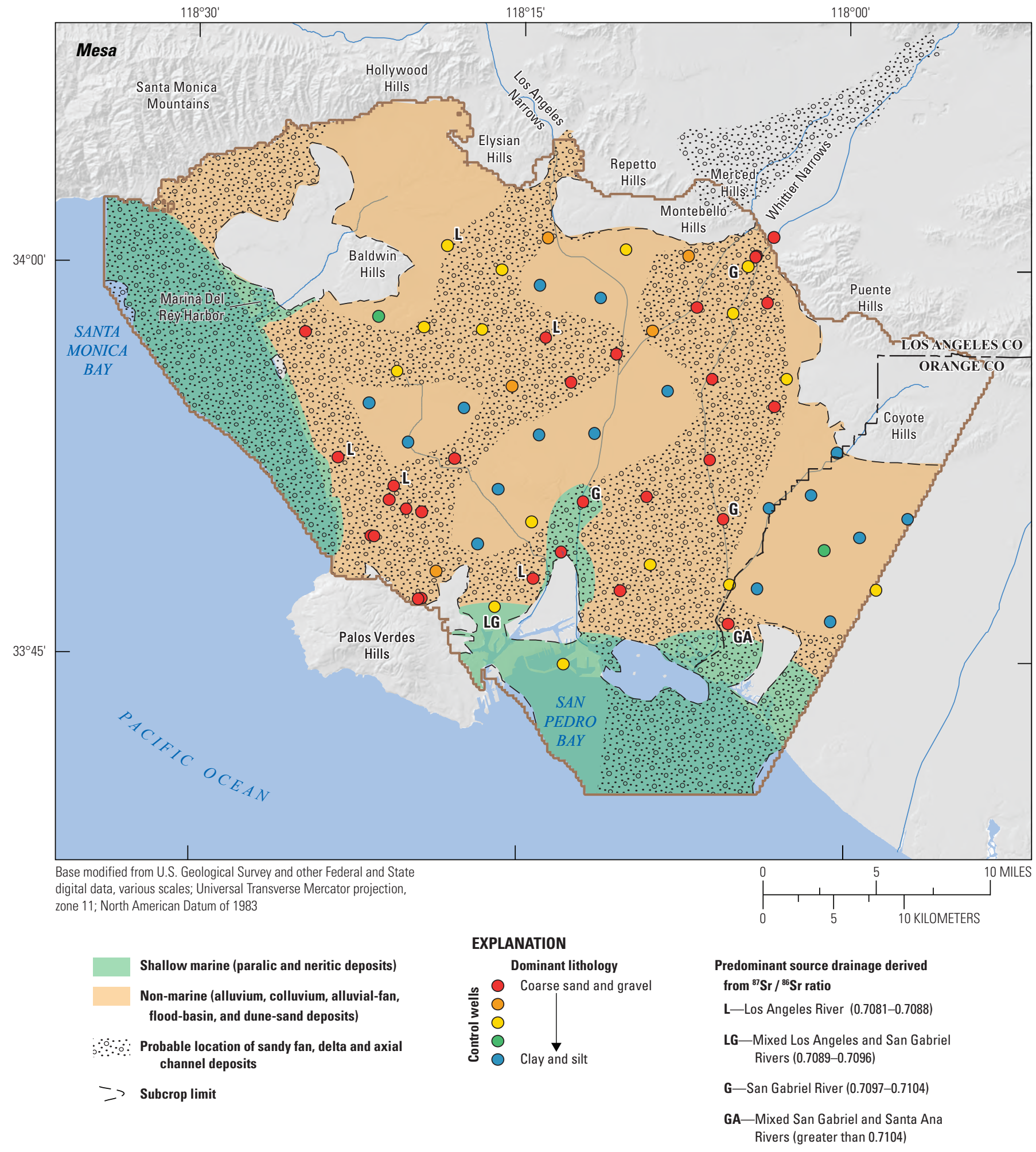

Figure B18. Inferred facies distribution of the Mesa chronostratigraphic unit, Los Angeles Coastal Plain, California, with dominant lithologies from control wells and source drainages derived from available strontium-isotope data. Abbreviation: ${ }^{87} \mathrm{Sr} /{ }^{86} \mathrm{Sr}$, strontium [Sr] isotope ratio, dimensionless values; $\mathrm{Sr}$ has two stable isotopes (strontium-87 [ $\left.{ }^{87} \mathrm{Sr}\right]$ and strontium-86 [ $\left.{ }^{86} \mathrm{Sr}\right]$ ). 


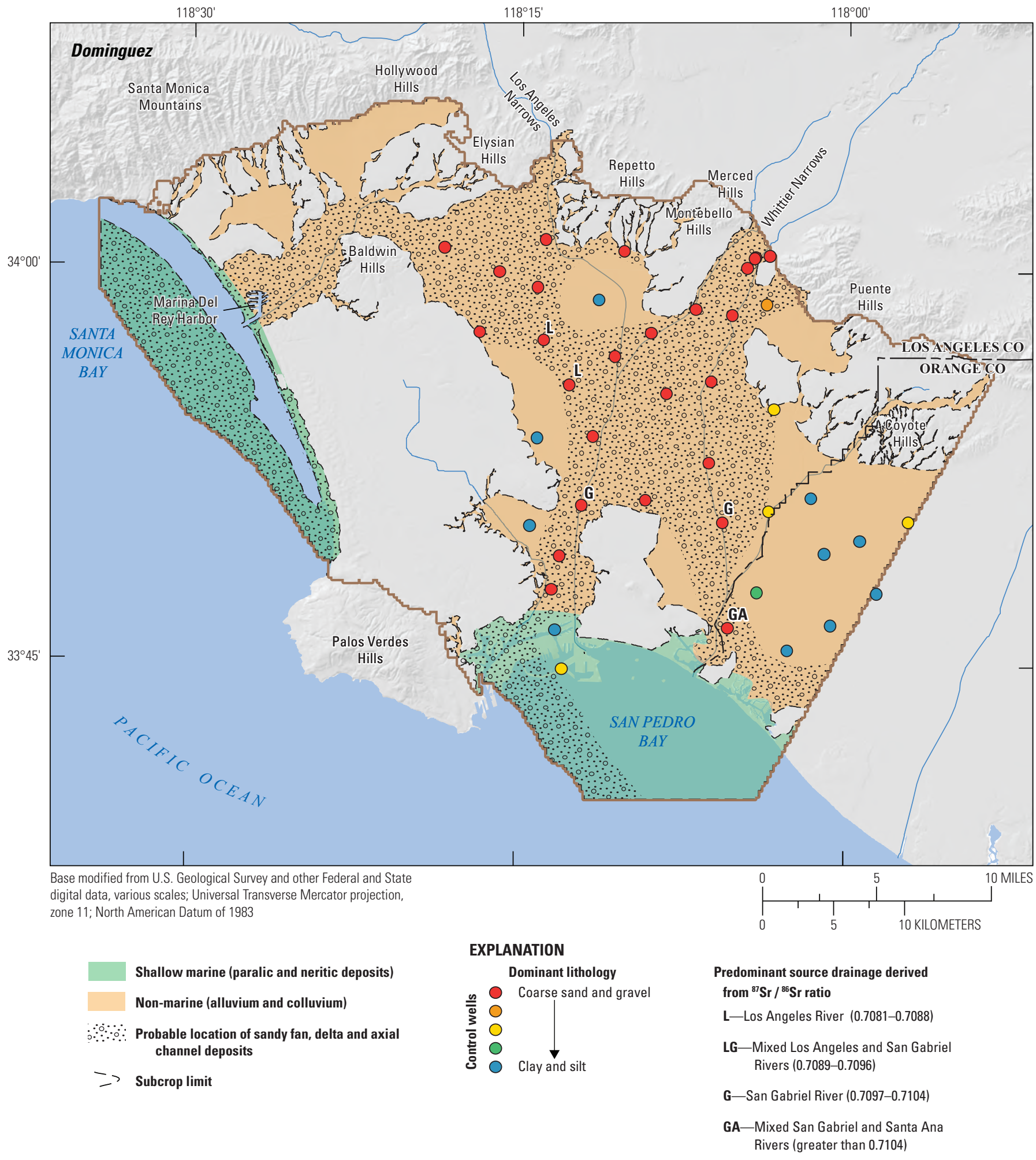

Figure B19. Inferred facies distribution of the Dominguez chronostratigraphic unit, Los Angeles Coastal Plain, California, with grain-size distribution from key wells and available strontium-isotope data. Abbreviation: ${ }^{87} \mathrm{Sr} /{ }^{86} \mathrm{Sr}$, strontium [Sr] isotope ratio, dimensionless values; $\mathrm{Sr}$ has two stable isotopes (strontium-87 [ $\left.{ }^{87} \mathrm{Sr}\right]$ and strontium-86 [ $\left.{ }^{86} \mathrm{Sr}\right]$ ). 


\section{Comparison of the Chronostratigraphic Framework to Previous Hydrogeologic Units and Aquifer Nomenclature}

Previously, the LACP was divided into five hydrogeologic units: (1) the Recent aquifer system, (2) the Lakewood aquifer system, (3) the Upper San Pedro aquifer system, (4) the Lower San Pedro aquifer system, and (5) the nontransmissive Pico unit (Reichard and others, 2003). These hydrostratigraphic units generally followed the architecture and geologic structure presented in the California Department of Water Resources (1961), modified slightly based on additional lithologic and borehole geophysical data collected by the USGS during construction of multiple-well monitoring sites in the LACP. In general, the Recent aquifer system corresponds to the shallow Gaspur, Ballona, and Talbert aquifers of the California Department of Water Resources (1961). The Lakewood aquifer system corresponds to a package of non-marine and marine (paralic) sediment that roughly correlates to the Lakewood Formation of the California Department of Water Resources (1961). The Upper San Pedro aquifer system corresponds to shallow marine deposits of the San Pedro Formation that contains the Lynwood and Silverado aquifers of the California Department of Water Resources (1961), and the Lower San Pedro aquifer system corresponds to shallow marine deposits of the lower portion of the San Pedro Formation that contains the Sunnyside aquifer of the California Department of Water Resources (1961). The Pico unit represents the base of the active groundwater system and corresponds to fine-grained marine deposits identified as the Pico Formation by the California Department of Water Resources (1961). Although there are slight differences in the location of unit boundaries between the framework of the California Department of Water Resources (1961) and that of Reichard and others (2003), there is essentially a one-to-one correspondence between the units across the entire LACP.

The chronostratigraphic framework model used for this study differs from frameworks of previous studies. In this study, chronostratigraphic units are defined and mapped based on their bounding unconformities and not based on lithologic characteristics and inferred depositional environments like in previous studies. Defining units based on bounding unconformities allows for a better understanding of the distribution of lithologic facies within each of the depositional units. The chronostratigraphic framework model also utilizes multiple seismic-reflection profiles collected throughout the LACP (fig. B3) to more accurately represent the geologic structure of the basin than the previous models (figs. B20-B22). Therefore, the chronostratigraphic layering can more accurately represent aquifer connectivity and the direction of anisotropy within the basin. Furthermore, a groundwater-flow model based on a chronostratigraphic model may more accurately model anisotropic flow and the connectivity of aquifer systems. Specific comparisons between the chronostratigraphic units defined for this study and the lithostratigraphic formations and aquifers defined by the California Department of Water Resources (1961) and Reichard and others (2003) are presented in table B2 for three specific locations in the basin (fig. B1).

Over much of the LACP, good agreement was observed between the youngest chronostratigraphic units (Dominguez and Mesa) and the youngest aquifers identified by California Department of Water Resources (CDWR; 1961; for example, Gaspur and Exposition aquifers; figs. B20-B22). This relation was not unexpected because in the previous frameworks, original depositional surfaces of Holocene and late Pleistocene alluvial-fan and basin deposits are mostly preserved and are delineated using geomorphology and stratigraphic position; thus, the CDWR youngest aquifer units are essentially equivalent to the chronostratigraphic units used for this study. However, the associations between the older chronostratigraphic units and the previously defined aquifer and formation boundaries became more complex from the basin margins to the Central Basin. The formations and aquifers, as represented in the lithostratigraphic frameworks of the California Department of Water Resources (1961) and Reichard and others (2003), cross timelines defined by the chronostratigraphic model and do not extend to the depths observed for the chronostratigraphic units. As a result, the structural relief of the Central Basin, and to a lesser extent the West Coast Basin, is considerably muted in the lithostratigraphic-framework models relative to the chronostratigraphic model (figs. B20-B22).

The chronostratigraphic units contain related packages of sediment that were deposited during the same time period in response to base-level change. However, the lithostratigraphically defined formations and aquifers contain sediments that were deposited at considerably different times from the basin margin to the basin center. This variability in deposition implies that many of the aquifers defined lithostratigraphically are composed of multiple depositional units and likely are not areally connected as inferred in the older models. For example, the Lynwood and Silverado aquifers of the California Department of Water Resources (1961; Upper San Pedro aquifer system of Reichard and others, 2003) generally are associated with the Bent Spring and Upper Wilmington A and B chronostratigraphic units along the eastern and western margins of the Central Basin, whereas the Lynwood and Silverado aquifers are associated with the Pacific and Harbor chronostratigraphic units in the middle of the Central Basin (fig. B22). Along the eastern edge of the Central Basin, the Silverado and Lynwood aquifers are typically associated with the Lower Wilmington and older chronostratigraphic units that have been uplifted to shallow depths (figs. B20-B22). In general, the Sunnyside aquifer (Lower San Pedro system of Reichard and others, 2003) is associated with the Lower Wilmington chronostratigraphic unit in the West Coast Basin but is within units as young as the Harbor unit in the Central Basin (figs. B20-B21). 


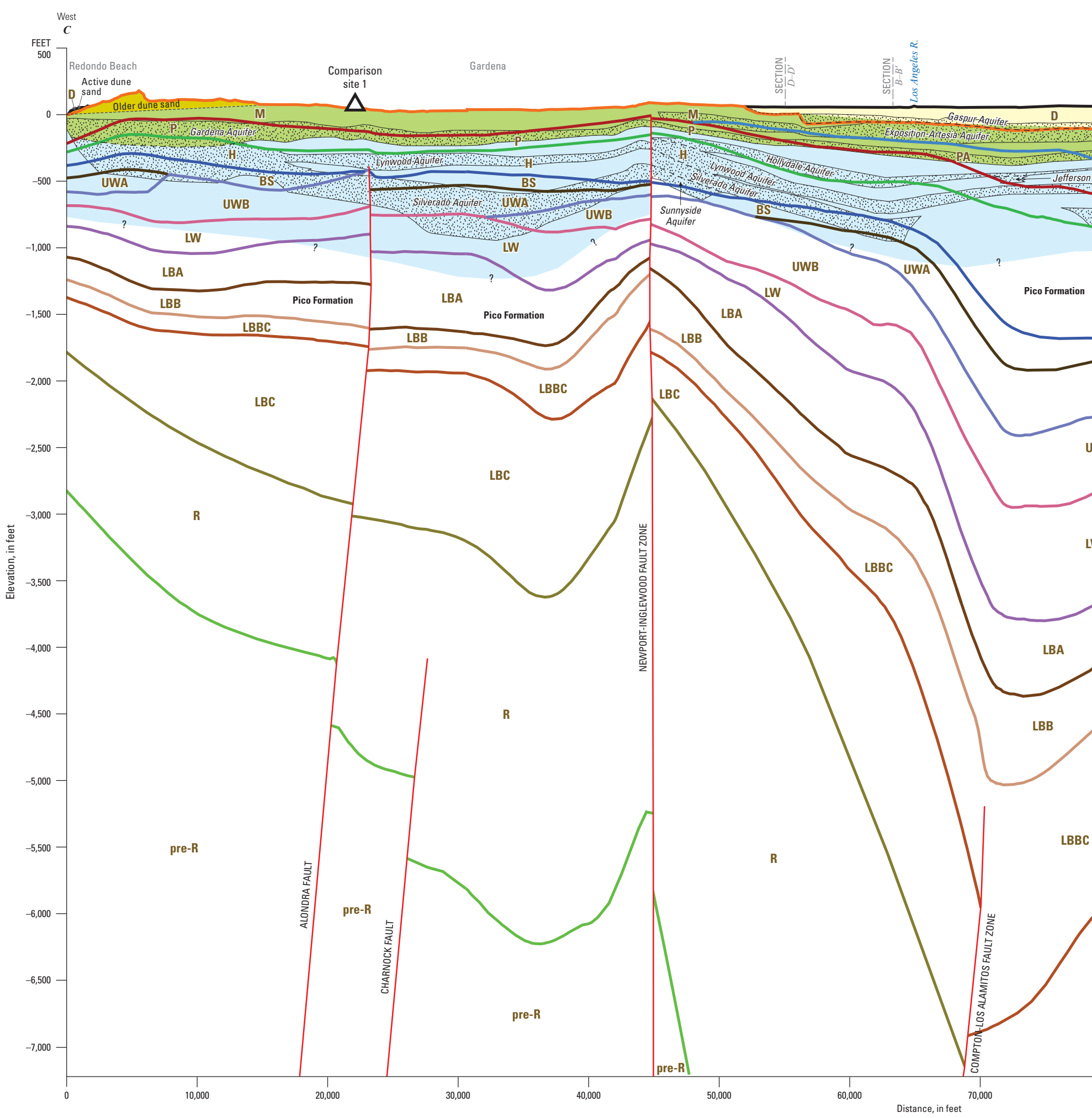

Figure B20. Modeled chronostratigraphic unit boundaries along cross-section C-C', this study, compared to lithostratigraphic formations (colored shading; queried where uncertain) and aquifers of the California Department of Water Resources (1961), Los Angeles Coastal Plain, California. (Trace of section is shown in fig. B1; colored lines mark the top of each unit; unit identifier codes: D, Dominguez; M, Mesa; PA, Pacific A; P, Pacific; H, Harbor; BS, Bent Spring; UWA, Upper Wilmington A; UWB, Upper Wilmington B; LW, Lower Wilmington; LBA, Long Beach A; LBB, Long Beach B; LBBC, Long Beach BC; LBC, Long Beach C; R, "Repetto"; pre-R, pre-Repetto.) 


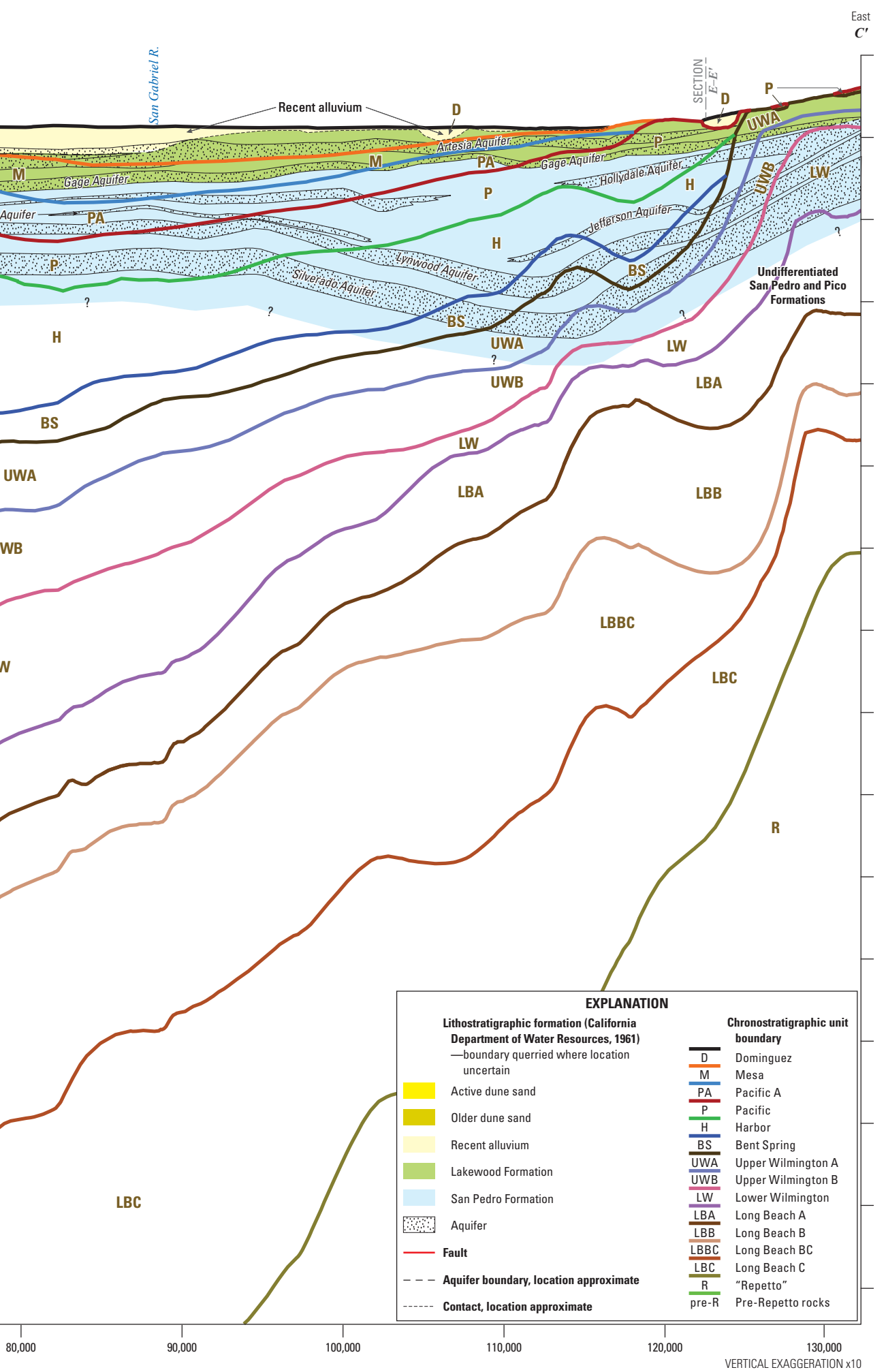




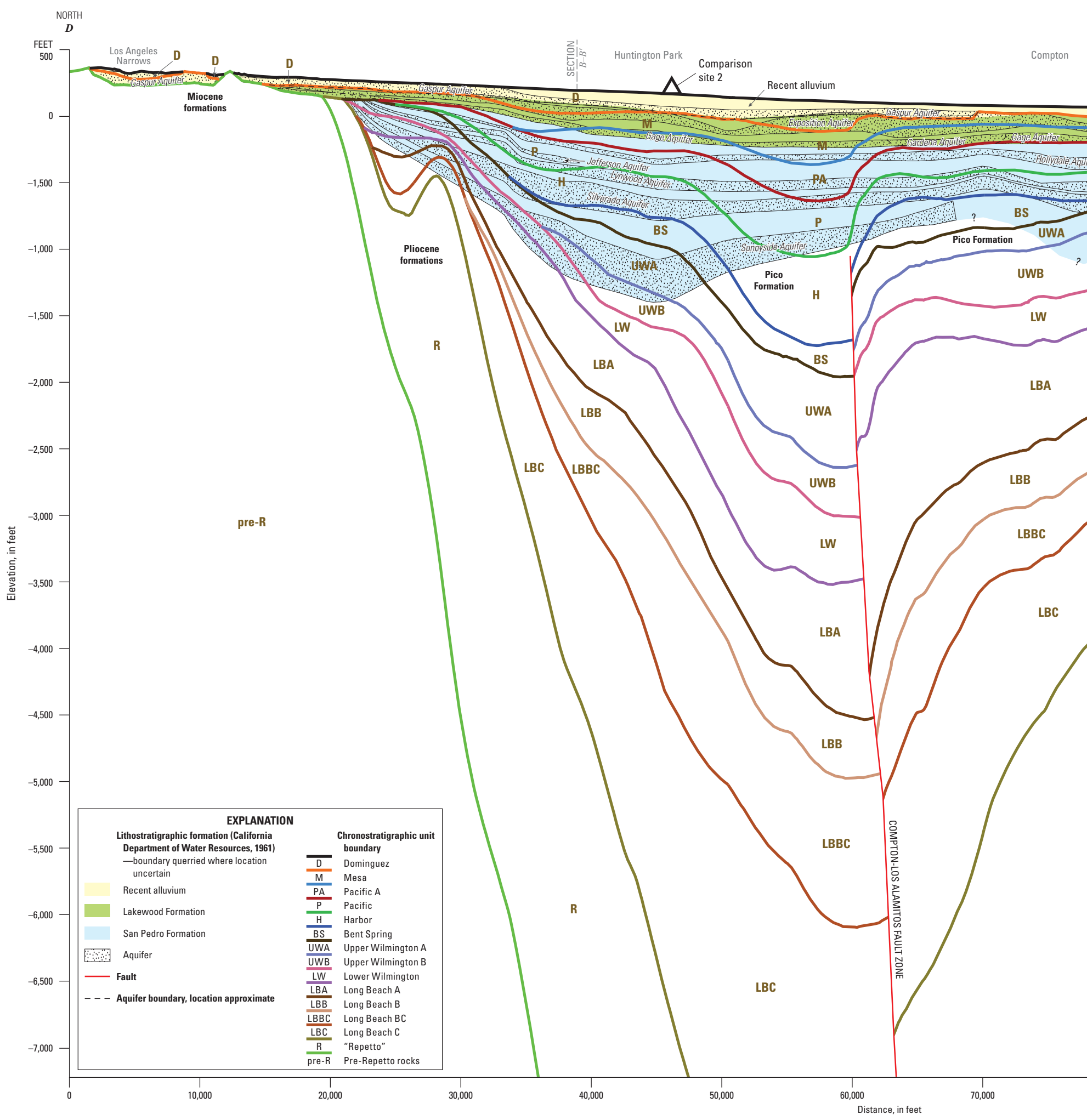

Figure B21. Modeled chronostratigraphic unit boundaries along cross-section D-D', this study, compared to lithostratigraphic formations (colored shading; queried where uncertain) and aquifers of the California Department of Water Resources (1961), Los Angeles Coastal Plain, California. Queried lithostratigraphic boundaries are as noted in California Department of Water Resources, 1961. (Trace of section is shown in fig. B1; colored lines mark the top of each unit; unit identifier codes: $D$, Dominguez; M, Mesa; PA, Pacific A; P, Pacific; H, Harbor; BS, Bent Spring; UWA, Upper Wilmington A; UWB, Upper Wilmington B; LW, Lower Wilmington; LBA, Long Beach $A$; LBB, Long Beach B; LBBC, Long Beach BC; LBC, Long Beach C; R, “Repetto”; pre-R, pre-Repetto.) 


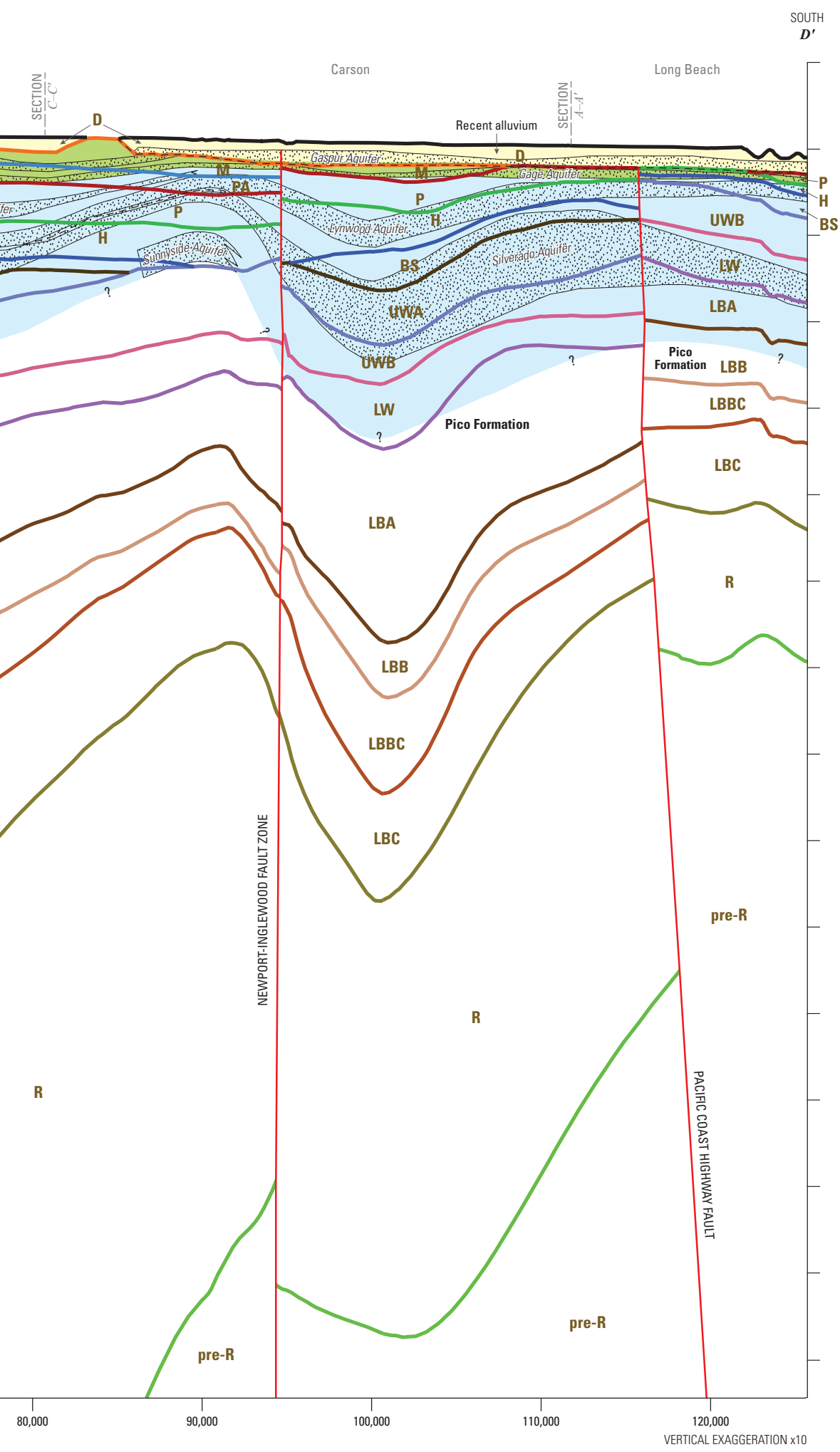




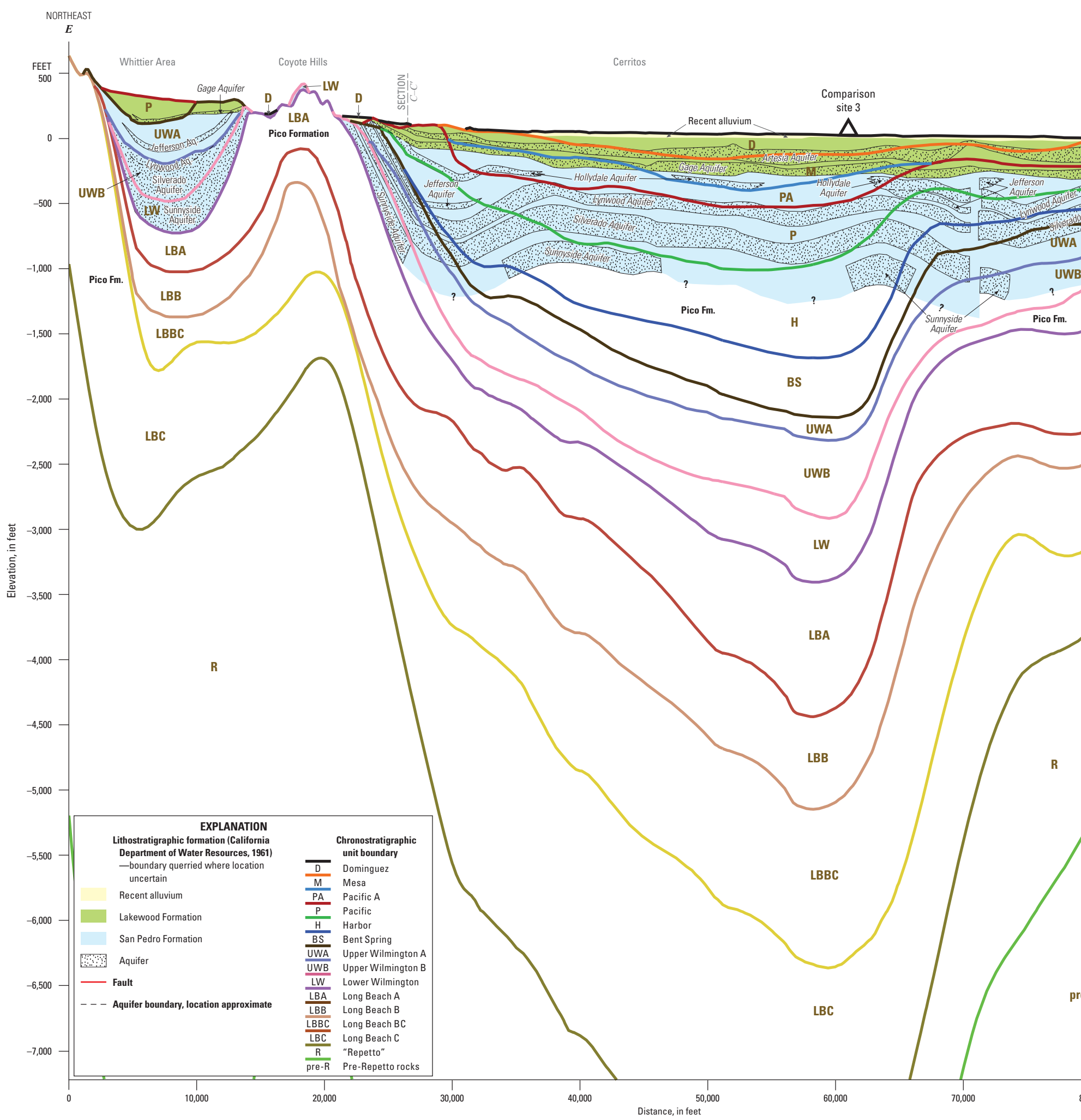

Figure B22. Modeled chronostratigraphic unit boundaries along cross-section E-E', this study, compared to lithostratigraphic formations (colored shading; queried where uncertain) and aquifers of the California Department of Water Resources (1961), Los Angeles Coastal Plain, California. (Trace of section is shown in fig. B1; colored lines mark the top of each unit; unit identifier codes: D, Dominguez; M, Mesa; PA, Pacific A; P, Pacific; H, Harbor; BS, Bent Spring; UWA, Upper Wilmington A; UWB, Upper Wilmington B; LW, Lower Wilmington; LBA, Long Beach A; LBB, Long Beach B; LBBC, Long Beach BC; LBC, Long Beach C; R, “Repetto"; pre-R, pre-Repetto.) 


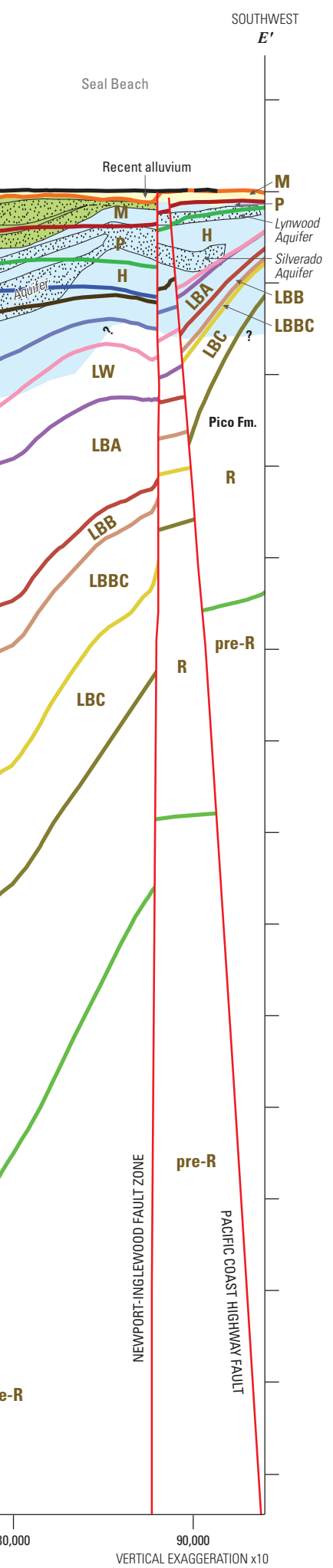




\section{Geological Structures}

The current understanding of the structural and tectonic history of the Los Angeles Basin has been described by Wright (1991), who summarized a considerable body of previous work, including the seminal work of Yerkes and others (1965). The Los Angeles Basin is at the northern end of the Peninsular Ranges geomorphic province (not shown). Structurally, the Peninsular Ranges province is characterized by fault zones that trend northwest to west-northwest (Wright, 1991). The Los Angeles Basin's structural character makes it of considerable geologic interest as an area of major oil production and active seismicity.

The LACP lies within the central and southwestern structural blocks of the Los Angeles Basin (Reichard and others, 2003). The most prominent feature of the basins in the LACP is the steep-sided Central Basin syncline (or Paramount syncline), which appears prominently in the structure contour map constructed on the base of the Long Beach $\mathrm{C}$ chronostratigraphic unit (fig. B23). The syncline is bounded on the west by the Compton-Los Alamitos fault and on the east by the Puente Hills thrust system (Shaw and others, 2002), which is mostly blind, except for a small portion of the Los Angeles section that offsets the base of the Long Beach $\mathrm{C}$ unit (fig. B23). Segmentation of the Puente Hills blind-thrust system has produced a number of localized uplifts east of the east limb of the syncline, most notably the Santa Fe Springs anticline, which trends west-northwest and steps over to the West Coyote anticlines to the east (Myers and others, 2003). Reichard and others (2003) inferred the existence of the Norwalk fault, which was believed to occur on the southwest side of these anticlines. However, our analysis reveals no evidence for any discrete stratigraphic offsets that could be attributable to a shallow Norwalk fault; instead, we conclude that these basin margin anticlines have been active from the late Pliocene to the present (Shaw and Shearer, 1999; Pratt and others, 2002; Shaw and others, 2002), resulting in thinning, pinching out, or both, of the stratigraphic units over the crest of these anticlines (Ponti and others, 2014). The thinning of the stratigraphic units over the crest would undoubtedly restrict the movement of groundwater and be a partial barrier to groundwater flow, as simulated by Reichard and others (2003) with the Norwalk fault.

The Compton-Los Alamitos fault, as defined in this study (fig. B23), extends the Los Alamitos fault of Reichard and others (2003). The Compton-Los Alamitos fault appears as an oblique right-lateral fault that extends from the eastern edge of the study area, about 2 miles (mi) northeast of the Alamitos Gap (Bray and others, 2007) northwest to the city of Inglewood (Leon and others, 2009). Based on seismic-reflection data, the fault tip appears to drop below the base of the Long Beach $\mathrm{C}$ sequence southwest of the Cerritos area (fig. B23). Similarly, the fault tip drops below the base of Long Beach C unit in the Inglewood area near the Baldwin Hills where the Compton-Los Alamitos fault appears to merge with the Newport-Inglewood fault zone. Between these end points, the fault progressively offsets (up on the west) all chronostratigraphic units through the Bent Spring unit. The overlying Harbor, Pacific, Pacific A, and Mesa units are folded over the tip of the fault and indicative of the activity of the Compton-Los Alamitos fault through the Pleistocene and possibly into the Holocene. As a result of activity of the Compton-Los Alamitos fault, and possibly the postulated underlying Compton blind thrust (Shaw and Suppe, 1996), a northeast-dipping shelf is produced between the Compton-Los Alamitos fault and Newport-Inglewood fault zone that broadens to the south and pinches out near the northern end of the basin; the structure produced by these faults affects groundwater flow as a result of bed thinning over the fold limb.

The Newport-Inglewood fault zone is a predominantly right lateral strike-slip fault system that cuts through the entire LACP and separates the Central and West Coast Basins (figs. B23 and B24). The Newport-Inglewood fault zone is part of the larger Newport-Inglewood-Rose Canyon fault zone (not shown), which extends approximately $125 \mathrm{mi}$ from the Santa Monica Mountains southeastward to San Diego Bay (Treiman and Lundberg, 1999). Although dominantly a strike-slip fault, the fault zone produces uplift and small-scale folds locally along its trend because of localized complexities in the fault zone near the surface in the Los Angeles Basin; the largest of these localized uplifts are the Baldwin Hills, Dominguez Hills, Signal Hill, and Landing Hill (fig. B24). Timing of the initiation of these uplifts appear to vary along the strike of the Newport-Inglewood fault zone, with the Baldwin Hills uplift affecting deposition beginning in Lower Wilmington time, whereas the Signal Hill uplift appears to have begun later, primarily after deposition of the Harbor sequence. The complicated nature of the fault zone and localized uplifts probably contributes to variability in fault zone permeability along its strike.

The Pacific Coast Highway (PCH) fault (figs. B23, B24) is a west-northwest trending, oblique-slip fault identified from borehole and gravity data in Ponti and others (2007) and is inferred to have a maximum vertical separation (down to the north) of approximately $800 \mathrm{ft}$. The fault offsets all units older than the Dominguez chronostratigraphic unit. The PCH fault runs mostly east-west in the West Coast Basin and is thought to merge with the Newport-Inglewood fault zone to the east. Few data constrain the modeled location of the $\mathrm{PCH}$ fault to the west of the Dominguez Gap Barrier Project; however, water-level and geochemical analyses for this study suggest that the fault may extend almost to the Palos Verdes fault to the west, with a possible left step (Pacific Coast Highway fault, Western Extension, figs. B23, B24). 


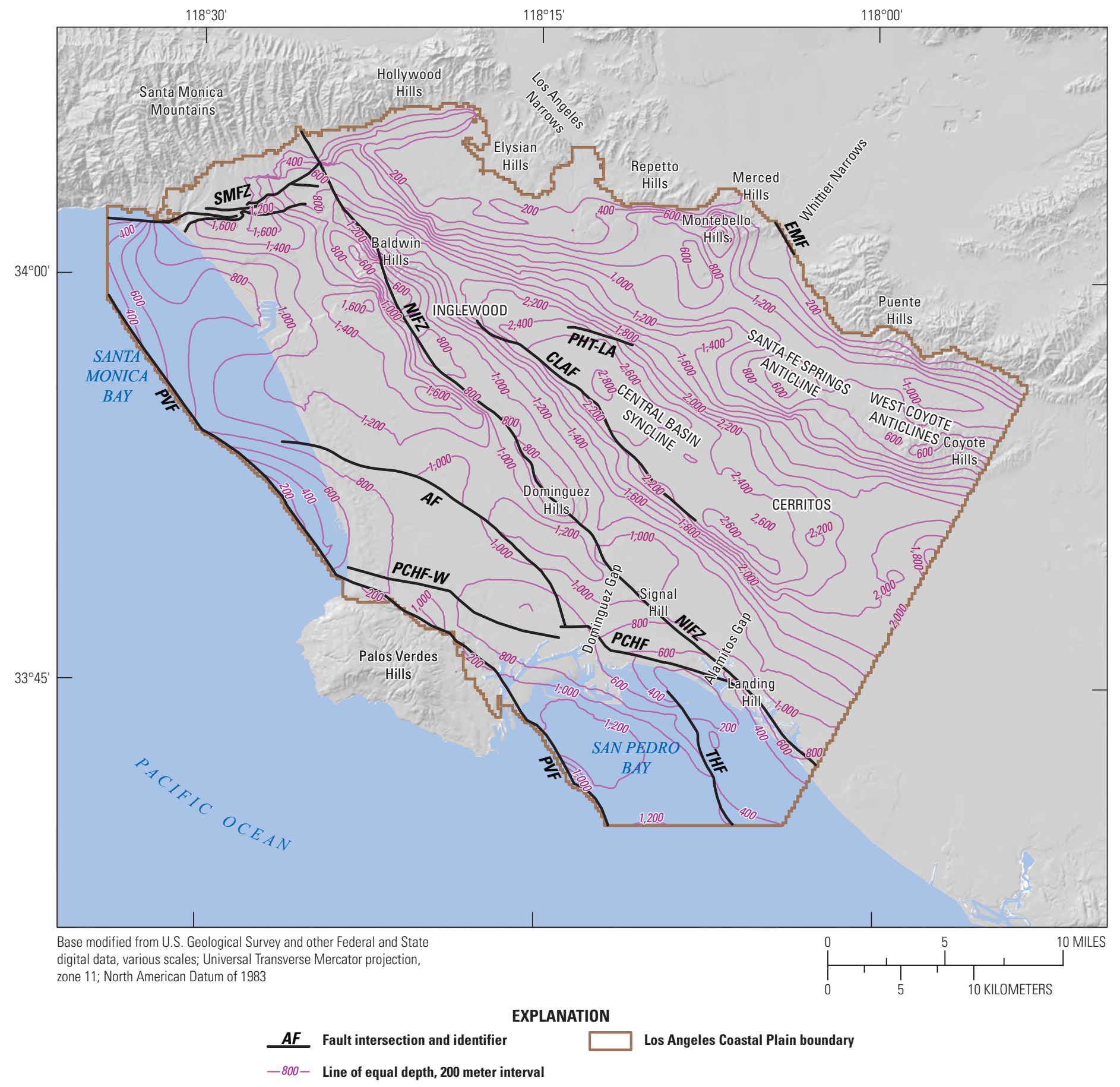

Figure B23. Depth from land surface to the base of water-bearing units (base of Long Beach C chronostratigraphic unit), Los Angeles Coastal Plain, California. (Fault identifiers: AF, Alondra fault; CLAF, Compton-Los Alamitos fault; EMF, East Montebello fault; NIFZ, Newport-Inglewood fault zone; PCHF, Pacific Coast Highway fault; PHT-LA, Puente Hills Thrust fault; SMFZ, Santa Monica fault zone; THF, Thums-Huntington Beach fault.) 


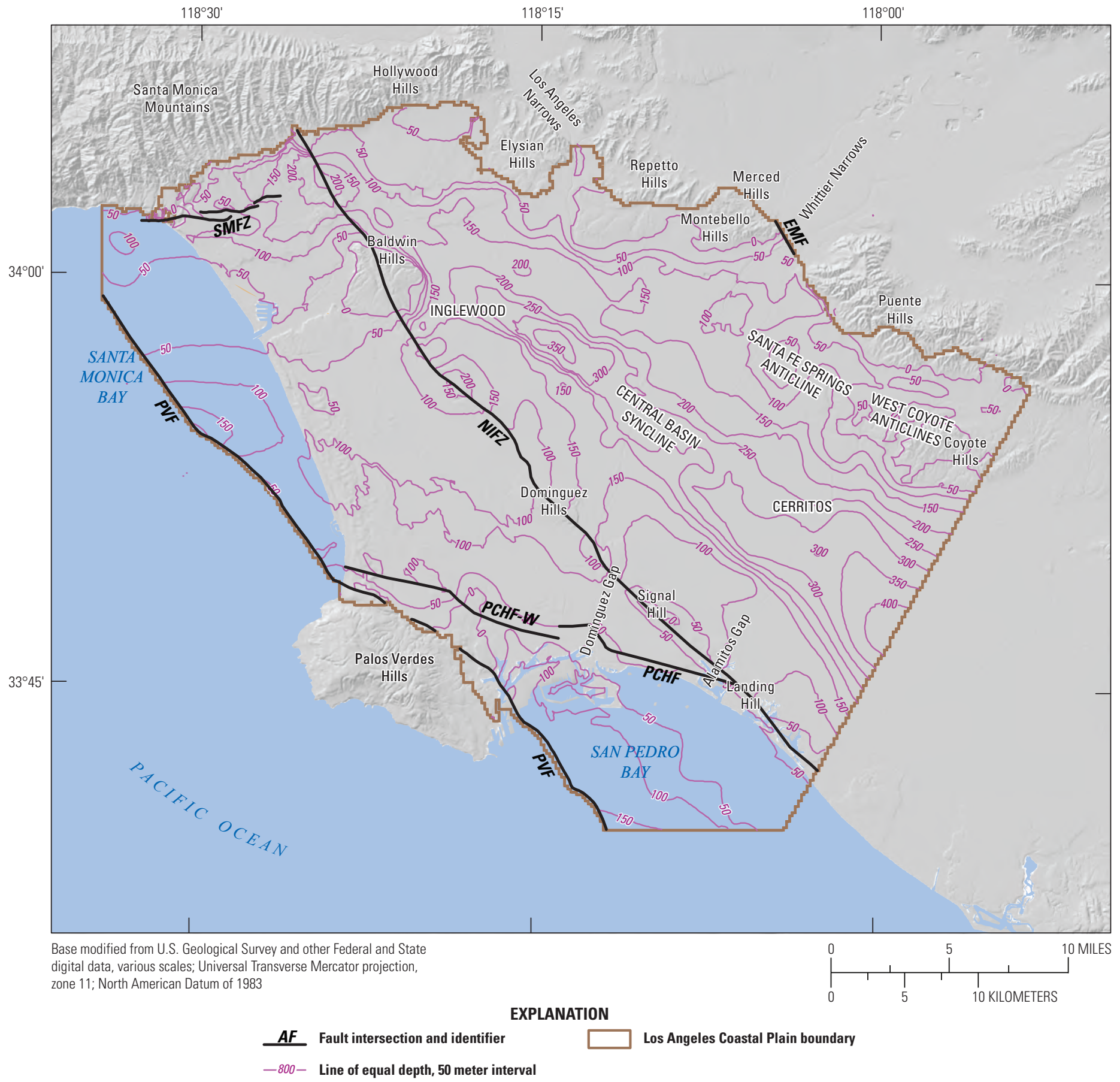

Figure B24. Depth from land surface to the base of the Pacific chronostratigraphic unit, Los Angeles Coastal Plain, California. (Fault identifiers: AF, Alondra fault; CLAF, Compton-Los Alamitos fault; EMF, East Montebello fault; NIFZ, Newport-Inglewood fault zone; PCHF, Pacific Coast Highway fault; PHT-LA, Puente Hills Thrust fault; SMFZ, Santa Monica fault zone; THF, Thums-Huntington Beach fault.) 
As part of this study, the Alondra fault (fig. B23) was identified from interpretation of oil industry seismic-reflection profiles within the West Coast Basin. At its western end, the strike of the Alondra fault (a probable oblique-slip fault) approximately parallels the $\mathrm{PCH}$ fault, which is located approximately $6 \mathrm{mi}$ to the south (fig. B23). Moving east along the Alondra fault, the strike changes to a northwest orientation and likely intersects the PCH fault along the trend of what Ponti and others (2007) initially interpreted as the Richfield fault. The Alondra fault appears to offset all sequences older than the Bent Spring unit, but little vertical separation (down to the north) is observed above the Lower Wilmington unit. Maximum vertical separation is estimated to be about 650 $\mathrm{ft}$ at the base of the Long Beach $\mathrm{C}$ chronostratigraphic unit (fig. B23).

The Thums-Huntington Beach fault occurs offshore in San Pedro Bay (fig. B23); based on our analysis of seismic data, we find the fault to be somewhat east of the location mapped by Saucedo and others (2003) and with a more northerly strike. The fault is located approximately $2-4 \mathrm{mi}$ west of the Newport-Inglewood fault zone (fig. B23). We observe apparent vertical separation of as much as 2,000 $\mathrm{ft}$ (down to the west) at the base of the Long Beach C chronostratigraphic unit (fig. B23), although fault movement appears to have ceased by the time of Bent Spring deposition. Offset on the fault has caused several of the units to be missing on the east (upthrown) side of the fault.

The Santa Monica fault zone bounds the LACP on the north (fig. B23). The fault zone trends east-west along the southern flank of the Santa Monica Mountains, extending about 25 mi eastward from the coast (Dolan and Pratt, 1997). The Santa Monica fault zone consists primarily of two strands, an inactive southern strand and an active northern strand. The fault zone is a steeply dipping reverse/left-lateral fault and cuts through all chronostratigraphic units older than the Mesa; as modeled, the fault zone may have a combined vertical separation of as much as $4,000 \mathrm{ft}$.

The East Montebello fault bounds the LACP on the northeast (fig. B23). The fault is the northern extension of the Whittier fault (not shown; Plesch and others, 2007) and cuts through all chronostratigraphic units across the Whittier Narrows (fig. B23). As modeled, the East Montebello fault has (down to the northeast) separation of as much as 1,600 ft.

The Palos Verdes fault is a major, active strike-slip fault that forms most of the western boundary of the LACP. Although principally a strike-slip fault offshore, a left bend in the fault is coincident with uplift of the Palos Verdes Hills, and outcrops of Miocene rocks in the seafloor of Santa Monica Bay indicate that there is substantial west-side-up separation of as much as $1,300 \mathrm{ft}$ that is associated with the fault along the western margin of the LACP.

Previous investigators have identified the Pico and Rio Hondo faults in the Montebello Forebay and the Charnock Fault in the West Coast Basin as barriers to groundwater flow (California Department of Water Resources, 1961; Reichard and others, 2003); however, we find little stratigraphic evidence for existence of the Pico and Rio Hondo faults within the water-bearing chronostratigraphic units modeled for this study. The existence and location of these faults primarily were inferred based on observed water-level variations. Seismic-reflection data used for this study showed no evidence of the Pico and Rio Hondo faults and indicated that the Charnock fault only offsets the "Repetto" and older rocks (fig. B20). As discussed previously in the case of the Charnock fault, observed water-level variations assumed to be attributable to these faults appear to be better explained by stratigraphic discontinuities that result from channel erosion and subsequent backfill of materials with different hydrogeologic properties.

\section{Summary}

The chronostratigraphic hydrogeologic-framework model was developed for this study by applying the concepts of sequence stratigraphy to interpret a wide variety of geologic, geophysical, and hydrologic data, much of which has been obtained recently. This approach has resulted in a more refined representation of the Quaternary geology and structure of the Los Angeles Coastal Plain (LACP) relative to previous studies. In particular, seismic reflection data were incorporated to identify and laterally correlate unconformities that bound the chronostratigraphic units. Seismic reflection data demonstrated that there is substantially greater structural relief in the water-bearing Quaternary sedimentary section than represented in earlier hydrogeologic studies, and several previously defined aquifers consist of deposits of different ages that are not lithologically correlated. The current framework model has identified several new faults or fault extensions that may function as groundwater barriers and additional folds and channel systems that also may restrict groundwater flow locally within the LACP.

The resulting chronostratigraphic hydrogeologic-framework model consists of 15 units, 13 of which compose the actively producing groundwater system. In comparison to the Reichard and others (2003) model, comprising five layers, the refined vertical discretization within the present framework model improved the capability of the resulting groundwater-flow model to match observed water-level data and simulate groundwater flowpaths.

Evaluations of stacking patterns in geophysical well logs were used to identify unit boundaries that were tied to seismic data and paired with lithologic descriptions to identify of various depositional facies that were correlated regionally within each chronostratigraphic unit; these interpretations informed parameterization of the resulting groundwater-flow model (Chapter C). Facies interpretations and correlations were aided by using water-level hydrographs and water-quality samples from short-screen wells at multiple-well monitoring sites to provide insight into groundwater source areas and likely groundwater flowpaths. 


\section{References Cited}

American Geological Institute, 1957, Glossary of geology and related sciences: Washington, D.C., 325 p.

American Society for Testing and Materials (ASTM), 1985, Standard practice for classification of soils for engineering purposes (Unified Soil Classification System): Annual Book of ASTM Standards D2487-83, v. 04.08, p. 395-408, https://www.astm.org/Standards/D2487.htm.

Aitken, M.J., 1985, Thermoluminescence dating: London, Academic Press, $351 \mathrm{p}$.

Aitken, M.J., 1998, An introduction to optical dating: Oxford, U.K., Oxford Science Publications, 267 p.

Bassinot, F.C., Labeyrie, L.D., Vincent, E., Quidelleur, X., Shackleton, N.J., and Lancelot, Y., 1994, The astronomical theory of climate and the age of the Brunhes-Matuyama magnetic reversal: Earth and Planetary Science Letters, v. 126, no. 1-3, p. 91-108, https://doi.org/10.1016/0012-821X(94)90244-5.

Blake, G.H., 1991, Review of the neogene biostratigraphy and stratigraphy of the Los Angeles basin and implications for basin evolution, chap. 4 of Biddle, K.T., ed., Active margin basins: American Association of Petroleum Geologists Memoir 52, p. 135-184.

Bray, B., Tsai, F.T.-C., Sim, Y., and Yeh, W.W.-G., 2007, Model development and calibration of a saltwater intrusion model in Southern California: Journal of the American Water Resources Association, v. 43, no. 5, p. 1329-1343, https://doi.org/10.1111/j.1752-1688.2007.00098.x.

Bull, W.B., 1991, Climatic Geomorphology: Oxford, U.K., Oxford University Press, 326 p.

California Department of Conservation, 2017, Oil and gas online data: Geologic Energy Management Division (CalGEM), accessed 2017 at https://www.conservation.ca.gov/calgem/Online_Data/ Pages/Index.aspx.

California Department of Water Resources, 1961, Planned utilization of the ground water basins of the coastal plain of Los Angeles County, Appendix A, Ground water geology: California Department of Water Resources Bulletin 104, 191 p., http://wdl.water.ca.gov/waterdatalibrary/docs/ historic/Bulletins/Bulletin_104/Bulletin_104-A_1961.pdf

Campbell, R.H., Wills, C.J., Irvine, P.J., and Swanson, B.J., 2014, Preliminary geologic map of the Los Angeles 30' $x$ 60' quadrangle, California: California Geological Survey Preliminary Geologic Maps, scale 1:100,000.
Catuneanu, O., 2006, Principles of sequence stratigraphy: New York, Elsevier, 386 p.

Dolan, J.F., and Pratt, T.L., 1997, High-resolution seismic reflection profiling of the Santa Monica fault zone, west Los Angeles, California: Geophysical Research Letters, v. 24, no. 16, p. 2051-2054, https://doi.org/10.1029/97GL01940.

Durham, D.L., and Yerkes, R.F., 1964, Geology and oil resources of the eastern Puente Hills area, southern California: U.S. Geological Survey Professional Paper 420-B, 62 p., https://doi.org/10.3133/pp420B.

Ehman, K.D., Edwards, B.D., and Ponti, D.J., 2014, Sequence stratigraphic framework of upper Pliocene to Holocene sediments of the Los Angeles Basin, CaliforniaImplications for aquifer architecture: Pacific Section, SEPM, Society for Sedimentary Geology, $49 \mathrm{p}$.

Freeze, R.A., and Cherry, J.A., 1979, Groundwater: Englewood Cliffs, N.J., Prentice-Hall, 604 p.

Gibbard, P.L., Head, M.J., Walker, M.J.C. and the Subcommission on Quaternary Stratigraphy, 2010, Formal ratification of the Quaternary System/Period and the Pleistocene Series/Epoch with a base at 2.58 Ma: Journal Quaternary Science, v. 25 p. 96-102.

Gould, A.A., 1850, Descriptions with drawings of several new species of shells brought home from the United States exploring expedition: Proceedings of the Boston Society of Natural History, v. 3, p. 151-156, 169-172, 275-278, and 292-296.

Imbrie, J., Hays, J.D., Martinson, D.G., McIntyre, A., Mix, A.C., Morley, J.J., Pisias, N.G., Prell, W.L., and Shackleton, N.J., 1984, The orbital theory of Pleistocene climate-Support from a revised chronology of the marine $\delta^{18} \mathrm{O}$ record, in Berger, A.L., Imbrie, J., Hays, J., Kukla, G., and Saltzman, B., eds., Milankovich and climate, Part 1: Dordrecht, The Netherlands, D. Reidel, NATO Advanced Science Institutes Series C, v. 126, p. 269-305.

Kew, W.S.W., 1937, Los Angeles Basin excursion-Santa Monica Mountains-Inglewood Field, in Guidebook-Field Excursions-Southern California: American Association of Petroleum Geologists, 22nd annual meeting, p. 7-8.

Legg Geophysical, Inc., 2016, Process and interpret 2-D seismic reflection profiles, West Basin-Charnock fault area: Prepared for Water Replenishment District of Southern California, $31 \mathrm{p}$.

Leon, L.A., Dolan, J.F., Shaw, J.H., and Pratt, T.L., 2009, Evidence for large Holocene earthquakes on the Compton thrust fault, Los Angeles, California: Journal of Geophysical Research, v. 114, no. B12, B12305, https://doi.org/10.1029/2008JB006129. 
McDougall, K., Hillhouse, J., Powell, C.I.I., Mahan, S., Wan, E., and Sarna-Wojcicki, A.M., 2012, Paleontology and geochronology of the Long Beach core sites and monitoring wells, Long Beach, California: U.S. Geological Survey Open-File Report 2011-1274, 223 p., https://doi.org/10.3133/ofr20111274.

Morton, D.M., and Miller, F.K., 2006, Geologic map of the San Bernardino and Santa Ana 30' x 60' quadrangles, California: U.S. Geological Survey Open-File Report 2006-1217, scale 1:100,000, https://doi.org/10.3133/ofr20061217.

Myers, D.J., Nabelek, J.L., and Yeats, R.S., 2003, Dislocation modeling of blind thrusts in the eastern Los Angeles Basin, California: Journal of Geophysical Research, v. 108, no. B9, 2443, https://doi.org/10.1029/2002JB002150.

Nagle, H.E., and Parker, E.S., 1971, Future oil and gas potential of onshore Ventura Basin, California in Cram, I.H., ed., Future petroleum provinces of the United States-Their geology and potential: American Association of Petroleum Geologists Memoir 15, v. 1, p. 254-297, http://archives.datapages.com/data/specpubs/basinar1/ images/a128/a1280001/0250/02540.pdf.

Namson, J.S., 1987, Structural transect through the Ventura Basin and western Transverse Ranges, in Davis, T.L., and Namson, J.S., eds., Structural evolution of the western Transverse Ranges: Pacific Section, Society of Economic Paleontologists and Mineralogists, v. 48A. p. 29-41, http://archives.datapages.com/data/pac_sepm/068/068001/ pdfs/29.htm.

Natland, M.L., 1953, Pleistocene and Pliocene stratigraphy of southern California: Los Angeles, University of California, Ph.D. dissertation, $165 \mathrm{p}$.

Natland, M.L., and Rothwell, W.T., Jr., 1954, Fossil foraminifera of the Los Angeles and Ventura regions, chap. III of Jahns, R.H., ed., Geology of southern California: California Division of Mines Bulletin 170, p. 33-42.

Plesch, A., Shaw, J.H., Benson, C., Bryant, W.A., Carena, S., Cooke, M., Dolan, J., Fuis, G., Gath, E., Grant, L., Hauksson, E., Jordan, T., Kamerling, M., Legg, M., Lindvall, S., Magistrale, H., Nicholson, C., Niemi, N., Oskin, M., Perry, S., Planansky, G., Rockwell, T., Shearer, P., Sorlien, C., Süss, M.P., Suppe, J., Treiman, J., and Yeats, R., 2007, Community fault model (CFM) for southern California: Bulletin of the Seismological Society of America, v. 97, no. 6, p. 1793-1802, https://doi.org/10.1785/0120050211.
Poland, J.F., Garrett, A.A., and Sinnott, A., 1959, Geology, hydrology, and chemical character of ground waters in the Torrance-Santa Monica area, California: U.S. Geological Survey Water- Supply Paper 1461, 425 p., https://doi.org/10.3133/wsp1461.

Poland, J.F., and Piper, A.M., 1956, Ground-water geology of the coastal zone, Long Beach-Santa Ana area, California: U.S. Geological Survey Water-Supply Paper 1109, 162 p., https://doi.org/10.3133/wsp1109.

Ponti, D.J., 1989, Aminostratigraphy and chronostratigraphy of Pleistocene marine sediments, southwestern Los Angeles Basin, California: University of Colorado, Ph.D. thesis, 409 p.

Ponti, D.J., Ehman, K.D., Edwards, B.D., Tinsley, J.C., III, Hildenbrand, T., Hillhouse, J.W., Hanson, R.T., McDougall, K., Powell, C.L., II, Wan, E., Land, M., Mahan, S., and Sarna-Wojcicki, A.M., 2007, A 3-dimensional model of water-bearing sequences in the Dominguez Gap Region, Long Beach, California: U.S. Geological Survey Open-File Report 2007-1013, 34 p., https://doi.org/10.3133/ofr20071013.

Ponti, D.J., Wagner, B.J., Land, M., and Landon, M.K., 2014, Characterization of potential transport pathways and implications for groundwater management near an anticline in the Central Basin area, Los Angeles County, California: U.S. Geological Survey Open-File Report 2014-1087, 75 p., https://doi.org/10.3133/ofr20141087.

Powell, C.L., II, and Stevens, D., 2000, Age and paleoenvironmental significance of mega-invertebrates from the "San Pedro" Formation in the Coyote Hills, Fullerton, and Buena Park, Orange County, southern California: U.S. Geological Survey Open-File Report 2000-319, 83 p., https://doi.org/10.3133/ofr2000319.

Pratt, T.L., Shaw, J.H., Dolan, J.F., Christofferson, S.A., Williams, R.A., Odum, J.K., and Plesch, A., 2002, Shallow seismic imaging of folds above the Puente Hills blind-thrust fault, Los Angeles, California: Geophysical Research Letters, v. 29, no. 9, p. 18-1-18-4, https://doi.org/10.1029/2001GL014313.

Quinn, J.P., Ponti, D.J., Hillhouse, J.W., Powell, C.L., II, McDougall, K., Sarna-Wojcicki, A.M., Barron, J.A., and Fleck, R.J., 2000, Quaternary chronostratigraphic constraints on deformation and blind thrust faulting, northern Los Angeles Basin, in Quinn, J.P., Collaborative research (Gorian and Associates, Inc. and U.S. Geological Survey) - Geological investigations to evaluate the Wilshire fault blind thrust model; Final Technical Report, 1434-95-G-2523, 31 p.

Reed, R.D., 1933, Geology of California, v. 2: Tulsa, Okla., American Association of Petroleum Geologists, 355 p. 
Reichard, E.G., Land, M., Crawford, S.M., Johnson, T.D., Everett, R.R., Kulshan, T.V., Ponti, D.J., Halford, K.L., Johnson, T.A., Paybins, K.S., and Nishikawa, T., 2003, Geohydrology, geochemistry, and ground-water simulation-optimization of the Central and West Coast Basins, Los Angeles County, California: U.S. Geological Survey Water-Resources Investigations Report 2003-4065, 196 p., https://doi.org/10.3133/wri034065.

Saucedo, G.J., Greene, H.G., Kennedy, M.P., and Bezore, S.P., 2003, Geologic map of the Long Beach 30' x 60' quadrangle, California-A digital database: California Geological Survey Preliminary Geologic Maps, scale 1:100,000.

Shaw, J.H., and Shearer, P.M., 1999, An elusive blind-thrust fault beneath metropolitan Los Angeles: Science, v. 283, no. 5407, p. 1516-1518, https://doi.org/10.1126/science.283.5407.1516.

Shaw, J.H., and Suppe, J., 1996, Earthquake hazards of active blind-thrust faults under the central Los Angeles Basin, California: Journal of Geophysical Research, v. 101, no. B4, p. 8623-8642, https://doi.org/10.1029/95JB03453.

Shaw, J.H., Plesch, A., Dolan, J.F., Pratt, T.L., and Fiore, P., 2002, Puente Hills blind-thrust system, Los Angeles, California: Bulletin of the Seismological Society of America, v. 92, no. 8, p. 2946-2960, http://activetectonics.asu.edu/bidart/bibliography/bssa/ bssa_92_8/shaw_plesch_dolan_pratt_fiore_2002.pdf; https://doi.org/10.1785/0120010291.

Süss, M.P., and Shaw, J.H., 2003, P wave seismic velocity structure derived from sonic logs and industry reflection data in the Los Angeles Basin, California: Journal of Geophysical Research, v. 108, no. B3, 2170, 18 p., https://doi.org/10.1029/2001JB001628.

Treiman, J.A., and Lundberg, M., comps., 1999, Fault number $127 \mathrm{~b}$, Newport-Inglewood-Rose Canyon fault zone, south Los Angeles Basin section, in U.S. Geological Survey and California Geological Survey, Quaternary fault and fold database of the United States: U.S. Geological Survey website, accessed June 14, 2017, at https://earthquakes.usgs.gov/hazards/qfaults.
U.S. Geological Survey and California Geological Survey, 2006, Quaternary fault and fold database for the United States: U.S. Geological Survey website, accessed June 14, 2017, at http://earthquake.usgs.gov/hazards/qfaults/.

Van Wagoner, J.C., Mitchum, R.M., Campion, K.M., and Rahmanian, V.D., 1990, Siliciclastic sequence stratigraphy in well logs, cores, and outcropsConcepts for high-resolution correlation of time and facies: American Association of Petroleum Geologists Methods in Exploration Series, no. 7, 55 p., https://doi.org/10.1306/Mth7510.

Weber, F.H., Jr., Hsu, E.Y., Saul, R.B., Tan, S.S., and Treiman, J.A., 1982, Slope stability and geology of the Baldwin Hills, Los Angeles County, California: California Division of Mines and Geology, Special Report 152, 93 p., ftp://ftp.consrv.ca.gov/pub/dmg/pubs/sr/SR_152/SR_152_ Text.pdf.

Woodring, W.P., Bramlette, M.N., and Kew, W.S.W., 1946, Geology and paleontology of Palos Verdes Hills, California: U.S. Geological Survey Professional Paper 207, 145 p., https://doi.org/10.3133/pp207.

Wright, T.L., 1991, Structural geology and tectonic evolution of the Los Angeles Basin, California, chap. 3 of Biddle, K.T., ed., Active margin basins: American Association of Petroleum Geologists Memoir 52, p. 35-79.

Yeats, R.S., 1983, Large-scale Quaternary detachments in Ventura basin, southern California: Journal of Geophysical Research, v. 88, no. B1, p. 569-583, https://doi.org/10.1029/JB088iB01p00569.

Yerkes, R.F., 1972, Geology and oil resources of the western Puente Hills area, southern California: U.S. Geological Survey Professional Paper 420-C, 62 p., https://doi.org/10.3133/pp420C.

Yerkes, R.F., McCulloh, T.H., Schoellhamer, J.E., and Vedder, J.G., 1965, Geology of the Los Angeles Basin, California-An introduction: U.S. Geological Survey Professional Paper 420-A, 57 p., https://doi.org/10.3133/pp420A. 


\title{
Chapter C. Groundwater Hydrology
}

\author{
By Scott Paulinski, Peter Martin, Claudia Faunt, Rhett Everett, Whitney Seymour, and Michael Land
}

The groundwater hydrology of the Los Angeles Coastal Plain (LACP) was characterized by summarizing previously published research (Poland and Piper, 1956; Poland and others, 1959; California Department of Water Resources (CDWR), 1961, 1962, 1966; Reichard and others, 2003), compiling and analyzing available hydrogeologic data from local, State, and Federal agencies, and analyzing data collected as part of this study.

\section{Groundwater Basins and Areas}

The California Department of Water Resources (1961) subdivided the LACP into four groundwater basins: Central, West Coast, Hollywood, and Santa Monica Basins (fig. C1). A groundwater basin is defined by the CDWR (1975) as an alluvial aquifer or a stacked series of alluvial aquifers with reasonably well-defined boundaries in a lateral direction and a definable bottom. The lateral boundaries of the groundwater basins within the LACP generally are low-permeability rocks or faults. This study also includes the western portion of the adjacent Orange County Basin, which is physically connected to the Central Basin but is separated by the political boundary between Los Angeles and Orange Counties (fig. C1). For the purposes of this report, the four groundwater basins of CDWR (1961) in Los Angeles County, and the portion of the Orange County Basin included in the study area, are referred to as the LACP. In addition, the bottom boundary of the LACP is the top of the "Repetto" of Pliocene age, or older sediments if the "Repetto" is missing.

The groundwater basins of the LACP have been divided into 14 subareas based on hydrogeological characteristics and management interests for this study: six in the Central Basin, one in the West Coast Basin, three in the Orange County Basin, one in the Santa Monica Basin, one in the Hollywood Basin, and two offshore (fig. C1). The Central Basin is divided into the Los Angeles Forebay, Montebello Forebay, Whittier Area, and Central Basin Pressure Area. The Central Basin Pressure Area is deeper than the forebays with hydraulic heads varying more with depth (Chapter A; Chapter D). The forebays tend to have coarser sediments, especially in the upper units. The Central Basin Pressure Area and the Los Angeles Forebay have been further divided by administrative area (Water Replenishment District of Southern California [WRD] versus non-WRD; fig. C1). The groundwater basin or subarea boundaries of this study vary slightly from the boundaries defined by the CDWR (1975). The overall change is not substantial, and the size of each groundwater basin remains close to the size defined by the CDWR (fig. C1). The basins and associated subareas are discussed in Reichard and others (2003).

As stated above, the Central and Orange County Basins are separated by a political boundary. There are no known geologic boundaries that separate the two groundwater basins, and water-level data indicate that they are hydrologically connected. The Central Basin has been managed by WRD since 1959, and the Orange County Basin has been managed by the Orange County Water District (OCWD) since 1933. For this report, only the western part of the Orange County Basin was included as part of the investigation (fig. C1). The area extends about $5 \mathrm{mi}$ to the southeast of the Los Angeles/ Orange County boundary and is bounded by the Puente Hills to the north and the San Pedro Bay to the south (fig. C1). The boundary was chosen near several multiple-well monitoring sites, which allowed for a more accurate assessment of conditions along this boundary. The Orange County Basin within the study area is divided into three subareas: Orange County North, Orange County Central, and Orange County South subareas (fig. C1).

\section{Definition of Aquifer Systems}

The main water-bearing deposits in the LACP are the saturated portions of the late Pliocene and Quaternary chronostratigraphic units defined in the "Late Pliocene and Quaternary Chronostratigraphic Units" section of this report (Chapter B). Thirteen chronostratigraphic units (Long Beach C, Long Beach BC, Long Beach A, Lower Wilmington, Upper Wilmington B, Upper Wilmington A, Bent Spring, Harbor, Pacific, Pacific A, Mesa, and Dominguez) were identified overlying bedrock units, ranging in age from latest Pliocene through Holocene (table B2). For the purposes of this report, these chronostratigraphic units were considered as separate aquifer systems, except for the lower two units (Long Beach BC and Long Beach C), which were combined into a single aquifer system (Long Beach C).

The "Repetto" and pre-Repetto Rocks are consolidated sedimentary deposits of mid-Pliocene and older age. These low-permeability rocks yield only small quantities of water to wells. Although the lithologies of the older sedimentary rocks have considerable variability, they are similar in terms of the greater degree of compaction, consolidation, and cementation relative to the younger chronostratigraphic units defined for this study. For the purposes of this study, "Repetto" and older rocks form the base and, in many areas, the lateral boundaries of the groundwater basins of the LACP. 


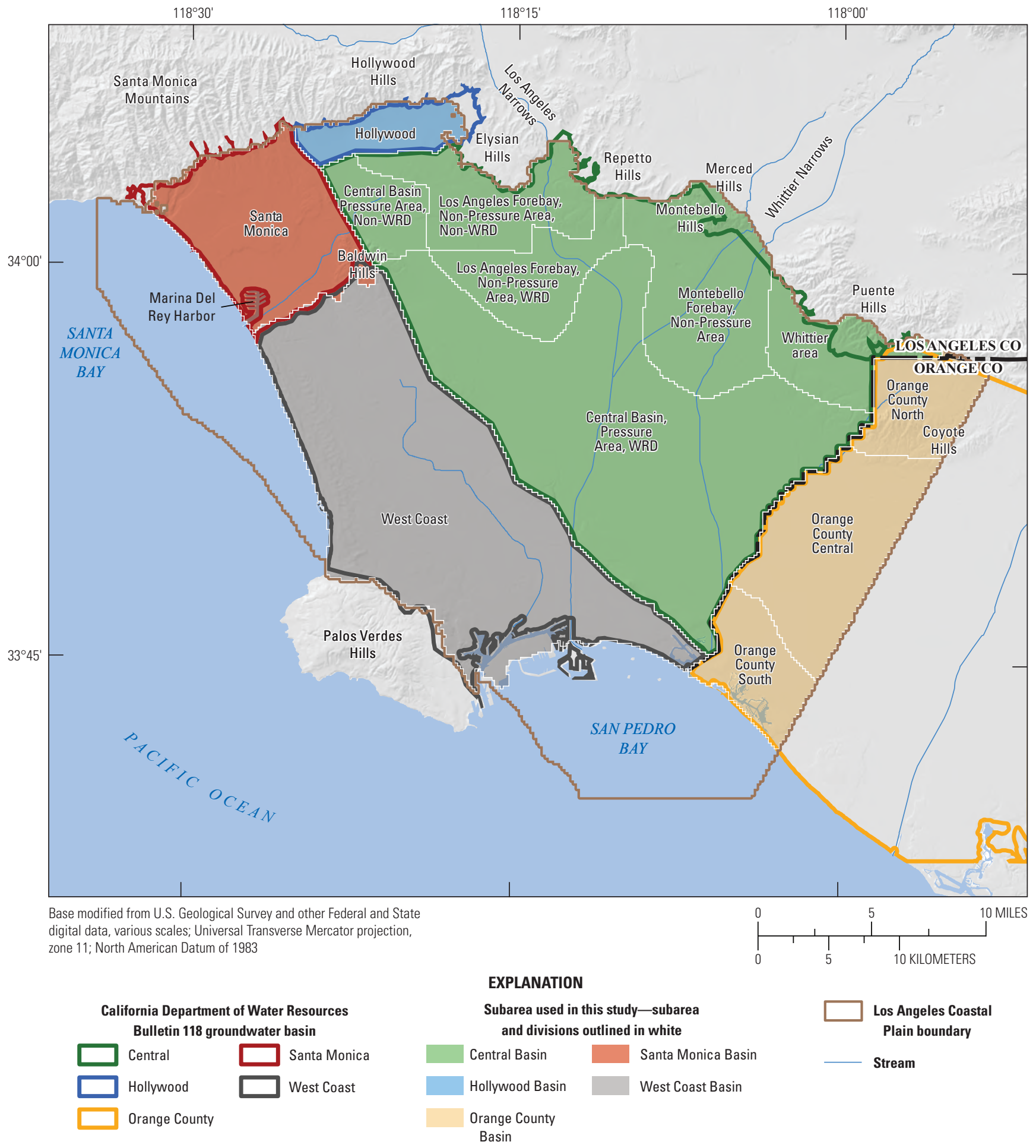

Figure C1. Groundwater basins and subareas of the Los Angeles Coastal Plain, California. California Department of Water Resources (CDWR) groundwater basins are from CDWR Bulletin 118 (1975). 
The chronostratigraphic units delineate the aquifer systems for this study and consist of layers of coarse- and fine-grained sediments that vary laterally and vertically. As explained in Chapter B, these units generally were formed in response to sea-level changes resulting from worldwide glaciation cycles (Imbrie and others, 1984). During glacial periods, when sea levels were low, erosion on the exposed shelf occurred, forming a basal unconformity. The deposits overlying this basal unconformity are dominantly coarse-grained and regionally extensive on the groundwater basin floor (Van Wagoner and others, 1990); consequently, these deposits are often the most water-bearing of a particular aquifer system. The upper part of a chronostratigraphic unit represents the period when sea levels were high and starting to fall. If these deposits are not truncated by the overlying unit boundary, they are usually fine-grained (Van Wagoner and others, 1990) and confine the underlying aquifer system.

The predominant sediment grain size in the different aquifer systems was estimated by analyzing downhole lithologic and geophysical logs collected at the multiple-well monitoring sites constructed by the U.S. Geological Survey (USGS) in cooperation with WRD, as described in appendix 2. The downhole geophysical logs used in the analysis include nuclear magnetic resonance (NMR), array induction 2-foot (ft) resistivity (AIT), long-normal resistivity, short-normal resistivity, and gamma logs. Grain sizes were analyzed at $0.5 \mathrm{ft}$ vertical intervals. The grain sizes from these intervals were averaged to determine the percentage of coarse-, medium-, and fine-grained sediment in each unit. The results of the analysis for the NMR and AIT methods were plotted for each chronostratigraphic unit to help identify high-permeability (coarse-grained) and low-permeability (fine-grained) zones in the different aquifer systems (appendix 2, fig. 2.1). The Harbor and Upper Wilmington A chronostratigraphic units have the greatest number of wells in which medium- to coarse-grained sediments dominate (appendix 2, figs. 2.1E, 2.1G). The Long Beach A, Long Beach, B, and Long Beach C chronostratigraphic units are, in general, finer-grained than the overlying aquifer systems (appendix 2, units; figs. 2.1J-L).

The results of the grain-size analysis show different patterns of spatial variability within the upper/middle and lower chronostratigraphic units. The upper and middle chronostratigraphic units tend to have coarser-grained sediments in the Montebello Forebay and along the western portion of the West Coast Basin and finer sediments in parts of the Central Basin Pressure Area and parts of the West Coast Basin (appendix 2, figs. 2.1A-I). The lower chronostratigraphic units contain mostly medium- and fine-grained sediments throughout most of the LACP, though some wells in the Montebello Forebay and West Coast Basin contain coarse-grained sediments (appendix 2, figs. 2.1J-L).

\section{Groundwater Recharge}

Sources of groundwater recharge in the LACP include (1) natural recharge in response to precipitation and percolation on the coastal plain, (2) natural mountain-front recharge, (3) infiltration of stream flow along river channels, (4) return flow from urban landscape irrigation, (5) return flow from leakage of water lines and sewer lines, (6) net underflow from adjacent groundwater basins, (7) net subsurface inflow from offshore, (8) managed aquifer recharge from spreading grounds, and (9) managed aquifer recharge through injection wells at seawater barriers. A rainfall-runoff-infiltration model was developed to estimate the spatial and temporal distribution of natural recharge on the coastal plain, mountain-front recharge, infiltration of streamflow, and return flow from urban landscape irrigation. The development, calibration, and results of this model are described in detail in Hevesi and Johnson (2016). The major results of the rainfall-runoff-infiltration model are presented in the following sections.

\section{Natural Recharge on the Coastal Plain}

Natural recharge is a result of downward percolation of precipitation that falls on the coastal plain of the study area. The distribution and magnitude of recharge change both spatially and temporally and are influenced by two main factors: climate and land cover. The mean annual precipitation at the University of Southern California (USC) campus near Los Angeles is 14.8 in. for the period 1914-2016 (Los Angeles Almanac, 2018). The cumulative departure from the mean for annual precipitation shows major and minor wet and dry periods which are typical of the long-term climate record for the Los Angeles Basin (fig. C2). Historically, the land cover of the LACP has changed as the area has urbanized. However, most development was completed prior to the beginning of the period of interest for this study (1971-2015); therefore, land-cover changes during the study period are small. Hevesi and Johnson (2016) estimated that the average annual precipitation for the LACP ranged from 11.1 to 15.7 inches per year (in/yr) for calendar years 1915-2014. Hevesi and Johnson (2016) also reported that precipitation falls primarily during the cooler months of October through May and that February is historically the wettest month. The average annual precipitation in the study area is about $13 \mathrm{in} / \mathrm{yr}$ or about 359,000 acre feet per year (acre-ft/yr), which along with urban irrigation contributes to $42,000 \mathrm{acre}-\mathrm{ft} / \mathrm{yr}$ of average potential recharge to the LACP groundwater-flow system from 1915 to 2014 (Hevesi and Johnson, 2016). 


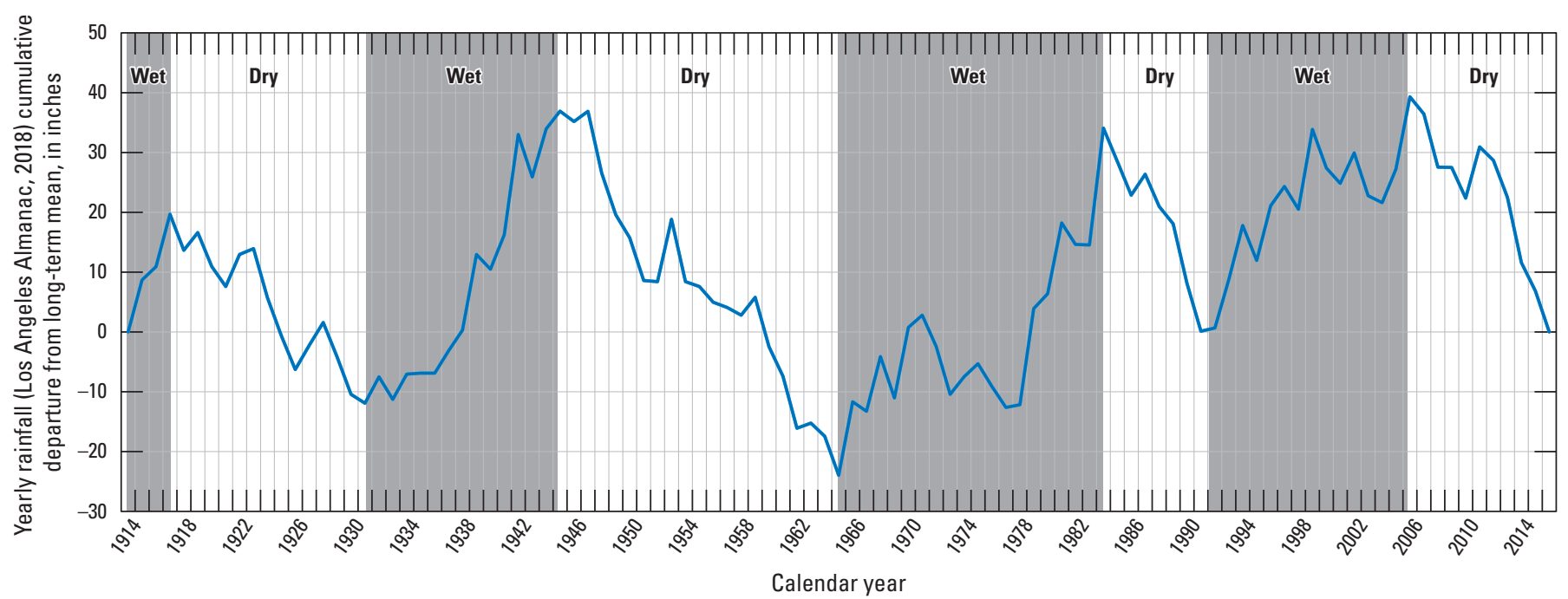

Figure C2. Cumulative departure from the long-term mean for annual precipitation based on annual rainfall totals measured at the University of Southern California (USC) campus (Los Angeles Almanac, 2018), Los Angeles County, California, 1914-2016.

\section{Natural Mountain-Front Recharge}

The magnitude of mountain-front recharge is related to the size, topography, precipitation, soil, and vegetation of the contributing watersheds in the uplands. Permeability of geologic units at the recharge areas influences the percolation rate of the mountain-front recharge. Similar to natural recharge on the coastal plain, natural mountain-front recharge is affected by climate and land cover of the contributing watersheds. Mountain-front recharge occurs primarily in areas bordering the mountains and hills, including the Santa Monica Mountains and Hollywood Hills to the north, the Elysian, Repetto, Merced, and Puente Hills to the northeast, and the Palos Verdes Hills to the southwest (fig. A1). These areas are at the edges of the groundwater basins where younger aquifer systems are often missing and the older aquifer systems are near the surface, which allows direct recharge of the older aquifer systems in the LACP. Hevesi and Johnson (2016) estimated the total potential annual mountain-front recharge to the LACP from 1915 to 2014 at about 22,000 acre-ft/yr.

\section{Infiltration of Streamflow}

The San Gabriel River, Rio Hondo, and Los Angeles River drain the San Gabriel and San Fernando Valleys and enter into the LACP coastal plain from the Whittier and Los Angeles Narrows (see fig. A1). The magnitude of the flows can be substantial because the drainage areas of the rivers extend into the higher elevations of the San Gabriel Mountains where the precipitation is substantially greater than on the coastal plain. Infiltration of streamflow was the main source of recharge to the LACP groundwater-flow system under pre-development conditions (Mendenhall, 1905c). However, urbanization of the study area as well as the upper San Gabriel and San Fernando Valleys over the 20th century has eliminated stream-flow infiltration in most parts of the study area because of stream channel and streamflow modifications.

The U.S. Army Corp of Engineers (USACE) has channelized the Los Angeles and San Gabriel Rivers for flood-control purposes. The USACE also constructed a number of dams in the mountainous areas and upper watersheds of the rivers, including the Whittier Narrows Dam, which is within the boundary of LACP (fig. A1). Since 1960, stream inflow from the San Gabriel and the San Fernando Valleys to the study area has been regulated.

Recharge from streambed infiltration is limited because most of the river channels in LACP have been lined with concrete. The Los Angeles River is lined throughout the study area except just upstream from the confluence with San Pedro Bay. The San Gabriel River is lined except in the upper parts of the Montebello Forebay and near the Alamitos Gap. The Rio Hondo also is lined throughout the study area. Most of Ballona Creek and the upper sections of Dominguez Channel also are lined (fig. A1). All infiltration of streamflow across LACP during the 1971-2015 study period is accounted for by the infiltration of water spreading at the San Gabriel River spreading grounds (SGRSG), Rio Hondo spreading grounds (RHSG), and behind the Rio Hondo side of the Whittier Narrows Dam. Infiltration of water spreading is described in the "Managed Aquifer Recharge from Spreading Grounds" report section. Recharge at the lower end of the Los Angeles River, Rio Hondo, and San Gabriel Rivers is assumed to be negligible. 


\section{Return Flow from Urban Landscape Irrigation}

Return flow from urban landscape irrigation is a source of areal recharge to the LACP groundwater system. Urban irrigation can affect the natural precipitation and percolation process by increasing the amount of water available for infiltration through on-site percolation (Grimmond and others, 1986), and by affecting runoff rates from rainfall events (Sample and Heaney, 2006). The volume of urban irrigation being applied to the landscape has been substantial, exceeding natural rainfall in certain areas (California Department of Water Resources, 1975). The average annual rate of urban irrigation estimated by Hevesi and Johnson (2016) for the LACP is about 163,000 acre-ft, which is about 40 percent of the volume of average annual precipitation for the LACP.

Urban irrigation is highly influenced by the water demand of landscape vegetation and the availability of irrigation water. Because little precipitation falls during the summer months in the LACP, the highest irrigation demand typically occurs from July to September (Hevesi and Johnson, 2016).

\section{Return Flow from Leakage of Water and Sewer Lines}

The LACP, being one of the most populated metropolitan areas in the United States, has a network of underground sewer and water lines beneath it. For this report, sewer lines include storm drains and sanitary sewers. Although leakage from water and sewer lines could be another source of managed aquifer recharge to the LACP groundwater system, this component has not been well- studied and was not included in the rainfall-runoff-infiltration model developed for this study (Hevesi and Johnson, 2016). Therefore, the location and magnitude of managed aquifer recharge due to leakage from water and sewer lines is still largely unknown and is not explicitly accounted for in the groundwater-flow modeling section of this report, although total recharge (including return flow from leaking water and sewer lines as well as the other sources) was determined as part of model calibration. Given the aging sewer and water transmission system and the substantial volume of water being delivered through them, an improved understanding could improve estimates of return flow from leakage of water and sewer lines in the LACP.

\section{Underflow from Adjacent Groundwater Basins}

The Central Basin receives groundwater underflow from up-gradient groundwater basins in the San Gabriel and San Fernando Valleys, through the Whittier and Los
Angeles Narrows, respectively (fig. A1). The San Gabriel River Watermaster's (SGRWM) responsibilities include the measuring of groundwater elevation and the estimating of groundwater underflow through the Whittier Narrows every spring and fall. The SGRWM estimates the quantity of underflow using a method based on Darcy's Law (San Gabriel River Watermaster, 1997). The average annual underflow estimated by the SGRWM is 26,000 acre-ft/yr for the period 1962 to 2015 (table C1). Similar measurements and estimates are not available regarding underflow through the Los Angeles Narrows because of the highly urbanized condition of the area.

Reichard and others (2003) estimated underflow through the Los Angeles and Whittier Narrows in a regional groundwater-flow model of the Los Angeles Basin. General-head boundaries were used at the Los Angeles and Whittier Narrows to represent groundwater underflow from the San Fernando and San Gabriel Valleys, respectively. These general-head boundaries were applied using average measured water levels over the simulation period at wells immediately upgradient of both boundaries (Reichard and others, 2003). The simulated average annual groundwater underflows through the Los Angeles and Whittier Narrows for the period of 1971 to 2000 were approximately 6,300 and 27,000 acre-ft, respectively (Reichard and others, 2003).

\section{Managed Aquifer Recharge from Spreading Grounds}

Spreading grounds have been used in the LACP since the 1930s as a means to replenish groundwater basins and store water underground during times of water surplus to meet demands in times of shortage. Spreading grounds were constructed at the Montebello Forebay, an area south of Whittier Narrows, where highly permeable, coarse-grained deposits allow substantial percolation of surface waters into the Central Basin (fig. A1). The RHSG are adjacent to the Rio Hondo channel and cover about 570 acres. The SGRSG are within and adjacent to the San Gabriel River channel. The off-channel portion of the SGRSG covers about 128 acres, and the in-channel portion, where inflatable rubber dams are used to promote groundwater recharge, covers about 308 acres. Both the RHSG and SGRSG are owned and operated by the Los Angeles County Flood Control District (LACFCD). The facilities have been improved to increase intake and storage capacity since they were built in the 1930s. The average annual recharge based on measured water delivery rates (Central Basin Watermaster, 2017) to the spreading grounds from RHSG and SGRSG for calendar years 1971 to 2015 was about 57,000 and 46,000 acre-ft, respectively (fig. C3). 


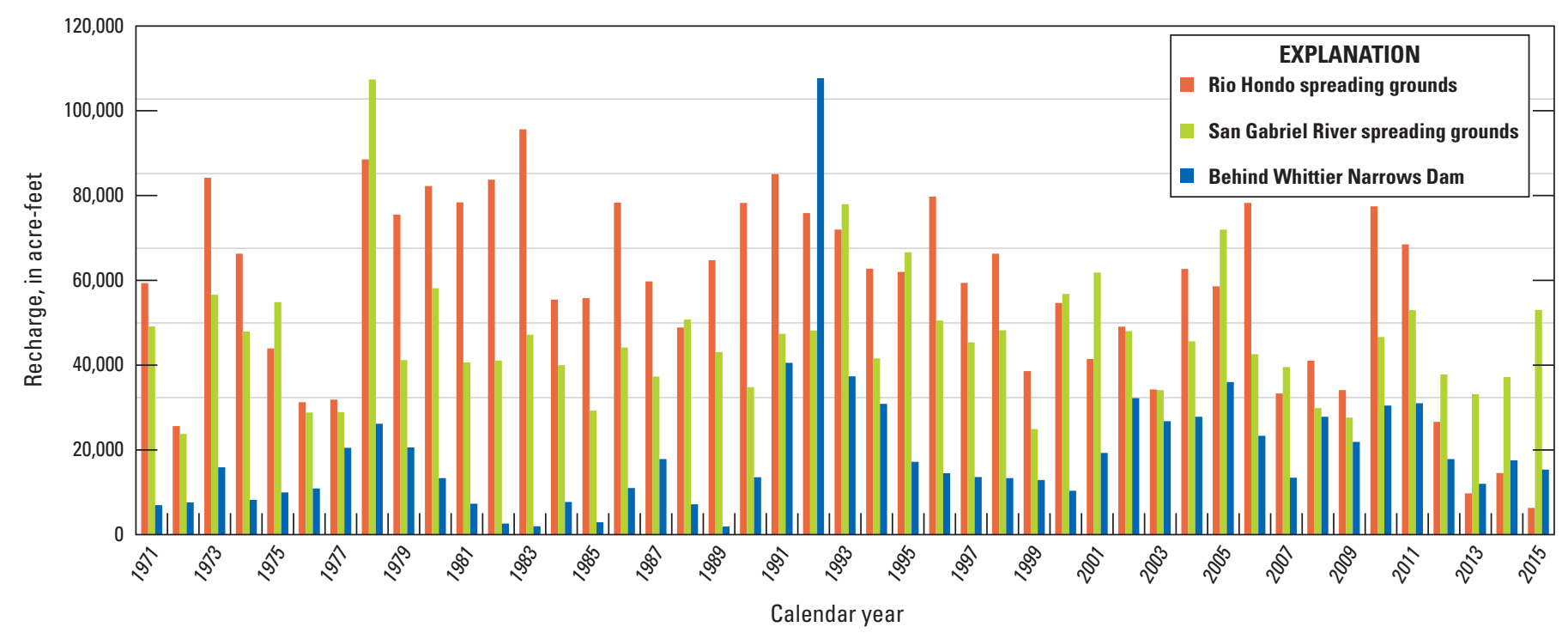

Figure C3. Annual recharge at Rio Hondo spreading grounds, San Gabriel River spreading grounds, and Whittier Narrows Dam for calendar years 1971 to 2015, Los Angeles County, California.

Table C1. Estimated underflow in acre-feet from the San Gabriel Valley into the Los Angeles Coastal Plain provided by the San Gabriel Water Master, Los Angeles County, California, 1962 to 2015.

[Data provided by San Gabriel River Watermaster.]

\begin{tabular}{cccccccc}
\hline Year & Subsurface flow & & Year & Subsurface flow & & Year & Subsurface flow \\
\cline { 1 - 3 } \cline { 6 - 7 } 1962 & 21,600 & & 1976 & 27,800 & & 1990 & 32,100 \\
1963 & 20,050 & & 1977 & 31,700 & & 1991 & 26,200 \\
1964 & 21,000 & & 1978 & 30,900 & & 1992 & 22,700 \\
1965 & 18,800 & & 1979 & 27,400 & & 1993 & 21,600 \\
1966 & 17,000 & & 1980 & 25,300 & & 1994 & 24,000 \\
1967 & 17,500 & & 1981 & 27,400 & & 1995 & 25,300 \\
1968 & 20,700 & & 1982 & 29,900 & & 1996 & 27,400 \\
1969 & 24,400 & & 1983 & 29,100 & & 1997 & 28,100 \\
1970 & 23,900 & & 1984 & 28,200 & & 1998 & 27,900 \\
1971 & 22,900 & & 1985 & 28,600 & & 1999 & 27,000 \\
1972 & 24,000 & & 1986 & 30,500 & & 2000 & 27,200 \\
1973 & 25,900 & & 1987 & 31,900 & & 2001 & 27,900 \\
1974 & 26,600 & & 1988 & 33,200 & & 2002 & 27,400 \\
1975 & 25,600 & & 1989 & 33,000 & & 2003 & 24,000
\end{tabular}

\begin{tabular}{cc}
\hline Year & Subsurface flow \\
\hline 2004 & 24,200 \\
2005 & 21,600 \\
2006 & 24,300 \\
2007 & 26,400 \\
2008 & 30,300 \\
2009 & 31,300 \\
2010 & 29,400 \\
2011 & 25,400 \\
2012 & 23,700 \\
2013 & 27,200 \\
2014 & 35,100 \\
2015 & 35,700 \\
Average & $\mathbf{2 6 , 2 9 6}$ \\
\hline
\end{tabular}


The reservoir behind the Whittier Narrows Dam (WND) on the Rio Hondo side collects and stores local runoff and the water released into the San Gabriel River from the upstream Santa Fe Dam (not shown). Both the dam and the reservoir are earthen; therefore, seepage occurs when water is impounded behind the dam after storm events. Seepage also occurs in the reservoir behind the dam throughout the year if water is present in the Rio Hondo or its tributaries. Groundwater recharge at the reservoir functions similarly to the RHSG and SRSG downstream. The average annual recharge at WND for calendar years 1971 to 2015 was about 19,000 acre-ft (fig. C3). In addition to local runoff, recycled and imported water is purchased by WRD for spreading at these recharge facilities. The total average annual spreading for RHSG, SGRSG, and WND was about 120,000 acre-ft for calendar years 1971 to 2015 .

WND, RHSG, and SGRSG are also central elements of the San Gabriel River flood control and conservation system. Water collected and stored in the reservoir behind the WND is routed to the RHSG and SGRSG or released to the San Gabriel River in a regulated manner to facilitate groundwater recharge and minimize flooding downstream. Therefore, distribution of recharge water at the three facilities is determined not only by the total amount of excess water and the capacity of each facility, but also by the operation and maintenance schedule and other engineering-related factors.

\section{Managed Aquifer Recharge Through Injection Wells at Seawater Barriers}

Injection of freshwater through seawater-barrier wells has been used as a method of managed aquifer recharge in the LACP since the 1950s. Groundwater in the coastal aquifers of the LACP is in hydraulic connection with the Pacific Ocean. Under natural conditions, groundwater flows from the forebays to the ocean; however, the flow direction can be reversed when inland pumping of freshwater lowers the water-level elevation in the coastal groundwater basins below sea level. In the LACP, seawater intrusion resulting from freshwater pumping started to become a problem in the 1940s (Poland and others, 1959). As a result, injection of imported water through wells at what is now the West Coast Basin Barrier Project (WCBBP) began on an experimental basis in 1951 (Water Replenishment District of Southern California, 2007). Injecting water through wells allows fresh water to displace saltwater and creates a hydraulic pressure ridge (or barrier) along the line of injection wells. Three barrier projects have been constructed and operated near the shoreline of the
Central and West Coast Basins (fig. A1). In the West Coast Basin, water is injected at WCBBP and the Dominguez Gap Barrier Project (DGBP). In the Central Basin, water is injected at the Alamitos Barrier Project (ABP). The alignment of each barrier project was based on geologic and hydrologic conditions at each location, as well as land availability. Factors such as seawater intrusion path, rate, and areal extent were also considered when each barrier was designed and constructed. The barrier wells allow injected water to reach depths up to $700 \mathrm{ft}$ at the WCBBP (Water Replenishment District of Southern California, 2007).

Among the three barrier projects, the WCBBP is the largest, extending about 9 miles (mi) along the Santa Monica Bay shoreline in the West Coast Basin (fig. A1). The WCBBP consists of 153 injection wells and 302 observation wells (Water Replenishment District of Southern California, 2007). The DGBP is the second largest barrier project, extending over $6 \mathrm{mi}$ along the Dominguez Gap, in the southern part of the West Coast Basin (fig. A1). The DGBP has 94 injection wells and 232 observation wells (Water Replenishment District of Southern California, 2007). The ABP is the smallest barrier project, extending about $2.2 \mathrm{mi}$ through Long Beach and Seal Beach, in the southeastern part of the Central Basin and crosses the Los Angeles/Orange County line (fig. A1). The ABP includes injection wells that form a freshwater ridge, extraction wells that were intended to form a saltwater trough, and 239 observation wells (Los Angeles County Department of Public Works, 2005).

Similar to the spreading facilities, the LACFCD operates and maintains the barrier projects. The LACFCD owns the wells, WRD purchases the injection water for the WCBBP, the DGBP, and the Los Angeles County side of the ABP, and the Los Angeles County Department of Public Works pays for the operational costs. The OCWD owns the ABP injection and monitoring wells, purchases the water, and pays for the operational costs for the Orange County side of the ABP. Presently, both imported and recycled water are used for injection. The WRD reported (West Coast Basin Watermaster, 2017) average annual injection volumes for WCBBP, DGBP, and ABP from 1971 to 2015 were approximately 21,200, 6,500 , and 5,300 acre-ft, respectively (fig. C4). The annual injection volume varied on an annual basis at all barrier projects during this period. For example, injection at the WCBBP ranged from more than 35,000 acre-ft/yr in 1976 to less than 10,000 acre-ft/yr in 2005 (fig. C4). The location and injection rates of barrier wells for 1971 to 1979 and 2010 to 2015 are shown on figure C5. 


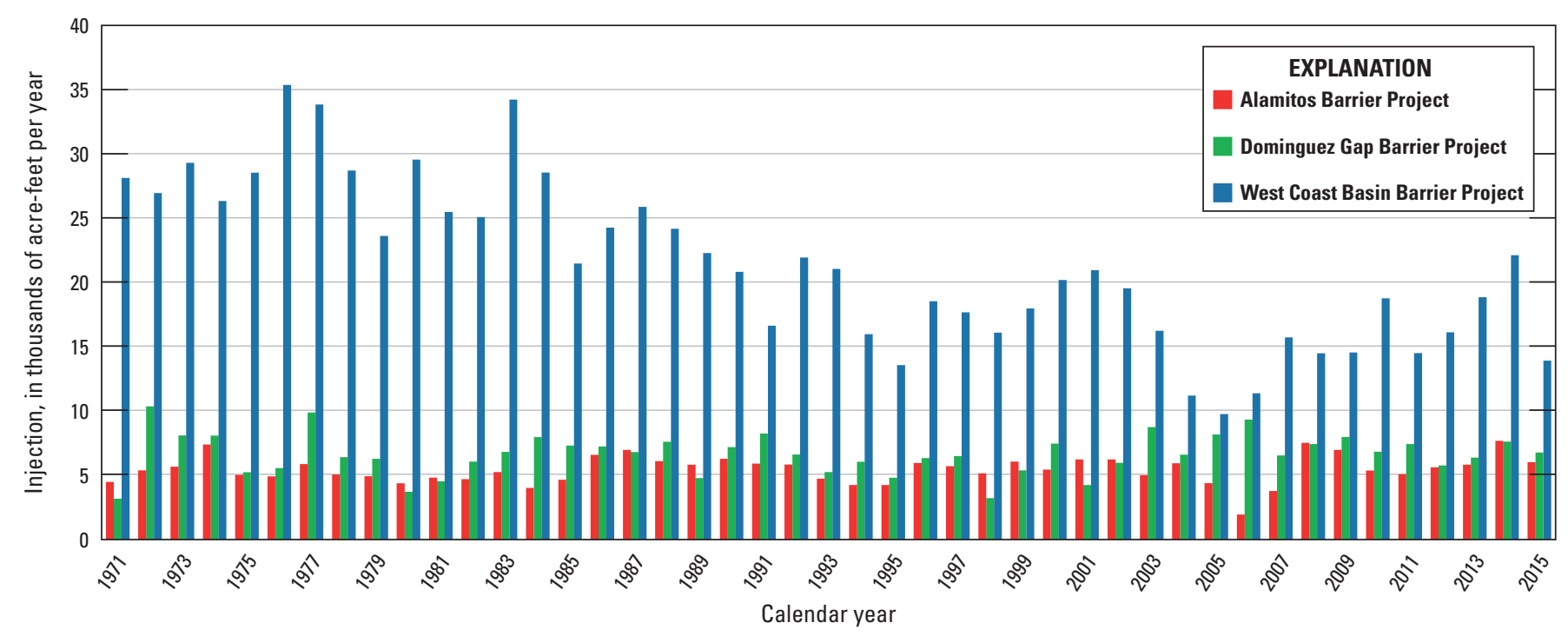

Figure C4. Annual injection during calendar years 1971-2015 at Alamitos, Dominguez Gap, and West Coast Basin Barrier Projects, Los Angeles Coastal Plain, California. Injection data provided by Water Replenishment District of Southern California.

\section{Net Subsurface Inflow}

Sources of subsurface inflow include underflow from the neighboring Orange County groundwater basin and from offshore. Under predevelopment conditions, there were artesian conditions along the county line (Mendenhall, 1905c) with flow discharging to the Pacific Ocean. After a century of groundwater development, water levels are no longer artesian in the two groundwater basins, and the natural hydraulic gradient and flow paths have been altered (Chapter D). A previous USGS regional groundwater-flow model simulated a net inflow of about 8,000 acre-ft/yr from the Orange County Basin into the Central Basin for the period from 1971 to 2000 (Reichard and others, 2003, fig. 34). However, the last five years of this simulation (1996-2000) indicated increased flow from the Central Basin to the Orange County Basin and a reduced amount of flow from the Orange County Basin to the Central Basin.
The location and magnitude of onshore or offshore groundwater flow varies depending on the amount of groundwater recharge and discharge to or from the coastal groundwater basins. Offshore flow occurs in areas where the groundwater elevation is higher than sea level because of injection or other managed aquifer recharge activities. In other areas, onshore flow occurs when groundwater elevation is lower than sea level due to the pumping of groundwater. A previous USGS regional groundwater-flow model simulated a net average annual inflow of about 3,000 acre-ft from the Pacific Ocean into the entire LACP for the period of 1971 to 2000 (Reichard and others, 2003, fig. 34). Simulated net average annual inflow from the Pacific Ocean into the West Coast Basin was about 7,100 acre-ft, with inflow of 8,900 acre- $\mathrm{ft}$ from the lower two model layers and 1,800 acre- $\mathrm{ft}$ of outflow from the upper two model layers (Reichard and others, 2003). 
A

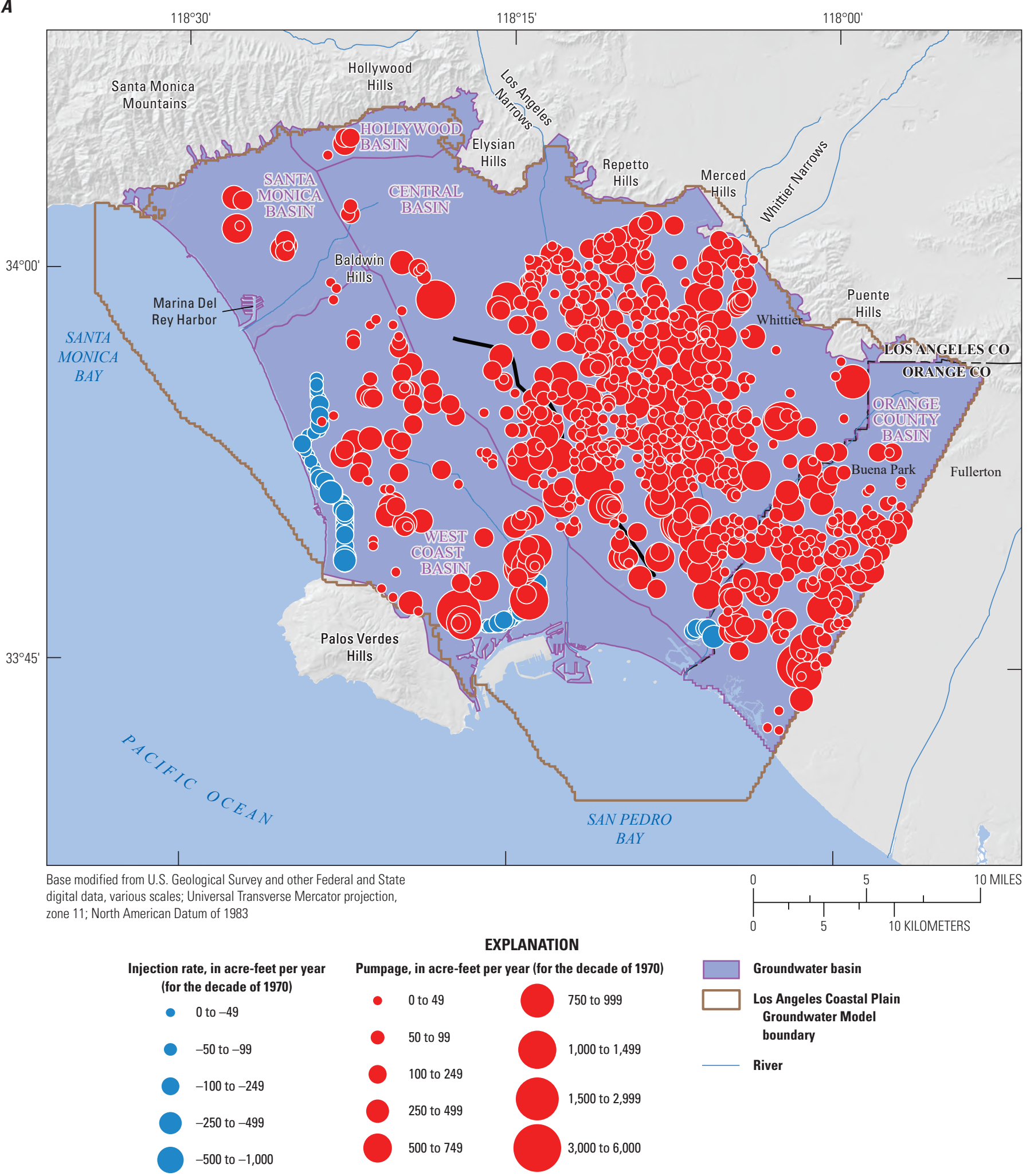

Figure C5. Average injections and pumpage for $A, 1971$ to 1979, and B, 2010 to 2015, in Los Angeles Coastal Plain, California. Data provided by Water Replenishment District of Southern California. 


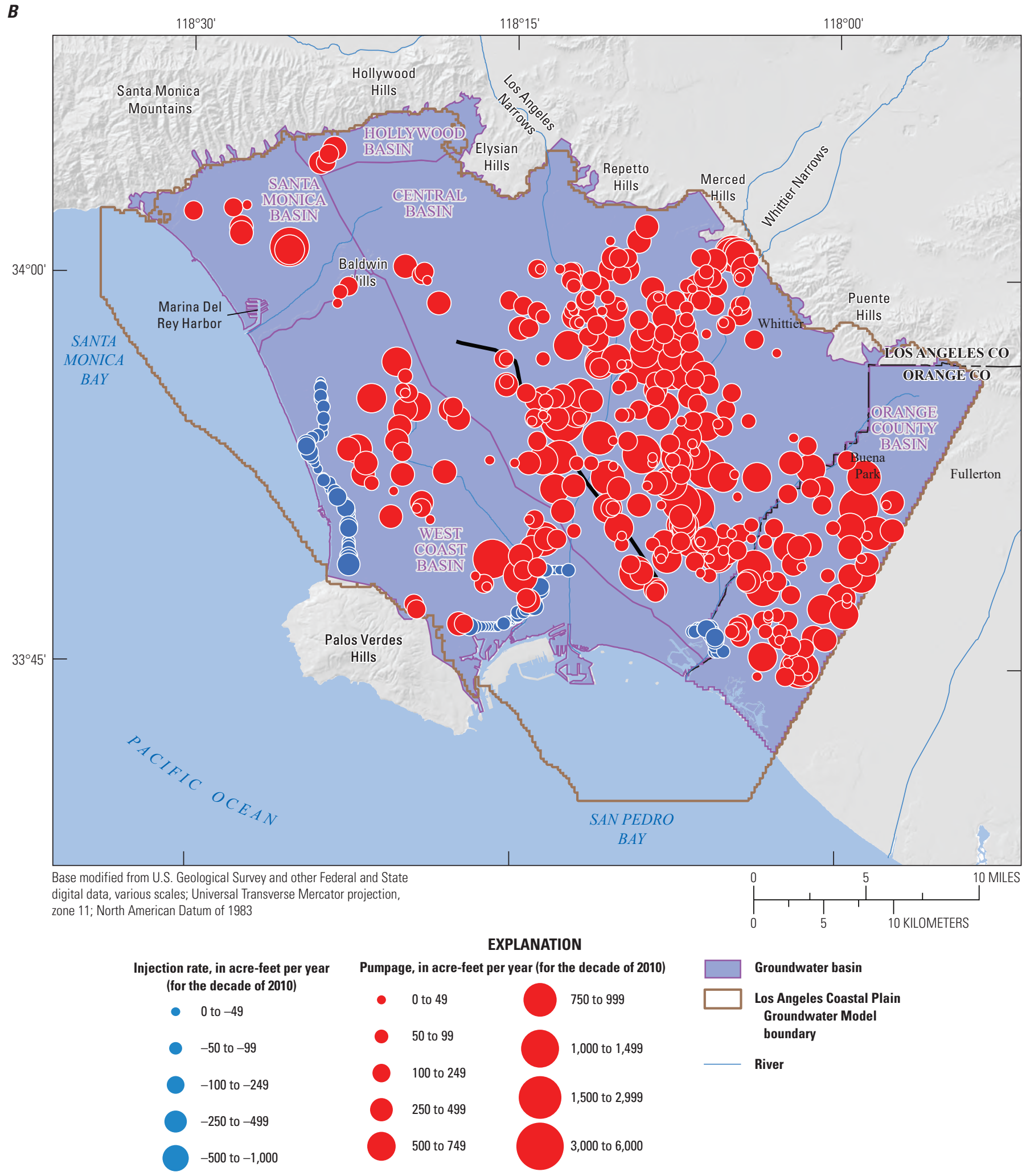

Figure C5.-Continued 


\section{Groundwater Discharge}

Groundwater pumping is the primary discharge from the LACP groundwater basins. Other potential groundwater discharges include outflow to the ocean, underflow to adjacent basins, evapotranspiration, and baseflow to streams; however, evapotranspiration and baseflow are incorporated into the groundwater recharge estimates of Hevesi and Johnson (2016).

The first water wells were drilled in the mid-1800s, and by the early 1900 s there were more than 4,000 wells in the LACP (Mendenhall, 1905a, b, c). From the early 1900s through the 1950s groundwater pumping from wells continued to increase because of increasing urban demand for water (Reichard and others, 2003, fig. 5). The groundwater pumping led to large water-level declines throughout the LACP. The continuing depletion of groundwater storage and water-level declines eventually led to the adjudication of both the Central and West Coast Basins in the early 1960s. The adjudications of both groundwater basins resulted in large decreases in pumping in both groundwater basins (Reichard and others, 2003). Approximately 4,000 wells are located within the LACP boundary; however, only about 1,500 wells were active at some time during 1971 to 2015 (fig. C6). Annual pumpage compiled for this study (see Chapter A) during this period ranged from a high of about 389,000 acre-ft in 1971 to a low of about 242,000 acre-ft in 1993, with an average of about 307,000 acre-ft (fig. C7; table C2).

Most of the production wells are screened over large intervals and withdraw water from multiple aquifers (fig. C6). The deepest production well record found was in the southern Central Basin, with a well depth of 2,200 ft below land surface (bls); however, the depth to the bottom perforation of most of the wells is $600 \mathrm{ft}$ bls or less (fig. C6B). Unfortunately, some production wells lacked information on well depth and screened interval details. To accurately simulate the effects of pumping on water levels in the different aquifers, we had to assign a well depth and screened interval depths for each production well. If the well depth was known but information on the screened interval was missing, we assumed that the well was screened similarly to nearby wells constructed to a similar depth. The unknown screened interval depths were calculated by averaging the screened interval depths of nearby pumping wells with similar depths. If the depth and screened interval were both missing, we assumed that the well was screened similar to nearby wells that pumped about the same quantity of water.

The distribution of groundwater pumping across the LACP during the study period was not uniform (fig. C5). Active groundwater production wells were sparse in the Santa Monica Basin, Hollywood Basin, the northwestern portion of the Central Basin, the Whittier area in the Central Basin, and the area north of Buena Park and Fullerton in the Orange County Basin. The greatest density of active production wells is in the central and southeastern parts of the Central Basin and the southern part of the Orange County Basin (fig. C5).

\section{Water Levels and Movement}

Knowledge of water levels and how they vary spatially and temporally is fundamental to understanding and managing water resources. The shapes and relations among water tables and potentiometric surfaces can reveal important hydrogeologic characteristics of the watershed, such as locations of key areas of recharge and discharge and effects of geology on groundwater flow. Declining long-term hydrographs can indicate that an aquifer is being pumped in excess of recharge.

\section{Pre- or Early Development Water Levels}

Mendenhall (1905b, plate 1; 1905c, plate 1) presented water-level contour maps that included the LACP. The exact years represented by water-level contours are unknown, but by 1905 the groundwater basin had been pumped for about 50 years. In addition, the chronostratigraphic units represented by these water-level contours are unknown. Nonetheless, these maps are the most representative of pre-development conditions available. Groundwater generally flowed from the hills and foothills along the northern and eastern edges of the LACP toward the ocean to the southwest. Both Mendenhall (1905a, b, c) and Poland and others (1959) reported the presence of artesian conditions in the study area. Poland and others (1959) reported a flowing well 2 mi north of Signal Hill. Mendenhall (1905a, b, c) reported that about 30 percent of the area had flowing artesian conditions.

\section{Post-Development Water Levels}

Water-level hydrographs were constructed for eight well pairs located in the Central, West Coast, and Santa Monica Basins of the LACP to show long-term changes in water levels (figs. C8, C9). Water-level data collected by Los Angeles County were used to construct the long-term hydrographs. Measurements from some of these wells span 80 years, starting from the 1930s to present. Water levels were collected from most of these wells on a quarterly or semiannual basis. Most of these wells are production wells constructed with long screened intervals open to multiple aquifers; therefore, the water levels measured in such wells are a composite of the water levels present in the different aquifers open to the well. These long-term hydrographs were paired with short-term hydrographs from nearby WRD/USGS multiple-well monitoring sites, where available, to provide aquifer-dependent water-level data for the later time period (fig. C9). Water levels at most of the multiple-well monitoring sites are recorded on a continuous basis. These data were averaged and plotted as quarterly data on the hydrographs. 
A

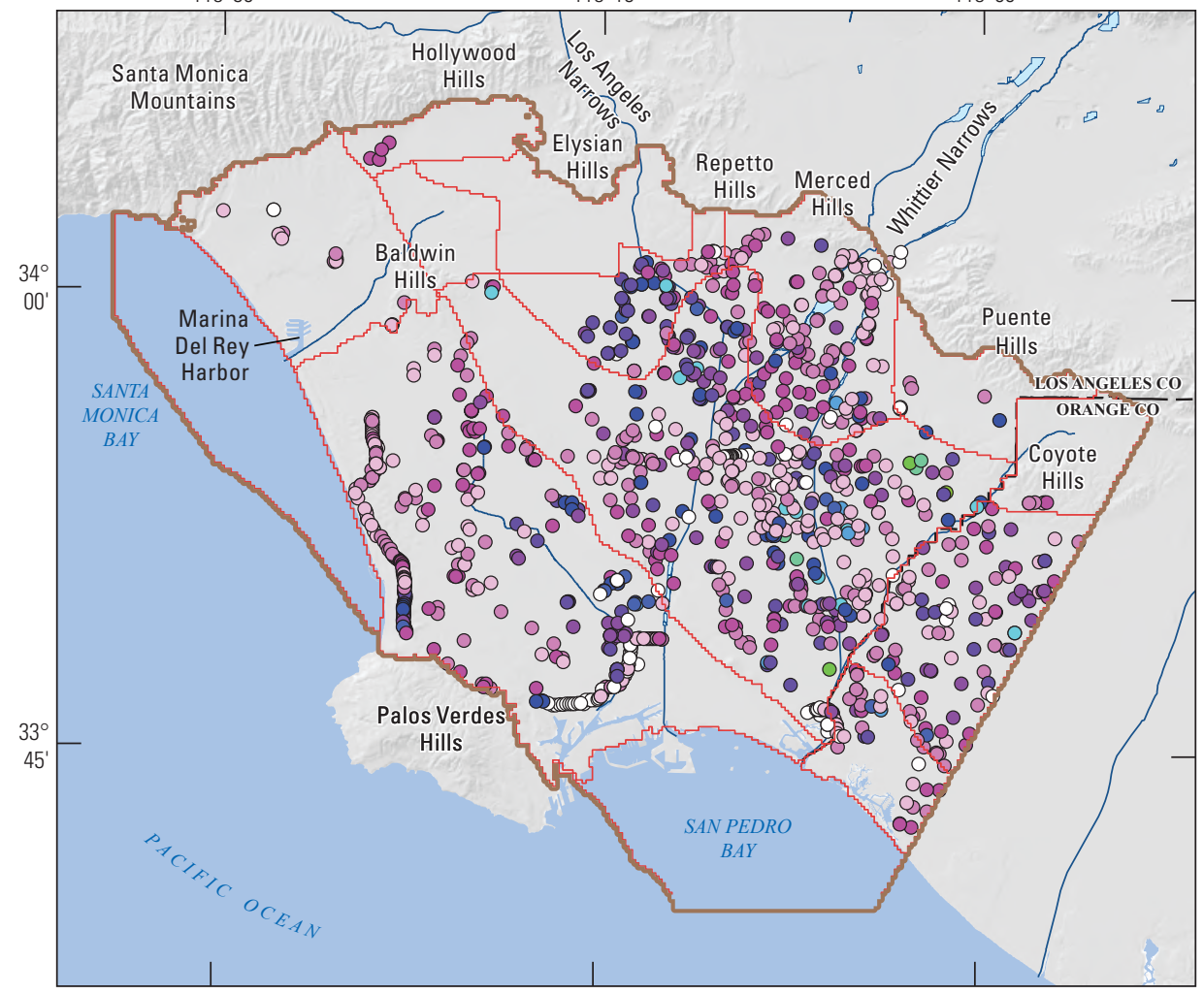

B

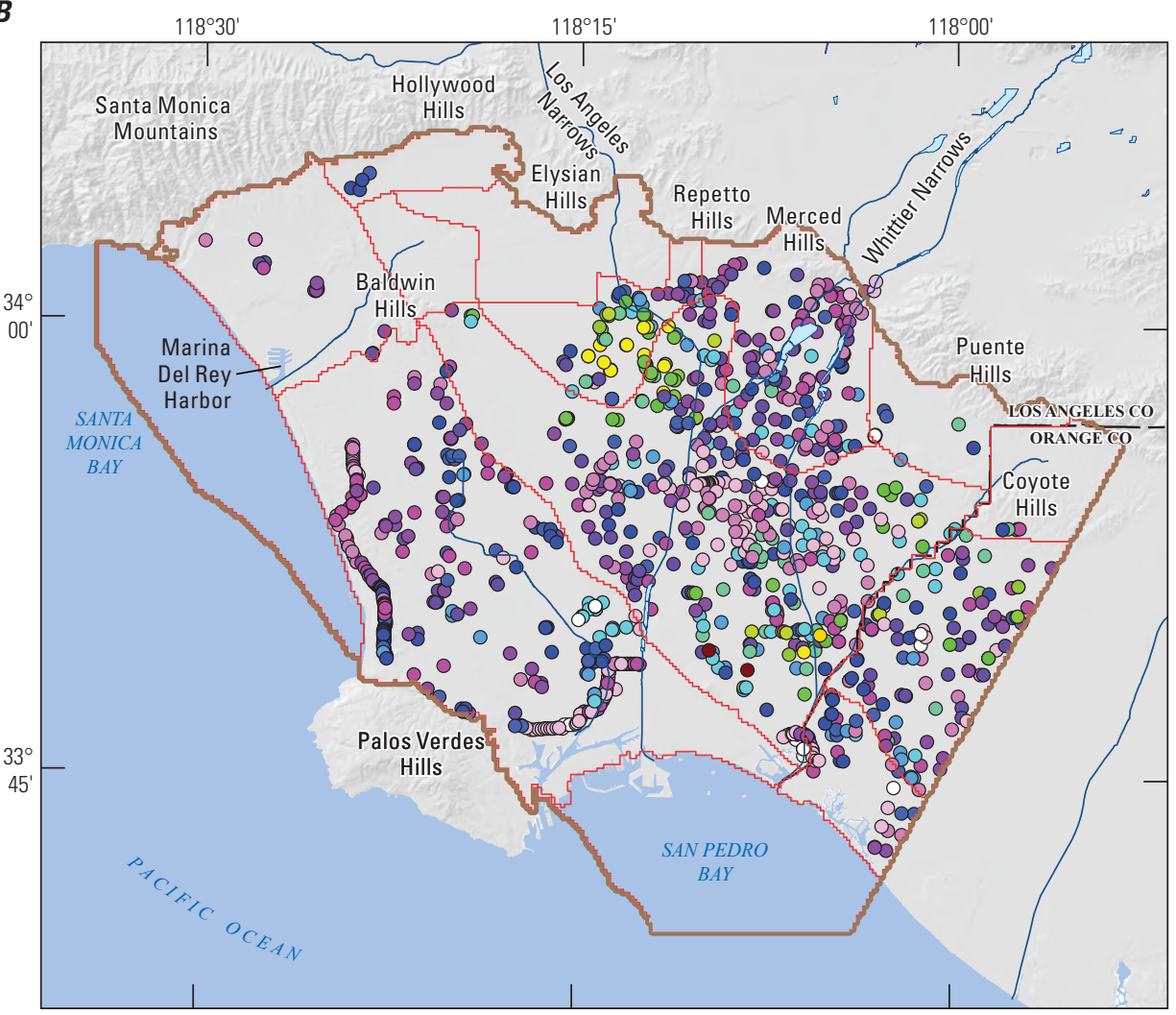

EXPLANATION

Subarea

Los Angeles Coastal Plain Groundwater Model boundary

River

Depth to top of perforation, in feet below land surface

\begin{tabular}{|c|c|}
\hline 6 to 99 & 1,100 to 1,199 \\
\hline 100 to 199 & 1,200 to 1,299 \\
\hline 200 to 299 & O 1,300 to 1,399 \\
\hline 300 to 399 & 1,400 to 1,499 \\
\hline 400 to 499 & (O) 1,500 to 1,599 \\
\hline 500 to 599 & O 1,600 to 1,699 \\
\hline 600 to 699 & 1,700 to 1,799 \\
\hline 700 to 799 & - 1,800 to 1,899 \\
\hline 800 to 899 & - 1,900 to 1,999 \\
\hline 900 to 999 & - 2,000 to 2,099 \\
\hline 1,000 to 1,099 & - 2,100 to 2,199 \\
\hline & 10 MILES \\
\hline
\end{tabular}

Base modified from U.S. Geological Survey and other Federal and State digital data; various scales Transverse Mercator projection, zone 11; North American Datum of 1983

\section{EXPLANATION}

Subarea

Los Angeles Coastal Plain Groundwater Model boundary

River

Depth to bottom of perforation, in feet below land surface

$\bigcirc 6$ to $99 \quad \bigcirc 1,100$ to 1,199

O 100 to 199 O 1,200 to 1,299

- 200 to $299 \quad \bigcirc, 300$ to 1,399

300 to 399 ○ 1,400 to 1,499

- 400 to 499 ○ 1,500 to 1,599

- 500 to $599 \quad \bigcirc 1,600$ to 1,699

- 600 to 699 O 1,700 to 1,799

- 700 to 799 O 1,800 to 1,899

○ 800 to 899 O 1,900 to 1,999

○ 900 to 999 2,000 to 2,099

- 1,000 to 1,099 2,100 to 2,199

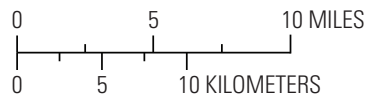

Base modified from U.S. Geological Survey and other Federal and State digital data; various scales Transverse Mercator projection, zone 11; North American Datum of 1983

Figure C6. Depth to $A$, top of perforations, and $B$, bottom of perforations of production and injection wells active during 1971 to 2015 , Los Angeles Coastal Plain, California. 


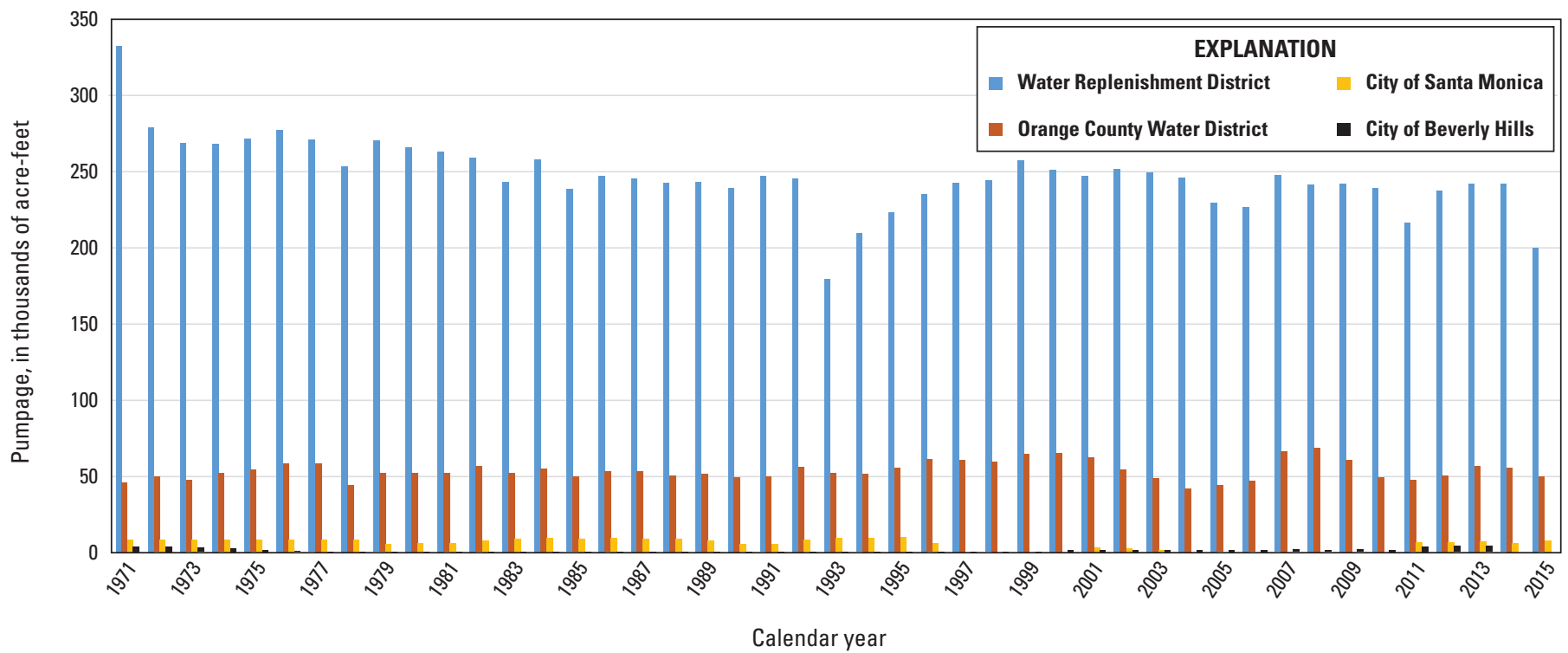

Figure C7. Annual pumpage by calendar year in the Los Angeles Coastal Plain by reporting agency. (Reporting agency codes: WRD, Water Replenishment District of Southern California; OCWD, Orange County Water District.)

Table C2. Estimated annual groundwater-flow budget in acre-feet of saturated zone, 1971 to 2015, Los Angeles Coastal Plain, California.

[Data from Reichard and others, 2003; Hevesi and Johnson, 2016; and local water agencies. Abbreviations: SG, San Gabriel; SF, San Fernando; SM, Santa Monica; SP, San Pedro; OC, Orange County]

\begin{tabular}{|c|c|}
\hline Budget components & With irrigation \\
\hline \multicolumn{2}{|c|}{ Estimated inflows } \\
\hline Spreading & 122,700 \\
\hline Areal recharge & 55,200 \\
\hline Injection & 32,500 \\
\hline Underflows from SG Basin & 27,600 \\
\hline Underflows from SF Basin & 6,200 \\
\hline Onshore flow from SM Bay & 1,400 \\
\hline Onshore flow from SP Bay & 7,500 \\
\hline Cross-boundary flow from OC & 8,000 \\
\hline Total & 261,100 \\
\hline \multicolumn{2}{|l|}{ Estimated outflows } \\
\hline Pumpage & 304,900 \\
\hline Offshore flow to SM Bay & 4,500 \\
\hline Offshore flow to SP Bay & 1,400 \\
\hline Total & 310,800 \\
\hline Change in storage & $-49,700$ \\
\hline
\end{tabular}




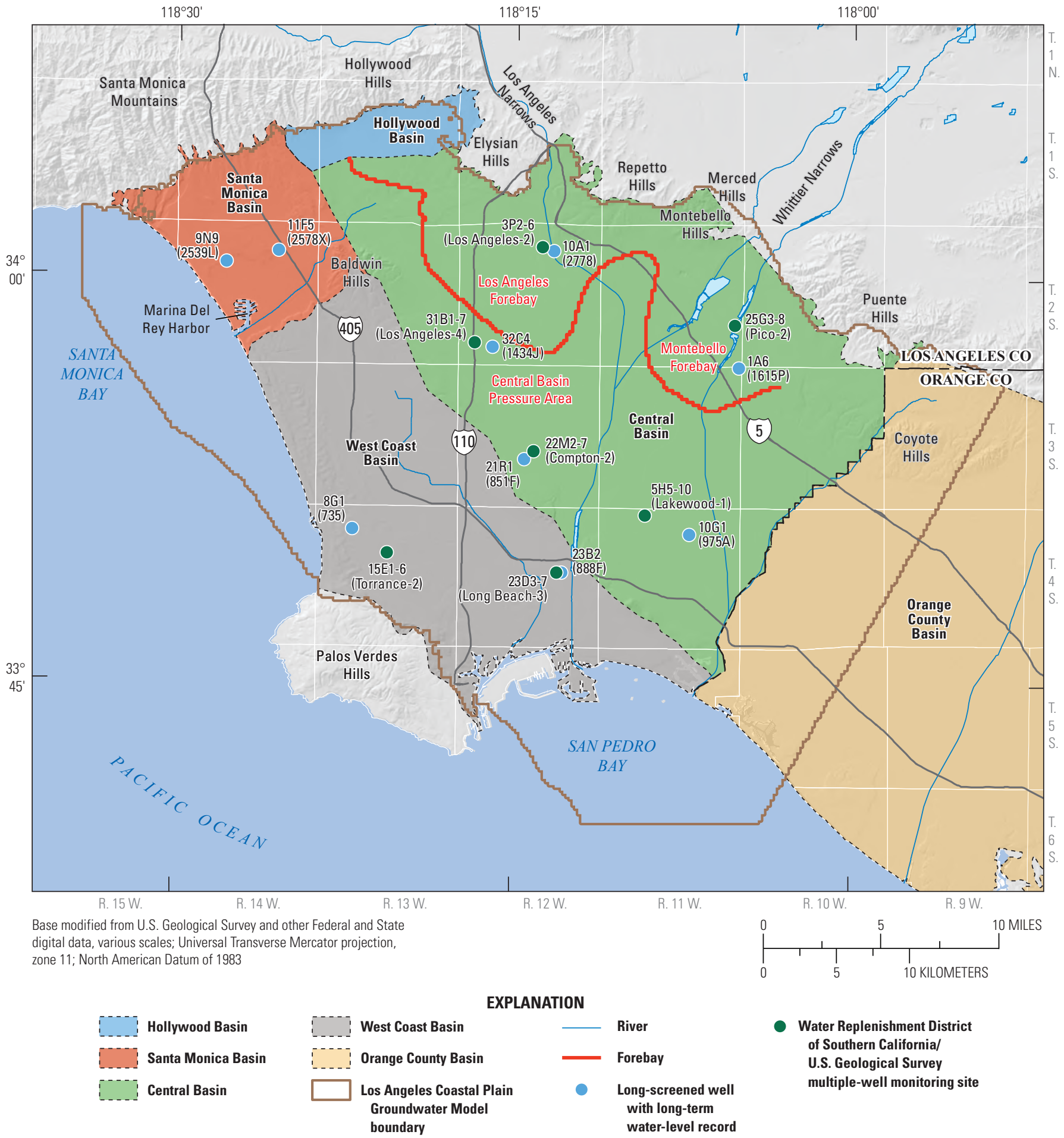

Figure C8. Locations of selected long-screened basin-monitoring wells and (generally) paired multiple-well monitoring sites in the Los Angeles Coastal Plain, Los Angeles County, California. 

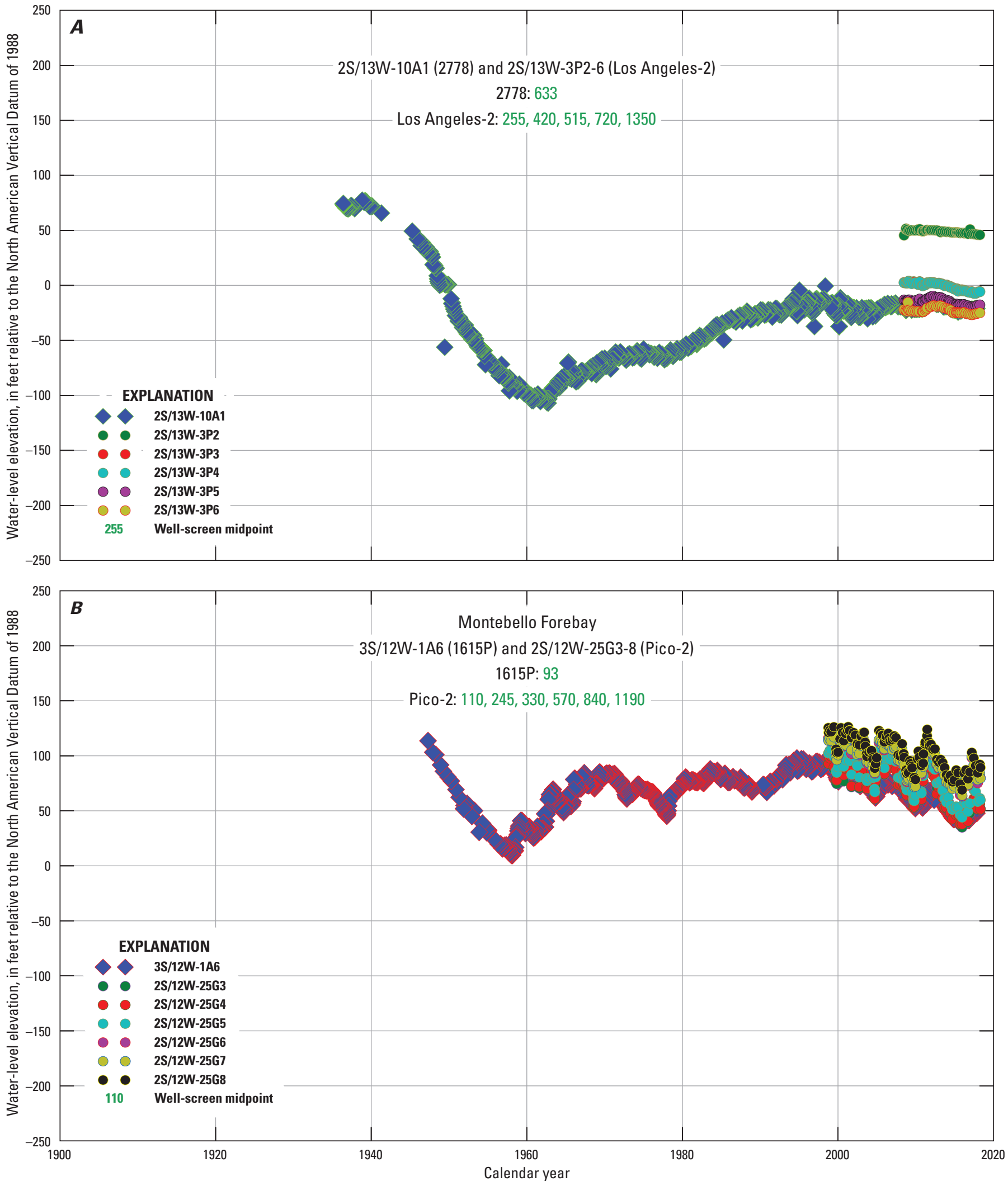

Figure C9. Long-term hydrographs for selected long-screened, basin-monitoring wells and (generally) paired multiple-well monitoring sites in the $A$, Los Angeles Forebay; $B$, Montebello Forebay; $C$, Central Basin Pressure Area (North); $D$, Central Basin Pressure Area (Central); E, Central Pressure Area (South); F, West Coast Basin (East); G, West Coast Basin (West); and H, Santa Monica Basin, Los Angeles Coastal Plain, Los Angeles County, California. 

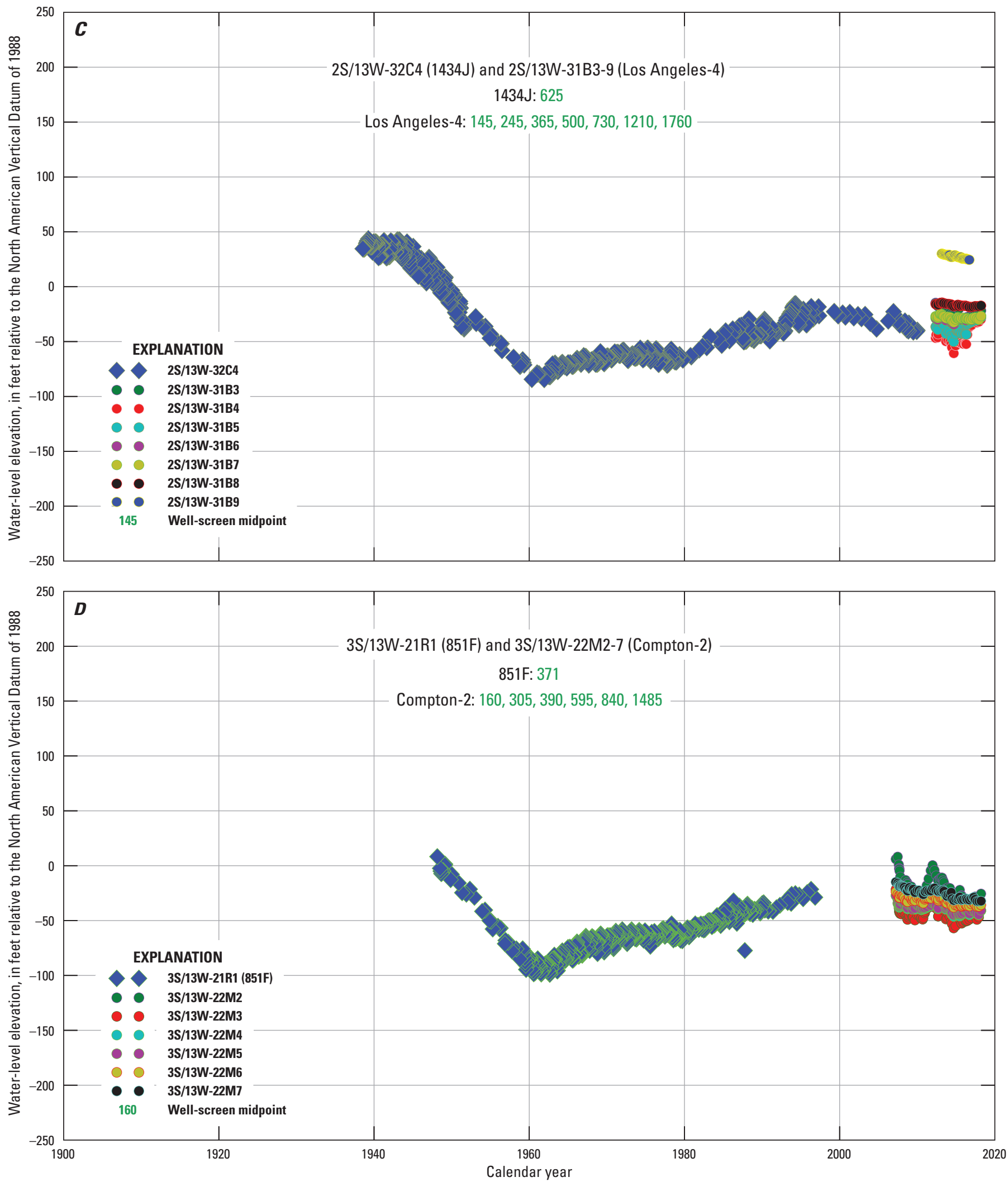

Figure C9.-Continued 

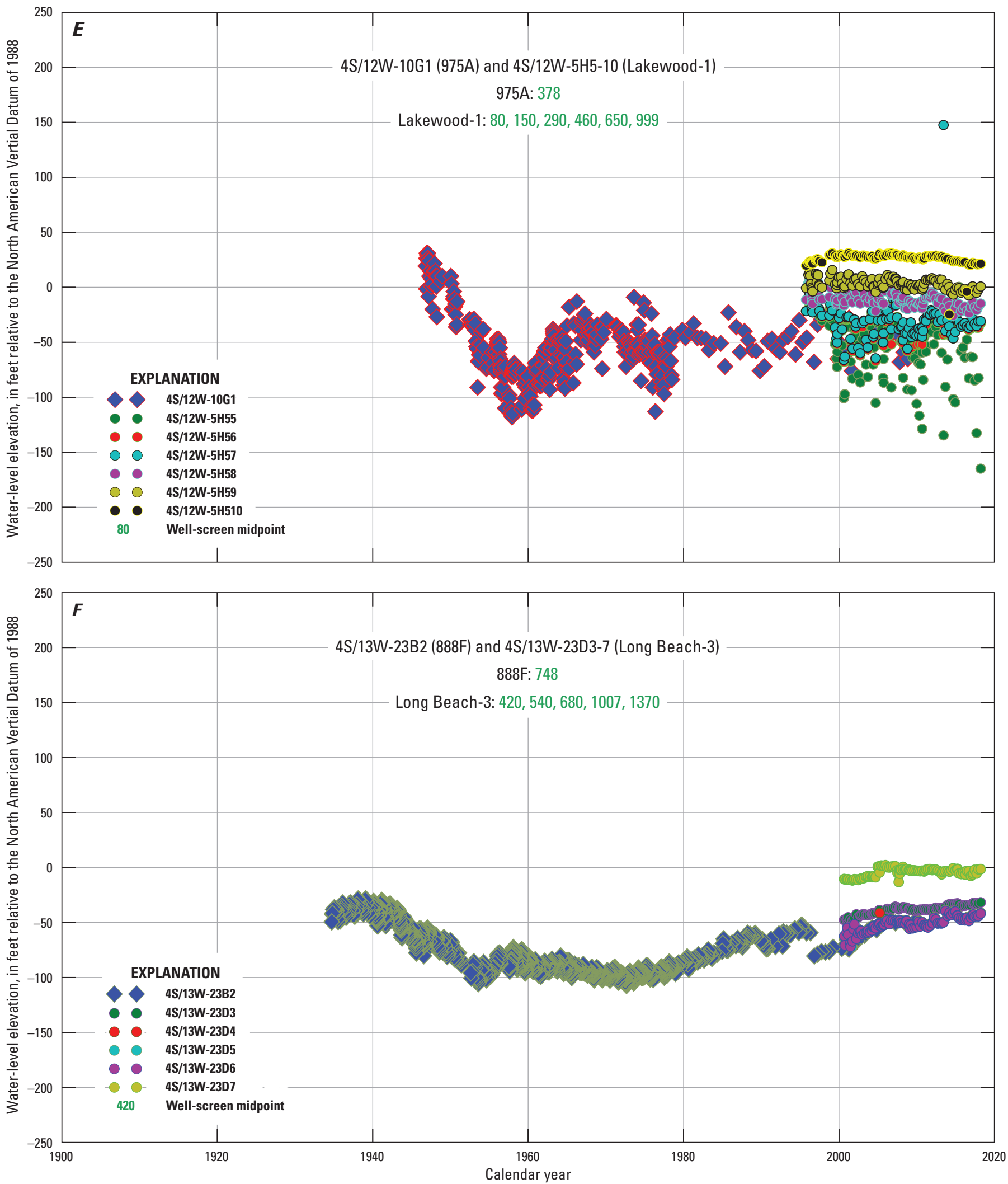

Figure C9.-Continued 

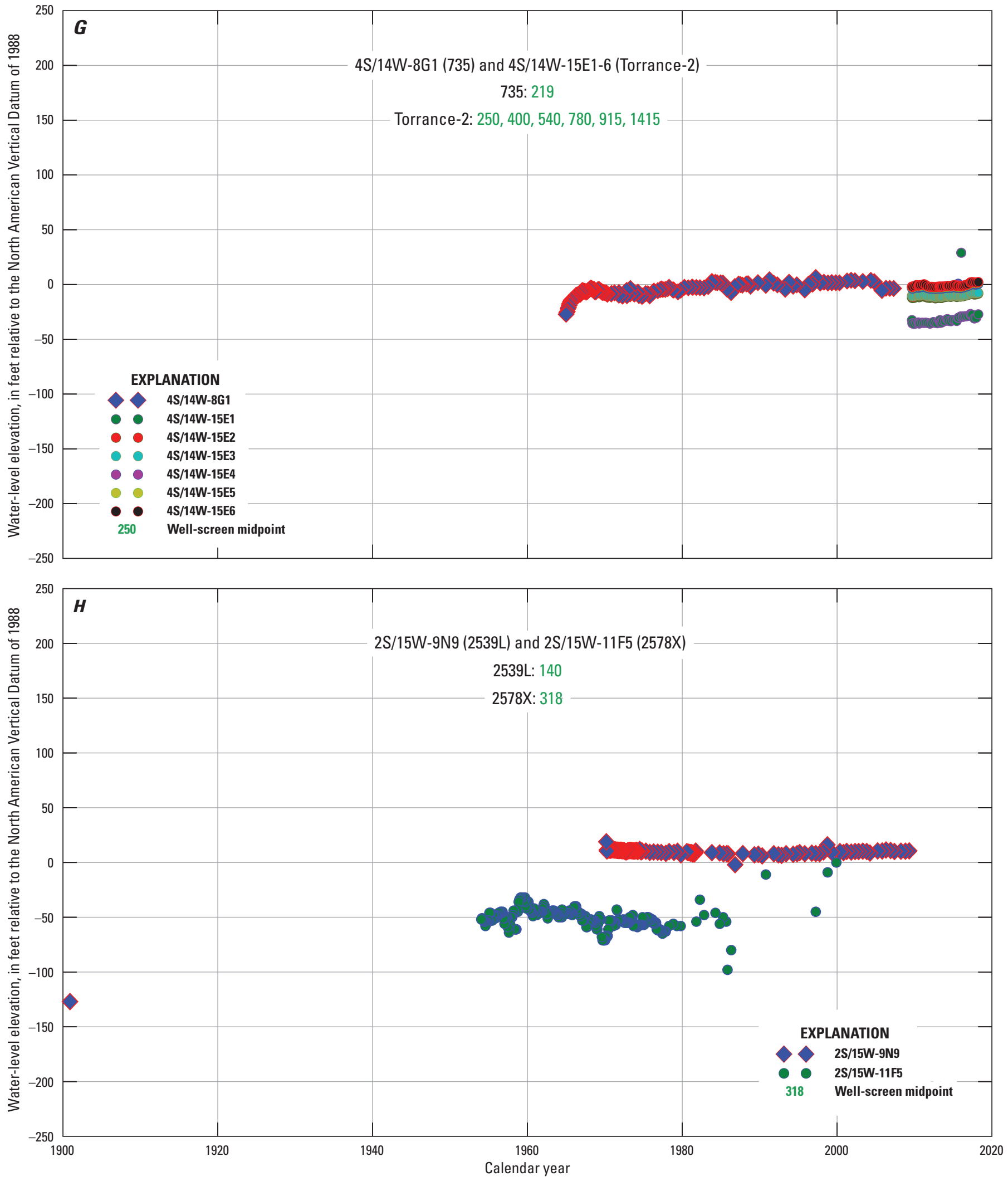

Figure C9.-Continued 
Groundwater pumping from the early 1900s until the early-to-mid 1960s, when the Central and West Coast Basins were adjudicated, resulted in large water-level declines throughout most of the LACP (fig. C9). From 1930 to the early 1960s, pumping in excess of recharge resulted in water-level declines greater than $100 \mathrm{ft}$ in the Los Angeles Forebay, Montebello Forebay, and the Central Basin Pressure Area (fig. $\mathrm{C} 9 A-E$ ). Water levels in the West Coast Basin and Santa Monica Basins declined to more than $60 \mathrm{ft}$ below NAVD 88 by 1960 (fig. $\mathrm{C} 9 F-H$ ). Reduction in pumping and increased managed aquifer recharge as a result of the adjudications of the Central and West Coast Basins resulted in water-level rises throughout most of the LACP from the early 1960s to 1970 (fig. C9). Each of the paired monitoring sites is discussed in detail below.

\section{Los Angeles Forebay}

Well 10A1 $(2 \mathrm{~S} / 13 \mathrm{~W}-10 \mathrm{~A} 1 ; 2778)$ is a production well in the Los Angeles Forebay of the Central Basin (fig. C8) that is screened in the Pacific, Harbor, and Upper Wilmington A aquifer systems. Water levels have been measured at well 10A1 from 1936 to 2017 (fig. C9A). Water levels in this well declined more than $190 \mathrm{ft}$ from the late 1930s to the early $1960 \mathrm{~s}$, from an altitude high of about $80 \mathrm{ft}$ in the late 1930s to a low of about $114 \mathrm{ft}$ below NAVD 88 in the early 1960s (fig. C9A). From the early 1960s until the mid 1990s, water levels recovered about $90 \mathrm{ft}$, to an elevation of about $20 \mathrm{ft}$ below NAVD 88, in response to the reduction of pumping and increased replenishment activities in the LACP. Since 1990, water levels in the well have been relatively constant with likely seasonal changes in response to pumping. Water levels measured in 2017 in well 10A1 in the Los Angeles Forebay were about $100 \mathrm{ft}$ lower than historical highs recorded in the late 1930s.

Monitoring wells 3P2-6 (2S/13W-3P2 to 3P6) compose the Los Angeles2 multiple-well monitoring site in the Los Angeles Forebay (fig. C8), and are screened in the Long Beach C (3P2), Upper Wilmington A (3P3, 3P4), Harbor (3P5), and Pacific (3P6) aquifer systems (appendix 1, table 1.1). Land-surface elevation at 3P2-6 is within $5 \mathrm{ft}$ of the land-surface elevation at well 10A1. Water levels have been collected at wells 3P2-6 since the site was constructed in 2008. Water levels in well 10A1 are similar to those measured in the Pacific aquifer system at well 3P6 (fig. C9A), indicating that well $10 \mathrm{~A} 1$ is receiving most of its water from the Pacific aquifer system even though it also is screened in the Harbor and Upper Wilmington A aquifer systems. Water levels in the Long Beach $\mathrm{C}$ aquifer system are about $50 \mathrm{ft}$ higher than water levels in Upper Wilmington A aquifer system and about $70 \mathrm{ft}$ higher than levels in the Harbor and Pacific aquifer systems. The total dissolved solids (TDS) of a sample from well 3P2 screened in Long Beach C was 18,000 milligrams per liter (mg/L; January 2013), or about one-half the concentration found in present-day seawater $(35,000 \mathrm{mg} / \mathrm{L})$; in contrast, wells 3P3-3P6 had TDS of 1,400 mg/L or less (June 2010 and April 2013; appendix 1, table 1.2).

The high water levels and high TDS concentration of a sample from well 3P2 indicate that the Long Beach $\mathrm{C}$ aquifer system at this location is not part of the active groundwater-flow system. Low-permeability clays in the Long Beach C aquifer system at the 3P2-6 wells likely limit the hydraulic connection to the overlying aquifer systems. Water levels in the Upper Wilmington A aquifer system (fig. C9A, 3P4) follow a similar pattern to the overlying Harbor (fig. C9A, 3P5) and Pacific (fig. C9A, 3P5) aquifer systems but are about $20 \mathrm{ft}$ higher. As a result of folding and subsequent erosion, the Upper Wilmington A aquifer system is exposed to potential recharge from the Los Angeles River at a higher elevation than the Pacific and Harbor aquifer systems in the Los Angeles Narrows (fig. B5), which accounts for the higher water levels. A water sample from the Upper Wilmington A aquifer system (well 3P4) had tritium concentration in excess of 0.9 tritium unit (TU; appendix 1 , table 1.2), indicating that the aquifer system is receiving at least some modern water recharge. The water-level difference between the overlying and underlying aquifer systems indicates that the Upper Wilmington A aquifer system is confined in this part of the Los Angeles Forebay.

\section{Montebello Forebay}

Well 1A6 (3S/12W-1A6; 1615P) is a production well in the Montebello Forebay (fig. C8) and is screened in the Mesa and Pacific aquifer systems. Water levels have been measured at well 1A6 from 1947 to 2017 (fig. C9B). Water levels in well $1 \mathrm{~A} 6$ declined about $104 \mathrm{ft}$ from the late 1940s to the late 1950s, from a high altitude of about $114 \mathrm{ft}$ in 1947 to a low altitude of about $10 \mathrm{ft}$ in 1958 (fig. C9B). From the late 1950s until about 1970, water levels recovered about $70 \mathrm{ft}$, to an altitude of about $80 \mathrm{ft}$. From 1970 until the mid 1990s, water levels rose during wet periods and declined during dry periods, for a net water-level rise of about $20 \mathrm{ft}$ (figs. C2, C9B). Since the mid-1990s, water levels have declined by about $60 \mathrm{ft}$ to an altitude of about $40 \mathrm{ft}$ in 2015. During this period, water levels rose during wet cycles and declined during dry cycles (figs. C2, C9B). Water levels in the Montebello Forebay varied in response to nearby RHSG and SGRSG recharge and pumping (fig. C9B). 
Monitoring wells 25G3-8 (2S/12W-25G3 to 25G8) compose the Pico Rivera2 multiple-well monitoring site in the Montebello Forebay (fig. C8) and are screened in the Long Beach A (25G3), Upper Wilmington B (25G4), Upper Wilmington A (25G5), Pacific (25G6), Mesa (25G7), and Dominguez (25G8) aquifer systems (appendix 1, table 1.1). Land-surface elevation at $25 \mathrm{G} 3-8$ is about $10 \mathrm{ft}$ higher than well 1A6. Water-level data have been collected at the 25G3-8 wells since they were constructed in 1999 (fig. C9B). Water levels measured at the 25G3-8 wells follow a similar seasonal pattern and wet and dry cycle pattern as those in well $1 \mathrm{~A} 6$ but are about $20 \mathrm{ft}$ higher because the 25G3-8 wells are at a higher elevation in the Montebello Forebay (fig. C9B). Water levels decreased with depth from the Dominguez through Long Beach A aquifer systems within the Montebello Forebay, and the largest difference in water levels occurred between the Pacific and Upper Wilmington A aquifer systems. The downward vertical gradient indicates the potential for water to move from the overlying to the underlying aquifer systems.

The Dominguez, Mesa, and Pacific aquifer systems are relatively flat lying in the Montebello Forebay (fig. B4) and are predominantly coarse-grained (figs. B16, B18, B19), which allows for relatively unrestricted groundwater movement between the aquifer systems. Folding of the Upper Wilmington A and Long Beach A aquifer systems, and subsequent erosion or non-deposition of the Harbor, Bent Spring, Upper Wilmington B, and Lower Wilmington aquifer systems, puts the Upper Wilmington A and Long Beach A aquifer systems in direct connection with the Pacific aquifer system in the Montebello Forebay (fig. B4). Direct connection with the Pacific aquifer system allows groundwater from the Pacific to recharge the deeper aquifer systems, and water-chemistry data provide evidence of this connection. Samples from all aquifer systems contained tritium greater than $1 \mathrm{TU}$ (appendix 1, table 1.2), indicating they are being recharged by modern water. Stable-isotope data indicate that managed aquifer recharge from the nearby spreading grounds is being sampled from the wells (appendix 1, table 1.2).

\section{Central Basin Pressure Area, North}

Well $32 \mathrm{C} 4(2 \mathrm{~S} / 13 \mathrm{~W}-32 \mathrm{C} 4 ; 1434 \mathrm{~J})$ is a production well in the northern part of the Central Basin Pressure Area (fig. C8) and is screened in the Harbor, Bent Spring, and Upper Wilmington A aquifer systems. Water levels have been measured at well 32C4 from 1938 to 2010 (fig. C9C). Water levels in this well declined about $125 \mathrm{ft}$ from 1940 to 1960 , from an altitude high of about $41 \mathrm{ft}$ in 1940 to a low of about $84 \mathrm{ft}$ below NAVD 88 in 1960 (fig. C9C). From 1960 until about 1980, water levels slowly recovered to about $60 \mathrm{ft}$ below NAVD 88 (fig. C9C). From 1980 to the late 1990s, water levels continued to recover, at a faster rate, to about $20 \mathrm{ft}$ below NAVD 88 (fig. C9C). By the end of the 1990s, water levels stopped recovering, and began to slowly decline. From the late 1990s until 2010, water levels declined about $20 \mathrm{ft}$, to about $40 \mathrm{ft}$ below NAVD 88 in 2010 (fig. C9C).

Monitoring wells 31B3-8 (2S/13W-31B3 to 31B8) compose the Los Angeles4 multiple-well monitoring site in the northern part of the Central Basin Pressure Area (fig. C8) and are screened in the Long Beach A (31B3), Lower Wilmington (31B4), Upper Wilmington A (13B5), Harbor (31B6 and B7), and Pacific (31B8) aquifer systems (appendix 1, table 1.1). In addition to the wells installed at the 31B3-8 wells, a vibrating wireline piezometer was also installed to record water levels in the Mesa aquifer system (31B9); However, a well screen was not installed in the Mesa layer; therefore, the Mesa layer piezometer is not shown in table 1.1. Land-surface elevation at 31B3-8 is within $5 \mathrm{ft}$ of the land-surface elevation at well $32 \mathrm{C} 4$. Water levels have been collected at the 31B3-8 wells since the wells were constructed in 2012. Because the 31B3-8 wells were not constructed until 2012, water-level measurements collected from this site do not overlap with measurements from well 32C4 (fig. C9C). However, water levels in the Upper Wilmington A and the Lower Wilmington aquifer systems had the same downward trend as observed in the later part of the record collected at well 32C4. Water levels at the 31B3-8 wells decreased with depth, with the exception of the Long Beach A aquifer system. Water levels in the Mesa aquifer system are about $25 \mathrm{ft}$ above NAVD 88, which is more than $40 \mathrm{ft}$ higher than water levels in the Pacific aquifer system. Water levels in both the Mesa and Pacific aquifer systems slowly declined less than $6 \mathrm{ft}$ during the period of record, with minimal response to seasonal pumping or recharge. Water levels in the Harbor aquifer system are about $10 \mathrm{ft}$ lower than water levels in the Pacific aquifer system. Water levels in the Upper Wilmington A and Lower Wilmington aquifer systems were about the same as those in the Harbor aquifer system in 2012 but declined to more than $10 \mathrm{ft}$ lower in the Upper Wilmington A aquifer system and about $20 \mathrm{ft}$ lower in the Lower Wilmington aquifer system by the end of 2015 (fig. C9C).

The largest water-level declines at the 31B3-8 wells were observed in the Lower Wilmington aquifer system even though there are only a few production wells that are screened in the Lower Wilmington aquifer system near the site. Most of the nearby production wells are screened in the Pacific A through Upper Wilmington A aquifer systems. The Lower Wilmington aquifer system is dominated by fine-grained deposits with a few isolated sand zones, one of which is open to well 31B4. Because these sand zones are tightly confined by fine-grained deposits, pressure responses caused by pumping in these zones can cause water-level changes over large distances.

The water levels in the Long Beach A aquifer system were similar to Pacific aquifer system water levels in 2012 and then declined about $10 \mathrm{ft}$ by 2015 (fig. C9C). Water level declines in the Long Beach A aquifer system were probably responding to pumping in the overlying aquifer systems. 


\section{Central Basin Pressure Area, Central}

Well 21R1 (3S/13W-21R1; 851F) is a production well in the Central Basin Pressure Area near the Newport-Inglewood fault zone (fig. C8) and is screened in the Harbor aquifer system (appendix 1, table 1.1). Water levels in well 21R1 declined from a high of about $8 \mathrm{ft}$ above NAVD 88 in 1948 to a low of about $100 \mathrm{ft}$ below NAVD 88 in 1960 (fig. C9D). From 1960 until about 1970, water levels recovered rapidly to about $60 \mathrm{ft}$ below NAVD 88 (fig. C9D). From 1970 until about 1980, water levels were relatively constant, except for seasonally variable pumping. From about 1980 through the end of the record in 1996, water levels recovered about $40 \mathrm{ft}$ but were still about $30 \mathrm{ft}$ lower than the highest measured water level in 1948 (fig. C9D).

Monitoring wells 22M2-7 (3S/13W-22M2 to 22M7) compose the Compton2 multiple-well monitoring site in the central part of the Central Basin Pressure Area (fig. C8) and are screened in the Long Beach A (22M2), Upper Wilmington B (22M3), Harbor (22M4, 22M5), Pacific (22M6), and Pacific A (22M7) aquifer systems (appendix 1, table 1.1). Land-surface elevation at wells $22 \mathrm{M} 2-7$ is about $20 \mathrm{ft}$ below well 21R1. Water levels have been collected at the 22M2-7 wells since they were constructed in 2007. Because the 22M2-7 wells were not constructed until 2007, water-level measurements collected from this site do not overlap with measurements from well 21R1. Water levels at wells 22M2-7 decreased with depth throughout most of the period of record, with the exception of the Long Beach A aquifer system, which has water levels higher than the Pacific A aquifer system during part of the record (fig. C9D). Water levels in all aquifer systems monitored at wells 22M2-7 declined more than $10 \mathrm{ft}$ from 2007 to 2012, with seasonal fluctuations reflecting pumpage and recharge (fig. C9D). The largest water-level declines were observed in the Upper Wilmington B (about $30 \mathrm{ft}$ ) and Long Beach A (about $35 \mathrm{ft}$ ) aquifer systems, although nearby production wells are not screened to the depth of these aquifer systems. The Upper Wilmington B and Long Beach A aquifer systems are composed predominantly of fine-grained deposits with intermittent sand layers at wells 22M2-7. The nearest active production wells that are completed in these aquifer systems are more than $5 \mathrm{mi}$ southeast of wells 22M2-7. The presence of large water-level fluctuations, caused by pumping at such a large distance, indicates that the vertical permeability of the confining layers is very low.

\section{Central Basin Pressure Area, South}

Well 10G1 (4S/12W-10G1; 975A) is a production well in the southern part of the Central Basin Pressure Area and is screened in the Pacific aquifer system (fig. C8). Water levels were measured at well 10G1 from 1946 to 2008 (fig. C9E). Water levels in this well declined about $147 \mathrm{ft}$ from a high altitude of about $29 \mathrm{ft}$ in 1947 to a low of about $118 \mathrm{ft}$ below
NAVD 88 in 1957 (fig. C9E). From the late 1950s until the mid-1960s, water levels recovered rapidly to about $20 \mathrm{ft}$ below NAVD 88 (fig. C9E). From the mid-1960s until the end of the record in 2008 , water levels fluctuated $50 \mathrm{ft}$ or more on a seasonal basis but recovered to between 20 and $30 \mathrm{ft}$ below NAVD 88 during wet periods when pumping was reduced (figs. C2, C9E).

Monitoring wells 5W5-10 (4S/12W-5H5 to 5H10) compose the Lakewood1 multiple-well monitoring site in the southern part of the Central Basin Pressure Area (fig. C8) and are screened in the Upper Wilmington A (5H5), Harbor (5H6-7), Pacific A (5H8), Mesa (5H9), and Dominguez (5H10) aquifer systems (appendix 1, table 1.1). Land-surface elevation at wells $5 \mathrm{~W} 5-10$ is within $5 \mathrm{ft}$ of the land-surface elevation at well $10 \mathrm{G} 1$. Water levels have been collected at wells 5W5-10 since its construction in 1995. None of the monitoring wells 5W5-10 is screened in the Pacific aquifer system, but water levels in the Harbor aquifer system are similar to those in well 10G1 (fig. C9E). Water levels at wells 5W5-10 indicated a downward hydraulic gradient between the aquifer systems, with the largest gradient between the Dominguez and Mesa aquifer systems. Water levels in the Dominguez aquifer system declined about $7 \mathrm{ft}$ from 1999 to 2015, with minimal seasonal fluctuations. There are active production wells in the Dominguez aquifer system east of wells 5W5-10; therefore, the lack of large seasonal water-level fluctuations probably is the result of the unconfined properties of the Dominguez aquifer system. Water levels in the Mesa and Pacific A aquifer systems behaved similarly, with water levels in the Pacific A aquifer system about $15 \mathrm{ft}$ lower than those in the Mesa aquifer system. Water levels in both aquifer systems had 10 to $15 \mathrm{ft}$ seasonal water-level changes, with the Pacific A aquifer system having the larger fluctuations.

Water levels in the Harbor and Upper Wilmington A aquifer systems at 5W5-10 followed similar seasonal pattern and wet and dry cycle pattern from 1999 to about 2008, with large seasonal fluctuations (about $30 \mathrm{ft}$ in the Harbor and more than $50 \mathrm{ft}$ in the Upper Wilmington A aquifer systems). The large seasonal fluctuations indicated that both aquifer systems are confined and isolated from the overlying aquifer systems. From about 2008 to 2015, water levels in the Upper Wilmington A aquifer system started to diverge from the water levels in the Harbor aquifer system. In fact, in the summers of 2013 and 2014, water levels in the Upper Wilmington A aquifer system were the lowest recorded, about $80 \mathrm{ft}$ lower than water levels measured in the Harbor aquifer system at the same time (fig. C9). Monitoring wells 5W5-10 are surrounded by wells screened in the Harbor aquifer system, but production wells screened in the Upper Wilmington A aquifer system only are present southwest of the site. The Pacific and underlying (older) aquifer systems are folded up to the west of 5W5-10; therefore, the Upper Wilmington A aquifer system is closer to land surface southwest of the site, and more production wells are withdrawing water from the deeper aquifer systems in this part of the LACP. 


\section{West Coast Basin, East}

Well 23B2 (4S/13W-23B2; 888F) is a production well in the southeast part of the West Coast Basin (fig. C8; table 1.1) and is screened in the Upper Wilmington A aquifer system. Water levels were measured at well 23B2 from 1934 to 2010 (fig. C9F). Water levels in well 23B2 declined about $60 \mathrm{ft}$ from a high of about $28 \mathrm{ft}$ below NAVD 88 in 1939 to a low of about $106 \mathrm{ft}$ below NAVD 88 in 1953 (fig. C9F). Seasonal water-level changes are about $20 \mathrm{ft}$ during this period. From the mid-1950s until about 1958, water levels recovered to about $73 \mathrm{ft}$ below NAVD 88, and then declined slowly to about $107 \mathrm{ft}$ below NAVD 88 in the early 1970s (fig. C9F). From the early 1970s until the mid 1990s, water levels recovered almost $40 \mathrm{ft}$, reaching a high of $53 \mathrm{ft}$ below NAVD 88 in 1995. In 1995, water levels declined by about $30 \mathrm{ft}$ but recovered to about $50 \mathrm{ft}$ below NAVD 88 in 2010, the end of the record (fig. C9F). Water levels in 2010 were more than $20 \mathrm{ft}$ lower than the highest measured water level in 1939 (fig. C9F).

Monitoring wells 23D3-7 (4S/13W-23D3 to 23D7) compose the Long Beach3 multiple-well monitoring site in the southeastern part of the West Coast Basin (fig. C8) and are screened in the Long Beach A (23D3), Upper Wilmington B (23D4), Upper Wilmington A (23D5), Bent Spring (23D6), and Harbor (23D7) aquifer systems (appendix 1, table 1.1). Land-surface elevation at wells 23D3-7 is within $5 \mathrm{ft}$ of well 23B2. Water levels have been collected at the 23D3-7 wells since the wells were constructed in 2000. Water levels in the Upper Wilmington A aquifer system are similar to water levels measured in well 23B2, and water levels in all except the Harbor aquifer system have been recovering since 2000, when wells 23D3-7 were constructed (fig. C9F). Water levels in the Harbor aquifer system were about $30 \mathrm{ft}$ higher than water levels in the underlying Bent Spring aquifer system (fig. C9F). Injection wells of the Dominguez Gap Barrier Project inject recharge water into the Harbor aquifer system near wells 23D3-7 and, along with minimal pumping, help maintain the high water levels in the Dominguez, Mesa, Pacific, and Harbor aquifer systems in this area of the West Coast Basin. The effect of the northern extension of the barrier project in the mid-1990s is shown by the approximate $10 \mathrm{ft}$ rise in water levels in the Harbor aquifer system between 2004 and 2005 (fig. C9F). However, even with the extension of the barrier project, water levels were below NAVD 88 in the Harbor aquifer system during most of the period of record, indicating continued potential for seawater intrusion into the Harbor aquifer system.

The Bent Spring, Upper Wilmington A, and Upper Wilmington B aquifer systems have similar water levels at wells 23D3-7 (fig. C9F). The geologic and geophysical logs collected at wells 23D3-7 indicated that these aquifer systems are all coarse grained, with few fine-grained layers to limit hydraulic connection between aquifer systems. However, the large water-level differences between the Harbor and Bent Spring aquifer systems indicated the presence of a low-permeability layer between these two aquifer systems. Water levels in the Long Beach A aquifer system at wells 23D3-7 were 10 to $15 \mathrm{ft}$ higher than water levels in the Upper Wilmington B aquifer system and did not show seasonal fluctuations like the overlying aquifer systems (fig. C9F). Fine-grained layers in the overlying Lower Wilmington aquifer system limited hydraulic connection between the Long Beach A aquifer system and the overlying pumped aquifer systems.

\section{West Coast Basin, West}

Well 8G1 (4S/14W-8G1; 735) is an observation well in the western part of the West Coast Basin, about 1.6 mi east of the coastline (fig. C8; table 1.1) and is screened in the Pacific aquifer system. Water levels were measured at well 8G1 from 1964 to 2007 (fig. C9G). Water levels in well 8G1 rose rapidly about $20 \mathrm{ft}$ from a low of $27 \mathrm{ft}$ below NAVD 88 in 1964 to $7 \mathrm{ft}$ below NAVD 88 in 1968 (fig. C9G). The rise in water levels resulted from water injected along the WCBBP and decreased pumping in areas affected by seawater intrusion. From the late 1960 s to 2004, water levels in well $8 \mathrm{G} 1$ continued to rise to about $3 \mathrm{ft}$ above NAVD 88 in 2004 (fig. C9G). In 2005, water levels declined to about $5 \mathrm{ft}$ below NAVD 88 and remained below NAVD 88 until measurements at the well were discontinued in 2007 (fig. C9G). 
Monitoring wells 15E1-6 (4S/14W-15E1 to 15E6) compose the PM-6 Torrance2 multiple-well monitoring site in the southwestern part of the West Coast Basin (fig. C8) and are screened in the Long Beach A (15E1), Upper Wilmington B (15E2), Upper Wilmington A (15E3), Bent Spring (15E4), Harbor (15E5), and Pacific (15E6) aquifer systems (appendix 1, table 1.1). Wells 15E1-6 are about $1.8 \mathrm{mi}$ southeast of well $8 \mathrm{G} 1$ and has a land-surface elevation about $15 \mathrm{ft}$ lower than well 8G1 (fig. C8). Water levels have been measured at wells 15E1-6 since the wells were constructed in 2009, and water-level measurements at this site did not overlap with measurements from well 8G1. However, water-level measurements from the Pacific, Harbor, and Bent Spring aquifer systems were similar to the last recorded measurements at well 8G1 (fig. C9G). Injection wells in the WCBBP near wells 15E1-6 injected water into the Mesa, Pacific, Harbor, and Bent Spring aquifer systems, which resulted in similar water levels in these aquifer systems. Water levels in the underlying Upper Wilmington A and B aquifer systems were about $10 \mathrm{ft}$ below NAVD 88 from 2010 to 2015 , indicating these aquifer systems are susceptible to seawater intrusion. Water-quality data collected from these aquifer systems at wells 15E1-6 indicated that these aquifer systems were affected by seawater intrusion (appendix 1 , table 1.2). The Upper Wilmington A and B aquifer systems were probably being intruded by seawater entering through Redondo Canyon to the west of wells 15E1-6 (fig. C8). Water levels in the Long Beach A aquifer system were about $35 \mathrm{ft}$ below NAVD 88 in 2010 and rose to about $30 \mathrm{ft}$ below NAVD 88 in 2015 (fig. C9G). Production wells were not screened in the Long Beach A aquifer system near the wells 15E1-6; therefore, the water levels probably were still recovering from the late 1950s when the West Coast Basin was at its historical low water levels, prior to the initiation of the seawater barriers and water-management plans.

\section{Santa Monica Basin}

Since USGS multiple-well monitoring sites had not been constructed in the Santa Monica Basin until after this study completed, long-term water-level measurements from two wells completed in different aquifers were compared to examine water-level change with depth in this basin. Well 11F5 (2S/15W-11F5; 2578X) is a production well in the central part of the Santa Monica Basin (fig. C8) and is screened in the Bent Spring aquifer system (table 1.1). Water levels were measured at well 11F5 from 1954 to 1999 (fig. C9H). From the mid-1950s until the mid-1980s, water levels at well 11F5 averaged about $50 \mathrm{ft}$ below NAVD 88, with highs of about $35 \mathrm{ft}$ below NAVD 88 and lows of about $65 \mathrm{ft}$ below NAVD 88 (fig. C9H). In 1985, water levels declined to a low of $100 \mathrm{ft}$ below NAVD 88, but this measurement probably was affected by pumping from nearby wells; there was over 6,000 acre-ft of pumping from the nearby Santa
Monica municipal well field in 1985 . Water levels measured in the 1990s showed a considerable rise, with water levels in 1999 reaching NAVD 88 (fig. C9H). The low water levels measured at well 11F5 from the mid-1950s to mid-1980s probably were in response to pumping from a nearby Santa Monica municipal well field. Pumping from this well field was substantially reduced in the 1990s, which resulted in the observed water-level rise in well 11F5.

Well 9N9 (2S/15W-9N9; 2539L) is in the western part of the Santa Monica Basin (fig. C8) and is screened in the Pacific aquifer system (table 1.1). Land-surface elevation at well 9N9 is about $55 \mathrm{ft}$ lower than well 11F5. Water levels were measured at well 9N9 from 1970 to 2009 (fig. C9H). Water levels in well 9N9 were at about $10 \mathrm{ft}$ above NAVD 88 during the period of record. During the 1970s and 1980s, water levels in well 9N9 were more than $50 \mathrm{ft}$ higher than water levels measured in well 11F5 (fig. C9H). The large difference in water levels indicated that there was minimal hydraulic connection between the Pacific and Bent Spring aquifer systems in the western part of the Santa Monica Basin. Depth-dependent data from a multiple-well monitoring site in the Santa Monica Basin can improve the understanding of the hydrogeology and water movement in this part of the LACP.

\section{References Cited}

California Department of Water Resources, 1961, Planned utilization of the ground water basins of the coastal plain of Los Angeles County, Appendix A, Ground water geology: California Department of Water Resources Bulletin 104, 191 p., http://wdl.water.ca.gov/waterdatalibrary/docs/ historic/Bulletins/Bulletin_104/Bulletin_104-A_1961.pdf.

California Department of Water Resources, 1962, Planned utilization of the ground water basins of the coastal plain of Los Angeles County, Appendix B, Safe yield determinations: California Department of Water Resources Bulletin 104, 129 p.

California Department of Water Resources, 1966, Planned utilization of ground water basins of the coastal plain of Los Angeles County: California Department of Water Resources Bulletin 104, 25 p.

California Department of Water Resources, 1975, California's ground water: California Department of Water Resources Bulletin 118, 135 p., https://water.ca.gov/LegacyFiles/pubs/ groundwater/bulletin_118/california's_ground_water bulletin_118-75_/b118-1975.pdf.

Central Basin Watermaster, 2017, Watermaster Service in the Central Basin - Los Angeles County, for 2015-2016, 103 p. 
Grimmond, C.S.B., Oke, T.R., and Steyn, D.G., 1986, Urban water balance-1. A model for daily totals: Water Resources Research, v. 22, no. 10, p. 1397-1403, https://agupubs.onlinelibrary.wiley.com/doi/pdf/ 10.1029/WR022i010p01397; https://doi.org/10.1029/ WR022i010p01397.

Hevesi, J.A., and Johnson, T.D., 2016, Estimating spatially and temporally varying recharge and runoff from precipitation and urban irrigation in the Los Angeles Basin, California: U.S. Geological Survey Scientific Investigations Report 2016-5068, 192 p., https://doi.org/10.3133/sir20165068.

Imbrie, J., Hays, J.D., Martinson, D.G., McIntyre, A., Mix, A.C., Morley, J.J., Pisias, N.G., Prell, W.L., and Shackleton, N.J., 1984, The orbital theory of Pleistocene climate-Support from a revised chronology of the marine $\delta^{18} \mathrm{O}$ record, in Berger, A.L., Imbrie, J., Hays, J., Kukla, G., and Saltzman, B., eds., Milankovich and climate, Part 1: Dordrecht, The Netherlands, D. Reidel, NATO Advanced Science Institutes Series C, v. 126, p. 269-305.

Los Angeles Almanac, 2018, Monthly Rainfall by Season Downtown Los Angeles (USC Campus) 1877-2017, accessed on June 2018 at http://www.laalmanac.com/weather/we08aa.php.

Los Angeles County Department of Public Works, 2005, Alamitos Barrier Project Annual Report on the Control of Seawater Intrusion: Los Angeles, Los Angeles County Department of Public Works, 43 p.

Mendenhall, W.C., 1905a, Development of underground waters in the eastern coastal-plain region of Southern California: U S. Geological Survey Water-Supply Paper 137, 140 p., https://doi.org/10.3133/wsp137.

Mendenhall, W.C., 1905b, Development of underground waters in the central coastal-plain region of Southern California: U.S. Geological Survey Water-Supply Paper 138, 162 p., https://doi.org/10.3133/wsp138.

Mendenhall, W.C., 1905c, Development of underground waters in the western coastal-plain region of southern California: U.S. Geological Survey Water-Supply Paper 139, 105 p., https://doi.org/10.3133/wsp139.
Poland, J.F., Garrett, A.A., and Sinnott, A., 1959, Geology, hydrology, and chemical character of ground waters in the Torrance-Santa Monica area, California: U.S. Geological Survey Water-Supply Paper 1461, 425 p., https://doi.org/10.3133/wsp1461.

Poland, J.F., and Piper, A.M., 1956, Ground-water geology of the coastal zone, Long Beach-Santa Ana area, California: U.S. Geological Survey Water-Supply Paper 1109, 162 p., https://doi.org/10.3133/wsp1109.

Reichard, E.G., Land, M., Crawford, S.M., Johnson, T.D., Everett, R.R., Kulshan, T.V., Ponti, D.J., Halford, K.L., Johnson, T.A., Paybins, K.S., and Nishikawa, T., 2003, Geohydrology, geochemistry, and ground-water simulation-optimization of the Central and West Coast Basins, Los Angeles County, California: U.S. Geological Survey Water-Resources Investigations Report 2003-4065, 196 p., https://doi.org/10.3133/wri034065.

Sample, D.J., and Heaney, J.P., 2006, Integrated management of irrigation and urban storm-water infiltration: Journal of Water Resources Planning and Management, v. 132, no. 5, p. 362-373, https://doi.org/10.1061/(ASCE)07339496(2006)132:5(362).

San Gabriel River Watermaster, 1997, Thirty-Third Annual Report, for 1995-96: Glendale, California, 46 p.

Van Wagoner, J.C., Mitchum, R.M., Campion, K.M., and Rahmanian, V.D., 1990, Siliciclastic sequence stratigraphy in well logs, cores, and outcropsConcepts for high-resolution correlation of time and facies: American Association of Petroleum Geologists Methods in Exploration Series, no. 7, 55 p., https://doi.org/10.1306/Mth7510.

Water Replenishment District of Southern California, 2007, Battling seawater intrusion in the Central and West Coast Basins: Water Replenishment District of Southern California Technical Bulletin, v. 13, 2 p.

West Coast Basin Watermaster, 2017, Watermaster Service in the West Coast Basin - Los Angeles County, for 2015-2016, 51p. 


\title{
Chapter D. Development of a Groundwater-Simulation Model and Future Water- Management Scenarios
}

\author{
By Scott Paulinski, Peter Martin, Donald Martin, Ted Johnson, and Claudia Faunt
}

A regional groundwater-flow model was developed for the Los Angeles Coastal Plain (LACP) to better understand the groundwater-flow system that provides a large portion of the water supply for its millions of residents and to provide a tool to help inform groundwater-resources management decisions in the region. The U.S. Geological Survey (USGS) had previously developed a regional groundwater-flow model of the LACP (Reichard and others, 2003), which has been used by water-management agencies to help characterize groundwater flow and evaluate groundwater-management issues in the LACP during the past 17 years. The previous model simplified the complex groundwater-flow system of the LACP into four aquifer systems based on a lithostratigraphic approach (Reichard and others, 2003). Detailed hydrogeologic data collected from recently constructed Water Replenishment District of Southern California (WRD) and USGS multiple-well monitoring sites, in conjunction with available seismic-reflection profiles, provided the opportunity to reevaluate the hydrogeologic framework of the LACP using a sequence-stratigraphy approach (see Chapter B). Compared to the lithostratigraphic approach, the sequence-stratigraphy approach can produce a more realistic representation of geologic structure, the distribution of lithologic facies, and aquifer architecture - all of which can influence groundwater flow. Chronostratigraphic unit layering provides a more realistic representation of the geologic structure, the distribution of lithologic facies, and aquifer architecture, which improves our ability to predict the lateral distribution of coarse-grained aquifers and their fine-grained confining aquitards. A groundwater-flow model based on chronostratigraphic unit layering can

(1) Leverage knowledge of the distribution of grain size to better model groundwater flow within the aquifer systems.

(2) Apply a more realistic representation of geologic structure to better predict the direction of anisotropy within complex geologic structures (for example, folds), and can therefore better model anisotropy within these structures.

This chapter describes how the updated hydrogeologic framework was used to develop a new groundwater-flow simulation model of the LACP, which is referred to as the Los Angeles Coastal Plain Groundwater-flow Model (LACPGM).

\section{Model Development}

The active domain of the LACPGM covers 580 square miles, and includes the West Coast Basin, the Central Basin, the Santa Monica Basin, the Hollywood Basin, part of the Orange County Basin, and parts of Santa Monica and San Pedro Bays (fig. D1). Model inputs include boundary conditions, top and bottom elevations of each model cell, connections of each model cell to other model cells and conduits, cross-sectional area of each connection, hydraulic conductivities of each connection, storage properties of each model cell, conductance across faults, recharge, pumpage, and injection.

\section{Modeling Software}

The LACPGM uses MODFLOW-USG (Panday and others, 2013) for its unstructured grid, which can simulate geological layer pinch-outs because, "The gridding flexibility in MODFLOW-USG offers advantages for representing discontinuous (pinching) aquifer layers and faults compared to traditional MODFLOW approaches" (Panday and others, 2013). Also, MODFLOW-USG was used for its ability to model hydraulic properties by connection rather than by cell, which allowed vertical hydraulic conductivity (VK) between layers to be explicitly defined. This allowed us to explicitly state the VK connection values for layers containing confining aquitards near the top of the layer, with VK connection values to the unit above sometimes being orders of magnitude different than the VK connection values to the unit below.

MODFLOW-USG packages used in the LACPGM are shown in table D1. The LACPGM simulates areal recharge using the recharge $(\mathrm{RCH})$ package. Pumping and injection were simulated using conduits from the connected linear network (CLN) package and the well (WEL) package. Faults and other flow barriers were simulated using the horizontal-flow barrier (HFB) package. Inflow from the Los Angeles (LA) Narrows (fig. D1) was simulated using the time-variant specified-head (CHD) package. Inflow from the Whittier Narrows, flow across the eastern Orange County edge of the model, and flow across the southern and western ocean boundaries were simulated using the general-head boundary (GHB) package (fig. D1). Model calibration was completed using PEST (Doherty, 2010), an automatic parameter inversion program. 


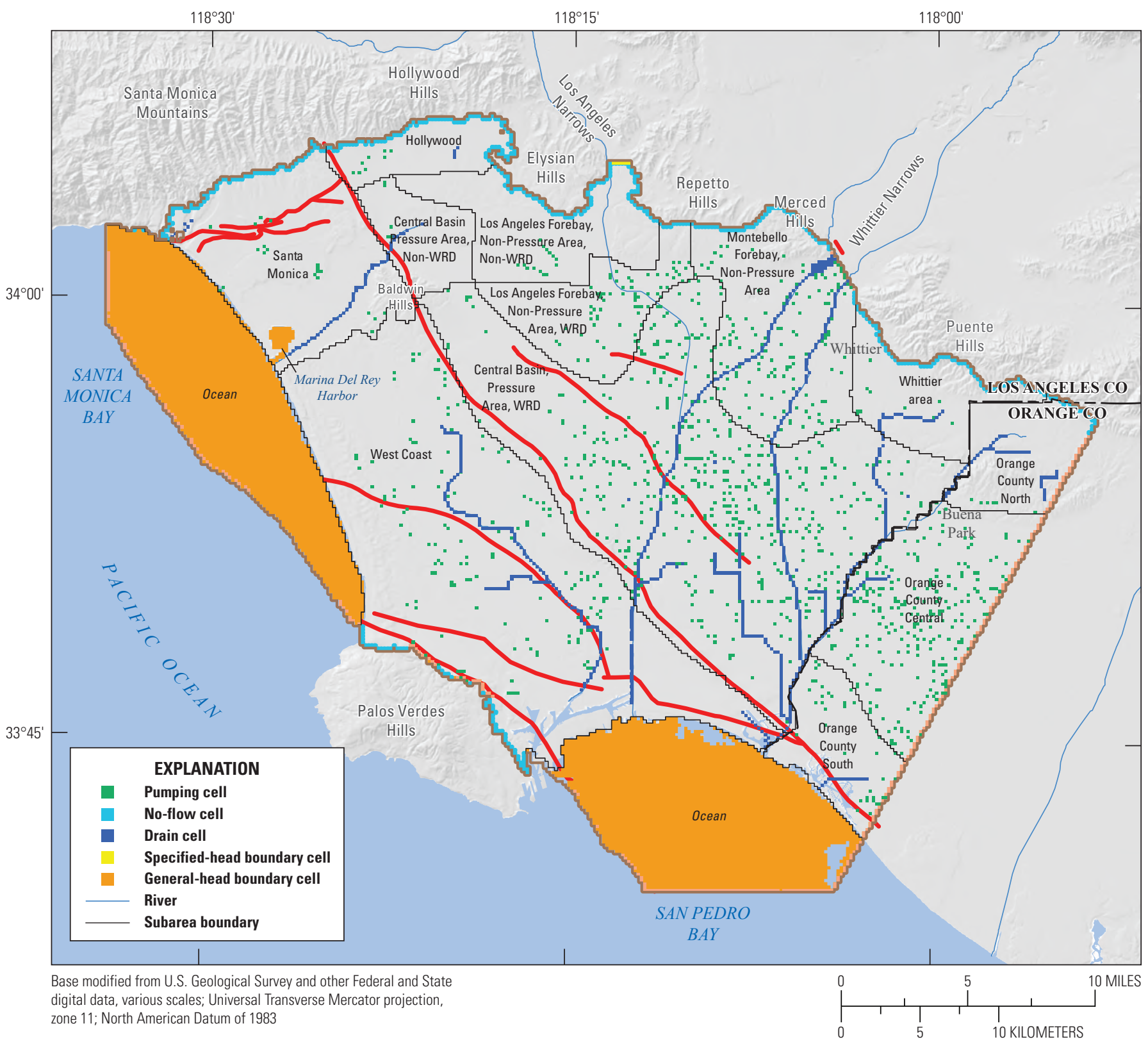

Figure D1. Pumping, drain, and boundary condition cells in the Los Angeles Coastal Plain Groundwater-flow Model as a composite of all model layers, Los Angeles and Orange Counties, California. (Abbreviation: WRD, Water Replenishment District of Southern California) 
Table D1. MODFLOW-USG Version 1.3 packages and processes used with the Los Angeles Coastal Plain Groundwater-flow Model, California.

[-, no data]

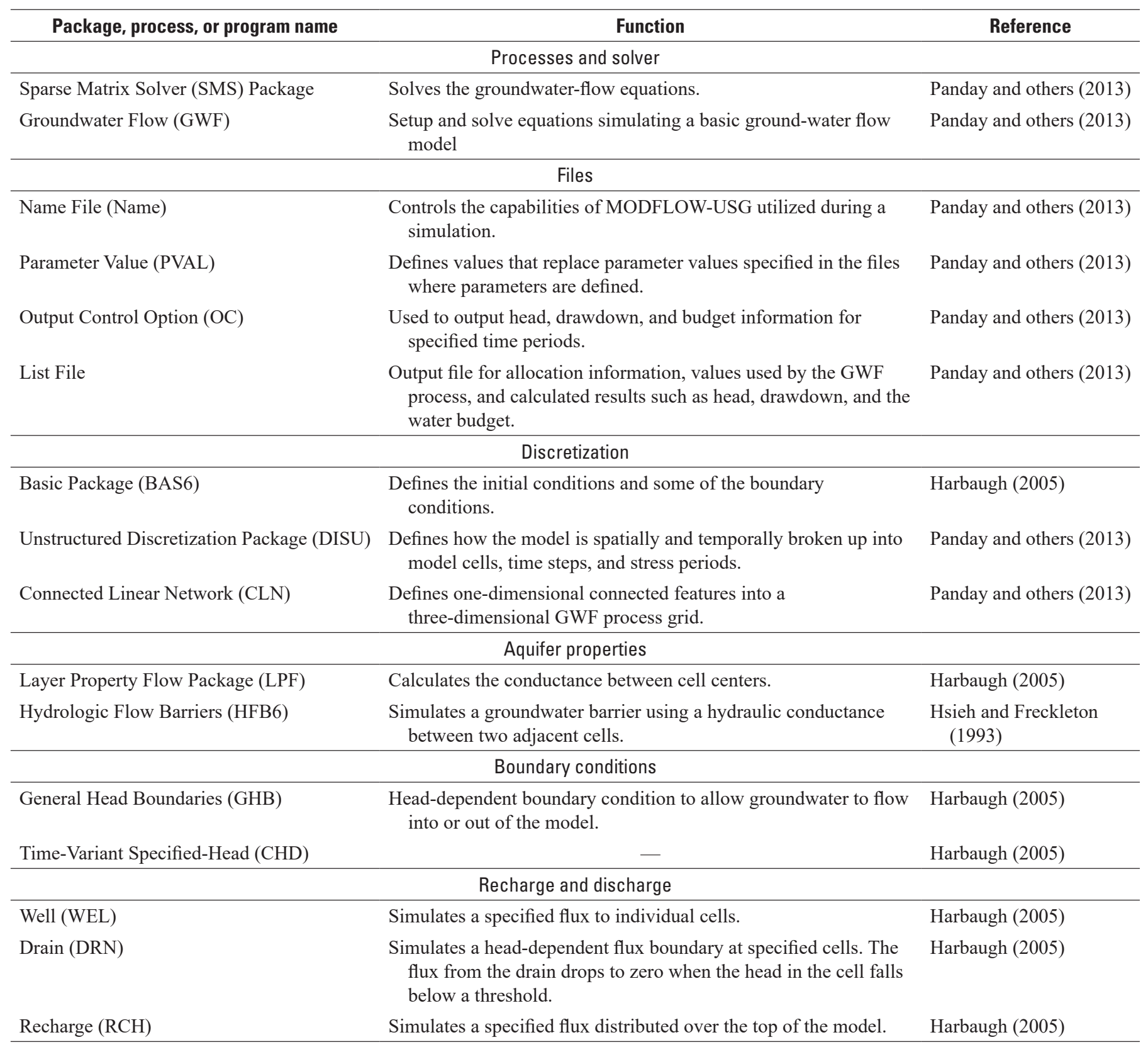




\section{Model Discretization}

The LACPGM simulates transient conditions of the LACP from January 1971 through December 2015. To numerically solve for the distribution of hydraulic heads within the aquifer system, the aquifer system must be spatially and temporally discretized.

\section{Spatial Discretization and Layering}

The LACPGM expands the model area of Reichard and others (2003), extending the eastern border of the model three to five miles (mi) into Orange County (fig. D1). The unstructured finite-difference grid of the LACPGM has 256 rows and 312 columns that are uniform in size; each cell has a length and width of $1 / 8$ mile (660 feet [ft]). A total of 440,172 model cells were included in the grid. The model grid is parallel to the grid of the Universal Transverse Mercator (UTM) System; columns are oriented north-south, and rows are oriented east-west. The coordinates of the lower left corner of the model grid are 355046.48 meters (m) easting, and 3725532.39 m northing in North American Datum (NAD) 1983 UTM Zone $11 \mathrm{~N}$.

The LACPGM consists of 13 layers. The top layer is an inactive $(\mathrm{IBOUND}=0)$ layer extending over the entire model grid. The inactive top layer extends from land surface to $30 \mathrm{ft}$ above land surface. Flow does not occur through this inactive layer, and the sole purpose of the layer is to simulate areal recharge to the first active model layer as described in the "Simulated Areal Recharge" section of this chapter. The 12 other layers represent the Dominguez, Mesa, Pacific A, Pacific, Harbor, Bent Spring, Upper Wilmington A, Upper Wilmington B, Lower Wilmington, Long Beach A, Long Beach B, and the combined Long Beach BC and C aquifer systems (referred to hereinafter as the Long Beach $\mathrm{C}$ aquifer system), which represent the chronostratigraphic units previously defined in Chapter B. Long Beach BC and $\mathrm{C}$ aquifer systems were combined in the model because there was limited information available about the lower units, and combining the units improved numerical stability. An unstructured grid was used to explicitly represent any thinning or pinching-out of the layers. Aquifer systems only were included in the model in areas where their thickness exceeded $15 \mathrm{ft}$.

All layers except the top inactive layer were designated as convertible (either unconfined or confined); a cell in a convertible layer converts from confined to unconfined conditions when an overlying cell is simulated as being unsaturated. Specific storage and hydraulic conductivity are used in the flow equation when the model layer represents confined conditions. Specific yield and hydraulic conductivity are used in the flow equation when the model layer represents unconfined conditions, and transmissivity is computed using the hydraulic conductivity and saturated thickness of the layer. For the confined case, saturated thickness is equal to layer thickness; for the unconfined case, saturated thickness is calculated using an upstream weighting approach (Niswonger and others, 2011).

\section{Temporal Discretization}

The LACPGM uses 180 quarterly stress periods to simulate the 45-year period from calendar year 1971 through calendar year 2015. Quarterly stress periods were chosen to reduce computation time while still approximating seasonal stresses. A stress period is a time interval during which all stresses (for example, pumping rates) are considered constant for modeling purposes. Each stress period is discretized into five equal length time steps. The numerical stability of the model associated with this temporal discretization was evaluated by analyzing the time-varying mass-balance and cumulative mass-balance errors. In general, the time-varying mass-balance errors did not fluctuate in an unstable manner, and the cumulative mass-balance errors were less than 0.10 percent.

\section{Boundary Conditions}

Boundary conditions must be prescribed along the boundaries of the model domain and are used to represent flow conditions between the simulated groundwater-flow system and systems beyond the boundaries. Three general types of boundary conditions are used in the LACPGM: no-flow, CHD, and GHB. The lower boundary of the LACPGM and many of the lateral boundaries were simulated as no-flow boundaries (specified flow equal to zero; fig. D1). No-flow conditions were simulated along the boundary with Tertiary deposits to the north and northeast at the edge of the Santa Monica Mountains and Hollywood Hills; along the Elysian, Repetto, Merced, and Puente Hills; and to the southwest along the base of the Palos Verdes Hills in the Dominguez through Upper Wilmington B model layers (fig. D1). These lateral boundaries were simulated as no-flow boundaries because the bordering Tertiary deposits are believed to impede flow into the LACP. Additionally, no-flow boundaries were applied to the lateral edges of each of the aquifer systems that were not specified as another boundary type. 
CHD boundaries were used at the Los Angeles Narrows to represent groundwater underflow through the Mesa aquifer system from the San Fernando Valley (fig. D1). The Mesa aquifer system is the only aquifer system that is spatially continuous in the Los Angeles Narrows (fig. D1). Time-varying heads were determined based on measured water levels at wells 1S/13W-15R2 (2772E) for 1971 to 2010 (appendix 3, fig. 3.1, table 3.2) and 1S/13W-15H1 (2771I; appendix 3, fig. 3.1). These wells were believed to accurately reflect water levels at the boundary because the wells are in close proximity to the boundary and the near-boundary region is narrow. Therefore, water levels at the boundary were set to measured water levels using time-varying specified-head boundaries. Water-level data from these wells were linearly interpolated over periods without measurements. Water-level data were not available for well 2772E for 2010-15 (appendix 3, fig. 3.1), so a linear relation was established between water levels from well 2772E and nearby well 2771I during the period of time that the wells had overlapping measurements, and that relation was used to approximate water levels at $2772 \mathrm{E}$ during these years.

Flow across boundaries at Whittier Narrows, Orange County, Palos Verdes Hills, San Pedro Bay, and Santa Monica Bay were simulated using a GHB (fig. D1). A GHB is a head-dependent flux boundary used to simulate a source of water outside the model area that either supplies water to, or receives water from, the general-head cells at a rate proportional to the hydraulic-head differences between the source and the model cell (McDonald and Harbaugh, 1988). The time-varying head values assigned to a GHB were estimated from available water-level data compiled for this study.

The East Montebello fault (EMF; fig. B23) forms the model boundary in the Whittier Narrows and cuts through all present aquifer systems. The Dominguez, Mesa, Long Beach $\mathrm{B}$, and Long Beach $\mathrm{C}$ aquifer systems are the only aquifer systems that contact the EMF on the LACP side of the fault in the Whittier Narrows (fig. D1). Water-level data collected from multiple-well monitoring sites 5P6-14 (2S/11W-5P6 to 5P14; Whittier Narrows1) and 8L8-16 (2S/11W-8L9-16; Whittier Narrows2) indicated that the Dominguez and Mesa aquifer systems had similar water levels and the Long Beach $\mathrm{B}$ and Long Beach $\mathrm{C}$ aquifer systems had similar water levels.

A GHB was used in the Mesa layer to simulate groundwater flow across the EMF into the Dominguez and Mesa layers, and a second GHB was used in the Long Beach $\mathrm{C}$ layer to simulate groundwater flow into the Long Beach B and Long Beach C layers (fig. D1). Head values for the Whittier Narrows GHB in the Mesa layer were estimated using water-level measurements from well 6G2 (2S/11W-6G2;
2927A) for the northwestern end of the GHB and from site 5P7-15 (Whittier Narrows1_8) for the southeastern end of the GHB (appendix 3, fig. 3.1). Water-levels have only been collected at 5P7-14 since 1992, so a linear relation was established between water levels measured at wells 5P7-14 and $6 \mathrm{G} 2(2 \mathrm{~S} / 11 \mathrm{~W}-6 \mathrm{G} 2 ; 2927 \mathrm{~A})$ to estimate water levels at 5P7-14 from 1971 to 1992 . Head values for GHB cells between these two wells were interpolated from data collected from these wells, based on the distance of the cell from either well. Head values for the Whittier Narrows GHB in the Long Beach C layer were estimated using water levels collected at well 8B1 (2S/11W-8B1; 2948C) for 1971 to 1992 and from 5P7-14 (Whittier Narrows1_1) for 1992 to 2015 (appendix 3, fig. 3.1). The heads assigned to the Whittier Narrows GHB in the Long Beach $\mathrm{C}$ layer were assumed to be the same along the entire length of the boundary. Conductance values for the GHB cells in the Whittier Narrows were determined during model calibration.

Groundwater underflow along the Orange County boundary (approximately 3 to $5 \mathrm{mi}$ east of the Los Angeles/ Orange County line) was simulated in all the model layers with GHB cells. The Orange County Water District (OCWD) has installed a series of multi-completion wells in the Orange County Basin to monitor water levels and water quality (fig. A3), and water-level data from multi-completion wells near the LACPGM boundary were used to assign time-varying heads to the GHB cells. Multi-completion wells were not constructed until the early 1990s; consequently, additional water-level data collected from monitoring and production wells along the boundary were used with water-level data from multi-completion wells to estimate the GHB heads for the period prior to the construction of the OCWD multi-completion wells. A more complete description of the methods used to construct the Orange County GHB is provided in appendix 3.

Groundwater underflow across the Palos Verdes fault at the base of the Palos Verdes Hills was simulated with GHB cells in the Lower Wilmington and Long Beach A-C layers for active cells at the boundary of Palos Verdes Hills. Groundwater underflow into the Dominguez through Upper Wilmington B layers from the Palos Verdes Hills was believed to be limited due to most of these layers pinching out around the Palos Verdes Hills. Water levels from well 5S/13W-7D (MW-1R) were used to assign the GHB heads for the Palos Verdes fault boundary (appendix 3, fig. 3.1). Underflow is likely restricted by the Palos Verdes fault; therefore, low conductance values were initially assigned to the GHB cells. Final conductance values were determined by parameter estimation using PEST (Doherty, 2010). 
All offshore cells in the uppermost layer (the Dominguez layer, or the Mesa layer where the Dominguez is not present) were simulated with GHB cells to allow interaction with the overlying ocean (fig. D1). In addition, the Marina Del Rey Harbor was simulated with GHB cells in the Mesa layer. Model cells along the offshore edge of the LACPGM were simulated with GHB cells (fig. D1). All the offshore GHB cells were assigned a freshwater-equivalent head by multiplying the bathymetric depth of the midpoint of each cell by 0.025 to account for the relative density difference between seawater and freshwater. The assignment of a freshwater-equivalent head is a simplified way to account for the effect of higher-density overlying seawater on groundwater flow. The initial conductance values for the offshore GHB cells were based on previous model results (Reichard and other, 2003). Conductance values for the interior offshore GHB cells were about two orders of magnitude lower than for the outermost offshore cells (Reichard and others, 2003). The conductance values for the interior offshore GHB cells are lower because they simulate the vertical movement of groundwater through the uppermost aquifer system layer to or from the ocean; in contrast, the conductance values for the outermost offshore cells simulate the horizontal flow between the aquifer system layers and the ocean. Final conductance values were determined by parameter estimation using PEST (Doherty, 2010).

\section{Model-Layer Elevations}

Elevations for the tops and bottoms of the 12 aquifer system layers were determined from the geologic model described in Chapter B of this report. The top and bottom layer elevations from this geologic model were mapped onto the LACPGM cells. This mapping was done using the top and bottom layer elevations at the geographic center of each cell.

Model-layer thickness varies greatly throughout the model area. The Dominguez, Mesa, and Pacific A model layers are relatively thin throughout the model area, with average thicknesses of 115,135 , and $146 \mathrm{ft}$, respectively, and maximum thicknesses not exceeding $450 \mathrm{ft}$ (table D2). Model-layer thickness generally increases from the upper layers to the lower layers, with the bottom two layers (Long Beach B and C) being considerably thicker than the other layers (table D2). Areal variation in layer thickness increases from the upper to lower layers. Maximum layer thickness is generally found near the center of the Central Basin syncline between the Compton-Los Alamitos fault and the Santa Fe Springs anticline. Layers are thinner or pinch out toward the northern edges of the model.

The chronostratigraphic model contains small regions at the edge of the model and near some faults, where the initial interpolation in the chronostratigraphic model resulted in unrealistic cell top and bottom elevations. These unrealistic elevations were thousands of feet deeper than neighboring cells on the same side of the fault, which translated into unrealistic groundwater-flow model top and bottom elevations. Quality-assurance checks were done to locate any cells with suspected interpolation error; these errors were corrected by interpolation from the nearest realistic neighbor cell(s). As indicated above, minimum model-layer thicknesses were set at $15 \mathrm{ft}$ to achieve a numerically stable model. Where model layers were less than 15-ft thick, they were treated as if they had pinched out, and the thickness of the pinched-out layer was incorporated into the layer above the pinched out layer (or the layer below if the pinched out layer was the top-most layer).

\section{Hydraulic Properties}

Hydraulic properties assigned to the LACPGM include horizontal and vertical hydraulic conductivity, specific yield, and specific storage. These properties affect the rate at which groundwater moves through an aquifer system, the volume of water in storage, and the rate and areal extent of groundwater response to aquifer system stresses. Horizontal and vertical hydraulic conductivities were initially estimated by dividing each layer into areal zones, with different zones for each layer. Each zone's hydraulic conductivities were estimated based on an analysis of well-log data (see "Calibration Results" section), regional depositional patterns, and local lithologic variations of groundwater basin sediments reported in previous investigations (Reichard and others, 2003).

During calibration, hydraulic conductivities were modified by parameter estimation, and zones were modified based on model results and re-examination of well logs, water-quality data, and other relevant data. Hydraulic-conductivity zone maps with final calibrated values are shown and discussed in the "Model Calibration" section of this chapter.

Table D2. Los Angeles Coastal Plain Groundwater-flow Model layer average and maximum thickness.

[ft, foot]

\begin{tabular}{lcc}
\hline \multicolumn{1}{c}{ Layer } & $\begin{array}{c}\text { Average thickness } \\
\text { (ft) }\end{array}$ & $\begin{array}{c}\text { Maximum thickness } \\
\text { (ft) }\end{array}$ \\
\hline Dominguez & 115 & 337 \\
Mesa & 135 & 449 \\
Pacific A & 146 & 399 \\
Pacific & 178 & 809 \\
Harbor & 249 & 1,031 \\
Bent Spring & 221 & 1,516 \\
Upper Wilmington A & 230 & 781 \\
Upper Wilmington B & 264 & 1,294 \\
Lower Wilmington & 307 & 1,276 \\
Long Beach A & 414 & 2,164 \\
Long Beach B & 812 & 3,231 \\
Long Beach C and BC & 1,284 & 4,555 \\
\hline
\end{tabular}


Chronostratigraphic units generally consist of finer sediments near the top and coarser sediments on bottom. Representing each chronostratigraphic unit as a single model layer and defining a single vertical hydraulic conductivity value for each cell can lead to modeling errors because the top of the cell often consists of finer sediments than the bottom of the cell. To limit these modeling errors, additional confining layers could have been added to the model. However, additional confining layers would have added to the model's runtime. Instead, modeling errors were limited by defining vertical hydraulic conductivities for each cell connection (IKCFLAG=1). Each connection's vertical hydraulic conductivity was defined by the vertical hydraulic conductivity assigned to the zone of the lower of the two connected layers. The lower layer was chosen to define the vertical connection properties because the lower layer usually represents the finer sediments in the connection. The zones constructed for horizontal hydraulic conductivity were also used for vertical hydraulic conductivity.

Specific storage and specific yield were defined using the same zones as used for hydraulic conductivity. Initial storage values were based on calibrated values from Reichard and others (2003). The final values were determined by parameter estimation using PEST (Doherty, 2010).

\section{Horizontal-Flow Barriers}

The MODFLOW-USG HFB package based on Hsieh and Freckleton (1993) was used to simulate faults and folds within the model domain that are believed to restrict groundwater flow. The HFB package simulates these features as thin, vertical, low-permeability geologic features that impede the horizontal flow of groundwater. Flow across a simulated HFB is proportional to the hydraulic-head difference between adjacent cells where the constant of proportionality is the hydraulic characteristic. For unconfined aquifers, the hydraulic characteristic equals the hydraulic conductivity of the flow barrier divided by the width of the barrier and has dimensions of per time $\left(\mathrm{T}^{-1}\right)$. For confined aquifers, the hydraulic characteristic equals the transmissivity of the flow barrier divided by the width of the barrier and has dimensions of length per time $\left(\mathrm{LT}^{-1}\right)$.

The LACPGM uses HFBs to simulate groundwater flow across the Newport-Inglewood fault zone, Santa Monica, Compton-Los Alamitos, Pacific Coast Highway (PCH), and Alondra faults, and the Santa Fe Springs anticline and related structures. The locations and areal extents of the flow barriers were identified from geological information (as described in Chapter B) or inferred from localized hydraulic-head (water-level) gradients. Some of the longer HFBs were broken into segments and assigned different hydraulic-characteristic values for each segment. Initially, the hydraulic-characteristic values were set to large values to allow groundwater to flow freely across fault segments. Final calibrated values were determined through PEST calibration and are shown in the "Calibration Results" section of this chapter.

\section{Simulated Areal Recharge}

The LACPGM simulates areal recharge using the $\mathrm{RCH}$ package (Harbaugh, 2005). The quantity and distribution of areal recharge were based on a watershed-scale, precipitation-runoff infiltration model developed for this study (Hevesi and Johnson, 2016). Areal recharge represents both mountain-front recharge on the perimeter of the model from bordering tributary drainages and direct precipitation. The recharge estimates from Hevesi and Johnson (2016) were used as initial quarterly areal recharge values from 1971 through 2014 for each model cell. Initial quarterly areal recharge for 2015 was estimated by using a correlation developed between historical precipitation data and recharge estimates (described in appendix 5).

Recharge estimates from Hevesi and Johnson (2016) were allowed to vary during model calibration. Recharge estimates were allowed to vary by first dividing the model area into 17 recharge zones based on geographical features (fig. D2A). Recharge estimates from Hevesi and Johnson (2016) were modified with a multiplier applied to each recharge zone. The recharge zone multipliers were calibrated as PEST parameters. The calibrated recharge-zone multipliers changed the distribution of recharge in some regions of the study area, but only had a minor effect on the overall model-area recharge estimates of Hevesi and Johnson (2016).

Water levels in the Dominguez aquifer system, south of Merced Hills, indicate that the Dominguez aquifer system is receiving local recharge. Runoff from the Merced Hills probably is a source of recharge to the Dominguez aquifer system in this part of the LACPGM, and the Dominguez aquifer system probably extends through recharge zone 18 to the Merced Hills. Because the chronostratigraphic model does not extend the Dominguez unit all the way to the Merced Hills, recharge estimated for zone 18 by Hevesi and Johnson (2016) was transferred to zone 14 to simulate recharge from the Merced Hills to the Dominguez aquifer system (fig. D2A).

Areal recharge varies throughout the model area, with the highest recharge generally occurring near the Santa Monica Mountains and the hills bordering the model area to the north and northeast (fig. D2B). Simulated areal recharge in the model area varied greatly between wet and dry periods (fig. D3), reaching a high of about 190,000 acre-feet per year (acre-ft/yr) during 1978 and a low of about 5,500 acre-ft/yr during 2014. 


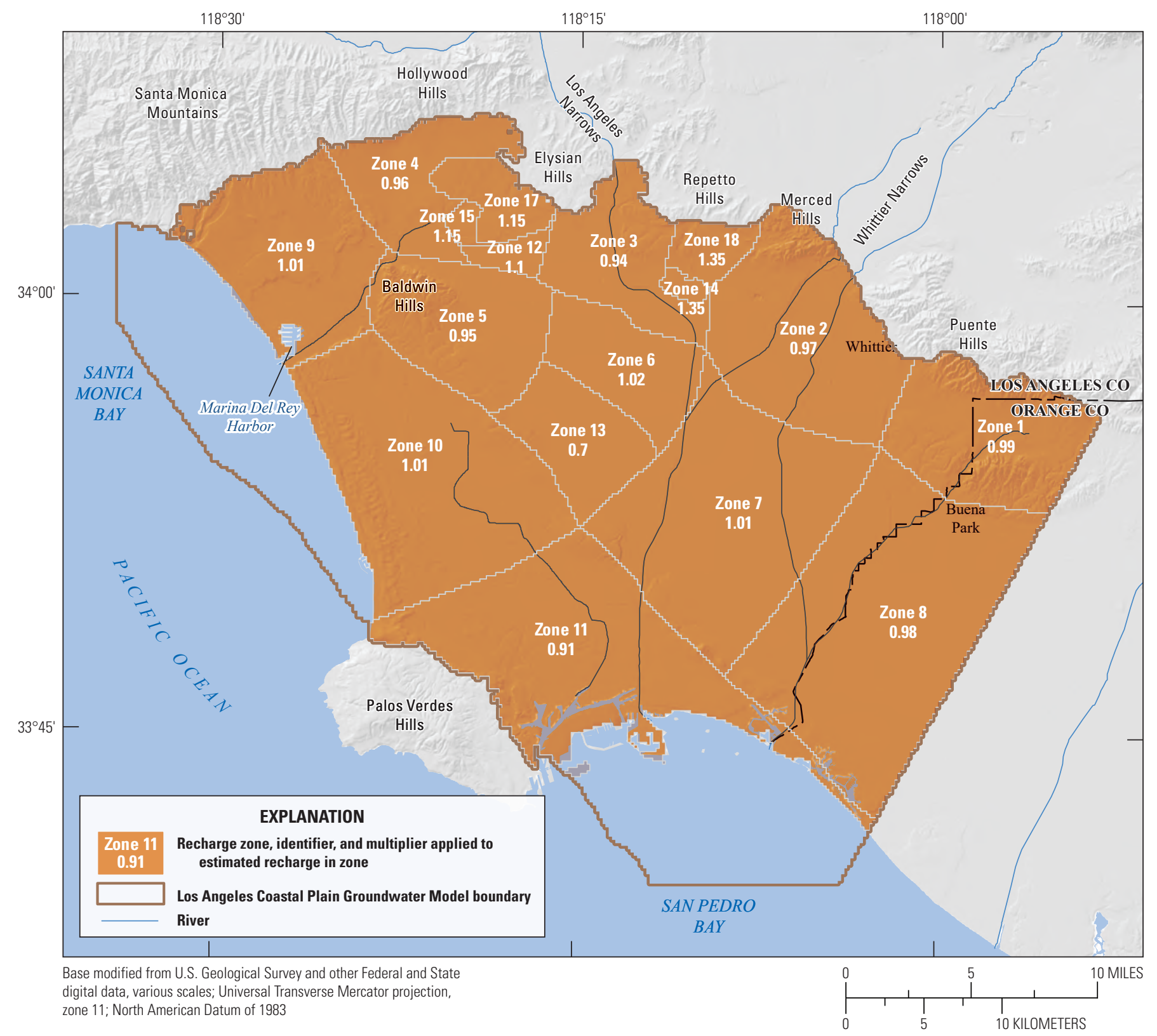

Figure D2. Areal recharge as $A$, areal recharge zones and multipliers, and $B$, simulated average areal recharge rates, calendar years 1971 to 2015, of the Los Angeles Coastal Plain Groundwater-flow Model, Los Angeles and Orange Counties, California.

The Mesa model layer is the topmost layer (and mostly the only layer) in recharge zone 17 (fig. D2A). Folding and subsequent erosion of the aquifers older than the relatively flat-lying Mesa aquifer system has resulted in the Mesa aquifer system directly overlying low permeability Repetto Rocks throughout most of the recharge zone. Due to the low permeability of the Repetto Rocks, recharge in recharge zone 17 probably moves laterally through the Mesa model layer in zone 17 and then downward into the surrounding aquifer system. The base of the Mesa layer in zone 17 is higher than the groundwater elevation of the surrounding aquifers; therefore, the aquifers are not in direct hydraulic connection. Consequently, pumping from the surrounding aquifers should not induce groundwater flow from recharge zone 17. However, in the LACPGM, the Mesa model layer in recharge zone 17 is contiguous with the Mesa model layer in the surrounding model zones. The Mesa model layer in recharge zone 17 was assigned a very low specific yield $(0.0075)$ to limit the quantity of groundwater flow from the Mesa model layer in recharge zone 17 to the surrounding recharge zones. Areal recharge was not applied to recharge zone 17 to avoid water levels rising above land surface in this model zone. Instead, the areal recharge intended for recharge zone 17 was distributed equally around the south and west perimeter of zone 17, which is along the southern and eastern edges of recharge zone 17 (fig. D2A). 


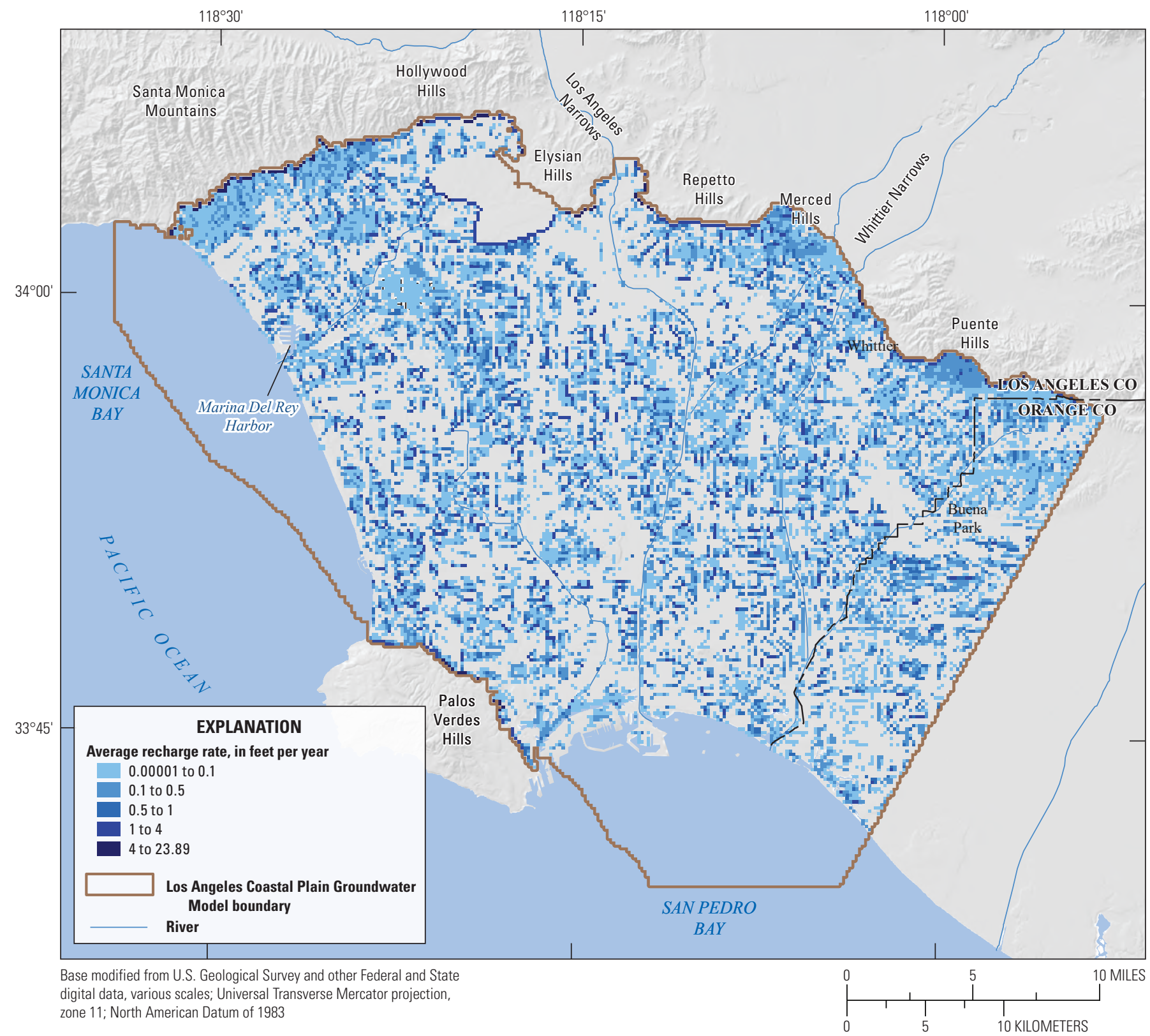

Figure D2.-Continued

Areal recharge was assumed to occur in the uppermost active model layer and was applied using the $\mathrm{RCH}$ package. Areal recharge was added to uppermost active model layer by first creating an inactive top layer that extends over the entire model area, which was the simplest way to use the RCH package with the LACPGM's unstructured grid. Simulated recharge passes through this layer to the uppermost active model layer, which is the Dominguez or Mesa layer throughout most of the LACPGM (fig. D4).

\section{Water Spreading}

The LACPGM simulates water spreading from three spreading grounds in the model area: the San Gabriel River spreading grounds (SGRSG), Rio Hondo spreading grounds (RHSG), and the west side of the reservoir behind Whittier Narrows Dam (WND; fig. D5).

The WRD provided monthly water spreading data, which were processed into a quarterly recharge rate for each model cell in the spreading grounds. Spreading amounts were assumed to be spatially uniform within each set of spreading grounds. Given the quantity and duration of the recharge and the highly permeable nature of the sediments under the facilities, retention of recharge water and transit time in the unsaturated zone was expected to be minimal. Water spreading was simulated using the WEL package (Harbaugh, 2005) by injecting water into the uppermost active model layer. 


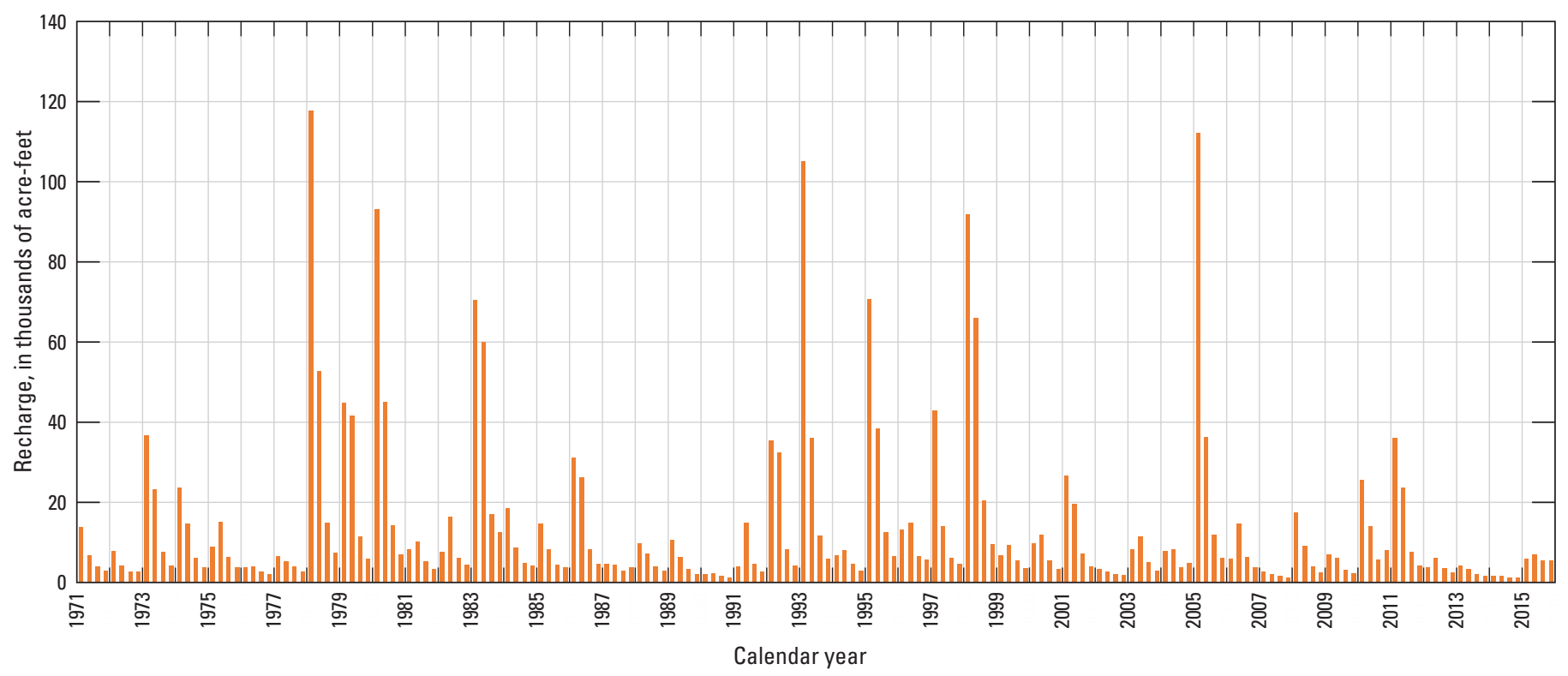

Figure D3. Areal recharge applied to the Los Angeles Coastal Plain Groundwater-flow Model, quarterly estimates from 1971 to 2015 , Los Angeles and Orange Counties, California.

\section{Water-Supply and Injection Wells}

Injection and production wells were simulated throughout the model area. Injection wells were simulated for the three barrier projects in the study area: the West Coast Basin Barrier Project (WCBBP), the Dominguez Gap Barrier Project (DGBP), and the Alamitos Barrier Project (ABP; fig. D5). Injection and production wells were simulated using the MODFLOW-USG CLN package (Panday and others, 2013) and the WEL package (Harbaugh, 2005). The LACPGM uses the CLN process to simulate flow through vertical conduits that represent injection and production wells and uses the WEL package to inject/pump water to/from each conduit. Each well was represented by a single vertical conduit segment. Conduits representing wells constructed during the model period (1971 to 2015) were set to no-flow for stress periods prior to well construction and were set to variable head such that flow can occur through the conduit for stress periods after construction. Conduits are connected to one or more model layers.

Within the CLN package, the option to use the Thiem equation was selected, which simulated flow between each CLN node and matrix node with the inclusion of skin effects. The CLN package using the Thiem equation is similar to the approach used by the revised Multi-Node Well package of MODFLOW-2005 (Konikow and others, 2009). Flow between a conduit and each connected model cell is computed across the wetted perimeter of the conduit and can occur both during periods of pumping and when the well is idle. Conduit properties, including skin resistance, hydraulic conductivity, and radius, are used to compute the effective leakance between a conduit and its connected model cells. For the LACPGM, the radius of the conduit was determined from well-construction logs. A conduit skin factor was used to regulate borehole flow between layers. A conduit skin factor of 16,000 was used. The skin factor of 16,000 led to a numerically stable model in all but one conduit, and the skin factor was reduced for this conduit. Reducing the skin factor of one conduit had minimal effect on model results because that conduit is only connected to one model layer.

The conduit skin factor and conduit hydraulic conductivity were initially set as parameters and were calibrated to minimize the difference between observed and simulated head values. Conduit skin factor and conduit hydraulic conductivity were also manually calibrated to maximize model numerical stability. The skin factor was determined based on an initial calibration and not varied for the remainder of the calibration due to the sensitivity of the model's numerical stability to high skin factor values. 


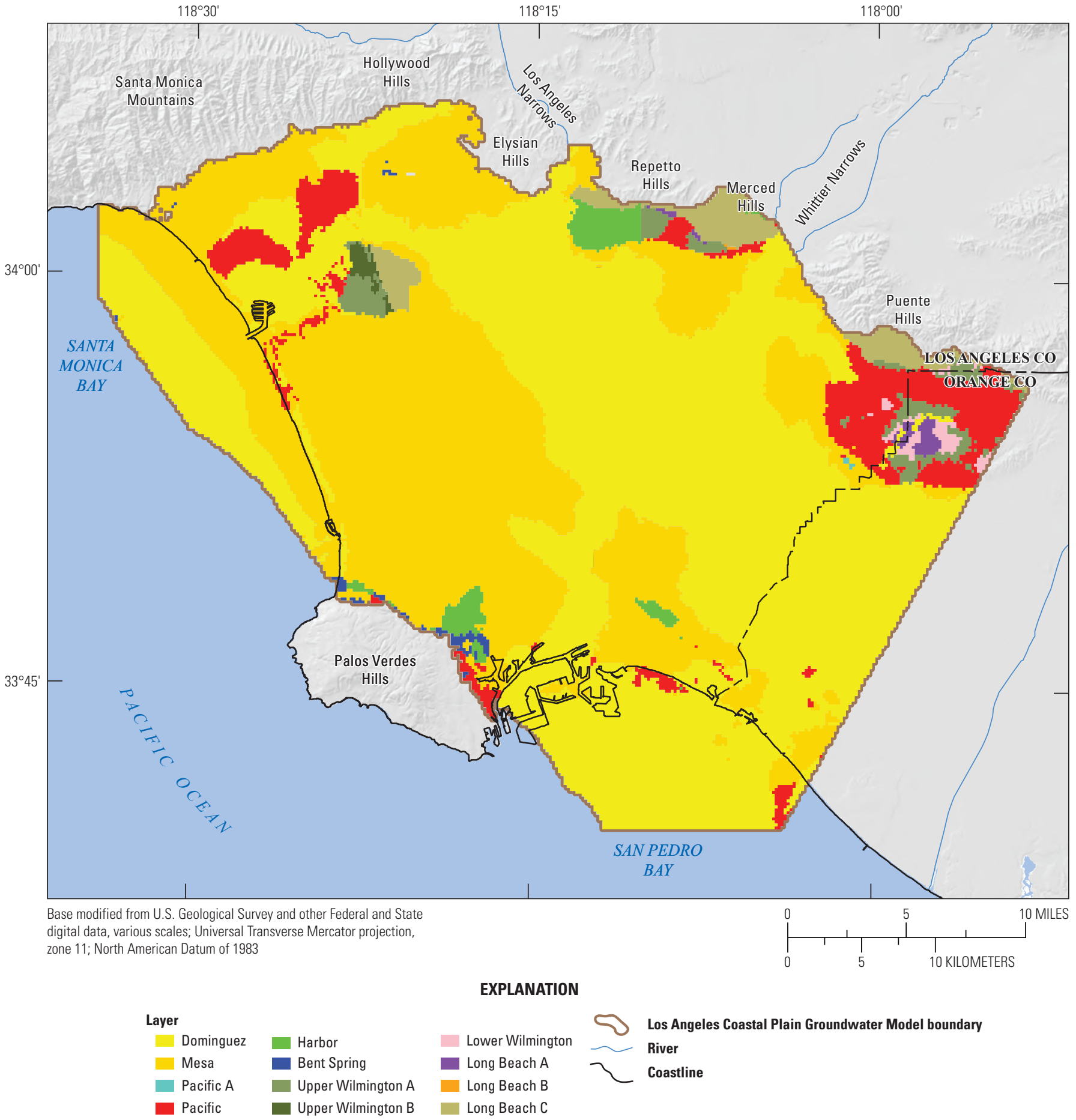

Figure D4. Uppermost model layer in the Los Angeles Coastal Plain Groundwater-flow Model, Los Angeles and Orange Counties, California. 


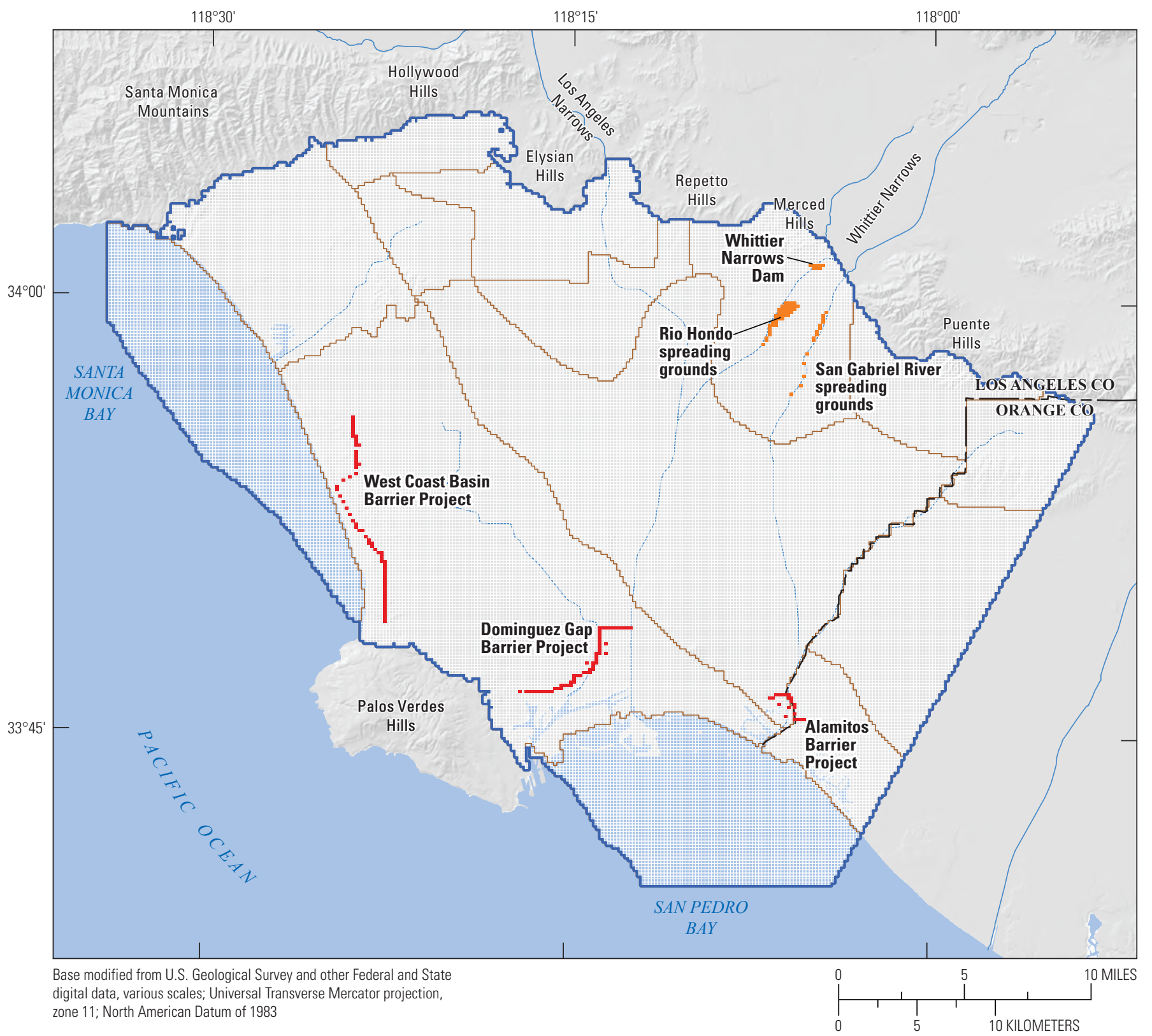

EXPLANATION

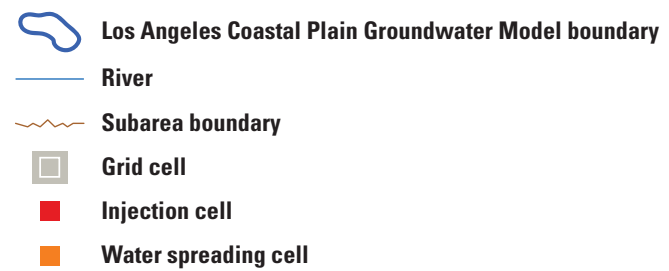

Figure D5. Cells with injection or spreading for all layers of the Los Angeles Coastal Plain Groundwater-flow Model, Los Angeles and Orange Counties, California. 


\section{Drains}

The MODFLOW-USG drain (DRN) package was used to represent drained runoff caused by rising water levels from the WND spreading grounds, the San Gabriel River, Rio Hondo, Dominguez Channel, the northern part of Ballona Creek, Coyote Creek, and areas of runoff in the foothills of the Santa Monica Mountains (figs. A1, D1, D5). These areas were simulated as drains because creek flow is ephemeral and water levels are near land surface in many of the creek beds. A drain is a head-dependent flux boundary condition that allows water to drain from a model cell at a rate proportional to the difference between the simulated head in the cell and some specified drain head or elevation, as long as the simulated head is above the specified head or elevation. The drain has no effect on the model cell if the simulated head falls below the specified drain elevation (McDonald and Harbaugh, 1988). The constant of proportionality is termed the drain conductance (L2T-1). Drain elevation was set to $230 \mathrm{ft}$ at the WND spreading grounds, slightly below the top of Whittier Narrows Dam. This drain elevation was selected to simulate flow out of the WND spreading grounds when water levels approach the top of the dam. Drain elevations in other areas were set to the bottom of the river/drainage being simulated. Drain conductance values were determined during the calibration process.

\section{Model Calibration}

The LACPGM was calibrated using a combination of automated inverse modeling with PEST (Doherty, 2010) and manual trial-and-error calibration for the simulation period January 1971 through December 2015. Initial estimates of aquifer hydraulic properties, HFB hydraulic-characteristic values, GHB conductance values and heads, CLN parameters, DRN conductances, and the distribution and quantity of areal recharge were iteratively adjusted to improve the match between simulated and measured hydraulic heads (water-level elevations).

The LACPGM parameterized horizontal and vertical hydraulic conductivity, specific storage, and specific yield using zones defined for each model layer. Zones were based on well-log data, flow-barrier locations, and geographical features. HFB hydraulic-characteristics and GHB conductance values were also parameterized by model layer for each flow barrier. Longer HFBs or model boundaries, such as the Newport-Inglewood fault zone and the Orange County GHB, were broken up and parameterized by segments. Recharge was parameterized with a recharge multiplier for each of the 17 recharge zones (fig. D2).

Initial hydraulic-conductivity and specific-storage values were based on geologic features and borehole logs. Initial specific-yield values were based on the calibrated values of a previous groundwater-flow model (Reichard and others, 2003). Initial HFB hydraulic-characteristic values were set to large values to allow groundwater to flow freely across the barrier segments. Conductance values for the Whittier Narrows and Orange County GHB cells were initially assigned large values to allow unrestricted flow across the boundary cells. The offshore and Palos Verdes GHB conductance values were initially assumed to allow only minimal flow, and their conductance values were initially set to small values. Initial recharge-zone multiplier parameters were set to 1.0, which left the recharge estimates from Hevesi and Johnson (2016) unchanged. Initial conductance values for the DRN cells were initially assigned large values to allow drainage of groundwater near land surface. Using conduit skin factor as a PEST parameter was found to cause model instability. The conduit skin factor for CLN conduits was therefore determined by manual calibration prior to PEST calibration.

\section{Initial Conditions}

Initial conditions define the state of the groundwater-flow system state at the beginning of a transient simulation. Ideally, initial conditions would represent pre-development conditions; however, groundwater resources development within the LACP began in the 19th century, and sufficient historical water levels and data for estimating stresses were not available until about the 1960s. Therefore, the simulation began with initial conditions representing relatively static hydrologic conditions during the modern period when data are available. Analysis of the long-term water-level hydrographs (see "Water Levels and Movement" section in Chapter C) indicated that water levels measured in 1971 were the earliest on record, after the adjudication of the Central and West Coast Basins in the early 1960s, when the water levels were relatively constant. Water levels collected in early 1971 were used to provide the initial conditions for the LACPGM because water levels were relatively constant and sufficient data are available to simulate the quantity and distribution of stresses to the system. 
Initial heads were determined for each model layer based on an interpolation of available water-level data collected in 1971. Aquifer-dependent water-level data were limited in the LACP prior to the construction of WRD/USGS multiple-well monitoring sites in the late 1990s; therefore, the assigned initial heads are uncertain, especially in the deeper aquifer systems, which could potentially lead to initial-condition errors. In areas of the model where these errors were likely to be small because data were plentiful, the model usually established a new equilibrium within several stress periods, resulting in only minimal error. However, some areas had sparse water-level data collected around 1971, including parts of the Santa Monica Basin, northern West Coast Basin, and Hollywood Basin. In areas where initial-condition errors were likely to be large because of sparse data, the inconsistent specified initial heads could take multiple stress periods to equilibrate in the model simulation, especially in aquifer systems with low hydraulic conductivities. To minimize the error associated with initial heads, these heads were modified in areas of the model in which initial model simulations showed major head changes in the early stress periods, which indicated that the initial heads in those areas were inconsistent with our initial conceptualization of the groundwater-flow system. If production wells were present and active in 1971 in the area, additional estimated water-level measurements were added to the water-level data being interpolated at cells representing the production wells and surrounding cells to reflect the initial heads at the pumping wells and approximately interpolate the drawdown around the wells.

\section{Observations Used in Model Calibration}

Four types of observation data were used during model calibration: water levels, changes in water level, vertical differences in water levels between layers, and estimated annual flow rates across the Whittier Narrows. The water-level-based calibration criteria were developed using 27,860 water-level measurements from 464 wells. Measurements were averaged for each stress period, and the averages were used to compute changes in water levels for each stress period. Vertical differences in water levels between layers were computed from water levels collected at 32 multiple-well monitoring sites. Locations of wells used for model calibration are shown in figure A3. The LACPGM was also calibrated to yearly estimated underflow across Whittier Narrows by the San Gabriel River Watermaster (San Gabriel River Watermaster, 1997).

\section{Calibration Process}

Calibration of the LACPGM was initially accomplished primarily with automated calibration, and a combination of automated and trial-and-error methods toward the end of calibration. PEST (Doherty, 2010) was used for automated calibration. The model was calibrated to achieve the best possible match to measured water levels, water-level drawdowns, vertical differences in water levels between different monitoring wells in the multiple-well monitoring sites, and underflow estimates at the Whittier Narrows, subject to a range of parameter values that realistically represent the geology of the groundwater basin. Each water-level measurement and estimated flow rate was considered a single data point. Data points were assigned different weights depending on whether they were collected from key multiple-well monitoring sites (table D3). Most water-level measurements from non-key wells were assigned a weight of 1.0; most measurements from key multiple-well monitoring sites were assigned a weight of 3.0. Key multiple-well monitoring sites (table D3) were chosen and assigned a higher weight due to their location, data quality (confidence in the measurements), number of wells at the site, and the temporal distribution of the data. Key wells were chosen to provide a good geographic distribution of key wells and avoid clustering of key wells in any given area. Key wells were primarily chosen within the WRD service area.

Calibration of the LACPGM was an iterative process that involved three steps:

(1) Running PEST to calibrate the model.

(2) Analyzing the results, including parameter values and their sensitivities, changes in objective function, and hydrographs. If the results indicated an inaccuracy with the groundwater or chronostratigraphic models, data used to build these models were reviewed to identify the specific problem. The most common chronostratigraphic model inaccuracies were layer boundaries at incorrect depths, which sometimes led to groundwater-flow model production wells pumping from the wrong layer.

(3) Changes were made based on the analysis in step 2 to any combination of PEST input, the groundwater-flow model, or the chronostratigraphic model. These changes included the following:

a. PEST observation weights and parametervalue bounds,

b. The hydraulic conductivity zones in the groundwater-flow model,

c. The initial conditions (hydraulic head in each cell),

d. The geometry of the chronostratigraphic layers. 
Table D3. Key multiple-well monitoring sites used during Los Angeles Coastal Plain Groundwater-flow Model calibration.

\begin{tabular}{ll}
\hline \multicolumn{1}{c}{ State well number } & \multicolumn{1}{c}{ Common name } \\
\hline 2S/12W-33D3-8 & Bell Garden1 \\
3S/12W-26K2-7 & Cerritos2 \\
3S/12W-9J1-6 & Downey1 \\
3S/14W-25K7-11 & Gardena2 \\
3S/14W-17G3-8 & Hawthorne1 \\
2S/13W-22C1-4 & Huntington Park1 \\
2S/14W-12E1-6 & Los Angeles3 \\
4S/12W-30J1-6 & Long Beach8 \\
4S/12W-5H5-10 & Lakewood1 \\
2S/11W-18C4-7 & Pico Rivera1 \\
2S/12W-25G3-8 & Pico Rivera2 \\
$4 \mathrm{~S} / 14 \mathrm{~W}-15 E 1-6$ & Torrance1 \\
$5 \mathrm{~S} / 12 \mathrm{~W}-1 \mathrm{C} 3-9$ & Seal Beach1 \\
3S/11W-2K4-8 & Whittier1 \\
4S/13W-28A3-7 & Wilmington1 \\
\hline
\end{tabular}

Additional steps were also performed when necessary. These included (4) manually running the model to test model adjustments prior to running PEST, and (5) updating and rebuilding the chronostratigraphic and groundwater-flow model layering as new information became available. All five steps were repeated until the model was reasonably calibrated. The majority of the calibration adjustments involved modifying the hydraulic-conductivity zones. In addition, the chronostratigraphic layer geometry was modified as needed, especially in the West Coast Basin, where small errors in the chronostratigraphic model could lead to placing production or injection wells in the wrong layer. Chronostratigraphic layer geometry was also modified at the northern and eastern edges of the LACPGM where steeply sloping model layers caused numerical instability.

\section{Calibration Results}

A total of 27,860 hydraulic-head (water-level elevation) measurements at 464 wells in the model area from 1971 through 2015 were compared to simulated heads to help calibrate the model (fig. D6). The simulated and measured heads closely follow a 1:1 correlation line, with a root-mean-squared error of $11.3 \mathrm{ft}$ (fig. D6A). About 76 percent of simulated heads are within $10 \mathrm{ft}$ of measured values and about 96 percent are within $25 \mathrm{ft}$. The simulated versus measured hydraulic-head residuals were mostly between -6 and $6 \mathrm{ft}$, with a very slight skew toward negative residual values (fig. D6B). A better match between simulated and measured heads was achieved for values greater than $0 \mathrm{ft}$ (fig. D6A). As values dropped below $0 \mathrm{ft}$, simulated heads were on average skewed slightly lower than measured heads. This skew is most likely due to model limitations when estimating heads in close proximity to production wells that produce substantial water-level drawdown. Measured heads in the Santa Monica Basin near the Santa Monica Mountains fluctuated seasonally by up to $150 \mathrm{ft}$. The model was not able to simulate this much fluctuation, possibly due to the complex geology along the Santa Monica fault.

\section{Calibrated Horizontal Conductivity}

Geologic and geophysical logs from WRD/USGS monitoring sites were used to determine grain sizes of the chronostratigraphic units. Grain sizes were used to help determine initial horizontal hydraulic conductivity and were also used as part of the calibration process.

The calibrated horizontal hydraulic conductivity (HK) for each layer and the interpretation of well data used to help constrain the calibrated HK values are shown in figure D7. Calibrated horizontal HK values were generally higher in the upper model layers and decreased with depth (fig. D7). The highest calibrated HK values in the model were $785 \mathrm{ft} / \mathrm{d}$ in the Dominguez layer along the Montebello Forebay near Whittier Narrows (figs. D1, D7A). This is consistent with the coarse- and medium-grain size of sediment at site 11A7-12 (3S/12W-11A7 to 11A12; Norwalk-2; fig. D7A). In general, the calibrated HK values were the highest in the Montebello Forebay for all layers, with HK values decreasing toward the coast (fig. D7). The Upper Wilmington $\mathrm{B}$ and lower layers have considerably lower calibrated HK values than the overlying layers, with most calibrated HK values of $25 \mathrm{ft} / \mathrm{d}$ or less (figs. D7B, D7C). These layers are predominantly compacted shallow to deep marine deposits, which accounts for their lower HK values (figs. B7-B11). These layers also are very thick, exceeding $2,000 \mathrm{ft}$ in the Long Beach $\mathrm{A}-\mathrm{C}$ layers in the central part of the Central Basin. Although these layers are thick, permeable deposits compose only a small percentage of the total thickness of these layers and generally are present at the base of these layers. The LACPGM calculates the transmissivity of a layer by multiplying the calibrated HK of a layer by the thickness of the layer. Therefore, a thick layer with a small percentage of coarse-grained deposits would have a lower calibrated HK value than would the thinner, coarse-grained zone of the layer. Consequently, the calibrated HK values for the Long Beach layers in the Central Basin, where the layers are the thickest, are some of the lowest calibrated HK values ( $1 \mathrm{ft} / \mathrm{d}$ or less) in the LACPGM (fig. D7C). 


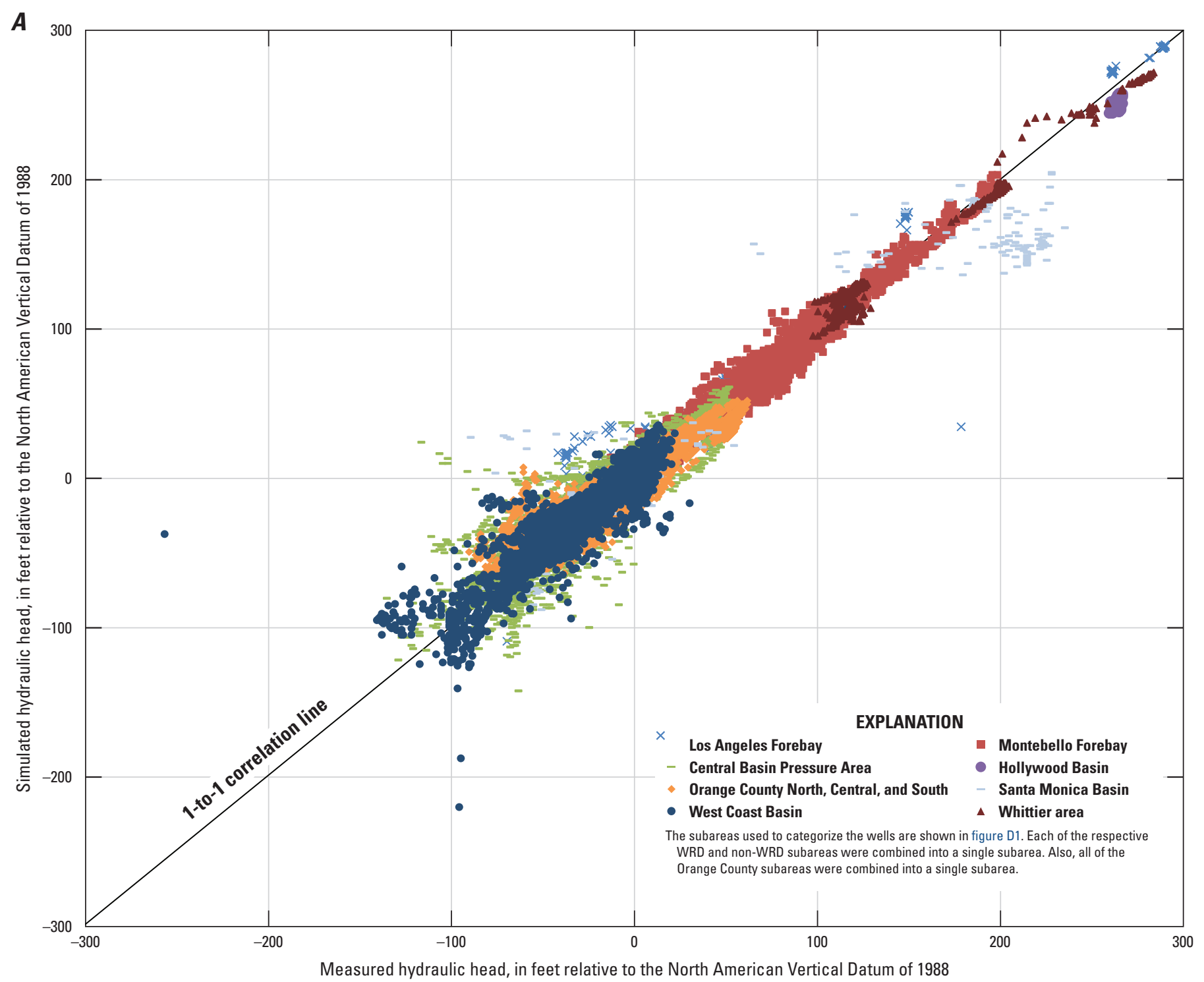

Figure D6. Simulated versus measured hydraulic heads of the Los Angeles Coastal Plain Groundwater-flow Model for 1971 through 2015, as $A$, scatter plot; and $B$, histogram of residual errors.

Grain-size analyses in well bores were used to guide calibration of horizontal hydraulic conductivity. As a result, calibrated horizontal hydraulic conductivities were generally consistent with grain-size analyses. Inconsistencies between the final calibrated horizontal hydraulic conductivities and grain-size analyses were allowed when there was reasonable justification. For example, at wells 22M2-7 (3S/13W-22M2 to 22M7; Compton2; fig. C8), we determined that the Dominguez and Mesa chronostratigraphic units contained only fine sediments; however, the LACPGM could not simulate production well 21J2 (3S/13W-21J2; screened entirely in the Dominguez and Mesa units near 22M2-7) at its recorded pumping rates using low modeled HKs in this area. Therefore, the Dominguez and Mesa chronostratigraphic units likely contained grain sizes other than fine sediments at wells 22M2-7. As a result, wells 22M2-7 were included in a zone with intermediate modeled HKs. We also recognized that coarse-grained sediment in the lower units (Lower Wilmington and Long Beach A through C) did not necessarily indicate high HK values because HK may be primarily affected by other factors at depth, such as level of induration. 


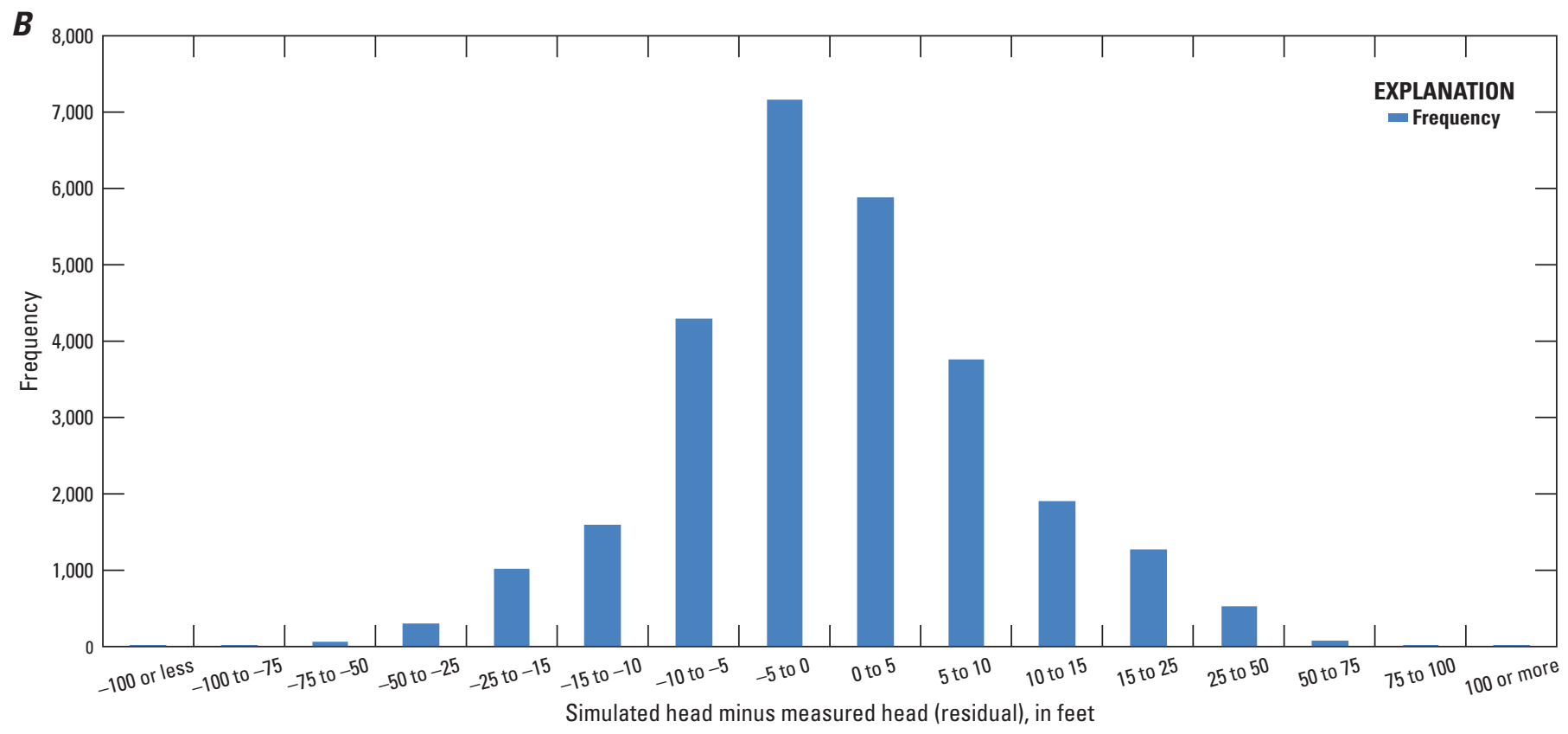

Figure D6.-Continued

\section{Calibrated Vertical Hydraulic Conductivity}

In the LACPGM, VK was defined by connection between adjacent model layers. VK connection values were directly assigned based on PEST parameters, as opposed to the VK value of each connection being calculated based on VK values of the two connecting model cells. The calibrated VK values in Central Basin generally are higher in the Montebello Forebay, lower in the Central Basin Pressure Area and Orange County Basin, and variable in the Los Angeles Forebay (figs. D1, D $8 A-K$ ). The calibrated VK values between the non-marine Dominguez and Mesa layers generally were higher than the calibrated VK between the underlying layers. The Pacific A layer, which is predominantly of shallow marine origin (fig. B17), had calibrated VK values about one order of magnitude lower than the VK values of the Mesa layer (figs. D8A-B). The calibrated VK values in the Pacific A and lower layers in the Central Basin Pressure Area generally were low $(0.009 \mathrm{ft} / \mathrm{d}$ or less); these values represent the fine-grained sediments commonly found in the upper part of the chronostratigraphic units (Van Wagoner and others, 1990) that these model layers represent.

In the West Coast Basin, calibrated VK values were variable but consistently low in the Mesa layer, with most zones having values of $0.007 \mathrm{ft} / \mathrm{d}$ or less (figs. D1, D8A). The calibrated VK values of the Pacific and Harbor layers generally were higher than those in the Mesa layer, with some zones having values in excess of $1.0 \mathrm{ft} / \mathrm{d}$ (figs. D8 $B-D$ ). Calibrated VK values are low (0.004 ft/d or less) in the Bent Spring layer throughout most of the West Coast Basin, except for the zones near the Palos Verdes Hills, which had values in excess $0.2 \mathrm{ft} / \mathrm{d}$ (fig. D8E). The Long Beach layers had the consistently lowest calibrated VK values, with values less than $0.0005 \mathrm{ft} / \mathrm{d}$ throughout most of the West Coast Basin (figs. D $8 I-K$ ).

\section{Calibrated Groundwater-Flow Barrier Hydraulic-Characteristic Values}

Groundwater flow barriers were simulated in all layers except for the Dominguez layer (figs. D $8 A-K$ ). Simulated HFB hydraulic-characteristic values were generally higher for the upper model layers and lower for the deeper model layers. The lowest hydraulic-characteristic values were simulated along the eastern section of the Santa Fe Springs anticline, where values are as low as $5.7 \mathrm{E}-10$ per day $(1 / \mathrm{d}$; fig. D8k). The Newport-Inglewood fault zone, and Alondra, Santa Monica, Compton-Los Alamitos, and PCH faults also are simulated as flow barriers in the deeper units, with hydraulic-characteristic values as low as $3.7 \mathrm{E}-6,8.8 \mathrm{E}-8$, 6.3 E-7, 8.3 E-5, and 2.6 E-5 feet squared per day $\left(\mathrm{ft}^{2} / \mathrm{d}\right)$, respectively. These low hydraulic-characteristic values severely restrict the flow across the fault zones in the deeper model layers where faults can have large vertical and/or horizontal offsets at depth (fig. B6).

\section{Calibrated Specific Storage and Specific Yield}

Calibrated model specific-storage values varied from 1.0 E-5 to 1.0 E- 6 per foot $\left(\mathrm{ft}^{-1}\right)$ across all layers, with most of the values equal to $1.0 \mathrm{E}-6 \mathrm{ft}^{-1}$ (Paulinski and others, 2021). The highest specific-storage values generally occurred in the Mesa aquifer system. 
A
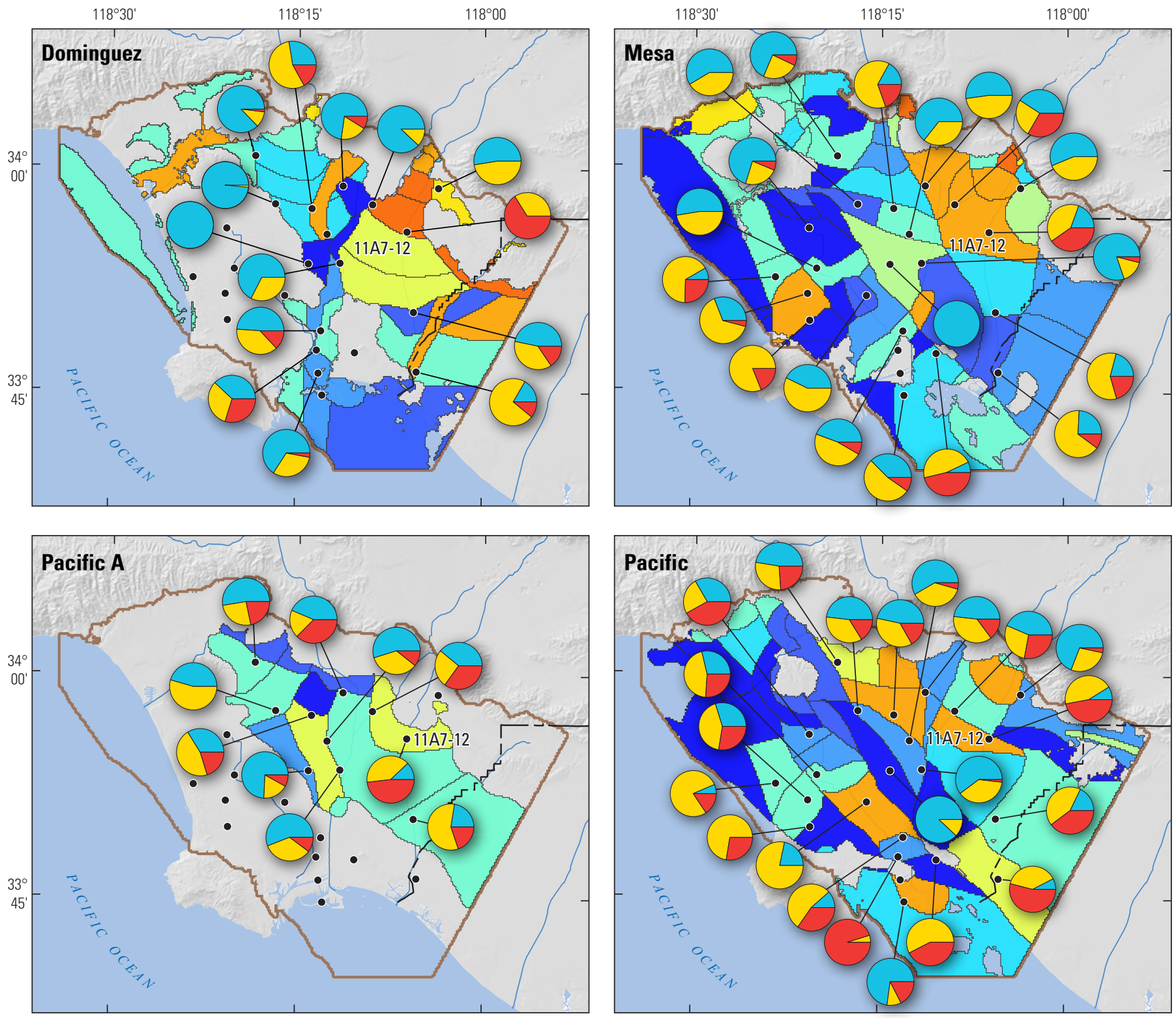

Base modified from U.S. Geological Survey and other Federal and State digital data, various scales; Universal Transverse Mercator projection, zone 11; North American Datum of 1983

\section{EXPLANATION}
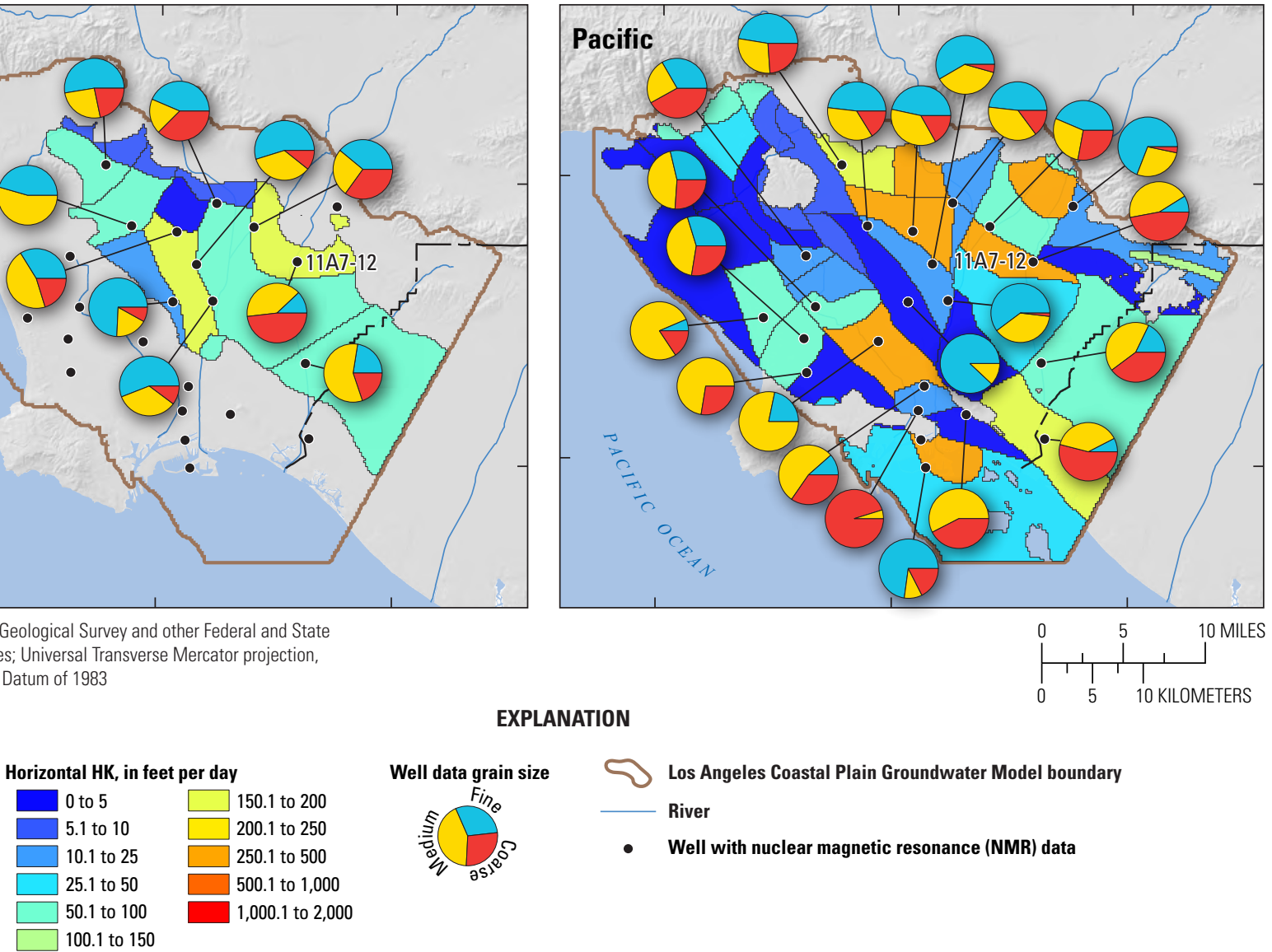

Figure D7. Calibrated horizontal hydraulic conductivities (HK) and grain-size distributions in well boreholes for model layers: $A$, Dominguez; Mesa; Pacific A; Pacific; $B$, Harbor; Bent Spring; Upper Wilmington A; Upper Wilmington B; and $C$, Lower Wilmington; Long Beach A; Long Beach B; Long Beach C, Los Angeles and Orange Counties, California. (NMR, nuclear magnetic resonance.) 
$\boldsymbol{B}$
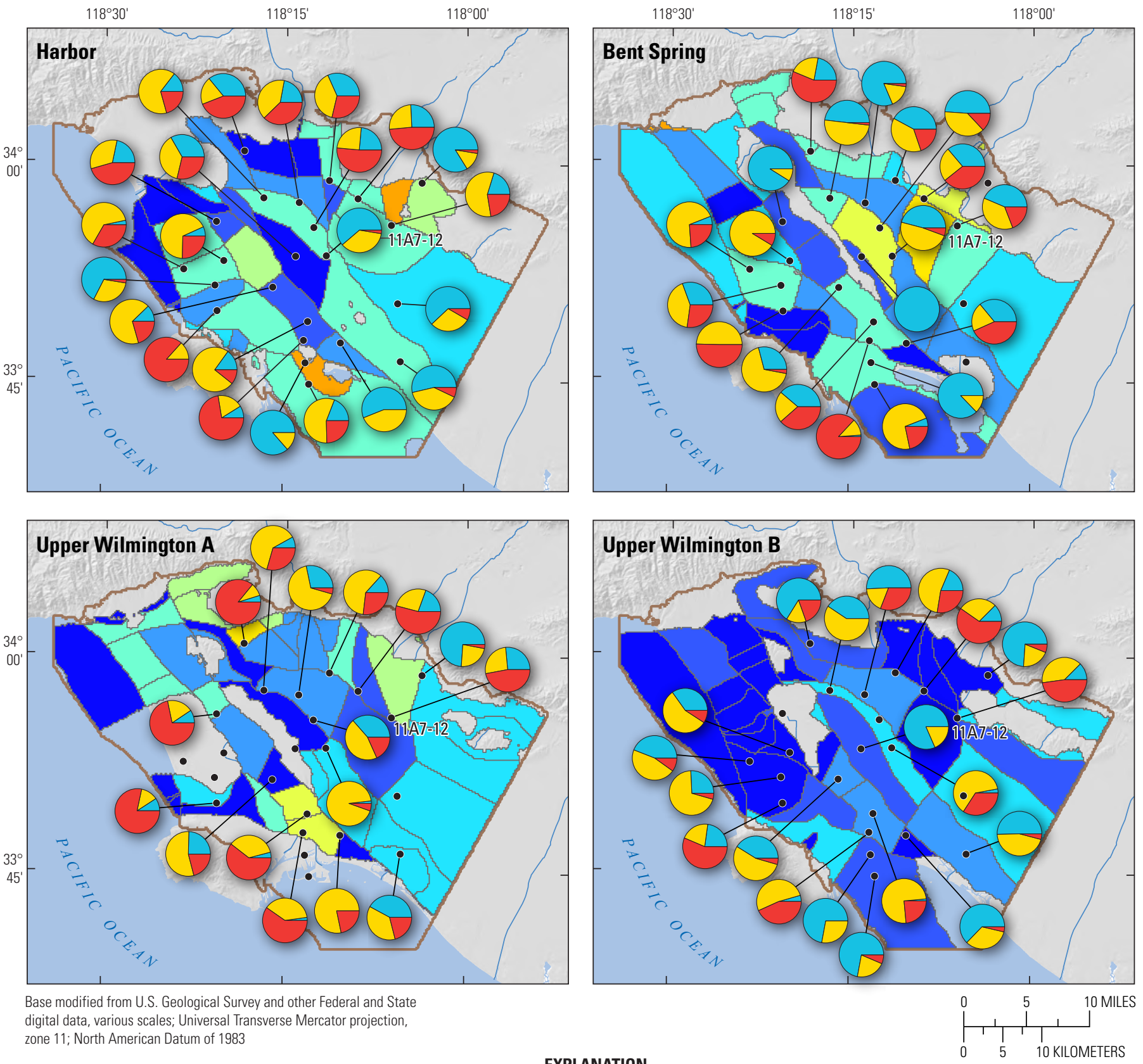

Base modified from U.S. Geological Survey and other Federal and State digital data, various scales; Universal Transverse Mercator projection, zone 11; North American Datum of 1983

EXPLANATION

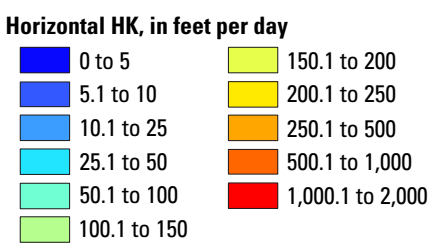

Figure D7.-Continued

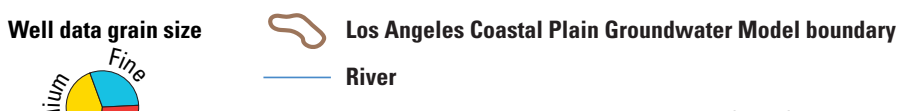

- Well with nuclear magnetic resonance (NMR) data 
c
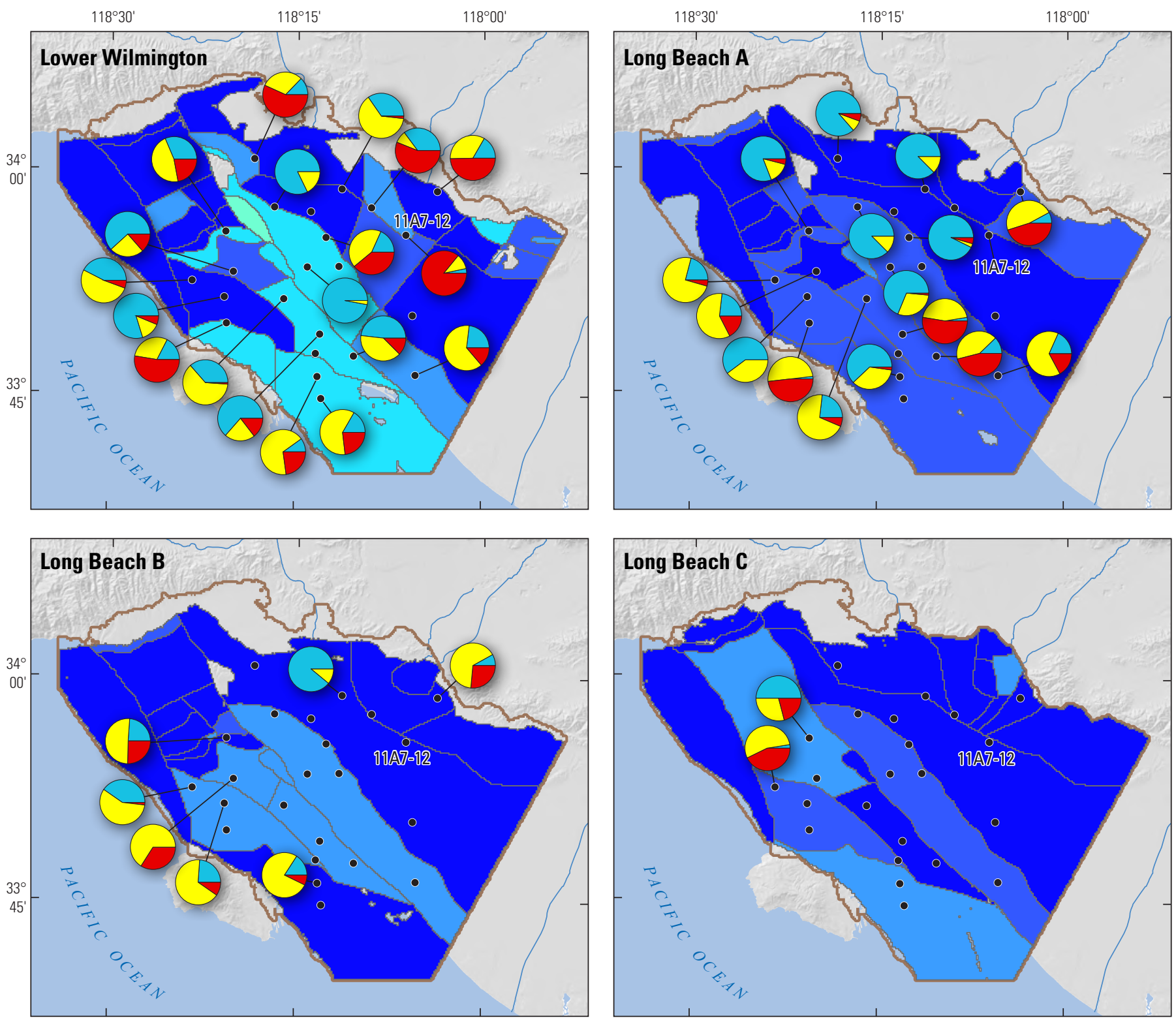

Base modified from U.S. Geological Survey and other Federal and State digital data, various scales; Universal Transverse Mercator projection, zone 11; North American Datum of 1983

EXPLANATION
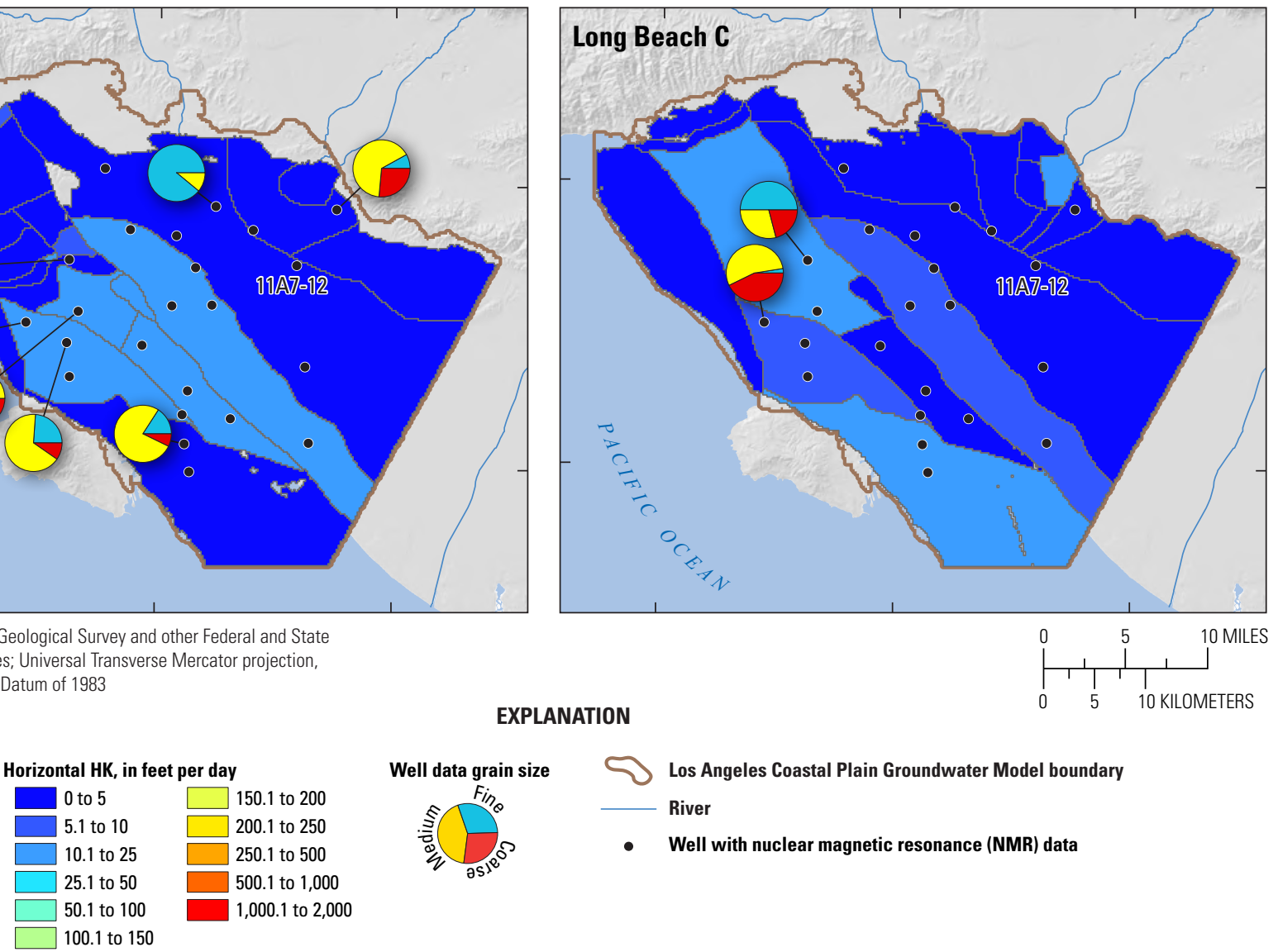

- Well with nuclear magnetic resonance (NMR) data

Figure D7.-Continued 


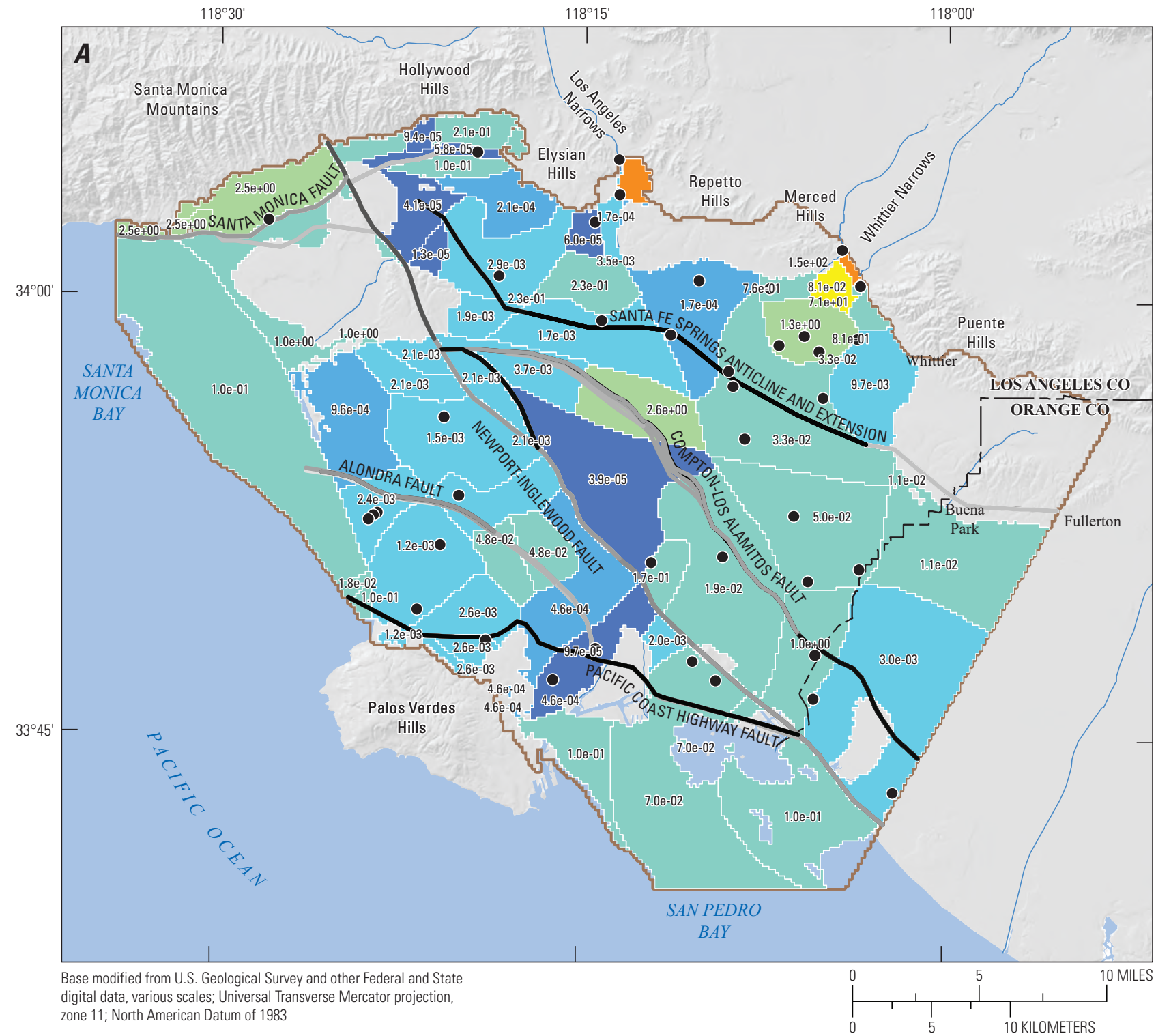

EXPLANATION

Los Angeles Coastal Plain Groundwater Model boundary
- River
$\quad$ Well
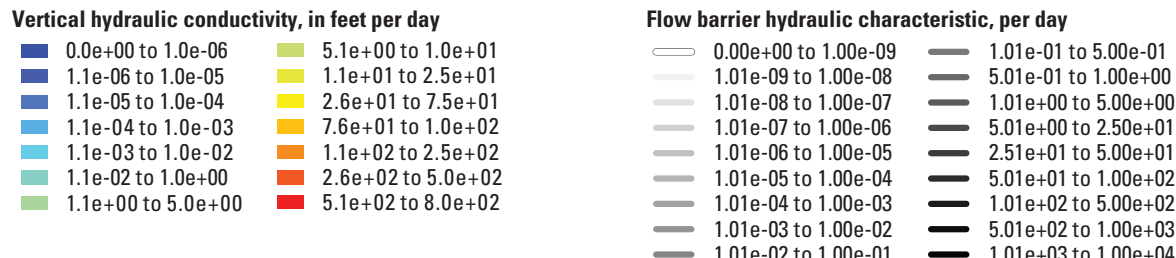

Figure D8. Calibrated vertical hydraulic conductivities (VK), specific yield (SY), and flow-barrier hydraulic characteristic values, for layers 2 to 13 of the Los Angeles Coastal Plain Groundwater-flow Model. The hydraulic characteristic is the horizontal-flow barrier's hydraulic conductivity divided by its width and has units of per day: $A$, VK Mesa; $B$, VK Pacific $A ; C$, VK Pacific; $D$, VK Harbor; $E$, VK Bent Spring; $F$, VK Upper Wilmington A; G, VK Upper Wilmington B; $H$, VK Lower Wilmington; I, VK Long Beach A; J, VK Long Beach B; $K$, VK Long Beach C; L, SY Dominguez; $M$, SY Mesa; N, SY Pacific A; O, SY Pacific; P, SY Harbor; $Q$, SY Bent Spring; $R$, SY Upper Wilmington A; S, SY Upper Wilmington B; T, SY Lower Wilmington; U, SY Long Beach A; V, SY Long Beach B; and W, SY Long Beach C; Los Angeles and Orange Counties, California. (Abbreviation: PCH, Pacific Coast Highway).I 


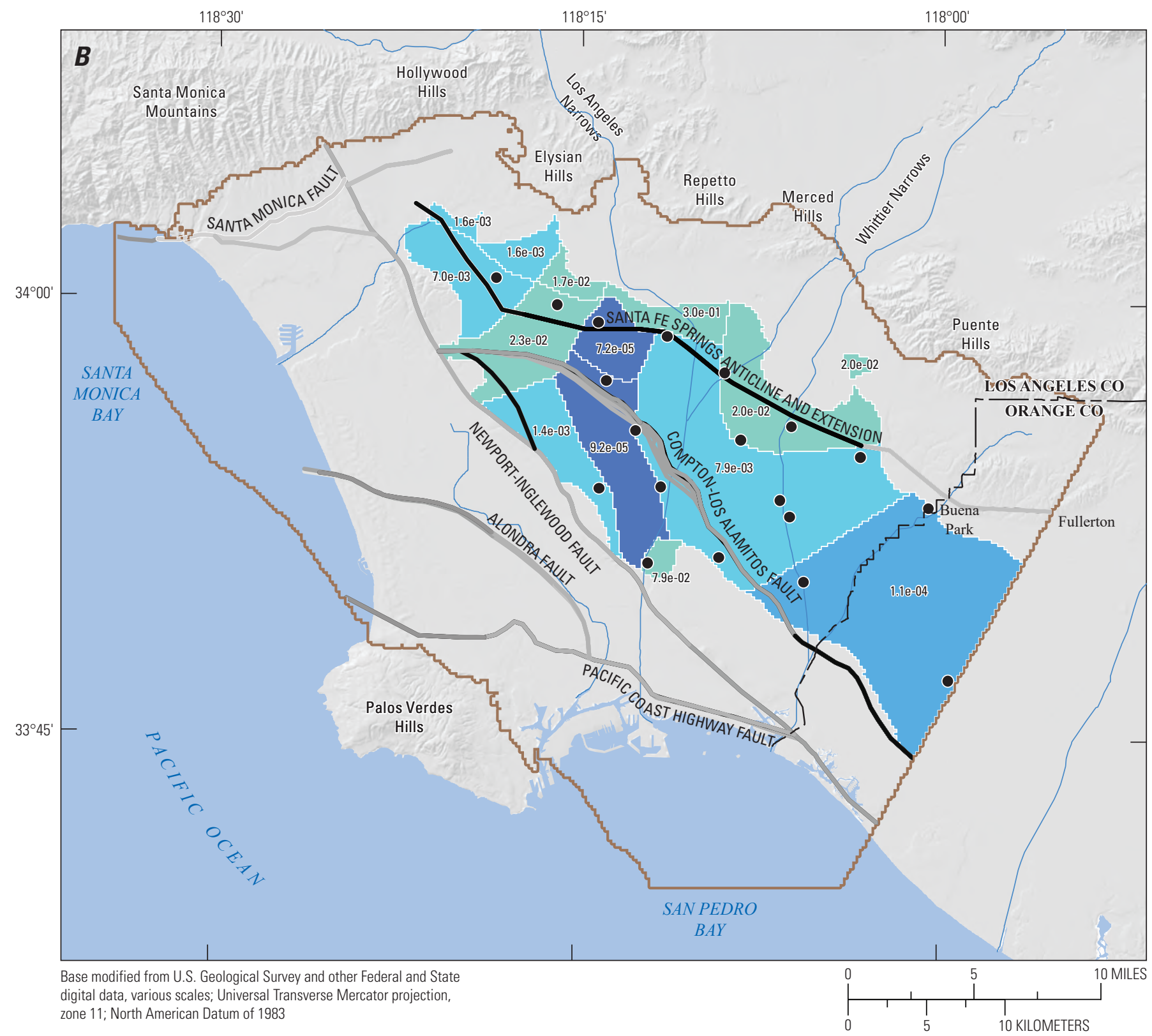

EXPLANATION

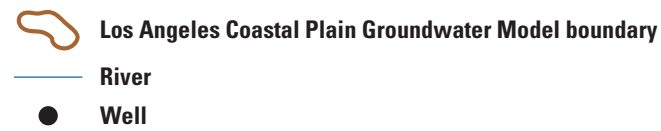

Flow barrier hydraulic characteristic, per day

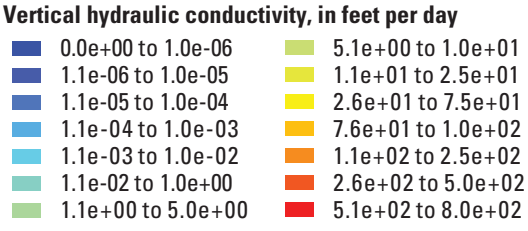

Figure D8.-Continued

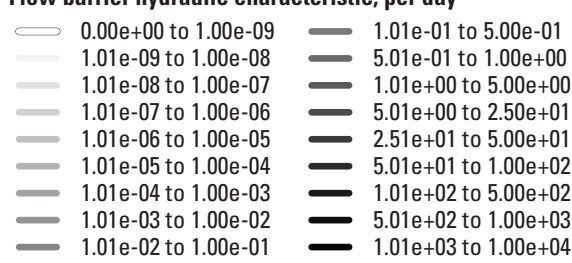




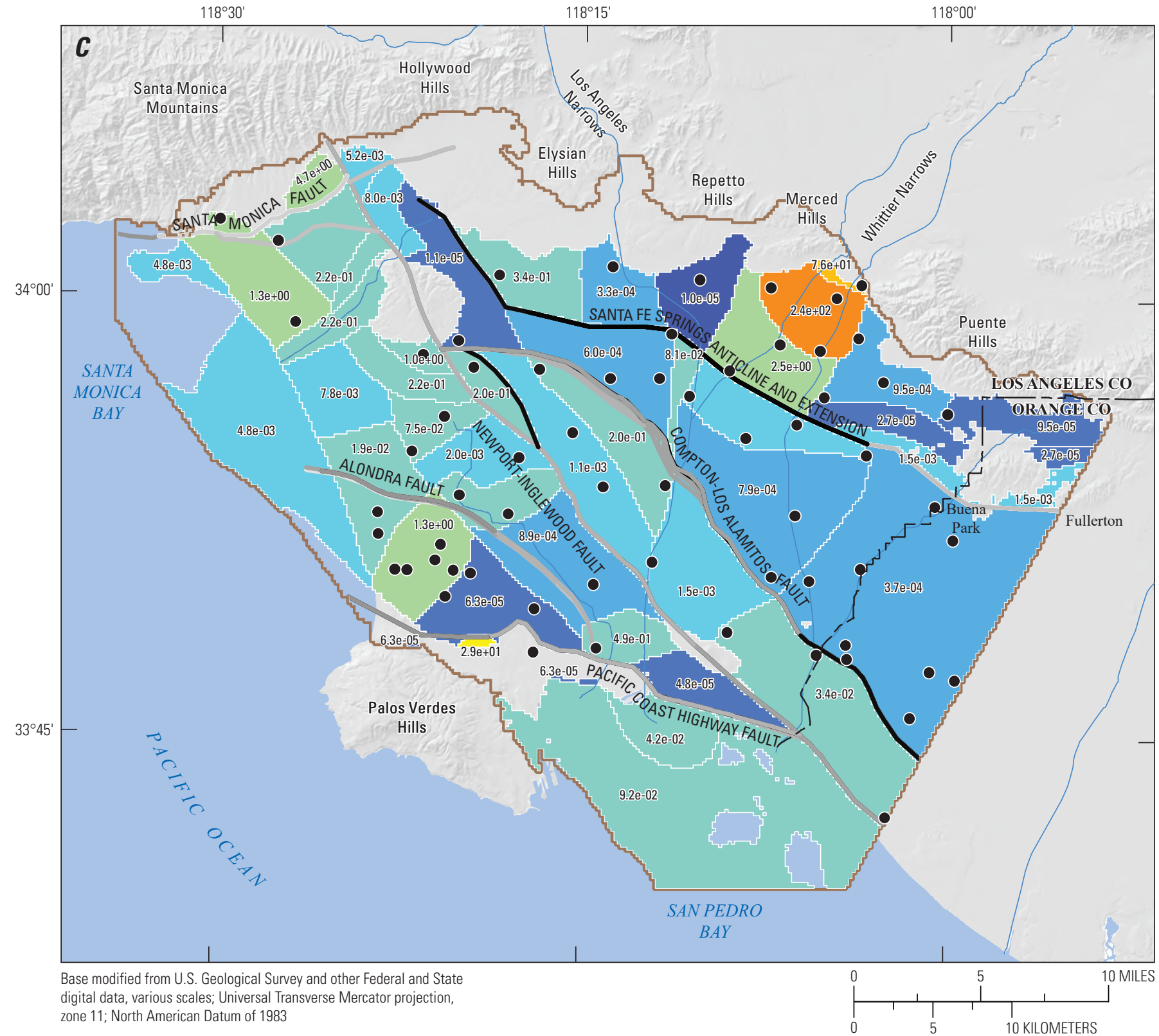

EXPLANATION

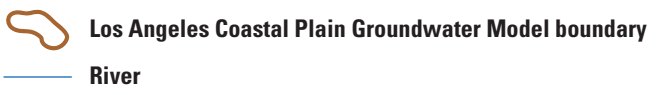

- Well

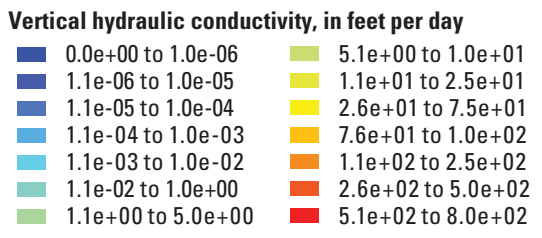

Flow barrier hydraulic characteristic, per day

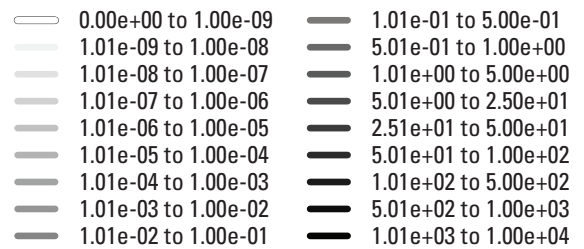

Figure D8.-Continued 


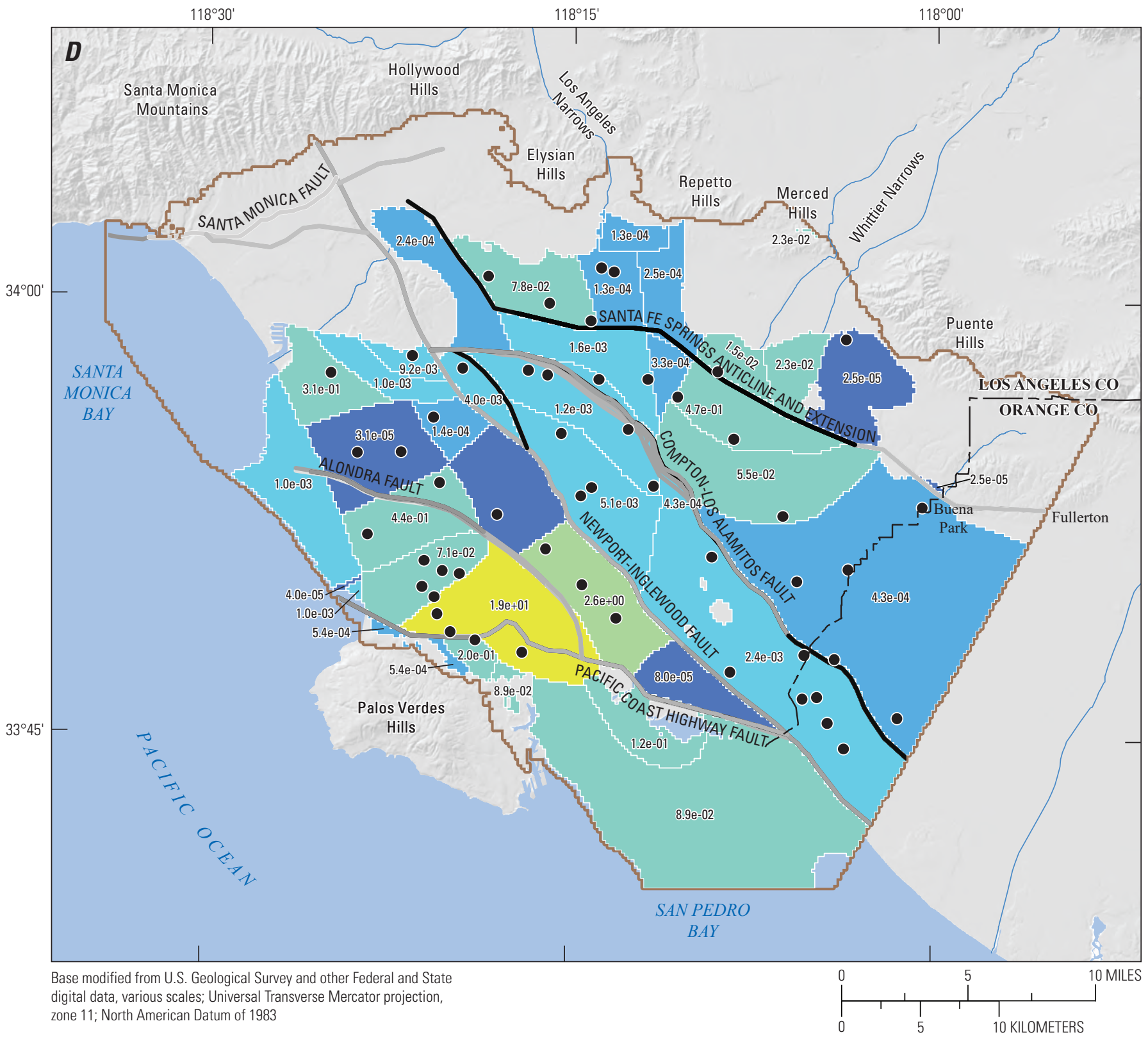

EXPLANATION
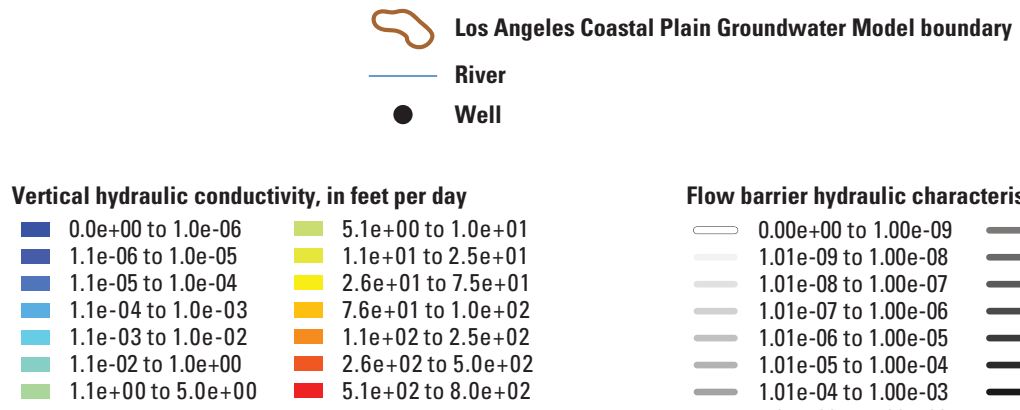

Flow barrier hydraulic characteristic, per day

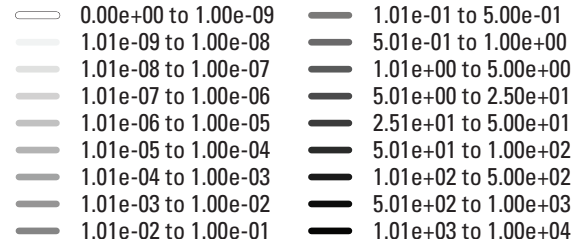

Figure D8.-Continued 


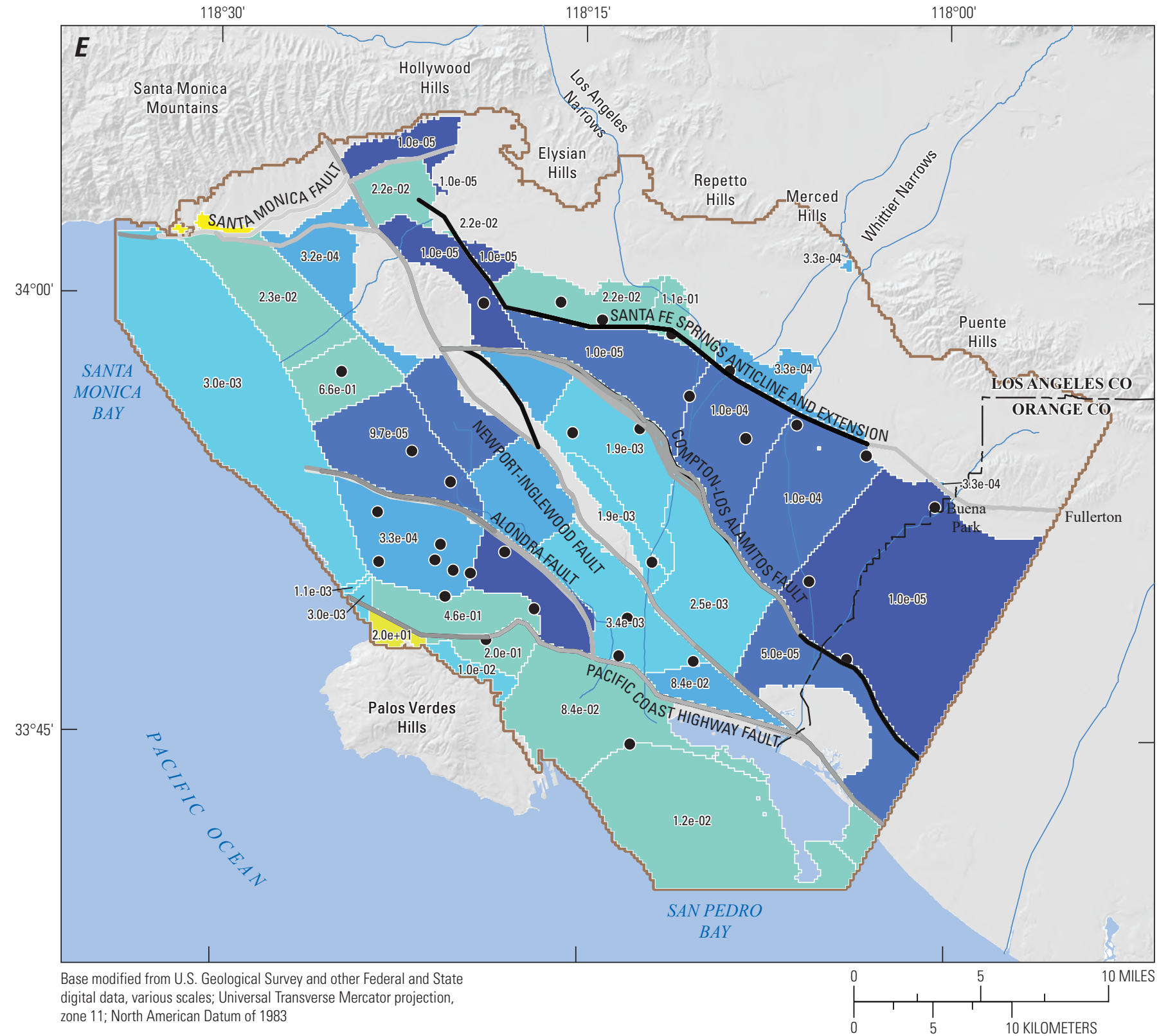

EXPLANATION

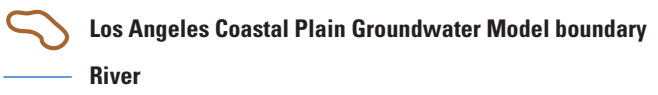

- Well

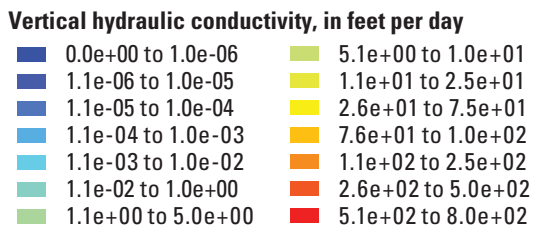

Flow barrier hydraulic characteristic, per day

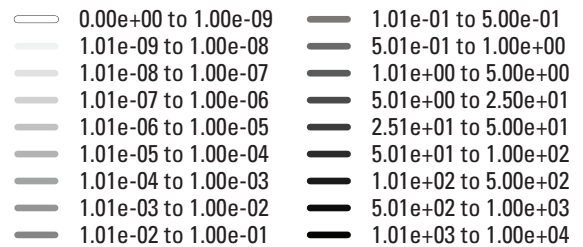

Figure D8.-Continued 


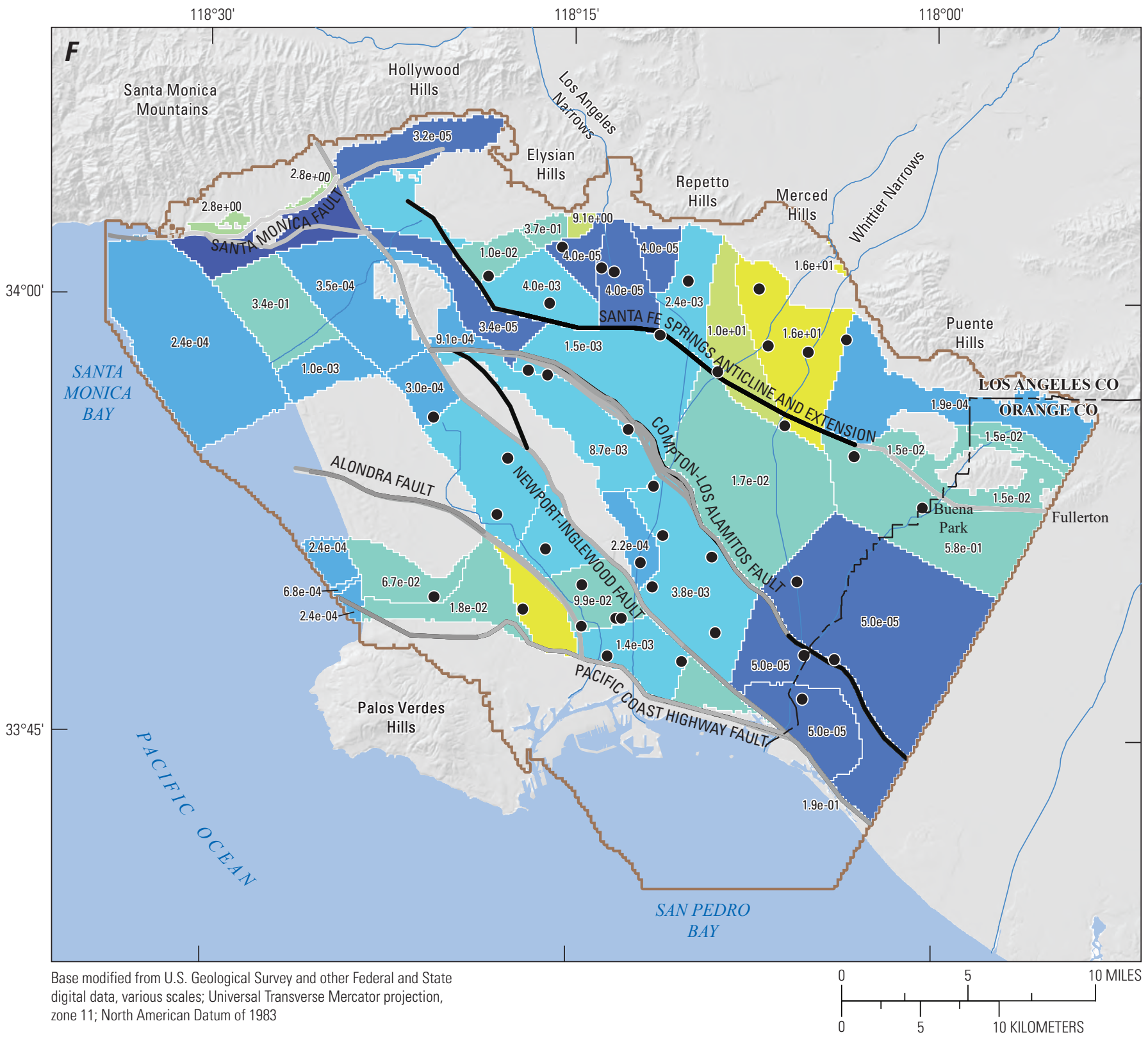

EXPLANATION
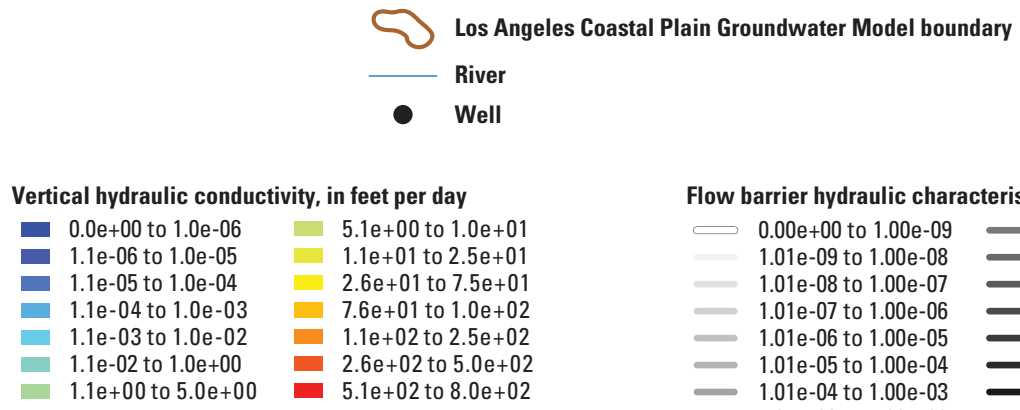

Flow barrier hydraulic characteristic, per day

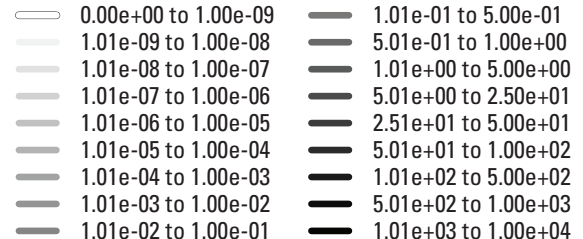

Figure D8.-Continued 


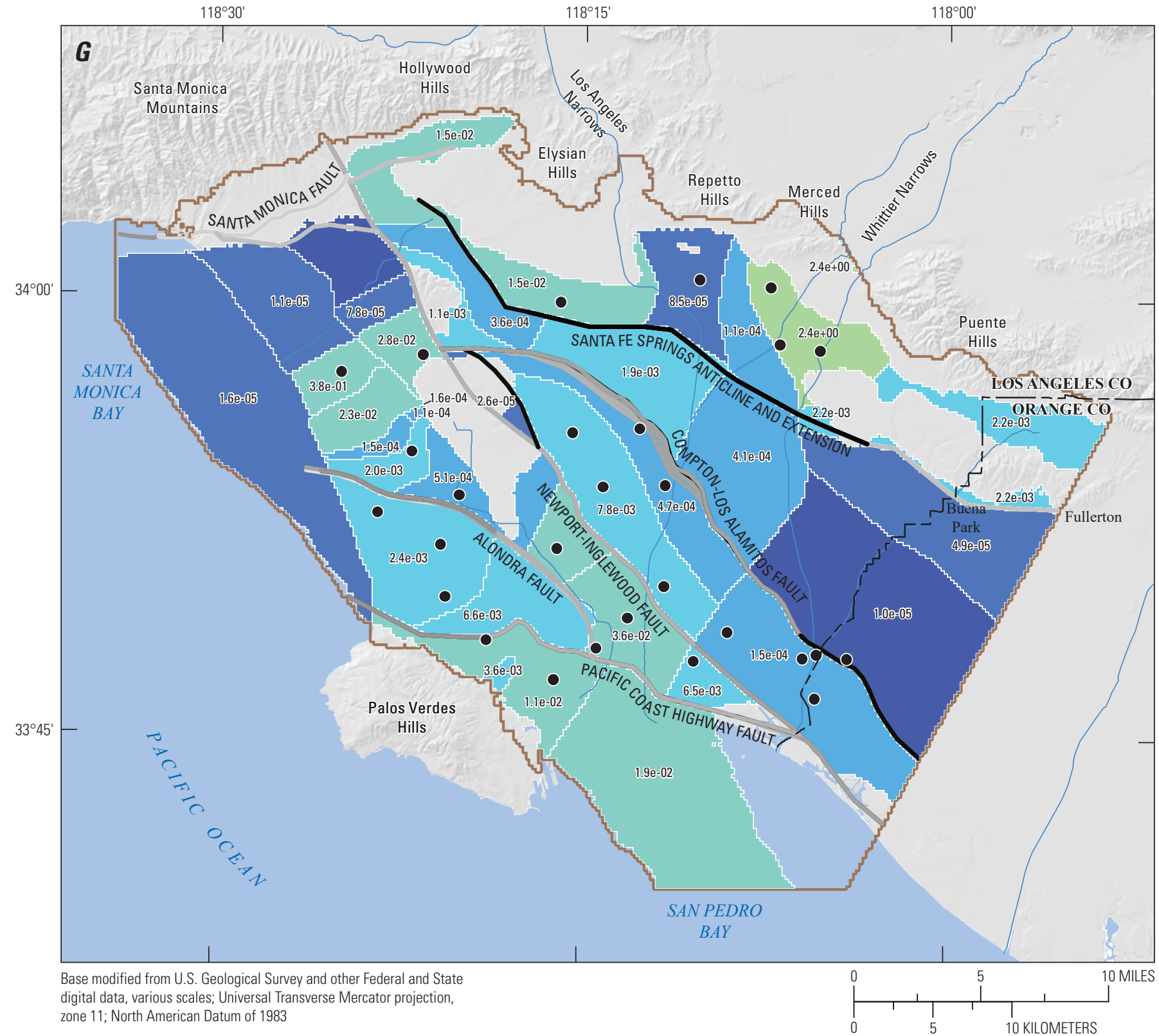

EXPLANATION

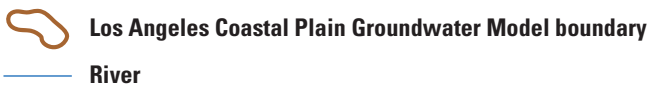

- Well

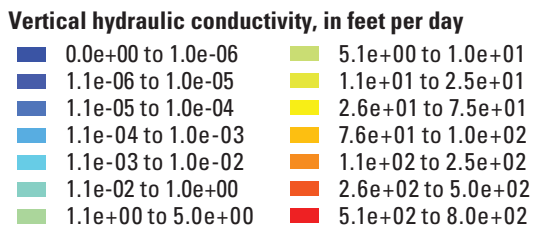

Flow barrier hydraulic characteristic, per day

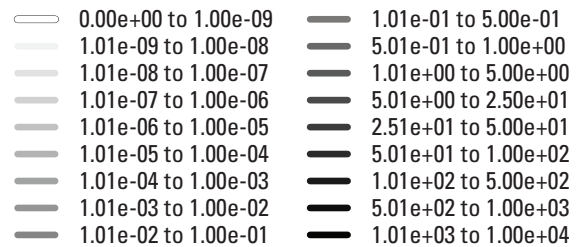

Figure D8.-Continued 


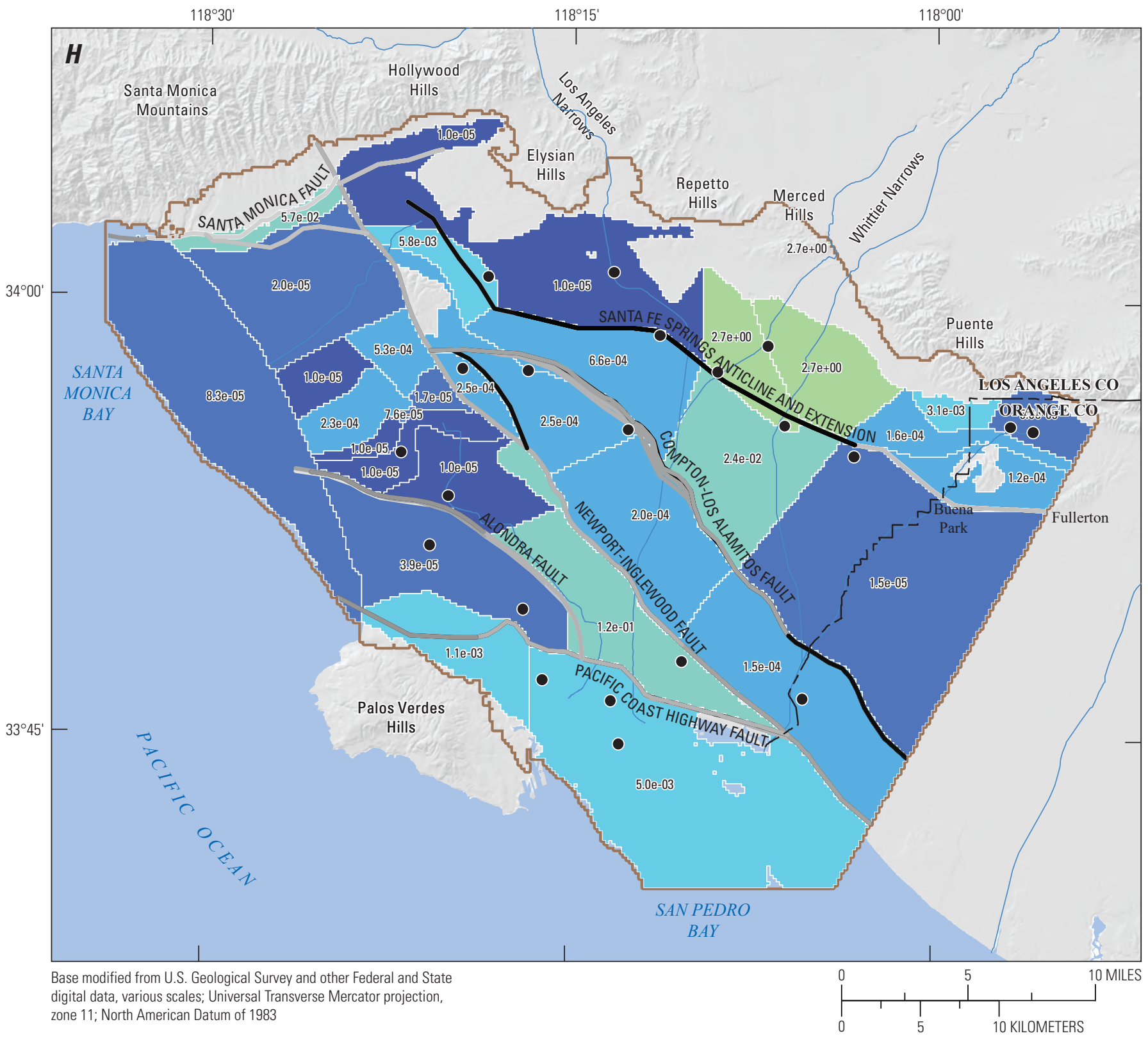

EXPLANATION
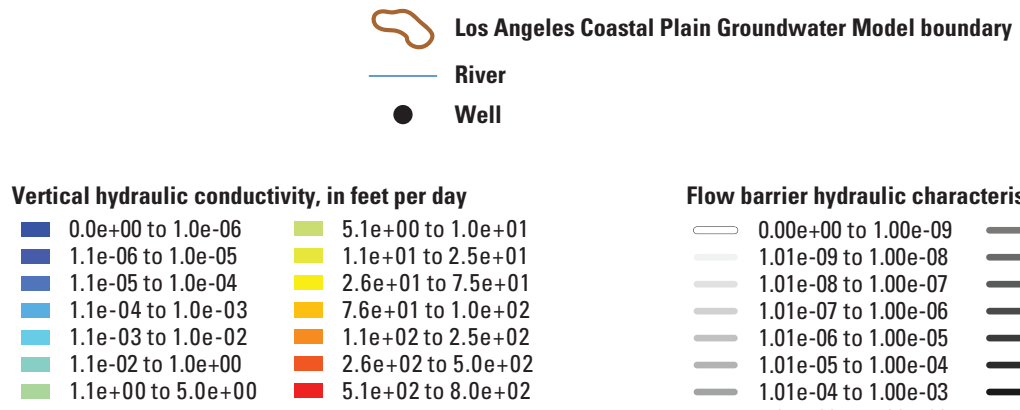

Flow barrier hydraulic characteristic, per day

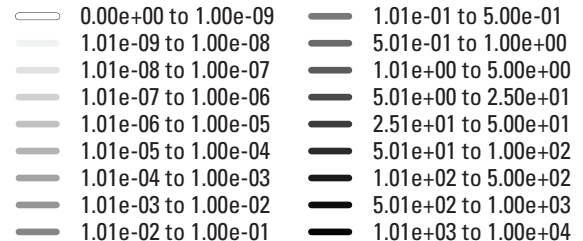

Figure D8.-Continued 


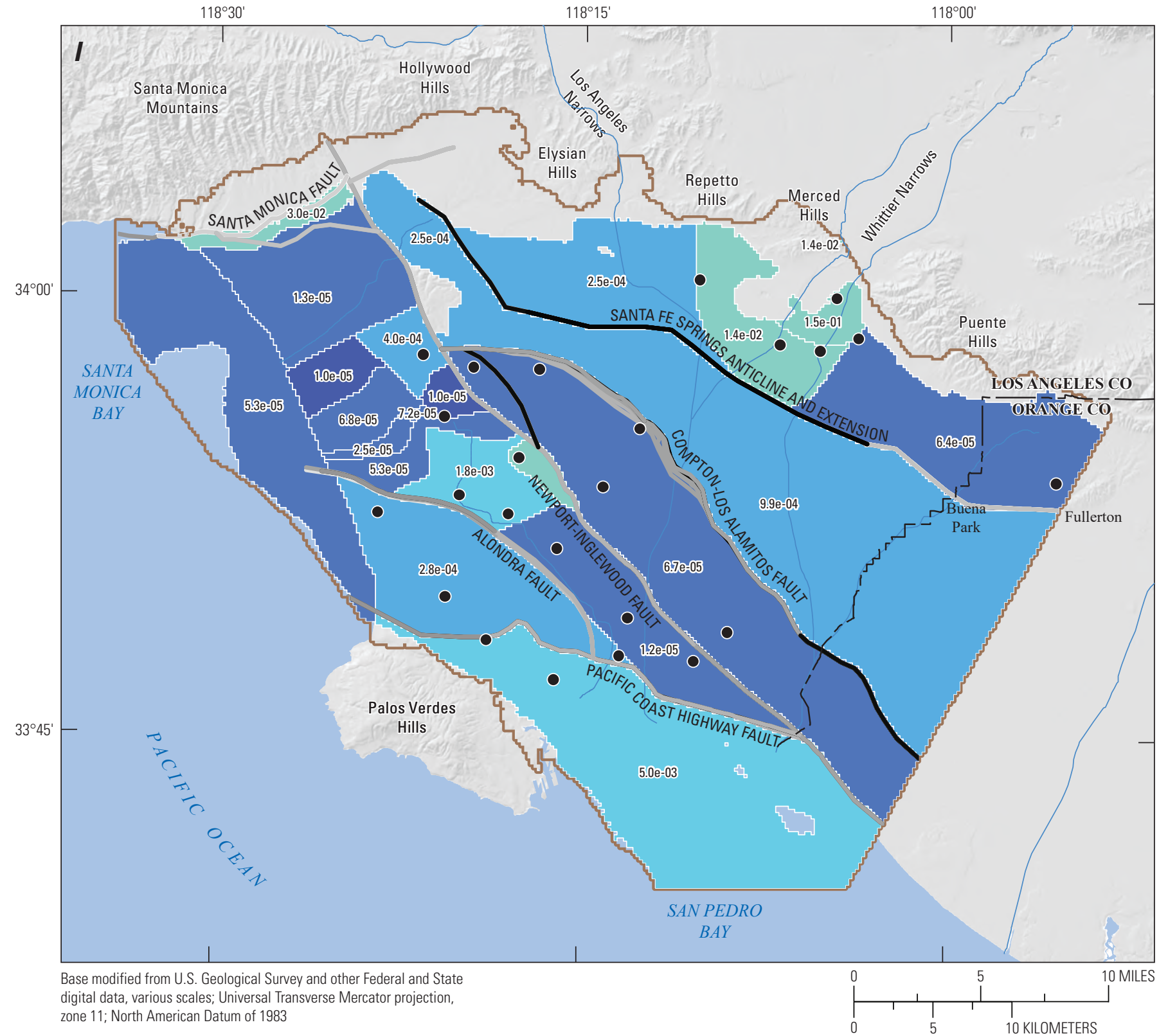

EXPLANATION

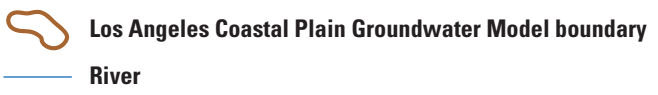

- Well

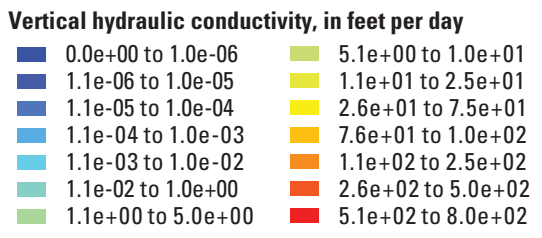

Flow barrier hydraulic characteristic, per day

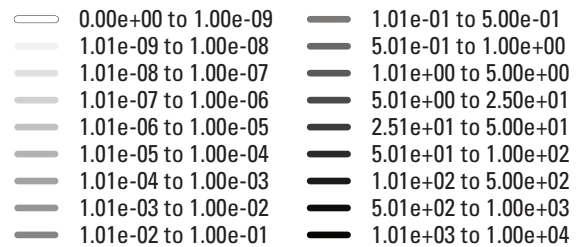

Figure D8.-Continued 


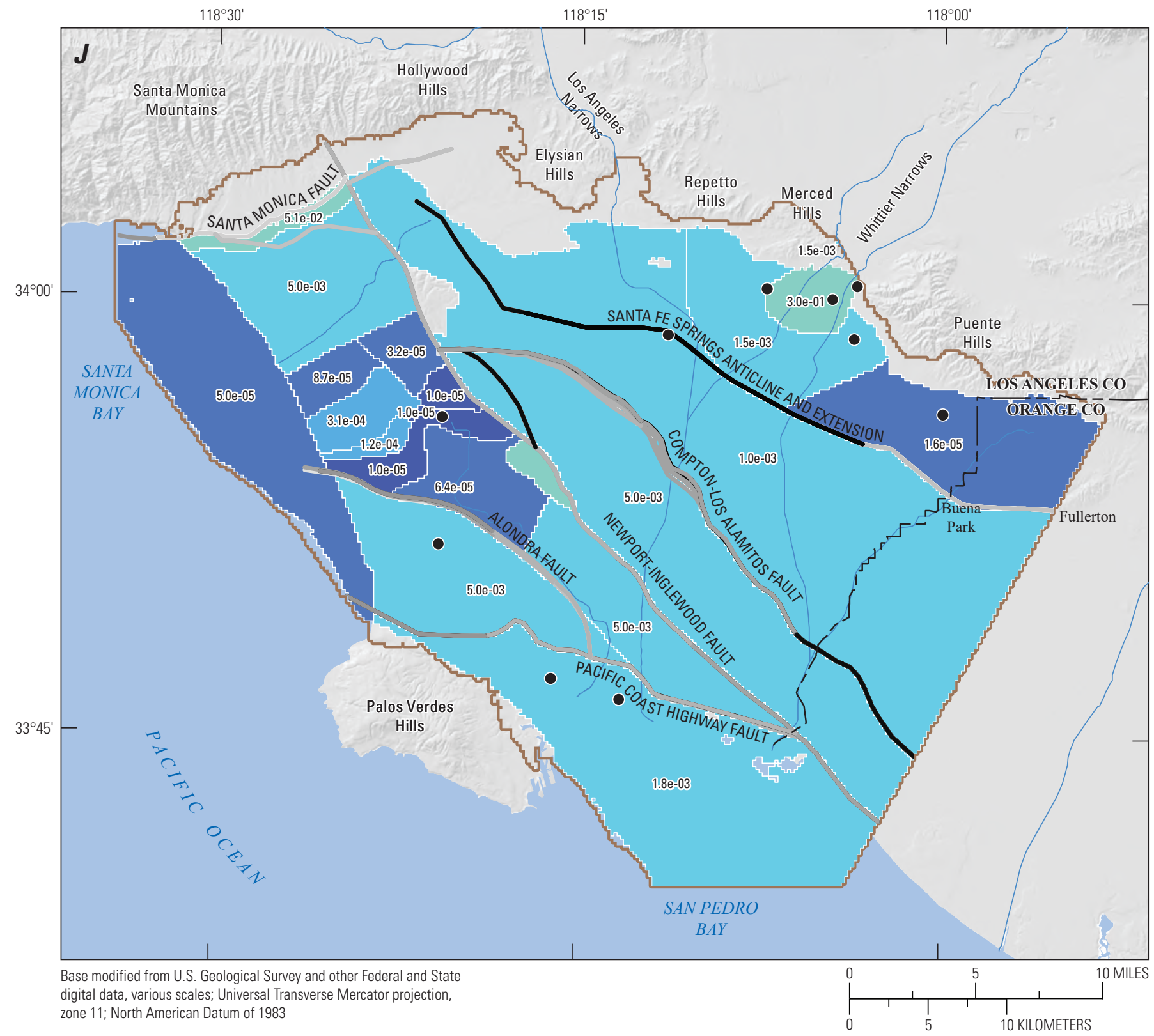

EXPLANATION
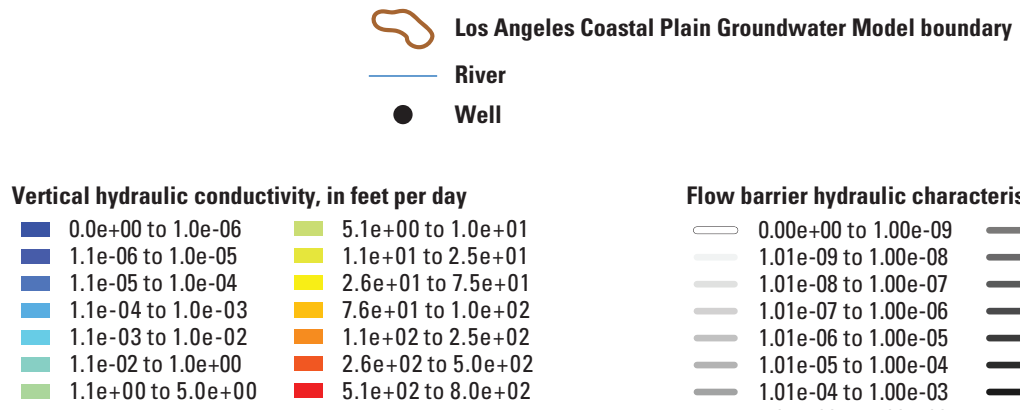

Flow barrier hydraulic characteristic, per day

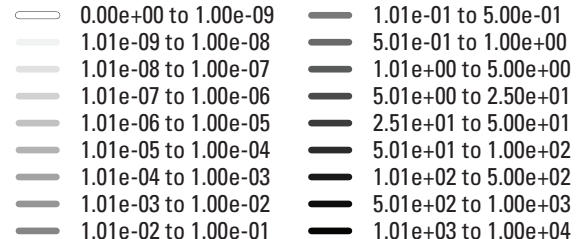

Figure D8.-Continued 


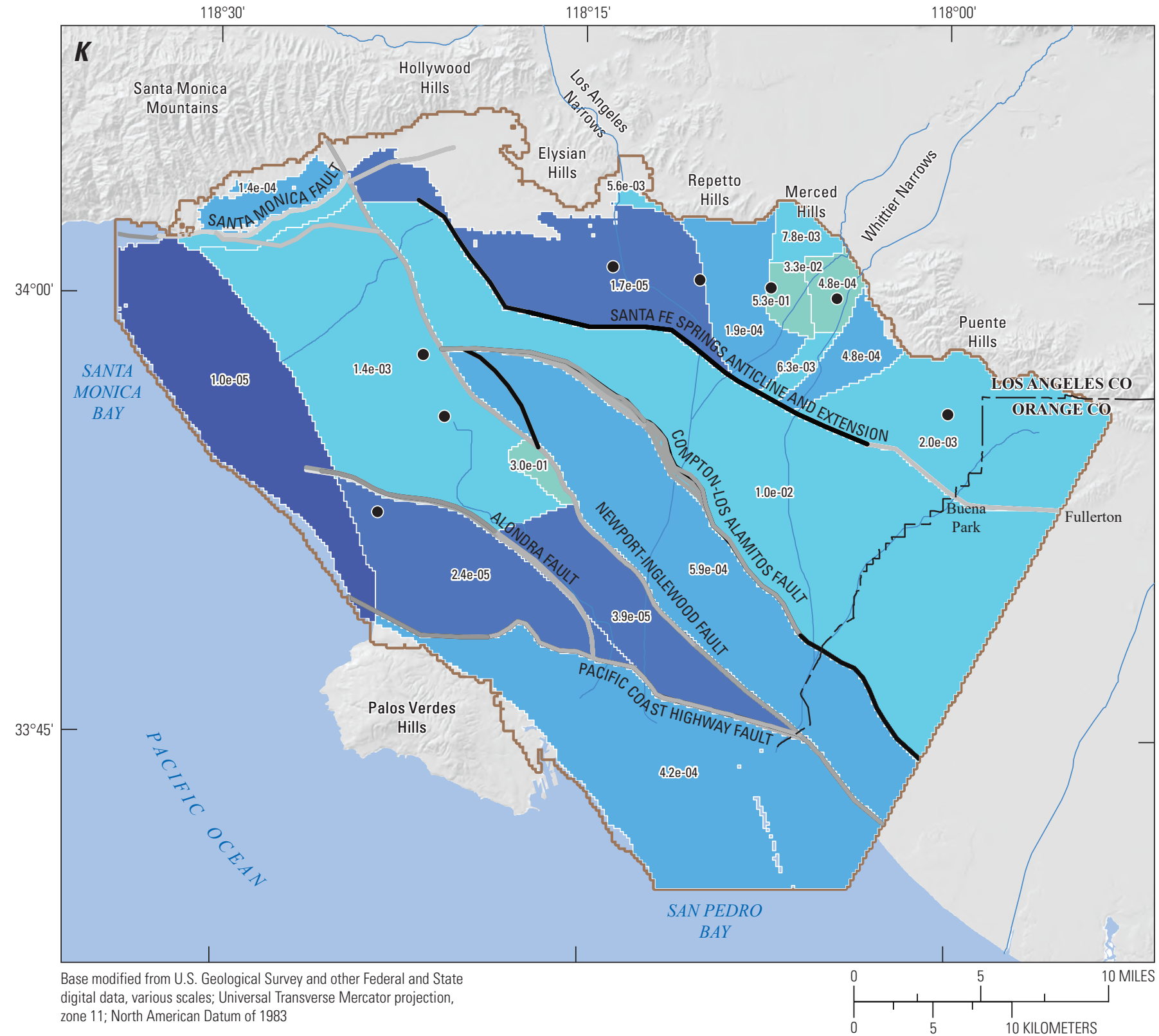

EXPLANATION

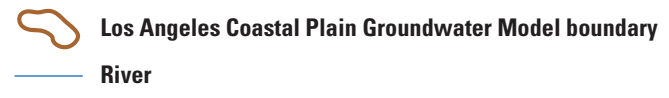

- Well

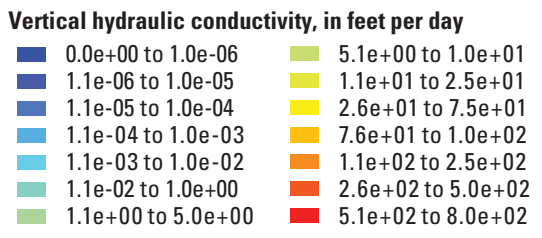

Flow barrier hydraulic characteristic, per day

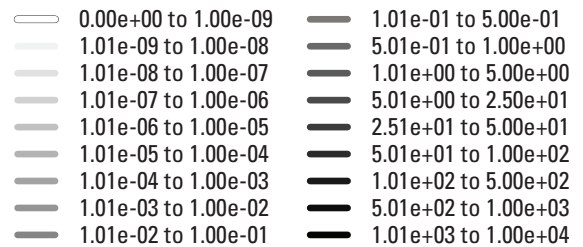

Figure D8.-Continued 


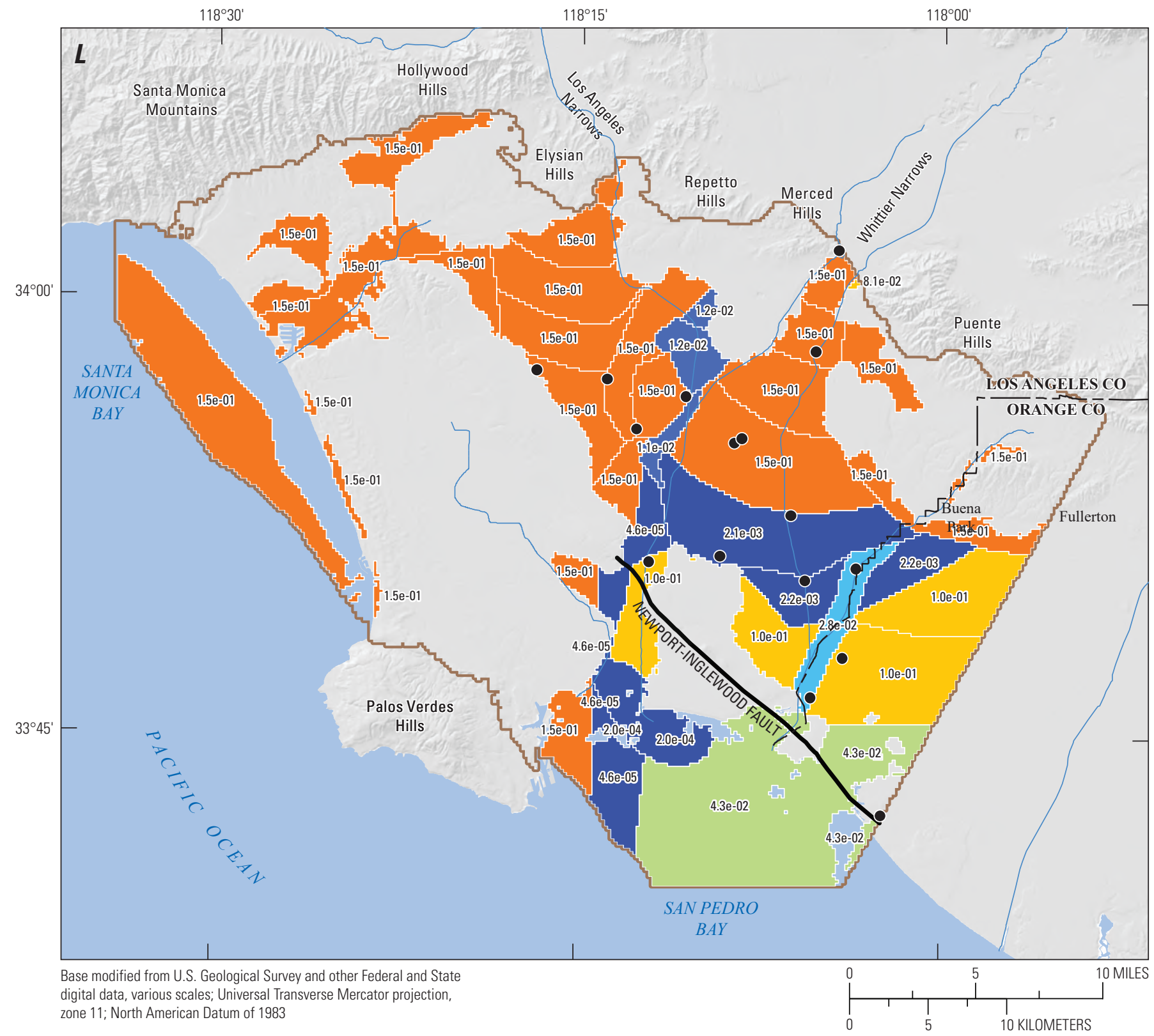

EXPLANATION
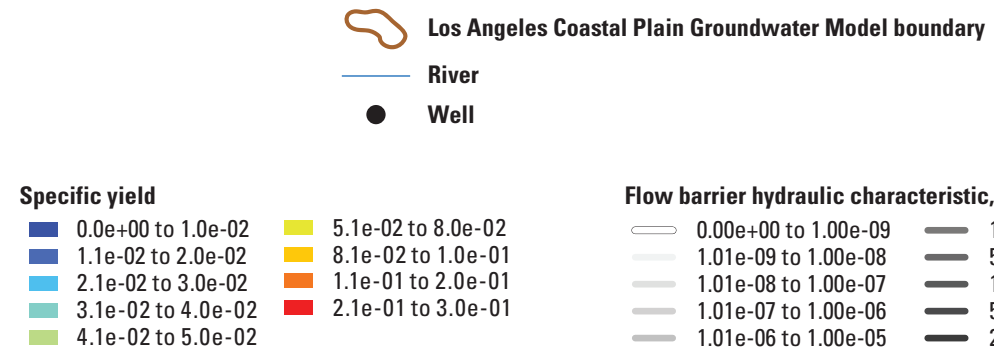

Flow barrier hydraulic characteristic, per day

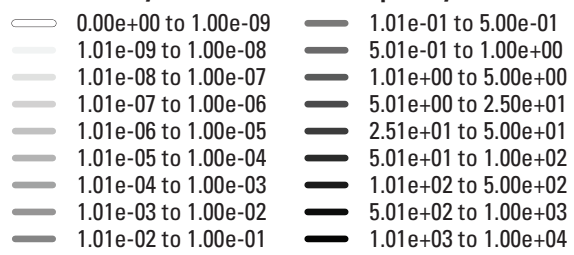

Figure D8.-Continued 


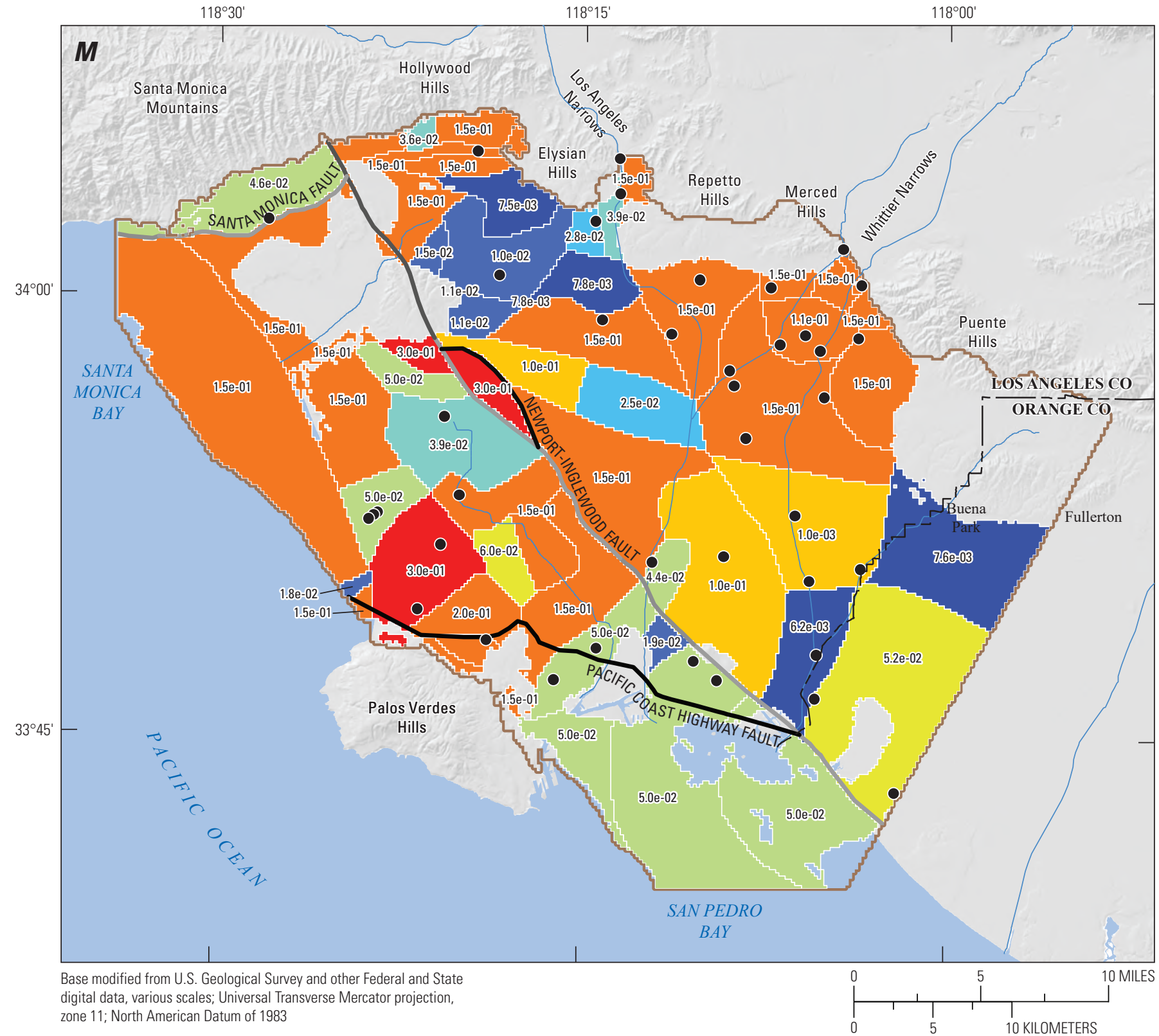

EXPLANATION
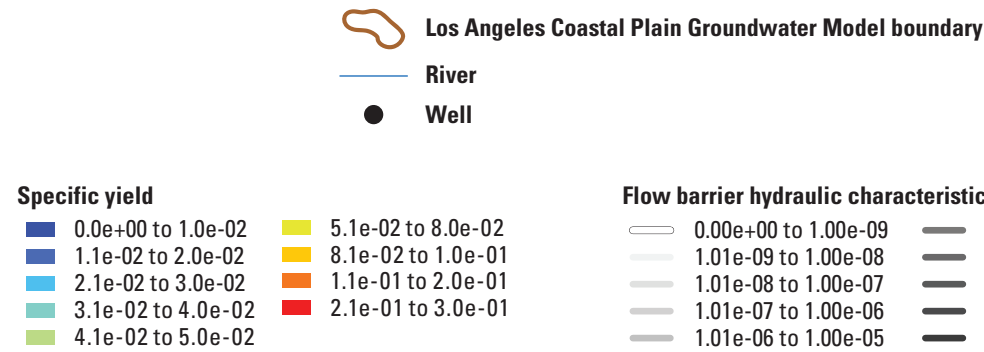

Flow barrier hydraulic characteristic, per day

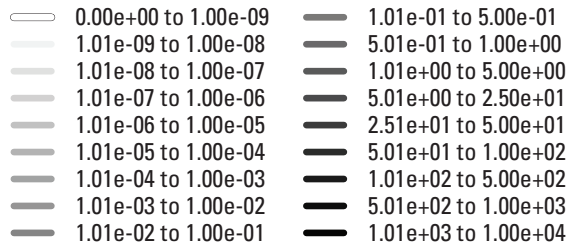

Figure D8.-Continued 


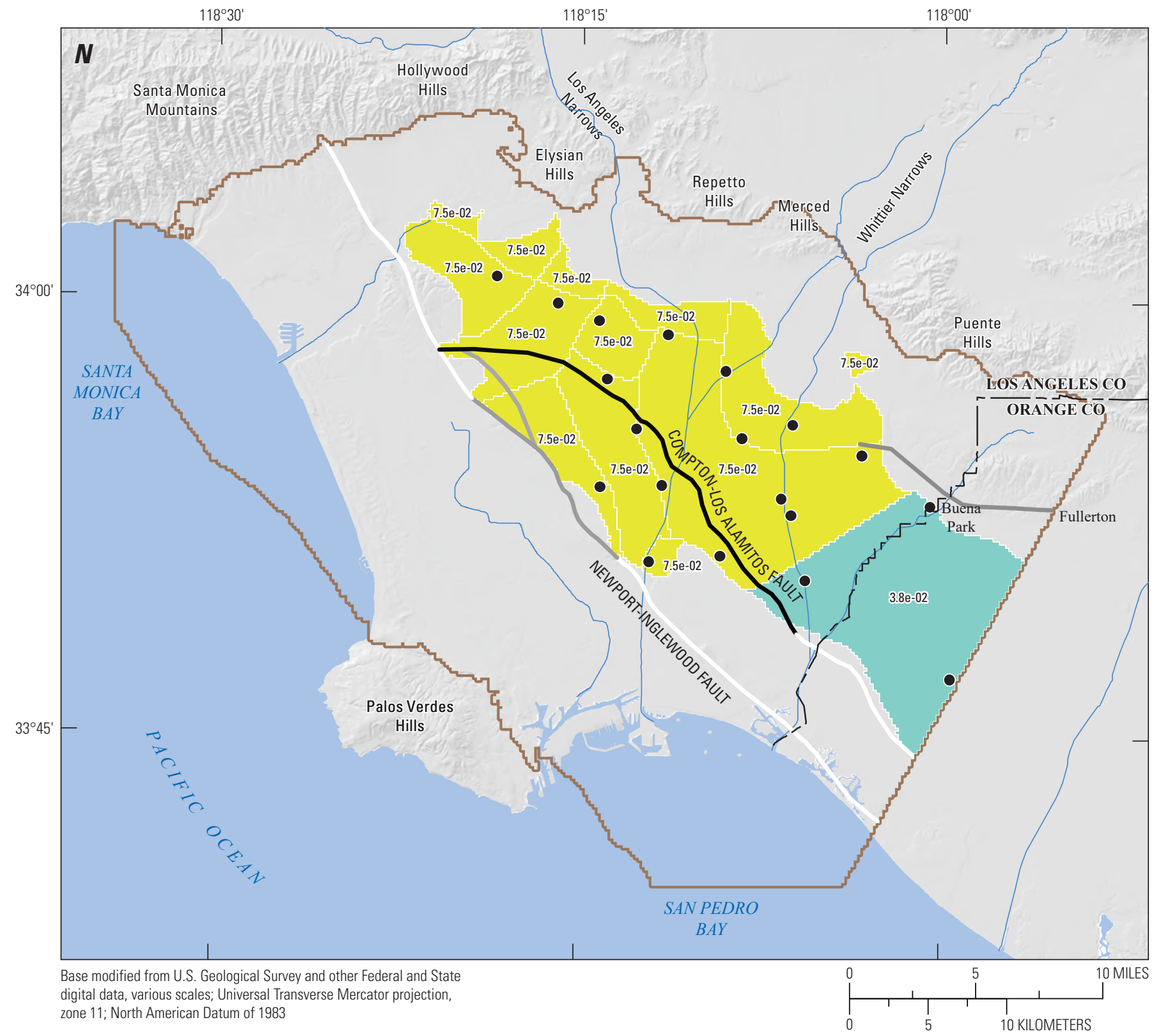

EXPLANATION

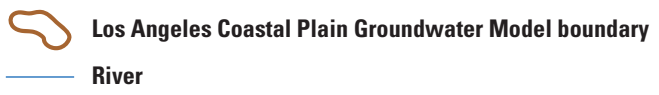

- Well
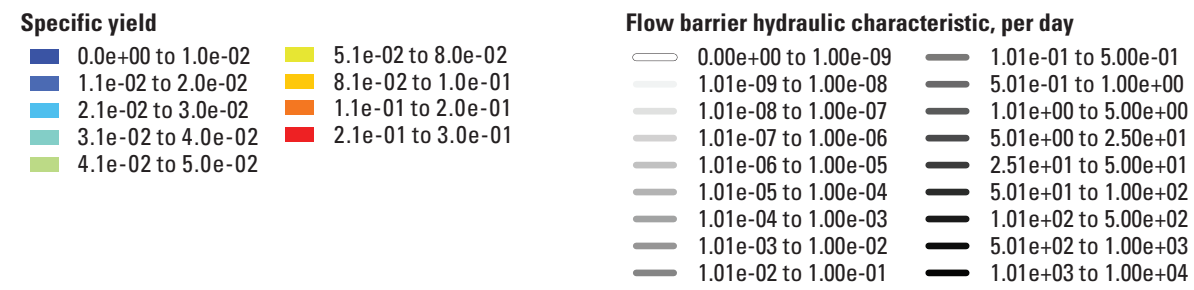

Figure D8.-Continued 


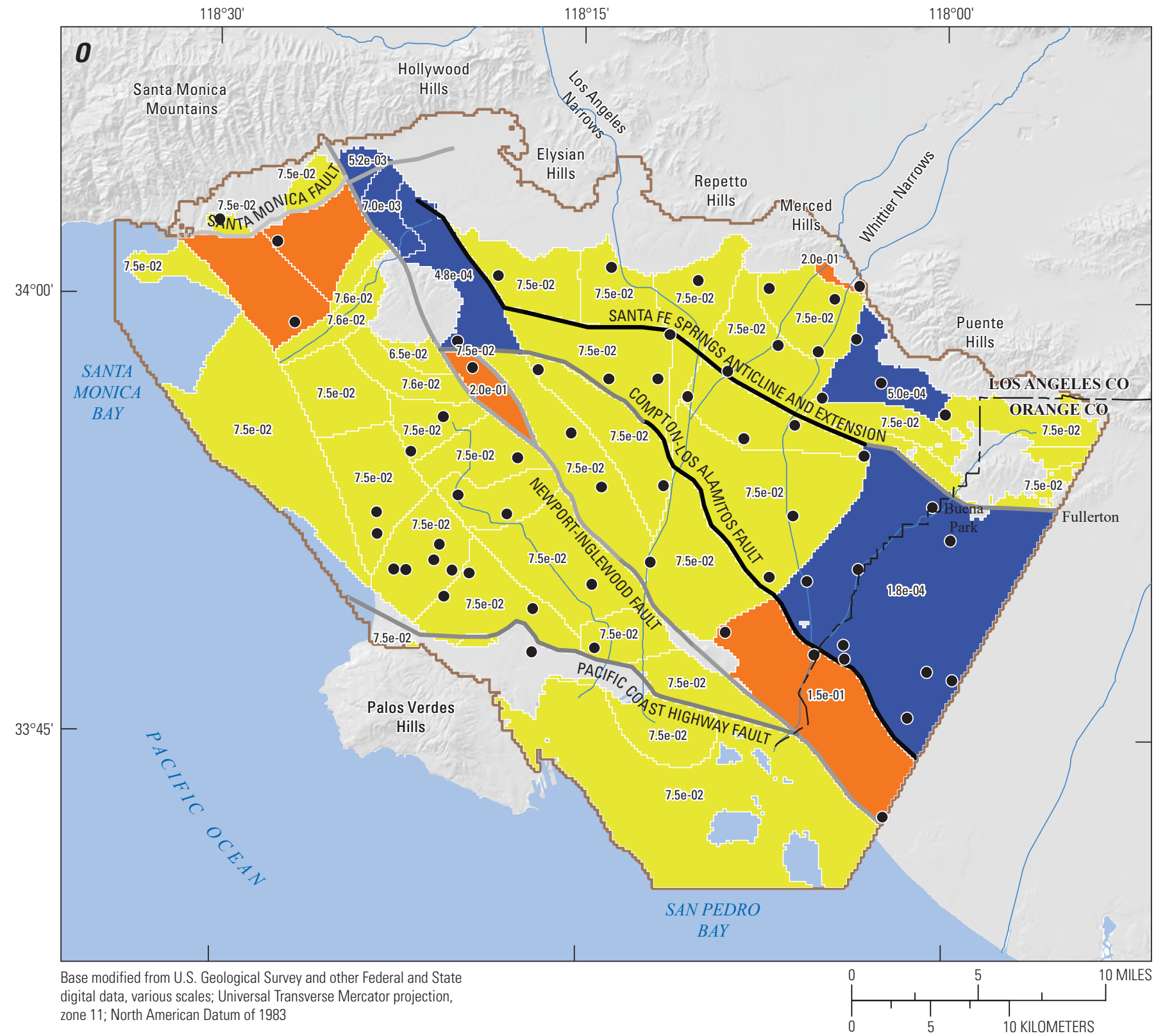

EXPLANATION
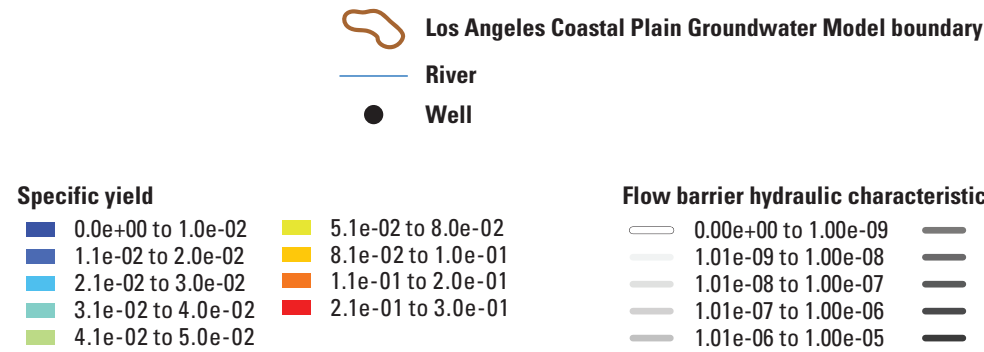

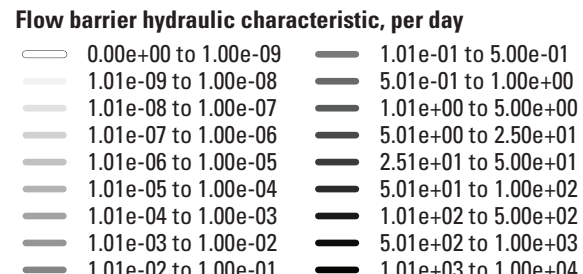

Figure D8.-Continued 


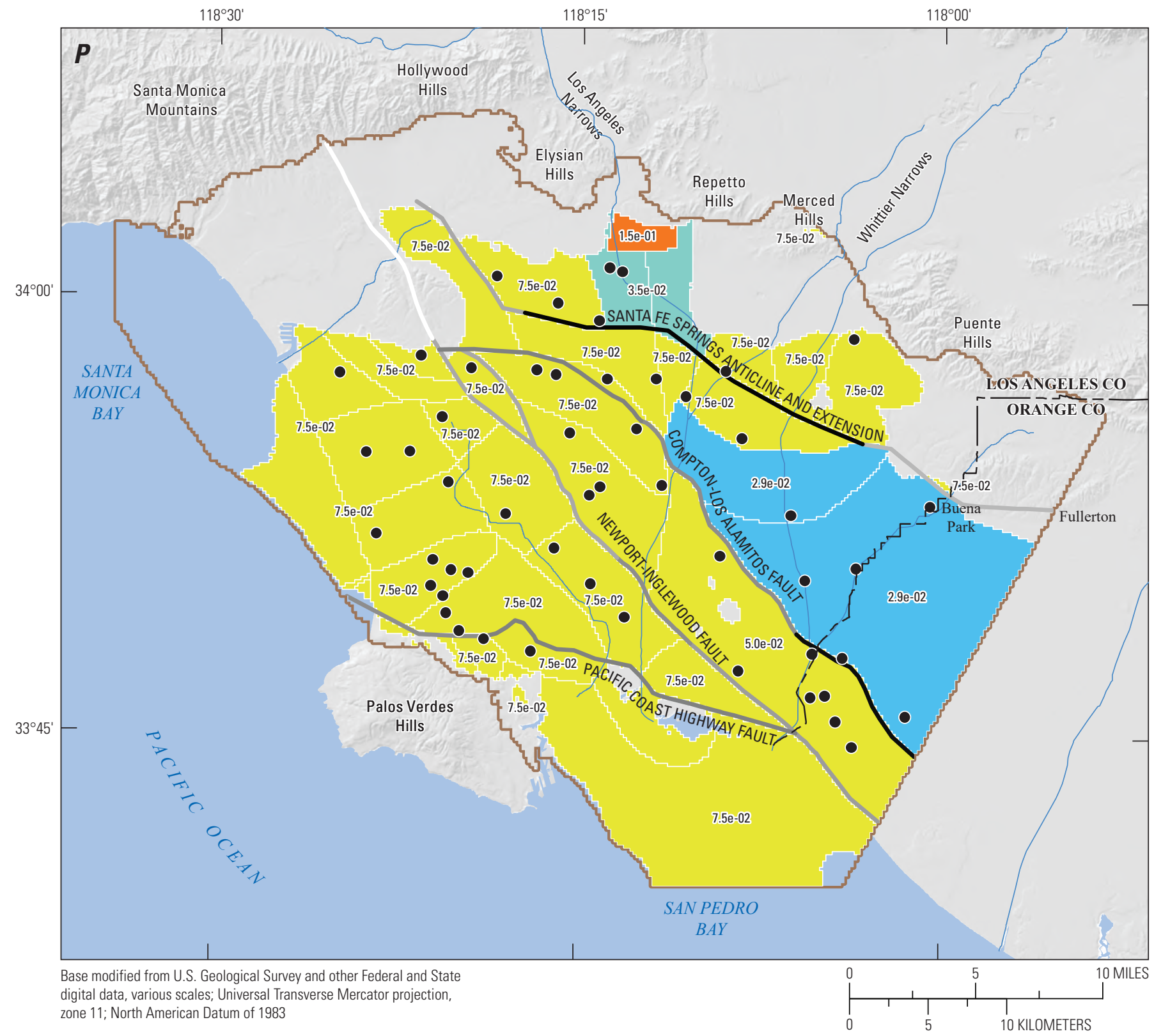

EXPLANATION

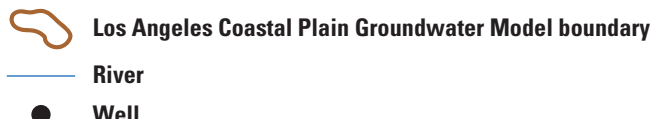

- Well
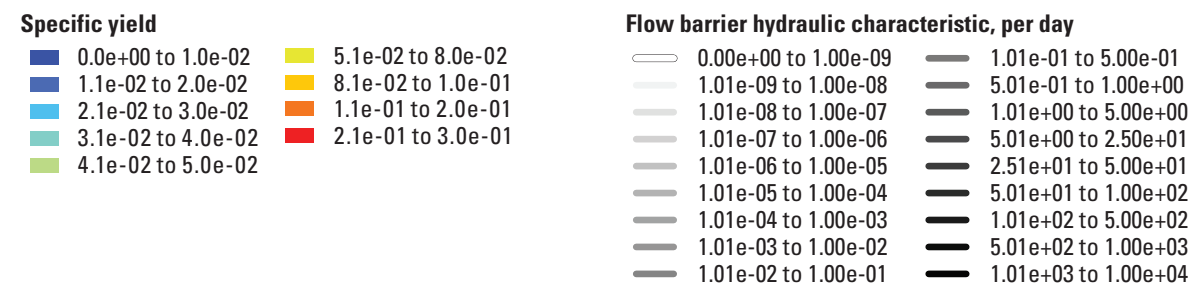

Figure D8.-Continued 


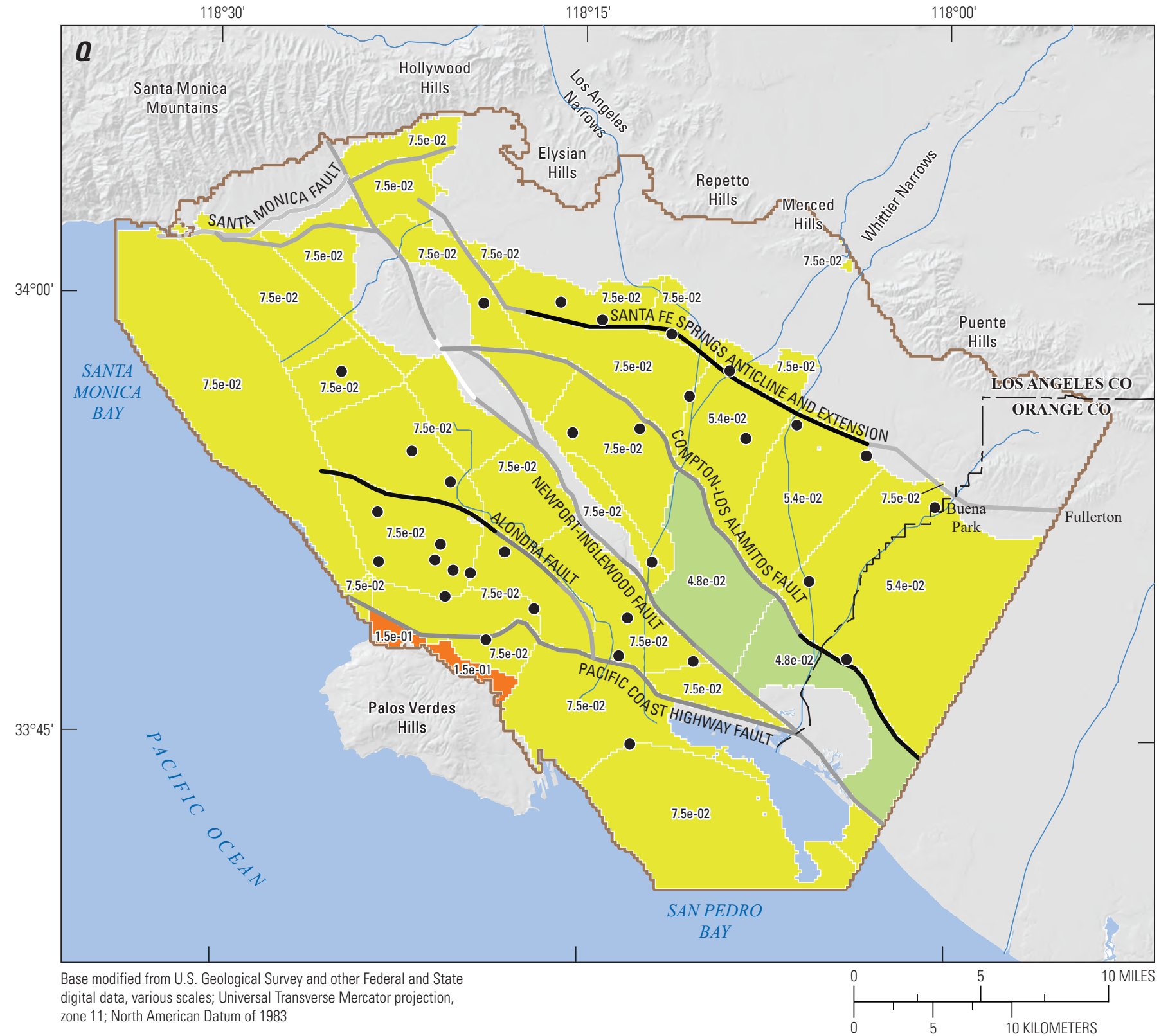

EXPLANATION

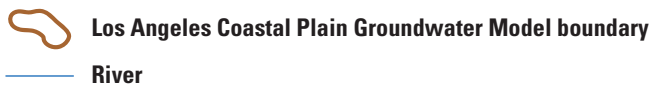

- Well

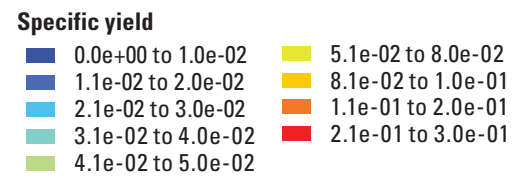

Flow barrier hydraulic characteristic, per day

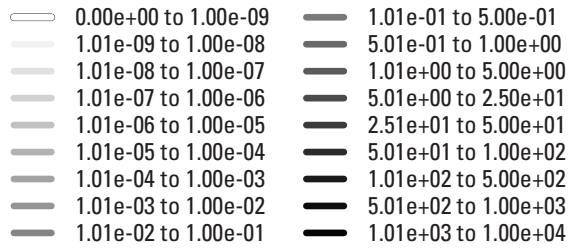

Figure D8.-Continued 


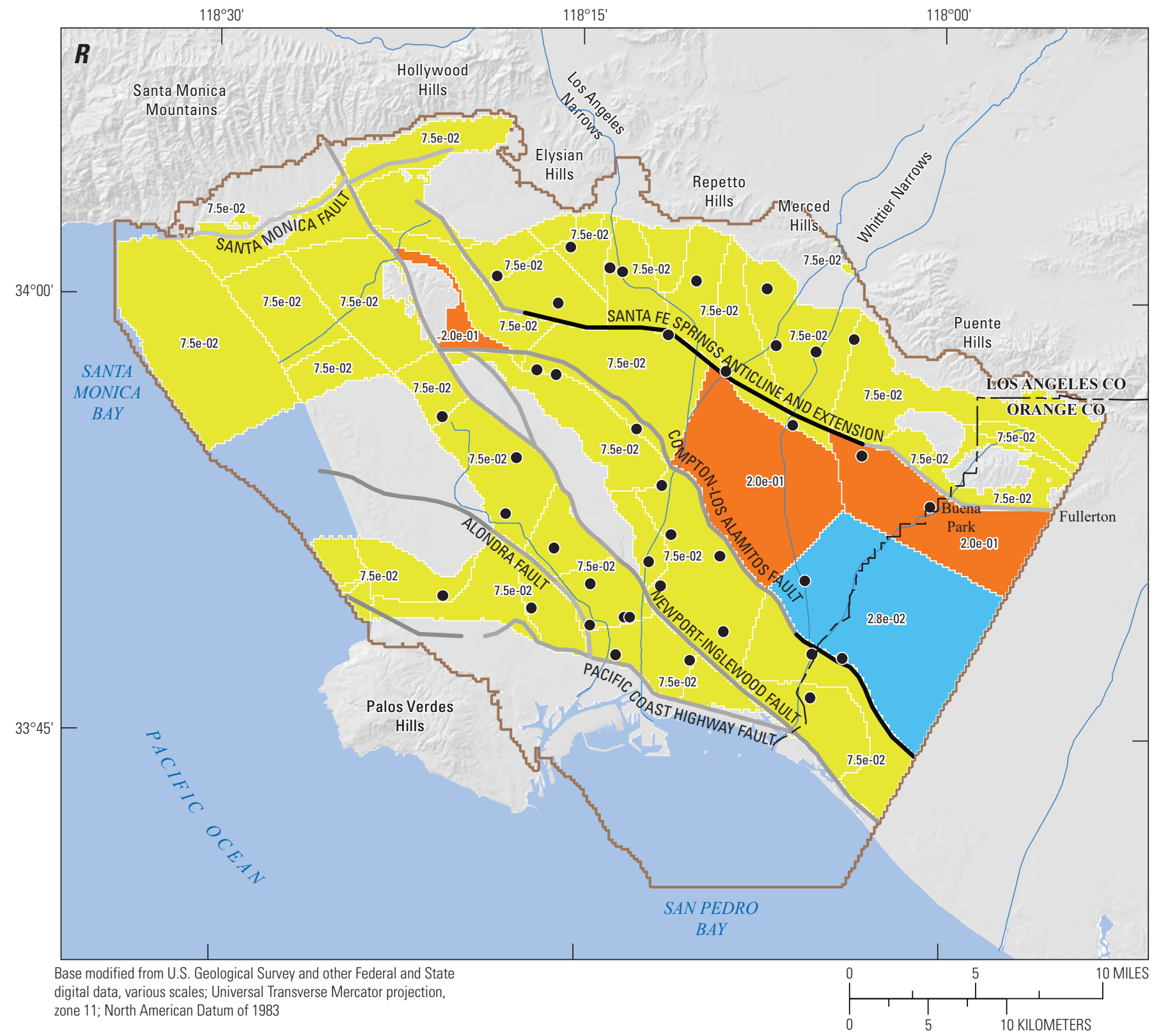

EXPLANATION
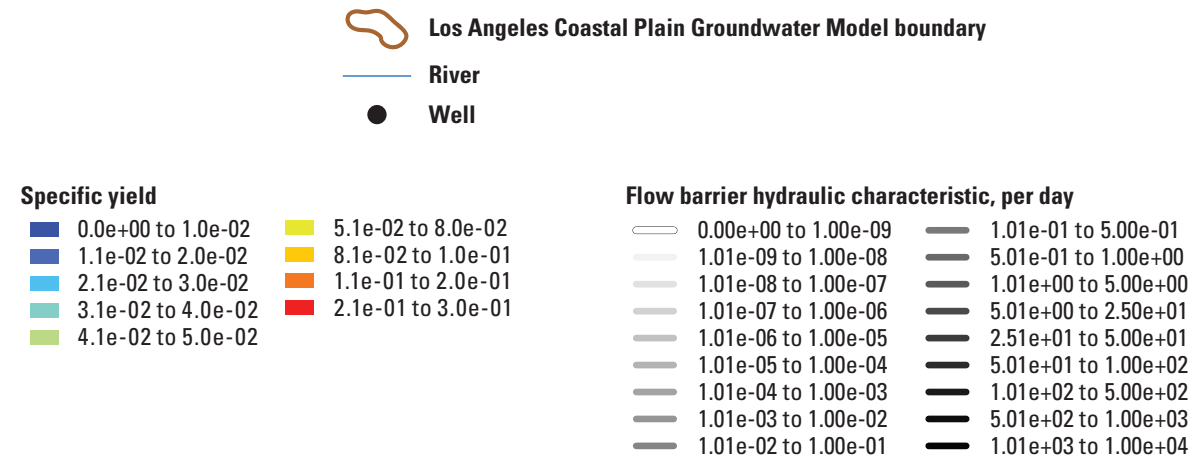

Figure D8.-Continued 


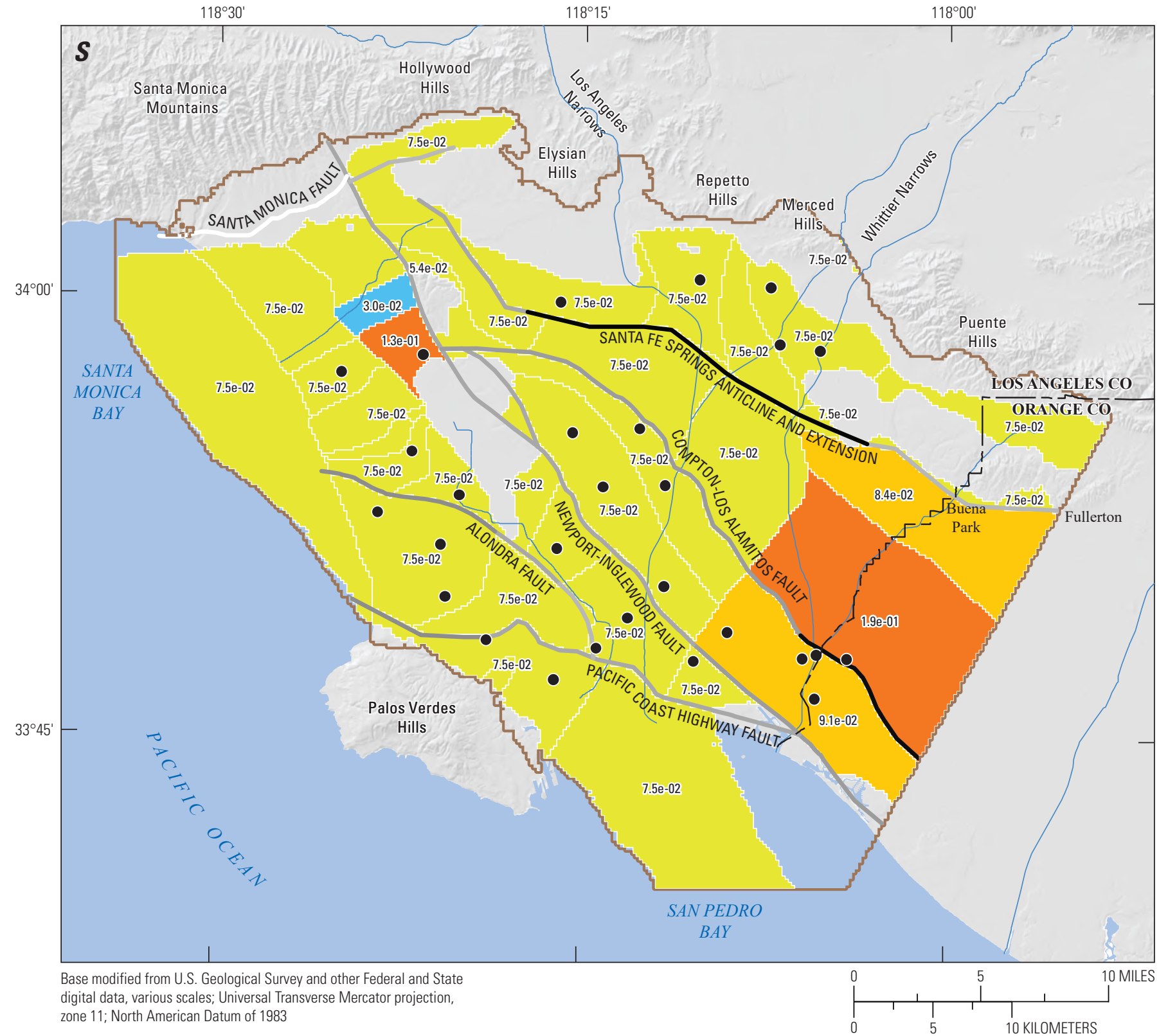

EXPLANATION

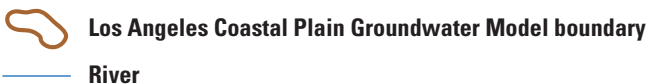

- Well

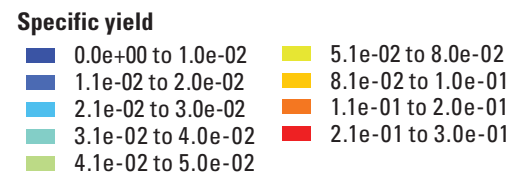

Flow barrier hydraulic characteristic, per day

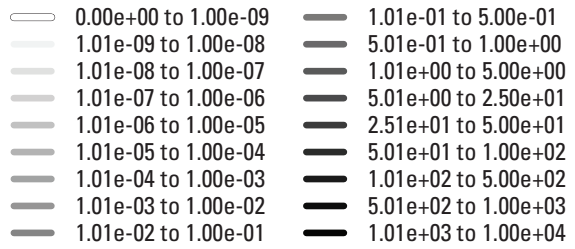

Figure D8.-Continued 


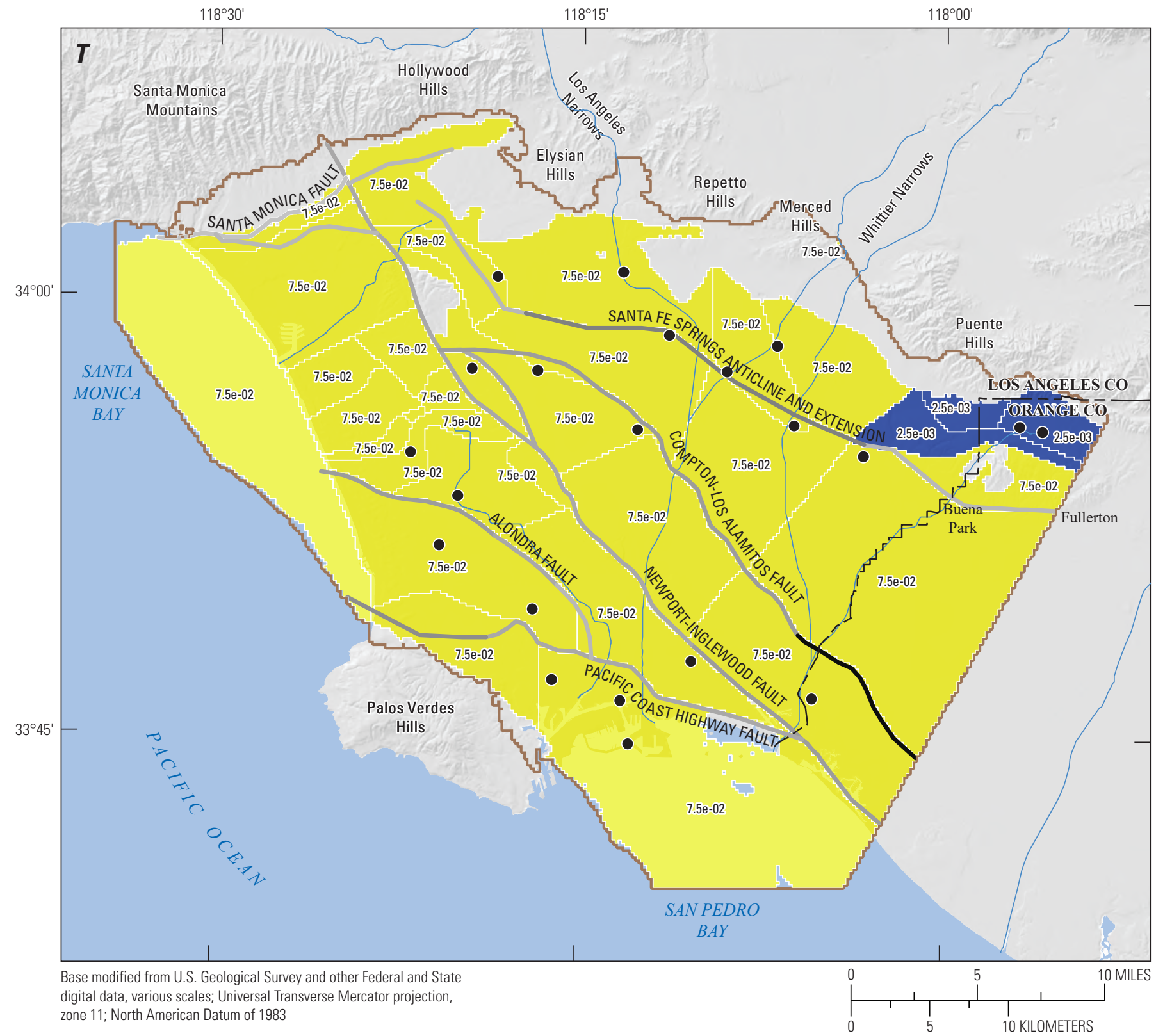

EXPLANATION
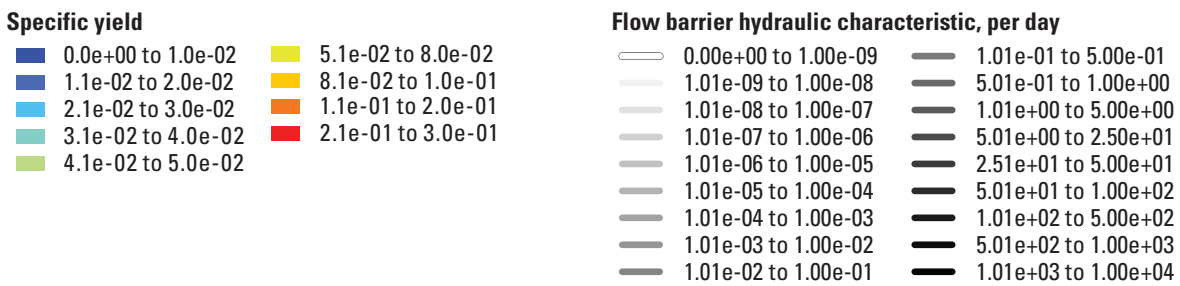

Figure D8.-Continued 


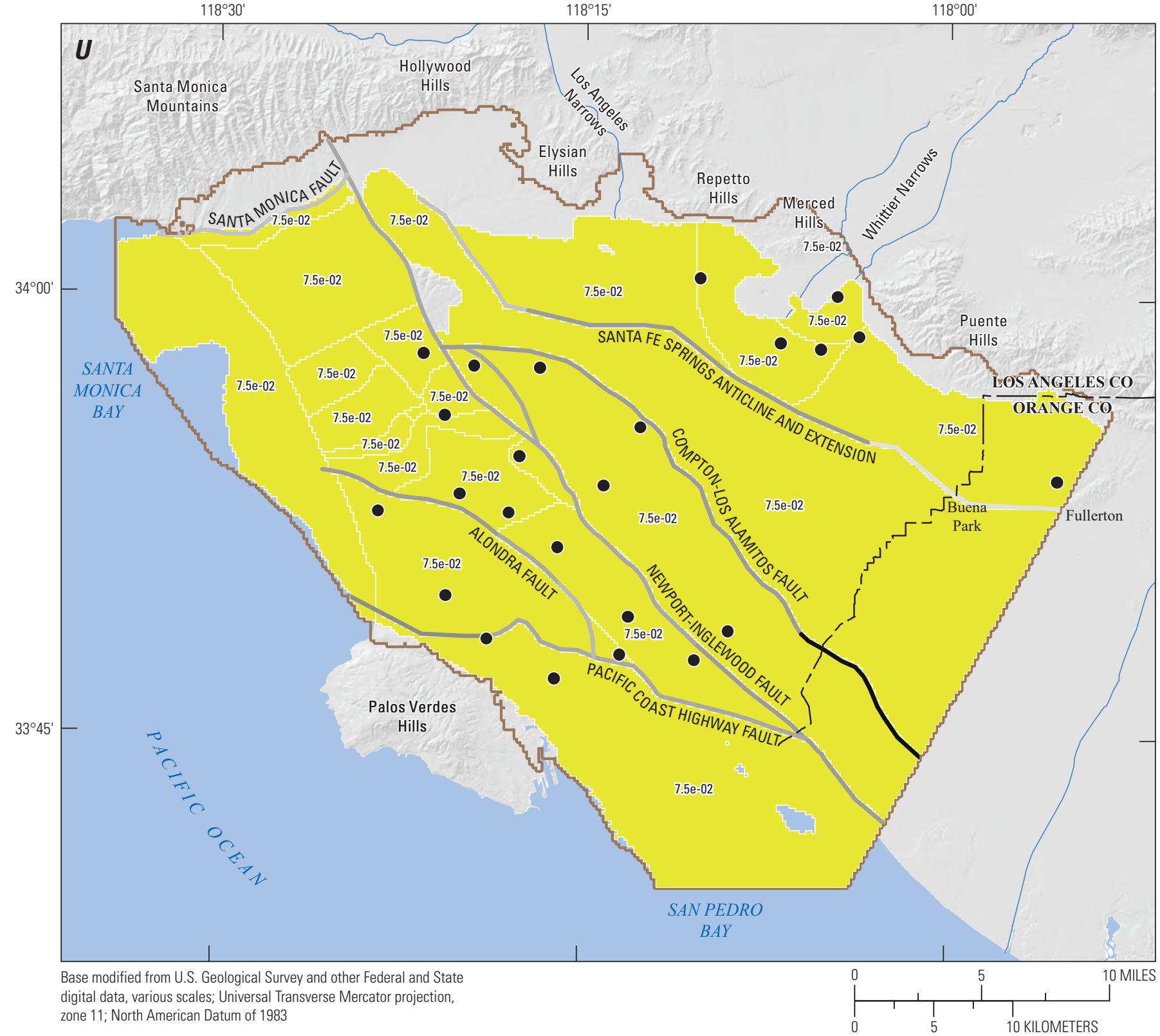

EXPLANATION

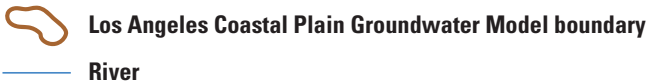

- Well
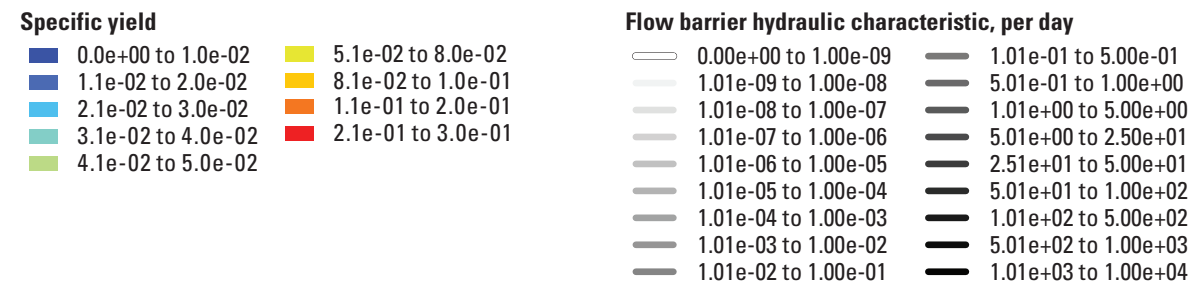

Figure D8.-Continued 


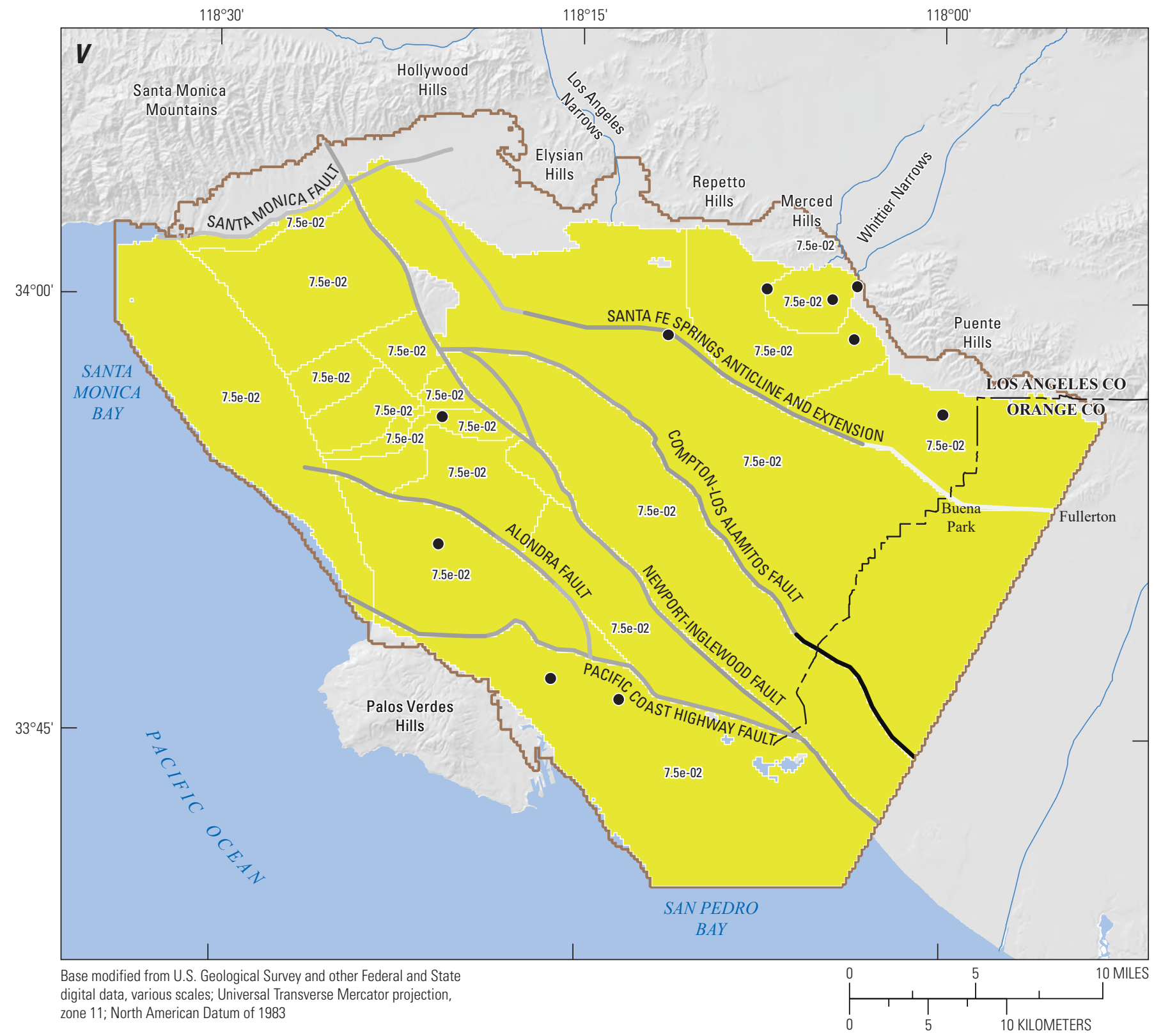

EXPLANATION

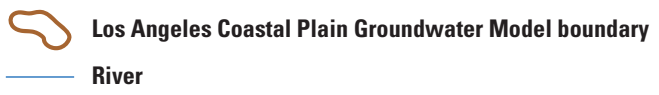

- Well
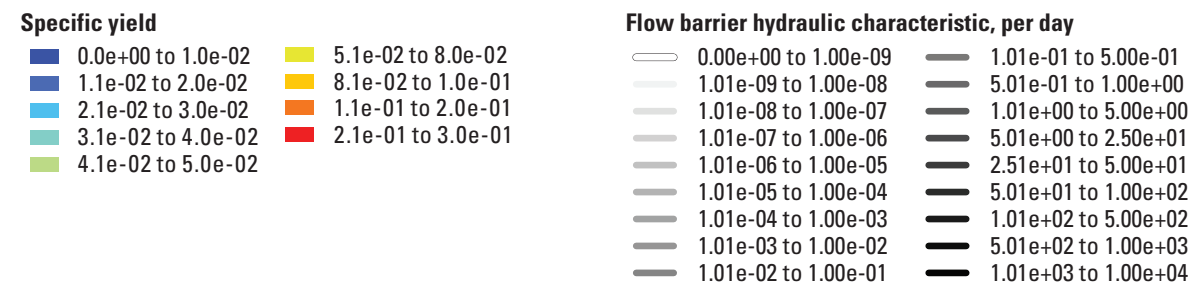

Figure D8.-Continued 


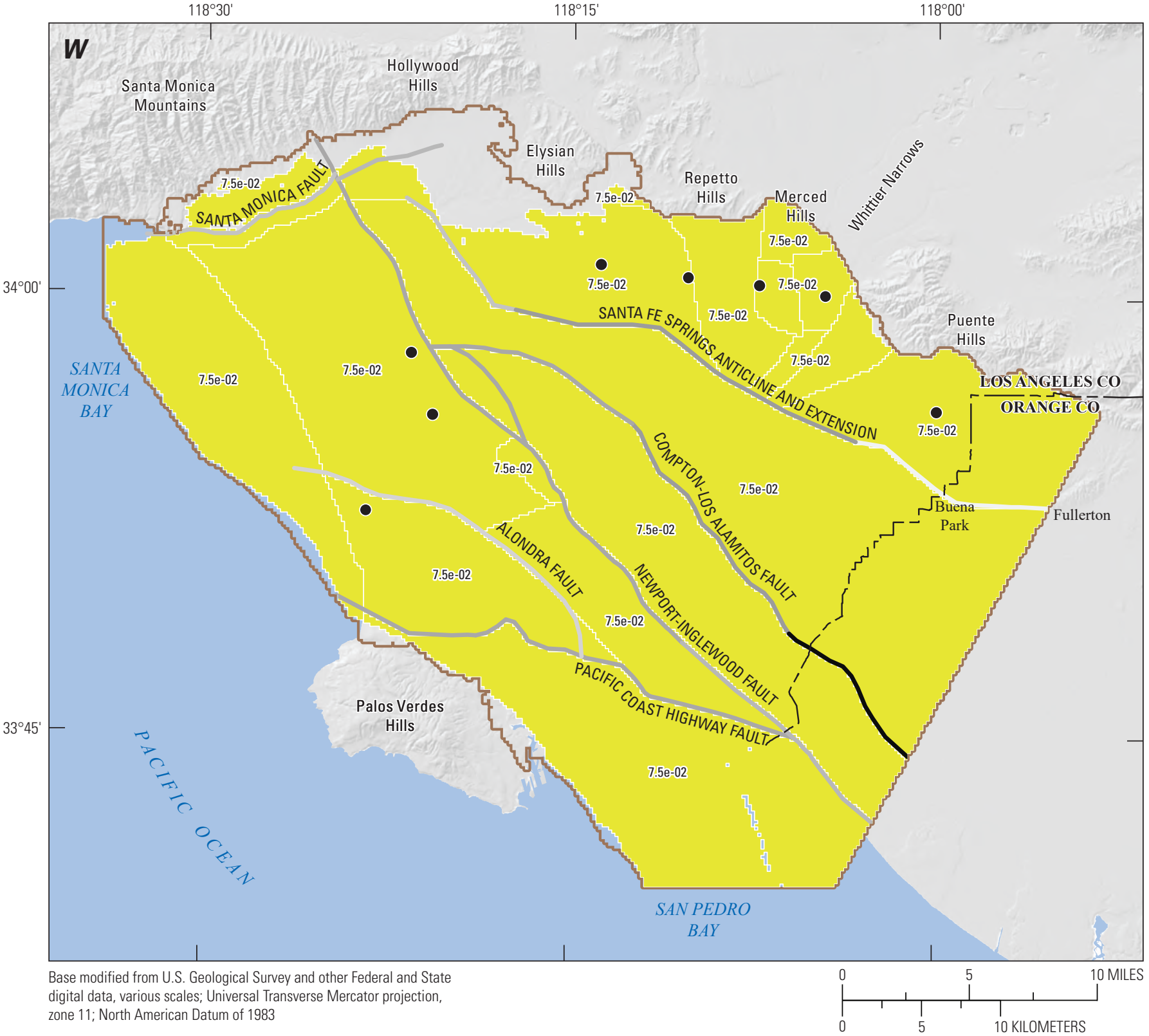

EXPLANATION
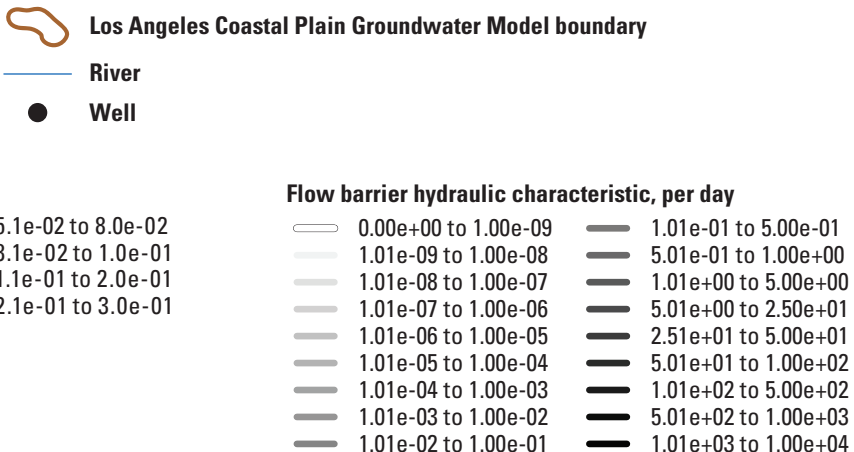

Figure D8.-Continued 
Specific-yield values were assigned to all model layers; however, specific yield was applied to a model cell only if that cell is the top-most active cell at a given row-column location in the model (if the cell was under a water-table condition; fig. D $8 L-W$ ). The Dominguez and Mesa layers were the top-most active layers throughout most of the model domain (fig. D4). Calibrated specific-yield values (dimensionless) in the Dominguez layer varied from 0.15 in the Montebello Forebay to 0.00046 in parts of the Central Basin Pressure Area (figs. D1, D8L). Calibrated specific-yield values in the Mesa layer varied from 0.3 in the southwestern West Coast Basin to 0.0062 in the far southeastern portion of Central Basin (fig. D8M). The high specific-yield values in some zones of the West Coast Basin may be due to high-yield sandy beach deposits. The low specific-yield values were in zones where the top-most active model layer was effectively semi-confined to confined by overlying fine-grained deposits in that layer.

\section{Hydrographs Comparing Simulated Head and Measured Water Levels}

Simulated and measured hydraulic heads were compared at selected long-screened wells and multiple-well monitoring sites for 1971 to 2015 (figs. A3, C8, D9). In general, the simulated heads followed the long-term trends of measured heads and reflected the vertical differences in heads between aquifer systems. Where the model did not reproduce measured heads in individual aquifer systems or vertical differences in heads between aquifer systems, simulation of pumpage from the different aquifer systems may be inaccurate. The total quantity of pumpage from a well was known; however, the distribution of pumpage from the different aquifer systems to which a well is open must be estimated. The distribution of pumpage among the aquifer systems open to a well was simulated in the model based on the calibrated transmissivity of each aquifer system and the length of the screened interval in each aquifer system. Inaccurate estimates of the screened interval, well efficiency, incorrect assignments of the chronostratigraphic units, and scaling errors due to cell size and the respective locations of monitoring and pumping wells within cells can cause errors in the simulated pumpage from a particular aquifer system.

Initial simulated heads were approximated based on available measured heads data at the beginning of the model runtime. Errors in initial simulated heads were attributed to interpolation errors in layers with sparse data. In most areas of the model, where errors in initial simulated heads were suspected, initial simulated heads equilibrated within a few years of model runtime.

The comparison between simulated and measured heads is briefly discussed for eight sites in the LACP that have long-term and nearby short-term aquifer-system-dependent water-level data (fig. C8). The sites discussed are the same sites that are discussed in detail in the "Water Levels and Movement" section of Chapter C.

\section{Los Angeles Forebay}

Well 10A1 (2S/13W-10A1; 2778) is a production well in the Los Angeles Forebay of the Central Basin (fig. C8) that is screened in the Pacific, Harbor, and Upper Wilmington A aquifer systems. Monitoring wells 3P2-6 (2S/13W-3P2 to 3P6) compose the multiple-well monitoring site Los Angeles2, which is adjacent to well 10A1, and has wells screened in the Long Beach C (3P2), Upper Wilmington A (3P3, 3P4), Harbor (3P5), and Pacific (3P6) aquifer systems. Simulated heads in the Pacific and Harbor aquifer systems followed measured heads closely at well 10A1 and the wells completed in the Pacific and Harbor systems at wells 3P2-6 (fig. D9A). Simulated heads in the Upper Wilmington A aquifer system were about $20 \mathrm{ft}$ higher than measured heads at well 10A1 and about the same as measured heads in monitoring wells 3P2-6. Simulated heads were about $10 \mathrm{ft}$ lower than measured heads in well 3P2 completed in the Long Beach C system. Although the simulated and measured heads did not match exactly, the gradient direction between Harbor, Upper Wilmington A, and Long Beach $\mathrm{C}$ aquifer systems was simulated correctly.

\section{Montebello Forebay}

Well 1A6 (3S/12W-1A6; 1615P) is a production well in the Montebello Forebay (fig. C8) that is screened in the Mesa and Pacific aquifer systems. Monitoring wells 25G3-8 (2S/12W-25G3 to 25G8) compose the Pico Rivera2 multiple-well monitoring site, which is near well $1 \mathrm{~A} 6$ and has wells screened in the Long Beach A (25G3), Upper Wilmington B (25G4), Upper Wilmington A (25G5), Pacific (25G6), Mesa (25G7), and Dominguez (25G8) aquifer systems. Simulated heads in the Mesa and Pacific aquifer systems followed the trends in measured heads at well $1 \mathrm{~A} 6$ but were about $10 \mathrm{ft}$ lower than measured heads (fig. D9B).

In general, simulated heads at wells 25G3-8 reasonably matched measured heads, head temporal trends, and head differences between wells (fig. D9B). Simulated heads did not have as much seasonal variation as measured heads, especially in the deeper aquifer systems. Reduced seasonal variation was probably the result of quarterly stress periods and scaling errors due to cell size and the respective locations of monitoring and pumping wells within cells. Simulated heads were higher than measured heads for the Long Beach A aquifer system, and the gradient between the Long Beach A aquifer system and the Upper Wilmington $A$ and $B$ aquifer systems was reversed compared to head measurements at 25G3-8 (fig. D9B). The differences in simulated and measured heads probably were the result of how underflow at the Whittier Narrows was simulated in the model. As stated in the "Boundary Conditions" section of this chapter, underflow from the San Gabriel Valley was simulated in the Mesa and Long Beach $\mathrm{C}$ aquifer systems. The model simulated too much upward leakage to the Long Beach A aquifer system from the underlying Long Beach $\mathrm{C}$ aquifer system through the Whittier Narrows. 

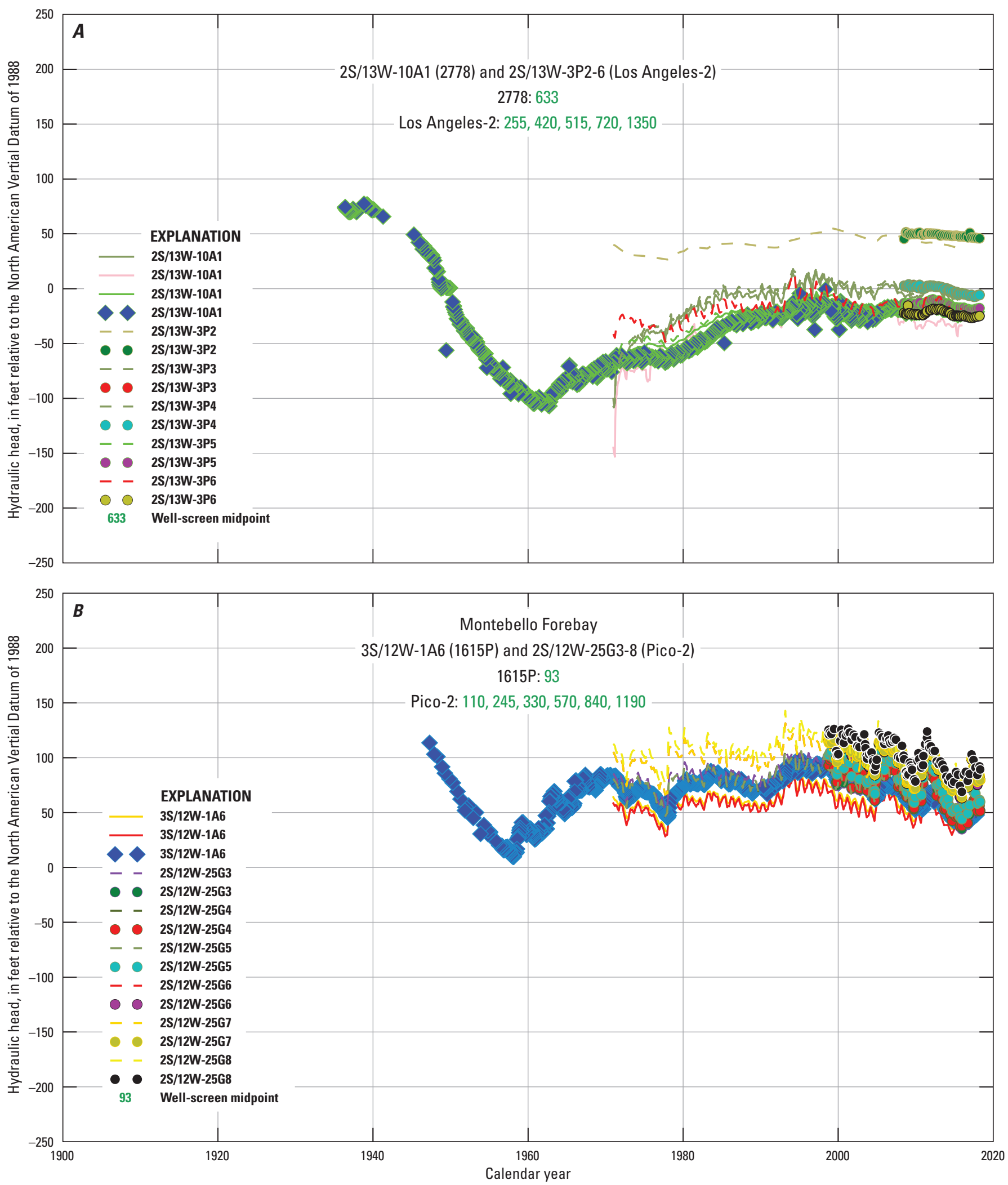

Figure D9. Measured (dots) and simulated (lines) hydraulic heads for selected long-screened basin-monitoring wells and paired multiple-well monitoring sites in the $A$, Los Angeles Forebay; $B$, Montebello Forebay; $C$, Central Basin Pressure Area (North); $D$, Central Basin Pressure Area (Central); $E$, Central Basin Pressure Area (South); F, West Coast Basin (East); G, West Coast Basin (West); and $H$, Santa Monica Basin, Los Angeles and Orange Counties, California. For long-screened monitoring wells screened in multiple layers, simulated heads are shown as separate lines for each layer. 

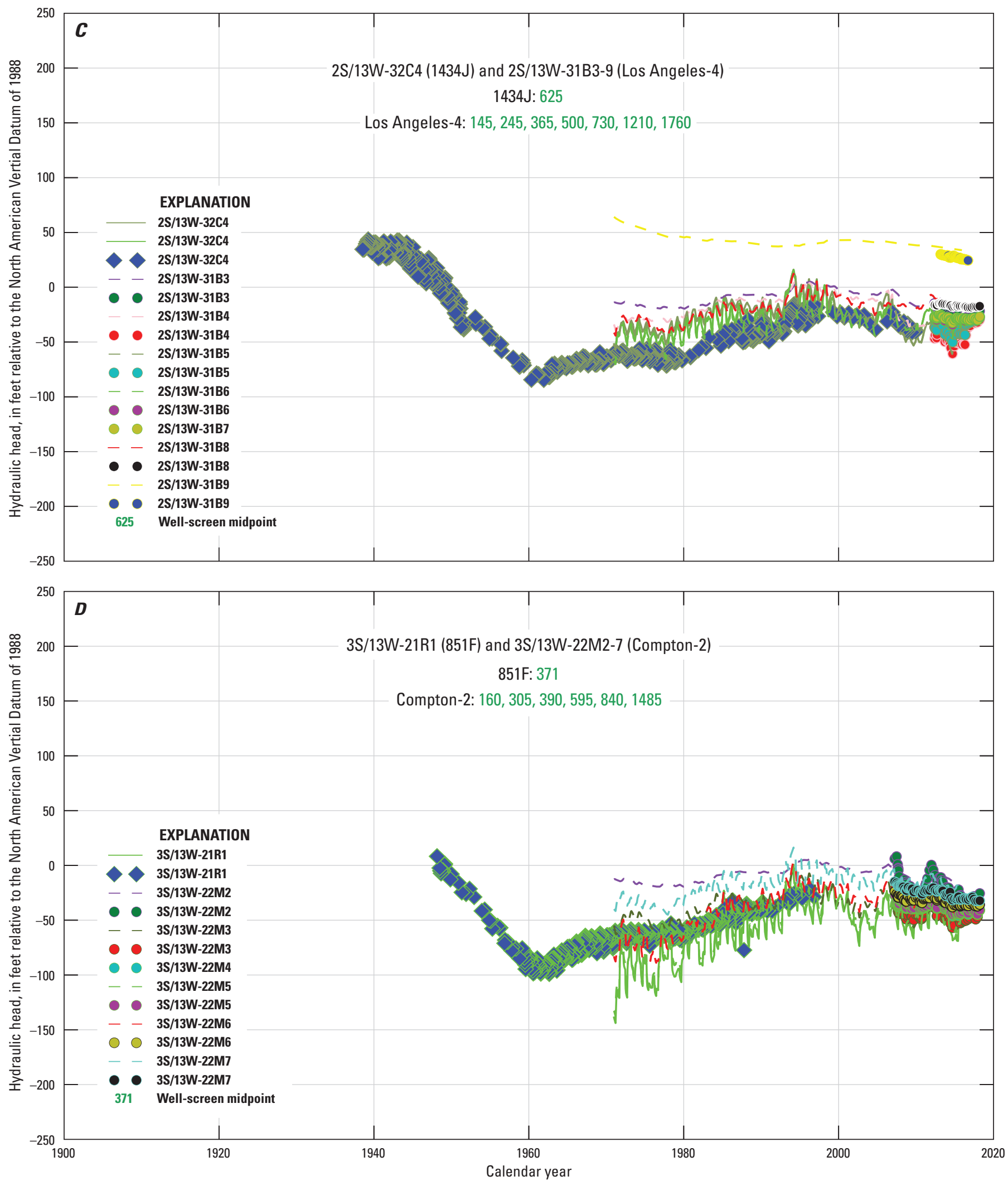

Figure D9.-Continued 

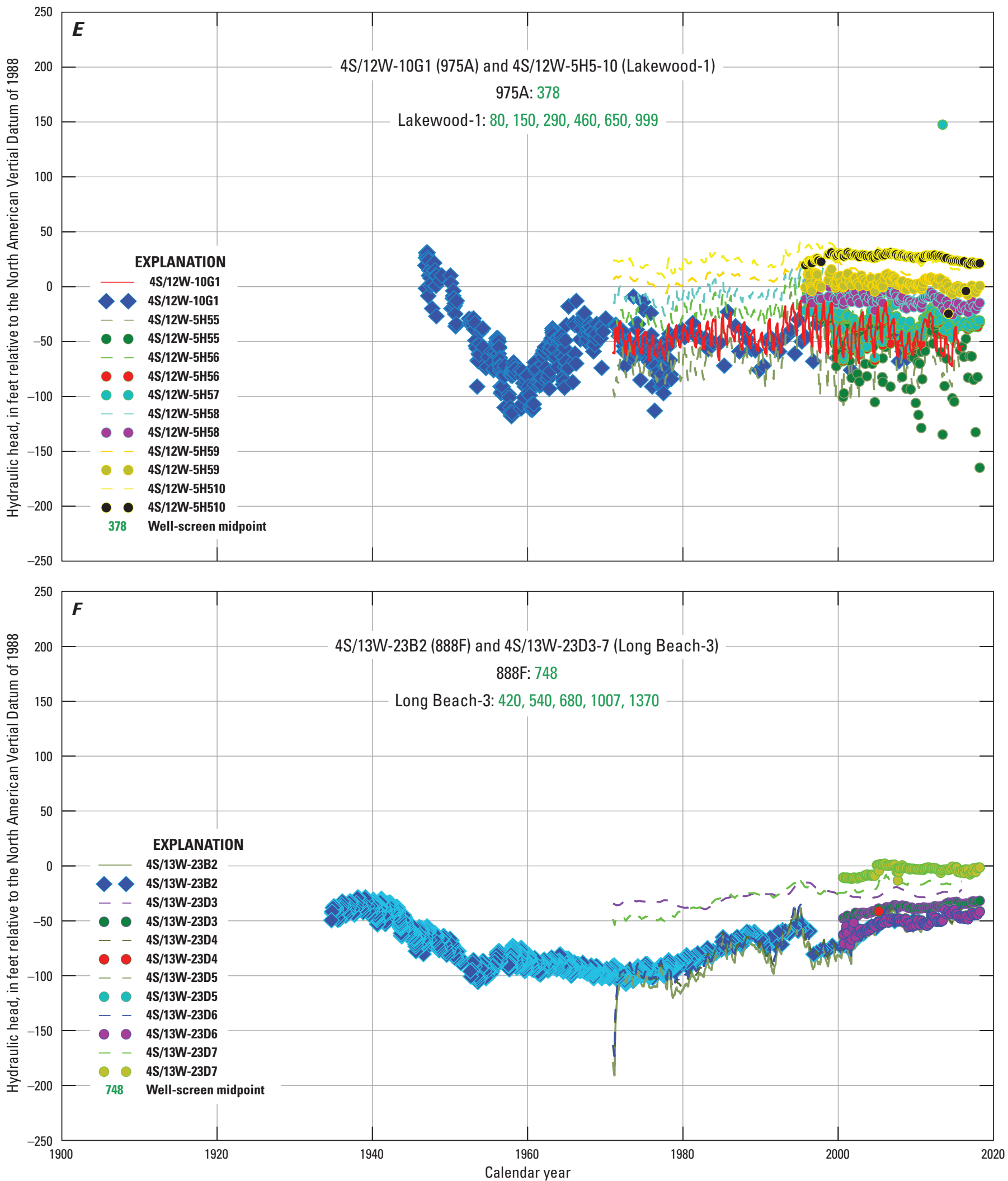

Figure D9.-Continued 

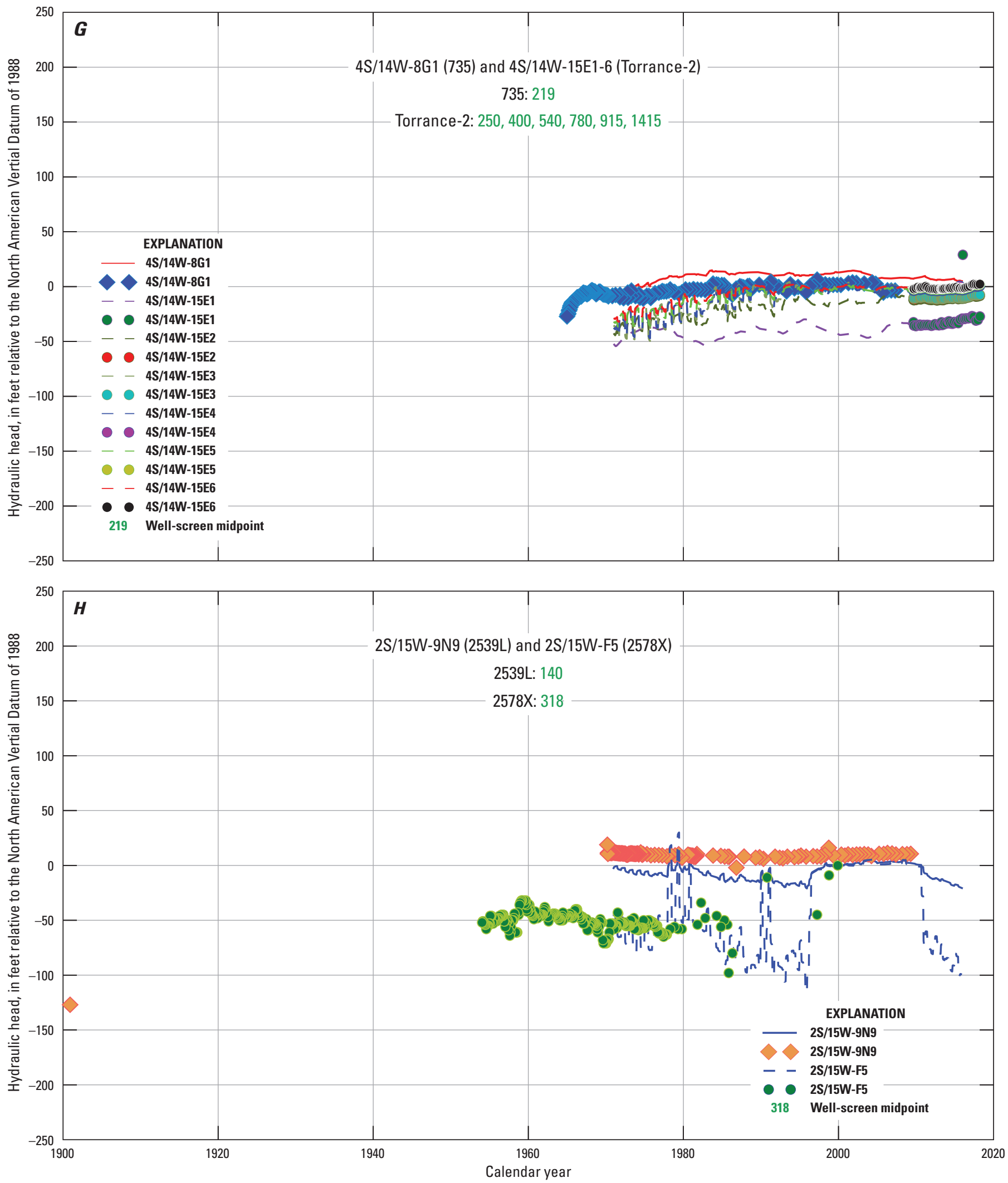

Figure D9.-Continued 


\section{Central Basin Pressure Area, North}

Well $2 \mathrm{~S} / 13 \mathrm{~W}-32 \mathrm{C} 4(1434 \mathrm{~J})$ is a production well in the northern part of the Central Basin Pressure Area (fig. C8) and is screened in the Harbor, Bent Spring, and Upper Wilmington A aquifer systems (table 1.1). Wells 31B3-8 (2S/13W-31B3 to 31B8) compose the Los Angeles4 multiple-well monitoring site, which is near well $32 \mathrm{C} 4$ and has wells screened in the Long Beach A (31B3), Lower Wilmington (31B4), Upper Wilmington A (31B5), Harbor (31B6, 31B7), and Pacific (31B8) aquifer systems, with a vibrating wire piezometer in the Dominguez aquifer system (31B9; appendix 1, table 1.1). Simulated heads in the Pacific, Harbor, and Upper Wilmington A aquifer systems closely followed the trends in measured heads from the mid-1990s until the end of the period of record in 2009 (fig. D9C). The simulated heads overestimated measured heads at well $32 \mathrm{C} 4$ by as much as $20 \mathrm{ft}$ for 1971 to 1993. However, the model accurately simulated the measured heads in well 32C4 in the period from the 1995 to 2009, so pumpage in the period from 1971 to 1993 may not have been estimated accurately.

Simulated heads closely matched measured heads and gradients in the Pacific, Harbor, and Upper Wilmington A aquifer systems at wells 31B3-8 (fig. D9C). However, simulated heads were higher than measured heads in the Dominguez, Lower Wilmington, and Long Beach A aquifer systems (fig. D9C). Measured heads in the Lower Wilmington aquifer system at wells 31B3-8 were the lowest and showed the most seasonal variation. Nearby pumping from the Lower Wilmington aquifer system could have caused the low and minimally variable heads. However, wells with perforations extending down into the Lower Wilmington aquifer system were not pumping near wells $31 \mathrm{~B} 3-8$ during the time period of the head measurements. The nearest deep pumping well was only screened as deep as the Upper Wilmington B aquifer system. If the assumed elevation of the top of the Lower Wilmington was higher in this part of the LACPGM, some of the deep pumping would have been withdrawn from the Lower Wilmington, which might have allowed the model to more accurately simulate heads at 31B3-8.

\section{Central Basin Pressure Area, Central}

Well 21R1 (3S/13W-21R1; 851F) is a production well in the Central Basin Pressure Area (fig. C8) near the Newport-Inglewood fault zone that is screened in the Harbor aquifer system (table 1.1). Monitoring wells 22M2-7 (3S/13W-22M2 to 22M7) compose monitoring site Compton2, which is near well $21 \mathrm{R} 1$ and has wells screened in the Long
Beach A (22M2), Upper Wilmington B (22M3), Harbor (22M4, 22M5), Pacific (22M6), and Pacific A (22M7) aquifer systems (table 1.1, fig. D9D). Simulated heads in the Harbor aquifer system followed the general trends of measured heads at well 21R1; however, variations in simulated seasonal head were much higher than variations in measured heads (fig. D9D). Simulated heads at wells 22M2-7 were similar to measured heads in the Pacific A, Pacific, and Harbor aquifer systems, except the simulated heads had greater seasonal variation than measured heads (fig. D9D). The higher simulated seasonal head variations indicated that the calibrated storage coefficient and/or VK values may have been too low in the model domain near wells 22M2-7.

The simulated and measured heads for the Upper Wilmington B aquifer system are similar at wells 22M2-7; however, the simulated seasonal response was slightly muted compared to the measured seasonal response (fig. D9D). The measured seasonal response indicated that a nearby well was pumping from the Upper Wilmington B aquifer system. However, nearby wells were not simulated to pump from the Upper Wilmington B aquifer system. The nearest simulated deep pumping wells were screened in the Bent Spring aquifer system. Well 22M3 is screened near the top of the Upper Wilmington B aquifer system. The measured head response indicated that model results could be improved in this area by modifying either the chronostratigraphic model to include well 22M3 in the Bent Spring aquifer system or the screened intervals of nearby pumping wells in the Upper Wilmington B aquifer system. Wells 22M2-7 are about $1 \mathrm{mi}$ east-northeast of the Newport-Inglewood fault zone, where the chronostratigraphic units dip from the Newport-Inglewood fault zone to the Compton-Los Alamitos fault (fig. B20). Slightly modifying the local steepness of this dip would move the screen in well 22M3 from the Upper Wilmington B to the Bent Spring chronostratigraphic unit. A local change like this would most likely result in minimal effects on adjacent areas of the LACPGM.

The simulated heads for the Long Beach A aquifer system were about $10 \mathrm{ft}$ higher than the lowest measured heads in well 22M2 screened in the Long Beach A aquifer system, at wells $22 \mathrm{M} 2-7$, and did not show the large $(25 \mathrm{ft}$ ) variations observed at wells 22M2-7 (fig. D9D). The nearest active production well that withdrew water from the Long Beach A aquifer system is more than $5 \mathrm{mi}$ southeast of wells 22M2-7 (fig. C6). The presence of large head fluctuations, caused by pumping at such a large distance, indicated that the VK of the Long Beach A aquifer system may be lower than the one used in the currently calibrated model. 


\section{Central Basin Pressure Area, South}

Well 10G1 (4S/12W-10G1; 975A) is a production well in the southern part of the Central Basin Pressure Area that is screened in the Pacific aquifer system (fig. C8; table 1.1). Monitoring wells 5H5-10 (4S/12W-5H5 to 5H10) compose multiple-well monitoring site Lakewood1, which is near well 10G1 and has wells screened in Upper Wilmington A (5H5), Harbor (5H6, 5H7), Pacific A (5H8), Mesa (5H9), and Dominguez (5H10) aquifer systems (table 1.1; fig. D9E). Simulated heads in the Pacific aquifer system closely followed measured heads in well 10G1 (fig. D9E). The simulated heads, seasonal head changes, and head differences among aquifer systems at site 5H5-10 matched measured heads in the Dominguez, Harbor, and Upper Wilmington A aquifer systems at the site (fig. D9E). Simulated heads in the Mesa and Pacific A aquifer systems were about $10 \mathrm{ft}$ higher than measured heads but followed the same temporal trends.

The previous USGS groundwater-flow model for the LACP reasonably simulated heads in the wells $(5 \mathrm{H} 6-5 \mathrm{H} 10)$ shallower than the Upper Wilmington A at wells 5H5-10 but was less successful in simulating heads in the deepest well (5H5; Reichard and others, 2003). The previous model did not account for the steepness of the upward folding of the Pacific and older aquifer systems near wells 5H5-10 (figs. B4, B22), which resulted in multiple wells producing water from the Upper Wilmington A aquifer system in the southwestern part of the Central Basin (fig. C6). Finer discretization and more accurate simulation of the aquifer structure in the LACPGM, compared to the previous USGS model, undoubtedly contributed to improved simulation of measured heads at wells 5H6-5H10. A production well was installed in the late 1990s near well 5H5-10 (site Lakewood1). Pumping from production wells in the vicinity of $10 \mathrm{G} 1$ resulted in large seasonal head declines in well 5H5 (site Lakewood1) screened in the Upper Wilmington A aquifer system (fig. D9E). Measured seasonal head declines were slightly underpredicted by the LACPGM.

\section{West Coast Basin, East}

Well 23B2 (4S/13W-23B2; 888F) is a production well in the southeast part of the West Coast Basin (fig. C8) that is screened in the Upper Wilmington A aquifer system (table 1.1). Monitoring wells 23D3-7 (4S/13W-23D3 to 23D7) compose multiple-well monitoring site Long Beach3, which is near well 23B2 and has wells screened in the Long Beach A (23D3), Upper Wilmington B (23D4), Upper Wilmington A (23D5), Bent Spring (23D6), and Harbor (23D7) aquifer systems (fig. D9F). Simulated heads in the Upper Wilmington A aquifer system reasonably matched measured heads and temporal trends at well 23B2, especially from 1998 to 2015 (fig. D9F). Simulated heads matched measured heads and head differences between the Bent Spring and Upper Wilmington A aquifer systems at wells 23D3-7 (fig. D9F). Simulated heads for the Harbor aquifer system at wells 23D3-7 closely tracked measured heads but were about $15 \mathrm{ft}$ lower than the measured heads (fig. D9F). Simulated heads for the Long Beach A aquifer system also closely tracked measured heads but were about $15 \mathrm{ft}$ higher than the measured heads (fig. D9F). The calibrated VK of the Bent Spring aquifer system probably was too high in this part of the West Coast Basin. Additionally, the initial heads for the Bent Spring and Upper Wilmington A aquifer systems were too low in this area of the West Coast Basin, though simulated heads recovered and stabilized within a year.

\section{West Coast Basin, West}

Well 8G1 (4S/14W-8G1; 735) is an observation well in the western part of the West Coast Basin, about 1.6 mi east of the coastline (fig. C8), that is screened in the Pacific aquifer system (table 1.1). Monitoring wells 15E1-6 (4S/14W-15E1 to $15 \mathrm{E} 6$ ) compose multiple-well monitoring site Torrance2, which is near well $8 \mathrm{G} 1$ and has wells screened in the Long Beach A (15E1), Upper Wilmington B (15E2), Upper Wilmington A (15E3), Bent Spring (15E4), Harbor (15E5), and Pacific (15E6) aquifer systems (fig. D9G). Simulated heads for the Pacific aquifer system matched measured heads within $10 \mathrm{ft}$ at well 8G1 (fig. D9 $G$ ). Simulated heads for the Pacific, Harbor, Bent Spring, and Upper Wilmington A aquifer systems at wells 15E1-6 plotted together closely (fig. D9 $G$ ). Heads measured in the Pacific, Harbor, and Bent Spring aquifer systems at wells 15E1-6 also plotted together closely, within $5 \mathrm{ft}$ of simulated heads (fig. D9G). Measured heads in all four of these aquifer systems were similar at wells 15E1-6 because the nearby West Coast Basin Barrier Project injects water into these aquifer systems (fig. D5). The measured differences between heads in the Bent Spring and Upper Wilmington A aquifer systems indicated that the VK of the Upper Wilmington A aquifer system is low enough to retard movement of water between the Bent Spring and underlying Upper Wilmington A aquifer systems. In contrast, the calibrated VK values for the Upper Wilmington A aquifer system $(0.07 \mathrm{ft} / \mathrm{d})$ probably were too high to sufficiently retard the simulated movement of water between these two aquifer systems in this part of the West Coast Basin (fig. D9G). Simulated heads for the Long Beach A aquifer system were within $5 \mathrm{ft}$ of measured heads (fig. D9G). 


\section{Santa Monica Basin}

Well 11F5 (2S/15W-11F5; 2578X) is a production well in the central part of the Santa Monica Basin (fig. C8) that is screened in the Bent Spring aquifer system (table 1.1). USGS multiple-well monitoring sites have not been constructed in the Santa Monica Basin, so head measurements from well 9N9 (2S/15W-9N9; 2539L; table 1.1) were compared to head measurements at well $11 \mathrm{~F} 5$ to illustrate changes in heads with depth in the Santa Monica Basin. Well 9N9 is in the western part of the Santa Monica Basin (fig. C8) and screened in the Pacific aquifer system. Simulated heads in the Bent Spring aquifer system reproduced the large head fluctuations observed at well 11F5 (fig. D9H). Simulated heads in the Pacific aquifer system remained within $25 \mathrm{ft}$ of observed heads in well 9N9 (fig. D9H). The simulated difference in head between the Pacific and Bent Spring aquifer systems was within $15 \mathrm{ft}$ of measured head differences between wells 9N9 (Pacific aquifer system) and 11F5 (Bent Spring aquifer system; fig. D9H).

\section{Simulated Hydraulic Heads for Fall 2013 and Spring 2006}

Simulated hydraulic heads were compared to measured heads for fall 2013 (a dry time) and spring 2006 (a wet time) to ensure similarity between the areal distributions of simulated and measured heads and of hydraulic gradients between aquifer systems (fig. D10). For measured heads, we selected the earliest available head measurements from September 2013 and March 2006, respectively. The density of head measurements was substantially greater in shallow aquifer systems than in deeper aquifer systems. Most data from deeper aquifer systems are from WRD/USGS multiple-well monitoring sites in the Central and West Coast Basins and OCWD multi-completion wells in the Orange County Basin.

\section{Dominguez Aquifer System}

Fall 2013 simulated hydraulic heads in the Dominguez aquifer system indicated that groundwater flows from the surrounding highlands toward the Central Basin Pressure Area then flows in a southeasterly direction toward the Dominguez Gap and the San Gabriel River (fig. A1, C1, D10A). Simulated heads were highest at the Los Angeles Narrows in the Los Angeles Forebay (approximately $320 \mathrm{ft}$ ) and Whittier Narrows in the Montebello Forebay (approximately $160 \mathrm{ft}$; figs. D10A, D10C). Fall 2013 simulated head gradient declined steeply from a high of about $320 \mathrm{ft}$ in the Los Angeles Narrows to about $30 \mathrm{ft}$ in the southern part of the Los Angeles Forebay, and then continued to gently decline into the northern part of the Central Basin Pressure Area. Simulated heads in the Montebello Forebay declined from a high of about $160 \mathrm{ft}$ in the Whittier Narrows to about $40 \mathrm{ft}$ at the southern end of the Montebello Forebay. The simulated hydraulic heads indicated that groundwater flows from the southeastern margin of the model in the Orange County Basin toward the San Gabriel River.

Spring 2006 simulated heads were about 5 to $15 \mathrm{ft}$ higher than simulated heads for fall 2013 in the Central Basin Pressure Area, as much as 20 to $30 \mathrm{ft}$ higher in the Montebello Forebay, and less than $5 \mathrm{ft}$ higher throughout most of the Los Angeles Forebay (figs. D10A, D10C). Simulated heads were in good agreement with available measured heads. Based on simulations, groundwater flow in the Dominguez aquifer system was minimally impacted by the Newport-Inglewood fault zone.

\section{Mesa Aquifer System}

Fall 2013 simulated hydraulic heads in the Mesa aquifer system were highest in the Central Basin at Whittier Narrows and Los Angeles Narrows, at about $160 \mathrm{ft}$ and 280 $\mathrm{ft}$, respectively (fig. D10A). Pumping in the Mesa and deeper aquifer systems in the Los Angeles Forebay and northern part of the Central Basin Pressure Area resulted in a depression in the fall 2013 simulated heads, with heads lower than $0 \mathrm{ft}$ in the center of the depression (fig. D10A). Simulated heads declined steeply from $160 \mathrm{ft}$ at the Whittier Narrows to about $30 \mathrm{ft}$ at the edge of the Central Basin Pressure Area then declined to a low of about $-20 \mathrm{ft}$ in the southeastern part of the Central Basin Pressure Area (fig. D10A). Similar to the Dominguez aquifer system, the simulated heads indicated that groundwater in the Mesa aquifer system flows from the southeastern model margin in the Orange County Basin toward the San Gabriel River. In the West Coast Basin, simulated and measured heads were below NAVD 88 except in the northern part of the groundwater basin and along the West Coast Basin Barrier Project (fig. D10A). Simulated hydraulic heads below NAVD 88 along the coast in the southern part of the West Coast Basin indicated potential for seawater intrusion into the Mesa aquifer system. Large differences in simulated heads across the Newport-Inglewood fault zone reflected the barrier effect of the fault zone on groundwater flow in this part of the Mesa aquifer system (fig. D10A).

Spring 2006 simulated hydraulic heads in the Montebello Forebay were up to $25 \mathrm{ft}$ higher than fall 2013 simulated heads, up to $15 \mathrm{ft}$ higher in the Central Basin Pressure Area, from $15 \mathrm{ft}$ higher to $15 \mathrm{ft}$ lower in the Los Angeles Forebay, and from about $20 \mathrm{ft}$ higher to $5 \mathrm{ft}$ lower in the West Coast Basin (figs. D10A, D10C). Available measured heads agreed well with simulated heads in the Central and West Coast Basins (fig. D10A). Groundwater flow within the Mesa aquifer system was impeded by (1) the Newport-Inglewood fault zone, and (2) the Santa Monica fault. 

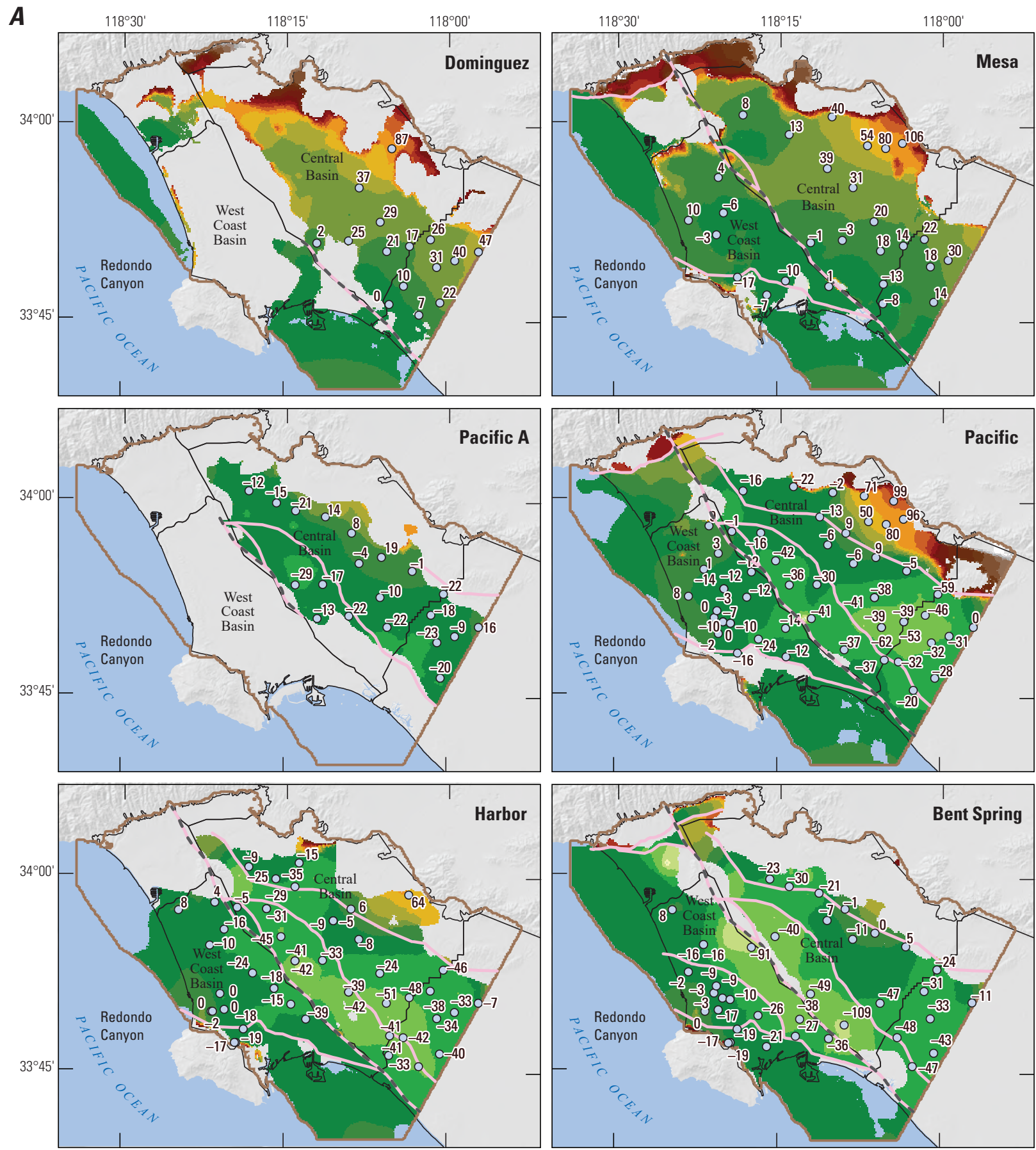

\section{EXPLANATION}

Simulated hydraulic head (groundwater elevation),

in feet above North American Vertical Datum of 1988

\begin{tabular}{|c|c|c|c|c|}
\hline-180 to -160 & -59 to -40 & 60 to 80 & 180 to 200 & 300 to 320 \\
\hline-159 to -140 & -39 to -20 & 80 to 100 & 200 to 220 & 320 to 340 \\
\hline-139 to -120 & -19 to 0 & 100 to 120 & 220 to 240 & 340 to 360 \\
\hline-119 to -100 & 0 to 20 & 120 to 140 & 240 to 260 & 360 to 380 \\
\hline-99 to -80 & 20 to 40 & 140 to 160 & 260 to 280 & 380 to 400 \\
\hline-79 to -60 & 40 to 60 & 160 to 180 & 280 to 300 & greater th \\
\hline
\end{tabular}
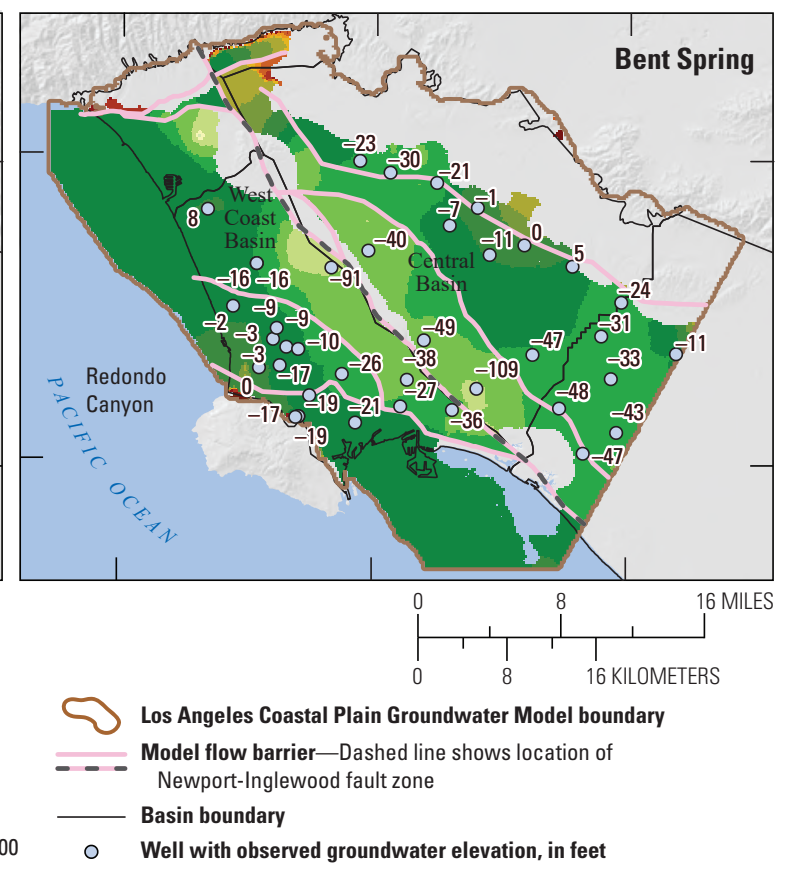

Figure D10. Simulated hydraulic head for Fall of 2013 and Spring of 2006 for layers 2 through 13 of the Los Angeles Coastal Plain Groundwater-flow model, California: A, Fall of 2013 Dominguez, Mesa, Pacific A, Pacific, Harbor, Bent Spring; B, Fall of 2013 Upper Wilmington A, Upper Wilmington B, Lower Wilmington, Long Beach A, Long Beach B, and Long Beach C; C, Spring of 2006 Dominguez, Mesa, Pacific A, Pacific, Harbor, Bent Spring; and D, Spring of 2006 Upper Wilmington A, Upper Wilmington B, Lower Wilmington, Long Beach A, Long Beach B, and Long Beach C aquifer systems. 

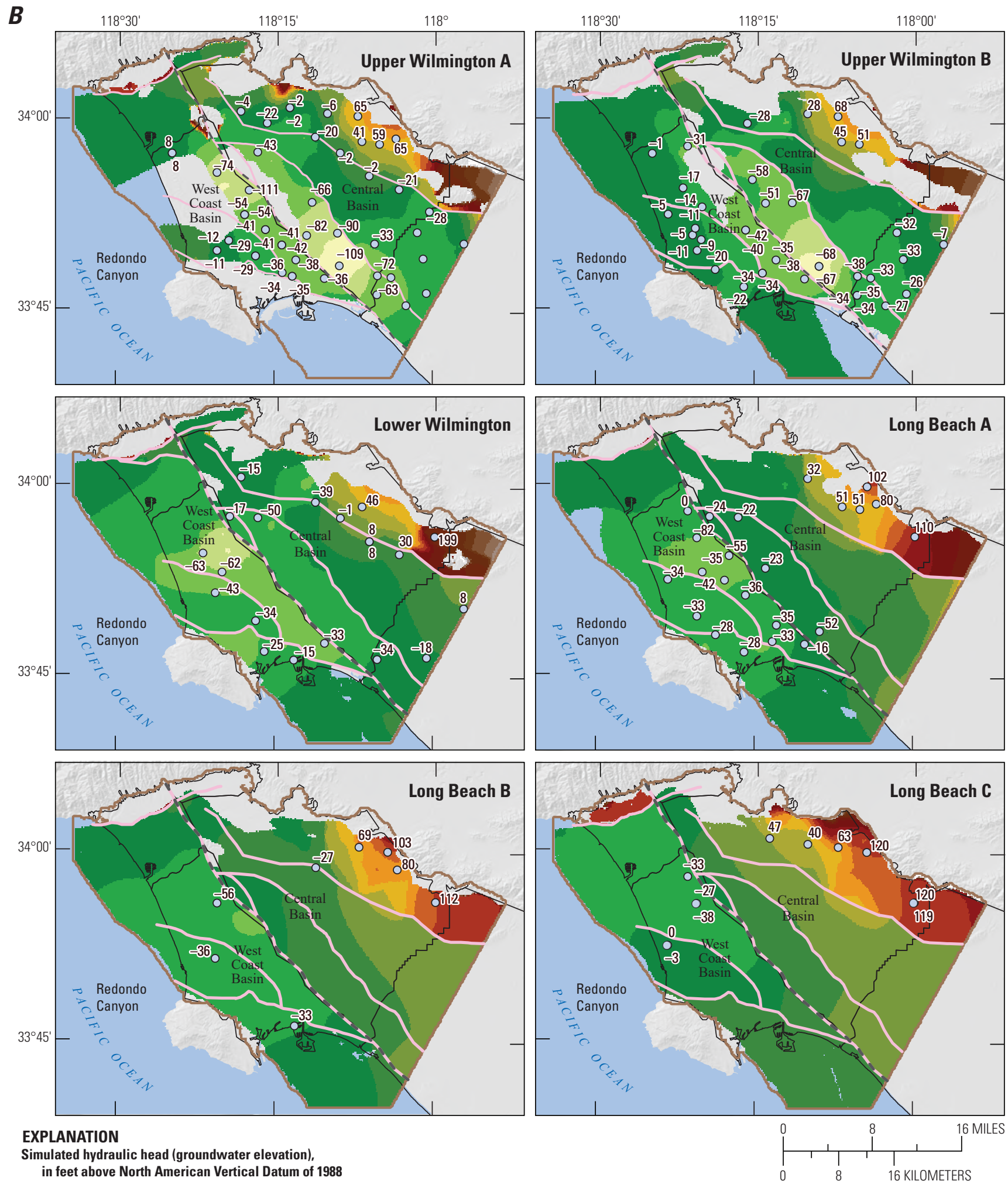

Simulated hydraulic head (groundwater elevation), in feet above North American Vertical Datum of 1988

\begin{tabular}{|c|c|c|c|c|}
\hline-180 to -160 & -59 to -40 & 60 to 80 & 180 to 200 & 300 to 320 \\
\hline-159 to -140 & -39 to -20 & 80 to 100 & 200 to 220 & 320 to 340 \\
\hline-139 to -120 & -19 to 0 & 100 to 120 & 220 to 240 & 340 to 360 \\
\hline-119 to -100 & 0 to 20 & 120 to 140 & 240 to 260 & 360 to 380 \\
\hline-99 to -80 & 20 to 40 & 140 to 160 & 260 to 280 & 380 to 400 \\
\hline-79 to -60 & 40 to 60 & 160 to 180 & 280 to 300 & greater the \\
\hline
\end{tabular}

$\checkmark$ Los Angeles Coastal Plain Groundwater Model boundary Model flow barrier-Dashed line shows location of Newport-Inglewood fault zone

Basin boundary

O Well with observed groundwater elevation, in feet

Figure D10.-Continued 

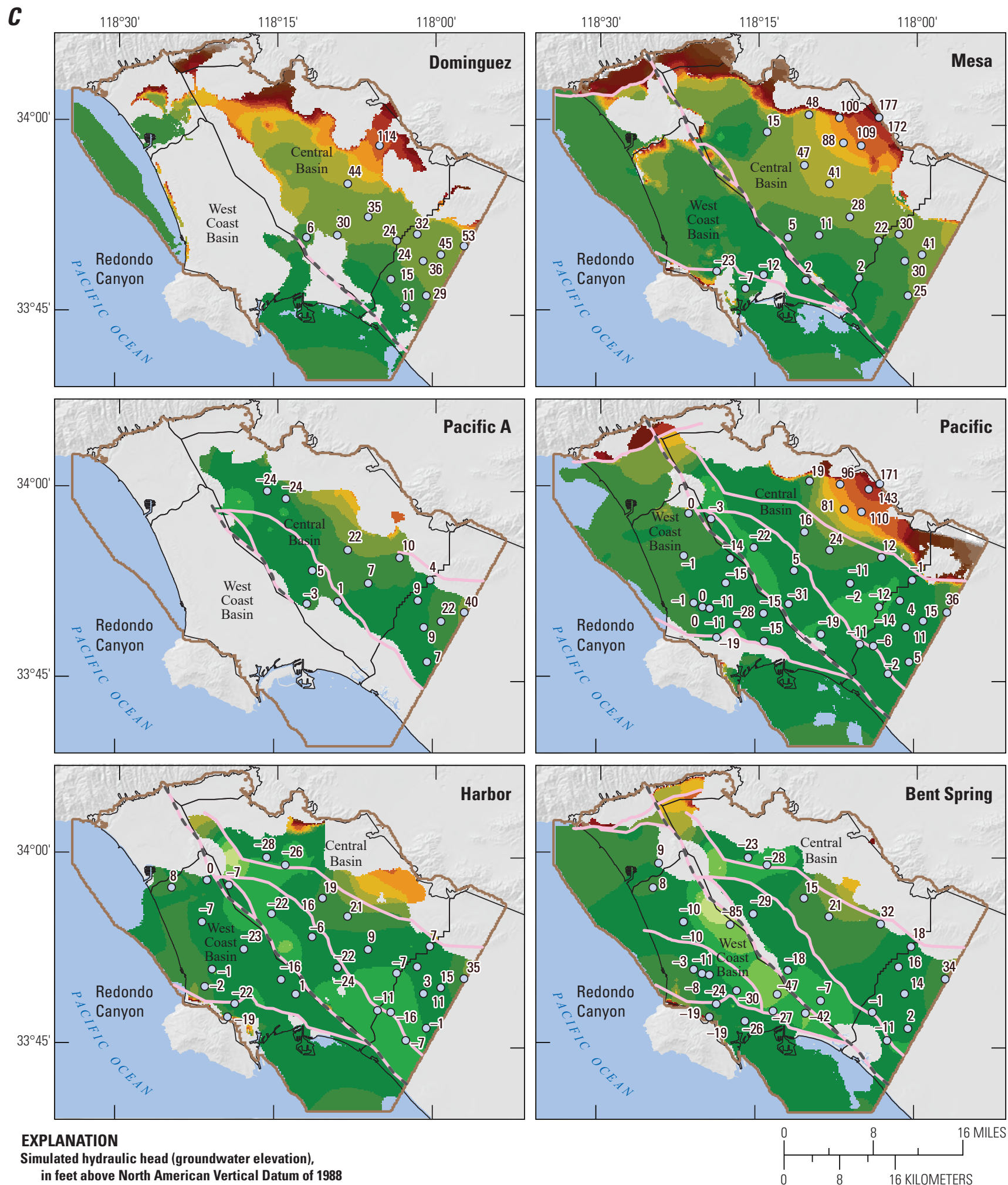

Simulated hydraulic head (groundwater elevation),

in feet above North American Vertical Datum of 1988

\begin{tabular}{|c|c|c|c|c|}
\hline-180 to -160 & -59 to -40 & 60 to 80 & 180 to 200 & 300 to 320 \\
\hline-159 to -140 & -39 to -20 & 80 to 100 & 200 to 220 & 320 to 340 \\
\hline-139 to -120 & -19 to 0 & 100 to 120 & 220 to 240 & 340 to 360 \\
\hline-119 to -100 & 0 to 20 & 120 to 140 & 240 to 260 & 360 to 380 \\
\hline-99 to -80 & 20 to 40 & 140 to 160 & 260 to 280 & 380 to 400 \\
\hline-79 to -60 & 40 to 60 & 160 to 180 & 280 to 300 & greater than 400 \\
\hline
\end{tabular}

$\checkmark$ Los Angeles Coastal Plain Groundwater Model boundary

Model flow barrier-Dashed line shows location of

Newport-Inglewood fault zone

Basin boundary

O Well with observed groundwater elevation, in feet

Figure D10.-Continued 
D
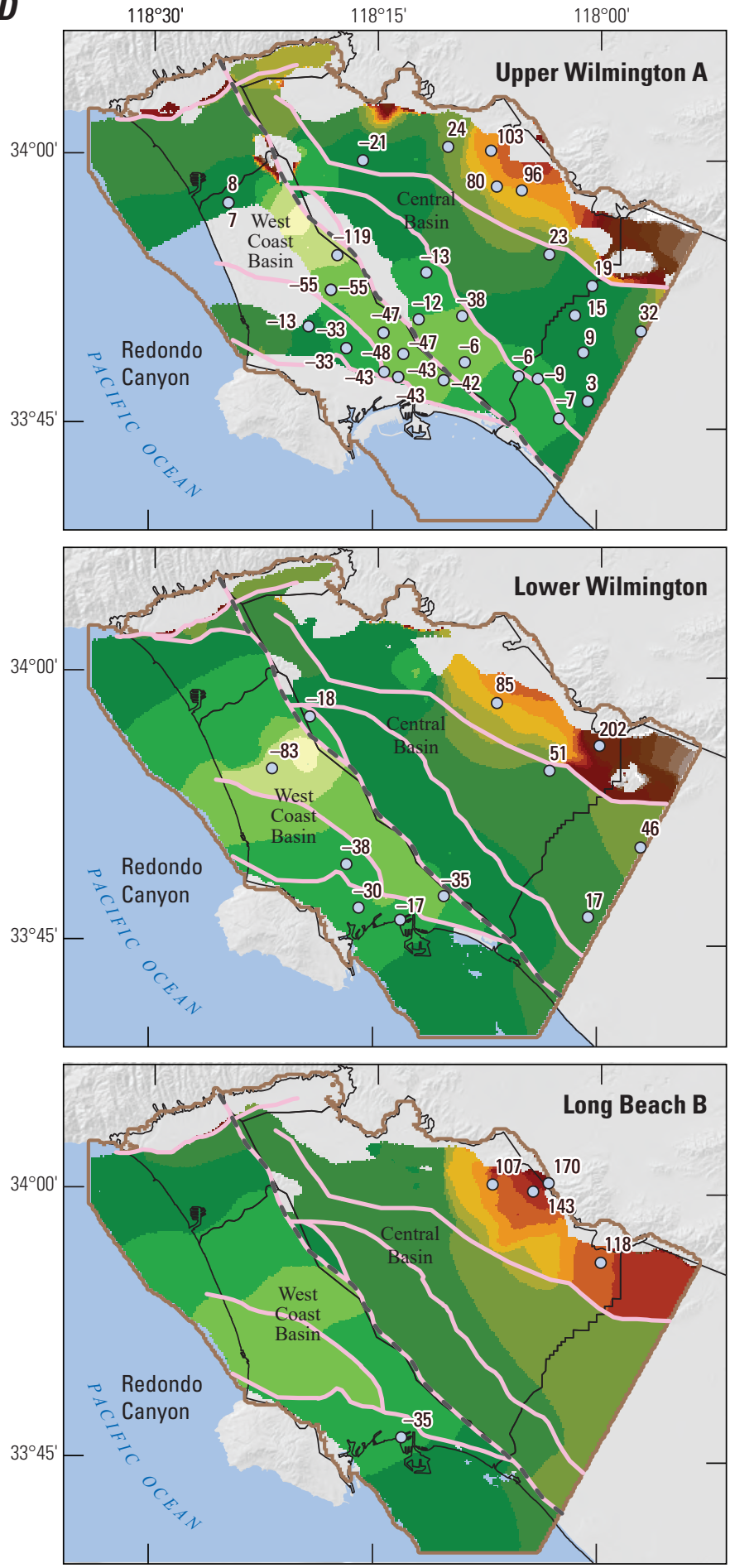

\section{EXPLANATION}

Simulated hydraulic head (groundwater elevation), in feet above North American Vertical Datum of 1988

\begin{tabular}{|c|c|}
\hline-180 to -160 & -59 to -40 \\
\hline-159 to -140 & -39 to -20 \\
\hline-139 to -120 & -19 to 0 \\
\hline-119 to -100 & 0 to 20 \\
\hline-99 to -80 & 20 to 40 \\
\hline-79 to -60 & 40 to 60 \\
\hline
\end{tabular}

60 to 80
80 to 100
100 to 120
120 to 140
140 to 160
160 to 180

180 to 200 200 to 220 220 to 240 240 to 260 260 to 280 280 to 300

360 to 380

380 to 400
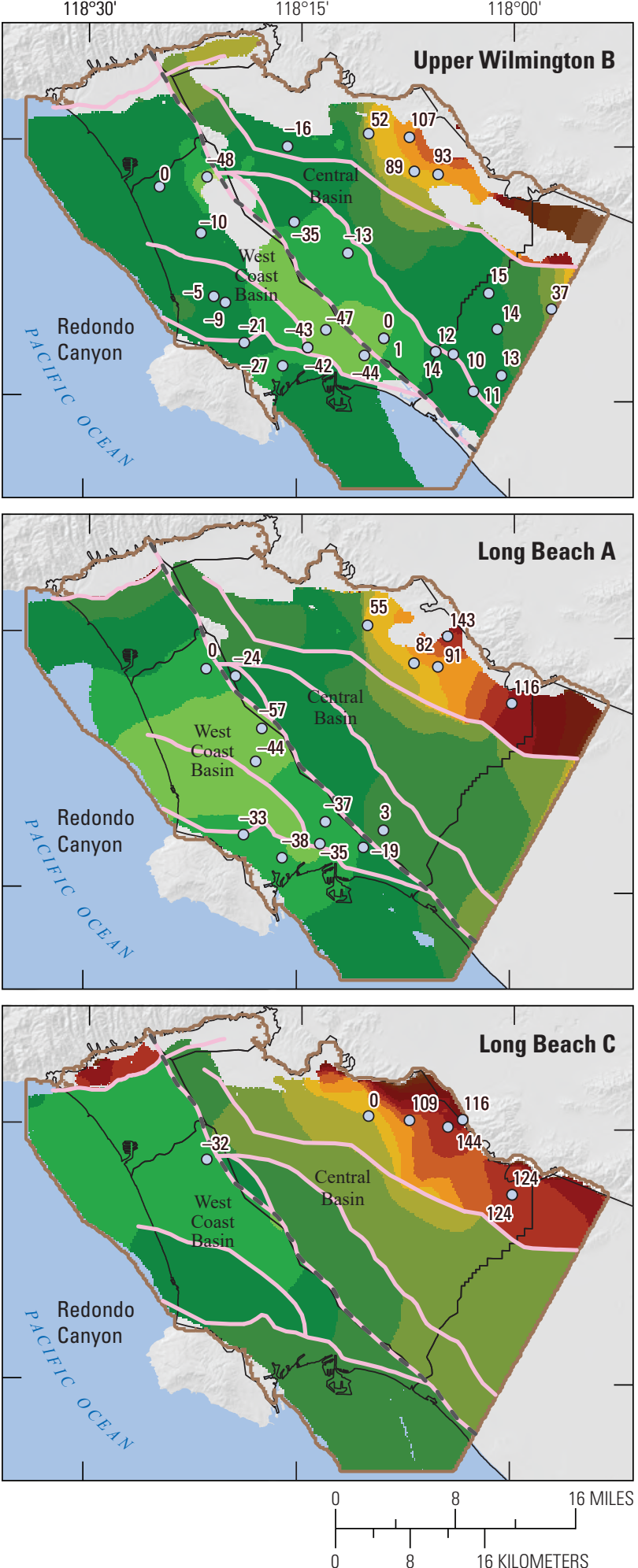

$\checkmark$ Los Angeles Coastal Plain Groundwater Model boundary

Model flow barrier-Dashed line shows location of

Newport-Inglewood fault zone

greater than 400
Basin boundary

- Well with observed groundwater elevation, in feet

Figure D10.-Continued 


\section{Pacific A Aquifer System}

The Pacific A aquifer system does not extend into the Los Angeles or Whittier Narrows; therefore, fall 2013 simulated hydraulic heads in the Los Angeles and Montebello Forebays were not as high as in the overlying aquifer systems. Simulated heads were as high as $95 \mathrm{ft}$ on the northeastern edge of the aquifer system (fig. D10A). With the exception of the northeastern edge of the Pacific A aquifer system, simulated hydraulic heads were below NAVD 88 throughout the aquifer system extent, as low as about $-25 \mathrm{ft}$ near the southwestern edge (fig. D10A).

Spring 2006 simulated heads were about the same as fall 2013 simulated heads in the Los Angeles Forebay, up to $15 \mathrm{ft}$ lower in the northern Central Basin Pressure Area, and as much as $30 \mathrm{ft}$ higher in the central and southern Central Basin Pressure Area (figs. D10A, D10C). In general, simulated heads agreed well with measured heads (fig. D10A). Groundwater flow within the Pacific A aquifer system was impeded by (1) the Newport-Inglewood fault zone and (2) the Santa Fe Springs anticline and related structures (figs. D10A, B4). These two structural features do not cross much of the Pacific A aquifer system and, therefore, likely had a limited effect on groundwater flow.

\section{Pacific Aquifer System}

The Pacific aquifer system extends to the Whittier Narrows in the Montebello Forebay but does not extend to the Los Angeles Narrows in the Los Angeles Forebay (fig. D10A). Fall 2013 simulated hydraulic heads in this system were highest in the Montebello Forebay, exceeding $150 \mathrm{ft}$ in the northernmost part of the Forebay (fig. D10A). Simulated heads are 5 to $20 \mathrm{ft}$ higher than measured heads in the Montebello Forebay (fig. D10A). Simulated heads declined steeply to about $10 \mathrm{ft}$ at the western edge of the Montebello Forebay, then continued to decline in high-pumping areas in the southeastern part of the Central Basin Pressure Area, where simulated heads were as low as $-45 \mathrm{ft}$ (fig. D10A). Simulated heads indicated that groundwater flows from the southeastern model margin in the Orange County Basin toward the pumping depression in the southwestern part of the Central Basin Pressure Area (fig. D10A).

Spring 2006 simulated heads were more than $20 \mathrm{ft}$ higher than simulated fall 2013 heads in much of the Montebello Forebay, 20 to $35 \mathrm{ft}$ higher in much of eastern Central Basin Pressure Area, and $5 \mathrm{ft}$ higher to $10 \mathrm{ft}$ lower in the Los Angeles Forebay and far western Central Basin Pressure Area (figs. D10A, D10C). Simulated heads in the pumping depression were about $10 \mathrm{ft}$ lower than measured heads (fig. D10A), which may have been because the LACPGM averages pumping quarterly; therefore, intra-quarterly fluctuations in pumping and corresponding effects on heads in nearby monitoring wells were not simulated.
In the West Coast Basin, fall 2013 simulated heads were above sea level in the northwestern part of the groundwater basin and along the West Coast Basin Barrier Project in the western part of the basin (fig. D10A). In the interior and along the southern coastline of the West Coast Basin, simulated heads were mostly below NAVD 88 , as low as about $-20 \mathrm{ft}$ (fig. D10A). Simulated heads below NAVD 88 along the coast indicated that there was a potential for seawater intrusion into the Pacific aquifer system.

Spring 2006 simulated heads in the West Coast Basin were about 0 to $10 \mathrm{ft}$ higher than fall 2013 simulated heads (fig. D10C). The PCH fault juxtaposes the Pacific aquifer system opposite older aquifer systems on the ocean side of the fault, which probably retards lateral migration of intruding seawater (see figs. B1, B4, B21). Simulated heads in much of the West Coast Basin were mostly within $5 \mathrm{ft}$ of measured heads (fig. D10A). Groundwater flow in the Pacific aquifer system was impeded by (1) the Newport-Inglewood fault zone; (2) Santa Monica, PCH, and (parts of) the Compton-Los Alamitos fault; and (3) Santa Fe Springs anticline and related structures. The Los Alamitos fault does not cut the Pacific aquifer system, but the steep fold of the system at this fault may have impeded flow (fig. B4).

\section{Harbor Aquifer System}

Fall 2013 simulated hydraulic heads in the Harbor aquifer system followed the same general patterns as simulated hydraulic heads in the Pacific aquifer system, except that heads in the Harbor aquifer system generally were slightly lower (fig. D10A). Simulated heads in the Central Basin Pressure Area were mostly within $10 \mathrm{ft}$ of measured heads (fig. C1, D10A). Simulated heads along the Newport-Inglewood fault zone were about $20 \mathrm{ft}$ lower on the Central Basin side of the fault zone than on the West Coast Basin side, indicating the fault zone acts as a barrier to groundwater flow (fig. D10A). Simulated heads were at or below NAVD 88 throughout most of the West Coast Basin and generally decreased in altitude near the West Coast Basin Barrier Project to less than $-20 \mathrm{ft}$ in the eastern part of the groundwater basin (fig. A1, D10A).

Spring 2006 simulated heads were $20 \mathrm{ft}$ to more than $40 \mathrm{ft}$ higher than fall 2013 heads in the Montebello Forebay and throughout all but the northern part of the Central Basin Pressure Area (figs. C1, D10A, D10C). Spring 2006 simulated heads agreed closely with fall 2013 heads in the Los Angeles Forebay and northern Central Basin Pressure Area, and up to $10 \mathrm{ft}$ higher than fall 2013 simulated heads in West Coast Basin. Simulated heads in the Harbor aquifer system were mostly within $10 \mathrm{ft}$ of measured heads in the West Coast Basin (fig. C1, D10A). Groundwater flow in the Harbor aquifer system was impeded by (1) the Newport-Inglewood fault zone; (2) PCH fault; and (3) parts of the Compton-Los Alamitos fault and Santa Fe Springs anticline and related structures. 


\section{Bent Spring Aquifer System}

In the Central Basin, the Bent Spring aquifer system is present mainly in the Central Basin Pressure Area (fig. C1, D10A). Simulated fall 2013 hydraulic heads were as high as about $50 \mathrm{ft}$ in the northeastern part of the Central Basin where the Bent Spring aquifer system extends into the western part of the Montebello Forebay (fig. C1, D10A). From the northeastern edge of the Central Basin, simulated fall 2013 heads steeply declined from the northeastern edge of the Central Basin to below NAVD 88 in the southern part of the groundwater basin, where they reached a low of near $-70 \mathrm{ft}$ (fig. C1, D10A). Simulated heads were within $10 \mathrm{ft}$ of measured heads throughout most of the Central Basin. Spring 2006 simulated heads were up to $50 \mathrm{ft}$ higher than fall 2013 heads everywhere in the Central Basin Pressure Area and the Los Angeles Forebay except in the northwestern Central Basin Pressure Area where heads were up to $10 \mathrm{ft}$ lower than fall 2013 heads (figs. C1, D10A, D10C).

In the West Coast Basin, simulated fall 2013 heads were below NAVD 88 throughout most of the groundwater basin, ranging from near NAVD 88 along the western coast to as low as $-70 \mathrm{ft}$ in the northeastern part of the West Coast Basin (fig. C1, D10A). In the eastern part of the West Coast Basin, simulated heads were at least $20 \mathrm{ft}$ lower than simulated heads in the overlying Harbor aquifer system (fig. C1, $\mathrm{D} 10 \mathrm{~A})$. Simulated heads were within $10 \mathrm{ft}$ of measured heads in most of West Coast Basin, with the exception of the northeastern part of the groundwater basin at well $13 \mathrm{~J} 7$ (3S/14W-13J7; fig. C1, D10A), where measured heads were more than $30 \mathrm{ft}$ lower than simulated heads. Cell size and an active production well near well $13 \mathrm{~J} 7$ may have caused scaling errors that contributed to large differences between measured and simulated heads in the northeastern part of the West Coast Basin (fig. A3, C5B). Spring 2006 simulated heads were mostly within $10 \mathrm{ft}$ of fall 2013 heads, with heads up to $10 \mathrm{ft}$ higher in the central part of the West Coast Basin and heads within $5 \mathrm{ft}$ near multiple-well monitoring site 4R1-7 (3S/14W-4R1 to 4R7; fig. A3; figs. D10A, D10C). Groundwater flow in the Bent Spring aquifer system was impeded by (1) the Newport-Inglewood fault zone; (2) the Santa Monica, Compton-Los Alamitos, $\mathrm{PCH}$, and Alondra faults; and (3) parts of the Santa Fe Springs anticline and related structures impede groundwater flow in the Bent Spring aquifer system.

\section{Upper Wilmington A Aquifer System}

In the Central Basin, the Upper Wilmington A aquifer system extends to higher elevations in the Los Angeles and Montebello Forebays compare to the overlying Bent Spring aquifer system; consequently, fall 2013 simulated hydraulic heads in the forebays were higher in the Upper Wilmington A aquifer system than in the Bent Spring aquifer system (figs. D10A, D10B). Simulated heads were as high as about 200 and $100 \mathrm{ft}$ in the upper parts of the Los Angeles and Montebello Forebays, respectively, but declined steeply to below NAVD 88 in the eastern part of the Central Basin Pressure Area (fig. D10B). Simulated heads were the highest in the Whittier area of the Central Basin, where the Santa Fe Springs anticline effectively retards groundwater flow from the Whittier area to the Central Basin Pressure Area. Simulated heads were nearly $290 \mathrm{ft}$ in the northeastern part of the Whittier area but were $-20 \mathrm{ft}$ in the Central Basin Pressure Area south of the Santa Fe Springs anticline (fig. D10B). Simulated heads declined to as low as $-95 \mathrm{ft}$ on the west side of the Compton-Los Alamitos fault. Simulated declines likely resulted from (1) the barrier effect of the Compton-Los Alamitos fault and the Newport-Inglewood fault zone to the west, which compartmentalizes the western part of the Central Basin Pressure Area and (2) folding that uplifted the Upper Wilmington A aquifer system in this part of the groundwater basin to a shallow enough depth such that wells are producing water from this aquifer system (see figs. B1, B4, B21). In the southwestern part of the Central Basin, the Compton-Los Alamitos fault does not cut the Upper Wilmington A aquifer system (fig. B22), which allowed the drawdown from pumping in the Seal Beach area to extend into the south-central part of the groundwater basin (fig. D10B). Simulated hydraulic heads were 0 to $10 \mathrm{ft}$ above measured heads in the Montebello Forebay and southern Central Basin (fig. D10B). Spring 2006 simulated heads ranged from within 1 foot of fall 2013 simulated heads in the northwestern Los Angeles Forebay and Central Basin Pressure Area to over $70 \mathrm{ft}$ higher than fall 2013 simulated heads in parts of the southwestern Central Basin (figs. D10B, D10D).

In the West Coast Basin, fall 2013 simulated heads ranged from $10 \mathrm{ft}$ to less than $-80 \mathrm{ft}$ of NAVD 88 and only exceeded NAVD 88 near the barrier wells (fig. D10B). Simulated heads in the West Coast Basin were mostly within $10 \mathrm{ft}$ of measured heads, with the exception of monitoring well $13 \mathrm{~J} 6$ (3S/14W-13J6; fig. A3) in the northeastern part of the groundwater basin (fig. D10B). In well 13J6, measured heads were $-111 \mathrm{ft}$ and simulated heads were about $-90 \mathrm{ft}$. Well $13 \mathrm{~J} 6$ is in close proximity to a production well, which probably caused scaling errors that resulted in differences in simulated and measured heads, as described previously. Spring 2006 simulated heads ranged from about $15 \mathrm{ft}$ lower than fall 2013 simulated heads in the northwestern West Coast Basin to about $5 \mathrm{ft}$ higher than fall 2013 simulated heads in the central and southern West Coast Basin (figs. D10B, D10D). Groundwater flow in the Upper Wilmington A aquifer system was impeded by (1) the Newport-Inglewood fault zone; (2) the Santa Monica, Compton-Los Alamitos, $\mathrm{PCH}$, and Alondra faults; and (3) parts of the Santa Fe Springs anticline and related structures. 


\section{Upper Wilmington B Aquifer System}

Fall 2013 simulated hydraulic heads in the Upper Wilmington B aquifer system in the Central Basin were similar to fall 2013 simulated hydraulic heads in the Upper Wilmington A aquifer system, with the exception of the Central Basin Pressure Area west of the Compton-Los Alamitos fault (fig. D10B). In the area west of the Compton-Los Alamitos fault, simulated heads for the Upper Wilmington B aquifer system ranged from -40 to $-90 \mathrm{ft}$, which was slightly higher than simulated heads in the Upper Wilmington A aquifer system. Spring 2006 simulated heads ranged from about the same as fall 2013 simulated heads in northwestern Central Basin to more than $45 \mathrm{ft}$ higher than fall 2013 simulated heads in the southeastern Central Basin (figs. D10B, D10D).

Fall 2013 simulated heads for the Upper Wilmington $\mathrm{B}$ aquifer system in the West Coast Basin were similar to or slightly higher than simulated heads for the Upper Wilmington A aquifer system, where both aquifer systems are present (fig. D10B). The Upper Wilmington B aquifer system is not present in the northeastern part of the groundwater basin, where simulated pumping in the Upper Wilmington A aquifer system resulted in simulated heads of $-70 \mathrm{ft}$ (fig. D10B). Pumping in the northeastern West Coast Basin did not cause declines in the Upper Wilmington B aquifer system, where the system is present west of the pumping center at well $17 \mathrm{G} 4$ (3S/14W-17G4; figs. A3, D10B). Reichard and others (2003) concluded that a southeastern extension of the Charnock fault caused water-level offsets and prevented head changes in response to pumping. However, the chronostratigraphic model developed for this study indicated that the Charnock fault only extends up into the "Repetto" rock unit and does not cut the overlying units (see Chapter B; fig. B5). Data collected for this study indicated that the deposition of the Upper Wilmington A chronostratigraphic unit coincided with erosion and complete removal of the Upper Wilmington B unit in the northeastern West Coast Basin, forming a channel with different hydraulic properties on either side of the channel wall. This channelization is the suspected reason for observed water-level offsets and the lack of response to pumping in wells west of the pumping center in the Upper Wilmington B aquifer system (fig. D10B). Spring 2006 simulated heads were mostly about 0 to $10 \mathrm{ft}$ higher than fall 2013 heads, with the exception of the northeastern West Coast Basin where spring 2006 simulated heads were up to $10 \mathrm{ft}$ lower than fall 2013 simulated heads (figs. D10B, D10D). Groundwater flow in the Upper Wilmington B aquifer system was impeded by
(1) the Newport-Inglewood fault zone; (2) the Compton-Los Alamitos, $\mathrm{PCH}$, and Alondra faults; and (3) parts of the Santa Fe Springs anticline and related structures.

\section{Lower Wilmington Aquifer System}

Fall 2013 simulated hydraulic heads in the Lower Wilmington aquifer system in the Central Basin were similar to fall 2013 simulated hydraulic heads in the Upper Wilmington B aquifer system. However, fall 2013 simulated hydraulic heads in the Lower Wilmington aquifer system were slightly lower in the Montebello Forebay and 20 to $40 \mathrm{ft}$ higher in the Central Basin Pressure Area west of the Compton-Los Alamitos fault compared to fall 2013 simulated hydraulic heads in the Upper Wilmington B aquifer system (fig. D10B). Simulated heads were 0 to $10 \mathrm{ft}$ higher than measured heads in the Montebello Forebay and within $15 \mathrm{ft}$ of measured heads in most of the Central Basin Pressure Area (fig. D10B). Spring 2006 simulated heads were mostly higher than fall 2013 simulated heads in the Central Basin, with simulated heads 0 to $15 \mathrm{ft}$ higher in the northwestern Central Basin, 15 to $50 \mathrm{ft}$ higher in the central Central Basin, and 10 to $25 \mathrm{ft}$ higher in the southwestern and southeastern Central Basin (figs. D10B, D10D).

Fall 2013 simulated hydraulic heads in the Lower Wilmington aquifer system in the West Coast Basin ranged from as high as $-25 \mathrm{ft}$ on the northwest and southeastern ends of the groundwater basin to as low as $-80 \mathrm{ft}$ in the northeastern end of the groundwater basin (fig. D10B). Pumping in the northeastern part of the groundwater basin caused a drawdown cone in both simulated and measured heads that extends to the west (fig. D10B). The presence of the drawdown cone provided further evidence that the Charnock fault is not a barrier to flow in the West Coast Basin. Instead, the groundwater barrier effect observed in the overlying Upper Wilmington A and B aquifer systems likely is related to the previously discussed channelization in those units. In general, simulated hydraulic heads reasonably matched measured heads in the West Coast Basin (fig. D10B). Spring 2006 simulated heads were up to $10 \mathrm{ft}$ lower than fall 2013 simulated heads in the northern West Coast Basin and up to $10 \mathrm{ft}$ higher than fall 2013 simulated heads in the southern West Coast Basin (figs. D10B, D10D). Groundwater flow in the Lower Wilmington aquifer system was impeded by (1) the Newport-Inglewood fault zone; (2) the Compton-Los Alamitos, $\mathrm{PCH}$, and Alondra faults; and (3) parts of the Santa Fe Springs anticline and related structures. 


\section{Long Beach A Aquifer System}

Fall 2013 simulated hydraulic heads in the Long Beach A aquifer system were similar to fall 2013 simulated hydraulic heads in the Lower Wilmington aquifer system but were 10 to $20 \mathrm{ft}$ higher in the Central Basin Pressure Area west of the Compton-Los Alamitos fault (fig. D10B). In the West Coast Basin, simulated heads in the Long Beach A aquifer system were similar in the overlying Lower Wilmington aquifer system but were about $20 \mathrm{ft}$ higher in the pumping depression in the northeastern part of the groundwater basin (fig. D10B). Simulated heads were mostly between 0 and $20 \mathrm{ft}$ higher than measured heads, except for the northwestern West Coast Basin where simulated heads were more than $30 \mathrm{ft}$ higher than measured heads (fig. D10B). Spring 2006 simulated heads were 10 to $25 \mathrm{ft}$ higher in the Montebello Forebay than fall 2013 simulated heads, 0 to $10 \mathrm{ft}$ higher in the Los Angeles Forebay and Central Basin Pressure Area, and $5 \mathrm{ft}$ lower to $5 \mathrm{ft}$ higher in West Coast Basin (figs. D10B, D10D). Groundwater flow in the Long Beach A aquifer system was impeded by (1) the Newport-Inglewood fault zone; (2) the Compton-Los Alamitos, $\mathrm{PCH}$, and Alondra faults; and (3) parts of the Santa Fe Springs anticline and related structures.

\section{Long Beach B Aquifer System}

Fall 2013 simulated heads in the Long Beach B aquifer system were similar to fall 2013 simulated hydraulic heads in the overlying Long Beach A aquifer system in the Central and West Coast Basins but generally were higher and showed less response to pumping (fig. D10B). Simulated heads were up to $35 \mathrm{ft}$ higher than measured heads in the Central Basin Pressure Area but were mostly within $10 \mathrm{ft}$ of measured heads in the remainder of the model area (fig. D10B). Spring 2006 simulated heads were 5 to $25 \mathrm{ft}$ higher than fall 2013 simulated heads in the Montebello Forebay, 5 to $15 \mathrm{ft}$ higher in the northeastern Central Basin, 0 to $5 \mathrm{ft}$ higher in the central and southern Central Basin, and 0 to $10 \mathrm{ft}$ lower in the West Coast Basin. Groundwater flow in the Long Beach B aquifer system was impeded by (1) the Newport-Inglewood fault zone; (2) the Compton-Los Alamitos, $\mathrm{PCH}$, and Alondra faults; and (3) parts of the Santa Fe Springs anticline and related structures.

\section{Long Beach C Aquifer System}

Simulated hydraulic heads in the Long Beach $\mathrm{C}$ aquifer system in the Central and West Coast Basins were higher than simulated heads in the Long Beach B aquifer system (fig. D10B). Simulated heads were highest in the Montebello Forebay, where they were above $220 \mathrm{ft}$ in some areas, and lowest in the northwestern West Coast Basin, where they were below $-20 \mathrm{ft}$ (fig. D10B). Simulated heads in the Long Beach $\mathrm{C}$ aquifer system were mostly within $10 \mathrm{ft}$ of measured heads in the Montebello Forebay and were within $5 \mathrm{ft}$ of measured heads in the northeastern West Coast Basin (fig. D10B). Spring 2006 simulated heads were 5 to $25 \mathrm{ft}$ higher than fall 2013 simulated heads in the northern Central Basin, 0 to $5 \mathrm{ft}$ higher than fall 2013 simulated heads in the southern Central Basin, and within $5 \mathrm{ft}$ of fall 2013 simulated heads in the West Coast Basin. Groundwater flow in the Long Beach C aquifer system was impeded by (1) the Newport-Inglewood fault zone; (2) the Santa Monica, Compton-Los Alamitos, $\mathrm{PCH}$, and Alondra faults; and (3) parts of the Santa Fe Springs anticline and related structures.

\section{Model-Parameter Sensitivity}

A sensitivity analysis evaluates the sensitivity of model results to variations in model input parameters. The input parameters for the LACPGM included (1) areal recharge, (2) aquifer system properties (HK, VK, specific yield, and specific storage), (3) HFB hydraulic-characteristic values, (4) GHB conductances and heads, (5) CLN parameters, and (6) drain conductance. Each of the input parameters was assigned according to zones or segments for each layer of the mode1 (figs. D1, D2A, D7, D8). Because there were 12 active model layers, there were a large number of parameters $(1,726)$ to estimate for the LACPGM: 17 areal recharge, $381 \mathrm{HK}$, 381 VK, 381 specific yield, 381 specific storage, 147 HFB, and 88 GHB parameters.

Model-parameter sensitivity analyses were done using PEST, an automatic parameter inversion program. PEST calculates an objective-function value based on the weighted sum of squared differences between measured and simulated results (Doherty, 2010). Parameter sensitivity is determined by the amount the objective function changes when a parameter is varied incrementally. The more the objective function changes when a parameter is varied, the more sensitive the objective function is to that parameter. There were three main types of observations - or values derived from observations - used to calibrate the model: (1) hydraulic-head, (2) change in hydraulic-head, and (3) vertical difference in hydraulic-head. Sensitivities with respect to each parameter were computed for contributions to the objective function from four subsets of observations: (1) all observations (the complete objective function), (2) head observations only, (3) drawdown observations only, and (4) vertical head difference observations only. 
Composite scale sensitivity (CSS), described in Doherty (2010), can help evaluate the relative sensitivities with respect to groups of parameters (for example, all horizontal hydraulic conductivity parameters). The groups of parameters evaluated for composite scale sensitivity were (1) HK, (2) VK, (3) specific storage, (4) specific yield, (5) general-head boundary, and (6) recharge, and horizontal-flow barrier parameters. Composite scale sensitivities help show relative sensitivities with respect to parameter groups that may not be obvious from an evaluation of sensitivities with respect to single parameters. For example, recharge parameters were among the most sensitive parameters, but their composite sensivitity was lower than other parameter groups. The fewer parameters there are in a parameter group, the greater the average individual sensitivity of each parameter. Since there are considerably fewer recharge parameters than there are HK and VK parameters, individual recharge parameters have a higher sensitivity as a percentage of the recharge group sensitivity than the HK and VK parameters sensitivities as a percentage of the HK and VK group sensitivities.

The parameter types and their upper and lower bounds are shown in table D4, and the naming convention of the parameters is described in table D5. The types of parameters to which the composite of all observations (the complete objective function) was most sensitive were HK parameters and areal-recharge parameters (fig. D11A). The five most sensitive individual parameters were rch_mlt_1 (areal-recharge multiplier zone 1; fig. D2A), geohk05-34 (HK layer 5 zone 34), rch_mlt_10 (areal-recharge multiplier zone 10), geohk03-01 (HK layer 3 zone 1), and geohk03-07 (HK layer 3 zone 7). Parameter geohk05-34 controlled the HK of Pacific layer in the eastern Central Basin and the Orange County. Observations were most likely sensitive to geohk05-34 because it regulated flow between the Central Basin and Orange County. Parameters rch_mlt_1 and rch_mlt_10 controlled the amount of areal recharge in the eastern Whittier and northern Orange County areas and the northern West Coast Basin, respectively. Observations were most likely sensitive to rch_mlt_1 (Zone 1, fig. D02A) due to its upgradient location and rch_mlt_10 (Zone 10, fig. D02A) due to the large area of recharge it controls. Parameters geohk03-01 and geohk03-07 controlled the HK of the Mesa layer in the northern and southern regions of the Montebello Forebay, respectively. Observations were sensitive to geohk03-01 and geohk03-07 because they are two of the key parameters that regulated the rate of flow from the spreading grounds and the Whittier Narrows into the Central Basin.

The 30 parameters that observations were most sensitive to also included one VK parameter (geovk04-03) and one GHB conductance parameter (ghbwht_mes). Geovk04-03 controlled VK between the Pacific A layer and the layer above it in the Central Basin Pressure Area just south of the Montebello Forebay. Heads between the Pacific A layer and the layer above it were up to $50 \mathrm{ft}$ different in this area. Observations were sensitive to geovk04-03 because it controlled the VK between the Pacific A layer and the layer above it and therefore influenced the vertical separation in heads in this area. Parameter wht_mes controlled the conductance of the Whittier Narrows GHB in the Mesa layer, where the majority of the $36,000 \mathrm{acre}-\mathrm{ft} / \mathrm{yr}$ of underflow from the San Gabriel Valley entered the model.

The most sensitive parameters for hydraulic-head observations were those for areal recharge (for example, rech mult 1, 10 and 11) and HK (fig. D11B). The most sensitive parameters for change in hydraulic-head observations included a variety of different types, including (1) areal-recharge parameters, (2) specific-yield parameters, (3) specific-storage parameters, (4) HK and VK parameters, and (5)

horizontal-flow barrier conductance parameters (fig. D11C). Sensitivities varied much less for the change in hydraulic-head observations than any other observation type. The most sensitive parameters for vertical difference in hydraulic-head observations were HK, VK, and areal recharge (fig. D11D). More of the areal-recharge parameters were sensitive for the hydraulic-head observations than for all simulated values. The two most sensitive parameters for hydraulic-head observations and 8 of the top 30 most sensitive parameters to hydraulic-head observations were areal recharge parameters (fig. D11B). In contrast only 6 of the top 30 most sensitive parameters for all simulated values were areal recharge.

CSS values are shown in figure D12. Observations were most sensitive to the HK parameter group, followed by VK, specific-yield, and $\mathrm{GHB} / \mathrm{RCH}$ parameter groups (fig. D12). Observations were considerably less sensitive to the horizontal-flow barrier parameter group. While recharge parameters were among the most sensitive (fig. D11), the composite sensivitity of the recharge parameter group was lower than the composite sensitivities of most other parameter groups (fig. D12).

\section{Simulated Regional Groundwater Budget and Flow Between Subareas}

The calibrated LACPGM was used to evaluate the average annual groundwater budget by model layer and subarea, averaged over the 45 -year simulation period, 1971 to 2015 (table D6) and for a shorter 10-year simulation period, 2006-15 (table D7). The average-annual budget also was simulated for the entire model area and each model subarea for 1971 to 2015 to show changes in the major budget components over time (fig. D13 and appendix 4, fig. 4.1). Average annual model-simulated lateral flows between model subareas and vertical flows between model layers were used to quantify groundwater flow within the LACPGM (fig. D14 and appendix 4, fig. 4.2). 
$\boldsymbol{A}$

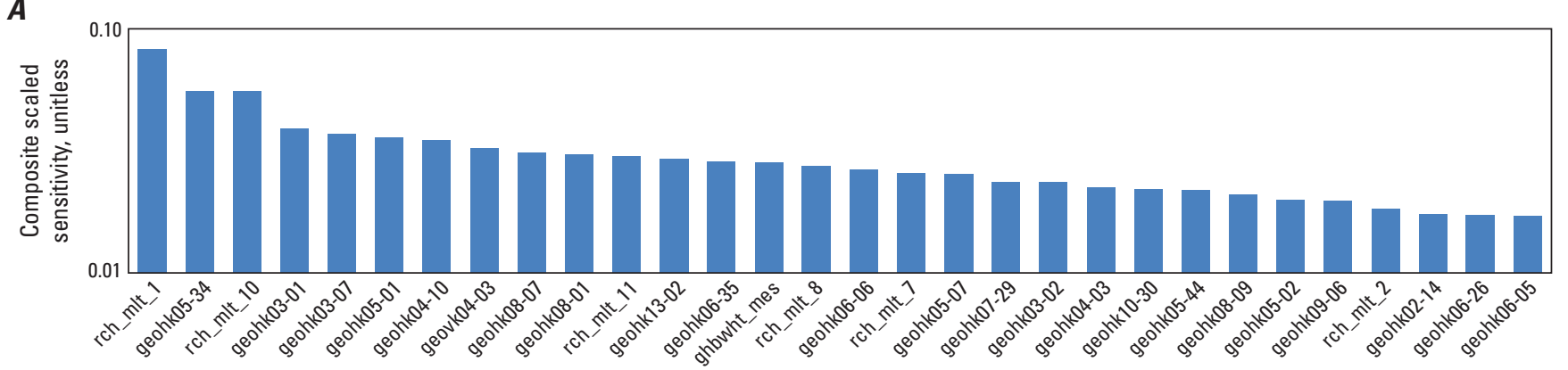

B

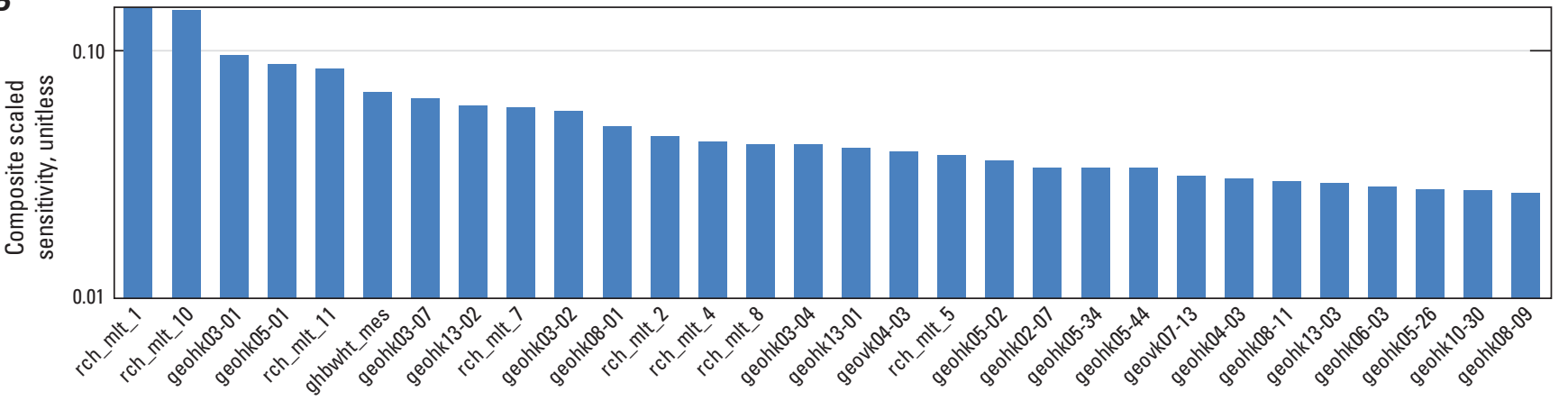

C

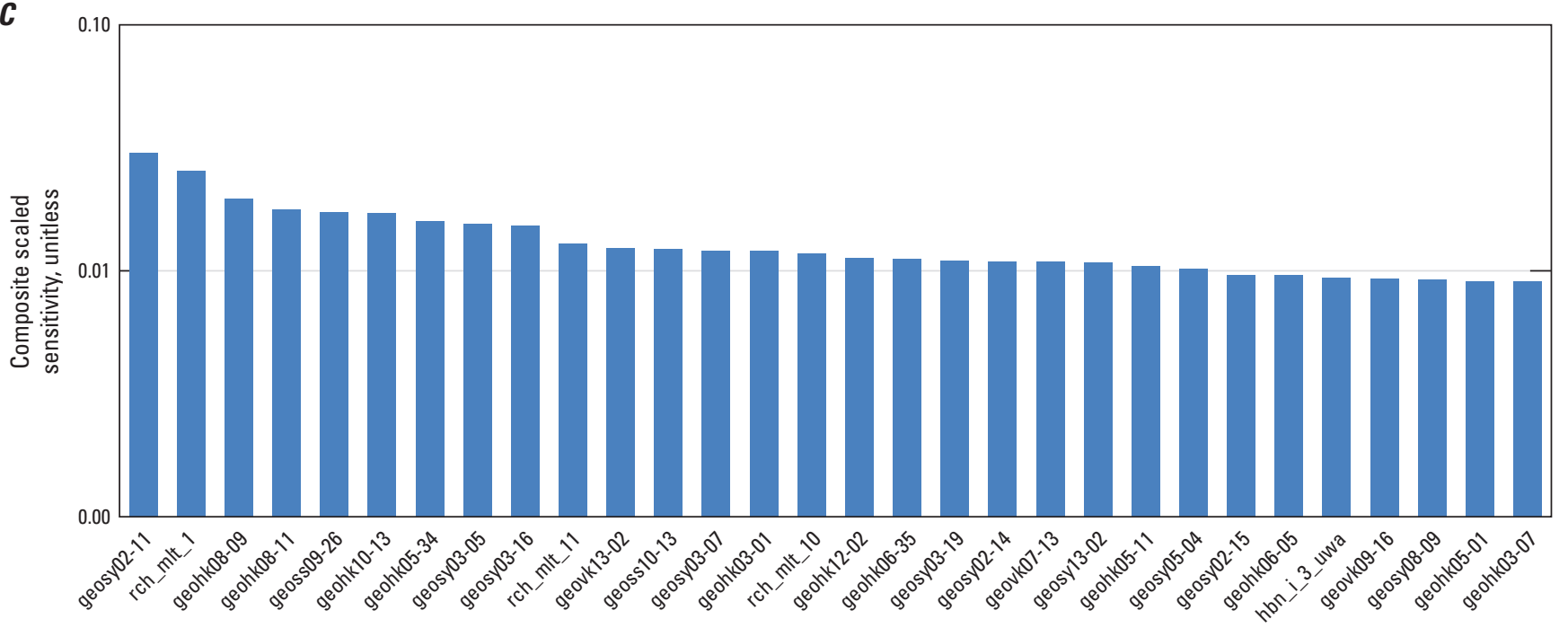

D

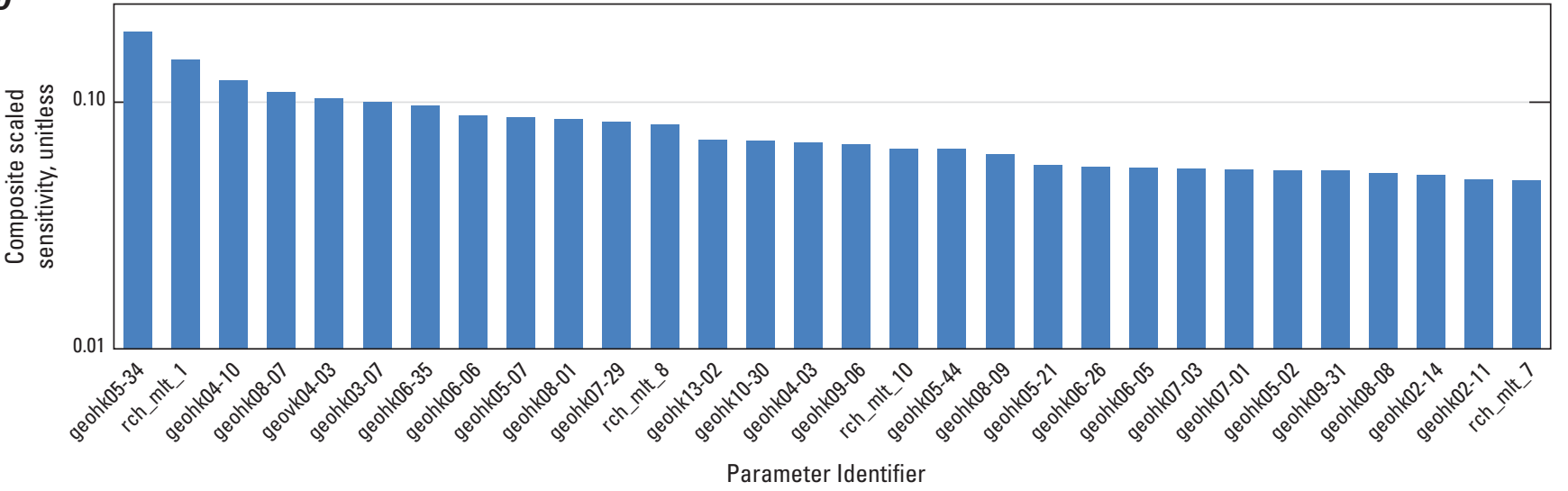

Figure D11. Top 30 parameters with high observation sensitivity values for $A$, all simulated values; $B$, hydraulic heads only; $C$, changes in hydraulic head only; and $D$, vertical differences in hydraulic head only, Los Angeles Coastal Plain Groundwater-flow Model, Los Angeles and Orange Counties, California. 
Table D4. Parameter type and upper and lower bound for parameters in the Los Angeles Coastal Plain Groundwater-flow Model.

$\left[\mathrm{ft}^{2} / \mathrm{day}\right.$, square foot per day; $\mathrm{ft} / \mathrm{day}$, foot per day; $\mathrm{ft}^{-1}$, per foot]

\begin{tabular}{lcc}
\hline \multicolumn{1}{c}{ Parameter type } & $\begin{array}{c}\text { Lower } \\
\text { bound }\end{array}$ & $\begin{array}{c}\text { Upper } \\
\text { bound }\end{array}$ \\
\hline Drain (DRN) conductance (ft ${ }^{2} /$ day) & $1.00 \mathrm{E}-04$ & $1.00 \mathrm{E}+06$ \\
General head boundary (GHB) conductance ( $\left.\mathrm{ft}^{2} / \mathrm{day}\right)$ & $1.00 \mathrm{E}-04$ & $1.00 \mathrm{E}+06$ \\
Horizonal flow barrier (HFB) conductance $\left(\mathrm{ft}^{2} /\right.$ day) & $1.00 \mathrm{E}-10$ & $1.00 \mathrm{E}+05$ \\
Horizontal hydraulic conductivity (HK; ft/day) & $1.00 \mathrm{E}-09$ & $1.50 \mathrm{E}+03$ \\
Areal recharge (RCH) multiplier (unitless) & $5.00 \mathrm{E}-01$ & $2.00 \mathrm{E}+00$ \\
Specific storage (SS) (ft ${ }^{1}$ ) & $1.00 \mathrm{E}-06$ & $1.00 \mathrm{E}-04$ \\
Specific yield (SY) & $1.00 \mathrm{E}-06$ & $3.00 \mathrm{E}-01$ \\
Vertical hydraulic conductivity (VK; ft/day) & $1.00 \mathrm{E}-09$ & $1.50 \mathrm{E}+03$ \\
\hline
\end{tabular}

Table D5. Parameter code explanation for the Los Angeles Coastal Plain Groundwater-flow Model.

\begin{tabular}{|c|c|c|c|}
\hline Parameter type & Name construction & Example & Example description \\
\hline $\begin{array}{l}\text { General head boundary (GHB) con- } \\
\text { ductance }\end{array}$ & ghb $<$ name $>_{-}<$layer $>_{-}<$subname $>$ & ghboc_dm_mn & $\begin{array}{l}\text { GHB for Orange County Dominguez layer } \\
\text { mid-north }\end{array}$ \\
\hline $\begin{array}{l}\text { Horizonal flow barrier (HFB) conduc- } \\
\text { tance }\end{array}$ & $\mathrm{hb}<$ name $>$ _ layer $>$ & hbpch_lw & $\begin{array}{l}\text { HFB for Pacific Coast Highway fault in } \\
\text { Lower Wilmington }\end{array}$ \\
\hline Areal recharge $(\mathrm{RCH})$ multiplier & rch_mlt $<$ zone $>$ & rch_mlt_11 & $\mathrm{RCH}$ multiplier for recharge zone 11 \\
\hline Specific storage (SS) & geoss $<$ layer $>$-_zone $>$ & geoss06-08 & SS for layer 6 zone 8 \\
\hline Specific yield (SY) & geosy $<$ layer $>$ - $<$ zone $>$ & geosy03-15 & SY for layer 3 zone 15 \\
\hline Vertical hydraulic conductivity (VK) & geovk $<$ layer $>$-_zone $>$ & geovk04-03 & VK for layer 4 zone 3 \\
\hline
\end{tabular}

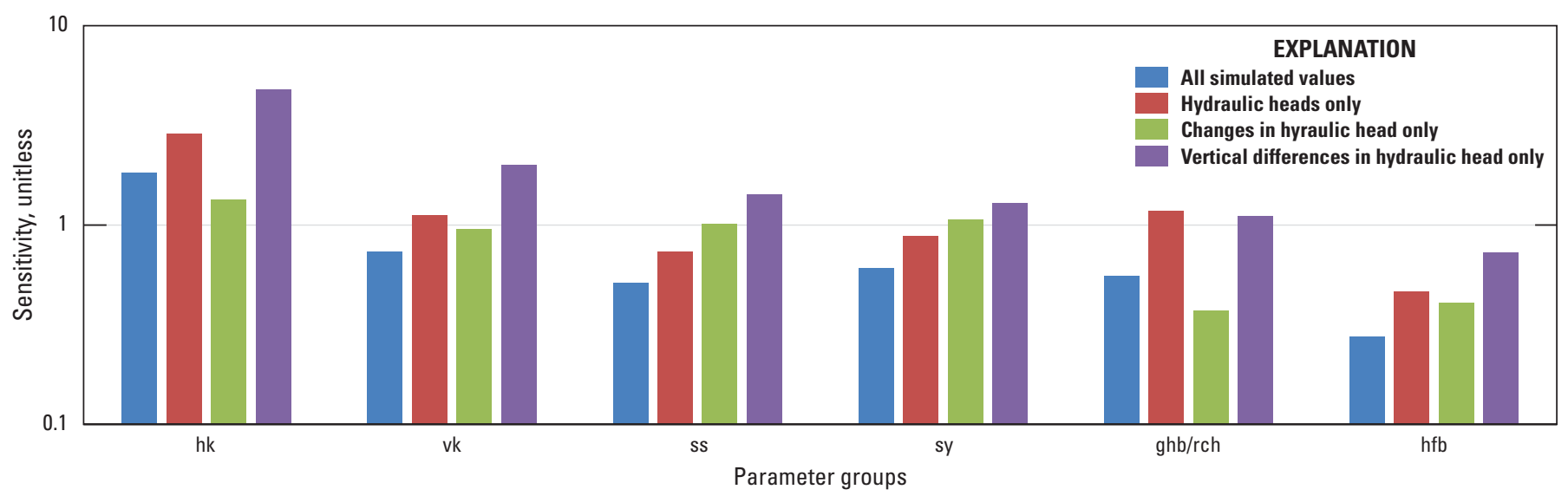

Figure D12. Composite scale sensitivity values for all simulated values, hydraulic heads only, changes in hydraulic head only, and vertical differences in hydraulic head only, for selected parameter types, Los Angeles Coastal Plain Groundwater-flow Model, Los Angeles and Orange Counties, California. 
Table D6. Simulated average 45-year water budget (acre-feet per year) by model layer and subarea of the Los Angeles Coastal Plain Groundwater-flow Model, 1971 to 2015 , Los Angeles County, California.

[Negative numbers represent groundwater removed from the model/zone, and positive numbers represent groundwater added to the model/zone. Pumping and injection by layer includes interborehole flow from all wells. Pumping and injection totals without interborehole flow included separately in this table. Abbreviation: WRD, Water Replenishment District of Southern California]

\begin{tabular}{|c|c|c|c|c|c|c|c|c|c|c|c|c|c|c|}
\hline $\begin{array}{c}\text { Chronostratigraphic unit } \\
\text { name }\end{array}$ & $\begin{array}{l}\text { Model } \\
\text { layer }\end{array}$ & $\begin{array}{c}\text { Los } \\
\text { Angeles } \\
\text { Forebay }\end{array}$ & $\begin{array}{l}\text { WRD } \\
\text { Central } \\
\text { Basin }\end{array}$ & $\begin{array}{l}\text { Orange } \\
\text { County }\end{array}$ & $\begin{array}{l}\text { West } \\
\text { Coast }\end{array}$ & $\begin{array}{l}\text { Santa } \\
\text { Monica }\end{array}$ & Hollywood & $\begin{array}{l}\text { WRD Los } \\
\text { Angeles } \\
\text { Forebay }\end{array}$ & $\begin{array}{l}\text { Montebello } \\
\text { Forebay }\end{array}$ & Whitter & $\begin{array}{l}\text { Central } \\
\text { Basin }\end{array}$ & $\begin{array}{c}\text { North } \\
\text { Orange } \\
\text { County }\end{array}$ & $\begin{array}{l}\text { South } \\
\text { Orange } \\
\text { County } \\
\end{array}$ & Total \\
\hline \multicolumn{15}{|c|}{ Pumping and net interborehole flow out } \\
\hline Dominguez & 2 & 0.00 & $-8,970$ & $-4,090$ & -32.4 & 0.00 & 0.00 & -9.5 & -308 & 0.00 & 0.00 & 0.00 & -44.8 & $-13,500$ \\
\hline Mesa & 3 & 0.00 & $-8,200$ & $-4,040$ & $-1,060$ & -403 & 0.00 & $-2,470$ & $-6,190$ & -8.3 & -8.01 & 0.00 & -73.0 & $-22,400$ \\
\hline Pacific A & 4 & 0.00 & $-33,500$ & $-10,800$ & -6.39 & 0.00 & 0.00 & -641 & $-2,390$ & 0.00 & 0.00 & 0.00 & 0.00 & $-47,400$ \\
\hline Pacific & 5 & 0.00 & $-23,600$ & $-21,500$ & $-7,570$ & $-1,100$ & -92.5 & $-7,250$ & $-18,900$ & -63.5 & -47.4 & 0.00 & $-3,220$ & $-83,400$ \\
\hline Harbor & 6 & 0.00 & $-28,600$ & $-6,300$ & $-8,370$ & 0.00 & 0.00 & $-1,250$ & $-6,540$ & -1.59 & -46.8 & 0.00 & $-1,210$ & $-52,300$ \\
\hline Bent Spring & 7 & 0.00 & $-8,240$ & $-1,100$ & $-6,720$ & $-4,580$ & -400 & $-3,130$ & $-1,280$ & 0.00 & -137 & 0.00 & -99.5 & $-25,700$ \\
\hline Upper Wilmington A & 8 & $-1,220$ & $-16,100$ & $-3,180$ & $-18,800$ & -78.2 & -344 & $-4,490$ & $-6,590$ & -10.2 & 0.00 & -15.1 & -992 & $-51,800$ \\
\hline Upper Wilmington B & 9 & 0.00 & $-6,530$ & -410 & $-2,400$ & -131 & -4.52 & -755 & -384 & -25.5 & 0.00 & -28.2 & 0.00 & $-10,700$ \\
\hline Lower Wilmington & 10 & 0.00 & $-1,920$ & 0.00 & $-5,770$ & -86.6 & 0.00 & -791 & -635 & -329 & 0.00 & -503 & 0.00 & $-10,000$ \\
\hline Long Beach A & 11 & 0.00 & -453 & 0.00 & -687 & 0.00 & 0.00 & -6.78 & -421 & -1.34 & 0.00 & -122 & 0.00 & $-1,690$ \\
\hline Long Beach B & 12 & 0.00 & -296 & 0.00 & -153 & 0.00 & 0.00 & -99.2 & -152 & -697 & 0.00 & 0.00 & 0.00 & $-1,400$ \\
\hline Long Beach C & 13 & 0.00 & 0.00 & 0.00 & 0.00 & -2.24 & 0.00 & -11.5 & $-2,940$ & 0.00 & 0.00 & 0.00 & 0.00 & $-2,950$ \\
\hline Total & & $-1,220$ & $-136,000$ & $-51,500$ & $-51,500$ & $-6,380$ & -841 & $-20,900$ & $-46,800$ & $-1,140$ & -239 & -668 & $-5,640$ & $-323,000$ \\
\hline \multicolumn{15}{|c|}{ Pumping without interborehole flow } \\
\hline Total & & 0.00 & $-130,224$ & $-47,681$ & $-49,763$ & $-6,704$ & -809 & $-18,535$ & $-45,498$ & -986 & -238 & -649 & $-5,101$ & $-306,188$ \\
\hline \multicolumn{15}{|c|}{ Net flow from adjacent inland zones } \\
\hline Dominguez & 2 & -459 & 11,600 & $-2,690$ & 17.4 & 12.9 & -99 & 235 & $-10,900$ & -82.6 & 73.7 & 6.37 & 2,250 & $-3.68 \mathrm{E}-11$ \\
\hline Mesa & 3 & $-1,130$ & 25,700 & -317 & 976 & -303 & $-1,030$ & 3,690 & $-28,500$ & -670 & 669 & 0.00 & 931 & $4.23 \mathrm{E}-11$ \\
\hline Pacific A & 4 & -259 & 11,200 & 1,630 & -65.9 & 0.00 & 0.00 & $-2,210$ & $-9,020$ & -243 & $-1,030$ & 0.00 & 0.00 & $-3.09 \mathrm{E}-11$ \\
\hline Pacific & 5 & $-3,010$ & 18,600 & 8,590 & -366 & 261 & -219 & 6,100 & $-24,500$ & -360 & -542 & -533 & $-3,980$ & $-6.68 \mathrm{E}-11$ \\
\hline Harbor & 6 & -322 & 19,300 & 1,420 & -692 & -9.25 & 0.00 & -78.8 & $-17,500$ & -77.6 & -271 & 0.00 & $-1,820$ & $-6.82 \mathrm{E}-13$ \\
\hline Bent Spring & 7 & -801 & 11,600 & 672 & 365 & 372 & $-1,150$ & 1,320 & $-13,200$ & 0.00 & 910 & 0.00 & -59.5 & $2.57 \mathrm{E}-11$ \\
\hline Upper Wilmington A & 8 & $-1,930$ & 6,300 & -654 & 1,830 & $-1,390$ & -33.4 & 5,050 & $-7,540$ & -202 & -129 & -738 & -550 & $-1.73 \mathrm{E}-11$ \\
\hline Upper Wilmington B & 9 & -119 & 3,460 & $-2,660$ & 320 & 120 & -19.3 & 570 & $-1,440$ & 296 & -238 & -349 & 56.8 & $-4.03 \mathrm{E}-12$ \\
\hline Lower Wilmington & 10 & -61.1 & 2,960 & -463 & 1,900 & -257 & 4.62 & 690 & $-4,090$ & 113 & -161 & -475 & -168 & $-3.04 \mathrm{E}-12$ \\
\hline Long Beach A & 11 & -0.181 & 662 & 15.4 & 801 & -143 & -0.0162 & 41.5 & 314 & -18.5 & -1.15 & $-1,110$ & -556 & $6.82 \mathrm{E}-13$ \\
\hline Long Beach B & 12 & 37.7 & 782 & -203 & 546 & -103 & 0.968 & -1.67 & -300 & 316 & 10.2 & -447 & -639 & $1.93 \mathrm{E}-12$ \\
\hline Long Beach C & 13 & -662 & 1,880 & 108 & 1,070 & -340 & -0.311 & 48.6 & $-1,030$ & -916 & -43.2 & 23.4 & -134 & $3.41 \mathrm{E}-13$ \\
\hline Total & & $-8,720$ & 114,000 & 5,450 & 6,690 & $-1,780$ & $-2,540$ & 15,500 & $-118,000$ & $-1,840$ & -758 & $-3,630$ & $-4,670$ & $-9.82 \mathrm{E}-11$ \\
\hline
\end{tabular}


Table D6. Simulated average 45-year water budget (acre-feet per year) by model layer and subarea of the Los Angeles Coastal Plain Groundwater-flow Model, 1971 to 2015 , Los Angeles County, California.-Continued

[Negative numbers represent groundwater removed from the model/zone, and positive numbers represent groundwater added to the model/zone. Pumping and injection by layer includes interborehole flow from all wells. Pumping and injection totals without interborehole flow included separately in this table. Abbreviation: WRD, Water Replenishment District of Southern California]

\begin{tabular}{|c|c|c|c|c|c|c|c|c|c|c|c|c|c|c|}
\hline $\begin{array}{c}\text { Chronostratigraphic unit } \\
\text { name }\end{array}$ & $\begin{array}{l}\text { Model } \\
\text { layer }\end{array}$ & $\begin{array}{c}\text { Los } \\
\text { Angeles } \\
\text { Forebay }\end{array}$ & $\begin{array}{l}\text { WRD } \\
\text { Central } \\
\text { Basin }\end{array}$ & $\begin{array}{l}\text { Orange } \\
\text { County }\end{array}$ & $\begin{array}{l}\text { West } \\
\text { Coast }\end{array}$ & $\begin{array}{c}\text { Santa } \\
\text { Monica }\end{array}$ & Hollywood & $\begin{array}{l}\text { WRD Los } \\
\text { Angeles } \\
\text { Forebay }\end{array}$ & $\begin{array}{l}\text { Montebello } \\
\text { Forebay }\end{array}$ & Whitter & $\begin{array}{l}\text { Central } \\
\text { Basin }\end{array}$ & $\begin{array}{l}\text { North } \\
\text { Orange } \\
\text { County }\end{array}$ & $\begin{array}{c}\text { South } \\
\text { Orange } \\
\text { County }\end{array}$ & Total \\
\hline \multicolumn{15}{|c|}{ Water spreading } \\
\hline Dominguez & 2 & 0.00 & 0.00 & 0.00 & 0.00 & 0.00 & 0.00 & 0.00 & 82,800 & 0.00 & 0.00 & 0.00 & 0.00 & 82,800 \\
\hline Mesa & 3 & 0.00 & 0.00 & 0.00 & 0.00 & 0.00 & 0.00 & 0.00 & 37,500 & 0.00 & 0.00 & 0.00 & 0.00 & 37,500 \\
\hline Pacific A & 4 & 0.00 & 0.00 & 0.00 & 0.00 & 0.00 & 0.00 & 0.00 & 0.00 & 0.00 & 0.00 & 0.00 & 0.00 & 0.00 \\
\hline Pacific & 5 & 0.00 & 0.00 & 0.00 & 0.00 & 0.00 & 0.00 & 0.00 & 2,400 & 0.00 & 0.00 & 0.00 & 0.00 & 2,400 \\
\hline Harbor & 6 & 0.00 & 0.00 & 0.00 & 0.00 & 0.00 & 0.00 & 0.00 & 0.00 & 0.00 & 0.00 & 0.00 & 0.00 & 0.00 \\
\hline Bent Spring & 7 & 0.00 & 0.00 & 0.00 & 0.00 & 0.00 & 0.00 & 0.00 & 0.00 & 0.00 & 0.00 & 0.00 & 0.00 & 0.00 \\
\hline Upper Wilmington A & 8 & 0.00 & 0.00 & 0.00 & 0.00 & 0.00 & 0.00 & 0.00 & 0.00 & 0.00 & 0.00 & 0.00 & 0.00 & 0.00 \\
\hline Upper Wilmington B & 9 & 0.00 & 0.00 & 0.00 & 0.00 & 0.00 & 0.00 & 0.00 & 0.00 & 0.00 & 0.00 & 0.00 & 0.00 & 0.00 \\
\hline Lower Wilmington & 10 & 0.00 & 0.00 & 0.00 & 0.00 & 0.00 & 0.00 & 0.00 & 0.00 & 0.00 & 0.00 & 0.00 & 0.00 & 0.00 \\
\hline Long Beach A & 11 & 0.00 & 0.00 & 0.00 & 0.00 & 0.00 & 0.00 & 0.00 & 0.00 & 0.00 & 0.00 & 0.00 & 0.00 & 0.00 \\
\hline Long Beach B & 12 & 0.00 & 0.00 & 0.00 & 0.00 & 0.00 & 0.00 & 0.00 & 0.00 & 0.00 & 0.00 & 0.00 & 0.00 & 0.00 \\
\hline Long Beach C & 13 & 0.00 & 0.00 & 0.00 & 0.00 & 0.00 & 0.00 & 0.00 & 0.00 & 0.00 & 0.00 & 0.00 & 0.00 & 0.00 \\
\hline Total & & 0.00 & 0.00 & 0.00 & 0.00 & 0.00 & 0.00 & 0.00 & 123,000 & 0.00 & 0.00 & 0.00 & 0.00 & 123,000 \\
\hline \multicolumn{15}{|c|}{ Injection and net interborehole flow in } \\
\hline Dominguez & 2 & 0.00 & $7.33 \mathrm{E}-05$ & 0.000192 & 28.0 & 0.00 & 0.00 & 0.00 & 0.00 & 0.00 & 0.00 & 0.00 & 0.00 & 28.0 \\
\hline Mesa & 3 & 0.00 & 631 & 220 & 2,760 & 0.00 & 0.00 & 0.00 & 11.6 & 0.00 & 0.00 & 0.00 & 758 & 4,380 \\
\hline Pacific A & 4 & 0.00 & 1,520 & 2,530 & 0.00 & 0.00 & 0.00 & 0.00 & 549 & 0.00 & 0.00 & 0.00 & 0.00 & 4,590 \\
\hline Pacific & 5 & 0.00 & 4,560 & 1,000 & 9,720 & 0.00 & 0.00 & 1,180 & 137 & 0.00 & 0.00 & 0.00 & 1,190 & 17,800 \\
\hline Harbor & 6 & 0.00 & 1,020 & 41.3 & 5,460 & 0.00 & 0.00 & 980 & 377 & 0.00103 & 0.00 & 0.00 & 1,240 & 9,110 \\
\hline Bent Spring & 7 & 0.00 & 414 & 0.00 & 9,860 & 45.3 & 31.6 & 199 & 19.0 & 0.00 & 0.549 & 0.00 & 0.792 & 10,600 \\
\hline Upper Wilmington A & 8 & 1,220 & 376 & 0.00 & 1,110 & 0.00 & 0.00 & 13.5 & 170 & 2.27 & 0.00 & 1.42 & 13.4 & 2,910 \\
\hline Upper Wilmington B & 9 & 0.00 & 199 & 3.06 & 16.1 & 0.724 & 0.00 & 0.00 & $3.48 \mathrm{E}-05$ & 0.899 & 0.00 & 9.54 & 0.00 & 229 \\
\hline Lower Wilmington & 10 & 0.00 & 14.1 & 0.00 & 51.8 & 0.00 & 0.00 & 0.00 & 5.70 & 0.793 & 0.00 & 5.64 & 0.00 & 78.0 \\
\hline Long Beach A & 11 & 0.00 & 0.00211 & 0.00 & 0.0878 & 0.00 & 0.00 & 0.00 & 0.00119 & 25.9 & 0.00 & 2.26 & 0.00 & 28.2 \\
\hline Long Beach B & 12 & 0.00 & 0.00 & 0.00 & 0.00 & 0.00 & 0.00 & 0.00 & 0.00158 & 120 & 0.00 & 0.00 & 0.00 & 120 \\
\hline Long Beach C & 13 & 0.00 & 0.00 & 0.00 & 0.00 & 0.00 & 0.00 & 0.00 & $4.03 \mathrm{E}-05$ & 0.00 & 0.00 & 0.00 & 0.00 & $4.03 \mathrm{E}-05$ \\
\hline Total & & 1,220 & 8,730 & 3,800 & 29,000 & 46.1 & 31.6 & 2,370 & 1,270 & 150 & 0.549 & 18.9 & 3,200 & 49,800 \\
\hline
\end{tabular}


Table D6. Simulated average 45-year water budget (acre-feet per year) by model layer and subarea of the Los Angeles Coastal Plain Groundwater-flow Model, 1971 to 2015 , Los Angeles County, California.-Continued

[Negative numbers represent groundwater removed from the model/zone, and positive numbers represent groundwater added to the model/zone. Pumping and injection by layer includes interborehole flow from all wells. Pumping and injection totals without interborehole flow included separately in this table. Abbreviation: WRD, Water Replenishment District of Southern California]

\begin{tabular}{|c|c|c|c|c|c|c|c|c|c|c|c|c|c|c|}
\hline $\begin{array}{c}\text { Chronostratigraphic unit } \\
\text { name }\end{array}$ & $\begin{array}{l}\text { Model } \\
\text { layer }\end{array}$ & $\begin{array}{c}\text { Los } \\
\text { Angeles } \\
\text { Forebay }\end{array}$ & $\begin{array}{c}\text { WRD } \\
\text { Central } \\
\text { Basin }\end{array}$ & $\begin{array}{l}\text { Orange } \\
\text { County }\end{array}$ & $\begin{array}{l}\text { West } \\
\text { Coast }\end{array}$ & $\begin{array}{c}\text { Santa } \\
\text { Monica }\end{array}$ & Hollywood & $\begin{array}{l}\text { WRD Los } \\
\text { Angeles } \\
\text { Forebay }\end{array}$ & $\begin{array}{l}\text { Montebello } \\
\text { Forebay }\end{array}$ & Whitter & $\begin{array}{l}\text { Central } \\
\text { Basin }\end{array}$ & $\begin{array}{l}\text { North } \\
\text { Orange } \\
\text { County }\end{array}$ & $\begin{array}{l}\text { South } \\
\text { Orange } \\
\text { County }\end{array}$ & Total \\
\hline \multicolumn{15}{|c|}{ Injection without interborehole flow } \\
\hline Total & & 0.00 & 2,615 & 0.00 & 27,253 & 365 & 0.00 & 0.00 & 0.00 & 0.00 & 0.00 & 0.00 & 2,660 & 32,893 \\
\hline \multicolumn{15}{|c|}{ Areal recharge } \\
\hline Dominguez & 2 & 1,160 & 8,280 & 2,900 & 1,110 & 1,400 & 1,730 & 1,400 & 2,070 & 281 & 435 & 25.3 & 423 & 21,200 \\
\hline Mesa & 3 & 1,660 & 3,490 & 23.7 & 8,990 & 6,380 & 1,030 & 40.2 & 1,000 & 362 & 788 & 0.00 & 208 & 24,000 \\
\hline Pacific A & 4 & 0.00 & 0.00 & 0.00 & 0.00 & 0.00 & 0.00 & 0.00 & 0.00 & 0.00 & 0.00 & 0.00 & 0.00 & 0.00 \\
\hline Pacific & 5 & 0.00 & 315 & 41.3 & 701 & 902 & 0.0458 & 0.00 & 200 & 464 & 177 & 752 & 0.00142 & 3,550 \\
\hline Harbor & 6 & 197 & 3.29 & 0.00 & 237 & 0.00 & 0.00 & 182 & 1.34 & 0.00 & 0.00 & 0.00 & 0.00 & 620 \\
\hline Bent Spring & 7 & 14.9 & 0.00 & 0.00 & 779 & 6.40 & 0.00 & 0.00 & 0.00 & 0.00 & 0.00 & 0.00 & 0.00 & 801 \\
\hline Upper Wilmington A & 8 & 0.00 & 27.1 & 8.07 & 136 & 61.3 & 0.00 & 33.4 & 176 & 46.7 & 0.00 & 198 & 0.00 & 686 \\
\hline Upper Wilmington B & 9 & 0.00 & 0.00 & 0.00 & 16.5 & 8.66 & 0.00 & 0.00 & 0.00 & 0.00 & 0.00 & 0.00 & 0.00 & 25.2 \\
\hline Lower Wilmington & 10 & 0.00 & 20.6 & 0.00 & 0.00 & 0.00 & 0.00 & 0.00 & 0.00 & 23.8 & 0.00 & 68.9 & 0.00 & 113 \\
\hline Long Beach A & 11 & 0.00 & 5.82 & 0.00 & 0.00 & 0.00 & 0.00 & 0.00 & 24.8 & 1.34 & 0.00 & 62.7 & 0.00 & 94.6 \\
\hline Long Beach B & 12 & 0.00 & 0.00 & 0.00 & 0.00 & 0.00 & 0.00 & 0.00 & 6.22 & 0.00 & 0.00 & 0.00 & 0.00 & 6.22 \\
\hline Long Beach C & 13 & 209 & 95.1 & 0.00 & 93.7 & 2.99 & 0.00 & 125 & 1,190 & 1,090 & 54 & 112 & 0.00 & 2,980 \\
\hline Total & & 3,240 & 12,200 & 2,970 & 12,100 & 8,760 & 2,760 & 1,780 & 4,670 & 2,270 & 1,450 & 1,220 & 631 & 54,000 \\
\hline \multicolumn{15}{|c|}{ Flow from Santa Monica Bay } \\
\hline Dominguez & 2 & 0.00 & 0.00 & 0.00 & 0.00 & 0.00068 & 0.00 & 0.00 & 0.00 & 0.00 & 0.00 & 0.00 & 0.00 & 0.00068 \\
\hline Mesa & 3 & 0.00 & 0.00 & 0.00 & -74.3 & -156 & 0.00 & 0.00 & 0.00 & 0.00 & 0.00 & 0.00 & 0.00 & -230 \\
\hline Pacific A & 4 & 0.00 & 0.00 & 0.00 & 0.00 & 0.00 & 0.00 & 0.00 & 0.00 & 0.00 & 0.00 & 0.00 & 0.00 & 0.00 \\
\hline Pacific & 5 & 0.00 & 0.00 & 0.00 & -74.6 & 21.5 & 0.00 & 0.00 & 0.00 & 0.00 & 0.00 & 0.00 & 0.00 & -53.1 \\
\hline Harbor & 6 & 0.00 & 0.00 & 0.00 & -58.7 & 0.00 & 0.00 & 0.00 & 0.00 & 0.00 & 0.00 & 0.00 & 0.00 & -58.7 \\
\hline Bent Spring & 7 & 0.00 & 0.00 & 0.00 & 187 & 29.6 & 0.00 & 0.00 & 0.00 & 0.00 & 0.00 & 0.00 & 0.00 & 216 \\
\hline Upper Wilmington A & 8 & 0.00 & 0.00 & 0.00 & -5.59 & 95.4 & 0.00 & 0.00 & 0.00 & 0.00 & 0.00 & 0.00 & 0.00 & 89.8 \\
\hline Upper Wilmington B & 9 & 0.00 & 0.00 & 0.00 & -61.6 & -14.1 & 0.00 & 0.00 & 0.00 & 0.00 & 0.00 & 0.00 & 0.00 & -75.7 \\
\hline Lower Wilmington & 10 & 0.00 & 0.00 & 0.00 & 180 & -38.6 & 0.00 & 0.00 & 0.00 & 0.00 & 0.00 & 0.00 & 0.00 & 142 \\
\hline Long Beach A & 11 & 0.00 & 0.00 & 0.00 & -3.68 & -15.1 & 0.00 & 0.00 & 0.00 & 0.00 & 0.00 & 0.00 & 0.00 & -18.8 \\
\hline Long Beach B & 12 & 0.00 & 0.00 & 0.00 & 2.85 & -7.25 & 0.00 & 0.00 & 0.00 & 0.00 & 0.00 & 0.00 & 0.00 & -4.40 \\
\hline Long Beach C & 13 & 0.00 & 0.00 & 0.00 & 2.08 & 9.39 & 0.00 & 0.00 & 0.00 & 0.00 & 0.00 & 0.00 & 0.00 & 11.5 \\
\hline Total & & 0.00 & 0.00 & 0.00 & 93.5 & -74.9 & 0.00 & 0.00 & 0.00 & 0.00 & 0.00 & 0.00 & 0.00 & 18.6 \\
\hline
\end{tabular}


Table D6. Simulated average 45-year water budget (acre-feet per year) by model layer and subarea of the Los Angeles Coastal Plain Groundwater-flow Model, 1971 to 2015 , Los Angeles County, California.-Continued

[Negative numbers represent groundwater removed from the model/zone, and positive numbers represent groundwater added to the model/zone. Pumping and injection by layer includes interborehole flow from all wells. Pumping and injection totals without interborehole flow included separately in this table. Abbreviation: WRD, Water Replenishment District of Southern California]

\begin{tabular}{|c|c|c|c|c|c|c|c|c|c|c|c|c|c|c|}
\hline $\begin{array}{c}\text { Chronostratigraphic unit } \\
\text { name }\end{array}$ & $\begin{array}{l}\text { Model } \\
\text { layer }\end{array}$ & $\begin{array}{c}\text { Los } \\
\text { Angeles } \\
\text { Forebay }\end{array}$ & $\begin{array}{c}\text { WRD } \\
\text { Central } \\
\text { Basin }\end{array}$ & $\begin{array}{l}\text { Orange } \\
\text { County }\end{array}$ & $\begin{array}{l}\text { West } \\
\text { Coast }\end{array}$ & $\begin{array}{l}\text { Santa } \\
\text { Monica }\end{array}$ & Hollywood & $\begin{array}{l}\text { WRD Los } \\
\text { Angeles } \\
\text { Forebay }\end{array}$ & $\begin{array}{l}\text { Montebello } \\
\text { Forebay }\end{array}$ & Whitter & $\begin{array}{c}\text { Central } \\
\text { Basin }\end{array}$ & $\begin{array}{l}\text { North } \\
\text { Orange } \\
\text { County }\end{array}$ & $\begin{array}{c}\text { South } \\
\text { Orange } \\
\text { County }\end{array}$ & Total \\
\hline \multicolumn{15}{|c|}{ Flow from San Pedro Bay } \\
\hline Dominguez & 2 & 0.00 & 0.00 & 0.00 & 344 & 0.00 & 0.00 & 0.00 & 0.00 & 0.00 & 0.00 & 0.00 & 42.3 & 386 \\
\hline Mesa & 3 & 0.00 & 0.00 & 0.00 & 43.9 & 0.00 & 0.00 & 0.00 & 0.00 & 0.00 & 0.00 & 0.00 & 188 & 232 \\
\hline Pacific A & 4 & 0.00 & 0.00 & 0.00 & 0.00 & 0.00 & 0.00 & 0.00 & 0.00 & 0.00 & 0.00 & 0.00 & 0.00 & 0.00 \\
\hline Pacific & 5 & 0.00 & 0.00 & 0.00 & 1,380 & 0.00 & 0.00 & 0.00 & 0.00 & 0.00 & 0.00 & 0.00 & 310 & 1,690 \\
\hline Harbor & 6 & 0.00 & 0.00 & 0.00 & 1,320 & 0.00 & 0.00 & 0.00 & 0.00 & 0.00 & 0.00 & 0.00 & 851 & 2,170 \\
\hline Bent Spring & 7 & 0.00 & 0.00 & 0.00 & 540 & 0.00 & 0.00 & 0.00 & 0.00 & 0.00 & 0.00 & 0.00 & 73.3 & 613 \\
\hline Upper Wilmington A & 8 & 0.00 & 0.00 & 0.00 & 0.00 & 0.00 & 0.00 & 0.00 & 0.00 & 0.00 & 0.00 & 0.00 & 0.00 & 0.00 \\
\hline Upper Wilmington B & 9 & 0.00 & 0.00 & 0.00 & 222 & 0.00 & 0.00 & 0.00 & 0.00 & 0.00 & 0.00 & 0.00 & 0.00 & 222 \\
\hline Lower Wilmington & 10 & 0.00 & 0.00 & 0.00 & 1,650 & 0.00 & 0.00 & 0.00 & 0.00 & 0.00 & 0.00 & 0.00 & 82.6 & 1,730 \\
\hline Long Beach A & 11 & 0.00 & 0.00 & 0.00 & 327 & 0.00 & 0.00 & 0.00 & 0.00 & 0.00 & 0.00 & 0.00 & -341 & -14.3 \\
\hline Long Beach B & 12 & 0.00 & 0.00 & 0.00 & 340 & 0.00 & 0.00 & 0.00 & 0.00 & 0.00 & 0.00 & 0.00 & -101 & 238 \\
\hline Long Beach C & 13 & 0.00 & 0.00 & 0.00 & 98.9 & 0.00 & 0.00 & 0.00 & 0.00 & 0.00 & 0.00 & 0.00 & -332 & -233 \\
\hline Total & & 0.00 & 0.00 & 0.00 & 6,270 & 0.00 & 0.00 & 0.00 & 0.00 & 0.00 & 0.00 & 0.00 & 775 & 7,050 \\
\hline \multicolumn{15}{|c|}{ Underflow from Orange County } \\
\hline Dominguez & 2 & 0.00 & 0.00 & 6,200 & 0.00 & 0.00 & 0.00 & 0.00 & 0.00 & 0.00 & 0.00 & 0.00 & 78.5 & 6,280 \\
\hline Mesa & 3 & 0.00 & 0.00 & 2,080 & 0.00 & 0.00 & 0.00 & 0.00 & 0.00 & 0.00 & 0.00 & 0.00 & 569 & 2,640 \\
\hline Pacific A & 4 & 0.00 & 0.00 & 6,590 & 0.00 & 0.00 & 0.00 & 0.00 & 0.00 & 0.00 & 0.00 & 0.00 & 0.00 & 6,590 \\
\hline Pacific & 5 & 0.00 & 0.00 & 10,500 & 0.00 & 0.00 & 0.00 & 0.00 & 0.00 & 0.00 & 0.00 & -42.1 & 824 & 11,200 \\
\hline Harbor & 6 & 0.00 & 0.00 & 4,040 & 0.00 & 0.00 & 0.00 & 0.00 & 0.00 & 0.00 & 0.00 & 0.00 & 282 & 4,330 \\
\hline Bent Spring & 7 & 0.00 & 0.00 & 131 & 0.00 & 0.00 & 0.00 & 0.00 & 0.00 & 0.00 & 0.00 & 0.00 & 78.2 & 209 \\
\hline Upper Wilmington A & 8 & 0.00 & 0.00 & 6,020 & 0.00 & 0.00 & 0.00 & 0.00 & 0.00 & 0.00 & 0.00 & 934 & 1,500 & 8,450 \\
\hline Upper Wilmington B & 9 & 0.00 & 0.00 & 3,070 & 0.00 & 0.00 & 0.00 & 0.00 & 0.00 & 0.00 & 0.00 & 321 & -41.2 & 3,350 \\
\hline Lower Wilmington & 10 & 0.00 & 0.00 & 276 & 0.00 & 0.00 & 0.00 & 0.00 & 0.00 & 0.00 & 0.00 & 890 & 40.6 & 1,210 \\
\hline Long Beach A & 11 & 0.00 & 0.00 & 62.2 & 0.00 & 0.00 & 0.00 & 0.00 & 0.00 & 0.00 & 0.00 & 1,270 & 941 & 2,270 \\
\hline Long Beach B & 12 & 0.00 & 0.00 & 106 & 0.00 & 0.00 & 0.00 & 0.00 & 0.00 & 0.00 & 0.00 & 136 & 771 & 1,010 \\
\hline Long Beach C & 13 & 0.00 & 0.00 & 41.0 & 0.00 & 0.00 & 0.00 & 0.00 & 0.00 & 0.00 & 0.00 & 138 & 483 & 662 \\
\hline Total & & 0.00 & 0.00 & 39,100 & 0.00 & 0.00 & 0.00 & 0.00 & 0.00 & 0.00 & 0.00 & 3,640 & 5,520 & 48,200 \\
\hline
\end{tabular}


Table D6. Simulated average 45-year water budget (acre-feet per year) by model layer and subarea of the Los Angeles Coastal Plain Groundwater-flow Model, 1971 to 2015 , Los Angeles County, California.-Continued

[Negative numbers represent groundwater removed from the model/zone, and positive numbers represent groundwater added to the model/zone. Pumping and injection by layer includes interborehole flow from all wells. Pumping and injection totals without interborehole flow included separately in this table. Abbreviation: WRD, Water Replenishment District of Southern California]

\begin{tabular}{|c|c|c|c|c|c|c|c|c|c|c|c|c|c|c|}
\hline $\begin{array}{c}\text { Chronostratigraphic unit } \\
\text { name }\end{array}$ & $\begin{array}{l}\text { Model } \\
\text { layer }\end{array}$ & $\begin{array}{c}\text { Los } \\
\text { Angeles } \\
\text { Forebay }\end{array}$ & $\begin{array}{c}\text { WRD } \\
\text { Central } \\
\text { Basin }\end{array}$ & $\begin{array}{l}\text { Orange } \\
\text { County }\end{array}$ & $\begin{array}{l}\text { West } \\
\text { Coast }\end{array}$ & $\begin{array}{c}\text { Santa } \\
\text { Monica }\end{array}$ & Hollywood & $\begin{array}{c}\text { WRD Los } \\
\text { Angeles } \\
\text { Forebay }\end{array}$ & $\begin{array}{l}\text { Montebello } \\
\text { Forebay }\end{array}$ & Whitter & $\begin{array}{l}\text { Central } \\
\text { Basin }\end{array}$ & $\begin{array}{c}\text { North } \\
\text { Orange } \\
\text { County }\end{array}$ & $\begin{array}{c}\text { South } \\
\text { Orange } \\
\text { County }\end{array}$ & Total \\
\hline \multicolumn{15}{|c|}{ Underflow from San Gabriel Valley } \\
\hline Dominguez & 2 & 0.00 & 0.00 & 0.00 & 0.00 & 0.00 & 0.00 & 0.00 & 0.00 & 0.00 & 0.00 & 0.00 & 0.00 & 0.00 \\
\hline Mesa & 3 & 0.00 & 0.00 & 0.00 & 0.00 & 0.00 & 0.00 & 0.00 & 30,200 & 0.00 & 0.00 & 0.00 & 0.00 & 30,200 \\
\hline Pacific A & 4 & 0.00 & 0.00 & 0.00 & 0.00 & 0.00 & 0.00 & 0.00 & 0.00 & 0.00 & 0.00 & 0.00 & 0.00 & 0.00 \\
\hline Pacific & 5 & 0.00 & 0.00 & 0.00 & 0.00 & 0.00 & 0.00 & 0.00 & 0.00 & 0.00 & 0.00 & 0.00 & 0.00 & 0.00 \\
\hline Harbor & 6 & 0.00 & 0.00 & 0.00 & 0.00 & 0.00 & 0.00 & 0.00 & 0.00 & 0.00 & 0.00 & 0.00 & 0.00 & 0.00 \\
\hline Bent Spring & 7 & 0.00 & 0.00 & 0.00 & 0.00 & 0.00 & 0.00 & 0.00 & 0.00 & 0.00 & 0.00 & 0.00 & 0.00 & 0.00 \\
\hline Upper Wilmington A & 8 & 0.00 & 0.00 & 0.00 & 0.00 & 0.00 & 0.00 & 0.00 & 0.00 & 0.00 & 0.00 & 0.00 & 0.00 & 0.00 \\
\hline Upper Wilmington B & 9 & 0.00 & 0.00 & 0.00 & 0.00 & 0.00 & 0.00 & 0.00 & 0.00 & 0.00 & 0.00 & 0.00 & 0.00 & 0.00 \\
\hline Lower Wilmington & 10 & 0.00 & 0.00 & 0.00 & 0.00 & 0.00 & 0.00 & 0.00 & 0.00 & 0.00 & 0.00 & 0.00 & 0.00 & 0.00 \\
\hline Long Beach A & 11 & 0.00 & 0.00 & 0.00 & 0.00 & 0.00 & 0.00 & 0.00 & 0.00 & 0.00 & 0.00 & 0.00 & 0.00 & 0.00 \\
\hline Long Beach B & 12 & 0.00 & 0.00 & 0.00 & 0.00 & 0.00 & 0.00 & 0.00 & 0.00 & 0.00 & 0.00 & 0.00 & 0.00 & 0.00 \\
\hline Long Beach C & 13 & 0.00 & 0.00 & 0.00 & 0.00 & 0.00 & 0.00 & 0.00 & 6,120 & 0.00 & 0.00 & 0.00 & 0.00 & 6,120 \\
\hline Total & & 0.00 & 0.00 & 0.00 & 0.00 & 0.00 & 0.00 & 0.00 & 36,300 & 0.00 & 0.00 & 0.00 & 0.00 & 36,300 \\
\hline \multicolumn{15}{|c|}{ Underflow from Palos Verdes Hills } \\
\hline Dominguez & 2 & 0.00 & 0.00 & 0.00 & 0.00 & 0.00 & 0.00 & 0.00 & 0.00 & 0.00 & 0.00 & 0.00 & 0.00 & 0.00 \\
\hline Mesa & 3 & 0.00 & 0.00 & 0.00 & 0.00 & 0.00 & 0.00 & 0.00 & 0.00 & 0.00 & 0.00 & 0.00 & 0.00 & 0.00 \\
\hline Pacific A & 4 & 0.00 & 0.00 & 0.00 & 0.00 & 0.00 & 0.00 & 0.00 & 0.00 & 0.00 & 0.00 & 0.00 & 0.00 & 0.00 \\
\hline Pacific & 5 & 0.00 & 0.00 & 0.00 & 0.00 & 0.00 & 0.00 & 0.00 & 0.00 & 0.00 & 0.00 & 0.00 & 0.00 & 0.00 \\
\hline Harbor & 6 & 0.00 & 0.00 & 0.00 & 0.00 & 0.00 & 0.00 & 0.00 & 0.00 & 0.00 & 0.00 & 0.00 & 0.00 & 0.00 \\
\hline Bent Spring & 7 & 0.00 & 0.00 & 0.00 & 0.00 & 0.00 & 0.00 & 0.00 & 0.00 & 0.00 & 0.00 & 0.00 & 0.00 & 0.00 \\
\hline Upper Wilmington A & 8 & 0.00 & 0.00 & 0.00 & 0.00 & 0.00 & 0.00 & 0.00 & 0.00 & 0.00 & 0.00 & 0.00 & 0.00 & 0.00 \\
\hline Upper Wilmington B & 9 & 0.00 & 0.00 & 0.00 & 0.00 & 0.00 & 0.00 & 0.00 & 0.00 & 0.00 & 0.00 & 0.00 & 0.00 & 0.00 \\
\hline Lower Wilmington & 10 & 0.00 & 0.00 & 0.00 & 2.95 & 0.00 & 0.00 & 0.00 & 0.00 & 0.00 & 0.00 & 0.00 & 0.00 & 2.95 \\
\hline Long Beach A & 11 & 0.00 & 0.00 & 0.00 & 0.93 & 0.00 & 0.00 & 0.00 & 0.00 & 0.00 & 0.00 & 0.00 & 0.00 & 0.93 \\
\hline Long Beach B & 12 & 0.00 & 0.00 & 0.00 & 0.502 & 0.00 & 0.00 & 0.00 & 0.00 & 0.00 & 0.00 & 0.00 & 0.00 & 0.502 \\
\hline Long Beach C & 13 & 0.00 & 0.00 & 0.00 & 26.1 & 0.00 & 0.00 & 0.00 & 0.00 & 0.00 & 0.00 & 0.00 & 0.00 & 26.1 \\
\hline Total & & 0.00 & 0.00 & 0.00 & 30.5 & 0.00 & 0.00 & 0.00 & 0.00 & 0.00 & 0.00 & 0.00 & 0.00 & 30.5 \\
\hline
\end{tabular}


Table D6. Simulated average 45-year water budget (acre-feet per year) by model layer and subarea of the Los Angeles Coastal Plain Groundwater-flow Model, 1971 to 2015 , Los Angeles County, California.-Continued

[Negative numbers represent groundwater removed from the model/zone, and positive numbers represent groundwater added to the model/zone. Pumping and injection by layer includes interborehole flow from all wells. Pumping and injection totals without interborehole flow included separately in this table. Abbreviation: WRD, Water Replenishment District of Southern California]

\begin{tabular}{|c|c|c|c|c|c|c|c|c|c|c|c|c|c|c|}
\hline $\begin{array}{c}\text { Chronostratigraphic unit } \\
\text { name }\end{array}$ & $\begin{array}{l}\text { Model } \\
\text { layer }\end{array}$ & $\begin{array}{c}\text { Los } \\
\text { Angeles } \\
\text { Forebay }\end{array}$ & $\begin{array}{c}\text { WRD } \\
\text { Central } \\
\text { Basin }\end{array}$ & $\begin{array}{l}\text { Orange } \\
\text { County }\end{array}$ & $\begin{array}{l}\text { West } \\
\text { Coast }\end{array}$ & $\begin{array}{l}\text { Santa } \\
\text { Monica }\end{array}$ & Hollywood & $\begin{array}{l}\text { WRD Los } \\
\text { Angeles } \\
\text { Forebay }\end{array}$ & $\begin{array}{l}\text { Montebello } \\
\text { Forebay }\end{array}$ & Whitter & $\begin{array}{l}\text { Central } \\
\text { Basin }\end{array}$ & $\begin{array}{l}\text { North } \\
\text { Orange } \\
\text { County }\end{array}$ & $\begin{array}{c}\text { South } \\
\text { Orange } \\
\text { County }\end{array}$ & Total \\
\hline \multicolumn{15}{|c|}{ Flow from Marina Del Rey } \\
\hline Dominguez & 2 & 0.00 & 0.00 & 0.00 & 0.00 & 0.00 & 0.00 & 0.00 & 0.00 & 0.00 & 0.00 & 0.00 & 0.00 & 0.00 \\
\hline Mesa & 3 & 0.00 & 0.00 & 0.00 & 0.00 & 147 & 0.00 & 0.00 & 0.00 & 0.00 & 0.00 & 0.00 & 0.00 & 147 \\
\hline Pacific A & 4 & 0.00 & 0.00 & 0.00 & 0.00 & 0.00 & 0.00 & 0.00 & 0.00 & 0.00 & 0.00 & 0.00 & 0.00 & 0.00 \\
\hline Pacific & 5 & 0.00 & 0.00 & 0.00 & 0.00 & 0.00 & 0.00 & 0.00 & 0.00 & 0.00 & 0.00 & 0.00 & 0.00 & 0.00 \\
\hline Harbor & 6 & 0.00 & 0.00 & 0.00 & 0.00 & 0.00 & 0.00 & 0.00 & 0.00 & 0.00 & 0.00 & 0.00 & 0.00 & 0.00 \\
\hline Bent Spring & 7 & 0.00 & 0.00 & 0.00 & 0.00 & 0.00 & 0.00 & 0.00 & 0.00 & 0.00 & 0.00 & 0.00 & 0.00 & 0.00 \\
\hline Upper Wilmington A & 8 & 0.00 & 0.00 & 0.00 & 0.00 & 0.00 & 0.00 & 0.00 & 0.00 & 0.00 & 0.00 & 0.00 & 0.00 & 0.00 \\
\hline Upper Wilmington B & 9 & 0.00 & 0.00 & 0.00 & 0.00 & 0.00 & 0.00 & 0.00 & 0.00 & 0.00 & 0.00 & 0.00 & 0.00 & 0.00 \\
\hline Lower Wilmington & 10 & 0.00 & 0.00 & 0.00 & 0.00 & 0.00 & 0.00 & 0.00 & 0.00 & 0.00 & 0.00 & 0.00 & 0.00 & 0.00 \\
\hline Long Beach A & 11 & 0.00 & 0.00 & 0.00 & 0.00 & 0.00 & 0.00 & 0.00 & 0.00 & 0.00 & 0.00 & 0.00 & 0.00 & 0.00 \\
\hline Long Beach B & 12 & 0.00 & 0.00 & 0.00 & 0.00 & 0.00 & 0.00 & 0.00 & 0.00 & 0.00 & 0.00 & 0.00 & 0.00 & 0.00 \\
\hline Long Beach C & 13 & 0.00 & 0.00 & 0.00 & 0.00 & 0.00 & 0.00 & 0.00 & 0.00 & 0.00 & 0.00 & 0.00 & 0.00 & 0.00 \\
\hline Total & & 0.00 & 0.00 & 0.00 & 0.00 & 147 & 0.00 & 0.00 & 0.00 & 0.00 & 0.00 & 0.00 & 0.00 & 147 \\
\hline \multicolumn{15}{|c|}{ Flow from Port of Long Beach } \\
\hline Dominguez & 2 & 0.00 & 0.00 & 0.00 & 0.00 & 0.00 & 0.00 & 0.00 & 0.00 & 0.00 & 0.00 & 0.00 & 0.00 & 0.00 \\
\hline Mesa & 3 & 0.00 & 0.00 & 0.00 & -0.000962 & 0.00 & 0.00 & 0.00 & 0.00 & 0.00 & 0.00 & 0.00 & 0.00 & -0.000962 \\
\hline Pacific A & 4 & 0.00 & 0.00 & 0.00 & 0.00 & 0.00 & 0.00 & 0.00 & 0.00 & 0.00 & 0.00 & 0.00 & 0.00 & 0.00 \\
\hline Pacific & 5 & 0.00 & 0.00 & 0.00 & 0.00 & 0.00 & 0.00 & 0.00 & 0.00 & 0.00 & 0.00 & 0.00 & 0.00 & 0.00 \\
\hline Harbor & 6 & 0.00 & 0.00 & 0.00 & 0.00 & 0.00 & 0.00 & 0.00 & 0.00 & 0.00 & 0.00 & 0.00 & 0.00 & 0.00 \\
\hline Bent Spring & 7 & 0.00 & 0.00 & 0.00 & 0.00 & 0.00 & 0.00 & 0.00 & 0.00 & 0.00 & 0.00 & 0.00 & 0.00 & 0.00 \\
\hline Upper Wilmington A & 8 & 0.00 & 0.00 & 0.00 & 0.00 & 0.00 & 0.00 & 0.00 & 0.00 & 0.00 & 0.00 & 0.00 & 0.00 & 0.00 \\
\hline Upper Wilmington B & 9 & 0.00 & 0.00 & 0.00 & 0.00 & 0.00 & 0.00 & 0.00 & 0.00 & 0.00 & 0.00 & 0.00 & 0.00 & 0.00 \\
\hline Lower Wilmington & 10 & 0.00 & 0.00 & 0.00 & 0.00 & 0.00 & 0.00 & 0.00 & 0.00 & 0.00 & 0.00 & 0.00 & 0.00 & 0.00 \\
\hline Long Beach A & 11 & 0.00 & 0.00 & 0.00 & 0.00 & 0.00 & 0.00 & 0.00 & 0.00 & 0.00 & 0.00 & 0.00 & 0.00 & 0.00 \\
\hline Long Beach B & 12 & 0.00 & 0.00 & 0.00 & 0.00 & 0.00 & 0.00 & 0.00 & 0.00 & 0.00 & 0.00 & 0.00 & 0.00 & 0.00 \\
\hline Long Beach C & 13 & 0.00 & 0.00 & 0.00 & 0.00 & 0.00 & 0.00 & 0.00 & 0.00 & 0.00 & 0.00 & 0.00 & 0.00 & 0.00 \\
\hline Total & & 0.00 & 0.00 & 0.00 & -0.000962 & 0.00 & 0.00 & 0.00 & 0.00 & 0.00 & 0.00 & 0.00 & 0.00 & -0.000962 \\
\hline
\end{tabular}


Table D6. Simulated average 45-year water budget (acre-feet per year) by model layer and subarea of the Los Angeles Coastal Plain Groundwater-flow Model, 1971 to 2015 , Los Angeles County, California.-Continued

[Negative numbers represent groundwater removed from the model/zone, and positive numbers represent groundwater added to the model/zone. Pumping and injection by layer includes interborehole flow from all wells. Pumping and injection totals without interborehole flow included separately in this table. Abbreviation: WRD, Water Replenishment District of Southern California]

\begin{tabular}{|c|c|c|c|c|c|c|c|c|c|c|c|c|c|c|}
\hline $\begin{array}{c}\text { Chronostratigraphic unit } \\
\text { name }\end{array}$ & $\begin{array}{l}\text { Model } \\
\text { layer }\end{array}$ & $\begin{array}{c}\text { Los } \\
\text { Angeles } \\
\text { Forebay }\end{array}$ & $\begin{array}{l}\text { WRD } \\
\text { Central } \\
\text { Basin }\end{array}$ & $\begin{array}{l}\text { Orange } \\
\text { County }\end{array}$ & $\begin{array}{l}\text { West } \\
\text { Coast }\end{array}$ & $\begin{array}{l}\text { Santa } \\
\text { Monica }\end{array}$ & Hollywood & $\begin{array}{l}\text { WRD Los } \\
\text { Angeles } \\
\text { Forebay }\end{array}$ & $\begin{array}{l}\text { Montebello } \\
\text { Forebay }\end{array}$ & Whitter & $\begin{array}{l}\text { Central } \\
\text { Basin }\end{array}$ & $\begin{array}{l}\text { North } \\
\text { Orange } \\
\text { County }\end{array}$ & $\begin{array}{l}\text { South } \\
\text { Orange } \\
\text { County }\end{array}$ & Total \\
\hline \multicolumn{15}{|c|}{ Underflow from San Fernando Valley } \\
\hline Dominguez & 2 & 0.00 & 0.00 & 0.00 & 0.00 & 0.00 & 0.00 & 0.00 & 0.00 & 0.00 & 0.00 & 0.00 & 0.00 & 0.00 \\
\hline Mesa & 3 & 5,410 & 0.00 & 0.00 & 0.00 & 0.00 & 0.00 & 0.00 & 0.00 & 0.00 & 0.00 & 0.00 & 0.00 & 5,410 \\
\hline Pacific A & 4 & 0.00 & 0.00 & 0.00 & 0.00 & 0.00 & 0.00 & 0.00 & 0.00 & 0.00 & 0.00 & 0.00 & 0.00 & 0.00 \\
\hline Pacific & 5 & 0.00 & 0.00 & 0.00 & 0.00 & 0.00 & 0.00 & 0.00 & 0.00 & 0.00 & 0.00 & 0.00 & 0.00 & 0.00 \\
\hline Harbor & 6 & 0.00 & 0.00 & 0.00 & 0.00 & 0.00 & 0.00 & 0.00 & 0.00 & 0.00 & 0.00 & 0.00 & 0.00 & 0.00 \\
\hline Bent Spring & 7 & 0.00 & 0.00 & 0.00 & 0.00 & 0.00 & 0.00 & 0.00 & 0.00 & 0.00 & 0.00 & 0.00 & 0.00 & 0.00 \\
\hline Upper Wilmington A & 8 & 0.00 & 0.00 & 0.00 & 0.00 & 0.00 & 0.00 & 0.00 & 0.00 & 0.00 & 0.00 & 0.00 & 0.00 & 0.00 \\
\hline Upper Wilmington B & 9 & 0.00 & 0.00 & 0.00 & 0.00 & 0.00 & 0.00 & 0.00 & 0.00 & 0.00 & 0.00 & 0.00 & 0.00 & 0.00 \\
\hline Lower Wilmington & 10 & 0.00 & 0.00 & 0.00 & 0.00 & 0.00 & 0.00 & 0.00 & 0.00 & 0.00 & 0.00 & 0.00 & 0.00 & 0.00 \\
\hline Long Beach A & 11 & 0.00 & 0.00 & 0.00 & 0.00 & 0.00 & 0.00 & 0.00 & 0.00 & 0.00 & 0.00 & 0.00 & 0.00 & 0.00 \\
\hline Long Beach B & 12 & 0.00 & 0.00 & 0.00 & 0.00 & 0.00 & 0.00 & 0.00 & 0.00 & 0.00 & 0.00 & 0.00 & 0.00 & 0.00 \\
\hline Long Beach C & 13 & 0.00 & 0.00 & 0.00 & 0.00 & 0.00 & 0.00 & 0.00 & 0.00 & 0.00 & 0.00 & 0.00 & 0.00 & 0.00 \\
\hline Total & & 5,410 & 0.00 & 0.00 & 0.00 & 0.00 & 0.00 & 0.00 & 0.00 & 0.00 & 0.00 & 0.00 & 0.00 & 5,410 \\
\hline \multicolumn{15}{|c|}{ Drains } \\
\hline Dominguez & 2 & 0.00 & -133 & -12.3 & -7.31 & -298 & 0.00 & 0.00 & $-1,430$ & 0.00 & -421 & -32.2 & -3.50 & $-2,340$ \\
\hline Mesa & 3 & 0.00 & -66.8 & 0.00 & 0.00 & -850 & 0.00 & 0.00 & 0.00 & 0.00 & 0.00 & 0.00 & -0.291 & -917 \\
\hline Pacific A & 4 & 0.00 & 0.00 & 0.00 & 0.00 & 0.00 & 0.00 & 0.00 & 0.00 & 0.00 & 0.00 & 0.00 & 0.00 & 0.00 \\
\hline Pacific & 5 & 0.00 & 0.00 & 0.00 & 0.00 & -228 & 0.00 & 0.00 & $-1,020$ & -6.85 & 0.00 & -266 & 0.00 & $-1,520$ \\
\hline Harbor & 6 & 0.00 & 0.00 & 0.00 & 0.00 & 0.00 & 0.00 & 0.00 & 0.00 & 0.00 & 0.00 & 0.00 & 0.00 & 0.00 \\
\hline Bent Spring & 7 & 0.00 & 0.00 & 0.00 & 0.00 & $-1,390$ & 0.00 & 0.00 & 0.00 & 0.00 & 0.00 & 0.00 & 0.00 & $-1,390$ \\
\hline Upper Wilmington A & 8 & 0.00 & 0.00 & 0.00 & 0.00 & 0.00 & 0.00 & 0.00 & 0.00 & 0.00 & 0.00 & -384 & 0.00 & -384 \\
\hline Upper Wilmington B & 9 & 0.00 & 0.00 & 0.00 & 0.00 & 0.00 & 0.00 & 0.00 & 0.00 & 0.00 & 0.00 & 0.00 & 0.00 & 0.00 \\
\hline Lower Wilmington & 10 & 0.00 & 0.00 & 0.00 & 0.00 & 0.00 & 0.00 & 0.00 & 0.00 & 0.00 & 0.00 & -49.5 & 0.00 & -49.5 \\
\hline Long Beach A & 11 & 0.00 & -614 & 0.00 & 0.00 & 0.00 & 0.00 & 0.00 & 0.00 & 0.00 & 0.00 & -15.1 & 0.00 & -629 \\
\hline Long Beach B & 12 & 0.00 & 0.00 & 0.00 & 0.00 & 0.00 & 0.00 & 0.00 & 0.00 & 0.00 & 0.00 & 0.00 & 0.00 & 0.00 \\
\hline Long Beach C & 13 & 0.00 & 0.00 & 0.00 & 0.00 & 0.00 & 0.00 & 0.00 & 0.00 & 0.00 & 0.00 & 0.00 & 0.00 & 0.00 \\
\hline Total & & 0.00 & -814 & -12.3 & -7.31 & $-2,770$ & 0.00 & 0.00 & $-2,450$ & -6.85 & -421 & -747 & -3.79 & $-7,230$ \\
\hline Total net flow & & -73.5 & $-2,240$ & -207 & 2,630 & $-2,060$ & -598 & $-1,300$ & $-1,880$ & -565 & 35.8 & -161 & -190 & $-6,600$ \\
\hline
\end{tabular}


Table D6. Simulated average 45-year water budget (acre-feet per year) by model layer and subarea of the Los Angeles Coastal Plain Groundwater-flow Model, 1971 to 2015 , Los Angeles County, California.-Continued

[Negative numbers represent groundwater removed from the model/zone, and positive numbers represent groundwater added to the model/zone. Pumping and injection by layer includes interborehole flow from all wells. Pumping and injection totals without interborehole flow included separately in this table. Abbreviation: WRD, Water Replenishment District of Southern California]

\begin{tabular}{|c|c|c|c|c|c|c|c|c|c|c|c|c|c|c|}
\hline $\begin{array}{c}\text { Chronostratigraphic unit } \\
\text { name }\end{array}$ & $\begin{array}{l}\text { Model } \\
\text { layer }\end{array}$ & $\begin{array}{c}\text { Los } \\
\text { Angeles } \\
\text { Forebay }\end{array}$ & $\begin{array}{c}\text { WRD } \\
\text { Central } \\
\text { Basin }\end{array}$ & $\begin{array}{l}\text { Orange } \\
\text { County }\end{array}$ & $\begin{array}{l}\text { West } \\
\text { Coast }\end{array}$ & $\begin{array}{c}\text { Santa } \\
\text { Monica }\end{array}$ & Hollywood & $\begin{array}{l}\text { WRD Los } \\
\text { Angeles } \\
\text { Forebay }\end{array}$ & $\begin{array}{l}\text { Montebello } \\
\text { Forebay }\end{array}$ & Whitter & $\begin{array}{l}\text { Central } \\
\text { Basin }\end{array}$ & $\begin{array}{l}\text { North } \\
\text { Orange } \\
\text { County }\end{array}$ & $\begin{array}{l}\text { South } \\
\text { Orange } \\
\text { County }\end{array}$ & Total \\
\hline \multicolumn{15}{|c|}{ Change in storage } \\
\hline Dominguez & 2 & -461 & $-1,850$ & 29.9 & 45.0 & -687 & -75.4 & $-1,180$ & -969 & -42.3 & -210 & 24.8 & -135 & $-5,510$ \\
\hline Mesa & 3 & 22.5 & -331 & -4.94 & 2010 & -628 & -165 & -252 & -902 & -260 & 206 & 0.00 & -36.1 & -343 \\
\hline Pacific A & 4 & 12.6 & 205 & -1.35 & 0.686 & 0.00 & 0.00 & 0.733 & -8.05 & -5.67 & 3.88 & 0.00 & 0.00 & 208 \\
\hline Pacific & 5 & 7.77 & -226 & -8.81 & 82.0 & -739 & -5.25 & 40.1 & -69.8 & -131 & 2.48 & -98.8 & -10.8 & $-1,160$ \\
\hline Harbor & 6 & 4.86 & 1.52 & -5.83 & 99.6 & -0.00753 & 0.00 & 51.6 & -21.7 & -39.3 & 0.410 & 0.00 & -1.33 & 89.8 \\
\hline Bent Spring & 7 & 6.34 & 0.811 & -7.17 & 219 & -14.6 & -99.4 & 2.15 & -0.547 & 0.00 & 11.9 & 0.00 & -0.206 & 118 \\
\hline Upper Wilmington A & 8 & 242 & 6.35 & -145 & 30.9 & 46.2 & -257 & 29.3 & 24.0 & 4.97 & 5.02 & -179 & -0.505 & -193 \\
\hline Upper Wilmington B & 9 & 2.90 & 20.0 & -3.19 & 33.1 & 6.83 & -2.03 & 4.06 & -1.60 & 0.975 & 10.9 & -3.65 & -0.974 & 67.3 \\
\hline Lower Wilmington & 10 & 20.9 & 9.05 & -1.98 & 67.6 & 1.84 & 6.40 & 5.97 & -2.41 & -0.293 & 3.54 & -0.0903 & -0.416 & 110 \\
\hline Long Beach A & 11 & -2.97 & 9.54 & -7.71 & 26.6 & 0.968 & 0.00372 & -2.95 & -18.4 & 12.7 & 0.0503 & 117 & -0.617 & 135 \\
\hline Long Beach B & 12 & -0.440 & -27.6 & -24.5 & 17.9 & 2.35 & 0.0294 & -1.83 & -17.0 & -1.92 & 0.920 & -3.92 & -1.81 & -57.7 \\
\hline Long Beach C & 13 & 70.3 & -63.6 & -28.0 & 0.758 & -48.6 & -0.0741 & -1.33 & 101 & -103 & -0.297 & -16.9 & -3.05 & -92.9 \\
\hline Total & & -74.0 & $-2,250$ & -208 & 2,630 & $-2,060$ & -598 & $-1,300$ & $-1,880$ & -565 & 35.5 & -161 & -191 & $-6,630$ \\
\hline
\end{tabular}


Table D7. Simulated average 10-year water budget (acre-feet per year) by model layer and subarea of the Los Angeles Coastal Plain Groundwater-flow Model, 2006 to 2015, Los Angeles County, California.

[Negative numbers represent groundwater removed from the model/zone, and positive numbers represent groundwater added to the model/zone.]

\begin{tabular}{|c|c|c|c|c|c|c|c|c|c|c|c|c|c|c|}
\hline $\begin{array}{c}\text { Chronostratigraphic unit } \\
\text { name }\end{array}$ & $\begin{array}{l}\text { Model } \\
\text { layer }\end{array}$ & $\begin{array}{c}\text { Los } \\
\text { Angeles } \\
\text { Forebay }\end{array}$ & $\begin{array}{l}\text { WRD } \\
\text { Central } \\
\text { Basin }\end{array}$ & $\begin{array}{l}\text { Orange } \\
\text { County }\end{array}$ & $\begin{array}{l}\text { West } \\
\text { Coast }\end{array}$ & $\begin{array}{l}\text { Santa } \\
\text { Monica }\end{array}$ & Hollywood & $\begin{array}{c}\text { WRD Los } \\
\text { Angeles } \\
\text { Forebay }\end{array}$ & $\begin{array}{c}\text { Montebello } \\
\text { Forebay }\end{array}$ & Whitter & $\begin{array}{l}\text { Central } \\
\text { Basin }\end{array}$ & $\begin{array}{l}\text { North } \\
\text { Orange } \\
\text { County }\end{array}$ & $\begin{array}{c}\text { South } \\
\text { Orange } \\
\text { County }\end{array}$ & Total \\
\hline \multicolumn{15}{|c|}{ Pumping and net interborehole flow out } \\
\hline Dominguez & 2 & 0.00 & $-8,220$ & $-3,080$ & -24.1 & 0.00 & 0.00 & -0.00216 & -252 & 0.00 & 0.00 & 0.00 & -31.4 & $-11,600$ \\
\hline Mesa & 3 & 0.00 & $-7,910$ & $-3,350$ & $-1,480$ & -333 & 0.00 & $-2,170$ & $-5,230$ & -13.5 & 0.00 & 0.00 & -184 & $-20,700$ \\
\hline Pacific A & 4 & 0.00 & $-28,400$ & $-7,880$ & -0.00031 & 0.00 & 0.00 & -644 & $-2,420$ & 0.00 & 0.00 & 0.00 & 0.00 & $-39,300$ \\
\hline Pacific & 5 & 0.00 & $-25,200$ & $-25,500$ & $-5,080$ & $-1,160$ & -173 & $-5,600$ & $-18,000$ & -16.9 & -0.603 & 0.00 & $-3,210$ & $-83,900$ \\
\hline Harbor & 6 & 0.00 & $-32,600$ & $-9,610$ & $-9,190$ & 0.00 & 0.00 & -686 & $-7,910$ & -7.13 & 0.00 & 0.00 & $-1,000$ & $-61,000$ \\
\hline Bent Spring & 7 & 0.00 & $-11,100$ & $-2,090$ & $-4,130$ & $-4,390$ & -799 & $-3,310$ & $-2,390$ & 0.00 & -20.7 & 0.00 & -62.2 & $-28,300$ \\
\hline Upper Wilmington A & 8 & $-1,260$ & $-17,600$ & $-3,630$ & $-14,200$ & -113 & -974 & $-3,770$ & $-5,530$ & 0.00 & 0.00 & 0.00 & -353 & $-47,400$ \\
\hline Upper Wilmington B & 9 & 0.00 & $-6,730$ & -485 & $-1,730$ & -297 & -14.9 & -630 & -423 & 0.702 & 0.00 & 0.00 & 0.00 & $-10,300$ \\
\hline Lower Wilmington & 10 & 0.00 & $-2,210$ & 0.00 & $-5,690$ & -146 & 0.00 & -655 & -459 & -172 & 0.00 & -141 & 0.00 & $-9,470$ \\
\hline Long Beach A & 11 & 0.00 & -470 & 0.00 & -761 & 0.00 & 0.00 & -5.59 & -252 & 0.00 & 0.00 & 0.00 & 0.00 & $-1,490$ \\
\hline Long Beach B & 12 & 0.00 & -226 & 0.00 & -155 & 0.00 & 0.00 & -96.0 & -246 & 0.00 & 0.00 & 0.00 & 0.00 & -723 \\
\hline Long Beach C & 13 & 0.00 & 0.00 & 0.00 & 0.00 & -2.88 & 0.00 & -21.8 & $-4,130$ & 0.00 & 0.00 & 0.00 & 0.00 & $-4,150$ \\
\hline Total & & $-1,260$ & $-141,000$ & $-55,600$ & $-42,500$ & $-6,440$ & $-1,960$ & $-17,600$ & $-47,200$ & -210 & -21.3 & -141 & $-4,850$ & $-318,000$ \\
\hline \multicolumn{15}{|c|}{ Net flow from adjacent inland zones } \\
\hline Dominguez & 2 & -325 & 10,600 & $-3,570$ & 12.5 & 7.64 & -75.3 & 127 & $-9,170$ & -82.1 & 33.9 & 4.72 & 2,400 & $-2.86 \mathrm{E}-11$ \\
\hline Mesa & 3 & -794 & 21,500 & -663 & 716 & -160 & $-1,010$ & 3,310 & $-23,100$ & -963 & 241 & 0.00 & 917 & $-2.93 \mathrm{E}-11$ \\
\hline Pacific A & 4 & -133 & 8,880 & 958 & -52.7 & 0.00 & 0.00 & $-1,100$ & $-7,350$ & -221 & -990 & 0.00 & 0.00 & $-2.21 \mathrm{E}-11$ \\
\hline Pacific & 5 & $-2,810$ & 20,200 & 7,120 & -674 & 287 & -185 & 4,430 & $-22,600$ & -316 & -617 & -399 & $-4,460$ & $4.55 \mathrm{E}-12$ \\
\hline Harbor & 6 & -276 & 20,700 & 1,100 & $-1,030$ & -6.87 & 0.00 & -865 & $-16,100$ & -216 & -289 & 0.00 & $-3,000$ & $1.23 \mathrm{E}-11$ \\
\hline Bent Spring & 7 & -813 & 11,900 & 413 & -78.5 & 400 & $-1,060$ & 880 & $-12,400$ & 0.00 & 825 & 0.00 & -82.6 & $6.61 \mathrm{E}-11$ \\
\hline Upper Wilmington A & 8 & $-2,110$ & 7,930 & -488 & 1,480 & $-1,680$ & 39.9 & 4,400 & $-7,290$ & -273 & -157 & -711 & $-1,140$ & $6.59 \mathrm{E}-11$ \\
\hline Upper Wilmington B & 9 & -141 & 3,480 & $-2,000$ & -179 & 169 & -11.4 & 237 & $-1,300$ & 267 & -242 & -329 & 57.6 & $-9.31 \mathrm{E}-13$ \\
\hline Lower Wilmington & 10 & -166 & 3,200 & -342 & 1,380 & -230 & -15.2 & 503 & $-3,560$ & 58.2 & -202 & -492 & -139 & $-2.13 \mathrm{E}-12$ \\
\hline Long Beach A & 11 & -0.262 & 898 & 14.1 & 758 & -142 & -0.0131 & 34 & 359 & -76.5 & -1.33 & $-1,340$ & -506 & $-2.79 \mathrm{E}-12$ \\
\hline Long Beach B & 12 & 28.0 & 916 & -192 & 493 & -94.9 & 0.461 & -20.4 & -258 & -177 & 12.9 & -153 & -556 & $1.48 \mathrm{E}-12$ \\
\hline Long Beach C & 13 & -739 & 1,770 & 112 & 1,020 & -292 & -4.81 & 57.4 & -919 & -674 & -36.1 & -197 & -98.0 & $-1.15 \mathrm{E}-12$ \\
\hline Total & & $-8,280$ & 112,000 & 2,470 & 3,850 & $-1,740$ & $-2,320$ & 12,000 & $-104,000$ & $-2,670$ & $-1,420$ & $-3,610$ & $-6,600$ & $2.73 \mathrm{E}-11$ \\
\hline
\end{tabular}


Table D7. Simulated average 10-year water budget (acre-feet per year) by model layer and subarea of the Los Angeles Coastal Plain Groundwater-flow Model, 2006 to 2015, Los Angeles County, California.-Continued

[Negative numbers represent groundwater removed from the model/zone, and positive numbers represent groundwater added to the model/zone.]

\begin{tabular}{|c|c|c|c|c|c|c|c|c|c|c|c|c|c|c|}
\hline $\begin{array}{c}\text { Chronostratigraphic unit } \\
\text { name }\end{array}$ & $\begin{array}{l}\text { Model } \\
\text { layer }\end{array}$ & $\begin{array}{c}\text { Los } \\
\text { Angeles } \\
\text { Forebay }\end{array}$ & $\begin{array}{c}\text { WRD } \\
\text { Central } \\
\text { Basin }\end{array}$ & $\begin{array}{l}\text { Orange } \\
\text { County }\end{array}$ & $\begin{array}{l}\text { West } \\
\text { Coast }\end{array}$ & $\begin{array}{l}\text { Santa } \\
\text { Monica }\end{array}$ & Hollywood & $\begin{array}{c}\text { WRD Los } \\
\text { Angeles } \\
\text { Forebay }\end{array}$ & $\begin{array}{l}\text { Montebello } \\
\text { Forebay }\end{array}$ & Whitter & $\begin{array}{l}\text { Central } \\
\text { Basin }\end{array}$ & $\begin{array}{l}\text { North } \\
\text { Orange } \\
\text { County }\end{array}$ & $\begin{array}{l}\text { South } \\
\text { Orange } \\
\text { County }\end{array}$ & Total \\
\hline \multicolumn{15}{|c|}{ Water spreading } \\
\hline Dominguez & 2 & 0.00 & 0.00 & 0.00 & 0.00 & 0.00 & 0.00 & 0.00 & 71,400 & 0.00 & 0.00 & 0.00 & 0.00 & 71,400 \\
\hline Mesa & 3 & 0.00 & 0.00 & 0.00 & 0.00 & 0.00 & 0.00 & 0.00 & 26,100 & 0.00 & 0.00 & 0.00 & 0.00 & 26,100 \\
\hline Pacific A & 4 & 0.00 & 0.00 & 0.00 & 0.00 & 0.00 & 0.00 & 0.00 & 0.00 & 0.00 & 0.00 & 0.00 & 0.00 & 0.00 \\
\hline Pacific & 5 & 0.00 & 0.00 & 0.00 & 0.00 & 0.00 & 0.00 & 0.00 & 2,630 & 0.00 & 0.00 & 0.00 & 0.00 & 2,630 \\
\hline Harbor & 6 & 0.00 & 0.00 & 0.00 & 0.00 & 0.00 & 0.00 & 0.00 & 0.00 & 0.00 & 0.00 & 0.00 & 0.00 & 0.00 \\
\hline Bent Spring & 7 & 0.00 & 0.00 & 0.00 & 0.00 & 0.00 & 0.00 & 0.00 & 0.00 & 0.00 & 0.00 & 0.00 & 0.00 & 0.00 \\
\hline Upper Wilmington A & 8 & 0.00 & 0.00 & 0.00 & 0.00 & 0.00 & 0.00 & 0.00 & 0.00 & 0.00 & 0.00 & 0.00 & 0.00 & 0.00 \\
\hline Upper Wilmington B & 9 & 0.00 & 0.00 & 0.00 & 0.00 & 0.00 & 0.00 & 0.00 & 0.00 & 0.00 & 0.00 & 0.00 & 0.00 & 0.00 \\
\hline Lower Wilmington & 10 & 0.00 & 0.00 & 0.00 & 0.00 & 0.00 & 0.00 & 0.00 & 0.00 & 0.00 & 0.00 & 0.00 & 0.00 & 0.00 \\
\hline Long Beach A & 11 & 0.00 & 0.00 & 0.00 & 0.00 & 0.00 & 0.00 & 0.00 & 0.00 & 0.00 & 0.00 & 0.00 & 0.00 & 0.00 \\
\hline Long Beach B & 12 & 0.00 & 0.00 & 0.00 & 0.00 & 0.00 & 0.00 & 0.00 & 0.00 & 0.00 & 0.00 & 0.00 & 0.00 & 0.00 \\
\hline Long Beach C & 13 & 0.00 & 0.00 & 0.00 & 0.00 & 0.00 & 0.00 & 0.00 & 0.00 & 0.00 & 0.00 & 0.00 & 0.00 & 0.00 \\
\hline Total & & 0.00 & 0.00 & 0.00 & 0.00 & 0.00 & 0.00 & 0.00 & 100,000 & 0.00 & 0.00 & 0.00 & 0.00 & 100,000 \\
\hline \multicolumn{15}{|c|}{ Injection and net interborehole flow in } \\
\hline Dominguez & 2 & 0.00 & 1.07 & 0.000685 & 35.4 & 0.00 & 0.00 & 0.000061 & 0.0000582 & 0.00 & 0.00 & 0.00 & 0.00 & 36.5 \\
\hline Mesa & 3 & 0.00 & 709 & 244 & 1,950 & 0.000164 & 0.00 & 0.00 & 87.5 & 0.00 & 2.54 & 0.00 & 995 & 3,990 \\
\hline Pacific A & 4 & 0.00 & 2,090 & 2,520 & 0.00 & 0.00 & 0.00 & 28.7 & 605 & 0.00 & 0.00 & 0.00 & 0.00 & 5,250 \\
\hline Pacific & 5 & 0.00 & 6,060 & 1,920 & 7,940 & 0.00885 & 0.00 & 1,010 & 180 & 0.00 & 3.47 & 0.00 & 1,160 & 18,300 \\
\hline Harbor & 6 & 0.00 & 1,620 & 97.3 & 5,010 & 0.00 & 0.00 & 1,170 & 555 & 0.00141 & 13.5 & 0.00 & 1,620 & 10,100 \\
\hline Bent Spring & 7 & 0.00 & 793 & 0.00 & 8,430 & 148 & 29.1 & 564 & 25.7 & 0.00 & 0.604 & 0.00 & 4.12 & 10,000 \\
\hline Upper Wilmington A & 8 & 1,260 & 842 & 0.879 & 1,270 & 0.00 & 19.6 & 27.5 & 183 & 11.4 & 0.00 & 31.6 & 62.5 & 3,710 \\
\hline Upper Wilmington B & 9 & 0.00 & 360 & 11.7 & 68.1 & 2.80 & 0.00 & 4.78 & 1.11 & 0.933 & 0.00 & 25.7 & 0.00 & 475 \\
\hline Lower Wilmington & 10 & 0.00 & 38.6 & 0.00 & 109 & 0.00 & 0.00 & 20.7 & 24.1 & 0.824 & 0.00 & 0.00 & 0.00 & 194 \\
\hline Long Beach A & 11 & 0.00 & 2.40 & 0.00 & 0.223 & 0.00 & 0.00 & 0.00 & 0.0239 & 56.8 & 0.00 & 83.5 & 0.00 & 143 \\
\hline Long Beach B & 12 & 0.00 & 0.54 & 0.00 & 0.00 & 0.00 & 0.00 & 0.00 & 3.92 & 89.1 & 0.00 & 0.00 & 0.00 & 93.6 \\
\hline Long Beach C & 13 & 0.00 & 0.00 & 0.00 & 0.00 & 0.715 & 0.00 & 0.00 & 0.000464 & 0.00 & 0.00 & 0.00 & 0.00 & 0.715 \\
\hline Total & & 1,260 & 12,500 & 4,790 & 24,800 & 152 & 48.7 & 2,830 & 1,670 & 159 & 20.1 & 141 & 3,840 & 52,200 \\
\hline
\end{tabular}


Table D7. Simulated average 10-year water budget (acre-feet per year) by model layer and subarea of the Los Angeles Coastal Plain Groundwater-flow Model, 2006 to 2015, Los Angeles County, California.-Continued

[Negative numbers represent groundwater removed from the model/zone, and positive numbers represent groundwater added to the model/zone.]

\begin{tabular}{|c|c|c|c|c|c|c|c|c|c|c|c|c|c|c|}
\hline $\begin{array}{c}\text { Chronostratigraphic unit } \\
\text { name }\end{array}$ & $\begin{array}{l}\text { Model } \\
\text { layer }\end{array}$ & $\begin{array}{c}\text { Los } \\
\text { Angeles } \\
\text { Forebay }\end{array}$ & $\begin{array}{c}\text { WRD } \\
\text { Central } \\
\text { Basin }\end{array}$ & $\begin{array}{l}\text { Orange } \\
\text { County }\end{array}$ & $\begin{array}{l}\text { West } \\
\text { Coast }\end{array}$ & $\begin{array}{l}\text { Santa } \\
\text { Monica }\end{array}$ & Hollywood & $\begin{array}{l}\text { WRD Los } \\
\text { Angeles } \\
\text { Forebay }\end{array}$ & $\begin{array}{l}\text { Montebello } \\
\text { Forebay }\end{array}$ & Whitter & $\begin{array}{l}\text { Central } \\
\text { Basin }\end{array}$ & $\begin{array}{l}\text { North } \\
\text { Orange } \\
\text { County }\end{array}$ & $\begin{array}{c}\text { South } \\
\text { Orange } \\
\text { County }\end{array}$ & Total \\
\hline \multicolumn{15}{|c|}{ Areal recharge } \\
\hline Dominguez & 2 & 576 & 4,590 & 1,460 & 586 & 688 & 784 & 795 & 1,030 & 145 & 236 & 10.6 & 210 & 11,100 \\
\hline Mesa & 3 & 792 & 1,890 & 7.82 & 4,760 & 2,930 & 456 & 21.2 & 437 & 169 & 401 & 0.00 & 98.0 & 12,000 \\
\hline Pacific A & 4 & 0.00 & 0.00 & 0.00 & 0.00 & 0.00 & 0.00 & 0.00 & 0.00 & 0.00 & 0.00 & 0.00 & 0.00 & 0.00 \\
\hline Pacific & 5 & 0.00 & 165 & 12.1 & 307 & 383 & 0.00201 & 0.00 & 97.6 & 228 & 105 & 340 & 0.00 & 1,640 \\
\hline Harbor & 6 & 93.7 & 0.774 & 0.00 & 108 & 0.00 & 0.00 & 101 & 0.123 & 0.00 & 0.00 & 0.00 & 0.00 & 304 \\
\hline Bent Spring & 7 & 7.15 & 0.00 & 0.00 & 328 & 0.344 & 0.00 & 0.00 & 0.00 & 0.00 & 0.00 & 0.00 & 0.00 & 335 \\
\hline Upper Wilmington A & 8 & 0.00 & 11.6 & 2.39 & 71.1 & 25.7 & 0.00 & 12.7 & 86.0 & 14.9 & 0.00 & 78.9 & 0.00 & 303 \\
\hline Upper Wilmington B & 9 & 0.00 & 0.00 & 0.00 & 7.31 & 0.669 & 0.00 & 0.00 & 0.00 & 0.00 & 0.00 & 0.00 & 0.00 & 7.98 \\
\hline Lower Wilmington & 10 & 0.00 & 10.1 & 0.00 & 0.00 & 0.00 & 0.00 & 0.00 & 0.00 & 11.1 & 0.00 & 24.2 & 0.00 & 45.4 \\
\hline Long Beach A & 11 & 0.00 & 1.36 & 0.00 & 0.00 & 0.00 & 0.00 & 0.00 & 13.6 & 0.121 & 0.00 & 24.2 & 0.00 & 39.2 \\
\hline Long Beach B & 12 & 0.00 & 0.00 & 0.00 & 0.00 & 0.00 & 0.00 & 0.00 & 2.10 & 0.00 & 0.00 & 0.00 & 0.00 & 2.10 \\
\hline Long Beach C & 13 & 99.4 & 36.9 & 0.00 & 44.1 & 0.132 & 0.00 & 55.2 & 504 & 456 & 13.7 & 48.7 & 0.00 & 1,260 \\
\hline Total & & 1,570 & 6,710 & 1,480 & 6,210 & 4,020 & 1,240 & 986 & 2,180 & 1,020 & 755 & 527 & 308 & 27,000 \\
\hline \multicolumn{15}{|c|}{ Flow from Santa Monica Bay } \\
\hline Dominguez & 2 & 0.00 & 0.00 & 0.00 & 0.00 & 0.000132 & 0.00 & 0.00 & 0.00 & 0.00 & 0.00 & 0.00 & 0.00 & 0.000132 \\
\hline Mesa & 3 & 0.00 & 0.00 & 0.00 & -58.9 & -133 & 0.00 & 0.00 & 0.00 & 0.00 & 0.00 & 0.00 & 0.00 & -192 \\
\hline Pacific A & 4 & 0.00 & 0.00 & 0.00 & 0.00 & 0.00 & 0.00 & 0.00 & 0.00 & 0.00 & 0.00 & 0.00 & 0.00 & 0.00 \\
\hline Pacific & 5 & 0.00 & 0.00 & 0.00 & -43.9 & -11.7 & 0.00 & 0.00 & 0.00 & 0.00 & 0.00 & 0.00 & 0.00 & -55.6 \\
\hline Harbor & 6 & 0.00 & 0.00 & 0.00 & -38.6 & 0.00 & 0.00 & 0.00 & 0.00 & 0.00 & 0.00 & 0.00 & 0.00 & -38.6 \\
\hline Bent Spring & 7 & 0.00 & 0.00 & 0.00 & 130 & 61.5 & 0.00 & 0.00 & 0.00 & 0.00 & 0.00 & 0.00 & 0.00 & 191 \\
\hline Upper Wilmington A & 8 & 0.00 & 0.00 & 0.00 & -8.74 & 130 & 0.00 & 0.00 & 0.00 & 0.00 & 0.00 & 0.00 & 0.00 & 122 \\
\hline Upper Wilmington B & 9 & 0.00 & 0.00 & 0.00 & -56.6 & -5.94 & 0.00 & 0.00 & 0.00 & 0.00 & 0.00 & 0.00 & 0.00 & -62.5 \\
\hline Lower Wilmington & 10 & 0.00 & 0.00 & 0.00 & 161 & -32.3 & 0.00 & 0.00 & 0.00 & 0.00 & 0.00 & 0.00 & 0.00 & 129 \\
\hline 0Long Beach A & 11 & 0.00 & 0.00 & 0.00 & -2.72 & -8.31 & 0.00 & 0.00 & 0.00 & 0.00 & 0.00 & 0.00 & 0.00 & -11.0 \\
\hline Long Beach B & 12 & 0.00 & 0.00 & 0.00 & 2.60 & -2.32 & 0.00 & 0.00 & 0.00 & 0.00 & 0.00 & 0.00 & 0.00 & 0.286 \\
\hline Long Beach C & 13 & 0.00 & 0.00 & 0.00 & -3.73 & 2.17 & 0.00 & 0.00 & 0.00 & 0.00 & 0.00 & 0.00 & 0.00 & -1.55 \\
\hline Total & & 0.00 & 0.00 & 0.00 & 80.4 & 0.696 & 0.00 & 0.00 & 0.00 & 0.00 & 0.00 & 0.00 & 0.00 & 81.1 \\
\hline
\end{tabular}


Table D7. Simulated average 10-year water budget (acre-feet per year) by model layer and subarea of the Los Angeles Coastal Plain Groundwater-flow Model, 2006 to 2015, Los Angeles County, California.-Continued

[Negative numbers represent groundwater removed from the model/zone, and positive numbers represent groundwater added to the model/zone.]

\begin{tabular}{|c|c|c|c|c|c|c|c|c|c|c|c|c|c|c|}
\hline $\begin{array}{c}\text { Chronostratigraphic unit } \\
\text { name }\end{array}$ & $\begin{array}{l}\text { Model } \\
\text { layer }\end{array}$ & $\begin{array}{c}\text { Los } \\
\text { Angeles } \\
\text { Forebay }\end{array}$ & $\begin{array}{c}\text { WRD } \\
\text { Central } \\
\text { Basin }\end{array}$ & $\begin{array}{l}\text { Orange } \\
\text { County }\end{array}$ & $\begin{array}{l}\text { West } \\
\text { Coast }\end{array}$ & $\begin{array}{l}\text { Santa } \\
\text { Monica }\end{array}$ & Hollywood & $\begin{array}{c}\text { WRD Los } \\
\text { Angeles } \\
\text { Forebay }\end{array}$ & $\begin{array}{l}\text { Montebello } \\
\text { Forebay }\end{array}$ & Whitter & $\begin{array}{l}\text { Central } \\
\text { Basin }\end{array}$ & $\begin{array}{l}\text { North } \\
\text { Orange } \\
\text { County }\end{array}$ & $\begin{array}{l}\text { South } \\
\text { Orange } \\
\text { County }\end{array}$ & Total \\
\hline \multicolumn{15}{|c|}{ Flow from San Pedro Bay } \\
\hline Dominguez & 2 & 0.00 & 0.00 & 0.00 & 183 & 0.00 & 0.00 & 0.00 & 0.00 & 0.00 & 0.00 & 0.00 & 40.6 & 224 \\
\hline Mesa & 3 & 0.00 & 0.00 & 0.00 & 25.2 & 0.00 & 0.00 & 0.00 & 0.00 & 0.00 & 0.00 & 0.00 & 163 & 188 \\
\hline Pacific A & 4 & 0.00 & 0.00 & 0.00 & 0.00 & 0.00 & 0.00 & 0.00 & 0.00 & 0.00 & 0.00 & 0.00 & 0.00 & 0.00 \\
\hline Pacific & 5 & 0.00 & 0.00 & 0.00 & 752 & 0.00 & 0.00 & 0.00 & 0.00 & 0.00 & 0.00 & 0.00 & 232 & 984 \\
\hline Harbor & 6 & 0.00 & 0.00 & 0.00 & 756 & 0.00 & 0.00 & 0.00 & 0.00 & 0.00 & 0.00 & 0.00 & 717 & 1,470 \\
\hline Bent Spring & 7 & 0.00 & 0.00 & 0.00 & 181 & 0.00 & 0.00 & 0.00 & 0.00 & 0.00 & 0.00 & 0.00 & 67.1 & 248 \\
\hline Upper Wilmington A & 8 & 0.00 & 0.00 & 0.00 & 0.00 & 0.00 & 0.00 & 0.00 & 0.00 & 0.00 & 0.00 & 0.00 & 0.00 & 0.00 \\
\hline Upper Wilmington B & 9 & 0.00 & 0.00 & 0.00 & 126 & 0.00 & 0.00 & 0.00 & 0.00 & 0.00 & 0.00 & 0.00 & 0.00 & 126 \\
\hline Lower Wilmington & 10 & 0.00 & 0.00 & 0.00 & 1,520 & 0.00 & 0.00 & 0.00 & 0.00 & 0.00 & 0.00 & 0.00 & 73.9 & 1,600 \\
\hline Long Beach A & 11 & 0.00 & 0.00 & 0.00 & 317 & 0.00 & 0.00 & 0.00 & 0.00 & 0.00 & 0.00 & 0.00 & -321 & -3.57 \\
\hline Long Beach B & 12 & 0.00 & 0.00 & 0.00 & 318 & 0.00 & 0.00 & 0.00 & 0.00 & 0.00 & 0.00 & 0.00 & -94.8 & 224 \\
\hline Long Beach C & 13 & 0.00 & 0.00 & 0.00 & 85.1 & 0.00 & 0.00 & 0.00 & 0.00 & 0.00 & 0.00 & 0.00 & -316 & -231 \\
\hline Total & & 0.00 & 0.00 & 0.00 & 4,270 & 0.00 & 0.00 & 0.00 & 0.00 & 0.00 & 0.00 & 0.00 & 562 & 4,830 \\
\hline \multicolumn{15}{|c|}{ Underflow from Orange County } \\
\hline Dominguez & 2 & 0.00 & 0.00 & 6,770 & 0.00 & 0.00 & 0.00 & 0.00 & 0.00 & 0.00 & 0.00 & 0.00 & 66.5 & 6,840 \\
\hline Mesa & 3 & 0.00 & 0.00 & 1,750 & 0.00 & 0.00 & 0.00 & 0.00 & 0.00 & 0.00 & 0.00 & 0.00 & 403 & 2,150 \\
\hline Pacific A & 4 & 0.00 & 0.00 & 4,400 & 0.00 & 0.00 & 0.00 & 0.00 & 0.00 & 0.00 & 0.00 & 0.00 & 0.00 & 4,400 \\
\hline Pacific & 5 & 0.00 & 0.00 & 15,200 & 0.00 & 0.00 & 0.00 & 0.00 & 0.00 & 0.00 & 0.00 & -7.99 & 1,600 & 16,700 \\
\hline Harbor & 6 & 0.00 & 0.00 & 7,160 & 0.00 & 0.00 & 0.00 & 0.00 & 0.00 & 0.00 & 0.00 & 0.00 & 931 & 8,090 \\
\hline Bent Spring & 7 & 0.00 & 0.00 & 1,100 & 0.00 & 0.00 & 0.00 & 0.00 & 0.00 & 0.00 & 0.00 & 0.00 & 88 & 1,190 \\
\hline Upper Wilmington A & 8 & 0.00 & 0.00 & 6,510 & 0.00 & 0.00 & 0.00 & 0.00 & 0.00 & 0.00 & 0.00 & 946 & 1,360 & 8,820 \\
\hline Upper Wilmington B & 9 & 0.00 & 0.00 & 2,450 & 0.00 & 0.00 & 0.00 & 0.00 & 0.00 & 0.00 & 0.00 & 300 & -66.2 & 2,690 \\
\hline Lower Wilmington & 10 & 0.00 & 0.00 & 142 & 0.00 & 0.00 & 0.00 & 0.00 & 0.00 & 0.00 & 0.00 & 773 & 30.0 & 944 \\
\hline Long Beach A & 11 & 0.00 & 0.00 & 58.6 & 0.00 & 0.00 & 0.00 & 0.00 & 0.00 & 0.00 & 0.00 & 1,160 & 861 & 2,080 \\
\hline Long Beach B & 12 & 0.00 & 0.00 & 99.4 & 0.00 & 0.00 & 0.00 & 0.00 & 0.00 & 0.00 & 0.00 & 103 & 680 & 883 \\
\hline Long Beach C & 13 & 0.00 & 0.00 & 38.8 & 0.00 & 0.00 & 0.00 & 0.00 & 0.00 & 0.00 & 0.00 & 134 & 429 & 602 \\
\hline Total & & 0.00 & 0.00 & 45,600 & 0.00 & 0.00 & 0.00 & 0.00 & 0.00 & 0.00 & 0.00 & 3,410 & 6,390 & 55,400 \\
\hline
\end{tabular}


Table D7. Simulated average 10-year water budget (acre-feet per year) by model layer and subarea of the Los Angeles Coastal Plain Groundwater-flow Model, 2006 to 2015, Los Angeles County, California.-Continued

[Negative numbers represent groundwater removed from the model/zone, and positive numbers represent groundwater added to the model/zone.]

\begin{tabular}{|c|c|c|c|c|c|c|c|c|c|c|c|c|c|c|}
\hline $\begin{array}{c}\text { Chronostratigraphic unit } \\
\text { name }\end{array}$ & $\begin{array}{c}\text { Model } \\
\text { layer }\end{array}$ & $\begin{array}{c}\text { Los } \\
\text { Angeles } \\
\text { Forebay }\end{array}$ & $\begin{array}{c}\text { WRD } \\
\text { Central } \\
\text { Basin }\end{array}$ & $\begin{array}{l}\text { Orange } \\
\text { County }\end{array}$ & $\begin{array}{l}\text { West } \\
\text { Coast }\end{array}$ & $\begin{array}{l}\text { Santa } \\
\text { Monica }\end{array}$ & Hollywood & $\begin{array}{c}\text { WRD Los } \\
\text { Angeles } \\
\text { Forebay }\end{array}$ & $\begin{array}{l}\text { Montebello } \\
\text { Forebay }\end{array}$ & Whitter & $\begin{array}{l}\text { Central } \\
\text { Basin }\end{array}$ & $\begin{array}{c}\text { North } \\
\text { Orange } \\
\text { County }\end{array}$ & $\begin{array}{l}\text { South } \\
\text { Orange } \\
\text { County }\end{array}$ & Total \\
\hline \multicolumn{15}{|c|}{ Underflow from San Gabriel Basin } \\
\hline Dominguez & 2 & 0.00 & 0.00 & 0.00 & 0.00 & 0.00 & 0.00 & 0.00 & 0.00 & 0.00 & 0.00 & 0.00 & 0.00 & 0.00 \\
\hline Mesa & 3 & 0.00 & 0.00 & 0.00 & 0.00 & 0.00 & 0.00 & 0.00 & 31,600 & 0.00 & 0.00 & 0.00 & 0.00 & 31,600 \\
\hline Pacific A & 4 & 0.00 & 0.00 & 0.00 & 0.00 & 0.00 & 0.00 & 0.00 & 0.00 & 0.00 & 0.00 & 0.00 & 0.00 & 0.00 \\
\hline Pacific & 5 & 0.00 & 0.00 & 0.00 & 0.00 & 0.00 & 0.00 & 0.00 & 0.00 & 0.00 & 0.00 & 0.00 & 0.00 & 0.00 \\
\hline Harbor & 6 & 0.00 & 0.00 & 0.00 & 0.00 & 0.00 & 0.00 & 0.00 & 0.00 & 0.00 & 0.00 & 0.00 & 0.00 & 0.00 \\
\hline Bent Spring & 7 & 0.00 & 0.00 & 0.00 & 0.00 & 0.00 & 0.00 & 0.00 & 0.00 & 0.00 & 0.00 & 0.00 & 0.00 & 0.00 \\
\hline Upper Wilmington A & 8 & 0.00 & 0.00 & 0.00 & 0.00 & 0.00 & 0.00 & 0.00 & 0.00 & 0.00 & 0.00 & 0.00 & 0.00 & 0.00 \\
\hline Upper Wilmington B & 9 & 0.00 & 0.00 & 0.00 & 0.00 & 0.00 & 0.00 & 0.00 & 0.00 & 0.00 & 0.00 & 0.00 & 0.00 & 0.00 \\
\hline Lower Wilmington & 10 & 0.00 & 0.00 & 0.00 & 0.00 & 0.00 & 0.00 & 0.00 & 0.00 & 0.00 & 0.00 & 0.00 & 0.00 & 0.00 \\
\hline Long Beach A & 11 & 0.00 & 0.00 & 0.00 & 0.00 & 0.00 & 0.00 & 0.00 & 0.00 & 0.00 & 0.00 & 0.00 & 0.00 & 0.00 \\
\hline Long Beach B & 12 & 0.00 & 0.00 & 0.00 & 0.00 & 0.00 & 0.00 & 0.00 & 0.00 & 0.00 & 0.00 & 0.00 & 0.00 & 0.00 \\
\hline Long Beach C & 13 & 0.00 & 0.00 & 0.00 & 0.00 & 0.00 & 0.00 & 0.00 & 6,440 & 0.00 & 0.00 & 0.00 & 0.00 & 6,440 \\
\hline Total & & 0.00 & 0.00 & 0.00 & 0.00 & 0.00 & 0.00 & 0.00 & 38,000 & 0.00 & 0.00 & 0.00 & 0.00 & 38,000 \\
\hline \multicolumn{15}{|c|}{ Underflow from Palos Verdes Hills } \\
\hline Dominguez & 2 & 0.00 & 0.00 & 0.00 & 0.00 & 0.00 & 0.00 & 0.00 & 0.00 & 0.00 & 0.00 & 0.00 & 0.00 & 0.00 \\
\hline Mesa & 3 & 0.00 & 0.00 & 0.00 & 0.00 & 0.00 & 0.00 & 0.00 & 0.00 & 0.00 & 0.00 & 0.00 & 0.00 & 0.00 \\
\hline Pacific A & 4 & 0.00 & 0.00 & 0.00 & 0.00 & 0.00 & 0.00 & 0.00 & 0.00 & 0.00 & 0.00 & 0.00 & 0.00 & 0.00 \\
\hline Pacific & 5 & 0.00 & 0.00 & 0.00 & 0.00 & 0.00 & 0.00 & 0.00 & 0.00 & 0.00 & 0.00 & 0.00 & 0.00 & 0.00 \\
\hline Harbor & 6 & 0.00 & 0.00 & 0.00 & 0.00 & 0.00 & 0.00 & 0.00 & 0.00 & 0.00 & 0.00 & 0.00 & 0.00 & 0.00 \\
\hline Bent Spring & 7 & 0.00 & 0.00 & 0.00 & 0.00 & 0.00 & 0.00 & 0.00 & 0.00 & 0.00 & 0.00 & 0.00 & 0.00 & 0.00 \\
\hline Upper Wilmington A & 8 & 0.00 & 0.00 & 0.00 & 0.00 & 0.00 & 0.00 & 0.00 & 0.00 & 0.00 & 0.00 & 0.00 & 0.00 & 0.00 \\
\hline Upper Wilmington B & 9 & 0.00 & 0.00 & 0.00 & 0.00 & 0.00 & 0.00 & 0.00 & 0.00 & 0.00 & 0.00 & 0.00 & 0.00 & 0.00 \\
\hline Lower Wilmington & 10 & 0.00 & 0.00 & 0.00 & 2.80 & 0.00 & 0.00 & 0.00 & 0.00 & 0.00 & 0.00 & 0.00 & 0.00 & 2.80 \\
\hline Long Beach A & 11 & 0.00 & 0.00 & 0.00 & 0.876 & 0.00 & 0.00 & 0.00 & 0.00 & 0.00 & 0.00 & 0.00 & 0.00 & 0.876 \\
\hline Long Beach B & 12 & 0.00 & 0.00 & 0.00 & 0.474 & 0.00 & 0.00 & 0.00 & 0.00 & 0.00 & 0.00 & 0.00 & 0.00 & 0.474 \\
\hline Long Beach C & 13 & 0.00 & 0.00 & 0.00 & 25.8 & 0.00 & 0.00 & 0.00 & 0.00 & 0.00 & 0.00 & 0.00 & 0.00 & 25.8 \\
\hline Total & & 0.00 & 0.00 & 0.00 & 30.0 & 0.00 & 0.00 & 0.00 & 0.00 & 0.00 & 0.00 & 0.00 & 0.00 & 30.0 \\
\hline
\end{tabular}


Table D7. Simulated average 10-year water budget (acre-feet per year) by model layer and subarea of the Los Angeles Coastal Plain Groundwater-flow Model, 2006 to 2015, Los Angeles County, California.-Continued

[Negative numbers represent groundwater removed from the model/zone, and positive numbers represent groundwater added to the model/zone.]

\begin{tabular}{|c|c|c|c|c|c|c|c|c|c|c|c|c|c|c|}
\hline $\begin{array}{c}\text { Chronostratigraphic unit } \\
\text { name }\end{array}$ & $\begin{array}{l}\text { Model } \\
\text { layer }\end{array}$ & $\begin{array}{c}\text { Los } \\
\text { Angeles } \\
\text { Forebay }\end{array}$ & $\begin{array}{c}\text { WRD } \\
\text { Central } \\
\text { Basin }\end{array}$ & $\begin{array}{l}\text { Orange } \\
\text { County }\end{array}$ & $\begin{array}{l}\text { West } \\
\text { Coast }\end{array}$ & $\begin{array}{l}\text { Santa } \\
\text { Monica }\end{array}$ & Hollywood & $\begin{array}{l}\text { WRD Los } \\
\text { Angeles } \\
\text { Forebay }\end{array}$ & $\begin{array}{l}\text { Montebello } \\
\text { Forebay }\end{array}$ & Whitter & $\begin{array}{l}\text { Central } \\
\text { Basin }\end{array}$ & $\begin{array}{l}\text { North } \\
\text { Orange } \\
\text { County }\end{array}$ & $\begin{array}{l}\text { South } \\
\text { Orange } \\
\text { County }\end{array}$ & Total \\
\hline \multicolumn{15}{|c|}{ Flow from Marina Del Rey } \\
\hline Dominguez & 2 & 0.00 & 0.00 & 0.00 & 0.00 & 0.00 & 0.00 & 0.00 & 0.00 & 0.00 & 0.00 & 0.00 & 0.00 & 0.00 \\
\hline Mesa & 3 & 0.00 & 0.00 & 0.00 & 0.00 & 126 & 0.00 & 0.00 & 0.00 & 0.00 & 0.00 & 0.00 & 0.00 & 126 \\
\hline Pacific A & 4 & 0.00 & 0.00 & 0.00 & 0.00 & 0.00 & 0.00 & 0.00 & 0.00 & 0.00 & 0.00 & 0.00 & 0.00 & 0.00 \\
\hline Pacific & 5 & 0.00 & 0.00 & 0.00 & 0.00 & 0.00 & 0.00 & 0.00 & 0.00 & 0.00 & 0.00 & 0.00 & 0.00 & 0.00 \\
\hline Harbor & 6 & 0.00 & 0.00 & 0.00 & 0.00 & 0.00 & 0.00 & 0.00 & 0.00 & 0.00 & 0.00 & 0.00 & 0.00 & 0.00 \\
\hline Bent Spring & 7 & 0.00 & 0.00 & 0.00 & 0.00 & 0.00 & 0.00 & 0.00 & 0.00 & 0.00 & 0.00 & 0.00 & 0.00 & 0.00 \\
\hline Upper Wilmington A & 8 & 0.00 & 0.00 & 0.00 & 0.00 & 0.00 & 0.00 & 0.00 & 0.00 & 0.00 & 0.00 & 0.00 & 0.00 & 0.00 \\
\hline Upper Wilmington B & 9 & 0.00 & 0.00 & 0.00 & 0.00 & 0.00 & 0.00 & 0.00 & 0.00 & 0.00 & 0.00 & 0.00 & 0.00 & 0.00 \\
\hline Lower Wilmington & 10 & 0.00 & 0.00 & 0.00 & 0.00 & 0.00 & 0.00 & 0.00 & 0.00 & 0.00 & 0.00 & 0.00 & 0.00 & 0.00 \\
\hline Long Beach A & 11 & 0.00 & 0.00 & 0.00 & 0.00 & 0.00 & 0.00 & 0.00 & 0.00 & 0.00 & 0.00 & 0.00 & 0.00 & 0.00 \\
\hline Long Beach B & 12 & 0.00 & 0.00 & 0.00 & 0.00 & 0.00 & 0.00 & 0.00 & 0.00 & 0.00 & 0.00 & 0.00 & 0.00 & 0.00 \\
\hline Long Beach C & 13 & 0.00 & 0.00 & 0.00 & 0.00 & 0.00 & 0.00 & 0.00 & 0.00 & 0.00 & 0.00 & 0.00 & 0.00 & 0.00 \\
\hline Total & & 0.00 & 0.00 & 0.00 & 0.00 & 126 & 0.00 & 0.00 & 0.00 & 0.00 & 0.00 & 0.00 & 0.00 & 126 \\
\hline \multicolumn{15}{|c|}{ Flow from Port of Long Beach } \\
\hline Dominguez & 2 & 0.00 & 0.00 & 0.00 & 0.00 & 0.00 & 0.00 & 0.00 & 0.00 & 0.00 & 0.00 & 0.00 & 0.00 & 0.00 \\
\hline Mesa & 3 & 0.00 & 0.00 & 0.00 & 0.00074 & 0.00 & 0.00 & 0.00 & 0.00 & 0.00 & 0.00 & 0.00 & 0.00 & -0.00074 \\
\hline Pacific A & 4 & 0.00 & 0.00 & 0.00 & 0.00 & 0.00 & 0.00 & 0.00 & 0.00 & 0.00 & 0.00 & 0.00 & 0.00 & 0.00 \\
\hline Pacific & 5 & 0.00 & 0.00 & 0.00 & 0.00 & 0.00 & 0.00 & 0.00 & 0.00 & 0.00 & 0.00 & 0.00 & 0.00 & 0.00 \\
\hline Harbor & 6 & 0.00 & 0.00 & 0.00 & 0.00 & 0.00 & 0.00 & 0.00 & 0.00 & 0.00 & 0.00 & 0.00 & 0.00 & 0.00 \\
\hline Bent Spring & 7 & 0.00 & 0.00 & 0.00 & 0.00 & 0.00 & 0.00 & 0.00 & 0.00 & 0.00 & 0.00 & 0.00 & 0.00 & 0.00 \\
\hline Upper Wilmington A & 8 & 0.00 & 0.00 & 0.00 & 0.00 & 0.00 & 0.00 & 0.00 & 0.00 & 0.00 & 0.00 & 0.00 & 0.00 & 0.00 \\
\hline Upper Wilmington B & 9 & 0.00 & 0.00 & 0.00 & 0.00 & 0.00 & 0.00 & 0.00 & 0.00 & 0.00 & 0.00 & 0.00 & 0.00 & 0.00 \\
\hline Lower Wilmington & 10 & 0.00 & 0.00 & 0.00 & 0.00 & 0.00 & 0.00 & 0.00 & 0.00 & 0.00 & 0.00 & 0.00 & 0.00 & 0.00 \\
\hline Long Beach A & 11 & 0.00 & 0.00 & 0.00 & 0.00 & 0.00 & 0.00 & 0.00 & 0.00 & 0.00 & 0.00 & 0.00 & 0.00 & 0.00 \\
\hline Long Beach B & 12 & 0.00 & 0.00 & 0.00 & 0.00 & 0.00 & 0.00 & 0.00 & 0.00 & 0.00 & 0.00 & 0.00 & 0.00 & 0.00 \\
\hline Long Beach C & 13 & 0.00 & 0.00 & 0.00 & 0.00 & 0.00 & 0.00 & 0.00 & 0.00 & 0.00 & 0.00 & 0.00 & 0.00 & 0.00 \\
\hline Total & & 0.00 & 0.00 & 0.00 & -0.00074 & 0.00 & 0.00 & 0.00 & 0.00 & 0.00 & 0.00 & 0.00 & 0.00 & -0.00074 \\
\hline
\end{tabular}


Table D7. Simulated average 10-year water budget (acre-feet per year) by model layer and subarea of the Los Angeles Coastal Plain Groundwater-flow Model, 2006 to 2015, Los Angeles County, California.-Continued

[Negative numbers represent groundwater removed from the model/zone, and positive numbers represent groundwater added to the model/zone.]

\begin{tabular}{|c|c|c|c|c|c|c|c|c|c|c|c|c|c|c|}
\hline $\begin{array}{c}\text { Chronostratigraphic unit } \\
\text { name }\end{array}$ & $\begin{array}{c}\text { Model } \\
\text { layer }\end{array}$ & $\begin{array}{c}\text { Los } \\
\text { Angeles } \\
\text { Forebay }\end{array}$ & $\begin{array}{c}\text { WRD } \\
\text { Central } \\
\text { Basin }\end{array}$ & $\begin{array}{l}\text { Orange } \\
\text { County }\end{array}$ & $\begin{array}{l}\text { West } \\
\text { Coast }\end{array}$ & $\begin{array}{l}\text { Santa } \\
\text { Monica }\end{array}$ & Hollywood & $\begin{array}{l}\text { WRD Los } \\
\text { Angeles } \\
\text { Forebay }\end{array}$ & $\begin{array}{l}\text { Montebello } \\
\text { Forebay }\end{array}$ & Whitter & $\begin{array}{l}\text { Central } \\
\text { Basin }\end{array}$ & $\begin{array}{l}\text { North } \\
\text { Orange } \\
\text { County }\end{array}$ & $\begin{array}{l}\text { South } \\
\text { Orange } \\
\text { County }\end{array}$ & Total \\
\hline \multicolumn{15}{|c|}{ Underflow from San Fernando Basin } \\
\hline Dominguez & 2 & 0.00 & 0.00 & 0.00 & 0.00 & 0.00 & 0.00 & 0.00 & 0.00 & 0.00 & 0.00 & 0.00 & 0.00 & 0.00 \\
\hline Mesa & 3 & 5,470 & 0.00 & 0.00 & 0.00 & 0.00 & 0.00 & 0.00 & 0.00 & 0.00 & 0.00 & 0.00 & 0.00 & 5,470 \\
\hline Pacific A & 4 & 0.00 & 0.00 & 0.00 & 0.00 & 0.00 & 0.00 & 0.00 & 0.00 & 0.00 & 0.00 & 0.00 & 0.00 & 0.00 \\
\hline Pacific & 5 & 0.00 .00 & 0.00 .00 & 0.00 & 0.00 & 0.00 & 0.00 & 0.00 & 0.00 & 0.00 & 0.00 & 0.00 & 0.00 & 0.00 \\
\hline Harbor & 6 & 0.00 & 0.00 & 0.00 & 0.00 & 0.00 & 0.00 & 0.00 & 0.00 & 0.00 & 0.00 & 0.00 & 0.00 & 0.00 \\
\hline Bent Spring & 7 & 0.00 & 0.00 & 0.00 & 0.00 & 0.00 & 0.00 & 0.00 & 0.00 & 0.00 & 0.00 & 0.00 & 0.00 & 0.00 \\
\hline Upper Wilmington A & 8 & 0.00 & 0.00 & 0.00 & 0.00 & 0.00 & 0.00 & 0.00 & 0.00 & 0.00 & 0.00 & 0.00 & 0.00 & 0.00 \\
\hline Upper Wilmington B & 9 & 0.00 & 0.00 & 0.00 & 0.00 & 0.00 & 0.00 & 0.00 & 0.00 & 0.00 & 0.00 & 0.00 & 0.00 & 0.00 \\
\hline Lower Wilmington & 10 & 0.00 & 0.00 & 0.00 & 0.00 & 0.00 & 0.00 & 0.00 & 0.00 & 0.00 & 0.00 & 0.00 & 0.00 & 0.00 \\
\hline Long Beach A & 11 & 0.00 & 0.00 & 0.00 & 0.00 & 0.00 & 0.00 & 0.00 & 0.00 & 0.00 & 0.00 & 0.00 & 0.00 & 0.00 \\
\hline Long Beach B & 12 & 0.00 & 0.00 & 0.00 & 0.00 & 0.00 & 0.00 & 0.00 & 0.00 & 0.00 & 0.00 & 0.00 & 0.00 & 0.00 \\
\hline Long Beach C & 13 & 0.00 & 0.00 & 0.00 & 0.00 & 0.00 & 0.00 & 0.00 & 0.00 & 0.00 & 0.00 & 0.00 & 0.00 & 0.00 \\
\hline Total & & 5,470 & 0.00 & 0.00 & 0.00 & 0.00 & 0.00 & 0.00 & 0.00 & 0.00 & 0.00 & 0.00 & 0.00 & 5,470 \\
\hline \multicolumn{15}{|c|}{ Drains } \\
\hline Dominguez & 2 & 0.00 & -5.91 & 0.00 & 0.00 & -220 & 0.00 & 0.00 & -31.1 & 0.00 & -233 & -37.2 & 0.00 & -526 \\
\hline Mesa & 3 & 0.00 & -109 & 0.00 & 0.00 & -273 & 0.00 & 0.00 & 0.00 & 0.00 & 0.00 & 0.00 & 0.00 & -382 \\
\hline Pacific A & 4 & 0.00 & 0.00 & 0.00 & 0.00 & 0.00 & 0.00 & 0.00 & 0.00 & 0.00 & 0.00 & 0.00 & 0.00 & 0.00 \\
\hline Pacific & 5 & 0.00 & 0.00 & 0.00 & 0.00 & -195 & 0.00 & 0.00 & -604 & -0.624 & 0.00 & -179 & 0.00 & -978 \\
\hline Harbor & 6 & 0.00 & 0.00 & 0.00 & 0.00 & 0.00 & 0.00 & 0.00 & 0.00 & 0.00 & 0.00 & 0.00 & 0.00 & 0.00 \\
\hline Bent Spring & 7 & 0.00 & 0.00 & 0.00 & 0.00 & -530 & 0.00 & 0.00 & 0.00 & 0.00 & 0.00 & 0.00 & 0.00 & -530 \\
\hline Upper Wilmington A & 8 & 0.00 & 0.00 & 0.00 & 0.00 & 0.00 & 0.00 & 0.00 & 0.00 & 0.00 & 0.00 & -353 & 0.00 & -353 \\
\hline Upper Wilmington B & 9 & 0.00 & 0.00 & 0.00 & 0.00 & 0.00 & 0.00 & 0.00 & 0.00 & 0.00 & 0.00 & 0.00 & 0.00 & 0.00 \\
\hline Lower Wilmington & 10 & 0.00 & 0.00 & 0.00 & 0.00 & 0.00 & 0.00 & 0.00 & 0.00 & 0.00 & 0.00 & -183 & 0.00 & -183 \\
\hline Long Beach A & 11 & 0.00 & -881 & 0.00 & 0.00 & 0.00 & 0.00 & 0.00 & 0.00 & 0.00 & 0.00 & -58.5 & 0.00 & -940 \\
\hline Long Beach B & 12 & 0.00 & 0.00 & 0.00 & 0.00 & 0.00 & 0.00 & 0.00 & 0.00 & 0.00 & 0.00 & 0.00 & 0.00 & 0.00 \\
\hline Long Beach C & 13 & 0.00 & 0.00 & 0.00 & 0.00 & 0.00 & 0.00 & 0.00 & 0.00 & 0.00 & 0.00 & 0.00 & 0.00 & 0.00 \\
\hline Total & & 0.00 & -997 & 0.00 & 0.00 & $-1,220$ & 0.00 & 0.00 & -635 & -0.624 & -233 & -811 & 0.00 & $-3,890$ \\
\hline Total net flow & & $-1,240$ & $-10,400$ & $-1,260$ & $-3,200$ & $-5,100$ & $-2,990$ & $-1,780$ & $-9,570$ & $-1,700$ & -901 & -485 & -353 & $-39,000$ \\
\hline
\end{tabular}


Table D7. Simulated average 10-year water budget (acre-feet per year) by model layer and subarea of the Los Angeles Coastal Plain Groundwater-flow Model, 2006 to 2015, Los Angeles County, California.-Continued

[Negative numbers represent groundwater removed from the model/zone, and positive numbers represent groundwater added to the model/zone.]

\begin{tabular}{|c|c|c|c|c|c|c|c|c|c|c|c|c|c|c|}
\hline $\begin{array}{c}\text { Chronostratigraphic unit } \\
\text { name }\end{array}$ & $\begin{array}{l}\text { Model } \\
\text { layer }\end{array}$ & $\begin{array}{c}\text { Los } \\
\text { Angeles } \\
\text { Forebay }\end{array}$ & $\begin{array}{c}\text { WRD } \\
\text { Central } \\
\text { Basin }\end{array}$ & $\begin{array}{l}\text { Orange } \\
\text { County }\end{array}$ & $\begin{array}{l}\text { West } \\
\text { Coast }\end{array}$ & $\begin{array}{l}\text { Santa } \\
\text { Monica }\end{array}$ & Hollywood & $\begin{array}{c}\text { WRD Los } \\
\text { Angeles } \\
\text { Forebay }\end{array}$ & $\begin{array}{l}\text { Montebello } \\
\text { Forebay }\end{array}$ & Whitter & $\begin{array}{l}\text { Central } \\
\text { Basin }\end{array}$ & $\begin{array}{l}\text { North } \\
\text { Orange } \\
\text { County }\end{array}$ & $\begin{array}{c}\text { South } \\
\text { Orange } \\
\text { County }\end{array}$ & Total \\
\hline \multicolumn{15}{|c|}{ Change in storage } \\
\hline Dominguez & 2 & -453 & $-5,090$ & -640 & -40.6 & -926 & -224 & -847 & $-3,980$ & -81.2 & -146 & -6.72 & -165 & $-12,600$ \\
\hline Mesa & 3 & -326 & $-3,950$ & -22.5 & $-2,550$ & $-1,450$ & $-1,410$ & -546 & $-3,530$ & -814 & -654 & 0.00 & -110 & $-15,400$ \\
\hline Pacific A & 4 & -7.39 & -77.9 & -9.26 & 0.000415 & 0.00 & 0.00 & -1.06 & -38.1 & -24.8 & -1.71 & 0.00 & 0.00 & -160 \\
\hline Pacific & 5 & -7.66 & -259 & -35.4 & -473 & $-2,340$ & -21.6 & -79.6 & -280 & -204 & -22.6 & -221 & -37.3 & $-3,980$ \\
\hline Harbor & 6 & -60.5 & -138 & -33.4 & -65.3 & -0.0361 & 0.00 & -124 & -99.0 & -177 & -0.388 & 0.00 & -7.12 & -705 \\
\hline Bent Spring & 7 & -47.2 & -122 & -63.5 & -244 & -60.0 & -526 & -2.49 & -4.10 & 0.00 & -21.2 & 0.00 & -2.36 & $-1,090$ \\
\hline Upper Wilmington A & 8 & -99.2 & -139 & -352 & 5.52 & -118 & -790 & -56.5 & -486 & -44.1 & -2.28 & -111 & -7.66 & $-2,200$ \\
\hline Upper Wilmington B & 9 & 0.525 & -266 & -30.2 & -54.3 & -88.6 & -5.80 & -7.50 & -8.74 & -0.476 & -20.1 & -2.67 & -6.33 & -491 \\
\hline Lower Wilmington & 10 & -86.4 & -92.9 & -26.3 & 98.7 & -50.4 & -13.9 & -13.4 & -13.2 & -6.51 & -5.02 & -11.3 & -5.21 & -226 \\
\hline Long Beach A & 11 & -3.60 & -69.1 & -18.7 & 48.8 & -9.54 & -0.0141 & -8.73 & -52.0 & -5.47 & -4.00 & -79.3 & -3.62 & -205 \\
\hline Long Beach B & 12 & -1.65 & -75.5 & -17.9 & 31.9 & -14.8 & -0.159 & -13.5 & -64.2 & -0.645 & -9.19 & 3.33 & -4.21 & -166 \\
\hline Long Beach C & 13 & -148 & -101 & -14.5 & 32.9 & -33.8 & -4.68 & -78.7 & $-1,010$ & -343 & -14.8 & -56.0 & -3.88 & $-1,780$ \\
\hline Total & & $-1,240$ & $-10,400$ & $-1,260$ & $-3,200$ & $-5,100$ & $-2,990$ & $-1,780$ & $-9,570$ & $-1,700$ & -901 & -485 & -353 & $-39,000$ \\
\hline
\end{tabular}




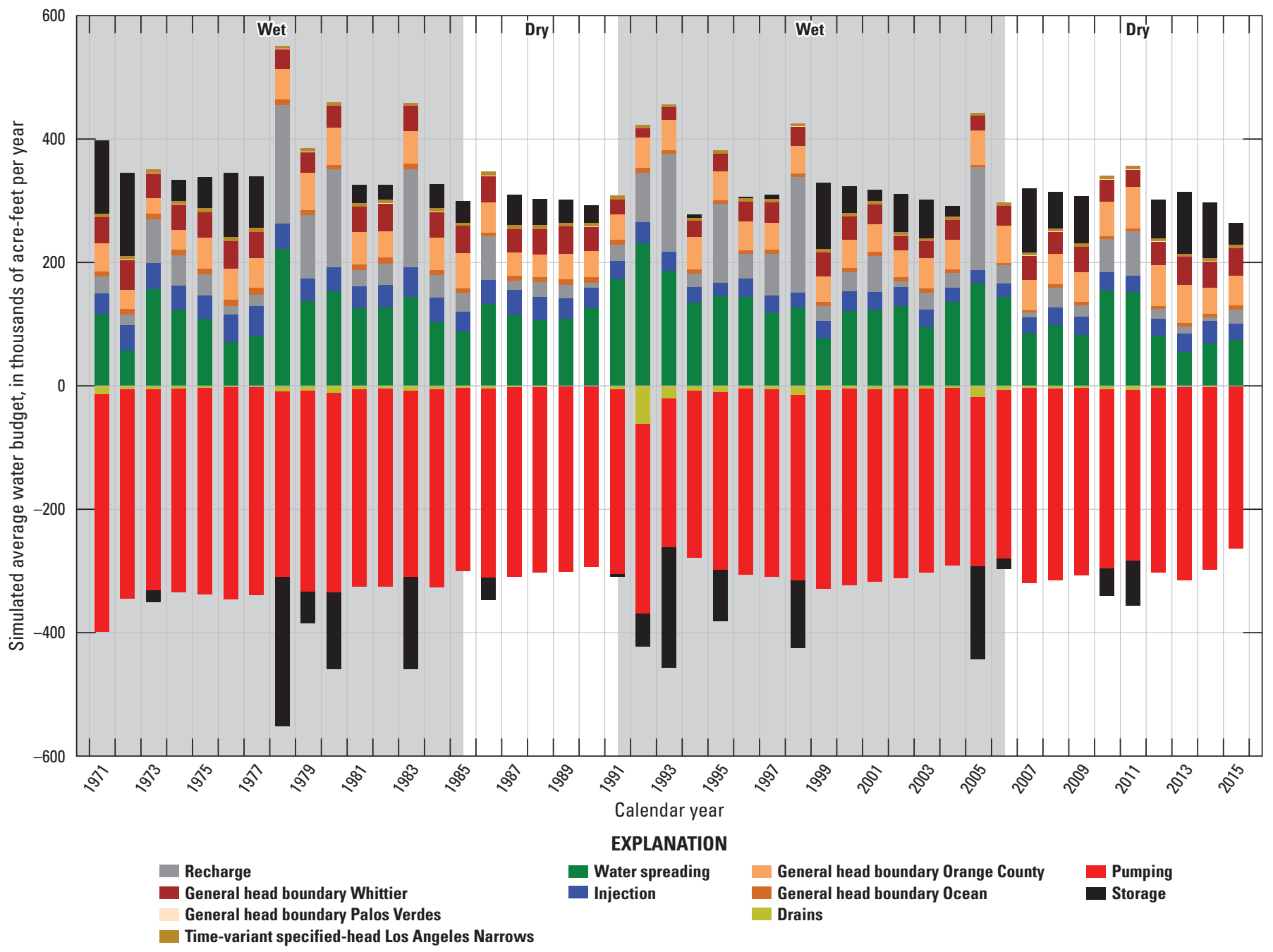

Figure D13. Simulated annual groundwater-flow budget for the Los Angeles Coastal Plain, 1971 to 2015, Los Angeles and Orange Counties, California. 


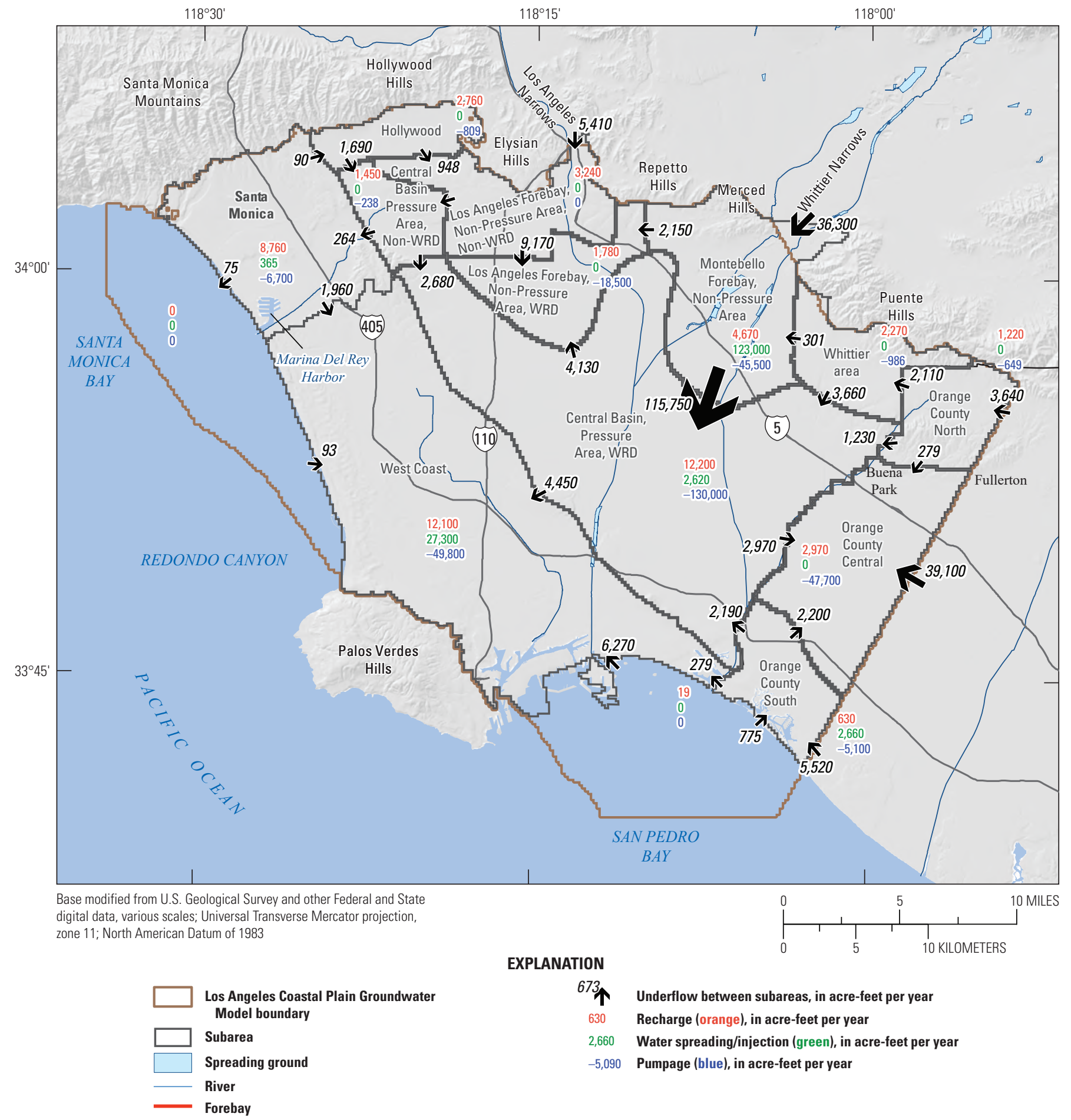

Figure D14. Simulated average annual groundwater flow between subareas in the Los Angeles Coastal Plain, 1971 to 2015, Los Angeles and Orange Counties, California. (Abbreviation: WRD, Water Replenishment District of Southern California) 


\section{Simulated Average Groundwater Budget, 1971 to 2015}

Total simulated groundwater inflows averaged 312,800 acre-ft/yr for the 45-year simulation period, 1971 to 2015 . Water spreading, which was specified in model input, was the largest inflow component, averaging 123,000 acre-ft/yr (table D6). Areal recharge is the next largest component, averaging 54,000 acre-ft/yr (table D6), which is 1,200 acre-ft/yr less than estimated by Hevesi and Johnson (2016; table C2). Injection was specified as model input and averaged 32,900 acre-ft/yr (table C2). Average underflows from San Fernando Valley and San Gabriel Valley were simulated as 5,410 and 36,300 acre-ft/yr, respectively (table D6). The simulated San Fernando Valley underflow is similar to previously estimated values of 6,200 acre-ft/yr (table C2); however, the simulated San Gabriel Valley underflow was about 8,700 acre-ft/yr higher than previous estimates of 27,600 acre-ft/yr (table C2). San Gabriel River Watermaster estimates of San Gabriel Valley underflow through the Whittier Narrows were included as observations in the calibration of the LACPGM (San Gabriel River Watermaster, 1997). Although the total simulated San Gabriel Valley underflow was greater than previous estimates, the average simulated underflow in the Mesa layer (30,200 acre-ft/yr) was approximately equal to previous estimates of underflow through the Whittier Narrows (table D6). The remaining 6,120 acre-ft/yr of underflow was simulated in the Long Beach C aquifer system (table D6), which was not estimated by previous investigators. Simulated inflows between the Pacific Ocean and the LACPGM averaged 7,070 acre-ft/yr (combined flow from Santa Monica and San Pedro Bays, table D6) and were similar to previous estimates (table C2).

The simulated underflow entering the model domain along the eastern edge of the LACPGM in Orange County averaged 48,336 acre-ft/yr (table D6), although most of this underflow was removed through pumping in Orange County prior to the underflow crossing into the Central Basin. The eastern edge of the LACPGM is approximately $5 \mathrm{mi}$ east of the previous model boundary (Reichard and others, 2003), and the previous model simulated underflow across this boundary at 8,000 acre-ft/yr from 1971 to 2000 . Underflow estimates are not directly comparable given the 5-mi separation in model boundaries.

Total simulated groundwater outflows average $313,400 \mathrm{acre}-\mathrm{ft} / \mathrm{yr}$ (that is, about 306,200 acre-ft/yr of pumping and 7,200 acre-ft/yr from drains; averaged yearly values from tables 4.14-4.19) and were similar to previous estimates of outflow (310,800 acre-ft/yr, table C2). Pumpage, by far the largest component of outflow, is specified in the model input and averages 306,200 acre-ft/yr (tables 4.144.19). Simulated discharge to drains in LACP averaged
7,230 acre-ft/yr (table D6). Most of the simulated drain discharge occured in the Santa Monica Basin (2,770 acre-ft/yr) and the Montebello Forebay (2,450 acre-ft/yr; table D6). In the Montebello Forebay, the discharge included some of the underflow through the Whittier Narrows.

During the 45-year simulation period, average groundwater outflow exceeded inflow by about 6,600 acre-ft/ $\mathrm{yr}$ (table D6). The total simulated depletion of storage for the 45-year period was about 298,000 acre-ft (multiplying the average yearly value by 45). In just the WRD service area, the total simulated average storage depletion was 3,400 acre-ft/yr (adding up each of the subareas in the WRD service area), for a total depletion of 155,000 acre-ft over the 45-year simulation period (table D6). The simulated total depletion was close to the calculated 140,000 acre-ft/yr of depletion by the WRD over the same time period (Water Replenishment District of Southern California, 2018).

\section{Simulated Annual Groundwater Budget}

The simulated annual groundwater budget is provided in detail in appendix 4 (tables $4.1 \mathrm{~A}$ through $4.1 M$ ). Simulated inflow varied from about 211,000 acre-ft in 1972 to about 551,000 acre-ft in 1978 and is shown graphically in figure D13. Simulated annual groundwater outflow from pumping and drains varied from about 262,000 acre-ft in 1993 to about 398,000 acre-ft in 1971 (fig. D13). In some years, simulated inflows exceeded outflows, resulting in increases in simulated storage (figs. D13, D15); in other years simulated outflows exceeded inflows, resulting in simulated storage depletion (figs. D13, D15). Simulated storage decreased from 1971 through 1978 by about 504,000 acre-ft and then increased from 1979 through 1984 by about 513,000 acre-ft (fig. D15). Storage decreased by about 193,000 acre-ft from 1985 through 1991, and then increased by about 433,000 acre-ft from 1992 through 1999 (fig. D15). From 2000 through 2015, storage decreased by 546,000 acre-ft (fig. D15). Periods of increasing storage generally corresponded to wetter periods when there was more water spreading, more areal recharge, and less pumpage; periods of decreasing storage generally corresponded to drier periods associated with less water spreading and less areal recharge (figs. D13, D15).

Simulated inflow and outflow components showed considerable multi-year variability in the different subareas (appendix 4, fig. 4.1). Much of this variability was driven by wet and dry periods (fig. D15). For example, drain flows were highest during the wet years in the Santa Monica Basin (appendix 4, fig. 4.1J), and almost all drain flows in the Montebello Forebay occurred in 1992, which was one of the largest water-spreading years on record (fig. D13). 


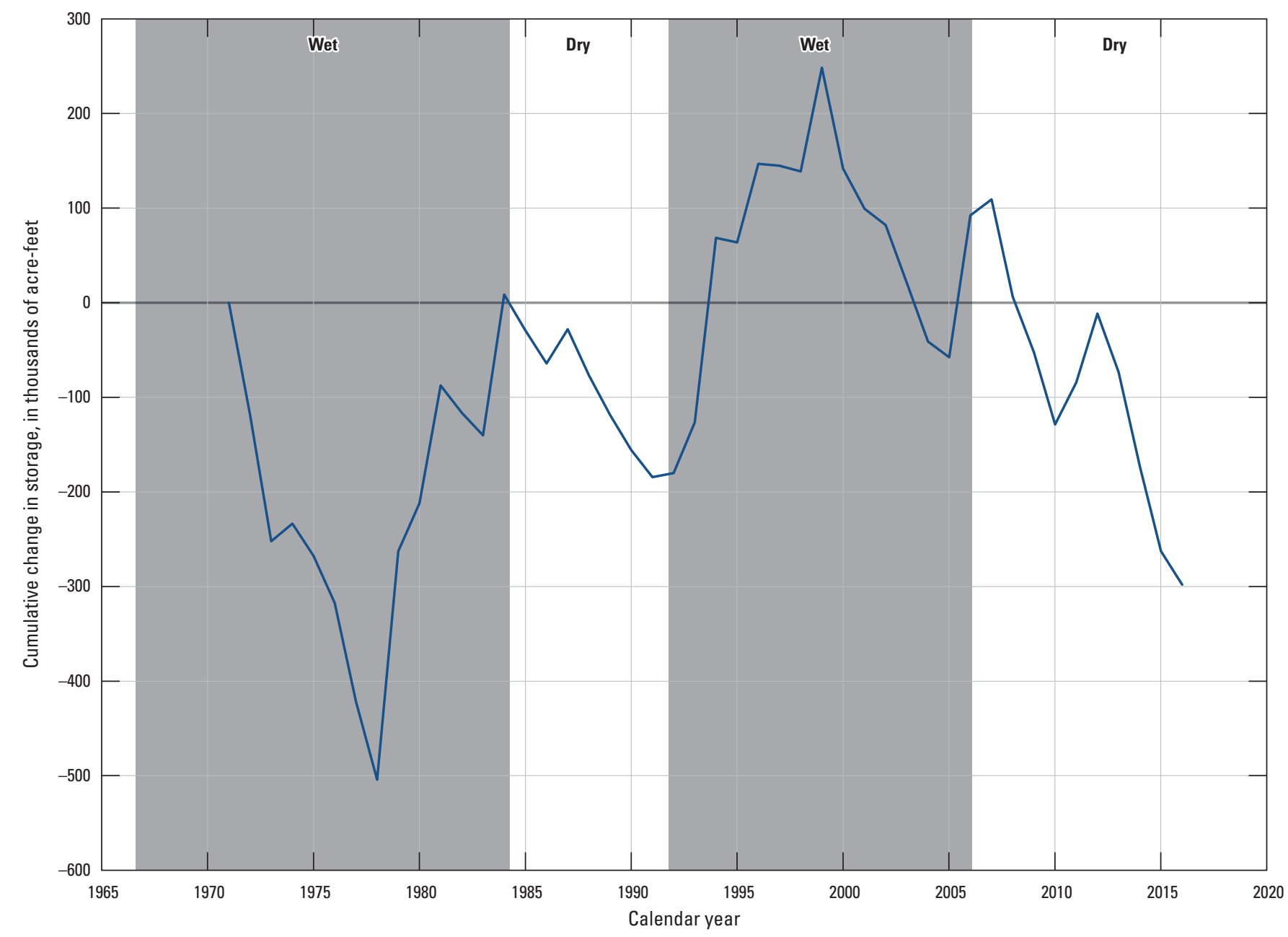

Figure D15. Simulated cumulative change in storage, 1971-2015, Los Angeles Coastal Plain Groundwater-flow Model, Los Angeles and Orange Counties, California.

\section{Simulated Flow between Subareas and Layers}

The calibrated model was used to simulate average lateral flow between the 14 model subareas and vertical flow between the 12 model layers for 1971 to 2015 (fig. D14 and appendix 4, fig. 4.2). The largest lateral and vertical flows were simulated in the Montebello Forebay (fig. D14 and appendix 4, fig. 4.2). Most of the flow into the model came from the Montebello Forebay and entered the model as water spreading $(123,000 \mathrm{acre}-\mathrm{ft} / \mathrm{yr})$ and underflow through the Whittier Narrows (36,300 acre-ft/yr; fig. D14). In the Montebello Forebay, groundwater mostly flowed downward from the Dominguez to the Harbor aquifer systems (appendix 4, figs. 4.2A-F). The major outflow from the Montebello Forebay was lateral flow to the Central Basin Pressure Area (116,000 acre-ft/yr; fig. D14). Most of this outflow occured through the Mesa, Pacific, Harbor, and Bent Spring aquifer systems.
Simulated average annual inflow from the southeastern edge of the model into the Orange County Central subarea of 39,100 acre-ft/yr is the largest simulated boundary flow (fig. D14). More than 25 percent of this inflow was simulated in the Pacific aquifer system (appendix 4, fig. 4.2D). Simulated pumping in the Orange County Central subarea $(47,700 \mathrm{acre}-\mathrm{ft} / \mathrm{yr})$ exceeded the simulated boundary flow, resulting in a small amount of lateral flow (3,000 acre-ft/yr) entering the Orange County Central subarea from the Central Basin Pressure Area (WRD; fig. D14). Although flow crosses the Orange County/Los Angeles County boundary from the Central Basin into the Orange County Central subarea (and a small amount - 279 acre-ft/yr - crosses from the West Coast Basin subarea into the Orange County South subarea), in Orange County South and Orange County North subareas flow crosses from Orange County into the Central Basin Pressure Area. The net simulated flow from the Orange County subareas (Orange County North, Central, and South) into Los Angeles County subareas (Whittier area, Central Basin Pressure Area, and West Coast) averaged about 2,300 acre-ft/yr for 1971 to 2015 (fig. D14). 
The modeled average net simulated flow across the county line for 1971 to 2000 was calculated from the model output and compared to the results of Reichard and others (2003). The modeled average net simulated flow was 1,400 acre-ft/year, which is 6,600 acre-ft/year less than the modeled simulated net inflow from Reichard and others (2003). Within, the LACP, the county line separating Orange County and Los Angeles County is over $17 \mathrm{mi}$ long and crosses an alluvial basin that is over 8,000 -ft thick in some areas; furthermore, there are over 200 production wells within $2 \mathrm{mi}$ of the county line. Given the size and complexity of the groundwater system near the county line, small differences in the two groundwater-flow models could account for a difference of 6,600 acre-ft/year in simulated flow from Orange County to Los Angeles County. Differences that might have affected this simulated inflow include the LACPGM's Orange County general-head boundary, located approximately $5 \mathrm{mi}$ east of the corresponding boundary in the model of Reichard and others (2003), and the LACPGM use of chronostratigraphic layering (13 model layers), in contrast to Reichard and others' (2003) use of lithostratigraphic layering (4 model layers).

The net simulated average groundwater flow from the Central Basin to the West Coast Basin was about 4,450 acre-ft/yr (fig. D14). The net direction of flow was from the Central Basin to the West Coast Basin in all aquifer systems except for the Pacific A, Pacific, and Harbor aquifer systems (appendix 4, figs. 4.2A-L). The relatively small average simulated groundwater flow between the Central and West Coast Basins reflected the large proportion of recharge water pumped from the Central Basin and the partial barrier effect of the Newport-Inglewood fault zone that separates the two groundwater basins, especially in the deeper layers.

The simulated lateral flows between the offshore and onshore subareas indicated potential onshore movement of seawater. Most of the simulated lateral flows between offshore and onshore subareas were small compared to the overall groundwater budget. Small changes in the groundwater budget could reverse offshore or onshore flow directions in many cases. In the West Coast Basin, the net simulated average flow moved onshore at a relatively small rate of about 93 acre-ft/yr from the Santa Monica Bay to the west, but at a substantially higher rate of about 6,270 acre-ft/yr from the San Pedro Bay to the south (fig. D14). Along the west coast of the West Coast Basin, the simulated average net flow was offshore or close to no flow in all aquifer systems except for the Bent Spring and Lower Wilmington aquifer systems, where the simulated average net flow was onshore (appendix 4, figs. 4.2A-L). Along the south coast of the West Coast Basin, the simulated average net flow was onshore in all aquifer systems, with the greatest rates simulated for the Pacific, Harbor, and Lower Wilmington aquifer systems (appendix 4, figs. 4.2A-L). In the Santa Monica Basin, the net simulated average flow was moving offshore at a relatively small rate of about 80 acre-ft/yr (fig. D14). Simulated average net flow was offshore or close to zero in all aquifer systems except for the Pacific, Bent Spring, Upper Wilmington A, and Long Beach $\mathrm{C}$ aquifer systems, where the simulated average net flow was onshore (appendix 4, figs. 4.2A-L).

\section{Model Limitations}

A groundwater-flow model is a valuable tool for testing the conceptualization of groundwater-flow systems and for predicting the response of the systems to changes in aquifer system stresses. However, a groundwater-flow model is only an approximation of the thirteen actual aquifer systems and therefore will not exactly represent the actual systems simulated. The model relied on estimates of aquifer system hydrogeologic structure, aquifer properties, and stresses, which had some degree of uncertainty.

The LACPGM chronostratigraphic model layers were based on seismic lines, well bore data, and other data. The chronostratigraphic model was interpolated between data points. In some areas of the model, available data were sparse, and interpolation occurred over distances of several miles. Interpolation error associated with sparse data regions in the chronostratigraphic model can cause mismatches between production well screens and result in incorrect estimation of the amount of pumping coming from each layer, which may cause errors in the LACPGM results. Some of these interpolation errors were corrected by analyzing pumping and monitoring-well data and correcting the layering based on this analysis. The LACPGM model layers represented mostly fining-upward units, which may contain a coarse-grained basal zone and a fine-grained upper zone. These zones were simulated together as a single model layer with specific hydraulic properties. Modeling a fining-upward sequence as a single layer containing the same hydraulic properties was a possible source of model error.

Areal recharge in the LACPGM accounted for about 16 percent of the total model recharge and was based on precipitation-runoff estimates from Hevesi and Johnson (2016). Therefore, many of the model limitations from Hevesi and Johnson (2016) precipitation-runoff model also apply to the LACPGM. Model limitations included not accounting for unregulated streamflow, certain cases of stream channel storage, water and sewer line leakage, and dispersive streamflow. These limitations could have led to errors in the precipitation-runoff estimates used as initial areal recharge in the LACPGM. Final areal recharge values were determined by model calibration. 
Underflow through Whittier Narrows accounted for approximately 11 percent of the total model recharge and was based on underflow estimates from San Gabriel River Watermaster (San Gabriel River Watermaster, 1997) and model calibration. Underflow estimates were based on observed heads in the Whittier Narrows area, hydraulic conductivity estimates for the area, and an estimated cross-sectional area of flow for the Whittier Narrows, all possible sources of error for the underflow estimate. Given the imprecise nature of the underflow estimate, it was only used as a starting point for model calibration and changed from the estimated 27,600 acre-ft/yr to about 30,200 acre-ft/yr of underflow from the upper Mesa aquifer system during parameter estimation. In addition, about $6,100 \mathrm{acre}-\mathrm{ft} / \mathrm{yr}$ of underflow was simulated from the lower Long Beach $\mathrm{C}$ aquifer system. The San Gabriel River Watermaster did not estimate underflow for the deeper Long Beach C aquifer system.

Underflow data were not available for Los Angeles Narrows. Underflow across Los Angeles Narrows was determined by estimated layer thicknesses in Los Angeles Narrows, available water-level data, and calibrated hydraulic conductivities in the Los Angeles Narrows area. Underflow across Los Angeles Narrows only accounted for about 2 percent of the total model recharge but was the primary source of recharge to the Los Angeles Forebay. Errors in the underflow estimate across Los Angeles Narrows could have led to inaccurately simulated water levels in the Los Angeles Forebay.

The eastern edge of the LACPGM, 3 to $5 \mathrm{mi}$ into the Orange County Basin, was simulated as a GHB. This boundary was simulated using water-level data from OCWD multi-completion wells during 1992 to 2015. Water-level data from 1971 to 1990 were sparse around the LACPGM's eastern boundary for some of the model layers. Combinations of spatial interpolation, temporal interpolation, and extrapolation of data were used to estimate water levels along this boundary for all layers (appendix 3 ). These interpolations and extrapolations may have resulted in some model error in the eastern area of the model from 1971 to 1990.
Pumpage occurred on both sides of the eastern edge of the LACPGM, with some pumpage occurring as close as $200 \mathrm{ft}$ from the eastern edge. The GHB water-levels were interpolated between monitoring wells along the boundary and may not have accurately reflected the effects of pumping wells close to the boundary. Additionally, this GHB may need to be modified for predictive scenarios in order to accurately reflect changes in pumping that occur just outside the eastern boundary of the LACPGM.

The model does not simulate subsidence. Minimal subsidence was expected since most measured water levels during the LACPGM simulation period were above historical low values. However, some water levels were near historical lows during the LACPGM simulation period, including seasonal low water levels during the 1990s in the Long Beach area. If subsidence had occurred in the LACP during the simulation period, this could affect groundwater flow in the LACP and therefore effect the accuracy of the LACPGM results.

Most conduits in the LACPGM were assigned a high skin factor of 16,000. A high skin factor was necessary to represent the large vertical head gradients observed in some areas of the model. A high skin factor can result in very low flows within conduits that are simulating production or injection wells. However, the water budget indicates that even with a high skin factor nearly all the water pumped from the conduits is coming from model cells connected to the conduit (only a very small fraction of water pumped from conduits is coming from conduit storage).

Changes to the groundwater-flow model by future users may result in numerical instability. The LACPGM included over 400,000 cells and 12 active layers with a complex geology of synclines, anticlines, faults, and layer pinchouts. The LACPGM also included about 1,500 production wells. Due to these factors, model cells often alternately dried and rewetted, processes under which certain conditions can lead to numerical instability. 


\section{Simulation of Future Water-Management Scenarios}

The WRD is responsible for the management of the Central and West Coast Basins. Although the annual pumping amounts in these groundwater basins are adjudicated, pumping permitted under the adjudications exceeds the natural replenishment to the groundwater basins (Water Replenishment District of Southern California, 2017). If the natural recharge was not supplemented by managed aquifer recharge in spreading grounds in the Montebello Forebay and injection wells in the Central and West Coast Basins, water levels in the groundwater basins would decline (Water Replenishment District of Southern California, 2017). The adjudicated production rates are $217,637 \mathrm{acre}-\mathrm{ft} / \mathrm{yr}$ in the Central Basin and 64,468.25 acre-ft/yr in the West Coast Basin (Water Replenishment District of Southern California, 2017). During water year 2014-15 (a water year is the annual period from October 1 through September 30 and is designated by the year in which the period ends), production rates averaged about 194,190 acre-ft/yr in the adjudicated subareas of the Central Basin (about 23,450 acre-ft/yr less than maximum adjudicated rates) and about $42,920 \mathrm{acre}-\mathrm{ft} / \mathrm{yr}$ in the West Coast Basin (about 21,550 acre-ft/yr less than maximum adjudicated rates; Water Replenishment District of Southern California, 2017). The WRD is considering future production rate increases to reach maximum adjudicated rates with plans to increase production from existing wells and to construct new well fields in the Central Basin, including wells at WRD's new Groundwater Reliability Improvement Project (GRIP) facility just south of Whittier Narrows (fig. D16), which has recently been renamed the Albert Robles Center for Water Recycling and Environmental Learning (Water Replenishment District of Southern California, 2016; fig. D16).

The calibrated LACPGM was used to help evaluate the effects of pumpage at the maximum adjudicated production rates on water levels and flows in the Central Basin and West Coast Basin under two different climatic scenarios: wet conditions and dry conditions. These increased-pumpage scenarios were compared to base-case scenarios, which were the model-simulated conditions assuming production rates remained the same as the average for water years 2012 to 2014. A base-case scenario was run for both wet and dry conditions. Each of the water-management scenarios started at the end of water year 2015 (September 30,2015), with initial heads set to LACPGM-simulated hydraulic heads for the end of the summer quarter (July-September) of 2015. The simulation period for each of the scenarios was 25 years, or water years 2016 through 2040.

\section{Description of Future Water-Management Scenarios}

To simulate different climatic conditions for the future water-management scenarios, the 45 -year calibration period (1971 to 2015) was evaluated to find the 25 contiguous-year periods that have the wettest and driest simulated areal recharges. These were considered the best- and worst-case scenarios for future water management through 2040. The base-case and increased-pumpage scenarios with wet climatic conditions used the areal-recharge rates, runoff entering the spreading grounds, and heads along the specified-head and general-head boundaries simulated for water years 1977 to 2001. The wet-period areal recharge averaged 69,000 acre-ft/ $\mathrm{yr}$, and the runoff entering the spreading grounds averaged about 65,000 acre-ft/yr. The base-case and increased-pumpage scenarios with dry climatic conditions used the areal-recharge rates, runoff entering the spreading grounds, and heads along the specified-head and general-head boundaries simulated for water years 1991 to 2015 . The dry-period areal recharge averaged about 53,000 acre-ft/yr, and the runoff entering the spreading grounds averaged about 57,000 acre-ft/yr.

WRD has targeted for purchase 71,000 acre- $\mathrm{ft} / \mathrm{yr}$ of imported and recycled spreading water in future years. This future purchased water was divided between the spreading grounds, receiving 66,000 acre-ft/yr, and the Groundwater Reliability Improvement Project (GRIP) facility injection wells, receiving 5,000 acre-ft/yr. (fig. D16; table D8). Spreading grounds recharge rates were divided between the different spreading grounds based on historical recharge rates. Seawater-barrier injection rates were the seasonally averaged rates for water years 2012 through 2014. The GRIP facility is in the Montebello Forebay and includes three new injection wells (SRW1, SRW2, and SRW3; fig. D16). A simulated injection rate of 5,000 acre-ft/yr was used for the GRIP facility, with 1,700 acre-ft/yr injected into wells SRW1 and SRW2 and 1,600 acre-ft/yr injected into well SRW3.

Pumping rates for the base-case scenarios were set based on seasonally averaged pumpage for water years 2012 to 2014 and were the same for each year of the future simulations. This rate is 306,200 acre- $\mathrm{ft} / \mathrm{yr}$, which was the same as the average pumping rate for the 45-year calibration period $(306,200$ acre-ft/yr). Pumping rates for the increased-pumpage scenarios included the base-case rates plus the planned production from six wells (about 9,000 acre-ft/yr) representing well fields recently constructed or soon to be constructed, and the projected increased pumpage (about 36,000 acre-ft/yr) from 75 existing wells (tables D9, D10; fig. D17). The projected increased pumping rates for the existing wells were scaled up to maximum adjudicated production rates, reaching maximum adjudicated production rates in the 10th year: for water years 2016 to 2019, pumping rates were the same as initial rates; for water years 2020 to 2024, pumping rates were halfway between the initial rates and the maximum adjudicated rates; and for water years 2025 to 2040, pumping rates were the maximum adjudicated rates (table D10). 


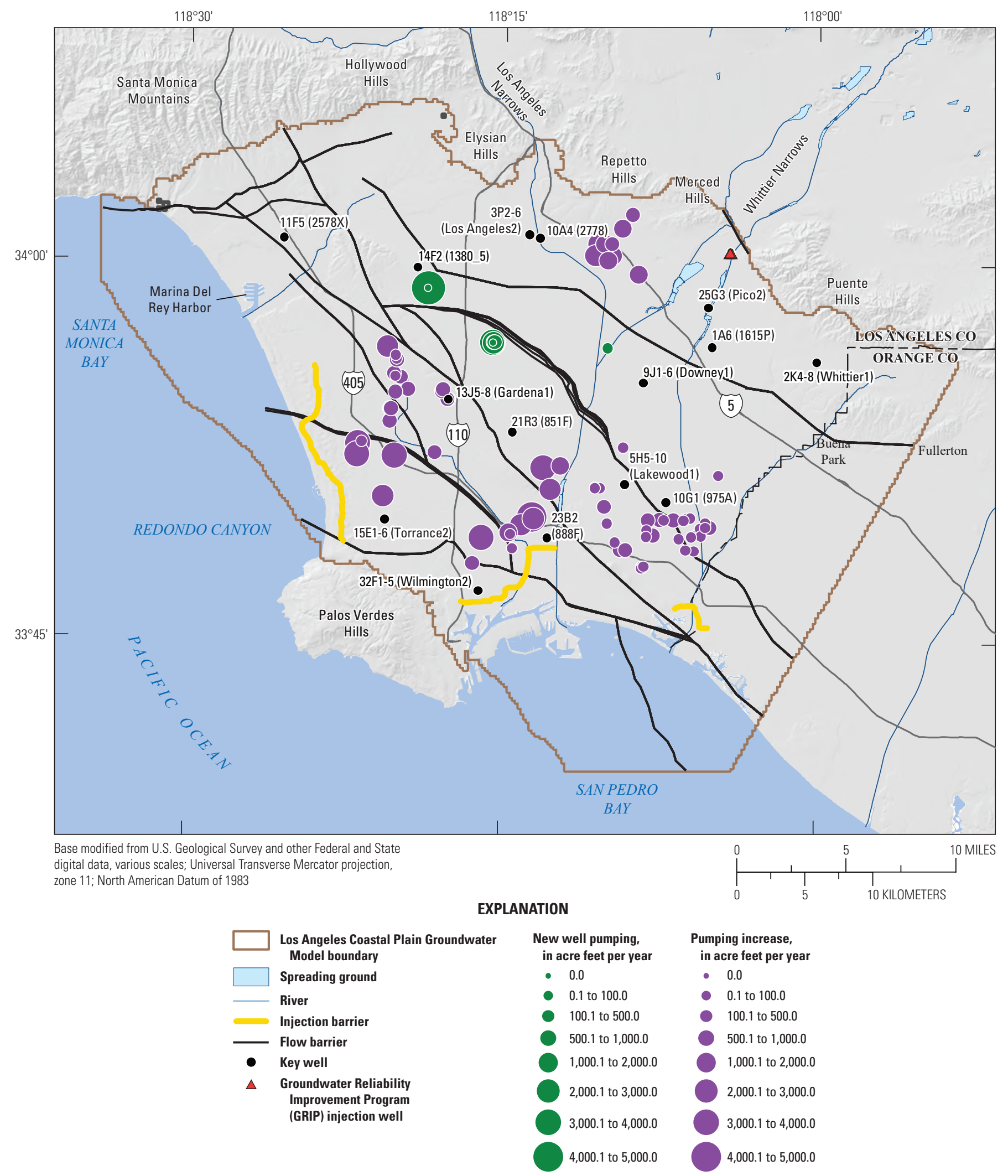

Figure D16. Groundwater Reliability Improvement Project (GRIP) injection wells, existing production wells whose pumping rates were increased during the management scenarios, and production wells that were added to the management scenarios, Los Angeles and Orange Counties, California. 
Table D8. Summary of inputs in acre-feet per year for future water-management scenarios.

[acre-ft/year; acre-foot per year; GRIP, Groundwater Reliability Improvement Program]

\begin{tabular}{|c|c|c|c|c|c|c|}
\hline Scenario & $\begin{array}{l}\text { Spreading grounds } \\
\text { (acre-ft/year) }\end{array}$ & $\begin{array}{c}\text { GRIP } \\
\text { injection } \\
\text { (acre-ft/year) }\end{array}$ & Barrier well injection & Areal recharge & $\begin{array}{l}\text { General- and } \\
\text { constant-head } \\
\text { boundary } \\
\text { water levels }\end{array}$ & Pumping \\
\hline Base-dry & $\begin{array}{l}66,000+\text { runoff water }(1991- \\
2015)\end{array}$ & 5,000 & $\begin{array}{l}\text { Averaged seasonal injection rates } \\
\quad(2012-14)\end{array}$ & $\begin{array}{l}\text { Areal recharge } \\
\text { estimates } \\
\quad(1991-2015)\end{array}$ & $\begin{array}{l}\text { Estimated } \\
\text { boundary heads } \\
(1991-2015)\end{array}$ & $\begin{array}{l}\text { Averaged seasonal pumping rates } \\
\quad(2012-14)\end{array}$ \\
\hline $\begin{array}{l}\text { Increased } \\
\text { pumpage-dry }\end{array}$ & $\begin{array}{l}66,000+\text { runoff water }(1991- \\
2015)\end{array}$ & 5,000 & $\begin{array}{l}\text { Averaged seasonal injection rates } \\
\quad(2012-14)\end{array}$ & $\begin{array}{l}\text { Areal recharge } \\
\text { estimates } \\
\quad(1991-2015)\end{array}$ & $\begin{array}{l}\text { Estimated } \\
\text { boundary heads } \\
\quad(1991-2015)\end{array}$ & $\begin{array}{l}\text { Averaged seasonal pumping rates } \\
(2012-14) \text { scaled up to new } \\
\text { rates over } 10 \text { years }\end{array}$ \\
\hline $\begin{array}{l}\text { Increased } \\
\text { pumpage/ } \\
\text { replenishment- } \\
\text { dry }\end{array}$ & $\begin{array}{l}66,000+\text { runoff water } \\
(1991-2015)+\text { additional } \\
\text { imported water determined by } \\
\text { optimization }\end{array}$ & 5,000 & $\begin{array}{l}\text { Averaged seasonal injection } \\
\text { rates }(2012-14)+\text { additional } \\
\text { imported water determined by } \\
\text { optimization }\end{array}$ & $\begin{array}{l}\text { Areal recharge } \\
\text { estimates } \\
\quad(1991-2015)\end{array}$ & $\begin{array}{l}\text { Estimated } \\
\text { boundary heads } \\
(1991-2015)\end{array}$ & $\begin{array}{l}\text { Averaged seasonal pumping rates } \\
(2012-14) \text { scaled up to new } \\
\text { rates over } 10 \text { years }\end{array}$ \\
\hline Base-wet & $\begin{array}{l}66,000+\text { runoff water }(1977- \\
2001)\end{array}$ & 5,000 & $\begin{array}{l}\text { Averaged seasonal injection rates } \\
\quad(2012-14)\end{array}$ & $\begin{array}{l}\text { Areal recharge } \\
\text { estimates } \\
\quad(1977-2001)\end{array}$ & $\begin{array}{l}\text { Estimated } \\
\text { boundary heads } \\
(1977-2001)\end{array}$ & $\begin{array}{l}\text { Averaged seasonal pumping rates } \\
\quad(2012-14)\end{array}$ \\
\hline $\begin{array}{l}\text { Increased } \\
\text { pumpage-wet }\end{array}$ & $\begin{array}{l}66,000+\text { runoff water }(1977- \\
2001)\end{array}$ & 5,000 & $\begin{array}{l}\text { Averaged seasonal injection rates } \\
\quad(2012-14)\end{array}$ & $\begin{array}{l}\text { Areal recharge } \\
\text { estimates } \\
\quad(1977-2001)\end{array}$ & $\begin{array}{l}\text { Estimated } \\
\text { boundary heads } \\
\quad(1977-2001)\end{array}$ & $\begin{array}{l}\text { Averaged seasonal pumping rates } \\
(2012-14) \text { scaled up to new } \\
\text { rates over } 10 \text { years }\end{array}$ \\
\hline $\begin{array}{l}\text { Increased } \\
\text { pumpage/ } \\
\text { replenishment- } \\
\text { wet }\end{array}$ & $\begin{array}{l}66,000+\text { runoff water } \\
(1977-2001)+\text { additional } \\
\text { imported water determined by } \\
\text { optimization }\end{array}$ & 5,000 & $\begin{array}{l}\text { Averaged seasonal injection } \\
\text { rates }(2012-14)+\text { additional } \\
\text { imported water determined by } \\
\text { optimization }\end{array}$ & $\begin{array}{l}\text { Areal recharge } \\
\text { estimates } \\
\quad(1977-2001)\end{array}$ & $\begin{array}{l}\text { Estimated } \\
\text { boundary heads } \\
(1977-2001)\end{array}$ & $\begin{array}{l}\text { Averaged seasonal pumping rates } \\
(2012-14) \text { scaled up to new } \\
\text { rates over } 10 \text { years }\end{array}$ \\
\hline
\end{tabular}

Table D9. Planned new pumping wells and simulated pumping rates for future water-management scenarios, Los Angeles Coastal Plain Groundwater-flow Model.

[acre-ft/yr; acre-feet per year; WRDID, Water Replenishment District of Southern California identification]

\begin{tabular}{lcc}
\hline \multicolumn{1}{c}{$\begin{array}{c}\text { State well } \\
\text { number }\end{array}$} & $\begin{array}{c}\text { New pumping } \\
\text { (acre-ft/yr) }\end{array}$ & WRDID \\
\hline 2S/14W-23H17 & 4,290 & 200220 \\
2S/13W-32R20 & 2,269 & 202904 \\
2S/13W-32R19 & 1,916 & 202903 \\
3S/12W-5D5 & 68 & 200294 \\
2S/13W-32R15 & 205 & 200199 \\
2S/13W-32R16 & 268 & 200200 \\
\hline
\end{tabular}


Table D10. Projected increased pumping rates for existing wells for future water-management scenarios, Los Angeles Coastal Plain Groundwater-flow Model.

[acre-ft/yr; acre-feet per year; WRDID, Water Replenishment District of Southern California identification]

\begin{tabular}{|c|c|c|}
\hline $\begin{array}{c}\text { State well } \\
\text { number }\end{array}$ & $\begin{array}{c}\text { Additional pumping added to } \\
\text { base pumping rate (acre-ft/ } \\
\text { yr) }\end{array}$ & WRDID \\
\hline $2 \mathrm{~S} / 12 \mathrm{~W}-4 \mathrm{C} 1$ & 410 & 200029 \\
\hline $2 \mathrm{~S} / 12 \mathrm{~W}-5 \mathrm{~J} 1$ & 523 & 200031 \\
\hline $2 \mathrm{~S} / 12 \mathrm{~W}-7 \mathrm{G} 2$ & 1,293 & 203136 \\
\hline $2 \mathrm{~S} / 12 \mathrm{~W}-7 \mathrm{H} 1$ & 546 & 200042 \\
\hline 2S/12W-7Q4 & 1,109 & 200044 \\
\hline $2 \mathrm{~S} / 12 \mathrm{~W}-8 \mathrm{~F} 1$ & 246 & 200046 \\
\hline $2 \mathrm{~S} / 12 \mathrm{~W}-8 \mathrm{P} 1$ & 673 & 200047 \\
\hline $2 \mathrm{~S} / 12 \mathrm{~W}-16 \mathrm{~L} 1$ & 892 & 200069 \\
\hline 2S/12W-17D2 & 541 & 200071 \\
\hline 3S/11W-31N2 & 10 & 200277 \\
\hline $3 \mathrm{~S} / 12 \mathrm{~W}-29 \mathrm{~J} 2$ & $<0.1$ & 200395 \\
\hline $3 \mathrm{~S} / 13 \mathrm{~W}-35 \mathrm{~F} 1$ & 2,000 & 200479 \\
\hline 3S/13W-35H2 & 800 & 200721 \\
\hline 3S/14W-3D3 & 1,582 & 202955 \\
\hline $3 \mathrm{~S} / 14 \mathrm{~W}-3 \mathrm{~F} 2$ & 1 & 202832 \\
\hline 3S/14W-3K4 & 141 & 202820 \\
\hline 3S/14W-3L2 & 87 & 202819 \\
\hline $3 \mathrm{~S} / 14 \mathrm{~W}-10 \mathrm{~F} 2$ & 277 & 200494 \\
\hline 3S/14W-10G3 & 63 & 200495 \\
\hline 3S/14W-10G4 & 381 & 200496 \\
\hline 3S/14W-13B3 & 168 & 202821 \\
\hline 3S/14W-13B4 & 201 & 202965 \\
\hline 3S/14W-13J9 & 216 & 201056 \\
\hline 3S/14W-13J10 & 325 & 202823 \\
\hline 3S/14W-14D2 & 356 & 202899 \\
\hline 3S/14W-15B3 & 282 & 200505 \\
\hline $3 \mathrm{~S} / 14 \mathrm{~W}-15 \mathrm{P} 1$ & 175 & 200506 \\
\hline 3S/14W-15P2 & 315 & 200507 \\
\hline 3S/14W-22L1 & 186 & 200512 \\
\hline $3 \mathrm{~S} / 14 \mathrm{~W}-25 \mathrm{P} 4$ & 185 & 200515 \\
\hline 3S/14W-29H1 & 3 & 200518 \\
\hline 3S/14W-29J1 & 2,631 & 200519 \\
\hline $3 \mathrm{~S} / 14 \mathrm{~W}-32 \mathrm{~A} 2$ & 2,021 & 200520 \\
\hline $3 \mathrm{~S} / 14 \mathrm{~W}-34 \mathrm{C} 3$ & 2,293 & 203135 \\
\hline $4 \mathrm{~S} / 12 \mathrm{~W}-6 \mathrm{~J} 2$ & 70 & 200547 \\
\hline 4S/12W-6K1 & 64 & 200548 \\
\hline $4 \mathrm{~S} / 12 \mathrm{~W}-6 \mathrm{~K} 2$ & 33 & 200549 \\
\hline
\end{tabular}

\begin{tabular}{ccc}
\hline $\begin{array}{c}\text { State well } \\
\text { number }\end{array}$ & $\begin{array}{c}\text { Additional pumping added to } \\
\text { base pumping rate (acre-ft/ }\end{array}$ & WRDID \\
yr) & \\
\hline 4S/12W-8M1 & 184 & 200552 \\
4S/12W-13B4 & 94 & 200719 \\
4S/12W-13F2 & 65 & 202900 \\
4S/12W-13G1 & 9 & 200566 \\
4S/12W-13H1 & 107 & 200720 \\
4S/12W-13K1 & 185 & 202901 \\
4S/12W-13N2 & 0.2 & 200568 \\
4S/12W-13Q1 & 48 & 202902 \\
4S/12W-14A2 & 85 & 200569 \\
4S/12W-14A4 & 76 & 200570 \\
4S/12W-14B2 & 11 & 200571 \\
4S/12W-14D4 & 290 & 200572 \\
4S/12W-15A1 & 69 & 200575 \\
4S/12W-15B3 & 192 & 200576 \\
4S/12W-15N1 & 116 & 202948 \\
4S/12W-16A1 & 115 & 202947 \\
4S/12W-16J3 & 22 & 200578 \\
4S/12W-16R1 & 12 & 200579 \\
4S/12W-17E1 & 33 & 200580 \\
4S/12W-20G1 & 27 & 200582 \\
4S/12W-20K1 & 272 & 200583 \\
4S/12W-21M7 & 114 & 200584 \\
4S/12W-23C1 & 60 & 200585 \\
4S/12W-23K3 & 0.2 & 200586 \\
4S/12W-24M8 & 26 & 200588 \\
4S/12W-28H1 & 69 & 200592 \\
4S/12W-28H6 & 58 & 200593 \\
4S/12W-28H12 & 42 & 200594 \\
4S/13W-2G2 & 1,347 & 202833 \\
4S/13W-15A11 & 1,313 & 200608 \\
4S/13W-15A14 & 3,237 & 202818 \\
4S/13W-15F1 & 1,478 & 200610 \\
4S/13W-16J5 & 508 & 200614 \\
4S/13W-16R2 & 0.1 & 200615 \\
4S/13W-20C1 & 2,130 & 200619 \\
4S/13W-21J2 & 89 & 200624 \\
\hline S/13W-29E6 & & 20642 \\
\hline
\end{tabular}




\section{Results}

Future water-management scenarios were evaluated by analyzing the simulated average 25 -year budgets (appendix 4, tables 4.14-4.19), simulated average annual water budgets (fig. D17), cumulative change in storage graphs (fig. D18), simulated hydraulic-head change maps (fig. D19), and hydrographs of simulated heads at selected calibration wells for 2016 to 2040 (fig. D20). For the purposes of this evaluation, only the simulated hydraulic-head change maps and hydrographs for the Pacific and Bent Spring aquifer systems are discussed in the report. The Pacific and Bent Spring aquifer systems were the two more heavily pumped aquifer systems in the LACPGM (appendix 4, tables 4.144.19). Hydraulic heads in the Pacific aquifer system were similar to the Pacific A and Harbor aquifer systems and were considered representative of the upper aquifer systems, the aquifer systems above the Bent Spring aquifer system. Hydraulic heads in the Bent Spring aquifer system were similar to heads in the Upper Wilmington A, Upper Wilmington B, and Lower Wilmington aquifer systems, and were considered representative of the lower aquifer systems, the aquifer systems below and including the Bent Spring aquifer system.

The simulated head-change maps are the difference between the lowest simulated head in each of the active model cells in the scenario being evaluated and the lowest simulated head in each of the active model cells in the corresponding base-case scenario (fig. D19). The simulated head-change maps show the maximum drawdown caused by increased pumping in each active model cell, which provides a useful comparison for water managers who wish to limit the maximum amount of drawdown throughout the study area (fig. D19). A positive hydraulic-head change indicates that hydraulic head increased compared to the base case (water level rising) and a negative hydraulic-head change indicates that hydraulic head decreased compared to the base case (water level declining).

\section{Base-Case Scenario with Wet Conditions}

The base-case scenario with wet conditions used the areal-recharge rates, runoff entering the spreading grounds, and heads along the specified-head and general-head boundaries simulated for water years 1977 to 2001 (table D8). Simulated inflows exceeded outflows in years 2017-19, 2022, 2025, 2031-32, 2034, 2037. During the base-case scenario with wet conditions, more water went into storage for 35 of the quarter-year stress periods and more water came out of storage for 65 of the quarter-year stress periods. Total gain in storage during the 25-year base case was about 142,000 acre- $\mathrm{ft}$ (average of 5,660 acre-ft per year; fig. D18). In general, simulated hydraulic heads declined during dry years and rose during wet years (fig. D20).

\section{Base-Case Scenario with Dry Conditions}

The base-case scenario with dry conditions used the areal-recharge rates, runoff entering the spreading grounds, and heads along the specified-head and general-head boundaries simulated for water years 1991 to 2015 (table D8). Simulated inflows exceeded outflows in years 2017, 2018, 2020, 2023, 2030, and 2036 (fig. D18). More water went into storage for 29 of the quarter-year stress periods and more water came out of storage for 71 of the quarter-year stress periods. Total loss from storage during the 25-year base case was about 285,000 acre-ft (average of 11,400 acre-ft per year; fig. D18). In general, simulated hydraulic heads declined during dry years and rose during wet years (fig. D20).

\section{Increased-Pumpage Scenario with Wet Conditions}

The increased-pumpage scenario with wet conditions used the areal-recharge rates, runoff entering the spreading grounds, and heads along the specified-head and general-head boundaries simulated for water years 1977 to 2001, the same as for the base-case scenario with wet conditions (table D8). For the increased-pumpage scenario with wet conditions, simulated average outflows were greater than inflows, with about 385,000 acre-ft coming from storage (average of 15,400 acre-ft per year, fig. D18; appendix 4, table 4.16). Simulated hydraulic-head change maps for the Pacific aquifer system showed that the increased pumpage resulted in hydraulic-head declines throughout the aquifer system compared to the base-case scenario with wet conditions (fig. D19A). Hydraulic-head declines ranged from less than $10 \mathrm{ft}$ in the Los Angeles Forebay to more than $100 \mathrm{ft}$ in the West Coast Basin (fig. D19A). Simulated hydraulic-head change maps for the Bent Spring aquifer system also showed that the increased pumpage resulted in hydraulic-head declines throughout the aquifer system compared to the base-case scenario with wet conditions (fig. D19A). Hydraulic-head declines ranged from less than $10 \mathrm{ft}$ in the Los Angeles Forebay and southern West Coast Basin to more than $50 \mathrm{ft}$ in the parts of West Coast Basin and Central Basin Pressure Area (fig. D19A). 


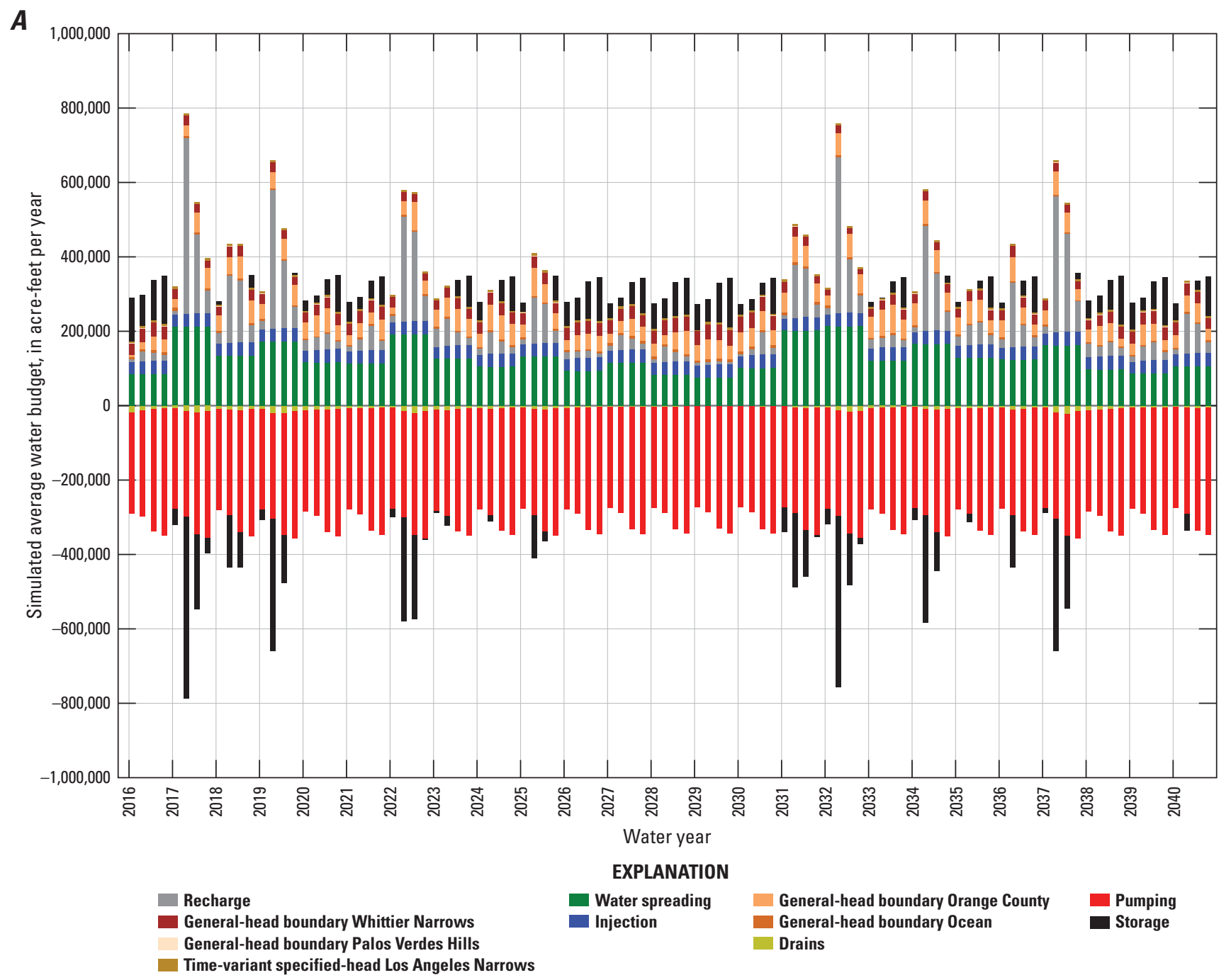

Figure D17. Simulated annual water budgets, 2016-40, for the $A$, base-case scenario with wet conditions; $B$, base-case scenario with dry conditions; $C$, increased-pumpage scenario with wet conditions; $D$, increased-pumpage scenario with dry conditions; $E$, optimized increased-pumpage and replenishment scenario with wet conditions; and $F$, optimized increase-pumpage and replenishment scenario with dry conditions, Los Angeles Coastal Plain Groundwater-flow Model. 


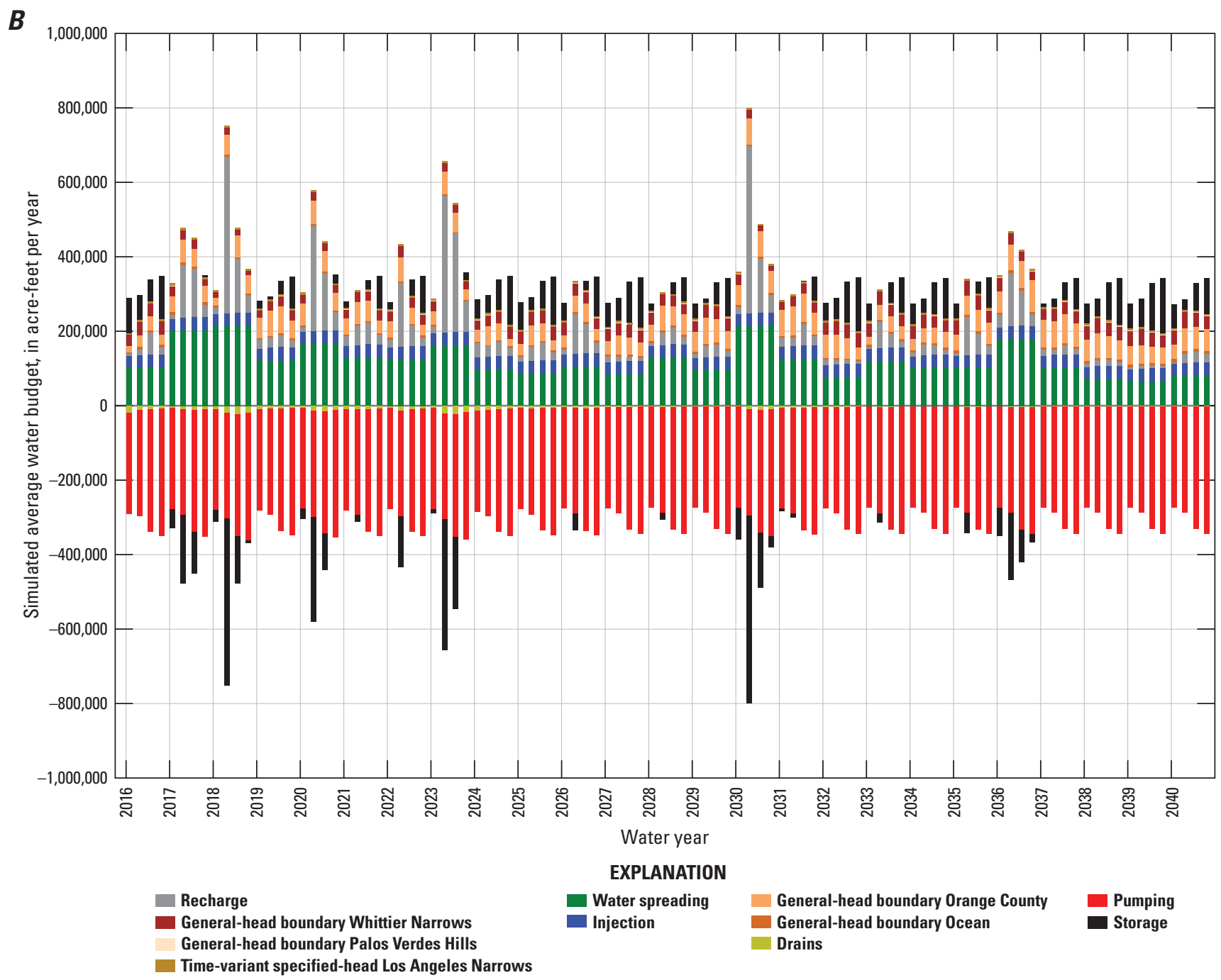

Figure D17.-Continued 


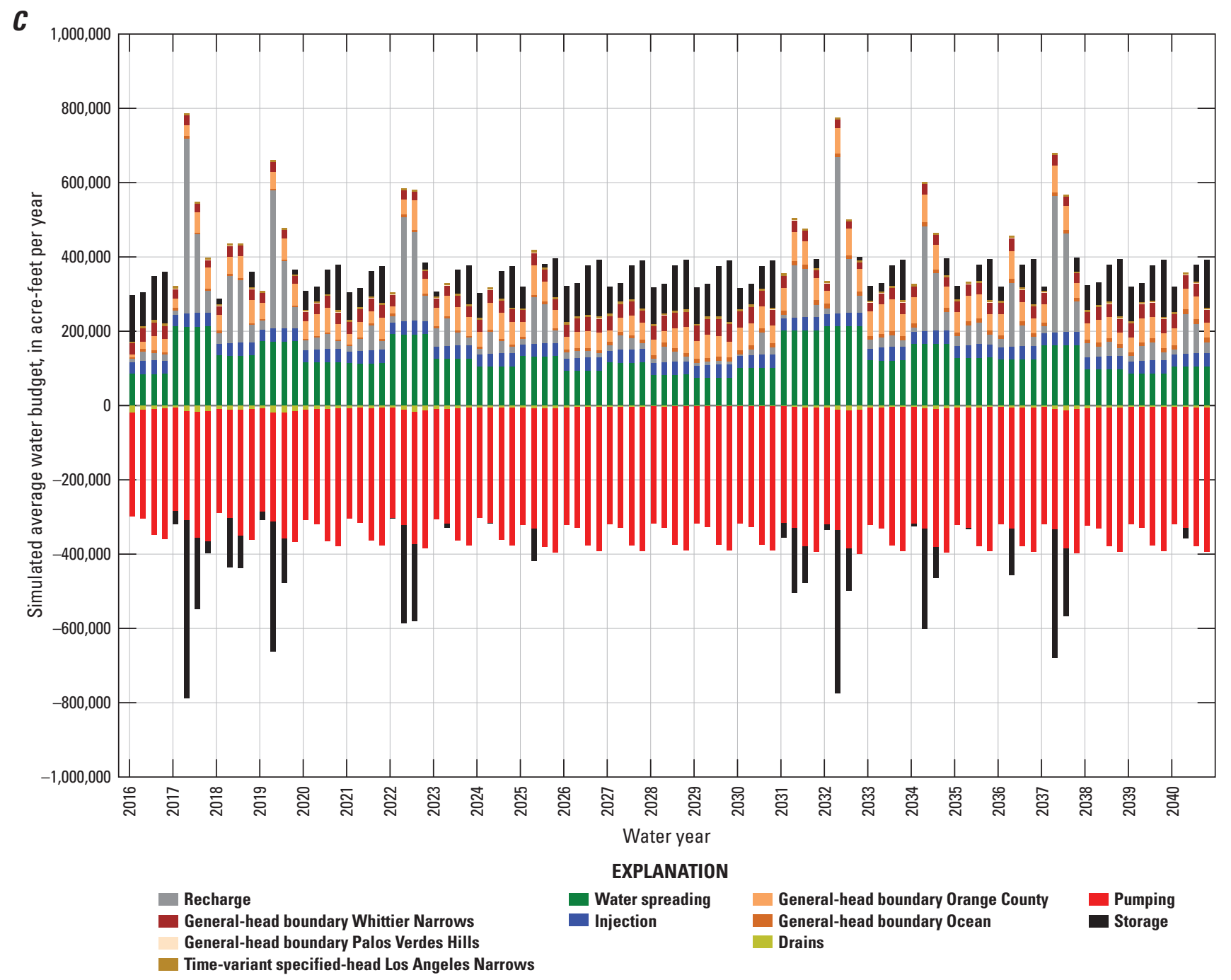

Figure D17.-Continued 


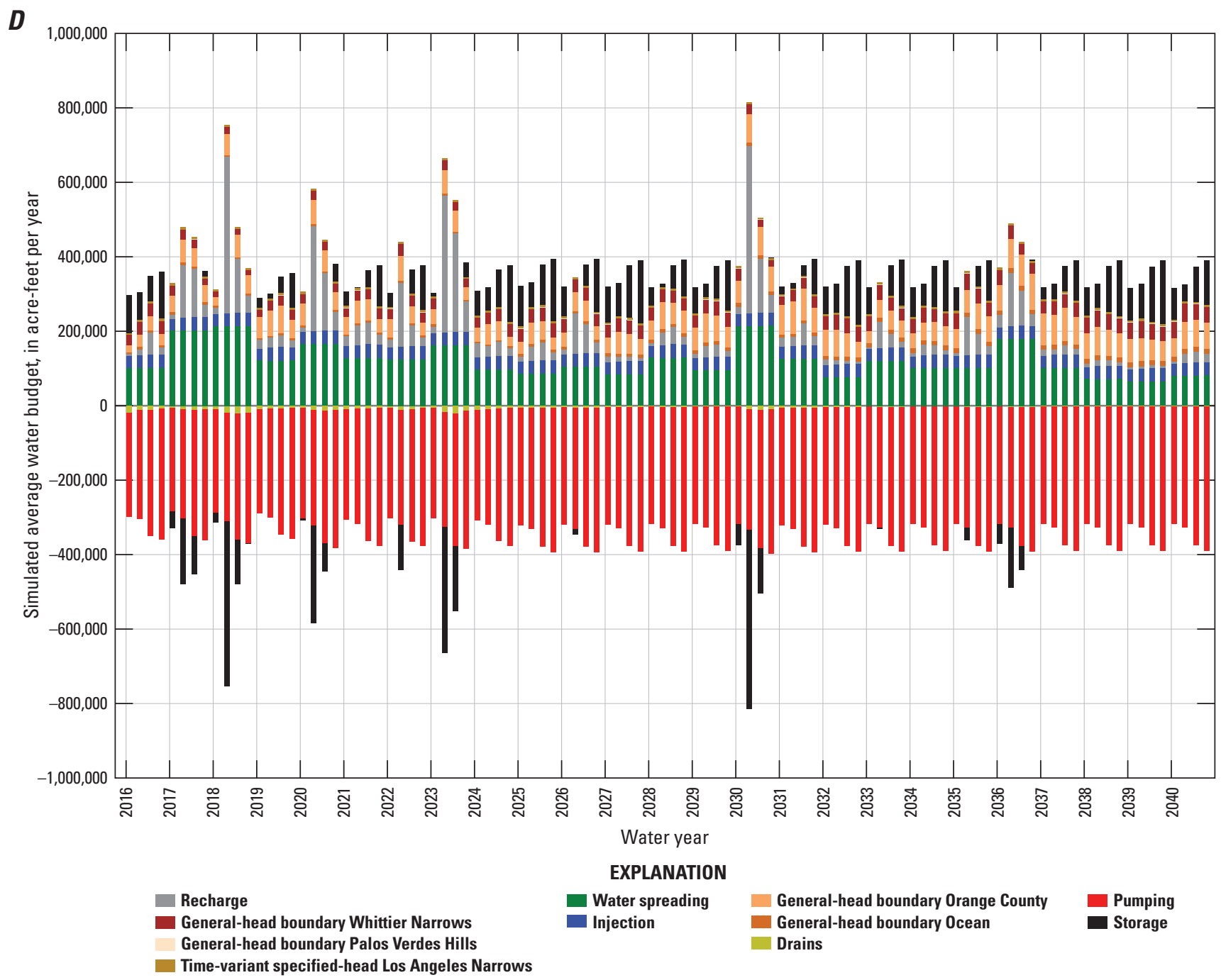

Figure D17.-Continued 


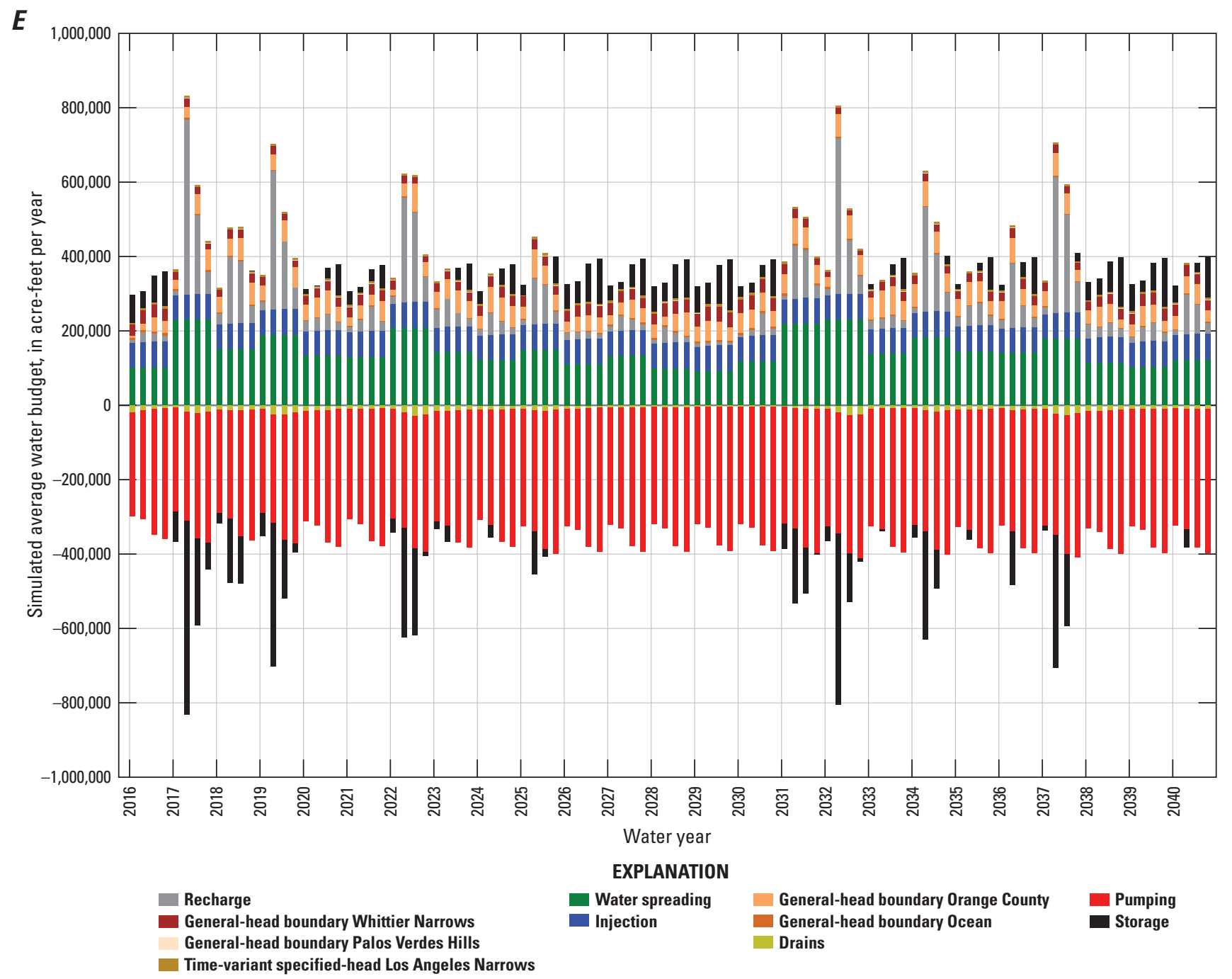

Figure D17.-Continued 


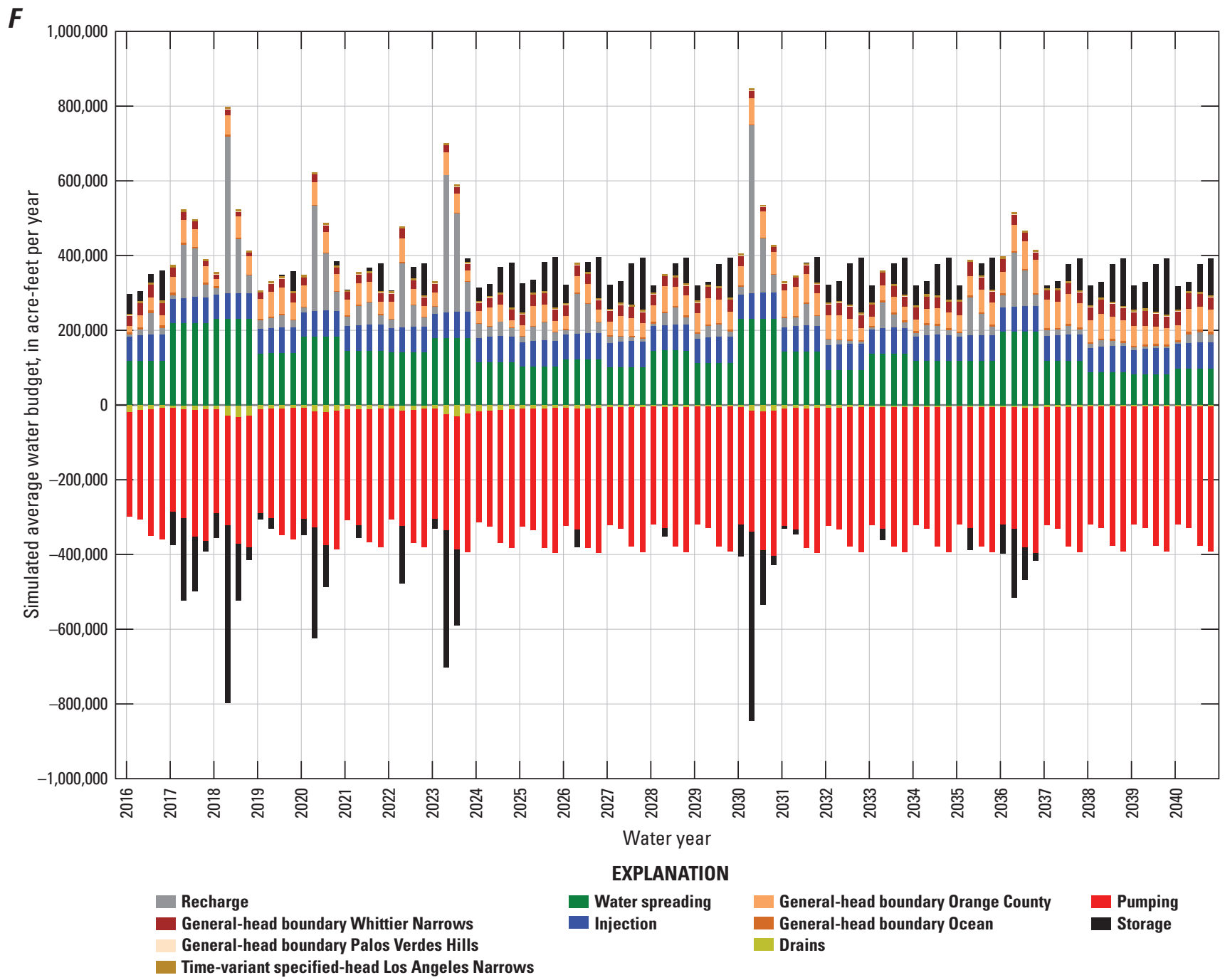

Figure D17.-Continued 


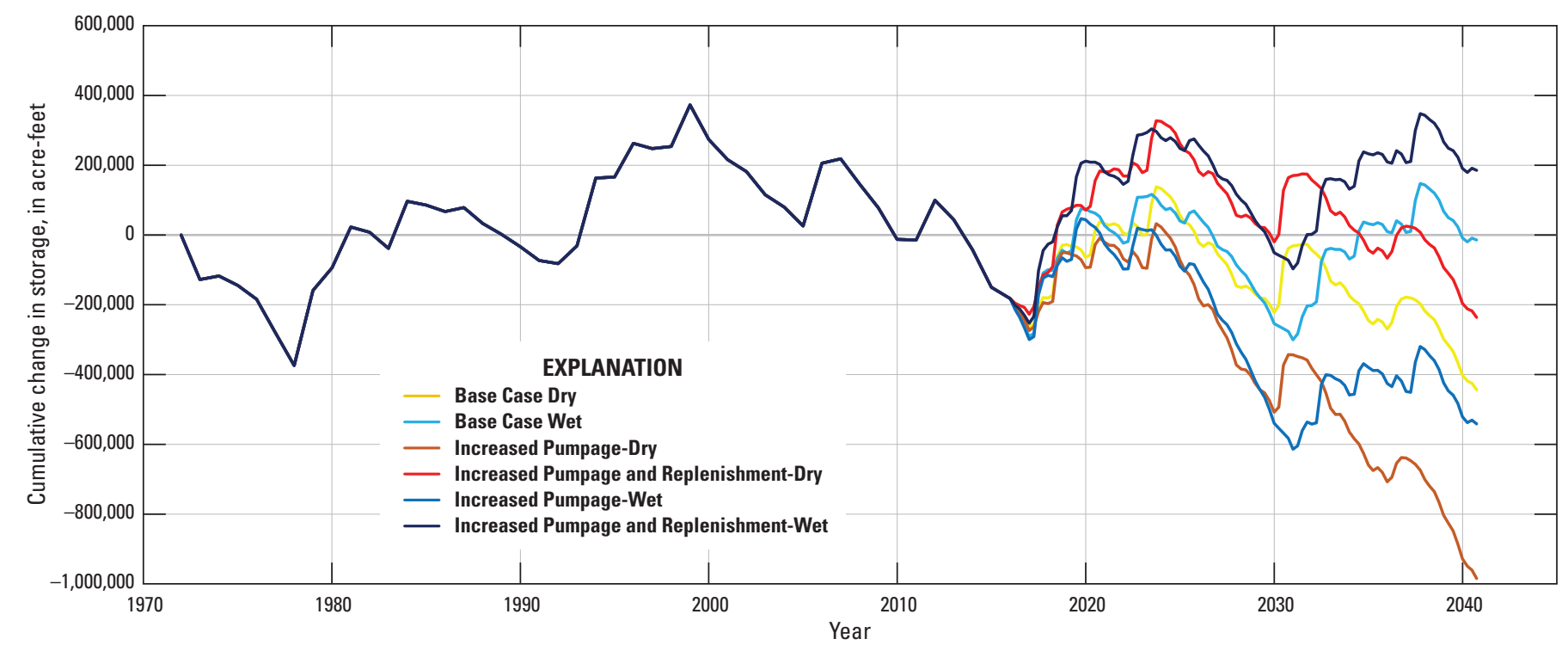

Figure D18. Cumulative change in storage for period 1971 through 2040, including future water-management scenarios, Los Angeles Coastal Plain Groundwater-flow Model. 


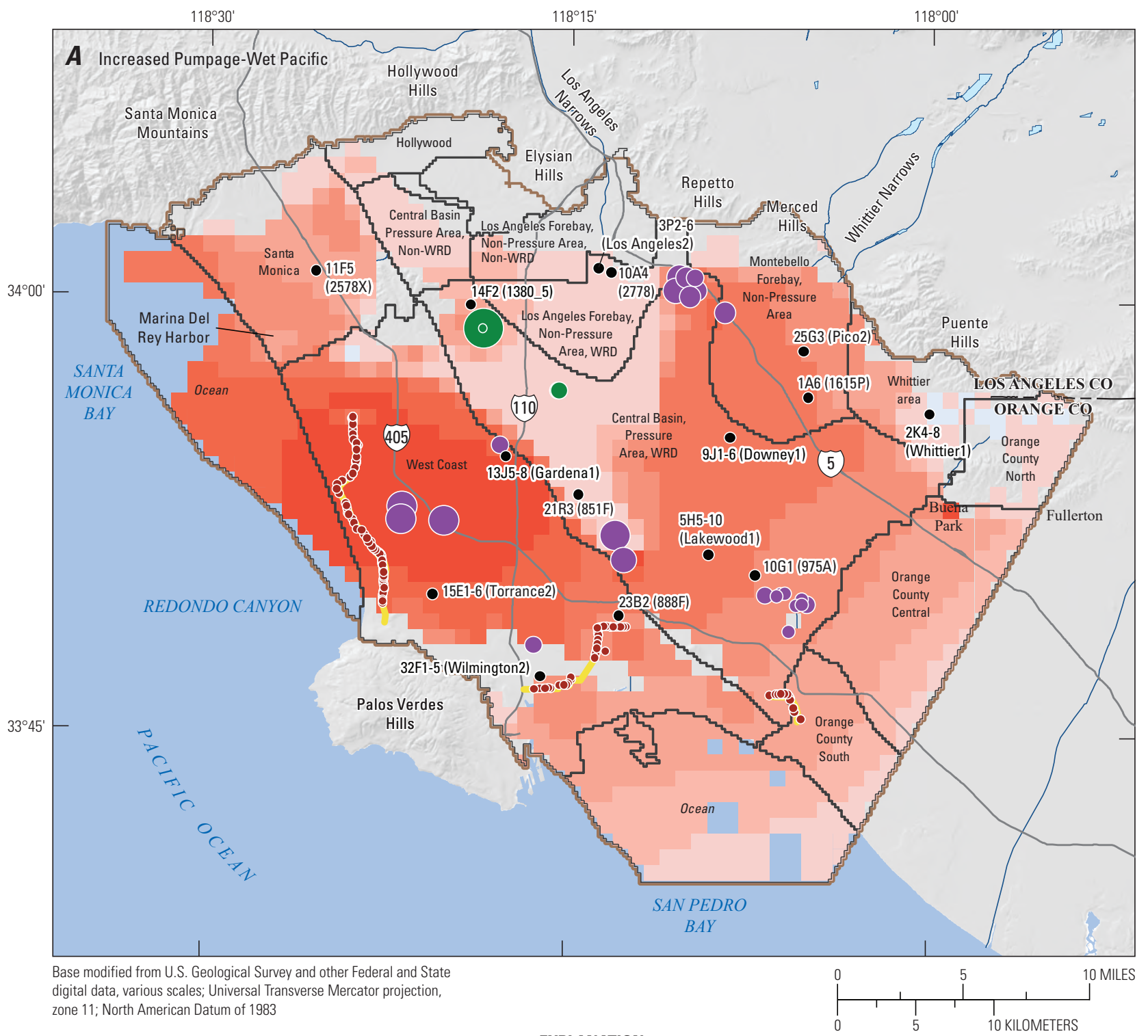

EXPLANATION

\begin{tabular}{ll}
$\square$ & $\begin{array}{l}\text { Los Angeles Coastal Plain Groundwater } \\
\text { Model boundary }\end{array}$ \\
& Subarea boundary \\
\hline & River \\
& Injection barrier \\
$\square \quad$ Spreading ground \\
$-\quad$ Injection well \\
$-\quad$ Key well
\end{tabular}
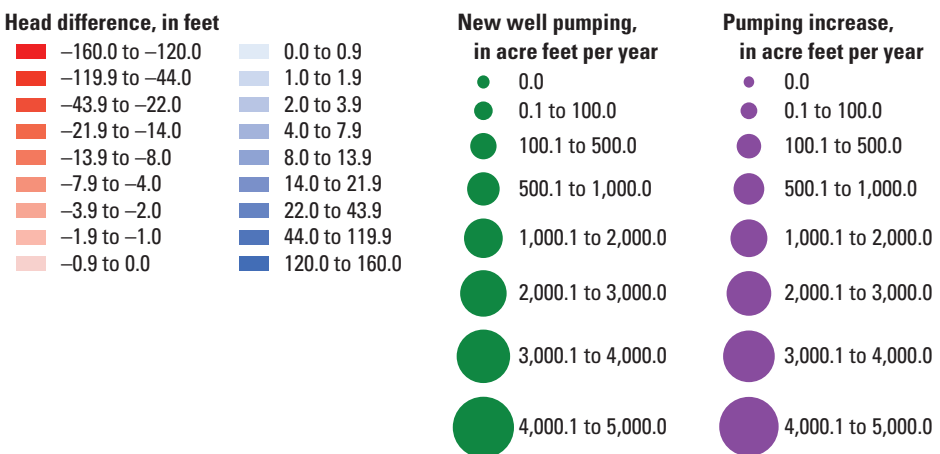

Figure D19. Simulated maximum relative difference in drawdown of hydraulic head in the Pacific and Bent Spring aquifer systems (map pages 1 and 2, respectively, of each lettered part of figure) for $A$, increased pumpage scenario with wet conditions compared to the base-case scenario with wet conditions; $B$, increased pumpage scenario with dry conditions compared to the base-case scenario with dry conditions; $C$, optimized increased-pumpage and replenishment scenario with wet conditions compared to the base-case scenario with wet conditions; and $D$, optimized increased-pumpage and replenishment scenario with dry conditions compared to the base-case scenario with dry conditions, Los Angeles Coastal Plain Groundwater-flow Model. (Negative head difference signifies a drawdown relative to the base-case scenario; positive head difference signifies a rise in head.) 


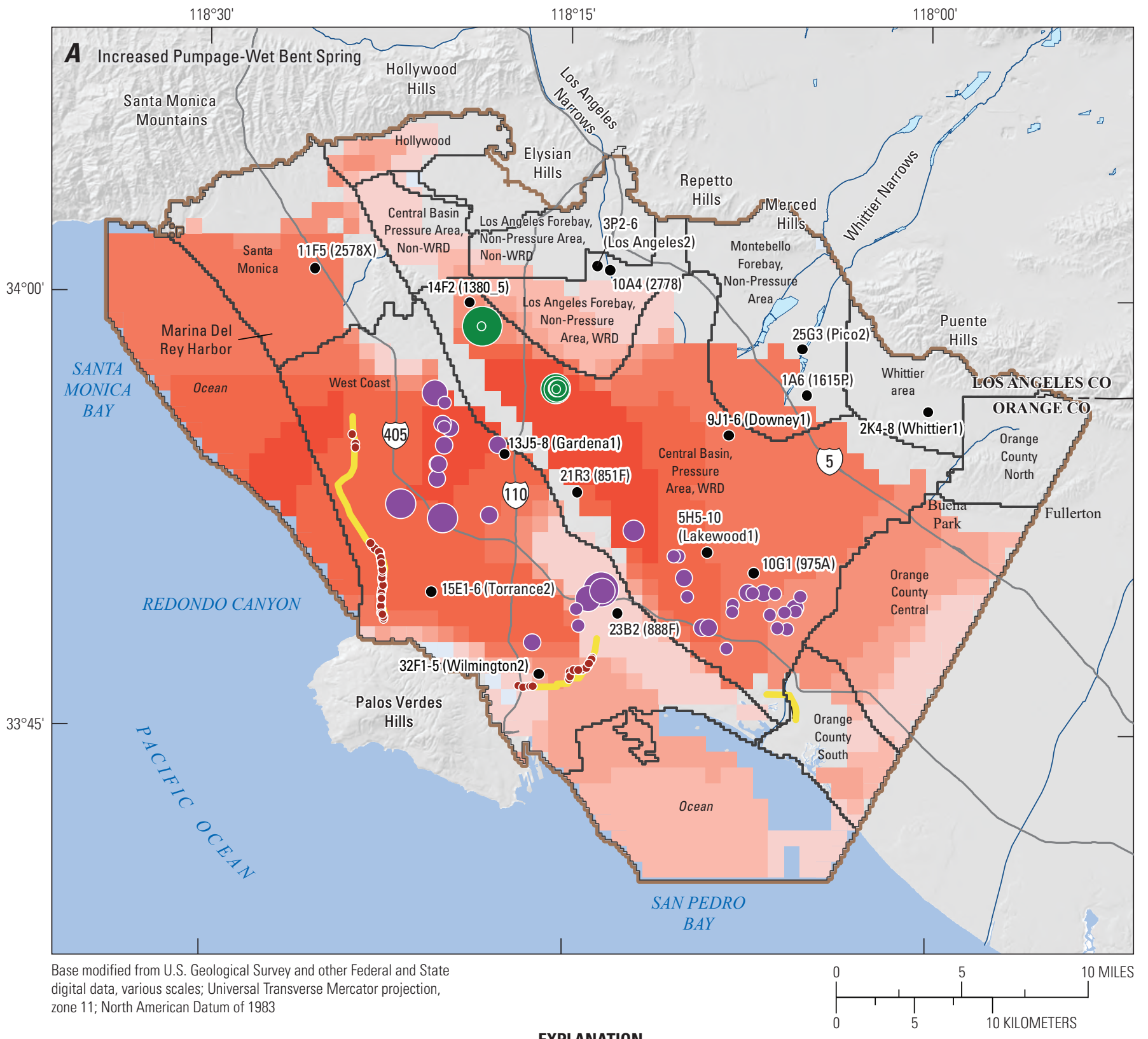

EXPLANATION

\begin{tabular}{ll}
$\square$ & Los Angeles Coastal Plain Groundwater \\
Model boundary \\
Subarea boundary \\
\hline & River \\
Injection barrier \\
$\square \quad$ Spreading ground \\
- Injection well \\
Key well
\end{tabular}

\begin{tabular}{|l|l}
\hline Head difference, in feet & \\
-160.0 to -120.0 & 0.0 to 0.9 \\
-119.9 to -44.0 & 1.0 to 1.9 \\
-43.9 to -22.0 & 2.0 to 3.9 \\
-21.9 to -14.0 & 4.0 to 7.9 \\
-13.9 to -8.0 & 8.0 to 13.9 \\
-7.9 to -4.0 & 14.0 to 21.9 \\
-3.9 to -2.0 & 22.0 to 43.9 \\
-1.9 to -1.0 & 44.0 to 119.9 \\
-0.9 to 0.0 & 120.0 to 160.0
\end{tabular}
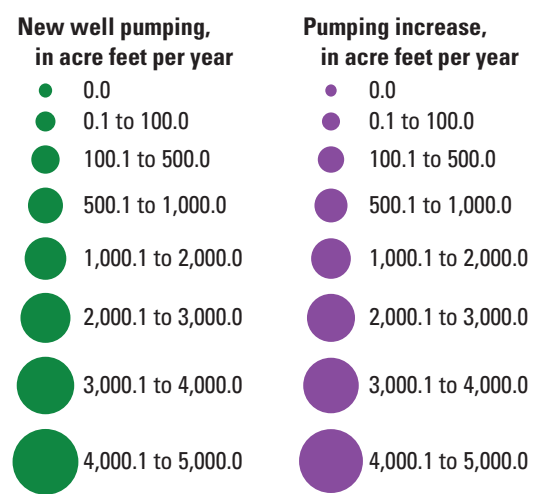

Figure D19.-Continued 


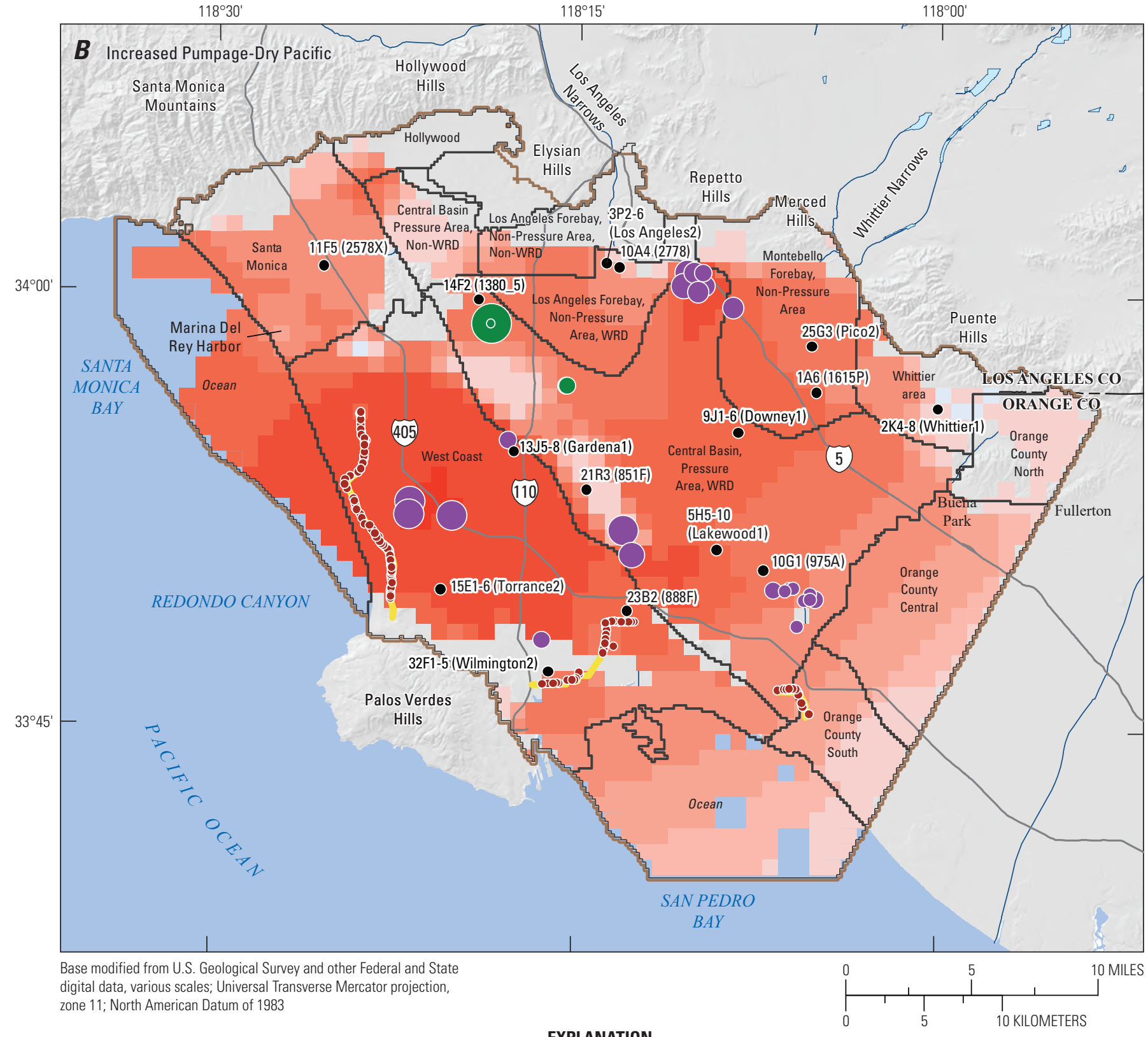

EXPLANATION

\begin{tabular}{ll}
$\square$ & Los Angeles Coastal Plain Groundwater \\
Model boundary \\
Subarea boundary \\
\hline & River \\
Injection barrier \\
$\square \quad$ Spreading ground \\
Injection well \\
Key well
\end{tabular}

\begin{tabular}{|l|l} 
Head difference, in feet & \\
-160.0 to -120.0 & 0.0 to 0.9 \\
-119.9 to -44.0 & 1.0 to 1.9 \\
-43.9 to -22.0 & 2.0 to 3.9 \\
-21.9 to -14.0 & 4.0 to 7.9 \\
-13.9 to -8.0 & 8.0 to 13.9 \\
-7.9 to -4.0 & 14.0 to 21.9 \\
-3.9 to -2.0 & 22.0 to 43.9 \\
-1.9 to -1.0 & 44.0 to 119.9 \\
-0.9 to 0.0 & 120.0 to 160.0
\end{tabular}

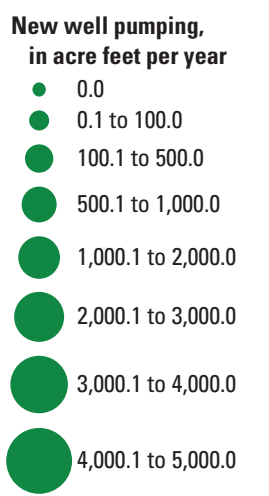

Pumping increase,

in acre feet per year

- 0.0

0.1 to 100.0

100.1 to 500.0

500.1 to $1,000.0$

$1,000.1$ to $2,000.0$

$2,000.1$ to $3,000.0$

$3,000.1$ to $4,000.0$

$4,000.1$ to $5,000.0$

Figure D19.-Continued 


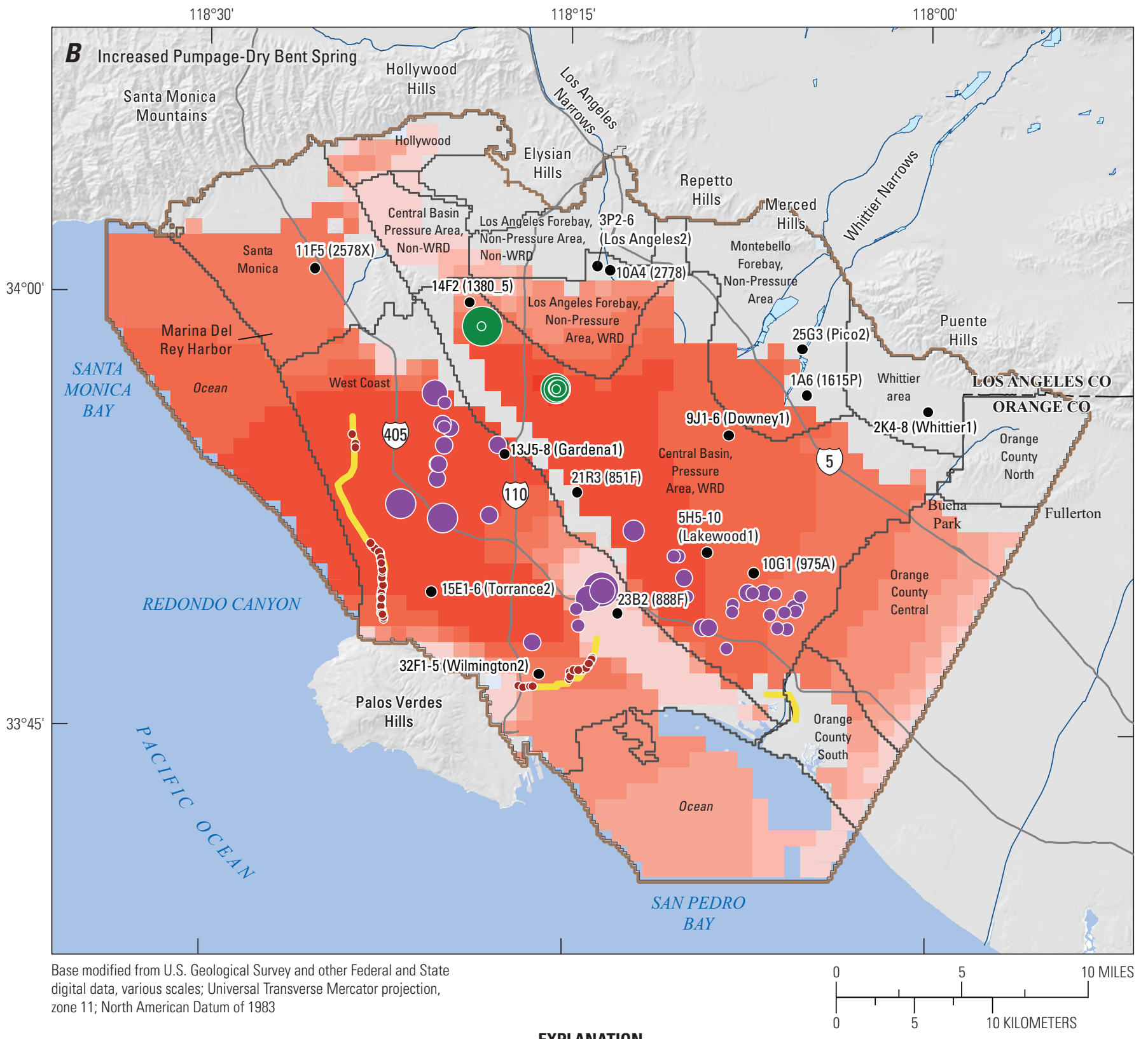

EXPLANATION

\begin{tabular}{ll}
$\square$ & Los Angeles Coastal Plain Groundwater \\
Model boundary \\
Subarea boundary \\
\hline & River \\
Injection barrier \\
$\square \quad$ Spreading ground \\
- Injection well \\
Key well
\end{tabular}

\begin{tabular}{|l|l}
\hline Head difference, in feet & \\
-160.0 to -120.0 & 0.0 to 0.9 \\
-119.9 to -44.0 & 1.0 to 1.9 \\
-43.9 to -22.0 & 2.0 to 3.9 \\
-21.9 to -14.0 & 4.0 to 7.9 \\
-13.9 to -8.0 & 8.0 to 13.9 \\
-7.9 to -4.0 & 14.0 to 21.9 \\
-3.9 to -2.0 & 22.0 to 43.9 \\
-1.9 to -1.0 & 44.0 to 119.9 \\
-0.9 to 0.0 & 120.0 to 160.0
\end{tabular}
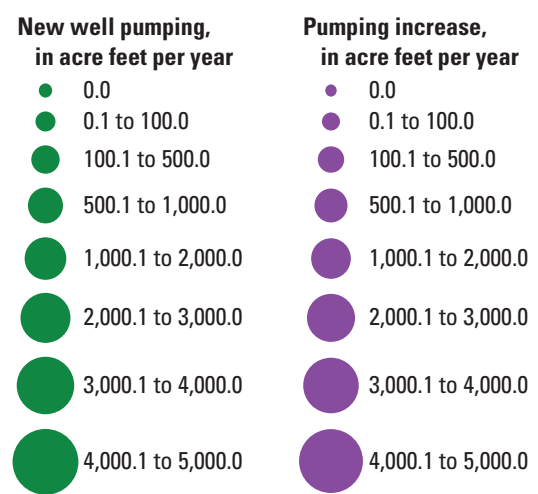

Figure D19.-Continued 


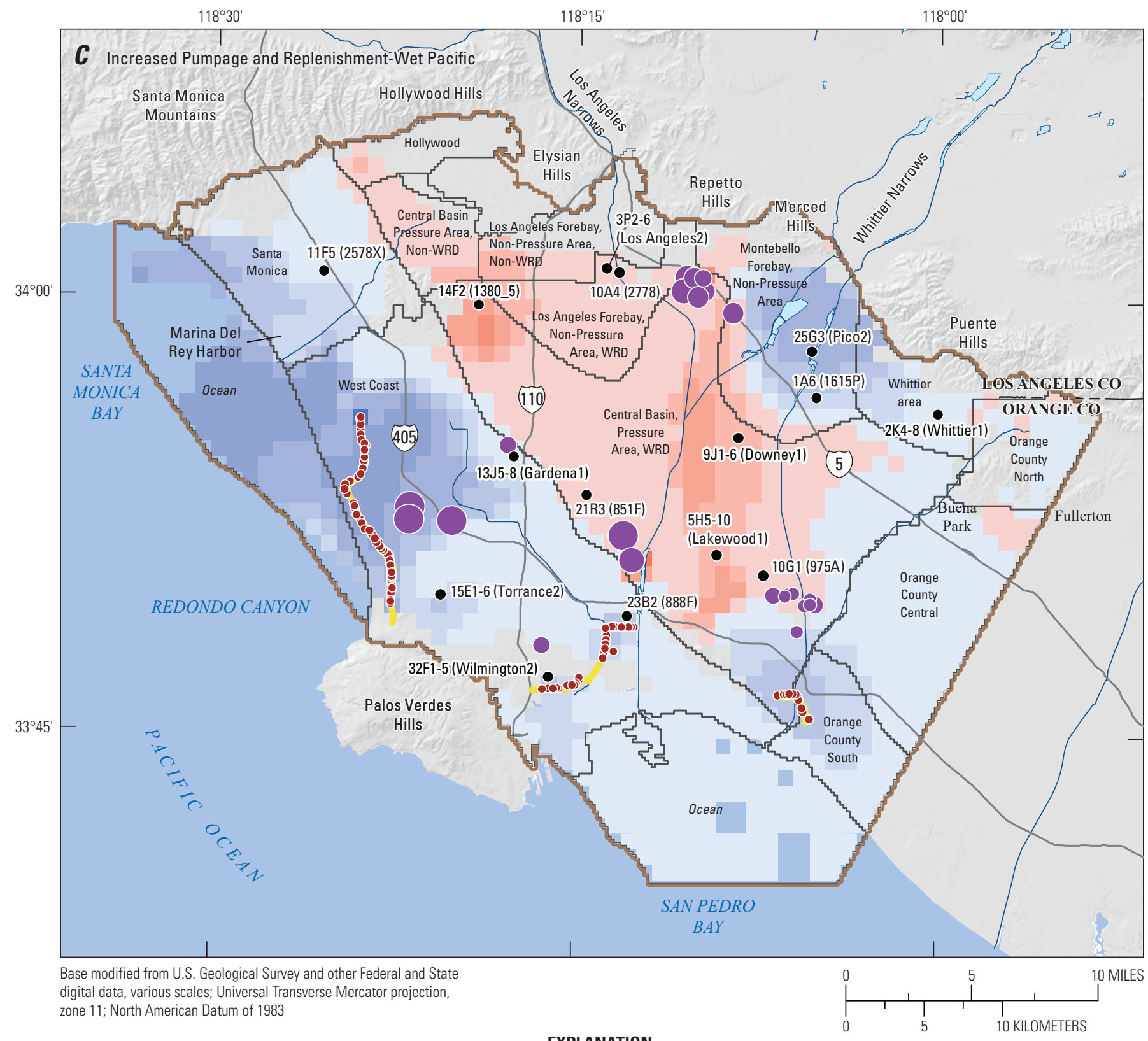

EXPLANATION

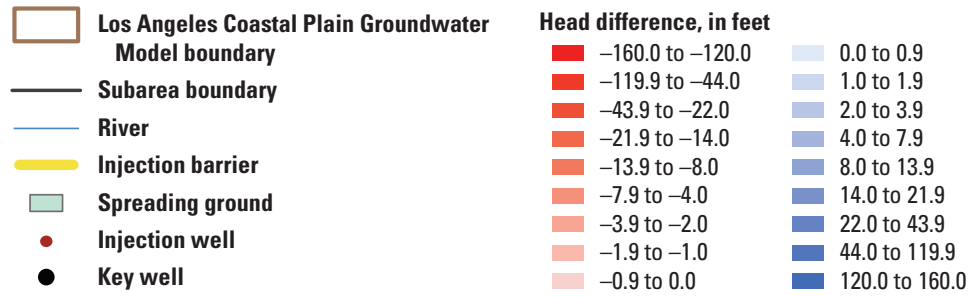

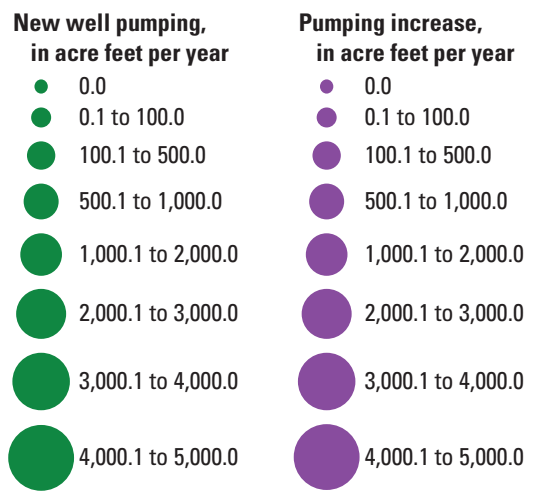

Figure D19.—Continued 


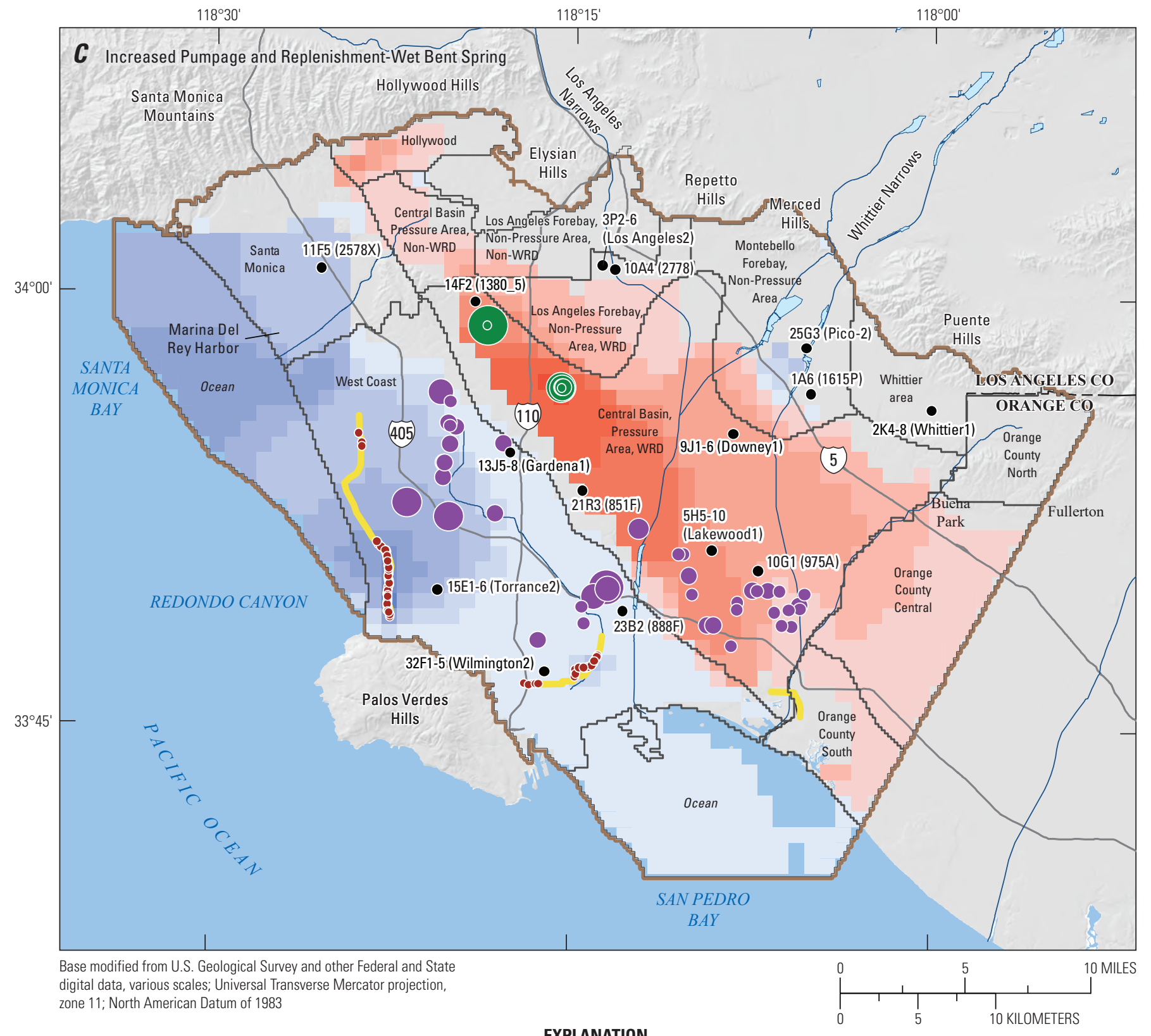

EXPLANATION

\begin{tabular}{ll}
$\square$ & Los Angeles Coastal Plain Groundwater \\
Model boundary \\
Subarea boundary \\
\hline & River \\
Injection barrier \\
$\square \quad$ Spreading ground \\
- Injection well \\
Key well
\end{tabular}

\begin{tabular}{|l|l}
\hline Head difference, in feet & \\
-160.0 to -120.0 & 0.0 to 0.9 \\
-119.9 to -44.0 & 1.0 to 1.9 \\
-43.9 to -22.0 & 2.0 to 3.9 \\
-21.9 to -14.0 & 4.0 to 7.9 \\
-13.9 to -8.0 & 8.0 to 13.9 \\
-7.9 to -4.0 & 14.0 to 21.9 \\
-3.9 to -2.0 & 22.0 to 43.9 \\
-1.9 to -1.0 & 44.0 to 119.9 \\
-0.9 to 0.0 & 120.0 to 160.0
\end{tabular}
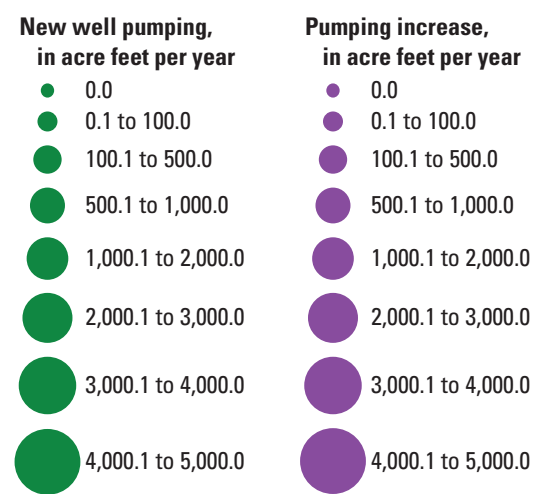

Figure D19.-Continued 


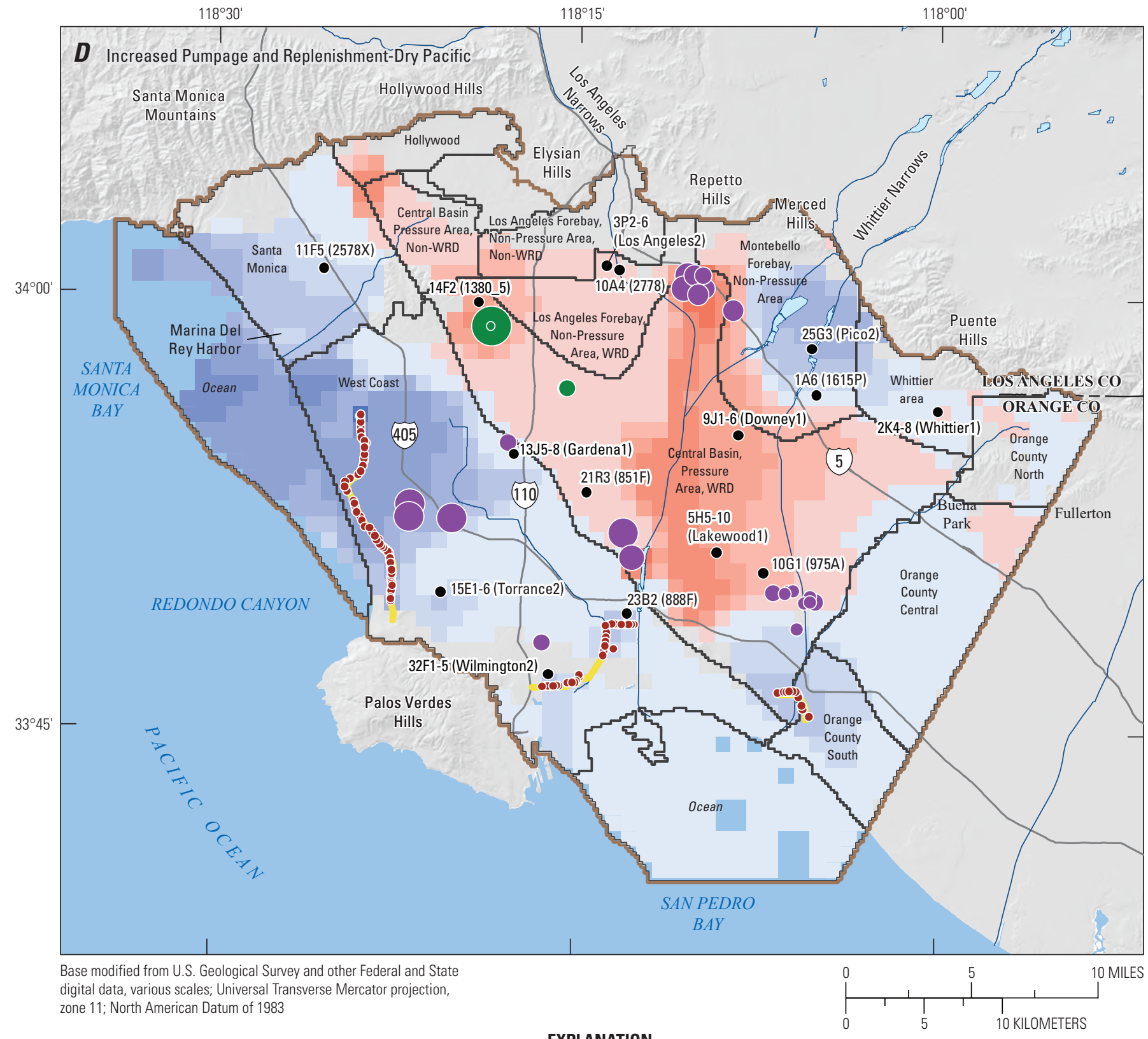

EXPLANATION

\begin{tabular}{lcl}
\hline $\begin{array}{l}\text { Los Angeles Coastal Plain Groundwater } \\
\text { Model boundary }\end{array}$ & Head difference, in feet & \\
\hline Subarea boundary & -160.0 to -120.0 & 0.0 to 0.9 \\
& -119.9 to -44.0 & 1.0 to 1.9 \\
River & -43.9 to -22.0 & 2.0 to 3.9 \\
Injection barrier & -21.9 to -14.0 & 4.0 to 7.9 \\
$\square \quad$ Spreading ground & -13.9 to -8.0 & 8.0 to 13.9 \\
$-\quad$ Injection well & -7.9 to -4.0 & 14.0 to 21.9 \\
$-\quad$ Key well & -3.9 to -2.0 & 22.0 to 43.9 \\
& -1.9 to -1.0 & 44.0 to 119.9 \\
& -0.9 to 0.0 & 120.0 to 160.0
\end{tabular}

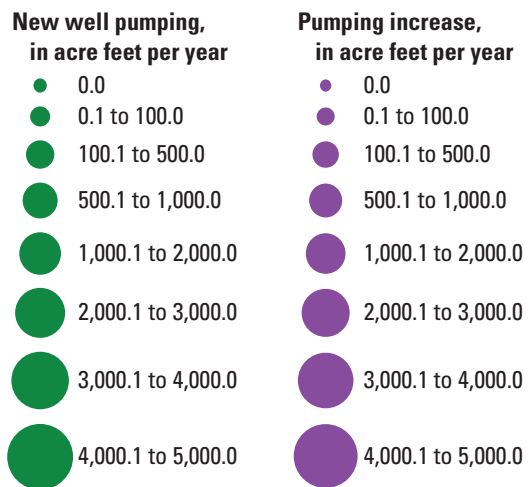

Figure D19.-Continued 


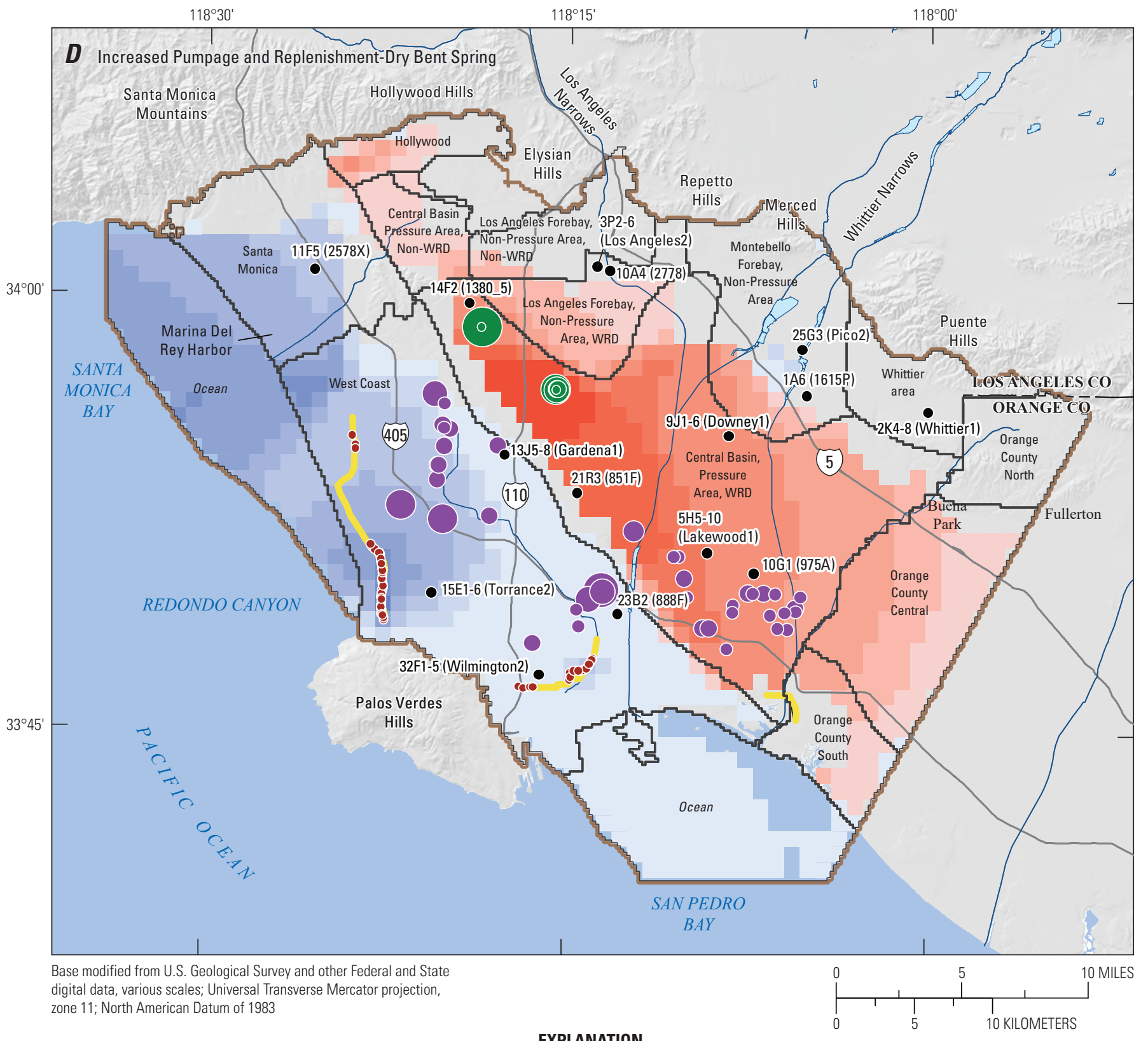

EXPLANATION

\begin{tabular}{ll}
$\square$ & Los Angeles Coastal Plain Groundwater \\
Model boundary \\
Subarea boundary \\
\hline & River \\
Injection barrier \\
$\square \quad$ Spreading ground \\
- Injection well \\
Key well
\end{tabular}

\begin{tabular}{|l|l}
\hline Head difference, in feet & \\
-160.0 to -120.0 & 0.0 to 0.9 \\
-119.9 to -44.0 & 1.0 to 1.9 \\
-43.9 to -22.0 & 2.0 to 3.9 \\
-21.9 to -14.0 & 4.0 to 7.9 \\
-13.9 to -8.0 & 8.0 to 13.9 \\
-7.9 to -4.0 & 14.0 to 21.9 \\
-3.9 to -2.0 & 22.0 to 43.9 \\
-1.9 to -1.0 & 44.0 to 119.9 \\
-0.9 to 0.0 & 120.0 to 160.0
\end{tabular}
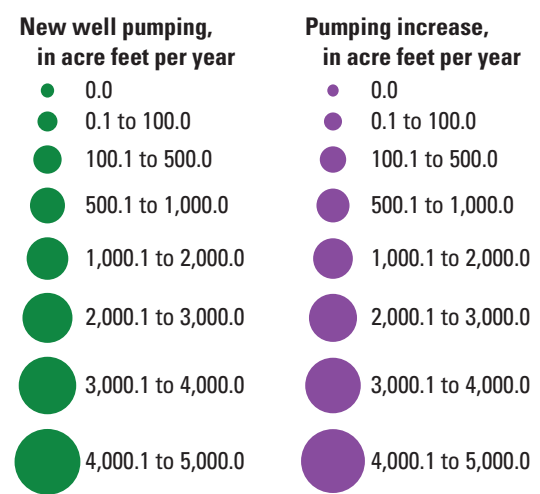

Figure D19.-Continued 

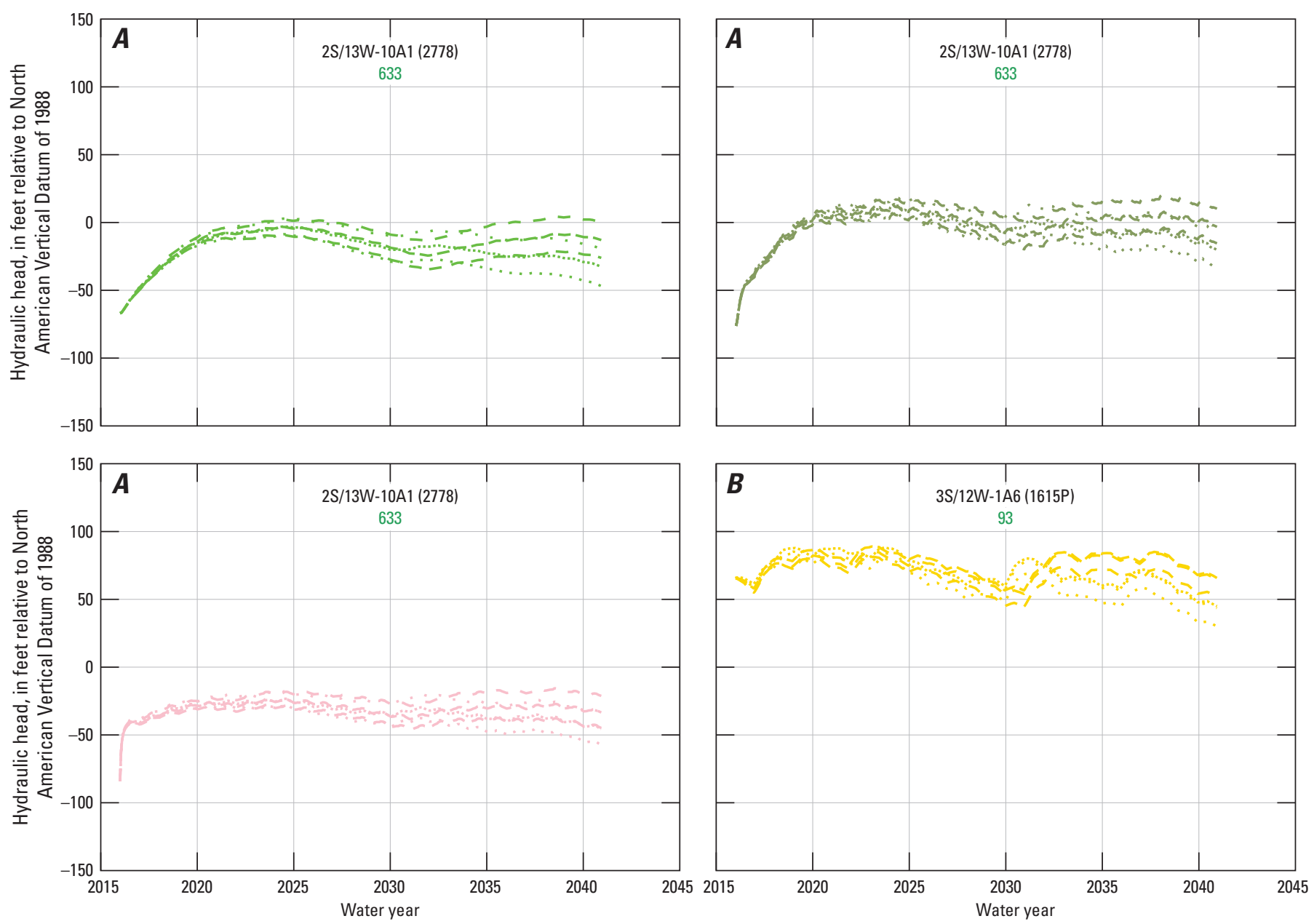

EXPLANATION

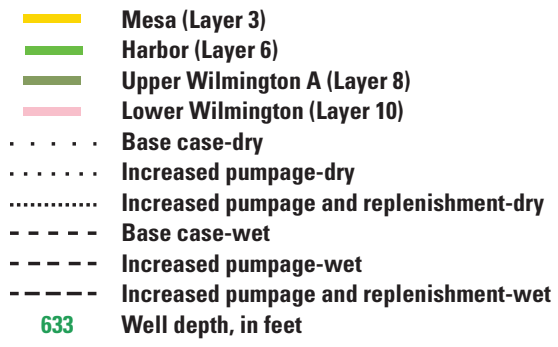

Figure D20. Simulated hydrographs for the Pacific and Bent Spring aquifer systems at selected calibration wells for future water-management scenarios, water years 2016-40: $A$, 2S/13W-10A1 (2778); B, 3S/12W-01A6 (1615P); C, 4S/12W-10G1 (975A); D, 3S/13W-21R1 (851F); E, 2S/14W-14F2 (1380); F, 4S/13W-23B2 (888F); and G, 2S/15W-11F5 (2578X), Los Angeles Coastal Plain Groundwater-flow Model. 

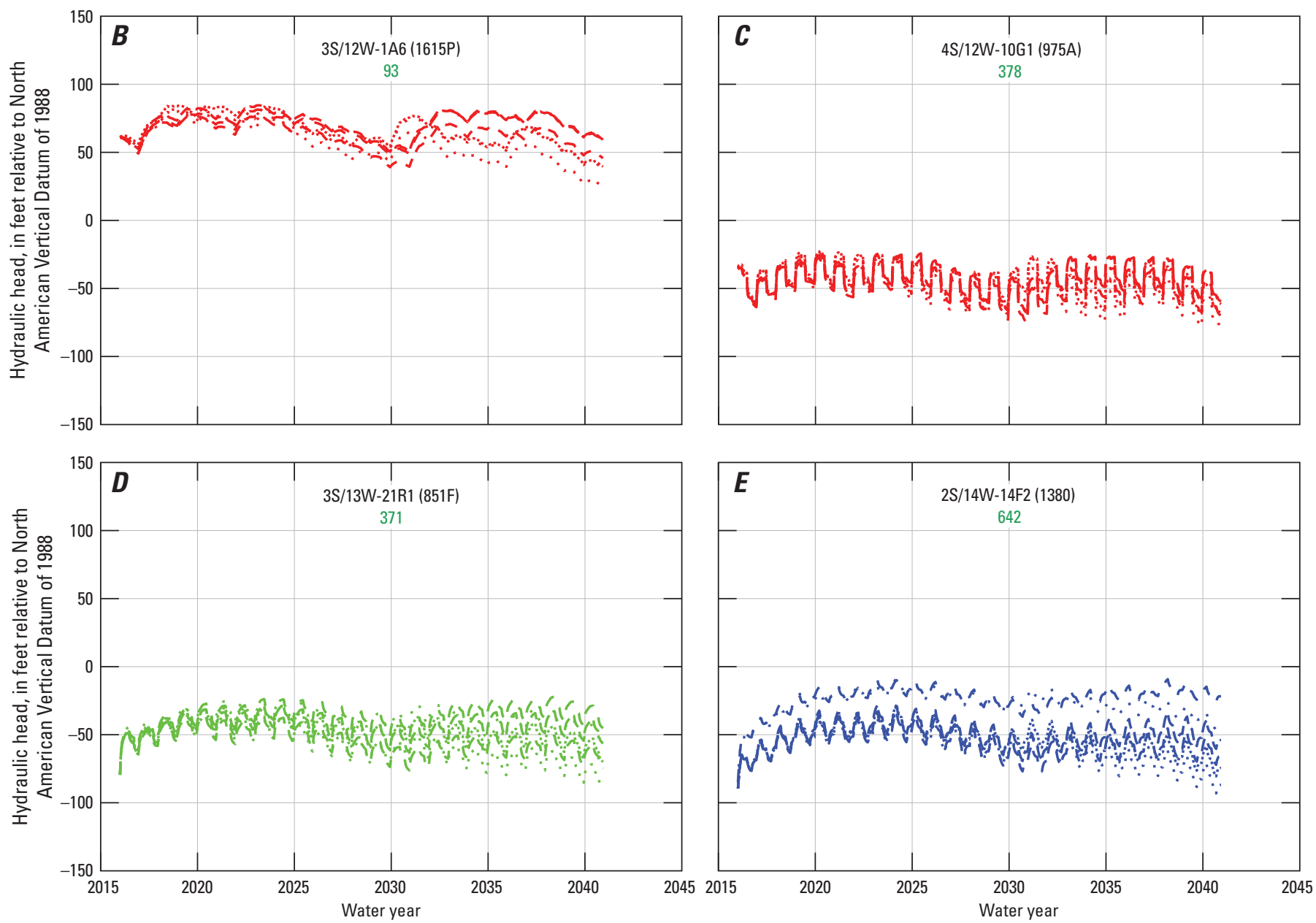

EXPLANATION

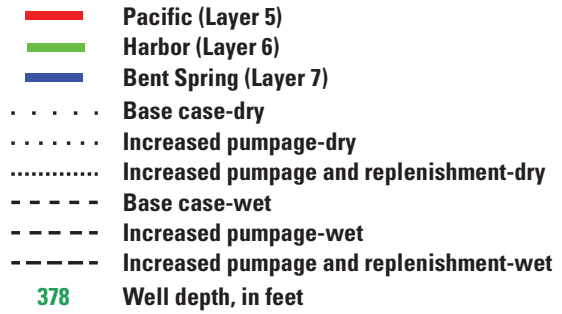

Figure D20.-Continued 


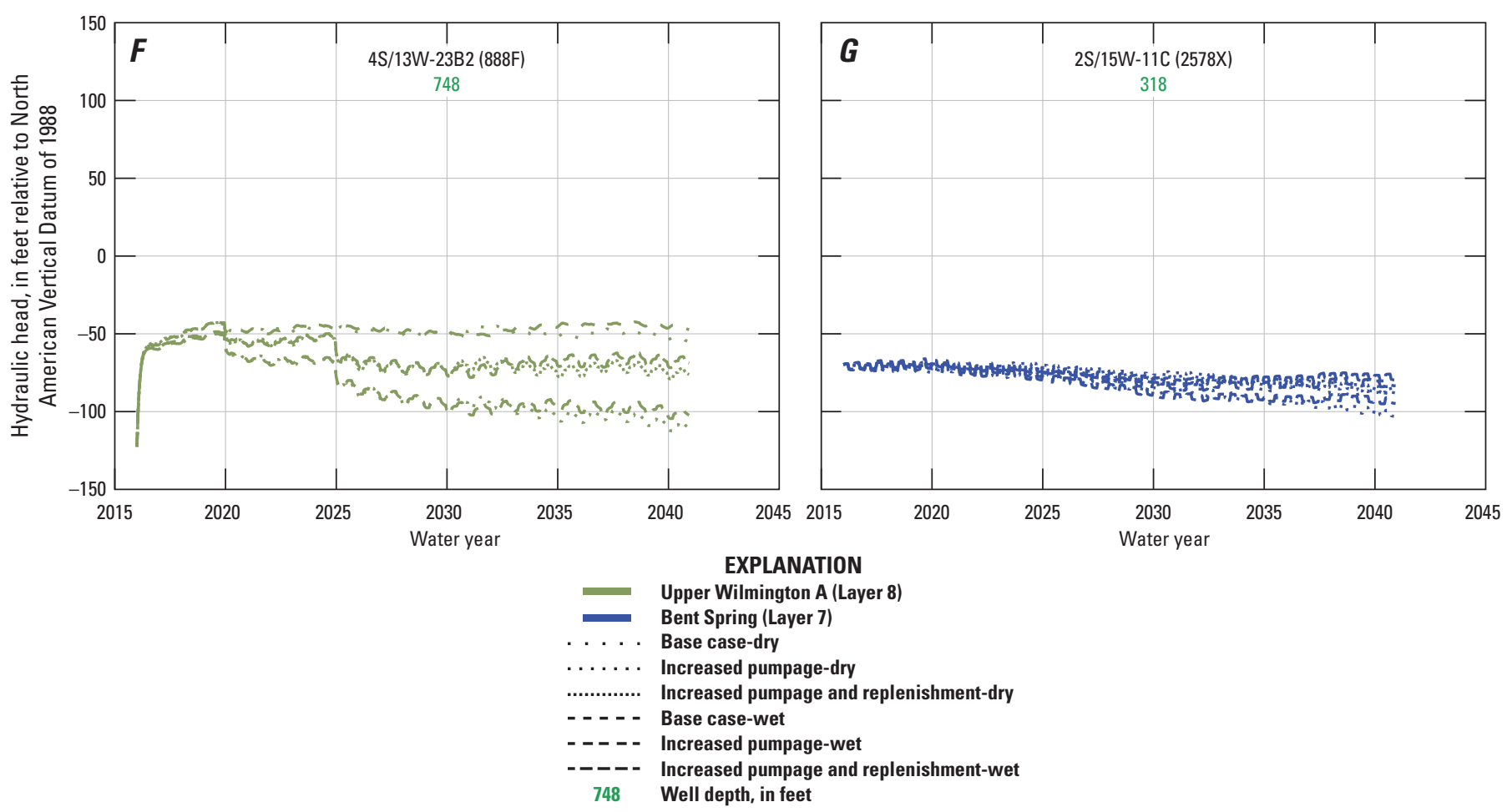

Figure D20.-Continued

\section{Increased-Pumpage Scenario with Dry Conditions}

The increased-pumpage scenario with dry conditions used the areal-recharge rates, runoff entering the spreading grounds, and heads along the specified-head and general-head boundaries simulated for water years 1991 to 2015, the same as for the base-case scenario with dry conditions (table D8). For this scenario, simulated average outflows also were greater than inflows, with about 830,000 acre-ft coming from storage (average of 33,000 acre-ft per year; fig. D18; appendix 4, table 4.17). Simulated hydraulic-head change maps for the Pacific aquifer system showed that the increased pumpage resulted in hydraulic-head declines throughout the aquifer system compared to the base-case scenario with dry conditions (fig. D19B). Hydraulic-head declines ranged from about $10 \mathrm{ft}$ in the eastern Whittier Area to more than $100 \mathrm{ft}$ in the West Coast Basin (figs. D1, D19B). Simulated hydraulic-head change maps for the Bent Spring aquifer system also showed that the increased pumpage resulted in hydraulic-head declines throughout the aquifer system compared to the base-case scenario with dry conditions (fig. D19B). Hydraulic-head declines ranged from about $10 \mathrm{ft}$ in the southeastern West Coast Basin to over $50 \mathrm{ft}$ in the northern part of West Coast Basin (fig. D19B). Increased-pumpage dry scenario hydraulic-head declines were more extreme than increased-pumpage wet scenario declines in most areas.

\section{Comparison of Scenarios}

The base case with dry conditions, the increased-pumpage with wet conditions, and the increased-pumpage with dry conditions scenarios all lost water from storage due to increased pumping, though the amount of water lost varied greatly between the increased-pumpage with wet conditions and the increased-pumpage scenario with dry conditions (fig. D18). The simulated hydraulic-head change maps and hydrographs showed that increasing pumping rates to adjudicated rates would result in water-level declines compared to the base case throughout the LACPGM, in all aquifer systems. 


\section{Simulation-Optimization Analysis}

The comparison between results from the base case and the increased-pumpage scenarios indicated that increasing pumping rates to adjudication levels results in considerably lower simulated heads throughout most of the LACP in all aquifer systems. The recharge rates simulated for these management scenarios were not adequate to prevent hydraulic heads from declining during the simulation period. To evaluate possible effects of increased recharge, it was assumed that the WRD could increase groundwater replenishment by an additional 15,000 acre-ft/yr at the spreading grounds and about $33,400 \mathrm{acre}-\mathrm{ft} / \mathrm{yr}$ into the injection wells to help offset the hydraulic-head declines caused from the increased pumpage. The additional 15,000 acre-ft/yr of recharge at the spreading grounds was in addition to any changes in runoff water due to wet or dry conditions. The increased recharge amounts were based on discussions with WRD and were derived from data from historical spreading and injection rates. The WRD could recharge this water at existing spreading grounds and injection wells at different times and at various rates, which results in multiple management decisions. The LACPGM was coupled with mathematical optimization algorithms to optimally identify the quantity and distribution of recharge that would minimize hydraulic-head declines. Optimization methodology was applied to the increased-pumpage scenarios with wet and dry conditions to determine if the simulated hydraulic-head declines could be mitigated by supplementing recharge at the existing spreading grounds and injection wells.

\section{Optimization Methodology}

The optimization of proposed management scenarios was done using PEST parameter estimation with recharge amounts as the estimated parameters. The optimization criteria for the increased-pumpage and replenishment scenarios with wet and dry conditions were set to minimize the amounts that simulated heads fall below the lowest simulated heads of the base case scenario and to not allow heads to rise above land surface. Recharge was added to the spreading grounds and barrier injection wells to meet the optimization criteria. The amounts of additional recharge water being added to the WND, SGRSG and RHSG spreading grounds and the WCBBP, DGBP, and ABP barrier wells each year remained fixed throughout each simulation run and were determined by optimization parameters. Total recharge at the spreading grounds was not allowed to exceed 250,000 acre-ft/yr for any given year based on historical maximums. Injections at the WCBBP, DGBP, and ABP were not allowed to exceed 45,000, 10,000 , and 8,000 acre-ft/yr for any given year, respectively, based on historical maximums.

The minimum and maximum hydraulic heads allowed by the optimization criteria were set up as observations in PEST. The minimum hydraulic heads allowed were the lowest simulated heads of the base-case scenario while the maximum hydraulic heads allowed for the topmost model cells were land surfaces. While the minimum and maximum hydraulic heads allowed are not measured values, they were set up as observations in PEST to make them part of PEST's objective function and allow PEST to optimize parameters to achieve these criteria. Because simulated hydraulic heads above or equal to the minimum level are acceptable in the management scenarios, simulated heads greater than the optimization criteria were set equal to the optimization criteria using a postprocessing Python script. Similarly, for maximum heads (land surfaces), simulated heads less than the optimization criteria were set equal to the optimization criteria so that simulated heads greater than the minimum heads did not add to PEST's objective function. The optimization criteria averaged simulated hydraulic heads over areas of five by five model cells. This averaging was done to reduce the number of PEST observations required from over 400,000 to under 16,000 and to smooth out simulated drawdowns at production wells.

Six PEST parameters were used for the management scenarios. Each parameter defined the amount of additional recharge added to each spreading ground or injection barrier project. A python script was written to read the additional recharge amounts from a text file produced by PEST and update the MODFLOW-USG management-scenario well package (WEL) file to reflect the additional spreading and injection. This script was run as a pre-processing step prior to running the MODFLOW-USG management-scenario models. All six parameters were used as prior information with a preferred value of zero to favor solutions with minimum recharge added. The six parameters were weighted several orders of magnitude lower than the optimization criteria to ensure that the optimization criteria were met first. Favoring solutions with minimum recharge added had little effect on the results of the optimization scenarios because the optimization could not achieve the other objectives in all areas of the model, even when using the maximum amount of additional recharge. 


\section{Simulation-Optimization Results}

The optimized increased-pumpage and replenishment scenarios with wet and dry conditions resulted in a simulated storage gain of about 340,000 acre- $\mathrm{ft}$ and a storage loss of 78,300 acre-ft of cumulative storage, respectively, by the end of the simulated period (fig. D18; appendix 4 , tables $4.2 E, 4.2 F$ ). The simulated average annual recharge rates at the spreading grounds and at the injection wells for the optimized increased-pumpage and replenishment scenario with wet conditions were about 148,000 acre-ft/yr (about 17,000 acre-ft/yr higher than the base-case; appendix 4, table 4.18) and 68,000 acre-ft/yr (about 33,400 acre-ft/yr higher than the base-case), respectively. The increases in average annual recharge rates at the spreading grounds were due to additional runoff water collected by the spreading grounds during wet conditions and additional water supplied by WRD. The simulated average annual recharge at the spreading grounds and at the injection wells for optimized increased-pumpage and replenishment scenario with dry conditions were about 140,000 acre-ft/yr (about 17,000 acre-ft/yr higher than the base-case and increased-pumpage scenarios with dry conditions; appendix 4, table 4.19) and about 68,000 acre-ft/yr (about 33,400 acre-ft/yr higher than the base-case and increased-pumpage scenarios with dry conditions), respectively.

Simulated hydraulic-head change maps for the Pacific aquifer system showed that the optimized increased-pumpage and replenishment scenario with wet conditions resulted in hydraulic-head rises in the Montebello Forebay, the eastern part of the Central Basin, and the entire West Coast Basin compared to the base-case scenario with wet conditions (figs. D1, D19C). However, simulated hydraulic-heads declined by as much as $20 \mathrm{ft}$ in the Los Angeles Forebay and the northwestern part of the Central Basin compared to the base-case scenario (figs. D1, D19C). Simulated hydraulic-head change maps for the Bent Spring aquifer system showed that the optimized increased-pumpage and replenishment scenario with wet conditions resulted in hydraulic-head rises in the Montebello Forebay and the western part of the West Coast Basin compared to the base-case scenario with wet conditions; however, the model simulated hydraulic-head declines throughout most of the Central Basin (fig. D19C). Simulated hydraulic-head change maps for the optimized increased-pumpage scenario and replenishment with dry conditions contained more pronounced hydraulic head decreases than the simulated hydraulic-head change maps for the optimized increased-pumpage and replenishment scenario with wet conditions (fig. D19D).

These results of the optimized increased-pumping and replenishment scenarios indicated that the supplemental recharge can control hydraulic-head declines throughout most of the Pacific aquifer system; however, the Los Angeles Forebay and northwestern part of the Central Basin are too far away from existing spreading grounds and injection wells to prevent hydraulic-head declines caused by the increased pumpage. The deeper aquifer systems, as represented by the Bent Spring aquifer system, received less benefit from the spreading grounds in the Central Basin than the shallower aquifer systems, as represented by the Pacific aquifer system. Simulated hydraulic heads in the Bent Spring aquifer system rose in the western and southern parts of the West Coast Basin because multiple injection wells are screened in the aquifer system, which allowed increased injection to offset the increased pumpage (fig. D19C). The calibrated LACPGM could be used in the future to help identify new spreading ground locations and injection sites that could be used to minimize the hydraulic-head declines caused from the presumed increased pumpage in the LACP. In this study, the costs of recharge were not included in the simulation-optimization analysis. Future work could include developing a simulation-optimization model that could identify least-cost solutions for mitigating hydraulic-head declines from potential increased pumpage in the LACP.

\section{Summary and Conclusions}

The primary goal of this study was to improve the understanding of groundwater basins to inform management of groundwater in the Los Angeles Coastal Plain (LACP) area. Our understanding of groundwater in the study area is built on geologic and hydrologic data. This study, in cooperation with the Water Replenishment District of Southern California (WRD), compiled comprehensive geologic and hydrologic data, including construction data and geophysical logs for wells, water-level measurements, and data associated with groundwater recharge and discharge. This study has also built upon previous studies, including a previous groundwater-flow model (Reichard and others, 2003), a geologic framework model (Ponti and others, 2007), and a precipitation-runoff model (Hevesi and Johnson, 2016). Available information on groundwater hydrology was assembled, and a conceptual groundwater-flow model of the study area was developed.

The conceptual groundwater-flow model, previous studies, and data compiled were used to develop the Los Angeles Coastal Plain Groundwater Model (LACPGM) using MODFLOW-USG. The LACPGM model area included the Central, West Coast, Hollywood, Santa Monica, and partial Orange County Basins. The LACPGM is a 12-layer unstructured-grid model based upon a 13-layer chronostratigraphic hydrogeologic-framework model developed for this study (Chapter B), with the bottom two layers of the framework combined into a single model layer in the LACPGM. Chronostratigraphic-unit layering provides a more realistic representation of the geologic structure, the distribution of lithologic facies, and aquifer architecture, which improves our ability to simulate the movement of groundwater in a complex aquifer system. 
The Reichard and others (2003) transient model runtime (1971 to 2000) was extended to 2015 in the LACPGM. Initial conditions were simulated using 1971 water levels interpolated across the study area. The LACPGM is a transient model with 180 quarterly stress periods. Areal recharge in LACPGM is based on the precipitation-runoff model from Hevesi and Johnson (2016). Geologic and geophysical logs from WRD/USGS monitoring sites were used to determine grain size of the chronostratigraphic units. Grain sizes were used to help determine initial horizontal hydraulic conductivity and were also used as part of the calibration process. Development of the LACPGM required compiling data to define boundary conditions, pumpage, injection, and water spreading. Water-level data were compiled from monitoring wells, including $57 \mathrm{WRD/USGS}$ multiple-well monitoring sites, multi-completion monitoring sites from the Orange County Water District, and long-screened monitoring wells. The LACPGM was calibrated to monitoring-well water levels, mostly in the Central and West Coast Basins, using PEST parameter estimation software (Doherty, 2010).

The calibrated model was used to analyze groundwater budgets for subareas within the study area. The Montebello Forebay had the highest average inflows of any subarea within the study area, including 122,700 acre-ft/year from water spreading and 36,300 acre-ft/year of underflow through the Whittier Narrows from 1971 to 2015. Inflows also were high into the Orange County Central subarea, averaging 39,100 acre-ft/year from areas of Orange County Basin to the east of the General Head Boundary (GHB). The West Coast Basin had substantial recharge, with an average 27,300 acre-ft/year of injection and 12,100 acre-ft/year of areal recharge from 1971 to 2015. Subareas with high discharge (pumpage) include the Central Basin Pressure Area, West Coast Basin, Orange County Central, and the Montebello Forebay, averaged about $130,000,50,000,48,000$, and 45,000 acre-ft/year from 1971 to 2015 , respectively. Most of the flow between subareas occurred in northern subareas of the model area, with a north to south flow direction. Flow from the Montebello Forebay to the Central Basin Pressure Area averaged 115,800 acre-ft/year, and flow from the Los Angeles Forebay (non-WRD) to the Los Angeles Forebay (WRD) averaged about 9,200 acre-ft/year from 1971 to 2015. Only 4,500 acre-ft/year flowed from the Central Basin Pressure Area (WRD) into the West Coast Basin subarea, due to flow being partially restricted by the Newport-Inglewood fault zone and a smaller hydraulic gradient between the Central and West Coast Basins subareas.

The LACPGM was used to predict water levels resulting from six future water-management scenarios: base case wet and dry scenarios, increased pumpage wet and dry scenarios, and optimized replenishment wet and dry scenarios. Model scenarios used data from selected wet and dry periods during the LACPGM runtime of 1971 to 2015. The model scenarios simulated expected future pumping rates and estimated increases in water spreading and injection needed to maintain water levels. Results of model scenarios showed that additional water spreading and injection had a limited effect on reducing drawdowns at production wells that are far away from existing recharge facilities and was unable to curtail large drawdowns in the northeastern and eastern Central Basin and eastern West Coast Basin subareas. Large drawdowns generally occurred in the upper (aquifer systems above Bent Spring) and lower (aquifer systems below and including Bent Spring) aquifer systems in the Central Basin, with more drawdown occurring in the lower aquifer system. In the West Coast Basin subarea, large drawdowns generally occurred in the lower aquifer systems. To mitigate the impacts of these larger drawdowns that are distal to the existing recharge facilities, new recharge facilities closer to the pumping centers could be constructed, or other measures could be applied to reduce overall pumping, in these high-drawdown areas. 


\section{References Cited}

Doherty, J.E., 2010, PEST, Model-independent parameter estimation, User manual, (5th ed.) (and addendum to the PEST manual): Watermark Numerical Computing, 336 p.

Harbaugh, A.W., 2005, MODFLOW-2005-The U.S. Geological Survey Modular Ground-Water Model-The Ground-Water Flow Process: U.S. Geological Survey Techniques and Methods 6-A16, https://doi.org/10.3133/tm6A16.

Hevesi, J.A., and Johnson, T.D., 2016, Estimating spatially and temporally varying recharge and runoff from precipitation and urban irrigation in the Los Angeles Basin, California: U.S. Geological Survey Scientific Investigations Report 2016-5068, 192 p., https://doi.org/10.3133/sir20165068.

Hsieh, P.A., and Freckleton, J.R., 1993, Documentation of a computer program to simulate horizontal-flow barriers using the U.S. Geological Survey's modular three-dimensional finite difference ground-water flow model: U.S. Geological Survey Open-File Report 92-477, 32 p.

Konikow, L.F., Hornberger, G.Z., Halford, K.J., and Hanson, R.T., 2009, Revised multi-node well (MNW2) package for MODFLOW ground-water flow model: U.S. Geological Survey Techniques and Methods 6-A30, 67 p., https://doi.org/10.3133/tm6A30.

McDonald, M.G., and Harbaugh, A.W., 1988, A Modular Three-dimensional Finite-Difference Ground-Water Flow Model: U.S. Geological Survey Techniques of Water-Resources Investigations 6-A1, 586 p., https://doi.org/10.3133/twri06A1.

Niswonger, R.G., Panday, S., and Ibaraki, M., 2011, MODFLOW-NWT, A Newton formulation for MODFLOW-2005: U.S. Geological Survey Techniques and Methods 6-A37, 44 p., https://doi.org/10.3133/tm6A37.

Panday, S., Langevin, C.D., Niswonger, R.G., Ibaraki, M., and Hughes, J.D., 2013, MODFLOW-USG version 1 - An unstructured grid version of MODFLOW for simulating groundwater flow and tightly coupled processes using a control volume finite-difference formulation: U.S. Geological Survey Techniques and Methods 6-A45, 66 p., https://doi.org/10.3133/tm6A45.
Paulinski, S.R., Martin, P., Martin, D.J., Johnson, T.A., and Faunt, C.C., 2021, MODFLOW-USG model used to evaluate water management issues in the Los Angeles Coastal Plain, California: U.S. Geological Survey Data Release, https://doi.org/10.5066/P9H15ZAX.

Ponti, D.J., Ehman, K.D., Edwards, B.D., Tinsley, J.C., III, Hildenbrand, T., Hillhouse, J.W., Hanson, R.T., McDougall, K., Powell, C.L., II, Wan, E., Land, M., Mahan, S., and Sarna-Wojcicki, A.M., 2007, A 3-dimensional model of water-bearing sequences in the Dominguez Gap Region, Long Beach, California: U.S. Geological Survey Open-File Report 2007-1013, 34 p., https://doi.org/10.3133/ofr20071013.

Reichard, E.G., Land, M., Crawford, S.M., Johnson, T., Everett, R.R., Kulshan, T.V., Ponti, D.J., Halford, K.J., Johnson, T.A., Paybins, K.S., and Nishikawa, T., 2003, Geohydrology, geochemistry, and ground-water simulation-optimization of the Central and West Coast Basins, Los Angeles, County, California: U.S. Geological Survey Water-Resources Investigations Report 03-4065, 184 p.

San Gabriel River Watermaster, 1997, Thirty-Third Annual Report, for 1995-96: Glendale, California, 46 p.

Van Wagoner, J.C., Mitchum, R.M., Campion, K.M., and Rahmanian, V.D., 1990, Siliciclastic sequence stratigraphy in well logs, cores, and outcropsConcepts for high-resolution correlation of time and facies: American Association of Petroleum Geologists Methods in Exploration Series, no. 7, 55 p., https://doi.org/10.1306/Mth7510.

Water Replenishment District of Southern California, 2016, Groundwater Basins Master Plan: CH2M HILL, Engineers, Inc., Los Angeles, California, 547 p.

Water Replenishment District of Southern California, 2017, Cost of service report: Water Replenishment District of Southern California, Lakewood, California, 96 p.

Water Replenishment District of Southern California, 2018, Engineering survey and report: Water Replenishment District of Southern California, Lakewood, California, 82 p. 


\title{
Appendix 1. The Use of Water-Quality Data to Help Identify Chronostratigraphic Unit Boundaries, Sediment Sources, Sediment Facies, Water Sources, and Model Zones
}

\author{
By Peter Martin, Michael Land, and Roy A. Schroeder
}

Water-quality data were used in this study to help identify chronostratigraphic unit boundaries, sediment sources, sediment facies, water sources, and model zones. Background information on the water-quality data or parameters used for this study and how they were applied are discussed in the following sections.

\section{Data Compilation}

The water-quality data used for this study were compiled from historical data stored on the USGS National Water Information System (NWIS, U.S. Geological Survey, 2016). Most of these data were collected and analyzed as part of an ongoing cooperative study between the USGS and the Water Replenishment District of Southern California (WRD) to examine groundwater resources in the Central and West Coast Basins in Los Angeles County, California (Land and others, 2002; Reichard and others, 2003; Land and others, 2004). Most of these water-quality samples were collected from a network of multiple-well monitoring sites constructed in cooperation with WRD (fig. 1.1, tables 1.1, 1.2). These multiple-well monitoring sites were mostly in the Central and
West Coast Basins, with one well, 5S/12W-1C3-9 (Seal Beach 1), in the Orange County Basin. Wells identified in figure 1.1 show only the section and sequence number from the State Well Number listed in table 1.1. These sites consist of two to nine nested wells isolated from one another in the borehole by a low-permeability grout. A detailed description of the construction of a typical USGS multiple-well monitoring site is presented in Land and others (2002). Additional data, from production wells in the Los Angeles and Orange County Basins (fig. 1.1, tables 1.1, 1.2), were collected for the Coastal Los Angeles Basin Study of the Statewide Basin Assessment Project of the Groundwater Ambient Monitoring and Assessment (GAMA) Program (Mathany and others, 2008). Data collection procedures, sample handling, preservation, analysis, and quality assurance are presented in Land and others $(2002,2004)$ for the multiple-well monitoring sites and in Mathany and others (2008) for the GAMA data. Water-quality data collected by the USGS and used for this study are stored in the NWIS and can be accessed by the public using the 15-digit USGS station identification (ID) numbers in table 1.1. Selected water-quality data were also compiled from the WRD (Water Replenishment District of Southern California, 2017). 


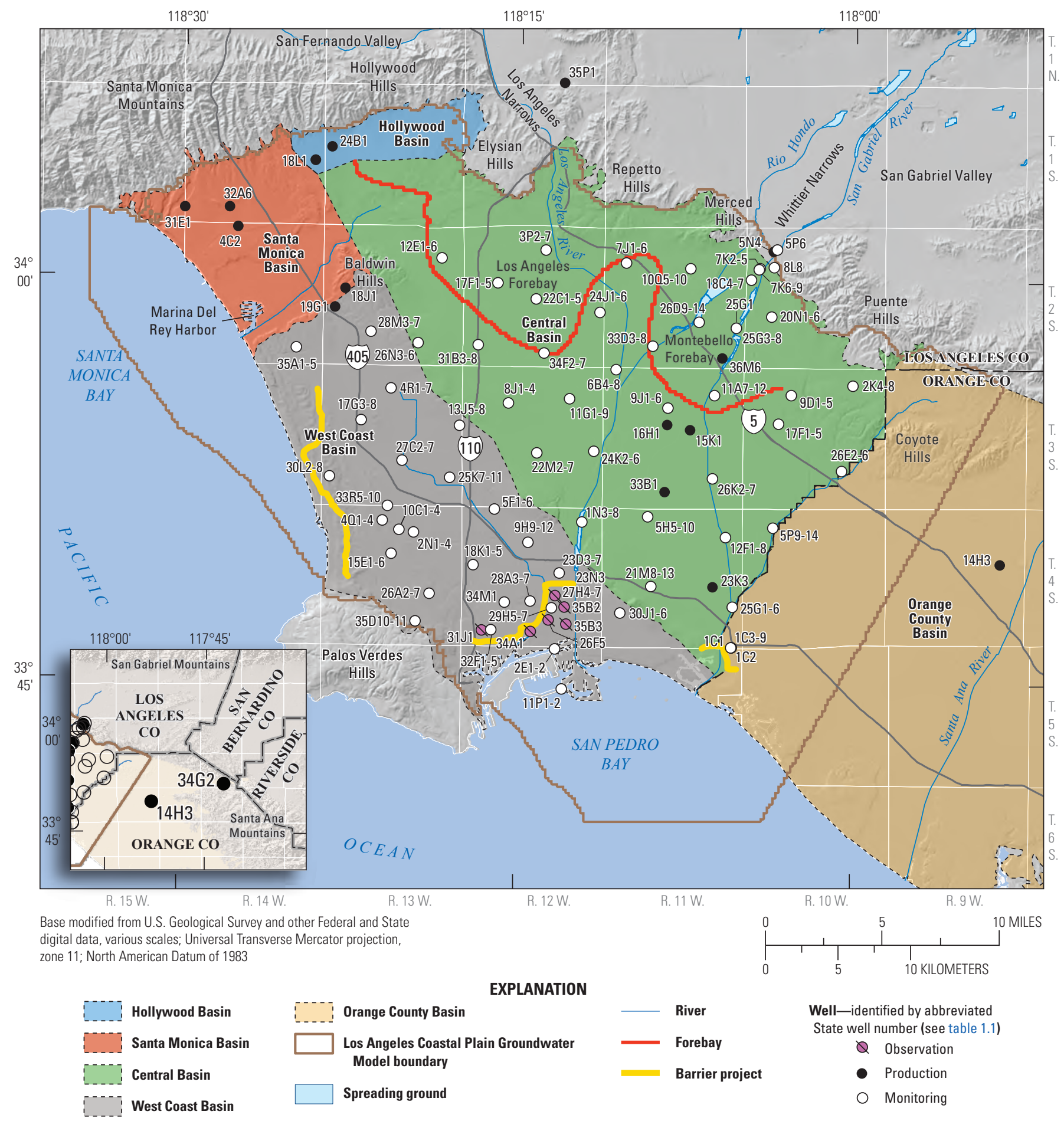

Figure 1.1. Locations of the multiple-well monitoring sites, observation wells, and production wells with water-quality data used for this study, Los Angeles and Orange Counties, California. 
Table 1.1. Site identification, well-construction, water-level, and chronostratigraphic unit information for wells used in this study, Los Angeles and Or

[USGS, U.S. Geological Survey; ft, foot; LSD, land surface datum; mm/dd/yyyy, month/day/year; NAVD 88, North American Vertical Datum of 1988; n.a., not assigned; -, not Fernando Valley; SGV, San Gabriel Valley; SMB, Santa Monica Basin; W, Whittier area. Well type: multi., multiple well; obs., observation; prod., production. Well data: wl, wa

\begin{tabular}{|c|c|c|c|c|c|c|c|}
\hline $\begin{array}{l}\text { State well } \\
\text { number }\end{array}$ & $\begin{array}{c}\text { State well } \\
\text { number } \\
\text { (abbreviated) }\end{array}$ & USGS site number & Local well name & $\begin{array}{c}\text { Well } \\
\text { location }\end{array}$ & $\begin{array}{l}\text { Well } \\
\text { type }\end{array}$ & $\begin{array}{l}\text { Well } \\
\text { data }\end{array}$ & $\begin{array}{c}\text { Altitude of LSD } \\
\text { (ft above NAVD 88) }\end{array}$ \\
\hline 1N/13W-35P1 & $35 \mathrm{P} 1$ & 340700118130001 & DS_WATERS & SFV & prod. & wq & 494 \\
\hline 1S/13W-15H1 & $15 \mathrm{H} 1$ & n.a. & $2771 \mathrm{I}$ & LAF & obs. & wl & 352 \\
\hline 1S/13W-15R2 & $15 \mathrm{R} 2$ & n.a. & $2772 \mathrm{E}$ & LAF & obs. & wl & 321 \\
\hline $1 \mathrm{~S} / 13 \mathrm{~W}-22 \mathrm{R} 1$ & 22R1 & n.a. & 2773 & LAF & prod. & wl & 279 \\
\hline 1S/13W-33A1 & $33 \mathrm{~A} 1$ & n.a. & 2765 & LAF & prod. & wl & 260 \\
\hline 1S/14W-14E1 & $14 \mathrm{E} 1$ & n.a. & $2671 \mathrm{~A}$ & HB & prod. & wl & 281 \\
\hline 1S/14W-18L1 & $18 \mathrm{~L} 1$ & 340400118230001 & BH_2 & HB & prod. & wq & 235 \\
\hline 1S/15W-24B1 & 24B1 & 340400118240001 & BH_5 & HB & prod. & wq & 268 \\
\hline 1S/15W-31E1 & $31 \mathrm{E} 1$ & 340235118295901 & SM 1 (2505) & SMB & prod. & wl, wq & 313 \\
\hline $1 \mathrm{~S} / 15 \mathrm{~W}-32 \mathrm{~A} 5$ & $32 \mathrm{~A} 5$ & 340238118272501 & $2535 \mathrm{~J}$ & SMB & prod. & wl & 239 \\
\hline $1 \mathrm{~S} / 15 \mathrm{~W}-32 \mathrm{~A} 6$ & $32 \mathrm{~A} 6$ & 340200118270001 & SM Arcadia_5 & SMB & prod. & wq & 243 \\
\hline 2S/11W-5N4 & $5 \mathrm{~N} 4$ & 340112118033701 & Whittier_14 & MF & prod. & wq & 202 \\
\hline $2 \mathrm{~S} / 11 \mathrm{~W}-5 \mathrm{P} 6$ & $5 \mathrm{P} 6$ & 340112118032601 & Whittier Narrows1_1 & SGV & multi. & wq & 215 \\
\hline $2 \mathrm{~S} / 11 \mathrm{~W}-5 \mathrm{P} 7$ & $5 \mathrm{P} 7$ & 340112118032602 & Whittier Narrows1_2 & SGV & multi. & wq & 215 \\
\hline $2 \mathrm{~S} / 11 \mathrm{~W}-5 \mathrm{P} 8$ & $5 \mathrm{P} 8$ & 340112118032603 & Whittier Narrows1_3 & SGV & multi. & wq & 215 \\
\hline $2 \mathrm{~S} / 11 \mathrm{~W}-5 \mathrm{P} 9$ & $5 \mathrm{P} 9$ & 340112118032604 & Whittier Narrows1_4 & SGV & multi. & wq & 215 \\
\hline 2S/11W-5P10 & $5 \mathrm{P} 10$ & 340112118032605 & Whittier Narrows1_5 & SGV & multi. & wq & 215 \\
\hline 2S/11W-5P11 & $5 \mathrm{P} 11$ & 340112118032606 & Whittier Narrows1_6 & SGV & multi. & wq & 215 \\
\hline 2S/11W-5P12 & 5P12 & 340112118032607 & Whittier Narrows1_7 & SGV & multi. & wq & 215 \\
\hline 2S/11W-5P13 & $5 \mathrm{P} 13$ & 340112118032608 & Whittier Narrows1_8 & SGV & multi. & wq & 215 \\
\hline 2S/11W-5P14 & $5 \mathrm{P} 14$ & 340112118032609 & Whittier Narrows1_9 & SGV & multi. & wq & 215 \\
\hline $2 \mathrm{~S} / 11 \mathrm{~W}-6 \mathrm{G} 2$ & $6 \mathrm{G} 2$ & n.a. & $2927 \mathrm{~A}$ & SGV & prod. & wl & 201 \\
\hline 2S/11W-7K2 & $7 \mathrm{~K} 2$ & 340030118041201 & Pico Rivera3_1 & MF & multi. & wq & 191 \\
\hline $2 \mathrm{~S} / 11 \mathrm{~W}-7 \mathrm{~K} 3$ & $7 \mathrm{~K} 3$ & 340030118041202 & Pico Rivera3_2 & MF & multi. & wq & 191 \\
\hline $2 \mathrm{~S} / 11 \mathrm{~W}-7 \mathrm{~K} 4$ & $7 \mathrm{~K} 4$ & 340030118041203 & Pico Rivera3_3 & MF & multi. & wq & 191 \\
\hline 2S/11W-7K5 & $7 \mathrm{~K} 5$ & 340030118041204 & Pico Rivera3_4 & MF & multi. & wq & 191 \\
\hline 2S/11W-7K6 & $7 \mathrm{~K} 6$ & 340027118041501 & Pico Rivera4_1 & $\mathrm{MF}$ & multi. & wq & 192 \\
\hline $2 \mathrm{~S} / 11 \mathrm{~W}-7 \mathrm{~K} 7$ & $7 \mathrm{~K} 7$ & 340027118041502 & Pico Rivera4_2 & MF & multi. & wq & 192 \\
\hline $2 \mathrm{~S} / 11 \mathrm{~W}-7 \mathrm{~K} 8$ & $7 \mathrm{~K} 8$ & 340027118041503 & Pico Rivera4_3 & MF & multi. & wq & 192 \\
\hline $2 \mathrm{~S} / 11 \mathrm{~W}-7 \mathrm{~K} 9$ & $7 \mathrm{~K} 9$ & 340027118041504 & Pico Rivera4_4 & MF & multi. & wq & 192 \\
\hline 2S/11W-8L8 & $8 \mathrm{~L} 8$ & 340033118033401 & Whittier Narrows2_1 & $\mathrm{MF}$ & multi. & wq & 209 \\
\hline 2S/11W-8L9 & $8 \mathrm{~L} 9$ & 340033118033402 & Whittier Narrows2_2 & $\mathrm{MF}$ & multi. & wq & 209 \\
\hline 2S/11W-8L10 & $8 \mathrm{~L} 10$ & 340033118033403 & Whittier Narrows2_3 & MF & multi. & wq & 209 \\
\hline 2S/11W-8L11 & 8L11 & 340033118033404 & Whittier Narrows2_4 & MF & multi. & wq & 209 \\
\hline 2S/11W-8L12 & $8 \mathrm{~L} 12$ & 340033118033405 & Whittier Narrows2_5 & MF & multi. & wq & 209 \\
\hline 2S/11W-8L13 & $8 \mathrm{~L} 13$ & 340033118033406 & Whittier Narrows2_6 & MF & multi. & wq & 209 \\
\hline 2S/11W-8L14 & $8 \mathrm{~L} 14$ & 340033118033407 & Whittier Narrows2_7 & MF & multi. & wq & 209 \\
\hline 2S/11W-8L15 & $8 \mathrm{~L} 15$ & 340033118033408 & Whittier Narrows2_8 & $\mathrm{MF}$ & multi. & wq & 209 \\
\hline 2S/11W-8L16 & 8L16 & 340033118033409 & Whittier Narrows2_9 & MF & multi. & wq & 209 \\
\hline $2 \mathrm{~S} / 11 \mathrm{~W}-18 \mathrm{C} 4$ & $18 \mathrm{C} 4$ & 340005118043301 & Pico Rivera1_1 & MF & multi. & wq & 183 \\
\hline $2 \mathrm{~S} / 11 \mathrm{~W}-18 \mathrm{C} 5$ & $18 \mathrm{C} 5$ & 340005118043302 & Pico Rivera1_2 & MF & multi. & wq & 183 \\
\hline
\end{tabular}


ange Counties, California.

available. Well location: CB, Central Basin Pressure Area; HB, Hollywood Basin; LAF, Los Angeles Forebay; MF, Montebello Forebay; OCB, Orange County Basin; SFV, San er level; wq, water quality]

\begin{tabular}{|c|c|c|c|c|c|c|}
\hline $\begin{array}{l}\text { Well depth } \\
\text { (ft below } \\
\text { LSD) }\end{array}$ & $\begin{array}{c}\text { Depth to top } \\
\text { perforation } \\
\text { (ft below LSD) }\end{array}$ & $\begin{array}{c}\text { Depth to bottom } \\
\text { perforation } \\
\text { (ft below LSD) }\end{array}$ & $\begin{array}{c}\text { Number of } \\
\text { perforated } \\
\text { intervals }\end{array}$ & $\begin{array}{c}\text { Date, water } \\
\text { level measured } \\
\text { (mm/dd/yyyy) }\end{array}$ & $\begin{array}{c}\text { Water-level } \\
\text { elevation } \\
\text { (ft above NAVD 88) }\end{array}$ & Chronostratigraphic unit \\
\hline 300 & 62 & 300 & 1 & - & - & n.a. \\
\hline 76 & - & - & - & $01 / 04 / 2010$ & 298.2 & Mesa \\
\hline- & 20 & 40 & 1 & 01/04/2010 & 288.6 & Mesa \\
\hline - & 33 & 99 & 1 & $04 / 14 / 1978$ & 263.5 & Mesa \\
\hline- & 87 & 254 & 1 & 03/13/1979 & 149.9 & Mesa \\
\hline - & 1 & 54 & 1 & $07 / 29 / 2009$ & 263.4 & Mesa \\
\hline 740 & 398 & 730 & 4 & - & - & Upper Wilmington A \\
\hline 665 & 360 & 630 & 3 & - & - & Pacific \\
\hline 282 & 151 & 250 & 1 & $04 / 27 / 2009$ & 112.7 & Pacific \\
\hline 218 & 85 & 218 & 1 & $04 / 27 / 2009$ & 211.2 & Mesa \\
\hline 250 & 120 & 220 & 1 & - & - & Mesa \\
\hline 414 & 183 & 386 & 3 & - & - & Mesa \\
\hline 808 & 749 & 769 & 1 & $09 / 17 / 2014$ & 146.8 & Long Beach BC \\
\hline 808 & 609 & 629 & 1 & $09 / 17 / 2014$ & 149.5 & Long Beach A \\
\hline 808 & 462 & 482 & 1 & $09 / 17 / 2014$ & 153.0 & Lower Wilmington \\
\hline 808 & 392 & 402 & 1 & $09 / 17 / 2014$ & 160.8 & Upper Wilmington B \\
\hline 808 & 334 & 344 & 1 & $09 / 17 / 2014$ & 161.6 & Upper Wilmington B \\
\hline 808 & 272 & 282 & 1 & $09 / 17 / 2014$ & 163.2 & Upper Wilmington A \\
\hline 808 & 233 & 243 & 1 & $09 / 17 / 2014$ & 163.3 & Upper Wilmington A \\
\hline 808 & 163 & 173 & 1 & $09 / 17 / 2014$ & 163.5 & Mesa \\
\hline 808 & 95 & 105 & 1 & $09 / 17 / 2014$ & 165.3 & Dominguez \\
\hline- & 15 & 44 & 1 & $10 / 24 / 2014$ & 173.7 & Mesa \\
\hline 735 & 680 & 735 & 1 & $06 / 27 / 2016$ & 132.1 & Long Beach C \\
\hline 620 & 530 & 620 & 1 & $06 / 27 / 2016$ & 132.9 & Long Beach C \\
\hline 330 & 270 & 330 & 1 & $06 / 27 / 2016$ & 114.9 & Long Beach A \\
\hline 130 & 100 & 130 & 1 & $06 / 27 / 2016$ & 134.1 & Mesa \\
\hline 780 & 750 & 780 & 1 & 07/12/2016 & 127.5 & Long Beach C \\
\hline 680 & 590 & 680 & 1 & 07/12/2016 & 128.7 & Long Beach C \\
\hline 310 & 260 & 310 & 1 & 07/12/2016 & 110.7 & Long Beach A \\
\hline 130 & 110 & 130 & 1 & 07/12/2016 & 129.8 & Mesa \\
\hline 718 & 659 & 678 & 1 & 09/18/2014 & -18.4 & "Repetto" \\
\hline 718 & 579 & 598 & 1 & 09/18/2014 & -18.3 & "Repetto" \\
\hline 718 & 469 & 488 & 1 & 09/18/2014 & -17.7 & "Repetto" \\
\hline 718 & 418 & 428 & 1 & 09/18/2014 & -10.8 & "Repetto" \\
\hline 718 & 328 & 338 & 1 & 09/18/2014 & 82.4 & Long Beach C \\
\hline 718 & 263 & 273 & 1 & 09/18/2014 & 129.0 & Long Beach B \\
\hline 718 & 213 & 223 & 1 & 09/18/2014 & 129.9 & Pacific \\
\hline 718 & 135 & 145 & 1 & 09/18/2014 & 132.8 & Mesa \\
\hline 718 & 90 & 100 & 1 & 09/18/2014 & 151.9 & Mesa \\
\hline 900 & 860 & 900 & 1 & 09/17/2014 & 104.1 & Long Beach C \\
\hline 480 & 460 & 480 & 1 & $09 / 17 / 2014$ & 73.6 & Long Beach B \\
\hline
\end{tabular}


Table 1.1. Site identification, well-construction, water-level, and chronostratigraphic unit information for wells used in this study, Los Angeles and Or

[USGS, U.S. Geological Survey; ft, foot; LSD, land surface datum; mm/dd/yyyy, month/day/year; NAVD 88, North American Vertical Datum of 1988; n.a., not assigned; -, not Fernando Valley; SGV, San Gabriel Valley; SMB, Santa Monica Basin; W, Whittier area. Well type: multi., multiple well; obs., observation; prod., production. Well data: wl, wa

\begin{tabular}{|c|c|c|c|c|c|c|c|}
\hline $\begin{array}{l}\text { State well } \\
\text { number }\end{array}$ & $\begin{array}{c}\text { State well } \\
\text { number } \\
\text { (abbreviated) }\end{array}$ & USGS site number & Local well name & $\begin{array}{l}\text { Well } \\
\text { location }\end{array}$ & $\begin{array}{l}\text { Well } \\
\text { type }\end{array}$ & $\begin{array}{l}\text { Well } \\
\text { data }\end{array}$ & $\begin{array}{c}\text { Altitude of LSD } \\
\text { (ft above NAVD 88) }\end{array}$ \\
\hline $2 \mathrm{~S} / 11 \mathrm{~W}-18 \mathrm{C} 6$ & $18 \mathrm{C} 6$ & 340005118043303 & Pico Rivera1_3 & MF & multi. & wq & 183 \\
\hline $2 \mathrm{~S} / 11 \mathrm{~W}-18 \mathrm{C} 7$ & $18 \mathrm{C} 7$ & 340005118043304 & Pico Rivera1_4 & MF & multi. & wq & 183 \\
\hline $2 \mathrm{~S} / 11 \mathrm{~W}-20 \mathrm{~N} 1$ & $20 \mathrm{~N} 1$ & 335842118034101 & Whittier2_1 & $\mathrm{MF}$ & multi. & wq & 169 \\
\hline $2 \mathrm{~S} / 11 \mathrm{~W}-20 \mathrm{~N} 2$ & $20 \mathrm{~N} 2$ & 335842118034102 & Whittier2_2 & MF & multi. & wq & 169 \\
\hline $2 \mathrm{~S} / 11 \mathrm{~W}-20 \mathrm{~N} 3$ & $20 \mathrm{~N} 3$ & 335842118034103 & Whittier2_3 & MF & multi. & wq & 169 \\
\hline $2 \mathrm{~S} / 11 \mathrm{~W}-20 \mathrm{~N} 4$ & $20 \mathrm{~N} 4$ & 335842118034104 & Whittier2_4 & MF & multi. & wq & 169 \\
\hline 2S/11W-20N5 & $20 \mathrm{~N} 5$ & 335842118034105 & Whittier2_5 & MF & multi. & wq & 169 \\
\hline 2S/11W-20N6 & $20 \mathrm{~N} 6$ & 335842118034106 & Whittier2_6 & MF & multi. & wq & 169 \\
\hline 2S/11W-33E2 & $33 \mathrm{E} 2$ & n.a. & $1654 \mathrm{H}$ & W & prod. & wl & 151 \\
\hline 2S/12W-7J1 & $7 \mathrm{~J} 1$ & 340040118100901 & Commerce1_1 & $\mathrm{CB}$ & multi. & wq & 164 \\
\hline $2 \mathrm{~S} / 12 \mathrm{~W}-7 \mathrm{~J} 2$ & $7 \mathrm{~J} 2$ & 340040118100902 & Commerce1_2 & $\mathrm{CB}$ & multi. & wq & 164 \\
\hline $2 \mathrm{~S} / 12 \mathrm{~W}-7 \mathrm{~J} 3$ & $7 \mathrm{~J} 3$ & 340040118100903 & Commerce1_3 & $\mathrm{CB}$ & multi. & wq & 164 \\
\hline $2 \mathrm{~S} / 12 \mathrm{~W}-7 \mathrm{~J} 4$ & $7 \mathrm{~J} 4$ & 340040118100904 & Commerce1_4 & $\mathrm{CB}$ & multi. & wq & 164 \\
\hline $2 \mathrm{~S} / 12 \mathrm{~W}-7 \mathrm{~J} 5$ & $7 \mathrm{~J} 5$ & 340040118100905 & Commerce1_5 & $\mathrm{CB}$ & multi. & wq & 164 \\
\hline $2 \mathrm{~S} / 12 \mathrm{~W}-7 \mathrm{~J} 6$ & $7 \mathrm{~J} 6$ & 340040118100906 & Commerce1_6 & $\mathrm{CB}$ & multi. & wq & 164 \\
\hline 2S/12W-10Q5 & 10Q5 & 340027118071901 & Montebello1_1 & MF & multi. & wq & 192 \\
\hline $2 \mathrm{~S} / 12 \mathrm{~W}-10 \mathrm{Q} 6$ & 10Q6 & 340027118071902 & Montebello1_2 & MF & multi. & wq & 192 \\
\hline 2S/12W-10Q7 & 10Q7 & 340027118071903 & Montebello1_3 & MF & multi. & wq & 192 \\
\hline $2 \mathrm{~S} / 12 \mathrm{~W}-10 \mathrm{Q} 8$ & 10Q8 & 340027118071904 & Montebello1_4 & MF & multi. & wq & 192 \\
\hline 2S/12W-10Q9 & 10Q9 & 340027118071905 & Montebello1_5 & MF & multi. & wq & 192 \\
\hline 2S/12W-10Q10 & 10Q10 & 340027118071906 & Montebello1_6 & MF & multi. & wq & 192 \\
\hline $2 \mathrm{~S} / 12 \mathrm{~W}-24 \mathrm{M} 3$ & $24 \mathrm{M} 3$ & n.a. & $1601 P$ & MF & prod. & wl & 162 \\
\hline $2 \mathrm{~S} / 12 \mathrm{~W}-25 \mathrm{G} 1$ & $25 \mathrm{G} 1$ & 335817118051301 & Pico Rivera W12 & MF & prod. & wq & 157 \\
\hline $2 \mathrm{~S} / 12 \mathrm{~W}-25 \mathrm{G} 3$ & $25 \mathrm{G} 3$ & 335818118051201 & Pico Rivera2_1 & MF & multi. & wq & 152 \\
\hline $2 \mathrm{~S} / 12 \mathrm{~W}-25 \mathrm{G} 4$ & $25 \mathrm{G} 4$ & 335818118051202 & Pico Rivera2_2 & $\mathrm{MF}$ & multi. & wq & 152 \\
\hline $2 \mathrm{~S} / 12 \mathrm{~W}-25 \mathrm{G} 5$ & $25 \mathrm{G} 5$ & 335818118051203 & Pico Rivera2_3 & MF & multi. & wq & 152 \\
\hline $2 \mathrm{~S} / 12 \mathrm{~W}-25 \mathrm{G} 6$ & $25 \mathrm{G} 6$ & 335818118051204 & Pico Rivera2_4 & MF & multi. & wq & 152 \\
\hline $2 \mathrm{~S} / 12 \mathrm{~W}-25 \mathrm{G} 7$ & $25 \mathrm{G} 7$ & 335818118051205 & Pico Rivera2_5 & MF & multi. & wq & 152 \\
\hline $2 \mathrm{~S} / 12 \mathrm{~W}-25 \mathrm{G} 8$ & $25 \mathrm{G} 8$ & 335818118051206 & Pico Rivera2_6 & MF & multi. & wq & 152 \\
\hline $2 \mathrm{~S} / 12 \mathrm{~W}-26 \mathrm{D} 9$ & 26D9 & 335829118065201 & Rio Hondo1_1 & MF & multi. & wq & 147 \\
\hline 2S/12W-26D10 & $26 \mathrm{D} 10$ & 335829118065202 & Rio Hondo1_2 & MF & multi. & wq & 147 \\
\hline 2S/12W-26D11 & 26D11 & 335829118065203 & Rio Hondo1_3 & MF & multi. & wq & 147 \\
\hline $2 \mathrm{~S} / 12 \mathrm{~W}-26 \mathrm{D} 12$ & $26 \mathrm{D} 12$ & 335829118065204 & Rio Hondo1_4 & MF & multi. & wq & 147 \\
\hline $2 \mathrm{~S} / 12 \mathrm{~W}-26 \mathrm{D} 13$ & $26 \mathrm{D} 13$ & 335829118065205 & Rio Hondo1_5 & MF & multi. & wq & 147 \\
\hline 2S/12W-26D14 & $26 \mathrm{D} 14$ & 335829118065206 & Rio Hondo1_6 & $\mathrm{MF}$ & multi. & wq & 147 \\
\hline $2 \mathrm{~S} / 12 \mathrm{~W}-33 \mathrm{D} 3$ & $33 \mathrm{D} 3$ & 335735118085801 & Bell Gardens1_1 & MF & multi. & wq & 120 \\
\hline $2 \mathrm{~S} / 12 \mathrm{~W}-33 \mathrm{D} 4$ & $33 \mathrm{D} 4$ & 335735118085802 & Bell Gardens1_2 & MF & multi. & wq & 120 \\
\hline 2S/12W-33D5 & 33D5 & 335735118085803 & Bell Gardens1_3 & MF & multi. & wq & 120 \\
\hline 2S/12W-33D6 & 33D6 & 335735118085804 & Bell Gardens1_4 & MF & multi. & wq & 120 \\
\hline 2S/12W-33D7 & $33 \mathrm{D} 7$ & 335735118085805 & Bell Gardens1_5 & MF & multi. & wq & 120 \\
\hline $2 \mathrm{~S} / 12 \mathrm{~W}-33 \mathrm{D} 8$ & 33D8 & 335735118085806 & Bell Gardens1_6 & $\mathrm{MF}$ & multi. & wq & 120 \\
\hline
\end{tabular}


ange Counties, California.-Continued

available. Well location: CB, Central Basin Pressure Area; HB, Hollywood Basin; LAF, Los Angeles Forebay; MF, Montebello Forebay; OCB, Orange County Basin; SFV, San er level; wq, water quality]

\begin{tabular}{|c|c|c|c|c|c|c|}
\hline $\begin{array}{l}\text { Well depth } \\
\text { (ft below } \\
\text { LSD) } \\
\end{array}$ & $\begin{array}{l}\text { Depth to top } \\
\text { perforation } \\
\text { (ft below LSD) }\end{array}$ & $\begin{array}{c}\text { Depth to bottom } \\
\text { perforation } \\
\text { (ft below LSD) }\end{array}$ & $\begin{array}{c}\text { Number of } \\
\text { perforated } \\
\text { intervals }\end{array}$ & $\begin{array}{c}\text { Date, water } \\
\text { level measured } \\
\text { (mm/dd/yyyy) }\end{array}$ & $\begin{array}{c}\text { Water-level } \\
\text { elevation } \\
\text { (ft above NAVD 88) } \\
\end{array}$ & Chronostratigraphic u \\
\hline 400 & 380 & 400 & 1 & $09 / 17 / 2014$ & 72.3 & Long Beach A \\
\hline 190 & 170 & 190 & 1 & $09 / 17 / 2014$ & 81.4 & Pacific \\
\hline 1,390 & 1,370 & 1,390 & 1 & $09 / 12 / 2014$ & 69.3 & Long Beach B \\
\hline 1,110 & 1,090 & 1,110 & 1 & $09 / 12 / 2014$ & 69.6 & Long Beach A \\
\hline 675 & 655 & 675 & 1 & $09 / 12 / 2014$ & 55.0 & Upper Wilmington A \\
\hline 445 & 425 & 445 & 1 & $09 / 12 / 2014$ & 55.2 & Harbor \\
\hline 335 & 315 & 335 & 1 & $09 / 12 / 2014$ & 87.0 & Pacific \\
\hline 170 & 150 & 170 & 1 & $09 / 12 / 2014$ & 97.0 & Mesa \\
\hline - & 15 & 296 & 1 & $04 / 20 / 2008$ & 118.1 & Pacific \\
\hline 1,390 & 1,330 & 1,390 & 1 & $09 / 22 / 2014$ & 35.1 & Long Beach C \\
\hline 960 & 940 & 960 & 1 & $09 / 23 / 2014$ & 23.4 & Long Beach A \\
\hline 780 & 760 & 780 & 1 & $09 / 23 / 2014$ & 19.2 & Upper Wilmington B \\
\hline 590 & 570 & 590 & 1 & $09 / 23 / 2014$ & -14.6 & Upper Wilmington A \\
\hline 345 & 325 & 345 & 1 & $09 / 23 / 2014$ & -9.1 & Pacific \\
\hline 225 & 205 & 225 & 1 & $09 / 23 / 2014$ & 36.8 & Mesa \\
\hline 980 & 900 & 960 & 1 & $09 / 22 / 2014$ & 61.6 & Long Beach C \\
\hline 710 & 690 & 710 & 1 & $09 / 22 / 2014$ & 54.7 & Long Beach B \\
\hline 520 & 500 & 520 & 1 & $09 / 22 / 2014$ & 54.2 & Upper Wilmington B \\
\hline 390 & 370 & 390 & 1 & $09 / 22 / 2014$ & 51.9 & Upper Wilmington A \\
\hline 230 & 210 & 230 & 1 & $09 / 22 / 2014$ & 54.7 & Pacific \\
\hline 110 & 90 & 110 & 1 & 09/19/2007 & 91.3 & Mesa \\
\hline - & 154 & 174 & 1 & 10/04/1992 & 112.3 & Mesa \\
\hline 520 & 242 & 446 & 3 & - & - & Mesa \\
\hline 1,200 & 1,180 & 1,200 & 1 & $09 / 15 / 2014$ & 40.6 & Long Beach A \\
\hline 850 & 830 & 850 & 1 & $09 / 15 / 2014$ & 40.2 & Upper Wilmington B \\
\hline 580 & 560 & 580 & 1 & $09 / 15 / 2014$ & 48.8 & Upper Wilmington A \\
\hline 340 & 320 & 340 & 1 & $09 / 15 / 2014$ & 68.1 & Pacific \\
\hline 255 & 235 & 255 & 1 & $09 / 15 / 2014$ & 67.7 & Mesa \\
\hline 120 & 100 & 120 & 1 & $09 / 15 / 2014$ & 74.0 & Dominguez \\
\hline 1,150 & 1,110 & 1,130 & 1 & $09 / 17 / 2014$ & 39.5 & Long Beach A \\
\hline 930 & 910 & 930 & 1 & $09 / 17 / 2014$ & 35.0 & Lower Wilmington \\
\hline 730 & 710 & 730 & 1 & $09 / 17 / 2014$ & 34.2 & Upper Wilmington B \\
\hline 450 & 430 & 450 & 1 & $09 / 17 / 2014$ & 29.2 & Upper Wilmington A \\
\hline 300 & 280 & 300 & 1 & $09 / 17 / 2014$ & 37.7 & Pacific \\
\hline 160 & 140 & 160 & 1 & $09 / 17 / 2014$ & 41.5 & Mesa \\
\hline 1,795 & 1,775 & 1,795 & 1 & $09 / 16 / 2014$ & -11.5 & Lower Wilmington \\
\hline 1,410 & 1,390 & 1,410 & 1 & $09 / 16 / 2014$ & -12.6 & Upper Wilmington A \\
\hline 1,110 & 1,090 & 1,110 & 1 & $09 / 16 / 2014$ & -10.7 & Bent Spring \\
\hline 875 & 855 & 875 & 1 & $09 / 16 / 2014$ & -3.0 & Harbor \\
\hline 575 & 555 & 575 & 1 & $09 / 16 / 2014$ & 1.3 & Pacific \\
\hline 390 & 370 & 390 & 1 & $09 / 16 / 2014$ & 1.0 & Pacific_A \\
\hline
\end{tabular}


Table 1.1. Site identification, well-construction, water-level, and chronostratigraphic unit information for wells used in this study, Los Angeles and Or

[USGS, U.S. Geological Survey; ft, foot; LSD, land surface datum; mm/dd/yyyy, month/day/year; NAVD 88, North American Vertical Datum of 1988; n.a., not assigned; -, not Fernando Valley; SGV, San Gabriel Valley; SMB, Santa Monica Basin; W, Whittier area. Well type: multi., multiple well; obs., observation; prod., production. Well data: wl, wa

\begin{tabular}{|c|c|c|c|c|c|c|c|}
\hline $\begin{array}{l}\text { State well } \\
\text { number }\end{array}$ & $\begin{array}{c}\text { State well } \\
\text { number } \\
\text { (abbreviated) }\end{array}$ & USGS site number & Local well name & $\begin{array}{c}\text { Well } \\
\text { location }\end{array}$ & $\begin{array}{l}\text { Well } \\
\text { type }\end{array}$ & $\begin{array}{l}\text { Well } \\
\text { data }\end{array}$ & $\begin{array}{c}\text { Altitude of LSD } \\
\text { (ft above NAVD 88) }\end{array}$ \\
\hline $2 \mathrm{~S} / 12 \mathrm{~W}-33 \mathrm{~L} 3$ & $33 \mathrm{~L} 3$ & n.a. & $1554 \mathrm{~F}$ & MF & obs. & wl & 118 \\
\hline 2S/12W-36M6 & $36 \mathrm{M} 6$ & 335712118054901 & Pico Rivera W8 & MF & prod. & wq & 140 \\
\hline $2 \mathrm{~S} / 13 \mathrm{~W}-3 \mathrm{P} 2$ & $3 \mathrm{P} 2$ & 340106118134801 & Los Angeles2_1 & LAF & multi. & wq & 223 \\
\hline $2 \mathrm{~S} / 13 \mathrm{~W}-3 \mathrm{P} 3$ & $3 \mathrm{P} 3$ & 340106118134802 & Los Angeles2_2 & LAF & multi. & wq & 223 \\
\hline $2 \mathrm{~S} / 13 \mathrm{~W}-3 \mathrm{P} 4$ & $3 \mathrm{P} 4$ & 340106118134803 & Los Angeles2_3 & LAF & multi. & wq & 223 \\
\hline 2S/13W-3P5 & $3 \mathrm{P} 5$ & 340106118134804 & Los Angeles2_4 & LAF & multi. & wq & 223 \\
\hline 2S/13W-3P6 & $3 \mathrm{P} 6$ & 340106118134805 & Los Angeles2_5 & LAF & multi. & wq & 223 \\
\hline 2S/13W-3P7 & $3 \mathrm{P} 7$ & 340106118134806 & Los Angeles2_6 & LAF & multi. & - & 223 \\
\hline 2S/13W-10A1 & $10 \mathrm{~A} 1$ & n.a. & 2778 & LAF & prod. & wl & 221 \\
\hline $2 \mathrm{~S} / 13 \mathrm{~W}-17 \mathrm{~F} 1$ & $17 \mathrm{~F} 1$ & 335952118155601 & Los Angeles1_1 & LAF & multi. & wq & 177 \\
\hline $2 \mathrm{~S} / 13 \mathrm{~W}-17 \mathrm{~F} 2$ & $17 \mathrm{~F} 2$ & 335952118155602 & Los Angeles1_2 & LAF & multi. & wq & 177 \\
\hline $2 \mathrm{~S} / 13 \mathrm{~W}-17 \mathrm{~F} 3$ & $17 \mathrm{~F} 3$ & 335952118155603 & Los Angeles1_3 & LAF & multi. & wq & 177 \\
\hline $2 \mathrm{~S} / 13 \mathrm{~W}-17 \mathrm{~F} 4$ & $17 \mathrm{~F} 4$ & 335952118155604 & Los Angeles1_4 & LAF & multi. & wq & 177 \\
\hline $2 \mathrm{~S} / 13 \mathrm{~W}-17 \mathrm{~F} 5$ & $17 F 5$ & 335952118155605 & Los Angeles1_5 & LAF & multi. & wq & 177 \\
\hline $2 \mathrm{~S} / 13 \mathrm{~W}-22 \mathrm{C} 1$ & $22 \mathrm{C} 1$ & 335917118141001 & Huntington Park1_1 & LAF & multi. & wq & 180 \\
\hline $2 \mathrm{~S} / 13 \mathrm{~W}-22 \mathrm{C} 2$ & $22 \mathrm{C} 2$ & 335917118141002 & Huntington Park1_2 & LAF & multi. & wq & 180 \\
\hline $2 \mathrm{~S} / 13 \mathrm{~W}-22 \mathrm{C} 3$ & $22 \mathrm{C} 3$ & 335917118141003 & Huntington Park1_3 & LAF & multi. & wq & 180 \\
\hline $2 \mathrm{~S} / 13 \mathrm{~W}-22 \mathrm{C} 4$ & $22 \mathrm{C} 4$ & 335917118141004 & Huntington Park1_4 & LAF & multi. & wq & 180 \\
\hline $2 \mathrm{~S} / 13 \mathrm{~W}-22 \mathrm{C} 5$ & $22 \mathrm{C} 5$ & 335917118141005 & Huntington Park1_5 & LAF & multi. & wq & 180 \\
\hline $2 \mathrm{~S} / 13 \mathrm{~W}-24 \mathrm{~J} 1$ & $24 \mathrm{~J} 1$ & 335849118112201 & Bell1_1 & $\mathrm{CB}$ & multi. & wq & 147 \\
\hline $2 \mathrm{~S} / 13 \mathrm{~W}-24 \mathrm{~J} 2$ & $24 \mathrm{~J} 2$ & 335849118112202 & Bell1_2 & $\mathrm{CB}$ & multi. & wq & 147 \\
\hline $2 \mathrm{~S} / 13 \mathrm{~W}-24 \mathrm{~J} 3$ & $24 \mathrm{~J} 3$ & 335849118112203 & Bell1_3 & $\mathrm{CB}$ & multi. & wq & 147 \\
\hline $2 \mathrm{~S} / 13 \mathrm{~W}-24 \mathrm{~J} 4$ & $24 J 4$ & 335849118112204 & Bell1_4 & $\mathrm{CB}$ & multi. & wq & 147 \\
\hline $2 \mathrm{~S} / 13 \mathrm{~W}-24 \mathrm{~J} 5$ & $24 J 5$ & 335849118112205 & Bell1_5 & $\mathrm{CB}$ & multi. & wq & 147 \\
\hline 2S/13W-24J6 & $24 J 6$ & 335849118112206 & Bell1_6 & $\mathrm{CB}$ & multi. & wq & 147 \\
\hline 2S/13W-31B3 & 31B3 & 335733118164701 & Los Angeles4_1 & $\mathrm{CB}$ & multi. & wq & 141 \\
\hline 2S/13W-31B4 & 31B4 & 335733118164702 & Los Angeles4_2 & $\mathrm{CB}$ & multi. & wq & 141 \\
\hline 2S/13W-31B5 & 31B5 & 335733118164703 & Los Angeles4_3 & $\mathrm{CB}$ & multi. & wq & 141 \\
\hline 2S/13W-31B6 & $31 \mathrm{~B} 6$ & 335733118164704 & Los Angeles4_4 & $\mathrm{CB}$ & multi. & wq & 141 \\
\hline 2S/13W-31B7 & $31 \mathrm{~B} 7$ & 335733118164705 & Los Angeles4_5 & $\mathrm{CB}$ & multi. & wq & 141 \\
\hline 2S/13W-31B8 & $31 \mathrm{~B} 8$ & 335733118164706 & Los Angeles4_6 & $\mathrm{CB}$ & multi. & wq & 141 \\
\hline 2S/13W-32C4 & $32 \mathrm{C} 4$ & n.a. & $1434 \mathrm{~J}$ & $\mathrm{CB}$ & prod. & wl & 132 \\
\hline 2S/13W-34F2 & $34 \mathrm{~F} 2$ & 335716118135101 & South Gate2_1 & LAF & multi. & wq & 122 \\
\hline $2 \mathrm{~S} / 13 \mathrm{~W}-34 \mathrm{~F} 3$ & $34 \mathrm{~F} 3$ & 335716118135102 & South Gate2_2 & LAF & multi. & wq & 122 \\
\hline $2 \mathrm{~S} / 13 \mathrm{~W}-34 \mathrm{~F} 4$ & $34 \mathrm{~F} 4$ & 335716118135103 & South Gate2_3 & LAF & multi. & wq & 122 \\
\hline $2 \mathrm{~S} / 13 \mathrm{~W}-34 \mathrm{~F} 5$ & $34 \mathrm{~F} 5$ & 335716118135104 & South Gate2_4 & LAF & multi. & wq & 122 \\
\hline $2 \mathrm{~S} / 13 \mathrm{~W}-34 \mathrm{~F} 6$ & $34 \mathrm{~F} 6$ & 335716118135105 & South Gate2_5 & LAF & multi. & wq & 122 \\
\hline 2S/13W-34F7 & $34 \mathrm{~F} 7$ & 335716118135106 & South Gate2_6 & LAF & multi. & wq & 122 \\
\hline $2 \mathrm{~S} / 13 \mathrm{~W}-36 \mathrm{~F} 2$ & $36 \mathrm{~F} 2$ & n.a. & $1504 \mathrm{C}$ & $\mathrm{CB}$ & prod. & wl & 124 \\
\hline $2 \mathrm{~S} / 14 \mathrm{~W}-5 \mathrm{D} 8$ & $5 \mathrm{D} 8$ & n.a. & 2626P & $\mathrm{CB}$ & prod. & wl & 79 \\
\hline $2 \mathrm{~S} / 14 \mathrm{~W}-12 \mathrm{E} 1$ & $12 \mathrm{E} 1$ & 340046118182701 & Los Angeles3_1 & LAF & multi. & wq & 147 \\
\hline
\end{tabular}


ange Counties, California.-Continued

available. Well location: CB, Central Basin Pressure Area; HB, Hollywood Basin; LAF, Los Angeles Forebay; MF, Montebello Forebay; OCB, Orange County Basin; SFV, San er level; wq, water quality]

\begin{tabular}{|c|c|c|c|c|c|c|}
\hline $\begin{array}{l}\text { Well depth } \\
\text { (ft below } \\
\text { LSD) }\end{array}$ & $\begin{array}{c}\text { Depth to top } \\
\text { perforation } \\
\text { (ft below LSD) }\end{array}$ & $\begin{array}{c}\text { Depth to bottom } \\
\text { perforation } \\
\text { (ft below LSD) }\end{array}$ & $\begin{array}{c}\text { Number of } \\
\text { perforated } \\
\text { intervals }\end{array}$ & $\begin{array}{c}\text { Date, water } \\
\text { level measured } \\
\text { (mm/dd/yyyy) }\end{array}$ & $\begin{array}{c}\text { Water-level } \\
\text { elevation } \\
\text { (ft above NAVD 88) }\end{array}$ & Chronostratigraphic unit \\
\hline - & 130 & 140 & 1 & $10 / 16 / 2014$ & 37.0 & Mesa \\
\hline 627 & 277 & 584 & 2 & - & - & Pacific \\
\hline 1,370 & 1,330 & 1,370 & 1 & $09 / 18 / 2014$ & 46.4 & Long Beach C \\
\hline 730 & 710 & 730 & 1 & $09 / 18 / 2014$ & -3.6 & Upper Wilmington A \\
\hline 525 & 505 & 525 & 1 & $09 / 18 / 2014$ & -4.1 & Upper Wilmington A \\
\hline 430 & 410 & 430 & 1 & $09 / 18 / 2014$ & -18.0 & Harbor \\
\hline 265 & 245 & 265 & 1 & $09 / 18 / 2014$ & -26.1 & Pacific \\
\hline 155 & 135 & 155 & 1 & $09 / 18 / 2014$ & dry & Mesa \\
\hline 770 & 160 & 645 & 1 & $10 / 16 / 2014$ & -22.4 & Harbor \\
\hline 1,370 & 1,350 & 1,370 & 1 & $09 / 15 / 2014$ & -32.5 & Upper Wilmington B \\
\hline 1,100 & 1,080 & 1,100 & 1 & $09 / 15 / 2014$ & -26.1 & Upper Wilmington A \\
\hline 940 & 920 & 940 & 1 & $09 / 15 / 2014$ & -26.8 & Bent Spring \\
\hline 660 & 640 & 660 & 1 & $09 / 15 / 2014$ & -28.5 & Harbor \\
\hline 370 & 350 & 370 & 1 & $09 / 15 / 2014$ & -17.9 & Pacific_A \\
\hline 910 & 890 & 910 & 1 & $09 / 18 / 2014$ & -34.6 & Bent Spring \\
\hline 710 & 690 & 710 & 1 & $09 / 18 / 2014$ & -38.7 & Harbor \\
\hline 440 & 420 & 440 & 1 & $09 / 18 / 2014$ & -25.4 & Pacific_A \\
\hline 295 & 275 & 295 & 1 & $09 / 18 / 2014$ & 11.5 & Mesa \\
\hline 134 & 114 & 134 & 1 & 09/19/2007 & 48.3 & Dominguez \\
\hline 1,750 & 1,730 & 1,750 & 1 & $09 / 17 / 2014$ & -33.7 & Long Beach B \\
\hline 1,215 & 1,195 & 1,215 & 1 & $09 / 17 / 2014$ & -40.8 & Lower Wilmington \\
\hline 985 & 965 & 985 & 1 & $09 / 17 / 2014$ & -29.1 & Upper Wilmington A \\
\hline 635 & 615 & 635 & 1 & $09 / 17 / 2014$ & -27.7 & Bent Spring \\
\hline 440 & 420 & 440 & 1 & $09 / 17 / 2014$ & -19.7 & Pacific \\
\hline 270 & 250 & 270 & 1 & $09 / 17 / 2014$ & 10.8 & Pacific_A \\
\hline 1,780 & 1,740 & 1,780 & 1 & $09 / 18 / 2014$ & -29.3 & Long Beach A \\
\hline 1,230 & 1,190 & 1,230 & 1 & $09 / 18 / 2014$ & -60.8 & Lower Wilmington \\
\hline 740 & 720 & 740 & 1 & $09 / 18 / 2014$ & -50.2 & Upper Wilmington A \\
\hline 510 & 490 & 510 & 1 & $09 / 18 / 2014$ & -34.6 & Harbor \\
\hline 375 & 355 & 375 & 1 & $09 / 18 / 2014$ & -32.4 & Harbor \\
\hline 255 & 235 & 255 & 1 & $09 / 18 / 2014$ & -17.8 & Pacific \\
\hline - & 604 & 785 & 1 & $01 / 06 / 2010$ & -39.8 & Upper Wilmington A \\
\hline 1,760 & 1,740 & 1,760 & 1 & $09 / 23 / 2014$ & -37.1 & Harbor \\
\hline 1,430 & 1,410 & 1,430 & 1 & $09 / 23 / 2014$ & -36.5 & Harbor \\
\hline 1,082 & 1,062 & 1,082 & 1 & $09 / 23 / 2014$ & -29.9 & Pacific \\
\hline 690 & 670 & 690 & 1 & $09 / 23 / 2014$ & -20.4 & Pacific_A \\
\hline 430 & 410 & 430 & 1 & $09 / 23 / 2014$ & 42.6 & Mesa \\
\hline 225 & 205 & 225 & 1 & $09 / 23 / 2014$ & 48.5 & Dominguez \\
\hline 1,400 & 978 & 1,266 & 1 & $10 / 01 / 1997$ & 18.5 & Harbor \\
\hline - & 70 & 370 & 1 & $09 / 15 / 2009$ & 20.0 & Mesa \\
\hline 1,570 & 1,210 & 1,230 & 1 & $09 / 18 / 2014$ & -19.4 & Lower Wilmington \\
\hline
\end{tabular}


Table 1.1. Site identification, well-construction, water-level, and chronostratigraphic unit information for wells used in this study, Los Angeles and Or

[USGS, U.S. Geological Survey; ft, foot; LSD, land surface datum; mm/dd/yyyy, month/day/year; NAVD 88, North American Vertical Datum of 1988; n.a., not assigned; -, not Fernando Valley; SGV, San Gabriel Valley; SMB, Santa Monica Basin; W, Whittier area. Well type: multi., multiple well; obs., observation; prod., production. Well data: wl, wa

\begin{tabular}{|c|c|c|c|c|c|c|c|}
\hline $\begin{array}{l}\text { State well } \\
\text { number }\end{array}$ & $\begin{array}{c}\text { State well } \\
\text { number } \\
\text { (abbreviated) }\end{array}$ & USGS site number & Local well name & $\begin{array}{c}\text { Well } \\
\text { location }\end{array}$ & $\begin{array}{l}\text { Well } \\
\text { type }\end{array}$ & $\begin{array}{l}\text { Well } \\
\text { data }\end{array}$ & $\begin{array}{c}\text { Altitude of LSD } \\
\text { (ft above NAVD 88) }\end{array}$ \\
\hline 2S/14W-12E2 & $12 \mathrm{E} 2$ & 340046118182702 & Los Angeles3_2 & LAF & multi. & wq & 147 \\
\hline 2S/14W-12E3 & $12 \mathrm{E} 3$ & 340046118182703 & Los Angeles3_3 & LAF & multi. & wq & 147 \\
\hline 2S/14W-12E4 & $12 \mathrm{E} 4$ & 340046118182704 & Los Angeles3_4 & LAF & multi. & wq & 147 \\
\hline 2S/14W-12E5 & $12 \mathrm{E} 5$ & 340046118182705 & Los Angeles3_5 & LAF & multi. & wq & 147 \\
\hline 2S/14W-12E6 & $12 \mathrm{E} 6$ & 340046118182706 & Los Angeles3_6 & LAF & multi. & wq & 147 \\
\hline 2S/14W-14F2 & $14 \mathrm{~F} 2$ & 345947118190401 & 1380 & $\mathrm{CB}$ & prod. & wl & 120 \\
\hline $2 \mathrm{~S} / 14 \mathrm{~W}-18 \mathrm{~J} 1$ & $18 \mathrm{~J} 1$ & 335900118220001 & Holy_Cross_AA & WCB & prod. & wq & 234 \\
\hline 2S/14W-19G1 & 19G1 & 335800118230001 & Hillside_Park_1 & WCB & prod. & wq & 76 \\
\hline $2 \mathrm{~S} / 14 \mathrm{~W}-22 \mathrm{P} 4$ & $22 \mathrm{P} 4$ & n.a. & $1362 \mathrm{P}$ & $\mathrm{CB}$ & prod. & wl & 172 \\
\hline $2 \mathrm{~S} / 14 \mathrm{~W}-26 \mathrm{~N} 3$ & $26 \mathrm{~N} 3$ & 335737118192501 & Inglewood2_1 & $\mathrm{CB}$ & multi. & wq & 217 \\
\hline 2S/14W-26N4 & $26 \mathrm{~N} 4$ & 335737118192502 & Inglewood2_2 & $\mathrm{CB}$ & multi. & wq & 217 \\
\hline $2 \mathrm{~S} / 14 \mathrm{~W}-26 \mathrm{~N} 5$ & $26 \mathrm{~N} 5$ & 335737118192503 & Inglewood2_3 & $\mathrm{CB}$ & multi. & wq & 117 \\
\hline 2S/14W-26N6 & $26 \mathrm{~N} 6$ & 335737118192504 & Inglewood2_4 & $\mathrm{CB}$ & multi. & wq & 117 \\
\hline 2S/14W-28M3 & $28 \mathrm{M} 3$ & 335801118213101 & Inglewood1_1 & WCB & multi. & wq & 117 \\
\hline 2S/14W-28M4 & $28 \mathrm{M} 4$ & 335801118213102 & Inglewood1_2 & WCB & multi. & wq & 117 \\
\hline 2S/14W-28M5 & 28M5 & 335801118213103 & Inglewood1_3 & WCB & multi. & wq & 117 \\
\hline 2S/14W-28M6 & 28M6 & 335801118213104 & Inglewood1_4 & WCB & multi. & wq & 117 \\
\hline 2S/14W-28M7 & $28 \mathrm{M} 7$ & 335801118213105 & Inglewood1_5 & WCB & multi. & wq & 117 \\
\hline 2S/14W-29H1 & $29 \mathrm{H} 1$ & n.a. & $1333 \mathrm{C}$ & WCB & prod. & wl & 94 \\
\hline 2S/14W-32C2 & $32 \mathrm{C} 2$ & n.a. & $1324 \mathrm{H}$ & WCB & prod. & wl & 95 \\
\hline $2 \mathrm{~S} / 15 \mathrm{~W}-4 \mathrm{C} 2$ & $4 \mathrm{C} 2$ & 340152118273601 & $2546 \mathrm{~K}$ & SMB & prod. & wl, wq & 154 \\
\hline $2 \mathrm{~S} / 15 \mathrm{~W}-9 \mathrm{~N} 9$ & 9N9 & n.a. & $2539 \mathrm{~L}$ & SMB & obs. & wl & 26 \\
\hline $2 \mathrm{~S} / 15 \mathrm{~W}-11 \mathrm{~F} 5$ & $11 \mathrm{~F} 5$ & n.a. & $2578 X$ & SMB & prod. & wl & 78 \\
\hline $2 \mathrm{~S} / 15 \mathrm{~W}-13 \mathrm{P} 7$ & $13 \mathrm{P} 7$ & n.a. & $1290 \mathrm{P}$ & SMB & obs. & wl & 34 \\
\hline 2S/15W-22E3 & 22E3 & n.a. & $1251 \mathrm{~T}$ & SMB & obs. & wl & 10 \\
\hline 2S/15W-28Q1 & 28Q1 & n.a. & 1243B & SMB & - & wl & 10 \\
\hline $2 \mathrm{~S} / 15 \mathrm{~W}-35 \mathrm{~A} 1$ & $35 \mathrm{~A} 1$ & 335723118245501 & Westchester1_1 & WCB & multi. & wq & 127 \\
\hline $2 \mathrm{~S} / 15 \mathrm{~W}-35 \mathrm{~A} 2$ & $35 \mathrm{~A} 2$ & 335723118245502 & Westchester1_2 & WCB & multi. & wq & 127 \\
\hline $2 \mathrm{~S} / 15 \mathrm{~W}-35 \mathrm{~A} 3$ & $35 \mathrm{~A} 3$ & 335723118245503 & Westchester1_3 & WCB & multi. & wq & 127 \\
\hline 2S/15W-35A4 & $35 \mathrm{~A} 4$ & 335723118245504 & Westchester1_4 & WCB & multi. & wq & 127 \\
\hline $2 \mathrm{~S} / 15 \mathrm{~W}-35 \mathrm{~A} 5$ & $35 \mathrm{~A} 5$ & 335723118245505 & Westchester1_5 & WCB & multi. & wq & 127 \\
\hline 3S/08W-34G2 & $34 \mathrm{G} 2$ & 335210117422801 & Canyon_RV_1_east & $\mathrm{OCB}$ & prod. & wq & 383 \\
\hline $3 \mathrm{~S} / 10 \mathrm{~W}-8 \mathrm{~B} 00$ & $8 \mathrm{~B} 00$ & n.a. & LH-FS142 & OCB & prod. & wl & 282 \\
\hline 3S/10W-9G1 & 9G1 & n.a. & LH-FS192 & $\mathrm{OCB}$ & prod. & wl & 307 \\
\hline 3S/10W-21H2 & $21 \mathrm{H} 2$ & n.a. & FM-6 & OCB & obs. & wl & 255 \\
\hline $3 \mathrm{~S} / 11 \mathrm{~W}-2 \mathrm{~K} 4$ & $2 \mathrm{~K} 4$ & 335609118000101 & Whittier1_1 & W & multi. & wq & 212 \\
\hline $3 \mathrm{~S} / 11 \mathrm{~W}-2 \mathrm{~K} 5$ & $2 \mathrm{~K} 5$ & 335609118000102 & Whittier1_2 & W & multi. & wq & 212 \\
\hline $3 \mathrm{~S} / 11 \mathrm{~W}-2 \mathrm{~K} 6$ & $2 \mathrm{~K} 6$ & 335609118000104 & Whittier1_4 & W & multi. & wq & 212 \\
\hline $3 \mathrm{~S} / 11 \mathrm{~W}-2 \mathrm{~K} 7$ & $2 \mathrm{~K} 7$ & 335609118000105 & Whittier1_5 & W & multi. & wq & 212 \\
\hline $3 \mathrm{~S} / 11 \mathrm{~W}-2 \mathrm{~K} 8$ & $2 \mathrm{~K} 8$ & 335609118000201 & Whittier1_3 & W & multi. & wq & 212 \\
\hline 3S/11W-9D2 & 9D2 & 335546118024302 & Santa Fe Springs1_2 & $\mathrm{W}$ & multi. & wq & 167 \\
\hline
\end{tabular}


ange Counties, California.-Continued

available. Well location: CB, Central Basin Pressure Area; HB, Hollywood Basin; LAF, Los Angeles Forebay; MF, Montebello Forebay; OCB, Orange County Basin; SFV, San er level; wq, water quality]

\begin{tabular}{|c|c|c|c|c|c|c|}
\hline $\begin{array}{l}\text { Well depth } \\
\text { (ft below } \\
\text { LSD) }\end{array}$ & $\begin{array}{l}\text { Depth to top } \\
\text { perforation } \\
\text { (ft below LSD) }\end{array}$ & $\begin{array}{c}\text { Depth to bottom } \\
\text { perforation } \\
\text { (ft below LSD) }\end{array}$ & $\begin{array}{c}\text { Number of } \\
\text { perforated } \\
\text { intervals }\end{array}$ & $\begin{array}{l}\text { Date, water } \\
\text { level measured } \\
\text { (mm/dd/yyyy) }\end{array}$ & $\begin{array}{c}\text { Water-level } \\
\text { elevation } \\
\text { (ft above NAVD 88) }\end{array}$ & Chronostratigraphic unit \\
\hline 895 & 875 & 895 & 1 & $09 / 18 / 2014$ & -6.6 & Upper Wilmington A \\
\hline 725 & 705 & 725 & 1 & $09 / 18 / 2014$ & -12.2 & Harbor \\
\hline 570 & 550 & 570 & 1 & $09 / 18 / 2014$ & -18.2 & Pacific \\
\hline 350 & 330 & 350 & 1 & $09 / 18 / 2014$ & -14.1 & Pacific_A \\
\hline 210 & 190 & 210 & 1 & $09 / 18 / 2014$ & 7.5 & Mesa \\
\hline 954 & 330 & 954 & 1 & $06 / 01 / 2010$ & -50.5 & Bent Spring \\
\hline 440 & 260 & 430 & 1 & - & - & Upper Wilmington B \\
\hline 620 & 200 & 600 & 3 & - & - & Upper Wilmington A \\
\hline- & 285 & 324 & 1 & $11 / 03 / 1998$ & -11.3 & Pacific \\
\hline 860 & 800 & 840 & 1 & $09 / 12 / 2014$ & -25.3 & Long Beach A \\
\hline 470 & 450 & 470 & 1 & $09 / 12 / 2014$ & -17.2 & Lower Wilmington \\
\hline 350 & 330 & 350 & 1 & $09 / 12 / 2014$ & -4.7 & Harbor \\
\hline 245 & 225 & 245 & 1 & $09 / 12 / 2014$ & 1.3 & Pacific \\
\hline 1,400 & 1,380 & 1,400 & 1 & $09 / 12 / 2014$ & -31.4 & Long Beach C \\
\hline 885 & 865 & 885 & 1 & $09 / 12 / 2014$ & -46.4 & Long Beach A \\
\hline 450 & 430 & 450 & 1 & $09 / 12 / 2014$ & -33.4 & Upper Wilmington B \\
\hline 300 & 280 & 300 & 1 & $09 / 12 / 2014$ & 2.3 & Harbor \\
\hline 170 & 150 & 170 & 1 & $09 / 12 / 2014$ & 7.8 & Pacific \\
\hline - & 246 & 432 & 1 & $04 / 12 / 1979$ & -19.6 & Upper Wilmington A \\
\hline 400 & 163 & 342 & 1 & $04 / 11 / 1979$ & -13.6 & Pacific \\
\hline 550 & 210 & 530 & 4 & $04 / 27 / 2009$ & -24.8 & Pacific \\
\hline - & 135 & 145 & 1 & $04 / 27 / 2009$ & 10.6 & Pacific \\
\hline 460 & 180 & 456 & 1 & $11 / 29 / 1999$ & 1.5 & Bent Spring \\
\hline - & 230 & 240 & 1 & $04 / 17 / 2011$ & 10.3 & Bent Spring \\
\hline - & 120 & 185 & 1 & $10 / 18 / 2010$ & 2.3 & Pacific \\
\hline - & 84 & 132 & 1 & $04 / 20 / 2008$ & 2.4 & Mesa \\
\hline 860 & 740 & 760 & 1 & 09/13/2014 & -2.8 & Lower Wilmington \\
\hline 580 & 560 & 580 & 1 & $09 / 13 / 2014$ & 7.3 & Upper Wilmington B \\
\hline 475 & 455 & 475 & 1 & $09 / 13 / 2014$ & 7.7 & Upper Wilmington B \\
\hline 330 & 310 & 330 & 1 & 09/13/2014 & 7.8 & Bent Spring \\
\hline 235 & 215 & 235 & 1 & $09 / 13 / 2014$ & 7.9 & Harbor \\
\hline 98 & 60 & 84 & 1 & - & - & n.a. \\
\hline 1,180 & 600 & 1,160 & - & $06 / 25 / 2012$ & 252.3 & Lower Wilmington \\
\hline - & 300 & 500 & - & $09 / 12 / 2014$ & 269.4 & Lower Wilmington \\
\hline- & 150 & 310 & 1 & 09/09/2014 & 192.8 & Long Beach A \\
\hline 1,280 & 1,180 & 1,200 & 1 & $09 / 15 / 2014$ & 114.4 & Long Beach C \\
\hline 940 & 920 & 940 & 1 & $09 / 15 / 2014$ & 114.4 & Long Beach BC \\
\hline 470 & 450 & 470 & 1 & $09 / 15 / 2014$ & 103.7 & Long Beach A \\
\hline 220 & 200 & 220 & 1 & $09 / 15 / 2014$ & 197.2 & Pacific \\
\hline 620 & 600 & 620 & 1 & $09 / 15 / 2014$ & 105.9 & Long Beach B \\
\hline 845 & 825 & 845 & 1 & $09 / 29 / 2002$ & 83.2 & Lower Wilmington \\
\hline
\end{tabular}


Table 1.1. Site identification, well-construction, water-level, and chronostratigraphic unit information for wells used in this study, Los Angeles and Or

[USGS, U.S. Geological Survey; ft, foot; LSD, land surface datum; mm/dd/yyyy, month/day/year; NAVD 88, North American Vertical Datum of 1988; n.a., not assigned; -, not Fernando Valley; SGV, San Gabriel Valley; SMB, Santa Monica Basin; W, Whittier area. Well type: multi., multiple well; obs., observation; prod., production. Well data: wl, wa

\begin{tabular}{|c|c|c|c|c|c|c|c|}
\hline $\begin{array}{l}\text { State well } \\
\text { number }\end{array}$ & $\begin{array}{c}\text { State well } \\
\text { number } \\
\text { (abbreviated) }\end{array}$ & USGS site number & Local well name & $\begin{array}{c}\text { Well } \\
\text { Iocation }\end{array}$ & $\begin{array}{l}\text { Well } \\
\text { type }\end{array}$ & $\begin{array}{l}\text { Well } \\
\text { data }\end{array}$ & $\begin{array}{c}\text { Altitude of LSD } \\
\text { (ft above NAVD 88) }\end{array}$ \\
\hline 3S/11W-9D3 & 9D3 & 335546118024303 & Santa Fe Springs1_3 & $\mathrm{W}$ & multi. & wq & 167 \\
\hline 3S/11W-9D4 & 9D4 & 335546118024304 & Santa Fe Springs 1_4 & W & multi. & wq & 167 \\
\hline $3 \mathrm{~S} / 11 \mathrm{~W}-17 \mathrm{~F} 1$ & $17 \mathrm{~F} 1$ & 335443118031901 & Norwalk1_1 & $\mathrm{CB}$ & multi. & wq & 97 \\
\hline $3 \mathrm{~S} / 11 \mathrm{~W}-17 \mathrm{~F} 2$ & $17 \mathrm{~F} 2$ & 335443118031902 & Norwalk1_2 & $\mathrm{CB}$ & multi. & wq & 97 \\
\hline $3 \mathrm{~S} / 11 \mathrm{~W}-17 \mathrm{~F} 3$ & $17 \mathrm{~F} 3$ & 335443118031903 & Norwalk1_3 & $\mathrm{CB}$ & multi. & wq & 97 \\
\hline 3S/11W-17F4 & $17 \mathrm{~F} 4$ & 335443118031904 & Norwalk1_4 & $\mathrm{CB}$ & multi. & wq & 97 \\
\hline 3S/11W-17F5 & 17F5 & 335443118031905 & Norwalk1_5 & $\mathrm{CB}$ & multi. & wq & 97 \\
\hline $3 \mathrm{~S} / 11 \mathrm{~W}-26 \mathrm{E} 2$ & 26E2 & 335258118002401 & La Mirada1_1 & $\mathrm{CB}$ & multi. & wq & 80 \\
\hline $3 \mathrm{~S} / 11 \mathrm{~W}-26 \mathrm{E} 3$ & $26 \mathrm{E} 3$ & 335258118002402 & La Mirada1_2 & $\mathrm{CB}$ & multi. & wq & 80 \\
\hline $3 \mathrm{~S} / 11 \mathrm{~W}-26 \mathrm{E} 4$ & $26 \mathrm{E} 4$ & 335258118002403 & La Mirada1_3 & $\mathrm{CB}$ & multi. & wq & 80 \\
\hline $3 \mathrm{~S} / 11 \mathrm{~W}-26 \mathrm{E} 5$ & $26 \mathrm{E} 5$ & 335258118002404 & La Mirada1_4 & $\mathrm{CB}$ & multi. & wq & 80 \\
\hline $3 \mathrm{~S} / 11 \mathrm{~W}-26 \mathrm{E} 6$ & $26 \mathrm{E} 6$ & 335258118002405 & La Mirada1_5 & $\mathrm{CB}$ & multi. & wq & 80 \\
\hline $3 \mathrm{~S} / 11 \mathrm{~W}-35 \mathrm{~J} 3$ & $35 \mathrm{~J} 3$ & n.a. & $\mathrm{BP}-\mathrm{CIVC}$ & OCB & prod. & wl & 78 \\
\hline $3 \mathrm{~S} / 12 \mathrm{~W}-1 \mathrm{~A} 6$ & $1 \mathrm{~A} 6$ & 335647118050301 & $1615 \mathrm{P}$ & MF & prod. & wl & 138 \\
\hline $3 \mathrm{~S} / 12 \mathrm{~W}-6 \mathrm{~B} 4$ & $6 \mathrm{~B} 4$ & 335642118103701 & South Gate1_1 & $\mathrm{CB}$ & multi. & wq & 104 \\
\hline $3 \mathrm{~S} / 12 \mathrm{~W}-6 \mathrm{~B} 5$ & $6 \mathrm{~B} 5$ & 335642118103702 & South Gate1_2 & $\mathrm{CB}$ & multi. & wq & 104 \\
\hline $3 \mathrm{~S} / 12 \mathrm{~W}-6 \mathrm{~B} 6$ & $6 \mathrm{~B} 6$ & 335642118103703 & South Gate1_3 & $\mathrm{CB}$ & multi. & wq & 104 \\
\hline $3 \mathrm{~S} / 12 \mathrm{~W}-6 \mathrm{~B} 7$ & $6 \mathrm{~B} 7$ & 335642118103704 & South Gate1_4 & $\mathrm{CB}$ & multi. & wq & 104 \\
\hline $3 \mathrm{~S} / 12 \mathrm{~W}-6 \mathrm{~B} 8$ & $6 \mathrm{~B} 8$ & 335642118103705 & South Gate1_5 & $\mathrm{CB}$ & multi. & wq & 104 \\
\hline $3 \mathrm{~S} / 12 \mathrm{~W}-8 \mathrm{~L} 3$ & $8 \mathrm{~L} 3$ & 335314118063601 & $1537 \mathrm{~A}$ & $\mathrm{CB}$ & prod. & wl & 94 \\
\hline $3 \mathrm{~S} / 12 \mathrm{~W}-9 \mathrm{~J} 1$ & $9 \mathrm{~J} 1$ & 335517118081301 & Downey1_1 & $\mathrm{CB}$ & multi. & wq & 100 \\
\hline $3 \mathrm{~S} / 12 \mathrm{~W}-9 \mathrm{~J} 2$ & $9 \mathrm{~J} 2$ & 335517118081302 & Downey1_2 & $\mathrm{CB}$ & multi. & wq & 100 \\
\hline $3 \mathrm{~S} / 12 \mathrm{~W}-9 \mathrm{~J} 3$ & $9 \mathrm{~J} 3$ & 335517118081303 & Downey1_3 & $\mathrm{CB}$ & multi. & wq & 100 \\
\hline $3 \mathrm{~S} / 12 \mathrm{~W}-9 \mathrm{~J} 4$ & $9 \mathrm{~J} 4$ & 335517118081304 & Downey1_4 & $\mathrm{CB}$ & multi. & wq & 100 \\
\hline $3 \mathrm{~S} / 12 \mathrm{~W}-9 \mathrm{~J} 5$ & $9 \mathrm{~J} 5$ & 335517118081305 & Downey1_5 & $\mathrm{CB}$ & multi. & wq & 100 \\
\hline $3 \mathrm{~S} / 12 \mathrm{~W}-9 \mathrm{~J} 6$ & $9 \mathrm{~J} 6$ & 335517118081306 & Downey1_6 & $\mathrm{CB}$ & multi. & wq & 100 \\
\hline $3 \mathrm{~S} / 12 \mathrm{~W}-11 \mathrm{~A} 7$ & $11 \mathrm{~A} 7$ & 335545118061101 & Norwalk2_1 & MF & multi. & wq & 117 \\
\hline $3 \mathrm{~S} / 12 \mathrm{~W}-11 \mathrm{~A} 8$ & $11 \mathrm{~A} 8$ & 335545118061102 & Norwalk2_2 & MF & multi. & wq & 117 \\
\hline 3S/12W-11A9 & $11 \mathrm{~A} 9$ & 335545118061103 & Norwalk2_3 & MF & multi. & wq & 117 \\
\hline 3S/12W-11A10 & $11 \mathrm{~A} 10$ & 335545118061104 & Norwalk2_4 & MF & multi. & wq & 117 \\
\hline $3 \mathrm{~S} / 12 \mathrm{~W}-11 \mathrm{~A} 11$ & $11 \mathrm{~A} 11$ & 335545118061105 & Norwalk2_5 & MF & multi. & wq & 117 \\
\hline 3S/12W-11A12 & $11 \mathrm{~A} 12$ & 335545118061106 & Norwalk2_6 & MF & multi. & wq & 117 \\
\hline $3 \mathrm{~S} / 12 \mathrm{~W}-15 \mathrm{~K} 1$ & $15 \mathrm{~K} 1$ & 335400118070001 & St. John Bosco & $\mathrm{CB}$ & prod. & wq & 91 \\
\hline 3S/12W-16H1 & $16 \mathrm{H} 1$ & 335440118081101 & Park 40D & $\mathrm{CB}$ & prod. & wq & 92 \\
\hline $3 \mathrm{~S} / 12 \mathrm{~W}-26 \mathrm{C} 2$ & $26 \mathrm{C} 2$ & 335314118063601 & $981 \mathrm{C}$ & $\mathrm{CB}$ & prod. & wl & 76 \\
\hline $3 \mathrm{~S} / 12 \mathrm{~W}-26 \mathrm{~K} 2$ & $26 \mathrm{~K} 2$ & 335239118061501 & Cerritos2_1 & $\mathrm{CB}$ & multi. & wq & 67 \\
\hline $3 \mathrm{~S} / 12 \mathrm{~W}-26 \mathrm{~K} 3$ & $26 \mathrm{~K} 3$ & 335239118061502 & Cerritos $2 \_2$ & $\mathrm{CB}$ & multi. & wq & 67 \\
\hline $3 \mathrm{~S} / 12 \mathrm{~W}-26 \mathrm{~K} 4$ & $26 \mathrm{~K} 4$ & 335239118061503 & Cerritos2_3 & $\mathrm{CB}$ & multi. & wq & 67 \\
\hline $3 \mathrm{~S} / 12 \mathrm{~W}-26 \mathrm{~K} 5$ & $26 \mathrm{~K} 5$ & 335239118061504 & Cerritos2_4 & $\mathrm{CB}$ & multi. & wq & 67 \\
\hline $3 \mathrm{~S} / 12 \mathrm{~W}-26 \mathrm{~K} 6$ & $26 \mathrm{~K} 6$ & 335239118061505 & Cerritos2_5 & $\mathrm{CB}$ & multi. & wq & 67 \\
\hline $3 \mathrm{~S} / 12 \mathrm{~W}-26 \mathrm{~K} 7$ & $26 \mathrm{~K} 7$ & 335239118061506 & Cerritos $2 \_6$ & $\mathrm{CB}$ & multi. & wq & 67 \\
\hline
\end{tabular}


ange Counties, California.-Continued

available. Well location: CB, Central Basin Pressure Area; HB, Hollywood Basin; LAF, Los Angeles Forebay; MF, Montebello Forebay; OCB, Orange County Basin; SFV, San er level; wq, water quality]

\begin{tabular}{|c|c|c|c|c|c|c|}
\hline $\begin{array}{l}\text { Well depth } \\
\text { (ft below } \\
\text { LSD) } \\
\end{array}$ & $\begin{array}{c}\text { Depth to top } \\
\text { perforation } \\
\text { (ft below LSD) }\end{array}$ & $\begin{array}{l}\text { Depth to bottom } \\
\text { perforation } \\
\text { (ft below LSD) }\end{array}$ & $\begin{array}{c}\text { Number of } \\
\text { perforated } \\
\text { intervals }\end{array}$ & $\begin{array}{c}\text { Date, water } \\
\text { level measured } \\
\text { (mm/dd/yyyy) }\end{array}$ & $\begin{array}{c}\text { Water-level } \\
\text { elevation } \\
\text { (ft above NAVD 88) }\end{array}$ & Chronostratigraphic unit \\
\hline 560 & 540 & 560 & 1 & $09 / 29 / 2002$ & 57.9 & Harbor \\
\hline 285 & 265 & 285 & 1 & 09/29/2002 & 43.9 & Pacific_A \\
\hline 1,420 & 1,400 & 1,420 & 1 & $09 / 15 / 2014$ & 18.5 & Lower Wilmington \\
\hline 1,010 & 990 & 1,010 & 1 & $09 / 15 / 2014$ & -30.7 & Upper Wilmington A \\
\hline 740 & 720 & 740 & 1 & $09 / 15 / 2014$ & -4.7 & Bent Spring \\
\hline 450 & 430 & 450 & 1 & $09 / 15 / 2014$ & -10.9 & Pacific \\
\hline 240 & 220 & 240 & 1 & $09 / 15 / 2014$ & -7.2 & Pacific_A \\
\hline 1,150 & 1,130 & 1,150 & 1 & $09 / 11 / 2014$ & -41.9 & Upper Wilmington A \\
\hline 985 & 965 & 985 & 1 & $09 / 11 / 2014$ & -36.9 & Bent Spring \\
\hline 710 & 690 & 710 & 1 & 09/11/2014 & -52.0 & Harbor \\
\hline 490 & 470 & 490 & 1 & $09 / 11 / 2014$ & -64.9 & Pacific \\
\hline 245 & 225 & 245 & 1 & $09 / 11 / 2014$ & -29.9 & Pacific_A \\
\hline - & 373 & 638 & 1 & $01 / 03 / 2001$ & -21.8 & Pacific \\
\hline 216 & 91 & 192 & 1 & $09 / 26 / 2014$ & 42.1 & Pacific \\
\hline 1,460 & 1,140 & 1,460 & 1 & 09/29/2014 & -18.9 & Bent Spring \\
\hline 1,340 & 1,320 & 1,340 & 1 & 09/29/2014 & -16.1 & Harbor \\
\hline 930 & 910 & 930 & 1 & 09/29/2014 & -11.6 & Harbor \\
\hline 585 & 565 & 585 & 1 & $09 / 29 / 2014$ & -12.7 & Pacific \\
\hline 250 & 220 & 240 & 1 & 09/29/2014 & 35.7 & Mesa \\
\hline- & 50 & 285 & 1 & $11 / 12 / 1998$ & 49.4 & Dominguez \\
\hline 1,190 & 1,170 & 1,190 & 1 & 09/16/2014 & -20.4 & Bent Spring \\
\hline 960 & 940 & 960 & 1 & 09/16/2014 & -16.2 & Harbor \\
\hline 600 & 580 & 600 & 1 & $09 / 16 / 2014$ & -13.6 & Pacific \\
\hline 390 & 370 & 390 & 1 & 09/16/2014 & -9.1 & Pacific_A \\
\hline 270 & 250 & 270 & 1 & $09 / 16 / 2014$ & 27.4 & Mesa \\
\hline 110 & 90 & 110 & 1 & 09/16/2014 & 33.4 & Dominguez \\
\hline 1,480 & 1,460 & 1,480 & 1 & 09/11/2014 & -3.2 & Lower Wilmington \\
\hline 1,280 & 1,260 & 1,280 & 1 & 09/11/2014 & -2.9 & Lower Wilmington \\
\hline 980 & 960 & 980 & 1 & 09/11/2014 & -12.2 & Upper Wilmington A \\
\hline 820 & 800 & 820 & 1 & 09/11/2014 & -9.9 & Bent Spring \\
\hline 500 & 480 & 500 & 1 & $09 / 11 / 2014$ & 1.4 & Pacific \\
\hline 256 & 236 & 256 & 1 & $09 / 11 / 2014$ & 11.9 & Pacific_A \\
\hline- & - & - & 1 & - & - & Dominguez \\
\hline 572 & 546 & 572 & 1 & - & - & Pacific \\
\hline 590 & 568 & 590 & 1 & 03/12/2009 & -14.0 & Pacific_A \\
\hline 1,470 & 1,350 & 1,370 & 1 & $09 / 15 / 2014$ & -32.7 & Harbor \\
\hline 935 & 915 & 935 & 1 & 09/15/2014 & -46.8 & Pacific \\
\hline 760 & 740 & 760 & 1 & $09 / 15 / 2014$ & -41.8 & Pacific \\
\hline 510 & 490 & 510 & 1 & $09 / 15 / 2014$ & -14.6 & Pacific_A \\
\hline 370 & 350 & 370 & 1 & $09 / 15 / 2014$ & 17.1 & Mesa \\
\hline 170 & 150 & 170 & 1 & 09/15/2014 & 26.4 & Dominguez \\
\hline
\end{tabular}


Table 1.1. Site identification, well-construction, water-level, and chronostratigraphic unit information for wells used in this study, Los Angeles and Or

[USGS, U.S. Geological Survey; ft, foot; LSD, land surface datum; mm/dd/yyyy, month/day/year; NAVD 88, North American Vertical Datum of 1988; n.a., not assigned; -, not Fernando Valley; SGV, San Gabriel Valley; SMB, Santa Monica Basin; W, Whittier area. Well type: multi., multiple well; obs., observation; prod., production. Well data: wl, wa

\begin{tabular}{|c|c|c|c|c|c|c|c|}
\hline $\begin{array}{l}\text { State well } \\
\text { number }\end{array}$ & $\begin{array}{c}\text { State well } \\
\text { number } \\
\text { (abbreviated) }\end{array}$ & USGS site number & Local well name & $\begin{array}{c}\text { Well } \\
\text { location }\end{array}$ & $\begin{array}{l}\text { Well } \\
\text { type }\end{array}$ & $\begin{array}{l}\text { Well } \\
\text { data }\end{array}$ & $\begin{array}{c}\text { Altitude of LSD } \\
\text { (ft above NAVD 88) }\end{array}$ \\
\hline $3 \mathrm{~S} / 12 \mathrm{~W}-31 \mathrm{E} 3$ & $31 \mathrm{E} 3$ & n.a. & $913 \mathrm{E}$ & $\mathrm{CB}$ & prod. & wl & 55 \\
\hline 3S/12W-33B1 & 33B1 & 335209118082001 & BSMWC_615 & $\mathrm{CB}$ & prod. & wq & 65 \\
\hline 3S/13W-8J1 & $8 \mathrm{~J} 1$ & 335524118152001 & Willowbrook1_1 & $\mathrm{CB}$ & multi. & wq & 99 \\
\hline $3 \mathrm{~S} / 13 \mathrm{~W}-8 \mathrm{~J} 2$ & $8 \mathrm{~J} 2$ & 335524118152002 & Willowbrook1_2 & $\mathrm{CB}$ & multi. & wq & 99 \\
\hline $3 \mathrm{~S} / 13 \mathrm{~W}-8 \mathrm{~J} 3$ & $8 \mathrm{~J} 3$ & 335524118152003 & Willowbrook1_3 & $\mathrm{CB}$ & multi. & wq & 99 \\
\hline $3 \mathrm{~S} / 13 \mathrm{~W}-8 \mathrm{~J} 4$ & $8 \mathrm{~J} 4$ & 335524118152004 & Willowbrook1_4 & $\mathrm{CB}$ & multi. & wq & 99 \\
\hline 3S/13W-11G1 & $11 \mathrm{G} 1$ & 335535118124001 & Lynwood1_1 & $\mathrm{CB}$ & multi. & wq & 87 \\
\hline 3S/13W-11G2 & $11 \mathrm{G} 2$ & 335535118124002 & Lynwood1_2 & $\mathrm{CB}$ & multi. & wq & 87 \\
\hline $3 \mathrm{~S} / 13 \mathrm{~W}-11 \mathrm{G} 3$ & $11 \mathrm{G} 3$ & 335535118124003 & Lynwood1_8 & $\mathrm{CB}$ & multi. & wq & 87 \\
\hline 3S/13W-11G4 & $11 \mathrm{G} 4$ & 335535118123901 & Lynwood1_3 & $\mathrm{CB}$ & multi. & wq & 87 \\
\hline 3S/13W-11G5 & $11 \mathrm{G} 5$ & 335535118123902 & Lynwood1_4 & $\mathrm{CB}$ & multi. & wq & 87 \\
\hline 3S/13W-11G6 & $11 \mathrm{G} 6$ & 335535118123903 & Lynwood1_5 & $\mathrm{CB}$ & multi. & wq & 87 \\
\hline 3S/13W-11G7 & $11 \mathrm{G} 7$ & 335535118123904 & Lynwood1_6 & $\mathrm{CB}$ & multi. & wq & 87 \\
\hline 3S/13W-11G8 & $11 \mathrm{G} 8$ & 335535118123905 & Lynwood1_7 & $\mathrm{CB}$ & multi. & wq & 87 \\
\hline 3S/13W-11G9 & $11 \mathrm{G} 9$ & 335535118123906 & Lynwood1_9 & $\mathrm{CB}$ & multi. & wq & 87 \\
\hline 3S/13W-21R1 & 21R1 & n.a. & $851 \mathrm{~F}$ & $\mathrm{CB}$ & prod. & wl & 94 \\
\hline 3S/13W-22M2 & $22 \mathrm{M} 2$ & 335333118140601 & Compton2_1 & $\mathrm{CB}$ & multi. & wq & 77 \\
\hline 3S/13W-22M3 & $22 \mathrm{M} 3$ & 335333118140602 & Compton2_2 & $\mathrm{CB}$ & multi. & wq & 77 \\
\hline 3S/13W-22M4 & $22 \mathrm{M} 4$ & 335333118140603 & Compton2_3 & $\mathrm{CB}$ & multi. & wq & 77 \\
\hline 3S/13W-22M5 & 22M5 & 335333118140604 & Compton2_4 & $\mathrm{CB}$ & multi. & wq & 77 \\
\hline 3S/13W-22M6 & 22M6 & 335333118140605 & Compton2_5 & $\mathrm{CB}$ & multi. & wq & 77 \\
\hline 3S/13W-22M7 & $22 \mathrm{M} 7$ & 335333118140606 & Compton2_6 & $\mathrm{CB}$ & multi. & wq & 77 \\
\hline $3 \mathrm{~S} / 13 \mathrm{~W}-24 \mathrm{~K} 2$ & $24 \mathrm{~K} 2$ & 335337118113401 & Compton1_1 & $\mathrm{CB}$ & multi. & wq & 68 \\
\hline 3S/13W-24K3 & $24 \mathrm{~K} 3$ & 335337118113402 & Compton1_2 & $\mathrm{CB}$ & multi. & wq & 68 \\
\hline 3S/13W-24K4 & $24 \mathrm{~K} 4$ & 335337118113403 & Compton1_3 & $\mathrm{CB}$ & multi. & wq & 68 \\
\hline 3S/13W-24K5 & $24 \mathrm{~K} 5$ & 335337118113404 & Compton1_4 & $\mathrm{CB}$ & multi. & wq & 68 \\
\hline $3 \mathrm{~S} / 13 \mathrm{~W}-24 \mathrm{~K} 6$ & $24 \mathrm{~K} 6$ & 335337118113405 & Compton1_5 & $\mathrm{CB}$ & multi. & wq & 68 \\
\hline $3 \mathrm{~S} / 14 \mathrm{~W}-4 \mathrm{R} 1$ & $4 \mathrm{R} 1$ & 335555118204001 & Inglewood3_1 & WCB & multi. & wq & 72 \\
\hline $3 \mathrm{~S} / 14 \mathrm{~W}-4 \mathrm{R} 2$ & $4 \mathrm{R} 2$ & 335555118204002 & Inglewood3_2 & WCB & multi. & wq & 72 \\
\hline 3S/14W-4R3 & $4 \mathrm{R} 3$ & 335555118204003 & Inglewood3_3 & WCB & multi. & wq & 72 \\
\hline $3 \mathrm{~S} / 14 \mathrm{~W}-4 \mathrm{R} 4$ & $4 \mathrm{R} 4$ & 335555118204004 & Inglewood3_4 & WCB & multi. & wq & 72 \\
\hline $3 \mathrm{~S} / 14 \mathrm{~W}-4 \mathrm{R} 5$ & $4 \mathrm{R} 5$ & 335555118204005 & Inglewood3_5 & WCB & multi. & wq & 72 \\
\hline $3 \mathrm{~S} / 14 \mathrm{~W}-4 \mathrm{R} 6$ & $4 \mathrm{R} 6$ & 335555118204006 & Inglewood3_6 & WCB & multi. & wq & 72 \\
\hline $3 \mathrm{~S} / 14 \mathrm{~W}-4 \mathrm{R} 7$ & $4 \mathrm{R} 7$ & 335555118204007 & Inglewood3_7 & WCB & multi. & wq & 72 \\
\hline 3S/14W-13J5 & $13 J 5$ & 335431118173101 & Gardena1_1 & WCB & multi. & wq & 86 \\
\hline $3 \mathrm{~S} / 14 \mathrm{~W}-13 \mathrm{~J} 6$ & $13 \mathrm{~J} 6$ & 335431118173102 & Gardena1_2 & WCB & multi. & wq & 86 \\
\hline $3 \mathrm{~S} / 14 \mathrm{~W}-13 \mathrm{~J} 7$ & $13 \mathrm{~J} 7$ & 335431118173103 & Gardena1_3 & WCB & multi. & wq & 86 \\
\hline $3 \mathrm{~S} / 14 \mathrm{~W}-13 \mathrm{~J} 8$ & $13 \mathrm{~J} 8$ & 335431118173104 & Gardena1_4 & WCB & multi. & wq & 86 \\
\hline 3S/14W-17G3 & $17 \mathrm{G} 3$ & 335443118215501 & Hawthorne1_1 & WCB & multi. & wq & 86 \\
\hline $3 \mathrm{~S} / 14 \mathrm{~W}-17 \mathrm{G} 4$ & 17G4 & 335443118215502 & Hawthorne1_2 & WCB & multi. & wq & 86 \\
\hline 3S/14W-17G5 & 17G5 & 335443118215503 & Hawthorne1_3 & WCB & multi. & wq & 86 \\
\hline
\end{tabular}


ange Counties, California.-Continued

available. Well location: CB, Central Basin Pressure Area; HB, Hollywood Basin; LAF, Los Angeles Forebay; MF, Montebello Forebay; OCB, Orange County Basin; SFV, San er level; wq, water quality]

\begin{tabular}{|c|c|c|c|c|c|c|}
\hline $\begin{array}{l}\text { Well depth } \\
\text { (ft below } \\
\text { LSD) }\end{array}$ & $\begin{array}{l}\text { Depth to top } \\
\text { perforation } \\
\text { (ft below LSD) }\end{array}$ & $\begin{array}{c}\text { Depth to bottom } \\
\text { perforation } \\
\text { (ft below LSD) }\end{array}$ & $\begin{array}{c}\text { Number of } \\
\text { perforated } \\
\text { intervals }\end{array}$ & $\begin{array}{l}\text { Date, water } \\
\text { level measured } \\
\text { (mm/dd/yyyy) }\end{array}$ & $\begin{array}{c}\text { Water-level } \\
\text { elevation } \\
\text { (ft above NAVD 88) }\end{array}$ & Chronostratigraphic unit \\
\hline - & 701 & 933 & 1 & $04 / 01 / 1999$ & -48.5 & Upper Wilmington A \\
\hline 674 & 602 & 644 & 2 & - & - & Pacific \\
\hline 905 & 885 & 905 & 1 & $09 / 17 / 2014$ & -71.7 & Upper Wilmington B \\
\hline 520 & 500 & 520 & 1 & 09/17/2014 & -45.6 & Bent Spring \\
\hline 380 & 360 & 380 & 1 & $09 / 17 / 2014$ & -50.7 & Harbor \\
\hline 220 & 200 & 220 & 1 & $09 / 17 / 2014$ & -49.1 & Pacific \\
\hline 2,900 & 2,880 & 2,900 & 1 & $09 / 23 / 2014$ & -26.6 & Long Beach A \\
\hline 2,450 & 2,430 & 2,450 & 1 & $09 / 23 / 2014$ & 46.4 & Lower Wilmington \\
\hline 335 & 315 & 335 & 1 & $09 / 23 / 2014$ & -30.0 & Pacific_A \\
\hline 1,670 & 1,650 & 1,670 & 1 & $09 / 23 / 2014$ & -47.6 & Upper Wilmington B \\
\hline 1,465 & 1,445 & 1,465 & 1 & $09 / 23 / 2014$ & -61.7 & Upper Wilmington A \\
\hline 1,220 & 1,200 & 1,220 & 1 & $09 / 23 / 2014$ & -43.3 & Bent Spring \\
\hline 900 & 880 & 900 & 1 & $09 / 23 / 2014$ & -37.1 & Harbor \\
\hline 660 & 640 & 660 & 1 & $09 / 23 / 2014$ & -37.8 & Harbor \\
\hline 180 & 160 & 180 & 1 & $09 / 23 / 2014$ & 40.8 & Dominguez \\
\hline - & 366 & 525 & 1 & $11 / 05 / 1996$ & -29.0 & Harbor \\
\hline 1,495 & 1,475 & 1,495 & 1 & $09 / 12 / 2014$ & -33.6 & Long Beach A \\
\hline 850 & 830 & 850 & 1 & $09 / 12 / 2014$ & -58.8 & Upper Wilmington B \\
\hline 605 & 585 & 605 & 1 & $09 / 12 / 2014$ & -48.2 & Harbor \\
\hline 400 & 380 & 400 & 1 & $09 / 12 / 2014$ & -46.8 & Harbor \\
\hline 315 & 295 & 315 & 1 & $09 / 12 / 2014$ & -39.9 & Pacific \\
\hline 170 & 150 & 170 & 1 & $09 / 12 / 2014$ & -33.4 & Pacific_A \\
\hline 1,410 & 1,370 & 1,390 & 1 & $09 / 16 / 2014$ & -80.0 & Upper Wilmington B \\
\hline 1,170 & 1,150 & 1,170 & 1 & $09 / 16 / 2014$ & -79.7 & Upper Wilmington A \\
\hline 820 & 800 & 820 & 1 & $09 / 16 / 2014$ & -36.6 & Harbor \\
\hline 480 & 460 & 480 & 1 & $09 / 16 / 2014$ & -35.0 & Pacific \\
\hline 325 & 305 & 325 & 1 & $09 / 16 / 2014$ & -21.4 & Pacific_A \\
\hline 1,940 & 1,900 & 1,940 & 1 & $09 / 12 / 2014$ & -27.6 & Long Beach C \\
\hline 1,460 & 1,440 & 1,460 & 1 & $09 / 12 / 2014$ & -37.7 & Long Beach BC \\
\hline 1,275 & 1,255 & 1,275 & 1 & $09 / 12 / 2014$ & -59.0 & Long Beach B \\
\hline 910 & 890 & 910 & 1 & $09 / 12 / 2014$ & -81.4 & Long Beach A \\
\hline 560 & 540 & 560 & 1 & $09 / 12 / 2014$ & -72.1 & Upper Wilmington A \\
\hline 390 & 370 & 390 & 1 & $09 / 12 / 2014$ & -15.2 & Harbor \\
\hline 265 & 245 & 265 & 1 & $09 / 12 / 2014$ & 1.8 & Pacific \\
\hline 990 & 970 & 990 & 1 & $09 / 15 / 2014$ & -56.9 & Long Beach A \\
\hline 465 & 445 & 465 & 1 & $09 / 15 / 2014$ & -134.7 & Upper Wilmington A \\
\hline 365 & 345 & 365 & 1 & $09 / 15 / 2014$ & -97.6 & Bent Spring \\
\hline 140 & 120 & 140 & 1 & $09 / 15 / 2014$ & -12.6 & Pacific \\
\hline 990 & 910 & 950 & 1 & $09 / 17 / 2014$ & -66.7 & Lower Wilmington \\
\hline 730 & 710 & 730 & 1 & $09 / 17 / 2014$ & -18.3 & Upper Wilmington B \\
\hline 540 & 520 & 540 & 1 & $09 / 17 / 2014$ & -17.2 & Bent Spring \\
\hline
\end{tabular}


Table 1.1. Site identification, well-construction, water-level, and chronostratigraphic unit information for wells used in this study, Los Angeles and Or

[USGS, U.S. Geological Survey; ft, foot; LSD, land surface datum; mm/dd/yyyy, month/day/year; NAVD 88, North American Vertical Datum of 1988; n.a., not assigned; -, not Fernando Valley; SGV, San Gabriel Valley; SMB, Santa Monica Basin; W, Whittier area. Well type: multi., multiple well; obs., observation; prod., production. Well data: wl, wa

\begin{tabular}{|c|c|c|c|c|c|c|c|}
\hline $\begin{array}{l}\text { State well } \\
\text { number }\end{array}$ & $\begin{array}{c}\text { State well } \\
\text { number } \\
\text { (abbreviated) }\end{array}$ & USGS site number & Local well name & $\begin{array}{c}\text { Well } \\
\text { location }\end{array}$ & $\begin{array}{l}\text { Well } \\
\text { type }\end{array}$ & $\begin{array}{l}\text { Well } \\
\text { data }\end{array}$ & $\begin{array}{c}\text { Altitude of LSD } \\
\text { (ft above NAVD 88) }\end{array}$ \\
\hline 3S/14W-17G6 & 17G6 & 335443118215504 & Hawthorne1_4 & WCB & multi. & wq & 86 \\
\hline 3S/14W-17G7 & $17 \mathrm{G} 7$ & 335443118215505 & Hawthorne1_5 & WCB & multi. & wq & 86 \\
\hline $3 \mathrm{~S} / 14 \mathrm{~W}-17 \mathrm{G} 8$ & $17 \mathrm{G} 8$ & 335443118215506 & Hawthorne1_6 & WCB & multi. & wq & 86 \\
\hline 3S/14W-22L1 & $22 \mathrm{~L} 1$ & 335340118201801 & $760 \mathrm{C}$ & WCB & prod. & wl & 53 \\
\hline $3 \mathrm{~S} / 14 \mathrm{~W}-25 \mathrm{~K} 7$ & $25 \mathrm{~K} 7$ & 335235118175901 & Gardena2_1 & WCB & multi. & wq & 28 \\
\hline $3 \mathrm{~S} / 14 \mathrm{~W}-25 \mathrm{~K} 8$ & $25 \mathrm{~K} 8$ & 335235118175902 & Gardena2_2 & WCB & multi. & wq & 28 \\
\hline 3S/14W-25K9 & $25 \mathrm{~K} 9$ & 335235118175903 & Gardena2_3 & WCB & multi. & wq & 28 \\
\hline $3 \mathrm{~S} / 14 \mathrm{~W}-25 \mathrm{~K} 10$ & $25 \mathrm{~K} 10$ & 335235118175904 & Gardena2_4 & WCB & multi. & wq & 28 \\
\hline 3S/14W-25K11 & $25 \mathrm{~K} 11$ & 335235118175905 & Gardena2_5 & WCB & multi. & wq & 28 \\
\hline $3 \mathrm{~S} / 14 \mathrm{~W}-27 \mathrm{C} 2$ & $27 \mathrm{C} 2$ & 335312118200701 & Lawndale1_1 & WCB & multi. & wq & 34 \\
\hline $3 \mathrm{~S} / 14 \mathrm{~W}-27 \mathrm{C} 3$ & $27 \mathrm{C} 3$ & 335312118200702 & Lawndale1_2 & WCB & multi. & wq & 34 \\
\hline $3 \mathrm{~S} / 14 \mathrm{~W}-27 \mathrm{C} 4$ & $27 \mathrm{C} 4$ & 335312118200703 & Lawndale1_3 & WCB & multi. & wq & 34 \\
\hline 3S/14W-27C5 & $27 \mathrm{C} 5$ & 335312118200704 & Lawndale1_4 & WCB & multi. & wq & 34 \\
\hline 3S/14W-27C6 & $27 \mathrm{C} 6$ & 335312118200705 & Lawndale1_5 & WCB & multi. & wq & 34 \\
\hline $3 \mathrm{~S} / 14 \mathrm{~W}-27 \mathrm{C} 7$ & $27 \mathrm{C} 7$ & 335312118200706 & Lawndale1_6 & WCB & multi. & wq & 34 \\
\hline 3S/14W-30L2 & $30 \mathrm{~L} 2$ & 335236118232101 & Manhattan Beach1_1 & WCB & multi. & wq & 136 \\
\hline 3S/14W-30L3 & 30L3 & 335236118232102 & Manhattan Beach1_2 & WCB & multi. & wq & 136 \\
\hline 3S/14W-30L4 & 30L4 & 335236118232103 & Manhattan Beach1_3 & WCB & multi. & wq & 136 \\
\hline 3S/14W-30L5 & $30 \mathrm{~L} 5$ & 335236118232104 & Manhattan Beach1_4 & WCB & multi. & wq & 136 \\
\hline 3S/14W-30L6 & 30L6 & 335236118232105 & Manhattan Beach1_5 & WCB & multi. & wq & 136 \\
\hline 3S/14W-30L7 & 30L 7 & 335236118232106 & Manhattan Beach1_6 & WCB & multi. & wq & 136 \\
\hline 3S/14W-30L8 & $30 \mathrm{~L} 8$ & 335236118232107 & Manhattan Beach1_7 & WCB & multi. & wq & 136 \\
\hline 3S/14W-30N1 & $30 \mathrm{~N} 1$ & n.a. & $702 \mathrm{E}$ & WCB & obs. & wl & 182 \\
\hline 3S/14W-31D1 & 31D1 & n.a. & $702 \mathrm{M}$ & WCB & obs. & wl & 170 \\
\hline 3S/14W-31L3 & $31 \mathrm{~L} 3$ & n.a. & $713 \mathrm{D}$ & WCB & obs. & wl & 169 \\
\hline 3S/14W-33R5 & $33 \mathrm{R} 5$ & 335131118204501 & Torrance1_1 & WCB & multi. & wq & 81 \\
\hline $3 \mathrm{~S} / 14 \mathrm{~W}-33 \mathrm{R} 6$ & $33 R 6$ & 335131118204502 & Torrance1_2 & WCB & multi. & wq & 81 \\
\hline $3 \mathrm{~S} / 14 \mathrm{~W}-33 \mathrm{R} 7$ & $33 \mathrm{R} 7$ & 335131118204503 & Torrance1_3 & WCB & multi. & wq & 81 \\
\hline 3S/14W-33R8 & $33 \mathrm{R} 8$ & 335131118204504 & Torrance1_4 & WCB & multi. & wq & 81 \\
\hline 3S/14W-33R9 & 33R9 & 335131118204505 & Torrance1_5 & WCB & multi. & wq & 81 \\
\hline 3S/14W-33R10 & $33 \mathrm{R} 10$ & 335131118204506 & Torrance1_6 & WCB & multi. & wq & 81 \\
\hline $3 \mathrm{~S} / 15 \mathrm{~W}-13 \mathrm{H} 9$ & $13 \mathrm{H} 9$ & n.a. & $1308 \mathrm{~T}$ & WCB & obs. & wl & 101 \\
\hline $4 \mathrm{~S} / 10 \mathrm{~W}-8 \mathrm{~F} 3$ & $8 \mathrm{~F} 3$ & n.a. & $\mathrm{CB}-1$ & OCB & multi & wl & 122 \\
\hline 4S/10W-14H3 & $14 \mathrm{H} 3$ & 334932117532401 & Anaheim_46 & OCB & prod. & wq & 180 \\
\hline 4S/11W-3E1 & $3 \mathrm{E} 1$ & n.a. & BPM-1 & OCB & multi & wl & 59 \\
\hline $4 \mathrm{~S} / 11 \mathrm{~W}-5 \mathrm{P} 9$ & $5 \mathrm{P} 9$ & 335049118032901 & Cerritos1_1 & $\mathrm{CB}$ & multi. & wq & 40 \\
\hline 4S/11W-5P10 & $5 \mathrm{P} 10$ & 335049118032902 & Cerritos1_2 & $\mathrm{CB}$ & multi. & wq & 40 \\
\hline 4S/11W-5P11 & $5 \mathrm{P} 11$ & 335049118032903 & Cerritos1_3 & $\mathrm{CB}$ & multi. & wq & 40 \\
\hline $4 \mathrm{~S} / 11 \mathrm{~W}-5 \mathrm{P} 12$ & $5 \mathrm{P} 12$ & 335049118032904 & Cerritos1_4 & $\mathrm{CB}$ & multi. & wq & 40 \\
\hline $4 \mathrm{~S} / 11 \mathrm{~W}-5 \mathrm{P} 13$ & $5 \mathrm{P} 13$ & 335049118032905 & Cerritos1_5 & $\mathrm{CB}$ & multi. & wq & 40 \\
\hline 4S/11W-5P14 & $5 \mathrm{P} 14$ & 335049118032906 & Cerritos1_6 & $\mathrm{CB}$ & multi. & wq & 40 \\
\hline
\end{tabular}


ange Counties, California.-Continued

available. Well location: CB, Central Basin Pressure Area; HB, Hollywood Basin; LAF, Los Angeles Forebay; MF, Montebello Forebay; OCB, Orange County Basin; SFV, San er level; wq, water quality]

\begin{tabular}{|c|c|c|c|c|c|c|}
\hline $\begin{array}{l}\text { Well depth } \\
\text { (ft below } \\
\text { LSD) }\end{array}$ & $\begin{array}{c}\text { Depth to top } \\
\text { perforation } \\
\text { (ft below LSD) }\end{array}$ & $\begin{array}{c}\text { Depth to bottom } \\
\text { perforation } \\
\text { (ft below LSD) }\end{array}$ & $\begin{array}{c}\text { Number of } \\
\text { perforated } \\
\text { intervals }\end{array}$ & $\begin{array}{c}\text { Date, water } \\
\text { level measured } \\
\text { (mm/dd/yyyy) }\end{array}$ & $\begin{array}{c}\text { Water-level } \\
\text { elevation } \\
\text { (ft above NAVD 88) }\end{array}$ & Chronostratigraphic unit \\
\hline 420 & 400 & 420 & 1 & $09 / 17 / 2014$ & -17.0 & Bent Spring \\
\hline 260 & 240 & 260 & 1 & $09 / 17 / 2014$ & -11.3 & Harbor \\
\hline 130 & 110 & 130 & 1 & $09 / 17 / 2014$ & 0.6 & Pacific \\
\hline 502 & 352 & 458 & 1 & $09 / 25 / 2014$ & -12.6 & Bent Spring \\
\hline 1,375 & 1,275 & 1,335 & 2 & $09 / 23 / 2014$ & -42.0 & Long Beach A \\
\hline 790 & 770 & 790 & 1 & $09 / 23 / 2014$ & -56.0 & Upper Wilmington A \\
\hline 630 & 610 & 630 & 1 & $09 / 23 / 2014$ & -56.3 & Upper Wilmington A \\
\hline 360 & 340 & 360 & 1 & $09 / 23 / 2014$ & -24.5 & Harbor \\
\hline 255 & 235 & 255 & 1 & $09 / 23 / 2014$ & -12.0 & Pacific \\
\hline 1,400 & 1,360 & 1,400 & 1 & $09 / 15 / 2014$ & -34.6 & Long Beach A \\
\hline 905 & 885 & 905 & 1 & $09 / 15 / 2014$ & -61.5 & Lower Wilmington \\
\hline 635 & 615 & 635 & 1 & $09 / 15 / 2014$ & -16.3 & Upper Wilmington B \\
\hline 415 & 395 & 415 & 1 & $09 / 15 / 2014$ & -15.9 & Harbor \\
\hline 310 & 290 & 310 & 1 & $09 / 15 / 2014$ & -13.2 & Harbor \\
\hline 190 & 170 & 190 & 1 & $09 / 15 / 2014$ & -6.5 & Pacific \\
\hline 1,990 & 1,950 & 1,990 & 1 & $09 / 16 / 2014$ & -0.5 & Long Beach C \\
\hline 1,590 & 1,570 & 1,590 & 1 & $09 / 16 / 2014$ & -2.6 & Long Beach BC \\
\hline 1,270 & 1,250 & 1,270 & 1 & $09 / 16 / 2014$ & -33.8 & Long Beach A \\
\hline 885 & 865 & 885 & 1 & $09 / 16 / 2014$ & -5.8 & Upper Wilmington B \\
\hline 660 & 640 & 660 & 1 & $09 / 16 / 2014$ & -3.4 & Bent Spring \\
\hline 340 & 320 & 340 & 1 & $09 / 16 / 2014$ & 6.4 & Pacific \\
\hline 200 & 180 & 200 & 1 & $09 / 16 / 2014$ & 10.0 & Mesa \\
\hline 532 & 232 & 350 & 1 & $10 / 14 / 2013$ & 7.7 & Mesa \\
\hline - & 140 & 296 & 1 & $10 / 14 / 2013$ & 7.7 & Mesa \\
\hline 460 & 270 & 450 & 1 & $10 / 14 / 2013$ & 9.6 & Pacific \\
\hline 1,480 & 1,360 & 1,380 & 1 & $09 / 15 / 2014$ & -34.6 & Long Beach B \\
\hline 960 & 940 & 960 & 1 & $09 / 15 / 2014$ & -44.6 & Lower Wilmington \\
\hline 790 & 770 & 790 & 1 & $09 / 15 / 2014$ & -11.4 & Upper Wilmington B \\
\hline 600 & 580 & 600 & 1 & $09 / 15 / 2014$ & -8.9 & Bent Spring \\
\hline 340 & 320 & 340 & 1 & $09 / 15 / 2014$ & -2.5 & Pacific \\
\hline 160 & 140 & 160 & 1 & $09 / 15 / 2014$ & -2.2 & Mesa \\
\hline 235 & 190 & 225 & 1 & $10 / 23 / 2013$ & 6.7 & Harbor \\
\hline 1,510 & 76 & 1,470 & 9 & $09 / 16 / 2014$ & 56.5 & Multiple* \\
\hline 1,550 & 599 & 1,530 & 1 & - & - & n.a. \\
\hline 2,155 & 128 & 2,115 & 14 & $09 / 03 / 2014$ & 25.0 & Multiple* \\
\hline 1,215 & 1,155 & 1,175 & 1 & $09 / 15 / 2014$ & -60.6 & Harbor \\
\hline 1,020 & 1,000 & 1,020 & 1 & $09 / 15 / 2014$ & -66.3 & Pacific \\
\hline 630 & 610 & 630 & 1 & $09 / 15 / 2014$ & -52.4 & Pacific \\
\hline 290 & 270 & 290 & 1 & $09 / 15 / 2014$ & 9.7 & Mesa \\
\hline 200 & 180 & 200 & 1 & $09 / 15 / 2014$ & 13.5 & Dominguez \\
\hline 135 & 125 & 135 & 1 & $09 / 15 / 2014$ & 13.5 & Dominguez \\
\hline
\end{tabular}


Table 1.1. Site identification, well-construction, water-level, and chronostratigraphic unit information for wells used in this study, Los Angeles and Or

[USGS, U.S. Geological Survey; ft, foot; LSD, land surface datum; mm/dd/yyyy, month/day/year; NAVD 88, North American Vertical Datum of 1988; n.a., not assigned; -, not Fernando Valley; SGV, San Gabriel Valley; SMB, Santa Monica Basin; W, Whittier area. Well type: multi., multiple well; obs., observation; prod., production. Well data: wl, wa

\begin{tabular}{|c|c|c|c|c|c|c|c|}
\hline $\begin{array}{l}\text { State well } \\
\text { number }\end{array}$ & $\begin{array}{c}\text { State well } \\
\text { number } \\
\text { (abbreviated) }\end{array}$ & USGS site number & Local well name & $\begin{array}{c}\text { Well } \\
\text { location }\end{array}$ & $\begin{array}{l}\text { Well } \\
\text { type }\end{array}$ & $\begin{array}{l}\text { Well } \\
\text { data }\end{array}$ & $\begin{array}{c}\text { Altitude of LSD } \\
\text { (ft above NAVD 88) }\end{array}$ \\
\hline $4 \mathrm{~S} / 11 \mathrm{~W}-13 \mathrm{C} 4$ & $13 \mathrm{C} 4$ & n.a. & AMD-8 & $\mathrm{OCB}$ & multi & wl & 81 \\
\hline 4S/11W-15Q2 & $15 \mathrm{Q} 2$ & n.a. & BPM-2 & OCB & multi & wl & 58 \\
\hline 4S/11W-19Q2 & 19Q2 & n.a. & SCWC-LAC3 & OCB & prod. & wl & 25 \\
\hline $4 \mathrm{~S} / 11 \mathrm{~W}-25 \mathrm{~J} 4$ & $25 \mathrm{~J} 4$ & n.a. & GGM-3 & $\mathrm{OCB}$ & multi & wl & 78 \\
\hline $4 \mathrm{~S} / 11 \mathrm{~W}-26 \mathrm{~N} 1$ & $26 \mathrm{~N} 1$ & 334719118003901 & GG-22 & OCB & prod. & wl & 49 \\
\hline 4S/11W-30H1 & $30 \mathrm{H} 1$ & n.a. & LAM1 & OCB & multi & wl & 22 \\
\hline 4S/11W-35H3 & $35 \mathrm{H} 3$ & n.a. & SCWC-SBCH & OCB & prod. & wl & 54 \\
\hline $4 \mathrm{~S} / 11 \mathrm{~W}-35 \mathrm{~N} 2$ & $35 \mathrm{~N} 2$ & n.a. & GGM-2 & OCB & multi & wl & 46 \\
\hline $4 \mathrm{~S} / 12 \mathrm{~W}-5 \mathrm{H} 5$ & $5 \mathrm{H} 5$ & 335112118090401 & Lakewood1_1 & $\mathrm{CB}$ & multi. & wq & 50 \\
\hline 4S/12W-5H6 & $5 \mathrm{H} 6$ & 335112118090402 & Lakewood1_2 & $\mathrm{CB}$ & multi. & wq & 50 \\
\hline 4S/12W-5H7 & $5 \mathrm{H} 7$ & 335112118090403 & Lakewood1_3 & $\mathrm{CB}$ & multi. & wq & 50 \\
\hline $4 \mathrm{~S} / 12 \mathrm{~W}-5 \mathrm{H} 8$ & $5 \mathrm{H} 8$ & 335112118090404 & Lakewood1_4 & $\mathrm{CB}$ & multi. & wq & 50 \\
\hline 4S/12W-5H9 & $5 \mathrm{H} 9$ & 335112118090405 & Lakewood1_5 & $\mathrm{CB}$ & multi. & wq & 50 \\
\hline 4S/12W-5H10 & $5 \mathrm{H} 10$ & 335112118090406 & Lakewood1_6 & $\mathrm{CB}$ & multi. & wq & 50 \\
\hline 4S/12W-10G1 & 10G1 & 335033118071401 & $975 \mathrm{~A}$ & $\mathrm{CB}$ & prod. & wl & 49 \\
\hline $4 \mathrm{~S} / 12 \mathrm{~W}-12 \mathrm{~F} 1$ & $12 \mathrm{~F} 1$ & 335028118053901 & Lakewood2_1 & $\mathrm{CB}$ & multi. & wq & 37 \\
\hline $4 \mathrm{~S} / 12 \mathrm{~W}-12 \mathrm{~F} 2$ & $12 \mathrm{~F} 2$ & 335028118053902 & Lakewood2_2 & $\mathrm{CB}$ & multi. & wq & 37 \\
\hline $4 \mathrm{~S} / 12 \mathrm{~W}-12 \mathrm{~F} 3$ & $12 \mathrm{~F} 3$ & 335028118053903 & Lakewood2_3 & $\mathrm{CB}$ & multi. & wq & 37 \\
\hline $4 \mathrm{~S} / 12 \mathrm{~W}-12 \mathrm{~F} 4$ & $12 \mathrm{~F} 4$ & 335028118053904 & Lakewood2_4 & $\mathrm{CB}$ & multi. & wq & 37 \\
\hline $4 \mathrm{~S} / 12 \mathrm{~W}-12 \mathrm{~F} 5$ & $12 \mathrm{~F} 5$ & 335028118053905 & Lakewood2_5 & $\mathrm{CB}$ & multi. & wq & 37 \\
\hline $4 \mathrm{~S} / 12 \mathrm{~W}-12 \mathrm{~F} 6$ & $12 \mathrm{~F} 6$ & 335028118053906 & Lakewood2_6 & $\mathrm{CB}$ & multi. & wq & 37 \\
\hline $4 \mathrm{~S} / 12 \mathrm{~W}-12 \mathrm{~F} 7$ & $12 \mathrm{~F} 7$ & 335028118053907 & Lakewood2_7 & $\mathrm{CB}$ & multi. & wq & 37 \\
\hline $4 \mathrm{~S} / 12 \mathrm{~W}-12 \mathrm{~F} 8$ & $12 \mathrm{~F} 8$ & 335028118053908 & Lakewood2_8 & $\mathrm{CB}$ & multi. & wq & 37 \\
\hline $4 \mathrm{~S} / 12 \mathrm{~W}-21 \mathrm{M} 8$ & $21 \mathrm{M} 8$ & 334837118085701 & Long Beach6_1 & $\mathrm{CB}$ & multi. & wq & 37 \\
\hline 4S/12W-21M9 & $21 \mathrm{M} 9$ & 334837118085702 & Long Beach6_2 & $\mathrm{CB}$ & multi. & wq & 37 \\
\hline 4S/12W-21M10 & 21M10 & 334837118085703 & Long Beach6_3 & $\mathrm{CB}$ & multi. & wq & 37 \\
\hline 4S/12W-21M11 & $21 \mathrm{M} 11$ & 334837118085704 & Long Beach6_4 & $\mathrm{CB}$ & multi. & wq & 37 \\
\hline 4S/12W-21M12 & $21 \mathrm{M} 12$ & 334837118085705 & Long Beach6_5 & $\mathrm{CB}$ & multi. & wq & 37 \\
\hline 4S/12W-21M13 & 21M13 & 334837118085706 & Long Beach6_6 & $\mathrm{CB}$ & multi. & wq & 37 \\
\hline $4 \mathrm{~S} / 12 \mathrm{~W}-23 \mathrm{~K} 3$ & $23 \mathrm{~K} 3$ & 334836118061201 & LB Annex 201 & $\mathrm{CB}$ & prod. & wq & 19 \\
\hline $4 \mathrm{~S} / 12 \mathrm{~W}-25 \mathrm{E} 1$ & $25 \mathrm{E} 1$ & 334747118055001 & $500 \mathrm{D}$ & $\mathrm{CB}$ & prod. & wl & 18 \\
\hline 4S/12W-25G1 & $25 \mathrm{G} 1$ & 334753118051901 & Long Beach1_1 & $\mathrm{CB}$ & multi. & wq & 33 \\
\hline $4 \mathrm{~S} / 12 \mathrm{~W}-25 \mathrm{G} 2$ & $25 \mathrm{G} 2$ & 334753118051902 & Long Beach1_2 & $\mathrm{CB}$ & multi. & wq & 33 \\
\hline $4 \mathrm{~S} / 12 \mathrm{~W}-25 \mathrm{G} 3$ & $25 \mathrm{G} 3$ & 334753118051903 & Long Beach1_3 & $\mathrm{CB}$ & multi. & wq & 33 \\
\hline $4 \mathrm{~S} / 12 \mathrm{~W}-25 \mathrm{G} 4$ & $25 \mathrm{G} 4$ & 334753118051904 & Long Beach1_4 & $\mathrm{CB}$ & multi. & wq & 33 \\
\hline $4 \mathrm{~S} / 12 \mathrm{~W}-25 \mathrm{G} 5$ & $25 \mathrm{G} 5$ & 334753118051905 & Long Beach1_5 & $\mathrm{CB}$ & multi. & wq & 33 \\
\hline 4S/12W-25G6 & $25 \mathrm{G} 6$ & 334753118051906 & Long Beach1_6 & $\mathrm{CB}$ & multi. & wq & 33 \\
\hline $4 \mathrm{~S} / 12 \mathrm{~W}-28 \mathrm{H} 9$ & $28 \mathrm{H} 9$ & 334746118081601 & $460 \mathrm{~K}$ & $\mathrm{CB}$ & prod. & wl & 29 \\
\hline $4 \mathrm{~S} / 12 \mathrm{~W}-30 \mathrm{~J} 1$ & $30 \mathrm{~J} 1$ & 334737118101901 & Long Beach8_1 & WCB & multi. & wq & 20 \\
\hline $4 \mathrm{~S} / 12 \mathrm{~W}-30 \mathrm{~J} 2$ & $30 \mathrm{~J} 2$ & 334737118101902 & Long Beach8_2 & WCB & multi. & wq & 20 \\
\hline 4S/12W-30J3 & $30 \mathrm{~J} 3$ & 334737118101903 & Long Beach8_3 & WCB & multi. & wq & 20 \\
\hline
\end{tabular}


ange Counties, California.-Continued

available. Well location: CB, Central Basin Pressure Area; HB, Hollywood Basin; LAF, Los Angeles Forebay; MF, Montebello Forebay; OCB, Orange County Basin; SFV, San er level; wq, water quality]

\begin{tabular}{|c|c|c|c|c|c|c|}
\hline $\begin{array}{l}\text { Well depth } \\
\text { (ft below } \\
\text { LSD) }\end{array}$ & $\begin{array}{l}\text { Depth to top } \\
\text { perforation } \\
\text { (ft below LSD) }\end{array}$ & $\begin{array}{l}\text { Depth to bottom } \\
\text { perforation } \\
\text { (ft below LSD) }\end{array}$ & $\begin{array}{c}\text { Number of } \\
\text { perforated } \\
\text { intervals }\end{array}$ & $\begin{array}{l}\text { Date, water } \\
\text { level measured } \\
\text { (mm/dd/yyyy) }\end{array}$ & $\begin{array}{c}\text { Water-level } \\
\text { elevation } \\
\text { (ft above NAVD 88) }\end{array}$ & Chronostratigraphic unit \\
\hline 2,060 & 78 & 2,020 & 15 & 09/03/2014 & 55.0 & Multiple* \\
\hline 2,220 & 180 & 2,180 & 15 & 09/03/2014 & 29.3 & Multiple* \\
\hline - & 348 & 595 & - & $09 / 14 / 2014$ & -46.9 & Pacific \\
\hline 2,000 & 195 & 2,180 & - & - & - & Multiple* \\
\hline - & 416 & 1,020 & 1 & $08 / 28 / 2014$ & -34.3 & Pacific \\
\hline 1,660 & 72 & 1,620 & 12 & $09 / 23 / 2014$ & 10.5 & Multiple* \\
\hline- & 200 & 570 & 1 & $09 / 21 / 2014$ & 3.2 & Pacific_A \\
\hline 2,050 & 212 & 2,000 & 13 & $09 / 23 / 2014$ & 18.7 & Multiple* \\
\hline 1,009 & 989 & 1,009 & 1 & $09 / 16 / 2014$ & -166.9 & Upper Wilmington A \\
\hline 660 & 640 & 660 & 1 & 09/16/2014 & -46.3 & Harbor \\
\hline 470 & 450 & 470 & 1 & 09/16/2014 & -50.7 & Harbor \\
\hline 300 & 280 & 300 & 1 & 09/16/2014 & -25.1 & Pacific_A \\
\hline 160 & 140 & 160 & 1 & 09/16/2014 & -6.9 & Mesa \\
\hline 90 & 70 & 90 & 1 & 09/16/2014 & 23.3 & Dominguez \\
\hline - & 367 & 388 & 1 & $11 / 05 / 2008$ & -65.0 & Pacific \\
\hline 2,000 & 1,960 & 2,000 & 1 & $09 / 15 / 2014$ & -45.6 & Upper Wilmington A \\
\hline 1,760 & 1,740 & 1,760 & 1 & $09 / 15 / 2014$ & -52.2 & Bent Spring \\
\hline 1,320 & 1,300 & 1,320 & 1 & $09 / 15 / 2014$ & -61.2 & Harbor \\
\hline 1,015 & 995 & 1,015 & 1 & $09 / 15 / 2014$ & -71.8 & Pacific \\
\hline 710 & 690 & 710 & 1 & $09 / 15 / 2014$ & -55.5 & Pacific \\
\hline 575 & 555 & 575 & 1 & $09 / 15 / 2014$ & -32.3 & Pacific_A \\
\hline 275 & 255 & 275 & 1 & $09 / 15 / 2014$ & 15.2 & Mesa \\
\hline 120 & 110 & 120 & 1 & $09 / 15 / 2014$ & 17.2 & Dominguez \\
\hline 1,530 & 1,490 & 1,510 & 1 & 09/16/2014 & -62.3 & Long Beach A \\
\hline 950 & 930 & 950 & 1 & 09/16/2014 & -78.7 & Upper Wilmington B \\
\hline 760 & 740 & 760 & 1 & 09/16/2014 & -80.0 & Upper Wilmington B \\
\hline 500 & 480 & 500 & 1 & 09/16/2014 & -126.3 & Upper Wilmington A \\
\hline 400 & 380 & 400 & 1 & 09/16/2014 & -126.3 & Bent Spring \\
\hline 240 & 220 & 240 & 1 & 09/16/2014 & -40.8 & Pacific \\
\hline 838 & 507 & 838 & 1 & - & - & Bent Spring \\
\hline 1,186 & 1,124 & 1,146 & 1 & 09/18/2009 & -55.3 & Pacific \\
\hline 1,470 & 1,430 & 1,450 & 1 & 09/16/2014 & -47.0 & Upper Wilmington B \\
\hline 1,250 & 1,230 & 1,250 & 1 & 09/16/2014 & -49.7 & Upper Wilmington B \\
\hline 990 & 970 & 990 & 1 & $09 / 16 / 2014$ & -88.0 & Upper Wilmington A \\
\hline 619 & 599 & 619 & 1 & $09 / 16 / 2014$ & -47.1 & Harbor \\
\hline 420 & 400 & 420 & 1 & 09/16/2014 & -43.7 & Pacific \\
\hline 175 & 155 & 175 & 1 & 09/16/2014 & -18.5 & Mesa \\
\hline 550 & 143 & 550 & 1 & 09/18/2014 & -108.2 & Harbor \\
\hline 1,495 & 1,435 & 1,455 & 1 & 09/19/2014 & -15.7 & Long Beach A \\
\hline 1,040 & 1,020 & 1,040 & 1 & 09/19/2014 & -31.0 & Lower Wilmington \\
\hline 800 & 780 & 800 & 1 & 09/19/2014 & -38.3 & Upper Wilmington B \\
\hline
\end{tabular}


Table 1.1. Site identification, well-construction, water-level, and chronostratigraphic unit information for wells used in this study, Los Angeles and Or

[USGS, U.S. Geological Survey; ft, foot; LSD, land surface datum; mm/dd/yyyy, month/day/year; NAVD 88, North American Vertical Datum of 1988; n.a., not assigned; -, not Fernando Valley; SGV, San Gabriel Valley; SMB, Santa Monica Basin; W, Whittier area. Well type: multi., multiple well; obs., observation; prod., production. Well data: wl, wa

\begin{tabular}{|c|c|c|c|c|c|c|c|}
\hline $\begin{array}{l}\text { State well } \\
\text { number }\end{array}$ & $\begin{array}{c}\text { State well } \\
\text { number } \\
\text { (abbreviated) }\end{array}$ & USGS site number & Local well name & $\begin{array}{c}\text { Well } \\
\text { location }\end{array}$ & $\begin{array}{l}\text { Well } \\
\text { type }\end{array}$ & $\begin{array}{l}\text { Well } \\
\text { data }\end{array}$ & $\begin{array}{c}\text { Altitude of LSD } \\
\text { (ft above NAVD 88) }\end{array}$ \\
\hline 4S/12W-30J4 & $30 \mathrm{~J} 4$ & 334737118101904 & Long Beach8_4 & WCB & multi. & wq & 20 \\
\hline 4S/12W-30J5 & $30 J 5$ & 334737118101905 & Long Beach8_5 & WCB & multi. & wq & 20 \\
\hline 4S/12W-30J6 & $30 \mathrm{~J} 6$ & 334737118101906 & Long Beach8_6 & WCB & multi. & wq & 20 \\
\hline 4S/12W-32G1 & $32 \mathrm{G} 1$ & n.a. & 441 & WCB & obs. & wl & 41 \\
\hline $4 \mathrm{~S} / 13 \mathrm{~W}-1 \mathrm{~N} 3$ & $1 \mathrm{~N} 3$ & 335100118120401 & Long Beach2_1 & $\mathrm{CB}$ & multi. & wq & 44 \\
\hline $4 \mathrm{~S} / 13 \mathrm{~W}-1 \mathrm{~N} 4$ & $1 \mathrm{~N} 4$ & 335100118120402 & Long Beach2_2 & $\mathrm{CB}$ & multi. & $\mathrm{wq}$ & 44 \\
\hline 4S/13W-1N5 & $1 \mathrm{~N} 5$ & 335100118120403 & Long Beach2_3 & $\mathrm{CB}$ & multi. & wq & 44 \\
\hline $4 \mathrm{~S} / 13 \mathrm{~W}-1 \mathrm{~N} 6$ & 1N6 & 335100118120404 & Long Beach2_4 & $\mathrm{CB}$ & multi. & wq & 44 \\
\hline $4 \mathrm{~S} / 13 \mathrm{~W}-1 \mathrm{~N} 7$ & $1 \mathrm{~N} 7$ & 335100118120405 & Long Beach2_5 & $\mathrm{CB}$ & multi. & wq & 44 \\
\hline $4 \mathrm{~S} / 13 \mathrm{~W}-1 \mathrm{~N} 8$ & $1 \mathrm{~N} 8$ & 335100118120406 & Long Beach2_6 & $\mathrm{CB}$ & multi. & wq & 44 \\
\hline $4 \mathrm{~S} / 13 \mathrm{~W}-5 \mathrm{~F} 1$ & $5 \mathrm{~F} 1$ & 335126118155801 & Carson3_1 & WCB & multi. & wq & 22 \\
\hline $4 \mathrm{~S} / 13 \mathrm{~W}-5 \mathrm{~F} 2$ & $5 \mathrm{~F} 2$ & 335126118155802 & Carson3_2 & WCB & multi. & wq & 22 \\
\hline 4S/13W-5F3 & $5 \mathrm{~F} 3$ & 335126118155803 & Carson3_3 & WCB & multi. & wq & 22 \\
\hline 4S/13W-5F4 & $5 \mathrm{~F} 4$ & 335126118155804 & Carson3_4 & WCB & multi. & wq & 22 \\
\hline 4S/13W-5F5 & $5 \mathrm{~F} 5$ & 335126118155805 & Carson3_5 & WCB & multi. & wq & 22 \\
\hline 4S/13W-5F6 & $5 \mathrm{~F} 6$ & 335126118155806 & Carson3_6 & WCB & multi. & wq & 22 \\
\hline 4S/13W-9H9 & $9 \mathrm{H} 9$ & 335013118142501 & Carson1_1 & WCB & multi. & wq & 27 \\
\hline 4S/13W-9H10 & $9 \mathrm{H} 10$ & 335013118142502 & Carson1_2 & WCB & multi. & wq & 27 \\
\hline 4S/13W-9H11 & $9 \mathrm{H} 11$ & 335013118142503 & Carson1_3 & WCB & multi. & wq & 27 \\
\hline 4S/13W-9H12 & $9 \mathrm{H} 12$ & 335013118142504 & Carson1_4 & WCB & multi. & wq & 27 \\
\hline 4S/13W-12K1 & $12 \mathrm{~K} 1$ & n.a. & $906 \mathrm{D}$ & $\mathrm{CB}$ & prod. & wl & 91 \\
\hline 4S/13W-18K1 & $18 \mathrm{~K} 1$ & 334921118165301 & Carson2_1 & WCB & multi. & wq & 42 \\
\hline 4S/13W-18K2 & $18 \mathrm{~K} 2$ & 334921118165302 & Carson2_2 & WCB & multi. & wq & 42 \\
\hline $4 \mathrm{~S} / 13 \mathrm{~W}-18 \mathrm{~K} 3$ & $18 \mathrm{~K} 3$ & 334921118165303 & Carson2_3 & WCB & multi. & wq & 42 \\
\hline 4S/13W-18K4 & $18 \mathrm{~K} 4$ & 334921118165304 & Carson2_4 & WCB & multi. & wq & 42 \\
\hline 4S/13W-18K5 & $18 \mathrm{~K} 5$ & 334921118165305 & Carson2_5 & WCB & multi. & wq & 42 \\
\hline $4 \mathrm{~S} / 13 \mathrm{~W}-21 \mathrm{H} 5$ & $21 \mathrm{H} 5$ & n.a. & $868 \mathrm{H}$ & WCB & prod. & wl & 23 \\
\hline $4 \mathrm{~S} / 13 \mathrm{~W}-23 \mathrm{~B} 2$ & 23B2 & 334905118124601 & $888 \mathrm{~F}$ & WCB & prod. & wl & 29 \\
\hline 4S/13W-23D3 & 23D3 & 334904118130301 & Long Beach3_1 & WCB & multi. & wq & 26 \\
\hline 4S/13W-23D4 & 23D4 & 334904118130302 & Long Beach3_2 & WCB & multi. & wq & 26 \\
\hline 4S/13W-23D5 & 23D5 & 334904118130303 & Long Beach3_3 & WCB & multi. & wq & 26 \\
\hline 4S/13W-23D6 & 23D6 & 334904118130304 & Long Beach3_4 & WCB & multi. & wq & 26 \\
\hline $4 \mathrm{~S} / 13 \mathrm{~W}-23 \mathrm{D} 7$ & $23 \mathrm{D} 7$ & 334904118130305 & Long Beach3_5 & WCB & multi. & wq & 26 \\
\hline $4 \mathrm{~S} / 13 \mathrm{~W}-23 \mathrm{~N} 3$ & $23 \mathrm{~N} 3$ & 334814118131301 & $889 \mathrm{P}$ & WCB & obs. & wq & 20 \\
\hline 4S/13W-26F5 & $26 \mathrm{~F} 5$ & 334749118124901 & $380 \mathrm{P}$ & WCB & obs. & wq & 15 \\
\hline $4 \mathrm{~S} / 13 \mathrm{~W}-27 \mathrm{H} 4$ & $27 \mathrm{H} 4$ & 334747118132301 & Long Beach7_1 & WCB & multi. & wq & 19 \\
\hline 4S/13W-27H5 & $27 \mathrm{H} 5$ & 334747118132302 & Long Beach7_2 & WCB & multi. & wq & 19 \\
\hline 4S/13W-27H6 & $27 \mathrm{H} 6$ & 334747118132303 & Long Beach7_3 & WCB & multi. & wq & 19 \\
\hline $4 \mathrm{~S} / 13 \mathrm{~W}-27 \mathrm{H} 7$ & $27 \mathrm{H} 7$ & 334747118132304 & Long Beach7_4 & WCB & multi. & wq & 19 \\
\hline $4 \mathrm{~S} / 13 \mathrm{~W}-28 \mathrm{~A} 3$ & $28 \mathrm{~A} 3$ & 334802118141801 & Wilmington1_1 & WCB & multi. & wq & 33 \\
\hline 4S/13W-28A4 & $28 \mathrm{~A} 4$ & 334802118141802 & Wilmington1_2 & WCB & multi. & wq & 33 \\
\hline
\end{tabular}


ange Counties, California.-Continued

available. Well location: CB, Central Basin Pressure Area; HB, Hollywood Basin; LAF, Los Angeles Forebay; MF, Montebello Forebay; OCB, Orange County Basin; SFV, San er level; wq, water quality]

\begin{tabular}{|c|c|c|c|c|c|c|}
\hline $\begin{array}{l}\text { Well depth } \\
\text { (ft below } \\
\text { LSD) }\end{array}$ & $\begin{array}{c}\text { Depth to top } \\
\text { perforation } \\
\text { (ft below LSD) }\end{array}$ & $\begin{array}{c}\text { Depth to bottom } \\
\text { perforation } \\
\text { (ft below LSD) }\end{array}$ & $\begin{array}{c}\text { Number of } \\
\text { perforated } \\
\text { intervals }\end{array}$ & $\begin{array}{c}\text { Date, water } \\
\text { level measured } \\
\text { (mm/dd/yyyy) }\end{array}$ & $\begin{array}{c}\text { Water-level } \\
\text { elevation } \\
\text { (ft above NAVD 88) }\end{array}$ & Chronostratigraphic unit \\
\hline 655 & 635 & 655 & 1 & $09 / 19 / 2014$ & -36.5 & Upper Wilmington A \\
\hline 435 & 415 & 435 & 1 & $09 / 19 / 2014$ & -36.1 & Bent Spring \\
\hline 185 & 165 & 185 & 1 & $09 / 19 / 2014$ & 1.5 & Mesa \\
\hline 130 & 110 & 130 & 1 & $10 / 01 / 2013$ & 3.5 & Mesa \\
\hline 1,090 & 970 & 990 & 1 & $09 / 15 / 2014$ & -102.7 & Upper Wilmington A \\
\hline 740 & 720 & 740 & 1 & $09 / 15 / 2014$ & -56.0 & Bent Spring \\
\hline 470 & 450 & 470 & 1 & $09 / 15 / 2014$ & -43.5 & Pacific \\
\hline 300 & 280 & 300 & 1 & $09 / 15 / 2014$ & -15.1 & Pacific_A \\
\hline 180 & 160 & 180 & 1 & $09 / 15 / 2014$ & -2.3 & Mesa \\
\hline 115 & 95 & 115 & 1 & $09 / 15 / 2014$ & 0.7 & Dominguez \\
\hline 1,800 & 1,600 & 1,620 & 1 & $09 / 15 / 2014$ & -34.6 & Long Beach A \\
\hline 1,240 & 1,220 & 1,240 & 1 & $09 / 15 / 2014$ & -39.9 & Upper Wilmington B \\
\hline 1,100 & 1,080 & 1,100 & 1 & $09 / 15 / 2014$ & -42.5 & Upper Wilmington B \\
\hline 890 & 870 & 890 & 1 & $09 / 15 / 2014$ & -42.7 & Upper Wilmington A \\
\hline 640 & 620 & 640 & 1 & $09 / 15 / 2014$ & -42.8 & Upper Wilmington A \\
\hline 380 & 360 & 380 & 1 & $09 / 15 / 2014$ & -18.1 & Harbor \\
\hline 1,010 & 990 & 1,010 & 1 & $10 / 09 / 2014$ & -43.1 & Upper Wilmington A \\
\hline 760 & 740 & 760 & 1 & $10 / 09 / 2014$ & -42.2 & Upper Wilmington A \\
\hline 480 & 460 & 480 & 1 & $10 / 09 / 2014$ & -14.5 & Harbor \\
\hline 270 & 250 & 270 & 1 & $10 / 09 / 2014$ & -13.2 & Pacific \\
\hline 1,285 & 915 & 1,000 & - & $10 / 16 / 2014$ & -74.7 & Upper Wilmington A \\
\hline 1,290 & 1,230 & 1,250 & 1 & $09 / 18 / 2014$ & -34.6 & Lower Wilmington \\
\hline 870 & 850 & 870 & 1 & $09 / 18 / 2014$ & -30.6 & Upper Wilmington A \\
\hline 620 & 600 & 620 & 1 & $09 / 18 / 2014$ & -30.3 & Upper Wilmington A \\
\hline 470 & 450 & 470 & 1 & $09 / 18 / 2014$ & -27.1 & Bent Spring \\
\hline 250 & 230 & 250 & 1 & $09 / 18 / 2014$ & -24.8 & Pacific \\
\hline 721 & 440 & 709 & 1 & $10 / 26 / 1994$ & -59.7 & Upper Wilmington A \\
\hline- & 650 & 900 & 1 & $10 / 22 / 2013$ & -43.3 & Upper Wilmington A \\
\hline 1,390 & 1,350 & 1,390 & 1 & $09 / 15 / 2014$ & -32.3 & Long Beach A \\
\hline 1,017 & 997 & 1,017 & 1 & $09 / 15 / 2014$ & -39.9 & Upper Wilmington B \\
\hline 690 & 670 & 690 & 1 & $09 / 15 / 2014$ & -39.9 & Upper Wilmington A \\
\hline 550 & 530 & 550 & 1 & $09 / 15 / 2014$ & -40.4 & Bent Spring \\
\hline 430 & 410 & 430 & 1 & $09 / 15 / 2014$ & 0.3 & Harbor \\
\hline 471 & 460 & 470 & 1 & $05 / 05 / 2014$ & -39.5 & Upper Wilmington A \\
\hline 500 & 483 & 493 & 1 & $02 / 12 / 2009$ & -9.8 & Upper Wilmington A \\
\hline 1,400 & 1,180 & 1,200 & 1 & $09 / 22 / 2014$ & -30.8 & Long Beach A \\
\hline 670 & 650 & 670 & 1 & $09 / 22 / 2014$ & -37.7 & Upper Wilmington A \\
\hline 490 & 470 & 490 & 1 & $09 / 22 / 2014$ & -37.7 & Upper Wilmington A \\
\hline 380 & 360 & 380 & 1 & $09 / 22 / 2014$ & -29.5 & Bent Spring \\
\hline 1,035 & 915 & 935 & 1 & $09 / 15 / 2014$ & -35.8 & Upper Wilmington B \\
\hline 800 & 780 & 800 & 1 & $09 / 15 / 2014$ & -36.5 & Upper Wilmington B \\
\hline
\end{tabular}


Table 1.1. Site identification, well-construction, water-level, and chronostratigraphic unit information for wells used in this study, Los Angeles and Or

[USGS, U.S. Geological Survey; ft, foot; LSD, land surface datum; mm/dd/yyyy, month/day/year; NAVD 88, North American Vertical Datum of 1988; n.a., not assigned; -, not Fernando Valley; SGV, San Gabriel Valley; SMB, Santa Monica Basin; W, Whittier area. Well type: multi., multiple well; obs., observation; prod., production. Well data: wl, wa

\begin{tabular}{|c|c|c|c|c|c|c|c|}
\hline $\begin{array}{l}\text { State well } \\
\text { number }\end{array}$ & $\begin{array}{c}\text { State well } \\
\text { number } \\
\text { (abbreviated) }\end{array}$ & USGS site number & Local well name & $\begin{array}{c}\text { Well } \\
\text { location }\end{array}$ & $\begin{array}{l}\text { Well } \\
\text { type }\end{array}$ & $\begin{array}{l}\text { Well } \\
\text { data }\end{array}$ & $\begin{array}{c}\text { Altitude of LSD } \\
\text { (ft above NAVD 88) }\end{array}$ \\
\hline 4S/13W-28A5 & $28 \mathrm{~A} 5$ & 334802118141803 & Wilmington1_3 & WCB & multi. & wq & 33 \\
\hline 4S/13W-28A6 & $28 \mathrm{~A} 6$ & 334802118141804 & Wilmington1_4 & WCB & multi. & wq & 33 \\
\hline 4S/13W-28A7 & $28 \mathrm{~A} 7$ & 334802118141805 & Wilmington1_5 & WCB & multi. & wq & 33 \\
\hline 4S/13W-29H5 & $29 \mathrm{H} 5$ & 334759118152801 & $340 \mathrm{~L}$ & WCB & multi. & wq & 43 \\
\hline 4S/13W-29H6 & $29 \mathrm{H} 6$ & 334759118152802 & $340 \mathrm{M}$ & WCB & multi. & wq & 43 \\
\hline 4S/13W-29H7 & $29 \mathrm{H} 7$ & 334759118152803 & $340 \mathrm{~N}$ & WCB & multi. & $\mathrm{wq}$ & 43 \\
\hline 4S/13W-30G1 & $30 \mathrm{G} 1$ & n.a. & $310 \mathrm{C}$ & WCB & prod. & wl & 40 \\
\hline 4S/13W-31J1 & $31 \mathrm{~J} 1$ & 334656118162801 & $321 \mathrm{~A}$ & WCB & obs. & wq & 24 \\
\hline $4 \mathrm{~S} / 13 \mathrm{~W}-32 \mathrm{~F} 1$ & $32 \mathrm{~F} 1$ & 334657118160001 & Wilmington2_1 & WCB & multi. & wq & 32 \\
\hline $4 \mathrm{~S} / 13 \mathrm{~W}-32 \mathrm{~F} 2$ & $32 \mathrm{~F} 2$ & 334657118160002 & Wilmington2_2 & WCB & multi. & wq & 32 \\
\hline $4 \mathrm{~S} / 13 \mathrm{~W}-32 \mathrm{~F} 3$ & $32 \mathrm{~F} 3$ & 334657118160003 & Wilmington2_3 & WCB & multi. & wq & 32 \\
\hline $4 \mathrm{~S} / 13 \mathrm{~W}-32 \mathrm{~F} 4$ & $32 \mathrm{~F} 4$ & 334657118160004 & Wilmington2_4 & WCB & multi. & wq & 32 \\
\hline 4S/13W-32F5 & $32 \mathrm{~F} 5$ & 334657118160005 & Wilmington2_5 & WCB & multi. & wq & 32 \\
\hline 4S/13W-34A1 & $34 \mathrm{~A} 1$ & 334720118133201 & $371 \mathrm{D}$ & WCB & obs. & wq & 9 \\
\hline 4S/13W-34M1 & 34M1 & 334654118141801 & $361 \mathrm{H}$ & WCB & obs. & wq & 6 \\
\hline 4S/13W-35B2 & $35 \mathrm{~B} 2$ & 334712118124301 & $381 \mathrm{~J}$ & WCB & obs. & wq & 9 \\
\hline 4S/13W-35B3 & $35 \mathrm{~B} 3$ & 334712118124302 & $381 \mathrm{~K}$ & WCB & obs. & wq & 9 \\
\hline $4 \mathrm{~S} / 14 \mathrm{~W}-1 \mathrm{~F} 2$ & $1 \mathrm{~F} 2$ & n.a. & 794B & WCB & prod. & wl & 53 \\
\hline 4S/14W-2N1 & $2 \mathrm{~N} 1$ & 335033118193101 & PM-3 Madrid_1 & WCB & multi. & wq & 67 \\
\hline $4 \mathrm{~S} / 14 \mathrm{~W}-2 \mathrm{~N} 2$ & $2 \mathrm{~N} 2$ & 335033118193102 & PM-3 Madrid_2 & WCB & multi. & wq & 67 \\
\hline $4 \mathrm{~S} / 14 \mathrm{~W}-2 \mathrm{~N} 3$ & $2 \mathrm{~N} 3$ & 335033118193103 & PM-3 Madrid_3 & WCB & multi. & wq & 67 \\
\hline $4 \mathrm{~S} / 14 \mathrm{~W}-2 \mathrm{~N} 4$ & $2 \mathrm{~N} 4$ & 335033118193104 & PM-3 Madrid_4 & WCB & multi. & wq & 67 \\
\hline 4S/14W-4Q1 & 4Q1 & 335059118205801 & PM-4 Mariner_1 & WCB & multi. & wq & 98 \\
\hline 4S/14W-4Q2 & 4Q2 & 335059118205802 & PM-4 Mariner_2 & WCB & multi. & wq & 98 \\
\hline 4S/14W-4Q3 & 4Q3 & 335059118205803 & PM-4 Mariner_3 & WCB & multi. & wq & 98 \\
\hline 4S/14W-4Q4 & 4Q4 & 335059118205804 & PM-4 Mariner_4 & WCB & multi. & wq & 98 \\
\hline 4S/14W-7C3 & $7 \mathrm{C} 3$ & n.a. & $715 \mathrm{D}$ & WCB & obs. & wl & 62 \\
\hline 4S/14W-8E3 & $8 \mathrm{E} 3$ & n.a. & $725 \mathrm{~J}$ & WCB & obs. & wl & 136 \\
\hline 4S/14W-8G1 & $8 \mathrm{G} 1$ & n.a. & 735 & WCB & obs. & wl & 97 \\
\hline 4S/14W-9Q1 & 9Q1 & n.a. & 746 & WCB & prod. & wl & 103 \\
\hline $4 \mathrm{~S} / 14 \mathrm{~W}-10 \mathrm{C} 1$ & $10 \mathrm{C} 1$ & 335038118201301 & PM-1 Columbia_1 & WCB & multi. & wq & 81 \\
\hline 4S/14W-10C2 & $10 \mathrm{C} 2$ & 335038118201302 & PM-1 Columbia_2 & WCB & multi. & wq & 81 \\
\hline 4S/14W-15E1 & $15 \mathrm{E} 1$ & 334944118203301 & Torrance2_1 & WCB & multi. & wq & 81 \\
\hline 4S/14W-15E2 & $15 \mathrm{E} 2$ & 334944118203302 & Torrance2_2 & WCB & multi. & wq & 81 \\
\hline 4S/14W-15E3 & $15 \mathrm{E} 3$ & 334944118203303 & Torrance2_3 & WCB & multi. & wq & 81 \\
\hline 4S/14W-15E4 & $15 \mathrm{E} 4$ & 334944118203304 & Torrance2_4 & WCB & multi. & wq & 81 \\
\hline 4S/14W-15E5 & $15 \mathrm{E} 5$ & 334944118203305 & Torrance2_5 & WCB & multi. & wq & 81 \\
\hline 4S/14W-15E6 & $15 \mathrm{E} 6$ & 334944118203306 & Torrance2_6 & WCB & multi. & wq & 81 \\
\hline 4S/14W-15N1 & $15 \mathrm{~N} 1$ & 334904118202401 & $758 \mathrm{~F}$ & WCB & obs. & wl & 78 \\
\hline 4S/14W-17R3 & $17 \mathrm{R} 3$ & n.a. & $737 \mathrm{H}$ & WCB & obs. & wl & 77 \\
\hline 4S/14W-22Q1 & 22Q1 & n.a. & 769 & WCB & - & wl & 74 \\
\hline
\end{tabular}


ange Counties, California.-Continued

available. Well location: CB, Central Basin Pressure Area; HB, Hollywood Basin; LAF, Los Angeles Forebay; MF, Montebello Forebay; OCB, Orange County Basin; SFV, San er level; wq, water quality]

\begin{tabular}{|c|c|c|c|c|c|c|}
\hline $\begin{array}{l}\text { Well depth } \\
\text { (ft below } \\
\text { LSD) }\end{array}$ & $\begin{array}{l}\text { Depth to top } \\
\text { perforation } \\
\text { (ft below LSD) }\end{array}$ & $\begin{array}{l}\text { Depth to bottom } \\
\text { perforation } \\
\text { (ft below LSD) }\end{array}$ & $\begin{array}{c}\text { Number of } \\
\text { perforated } \\
\text { intervals }\end{array}$ & $\begin{array}{l}\text { Date, water } \\
\text { level measured } \\
\text { (mm/dd/yyyy) }\end{array}$ & $\begin{array}{c}\text { Water-level } \\
\text { elevation } \\
\text { (ft above NAVD 88) }\end{array}$ & Chronostratigraphic unit \\
\hline 570 & 550 & 570 & 1 & $09 / 15 / 2014$ & -36.5 & Upper Wilmington A \\
\hline 245 & 225 & 245 & 1 & $09 / 15 / 2014$ & -11.5 & Pacific \\
\hline 140 & 120 & 140 & 1 & $09 / 15 / 2014$ & -8.4 & Mesa \\
\hline 166 & 121 & 156 & 1 & $09 / 02 / 2014$ & -17.8 & Pacific \\
\hline 391 & 201 & 381 & 1 & $09 / 02 / 2014$ & -25.8 & Harbor \\
\hline 734 & 424 & 724 & 1 & $09 / 02 / 2014$ & -28.1 & Upper Wilmington A \\
\hline 682 & 210 & 420 & 1 & $10 / 09 / 2013$ & -29.0 & Harbor \\
\hline 670 & 659 & 669 & 1 & $09 / 02 / 2014$ & -25.6 & Lower Wilmington \\
\hline 1,030 & 950 & 970 & 1 & $09 / 15 / 2014$ & -28.6 & Long Beach B \\
\hline 775 & 755 & 775 & 1 & $09 / 15 / 2014$ & -25.7 & Long Beach A \\
\hline 560 & 540 & 560 & 1 & $09 / 15 / 2014$ & -21.5 & Lower Wilmington \\
\hline 410 & 390 & 410 & 1 & $09 / 15 / 2014$ & -20.4 & Upper Wilmington B \\
\hline 140 & 120 & 140 & 1 & $09 / 15 / 2014$ & -5.1 & Mesa \\
\hline 650 & 640 & 650 & 1 & $10 / 23 / 2014$ & -36.9 & Long Beach A \\
\hline 735 & 724 & 734 & 1 & $10 / 22 / 2014$ & -29.6 & Long Beach A \\
\hline 713 & 693 & 703 & 1 & $10 / 23 / 2014$ & -62.7 & Lower Wilmington \\
\hline 398 & 378 & 388 & 1 & $10 / 23 / 2014$ & -2.4 & Upper Wilmington B \\
\hline 600 & 477 & 540 & 1 & $04 / 22 / 1999$ & -51.7 & Bent Spring \\
\hline 683 & 640 & 680 & 1 & $09 / 16 / 2014$ & -12.2 & Bent Spring \\
\hline 518 & 480 & 520 & 1 & $09 / 16 / 2014$ & -9.6 & Harbor \\
\hline 273 & 240 & 280 & 1 & $09 / 16 / 2014$ & -9.4 & Pacific \\
\hline 188 & 145 & 185 & 1 & $09 / 16 / 2014$ & -9.4 & Pacific \\
\hline 720 & 670 & 710 & 1 & $09 / 16 / 2014$ & -5.1 & Bent Spring \\
\hline 550 & 500 & 540 & 1 & $09 / 16 / 2014$ & -2.5 & Harbor \\
\hline 390 & 340 & 380 & 1 & $09 / 16 / 2014$ & 0.7 & Pacific \\
\hline 250 & 200 & 240 & 1 & $09 / 16 / 2014$ & 0.8 & Pacific \\
\hline - & 399 & 409 & 1 & $10 / 21 / 2013$ & 4.1 & Bent Spring \\
\hline 283 & 248 & 258 & 1 & $10 / 22 / 2013$ & 16.6 & Pacific \\
\hline 295 & 154 & 284 & 1 & $10 / 24 / 2013$ & 3.0 & Pacific \\
\hline - & 234 & 388 & 1 & $10 / 15 / 2013$ & -2.1 & Harbor \\
\hline 600 & 555 & 595 & 1 & $09 / 16 / 2014$ & -8.8 & Bent Spring \\
\hline 505 & 460 & 500 & 1 & $09 / 16 / 2014$ & -8.5 & Harbor \\
\hline 1,235 & 1,195 & 1,235 & 1 & $09 / 16 / 2014$ & -33.5 & Long Beach A \\
\hline 925 & 905 & 925 & 1 & $09 / 16 / 2014$ & -11.3 & Upper Wilmington B \\
\hline 790 & 770 & 790 & 1 & $09 / 16 / 2014$ & -10.4 & Upper Wilmington A \\
\hline 550 & 530 & 550 & 1 & 09/16/2014 & -2.9 & Bent Spring \\
\hline 410 & 390 & 410 & 1 & $09 / 16 / 2014$ & -1.9 & Harbor \\
\hline 260 & 240 & 260 & 1 & $09 / 16 / 2014$ & -1.4 & Pacific \\
\hline 380 & 360 & 370 & 1 & $04 / 23 / 2007$ & -4.9 & Harbor \\
\hline 190 & 150 & 180 & 1 & $04 / 17 / 2011$ & 4.2 & Mesa \\
\hline- & 310 & 320 & 1 & $10 / 09 / 2013$ & -7.6 & Harbor \\
\hline
\end{tabular}


Table 1.1. Site identification, well-construction, water-level, and chronostratigraphic unit information for wells used in this study, Los Angeles and Or

[USGS, U.S. Geological Survey; ft, foot; LSD, land surface datum; mm/dd/yyyy, month/day/year; NAVD 88, North American Vertical Datum of 1988; n.a., not assigned; -, not Fernando Valley; SGV, San Gabriel Valley; SMB, Santa Monica Basin; W, Whittier area. Well type: multi., multiple well; obs., observation; prod., production. Well data: wl, wa

\begin{tabular}{|c|c|c|c|c|c|c|c|}
\hline $\begin{array}{l}\text { State well } \\
\text { number }\end{array}$ & $\begin{array}{c}\text { State well } \\
\text { number } \\
\text { (abbreviated) }\end{array}$ & USGS site number & Local well name & $\begin{array}{c}\text { Well } \\
\text { location }\end{array}$ & $\begin{array}{l}\text { Well } \\
\text { type }\end{array}$ & $\begin{array}{l}\text { Well } \\
\text { data }\end{array}$ & $\begin{array}{c}\text { Altitude of LSD } \\
\text { (ft above NAVD 88) }\end{array}$ \\
\hline 4S/14W-26A2 & $26 \mathrm{~A} 2$ & 334815118184701 & Lomita1_1 & WCB & multi. & wq & 77 \\
\hline $4 \mathrm{~S} / 14 \mathrm{~W}-26 \mathrm{~A} 3$ & $26 \mathrm{~A} 3$ & 334815118184702 & Lomita1_2 & WCB & multi. & wq & 77 \\
\hline 4S/14W-26A4 & $26 \mathrm{~A} 4$ & 334815118184703 & Lomita1_3 & WCB & multi. & wq & 77 \\
\hline 4S/14W-26A5 & $26 \mathrm{~A} 5$ & 334815118184704 & Lomita1_4 & WCB & multi. & wq & 77 \\
\hline $4 \mathrm{~S} / 14 \mathrm{~W}-26 \mathrm{~A} 6$ & $26 \mathrm{~A} 6$ & 334815118184705 & Lomita1_5 & WCB & multi. & wq & 77 \\
\hline $4 \mathrm{~S} / 14 \mathrm{~W}-26 \mathrm{~A} 7$ & $26 \mathrm{~A} 7$ & 334815118184706 & Lomita1_6 & WCB & multi. & wq & 77 \\
\hline 4S/14W-35D10 & $35 \mathrm{D} 10$ & 334714118192701 & Chandler3_1 & WCB & multi. & wq & 156 \\
\hline 4S/14W-35D11 & $35 \mathrm{D} 11$ & 334714118192702 & Chandler3_2 & WCB & multi. & wq & 156 \\
\hline $5 \mathrm{~S} / 11 \mathrm{~W}-3 \mathrm{~N} 5$ & $3 \mathrm{~N} 5$ & n.a. & WM-RES2 & OCB & prod. & wl & 31 \\
\hline $5 \mathrm{~S} / 11 \mathrm{~W}-7 \mathrm{C} 1$ & $7 \mathrm{C} 1$ & 334534118042001 & NVLW-SB6 & OCB & - & wl & 12 \\
\hline $5 \mathrm{~S} / 11 \mathrm{~W}-8 \mathrm{~A} 1$ & $8 \mathrm{~A} 1$ & n.a. & SBM-1 & $\mathrm{OCB}$ & multi & wl & 19 \\
\hline 5S/11W-17D10 & $17 \mathrm{D} 10$ & n.a. & NVLW-SB3 & OCB & - & wl & 9 \\
\hline 5S/11W-21L5 & $21 \mathrm{~L} 5$ & 334310118020001 & PIRT-HB & OCB & prod. & wl & 25 \\
\hline $5 \mathrm{~S} / 11 \mathrm{~W}-28 \mathrm{M} 2$ & $28 \mathrm{M} 2$ & n.a. & OCWD-BSO2 & OCB & - & wl & 4 \\
\hline $5 \mathrm{~S} / 12 \mathrm{~W}-1 \mathrm{~A} 3$ & $1 \mathrm{~A} 3$ & n.a. & SB-LEI & $\mathrm{OCB}$ & prod. & wl & 13 \\
\hline $5 \mathrm{~S} / 12 \mathrm{~W}-1 \mathrm{C} 1$ & $1 \mathrm{C} 1$ & 334620118051802 & $512 \mathrm{~B}$ & OCB & multi. & wq & 11 \\
\hline $5 \mathrm{~S} / 12 \mathrm{~W}-1 \mathrm{C} 2$ & $1 \mathrm{C} 2$ & 334620118051801 & $512 \mathrm{C}$ & OCB & multi. & $\mathrm{wq}$ & 11 \\
\hline $5 \mathrm{~S} / 12 \mathrm{~W}-1 \mathrm{C} 3$ & $1 \mathrm{C} 3$ & 334622118052001 & Seal Beach1_1 & $\mathrm{OCB}$ & multi. & wq & 12 \\
\hline $5 \mathrm{~S} / 12 \mathrm{~W}-1 \mathrm{C} 4$ & $1 \mathrm{C} 4$ & 334622118052002 & Seal Beach1_2 & OCB & multi. & wq & 12 \\
\hline $5 \mathrm{~S} / 12 \mathrm{~W}-1 \mathrm{C} 5$ & $1 \mathrm{C} 5$ & 334622118052003 & Seal Beach1_3 & OCB & multi. & wq & 12 \\
\hline $5 \mathrm{~S} / 12 \mathrm{~W}-1 \mathrm{C} 6$ & $1 \mathrm{C} 6$ & 334622118052004 & Seal Beach1_4 & OCB & multi. & wq & 12 \\
\hline $5 \mathrm{~S} / 12 \mathrm{~W}-1 \mathrm{C} 7$ & $1 \mathrm{C} 7$ & 334622118052005 & Seal Beach1_5 & $\mathrm{OCB}$ & multi. & wq & 12 \\
\hline $5 \mathrm{~S} / 12 \mathrm{~W}-1 \mathrm{C} 8$ & $1 \mathrm{C} 8$ & 334622118052006 & Seal Beach1_6 & $\mathrm{OCB}$ & multi. & wq & 12 \\
\hline $5 \mathrm{~S} / 12 \mathrm{~W}-1 \mathrm{C} 9$ & $1 \mathrm{C} 9$ & 334622118052007 & Seal Beach1_7 & OCB & multi. & wq & 12 \\
\hline $5 \mathrm{~S} / 13 \mathrm{~W}-2 \mathrm{E} 1$ & $2 \mathrm{E} 1$ & 334615118131001 & Long Beach4_1 & WCB & multi. & wq & 8 \\
\hline $5 \mathrm{~S} / 13 \mathrm{~W}-2 \mathrm{E} 2$ & $2 \mathrm{E} 2$ & 334615118131002 & Long Beach4_2 & WCB & multi. & wq & 8 \\
\hline 5S/13W-11P1 & $11 \mathrm{P} 1$ & 334445118125301 & Long Beach5_1 & WCB & multi. & wq & 13 \\
\hline $5 \mathrm{~S} / 13 \mathrm{~W}-11 \mathrm{P} 2$ & $11 \mathrm{P} 2$ & 334445118125302 & Long Beach5_2 & WCB & multi. & $\mathrm{wq}$ & 13 \\
\hline
\end{tabular}

*Full screen depths and chronostratigraphic unit information is included in the model archive. 
ange Counties, California.-Continued

available. Well location: CB, Central Basin Pressure Area; HB, Hollywood Basin; LAF, Los Angeles Forebay; MF, Montebello Forebay; OCB, Orange County Basin; SFV, San er level; wq, water quality]

\begin{tabular}{|c|c|c|c|c|c|c|}
\hline $\begin{array}{l}\text { Well depth } \\
\text { (ft below } \\
\text { LSD) }\end{array}$ & $\begin{array}{l}\text { Depth to top } \\
\text { perforation } \\
\text { (ft below LSD) }\end{array}$ & $\begin{array}{l}\text { Depth to bottom } \\
\text { perforation } \\
\text { (ft below LSD) }\end{array}$ & $\begin{array}{c}\text { Number of } \\
\text { perforated } \\
\text { intervals }\end{array}$ & $\begin{array}{c}\text { Date, water } \\
\text { level measured } \\
\text { (mm/dd/yyyy) }\end{array}$ & $\begin{array}{c}\text { Water-level } \\
\text { elevation } \\
\text { (ft above NAVD 88) }\end{array}$ & Chronostratigraphic unit \\
\hline 1,340 & 1,240 & 1,260 & 1 & $09 / 17 / 2014$ & -27.6 & Long Beach A \\
\hline 720 & 700 & 720 & 1 & 09/17/2014 & -17.9 & Upper Wilmington B \\
\hline 570 & 550 & 570 & 1 & 09/17/2014 & -16.6 & Bent Spring \\
\hline 420 & 400 & 420 & 1 & 09/17/2014 & -17.2 & Harbor \\
\hline 240 & 220 & 240 & 1 & 09/17/2014 & -15.8 & Pacific \\
\hline 120 & 100 & 120 & 1 & 09/17/2014 & -13.4 & Mesa \\
\hline 363 & 341 & 363 & 1 & 09/17/2014 & -18.6 & Bent Spring \\
\hline 192 & 165 & 192 & 1 & 09/17/2014 & -18.1 & Harbor \\
\hline- & 340 & 937 & 1 & $09 / 19 / 2014$ & -46.7 & Pacific \\
\hline - & 579 & 802 & - & $06 / 30 / 2016$ & -45.6 & Harbor \\
\hline 1,300 & 74 & 1,260 & 8 & $09 / 23 / 2014$ & 6.2 & Dominguez \\
\hline- & 300 & 680 & - & 07/01/2014 & -63.4 & Harbor \\
\hline- & 50 & 156 & 1 & $06 / 26 / 2014$ & -13.8 & Mesa \\
\hline- & 44 & 106 & - & 09/05/2014 & -12.0 & Harbor \\
\hline - & 420 & 840 & 1 & 09/29/2014 & -68.2 & Harbor \\
\hline 372 & 330 & 365 & 1 & 03/03/2016 & -7.0 & Pacific \\
\hline 470 & 425 & 465 & 1 & 03/03/2016 & -12.8 & Harbor \\
\hline 1,485 & 1,345 & 1,365 & 1 & 09/16/2014 & -45.5 & Lower Wilmington \\
\hline 1,180 & 1,160 & 1,180 & 1 & 09/16/2014 & -45.7 & Upper Wilmington B \\
\hline 1,040 & 1,020 & 1,040 & 1 & $09 / 16 / 2014$ & -45.6 & Upper Wilmington B \\
\hline 795 & 775 & 795 & 1 & 09/16/2014 & -79.0 & Upper Wilmington A \\
\hline 625 & 605 & 625 & 1 & $09 / 16 / 2014$ & -51.2 & Bent Spring \\
\hline 235 & 215 & 235 & 1 & 09/16/2014 & -10.3 & Mesa \\
\hline 70 & 60 & 70 & 1 & 09/16/2014 & -1.7 & Dominguez \\
\hline 1,380 & 1,200 & 1,220 & 1 & 09/17/2014 & -31.3 & Long Beach B \\
\hline 820 & 800 & 820 & 1 & 09/17/2014 & -12.9 & Long Beach A \\
\hline 1,110 & 1,090 & 1,110 & 1 & $09 / 16 / 2014$ & -17.1 & Long Beach A \\
\hline 355 & 335 & 355 & 1 & $09 / 16 / 2014$ & 5.5 & Bent Spring \\
\hline
\end{tabular}


Table 1.2. Groundwater-quality data used for this study from multiple-well monitoring sites, and selected production and observation wells, Los Angeles and Orange Counties, California.

[See appendix 1 for explanation. Abbreviations: ft, foot; mg/L, milligrams per liter; mm/dd/yyyy, month/day/year; ug/L, micrograms per liter; CaCO ${ }_{3}$, calcium carbonate; \%, percent; <, less than; - , no data.

\begin{tabular}{|c|c|c|c|c|c|c|c|c|c|c|c|}
\hline $\begin{array}{l}\text { State well } \\
\text { number }\end{array}$ & Local well name & $\begin{array}{c}\text { Chronostratigraphic } \\
\text { unit }\end{array}$ & $\begin{array}{c}\text { Sample } \\
\text { collection } \\
\text { date } \\
\text { (mm/dd/yyyy) }\end{array}$ & $\mathrm{pH}$ & $\begin{array}{l}\text { Dissolved solids, } \\
\text { filtered, sum of } \\
\text { constituents } \\
\text { (mg/L) }\end{array}$ & $\begin{array}{c}\text { Calcium, } \\
\text { filtered } \\
\text { (mg/L) }\end{array}$ & $\begin{array}{l}\text { Magnesium, } \\
\text { filtered } \\
\text { (mg/L) }\end{array}$ & $\begin{array}{l}\text { Potassium, } \\
\text { filtered } \\
\text { (mg/L) }\end{array}$ & $\begin{array}{l}\text { Sodium, } \\
\text { filtered } \\
\text { (mg/L) }\end{array}$ & $\begin{array}{l}\text { Alkalinity, } \\
\text { filtered } \\
\text { (mg/L as } \\
\mathrm{CaCO}_{3} \text { ) }\end{array}$ & $\begin{array}{c}\text { Chloride, } \\
\text { filtered } \\
\text { (mg/L) }\end{array}$ \\
\hline \multicolumn{12}{|c|}{ Central Basin } \\
\hline \multicolumn{12}{|c|}{ Los Angeles Forebay } \\
\hline $2 \mathrm{~S} / 13 \mathrm{~W}-3 \mathrm{P} 2$ & Los Angeles2_1 & Long Beach C & $01 / 29 / 2013$ & 7.7 & 17,000 & 210 & 240 & 59.0 & 5,700 & 560 & 10,000 \\
\hline $2 \mathrm{~S} / 13 \mathrm{~W}-3 \mathrm{P} 3$ & Los Angeles2_2 & Upper Wilmington A & 06/09/2010 & 7.5 & 1,090 & 208 & 53.7 & 9.38 & 93.0 & 322 & 204 \\
\hline $2 \mathrm{~S} / 13 \mathrm{~W}-3 \mathrm{P} 4$ & Los Angeles2_3 & Upper Wilmington A & 06/09/2010 & 7.4 & 1,080 & 216 & 52.3 & 6.76 & 95.5 & 330 & 236 \\
\hline $2 \mathrm{~S} / 13 \mathrm{~W}-3 \mathrm{P} 5$ & Los Angeles2_4 & Harbor & 06/09/2010 & 7.3 & 1,150 & 221 & 54.6 & 7.45 & 114 & 371 & 283 \\
\hline $2 \mathrm{~S} / 13 \mathrm{~W}-3 \mathrm{P} 6$ & Los Angeles2_5 & Pacific & 04/24/2013 & 7.6 & 1,400 & 190 & 62.0 & 11.0 & 160 & 300 & 170 \\
\hline $2 \mathrm{~S} / 13 \mathrm{~W}-17 \mathrm{~F} 1$ & Los Angeles1_1 & Upper Wilmington B & $04 / 25 / 2001$ & 8.1 & 351 & 54.1 & 11.7 & 4.07 & 45.2 & 186 & 22.3 \\
\hline $2 \mathrm{~S} / 13 \mathrm{~W}-17 \mathrm{~F} 2$ & Los Angeles1_2 & Upper Wilmington A & $04 / 24 / 2001$ & 7.6 & 373 & 59.6 & 14.3 & 3.58 & 47.2 & 193 & 23.3 \\
\hline 2S/13W-17F3 & Los Angeles1_3 & Bent Spring & $04 / 27 / 2001$ & 7.6 & 377 & 57.6 & 14.7 & 3.62 & 49.1 & 194 & 23.5 \\
\hline $2 \mathrm{~S} / 13 \mathrm{~W}-17 \mathrm{~F} 4$ & Los Angeles1_4 & Harbor & $04 / 26 / 2001$ & 7.6 & 462 & 78.6 & 19.7 & 4.30 & 50.3 & 212 & 42.0 \\
\hline 2S/13W-17F5 & Los Angeles1_5 & Pacific_A & $04 / 26 / 2001$ & 7.3 & 641 & 113 & 28.6 & 4.48 & 57.6 & 243 & 83.2 \\
\hline $2 \mathrm{~S} / 13 \mathrm{~W}-22 \mathrm{C} 1$ & Huntington Park1_1 & Bent Spring & 04/09/1997 & 7.8 & 341 & 58.6 & 13.9 & 3.43 & 38.7 & 185 & 21.1 \\
\hline $2 \mathrm{~S} / 13 \mathrm{~W}-22 \mathrm{C} 2$ & Huntington Park1_2 & Harbor & 04/10/1997 & 8.0 & 353 & 59.1 & 14.1 & 3.42 & 39.7 & 189 & 22.5 \\
\hline $2 \mathrm{~S} / 13 \mathrm{~W}-22 \mathrm{C} 3$ & Huntington Park1_3 & Pacific_A & 04/10/1997 & 8.0 & 466 & 79.1 & 18.8 & 3.91 & 49.0 & 202 & 42.6 \\
\hline $2 \mathrm{~S} / 13 \mathrm{~W}-22 \mathrm{C} 4$ & Huntington Park1_4 & Mesa & 04/09/1997 & 7.8 & 658 & 122 & 29.3 & 4.62 & 55.6 & 262 & 59.9 \\
\hline $2 \mathrm{~S} / 13 \mathrm{~W}-34 \mathrm{~F} 2$ & South Gate2_1 & Harbor & 09/22/2014 & 8.0 & 350 & 59.3 & 12.8 & 3.19 & 40.5 & 181 & 20.7 \\
\hline $2 \mathrm{~S} / 13 \mathrm{~W}-34 \mathrm{~F} 3$ & South Gate2_2 & Harbor & 09/22/2014 & 8.0 & 351 & 57.4 & 12.7 & 3.68 & 46.0 & 188 & 20.7 \\
\hline $2 \mathrm{~S} / 13 \mathrm{~W}-34 \mathrm{~F} 4$ & South Gate2_3 & Pacific & $09 / 22 / 2014$ & 8.0 & 340 & 53.7 & 11.2 & 2.98 & 48.6 & 184 & 21.1 \\
\hline 2S/13W-34F5 & South Gate2_4 & Pacific_A & $09 / 22 / 2014$ & 7.9 & 397 & 62.3 & 16.2 & 3.98 & 52.1 & 186 & 34.5 \\
\hline 2S/13W-34F6 & South Gate2_5 & Mesa & 09/22/2014 & 8.0 & 349 & 54.7 & 12.2 & 3.52 & 48.6 & 181 & 23.1 \\
\hline 2S/13W-34F7 & South Gate2_6 & Dominguez & 09/22/2014 & 7.9 & 367 & 61.2 & 15.2 & 2.97 & 48.0 & 207 & 23.3 \\
\hline 2S/14W-12E1 & Los Angeles3_1 & Lower Wilmington & 04/03/2012 & 8.2 & 392 & 15.0 & 5.44 & 4.09 & 112 & 255 & 36.5 \\
\hline $2 \mathrm{~S} / 14 \mathrm{~W}-12 \mathrm{E} 2$ & Los Angeles3_2 & Upper Wilmington A & $04 / 03 / 2012$ & 8.0 & 350 & 51.2 & 13.2 & 3.80 & 48.6 & 185 & 23.1 \\
\hline 2S/14W-12E3 & Los Angeles3_3 & Harbor & 04/03/2012 & 7.8 & 361 & 58.2 & 14.0 & 4.11 & 46.7 & 194 & 21.8 \\
\hline 2S/14W-12E4 & Los Angeles3_4 & Pacific & 04/03/2012 & 7.8 & 397 & 69.1 & 15.4 & 4.26 & 44.5 & 204 & 38.7 \\
\hline 2S/14W-12E5 & Los Angeles3_5 & Pacific_A & 04/03/2012 & 7.7 & 551 & 94.2 & 22.9 & 4.43 & 59.2 & 220 & 54.1 \\
\hline 2S/14W-12E6 & Los Angeles3_6 & Mesa & 04/03/2012 & 7.7 & 697 & 129 & 29.7 & 4.33 & 63.2 & 235 & 114 \\
\hline
\end{tabular}


Table 1.2. Groundwater-quality data used for this study from multiple-well monitoring sites, and selected production and observation wells, Los Angeles and Orange Counties, California.-Continued

[See appendix 1 for explanation. Abbreviations: ft, foot; mg/L, milligrams per liter; mm/dd/yyyy, month/day/year; ug/L, micrograms per liter; CaCO 3 , calcium carbonate; \%, percent; <, less than; - , no data. Sediment source/facies: LAR, Los Angeles River; n.a., not assigned; SGR, San Gabriel River; SAR, Santa Ana River, *, potentially affected by mixing with anthropogenic sources of water or seawater]

\begin{tabular}{|c|c|c|c|c|c|c|c|c|c|c|c|}
\hline $\begin{array}{l}\text { State well } \\
\text { number }\end{array}$ & Local well name & $\begin{array}{c}\text { Chronostratigraphic } \\
\text { unit }\end{array}$ & $\begin{array}{c}\text { Sample } \\
\text { collection } \\
\text { date } \\
\text { (mm/dd/yyyy) }\end{array}$ & $\mathrm{pH}$ & $\begin{array}{c}\text { Dissolved solids, } \\
\text { filtered, sum of } \\
\text { constituents } \\
\text { (mg/L) }\end{array}$ & $\begin{array}{l}\text { Calcium, } \\
\text { filtered } \\
\text { (mg/L) }\end{array}$ & $\begin{array}{l}\text { Magnesium, } \\
\text { filtered } \\
\text { (mg/L) }\end{array}$ & $\begin{array}{c}\text { Potassium, } \\
\text { filtered } \\
\text { (mg/L) }\end{array}$ & $\begin{array}{l}\text { Sodium, } \\
\text { filtered } \\
\text { (mg/L) }\end{array}$ & $\begin{array}{c}\text { Alkalinity, } \\
\text { filtered } \\
\text { (mg/L as } \\
\mathrm{CaCO}_{3} \text { ) }\end{array}$ & $\begin{array}{l}\text { Chloride, } \\
\text { filtered } \\
\text { (mg/L) }\end{array}$ \\
\hline \multicolumn{12}{|c|}{ Montebello Forebay } \\
\hline $2 \mathrm{~S} / 11 \mathrm{~W}-5 \mathrm{~N} 4$ & Whittier_14 & Mesa & $09 / 13 / 2006$ & 7.7 & 519 & 88.2 & 15.2 & 4.48 & 56.7 & 178 & 81.1 \\
\hline $2 \mathrm{~S} / 11 \mathrm{~W}-7 \mathrm{~K} 2$ & Pico Rivera3_1 & Long Beach C & 07/19/2016 & 7.7 & 379 & 84.6 & 13.4 & 3.10 & 23.5 & 149 & 30.8 \\
\hline $2 \mathrm{~S} / 11 \mathrm{~W}-7 \mathrm{~K} 3$ & Pico Rivera3_2 & Long Beach C & $07 / 19 / 2016$ & 8.0 & 317 & 66.5 & 11.6 & 3.31 & 25.6 & 164 & 17.4 \\
\hline $2 \mathrm{~S} / 11 \mathrm{~W}-7 \mathrm{~K} 4$ & Pico Rivera3_3 & Long Beach A & 07/19/2016 & 8.0 & 485 & 112 & 18.0 & 3.97 & 27.8 & 189 & 47.8 \\
\hline $2 \mathrm{~S} / 11 \mathrm{~W}-7 \mathrm{~K} 5$ & Pico Rivera3_4 & Mesa & $07 / 19 / 2016$ & 7.8 & 531 & 71.0 & 15.3 & 4.80 & 95.5 & 159 & 97.9 \\
\hline $2 \mathrm{~S} / 11 \mathrm{~W}-7 \mathrm{~K} 6$ & Pico Rivera4_1 & Long Beach C & $07 / 20 / 2016$ & 7.8 & 426 & 90.4 & 14.6 & 3.59 & 30.9 & 171 & 33.4 \\
\hline $2 \mathrm{~S} / 11 \mathrm{~W}-7 \mathrm{~K} 7$ & Pico Rivera4_2 & Long Beach C & 07/20/2016 & 7.9 & 296 & 55.9 & 8.64 & 3.13 & 32.8 & 159 & 13.1 \\
\hline $2 \mathrm{~S} / 11 \mathrm{~W}-7 \mathrm{~K} 8$ & Pico Rivera4_3 & Long Beach A & $07 / 20 / 2016$ & 7.9 & 527 & 121 & 18.6 & 4.44 & 32.7 & 200 & 58.7 \\
\hline $2 \mathrm{~S} / 11 \mathrm{~W}-7 \mathrm{~K} 9$ & Pico Rivera4_4 & Mesa & $07 / 20 / 2016$ & 7.7 & 528 & 73.1 & 14.7 & 4.71 & 92.8 & 164 & 96.0 \\
\hline $2 \mathrm{~S} / 11 \mathrm{~W}-8 \mathrm{~L} 8$ & Whittier Narrows2_1 & Tertiary & 09/18/2014 & 7.9 & 240 & 6.4 & 1.90 & 1.40 & 78.0 & 150 & 14.0 \\
\hline $2 \mathrm{~S} / 11 \mathrm{~W}-8 \mathrm{~L} 9$ & Whittier Narrows2_2 & Tertiary & 09/18/2014 & 7.9 & 210 & 12 & 3.40 & $<1.0$ & 59.0 & 140 & 8.60 \\
\hline 2S/11W-8L10 & Whittier Narrows2_3 & Tertiary & 09/18/2014 & 7.8 & 210 & 9.4 & 2.60 & 1.60 & 57.0 & 120 & 6.00 \\
\hline 2S/11W-8L11 & Whittier Narrows2_4 & Tertiary & 09/18/2014 & 7.9 & 200 & 12 & 2.80 & 2.30 & 50.0 & 110 & 4.30 \\
\hline 2S/11W-8L12 & Whittier Narrows2_5 & Long Beach C & 09/18/2014 & 7.9 & 330 & 68 & 9.90 & 2.50 & 26.0 & 150 & 21.0 \\
\hline 2S/11W-8L13 & Whittier Narrows2_6 & Long Beach B & 09/18/2014 & 8.0 & 200 & 34 & 3.90 & 2.00 & 27.0 & 120 & 4.00 \\
\hline 2S/11W-8L14 & Whittier Narrows2_7 & Pacific & 09/18/2014 & 8.1 & 220 & 38 & 5.30 & 2.30 & 24.0 & 110 & 9.80 \\
\hline 2S/11W-8L15 & Whittier Narrows2_8 & Mesa & 09/18/2014 & 7.9 & 1,900 & 230 & 77.0 & 5.00 & 240 & 400 & 220 \\
\hline $2 \mathrm{~S} / 11 \mathrm{~W}-8 \mathrm{~L} 16$ & Whittier Narrows2_9 & Mesa & 09/18/2014 & 7.8 & 2,000 & 230 & 110 & 4.90 & 240 & 430 & 230 \\
\hline $2 \mathrm{~S} / 11 \mathrm{~W}-18 \mathrm{C} 4$ & Pico Rivera1_1 & Long Beach C & 05/09/1997 & 7.8 & 356 & 8.21 & 2.88 & 4.70 & 119 & 291 & 4.02 \\
\hline $2 \mathrm{~S} / 11 \mathrm{~W}-18 \mathrm{C} 5$ & Pico Rivera1_2 & Long Beach B & 04/30/1997 & 7.6 & 307 & 67.7 & 11.7 & 3.13 & 20.7 & 171 & 19.0 \\
\hline $2 \mathrm{~S} / 11 \mathrm{~W}-18 \mathrm{C} 6$ & Pico Rivera1_3 & Long Beach A & 04/30/1997 & 7.0 & 649 & 119 & 22.8 & 4.69 & 63.3 & 206 & 84.0 \\
\hline $2 \mathrm{~S} / 11 \mathrm{~W}-18 \mathrm{C} 7$ & Pico Rivera1_4 & Pacific & 04/30/1997 & 7.3 & 577 & 98.3 & 17.3 & 4.70 & 71.5 & 208 & 68.8 \\
\hline $2 \mathrm{~S} / 11 \mathrm{~W}-20 \mathrm{~N} 1$ & Whittier2_1 & Long Beach B & 09/22/2008 & 7.5 & 850 & 91.6 & 22.4 & 5.35 & 184 & 240 & 238 \\
\hline $2 \mathrm{~S} / 11 \mathrm{~W}-20 \mathrm{~N} 2$ & Whittier2_2 & Long Beach A & 09/22/2008 & 8.0 & 253 & 22.0 & 3.97 & 2.55 & 61.3 & 173 & 11.4 \\
\hline $2 \mathrm{~S} / 11 \mathrm{~W}-20 \mathrm{~N} 3$ & Whittier2_3 & Upper Wilmington A & $09 / 22 / 2008$ & 7.8 & 727 & 86.1 & 33.4 & 4.26 & 116 & 210 & 119 \\
\hline $2 \mathrm{~S} / 11 \mathrm{~W}-20 \mathrm{~N} 4$ & Whittier2_4 & Harbor & 09/22/2008 & 7.3 & 1,690 & 138 & 82.1 & 4.31 & 321 & 400 & 235 \\
\hline $2 \mathrm{~S} / 11 \mathrm{~W}-20 \mathrm{~N} 5$ & Whittier2_5 & Pacific & 09/22/2008 & 7.7 & 701 & 131 & 24.7 & 4.93 & 74.8 & 222 & 116 \\
\hline $2 \mathrm{~S} / 11 \mathrm{~W}-20 \mathrm{~N} 6$ & Whittier2_6 & Mesa & 09/22/2008 & 7.4 & 1,030 & 173 & 39.9 & 4.95 & 126 & 370 & 89.6 \\
\hline
\end{tabular}


Table 1.2. Groundwater-quality data used for this study from multiple-well monitoring sites, and selected production and observation wells, Los Angeles and Orange Counties, California.-Continued

[See appendix 1 for explanation. Abbreviations: ft, foot; mg/L, milligrams per liter; mm/dd/yyyy, month/day/year; ug/L, micrograms per liter; CaCO 3 , calcium carbonate; \%, percent; <, less than; - , no data. Sediment source/facies: LAR, Los Angeles River; n.a., not assigned; SGR, San Gabriel River; SAR, Santa Ana River, *, potentially affected by mixing with anthropogenic sources of water or seawater]

\begin{tabular}{|c|c|c|c|c|c|c|c|c|c|c|c|}
\hline $\begin{array}{l}\text { State well } \\
\text { number }\end{array}$ & Local well name & $\begin{array}{c}\text { Chronostratigraphic } \\
\text { unit }\end{array}$ & $\begin{array}{c}\text { Sample } \\
\text { collection } \\
\text { date } \\
\text { (mm/dd/yyyy) }\end{array}$ & pH & $\begin{array}{l}\text { Dissolved solids, } \\
\text { filtered, sum of } \\
\text { constituents } \\
\text { (mg/L) }\end{array}$ & $\begin{array}{c}\text { Calcium, } \\
\text { filtered } \\
\text { (mg/L) }\end{array}$ & $\begin{array}{c}\text { Magnesium, } \\
\text { filtered } \\
\text { (mg/L) }\end{array}$ & $\begin{array}{l}\text { Potassium, } \\
\text { filtered } \\
\text { (mg/L) }\end{array}$ & $\begin{array}{l}\text { Sodium, } \\
\text { filtered } \\
\text { (mg/L) }\end{array}$ & $\begin{array}{l}\text { Alkalinity, } \\
\text { filtered } \\
\text { (mg/L as } \\
\mathrm{CaCO}_{3} \text { ) }\end{array}$ & $\begin{array}{c}\text { Chloride, } \\
\text { filtered } \\
\text { (mg/L) }\end{array}$ \\
\hline \multicolumn{12}{|c|}{ Montebello Forebay-Continued } \\
\hline 2S/12W-10Q5 & Montebello1_1 & Long Beach C & $05 / 01 / 2002$ & 8.1 & 2,050 & 13.3 & 5.75 & 7.72 & 780 & 922 & 658 \\
\hline 2S/12W-10Q6 & Montebello1_2 & Long Beach B & $04 / 30 / 2002$ & 8.0 & 888 & 18.8 & 7.57 & 5.86 & 331 & 598 & 126 \\
\hline 2S/12W-10Q7 & Montebello1_3 & Upper Wilmington B & $04 / 30 / 2002$ & 7.7 & 607 & 88.5 & 15.5 & 4.37 & 99.6 & 213 & 83.7 \\
\hline 2S/12W-10Q8 & Montebello1_4 & Upper Wilmington A & 05/01/2002 & 7.8 & 539 & 107 & 17.3 & 3.72 & 51.7 & 198 & 75.2 \\
\hline 2S/12W-10Q9 & Montebello1_5 & Pacific & 05/02/2002 & 7.6 & 488 & 80.2 & 15.4 & 3.24 & 66.0 & 175 & 63.4 \\
\hline 2S/12W-10Q10 & Montebello1_6 & Mesa & 05/02/2002 & 7.3 & 833 & 131 & 30.1 & 4.81 & 117 & 283 & 189 \\
\hline $2 \mathrm{~S} / 12 \mathrm{~W}-25 \mathrm{G} 1$ & Pico Rivera W12 & Mesa & 08/16/2006 & 7.4 & 451 & 58.4 & 13.8 & 3.81 & 70.8 & 144 & 83.3 \\
\hline $2 \mathrm{~S} / 12 \mathrm{~W}-25 \mathrm{G} 3$ & Pico Rivera2_1 & Long Beach A & 03/31/1999 & 7.6 & 455 & 70.5 & 20.8 & 6.35 & 52.1 & 181 & 58.9 \\
\hline $2 \mathrm{~S} / 12 \mathrm{~W}-25 \mathrm{G} 4$ & Pico Rivera2_2 & Upper Wilmington B & 03/30/1999 & 7.8 & 523 & 117 & 23.1 & 3.66 & 29.6 & 242 & 54.1 \\
\hline 2S/12W-25G5 & Pico Rivera2_3 & Upper Wilmington A & 04/01/1999 & 7.7 & 494 & 101 & 19.9 & 3.97 & 34.2 & 201 & 58.6 \\
\hline $2 \mathrm{~S} / 12 \mathrm{~W}-25 \mathrm{G} 6$ & Pico Rivera2_4 & Pacific & 03/30/1999 & 7.6 & 547 & 81.5 & 17.3 & 4.41 & 79.1 & 176 & 94.1 \\
\hline $2 \mathrm{~S} / 12 \mathrm{~W}-25 \mathrm{G} 7$ & Pico Rivera2_5 & Mesa & 04/01/1999 & 7.5 & 503 & 71.5 & 16.7 & 4.37 & 73.5 & 168 & 88.1 \\
\hline $2 \mathrm{~S} / 12 \mathrm{~W}-25 \mathrm{G} 8$ & Pico Rivera2_6 & Dominguez & 03/31/1999 & 7.5 & 524 & 72.2 & 21.3 & 7.22 & 73.0 & 140 & 93.1 \\
\hline 2S/12W-26D9 & Rio Hondo1_1 & Long Beach A & 01/28/1998 & 8.0 & 280 & 39.9 & 7.89 & 2.94 & 41.9 & 150 & 18.8 \\
\hline 2S/12W-26D10 & Rio Hondo1_2 & Lower Wilmington & 01/28/1998 & 7.8 & 446 & 95.1 & 16.5 & 3.67 & 28.5 & 172 & 50.2 \\
\hline 2S/12W-26D11 & Rio Hondo1_3 & Upper Wilmington B & 01/29/1998 & 7.7 & 450 & 79.6 & 14.5 & 4.04 & 49.0 & 159 & 59.2 \\
\hline 2S/12W-26D12 & Rio Hondo1_4 & Upper Wilmington A & 01/30/1998 & 7.6 & 467 & 74.8 & 14.1 & 3.96 & 61.6 & 154 & 68.7 \\
\hline 2S/12W-26D13 & Rio Hondo1_5 & Pacific & 01/30/1998 & 7.5 & 355 & 50.5 & 10.1 & 3.71 & 52.5 & 129 & 48.5 \\
\hline 2S/12W-26D14 & Rio Hondo1_6 & Mesa & 01/29/1998 & 7.3 & 341 & 46.0 & 12.4 & 4.19 & 49.7 & 105 & 58.3 \\
\hline 2S/12W-33D3 & Bell Gardens1_1 & Lower Wilmington & 09/25/2008 & 8.0 & 438 & 97.5 & 13.5 & 2.42 & 31.0 & 172 & 47.3 \\
\hline $2 \mathrm{~S} / 12 \mathrm{~W}-33 \mathrm{D} 4$ & Bell Gardens1_2 & Upper Wilmington A & 09/25/2008 & 8.1 & 291 & 37.5 & 7.20 & 2.75 & 55.4 & 167 & 28.3 \\
\hline $2 \mathrm{~S} / 12 \mathrm{~W}-33 \mathrm{D} 5$ & Bell Gardens1_3 & Bent Spring & 09/25/2008 & 7.8 & 439 & 78.1 & 12.8 & 3.73 & 52.6 & 152 & 59.3 \\
\hline $2 \mathrm{~S} / 12 \mathrm{~W}-33 \mathrm{D} 6$ & Bell Gardens1_4 & Harbor & 09/25/2008 & 7.8 & 376 & 60.2 & 10.5 & 3.54 & 52.1 & 136 & 50.5 \\
\hline $2 \mathrm{~S} / 12 \mathrm{~W}-33 \mathrm{D} 7$ & Bell Gardens1_5 & Pacific & 09/25/2008 & 7.6 & 354 & 58.1 & 10.8 & 3.15 & 46.3 & 148 & 36.6 \\
\hline $2 \mathrm{~S} / 12 \mathrm{~W}-33 \mathrm{D} 8$ & Bell Gardens1_6 & Pacific_A & 09/25/2008 & 7.7 & 389 & 67.5 & 12.2 & 3.56 & 47.6 & 164 & 43.2 \\
\hline $2 \mathrm{~S} / 12 \mathrm{~W}-36 \mathrm{M} 6$ & Pico Rivera W8 & Pacific & $08 / 25 / 2010$ & 7.6 & 514 & 109 & 21.4 & 3.53 & 32.0 & 225 & 56.4 \\
\hline $3 \mathrm{~S} / 12 \mathrm{~W}-11 \mathrm{~A} 7$ & Norwalk2_1 & Lower Wilmington & 09/18/2008 & 8.0 & 438 & 61.5 & 11.7 & 4.15 & 77.3 & 184 & 66.5 \\
\hline $3 \mathrm{~S} / 12 \mathrm{~W}-11 \mathrm{~A} 8$ & Norwalk2_2 & Lower Wilmington & 09/18/2008 & 8.3 & 293 & 11.5 & 2.15 & 2.61 & 96.0 & 188 & 30.1 \\
\hline
\end{tabular}


Table 1.2. Groundwater-quality data used for this study from multiple-well monitoring sites, and selected production and observation wells, Los Angeles and Orange Counties, California.-Continued

[See appendix 1 for explanation. Abbreviations: ft, foot; mg/L, milligrams per liter; mm/dd/yyyy, month/day/year; ug/L, micrograms per liter; CaCO 3 , calcium carbonate; \%, percent; <, less than; - , no data. Sediment source/facies: LAR, Los Angeles River; n.a., not assigned; SGR, San Gabriel River; SAR, Santa Ana River, *, potentially affected by mixing with anthropogenic sources of water or seawater]

\begin{tabular}{|c|c|c|c|c|c|c|c|c|c|c|c|}
\hline $\begin{array}{l}\text { State well } \\
\text { number }\end{array}$ & Local well name & $\begin{array}{c}\text { Chronostratigraphic } \\
\text { unit }\end{array}$ & $\begin{array}{c}\text { Sample } \\
\text { collection } \\
\text { date } \\
\text { (mm/dd/yyyy) }\end{array}$ & $\mathrm{pH}$ & $\begin{array}{l}\text { Dissolved solids, } \\
\text { filtered, sum of } \\
\text { constituents } \\
\text { (mg/L) }\end{array}$ & $\begin{array}{c}\text { Calcium, } \\
\text { filtered } \\
\text { (mg/L) }\end{array}$ & $\begin{array}{l}\text { Magnesium, } \\
\text { filtered } \\
\text { (mg/L) }\end{array}$ & $\begin{array}{l}\text { Potassium, } \\
\text { filtered } \\
\text { (mg/L) }\end{array}$ & $\begin{array}{l}\text { Sodium, } \\
\text { filtered } \\
\text { (mg/L) }\end{array}$ & $\begin{array}{l}\text { Alkalinity, } \\
\text { filtered } \\
\text { (mg/L as } \\
\mathrm{CaCO}_{3} \text { ) }\end{array}$ & $\begin{array}{c}\text { Chloride, } \\
\text { filtered } \\
\text { (mg/L) }\end{array}$ \\
\hline \multicolumn{12}{|c|}{ Montebello Forebay-Continued } \\
\hline $3 \mathrm{~S} / 12 \mathrm{~W}-11 \mathrm{~A} 9$ & Norwalk2_3 & Upper Wilmington A & 09/18/2008 & 8.2 & 248 & 43.7 & 4.97 & 2.83 & 37.4 & 156 & 12.7 \\
\hline $3 \mathrm{~S} / 12 \mathrm{~W}-11 \mathrm{~A} 10$ & Norwalk2_4 & Bent Spring & $09 / 18 / 2008$ & 8.0 & 321 & 65.3 & 10.5 & 3.43 & 30.6 & 171 & 20.1 \\
\hline $3 \mathrm{~S} / 12 \mathrm{~W}-11 \mathrm{~A} 11$ & Norwalk2_5 & Pacific & 09/18/2008 & 7.9 & 450 & 85.3 & 16.0 & 4.22 & 45.2 & 162 & 65.6 \\
\hline $3 \mathrm{~S} / 12 \mathrm{~W}-11 \mathrm{~A} 12$ & Norwalk2_6 & Pacific_A & 09/18/2008 & 7.7 & 517 & 89.8 & 17.7 & 4.24 & 61.3 & 193 & 71.9 \\
\hline \multicolumn{12}{|c|}{ Whittier area } \\
\hline $3 \mathrm{~S} / 11 \mathrm{~W}-2 \mathrm{~K} 4$ & Whittier1_1 & Long Beach C & $03 / 17 / 2000$ & 7.5 & 2,540 & 201 & 129 & 10.0 & 421 & 276 & 279 \\
\hline $3 \mathrm{~S} / 11 \mathrm{~W}-2 \mathrm{~K} 5$ & Whittier1_2 & Long Beach BC & 03/16/2000 & 7.5 & 2,390 & 199 & 124 & 10.1 & 396 & 297 & 239 \\
\hline $3 \mathrm{~S} / 11 \mathrm{~W}-2 \mathrm{~K} 6$ & Whittier1_4 & Long Beach A & $03 / 16 / 2000$ & 7.6 & 679 & 80.9 & 33.3 & 3.83 & 97.9 & 265 & 79.6 \\
\hline $3 \mathrm{~S} / 11 \mathrm{~W}-2 \mathrm{~K} 7$ & Whittier1_5 & Pacific & $03 / 15 / 2000$ & 7.6 & 670 & 83.1 & 38.1 & 3.28 & 85.5 & 245 & 80.2 \\
\hline $3 \mathrm{~S} / 11 \mathrm{~W}-2 \mathrm{~K} 8$ & Whittier1_3 & Long Beach B & 03/16/2000 & 7.6 & 1,490 & 141 & 77.3 & 7.51 & 236 & 305 & 173 \\
\hline $3 \mathrm{~S} / 11 \mathrm{~W}-9 \mathrm{D} 2$ & Santa Fe Springs1_2 & Lower Wilmington & 04/23/1999 & 8.2 & 781 & 5.50 & 2.25 & 2.57 & 280 & 325 & 167 \\
\hline 3S/11W-9D3 & Santa Fe Springs1_3 & Harbor & 04/23/1999 & 8.2 & 826 & 36.0 & 27.9 & 5.23 & 220 & 491 & 119 \\
\hline $3 \mathrm{~S} / 11 \mathrm{~W}-9 \mathrm{D} 4$ & Santa Fe Springs 1_4 & Pacific_A & 04/23/1999 & 7.7 & 771 & 19.1 & 9.60 & 3.41 & 243 & 326 & 158 \\
\hline \multicolumn{12}{|c|}{ Pressure area } \\
\hline $2 \mathrm{~S} / 12 \mathrm{~W}-7 \mathrm{~J} 1$ & Commerce1_1 & Long Beach C & $04 / 06 / 2001$ & 7.5 & 12,200 & 183 & 144 & 45.4 & 4,280 & 508 & 7,070 \\
\hline $2 \mathrm{~S} / 12 \mathrm{~W}-7 \mathrm{~J} 2$ & Commerce1_2 & Long Beach A & 08/18/1999 & 7.7 & 486 & 71.8 & 13.6 & 3.16 & 40.0 & 151 & 46.1 \\
\hline $2 \mathrm{~S} / 12 \mathrm{~W}-7 \mathrm{~J} 3$ & Commerce1_3 & Upper Wilmington B & 08/18/1999 & 7.8 & 457 & 55.4 & 17.9 & 3.41 & 75.2 & 215 & 73.5 \\
\hline $2 \mathrm{~S} / 12 \mathrm{~W}-7 \mathrm{~J} 4$ & Commerce1_4 & Upper Wilmington A & 08/19/1999 & 7.7 & 504 & 46.1 & 18.0 & 3.49 & 106 & 208 & 123 \\
\hline $2 \mathrm{~S} / 12 \mathrm{~W}-7 \mathrm{~J} 5$ & Commerce1_5 & Pacific & 08/17/1999 & 7.6 & 556 & 91.7 & 24.3 & 2.47 & 57.7 & 202 & 88.3 \\
\hline $2 \mathrm{~S} / 12 \mathrm{~W}-7 \mathrm{~J} 6$ & Commerce1_6 & Mesa & 08/17/1999 & 7.7 & 384 & 53.6 & 16.4 & 1.80 & 50.5 & 172 & 60.8 \\
\hline $2 \mathrm{~S} / 13 \mathrm{~W}-24 \mathrm{~J} 1$ & Bell1_1 & Long Beach B & $05 / 20 / 2010$ & 8.0 & 948 & 12.6 & 5.08 & 5.31 & 342 & 653 & 144 \\
\hline $2 \mathrm{~S} / 13 \mathrm{~W}-24 \mathrm{~J} 2$ & Bell1_2 & Lower Wilmington & $05 / 20 / 2010$ & 8.0 & 342 & 52.0 & 10.1 & 2.74 & 51.0 & 174 & 21.5 \\
\hline $2 \mathrm{~S} / 13 \mathrm{~W}-24 \mathrm{~J} 3$ & Bell1_3 & Upper Wilmington A & 05/20/2010 & 8.0 & 312 & 46.1 & 10.3 & 3.31 & 47.0 & 164 & 27.3 \\
\hline $2 \mathrm{~S} / 13 \mathrm{~W}-24 \mathrm{~J} 4$ & Bell1_4 & Bent Spring & $05 / 20 / 2010$ & 7.6 & 354 & 57.3 & 13.2 & 3.20 & 45.9 & 184 & 25.5 \\
\hline $2 \mathrm{~S} / 13 \mathrm{~W}-24 \mathrm{~J} 5$ & Bell1_5 & Pacific & $05 / 20 / 2010$ & 7.8 & 446 & 75.5 & 17.8 & 2.75 & 51.3 & 185 & 47.3 \\
\hline $2 \mathrm{~S} / 13 \mathrm{~W}-24 \mathrm{~J} 6$ & Bell1_6 & Pacific_A & $05 / 20 / 2010$ & 7.6 & 648 & 120 & 30.0 & 2.81 & 60.0 & 252 & 110 \\
\hline 2S/13W-31B3 & Los Angeles4_1 & Long Beach A & $05 / 03 / 2013$ & 8.1 & 1,880 & 11.8 & 6.18 & 14.1 & 753 & 1650 & 36.0 \\
\hline $2 \mathrm{~S} / 13 \mathrm{~W}-31 \mathrm{~B} 4$ & Los Angeles4_2 & Lower Wilmington & $05 / 03 / 2013$ & 7.9 & 584 & 15.8 & 6.58 & 10.6 & 193 & 485 & 10.0 \\
\hline
\end{tabular}


Table 1.2. Groundwater-quality data used for this study from multiple-well monitoring sites, and selected production and observation wells, Los Angeles and Orange Counties, California.-Continued

[See appendix 1 for explanation. Abbreviations: ft, foot; mg/L, milligrams per liter; mm/dd/yyyy, month/day/year; ug/L, micrograms per liter; CaCO 3 , calcium carbonate; \%, percent; <, less than; - , no data. Sediment source/facies: LAR, Los Angeles River; n.a., not assigned; SGR, San Gabriel River; SAR, Santa Ana River, *, potentially affected by mixing with anthropogenic sources of water or seawater]

\begin{tabular}{|c|c|c|c|c|c|c|c|c|c|c|c|}
\hline $\begin{array}{l}\text { State well } \\
\text { number }\end{array}$ & Local well name & $\begin{array}{c}\text { Chronostratigraphic } \\
\text { unit }\end{array}$ & $\begin{array}{c}\text { Sample } \\
\text { collection } \\
\text { date } \\
\text { (mm/dd/yyyy) }\end{array}$ & pH & $\begin{array}{c}\text { Dissolved solids, } \\
\text { filtered, sum of } \\
\text { constituents } \\
\text { (mg/L) }\end{array}$ & $\begin{array}{l}\text { Calcium, } \\
\text { filtered } \\
\text { (mg/L) }\end{array}$ & $\begin{array}{c}\text { Magnesium, } \\
\text { filtered } \\
\text { (mg/L) }\end{array}$ & $\begin{array}{l}\text { Potassium, } \\
\text { filtered } \\
\text { (mg/L) }\end{array}$ & $\begin{array}{l}\text { Sodium, } \\
\text { filtered } \\
\text { (mg/L) }\end{array}$ & $\begin{array}{l}\text { Alkalinity, } \\
\text { filtered } \\
\text { (mg/L as } \\
\mathrm{CaCO}_{3} \text { ) }\end{array}$ & $\begin{array}{l}\text { Chloride, } \\
\text { filtered } \\
\text { (mg/L) }\end{array}$ \\
\hline \multicolumn{12}{|c|}{ Pressure area-Continued } \\
\hline 2S/13W-31B5 & Los Angeles4_3 & Upper Wilmington A & $05 / 03 / 2013$ & 8.1 & 348 & 56.0 & 11.6 & 3.06 & 46.3 & 181 & 20.4 \\
\hline $2 \mathrm{~S} / 13 \mathrm{~W}-31 \mathrm{~B} 6$ & Los Angeles4_4 & Harbor & 05/03/2013 & 7.9 & 354 & 52.4 & 12.3 & 3.99 & 48.9 & 188 & 20.8 \\
\hline $2 \mathrm{~S} / 13 \mathrm{~W}-31 \mathrm{~B} 7$ & Los Angeles4_5 & Harbor & 05/03/2013 & 8.1 & 378 & 48.2 & 10.4 & 3.93 & 66.1 & 194 & 21.9 \\
\hline $2 \mathrm{~S} / 13 \mathrm{~W}-31 \mathrm{~B} 8$ & Los Angeles4_6 & Pacific & 05/03/2013 & 7.8 & 389 & 61.6 & 14.9 & 3.74 & 46.5 & 191 & 28.5 \\
\hline $2 \mathrm{~S} / 14 \mathrm{~W}-26 \mathrm{~N} 3$ & Inglewood2_1 & Long Beach A & 04/28/1999 & 7.9 & 1,640 & 18.5 & 17.4 & 0.71 & 605 & 1,450 & 73.5 \\
\hline $2 \mathrm{~S} / 14 \mathrm{~W}-26 \mathrm{~N} 4$ & Inglewood2_2 & Lower Wilmington & 04/28/1999 & 7.9 & 1,480 & 11.5 & 9.00 & 18.8 & 566 & 1,340 & 21.9 \\
\hline $2 \mathrm{~S} / 14 \mathrm{~W}-26 \mathrm{~N} 5$ & Inglewood2_3 & Harbor & 04/26/1999 & 7.7 & 293 & 27.0 & 9.51 & 6.45 & 55.9 & 219 & 20.7 \\
\hline 3S/11W-17F1 & Norwalk1_1 & Lower Wilmington & 05/19/2004 & 7.8 & 470 & 13.1 & 5.84 & 2.49 & 164 & 307 & 68.7 \\
\hline 3S/11W-17F2 & Norwalk1_2 & Upper Wilmington A & 05/19/2004 & 8.1 & 301 & 7.88 & 1.05 & 1.60 & 110 & 181 & 57.5 \\
\hline $3 \mathrm{~S} / 11 \mathrm{~W}-17 \mathrm{~F} 3$ & Norwalk1_3 & Bent Spring & 05/19/2004 & 8.2 & 262 & 18.7 & 2.44 & 2.25 & 76.8 & 141 & 50.2 \\
\hline 3S/11W-17F4 & Norwalk1_4 & Pacific & $12 / 20 / 2004$ & 7.9 & 207 & 22.8 & 4.73 & 2.34 & 45.5 & 137 & 17.5 \\
\hline $3 \mathrm{~S} / 11 \mathrm{~W}-17 \mathrm{~F} 5$ & Norwalk1_5 & Pacific_A & $12 / 20 / 2004$ & 7.6 & 424 & 69.2 & 15.6 & 3.61 & 68.2 & 210 & 113 \\
\hline 3S/11W-26E2 & La Mirada1_1 & Upper Wilmington A & 08/04/1999 & 8.2 & 359 & 16.3 & 3.51 & 2.09 & 108 & 159 & 26.1 \\
\hline $3 \mathrm{~S} / 11 \mathrm{~W}-26 \mathrm{E} 3$ & La Mirada1_2 & Bent Spring & 08/04/1999 & 8.1 & 264 & 36.5 & 5.86 & 2.23 & 47.2 & 142 & 15.8 \\
\hline 3S/11W-26E4 & La Mirada1_3 & Harbor & 08/05/1999 & 8.1 & 326 & 22.0 & 6.96 & 2.59 & 84.1 & 228 & 15.8 \\
\hline $3 \mathrm{~S} / 11 \mathrm{~W}-26 \mathrm{E} 5$ & La Mirada1_4 & Pacific & 08/05/1999 & 7.8 & 429 & 42.8 & 13.8 & 3.20 & 83.0 & 203 & 27.0 \\
\hline 3S/11W-26E6 & La Mirada1_5 & Pacific_A & 08/05/1999 & 7.9 & 492 & 60.6 & 18.0 & 3.04 & 83.0 & 204 & 61.8 \\
\hline $3 \mathrm{~S} / 12 \mathrm{~W}-6 \mathrm{~B} 4$ & South Gate1_1 & Bent Spring & 08/06/1999 & 8.0 & 308 & 48.9 & 7.94 & 2.37 & 46.5 & 170 & 21.0 \\
\hline $3 \mathrm{~S} / 12 \mathrm{~W}-6 \mathrm{~B} 5$ & South Gate1_2 & Harbor & 08/16/1999 & 7.7 & 556 & 53.6 & 23.3 & 6.04 & 143 & 301 & 183 \\
\hline $3 \mathrm{~S} / 12 \mathrm{~W}-6 \mathrm{~B} 6$ & South Gate1_3 & Harbor & 08/16/1999 & 7.8 & 447 & 83.1 & 16.2 & 2.95 & 42.2 & 169 & 50.1 \\
\hline $3 \mathrm{~S} / 12 \mathrm{~W}-6 \mathrm{~B} 7$ & South Gate1_4 & Pacific & 08/06/1999 & 7.8 & 477 & 86.3 & 16.5 & 3.04 & 49.2 & 183 & 56.0 \\
\hline $3 \mathrm{~S} / 12 \mathrm{~W}-6 \mathrm{~B} 8$ & South Gate1_5 & Mesa & 08/06/1999 & 7.7 & 413 & 65.2 & 17.1 & 2.79 & 60.0 & 200 & 33.8 \\
\hline $3 \mathrm{~S} / 12 \mathrm{~W}-9 \mathrm{~J} 1$ & Downey1_1 & Bent Spring & $12 / 30 / 1997$ & 7.9 & 208 & 39.4 & 5.56 & 3.04 & 25.5 & 160 & 5.84 \\
\hline $3 \mathrm{~S} / 12 \mathrm{~W}-9 \mathrm{~J} 2$ & Downey1_2 & Harbor & $12 / 29 / 1997$ & 7.8 & 348 & 72.4 & 11.6 & 3.65 & 26.3 & 179 & 26.0 \\
\hline $3 \mathrm{~S} / 12 \mathrm{~W}-9 \mathrm{~J} 3$ & Downey1_3 & Pacific & $12 / 31 / 1997$ & 7.6 & 488 & 103 & 19.2 & 3.49 & 28.5 & 172 & 66.3 \\
\hline $3 \mathrm{~S} / 12 \mathrm{~W}-9 \mathrm{~J} 4$ & Downey1_4 & Pacific_A & $12 / 29 / 1997$ & 7.5 & 529 & 92.8 & 19.0 & 4.64 & 54.4 & 202 & 74.1 \\
\hline $3 \mathrm{~S} / 12 \mathrm{~W}-9 \mathrm{~J} 5$ & Downey1_5 & Mesa & 12/30/1997 & 7.6 & 531 & 118 & 22.5 & 4.42 & 29.5 & 260 & 62.6 \\
\hline $3 \mathrm{~S} / 12 \mathrm{~W}-9 \mathrm{~J} 6$ & Downey1_6 & Dominguez & $12 / 31 / 1997$ & 7.3 & 812 & 151 & 31.0 & 5.88 & 73.0 & 302 & 93.8 \\
\hline
\end{tabular}


Table 1.2. Groundwater-quality data used for this study from multiple-well monitoring sites, and selected production and observation wells, Los Angeles and Orange Counties, California.-Continued

[See appendix 1 for explanation. Abbreviations: ft, foot; mg/L, milligrams per liter; mm/dd/yyyy, month/day/year; ug/L, micrograms per liter; CaCO 3 , calcium carbonate; \%, percent; <, less than; - , no data. Sediment source/facies: LAR, Los Angeles River; n.a., not assigned; SGR, San Gabriel River; SAR, Santa Ana River, *, potentially affected by mixing with anthropogenic sources of water or seawater]

\begin{tabular}{|c|c|c|c|c|c|c|c|c|c|c|c|}
\hline $\begin{array}{l}\text { State well } \\
\text { number }\end{array}$ & Local well name & $\begin{array}{c}\text { Chronostratigraphic } \\
\text { unit }\end{array}$ & $\begin{array}{c}\text { Sample } \\
\text { collection } \\
\text { date } \\
\text { (mm/dd/yyyy) }\end{array}$ & pH & $\begin{array}{l}\text { Dissolved solids, } \\
\text { filtered, sum of } \\
\text { constituents } \\
\text { (mg/L) }\end{array}$ & $\begin{array}{c}\text { Calcium, } \\
\text { filtered } \\
\text { (mg/L) }\end{array}$ & $\begin{array}{c}\text { Magnesium, } \\
\text { filtered } \\
\text { (mg/L) }\end{array}$ & $\begin{array}{c}\text { Potassium, } \\
\text { filtered } \\
\text { (mg/L) }\end{array}$ & $\begin{array}{c}\text { Sodium, } \\
\text { filtered } \\
\text { (mg/L) }\end{array}$ & $\begin{array}{l}\text { Alkalinity, } \\
\text { filtered } \\
\text { (mg/L as } \\
\mathrm{CaCO}_{3} \text { ) }\end{array}$ & $\begin{array}{c}\text { Chloride, } \\
\text { filtered } \\
\text { (mg/L) }\end{array}$ \\
\hline \multicolumn{12}{|c|}{ Pressure area-Continued } \\
\hline $3 \mathrm{~S} / 12 \mathrm{~W}-15 \mathrm{~K} 1$ & St. John Bosco & Dominguez & $11 / 16 / 2006$ & 7.3 & 938 & 180 & 33.6 & 5.36 & 95.8 & 336 & 116 \\
\hline $3 \mathrm{~S} / 12 \mathrm{~W}-16 \mathrm{H} 1$ & Park 40D & Pacific & 08/14/2006 & 7.5 & 531 & 106 & 20.6 & 4.45 & 47.0 & 219 & 64.2 \\
\hline $3 \mathrm{~S} / 12 \mathrm{~W}-26 \mathrm{~K} 2$ & Cerritos2_1 & Harbor & 05/29/2002 & 8.0 & 215 & 41.0 & 5.16 & 2.82 & 24.8 & 158 & 6.49 \\
\hline $3 \mathrm{~S} / 12 \mathrm{~W}-26 \mathrm{~K} 3$ & Cerritos2_2 & Pacific & 05/30/2002 & 7.7 & 475 & 98.2 & 17.0 & 3.98 & 34.5 & 179 & 63.6 \\
\hline $3 \mathrm{~S} / 12 \mathrm{~W}-26 \mathrm{~K} 4$ & Cerritos2_3 & Pacific & $05 / 31 / 2002$ & 8.1 & 228 & 41.0 & 5.40 & 2.60 & 29.3 & 168 & 6.76 \\
\hline $3 \mathrm{~S} / 12 \mathrm{~W}-26 \mathrm{~K} 5$ & Cerritos2_4 & Pacific_A & $05 / 31 / 2002$ & 7.9 & 254 & 49.2 & 8.07 & 2.82 & 27.7 & 194 & 7.65 \\
\hline $3 \mathrm{~S} / 12 \mathrm{~W}-26 \mathrm{~K} 6$ & Cerritos2_5 & Mesa & 05/30/2002 & 7.9 & 243 & 48.5 & 7.02 & 2.99 & 25.4 & 190 & 7.17 \\
\hline $3 \mathrm{~S} / 12 \mathrm{~W}-26 \mathrm{~K} 7$ & Cerritos2_6 & Dominguez & 05/29/2002 & 7.5 & 644 & 140 & 26.5 & 3.83 & 43.2 & 323 & 59.2 \\
\hline $3 \mathrm{~S} / 12 \mathrm{~W}-33 \mathrm{~B} 1$ & BSMWC_615 & Pacific & $08 / 15 / 2006$ & 7.5 & 376 & 81.2 & 14.4 & 3.33 & 27.7 & 198 & 30.9 \\
\hline $3 \mathrm{~S} / 13 \mathrm{~W}-8 \mathrm{~J} 1$ & Willowbrook1_1 & Upper Wilmington B & 01/07/1998 & 7.9 & 311 & 27.0 & 5.45 & 5.66 & 79.3 & 255 & 17.5 \\
\hline $3 \mathrm{~S} / 13 \mathrm{~W}-8 \mathrm{~J} 2$ & Willowbrook1_2 & Bent Spring & 01/07/1998 & 8.0 & 319 & 52.4 & 9.26 & 2.97 & 43.6 & 168 & 20.6 \\
\hline $3 \mathrm{~S} / 13 \mathrm{~W}-8 \mathrm{~J} 3$ & Willowbrook1_3 & Harbor & 01/08/1998 & 7.8 & 332 & 56.4 & 11.6 & 3.35 & 41.0 & 183 & 20.3 \\
\hline $3 \mathrm{~S} / 13 \mathrm{~W}-8 \mathrm{~J} 4$ & Willowbrook1_4 & Pacific & 01/08/1998 & 7.9 & 347 & 52.6 & 9.55 & 3.42 & 53.2 & 185 & 24.8 \\
\hline $3 \mathrm{~S} / 13 \mathrm{~W}-11 \mathrm{G} 1$ & Lynwood1_1 & Long Beach A & $10 / 16 / 2014$ & 8.2 & 665 & 9.56 & 2.11 & 2.96 & 262 & 587 & 12.0 \\
\hline $3 \mathrm{~S} / 13 \mathrm{~W}-11 \mathrm{G} 2$ & Lynwood1_2 & Lower Wilmington & $10 / 16 / 2014$ & 8.7 & 299 & 4.89 & 0.31 & 1.02 & 105 & 165 & 22.6 \\
\hline 3S/13W-11G3 & Lynwood1_8 & Pacific_A & $10 / 16 / 2014$ & 7.8 & 444 & 81.1 & 17.9 & 3.34 & 42.6 & 184 & 48.6 \\
\hline $3 \mathrm{~S} / 13 \mathrm{~W}-11 \mathrm{G} 4$ & Lynwood1_3 & Upper Wilmington B & $10 / 17 / 2014$ & 8.2 & 286 & 38.2 & 5.55 & 1.56 & 51.2 & 123 & 21.8 \\
\hline $3 \mathrm{~S} / 13 \mathrm{~W}-11 \mathrm{G} 5$ & Lynwood1_4 & Upper Wilmington A & $10 / 17 / 2014$ & 8.2 & 319 & 45.0 & 6.12 & 2. & 54.5 & 146 & 22.3 \\
\hline $3 \mathrm{~S} / 13 \mathrm{~W}-11 \mathrm{G} 6$ & Lynwood1_5 & Bent Spring & $10 / 16 / 2014$ & 8.2 & 289 & 39.7 & 2.80 & 2.48 & 58.6 & 164 & 22.4 \\
\hline $3 \mathrm{~S} / 13 \mathrm{~W}-11 \mathrm{G} 7$ & Lynwood1_6 & Harbor & $10 / 16 / 2014$ & 8.1 & 334 & 45.8 & 10.6 & 4.16 & 53.4 & 178 & 21.5 \\
\hline $3 \mathrm{~S} / 13 \mathrm{~W}-11 \mathrm{G} 8$ & Lynwood1_7 & Harbor & $10 / 16 / 2014$ & 8.1 & 348 & 52.6 & 11.1 & 3.18 & 51.1 & 189 & 22.4 \\
\hline 3S/13W-11G9 & Lynwood1_9 & Dominguez & $10 / 16 / 2014$ & 7.5 & 975 & 201 & 42.8 & 4.99 & 73.2 & 310 & 145 \\
\hline $3 \mathrm{~S} / 13 \mathrm{~W}-22 \mathrm{M} 2$ & Compton2_1 & Long Beach A & 05/21/2009 & 8.3 & 526 & 12.1 & 2.06 & 2.81 & 200 & 488 & 15.0 \\
\hline $3 \mathrm{~S} / 13 \mathrm{~W}-22 \mathrm{M} 3$ & Compton2_2 & Upper Wilmington B & 05/21/2009 & 8.1 & 330 & 28.1 & 5.08 & 4.25 & 95.8 & 290 & 14.3 \\
\hline $3 \mathrm{~S} / 13 \mathrm{~W}-22 \mathrm{M} 4$ & Compton2_3 & Harbor & $05 / 21 / 2009$ & 8.2 & 295 & 44.6 & 6.07 & 2.72 & 50.5 & 164 & 19.3 \\
\hline 3S/13W-22M5 & Compton2_4 & Harbor & $05 / 21 / 2009$ & 8.0 & 348 & 64.1 & 10.5 & 2.61 & 43.8 & 189 & 26.4 \\
\hline $3 \mathrm{~S} / 13 \mathrm{~W}-22 \mathrm{M} 6$ & Compton2_5 & Pacific & 05/21/2009 & 8.1 & 381 & 61.6 & 13.2 & 4.42 & 54.0 & 195 & 33.8 \\
\hline $3 \mathrm{~S} / 13 \mathrm{~W}-22 \mathrm{M} 7$ & Compton2_6 & Pacific_A & $05 / 21 / 2009$ & 7.8 & 430 & 78.0 & 17.2 & 3.94 & 46.4 & 185 & 65.3 \\
\hline
\end{tabular}


Table 1.2. Groundwater-quality data used for this study from multiple-well monitoring sites, and selected production and observation wells, Los Angeles and Orange Counties, California.-Continued

[See appendix 1 for explanation. Abbreviations: ft, foot; mg/L, milligrams per liter; mm/dd/yyyy, month/day/year; ug/L, micrograms per liter; CaCO 3 , calcium carbonate; \%, percent; <, less than; - , no data. Sediment source/facies: LAR, Los Angeles River; n.a., not assigned; SGR, San Gabriel River; SAR, Santa Ana River, *, potentially affected by mixing with anthropogenic sources of water or seawater]

\begin{tabular}{|c|c|c|c|c|c|c|c|c|c|c|c|}
\hline $\begin{array}{l}\text { State well } \\
\text { number }\end{array}$ & Local well name & $\begin{array}{c}\text { Chronostratigraphic } \\
\text { unit }\end{array}$ & $\begin{array}{c}\text { Sample } \\
\text { collection } \\
\text { date } \\
\text { (mm/dd/yyyy) }\end{array}$ & pH & $\begin{array}{l}\text { Dissolved solids, } \\
\text { filtered, sum of } \\
\text { constituents } \\
\text { (mg/L) }\end{array}$ & $\begin{array}{l}\text { Calcium, } \\
\text { filtered } \\
\text { (mg/L) }\end{array}$ & $\begin{array}{l}\text { Magnesium, } \\
\text { filtered } \\
\text { (mg/L) }\end{array}$ & $\begin{array}{l}\text { Potassium, } \\
\text { filtered } \\
\text { (mg/L) }\end{array}$ & $\begin{array}{l}\text { Sodium, } \\
\text { filtered } \\
\text { (mg/L) }\end{array}$ & $\begin{array}{l}\text { Alkalinity, } \\
\text { filtered } \\
\text { (mg/L as } \\
\mathrm{CaCO}_{3} \text { ) }\end{array}$ & $\begin{array}{l}\text { Chloride, } \\
\text { filtered } \\
\text { (mg/L) }\end{array}$ \\
\hline \multicolumn{12}{|c|}{ Pressure area-Continued } \\
\hline $3 \mathrm{~S} / 13 \mathrm{~W}-24 \mathrm{~K} 2$ & Compton1_1 & Upper Wilmington B & $05 / 19 / 2004$ & 8.0 & 215 & 19.1 & 1.47 & 1.60 & 62.5 & 169 & 14.7 \\
\hline $3 \mathrm{~S} / 13 \mathrm{~W}-24 \mathrm{~K} 3$ & Compton1_2 & Upper Wilmington A & 05/19/2004 & 8.0 & 293 & 41.2 & 3.19 & 1.79 & 57.6 & 148 & 22.9 \\
\hline $3 \mathrm{~S} / 13 \mathrm{~W}-24 \mathrm{~K} 4$ & Compton1_3 & Harbor & 05/19/2004 & 7.9 & 312 & 47.9 & 7.70 & 2.93 & 48.4 & 165 & 24.8 \\
\hline $3 \mathrm{~S} / 13 \mathrm{~W}-24 \mathrm{~K} 5$ & Compton1_4 & Pacific & 05/19/2004 & 7.9 & 330 & 60.7 & 5.62 & 2.71 & 48.1 & 173 & 22.0 \\
\hline $3 \mathrm{~S} / 13 \mathrm{~W}-24 \mathrm{~K} 6$ & Compton1_5 & Pacific_A & 05/19/2004 & 7.8 & 329 & 57.5 & 9.08 & 2.83 & 45.1 & 187 & 20.5 \\
\hline 4S/11W-5P9 & Cerritos1_1 & Harbor & 08/03/1999 & 8.2 & 282 & 35.4 & 4.98 & 2.50 & 59.5 & 166 & 15.2 \\
\hline 4S/11W-5P10 & Cerritos1_2 & Pacific & 08/03/1999 & 8.3 & 263 & 9.60 & 1.74 & 1.94 & 83.2 & 157 & 13.6 \\
\hline 4S/11W-5P11 & Cerritos1_3 & Pacific & 08/03/1999 & 8.0 & 308 & 42.5 & 5.55 & 1.95 & 58.6 & 171 & 19.7 \\
\hline $4 \mathrm{~S} / 11 \mathrm{~W}-5 \mathrm{P} 12$ & Cerritos1_4 & Mesa & 08/02/1999 & 8.0 & 278 & 46.5 & 10.7 & 1.94 & 36.9 & 181 & 12.5 \\
\hline $4 \mathrm{~S} / 11 \mathrm{~W}-5 \mathrm{P} 13$ & Cerritos1_5 & Dominguez & 08/03/1999 & 7.9 & 274 & 39.3 & 9.53 & 2.10 & 43.8 & 183 & 10.8 \\
\hline 4S/11W-5P14 & Cerritos1_6 & Dominguez & 08/04/1999 & 7.9 & 278 & 48.2 & 9.66 & 2.12 & 33.8 & 192 & 11.3 \\
\hline $4 \mathrm{~S} / 12 \mathrm{~W}-5 \mathrm{H} 5$ & Lakewood1_1 & Upper Wilmington A & $04 / 25 / 1997$ & 8.7 & 181 & 10.5 & 0.35 & 0.85 & 54.2 & 98 & 19.2 \\
\hline 4S/12W-5H6 & Lakewood1_2 & Harbor & 04/23/1997 & 8.2 & 206 & 31.4 & 3.70 & 2.04 & 35.0 & 145 & 17.3 \\
\hline $4 \mathrm{~S} / 12 \mathrm{~W}-5 \mathrm{H} 7$ & Lakewood1_3 & Harbor & 04/23/1997 & 8.1 & 247 & 39.3 & 4.52 & 2.38 & 30.8 & 158 & 9.13 \\
\hline $4 \mathrm{~S} / 12 \mathrm{~W}-5 \mathrm{H} 8$ & Lakewood1_4 & Pacific_A & 04/24/1997 & 7.9 & 278 & 55.7 & 6.93 & 2.97 & 32.0 & 172 & 27.3 \\
\hline $4 \mathrm{~S} / 12 \mathrm{~W}-5 \mathrm{H} 9$ & Lakewood1_5 & Mesa & 04/24/1997 & 7.9 & 256 & 50.3 & 8.82 & 2.52 & 25.2 & 185 & 9.84 \\
\hline 4S/12W-5H10 & Lakewood1_6 & Dominguez & 04/24/1997 & 7.5 & 610 & 142 & 13.5 & 4.59 & 52.4 & 199 & 208 \\
\hline $4 \mathrm{~S} / 12 \mathrm{~W}-12 \mathrm{~F} 1$ & Lakewood2_1 & Upper Wilmington A & $05 / 29 / 2014$ & 8.7 & 219 & 10.2 & 0.39 & 1. & 68.0 & 106 & 13.3 \\
\hline $4 \mathrm{~S} / 12 \mathrm{~W}-12 \mathrm{~F} 2$ & Lakewood2_2 & Bent Spring & $05 / 29 / 2014$ & 8.3 & 188 & 23.1 & 3.05 & 2.18 & 38.5 & 140 & 5.73 \\
\hline $4 \mathrm{~S} / 12 \mathrm{~W}-12 \mathrm{~F} 3$ & Lakewood2_3 & Harbor & $05 / 29 / 2014$ & 8.4 & 181 & 26 & 2.26 & 1.65 & 35.7 & 137 & 6. \\
\hline $4 \mathrm{~S} / 12 \mathrm{~W}-12 \mathrm{~F} 4$ & Lakewood2_4 & Pacific & $05 / 29 / 2014$ & 8.0 & 289 & 62.1 & 8.75 & 3.11 & 23.2 & 187 & 13.2 \\
\hline $4 \mathrm{~S} / 12 \mathrm{~W}-12 \mathrm{~F} 5$ & Lakewood2_5 & Pacific & $05 / 19 / 2015$ & 8.1 & 245 & 46.1 & 4.44 & 2.55 & 35.5 & 179 & 6.16 \\
\hline $4 \mathrm{~S} / 12 \mathrm{~W}-12 \mathrm{~F} 6$ & Lakewood2_6 & Pacific_A & $05 / 29 / 2014$ & 8.2 & 248 & 31.2 & 4.60 & 2.51 & 52.7 & 202 & 5.76 \\
\hline $4 \mathrm{~S} / 12 \mathrm{~W}-12 \mathrm{~F} 7$ & Lakewood2_7 & Mesa & $05 / 29 / 2014$ & 8.1 & 233 & 52.8 & 3.42 & 2.31 & 24.6 & 182 & 5.78 \\
\hline $4 \mathrm{~S} / 12 \mathrm{~W}-12 \mathrm{~F} 8$ & Lakewood2_8 & Dominguez & $05 / 29 / 2014$ & 8.1 & 258 & 43.9 & 5.53 & 2.56 & 40.9 & 216 & 6.73 \\
\hline $4 \mathrm{~S} / 12 \mathrm{~W}-21 \mathrm{M} 8$ & Long Beach6_1 & Long Beach A & 07/16/2002 & 8.3 & 645 & 7.66 & 1.58 & 1.92 & 258 & 563 & 19.6 \\
\hline $4 \mathrm{~S} / 12 \mathrm{~W}-21 \mathrm{M} 9$ & Long Beach6_2 & Upper Wilmington B & 07/16/2002 & 8.4 & 283 & 3.79 & 0.52 & 1.04 & 106 & 215 & 19.3 \\
\hline $4 \mathrm{~S} / 12 \mathrm{~W}-21 \mathrm{M} 10$ & Long Beach6_3 & Upper Wilmington B & $07 / 17 / 2002$ & 8.4 & 225 & 3.21 & 0.44 & 1.19 & 84.4 & 168 & 16.7 \\
\hline
\end{tabular}


Table 1.2. Groundwater-quality data used for this study from multiple-well monitoring sites, and selected production and observation wells, Los Angeles and Orange Counties, California.-Continued

[See appendix 1 for explanation. Abbreviations: ft, foot; mg/L, milligrams per liter; mm/dd/yyyy, month/day/year; ug/L, micrograms per liter; CaCO 3 , calcium carbonate; \%, percent; <, less than; - , no data. Sediment source/facies: LAR, Los Angeles River; n.a., not assigned; SGR, San Gabriel River; SAR, Santa Ana River, *, potentially affected by mixing with anthropogenic sources of water or seawater]

\begin{tabular}{|c|c|c|c|c|c|c|c|c|c|c|c|}
\hline $\begin{array}{l}\text { State well } \\
\text { number }\end{array}$ & Local well name & $\begin{array}{c}\text { Chronostratigraphic } \\
\text { unit }\end{array}$ & $\begin{array}{c}\text { Sample } \\
\text { collection } \\
\text { date } \\
\text { (mm/dd/yyyy) }\end{array}$ & pH & $\begin{array}{c}\text { Dissolved solids, } \\
\text { filtered, sum of } \\
\text { constituents } \\
\text { (mg/L) }\end{array}$ & $\begin{array}{l}\text { Calcium, } \\
\text { filtered } \\
\text { (mg/L) }\end{array}$ & $\begin{array}{c}\text { Magnesium, } \\
\text { filtered } \\
\text { (mg/L) }\end{array}$ & $\begin{array}{l}\text { Potassium, } \\
\text { filtered } \\
\text { (mg/L) }\end{array}$ & $\begin{array}{l}\text { Sodium, } \\
\text { filtered } \\
\text { (mg/L) }\end{array}$ & $\begin{array}{l}\text { Alkalinity, } \\
\text { filtered } \\
\text { (mg/L as } \\
\mathrm{CaCO}_{3} \text { ) }\end{array}$ & $\begin{array}{c}\text { Chloride, } \\
\text { filtered } \\
\text { (mg/L) }\end{array}$ \\
\hline \multicolumn{12}{|c|}{ Pressure area-Continued } \\
\hline 4S/12W-21M11 & Long Beach6_4 & Upper Wilmington A & $08 / 21 / 2002$ & 8.3 & 226 & 3.54 & 0.48 & 1.39 & 77.0 & 149 & 15.4 \\
\hline 4S/12W-21M12 & Long Beach6_5 & Bent Spring & 08/22/2002 & 8.5 & 192 & 11.9 & 1. & 1.13 & 55.4 & 125 & 17.6 \\
\hline 4S/12W-21M13 & Long Beach6_6 & Pacific & $07 / 17 / 2002$ & 8.0 & 248 & 35.0 & 3.42 & 2.20 & 45.9 & 139 & 32.9 \\
\hline $4 \mathrm{~S} / 12 \mathrm{~W}-23 \mathrm{~K} 3$ & LB Annex 201 & Bent Spring & 08/17/2006 & 8.8 & 205 & 9.10 & 0.38 & 0.74 & 62.7 & 128 & 12.0 \\
\hline $4 \mathrm{~S} / 12 \mathrm{~W}-25 \mathrm{G} 1$ & Long Beach1_1 & Upper Wilmington B & $03 / 14 / 2000$ & 8.6 & 202 & 2.24 & 0.24 & 0.80 & 79.0 & 166 & 15.2 \\
\hline $4 \mathrm{~S} / 12 \mathrm{~W}-25 \mathrm{G} 2$ & Long Beach1_2 & Upper Wilmington B & $03 / 15 / 2000$ & 8.6 & 208 & 2.58 & 0.15 & 0.57 & 78.5 & 162 & 15.0 \\
\hline $4 \mathrm{~S} / 12 \mathrm{~W}-25 \mathrm{G} 3$ & Long Beach1_3 & Upper Wilmington A & $03 / 10 / 2000$ & 8.5 & 196 & 4.45 & 0.31 & 0.74 & 65.9 & 126 & 12.4 \\
\hline $4 \mathrm{~S} / 12 \mathrm{~W}-25 \mathrm{G} 4$ & Long Beach1_4 & Harbor & $03 / 15 / 2000$ & 8.1 & 232 & 19.6 & 1.96 & 1.42 & 58.7 & 138 & 12.3 \\
\hline $4 \mathrm{~S} / 12 \mathrm{~W}-25 \mathrm{G} 5$ & Long Beach1_5 & Pacific & $03 / 14 / 2000$ & 7.6 & 1,630 & 282 & 39.7 & 5.53 & 246 & 164 & 647 \\
\hline $4 \mathrm{~S} / 12 \mathrm{~W}-25 \mathrm{G} 6$ & Long Beach1_6 & Mesa & 03/14/2000 & 7.8 & 742 & 146 & 22.8 & 3.44 & 72.6 & 210 & 132 \\
\hline $4 \mathrm{~S} / 13 \mathrm{~W}-1 \mathrm{~N} 3$ & Long Beach2_1 & Upper Wilmington A & 03/09/2000 & 7.9 & 391 & 6.75 & 1.47 & 2.42 & 143 & 328 & 20.9 \\
\hline $4 \mathrm{~S} / 13 \mathrm{~W}-1 \mathrm{~N} 4$ & Long Beach2_2 & Bent Spring & $03 / 30 / 2001$ & 7.9 & 280 & 12.9 & 1.62 & 2.13 & 89.7 & 212 & 19.8 \\
\hline $4 \mathrm{~S} / 13 \mathrm{~W}-1 \mathrm{~N} 5$ & Long Beach2_3 & Pacific & 03/09/2000 & 8.0 & 248 & 12.4 & 1.27 & 1.56 & 73.5 & 144 & 22.3 \\
\hline $4 \mathrm{~S} / 13 \mathrm{~W}-1 \mathrm{~N} 6$ & Long Beach2_4 & Pacific_A & 03/08/2000 & 8.0 & 294 & 35.1 & 3.99 & 2.97 & 60.1 & 154 & 28.8 \\
\hline $4 \mathrm{~S} / 13 \mathrm{~W}-1 \mathrm{~N} 7$ & Long Beach2_5 & Mesa & 03/07/2000 & 7.7 & 840 & 149 & 21.4 & 5.05 & 107 & 302 & 97.1 \\
\hline $4 \mathrm{~S} / 13 \mathrm{~W}-1 \mathrm{~N} 8$ & Long Beach2_6 & Dominguez & 03/08/2000 & 7.6 & 1,190 & 209 & 34.5 & 6.85 & 138 & 322 & 153 \\
\hline \multicolumn{12}{|c|}{ Orange County Basin } \\
\hline $3 \mathrm{~S} / 8 \mathrm{~W}-34 \mathrm{G} 2$ & Canyon_RV_1_EAST & n.a. & 09/13/2006 & 7.6 & 634 & 93.4 & 21.6 & 6.10 & 86.0 & 218 & 96.1 \\
\hline $4 \mathrm{~S} / 10 \mathrm{~W}-14 \mathrm{H} 3$ & Anaheim_46 & n.a. & 06/07/2006 & 7.8 & 575 & 96.9 & 17.3 & 4.23 & 67.5 & 210 & 91.4 \\
\hline $5 \mathrm{~S} / 12 \mathrm{~W}-1 \mathrm{C} 1$ & $512 \mathrm{~B}$ & Pacific & $05 / 12 / 2011$ & 8.2 & 434 & 56.7 & 11.3 & 1.78 & 62.6 & 98 & 74.6 \\
\hline $5 \mathrm{~S} / 12 \mathrm{~W}-1 \mathrm{C} 2$ & $512 \mathrm{C}$ & Harbor & 05/12/2011 & 8.3 & 401 & 57.9 & 4.64 & 2.02 & 68.7 & 106 & 69.4 \\
\hline $5 \mathrm{~S} / 12 \mathrm{~W}-1 \mathrm{C} 3$ & Seal Beach1_1 & Lower Wilmington & 05/12/2011 & 8.4 & 289 & 4.59 & 0.83 & 1.08 & 110 & 226 & 18.3 \\
\hline $5 \mathrm{~S} / 12 \mathrm{~W}-1 \mathrm{C} 4$ & Seal Beach1_2 & Upper Wilmington B & 05/12/2011 & 8.7 & 219 & 2.97 & 0.36 & 0.71 & 79.3 & 167 & 16.5 \\
\hline $5 \mathrm{~S} / 12 \mathrm{~W}-1 \mathrm{C} 5$ & Seal Beach1_3 & Upper Wilmington B & $05 / 12 / 2011$ & 8.8 & 212 & 2.73 & 0.49 & 0.89 & 77.1 & 161 & 15.3 \\
\hline $5 \mathrm{~S} / 12 \mathrm{~W}-1 \mathrm{C} 6$ & Seal Beach1_4 & Upper Wilmington A & $05 / 12 / 2011$ & 7.9 & 250 & 4.56 & 0.64 & 1.03 & 84.7 & 196 & 19.1 \\
\hline $5 \mathrm{~S} / 12 \mathrm{~W}-1 \mathrm{C} 7$ & Seal Beach1_5 & Bent Spring & $04 / 24 / 2014$ & 8.4 & 215 & 7.03 & 1.49 & 1.61 & 71.8 & 127 & 14.9 \\
\hline $5 \mathrm{~S} / 12 \mathrm{~W}-1 \mathrm{C} 8$ & Seal Beach1_6 & Mesa & 05/12/2011 & 8.2 & 501 & 65.0 & 11.8 & 2.74 & 84.2 & 130 & 86.1 \\
\hline $5 \mathrm{~S} / 12 \mathrm{~W}-1 \mathrm{C} 9$ & Seal Beach1_7 & Dominguez & $05 / 12 / 2011$ & 7.8 & 1,620 & 268 & 59.1 & 7.34 & 225 & 180 & 764 \\
\hline
\end{tabular}


Table 1.2. Groundwater-quality data used for this study from multiple-well monitoring sites, and selected production and observation wells, Los Angeles and Orange Counties, California.-Continued

[See appendix 1 for explanation. Abbreviations: ft, foot; mg/L, milligrams per liter; mm/dd/yyyy, month/day/year; ug/L, micrograms per liter; CaCO ${ }_{3}$, calcium carbonate; $\%$, percent; <, less than; - , no data. Sediment source/facies: LAR, Los Angeles River; n.a., not assigned; SGR, San Gabriel River; SAR, Santa Ana River, *, potentially affected by mixing with anthropogenic sources of water or seawater]

\begin{tabular}{|c|c|c|c|c|c|c|c|c|c|c|c|}
\hline $\begin{array}{l}\text { State well } \\
\text { number }\end{array}$ & Local well name & $\begin{array}{c}\text { Chronostratigraphic } \\
\text { unit }\end{array}$ & $\begin{array}{c}\text { Sample } \\
\text { collection } \\
\text { date } \\
\text { (mm/dd/yyyy) }\end{array}$ & $\mathrm{pH}$ & $\begin{array}{c}\text { Dissolved solids, } \\
\text { filtered, sum of } \\
\text { constituents } \\
\text { (mg/L) }\end{array}$ & $\begin{array}{l}\text { Calcium, } \\
\text { filtered } \\
\text { (mg/L) }\end{array}$ & $\begin{array}{c}\text { Magnesium, } \\
\text { filtered } \\
\text { (mg/L) }\end{array}$ & $\begin{array}{l}\text { Potassium, } \\
\text { filtered } \\
\text { (mg/L) }\end{array}$ & $\begin{array}{l}\text { Sodium, } \\
\text { filtered } \\
\text { (mg/L) }\end{array}$ & $\begin{array}{l}\text { Alkalinity, } \\
\text { filtered } \\
\text { (mg/L as } \\
\mathrm{CaCO}_{3} \text { ) }\end{array}$ & $\begin{array}{c}\text { Chloride, } \\
\text { filtered } \\
\text { (mg/L) }\end{array}$ \\
\hline \multicolumn{12}{|c|}{ West Coast Basin } \\
\hline $2 \mathrm{~S} / 14 \mathrm{~W}-18 \mathrm{~J} 1$ & Holy_Cross_AA & Upper Wilmington B & $11 / 15 / 2006$ & 7.4 & 2,360 & 252 & 110 & 14.8 & 438 & 485 & 640 \\
\hline 2S/14W-19G1 & Hillside_Park_1 & Upper Wilmington A & 09/12/2006 & 7.8 & 743 & 62.4 & 28.4 & 13.4 & 160 & 456 & 106 \\
\hline 2S/14W-28M3 & Inglewood1_1 & Long Beach C & 04/27/1999 & 7.8 & 4,350 & 38.2 & 29.5 & 36.0 & 1,600 & 1,560 & 1,620 \\
\hline 2S/14W-28M4 & Inglewood1_2 & Long Beach A & 09/29/2014 & 7.4 & 1,350 & 197 & 68.2 & 10.2 & 184 & 390 & 399 \\
\hline 2S/14W-28M5 & Inglewood1_3 & Upper Wilmington B & 04/26/1999 & 7.6 & 861 & 85.5 & 35.8 & 6.71 & 156 & 318 & 228 \\
\hline 2S/14W-28M6 & Inglewood1_4 & Harbor & 04/27/1999 & 7.6 & 624 & 77.9 & 34.2 & 8.43 & 82.7 & 226 & 170 \\
\hline 2S/14W-28M7 & Inglewood1_5 & Pacific & 04/26/1999 & 7.3 & 921 & 145 & 45.6 & 6.12 & 104 & 253 & 300 \\
\hline $2 \mathrm{~S} / 15 \mathrm{~W}-35 \mathrm{~A} 1$ & Westchester1_1 & Lower Wilmington & $05 / 22 / 2002$ & 7.9 & 1,290 & 15.8 & 13.8 & 17.7 & 468 & 997 & 129 \\
\hline $2 \mathrm{~S} / 15 \mathrm{~W}-35 \mathrm{~A} 2$ & Westchester1_2 & Upper Wilmington B & $05 / 22 / 2002$ & 7.9 & 781 & 24.1 & 14.1 & 14.9 & 258 & 597 & 72.1 \\
\hline $2 \mathrm{~S} / 15 \mathrm{~W}-35 \mathrm{~A} 3$ & Westchester1_3 & Upper Wilmington B & $05 / 20 / 2002$ & 7.8 & 631 & 40.0 & 18.6 & 12.9 & 168 & 466 & 65.8 \\
\hline $2 \mathrm{~S} / 15 \mathrm{~W}-35 \mathrm{~A} 4$ & Westchester1_4 & Bent Spring & $05 / 21 / 2002$ & 7.8 & 603 & 68.3 & 26.8 & 9.82 & 103 & 361 & 63.5 \\
\hline $2 \mathrm{~S} / 15 \mathrm{~W}-35 \mathrm{~A} 5$ & Westchester1_5 & Harbor & $05 / 21 / 2002$ & 7.8 & 586 & 65.1 & 25.3 & 8.50 & 106 & 339 & 66.6 \\
\hline 3S/14W-4R1 & Inglewood3_1 & Long Beach C & $05 / 17 / 2013$ & 7.9 & 2,440 & 22.2 & 11.3 & 17.1 & 862 & 684 & 1,040 \\
\hline $3 \mathrm{~S} / 14 \mathrm{~W}-4 \mathrm{R} 2$ & Inglewood3_2 & Long Beach BC & $05 / 17 / 2013$ & 8.1 & 1,370 & 10.7 & 5.86 & 13.7 & 530 & 1160 & 55.1 \\
\hline 3S/14W-4R3 & Inglewood3_3 & Long Beach B & 05/17/2013 & 8.1 & 712 & 5.71 & 2.85 & 7.67 & 264 & 589 & 17.7 \\
\hline $3 \mathrm{~S} / 14 \mathrm{~W}-4 \mathrm{R} 4$ & Inglewood3_4 & Long Beach A & 05/17/2013 & 8.0 & 989 & 13.3 & 8.48 & 16.8 & 354 & 840 & 29.1 \\
\hline $3 \mathrm{~S} / 14 \mathrm{~W}-4 \mathrm{R} 5$ & Inglewood3_5 & Upper Wilmington A & $05 / 17 / 2013$ & 7.7 & 589 & 65.5 & 21.7 & 9.24 & 111 & 392 & 98.8 \\
\hline 3S/14W-4R6 & Inglewood3_6 & Harbor & 05/17/2013 & 8.0 & 464 & 62.1 & 21.5 & 7.53 & 64.2 & 208 & 136 \\
\hline $3 \mathrm{~S} / 14 \mathrm{~W}-4 \mathrm{R} 7$ & Inglewood3_7 & Pacific & 05/17/2013 & 7.8 & 910 & 146 & 44.9 & 7.38 & 109 & 254 & 380 \\
\hline $3 \mathrm{~S} / 14 \mathrm{~W}-13 \mathrm{~J} 5$ & Gardena1_1 & Long Beach A & 06/06/1996 & 7.7 & 369 & 14.0 & 7.20 & 12.0 & 96.0 & 295 & 17.0 \\
\hline $3 \mathrm{~S} / 14 \mathrm{~W}-13 \mathrm{~J} 6$ & Gardena1_2 & Upper Wilmington A & 06/07/1996 & 7.7 & 324 & 53.0 & 11.0 & 3.50 & 38.0 & 188 & 21.0 \\
\hline $3 \mathrm{~S} / 14 \mathrm{~W}-13 \mathrm{~J} 7$ & Gardena1_3 & Bent Spring & 06/07/1996 & 7.8 & 325 & 53.0 & 10.0 & 3.30 & 39.0 & 175 & 22.0 \\
\hline $3 \mathrm{~S} / 14 \mathrm{~W}-13 \mathrm{~J} 8$ & Gardena1_4 & Pacific & 06/06/1996 & 7.2 & 842 & 150 & 37.0 & 5.40 & 87.0 & 163 & 370 \\
\hline $3 \mathrm{~S} / 14 \mathrm{~W}-17 \mathrm{G} 3$ & Hawthorne1_1 & Lower Wilmington & 08/17/1999 & 7.8 & 886 & 14.8 & 12.0 & 21.2 & 292 & 725 & 47.9 \\
\hline $3 \mathrm{~S} / 14 \mathrm{~W}-17 \mathrm{G} 4$ & Hawthorne1_2 & Upper Wilmington B & 08/07/1999 & 7.9 & 765 & 11.2 & 7.85 & 15.2 & 277 & 632 & 42.6 \\
\hline $3 \mathrm{~S} / 14 \mathrm{~W}-17 \mathrm{G} 5$ & Hawthorne1_3 & Bent Spring & 08/07/1999 & 7.8 & 564 & 33.6 & 20.9 & 14.2 & 143 & 441 & 50.0 \\
\hline $3 \mathrm{~S} / 14 \mathrm{~W}-17 \mathrm{G} 6$ & Hawthorne1_4 & Bent Spring & 08/07/1999 & 7.6 & 484 & 37.2 & 17.7 & 10.2 & 112 & 355 & 52.5 \\
\hline $3 \mathrm{~S} / 14 \mathrm{~W}-17 \mathrm{G} 7$ & Hawthorne1_5 & Harbor & 08/07/1999 & 7.6 & 558 & 79.0 & 27.4 & 5.94 & 78.7 & 209 & 187 \\
\hline
\end{tabular}


Table 1.2. Groundwater-quality data used for this study from multiple-well monitoring sites, and selected production and observation wells, Los Angeles and Orange Counties, California.-Continued

[See appendix 1 for explanation. Abbreviations: ft, foot; mg/L, milligrams per liter; mm/dd/yyyy, month/day/year; ug/L, micrograms per liter; CaCO 3 , calcium carbonate; \%, percent; <, less than; - , no data. Sediment source/facies: LAR, Los Angeles River; n.a., not assigned; SGR, San Gabriel River; SAR, Santa Ana River, *, potentially affected by mixing with anthropogenic sources of water or seawater]

\begin{tabular}{|c|c|c|c|c|c|c|c|c|c|c|c|}
\hline $\begin{array}{l}\text { State well } \\
\text { number }\end{array}$ & Local well name & $\begin{array}{l}\text { Chronostratigraphic } \\
\text { unit }\end{array}$ & $\begin{array}{c}\text { Sample } \\
\text { collection } \\
\text { date } \\
\text { (mm/dd/yyyy) }\end{array}$ & pH & $\begin{array}{c}\text { Dissolved solids, } \\
\text { filtered, sum of } \\
\text { constituents } \\
\text { (mg/L) }\end{array}$ & $\begin{array}{c}\text { Calcium, } \\
\text { filtered } \\
\text { (mg/L) }\end{array}$ & $\begin{array}{l}\text { Magnesium, } \\
\text { filtered } \\
\text { (mg/L) }\end{array}$ & $\begin{array}{l}\text { Potassium, } \\
\text { filtered } \\
\text { (mg/L) }\end{array}$ & $\begin{array}{l}\text { Sodium, } \\
\text { filtered } \\
\text { (mg/L) }\end{array}$ & $\begin{array}{l}\text { Alkalinity, } \\
\text { filtered } \\
\text { (mg/L as } \\
\mathrm{CaCO}_{3} \text { ) }\end{array}$ & $\begin{array}{c}\text { Chloride, } \\
\text { filtered } \\
\text { (mg/L) }\end{array}$ \\
\hline \multicolumn{12}{|c|}{ West Coast Basin-Continued } \\
\hline 3S/14W-17G8 & Hawthorne1_6 & Pacific & 08/17/1999 & 7.4 & 2,060 & 304 & 88.7 & 8.45 & 273 & 285 & 577 \\
\hline $3 \mathrm{~S} / 14 \mathrm{~W}-25 \mathrm{~K} 7$ & Gardena2_1 & Long Beach A & 09/26/2004 & 8.1 & 346 & 15.4 & 5.93 & 5.67 & 107 & 295 & 13.7 \\
\hline $3 \mathrm{~S} / 14 \mathrm{~W}-25 \mathrm{~K} 8$ & Gardena2_2 & Upper Wilmington A & $09 / 26 / 2004$ & 7.8 & 326 & 36.3 & 11.1 & 5.86 & 55.0 & 188 & 22.1 \\
\hline $3 \mathrm{~S} / 14 \mathrm{~W}-25 \mathrm{~K} 9$ & Gardena2_3 & Upper Wilmington A & $09 / 26 / 2004$ & 7.9 & 322 & 48.9 & 11.7 & 3.81 & 41.5 & 183 & 22.6 \\
\hline $3 \mathrm{~S} / 14 \mathrm{~W}-25 \mathrm{~K} 10$ & Gardena2_4 & Harbor & $09 / 26 / 2004$ & 7.7 & 239 & 31.4 & 8.60 & 3.29 & 40.0 & 180 & 21.1 \\
\hline $3 \mathrm{~S} / 14 \mathrm{~W}-25 \mathrm{~K} 11$ & Gardena2_5 & Pacific & 09/26/2004 & 8.0 & 313 & 47.6 & 10.6 & 3.26 & 48.4 & 198 & 35.7 \\
\hline $3 \mathrm{~S} / 14 \mathrm{~W}-27 \mathrm{C} 2$ & Lawndale1_1 & Long Beach A & 09/08/2014 & 8.1 & 576 & 10.2 & 3.56 & 6.04 & 209 & 490 & 17.5 \\
\hline $3 \mathrm{~S} / 14 \mathrm{~W}-27 \mathrm{C} 3$ & Lawndale1_2 & Lower Wilmington & 09/08/2014 & 8.0 & 759 & 4.59 & 3.58 & 9.12 & 290 & 644 & 33.3 \\
\hline $3 \mathrm{~S} / 14 \mathrm{~W}-27 \mathrm{C} 4$ & Lawndale1_3 & Upper Wilmington B & 09/08/2014 & 8.0 & 358 & 16.4 & 9.79 & 9.80 & 100 & 266 & 26.9 \\
\hline $3 \mathrm{~S} / 14 \mathrm{~W}-27 \mathrm{C} 5$ & Lawndale1_4 & Harbor & 09/08/2014 & 8.0 & 395 & 43.8 & 16.2 & 5.49 & 71.6 & 203 & 58.3 \\
\hline $3 \mathrm{~S} / 14 \mathrm{~W}-27 \mathrm{C} 6$ & Lawndale1_5 & Harbor & 09/08/2014 & 8.0 & 393 & 52.9 & 17.7 & 5.34 & 58.9 & 198 & 55.8 \\
\hline $3 \mathrm{~S} / 14 \mathrm{~W}-27 \mathrm{C} 7$ & Lawndale1_6 & Pacific & $09 / 08 / 2014$ & 7.6 & 1,380 & 201 & 56.1 & 8.84 & 220 & 264 & 544 \\
\hline $3 \mathrm{~S} / 14 \mathrm{~W}-30 \mathrm{~L} 2$ & Manhattan Beach1_1 & Long Beach C & $08 / 28 / 2013$ & 7.9 & 6,910 & 47.6 & 35.7 & 20.3 & 2,410 & 594 & 3,940 \\
\hline $3 \mathrm{~S} / 14 \mathrm{~W}-30 \mathrm{~L} 3$ & Manhattan Beach1_2 & Long Beach BC & $08 / 28 / 2013$ & 8.0 & 2,610 & 31.2 & 12.9 & 16.6 & 885 & 463 & 1,320 \\
\hline $3 \mathrm{~S} / 14 \mathrm{~W}-30 \mathrm{~L} 4$ & Manhattan Beach1_3 & Long Beach A & $08 / 28 / 2013$ & 8.1 & 1,230 & 15.3 & 10.8 & 25.6 & 404 & 958 & 126 \\
\hline 3S/14W-30L5 & Manhattan Beach1_4 & Upper Wilmington B & $08 / 28 / 2013$ & 8.1 & 899 & 25.5 & 9.44 & 9.84 & 181 & 503 & 36.5 \\
\hline 3S/14W-30L6 & Manhattan Beach1_5 & Bent Spring & $08 / 28 / 2013$ & 7.2 & 20,900 & 1,990 & 939 & 106 & 4,160 & 130 & 12,100 \\
\hline $3 \mathrm{~S} / 14 \mathrm{~W}-30 \mathrm{~L} 7$ & Manhattan Beach1_6 & Pacific & $08 / 28 / 2013$ & 7.5 & 7,250 & 1,010 & 273 & 38.1 & 1,250 & 166 & 4,010 \\
\hline $3 \mathrm{~S} / 14 \mathrm{~W}-30 \mathrm{~L} 8$ & Manhattan Beach1_7 & Mesa & $08 / 28 / 2013$ & 8.0 & 675 & 57.5 & 15.8 & 5.38 & 136 & 140 & 139 \\
\hline $3 \mathrm{~S} / 14 \mathrm{~W}-33 \mathrm{R} 5$ & Torrance1_1 & Long Beach B & $06 / 17 / 2010$ & 8.0 & 967 & 13.8 & 5.86 & 12.6 & 353 & 700 & 96.4 \\
\hline $3 \mathrm{~S} / 14 \mathrm{~W}-33 \mathrm{R} 6$ & Torrance1_2 & Lower Wilmington & $06 / 17 / 2010$ & 8.1 & 1,070 & 7.21 & 4.86 & 10.2 & 427 & 925 & 16.6 \\
\hline $3 \mathrm{~S} / 14 \mathrm{~W}-33 \mathrm{R} 7$ & Torrance1_3 & Upper Wilmington B & $06 / 17 / 2010$ & 7.9 & 512 & 13.2 & 6.61 & 14.3 & 173 & 426 & 29.1 \\
\hline $3 \mathrm{~S} / 14 \mathrm{~W}-33 \mathrm{R} 8$ & Torrance1_4 & Bent Spring & $06 / 17 / 2010$ & 8.0 & 384 & 23.2 & 10.8 & 10.6 & 103 & 294 & 29.9 \\
\hline 3S/14W-33R9 & Torrance1_5 & Pacific & $06 / 17 / 2010$ & 7.5 & 3,040 & 474 & 112 & 15.2 & 433 & 174 & 1,560 \\
\hline 3S/14W-33R10 & Torrance1_6 & Mesa & $06 / 17 / 2010$ & 7.9 & 805 & 104 & 23.3 & 6.25 & 139 & 227 & 183 \\
\hline 4S/12W-30J1 & Long Beach8_1 & Long Beach A & 09/29/2004 & 7.9 & 638 & 6.14 & 1.89 & 2.56 & 253 & 544 & 23.6 \\
\hline 4S/12W-30J2 & Long Beach8_2 & Lower Wilmington & 09/29/2004 & 7.9 & 609 & 7.81 & 2.73 & 4.38 & 228 & 500 & 35.9 \\
\hline $4 \mathrm{~S} / 12 \mathrm{~W}-30 \mathrm{~J} 3$ & Long Beach8_3 & Upper Wilmington B & 09/30/2004 & 7.9 & 851 & 9.81 & 4.71 & 7.72 & 329 & 636 & 88.9 \\
\hline
\end{tabular}


Table 1.2. Groundwater-quality data used for this study from multiple-well monitoring sites, and selected production and observation wells, Los Angeles and Orange Counties, California.-Continued

[See appendix 1 for explanation. Abbreviations: ft, foot; mg/L, milligrams per liter; mm/dd/yyyy, month/day/year; ug/L, micrograms per liter; CaCO 3 , calcium carbonate; \%, percent; <, less than; - , no data. Sediment source/facies: LAR, Los Angeles River; n.a., not assigned; SGR, San Gabriel River; SAR, Santa Ana River, *, potentially affected by mixing with anthropogenic sources of water or seawater]

\begin{tabular}{|c|c|c|c|c|c|c|c|c|c|c|c|}
\hline $\begin{array}{l}\text { State well } \\
\text { number }\end{array}$ & Local well name & $\begin{array}{c}\text { Chronostratigraphic } \\
\text { unit }\end{array}$ & $\begin{array}{c}\text { Sample } \\
\text { collection } \\
\text { date } \\
\text { (mm/dd/yyyy) }\end{array}$ & $\mathbf{p H}$ & $\begin{array}{l}\text { Dissolved solids, } \\
\text { filtered, sum of } \\
\text { constituents } \\
\text { (mg/L) }\end{array}$ & $\begin{array}{l}\text { Calcium, } \\
\text { filtered } \\
\text { (mg/L) }\end{array}$ & $\begin{array}{l}\text { Magnesium, } \\
\text { filtered } \\
\text { (mg/L) }\end{array}$ & $\begin{array}{l}\text { Potassium, } \\
\text { filtered } \\
\text { (mg/L) }\end{array}$ & $\begin{array}{l}\text { Sodium, } \\
\text { filtered } \\
\text { (mg/L) }\end{array}$ & $\begin{array}{l}\text { Alkalinity, } \\
\text { filtered } \\
\text { (mg/L as } \\
\mathrm{CaCO}_{3} \text { ) }\end{array}$ & $\begin{array}{c}\text { Chloride, } \\
\text { filtered } \\
\text { (mg/L) }\end{array}$ \\
\hline \multicolumn{12}{|c|}{ West Coast Basin-Continued } \\
\hline $4 \mathrm{~S} / 12 \mathrm{~W}-30 \mathrm{~J} 4$ & Long Beach8_4 & Upper Wilmington A & 09/30/2004 & 7.7 & 1,390 & 49.6 & 34.7 & 12.8 & 435 & 408 & 585 \\
\hline $4 \mathrm{~S} / 12 \mathrm{~W}-30 \mathrm{~J} 5$ & Long Beach8_5 & Bent Spring & 09/30/2004 & 7.4 & 1,030 & 61.4 & 26.3 & 10.3 & 294 & 313 & 419 \\
\hline $4 \mathrm{~S} / 12 \mathrm{~W}-30 \mathrm{~J} 6$ & Long Beach8_6 & Mesa & 09/30/2004 & 7.5 & 938 & 107 & 31.8 & 6.75 & 200 & 212 & 418 \\
\hline 4S/13W-5F1 & Carson3_1 & Long Beach A & $04 / 02 / 2012$ & 8.1 & 456 & 8.07 & 2.33 & 2.87 & 163 & 369 & 13.6 \\
\hline $4 \mathrm{~S} / 13 \mathrm{~W}-5 \mathrm{~F} 2$ & Carson3_2 & Upper Wilmington B & $04 / 02 / 2012$ & 8.3 & 236 & 19.0 & 3.84 & 3.26 & 60.0 & 159 & 20.1 \\
\hline $4 \mathrm{~S} / 13 \mathrm{~W}-5 \mathrm{~F} 3$ & Carson3_3 & Upper Wilmington B & $04 / 02 / 2012$ & 7.9 & 247 & 15.2 & 2.93 & 3.31 & 71.2 & 177 & 21.2 \\
\hline 4S/13W-5F4 & Carson3_4 & Upper Wilmington A & 04/02/2012 & 7.8 & 235 & 21.6 & 5.93 & 3.78 & 54.6 & 175 & 20.6 \\
\hline 4S/13W-5F5 & Carson3_5 & Upper Wilmington A & 04/02/2012 & 7.8 & 245 & 31.9 & 8.52 & 3.06 & 44.5 & 184 & 20.6 \\
\hline 4S/13W-5F6 & Carson3_6 & Harbor & $04 / 02 / 2012$ & 8.1 & 323 & 44.6 & 11.4 & 3.79 & 51.5 & 186 & 21.0 \\
\hline 4S/13W-9H9 & Carson1_1 & Upper Wilmington A & 01/06/1998 & 8.2 & 202 & 18.8 & 3.77 & 3.09 & 50.7 & 150 & 20.1 \\
\hline $4 \mathrm{~S} / 13 \mathrm{~W}-9 \mathrm{H} 10$ & Carson1_2 & Upper Wilmington A & 01/05/1998 & 8.1 & 228 & 31.9 & 6.71 & 2.37 & 42.3 & 177 & 20.5 \\
\hline 4S/13W-9H11 & Carson1_3 & Harbor & 01/06/1998 & 8.0 & 311 & 43.5 & 11.9 & 3.14 & 46.6 & 171 & 22.6 \\
\hline 4S/13W-9H12 & Carson1_4 & Pacific & 01/06/1998 & 7.8 & 553 & 86.5 & 20.8 & 4.45 & 74.4 & 215 & 112 \\
\hline $4 \mathrm{~S} / 13 \mathrm{~W}-18 \mathrm{~K} 1$ & Carson2_1 & Lower Wilmington & 08/07/2002 & 8.1 & 224 & 4.74 & 1.11 & 3.14 & 80.6 & 169 & 19.7 \\
\hline $4 \mathrm{~S} / 13 \mathrm{~W}-18 \mathrm{~K} 2$ & Carson2_2 & Upper Wilmington A & 08/08/2002 & 8.3 & 266 & 12.4 & 4.29 & 4.27 & 81.0 & 197 & 21.2 \\
\hline $4 \mathrm{~S} / 13 \mathrm{~W}-18 \mathrm{~K} 3$ & Carson2_3 & Upper Wilmington A & 08/09/2002 & 8.2 & 263 & 21.9 & 7.56 & 4.57 & 60.4 & 192 & 21.3 \\
\hline $4 \mathrm{~S} / 13 \mathrm{~W}-18 \mathrm{~K} 4$ & Carson2_4 & Bent Spring & 08/08/2002 & 7.8 & 277 & 34.3 & 11.7 & 4.27 & 51.0 & 219 & 21.3 \\
\hline $4 \mathrm{~S} / 13 \mathrm{~W}-18 \mathrm{~K} 5$ & Carson2_5 & Pacific & 08/07/2002 & 8.0 & 270 & 37.4 & 8.61 & 3.28 & 47.0 & 190 & 21.3 \\
\hline 4S/13W-23D3 & Long Beach3_1 & Long Beach A & 03/29/2001 & 8.0 & 448 & 11.0 & 3.47 & 3.81 & 156 & 392 & 18.5 \\
\hline 4S/13W-23D4 & Long Beach3_2 & Upper Wilmington B & $03 / 29 / 2001$ & 8.2 & 235 & 15.9 & 2.73 & 2.50 & 61.5 & 144 & 18.8 \\
\hline 4S/13W-23D5 & Long Beach3_3 & Upper Wilmington A & 03/28/2001 & 7.9 & 221 & 17.9 & 3.24 & 2.71 & 55.8 & 159 & 24.8 \\
\hline $4 \mathrm{~S} / 13 \mathrm{~W}-23 \mathrm{D} 6$ & Long Beach3_4 & Bent Spring & $03 / 27 / 2001$ & 7.8 & 577 & 88.8 & 24.0 & 6.24 & 72.9 & 139 & 213 \\
\hline 4S/13W-23D7 & Long Beach3_5 & Harbor & $03 / 26 / 2001$ & 7.8 & 1,210 & 238 & 57.3 & 7.84 & 98.6 & 148 & 619 \\
\hline $4 \mathrm{~S} / 13 \mathrm{~W}-23 \mathrm{~N} 3$ & $889 \mathrm{P}$ & Upper Wilmington A & 02/11/1999 & 7.7 & 394 & 29.2 & 5.59 & 3.53 & 109 & 194 & 107 \\
\hline $4 \mathrm{~S} / 13 \mathrm{~W}-26 \mathrm{~F} 5$ & $380 \mathrm{P}$ & Upper Wilmington A & 02/04/1999 & 8.3 & 261 & 9.37 & 2. & 2.91 & 86.2 & 177 & 36.9 \\
\hline $4 \mathrm{~S} / 13 \mathrm{~W}-27 \mathrm{H} 4$ & Long Beach7_1 & Long Beach A & $08 / 27 / 2003$ & 8.3 & 573 & 6.2 & 3.03 & 4.77 & 206 & 503 & 22.9 \\
\hline $4 \mathrm{~S} / 13 \mathrm{~W}-27 \mathrm{H} 5$ & Long Beach7_2 & Upper Wilmington A & $08 / 26 / 2003$ & 8.0 & 329 & 13.5 & 4.08 & 3.46 & 107 & 181 & 74.4 \\
\hline 4S/13W-27H6 & Long Beach7_3 & Upper Wilmington A & $08 / 26 / 2003$ & 7.9 & 313 & 12.8 & 4.43 & 3.21 & 97.1 & 177 & 67.6 \\
\hline
\end{tabular}


Table 1.2. Groundwater-quality data used for this study from multiple-well monitoring sites, and selected production and observation wells, Los Angeles and Orange Counties, California.-Continued

[See appendix 1 for explanation. Abbreviations: ft, foot; mg/L, milligrams per liter; mm/dd/yyyy, month/day/year; ug/L, micrograms per liter; CaCO 3 , calcium carbonate; \%, percent; <, less than; —, no data. Sediment source/facies: LAR, Los Angeles River; n.a., not assigned; SGR, San Gabriel River; SAR, Santa Ana River, *, potentially affected by mixing with anthropogenic sources of water or seawater]

\begin{tabular}{|c|c|c|c|c|c|c|c|c|c|c|c|}
\hline $\begin{array}{l}\text { State well } \\
\text { number }\end{array}$ & Local well name & $\begin{array}{c}\text { Chronostratigraphic } \\
\text { unit }\end{array}$ & $\begin{array}{c}\text { Sample } \\
\text { collection } \\
\text { date } \\
\text { (mm/dd/yyyy) }\end{array}$ & pH & $\begin{array}{c}\text { Dissolved solids, } \\
\text { filtered, sum of } \\
\text { constituents } \\
\text { (mg/L) }\end{array}$ & $\begin{array}{c}\text { Calcium, } \\
\text { filtered } \\
\text { (mg/L) }\end{array}$ & $\begin{array}{c}\text { Magnesium, } \\
\text { filtered } \\
\text { (mg/L) }\end{array}$ & $\begin{array}{l}\text { Potassium, } \\
\text { filtered } \\
\text { (mg/L) }\end{array}$ & $\begin{array}{l}\text { Sodium, } \\
\text { filtered } \\
\text { (mg/L) }\end{array}$ & $\begin{array}{l}\text { Alkalinity, } \\
\text { filtered } \\
\text { (mg/L as } \\
\mathrm{CaCO}_{3} \text { ) }\end{array}$ & $\begin{array}{c}\text { Chloride, } \\
\text { filtered } \\
\text { (mg/L) }\end{array}$ \\
\hline \multicolumn{12}{|c|}{ West Coast Basin—Continued } \\
\hline $4 \mathrm{~S} / 13 \mathrm{~W}-27 \mathrm{H} 7$ & Long Beach7_4 & Bent Spring & $08 / 25 / 2003$ & 7.5 & 3,770 & 463 & 174 & 20.9 & 615 & 145 & 2,100 \\
\hline 4S/13W-28A3 & Wilmington1_1 & Upper Wilmington B & 04/24/1999 & 7.9 & 498 & 50.0 & 16.1 & 7.14 & 106 & 138 & 213 \\
\hline 4S/13W-28A4 & Wilmington1_2 & Upper Wilmington B & 04/25/1999 & 7.8 & 787 & 124 & 26.9 & 5.61 & 130 & 138 & 337 \\
\hline $4 \mathrm{~S} / 13 \mathrm{~W}-28 \mathrm{~A} 5$ & Wilmington1_3 & Upper Wilmington A & 04/25/1999 & 7.3 & 1,720 & 214 & 46.5 & 9.42 & 346 & 153 & 907 \\
\hline 4S/13W-28A6 & Wilmington1_4 & Pacific & 04/25/1999 & 7.6 & 2,470 & 282 & 95.9 & 12.9 & 457 & 148 & 1,210 \\
\hline $4 \mathrm{~S} / 13 \mathrm{~W}-28 \mathrm{~A} 7$ & Wilmington1_5 & Mesa & 04/24/1999 & 7.6 & 789 & 85.2 & 30.6 & 7.37 & 145 & 204 & 233 \\
\hline $4 \mathrm{~S} / 13 \mathrm{~W}-29 \mathrm{H} 5$ & $340 \mathrm{~L}$ & Pacific & 02/03/1999 & 7.5 & 1,260 & 180 & 61.0 & 13.0 & 614 & 260 & 1,300 \\
\hline $4 \mathrm{~S} / 13 \mathrm{~W}-29 \mathrm{H} 6$ & $340 \mathrm{M}$ & Harbor & 02/03/1999 & 7.4 & 2,500 & 170 & 53.0 & 7.80 & 231 & 220 & 570 \\
\hline $4 \mathrm{~S} / 13 \mathrm{~W}-29 \mathrm{H} 7$ & $340 \mathrm{~N}$ & Upper Wilmington A & 02/03/1999 & 8.0 & 2,560 & 57.0 & 16.0 & 3.40 & 81.0 & 180 & 140 \\
\hline 4S/13W-31J1 & $321 \mathrm{~A}$ & Lower Wilmington & 02/06/1999 & 7.6 & 3,660 & 202 & 155 & 20.1 & 957 & 306 & 2,110 \\
\hline $4 \mathrm{~S} / 13 \mathrm{~W}-32 \mathrm{~F} 1$ & Wilmington2_1 & Long Beach B & 04/21/1999 & 8.2 & 515 & 3.31 & 2.24 & 5.46 & 195 & 391 & 56.5 \\
\hline $4 \mathrm{~S} / 13 \mathrm{~W}-32 \mathrm{~F} 2$ & Wilmington2_2 & Long Beach A & 02/18/1999 & 8.0 & 1,310 & 29.8 & 21.6 & 12.7 & 437 & 472 & 513 \\
\hline $4 \mathrm{~S} / 13 \mathrm{~W}-32 \mathrm{~F} 3$ & Wilmington2_3 & Lower Wilmington & 02/18/1999 & 7.6 & 336 & 19.8 & 7.47 & 4.34 & 102 & 187 & 72.3 \\
\hline $4 \mathrm{~S} / 13 \mathrm{~W}-32 \mathrm{~F} 4$ & Wilmington2_4 & Upper Wilmington B & 04/21/1999 & 7.5 & 1,990 & 143 & 66.7 & 16.4 & 492 & 290 & 1,010 \\
\hline $4 \mathrm{~S} / 13 \mathrm{~W}-32 \mathrm{~F} 5$ & Wilmington2_5 & Mesa & 02/18/1999 & 7.5 & 9,580 & 640 & 310 & 30.9 & 2,600 & 206 & 5,230 \\
\hline $4 \mathrm{~S} / 13 \mathrm{~W}-34 \mathrm{~A} 1$ & $371 \mathrm{D}$ & Long Beach A & 02/11/1999 & 8.4 & 257 & 6.42 & 1.41 & 3.41 & 89.3 & 165 & 41.9 \\
\hline 4S/13W-34M1 & $361 \mathrm{H}$ & Long Beach A & 02/10/1999 & 7.8 & 319 & 17.6 & 4.38 & 3.03 & 95.3 & 175 & 71.2 \\
\hline 4S/13W-35B2 & $381 \mathrm{~J}$ & Lower Wilmington & 03/18/1999 & 8.1 & 812 & 12.1 & 8.16 & 1.68 & 298 & 687 & 75.7 \\
\hline $4 \mathrm{~S} / 13 \mathrm{~W}-35 \mathrm{~B} 3$ & $381 \mathrm{~K}$ & Upper Wilmington B & 03/19/1999 & 8.0 & 5,450 & 293 & 251 & 42.2 & 1,410 & 203 & 3,050 \\
\hline $4 \mathrm{~S} / 14 \mathrm{~W}-2 \mathrm{~N} 1$ & PM-3 Madrid_1 & Bent Spring & 08/29/1995 & 7.7 & 390 & 16.0 & 10.0 & - & 130 & 320 & 28.0 \\
\hline $4 \mathrm{~S} / 14 \mathrm{~W}-2 \mathrm{~N} 2$ & PM-3 Madrid_2 & Harbor & 08/28/1995 & 7.9 & 710 & 32.0 & 10.0 & - & 57.0 & 190 & 35.0 \\
\hline $4 \mathrm{~S} / 14 \mathrm{~W}-2 \mathrm{~N} 3$ & PM-3 Madrid_3 & Pacific & 08/29/1995 & 7.7 & 700 & 70.0 & 22.0 & - & 81.0 & 180 & 180 \\
\hline $4 \mathrm{~S} / 14 \mathrm{~W}-2 \mathrm{~N} 4$ & PM-3 Madrid_4 & Pacific & 08/28/1995 & 7.8 & 1,100 & 70.0 & 20.0 & - & 120 & 190 & 210 \\
\hline 4S/14W-4Q1 & PM-4 Mariner_1 & Bent Spring & $04 / 27 / 2014$ & 8.4 & 340 & 26 & 11.0 & 6.80 & 78.0 & 240 & 27.0 \\
\hline 4S/14W-4Q2 & PM-4 Mariner_2 & Harbor & 09/07/2014 & 7.5 & 16,000 & 1,400 & 450 & 52.0 & 2,100 & 150 & 6,500 \\
\hline 4S/14W-4Q3 & PM-4 Mariner_3 & Pacific & $09 / 07 / 2014$ & 8.2 & 670 & 65 & 18.0 & 6.20 & 120 & 160 & 100 \\
\hline 4S/14W-4Q4 & PM-4 Mariner_4 & Pacific & 09/07/2014 & 8.1 & 630 & 69 & 19.0 & 6.00 & 110 & 190 & 110 \\
\hline 4S/14W-10C1 & PM-1 Columbia_1 & Bent Spring & $08 / 21 / 2014$ & 8.3 & 280 & 26 & 15.0 & 9.20 & 66.0 & 200 & 22.0 \\
\hline
\end{tabular}


Table 1.2. Groundwater-quality data used for this study from multiple-well monitoring sites, and selected production and observation wells, Los Angeles and Orange Counties, California.-Continued

[See appendix 1 for explanation. Abbreviations: ft, foot; mg/L, milligrams per liter; mm/dd/yyyy, month/day/year; ug/L, micrograms per liter; CaCO ${ }_{3}$, calcium carbonate; \%, percent; <, less than; - , no data. Sediment source/facies: LAR, Los Angeles River; n.a., not assigned; SGR, San Gabriel River; SAR, Santa Ana River, *, potentially affected by mixing with anthropogenic sources of water or seawater]

\begin{tabular}{|c|c|c|c|c|c|c|c|c|c|c|c|}
\hline $\begin{array}{l}\text { State well } \\
\text { number }\end{array}$ & Local well name & $\begin{array}{c}\text { Chronostratigraphic } \\
\text { unit }\end{array}$ & $\begin{array}{c}\text { Sample } \\
\text { collection } \\
\text { date } \\
\text { (mm/dd/yyyy) }\end{array}$ & $\mathrm{pH}$ & $\begin{array}{l}\text { Dissolved solids, } \\
\text { filtered, sum of } \\
\text { constituents } \\
\text { (mg/L) }\end{array}$ & $\begin{array}{l}\text { Calcium, } \\
\text { filtered } \\
\text { (mg/L) }\end{array}$ & $\begin{array}{l}\text { Magnesium, } \\
\text { filtered } \\
\text { (mg/L) }\end{array}$ & $\begin{array}{l}\text { Potassium, } \\
\text { filtered } \\
\text { (mg/L) }\end{array}$ & $\begin{array}{l}\text { Sodium, } \\
\text { filtered } \\
\text { (mg/L) }\end{array}$ & $\begin{array}{l}\text { Alkalinity, } \\
\text { filtered } \\
\text { (mg/L as } \\
\mathrm{CaCO}_{3} \text { ) }\end{array}$ & $\begin{array}{c}\text { Chloride, } \\
\text { filtered } \\
\text { (mg/L) }\end{array}$ \\
\hline \multicolumn{12}{|c|}{ West Coast Basin-Continued } \\
\hline $4 \mathrm{~S} / 14 \mathrm{~W}-10 \mathrm{C} 2$ & PM-1 Columbia_2 & Harbor & $08 / 21 / 2014$ & 7.9 & 2,400 & 300 & 100 & 14.0 & 210 & 140 & 880 \\
\hline 4S/14W-15E1 & Torrance2_1 & Long Beach A & 03/30/2011 & 7.8 & 1,590 & 104 & 80.7 & 15.4 & 372 & 493 & 672 \\
\hline $4 \mathrm{~S} / 14 \mathrm{~W}-15 \mathrm{E} 2$ & Torrance2_2 & Upper Wilmington B & 03/30/2011 & 7.3 & 4,220 & 183 & 89.1 & 42.8 & 1,230 & 136 & 2,540 \\
\hline 4S/14W-15E3 & Torrance $2 \_3$ & Upper Wilmington A & 03/30/2011 & 7.3 & 10,200 & 1,080 & 787 & 88.5 & 1,470 & 104 & 6,570 \\
\hline 4S/14W-15E4 & Torrance2_4 & Bent Spring & 03/30/2011 & 7.7 & 386 & 18.8 & 10.7 & 5.76 & 107 & 249 & 49.8 \\
\hline $4 \mathrm{~S} / 14 \mathrm{~W}-15 \mathrm{E} 5$ & Torrance2_5 & Harbor & 03/30/2011 & 7.4 & 3,230 & 486 & 143 & 19.7 & 458 & 192 & 1,720 \\
\hline 4S/14W-15E6 & Torrance2_6 & Pacific & 03/30/2011 & 7.8 & 874 & 117 & 33.0 & 7.04 & 141 & 205 & 286 \\
\hline $4 \mathrm{~S} / 14 \mathrm{~W}-26 \mathrm{~A} 2$ & Lomita1_1 & Long Beach A & 04/20/1999 & 7.7 & 1,300 & 99.9 & 28.7 & 15.7 & 323 & 245 & 580 \\
\hline $4 \mathrm{~S} / 14 \mathrm{~W}-26 \mathrm{~A} 3$ & Lomita1_2 & Upper Wilmington B & 04/20/1999 & 7.6 & 845 & 81.8 & 23.1 & 10.7 & 187 & 239 & 341 \\
\hline $4 \mathrm{~S} / 14 \mathrm{~W}-26 \mathrm{~A} 4$ & Lomita1_3 & Bent Spring & 04/22/1999 & 7.7 & 715 & 63.0 & 20.1 & 9.59 & 165 & 308 & 233 \\
\hline $4 \mathrm{~S} / 14 \mathrm{~W}-26 \mathrm{~A} 5$ & Lomita1_4 & Harbor & 04/19/1999 & 7.6 & 686 & 58.9 & 16.4 & 9. & 164 & 246 & 247 \\
\hline $4 \mathrm{~S} / 14 \mathrm{~W}-26 \mathrm{~A} 6$ & Lomita1_5 & Pacific & 04/19/1999 & 7.7 & 1,110 & 113 & 30.2 & 12.6 & 245 & 232 & 509 \\
\hline 4S/14W-35D10 & Chandler3_1 & Bent Spring & $09 / 25 / 2014$ & 7.4 & 620 & 100 & 28.0 & 4.00 & 130 & 400 & 160 \\
\hline 4S/14W-35D11 & Chandler3_2 & Harbor & $09 / 25 / 2014$ & 7.2 & 1,000 & 170 & 47.0 & 3.50 & 140 & 350 & 200 \\
\hline 5S/13W-02E1 & Long Beach4_1 & Long Beach B & 04/03/2001 & 7.8 & 630 & 9.57 & 4.63 & 5.78 & 259 & 492 & 21.4 \\
\hline $5 \mathrm{~S} / 13 \mathrm{~W}-02 \mathrm{E} 2$ & Long Beach4_2 & Long Beach A & 04/04/2001 & 8.0 & 1,180 & 6.55 & 7.18 & 10.8 & 422 & 614 & 337 \\
\hline $5 \mathrm{~S} / 13 \mathrm{~W}-11 \mathrm{P} 1$ & Long Beach5_1 & Long Beach A & $04 / 24 / 2002$ & 7.9 & 4,010 & 17.8 & 30.5 & 25.8 & 1,500 & 1,230 & 1,650 \\
\hline $5 \mathrm{~S} / 13 \mathrm{~W}-11 \mathrm{P} 2$ & Long Beach5_2 & Bent Spring & $04 / 24 / 2002$ & 6.9 & 35,600 & 519 & 1,220 & 272 & 10,800 & 289 & 19,900 \\
\hline \multicolumn{12}{|c|}{ Santa Monica Basin } \\
\hline 1S/15W-31E1 & SM 1 (2505) & Pacific & $08 / 10 / 2006$ & 7.0 & 623 & 112 & 55.0 & 3.08 & 88.6 & 335 & 102 \\
\hline 1S/15W-33A1 & SM Arcadia_5 & Mesa & 08/07/2006 & 6.8 & 593 & 115 & 53.2 & 3.04 & 72.9 & 272 & 111 \\
\hline $2 \mathrm{~S} / 15 \mathrm{~W}-4 \mathrm{C} 2$ & SM 3 (2646K) & Pacific & 08/24/2010 & 7.1 & 835 & 126 & 55.2 & 2.09 & 70.6 & 327 & 84.0 \\
\hline \multicolumn{12}{|c|}{ Hollywood Basin } \\
\hline 1S/14W-18L1 & BH_2 & Upper Wilmington A & $11 / 14 / 2006$ & 8.0 & 811 & 23.8 & 21.5 & 6.03 & 254 & 410 & 220 \\
\hline 1S/15W-24B1 & BH_5 & Pacific & 08/09/2006 & 7.7 & 381 & 59.5 & 32.3 & 4.68 & 85.6 & 308 & 36.9 \\
\hline \multicolumn{12}{|c|}{ San Fernando Valley } \\
\hline $1 \mathrm{~N} / 13 \mathrm{~W}-35 \mathrm{P} 1$ & DS_WATERS & n.a. & $11 / 16 / 2006$ & 7.3 & 841 & 136 & 61.4 & 1.62 & 59.4 & 290 & 105 \\
\hline
\end{tabular}


Table 1.2. Groundwater-quality data used for this study from multiple-well monitoring sites, and selected production and observation wells, Los Angeles and Orange Counties, California.-Continued

[See appendix 1 for explanation. Abbreviations: ft, foot; mg/L, milligrams per liter; mm/dd/yyyy, month/day/year; ug/L, micrograms per liter; CaCO 3 , calcium carbonate; \%, percent; <, less than; - , no data. Sediment source/facies: LAR, Los Angeles River; n.a., not assigned; SGR, San Gabriel River; SAR, Santa Ana River, *, potentially affected by mixing with anthropogenic sources of water or seawater]

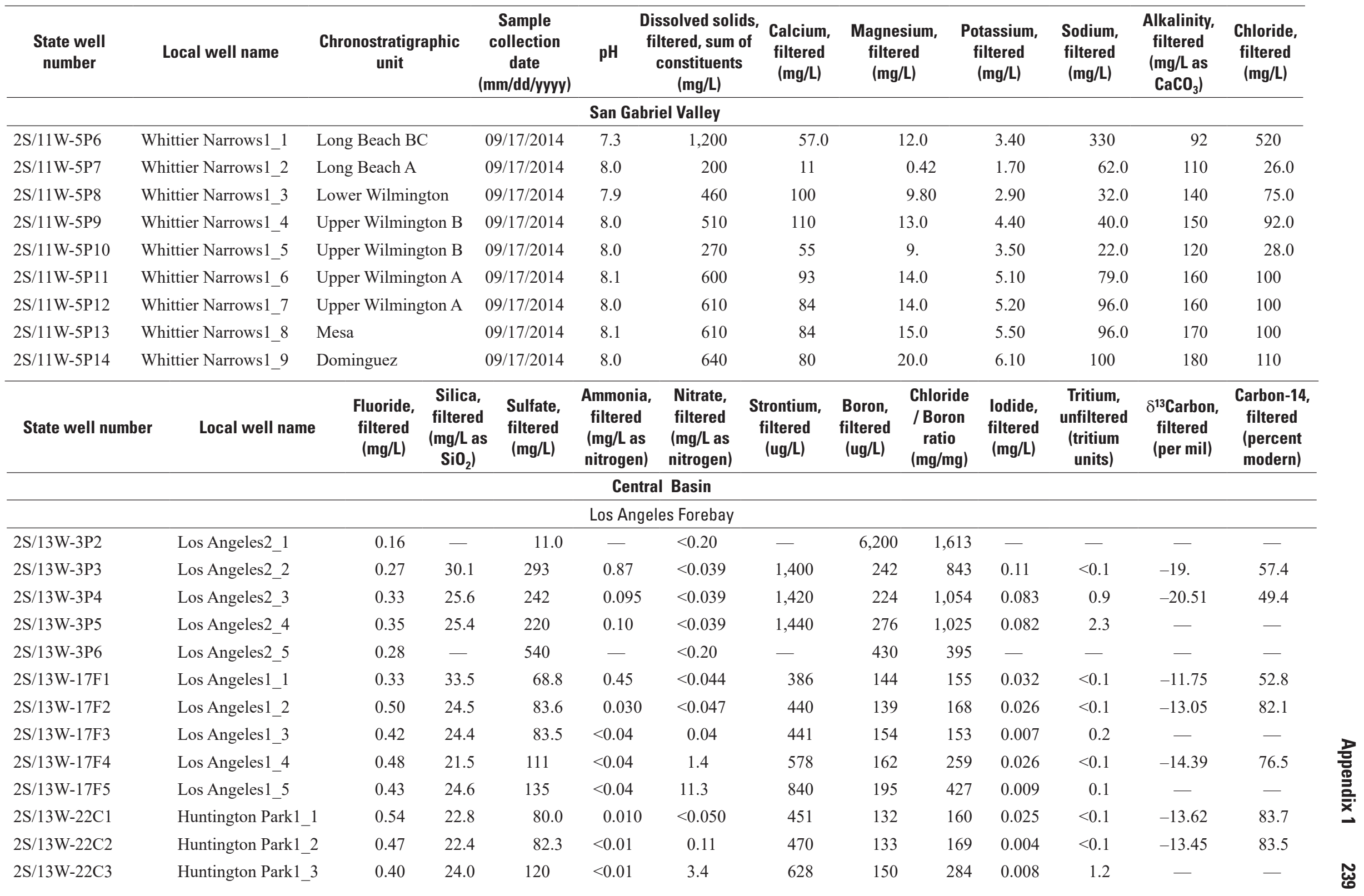


Table 1.2. Groundwater-quality data used for this study from multiple-well monitoring sites, and selected production and observation wells, Los Angeles and Orange Counties, California.-Continued

[See appendix 1 for explanation. Abbreviations: ft, foot; mg/L, milligrams per liter; mm/dd/yyyy, month/day/year; ug/L, micrograms per liter; CaCO 3 , calcium carbonate; \%, percent; <, less than; - , no data. Sediment source/facies: LAR, Los Angeles River; n.a., not assigned; SGR, San Gabriel River; SAR, Santa Ana River, *, potentially affected by mixing with anthropogenic sources of water or seawater]

\begin{tabular}{|c|c|c|c|c|c|c|c|c|c|c|c|c|c|}
\hline State well number & Local well name & $\begin{array}{c}\text { Fluoride, } \\
\text { filtered } \\
\text { (mg/L) }\end{array}$ & $\begin{array}{c}\text { Silica, } \\
\text { filtered } \\
(\mathrm{mg} / \mathrm{L} \text { as } \\
\left.\mathrm{SiO}_{2}\right)\end{array}$ & $\begin{array}{c}\text { Sulfate, } \\
\text { filtered } \\
\text { (mg/L) }\end{array}$ & $\begin{array}{c}\text { Ammonia, } \\
\text { filtered } \\
\text { (mg/L as } \\
\text { nitrogen) }\end{array}$ & $\begin{array}{l}\text { Nitrate, } \\
\text { filtered } \\
\text { (mg/L as } \\
\text { nitrogen) }\end{array}$ & $\begin{array}{c}\text { Strontium, } \\
\text { filtered } \\
\text { (ug/L) }\end{array}$ & $\begin{array}{c}\text { Boron, } \\
\text { filtered } \\
\text { (ug/L) }\end{array}$ & $\begin{array}{l}\text { Chloride } \\
\text { / Boron } \\
\text { ratio } \\
\text { (mg/mg) }\end{array}$ & $\begin{array}{c}\text { lodide, } \\
\text { filtered } \\
\text { (mg/L) }\end{array}$ & $\begin{array}{l}\text { Tritium, } \\
\text { unfiltered } \\
\text { (tritium } \\
\text { units) }\end{array}$ & $\begin{array}{c}\delta^{13} \text { Carbon, } \\
\text { filtered } \\
\text { (per mil) }\end{array}$ & $\begin{array}{c}\text { Carbon-14, } \\
\text { filtered } \\
\text { (percent } \\
\text { modern) }\end{array}$ \\
\hline \multicolumn{14}{|c|}{ Los Angeles Forebay } \\
\hline $2 \mathrm{~S} / 13 \mathrm{~W}-22 \mathrm{C} 4$ & Huntington Park1_4 & 0.40 & 25.3 & 196 & $<0.01$ & 5.0 & 919 & 168 & 357 & 0.006 & 0.6 & - & - \\
\hline 2S/13W-34F2 & South Gate2_1 & 0.45 & 25.3 & 77.7 & 0.13 & $<0.040$ & 406 & 123 & 168 & 0.027 & $<0.1$ & -13.23 & 72.9 \\
\hline $2 \mathrm{~S} / 13 \mathrm{~W}-34 \mathrm{~F} 3$ & South Gate2_2 & 0.39 & 21.5 & 75.0 & 0.030 & $<0.040$ & 480 & 119 & 174 & 0.021 & $<0.1$ & -13.14 & 75.0 \\
\hline $2 \mathrm{~S} / 13 \mathrm{~W}-34 \mathrm{~F} 4$ & South Gate2_3 & 0.38 & 19.0 & 72.0 & 0.020 & $<0.040$ & 472 & 111 & 190 & 0.022 & $<0.1$ & -13.56 & 68.8 \\
\hline 2S/13W-34F5 & South Gate2_4 & 0.44 & 21.3 & 91.6 & 0.020 & 0.39 & 482 & 127 & 272 & 0.005 & $<0.1$ & -13.45 & 77.4 \\
\hline $2 \mathrm{~S} / 13 \mathrm{~W}-34 \mathrm{~F} 6$ & South Gate2_5 & 0.43 & 18.6 & 78.0 & 0.030 & $<0.040$ & 510 & 126 & 183 & 0.017 & $<0.1$ & -13.26 & 75.1 \\
\hline 2S/13W-34F7 & South Gate2_6 & 0.50 & 22.5 & 75.9 & 0.048 & $<0.040$ & 491 & 130 & 179 & 0.017 & 0.1 & -13.59 & 74.1 \\
\hline 2S/14W-12E1 & Los Angeles3_1 & 0.38 & 39.1 & 23.3 & 1.66 & $<0.040$ & 56 & 332 & 110 & 0.098 & 0.3 & -16 & 17.5 \\
\hline $2 \mathrm{~S} / 14 \mathrm{~W}-12 \mathrm{E} 2$ & Los Angeles3_2 & 0.38 & 25.4 & 72.0 & 0.15 & $<0.040$ & 334 & 133 & 174 & 0.038 & $<0.1$ & -13.23 & 72.0 \\
\hline 2S/14W-12E3 & Los Angeles3_3 & 0.51 & 22.7 & 75.6 & 0.042 & $<0.040$ & 440 & 137 & 159 & 0.040 & $<0.1$ & -13.70 & 80.2 \\
\hline $2 \mathrm{~S} / 14 \mathrm{~W}-12 \mathrm{E} 4$ & Los Angeles3_4 & 0.48 & 24.3 & 76.4 & 0.031 & $<0.040$ & 492 & 140 & 276 & 0.057 & 0.2 & -14.02 & 74.9 \\
\hline 2S/14W-12E5 & Los Angeles3_5 & 0.38 & 23.3 & 116 & 0.010 & 9.7 & 728 & 168 & 322 & 0.003 & 2.3 & -15.82 & 85.5 \\
\hline $2 \mathrm{~S} / 14 \mathrm{~W}-12 \mathrm{E} 6$ & Los Angeles3_6 & 0.39 & 23.2 & 162 & $<0.010$ & 6.4 & 894 & 187 & 610 & 0.003 & 0.7 & -15.48 & 80.0 \\
\hline \multicolumn{14}{|c|}{ Montebello Forebay } \\
\hline $2 \mathrm{~S} / 11 \mathrm{~W}-5 \mathrm{~N} 4$ & Whittier_14 & 0.26 & 19.6 & 135 & $<0.010$ & 2.5 & 587 & 87 & 932 & 0.013 & 7.9 & -13.80 & 92.7 \\
\hline $2 \mathrm{~S} / 11 \mathrm{~W}-7 \mathrm{~K} 2$ & Pico Rivera3_1 & 0.30 & 20.7 & 114 & $<0.01$ & $<0.040$ & 626 & 47 & 655 & 0.003 & 3.4 & -11.19 & 86.1 \\
\hline $2 \mathrm{~S} / 11 \mathrm{~W}-7 \mathrm{~K} 3$ & Pico Rivera3_2 & 0.32 & 20.4 & 66.8 & 0.020 & 1.3 & 484 & 56 & 311 & 0.001 & 1.3 & -10.95 & 84.5 \\
\hline 2S/11W-7K4 & Pico Rivera3_3 & 0.28 & 21.7 & 128 & $<0.01$ & 2.6 & 766 & 61 & 784 & 0.003 & 4.2 & -12.99 & 90.1 \\
\hline $2 \mathrm{~S} / 11 \mathrm{~W}-7 \mathrm{~K} 5$ & Pico Rivera3_4 & 0.37 & 20.2 & 118 & 0.020 & 2.6 & 445 & 230 & 426 & 0.012 & 9.1 & -15.65 & 97.2 \\
\hline 2S/11W-7K6 & Pico Rivera4_1 & 0.26 & 24.3 & 125 & 0.040 & $<0.040$ & 697 & 59 & 566 & 0.003 & 3.0 & -11.49 & 86.3 \\
\hline 2S/11W-7K7 & Pico Rivera4_2 & 0.33 & 23.1 & 62.6 & 0.030 & $<0.040$ & 414 & 57 & 230 & 0.004 & 0.7 & -10.65 & 80.3 \\
\hline $2 \mathrm{~S} / 11 \mathrm{~W}-7 \mathrm{~K} 8$ & Pico Rivera4_3 & 0.25 & 21.3 & 134 & 0.010 & 3.2 & 833 & 82 & 716 & 0.004 & 4.2 & -13.88 & 91.5 \\
\hline $2 \mathrm{~S} / 11 \mathrm{~W}-7 \mathrm{~K} 9$ & Pico Rivera4_4 & 0.32 & 20.9 & 112 & 0.010 & 3.1 & 444 & 234 & 410 & 0.009 & 9.0 & -16.22 & 95.8 \\
\hline 2S/11W-8L8 & Whittier Narrows2_1 & 0.56 & - & 7.90 & - & $<0.20$ & - & 240 & 56 & 0.036 & - & - & - \\
\hline 2S/11W-8L9 & Whittier Narrows2_2 & 0.41 & - & 4. & - & $<0.20$ & - & 190 & 67 & 0.021 & - & - & - \\
\hline 2S/11W-8L10 & Whittier Narrows2_3 & 0.44 & - & 21.0 & - & $<0.20$ & - & 85 & 65 & 0.014 & - & - & - \\
\hline 2S/11W-8L11 & Whittier Narrows2_4 & 0.34 & - & 24.0 & - & $<0.20$ & - & 80 & 50 & 0.006 & - & - & - \\
\hline 2S/11W-8L12 & Whittier Narrows2_5 & 0.27 & - & 80.0 & - & $<0.20$ & - & 58 & 225 & $<0.001$ & - & - & - \\
\hline
\end{tabular}


Table 1.2. Groundwater-quality data used for this study from multiple-well monitoring sites, and selected production and observation wells, Los Angeles and Orange Counties, California.-Continued

[See appendix 1 for explanation. Abbreviations: ft, foot; mg/L, milligrams per liter; mm/dd/yyyy, month/day/year; ug/L, micrograms per liter; CaCO 3 , calcium carbonate; \%, percent; <, less than; —, no data . Sediment source/facies: LAR, Los Angeles River; n.a., not assigned; SGR, San Gabriel River; SAR, Santa Ana River, *, potentially affected by mixing with anthropogenic sources of water or seawater]

\begin{tabular}{|c|c|c|c|c|c|c|c|c|c|c|c|c|c|}
\hline State well number & Local well name & $\begin{array}{c}\text { Fluoride, } \\
\text { filtered } \\
\text { (mg/L) }\end{array}$ & $\begin{array}{c}\text { Silica, } \\
\text { filtered } \\
(\mathrm{mg} / \mathrm{L} \text { as } \\
\left.\mathrm{SiO}_{2}\right)\end{array}$ & $\begin{array}{c}\text { Sulfate, } \\
\text { filtered } \\
\text { (mg/L) }\end{array}$ & $\begin{array}{c}\text { Ammonia, } \\
\text { filtered } \\
\text { (mg/L as } \\
\text { nitrogen) }\end{array}$ & $\begin{array}{c}\text { Nitrate, } \\
\text { filtered } \\
\text { (mg/L as } \\
\text { nitrogen) }\end{array}$ & $\begin{array}{l}\text { Strontium, } \\
\text { filtered } \\
\text { (ug/L) }\end{array}$ & $\begin{array}{l}\text { Boron, } \\
\text { filtered } \\
\text { (ug/L) }\end{array}$ & $\begin{array}{l}\text { Chloride } \\
\text { / Boron } \\
\text { ratio } \\
(\mathrm{mg} / \mathrm{mg})\end{array}$ & $\begin{array}{c}\text { lodide, } \\
\text { filtered } \\
\text { (mg/L) }\end{array}$ & $\begin{array}{c}\text { Tritium, } \\
\text { unfiltered } \\
\text { (tritium } \\
\text { units) }\end{array}$ & $\begin{array}{c}\delta^{13} \text { Carbon, } \\
\text { filtered } \\
\text { (per mil) }\end{array}$ & $\begin{array}{c}\text { Carbon-14, } \\
\text { filtered } \\
\text { (percent } \\
\text { modern) }\end{array}$ \\
\hline \multicolumn{14}{|c|}{ Montebello Forebay-Continued } \\
\hline 2S/11W-8L13 & Whittier Narrows2_6 & 0.21 & - & 20.0 & - & 2.0 & - & 52 & 59 & $<0.001$ & - & - & - \\
\hline $2 \mathrm{~S} / 11 \mathrm{~W}-8 \mathrm{~L} 14$ & Whittier Narrows2_7 & 0.23 & - & 32.0 & - & 0.98 & - & 54 & 99 & $<0.001$ & - & - & - \\
\hline $2 \mathrm{~S} / 11 \mathrm{~W}-8 \mathrm{~L} 15$ & Whittier Narrows2_8 & 0.21 & - & 690 & - & 2.6 & - & 510 & 433 & 0.002 & - & - & - \\
\hline 2S/11W-8L16 & Whittier Narrows2_9 & 0.20 & - & 730 & - & 3.6 & - & 620 & 343 & 0.005 & - & - & - \\
\hline $2 \mathrm{~S} / 11 \mathrm{~W}-18 \mathrm{C} 4$ & Pico Rivera1_1 & 0.31 & 29.7 & 4.99 & 2.01 & $<0.050$ & 122 & 603 & 7 & 0.005 & 0.2 & -3.86 & 1.6 \\
\hline $2 \mathrm{~S} / 11 \mathrm{~W}-18 \mathrm{C} 5$ & Pico Rivera1_2 & 0.36 & 23.0 & 65.2 & 0.18 & $<0.050$ & 509 & 69 & 275 & 0.004 & 4.5 & -11.52 & 89.8 \\
\hline 2S/11W-18C6 & Pico Rivera1_3 & 0.21 & 22.2 & 217 & $<0.01$ & $<0.050$ & 665 & 194 & 433 & 0.012 & 12.2 & - & - \\
\hline $2 \mathrm{~S} / 11 \mathrm{~W}-18 \mathrm{C} 7$ & Pico Rivera1_4 & 0.38 & 20.9 & 171 & $<0.01$ & 1.7 & 609 & 215 & 320 & 0.012 & 14.7 & - & - \\
\hline $2 \mathrm{~S} / 11 \mathrm{~W}-20 \mathrm{~N} 1$ & Whittier2_1 & 0.30 & 26.8 & 134 & 0.16 & 0.03 & 514 & 518 & 459 & 0.41 & 1.1 & -10.88 & 57.6 \\
\hline $2 \mathrm{~S} / 11 \mathrm{~W}-20 \mathrm{~N} 2$ & Whittier2_2 & 0.30 & 28.6 & 17.8 & 0.10 & $<0.040$ & 211 & 224 & 51 & 0.018 & $<0.1$ & -11.29 & 38.3 \\
\hline $2 \mathrm{~S} / 11 \mathrm{~W}-20 \mathrm{~N} 3$ & Whittier2_3 & 0.35 & 25.4 & 212 & $<0.020$ & 0.58 & 686 & 218 & 546 & 0.025 & 1.1 & -13.11 & 51.8 \\
\hline $2 \mathrm{~S} / 11 \mathrm{~W}-20 \mathrm{~N} 4$ & Whittier2_4 & 0.51 & 44.5 & 613 & 0.015 & 2.5 & 1,310 & 804 & 292 & 0.25 & 0.2 & - & - \\
\hline $2 \mathrm{~S} / 11 \mathrm{~W}-20 \mathrm{~N} 5$ & Whittier2_5 & 0.28 & 23.0 & 170 & $<0.020$ & 4.7 & 812 & 173 & 671 & 0.004 & 7.5 & - & - \\
\hline 2S/11W-20N6 & Whittier2_6 & 0.30 & 27.6 & 308 & 0.010 & 8.0 & 873 & 319 & 281 & 0.006 & 3.9 & - & - \\
\hline 2S/12W-10Q5 & Montebello1_1 & 0.45 & 25.7 & 0.34 & 4.24 & $<0.041$ & 176 & 6,430 & 102 & 1.32 & $<0.1$ & -4.42 & 0.12 \\
\hline 2S/12W-10Q6 & Montebello1_2 & 0.29 & 31.6 & 0.70 & 2.57 & $<0.045$ & 187 & 2,380 & 53 & 0.19 & $<0.1$ & -5.30 & 1.2 \\
\hline 2S/12W-10Q7 & Montebello1_3 & 0.20 & 24.9 & 146 & 0.51 & $<0.050$ & 696 & 345 & 243 & 0.095 & 19.0 & -12.12 & 130.1 \\
\hline 2S/12W-10Q8 & Montebello1_4 & 0.17 & 23.3 & 143 & 0.18 & $<0.050$ & 769 & 186 & 404 & 0.069 & 19.6 & - & - \\
\hline 2S/12W-10Q9 & Montebello1_5 & 0.38 & 22.6 & 116 & $<0.04$ & 4.7 & 534 & 231 & 274 & 0.006 & 6.3 & - & - \\
\hline 2S/12W-10Q10 & Montebello1_6 & 0.30 & 25.1 & 117 & 0.23 & 9.8 & 1,020 & 425 & 445 & 0.046 & 6.0 & - & - \\
\hline 2S/12W-25G1 & Pico Rivera W12 & 0.35 & 20.1 & 99.6 & 0.010 & 3.3 & 451 & 228 & 365 & 0.012 & 9.8 & -12.91 & 95.6 \\
\hline $2 \mathrm{~S} / 12 \mathrm{~W}-25 \mathrm{G} 3$ & Pico Rivera2_1 & 0.41 & 17.0 & 120 & $<0.02$ & 2.7 & 584 & 162 & 364 & 0.007 & 8.4 & -12.34 & 93.2 \\
\hline $2 \mathrm{~S} / 12 \mathrm{~W}-25 \mathrm{G} 4$ & Pico Rivera2_2 & 0.31 & 22.0 & 130 & $<0.02$ & 2.8 & 747 & 97 & 558 & 0.001 & 16.8 & -13.59 & 111.2 \\
\hline $2 \mathrm{~S} / 12 \mathrm{~W}-25 \mathrm{G} 5$ & Pico Rivera2_3 & 0.36 & 21.4 & 129 & $<0.02$ & 3.2 & 715 & 124 & 473 & 0.002 & 18.3 & - & - \\
\hline 2S/12W-25G6 & Pico Rivera2_4 & 0.46 & 20.6 & 135 & $<0.02$ & 3.2 & 532 & 284 & 331 & 0.017 & 8.4 & - & - \\
\hline $2 \mathrm{~S} / 12 \mathrm{~W}-25 \mathrm{G} 7$ & Pico Rivera2_5 & 0.33 & 19.3 & 130 & $<0.02$ & 1.6 & 491 & 233 & 378 & 0.022 & 9.0 & - & - \\
\hline $2 \mathrm{~S} / 12 \mathrm{~W}-25 \mathrm{G} 8$ & Pico Rivera2_6 & 0.47 & 17.3 & 139 & $<0.02$ & 2.7 & - & 263 & 354 & 0.018 & 8.4 & - & - \\
\hline 2S/12W-26D9 & Rio Hondo1_1 & 0.29 & 25.6 & 51.7 & 0.16 & $<0.050$ & 287 & 61 & 308 & 0.029 & 0.2 & -12.95 & 35.5 \\
\hline
\end{tabular}


Table 1.2. Groundwater-quality data used for this study from multiple-well monitoring sites, and selected production and observation wells, Los Angeles and Orange Counties, California.-Continued

[See appendix 1 for explanation. Abbreviations: ft, foot; mg/L, milligrams per liter; mm/dd/yyyy, month/day/year; ug/L, micrograms per liter; CaCO ${ }_{3}$, calcium carbonate; \%, percent; <, less than; - , no data. Sediment source/facies: LAR, Los Angeles River; n.a., not assigned; SGR, San Gabriel River; SAR, Santa Ana River, *, potentially affected by mixing with anthropogenic sources of water or seawater]

\begin{tabular}{|c|c|c|c|c|c|c|c|c|c|c|c|c|c|}
\hline State well number & Local well name & $\begin{array}{c}\text { Fluoride, } \\
\text { filtered } \\
\text { (mg/L) }\end{array}$ & $\begin{array}{c}\text { Silica, } \\
\text { filtered } \\
(\mathrm{mg} / \mathrm{L} \text { as } \\
\left.\mathrm{SiO}_{2}\right)\end{array}$ & $\begin{array}{c}\text { Sulfate, } \\
\text { filtered } \\
\text { (mg/L) }\end{array}$ & $\begin{array}{c}\text { Ammonia, } \\
\text { filtered } \\
\text { (mg/L as } \\
\text { nitrogen) }\end{array}$ & $\begin{array}{c}\text { Nitrate, } \\
\text { filtered } \\
\text { (mg/L as } \\
\text { nitrogen) }\end{array}$ & $\begin{array}{l}\text { Strontium, } \\
\text { filtered } \\
\text { (ug/L) }\end{array}$ & $\begin{array}{c}\text { Boron, } \\
\text { filtered } \\
\text { (ug/L) }\end{array}$ & $\begin{array}{l}\text { Chloride } \\
\text { / Boron } \\
\text { ratio } \\
\text { (mg/mg) }\end{array}$ & $\begin{array}{c}\text { lodide, } \\
\text { filtered } \\
\text { (mg/L) }\end{array}$ & $\begin{array}{c}\text { Tritium, } \\
\text { unfiltered } \\
\text { (tritium } \\
\text { units) }\end{array}$ & $\begin{array}{c}\delta^{13} \text { Carbon, } \\
\text { filtered } \\
\text { (per mil) }\end{array}$ & $\begin{array}{c}\text { Carbon-14, } \\
\text { filtered } \\
\text { (percent } \\
\text { modern) }\end{array}$ \\
\hline \multicolumn{14}{|c|}{ Montebello Forebay-Continued } \\
\hline $2 \mathrm{~S} / 12 \mathrm{~W}-26 \mathrm{D} 10$ & Rio Hondo1_2 & 0.24 & 25.2 & 125 & 0.060 & $<0.050$ & 657 & 53 & 947 & 0.005 & 18.5 & -12.20 & 82.9 \\
\hline $2 \mathrm{~S} / 12 \mathrm{~W}-26 \mathrm{D} 11$ & Rio Hondo1_3 & 0.35 & 21.8 & 117 & $<0.02$ & 2.7 & 567 & 148 & 400 & 0.005 & 12.1 & - & - \\
\hline $2 \mathrm{~S} / 12 \mathrm{~W}-26 \mathrm{D} 12$ & Rio Hondo1_4 & 0.45 & 21.5 & 121 & $<0.02$ & 2.9 & 476 & 202 & 340 & 0.020 & 8.1 & -11.68 & 96.4 \\
\hline $2 \mathrm{~S} / 12 \mathrm{~W}-26 \mathrm{D} 13$ & Rio Hondo1_5 & 0.41 & 19.3 & 87.3 & $<0.02$ & 1.3 & 330 & 151 & 321 & 0.014 & 9.0 & - & - \\
\hline $2 \mathrm{~S} / 12 \mathrm{~W}-26 \mathrm{D} 14$ & Rio Hondo1_6 & 0.34 & 15.9 & 85.9 & $<0.02$ & 1.3 & 455 & 133 & 438 & 0.012 & 8.8 & - & - \\
\hline $2 \mathrm{~S} / 12 \mathrm{~W}-33 \mathrm{D} 3$ & Bell Gardens1_1 & 0.21 & 24.5 & 117 & 0.24 & $<0.040$ & 854 & 58 & 816 & 0.006 & 9.9 & -12 & 88.2 \\
\hline $2 \mathrm{~S} / 12 \mathrm{~W}-33 \mathrm{D} 4$ & Bell Gardens1_2 & 0.31 & 21.4 & 37.1 & 0.18 & $<0.040$ & 356 & 125 & 226 & 0.016 & 2.5 & -13.37 & 70.3 \\
\hline 2S/12W-33D5 & Bell Gardens1_3 & 0.32 & 21.1 & 107 & $<0.020$ & 2.6 & 565 & 165 & 359 & 0.005 & 5.4 & -12.24 & 109.5 \\
\hline 2S/12W-33D6 & Bell Gardens1_4 & 0.41 & 21.6 & 84.1 & $<0.020$ & 2.3 & 388 & 159 & 318 & 0.002 & 5.6 & - & - \\
\hline $2 \mathrm{~S} / 12 \mathrm{~W}-33 \mathrm{D} 7$ & Bell Gardens1_5 & 0.24 & 24.7 & 75.0 & $<0.020$ & 2.1 & 377 & 184 & 199 & 0.002 & 5.7 & - & - \\
\hline 2S/12W-33D8 & Bell Gardens1_6 & 0.37 & 23.3 & 82.4 & $<0.020$ & 2.1 & 425 & 160 & 270 & 0.002 & 5.7 & - & - \\
\hline 2S/12W-36M6 & Pico Rivera W8 & 0.31 & 21.3 & 122 & $<0.020$ & 2.8 & 772 & 74 & 762 & 0.002 & 5.6 & -13.96 & 103.7 \\
\hline $3 \mathrm{~S} / 12 \mathrm{~W}-11 \mathrm{~A} 7$ & Norwalk2_1 & 0.34 & 20.3 & 85.0 & $<0.020$ & 0.06 & 533 & 206 & 323 & 0.060 & 4.4 & -15.95 & 62.3 \\
\hline $3 \mathrm{~S} / 12 \mathrm{~W}-11 \mathrm{~A} 8$ & Norwalk2_2 & 0.50 & 23.9 & 12.1 & 0.20 & $<0.040$ & 105 & 247 & 122 & 0.050 & $<0.1$ & - & - \\
\hline $3 \mathrm{~S} / 12 \mathrm{~W}-11 \mathrm{~A} 9$ & Norwalk2_3 & 0.22 & 19.0 & 32.7 & 0.030 & $<0.040$ & 368 & 40 & 318 & 0.010 & $<0.1$ & -13.25 & 70.2 \\
\hline $3 \mathrm{~S} / 12 \mathrm{~W}-11 \mathrm{~A} 10$ & Norwalk2_4 & 0.30 & 22.0 & 60.2 & $<0.020$ & 1.1 & 600 & 57 & 353 & $<0.002$ & 1.4 & - & - \\
\hline $3 \mathrm{~S} / 12 \mathrm{~W}-11 \mathrm{~A} 11$ & Norwalk2_5 & 0.26 & 20.9 & 102 & $<0.020$ & 2.7 & 753 & 130 & 505 & 0.009 & 9.1 & - & - \\
\hline $3 \mathrm{~S} / 12 \mathrm{~W}-11 \mathrm{~A} 12$ & Norwalk2_6 & 0.40 & 23.7 & 118 & $<0.020$ & 3.0 & 519 & 173 & 416 & 0.010 & 6.4 & - & - \\
\hline \multicolumn{14}{|c|}{ Whittier area } \\
\hline $3 \mathrm{~S} / 11 \mathrm{~W}-2 \mathrm{~K} 4$ & Whittier1_1 & 0.31 & 33.3 & 1,300 & 2.84 & $<0.050$ & 2,270 & 850 & 328 & 0.25 & $<0.1$ & -14.92 & 15.5 \\
\hline 3S/11W-2K5 & Whittier1_2 & 0.32 & 33.5 & 1,240 & 2.18 & $<0.050$ & 2,060 & 922 & 259 & 0.23 & $<0.1$ & -15.01 & 14.9 \\
\hline $3 \mathrm{~S} / 11 \mathrm{~W}-2 \mathrm{~K} 6$ & Whittier1_4 & 0.22 & 39.4 & 168 & $<0.02$ & 4.5 & 741 & 183 & 435 & 0.091 & $<0.1$ & - & - \\
\hline $3 \mathrm{~S} / 11 \mathrm{~W}-2 \mathrm{~K} 7$ & Whittier1_5 & 0.32 & 43.4 & 169 & $<0.02$ & 5.2 & 743 & 153 & 524 & 0.022 & $<0.1$ & - & - \\
\hline $3 \mathrm{~S} / 11 \mathrm{~W}-2 \mathrm{~K} 8$ & Whittier1_3 & 0.55 & 33.3 & 645 & 0.63 & $<0.050$ & 1,290 & 567 & 305 & 0.15 & 0.1 & -15.01 & 15.3 \\
\hline 3S/11W-9D2 & Santa Fe Springs1_2 & 0.68 & 17.9 & 92.7 & 2.19 & $<0.050$ & 97.8 & 1,110 & 150 & 0.18 & $<0.1$ & - & - \\
\hline $3 \mathrm{~S} / 11 \mathrm{~W}-9 \mathrm{D} 3$ & Santa Fe Springs1_3 & 0.41 & 37.3 & 40.7 & 1.56 & $<0.050$ & 681 & 488 & 244 & 0.15 & 0.4 & - & - \\
\hline $3 \mathrm{~S} / 11 \mathrm{~W}-9 \mathrm{D} 4$ & Santa Fe Springs1_4 & 0.58 & 26.6 & 90.5 & 1.26 & $<0.050$ & 334 & 895 & 177 & 0.19 & $<0.1$ & - & - \\
\hline
\end{tabular}


Table 1.2. Groundwater-quality data used for this study from multiple-well monitoring sites, and selected production and observation wells, Los Angeles and Orange Counties, California.-Continued

[See appendix 1 for explanation. Abbreviations: ft, foot; mg/L, milligrams per liter; mm/dd/yyyy, month/day/year; ug/L, micrograms per liter; CaCO 3 , calcium carbonate; \%, percent; <, less than; —, no data . Sediment source/facies: LAR, Los Angeles River; n.a., not assigned; SGR, San Gabriel River; SAR, Santa Ana River, *, potentially affected by mixing with anthropogenic sources of water or seawater]

\begin{tabular}{|c|c|c|c|c|c|c|c|c|c|c|c|c|c|}
\hline State well number & Local well name & $\begin{array}{c}\text { Fluoride, } \\
\text { filtered } \\
\text { (mg/L) }\end{array}$ & $\begin{array}{c}\text { Silica, } \\
\text { filtered } \\
(\mathrm{mg} / \mathrm{L} \text { as } \\
\left.\mathrm{SiO}_{2}\right)\end{array}$ & $\begin{array}{c}\text { Sulfate, } \\
\text { filtered } \\
\text { (mg/L) }\end{array}$ & $\begin{array}{c}\text { Ammonia, } \\
\text { filtered } \\
\text { (mg/L as } \\
\text { nitrogen) }\end{array}$ & $\begin{array}{c}\text { Nitrate, } \\
\text { filtered } \\
\text { (mg/L as } \\
\text { nitrogen) }\end{array}$ & $\begin{array}{c}\text { Strontium, } \\
\text { filtered } \\
\text { (ug/L) }\end{array}$ & $\begin{array}{c}\text { Boron, } \\
\text { filtered } \\
\text { (ug/L) }\end{array}$ & $\begin{array}{c}\text { Chloride } \\
\text { / Boron } \\
\text { ratio } \\
\text { (mg/mg) }\end{array}$ & $\begin{array}{c}\text { lodide, } \\
\text { filtered } \\
\text { (mg/L) }\end{array}$ & $\begin{array}{c}\text { Tritium, } \\
\text { unfiltered } \\
\text { (tritium } \\
\text { units) }\end{array}$ & $\begin{array}{c}\delta^{13} \text { Carbon, } \\
\text { filtered } \\
\text { (per mil) }\end{array}$ & $\begin{array}{c}\text { Carbon-14, } \\
\text { filtered } \\
\text { (percent } \\
\text { modern) }\end{array}$ \\
\hline \multicolumn{14}{|c|}{ Pressure area } \\
\hline $2 \mathrm{~S} / 12 \mathrm{~W}-7 \mathrm{~J} 1$ & Commerce1_1 & 0.19 & 31.3 & 4.47 & 27.3 & 0.02 & 4,230 & 6,530 & 1,083 & 9.44 & $<0.1$ & -5.97 & 2.5 \\
\hline $2 \mathrm{~S} / 12 \mathrm{~W}-7 \mathrm{~J} 2$ & Commerce1_2 & 0.31 & 24.4 & 100 & 1.93 & $<0.050$ & 575 & 125 & 369 & 0.002 & $<0.1$ & -16.77 & 28.5 \\
\hline $2 \mathrm{~S} / 12 \mathrm{~W}-7 \mathrm{~J} 3$ & Commerce1_3 & 0.40 & 31.0 & 67.7 & 0.71 & $<0.050$ & 499 & 209 & 352 & 0.13 & 0.2 & -15.01 & 56.7 \\
\hline $2 \mathrm{~S} / 12 \mathrm{~W}-7 \mathrm{~J} 4$ & Commerce1_4 & 0.44 & 33.4 & 49.1 & 0.64 & $<0.040$ & 444 & 246 & 500 & 0.17 & 2.4 & -14.99 & 100.1 \\
\hline $2 \mathrm{~S} / 12 \mathrm{~W}-7 \mathrm{~J} 5$ & Commerce1_5 & 0.33 & 29.9 & 115 & $<0.02$ & 4.7 & 807 & 141 & 626 & 0.013 & 19.1 & - & - \\
\hline $2 \mathrm{~S} / 12 \mathrm{~W}-7 \mathrm{~J} 6$ & Commerce1_6 & 0.48 & 29.6 & 40.1 & $<0.02$ & 6.1 & 380 & 135 & 450 & 0.017 & $<0.1$ & - & - \\
\hline $2 \mathrm{~S} / 13 \mathrm{~W}-24 \mathrm{~J} 1$ & Bell1_1 & 0.52 & 38.5 & 0.24 & 3.20 & $<0.033$ & 129 & 1,600 & 90 & 0.25 & $<0.1$ & -4.82 & 0.46 \\
\hline $2 \mathrm{~S} / 13 \mathrm{~W}-24 \mathrm{~J} 2$ & Bell1_2 & 0.29 & 24.5 & 74.2 & 0.51 & $<0.040$ & 376 & 137 & 157 & 0.030 & $<0.1$ & -13.31 & 65.6 \\
\hline $2 \mathrm{~S} / 13 \mathrm{~W}-24 \mathrm{~J} 3$ & Bell1_3 & 0.47 & 23.8 & 54.3 & 0.14 & $<0.040$ & 313 & 128 & 213 & 0.044 & $<0.1$ & -14.64 & 46.0 \\
\hline $2 \mathrm{~S} / 13 \mathrm{~W}-24 \mathrm{~J} 4$ & Bell1_4 & 0.48 & 25.6 & 70.5 & 0.069 & $<0.040$ & 432 & 155 & 165 & 0.039 & 0.2 & -13.47 & 69.1 \\
\hline $2 \mathrm{~S} / 13 \mathrm{~W}-24 \mathrm{~J} 5$ & Bell1_5 & 0.41 & 24.3 & 108 & $<0.020$ & 1.5 & 642 & 143 & 331 & 0.011 & 3.6 & - & - \\
\hline $2 \mathrm{~S} / 13 \mathrm{~W}-24 \mathrm{~J} 6$ & Bell1_6 & 0.43 & 25.1 & 135 & $<0.020$ & 2.5 & 887 & 155 & 710 & 0.007 & $<0.1$ & -14.57 & 79.7 \\
\hline $2 \mathrm{~S} / 13 \mathrm{~W}-31 \mathrm{~B} 3$ & Los Angeles4_1 & $<1.00$ & 39.2 & $<9.00$ & 6.72 & $<0.040$ & 158 & 5,300 & 7 & 0.061 & $<0.1$ & -4.32 & 0.28 \\
\hline $2 \mathrm{~S} / 13 \mathrm{~W}-31 \mathrm{~B} 4$ & Los Angeles4_2 & 0.29 & 36.0 & 9.57 & 5.43 & $<0.040$ & 196 & 502 & 20 & 0.013 & $<0.1$ & -3.69 & 3.6 \\
\hline 2S/13W-31B5 & Los Angeles4_3 & 0.33 & 23.8 & 76.4 & 0.12 & $<0.040$ & 452 & 126 & 162 & 0.029 & $<0.1$ & -13.49 & 74.0 \\
\hline 2S/13W-31B6 & Los Angeles4_4 & 0.43 & 24.3 & 76.3 & 0.085 & $<0.040$ & 408 & 132 & 158 & 0.040 & $<0.1$ & -13.53 & 74.3 \\
\hline $2 \mathrm{~S} / 13 \mathrm{~W}-31 \mathrm{~B} 7$ & Los Angeles4_5 & 0.43 & 25.2 & 82.8 & 0.080 & $<0.040$ & 404 & 144 & 152 & 0.034 & $<0.1$ & -13.19 & 73.3 \\
\hline $2 \mathrm{~S} / 13 \mathrm{~W}-31 \mathrm{~B} 8$ & Los Angeles4_6 & 0.47 & 24.9 & 87.1 & $<0.010$ & 1.3 & 488 & 150 & 190 & 0.006 & $<0.1$ & -13.16 & 83.2 \\
\hline $2 \mathrm{~S} / 14 \mathrm{~W}-26 \mathrm{~N} 3$ & Inglewood2_1 & 0.65 & 32.8 & 10.9 & 12.4 & $<0.040$ & 276 & 3,750 & 20 & 0.040 & $<0.1$ & 23.28 & 0.02 \\
\hline $2 \mathrm{~S} / 14 \mathrm{~W}-26 \mathrm{~N} 4$ & Inglewood2_2 & 0.39 & 34.8 & 3.03 & 12.2 & $<0.050$ & 209 & 3,400 & 6 & 0.025 & $<0.1$ & 16.10 & 3.4 \\
\hline $2 \mathrm{~S} / 14 \mathrm{~W}-26 \mathrm{~N} 5$ & Inglewood2_3 & 0.28 & 36.2 & 7.70 & 1.60 & $<0.050$ & 306 & 211 & 98 & 0.027 & $<0.1$ & -7.59 & 30.6 \\
\hline $3 \mathrm{~S} / 11 \mathrm{~W}-17 \mathrm{~F} 1$ & Norwalk1_1 & 0.47 & 23.0 & 19.6 & - & - & 241 & 395 & 174 & 0.12 & $<0.1$ & -15.65 & 6.8 \\
\hline $3 \mathrm{~S} / 11 \mathrm{~W}-17 \mathrm{~F} 2$ & Norwalk1_2 & 0.61 & 18.5 & 0.15 & - & - & 78.1 & 201 & 286 & 0.14 & $<0.1$ & -10.59 & 0.92 \\
\hline $3 \mathrm{~S} / 11 \mathrm{~W}-17 \mathrm{~F} 3$ & Norwalk1_3 & 0.28 & 18.1 & 13.6 & - & - & 356 & 81 & 620 & 0.13 & $<0.1$ & -17.41 & 14.4 \\
\hline $3 \mathrm{~S} / 11 \mathrm{~W}-17 \mathrm{~F} 4$ & Norwalk1_4 & 0.33 & 19.8 & 10.7 & - & - & 438 & 53 & 330 & 0.029 & $<0.1$ & -13.96 & 39.4 \\
\hline $3 \mathrm{~S} / 11 \mathrm{~W}-17 \mathrm{~F} 5$ & Norwalk1_5 & 0.35 & 23.4 & 2.66 & - & - & 722 & 84 & 1,345 & 0.089 & 0.1 & -18.39 & 43.4 \\
\hline $3 \mathrm{~S} / 11 \mathrm{~W}-26 \mathrm{E} 2$ & La Mirada1_1 & 0.79 & 16.1 & 92.8 & 0.080 & $<0.050$ & 278 & 164 & 159 & 0.039 & $<0.1$ & -13.59 & 20.0 \\
\hline $3 \mathrm{~S} / 11 \mathrm{~W}-26 \mathrm{E} 3$ & La Mirada1_2 & 0.59 & 15.7 & 52.9 & 0.070 & $<0.050$ & 470 & 72 & 219 & 0.013 & $<0.1$ & -11.88 & 52.7 \\
\hline
\end{tabular}


Table 1.2. Groundwater-quality data used for this study from multiple-well monitoring sites, and selected production and observation wells, Los Angeles and Orange Counties, California.-Continued

[See appendix 1 for explanation. Abbreviations: ft, foot; mg/L, milligrams per liter; mm/dd/yyyy, month/day/year; ug/L, micrograms per liter; CaCO 3 , calcium carbonate; \%, percent; <, less than; - , no data. Sediment source/facies: LAR, LOs Angeles River; na., not assigned; SGR, San Gabriel River; SAR, Santa Ana River, *, potenlilly affected by mixing with anthropogenic solices of water or sea

\begin{tabular}{|c|c|c|c|c|c|c|c|c|c|c|c|c|c|}
\hline State well number & Local well name & $\begin{array}{c}\text { Fluoride, } \\
\text { filtered } \\
\text { (mg/L) }\end{array}$ & $\begin{array}{c}\text { Silica, } \\
\text { filtered } \\
(\mathrm{mg} / \mathrm{L} \text { as } \\
\left.\mathrm{SiO}_{2}\right)\end{array}$ & $\begin{array}{c}\text { Sulfate, } \\
\text { filtered } \\
\text { (mg/L) }\end{array}$ & $\begin{array}{c}\text { Ammonia, } \\
\text { filtered } \\
\text { (mg/L as } \\
\text { nitrogen) }\end{array}$ & $\begin{array}{c}\text { Nitrate, } \\
\text { filtered } \\
\text { (mg/L as } \\
\text { nitrogen) }\end{array}$ & $\begin{array}{c}\text { Strontium, } \\
\text { filtered } \\
\text { (ug/L) }\end{array}$ & $\begin{array}{c}\text { Boron, } \\
\text { filtered } \\
\text { (ug/L) }\end{array}$ & $\begin{array}{l}\text { Chloride } \\
\text { / Boron } \\
\text { ratio } \\
\text { (mg/mg) }\end{array}$ & $\begin{array}{c}\text { lodide, } \\
\text { filtered } \\
\text { (mg/L) }\end{array}$ & $\begin{array}{c}\text { Tritium, } \\
\text { unfiltered } \\
\text { (tritium } \\
\text { units) }\end{array}$ & $\begin{array}{c}\delta^{13} \text { Carbon, } \\
\text { filtered } \\
\text { (per mil) }\end{array}$ & $\begin{array}{c}\text { Carbon-14, } \\
\text { filtered } \\
\text { (percent } \\
\text { modern) }\end{array}$ \\
\hline \multicolumn{14}{|c|}{ Pressure area-Continued } \\
\hline $3 \mathrm{~S} / 11 \mathrm{~W}-26 \mathrm{E} 4$ & La Mirada1_3 & 0.74 & 21.2 & 57.8 & 0.13 & $<0.050$ & 270 & 155 & 102 & 0.027 & $<0.1$ & -12.77 & 22.1 \\
\hline $3 \mathrm{~S} / 11 \mathrm{~W}-26 \mathrm{E} 5$ & La Mirada1_4 & 0.59 & 25.9 & 94.5 & 0.15 & $<0.050$ & 525 & 144 & 188 & 0.044 & $<0.1$ & -12 & 53.2 \\
\hline 3S/11W-26E6 & La Mirada1_5 & 0.52 & 26.1 & 105 & $<0.02$ & 1.9 & 659 & 158 & 391 & 0.013 & $<0.1$ & - & - \\
\hline $3 \mathrm{~S} / 12 \mathrm{~W}-6 \mathrm{~B} 4$ & South Gate1_1 & 0.30 & 23.5 & 58.8 & 0.090 & $<0.050$ & 431 & 105 & 200 & 0.031 & $<0.1$ & -13.87 & 48.3 \\
\hline $3 \mathrm{~S} / 12 \mathrm{~W}-6 \mathrm{~B} 5$ & South Gate1_2 & 0.39 & 41.7 & 3.82 & $<0.02$ & 2.4 & 559 & 481 & 380 & 0.36 & 16.5 & -11.83 & 93.7 \\
\hline $3 \mathrm{~S} / 12 \mathrm{~W}-6 \mathrm{~B} 6$ & South Gate1_3 & 0.37 & 26.1 & 110 & $<0.02$ & 2.6 & 683 & 123 & 407 & 0.003 & 24.8 & - & - \\
\hline $3 \mathrm{~S} / 12 \mathrm{~W}-6 \mathrm{~B} 7$ & South Gate1_4 & 0.36 & 23.5 & 125 & $<0.02$ & 1.7 & 641 & 158 & 354 & 0.003 & 13.5 & - & - \\
\hline $3 \mathrm{~S} / 12 \mathrm{~W}-6 \mathrm{~B} 8$ & South Gate1_5 & 0.46 & 28.1 & 79.0 & 0.030 & $<0.050$ & 564 & 132 & 256 & 0.082 & $<0.1$ & - & - \\
\hline $3 \mathrm{~S} / 12 \mathrm{~W}-9 \mathrm{~J} 1$ & Downey1_1 & 0.39 & 20.2 & 16.2 & $<0.02$ & 0.07 & 363 & 55 & 106 & $<0.001$ & 0.7 & -12.14 & 74.0 \\
\hline $3 \mathrm{~S} / 12 \mathrm{~W}-9 \mathrm{~J} 2$ & Downey1_2 & 0.36 & 20.4 & 73.8 & $<0.02$ & 2.0 & 621 & 61 & 426 & $<0.001$ & 6.0 & -12.34 & 85.8 \\
\hline $3 \mathrm{~S} / 12 \mathrm{~W}-9 \mathrm{~J} 3$ & Downey1_3 & 0.41 & 21.6 & 133 & $<0.02$ & 2.9 & 811 & 78 & 850 & 0.001 & 34.5 & -11.18 & 123.5 \\
\hline $3 \mathrm{~S} / 12 \mathrm{~W}-9 \mathrm{~J} 4$ & Downey1_4 & 0.47 & 20.9 & 133 & $<0.02$ & 2.7 & 603 & 179 & 414 & 0.014 & 19.9 & - & - \\
\hline $3 \mathrm{~S} / 12 \mathrm{~W}-9 \mathrm{~J} 5$ & Downey1_5 & 0.38 & 22.4 & 124 & $<0.02$ & $<0.050$ & 837 & 94 & 666 & 0.011 & 6.9 & - & - \\
\hline $3 \mathrm{~S} / 12 \mathrm{~W}-9 \mathrm{~J} 6$ & Downey1_6 & 0.36 & 24.5 & 259 & $<0.02$ & $<0.050$ & 788 & 204 & 460 & 0.005 & 18.2 & - & - \\
\hline $3 \mathrm{~S} / 12 \mathrm{~W}-15 \mathrm{~K} 1$ & St. John Bosco & 0.34 & 24.9 & 279 & $<0.020$ & $<0.060$ & 856 & 232 & 500 & 0.013 & 8.6 & -13.91 & 106.4 \\
\hline $3 \mathrm{~S} / 12 \mathrm{~W}-16 \mathrm{H} 1$ & Park 40D & 0.42 & 20.6 & 133 & 0.008 & 1.2 & 745 & 155 & 414 & 0.009 & 22 & - & - \\
\hline $3 \mathrm{~S} / 12 \mathrm{~W}-26 \mathrm{~K} 2$ & Cerritos2_1 & 0.29 & 20.1 & 18.9 & $<0.04$ & 0.03 & 416 & 56 & 116 & 0.002 & $<0.1$ & -12.29 & 75.6 \\
\hline $3 \mathrm{~S} / 12 \mathrm{~W}-26 \mathrm{~K} 3$ & Cerritos2_2 & 0.35 & 20.2 & 117 & $<0.04$ & 2.9 & 682 & 94 & 677 & 0.002 & 16.0 & -11.79 & 143.9 \\
\hline $3 \mathrm{~S} / 12 \mathrm{~W}-26 \mathrm{~K} 4$ & Cerritos2_3 & 0.32 & 20.2 & 17.7 & 0.040 & $<0.050$ & 365 & 63 & 107 & 0.005 & $<0.1$ & -12.38 & 64.8 \\
\hline $3 \mathrm{~S} / 12 \mathrm{~W}-26 \mathrm{~K} 5$ & Cerritos2_4 & 0.43 & 22.0 & 17.6 & 0.060 & $<0.050$ & 344 & 77 & 99 & 0.005 & $<0.1$ & -12.44 & 78.1 \\
\hline $3 \mathrm{~S} / 12 \mathrm{~W}-26 \mathrm{~K} 6$ & Cerritos2_5 & 0.34 & 21.6 & 17.0 & 0.090 & $<0.050$ & 390 & 72 & 100 & 0.005 & $<0.1$ & -12.42 & 73.0 \\
\hline $3 \mathrm{~S} / 12 \mathrm{~W}-26 \mathrm{~K} 7$ & Cerritos2_6 & 0.36 & 23.8 & 156 & $<0.04$ & $<0.050$ & 917 & 87 & 680 & 0.015 & 3.2 & - & - \\
\hline $3 \mathrm{~S} / 12 \mathrm{~W}-33 \mathrm{~B} 1$ & BSMWC_615 & 0.48 & 22.6 & 73.2 & 0.012 & 0.58 & 595 & 75 & 412 & 0.002 & 6.6 & -12.34 & 93.4 \\
\hline $3 \mathrm{~S} / 13 \mathrm{~W}-8 \mathrm{~J} 1$ & Willowbrook1_1 & 0.34 & 26.0 & 0.70 & 2. & $<0.032$ & 279 & 166 & 105 & 0.025 & $<0.1$ & -11.41 & 15.9 \\
\hline $3 \mathrm{~S} / 13 \mathrm{~W}-8 \mathrm{~J} 2$ & Willowbrook1_2 & 0.37 & 22.4 & 70.8 & 0.29 & $<0.035$ & 448 & 113 & 182 & 0.028 & $<0.1$ & -13.54 & 67.8 \\
\hline $3 \mathrm{~S} / 13 \mathrm{~W}-8 \mathrm{~J} 3$ & Willowbrook1_3 & 0.47 & 21.7 & 70.7 & 0.080 & $<0.036$ & 442 & 118 & 172 & 0.028 & $<0.1$ & -12.97 & 71.5 \\
\hline $3 \mathrm{~S} / 13 \mathrm{~W}-8 \mathrm{~J} 4$ & Willowbrook1_4 & 0.46 & 20.3 & 76.2 & 0.10 & $<0.031$ & 458 & 129 & 192 & 0.034 & 0.1 & - & - \\
\hline $3 \mathrm{~S} / 13 \mathrm{~W}-11 \mathrm{G} 1$ & Lynwood1_1 & 0.55 & 22.4 & 3.17 & 1.69 & $<0.040$ & 139 & 1,380 & 9 & 0.023 & $<0.1$ & -5.26 & 0.49 \\
\hline
\end{tabular}


Table 1.2. Groundwater-quality data used for this study from multiple-well monitoring sites, and selected production and observation wells, Los Angeles and Orange Counties, California.-Continued

[See appendix 1 for explanation. Abbreviations: ft, foot; mg/L, milligrams per liter; mm/dd/yyyy, month/day/year; ug/L, micrograms per liter; CaCO 3 , calcium carbonate; \%, percent; <, less than; —, no data . Sediment source/facies: LAR, Los Angeles River; n.a., not assigned; SGR, San Gabriel River; SAR, Santa Ana River, *, potentially affected by mixing with anthropogenic sources of water or seawater]

\begin{tabular}{|c|c|c|c|c|c|c|c|c|c|c|c|c|c|}
\hline State well number & Local well name & $\begin{array}{c}\text { Fluoride, } \\
\text { filtered } \\
\text { (mg/L) }\end{array}$ & $\begin{array}{c}\text { Silica, } \\
\text { filtered } \\
(\mathrm{mg} / \mathrm{L} \text { as } \\
\left.\mathrm{SiO}_{2}\right)\end{array}$ & $\begin{array}{c}\text { Sulfate, } \\
\text { filtered } \\
\text { (mg/L) }\end{array}$ & $\begin{array}{c}\text { Ammonia, } \\
\text { filtered } \\
\text { (mg/L as } \\
\text { nitrogen) }\end{array}$ & $\begin{array}{c}\text { Nitrate, } \\
\text { filtered } \\
\text { (mg/L as } \\
\text { nitrogen) }\end{array}$ & $\begin{array}{l}\text { Strontium, } \\
\text { filtered } \\
\text { (ug/L) }\end{array}$ & $\begin{array}{c}\text { Boron, } \\
\text { filtered } \\
\text { (ug/L) }\end{array}$ & $\begin{array}{l}\text { Chloride } \\
\text { / Boron } \\
\text { ratio } \\
(\mathrm{mg} / \mathrm{mg})\end{array}$ & $\begin{array}{c}\text { lodide, } \\
\text { filtered } \\
\text { (mg/L) }\end{array}$ & $\begin{array}{c}\text { Tritium, } \\
\text { unfiltered } \\
\text { (tritium } \\
\text { units) }\end{array}$ & $\begin{array}{c}\delta^{13} \text { Carbon, } \\
\text { filtered } \\
\text { (per mil) }\end{array}$ & $\begin{array}{c}\text { Carbon-14, } \\
\text { filtered } \\
\text { (percent } \\
\text { modern) }\end{array}$ \\
\hline \multicolumn{14}{|c|}{ Pressure area-Continued } \\
\hline 3S/13W-11G2 & Lynwood1_2 & 0.47 & 17.2 & 49.1 & 0.23 & $<0.040$ & 17.6 & 180 & 126 & 0.030 & $<0.1$ & -14.52 & 13.3 \\
\hline $3 \mathrm{~S} / 13 \mathrm{~W}-11 \mathrm{G} 3$ & Lynwood1_8 & 0.43 & 22.2 & 112 & $<0.01$ & 1.7 & 616 & 131 & 371 & 0.002 & 4.6 & -13.39 & 98.8 \\
\hline $3 \mathrm{~S} / 13 \mathrm{~W}-11 \mathrm{G} 4$ & Lynwood1_3 & 0.32 & 15.8 & 78.4 & 0.27 & $<0.040$ & 135 & 101 & 216 & 0.025 & $<0.1$ & -13.95 & 55.2 \\
\hline $3 \mathrm{~S} / 13 \mathrm{~W}-11 \mathrm{G} 5$ & Lynwood1_4 & 0.29 & 20.2 & 82.9 & 0.19 & $<0.040$ & 529 & 90 & 248 & 0.027 & $<0.1$ & -13.26 & 41.1 \\
\hline $3 \mathrm{~S} / 13 \mathrm{~W}-11 \mathrm{G} 6$ & Lynwood1_5 & 0.30 & 17.4 & 52.0 & 0.16 & $<0.037$ & 454 & 91 & 246 & 0.031 & $<0.1$ & -13.66 & 52.4 \\
\hline $3 \mathrm{~S} / 13 \mathrm{~W}-11 \mathrm{G} 7$ & Lynwood1_6 & 0.41 & 23.1 & 73.4 & 0.19 & $<0.040$ & 378 & 124 & 173 & 0.027 & $<0.1$ & -13.38 & 61.9 \\
\hline $3 \mathrm{~S} / 13 \mathrm{~W}-11 \mathrm{G} 8$ & Lynwood1_7 & 0.37 & 22.1 & 75.0 & 0.080 & $<0.039$ & 441 & 120 & 187 & 0.027 & $<0.1$ & -13.47 & 62.6 \\
\hline $3 \mathrm{~S} / 13 \mathrm{~W}-11 \mathrm{G} 9$ & Lynwood1_9 & 0.29 & 21.9 & 304 & 0.20 & $<0.040$ & 1,660 & 165 & 879 & 0.23 & 0.3 & -14.15 & 84.2 \\
\hline $3 \mathrm{~S} / 13 \mathrm{~W}-22 \mathrm{M} 2$ & Compton2_1 & 0.45 & 25.6 & 0.74 & 2.24 & $<0.038$ & 144 & 680 & 22 & 0.018 & $<0.1$ & -4.28 & 0.13 \\
\hline $3 \mathrm{~S} / 13 \mathrm{~W}-22 \mathrm{M} 3$ & Compton2_2 & 0.30 & 24.4 & 0.43 & 1.41 & $<0.040$ & 307 & 193 & 74 & 0.019 & $<0.1$ & -5.38 & 3.8 \\
\hline 3S/13W-22M4 & Compton2_3 & 0.24 & 24.8 & 55.1 & 0.58 & $<0.040$ & 357 & 109 & 177 & 0.028 & $<0.1$ & -13.48 & 46.4 \\
\hline 3S/13W-22M5 & Compton2_4 & 0.25 & 25.8 & 73.7 & 0.48 & $<0.040$ & 520 & 121 & 218 & 0.030 & 0.2 & -13.41 & 72.5 \\
\hline 3S/13W-22M6 & Compton2_5 & 0.33 & 23.6 & 80.4 & 0.28 & $<0.040$ & 520 & 127 & 266 & 0.037 & 0.1 & - & - \\
\hline $3 \mathrm{~S} / 13 \mathrm{~W}-22 \mathrm{M} 7$ & Compton2_6 & 0.41 & 24.1 & 95.4 & 0.017 & 0.29 & 628 & 160 & 408 & 0.003 & 0.4 & - & - \\
\hline $3 \mathrm{~S} / 13 \mathrm{~W}-24 \mathrm{~K} 2$ & Compton1_1 & 0.36 & 18.1 & 2.55 & - & - & 59.9 & 144 & 102 & 0.035 & $<0.1$ & -17.85 & 9.6 \\
\hline $3 \mathrm{~S} / 13 \mathrm{~W}-24 \mathrm{~K} 3$ & Compton1_2 & 0.37 & 20.5 & 59.0 & - & - & 236 & 101 & 227 & 0.037 & $<0.1$ & -14.35 & 29.1 \\
\hline $3 \mathrm{~S} / 13 \mathrm{~W}-24 \mathrm{~K} 4$ & Compton1_3 & 0.32 & 26.2 & 57.2 & - & - & 426 & 112 & 221 & 0.060 & $<0.1$ & -3.50 & 44.4 \\
\hline $3 \mathrm{~S} / 13 \mathrm{~W}-24 \mathrm{~K} 5$ & Compton1_4 & 0.31 & 22.5 & 71.2 & - & - & 574 & 91 & 242 & 0.038 & $<0.1$ & - & - \\
\hline $3 \mathrm{~S} / 13 \mathrm{~W}-24 \mathrm{~K} 6$ & Compton1_5 & 0.41 & 23.6 & 64.3 & - & - & 536 & 127 & 161 & 0.036 & 0.1 & - & - \\
\hline 4S/11W-5P9 & Cerritos1_1 & 0.27 & 16.5 & 48.8 & 0.32 & $<0.050$ & 401 & 98 & 155 & 0.013 & $<0.1$ & -12.21 & 56.2 \\
\hline 4S/11W-5P10 & Cerritos1_2 & 0.34 & 21.4 & 40.4 & 0.11 & $<0.050$ & 150 & 110 & 124 & 0.020 & $<0.1$ & -11.73 & 46.0 \\
\hline 4S/11W-5P11 & Cerritos1_3 & 0.35 & 23.3 & 57.7 & 0.25 & $<0.050$ & 537 & 88 & 224 & 0.034 & $<0.1$ & -12.19 & 33.9 \\
\hline 4S/11W-5P12 & Cerritos1_4 & 0.54 & 23.5 & 37.2 & 0.11 & $<0.050$ & 409 & 95 & 132 & 0.019 & $<0.1$ & -12.40 & 57.0 \\
\hline $4 \mathrm{~S} / 11 \mathrm{~W}-5 \mathrm{P} 13$ & Cerritos1_5 & 0.47 & 26.1 & 29.1 & 0.18 & $<0.050$ & 393 & 98 & 110 & 0.023 & $<0.1$ & -12.88 & 58.7 \\
\hline $4 \mathrm{~S} / 11 \mathrm{~W}-5 \mathrm{P} 14$ & Cerritos1_6 & 0.31 & 29.5 & 24.2 & 0.29 & $<0.050$ & 467 & 86 & 131 & 0.067 & $<0.1$ & - & - \\
\hline 4S/12W-5H5 & Lakewood1_1 & 0.50 & 16.9 & 15.4 & 0.37 & $<0.050$ & 139 & 61 & 315 & 0.050 & $<0.1$ & -12.46 & 7.6 \\
\hline 4S/12W-5H6 & Lakewood1_2 & 0.44 & 23.4 & 15.9 & 0.090 & $<0.050$ & 247 & 63 & 275 & 0.050 & 0.3 & -12.50 & 54.2 \\
\hline 4S/12W-5H7 & Lakewood1_3 & 0.32 & 24.8 & 15.0 & 0.20 & $<0.050$ & 339 & 64 & 143 & 0.019 & $<0.1$ & -12.93 & 61.4 \\
\hline
\end{tabular}


Table 1.2. Groundwater-quality data used for this study from multiple-well monitoring sites, and selected production and observation wells, Los Angeles and Orange Counties, California.-Continued

[See appendix 1 for explanation. Abbreviations: ft, foot; mg/L, milligrams per liter; mm/dd/yyyy, month/day/year; ug/L, micrograms per liter; CaCO 3 , calcium carbonate; \%, percent; <, less than; - , no data.

\begin{tabular}{|c|c|c|c|c|c|c|c|c|c|c|c|c|c|}
\hline State well number & Local well name & $\begin{array}{c}\text { Fluoride, } \\
\text { filtered } \\
\text { (mg/L) }\end{array}$ & $\begin{array}{c}\text { Silica, } \\
\text { filtered } \\
(\mathrm{mg} / \mathrm{L} \text { as } \\
\left.\mathrm{SiO}_{2}\right)\end{array}$ & $\begin{array}{c}\text { Sulfate, } \\
\text { filtered } \\
\text { (mg/L) }\end{array}$ & $\begin{array}{c}\text { Ammonia, } \\
\text { filtered } \\
\text { (mg/L as } \\
\text { nitrogen) }\end{array}$ & $\begin{array}{c}\text { Nitrate, } \\
\text { filtered } \\
\text { (mg/L as } \\
\text { nitrogen) }\end{array}$ & $\begin{array}{l}\text { Strontium, } \\
\text { filtered } \\
\text { (ug/L) }\end{array}$ & $\begin{array}{c}\text { Boron, } \\
\text { filtered } \\
\text { (ug/L) }\end{array}$ & $\begin{array}{l}\text { Chloride } \\
\text { / Boron } \\
\text { ratio } \\
(\mathrm{mg} / \mathrm{mg})\end{array}$ & $\begin{array}{c}\text { lodide, } \\
\text { filtered } \\
\text { (mg/L) }\end{array}$ & $\begin{array}{c}\text { Tritium, } \\
\text { unfiltered } \\
\text { (tritium } \\
\text { units) }\end{array}$ & $\begin{array}{c}\delta^{13} \text { Carbon, } \\
\text { filtered } \\
\text { (per mil) }\end{array}$ & $\begin{array}{c}\text { Carbon-14, } \\
\text { filtered } \\
\text { (percent } \\
\text { modern) }\end{array}$ \\
\hline \multicolumn{14}{|c|}{ Pressure area-Continued } \\
\hline $4 \mathrm{~S} / 12 \mathrm{~W}-5 \mathrm{H} 8$ & Lakewood1_4 & 0.35 & 23.1 & 15.2 & 0.28 & $<0.050$ & 617 & 72 & 379 & 0.043 & 0.5 & -13.67 & 59.1 \\
\hline $4 \mathrm{~S} / 12 \mathrm{~W}-5 \mathrm{H} 9$ & Lakewood1_5 & 0.52 & 24.7 & 15.2 & 0.080 & $<0.050$ & 385 & 90 & 109 & 0.017 & $<0.1$ & -12.49 & 71.7 \\
\hline $4 \mathrm{~S} / 12 \mathrm{~W}-5 \mathrm{H} 10$ & Lakewood1_6 & 0.19 & 23.6 & 42.2 & 0.43 & $<0.050$ & 1,330 & 94 & 2,213 & 0.10 & 2.0 & - & - \\
\hline $4 \mathrm{~S} / 12 \mathrm{~W}-12 \mathrm{~F} 1$ & Lakewood2_1 & 0.45 & 13.6 & 50.6 & 0.18 & $<0.040$ & 123 & 61 & 218 & 0.036 & $<0.1$ & -12.54 & 23.0 \\
\hline $4 \mathrm{~S} / 12 \mathrm{~W}-12 \mathrm{~F} 2$ & Lakewood2_2 & 0.35 & 19.9 & 13.6 & 0.16 & $<0.040$ & 204 & 55 & 104 & 0.015 & $<0.1$ & -12.60 & 45.3 \\
\hline $4 \mathrm{~S} / 12 \mathrm{~W}-12 \mathrm{~F} 3$ & Lakewood2_3 & 0.29 & 19.3 & 11.1 & 0.32 & $<0.036$ & 257 & 46 & 130 & 0.023 & 0.1 & -13.35 & 34.9 \\
\hline $4 \mathrm{~S} / 12 \mathrm{~W}-12 \mathrm{~F} 4$ & Lakewood2_4 & 0.44 & 20.3 & 42.4 & $<0.010$ & 0.50 & 449 & 71 & 186 & 0.001 & 0.5 & -11.31 & 86.6 \\
\hline $4 \mathrm{~S} / 12 \mathrm{~W}-12 \mathrm{~F} 5$ & Lakewood2_5 & 0.32 & 24.3 & 16.8 & 0.14 & $<0.040$ & 378 & 63 & 98 & 0.008 & $<0.1$ & -12.73 & 61.7 \\
\hline $4 \mathrm{~S} / 12 \mathrm{~W}-12 \mathrm{~F} 6$ & Lakewood2_6 & 0.39 & 22.2 & 11.2 & 0.19 & $<0.038$ & 266 & 64 & 90 & 0.011 & $<0.1$ & -12.30 & 66.6 \\
\hline $4 \mathrm{~S} / 12 \mathrm{~W}-12 \mathrm{~F} 7$ & Lakewood2_7 & 0.24 & 22.6 & 14.9 & 0.26 & $<0.040$ & 501 & 65 & 89 & 0.015 & $<0.1$ & -12.78 & 64.1 \\
\hline $4 \mathrm{~S} / 12 \mathrm{~W}-12 \mathrm{~F} 8$ & Lakewood2_8 & 0.39 & 24.6 & 6.88 & 0.23 & $<0.040$ & 360 & 78 & 86 & 0.035 & $<0.1$ & -13.10 & 69.7 \\
\hline $4 \mathrm{~S} / 12 \mathrm{~W}-21 \mathrm{M} 8$ & Long Beach6_1 & 0.55 & 20.7 & 2.72 & 1.71 & $<0.044$ & 81.4 & 1,130 & 17 & 0.061 & $<0.1$ & -5.21 & 1.8 \\
\hline 4S/12W-21M9 & Long Beach6_2 & 0.61 & 19.0 & 1.52 & 0.49 & $<0.045$ & 48.1 & 338 & 57 & 0.028 & $<0.1$ & -10.59 & 9.8 \\
\hline $4 \mathrm{~S} / 12 \mathrm{~W}-21 \mathrm{M} 10$ & Long Beach6_3 & 0.57 & 17.8 & 1.17 & 0.21 & $<0.050$ & 34.5 & 242 & 69 & 0.019 & $<0.1$ & -15.86 & 22.5 \\
\hline $4 \mathrm{~S} / 12 \mathrm{~W}-21 \mathrm{M} 11$ & Long Beach6_4 & 0.67 & 17.2 & 9.81 & 0.22 & $<0.050$ & 49.9 & 133 & 116 & 0.015 & $<0.1$ & - & - \\
\hline $4 \mathrm{~S} / 12 \mathrm{~W}-21 \mathrm{M} 12$ & Long Beach6_5 & 0.54 & 17.0 & 11.4 & 0.31 & $<0.050$ & 78.4 & 86 & 205 & 0.030 & $<0.1$ & - & - \\
\hline $4 \mathrm{~S} / 12 \mathrm{~W}-21 \mathrm{M} 13$ & Long Beach6_6 & 0.23 & 22.7 & 16.8 & 0.28 & $<0.050$ & 274 & 50 & 658 & 0.067 & $<0.1$ & -13.14 & 44.4 \\
\hline $4 \mathrm{~S} / 12 \mathrm{~W}-23 \mathrm{~K} 3$ & LB Annex 201 & 0.62 & 16.1 & 27.2 & 0.23 & $<0.060$ & 28.5 & 70 & 171 & 0.010 & $<0.1$ & -13.64 & 28.1 \\
\hline $4 \mathrm{~S} / 12 \mathrm{~W}-25 \mathrm{G} 1$ & Long Beach1_1 & 0.72 & 20.5 & 1.59 & 0.60 & $<0.050$ & 23.6 & 186 & 82 & 0.019 & $<0.1$ & -15.30 & 30.5 \\
\hline $4 \mathrm{~S} / 12 \mathrm{~W}-25 \mathrm{G} 2$ & Long Beach1_2 & 0.73 & 20.2 & 0.31 & 0.34 & $<0.050$ & 26.8 & 197 & 76 & 0.019 & $<0.1$ & -15.24 & 30.1 \\
\hline $4 \mathrm{~S} / 12 \mathrm{~W}-25 \mathrm{G} 3$ & Long Beach1_3 & 0.66 & 19.8 & 15.2 & 0.17 & $<0.050$ & 25.3 & 88 & 141 & 0.009 & $<0.1$ & -14.90 & 23.7 \\
\hline $4 \mathrm{~S} / 12 \mathrm{~W}-25 \mathrm{G} 4$ & Long Beach1_4 & 0.39 & 18.8 & 32.9 & 0.27 & $<0.050$ & 191 & 64 & 192 & 0.006 & 0.1 & -12.24 & 52.9 \\
\hline 4S/12W-25G5 & Long Beach1_5 & 0.21 & 22.0 & 282 & 0.68 & $<0.050$ & 2,660 & 87 & 7,437 & 0.031 & 26.0 & -12.47 & 61.4 \\
\hline $4 \mathrm{~S} / 12 \mathrm{~W}-25 \mathrm{G} 6$ & Long Beach1_6 & 0.33 & 24.7 & 214 & 0.39 & $<0.050$ & 1,390 & 90 & 1,467 & 0.046 & 0.3 & - & - \\
\hline $4 \mathrm{~S} / 13 \mathrm{~W}-1 \mathrm{~N} 3$ & Long Beach2_1 & 0.69 & 22.6 & 0.27 & 1.41 & $<0.040$ & 66.8 & 546 & 38 & 0.018 & $<0.1$ & -8.31 & 1.3 \\
\hline $4 \mathrm{~S} / 13 \mathrm{~W}-1 \mathrm{~N} 4$ & Long Beach2_2 & 0.38 & 23.6 & 2.22 & 0.74 & $<0.047$ & 129 & 200 & 99 & 0.027 & $<0.1$ & -10.68 & 4.3 \\
\hline $4 \mathrm{~S} / 13 \mathrm{~W}-1 \mathrm{~N} 5$ & Long Beach2_3 & 0.58 & 21.2 & 27.2 & 0.38 & $<0.050$ & 74.3 & 141 & 158 & 0.036 & $<0.1$ & -16.68 & 22.3 \\
\hline 4S/13W-1N6 & Long Beach2_4 & 0.37 & 23.8 & 46.3 & 0.20 & $<0.050$ & 318 & 96 & 300 & 0.043 & $<0.1$ & -15.75 & 40.8 \\
\hline
\end{tabular}


Table 1.2. Groundwater-quality data used for this study from multiple-well monitoring sites, and selected production and observation wells, Los Angeles and Orange Counties, California.-Continued

[See appendix 1 for explanation. Abbreviations: ft, foot; mg/L, milligrams per liter; mm/dd/yyyy, month/day/year; ug/L, micrograms per liter; CaCO 3 , calcium carbonate; \%, percent; <, less than; —, no data . Sediment source/facies: LAR, Los Angeles River; n.a., not assigned; SGR, San Gabriel River; SAR, Santa Ana River, *, potentially affected by mixing with anthropogenic sources of water or seawater]

\begin{tabular}{|c|c|c|c|c|c|c|c|c|c|c|c|c|c|}
\hline State well number & Local well name & $\begin{array}{c}\text { Fluoride, } \\
\text { filtered } \\
\text { (mg/L) }\end{array}$ & $\begin{array}{c}\text { Silica, } \\
\text { filtered } \\
(\mathrm{mg} / \mathrm{L} \text { as } \\
\left.\mathrm{SiO}_{2}\right)\end{array}$ & $\begin{array}{c}\text { Sulfate, } \\
\text { filtered } \\
\text { (mg/L) }\end{array}$ & $\begin{array}{c}\text { Ammonia, } \\
\text { filtered } \\
\text { (mg/L as } \\
\text { nitrogen) }\end{array}$ & $\begin{array}{l}\text { Nitrate, } \\
\text { filtered } \\
\text { (mg/L as } \\
\text { nitrogen) }\end{array}$ & $\begin{array}{l}\text { Strontium, } \\
\text { filtered } \\
\text { (ug/L) }\end{array}$ & $\begin{array}{c}\text { Boron, } \\
\text { filtered } \\
\text { (ug/L) }\end{array}$ & $\begin{array}{l}\text { Chloride } \\
\text { / Boron } \\
\text { ratio } \\
\text { (mg/mg) }\end{array}$ & $\begin{array}{c}\text { lodide, } \\
\text { filtered } \\
\text { (mg/L) }\end{array}$ & $\begin{array}{c}\text { Tritium, } \\
\text { unfiltered } \\
\text { (tritium } \\
\text { units) }\end{array}$ & $\begin{array}{c}\delta^{13} \text { Carbon, } \\
\text { filtered } \\
\text { (per mil) }\end{array}$ & $\begin{array}{c}\text { Carbon-14, } \\
\text { filtered } \\
\text { (percent } \\
\text { modern) }\end{array}$ \\
\hline \multicolumn{14}{|c|}{ Pressure area-Continued } \\
\hline 4S/13W-1N7 & Long Beach2_5 & 0.18 & 27.4 & 257 & 0.22 & $<0.050$ & 1,120 & 254 & 382 & 0.035 & 5.1 & - & - \\
\hline $4 \mathrm{~S} / 13 \mathrm{~W}-1 \mathrm{~N} 8$ & Long Beach2_6 & 0.32 & 28.1 & 430 & 0.36 & $<0.050$ & 1,600 & 332 & 461 & 0.038 & 3.6 & - & - \\
\hline \multicolumn{14}{|c|}{ Orange County Basin } \\
\hline $3 \mathrm{~S} / 8 \mathrm{~W}-34 \mathrm{G} 2$ & Canyon_RV_1_EAST & 0.50 & 21.0 & 166 & 0.006 & 2.0 & 648 & 261 & 368 & 0.022 & 6.9 & -14.27 & 98.8 \\
\hline $4 \mathrm{~S} / 10 \mathrm{~W}-14 \mathrm{H} 3$ & Anaheim_46 & 0.49 & 21.4 & 133 & $<0.010$ & 4.1 & 669 & 184 & 497 & 0.010 & 4.3 & -12.31 & 105.0 \\
\hline $5 \mathrm{~S} / 12 \mathrm{~W}-1 \mathrm{C} 1$ & $512 \mathrm{~B}$ & 0.24 & 14.6 & 152 & 0.16 & $<0.020$ & 578 & 128 & 583 & 0.016 & 4.4 & -7.94 & 83.9 \\
\hline $5 \mathrm{~S} / 12 \mathrm{~W}-1 \mathrm{C} 2$ & $512 \mathrm{C}$ & 0.22 & 14.6 & 118 & 0.091 & $<0.020$ & 565 & 127 & 546 & 0.021 & 3.6 & -8.42 & 88.2 \\
\hline $5 \mathrm{~S} / 12 \mathrm{~W}-1 \mathrm{C} 3$ & Seal Beach1_1 & 0.44 & 17.3 & 0.25 & 0.23 & $<0.014$ & 50.7 & 218 & 84 & 0.012 & $<0.1$ & -9.72 & 4.1 \\
\hline $5 \mathrm{~S} / 12 \mathrm{~W}-1 \mathrm{C} 4$ & Seal Beach1_2 & 0.52 & 17.3 & 0.67 & 0.22 & $<0.017$ & 27.7 & 131 & 126 & 0.011 & $<0.1$ & -14.93 & 23.6 \\
\hline $5 \mathrm{~S} / 12 \mathrm{~W}-1 \mathrm{C} 5$ & Seal Beach1_3 & 0.59 & 16.9 & 0.39 & 0.20 & $<0.017$ & 28.6 & 192 & 80 & 0.012 & $<0.1$ & -15.38 & 26.7 \\
\hline $5 \mathrm{~S} / 12 \mathrm{~W}-1 \mathrm{C} 6$ & Seal Beach1_4 & 0.80 & 19.0 & 1.02 & 0.12 & $<0.015$ & 43.1 & 228 & 84 & 0.012 & 0.2 & -11.22 & 8.0 \\
\hline $5 \mathrm{~S} / 12 \mathrm{~W}-1 \mathrm{C} 7$ & Seal Beach1_5 & 0.62 & 14.4 & 30.7 & 0.091 & $<0.040$ & 67.5 & 81 & 184 & 0.022 & 0.4 & -13.58 & 38.7 \\
\hline $5 \mathrm{~S} / 12 \mathrm{~W}-1 \mathrm{C} 8$ & Seal Beach1_6 & 0.35 & 17.1 & 155 & 0.17 & $<0.020$ & 662 & 127 & 678 & 0.020 & 5.1 & -7.38 & 83.7 \\
\hline $5 \mathrm{~S} / 12 \mathrm{~W}-1 \mathrm{C} 9$ & Seal Beach1_7 & 0.40 & 19.8 & 164 & 0.35 & $<0.020$ & 2,210 & 144 & 5,306 & 0.15 & 1.3 & -13.29 & 69.3 \\
\hline \multicolumn{14}{|c|}{ West Coast Basin } \\
\hline $2 \mathrm{~S} / 14 \mathrm{~W}-18 \mathrm{~J} 1$ & Holy_Cross_AA & 0.26 & 39.2 & 561 & 2.07 & $<0.060$ & 1,950 & 1,260 & 508 & 1.12 & 5.1 & - & - \\
\hline 2S/14W-19G1 & Hillside_Park_1 & 0.36 & 37.2 & 54.2 & 2.93 & $<0.060$ & 482 & 492 & 215 & 0.20 & $<0.1$ & -13.50 & 35.7 \\
\hline $2 \mathrm{~S} / 14 \mathrm{~W}-28 \mathrm{M} 3$ & Inglewood1_1 & 0.38 & 34.5 & 3.57 & 25.8 & $<0.035$ & 652 & 10,700 & 151 & 12.8 & $<0.1$ & -0.50 & 2.2 \\
\hline 2S/14W-28M4 & Inglewood1_2 & 0.18 & 25.8 & 215 & 0.35 & 0.11 & 1,250 & 414 & 964 & 0.12 & 1.3 & -17.42 & 61.7 \\
\hline 2S/14W-28M5 & Inglewood1_3 & 0.57 & 43.2 & 116 & 0.69 & $<0.050$ & 654 & 391 & 583 & 0.47 & $<0.1$ & -13.62 & 53.5 \\
\hline 2S/14W-28M6 & Inglewood1_4 & 0.44 & 34.2 & 79.2 & 1.34 & $<0.050$ & 518 & 192 & 885 & 0.091 & 0.3 & - & - \\
\hline 2S/14W-28M7 & Inglewood1_5 & 0.27 & 34.4 & 101 & 0.050 & 8.1 & 1,110 & 217 & 1,382 & 0.033 & 1.6 & - & - \\
\hline $2 \mathrm{~S} / 15 \mathrm{~W}-35 \mathrm{~A} 1$ & Westchester1_1 & 0.30 & 39.7 & 1.22 & 4.15 & $<0.036$ & 249 & 2,330 & 55 & 0.16 & $<0.1$ & -6.36 & 2.2 \\
\hline $2 \mathrm{~S} / 15 \mathrm{~W}-35 \mathrm{~A} 2$ & Westchester1_2 & 0.32 & 36.4 & 2.72 & 3.01 & $<0.050$ & 305 & 949 & 76 & 0.15 & $<0.1$ & -12.27 & 6.4 \\
\hline $2 \mathrm{~S} / 15 \mathrm{~W}-35 \mathrm{~A} 3$ & Westchester1_3 & 0.34 & 39.0 & 13.2 & 1.79 & $<0.050$ & 406 & 481 & 137 & 0.13 & 0.2 & - & - \\
\hline $2 \mathrm{~S} / 15 \mathrm{~W}-35 \mathrm{~A} 4$ & Westchester1_4 & 0.29 & 38.0 & 75.8 & 0.90 & $<0.050$ & 575 & 234 & 271 & 0.10 & $<0.1$ & -17.41 & 30.2 \\
\hline $2 \mathrm{~S} / 15 \mathrm{~W}-35 \mathrm{~A} 5$ & Westchester1_5 & 0.26 & 33.3 & 79.0 & 0.58 & $<0.050$ & 506 & 234 & 285 & 0.10 & $<0.1$ & - & - \\
\hline 3S/14W-4R1 & Inglewood3_1 & 0.48 & 39.0 & 14.6 & 11.3 & $<0.040$ & 318 & 3,370 & 309 & 2.42 & 0.2 & -5.07 & 2.2 \\
\hline
\end{tabular}


Table 1.2. Groundwater-quality data used for this study from multiple-well monitoring sites, and selected production and observation wells, Los Angeles and Orange Counties, California.-Continued

[See appendix 1 for explanation. Abbreviations: ft, foot; mg/L, milligrams per liter; mm/dd/yyyy, month/day/year; ug/L, micrograms per liter; CaCO 3 , calcium carbonate; \%, percent; <, less than; - , no data.

\begin{tabular}{|c|c|c|c|c|c|c|c|c|c|c|c|c|c|}
\hline State well number & Local well name & $\begin{array}{c}\text { Fluoride, } \\
\text { filtered } \\
\text { (mg/L) }\end{array}$ & $\begin{array}{c}\text { Silica, } \\
\text { filtered } \\
(\mathrm{mg} / \mathrm{L} \text { as } \\
\left.\mathrm{SiO}_{2}\right)\end{array}$ & $\begin{array}{c}\text { Sulfate, } \\
\text { filtered } \\
\text { (mg/L) }\end{array}$ & $\begin{array}{c}\text { Ammonia, } \\
\text { filtered } \\
\text { (mg/L as } \\
\text { nitrogen) }\end{array}$ & $\begin{array}{c}\text { Nitrate, } \\
\text { filtered } \\
\text { (mg/L as } \\
\text { nitrogen) }\end{array}$ & $\begin{array}{l}\text { Strontium, } \\
\text { filtered } \\
\text { (ug/L) }\end{array}$ & $\begin{array}{c}\text { Boron, } \\
\text { filtered } \\
\text { (ug/L) }\end{array}$ & $\begin{array}{l}\text { Chloride } \\
\text { / Boron } \\
\text { ratio } \\
\text { (mg/mg) }\end{array}$ & $\begin{array}{c}\text { lodide, } \\
\text { filtered } \\
\text { (mg/L) }\end{array}$ & $\begin{array}{c}\text { Tritium, } \\
\text { unfiltered } \\
\text { (tritium } \\
\text { units) }\end{array}$ & $\begin{array}{c}\delta^{13} \text { Carbon, } \\
\text { filtered } \\
\text { (per mil) }\end{array}$ & $\begin{array}{c}\text { Carbon-14, } \\
\text { filtered } \\
\text { (percent } \\
\text { modern) }\end{array}$ \\
\hline \multicolumn{14}{|c|}{ West Coast Basin-Continued } \\
\hline $3 \mathrm{~S} / 14 \mathrm{~W}-4 \mathrm{R} 2$ & Inglewood3_2 & 0.51 & 40.5 & 4.03 & 9.06 & $<0.040$ & 162 & 4,680 & 12 & 0.34 & $<0.1$ & 2.91 & 0.48 \\
\hline $3 \mathrm{~S} / 14 \mathrm{~W}-4 \mathrm{R} 3$ & Inglewood3_3 & 0.28 & 42.5 & 9.57 & 3.70 & $<0.040$ & 75.8 & 1,040 & 17 & 0.006 & $<0.1$ & -0.41 & 3.1 \\
\hline $3 \mathrm{~S} / 14 \mathrm{~W}-4 \mathrm{R} 4$ & Inglewood3_4 & 0.23 & 42.3 & 7.45 & 5.70 & $<0.040$ & 200 & 2,020 & 14 & 0.009 & 0.2 & -5.52 & 1.3 \\
\hline $3 \mathrm{~S} / 14 \mathrm{~W}-4 \mathrm{R} 5$ & Inglewood3_5 & 0.17 & 42.4 & 0.49 & 1.60 & $<0.040$ & 735 & 326 & 303 & 0.19 & $<0.1$ & -18.78 & 24.1 \\
\hline 3S/14W-4R6 & Inglewood3_6 & 0.33 & 33.5 & 11.1 & 0.93 & $<0.040$ & 526 & 112 & 1,214 & 0.040 & 0.3 & -20.13 & 45.7 \\
\hline $3 \mathrm{~S} / 14 \mathrm{~W}-4 \mathrm{R} 7$ & Inglewood3_7 & 0.36 & 28.8 & 37.6 & 0.37 & $<0.040$ & 1,210 & 98 & 3,878 & 0.084 & 1.0 & -28.33 & 35.1 \\
\hline $3 \mathrm{~S} / 14 \mathrm{~W}-13 \mathrm{~J} 5$ & Gardena1_1 & 0.30 & 40.0 & 1.30 & 5.60 & 0.08 & 160 & 355 & 48 & 0.029 & 0.3 & -2.94 & 8.7 \\
\hline $3 \mathrm{~S} / 14 \mathrm{~W}-13 \mathrm{~J} 6$ & Gardena1_2 & 0.50 & 30.0 & 56.0 & 0.14 & 0.07 & 440 & 132 & 159 & 0.026 & 0.3 & -14.47 & 65.4 \\
\hline $3 \mathrm{~S} / 14 \mathrm{~W}-13 \mathrm{~J} 7$ & Gardena1_3 & 0.40 & 26.0 & 66.0 & 0.30 & 0.10 & 470 & 117 & 188 & 0.028 & 0.1 & - & - \\
\hline $3 \mathrm{~S} / 14 \mathrm{~W}-13 \mathrm{~J} 8$ & Gardena1_4 & 0.30 & 29.0 & 53.0 & 0.090 & 2.0 & 1,200 & 117 & 3,162 & 0.009 & 1.0 & - & - \\
\hline $3 \mathrm{~S} / 14 \mathrm{~W}-17 \mathrm{G} 3$ & Hawthorne1_1 & 0.16 & 46.1 & $<0.10$ & 5.63 & $<0.050$ & 248 & 1,380 & 35 & 0.026 & $<0.1$ & -13.47 & 2.8 \\
\hline $3 \mathrm{~S} / 14 \mathrm{~W}-17 \mathrm{G} 4$ & Hawthorne1_2 & 0.27 & 28.7 & 0.65 & 2.54 & $<0.050$ & 153 & 1,020 & 42 & 0.040 & $<0.1$ & -11.37 & 7.6 \\
\hline $3 \mathrm{~S} / 14 \mathrm{~W}-17 \mathrm{G} 5$ & Hawthorne1_3 & 0.24 & 34.4 & 1.08 & 2.40 & $<0.050$ & 415 & 486 & 103 & 0.077 & $<0.1$ & -15.89 & 9.6 \\
\hline $3 \mathrm{~S} / 14 \mathrm{~W}-17 \mathrm{G} 6$ & Hawthorne1_4 & 0.39 & 37.4 & 0.65 & 2. & $<0.050$ & 420 & 396 & 133 & 0.063 & $<0.1$ & -16.54 & 15.6 \\
\hline $3 \mathrm{~S} / 14 \mathrm{~W}-17 \mathrm{G} 7$ & Hawthorne1_5 & 0.34 & 32.7 & 18.8 & 0.74 & $<0.050$ & 808 & 142 & 1,317 & 0.046 & 1.0 & - & - \\
\hline 3S/14W-17G8 & Hawthorne1_6 & 0.23 & 19.7 & 602 & 0.13 & 0.64 & 2,780 & 262 & 2,202 & 0.21 & 17.6 & - & - \\
\hline $3 \mathrm{~S} / 14 \mathrm{~W}-25 \mathrm{~K} 7$ & Gardena2_1 & 0.29 & 20.4 & 0.25 & - & - & 221 & 311 & 44 & 0.025 & $<0.1$ & 11.55 & 4.6 \\
\hline $3 \mathrm{~S} / 14 \mathrm{~W}-25 \mathrm{~K} 8$ & Gardena2_2 & 0.32 & 28.6 & 53.0 & - & - & 377 & 165 & 134 & 0.026 & $<0.1$ & -14.56 & 53.9 \\
\hline $3 \mathrm{~S} / 14 \mathrm{~W}-25 \mathrm{~K} 9$ & Gardena2_3 & 0.41 & 31.1 & 51.5 & - & - & 429 & 127 & 178 & 0.026 & $<0.1$ & -14.30 & 58.3 \\
\hline $3 \mathrm{~S} / 14 \mathrm{~W}-25 \mathrm{~K} 10$ & Gardena2_4 & 0.34 & 25.8 & $<0.18$ & - & - & 417 & 93 & 227 & 0.025 & $<0.1$ & -10.30 & 38.5 \\
\hline $3 \mathrm{~S} / 14 \mathrm{~W}-25 \mathrm{~K} 11$ & Gardena2_5 & 0.37 & 27.8 & 19.5 & - & - & 490 & 122 & 293 & 0.028 & 0.1 & -16.72 & 64.3 \\
\hline $3 \mathrm{~S} / 14 \mathrm{~W}-27 \mathrm{C} 2$ & Lawndale1_1 & 0.46 & 26.8 & 2.34 & 4.22 & $<0.040$ & 122 & 796 & 22 & 0.068 & 0.4 & 6.56 & 1.0 \\
\hline $3 \mathrm{~S} / 14 \mathrm{~W}-27 \mathrm{C} 3$ & Lawndale1_2 & 0.34 & 28.0 & 0.41 & 2.81 & $<0.040$ & 62.7 & 1,070 & 31 & 0.035 & $<0.1$ & -12.27 & 3.5 \\
\hline $3 \mathrm{~S} / 14 \mathrm{~W}-27 \mathrm{C} 4$ & Lawndale1_3 & 0.33 & 23.8 & 9.84 & 0.92 & $<0.040$ & 201 & 180 & 149 & 0.039 & $<0.1$ & -19 & 18.6 \\
\hline $3 \mathrm{~S} / 14 \mathrm{~W}-27 \mathrm{C} 5$ & Lawndale1_4 & 0.39 & 26.7 & 50.2 & 0.45 & $<0.040$ & 443 & 107 & 545 & 0.030 & 0.2 & -16.37 & 48.7 \\
\hline $3 \mathrm{~S} / 14 \mathrm{~W}-27 \mathrm{C} 6$ & Lawndale1_5 & 0.45 & 22.9 & 60.3 & 0.40 & $<0.040$ & 562 & 91 & 613 & 0.028 & 0.2 & -15.22 & 47.4 \\
\hline $3 \mathrm{~S} / 14 \mathrm{~W}-27 \mathrm{C} 7$ & Lawndale1_6 & 0.26 & 23.4 & 150 & 0.070 & 3.0 & 1,550 & 320 & 1,700 & 0.026 & 1.2 & -17.58 & 64.6 \\
\hline $3 \mathrm{~S} / 14 \mathrm{~W}-30 \mathrm{~L} 2$ & Manhattan Beach1_1 & 0.51 & 27.2 & $<0.45$ & 20.7 & $<0.039$ & 1,170 & 14,200 & 277 & 6.72 & $<0.1$ & -3.22 & 0.24 \\
\hline
\end{tabular}


Table 1.2. Groundwater-quality data used for this study from multiple-well monitoring sites, and selected production and observation wells, Los Angeles and Orange Counties, California.-Continued

[See appendix 1 for explanation. Abbreviations: ft, foot; mg/L, milligrams per liter; mm/dd/yyyy, month/day/year; ug/L, micrograms per liter; CaCO 3 , calcium carbonate; \%, percent; <, less than; - , no data. Sediment source/facies: LAR, Los Angeles River; n.a., not assigned; SGR, San Gabriel River; SAR, Santa Ana River, *, potentially affected by mixing with anthropogenic sources of water or seawater]

\begin{tabular}{|c|c|c|c|c|c|c|c|c|c|c|c|c|c|}
\hline State well number & Local well name & $\begin{array}{c}\text { Fluoride, } \\
\text { filtered } \\
\text { (mg/L) }\end{array}$ & $\begin{array}{c}\text { Silica, } \\
\text { filtered } \\
(\mathrm{mg} / \mathrm{L} \text { as } \\
\left.\mathrm{SiO}_{2}\right)\end{array}$ & $\begin{array}{c}\text { Sulfate, } \\
\text { filtered } \\
\text { (mg/L) }\end{array}$ & $\begin{array}{c}\text { Ammonia, } \\
\text { filtered } \\
\text { (mg/L as } \\
\text { nitrogen) }\end{array}$ & $\begin{array}{l}\text { Nitrate, } \\
\text { filtered } \\
\text { (mg/L as } \\
\text { nitrogen) }\end{array}$ & $\begin{array}{l}\text { Strontium, } \\
\text { filtered } \\
\text { (ug/L) }\end{array}$ & $\begin{array}{l}\text { Boron, } \\
\text { filtered } \\
\text { (ug/L) }\end{array}$ & $\begin{array}{l}\text { Chloride } \\
\text { / Boron } \\
\text { ratio } \\
\text { (mg/mg) }\end{array}$ & $\begin{array}{c}\text { lodide, } \\
\text { filtered } \\
\text { (mg/L) }\end{array}$ & $\begin{array}{c}\text { Tritium, } \\
\text { unfiltered } \\
\text { (tritium } \\
\text { units) }\end{array}$ & $\begin{array}{c}\delta^{13} \text { Carbon, } \\
\text { filtered } \\
\text { (per mil) }\end{array}$ & $\begin{array}{c}\text { Carbon-14, } \\
\text { filtered } \\
\text { (percent } \\
\text { modern) }\end{array}$ \\
\hline \multicolumn{14}{|c|}{ West Coast Basin-Continued } \\
\hline 3S/14W-30L3 & Manhattan Beach1_2 & 0.62 & 29.8 & 1.50 & 13.5 & $<0.040$ & 422 & 6,500 & 203 & 2.63 & $<0.1$ & 3.60 & 0.52 \\
\hline $3 \mathrm{~S} / 14 \mathrm{~W}-30 \mathrm{~L} 4$ & Manhattan Beach1_3 & 0.38 & 43.7 & 4.16 & 16.3 & $<0.037$ & 244 & 3,560 & 35 & 0.70 & $<0.1$ & 4.29 & 0.36 \\
\hline 3S/14W-30L5 & Manhattan Beach1_4 & 0.22 & 26.3 & $<0.45$ & 1.33 & $<0.040$ & 295 & 401 & 91 & 0.11 & 0.2 & -11.85 & 3.5 \\
\hline 3S/14W-30L6 & Manhattan Beach1_5 & $<1.00$ & 28.0 & 1,410 & 12.5 & $<0.038$ & 20,000 & 570 & 21,228 & 0.26 & $<0.1$ & -18.14 & 8.2 \\
\hline 3S/14W-30L7 & Manhattan Beach1_6 & $<1.00$ & 30.7 & 504 & 1.15 & $<0.039$ & 9,760 & 122 & 32,869 & 0.044 & 0.2 & -17.24 & 37.2 \\
\hline 3S/14W-30L8 & Manhattan Beach1_7 & 0.33 & 22.5 & 188 & 0.12 & 4.9 & 454 & 177 & 785 & 0.062 & 7.5 & -12.98 & 76.2 \\
\hline $3 \mathrm{~S} / 14 \mathrm{~W}-33 \mathrm{R} 5$ & Torrance1_1 & 0.68 & 43.4 & 4.95 & 7.97 & $<0.032$ & 166 & 2,470 & 39 & 0.59 & $<0.1$ & 2.34 & 0.34 \\
\hline 3S/14W-33R6 & Torrance1_2 & 0.43 & 32.4 & 3.40 & 3.09 & $<0.022$ & 101 & 1,940 & 9 & - & $<0.1$ & -5.01 & 0.21 \\
\hline 3S/14W-33R7 & Torrance1_3 & 0.35 & 15.9 & 1.49 & 1.30 & $<0.038$ & 151 & 375 & 78 & 0.099 & $<0.1$ & -9.41 & 3.3 \\
\hline $3 \mathrm{~S} / 14 \mathrm{~W}-33 \mathrm{R} 8$ & Torrance1_4 & 0.37 & 23.0 & 3.56 & 0.58 & $<0.039$ & 285 & 186 & 161 & 0.065 & $<0.1$ & -17.56 & 7.8 \\
\hline $3 \mathrm{~S} / 14 \mathrm{~W}-33 \mathrm{R} 9$ & Torrance1_5 & 0.18 & 28.6 & 305 & 1.07 & $<0.039$ & 3,940 & 204 & 7,647 & 0.076 & 16.1 & - & - \\
\hline 3S/14W-33R10 & Torrance1_6 & 0.36 & 27.7 & 182 & 0.46 & $<0.038$ & 991 & 196 & 934 & 0.091 & 10.9 & - & - \\
\hline $4 \mathrm{~S} / 12 \mathrm{~W}-30 \mathrm{~J} 1$ & Long Beach8_1 & 0.89 & 22.1 & 0.48 & 1.45 & $<0.040$ & 81.2 & 395 & 60 & 0.061 & $<0.1$ & - & - \\
\hline $4 \mathrm{~S} / 12 \mathrm{~W}-30 \mathrm{~J} 2$ & Long Beach8_2 & 1.05 & 26.5 & 1.66 & - & - & 106 & 248 & 145 & 0.11 & $<0.1$ & -0.45 & 1.7 \\
\hline $4 \mathrm{~S} / 12 \mathrm{~W}-30 \mathrm{~J} 3$ & Long Beach8_3 & 0.78 & 26.3 & 1.69 & - & - & 173 & 417 & 213 & 0.11 & $<0.1$ & 2.12 & 1.0 \\
\hline $4 \mathrm{~S} / 12 \mathrm{~W}-30 \mathrm{~J} 4$ & Long Beach8_4 & 0.30 & 20.1 & $<0.90$ & - & - & 789 & 1,070 & 547 & 1.38 & $<0.1$ & 1.42 & 0.98 \\
\hline $4 \mathrm{~S} / 12 \mathrm{~W}-30 \mathrm{~J} 5$ & Long Beach8_5 & 0.24 & 22.4 & 0.81 & 1.65 & $<0.040$ & 710 & 185 & 2,265 & 0.95 & $<0.1$ & 1.05 & 1.0 \\
\hline $4 \mathrm{~S} / 12 \mathrm{~W}-30 \mathrm{~J} 6$ & Long Beach8_6 & 0.60 & 27.8 & 16.9 & - & - & 660 & 210 & 1,990 & 0.083 & $<0.1$ & -19.89 & 28.4 \\
\hline $4 \mathrm{~S} / 13 \mathrm{~W}-5 \mathrm{~F} 1$ & Carson3_1 & 0.63 & 38.7 & 2.04 & 1.56 & $<0.040$ & 52.2 & 612 & 22 & 0.12 & $<0.1$ & -0.99 & 0.70 \\
\hline 4S/13W-5F2 & Carson3_2 & 0.30 & 18.1 & 14.3 & 1.02 & $<0.040$ & 239 & 101 & 199 & 0.034 & $<0.1$ & -15.75 & 37.0 \\
\hline 4S/13W-5F3 & Carson3_3 & 0.39 & 20.9 & 3.51 & 0.89 & $<0.040$ & 170 & 103 & 206 & 0.030 & $<0.1$ & -15.27 & 28.7 \\
\hline 4S/13W-5F4 & Carson3_4 & 0.32 & 20.1 & 1.97 & 0.58 & $<0.040$ & 257 & 90 & 229 & 0.029 & $<0.1$ & -9.59 & 31.6 \\
\hline $4 \mathrm{~S} / 13 \mathrm{~W}-5 \mathrm{~F} 5$ & Carson3_5 & 0.29 & 24.3 & $<0.09$ & 0.35 & $<0.040$ & 393 & 110 & 187 & 0.030 & $<0.1$ & -13.29 & 45.0 \\
\hline $4 \mathrm{~S} / 13 \mathrm{~W}-5 \mathrm{~F} 6$ & Carson3_6 & 0.43 & 24.9 & 52.2 & 0.071 & $<0.040$ & 417 & 126 & 167 & 0.032 & 0.3 & -14.70 & 68.0 \\
\hline 4S/13W-9H9 & Carson1_1 & 0.33 & 18.8 & 0.34 & 0.52 & $<0.025$ & 185 & 96 & 209 & 0.028 & 0.1 & -12.36 & 27.6 \\
\hline 4S/13W-9H10 & Carson1_2 & 0.26 & 21.6 & 0.12 & 0.37 & $<0.033$ & 369 & 102 & 201 & 0.027 & $<0.1$ & -12.34 & 43.6 \\
\hline 4S/13W-9H11 & Carson1_3 & 0.35 & 22.9 & 60.7 & 0.23 & $<0.033$ & 398 & 105 & 215 & 0.032 & $<0.1$ & -14.22 & 56.1 \\
\hline 4S/13W-9H12 & Carson1_4 & 0.47 & 21.5 & 108 & 0.23 & $<0.032$ & 835 & 117 & 957 & 0.051 & 0.1 & - & - \\
\hline
\end{tabular}


Table 1.2. Groundwater-quality data used for this study from multiple-well monitoring sites, and selected production and observation wells, Los Angeles and Orange Counties, California.-Continued

[See appendix 1 for explanation. Abbreviations: ft, foot; mg/L, milligrams per liter; mm/dd/yyyy, month/day/year; ug/L, micrograms per liter; CaCO ${ }_{3}$, calcium carbonate; $\%$, percent; <, less than; - , no data. Sediment source/facies: LAR, Los Angeles River; n.a., not assigned; SGR, San Gabriel River; SAR, Santa Ana River, *, potentially affected by mixing with anthropogenic sources of water or seawater]

\begin{tabular}{|c|c|c|c|c|c|c|c|c|c|c|c|c|c|}
\hline State well number & Local well name & $\begin{array}{c}\text { Fluoride, } \\
\text { filtered } \\
\text { (mg/L) }\end{array}$ & $\begin{array}{c}\text { Silica, } \\
\text { filtered } \\
(\mathrm{mg} / \mathrm{L} \text { as } \\
\left.\mathrm{SiO}_{2}\right)\end{array}$ & $\begin{array}{c}\text { Sulfate, } \\
\text { filtered } \\
\text { (mg/L) }\end{array}$ & $\begin{array}{c}\text { Ammonia, } \\
\text { filtered } \\
\text { (mg/L as } \\
\text { nitrogen) }\end{array}$ & $\begin{array}{c}\text { Nitrate, } \\
\text { filtered } \\
\text { (mg/L as } \\
\text { nitrogen) }\end{array}$ & $\begin{array}{l}\text { Strontium, } \\
\text { filtered } \\
\text { (ug/L) }\end{array}$ & $\begin{array}{c}\text { Boron, } \\
\text { filtered } \\
\text { (ug/L) }\end{array}$ & $\begin{array}{l}\text { Chloride } \\
\text { / Boron } \\
\text { ratio } \\
(\mathrm{mg} / \mathrm{mg})\end{array}$ & $\begin{array}{c}\text { lodide, } \\
\text { filtered } \\
\text { (mg/L) }\end{array}$ & $\begin{array}{c}\text { Tritium, } \\
\text { unfiltered } \\
\text { (tritium } \\
\text { units) }\end{array}$ & $\begin{array}{c}\delta^{13} \text { Carbon, } \\
\text { filtered } \\
\text { (per mil) }\end{array}$ & $\begin{array}{c}\text { Carbon-14, } \\
\text { filtered } \\
\text { (percent } \\
\text { modern) }\end{array}$ \\
\hline \multicolumn{14}{|c|}{ West Coast Basin-Continued } \\
\hline 4S/13W-18K1 & Carson2_1 & 0.35 & 16.6 & 2.78 & 0.58 & $<0.050$ & 40.1 & 131 & 150 & 0.031 & $<0.1$ & -9.65 & 18.4 \\
\hline $4 \mathrm{~S} / 13 \mathrm{~W}-18 \mathrm{~K} 2$ & Carson2_2 & 0.23 & 17.3 & 8.16 & 0.57 & $<0.050$ & 146 & 132 & 161 & 0.028 & $<0.1$ & -17.43 & 37.2 \\
\hline $4 \mathrm{~S} / 13 \mathrm{~W}-18 \mathrm{~K} 3$ & Carson2_3 & 0.30 & 22.9 & 6.35 & 0.56 & $<0.050$ & 252 & 117 & 182 & 0.029 & $<0.1$ & -17.12 & 43.6 \\
\hline $4 \mathrm{~S} / 13 \mathrm{~W}-18 \mathrm{~K} 4$ & Carson2_4 & 0.29 & 24.5 & 0.81 & 0.56 & $<0.050$ & 401 & 115 & 185 & 0.033 & $<0.1$ & - & - \\
\hline $4 \mathrm{~S} / 13 \mathrm{~W}-18 \mathrm{~K} 5$ & Carson2_5 & 0.36 & 25.1 & 13.9 & 0.18 & $<0.050$ & 392 & 113 & 188 & 0.029 & $<0.1$ & -17.03 & 53.8 \\
\hline 4S/13W-23D3 & Long Beach3_1 & 0.51 & 20.2 & 1.04 & 2.47 & $<0.047$ & 120 & 372 & 50 & 0.032 & $<0.1$ & 6.28 & 1.8 \\
\hline 4S/13W-23D4 & Long Beach3_2 & 0.38 & 22.6 & 25.3 & 0.32 & $<0.047$ & 191 & 138 & 136 & 0.030 & 0.1 & -15.84 & 24.1 \\
\hline 4S/13W-23D5 & Long Beach3_3 & 0.38 & 23.8 & 0.17 & 0.36 & $<0.047$ & 226 & 132 & 188 & 0.047 & $<0.1$ & -18.92 & 14.1 \\
\hline 4S/13W-23D6 & Long Beach3_4 & 0.30 & 28.6 & 57.9 & 0.41 & $<0.047$ & 962 & 109 & 1,954 & 0.59 & $<0.1$ & -14.33 & 42.8 \\
\hline 4S/13W-23D7 & Long Beach3_5 & 0.21 & 23.7 & 62.7 & 0.56 & $<0.047$ & 2,530 & 110 & 5,627 & 1.66 & $<0.1$ & -13.85 & 55.1 \\
\hline $4 \mathrm{~S} / 13 \mathrm{~W}-23 \mathrm{~N} 3$ & $889 \mathrm{P}$ & 0.32 & 23.3 & 0.16 & - & - & 310 & 312 & 343 & 0.22 & - & - & - \\
\hline $4 \mathrm{~S} / 13 \mathrm{~W}-26 \mathrm{~F} 5$ & $380 \mathrm{P}$ & 0.53 & 21.3 & $<0.10$ & - & - & 142 & 203 & 182 & 0.072 & $<0.1$ & - & - \\
\hline $4 \mathrm{~S} / 13 \mathrm{~W}-27 \mathrm{H} 4$ & Long Beach7_1 & 0.63 & 35.6 & 2.98 & 2.84 & $<0.052$ & 77.2 & 785 & 29 & 0.15 & $<0.1$ & 4.20 & 3.5 \\
\hline $4 \mathrm{~S} / 13 \mathrm{~W}-27 \mathrm{H} 5$ & Long Beach7_2 & 0.42 & 20.6 & 1.16 & 0.31 & $<0.060$ & 171 & 238 & 313 & 0.16 & 0.1 & -14.42 & 8.8 \\
\hline 4S/13W-27H6 & Long Beach7_3 & 0.47 & 20.2 & 4. & 0.29 & $<0.060$ & 185 & 223 & 303 & 0.12 & $<0.1$ & -14.93 & 9.8 \\
\hline $4 \mathrm{~S} / 13 \mathrm{~W}-27 \mathrm{H} 7$ & Long Beach7_4 & $<0.17$ & 23.6 & 278 & 2.25 & $<0.060$ & 4,860 & 419 & 5,012 & 1.22 & 1.8 & -15.94 & 61.4 \\
\hline $4 \mathrm{~S} / 13 \mathrm{~W}-28 \mathrm{~A} 3$ & Wilmington1_1 & 0.18 & 21.8 & $<0.10$ & 0.62 & 0.09 & 371 & 123 & 1,732 & 0.87 & $<0.1$ & -15.82 & 29.6 \\
\hline $4 \mathrm{~S} / 13 \mathrm{~W}-28 \mathrm{~A} 4$ & Wilmington1_2 & 0.11 & 21.3 & 58.6 & 0.76 & 0.08 & 1,150 & 175 & 1,926 & 0.15 & $<0.1$ & -18.36 & 44.5 \\
\hline 4S/13W-28A5 & Wilmington1_3 & $<0.10$ & 24.0 & 49.5 & 1.59 & 0.09 & 2,130 & 240 & 3,779 & 0.39 & 1.6 & - & - \\
\hline $4 \mathrm{~S} / 13 \mathrm{~W}-28 \mathrm{~A} 6$ & Wilmington1_4 & $<0.10$ & 26.1 & 288 & 2.24 & 0.12 & 3,690 & 221 & 5,475 & 0.79 & 18.9 & - & - \\
\hline $4 \mathrm{~S} / 13 \mathrm{~W}-28 \mathrm{~A} 7$ & Wilmington1_5 & 0.13 & 26.2 & 140 & 0.88 & 0.08 & 1,090 & 203 & 1,148 & 0.17 & 11.8 & - & - \\
\hline 4S/13W-29H5 & $340 \mathrm{~L}$ & - & - & 98.0 & - & - & 2,200 & 1,400 & 929 & - & 3.1 & - & - \\
\hline 4S/13W-29H6 & $340 \mathrm{M}$ & - & - & 150 & - & - & 2,000 & 470 & 1,213 & - & 1.0 & - & - \\
\hline $4 \mathrm{~S} / 13 \mathrm{~W}-29 \mathrm{H} 7$ & $340 \mathrm{~N}$ & - & - & 18.0 & - & - & 600 & 130 & 1,077 & - & 0.1 & - & - \\
\hline 4S/13W-31J1 & $321 \mathrm{~A}$ & 0.23 & 23.8 & $<0.10$ & & & 2,240 & 853 & 2,474 & 0.45 & $<0.1$ & - & - \\
\hline $4 \mathrm{~S} / 13 \mathrm{~W}-32 \mathrm{~F} 1$ & Wilmington2_1 & 1. & 24.2 & $<0.10$ & 1.57 & 0.07 & 39.1 & 653 & 87 & 0.033 & $<0.1$ & -0.27 & 2.5 \\
\hline $4 \mathrm{~S} / 13 \mathrm{~W}-32 \mathrm{~F} 2$ & Wilmington2_2 & 0.38 & 20.3 & $<0.10$ & 2.31 & 0.09 & 360 & 1,350 & 380 & 1.07 & $<0.1$ & -0.32 & 5.2 \\
\hline $4 \mathrm{~S} / 13 \mathrm{~W}-32 \mathrm{~F} 3$ & Wilmington2_3 & 0.33 & 20.8 & $<0.10$ & 0.96 & 0.08 & 177 & 266 & 272 & 0.14 & $<0.1$ & -15.04 & 14.4 \\
\hline
\end{tabular}


Table 1.2. Groundwater-quality data used for this study from multiple-well monitoring sites, and selected production and observation wells, Los Angeles and Orange Counties, California.-Continued

[See appendix 1 for explanation. Abbreviations: ft, foot; mg/L, milligrams per liter; mm/dd/yyyy, month/day/year; ug/L, micrograms per liter; CaCO 3 , calcium carbonate; \%, percent; <, less than; —, no data . Sediment source/facies: LAR, Los Angeles River; n.a., not assigned; SGR, San Gabriel River; SAR, Santa Ana River, *, potentially affected by mixing with anthropogenic sources of water or seawater]

\begin{tabular}{|c|c|c|c|c|c|c|c|c|c|c|c|c|c|}
\hline State well number & Local well name & $\begin{array}{c}\text { Fluoride, } \\
\text { filtered } \\
\text { (mg/L) }\end{array}$ & $\begin{array}{c}\text { Silica, } \\
\text { filtered } \\
\text { (mg/L as } \\
\left.\mathrm{SiO}_{2}\right)\end{array}$ & $\begin{array}{c}\text { Sulfate, } \\
\text { filtered } \\
\text { (mg/L) }\end{array}$ & $\begin{array}{c}\text { Ammonia, } \\
\text { filtered } \\
\text { (mg/L as } \\
\text { nitrogen) }\end{array}$ & $\begin{array}{l}\text { Nitrate, } \\
\text { filtered } \\
\text { (mg/L as } \\
\text { nitrogen) }\end{array}$ & $\begin{array}{c}\text { Strontium, } \\
\text { filtered } \\
\text { (ug/L) }\end{array}$ & $\begin{array}{c}\text { Boron, } \\
\text { filtered } \\
\text { (ug/L) }\end{array}$ & $\begin{array}{l}\text { Chloride } \\
\text { / Boron } \\
\text { ratio } \\
(\mathrm{mg} / \mathrm{mg})\end{array}$ & $\begin{array}{c}\text { lodide, } \\
\text { filtered } \\
\text { (mg/L) }\end{array}$ & $\begin{array}{c}\text { Tritium, } \\
\text { unfiltered } \\
\text { (tritium } \\
\text { units) }\end{array}$ & $\begin{array}{c}\delta^{13} \text { Carbon, } \\
\text { filtered } \\
\text { (per mil) }\end{array}$ & $\begin{array}{c}\text { Carbon-14, } \\
\text { filtered } \\
\text { (percent } \\
\text { modern) }\end{array}$ \\
\hline \multicolumn{14}{|c|}{ West Coast Basin-Continued } \\
\hline $4 \mathrm{~S} / 13 \mathrm{~W}-32 \mathrm{~F} 4$ & Wilmington2_4 & 0.24 & 29.0 & 29.4 & 4.29 & 0.09 & 1,270 & 557 & 1,813 & 0.32 & 1.4 & - & - \\
\hline $4 \mathrm{~S} / 13 \mathrm{~W}-32 \mathrm{~F} 5$ & Wilmington2_5 & 0.11 & 24.3 & 595 & 2.48 & 0.09 & 5,990 & 621 & 8,422 & 0.10 & 16.8 & - & - \\
\hline 4S/13W-34A1 & $371 \mathrm{D}$ & 0.33 & 14.5 & $<0.10$ & - & - & 53.2 & 149 & 281 & 0.099 & $<0.1$ & - & - \\
\hline 4S/13W-34M1 & $361 \mathrm{H}$ & 0.41 & 20.5 & $<0.10$ & - & - & 129 & 251 & 284 & 0.18 & $<0.1$ & - & - \\
\hline 4S/13W-35B2 & $381 \mathrm{~J}$ & 0.62 & 16.3 & 0.52 & - & - & 184 & 1,320 & 57 & 0.022 & 0.1 & - & - \\
\hline $4 \mathrm{~S} / 13 \mathrm{~W}-35 \mathrm{~B} 3$ & $381 \mathrm{~K}$ & $<0.10$ & 19.3 & 259 & - & - & 3,760 & 370 & 8,243 & 0.31 & $<0.1$ & - & - \\
\hline 4S/14W-2N1 & PM-3 Madrid_1 & 0.40 & 19.0 & 17.0 & - & - & - & 360 & 78 & 0.029 & 0.8 & -13.18 & 9.8 \\
\hline $4 \mathrm{~S} / 14 \mathrm{~W}-2 \mathrm{~N} 2$ & PM-3 Madrid_2 & 0.40 & 27.0 & 3.30 & - & - & - & 120 & 292 & 0.040 & $<0.1$ & -17.27 & 38.5 \\
\hline $4 \mathrm{~S} / 14 \mathrm{~W}-2 \mathrm{~N} 3$ & PM-3 Madrid_3 & 0.40 & 29.0 & 13.0 & - & - & - & 130 & 1,385 & 0.22 & 0.9 & -19.73 & 37.8 \\
\hline $4 \mathrm{~S} / 14 \mathrm{~W}-2 \mathrm{~N} 4$ & PM-3 Madrid_4 & 0.40 & 23.0 & 31.0 & - & - & - & 230 & 913 & 0.24 & 4.3 & -19.29 & 39.7 \\
\hline 4S/14W-4Q1 & PM-4 Mariner_1 & 0.35 & - & $<2.0$ & - & $<0.20$ & - & 150 & 175 & - & - & - & - \\
\hline 4S/14W-4Q2 & PM-4 Mariner_2 & 0.11 & - & 830 & - & $<0.20$ & - & 240 & 27,083 & 0.086 & - & - & - \\
\hline 4S/14W-4Q3 & PM-4 Mariner_3 & 0.43 & - & 190 & - & $<0.20$ & - & 250 & 462 & 0.023 & - & - & - \\
\hline 4S/14W-4Q4 & PM-4 Mariner_4 & 0.27 & - & 140 & - & $<0.20$ & - & 230 & 500 & 0.067 & - & - & - \\
\hline $4 \mathrm{~S} / 14 \mathrm{~W}-10 \mathrm{C} 1$ & PM-1 Columbia_1 & 0.34 & - & $<2.0$ & - & $<0.20$ & - & 130 & 169 & 0.057 & - & - & - \\
\hline $4 \mathrm{~S} / 14 \mathrm{~W}-10 \mathrm{C} 2$ & PM-1 Columbia_2 & 0.16 & - & 110 & - & $<0.20$ & - & 270 & 3,259 & 0.11 & - & - & - \\
\hline 4S/14W-15E1 & Torrance2_1 & 0.57 & 28.6 & 10.0 & 3.20 & $<0.015$ & 1,540 & 777 & 865 & 0.15 & 0.1 & -1.73 & 0.60 \\
\hline 4S/14W-15E2 & Torrance2_2 & 0.11 & 31.2 & $<0.90$ & 6.94 & $<0.020$ & 2,170 & 539 & 4,712 & 0.59 & $<0.1$ & -9.56 & 1.4 \\
\hline $4 \mathrm{~S} / 14 \mathrm{~W}-15 \mathrm{E} 3$ & Torrance2_3 & 0.06 & 29.5 & 76.8 & 7.89 & $<0.020$ & 16,900 & 281 & 23,381 & 0.27 & $<0.1$ & -23.78 & 1.5 \\
\hline $4 \mathrm{~S} / 14 \mathrm{~W}-15 \mathrm{E} 4$ & Torrance2_4 & 0.58 & 41.7 & $<0.09$ & 0.41 & $<0.020$ & 228 & 252 & 198 & 0.072 & $<0.1$ & -10.46 & 12.5 \\
\hline 4S/14W-15E5 & Torrance2_5 & 0.19 & 34.6 & 240 & 0.48 & $<0.019$ & 4,110 & 209 & 8,230 & 0.18 & 24.8 & -19.32 & 30.8 \\
\hline $4 \mathrm{~S} / 14 \mathrm{~W}-15 \mathrm{E} 6$ & Torrance2_6 & 0.28 & 32.4 & 132 & 0.17 & $<0.020$ & 912 & 173 & 1,653 & 0.15 & 9.8 & -17 & 66.9 \\
\hline $4 \mathrm{~S} / 14 \mathrm{~W}-26 \mathrm{~A} 2$ & Lomita1_1 & 0.12 & 30.2 & 72.8 & 0.40 & $<0.040$ & 730 & 877 & 661 & 1.57 & $<0.1$ & -17.47 & 25.7 \\
\hline $4 \mathrm{~S} / 14 \mathrm{~W}-26 \mathrm{~A} 3$ & Lomita1_2 & 0.18 & 30.9 & 26.9 & 0.34 & $<0.040$ & 546 & 480 & 710 & 1.27 & $<0.1$ & -16.51 & 25.8 \\
\hline 4S/14W-26A4 & Lomita1_3 & 0.18 & 28.9 & 13.5 & - & - & 448 & 376 & 620 & 0.70 & 0.3 & - & - \\
\hline $4 \mathrm{~S} / 14 \mathrm{~W}-26 \mathrm{~A} 5$ & Lomita1_4 & 0.23 & 30.7 & 13.9 & 0.28 & $<0.040$ & 400 & 415 & 595 & 0.68 & $<0.1$ & -7.79 & 9.4 \\
\hline 4S/14W-26A6 & Lomita1_5 & 0.12 & 32.8 & 26.1 & - & - & 748 & 674 & 755 & 1.63 & 0.2 & - & - \\
\hline $4 \mathrm{~S} / 14 \mathrm{~W}-35 \mathrm{D} 10$ & Chandler3_1 & 0.24 & - & 30.0 & - & $<0.20$ & - & 200 & 800 & 0.094 & - & - & - \\
\hline
\end{tabular}


Table 1.2. Groundwater-quality data used for this study from multiple-well monitoring sites, and selected production and observation wells, Los Angeles and Orange Counties, California.-Continued

[See appendix 1 for explanation. Abbreviations: ft, foot; mg/L, milligrams per liter; mm/dd/yyyy, month/day/year; ug/L, micrograms per liter; $\mathrm{CaCO}_{3}$, calcium carbonate; \%, percent; <, less than; - , no data. Sediment source/facies: LAR, Los Angeles River; n.a., not assigned; SGR, San Gabriel River; SAR, Santa Ana River, *, potentially affected by mixing with anthropogenic sources of water or seawater]

\begin{tabular}{|c|c|c|c|c|c|c|c|c|c|c|c|c|c|}
\hline State well number & Local well name & $\begin{array}{c}\text { Fluoride, } \\
\text { filtered } \\
\text { (mg/L) }\end{array}$ & $\begin{array}{c}\text { Silica, } \\
\text { filtered } \\
(\mathrm{mg} / \mathrm{L} \text { as } \\
\left.\mathrm{SiO}_{2}\right)\end{array}$ & $\begin{array}{c}\text { Sulfate, } \\
\text { filtered } \\
\text { (mg/L) }\end{array}$ & $\begin{array}{c}\text { Ammonia, } \\
\text { filtered } \\
\text { (mg/L as } \\
\text { nitrogen) }\end{array}$ & $\begin{array}{c}\text { Nitrate, } \\
\text { filtered } \\
\text { (mg/L as } \\
\text { nitrogen) }\end{array}$ & $\begin{array}{l}\text { Strontium, } \\
\text { filtered } \\
\text { (ug/L) }\end{array}$ & $\begin{array}{c}\text { Boron, } \\
\text { filtered } \\
\text { (ug/L) }\end{array}$ & $\begin{array}{l}\text { Chloride } \\
\text { / Boron } \\
\text { ratio } \\
(\mathrm{mg} / \mathrm{mg})\end{array}$ & $\begin{array}{c}\text { lodide, } \\
\text { filtered } \\
\text { (mg/L) }\end{array}$ & $\begin{array}{c}\text { Tritium, } \\
\text { unfiltered } \\
\text { (tritium } \\
\text { units) }\end{array}$ & $\begin{array}{c}\delta^{13} \text { Carbon, } \\
\text { filtered } \\
\text { (per mil) }\end{array}$ & $\begin{array}{c}\text { Carbon-14, } \\
\text { filtered } \\
\text { (percent } \\
\text { modern) }\end{array}$ \\
\hline \multicolumn{14}{|c|}{ West Coast Basin-Continued } \\
\hline 4S/14W-35D11 & Chandler3_2 & 0.20 & - & 100 & - & 13.0 & - & 360 & 462 & $<0.001$ & - & - & - \\
\hline $5 \mathrm{~S} / 13 \mathrm{~W}-2 \mathrm{E} 1$ & Long Beach4_1 & 1.14 & 28.1 & 3.62 & 2.38 & $<0.044$ & 134 & 1,100 & 19 & 0.11 & 0.2 & 3.08 & 2.5 \\
\hline $5 \mathrm{~S} / 13 \mathrm{~W}-2 \mathrm{E} 2$ & Long Beach4_2 & 0.50 & 35.3 & 1.36 & 2.83 & $<0.044$ & 97.5 & 1,150 & 293 & 0.98 & $<0.1$ & -12.72 & 4.3 \\
\hline $5 \mathrm{~S} / 13 \mathrm{~W}-11 \mathrm{P} 1$ & Long Beach5_1 & 0.40 & 40.7 & 0.66 & 10.5 & $<0.044$ & 734 & 8,400 & 196 & 1.40 & $<0.1$ & -6.37 & 0.79 \\
\hline $5 \mathrm{~S} / 13 \mathrm{~W}-11 \mathrm{P} 2$ & Long Beach5_2 & 0.44 & 14.5 & 2,640 & 7.86 & $<0.050$ & 8,500 & 4,130 & 4,818 & 0.16 & $<0.1$ & -12.33 & 48.5 \\
\hline \multicolumn{14}{|c|}{ Santa Monica Basin } \\
\hline 1S/15W-31E1 & SM 1 (2505) & 0.36 & 27.5 & 215 & 0.012 & 4.2 & 557 & 149 & 685 & 0.002 & 4.3 & -16.12 & 93.9 \\
\hline $1 \mathrm{~S} / 15 \mathrm{~W}-33 \mathrm{~A} 1$ & SM Arcadia_5 & 0.34 & 35.0 & 188 & 0.036 & 2.9 & 514 & 127 & 874 & 0.018 & 3.7 & -15.65 & 89.0 \\
\hline $2 \mathrm{~S} / 15 \mathrm{~W}-4 \mathrm{C} 2$ & SM 3 (2646K) & 0.38 & 32.0 & 237 & $<0.020$ & 6.5 & 592 & 105 & 800 & 0.005 & 2.7 & -15.88 & 78.5 \\
\hline \multicolumn{14}{|c|}{ Hollywood Basin } \\
\hline 1S/14W-18L1 & BH_2 & 1.50 & 37.6 & 7.05 & 1.10 & $<0.060$ & 284 & 1,190 & 185 & 0.23 & 0.1 & -10 & 20.9 \\
\hline 1S/15W-24B1 & BH_5 & 0.53 & 40.0 & 121 & 0.29 & $<0.060$ & 432 & 239 & 154 & 0.037 & $<0.1$ & -15.45 & 41.2 \\
\hline \multicolumn{14}{|c|}{ San Fernando Valley } \\
\hline 1N013W-35P1 & DS_WATERS & 0.57 & 37.6 & 233 & $<0.020$ & 7.1 & 708 & 71 & 1,479 & 0.005 & 6.8 & -16.41 & 88.7 \\
\hline \multicolumn{14}{|c|}{ San Gabriel Valley } \\
\hline $2 \mathrm{~S} / 11 \mathrm{~W}-5 \mathrm{P} 6$ & Whittier Narrows1_1 & 0.78 & - & $<2.0$ & - & $<0.20$ & - & 1,100 & 650 & 1.30 & - & - & - \\
\hline $2 \mathrm{~S} / 11 \mathrm{~W}-5 \mathrm{P} 7$ & Whittier Narrows1_2 & 0.41 & - & 12.0 & - & $<0.20$ & - & 150 & 188 & 0.039 & - & - & - \\
\hline $2 \mathrm{~S} / 11 \mathrm{~W}-5 \mathrm{P} 8$ & Whittier Narrows1_3 & 0.25 & - & 110 & - & 1.3 & - & 70 & 943 & $<0.001$ & - & - & - \\
\hline 2S/11W-5P9 & Whittier Narrows1_4 & 0.26 & - & 120 & - & 1.5 & - & 110 & 989 & 0.007 & - & - & - \\
\hline 2S/11W-5P10 & Whittier Narrows1_5 & 0.30 & - & 50.0 & - & 0.83 & - & 54 & 730 & $<0.001$ & - & - & - \\
\hline 2S/11W-5P11 & Whittier Narrows1_6 & 0.27 & - & 130 & - & 2.1 & - & 240 & 417 & 0.012 & - & - & - \\
\hline $2 \mathrm{~S} / 11 \mathrm{~W}-5 \mathrm{P} 12$ & Whittier Narrows1_7 & 0.28 & - & 140 & - & 2.8 & - & 260 & 358 & 0.008 & - & - & - \\
\hline $2 \mathrm{~S} / 11 \mathrm{~W}-5 \mathrm{P} 13$ & Whittier Narrows1_8 & 0.29 & - & 120 & - & 4.2 & - & 250 & 429 & 0.009 & - & - & - \\
\hline $2 \mathrm{~S} / 11 \mathrm{~W}-5 \mathrm{P} 14$ & Whittier Narrows1_9 & 0.39 & - & 140 & - & 2.3 & - & 240 & 400 & 0.011 & - & - & - \\
\hline
\end{tabular}


Table 1.2. Groundwater-quality data used for this study from multiple-well monitoring sites, and selected production and observation wells, Los Angeles and Orange Counties, California.-Continued

[See appendix 1 for explanation. Abbreviations: ft, foot; mg/L, milligrams per liter; mm/dd/yyyy, month/day/year; ug/L, micrograms per liter; CaCO 3 , calcium carbonate; \%, percent; <, less than; -, no data. Sediment source/facies: LAR, Los Angeles River; n.a., not assigned; SGR, San Gabriel River; SAR, Santa Ana River, *, potentially affected by mixing with anthropogenic sources of water or seawater]

\begin{tabular}{|c|c|c|c|c|c|c|c|c|c|}
\hline State well number & Local well name & $\begin{array}{c}\delta^{2} \text { Hydrogen, } \\
\text { unfiltered } \\
\text { (per mil) }\end{array}$ & $\begin{array}{c}\delta^{18} \text { Oxygen, } \\
\text { unfiltered } \\
\text { (per mil) }\end{array}$ & $\begin{array}{l}\text { Strontium-87 / } \\
\text { Strontium-86, } \\
\text { filtered (atom } \\
\text { ratio) }\end{array}$ & $\begin{array}{l}\text { Chemical } \\
\text { facies }\end{array}$ & $\begin{array}{l}\text { Dissolved- } \\
\text { solids } \\
\text { classification }\end{array}$ & $\begin{array}{l}\text { Sediment } \\
\text { source }\end{array}$ & $\begin{array}{l}\text { Sediment } \\
\text { facies }\end{array}$ & $\begin{array}{l}\text { Groundwater } \\
\text { recharge source }\end{array}$ \\
\hline \multicolumn{10}{|c|}{ Central Basin } \\
\hline \multicolumn{10}{|c|}{ Los Angeles Forebay } \\
\hline $2 \mathrm{~S} / 13 \mathrm{~W}-3 \mathrm{P} 2$ & Los Angeles2_1 & - & - & - & - & Highly saline & n.a. & $*$ & n.a. \\
\hline $2 \mathrm{~S} / 13 \mathrm{~W}-3 \mathrm{P} 3$ & Los Angeles2_2 & -46.8 & -6.94 & - & $\mathrm{Ca} / \mathrm{Na}-$ mixed & Slightly saline & n.a. & n.a. & Los Angeles (slightly saline) \\
\hline $2 \mathrm{~S} / 13 \mathrm{~W}-3 \mathrm{P} 4$ & Los Angeles2_3 & -46.2 & -6.88 & - & $\mathrm{Ca} / \mathrm{Na}-$ mixed & Slightly saline & n.a. & n.a. & Los Angeles (slightly saline) \\
\hline $2 \mathrm{~S} / 13 \mathrm{~W}-3 \mathrm{P} 5$ & Los Angeles2_4 & -46.5 & -6.83 & - & $\mathrm{Ca} / \mathrm{Na}-$ mixed & Slightly saline & n.a. & n.a. & Los Angeles (slightly saline) \\
\hline 2S/13W-3P6 & Los Angeles2_5 & -46.5 & -6.83 & - & $\mathrm{Ca} / \mathrm{Na}-\mathrm{SO}_{4} / \mathrm{HCO}_{3}$ & Slightly saline & n.a. & non-marine & Los Angeles (slightly saline) \\
\hline $2 \mathrm{~S} / 13 \mathrm{~W}-17 \mathrm{~F} 1$ & Los Angeles1_1 & -49.0 & -7.29 & - & $\mathrm{Ca} / \mathrm{Na}-\mathrm{HCO}_{3}$ & Fresh & n.a. & shallow marine & Los Angeles \\
\hline $2 \mathrm{~S} / 13 \mathrm{~W}-17 \mathrm{~F} 2$ & Los Angeles1_2 & -46.6 & -7.32 & - & $\mathrm{Ca} / \mathrm{Na}-\mathrm{HCO}_{3}$ & Fresh & n.a. & shallow marine & Los Angeles \\
\hline $2 \mathrm{~S} / 13 \mathrm{~W}-17 \mathrm{~F} 3$ & Los Angeles1_3 & -47.8 & -7.24 & - & $\mathrm{Ca} / \mathrm{Na}-\mathrm{HCO}_{3}$ & Fresh & n.a. & shallow marine & Los Angeles \\
\hline $2 \mathrm{~S} / 13 \mathrm{~W}-17 \mathrm{~F} 4$ & Los Angeles1_4 & -47.2 & -7.19 & - & $\mathrm{Ca}-\mathrm{HCO}_{3} / \mathrm{SO}_{4}$ & Fresh & n.a. & shallow marine & Los Angeles \\
\hline $2 \mathrm{~S} / 13 \mathrm{~W}-17 \mathrm{~F} 5$ & Los Angeles1_5 & -47.6 & -7.24 & - & $\mathrm{Ca}-\mathrm{HCO}_{3} / \mathrm{SO}_{4}$ & Fresh & n.a. & non-marine & Los Angeles \\
\hline 2S/13W-22C1 & Huntington Park1_1 & -47.5 & -7.32 & 0.7085 & $\mathrm{Ca}-\mathrm{HCO}_{3}$ & Fresh & LAR & shallow marine & Los Angeles \\
\hline $2 \mathrm{~S} / 13 \mathrm{~W}-22 \mathrm{C} 2$ & Huntington Park1_2 & -47.3 & -7.23 & 0.7085 & $\mathrm{Ca}-\mathrm{HCO}_{3}$ & Fresh & LAR & shallow marine & Los Angeles \\
\hline $2 \mathrm{~S} / 13 \mathrm{~W}-22 \mathrm{C} 3$ & Huntington Park1_3 & -48.7 & -7.09 & 0.7085 & $\mathrm{Ca}-\mathrm{HCO}_{3}$ & Fresh & LAR & shallow marine & Los Angeles \\
\hline $2 \mathrm{~S} / 13 \mathrm{~W}-22 \mathrm{C} 4$ & Huntington Park1_4 & -44.2 & -6.78 & - & $\mathrm{Ca}-\mathrm{HCO}_{3} / \mathrm{SO}_{4}$ & Fresh & n.a. & non-marine & Mixed \\
\hline $2 \mathrm{~S} / 13 \mathrm{~W}-34 \mathrm{~F} 2$ & South Gate2_1 & -47.1 & -7.44 & 0.7083 & $\mathrm{Ca} / \mathrm{Na}-\mathrm{HCO}_{3}$ & Fresh & LAR & shallow marine & Los Angeles \\
\hline 2S/13W-34F3 & South Gate2_2 & -47.2 & -7.38 & 0.7083 & $\mathrm{Ca} / \mathrm{Na}-\mathrm{HCO}_{3}$ & Fresh & LAR & shallow marine & Los Angeles \\
\hline 2S/13W-34F4 & South Gate2_3 & -47.6 & -7.32 & 0.7084 & $\mathrm{Ca} / \mathrm{Na}-\mathrm{HCO}_{3}$ & Fresh & LAR & shallow marine & Los Angeles \\
\hline $2 \mathrm{~S} / 13 \mathrm{~W}-34 \mathrm{~F} 5$ & South Gate2_4 & -46.6 & -7.15 & 0.7085 & $\mathrm{Ca} / \mathrm{Na}-\mathrm{HCO}_{3}$ & Fresh & LAR & shallow marine & Los Angeles \\
\hline 2S/13W-34F6 & South Gate2_5 & -47.7 & -7.26 & 0.7083 & $\mathrm{Ca} / \mathrm{Na}-\mathrm{HCO}_{3}$ & Fresh & LAR & shallow marine & Los Angeles \\
\hline 2S/13W-34F7 & South Gate2_6 & -47.1 & -7.15 & 0.7085 & $\mathrm{Ca}-\mathrm{HCO}_{3}$ & Fresh & LAR & shallow marine & Los Angeles \\
\hline 2S/14W-12E1 & Los Angeles3_1 & -49.8 & -7.58 & 0.7084 & $\mathrm{Na}-\mathrm{HCO}_{3}$ & Fresh & LAR & shallow marine & Los Angeles \\
\hline $2 \mathrm{~S} / 14 \mathrm{~W}-12 \mathrm{E} 2$ & Los Angeles3_2 & -47.3 & -7.33 & 0.7082 & $\mathrm{Ca} / \mathrm{Na}-\mathrm{HCO}_{3}$ & Fresh & LAR & shallow marine & Los Angeles \\
\hline $2 \mathrm{~S} / 14 \mathrm{~W}-12 \mathrm{E} 3$ & Los Angeles3_3 & -48.4 & -7.38 & 0.7084 & $\mathrm{Ca} / \mathrm{Na}-\mathrm{HCO}_{3}$ & Fresh & LAR & shallow marine & Los Angeles \\
\hline 2S/14W-12E4 & Los Angeles3_4 & -47.3 & -7.25 & 0.7084 & $\mathrm{Ca} / \mathrm{Na}-\mathrm{HCO}_{3}$ & Fresh & LAR & shallow marine & Los Angeles \\
\hline 2S/14W-12E5 & Los Angeles3_5 & -56.2 & -7.99 & 0.7084 & $\mathrm{Ca} / \mathrm{Na}-\mathrm{HCO}_{3} / \mathrm{SO}_{4}$ & Fresh & LAR & non-marine & Los Angeles/artificial \\
\hline 2S/14W-12E6 & Los Angeles3_6 & -51.9 & -7.56 & 0.7085 & $\mathrm{Ca} / \mathrm{Na}-\mathrm{HCO}_{3} / \mathrm{Cl}$ & Fresh & LAR & non-marine & Los Angeles/artificial \\
\hline
\end{tabular}


Table 1.2. Groundwater-quality data used for this study from multiple-well monitoring sites, and selected production and observation wells, Los Angeles and Orange Counties, California.-Continued

[See appendix 1 for explanation. Abbreviations: ft, foot; mg/L, milligrams per liter; mm/dd/yyyy, month/day/year; ug/L, micrograms per liter; CaCO ${ }_{3}$, calcium carbonate; $\%$, percent; <, less than; - , no data. Sediment source/facies: LAR, Los Angeles River; n.a., not assigned; SGR, San Gabriel River; SAR, Santa Ana River, *, potentially affected by mixing with anthropogenic sources of water or seawater]

\begin{tabular}{|c|c|c|c|c|c|c|c|c|c|}
\hline State well number & Local well name & $\begin{array}{c}\delta^{2} \text { Hydrogen, } \\
\text { unfiltered } \\
\text { (per mil) }\end{array}$ & $\begin{array}{c}\delta^{18} 0 x y g e n, \\
\text { unfiltered } \\
\text { (per mil) }\end{array}$ & $\begin{array}{l}\text { Strontium-87 / } \\
\text { Strontium-86, } \\
\text { filtered (atom } \\
\text { ratio) }\end{array}$ & $\begin{array}{l}\text { Chemical } \\
\text { facies }\end{array}$ & $\begin{array}{l}\text { Dissolved- } \\
\text { solids } \\
\text { classification }\end{array}$ & $\begin{array}{l}\text { Sediment } \\
\text { source }\end{array}$ & $\begin{array}{l}\text { Sediment } \\
\text { facies }\end{array}$ & $\begin{array}{l}\text { Groundwater } \\
\text { recharge source }\end{array}$ \\
\hline \multicolumn{10}{|c|}{ Montebello Forebay } \\
\hline $2 \mathrm{~S} / 11 \mathrm{~W}-5 \mathrm{~N} 4$ & Whittier_14 & -57.6 & -7.97 & 0.7102 & $\mathrm{Ca} / \mathrm{Na}$-mixed & Fresh & SGR & non-marine & Montebello/spreading \\
\hline $2 \mathrm{~S} / 11 \mathrm{~W}-7 \mathrm{~K} 2$ & Pico Rivera3_1 & -57.4 & -8.34 & 0.0071 & $\mathrm{Ca}-\mathrm{HCO}_{3} / \mathrm{SO}_{4}$ & Fresh & SGR & non-marine & Montebello \\
\hline $2 \mathrm{~S} / 11 \mathrm{~W}-7 \mathrm{~K} 3$ & Pico Rivera3_2 & -56.5 & -8.36 & 0.0071 & $\mathrm{Ca}-\mathrm{HCO}_{3}$ & Fresh & SGR & non-marine & Montebello \\
\hline $2 \mathrm{~S} / 11 \mathrm{~W}-7 \mathrm{~K} 4$ & Pico Rivera3_3 & -59.8 & -8.29 & 0.7101 & $\mathrm{Ca}-\mathrm{HCO}_{3} / \mathrm{SO}_{4}$ & Fresh & SGR & non-marine & Montebello/spreading \\
\hline $2 \mathrm{~S} / 11 \mathrm{~W}-7 \mathrm{~K} 5$ & Pico Rivera3_4 & -59.0 & -8.02 & 0.7102 & $\mathrm{Na} / \mathrm{Ca}-$ mixed & Fresh & SGR & non-marine & Montebello/spreading \\
\hline 2S/11W-7K6 & Pico Rivera4_1 & -56.1 & -8.26 & 0.7098 & $\mathrm{Ca}-\mathrm{HCO}_{3} / \mathrm{SO}_{4}$ & Fresh & SGR & non-marine & Montebello \\
\hline $2 \mathrm{~S} / 11 \mathrm{~W}-7 \mathrm{~K} 7$ & Pico Rivera4_2 & -56.1 & -8.56 & 0.7098 & $\mathrm{Ca} / \mathrm{Na}-\mathrm{HCO}_{3}$ & Fresh & SGR & shallow marine & Montebello \\
\hline $2 \mathrm{~S} / 11 \mathrm{~W}-7 \mathrm{~K} 8$ & Pico Rivera4_3 & -57.9 & -8.08 & 0.7101 & $\mathrm{Ca}-\mathrm{HCO}_{3} / \mathrm{SO}_{4}$ & Fresh & SGR & non-marine & Montebello/spreading \\
\hline $2 \mathrm{~S} / 11 \mathrm{~W}-7 \mathrm{~K} 9$ & Pico Rivera4_4 & -60.2 & -8.12 & 0.7103 & $\mathrm{Na} / \mathrm{Ca}$-mixed & Fresh & SGR & non-marine & Montebello/spreading \\
\hline 2S/11W-8L8 & $\begin{array}{l}\text { Whittier Nar- } \\
\text { rows2_1 }\end{array}$ & -57.6 & -8.60 & - & $\mathrm{Na}-\mathrm{HCO}_{3}$ & Fresh & n.a. & deep marine & Montebello \\
\hline 2S/11W-8L9 & $\begin{array}{c}\text { Whittier Nar- } \\
\text { rows2_2 }\end{array}$ & -57.5 & -8.57 & - & $\mathrm{Na}-\mathrm{HCO}_{3}$ & Fresh & n.a. & deep marine & Montebello \\
\hline $2 \mathrm{~S} / 11 \mathrm{~W}-8 \mathrm{~L} 10$ & $\begin{array}{c}\text { Whittier Nar- } \\
\text { rows2_3 }\end{array}$ & -59.4 & -8.67 & - & $\mathrm{Na}-\mathrm{HCO}_{3}$ & Fresh & n.a. & deep marine & Montebello \\
\hline 2S/11W-8L11 & $\begin{array}{c}\text { Whittier Nar- } \\
\text { rows2_4 }\end{array}$ & -58.9 & -8.74 & - & $\mathrm{Na}-\mathrm{HCO}_{3}$ & Fresh & n.a. & deep marine & Montebello \\
\hline 2S/11W-8L12 & $\begin{array}{c}\text { Whittier Nar- } \\
\text { rows2_5 }\end{array}$ & -60.7 & -8.87 & - & $\mathrm{Ca}-\mathrm{HCO}_{3} / \mathrm{SO}_{4}$ & Fresh & n.a. & shallow marine & Montebello \\
\hline 2S/11W-8L13 & $\begin{array}{c}\text { Whittier Nar- } \\
\text { rows2_6 }\end{array}$ & -58.2 & -8.78 & - & $\mathrm{Ca} / \mathrm{Na}-\mathrm{HCO}_{3}$ & Fresh & n.a. & deep marine & Montebello \\
\hline 2S/11W-8L14 & $\begin{array}{c}\text { Whittier Nar- } \\
\text { rows } 2 \_7\end{array}$ & -58.2 & -8.68 & - & $\mathrm{Ca} / \mathrm{Na}-\mathrm{HCO}_{3}$ & Fresh & n.a. & deep marine & Montebello \\
\hline 2S/11W-8L15 & $\begin{array}{c}\text { Whittier Nar- } \\
\text { rows2_8 }\end{array}$ & -46.3 & -6.69 & - & $\mathrm{Ca} / \mathrm{Na}-\mathrm{SO}_{4} / \mathrm{HCO}_{3}$ & Slightly saline & n.a. & n.a. & Local (slightly saline) \\
\hline 2S/11W-8L16 & $\begin{array}{c}\text { Whittier Nar- } \\
\text { rows2_9 }\end{array}$ & -46.0 & -6.64 & - & mixed-SO $\mathrm{S}_{4} / \mathrm{HCO}_{3}$ & Slightly saline & n.a. & n.a. & Local (slightly saline) \\
\hline $2 \mathrm{~S} / 11 \mathrm{~W}-18 \mathrm{C} 4$ & Pico Rivera1_1 & -65.8 & -9.56 & - & $\mathrm{Na}-\mathrm{HCO}_{3}$ & Fresh & n.a. & deep marine & Montebello paleowater \\
\hline $2 \mathrm{~S} / 11 \mathrm{~W}-18 \mathrm{C} 5$ & Pico Rivera1_2 & -57.0 & -8.47 & - & $\mathrm{Ca}-\mathrm{HCO}_{3}$ & Fresh & n.a. & shallow marine & Montebello \\
\hline $2 \mathrm{~S} / 11 \mathrm{~W}-18 \mathrm{C} 6$ & Pico Riveral_3 & -59.0 & -8.09 & - & Ca-mixed & Fresh & n.a. & non-marine & Montebello/spreading \\
\hline
\end{tabular}


Table 1.2. Groundwater-quality data used for this study from multiple-well monitoring sites, and selected production and observation wells, Los Angeles and Orange Counties, California.-Continued

[See appendix 1 for explanation. Abbreviations: ft, foot; mg/L, milligrams per liter; mm/dd/yyyy, month/day/year; ug/L, micrograms per liter; CaCO 3 , calcium carbonate; \%, percent; <, less than; -, no data. Sediment source/facies: LAR, Los Angeles River; n.a., not assigned; SGR, San Gabriel River; SAR, Santa Ana River, *, potentially affected by mixing with anthropogenic sources of water or seawater]

\begin{tabular}{|c|c|c|c|c|c|c|c|c|c|}
\hline State well number & Local well name & $\begin{array}{c}\delta^{2} \text { Hydrogen, } \\
\text { unfiltered } \\
\text { (per mil) }\end{array}$ & $\begin{array}{c}\delta^{18} \text { Oxygen, } \\
\text { unfiltered } \\
\text { (per mil) }\end{array}$ & $\begin{array}{c}\text { Strontium-87 / } \\
\text { Strontium-86, } \\
\text { filtered (atom } \\
\text { ratio) }\end{array}$ & $\begin{array}{l}\text { Chemical } \\
\text { facies }\end{array}$ & $\begin{array}{l}\text { Dissolved- } \\
\text { solids } \\
\text { classification }\end{array}$ & $\begin{array}{l}\text { Sediment } \\
\text { source }\end{array}$ & $\begin{array}{l}\text { Sediment } \\
\text { facies }\end{array}$ & $\begin{array}{l}\text { Groundwater } \\
\text { recharge source }\end{array}$ \\
\hline \multicolumn{10}{|c|}{ Montebello Forebay-Continued } \\
\hline $2 \mathrm{~S} / 11 \mathrm{~W}-18 \mathrm{C} 7$ & Pico Rivera1_4 & -60.1 & -8.23 & - & Ca-mixed & Fresh & n.a. & non-marine & Montebello/spreading \\
\hline $2 \mathrm{~S} / 11 \mathrm{~W}-20 \mathrm{~N} 1$ & Whittier2_1 & -55.2 & -8.19 & - & $\mathrm{Na}-\mathrm{Cl} / \mathrm{HCO}_{3}$ & Fresh & n.a. & n.a. & Montebello \\
\hline $2 \mathrm{~S} / 11 \mathrm{~W}-20 \mathrm{~N} 2$ & Whittier2_2 & -57.2 & -8.71 & - & $\mathrm{Na}-\mathrm{HCO}_{3}$ & Fresh & n.a. & deep marine & Montebello \\
\hline $2 \mathrm{~S} / 11 \mathrm{~W}-20 \mathrm{~N} 3$ & Whittier2_3 & -56.4 & -8.34 & - & $\mathrm{Na} / \mathrm{Ca}-\mathrm{mixed}$ & Fresh & n.a. & non-marine & Montebello \\
\hline $2 \mathrm{~S} / 11 \mathrm{~W}-20 \mathrm{~N} 4$ & Whittier2_4 & -44.2 & -6.55 & - & $\mathrm{Na}-\mathrm{SO}_{4}$ & Slightly saline & n.a. & n.a. & Local (slightly saline) \\
\hline $2 \mathrm{~S} / 11 \mathrm{~W}-20 \mathrm{~N} 5$ & Whittier2_5 & -59.5 & -8.32 & - & Ca-mixed & Fresh & n.a. & non-marine & Montebello/spreading \\
\hline $2 \mathrm{~S} / 11 \mathrm{~W}-20 \mathrm{~N} 6$ & Whittier2_6 & -52.9 & -7.61 & - & $\mathrm{Ca} / \mathrm{Na}-\mathrm{HCO}_{3} / \mathrm{Cl}$ & Slightly saline & n.a. & shallow marine & $\begin{array}{l}\text { Montebello/spreading } \\
\text { (slightly saline) }\end{array}$ \\
\hline 2S/12W-10Q5 & Montebello1_1 & -55.2 & -8.29 & 0.7095 & $\mathrm{Na}-\mathrm{Cl} / \mathrm{HCO}_{3}$ & Slightly saline & LAR, SGR & n.a. & $\begin{array}{l}\text { Montebello paleowater } \\
\text { (slightly saline) }\end{array}$ \\
\hline 2S/12W-10Q6 & Montebello1_2 & -63.3 & -9.36 & - & $\mathrm{Na}-\mathrm{HCO}_{3}$ & Fresh & n.a. & deep marine & Montebello paleowater \\
\hline 2S/12W-10Q7 & Montebello1_3 & -62.2 & -8.62 & 0.7097 & $\mathrm{Ca} / \mathrm{Na}-\mathrm{HCO}_{3} / \mathrm{SO}_{4}$ & Fresh & SGR & shallow marine & Montebello/spreading \\
\hline 2S/12W-10Q8 & Montebello1_4 & -63.1 & -8.83 & - & $\mathrm{Ca}-\mathrm{HCO}_{3}$ & Fresh & n.a. & non-marine & Montebello/spreading \\
\hline 2S/12W-10Q9 & Montebello1_5 & -56.6 & -7.74 & - & $\mathrm{Ca} / \mathrm{Na}-\mathrm{HCO}_{3} / \mathrm{SO}_{4}$ & Fresh & n.a. & shallow marine & Montebello/spreading \\
\hline $2 \mathrm{~S} / 12 \mathrm{~W}-10 \mathrm{Q} 10$ & Montebello1_6 & - & - & - & $\mathrm{Ca} / \mathrm{Na}-\mathrm{HCO}_{3} / \mathrm{Cl}$ & Fresh & n.a. & non-marine & n.a. \\
\hline $2 \mathrm{~S} / 12 \mathrm{~W}-25 \mathrm{G} 1$ & Pico Rivera W12 & -57.0 & -8.08 & 0.7103 & $\mathrm{Na} / \mathrm{Ca}-\mathrm{mixed}$ & Fresh & SGR & non-marine & Montebello/spreading \\
\hline $2 \mathrm{~S} / 12 \mathrm{~W}-25 \mathrm{G} 3$ & Pico Rivera2_1 & -53.6 & -7.66 & - & $\mathrm{Ca}-\mathrm{HCO}_{3} / \mathrm{SO}_{4}$ & Fresh & n.a. & non-marine & Montebello/spreading \\
\hline $2 \mathrm{~S} / 12 \mathrm{~W}-25 \mathrm{G} 4$ & Pico Rivera2_2 & -59.4 & -8.32 & - & $\mathrm{Ca}-\mathrm{HCO}_{3} / \mathrm{SO}_{4}$ & Fresh & n.a. & non-marine & Montebello/spreading \\
\hline $2 \mathrm{~S} / 12 \mathrm{~W}-25 \mathrm{G} 5$ & Pico Rivera2_3 & -63.3 & -8.61 & - & $\mathrm{Ca}-\mathrm{HCO}_{3} / \mathrm{SO}_{4}$ & Fresh & n.a. & non-marine & Montebello/spreading \\
\hline $2 \mathrm{~S} / 12 \mathrm{~W}-25 \mathrm{G} 6$ & Pico Rivera2_4 & -57.1 & -8.08 & - & $\mathrm{Ca} / \mathrm{Na}$-mixed & Fresh & n.a. & non-marine & Montebello/spreading \\
\hline $2 \mathrm{~S} / 12 \mathrm{~W}-25 \mathrm{G} 7$ & Pico Rivera2_5 & -54.8 & -7.62 & - & $\mathrm{Na} / \mathrm{Ca}-\mathrm{mixed}$ & Fresh & n.a. & non-marine & Montebello/spreading \\
\hline $2 \mathrm{~S} / 12 \mathrm{~W}-25 \mathrm{G} 8$ & Pico Rivera2_6 & -50.1 & -7.06 & - & mixed-mixed & Fresh & n.a. & non-marine & Montebello/spreading \\
\hline 2S/12W-26D9 & Rio Hondo1_1 & -55.3 & -8.39 & - & $\mathrm{Ca} / \mathrm{Na}-\mathrm{HCO}_{3}$ & Fresh & n.a. & non-marine & Montebello \\
\hline $2 \mathrm{~S} / 12 \mathrm{~W}-26 \mathrm{D} 10$ & Rio Hondo1_2 & -62.4 & -8.92 & - & $\mathrm{Ca}-\mathrm{HCO}_{3} / \mathrm{SO}_{4}$ & Fresh & n.a. & non-marine & Montebello/spreading \\
\hline $2 \mathrm{~S} / 12 \mathrm{~W}-26 \mathrm{D} 11$ & Rio Hondo1_3 & -64.9 & -8.88 & - & $\mathrm{Ca}-\mathrm{HCO}_{3} / \mathrm{SO}_{4}$ & Fresh & n.a. & non-marine & Montebello/spreading \\
\hline 2S/12W-26D12 & Rio Hondo1_4 & -59.8 & -8.38 & - & $\mathrm{Ca} / \mathrm{Na}-\mathrm{HCO}_{3} / \mathrm{SO}_{4}$ & Fresh & n.a. & non-marine & Montebello/spreading \\
\hline $2 \mathrm{~S} / 12 \mathrm{~W}-26 \mathrm{D} 13$ & Rio Hondo1_5 & -54.2 & -7.48 & - & $\mathrm{Ca} / \mathrm{Na}-\mathrm{HCO}_{3} / \mathrm{SO}_{4}$ & Fresh & n.a. & non-marine & Montebello/spreading \\
\hline $2 \mathrm{~S} / 12 \mathrm{~W}-26 \mathrm{D} 14$ & Rio Hondo1_6 & -52.6 & -7.46 & - & $\mathrm{Ca} / \mathrm{Na}$-mixed & Fresh & n.a. & non-marine & Montebello/spreading \\
\hline 2S/12W-33D3 & Bell Gardens1_1 & -65.7 & -9.14 & - & $\mathrm{Ca}-\mathrm{HCO}_{3} / \mathrm{SO}_{4}$ & Fresh & n.a. & non-marine & Montebello/spreading \\
\hline
\end{tabular}


Table 1.2. Groundwater-quality data used for this study from multiple-well monitoring sites, and selected production and observation wells, Los Angeles and Orange Counties, California.-Continued

[See appendix 1 for explanation. Abbreviations: ft, foot; mg/L, milligrams per liter; mm/dd/yyyy, month/day/year; ug/L, micrograms per liter; CaCO 3 , calcium carbonate; \%, percent; <, less than; - , no data. Sediment source/facies: LAR, Los Angeles River; n.a., not assigned; SGR, San Gabriel River; SAR, Santa Ana River, *, potentially affected by mixing with anthropogenic sources of water or seawater]

\begin{tabular}{|c|c|c|c|c|c|c|c|c|c|}
\hline State well number & Local well name & $\begin{array}{c}\delta^{2} \text { Hydrogen, } \\
\text { unfiltered } \\
\text { (per mil) }\end{array}$ & $\begin{array}{c}\delta^{18} 0 x y g e n, \\
\text { unfiltered } \\
\text { (per mil) }\end{array}$ & $\begin{array}{c}\text { Strontium-87 / } \\
\text { Strontium-86, } \\
\text { filtered (atom } \\
\text { ratio) }\end{array}$ & $\begin{array}{l}\text { Chemical } \\
\text { facies }\end{array}$ & $\begin{array}{l}\text { Dissolved- } \\
\text { solids } \\
\text { classification }\end{array}$ & $\begin{array}{l}\text { Sediment } \\
\text { source }\end{array}$ & $\begin{array}{l}\text { Sediment } \\
\text { facies }\end{array}$ & $\begin{array}{l}\text { Groundwater } \\
\text { recharge source }\end{array}$ \\
\hline \multicolumn{10}{|c|}{ Montebello Forebay-Continued } \\
\hline $2 \mathrm{~S} / 12 \mathrm{~W}-33 \mathrm{D} 4$ & Bell Gardens1_2 & -55.4 & -8.23 & - & $\mathrm{Na} / \mathrm{Ca}-\mathrm{HCO}_{3}$ & Fresh & n.a. & shallow marine & Montebello \\
\hline $2 \mathrm{~S} / 12 \mathrm{~W}-33 \mathrm{D} 5$ & Bell Gardens1_3 & -60.3 & -8.35 & - & $\mathrm{Ca}-\mathrm{HCO}_{3} / \mathrm{SO}_{4}$ & Fresh & n.a. & non-marine & Montebello/spreading \\
\hline 2S/12W-33D6 & Bell Gardens1_4 & -53.8 & -7.78 & - & $\mathrm{Ca} / \mathrm{Na}-\mathrm{HCO}_{3} / \mathrm{SO}_{4}$ & Fresh & n.a. & non-marine & Montebello/spreading \\
\hline $2 \mathrm{~S} / 12 \mathrm{~W}-33 \mathrm{D} 7$ & Bell Gardens1_5 & -52.0 & -7.55 & - & $\mathrm{Ca} / \mathrm{Na}-\mathrm{HCO}_{3}$ & Fresh & n.a. & shallow marine & Montebello/spreading \\
\hline 2S/12W-33D8 & Bell Gardens1_6 & -51.9 & -7.59 & - & $\mathrm{Ca}-\mathrm{HCO}_{3}$ & Fresh & n.a. & shallow marine & Montebello/spreading \\
\hline $2 \mathrm{~S} / 12 \mathrm{~W}-36 \mathrm{M} 6$ & Pico Rivera W8 & -60.6 & -8.39 & 0.7101 & $\mathrm{Ca}-\mathrm{HCO}_{3} / \mathrm{SO}_{4}$ & Fresh & SGR & non-marine & Montebello/spreading \\
\hline $3 \mathrm{~S} / 12 \mathrm{~W}-11 \mathrm{~A} 7$ & Norwalk2_1 & -55.9 & -7.92 & - & $\mathrm{Na} / \mathrm{Ca}-\mathrm{HCO}_{3}$ & Fresh & n.a. & non-marine & Montebello/spreading \\
\hline $3 \mathrm{~S} / 12 \mathrm{~W}-11 \mathrm{~A} 8$ & Norwalk2_2 & -52.8 & -7.90 & - & $\mathrm{Na}-\mathrm{HCO}_{3}$ & Fresh & n.a. & shallow marine & Montebello \\
\hline $3 \mathrm{~S} / 12 \mathrm{~W}-11 \mathrm{~A} 9$ & Norwalk2_3 & -54.9 & -8.39 & - & $\mathrm{Ca}-\mathrm{HCO}_{3}$ & Fresh & n.a. & non-marine & Montebello \\
\hline $3 \mathrm{~S} / 12 \mathrm{~W}-11 \mathrm{~A} 10$ & Norwalk2_4 & -56.5 & -8.56 & - & $\mathrm{Ca}-\mathrm{HCO}_{3}$ & Fresh & n.a. & non-marine & Montebello \\
\hline $3 \mathrm{~S} / 12 \mathrm{~W}-11 \mathrm{~A} 11$ & Norwalk2_5 & -62.7 & -8.65 & - & $\mathrm{Ca}-\mathrm{HCO}_{3} / \mathrm{SO}_{4}$ & Fresh & n.a. & non-marine & Montebello/spreading \\
\hline $3 \mathrm{~S} / 12 \mathrm{~W}-11 \mathrm{~A} 12$ & Norwalk2_6 & -54.8 & -7.64 & - & $\mathrm{Ca}-\mathrm{HCO}_{3} / \mathrm{SO}_{4}$ & Fresh & n.a. & non-marine & Montebello/spreading \\
\hline \multicolumn{10}{|c|}{ Whitter area } \\
\hline $3 \mathrm{~S} / 11 \mathrm{~W}-2 \mathrm{~K} 4$ & Whittier1_1 & -42.5 & -6.63 & - & $\mathrm{Na}-\mathrm{SO}_{4}$ & Slightly saline & n.a. & n.a. & Local (slightly saline) \\
\hline $3 \mathrm{~S} / 11 \mathrm{~W}-2 \mathrm{~K} 5$ & Whittier1_2 & -41.0 & -6.42 & - & $\mathrm{Na}-\mathrm{SO}_{4}$ & Slightly saline & n.a. & n.a. & Local (slightly saline) \\
\hline $3 \mathrm{~S} / 11 \mathrm{~W}-2 \mathrm{~K} 6$ & Whittier1_4 & -37.0 & -5.78 & - & $\mathrm{Na} / \mathrm{Ca}-\mathrm{HCO}_{3} / \mathrm{SO}_{4}$ & Fresh & n.a. & non-marine & Local \\
\hline $3 \mathrm{~S} / 11 \mathrm{~W}-2 \mathrm{~K} 7$ & Whittier1_5 & -37.0 & -5.85 & - & mixed- $\mathrm{HCO}_{3} / \mathrm{SO}_{4}$ & Fresh & n.a. & non-marine & Local \\
\hline $3 \mathrm{~S} / 11 \mathrm{~W}-2 \mathrm{~K} 8$ & Whittier1_3 & -40.7 & -6.32 & - & $\mathrm{Na} / \mathrm{Ca}-\mathrm{SO}_{4}$ & Slightly saline & n.a. & non-marine & Local (slightly saline) \\
\hline 3S/11W-9D2 & Santa Fe Springs1_2 & -49.3 & -7.66 & - & $\mathrm{Na}-\mathrm{HCO}_{3} / \mathrm{Cl}$ & Fresh & n.a. & shallow marine & Local \\
\hline 3S/11W-9D3 & Santa Fe Springs1_3 & -44.0 & -6.73 & - & $\mathrm{Na}-\mathrm{HCO}_{3}$ & Fresh & n.a. & shallow marine & Local \\
\hline 3S/11W-9D4 & Santa Fe Springs $1 \_4$ & -49.4 & -7.51 & - & $\mathrm{Na}-\mathrm{HCO}_{3} / \mathrm{Cl}$ & Fresh & n.a. & shallow marine & Local \\
\hline \multicolumn{10}{|c|}{ Pressure area } \\
\hline $2 \mathrm{~S} / 12 \mathrm{~W}-7 \mathrm{~J} 1$ & Commerce1_1 & -31.9 & -5.72 & 0.7094 & $\mathrm{Na}-\mathrm{Cl}$ & Highly saline & LAR, SGR & * & $\begin{array}{l}\text { Los Angeles paleowater } \\
\text { (highly saline) }\end{array}$ \\
\hline $2 \mathrm{~S} / 12 \mathrm{~W}-7 \mathrm{~J} 2$ & Commerce1_2 & -45.1 & -7.04 & - & $\mathrm{Na}-\mathrm{HCO}_{3} / \mathrm{Cl}$ & Fresh & n.a. & non-marine & Los Angeles \\
\hline $2 \mathrm{~S} / 12 \mathrm{~W}-7 \mathrm{~J} 3$ & Commerce1_3 & -43.7 & -6.93 & - & $\mathrm{Na} / \mathrm{Ca}-\mathrm{HCO}_{3}$ & Fresh & n.a. & non-marine & Mixed \\
\hline $2 \mathrm{~S} / 12 \mathrm{~W}-7 \mathrm{~J} 4$ & Commerce1_4 & -50.0 & -7.55 & 0.7091 & $\mathrm{Na}-\mathrm{HCO}_{3} / \mathrm{Cl}$ & Fresh & LAR, SGR & non-marine & Los Angeles \\
\hline $2 \mathrm{~S} / 12 \mathrm{~W}-7 \mathrm{~J} 5$ & Commerce1_5 & -56.9 & -8.14 & - & $\mathrm{Ca} / \mathrm{Na}$-mixed & Fresh & n.a. & non-marine & Montebello/spreading \\
\hline
\end{tabular}


Table 1.2. Groundwater-quality data used for this study from multiple-well monitoring sites, and selected production and observation wells, Los Angeles and Orange Counties, California.-Continued

[See appendix 1 for explanation. Abbreviations: ft, foot; mg/L, milligrams per liter; mm/dd/yyyy, month/day/year; ug/L, micrograms per liter; CaCO 3 , calcium carbonate; \%, percent; <, less than; - , no data. Sediment source/facies: LAR, Los Angeles River; n.a., not assigned; SGR, San Gabriel River; SAR, Santa Ana River, *, potentially affected by mixing with anthropogenic sources of water or seawater]

\begin{tabular}{|c|c|c|c|c|c|c|c|c|c|}
\hline State well number & Local well name & $\begin{array}{c}\delta^{2} \text { Hydrogen, } \\
\text { unfiltered } \\
\text { (per mil) }\end{array}$ & $\begin{array}{c}\delta^{18} 0 x y g e n, \\
\text { unfiltered } \\
\text { (per mil) }\end{array}$ & $\begin{array}{l}\text { Strontium-87 / } \\
\text { Strontium-86, } \\
\text { filtered (atom } \\
\text { ratio) }\end{array}$ & $\begin{array}{l}\text { Chemical } \\
\text { facies }\end{array}$ & $\begin{array}{l}\text { Dissolved- } \\
\text { solids } \\
\text { classification }\end{array}$ & $\begin{array}{l}\text { Sediment } \\
\text { source }\end{array}$ & $\begin{array}{l}\text { Sediment } \\
\text { facies }\end{array}$ & $\begin{array}{c}\text { Groundwater } \\
\text { recharge source }\end{array}$ \\
\hline \multicolumn{10}{|c|}{ Pressure area-Continued } \\
\hline 2S/12W-7J6 & Commerce1_6 & -39.8 & -6.29 & - & $\mathrm{Ca} / \mathrm{Na}-\mathrm{HCO}_{3}$ & Fresh & n.a. & non-marine & Local \\
\hline $2 \mathrm{~S} / 13 \mathrm{~W}-24 \mathrm{~J} 1$ & Bell1_1 & -62.1 & -9.01 & 0.7091 & $\mathrm{Na}-\mathrm{HCO}_{3}$ & Fresh & LAR, SGR & deep marine & Montebello paleowater \\
\hline $2 \mathrm{~S} / 13 \mathrm{~W}-24 \mathrm{~J} 2$ & Bell1_2 & -47.8 & -7.29 & 0.7086 & $\mathrm{Na} / \mathrm{Ca}-\mathrm{HCO}_{3}$ & Fresh & LAR & shallow marine & Los Angeles \\
\hline $2 \mathrm{~S} / 13 \mathrm{~W}-24 \mathrm{~J} 3$ & Bell1_3 & -48.4 & -7.31 & 0.7085 & $\mathrm{Ca} / \mathrm{Na}-\mathrm{HCO}_{3}$ & Fresh & LAR & shallow marine & Los Angeles \\
\hline 2S/13W-24J4 & Bell1_4 & -46.9 & -7.33 & 0.7086 & $\mathrm{Ca} / \mathrm{Na}-\mathrm{HCO}_{3}$ & Fresh & LAR & shallow marine & Los Angeles \\
\hline $2 \mathrm{~S} / 13 \mathrm{~W}-24 \mathrm{~J} 5$ & Bell1_5 & -53.3 & -7.76 & 0.7092 & $\mathrm{Ca} / \mathrm{Na}-\mathrm{HCO}_{3}$ & Fresh & LAR, SGR & non-marine & Montebello/spreading \\
\hline $2 \mathrm{~S} / 13 \mathrm{~W}-24 \mathrm{~J} 6$ & Bell1_6 & -42.9 & -6.74 & 0.7088 & $\mathrm{Ca}-\mathrm{HCO}_{3}$ & Fresh & LAR & non-marine & Local \\
\hline $2 \mathrm{~S} / 13 \mathrm{~W}-31 \mathrm{~B} 3$ & Los Angeles4_1 & -60.3 & -9.01 & 0.7094 & $\mathrm{Na}-\mathrm{HCO}_{3}$ & Slightly saline & LAR, SGR & deep marine & $\begin{array}{l}\text { Montebello paleowater } \\
\text { (slightly saline) }\end{array}$ \\
\hline $2 \mathrm{~S} / 13 \mathrm{~W}-31 \mathrm{~B} 4$ & Los Angeles4_2 & -62.5 & -9.07 & 0.7090 & $\mathrm{Na}-\mathrm{HCO}_{3}$ & Fresh & LAR, SGR & deep marine & Montebello paleowater \\
\hline $2 \mathrm{~S} / 13 \mathrm{~W}-31 \mathrm{~B} 5$ & Los Angeles4_3 & -48.5 & -7.30 & 0.7080 & $\mathrm{Ca} / \mathrm{Na}-\mathrm{HCO}_{3}$ & Fresh & LAR & shallow marine & Los Angeles \\
\hline $2 \mathrm{~S} / 13 \mathrm{~W}-31 \mathrm{~B} 6$ & Los Angeles4_4 & -48.0 & -7.31 & 0.7083 & $\mathrm{Ca} / \mathrm{Na}-\mathrm{HCO}_{3}$ & Fresh & LAR & shallow marine & Los Angeles \\
\hline $2 \mathrm{~S} / 13 \mathrm{~W}-31 \mathrm{~B} 7$ & Los Angeles4_5 & -47.2 & -7.39 & 0.7082 & $\mathrm{Na} / \mathrm{Ca}-\mathrm{HCO}_{3}$ & Fresh & LAR & shallow marine & Los Angeles \\
\hline $2 \mathrm{~S} / 13 \mathrm{~W}-31 \mathrm{~B} 8$ & Los Angeles4_6 & -48.0 & -7.21 & 0.7085 & $\mathrm{Ca} / \mathrm{Na}-\mathrm{HCO}_{3}$ & Fresh & LAR & shallow marine & Los Angeles \\
\hline $2 \mathrm{~S} / 14 \mathrm{~W}-26 \mathrm{~N} 3$ & Inglewood2_1 & -60.8 & -8.98 & 0.7096 & $\mathrm{Na}-\mathrm{HCO}_{3}$ & Slightly saline & LAR, SGR & deep marine & $\begin{array}{l}\text { Montebello paleowater } \\
\text { (slightly saline) }\end{array}$ \\
\hline $2 \mathrm{~S} / 14 \mathrm{~W}-26 \mathrm{~N} 4$ & Inglewood2_2 & -56.3 & -8.30 & 0.7086 & $\mathrm{Na}-\mathrm{HCO}_{3}$ & Slightly saline & LAR & deep marine & $\begin{array}{l}\text { Montebello paleowater } \\
\text { (slightly saline) }\end{array}$ \\
\hline $2 \mathrm{~S} / 14 \mathrm{~W}-26 \mathrm{~N} 5$ & Inglewood2_3 & -38.4 & -6.18 & 0.7084 & $\mathrm{Na}-\mathrm{HCO}_{3}$ & Fresh & LAR & deep marine & Local \\
\hline $3 \mathrm{~S} / 11 \mathrm{~W}-17 \mathrm{~F} 1$ & Norwalk1_1 & -48.4 & -7.22 & 0.7086 & $\mathrm{Na}-\mathrm{HCO}_{3}$ & Fresh & Local & shallow marine & Local paleowater \\
\hline $3 \mathrm{~S} / 11 \mathrm{~W}-17 \mathrm{~F} 2$ & Norwalk1_2 & -63.8 & -9.20 & 0.7092 & $\mathrm{Na}-\mathrm{HCO}_{3}$ & Fresh & SGR, Local & shallow marine & Montebello paleowater \\
\hline $3 \mathrm{~S} / 11 \mathrm{~W}-17 \mathrm{~F} 3$ & Norwalk1_3 & -56.1 & -8.33 & 0.7091 & $\mathrm{Na}-\mathrm{HCO}_{3}$ & Fresh & SGR, Local & non-marine & Montebello \\
\hline $3 \mathrm{~S} / 11 \mathrm{~W}-17 \mathrm{~F} 4$ & Norwalk1_4 & -55.1 & -8.36 & 0.7093 & $\mathrm{Na} / \mathrm{Ca}-\mathrm{HCO}_{3}$ & Fresh & SGR, Local & non-marine & Montebello \\
\hline $3 \mathrm{~S} / 11 \mathrm{~W}-17 \mathrm{~F} 5$ & Norwalk1_5 & -48.7 & -7.55 & 0.7096 & $\mathrm{Ca} / \mathrm{Na}-\mathrm{HCO}_{3}$ & Fresh & SGR, Local & non-marine & Local \\
\hline $3 \mathrm{~S} / 11 \mathrm{~W}-26 \mathrm{E} 2$ & La Mirada1_1 & -52.5 & -7.89 & - & $\mathrm{Na}-\mathrm{HCO}_{3}$ & Fresh & n.a. & shallow marine & Montebello \\
\hline $3 \mathrm{~S} / 11 \mathrm{~W}-26 \mathrm{E} 3$ & La Mirada1_2 & -55.3 & -8.23 & - & $\mathrm{Na}-\mathrm{HCO}_{3}$ & Fresh & n.a. & shallow marine & Montebello \\
\hline 3S/11W-26E4 & La Mirada1_3 & -54.8 & -8.20 & - & $\mathrm{Na}-\mathrm{HCO}_{3}$ & Fresh & n.a. & shallow marine & Montebello \\
\hline 3S/11W-26E5 & La Mirada1_4 & -53.7 & -7.98 & - & $\mathrm{Na} / \mathrm{Ca}-\mathrm{HCO}_{3}$ & Fresh & n.a. & shallow marine & Montebello \\
\hline 3S/11W-26E6 & La Mirada1_5 & -51.7 & -7.79 & - & $\mathrm{Na} / \mathrm{Ca}-\mathrm{Cl} / \mathrm{HCO}_{3}$ & Fresh & n.a. & non-marine & Mixed \\
\hline
\end{tabular}


Table 1.2. Groundwater-quality data used for this study from multiple-well monitoring sites, and selected production and observation wells, Los Angeles and Orange Counties, California.-Continued

[See appendix 1 for explanation. Abbreviations: ft, foot; mg/L, milligrams per liter; mm/dd/yyyy, month/day/year; ug/L, micrograms per liter; CaCO ${ }_{3}$, calcium carbonate; $\%$, percent; <, less than; - , no data. Sediment source/facies: LAR, Los Angeles River; n.a., not assigned; SGR, San Gabriel River; SAR, Santa Ana River, *, potentially affected by mixing with anthropogenic sources of water or seawater]

\begin{tabular}{|c|c|c|c|c|c|c|c|c|c|}
\hline State well number & Local well name & $\begin{array}{c}\delta^{2} \text { Hydrogen, } \\
\text { unfiltered } \\
\text { (per mil) }\end{array}$ & $\begin{array}{c}\delta^{18} 0 x y g e n, \\
\text { unfiltered } \\
\text { (per mil) }\end{array}$ & $\begin{array}{l}\text { Strontium-87 / } \\
\text { Strontium-86, } \\
\text { filtered (atom } \\
\text { ratio) }\end{array}$ & $\begin{array}{l}\text { Chemical } \\
\text { facies }\end{array}$ & $\begin{array}{l}\text { Dissolved- } \\
\text { solids } \\
\text { classification }\end{array}$ & $\begin{array}{l}\text { Sediment } \\
\text { source }\end{array}$ & $\begin{array}{l}\text { Sediment } \\
\text { facies }\end{array}$ & $\begin{array}{l}\text { Groundwater } \\
\text { recharge source }\end{array}$ \\
\hline \multicolumn{10}{|c|}{ Pressure area-Continued } \\
\hline $3 \mathrm{~S} / 12 \mathrm{~W}-6 \mathrm{~B} 4$ & South Gate1_1 & -48.0 & -7.38 & - & $\mathrm{Ca} / \mathrm{Na}-\mathrm{HCO}_{3}$ & Fresh & n.a. & shallow marine & Los Angeles \\
\hline $3 \mathrm{~S} / 12 \mathrm{~W}-6 \mathrm{~B} 5$ & South Gate1_2 & -59.0 & -8.30 & - & $\mathrm{Ca}-\mathrm{HCO}_{3} / \mathrm{SO}_{4}$ & Fresh & n.a. & non-marine & Montebello/spreading \\
\hline $3 \mathrm{~S} / 12 \mathrm{~W}-6 \mathrm{~B} 6$ & South Gate1_3 & -61.3 & -8.72 & - & $\mathrm{Ca}-\mathrm{HCO}_{3} / \mathrm{SO}_{4}$ & Fresh & n.a. & non-marine & Montebello/spreading \\
\hline $3 \mathrm{~S} / 12 \mathrm{~W}-6 \mathrm{~B} 7$ & South Gate1_4 & -59.3 & -8.38 & - & $\mathrm{Ca}-\mathrm{HCO}_{3} / \mathrm{SO}_{4}$ & Fresh & n.a. & non-marine & Montebello/spreading \\
\hline $3 \mathrm{~S} / 12 \mathrm{~W}-6 \mathrm{~B} 8$ & South Gate1_5 & -47.8 & -7.36 & - & $\mathrm{Ca}-\mathrm{HCO}_{3} / \mathrm{Cl}$ & Fresh & n.a. & shallow marine & Los Angeles \\
\hline 3S/12W-9J1 & Downey1_1 & -55.2 & -8.40 & - & $\mathrm{Ca}-\mathrm{HCO}_{3}$ & Fresh & n.a. & shallow marine & Montebello \\
\hline $3 \mathrm{~S} / 12 \mathrm{~W}-9 \mathrm{~J} 2$ & Downey1_2 & -58.9 & -8.60 & - & $\mathrm{Ca}-\mathrm{HCO}_{3}$ & Fresh & n.a. & non-marine & Montebello \\
\hline $3 \mathrm{~S} / 12 \mathrm{~W}-9 \mathrm{~J} 3$ & Downey1_3 & -69.1 & -9.39 & - & $\mathrm{Ca}-\mathrm{HCO}_{3} / \mathrm{SO}_{4}$ & Fresh & n.a. & non-marine & Montebello/spreading \\
\hline $3 \mathrm{~S} / 12 \mathrm{~W}-9 \mathrm{~J} 4$ & Downey1_4 & -59.3 & -8.18 & - & $\mathrm{Ca}-\mathrm{HCO}_{3} / \mathrm{SO}_{4}$ & Fresh & n.a. & non-marine & Montebello/spreading \\
\hline $3 \mathrm{~S} / 12 \mathrm{~W}-9 \mathrm{~J} 5$ & Downey1_5 & -53.8 & -7.95 & - & $\mathrm{Ca}-\mathrm{HCO}_{3}$ & Fresh & n.a. & non-marine & Montebello/spreading \\
\hline $3 \mathrm{~S} / 12 \mathrm{~W}-9 \mathrm{~J} 6$ & Downey1_6 & -54.5 & -7.74 & - & $\mathrm{Ca}-\mathrm{HCO}_{3} / \mathrm{SO}_{4}$ & Fresh & n.a. & non-marine & Montebello/spreading \\
\hline $3 \mathrm{~S} / 12 \mathrm{~W}-15 \mathrm{~K} 1$ & St. John Bosco & -55.6 & -7.89 & 0.7102 & $\mathrm{Ca} / \mathrm{Na}-m i x e d$ & Fresh & SGR & non-marine & Montebello/spreading \\
\hline $3 \mathrm{~S} / 12 \mathrm{~W}-16 \mathrm{H} 1$ & Park 40D & -57.3 & -8.27 & 0.7103 & $\mathrm{Ca} / \mathrm{Na}$-mixed & Fresh & SGR & non-marine & Montebello/spreading \\
\hline $3 \mathrm{~S} / 12 \mathrm{~W}-26 \mathrm{~K} 2$ & Cerritos $2 \_1$ & -56.2 & -8.37 & - & $\mathrm{Ca}-\mathrm{HCO}_{3}$ & Fresh & n.a. & shallow marine & Montebello \\
\hline $3 \mathrm{~S} / 12 \mathrm{~W}-26 \mathrm{~K} 3$ & Cerritos2_2 & -64.6 & -8.65 & - & $\mathrm{Ca}-\mathrm{HCO}_{3} / \mathrm{SO}_{4}$ & Fresh & n.a. & non-marine & Montebello/spreading \\
\hline $3 \mathrm{~S} / 12 \mathrm{~W}-26 \mathrm{~K} 4$ & Cerritos2_3 & -53.9 & -8.12 & - & $\mathrm{Ca}-\mathrm{HCO}_{3}$ & Fresh & n.a. & shallow marine & Montebello \\
\hline $3 \mathrm{~S} / 12 \mathrm{~W}-26 \mathrm{~K} 5$ & Cerritos $2 \_4$ & -54.9 & -8.14 & - & $\mathrm{Ca}-\mathrm{HCO}_{3}$ & Fresh & n.a. & deep marine & Montebello \\
\hline $3 \mathrm{~S} / 12 \mathrm{~W}-26 \mathrm{~K} 6$ & Cerritos $2 \_5$ & -55.0 & -8.11 & - & $\mathrm{Ca}-\mathrm{HCO}_{3}$ & Fresh & n.a. & shallow marine & Montebello \\
\hline $3 \mathrm{~S} / 12 \mathrm{~W}-26 \mathrm{~K} 7$ & Cerritos2_6 & -48.4 & -7.34 & - & Ca-mixed & Fresh & n.a. & non-marine & Local \\
\hline $3 \mathrm{~S} / 12 \mathrm{~W}-33 \mathrm{~B} 1$ & BSMWC_615 & -57.0 & -8.34 & 0.7102 & $\mathrm{Ca}-\mathrm{HCO}_{3}$ & Fresh & SGR & non-marine & Montebello \\
\hline 3S/13W-8J1 & Willowbrook1_1 & -50.2 & -7.93 & 0.7085 & $\mathrm{Na} / \mathrm{Ca}-\mathrm{HCO}_{3}$ & Fresh & LAR & shallow marine & Los Angeles \\
\hline $3 \mathrm{~S} / 13 \mathrm{~W}-8 \mathrm{~J} 2$ & Willowbrook1_2 & -46.5 & -7.37 & 0.7085 & $\mathrm{Ca}-\mathrm{HCO}_{3}$ & Fresh & LAR & shallow marine & Los Angeles \\
\hline $3 \mathrm{~S} / 13 \mathrm{~W}-8 \mathrm{~J} 3$ & Willowbrook1_3 & -47.1 & -7.35 & 0.7084 & $\mathrm{Ca}-\mathrm{HCO}_{3}$ & Fresh & LAR & shallow marine & Los Angeles \\
\hline $3 \mathrm{~S} / 13 \mathrm{~W}-8 \mathrm{~J} 4$ & Willowbrook1_4 & -49.7 & -7.47 & - & $\mathrm{Ca}-\mathrm{HCO}_{3}$ & Fresh & n.a. & shallow marine & Los Angeles \\
\hline 3S/13W-11G1 & Lynwood1_1 & -62.2 & -9.27 & 0.7090 & $\mathrm{Na}-\mathrm{HCO}_{3}$ & Fresh & LAR, SGR & deep marine & Montebello paleowater \\
\hline $3 \mathrm{~S} / 13 \mathrm{~W}-11 \mathrm{G} 2$ & Lynwood1_2 & -50.6 & -7.80 & 0.7090 & $\mathrm{Na}-\mathrm{HCO}_{3}$ & Fresh & LAR, SGR & shallow marine & Mixed \\
\hline 3S/13W-11G3 & Lynwood1_8 & -57.2 & -8.12 & 0.7085 & Ca-mixed & Fresh & LAR & non-marine & Montebello/spreading \\
\hline 3S/13W-11G4 & Lynwood1_3 & -46.2 & -7.27 & 0.7087 & $\mathrm{Na} / \mathrm{Ca}-\mathrm{HCO}_{3}$ & Fresh & LAR & shallow marine & Los Angeles \\
\hline
\end{tabular}


Table 1.2. Groundwater-quality data used for this study from multiple-well monitoring sites, and selected production and observation wells, Los Angeles and Orange Counties, California.-Continued

[See appendix 1 for explanation. Abbreviations: ft, foot; mg/L, milligrams per liter; mm/dd/yyyy, month/day/year; ug/L, micrograms per liter; CaCO 3 , calcium carbonate; \%, percent; <, less than; - , no data. Sediment source/facies: LAR, Los Angeles River; n.a., not assigned; SGR, San Gabriel River; SAR, Santa Ana River, *, potentially affected by mixing with anthropogenic sources of water or seawater]

\begin{tabular}{|c|c|c|c|c|c|c|c|c|c|}
\hline State well number & Local well name & $\begin{array}{c}\delta^{2} \text { Hydrogen, } \\
\text { unfiltered } \\
\text { (per mil) }\end{array}$ & $\begin{array}{c}\delta^{18} \text { Oxygen, } \\
\text { unfiltered } \\
\text { (per mil) }\end{array}$ & $\begin{array}{l}\text { Strontium-87 / } \\
\text { Strontium-86, } \\
\text { filtered (atom } \\
\text { ratio) }\end{array}$ & $\begin{array}{l}\text { Chemical } \\
\text { facies }\end{array}$ & $\begin{array}{l}\text { Dissolved- } \\
\text { solids } \\
\text { classification }\end{array}$ & $\begin{array}{l}\text { Sediment } \\
\text { source }\end{array}$ & $\begin{array}{l}\text { Sediment } \\
\text { facies }\end{array}$ & $\begin{array}{l}\text { Groundwater } \\
\text { recharge source }\end{array}$ \\
\hline \multicolumn{10}{|c|}{ Pressure area-Continued } \\
\hline 3S/13W-11G5 & Lynwood1_4 & -45.9 & -7.28 & 0.7094 & $\mathrm{Na} / \mathrm{Ca}-\mathrm{HCO}_{3}$ & Fresh & LAR, SGR & shallow marine & Los Angeles \\
\hline $3 \mathrm{~S} / 13 \mathrm{~W}-11 \mathrm{G} 6$ & Lynwood1_5 & -48.0 & -7.45 & 0.7096 & $\mathrm{Na} / \mathrm{Ca}-\mathrm{HCO}_{3}$ & Fresh & LAR, SGR & shallow marine & Los Angeles \\
\hline 3S/13W-11G7 & Lynwood1_6 & -47.5 & -7.25 & 0.7084 & $\mathrm{Na} / \mathrm{Ca}-\mathrm{HCO}_{3}$ & Fresh & LAR & shallow marine & Los Angeles \\
\hline 3S/13W-11G8 & Lynwood1_7 & -46.2 & -7.22 & 0.7085 & $\mathrm{Ca} / \mathrm{Na}-\mathrm{HCO}_{3}$ & Fresh & LAR & shallow marine & Los Angeles \\
\hline 3S/13W-11G9 & Lynwood1_9 & -43.9 & -6.76 & 0.7084 & Ca-mixed & Fresh & LAR & non-marine & Local \\
\hline $3 \mathrm{~S} / 13 \mathrm{~W}-22 \mathrm{M} 2$ & Compton2_1 & -62.6 & -9.06 & - & $\mathrm{Na}-\mathrm{HCO}_{3}$ & Fresh & n.a. & deep marine & Montebello paleowater \\
\hline 3S/13W-22M3 & Compton2_2 & -56.4 & -8.34 & - & $\mathrm{Na}-\mathrm{HCO}_{3}$ & Fresh & n.a. & deep marine & Montebello paleowater \\
\hline 3S/13W-22M4 & Compton2_3 & -48.8 & -7.39 & - & $\mathrm{Na} / \mathrm{Ca}-\mathrm{HCO}_{3}$ & Fresh & n.a. & shallow marine & Los Angeles \\
\hline 3S/13W-22M5 & Compton2_4 & -48.4 & -7.26 & - & $\mathrm{Ca} / \mathrm{Na}-\mathrm{HCO}_{3}$ & Fresh & n.a. & shallow marine & Los Angeles \\
\hline $3 \mathrm{~S} / 13 \mathrm{~W}-22 \mathrm{M} 6$ & Compton2_5 & -49.1 & -7.43 & - & $\mathrm{Ca} / \mathrm{Na}-\mathrm{HCO}_{3}$ & Fresh & n.a. & shallow marine & Los Angeles \\
\hline 3S/13W-22M7 & Compton2_6 & -47.1 & -7.07 & - & $\mathrm{Ca}-\mathrm{HCO}_{3}$ & Fresh & n.a. & non-marine & Los Angeles \\
\hline $3 \mathrm{~S} / 13 \mathrm{~W}-24 \mathrm{~K} 2$ & Compton1_1 & -54.0 & -8.14 & - & $\mathrm{Na}-\mathrm{HCO}_{3}$ & Fresh & n.a. & shallow marine & Los Angeles paleowater \\
\hline $3 \mathrm{~S} / 13 \mathrm{~W}-24 \mathrm{~K} 3$ & Compton1_2 & -47.2 & -7.17 & - & $\mathrm{Na}-\mathrm{HCO}_{3}$ & Fresh & n.a. & shallow marine & Los Angeles \\
\hline $3 \mathrm{~S} / 13 \mathrm{~W}-24 \mathrm{~K} 4$ & Compton1_3 & -48.0 & -7.23 & - & $\mathrm{Ca} / \mathrm{Na}-\mathrm{HCO}_{3}$ & Fresh & n.a. & shallow marine & Los Angeles \\
\hline $3 \mathrm{~S} / 13 \mathrm{~W}-24 \mathrm{~K} 5$ & Compton1_4 & -48.8 & -7.26 & - & $\mathrm{Ca}-\mathrm{HCO}_{3}$ & Fresh & n.a. & shallow marine & Los Angeles \\
\hline $3 \mathrm{~S} / 13 \mathrm{~W}-24 \mathrm{~K} 6$ & Compton1_5 & -47.8 & -7.41 & - & $\mathrm{Ca}-\mathrm{HCO}_{3}$ & Fresh & n.a. & shallow marine & Los Angeles \\
\hline 4S/11W-5P9 & Cerritos1_1 & -56.3 & -8.26 & - & $\mathrm{Na}-\mathrm{HCO}_{3}$ & Fresh & n.a. & shallow marine & Montebello \\
\hline 4S/11W-5P10 & Cerritos1_2 & -53.3 & -8.13 & - & $\mathrm{Na}-\mathrm{HCO}_{3}$ & Fresh & n.a. & shallow marine & Montebello \\
\hline 4S/11W-5P11 & Cerritos1_3 & -53.1 & -8.14 & - & $\mathrm{Na}-\mathrm{HCO}_{3}$ & Fresh & n.a. & shallow marine & Montebello \\
\hline $4 \mathrm{~S} / 11 \mathrm{~W}-5 \mathrm{P} 12$ & Cerritos1_4 & -54.7 & -8.19 & - & $\mathrm{Ca} / \mathrm{Na}-\mathrm{HCO}_{3}$ & Fresh & n.a. & shallow marine & Montebello \\
\hline 4S/11W-5P13 & Cerritos1_5 & -52.3 & -8.13 & - & $\mathrm{Ca} / \mathrm{Na}-\mathrm{HCO}_{3}$ & Fresh & n.a. & shallow marine & Montebello \\
\hline $4 \mathrm{~S} / 11 \mathrm{~W}-5 \mathrm{P} 14$ & Cerritos1_6 & -53.0 & -8.08 & - & $\mathrm{Ca}-\mathrm{HCO}_{3}$ & Fresh & n.a. & shallow marine & Montebello \\
\hline $4 \mathrm{~S} / 12 \mathrm{~W}-5 \mathrm{H} 5$ & Lakewood1_1 & -58.6 & -8.91 & - & $\mathrm{Na}-\mathrm{HCO}_{3}$ & Fresh & n.a. & non-marine & Montebello Paleowater \\
\hline 4S/12W-5H6 & Lakewood1_2 & -53.1 & -8.18 & - & $\mathrm{Ca} / \mathrm{Na}-\mathrm{HCO}_{3}$ & Fresh & n.a. & shallow marine & Montebello \\
\hline 4S/12W-5H7 & Lakewood1_3 & -52.7 & -8.07 & - & $\mathrm{Ca}-\mathrm{HCO}_{3}$ & Fresh & n.a. & shallow marine & Montebello \\
\hline 4S/12W-5H8 & Lakewood1_4 & -50.8 & -7.85 & - & $\mathrm{Ca}-\mathrm{HCO}_{3}$ & Fresh & n.a. & non-marine & Mixed \\
\hline $4 \mathrm{~S} / 12 \mathrm{~W}-5 \mathrm{H} 9$ & Lakewood1_5 & -53.6 & -8.12 & - & $\mathrm{Ca}-\mathrm{HCO}_{3}$ & Fresh & n.a. & shallow marine & Montebello \\
\hline $4 \mathrm{~S} / 12 \mathrm{~W}-5 \mathrm{H} 10$ & Lakewood1_6 & -52.0 & -7.79 & - & $\mathrm{Ca}-\mathrm{HCO}_{3}$ & Fresh & n.a. & n.a. & Mixed \\
\hline
\end{tabular}


Table 1.2. Groundwater-quality data used for this study from multiple-well monitoring sites, and selected production and observation wells, Los Angeles and Orange Counties, California.-Continued

[See appendix 1 for explanation. Abbreviations: ft, foot; mg/L, milligrams per liter; mm/dd/yyyy, month/day/year; ug/L, micrograms per liter; CaCO ${ }_{3}$, calcium carbonate; $\%$, percent; <, less than; - , no data. Sediment source/facies: LAR, Los Angeles River; n.a., not assigned; SGR, San Gabriel River; SAR, Santa Ana River, *, potentially affected by mixing with anthropogenic sources of water or seawater]

\begin{tabular}{|c|c|c|c|c|c|c|c|c|c|}
\hline State well number & Local well name & $\begin{array}{c}\delta^{2} \text { Hydrogen, } \\
\text { unfiltered } \\
\text { (per mil) }\end{array}$ & $\begin{array}{c}\delta^{180 x y g e n}, \\
\text { unfiltered } \\
\text { (per mil) }\end{array}$ & $\begin{array}{c}\text { Strontium-87 / } \\
\text { Strontium-86, } \\
\text { filtered (atom } \\
\text { ratio) }\end{array}$ & $\begin{array}{l}\text { Chemical } \\
\text { facies }\end{array}$ & $\begin{array}{l}\text { Dissolved- } \\
\text { solids } \\
\text { classification }\end{array}$ & $\begin{array}{l}\text { Sediment } \\
\text { source }\end{array}$ & $\begin{array}{l}\text { Sediment } \\
\text { facies }\end{array}$ & $\begin{array}{l}\text { Groundwater } \\
\text { recharge source }\end{array}$ \\
\hline \multicolumn{10}{|c|}{ Pressure area-Continued } \\
\hline $4 \mathrm{~S} / 12 \mathrm{~W}-12 \mathrm{~F} 1$ & Lakewood2_1 & -56.9 & -8.32 & 0.7104 & $\mathrm{Na}-\mathrm{HCO}_{3}$ & Fresh & SGR, SAR & shallow marine & Montebello \\
\hline $4 \mathrm{~S} / 12 \mathrm{~W}-12 \mathrm{~F} 2$ & Lakewood2_2 & -56.0 & -8.38 & 0.7096 & $\mathrm{Na}-\mathrm{HCO}_{3}$ & Fresh & LAR, SGR & shallow marine & Montebello \\
\hline $4 \mathrm{~S} / 12 \mathrm{~W}-12 \mathrm{~F} 3$ & Lakewood2_3 & -54.5 & -8.30 & 0.7097 & $\mathrm{Na}-\mathrm{HCO}_{3}$ & Fresh & SGR & shallow marine & Montebello \\
\hline $4 \mathrm{~S} / 12 \mathrm{~W}-12 \mathrm{~F} 4$ & Lakewood2_4 & -55.1 & -8.20 & 0.7102 & $\mathrm{Ca}-\mathrm{HCO}_{3}$ & Fresh & SGR & shallow marine & Montebello \\
\hline $4 \mathrm{~S} / 12 \mathrm{~W}-12 \mathrm{~F} 5$ & Lakewood2_5 & -52.6 & -8.09 & 0.7098 & $\mathrm{Na} / \mathrm{Ca}-\mathrm{HCO}_{3}$ & Fresh & SGR & deep marine & Montebello \\
\hline $4 \mathrm{~S} / 12 \mathrm{~W}-12 \mathrm{~F} 6$ & Lakewood2_6 & -53.9 & -8.18 & 0.7106 & $\mathrm{Na}-\mathrm{HCO}_{3}$ & Fresh & SGR, SAR & deep marine & Montebello \\
\hline $4 \mathrm{~S} / 12 \mathrm{~W}-12 \mathrm{~F} 7$ & Lakewood2_7 & -53.8 & -8.18 & 0.7100 & $\mathrm{Ca}-\mathrm{HCO}_{3}$ & Fresh & SGR & deep marine & Montebello \\
\hline $4 \mathrm{~S} / 12 \mathrm{~W}-12 \mathrm{~F} 8$ & Lakewood2_8 & -54.2 & -8.14 & 0.7101 & $\mathrm{Ca} / \mathrm{Na}-\mathrm{HCO}_{3}$ & Fresh & SGR & deep marine & Montebello \\
\hline $4 \mathrm{~S} / 12 \mathrm{~W}-21 \mathrm{M} 8$ & Long Beach6_1 & -65.7 & -9.30 & - & $\mathrm{Na}-\mathrm{HCO}_{3}$ & Fresh & n.a. & deep marine & Montebello paleowater \\
\hline $4 \mathrm{~S} / 12 \mathrm{~W}-21 \mathrm{M} 9$ & Long Beach6_2 & -60.2 & -8.73 & - & $\mathrm{Na}-\mathrm{HCO}_{3}$ & Fresh & n.a. & deep marine & Montebello paleowater \\
\hline $4 \mathrm{~S} / 12 \mathrm{~W}-21 \mathrm{M} 10$ & Long Beach6_3 & -58.1 & -8.54 & - & $\mathrm{Na}-\mathrm{HCO}_{3}$ & Fresh & n.a. & deep marine & Montebello \\
\hline $4 \mathrm{~S} / 12 \mathrm{~W}-21 \mathrm{M} 11$ & Long Beach6_4 & -58.4 & -8.51 & - & $\mathrm{Na}-\mathrm{HCO}_{3}$ & Fresh & n.a. & shallow marine & Montebello \\
\hline $4 \mathrm{~S} / 12 \mathrm{~W}-21 \mathrm{M} 12$ & Long Beach6_5 & -58.6 & -8.57 & - & $\mathrm{Na}-\mathrm{HCO}_{3}$ & Fresh & n.a. & shallow marine & Montebello \\
\hline $4 \mathrm{~S} / 12 \mathrm{~W}-21 \mathrm{M} 13$ & Long Beach6_6 & -55.2 & -8.10 & - & $\mathrm{Ca} / \mathrm{Na}-\mathrm{HCO}_{3}$ & Fresh & n.a. & non-marine & Montebello \\
\hline $4 \mathrm{~S} / 12 \mathrm{~W}-23 \mathrm{~K} 3$ & LB Annex 201 & -56.6 & -8.39 & 0.7100 & $\mathrm{Na}-\mathrm{HCO}_{3}$ & Fresh & SGR & shallow marine & Montebello \\
\hline $4 \mathrm{~S} / 12 \mathrm{~W}-25 \mathrm{G} 1$ & Long Beach1_1 & -57.5 & -8.64 & - & $\mathrm{Na}-\mathrm{HCO}_{3}$ & Fresh & n.a. & deep marine & Montebello \\
\hline $4 \mathrm{~S} / 12 \mathrm{~W}-25 \mathrm{G} 2$ & Long Beach1_2 & -57.0 & -8.56 & - & $\mathrm{Na}-\mathrm{HCO}_{3}$ & Fresh & n.a. & deep marine & Montebello \\
\hline $4 \mathrm{~S} / 12 \mathrm{~W}-25 \mathrm{G} 3$ & Long Beach1_3 & -56.9 & -8.55 & - & $\mathrm{Na}-\mathrm{HCO}_{3}$ & Fresh & n.a. & shallow marine & Montebello \\
\hline $4 \mathrm{~S} / 12 \mathrm{~W}-25 \mathrm{G} 4$ & Long Beach1_4 & -57.0 & -8.39 & - & $\mathrm{Na}-\mathrm{HCO}_{3}$ & Fresh & n.a. & shallow marine & Montebello \\
\hline $4 \mathrm{~S} / 12 \mathrm{~W}-25 \mathrm{G} 5$ & Long Beach1_5 & -65.2 & -9.08 & - & $\mathrm{Na}-\mathrm{Cl} / \mathrm{SO}_{4}$ & Slightly saline & n.a. & $*$ & Injection/seawater (3\%) \\
\hline $4 \mathrm{~S} / 12 \mathrm{~W}-25 \mathrm{G} 6$ & Long Beach1_6 & -53.0 & -7.77 & - & Ca-mixed & Fresh & n.a. & non-marine & Montebello \\
\hline $4 \mathrm{~S} / 13 \mathrm{~W}-1 \mathrm{~N} 3$ & Long Beach2_1 & -63.6 & -9.17 & 0.7085 & $\mathrm{Na}-\mathrm{HCO}_{3}$ & Fresh & LAR & deep marine & Montebello paleowater \\
\hline $4 \mathrm{~S} / 13 \mathrm{~W}-1 \mathrm{~N} 4$ & Long Beach2_2 & -60.7 & -8.84 & 0.7096 & $\mathrm{Na}-\mathrm{HCO}_{3}$ & Fresh & LAR, SGR & deep marine & Montebello paleowater \\
\hline 4S/13W-1N5 & Long Beach2_3 & -51.1 & -7.87 & 0.7090 & $\mathrm{Na}-\mathrm{HCO}_{3}$ & Fresh & LAR, SGR & shallow marine & Montebello \\
\hline 4S/13W-1N6 & Long Beach2_4 & -49.0 & -7.55 & 0.7096 & $\mathrm{Na}-\mathrm{HCO}_{3}$ & Fresh & LAR, SGR & shallow marine & Los Angeles \\
\hline $4 \mathrm{~S} / 13 \mathrm{~W}-1 \mathrm{~N} 7$ & Long Beach2_5 & -41.7 & -6.44 & 0.7099 & $\mathrm{Ca}-\mathrm{SO}_{4} / \mathrm{HCO}_{3}$ & Fresh & SGR & non-marine & Local \\
\hline $4 \mathrm{~S} / 13 \mathrm{~W}-1 \mathrm{~N} 8$ & Long Beach2_6 & -41.8 & -6.20 & 0.7098 & $\mathrm{Ca}-\mathrm{SO}_{4} / \mathrm{HCO}_{3}$ & Slightly saline & SGR & non-marine & Local (slightly saline) \\
\hline
\end{tabular}


Table 1.2. Groundwater-quality data used for this study from multiple-well monitoring sites, and selected production and observation wells, Los Angeles and Orange Counties, California.-Continued

[See appendix 1 for explanation. Abbreviations: ft, foot; mg/L, milligrams per liter; mm/dd/yyyy, month/day/year; ug/L, micrograms per liter; CaCO 3 , calcium carbonate; \%, percent; <, less than; —, no data. Sediment source/facies: LAR, Los Angeles River; n.a., not assigned; SGR, San Gabriel River; SAR, Santa Ana River, *, potentially affected by mixing with anthropogenic sources of water or seawater]

\begin{tabular}{|c|c|c|c|c|c|c|c|c|c|}
\hline State well number & Local well name & $\begin{array}{c}\delta^{2} \text { Hydrogen, } \\
\text { unfiltered } \\
\text { (per mil) }\end{array}$ & $\begin{array}{c}\delta^{18} 0 x y g e n, \\
\text { unfiltered } \\
\text { (per mil) }\end{array}$ & $\begin{array}{c}\text { Strontium-87 / } \\
\text { Strontium-86, } \\
\text { filtered (atom } \\
\text { ratio) }\end{array}$ & $\begin{array}{l}\text { Chemical } \\
\text { facies }\end{array}$ & $\begin{array}{l}\text { Dissolved- } \\
\text { solids } \\
\text { classification }\end{array}$ & $\begin{array}{l}\text { Sediment } \\
\text { source }\end{array}$ & $\begin{array}{l}\text { Sediment } \\
\text { facies }\end{array}$ & $\begin{array}{l}\text { Groundwater } \\
\text { recharge source }\end{array}$ \\
\hline \multicolumn{10}{|c|}{ Orange County Basin } \\
\hline 3S/08W34G2 & $\begin{array}{l}\text { Canyon_RV_1 } \\
\text { EAST }\end{array}$ & -54.2 & -7.50 & 0.7106 & $\mathrm{Ca} / \mathrm{Na}$-mixed & Fresh & SAR, Local & non-marine & n.a. \\
\hline 4S/10W14H3 & Anaheim_46 & -56.3 & -7.85 & 0.7116 & $\mathrm{Ca} / \mathrm{Na}-$ mixed & Fresh & SAR & non-marine & n.a. \\
\hline $5 \mathrm{~S} / 12 \mathrm{~W}-1 \mathrm{C} 1$ & 512B & -75.8 & -9.76 & 0.7110 & $\mathrm{Ca} / \mathrm{Na}$-mixed & Fresh & SGR, SAR & non-marine & Injection \\
\hline $5 \mathrm{~S} / 12 \mathrm{~W}-1 \mathrm{C} 2$ & $512 \mathrm{C}$ & -75.1 & -9.85 & 0.7109 & $\mathrm{Na} / \mathrm{Ca}$-mixed & Fresh & SGR, SAR & non-marine & Injection \\
\hline $5 \mathrm{~S} / 12 \mathrm{~W}-1 \mathrm{C} 3$ & Seal Beach1_1 & -62.3 & -9.15 & 0.7104 & $\mathrm{Na}-\mathrm{HCO}_{3}$ & Fresh & SGR & deep marine & Montebello paleowater \\
\hline $5 \mathrm{~S} / 12 \mathrm{~W}-1 \mathrm{C} 4$ & Seal Beach1_2 & -58.9 & -8.69 & 0.7105 & $\mathrm{Na}-\mathrm{HCO}_{3}$ & Fresh & SGR, SAR & shallow marine & Montebello \\
\hline $5 \mathrm{~S} / 12 \mathrm{~W}-1 \mathrm{C} 5$ & Seal Beach1_3 & -58.0 & -8.63 & 0.7103 & $\mathrm{Na}-\mathrm{HCO}_{3}$ & Fresh & SGR & deep marine & Montebello \\
\hline $5 \mathrm{~S} / 12 \mathrm{~W}-1 \mathrm{C} 6$ & Seal Beach1_4 & -61.2 & -9.03 & 0.7101 & $\mathrm{Na}-\mathrm{HCO}_{3}$ & Fresh & SGR & deep marine & Montebello paleowater \\
\hline $5 \mathrm{~S} / 12 \mathrm{~W}-1 \mathrm{C} 7$ & Seal Beach1_5 & -57.4 & -8.42 & 0.7103 & $\mathrm{Na}-\mathrm{HCO}_{3}$ & Fresh & SGR & shallow marine & Montebello \\
\hline $5 \mathrm{~S} / 12 \mathrm{~W}-1 \mathrm{C} 8$ & Seal Beach1_6 & -79.8 & -10.28 & 0.7106 & $\mathrm{Na} / \mathrm{Ca}$-mixed & Fresh & SGR, SAR & non-marine & Montebello/Injection \\
\hline $5 \mathrm{~S} / 12 \mathrm{~W}-1 \mathrm{C} 9$ & Seal Beach1_7 & -53.1 & -7.81 & 0.7106 & $\mathrm{Ca} / \mathrm{Na}-\mathrm{Cl}$ & Slightly saline & SGR, SAR & $*$ & Montebello/seawater (4\%) \\
\hline \multicolumn{10}{|c|}{ West Coast Basin } \\
\hline $2 \mathrm{~S} / 14 \mathrm{~W}-18 \mathrm{~J} 1$ & Holy_Cross_AA & -45.6 & -6.63 & 0.7084 & mixed-mixed & Slightly saline & LAR & n.a. & Local (slightly saline) \\
\hline 2S/14W-19G1 & Hillside_Park_1 & -42.2 & -6.54 & 0.7085 & $\mathrm{Na} / \mathrm{Ca}-\mathrm{HCO}_{3}$ & Fresh & LAR & shallow marine & Local \\
\hline $2 \mathrm{~S} / 14 \mathrm{~W}-28 \mathrm{M} 3$ & Inglewood1_1 & -49.9 & -7.98 & 0.7089 & $\mathrm{Na}-\mathrm{Cl}$ & $\begin{array}{l}\text { Moderately } \\
\text { saline }\end{array}$ & LAR, SGR & n.a. & $\begin{array}{l}\text { Los Angeles paleowater } \\
\text { (moderately saline) }\end{array}$ \\
\hline 2S/14W-28M4 & Inglewood1_2 & -41.0 & -6.18 & 0.7083 & mixed-Cl/ $\mathrm{HCO}_{3}$ & Slightly saline & LAR & n.a. & Local (slightly saline) \\
\hline 2S/14W-28M5 & Inglewood1_3 & -41.1 & -6.09 & 0.7084 & $\mathrm{Na} / \mathrm{Ca}-\mathrm{Cl}$ & Fresh & LAR & n.a. & Local \\
\hline 2S/14W-28M6 & Inglewood1_4 & -39.4 & -6.14 & - & $\mathrm{Ca} / \mathrm{Na}-\mathrm{Cl}$ & Fresh & n.a. & non-marine & Local \\
\hline $2 \mathrm{~S} / 14 \mathrm{~W}-28 \mathrm{M} 7$ & Inglewood1_5 & -40.5 & -6.16 & - & $\mathrm{Ca} / \mathrm{Na}-\mathrm{Cl}$ & Fresh & n.a. & n.a. & Local \\
\hline $2 \mathrm{~S} / 15 \mathrm{~W}-35 \mathrm{~A} 1$ & Westchester1_1 & -50.4 & -7.54 & - & $\mathrm{Na}-\mathrm{HCO}_{3}$ & Slightly saline & n.a. & deep marine & $\begin{array}{l}\text { Los Angeles paleowater } \\
\text { (slightly saline) }\end{array}$ \\
\hline $2 \mathrm{~S} / 15 \mathrm{~W}-35 \mathrm{~A} 2$ & Westchester1_2 & -45.0 & -6.83 & - & $\mathrm{Na}-\mathrm{HCO}_{3}$ & Fresh & n.a. & deep marine & Local paleowater \\
\hline $2 \mathrm{~S} / 15 \mathrm{~W}-35 \mathrm{~A} 3$ & Westchester1_3 & -44.5 & -6.69 & - & $\mathrm{Na}-\mathrm{HCO}_{3}$ & Fresh & n.a. & shallow marine & Local \\
\hline $2 \mathrm{~S} / 15 \mathrm{~W}-35 \mathrm{~A} 4$ & Westchester1_4 & -40.1 & -6.18 & - & $\mathrm{Na} / \mathrm{Ca}-\mathrm{HCO}_{3}$ & Fresh & n.a. & shallow marine & Local \\
\hline $2 \mathrm{~S} / 15 \mathrm{~W}-35 \mathrm{~A} 5$ & Westchester1_5 & -40.8 & -6.18 & - & $\mathrm{Na} / \mathrm{Ca}-\mathrm{HCO}_{3}$ & Fresh & n.a. & shallow marine & Local \\
\hline $3 \mathrm{~S} / 14 \mathrm{~W}-4 \mathrm{R} 1$ & Inglewood3_1 & -55.4 & -8.30 & 0.7090 & $\mathrm{Na}-\mathrm{Cl}$ & Slightly saline & LAR, SGR & n.a. & $\begin{array}{l}\text { Montebello paleowater } \\
\quad \text { (slightly saline) }\end{array}$ \\
\hline
\end{tabular}


Table 1.2. Groundwater-quality data used for this study from multiple-well monitoring sites, and selected production and observation wells, Los Angeles and Orange Counties, California.-Continued

[See appendix 1 for explanation. Abbreviations: ft, foot; mg/L, milligrams per liter; mm/dd/yyyy, month/day/year; ug/L, micrograms per liter; CaCO ${ }_{3}$, calcium carbonate; $\%$, percent; <, less than; - , no data. Sediment source/facies: LAR, Los Angeles River; n.a., not assigned; SGR, San Gabriel River; SAR, Santa Ana River, *, potentially affected by mixing with anthropogenic sources of water or seawater]

\begin{tabular}{|c|c|c|c|c|c|c|c|c|c|}
\hline State well number & Local well name & $\begin{array}{c}\delta^{2} \text { Hydrogen, } \\
\text { unfiltered } \\
\text { (per mil) }\end{array}$ & $\begin{array}{c}\delta^{18} \text { Oxygen, } \\
\text { unfiltered } \\
\text { (per mil) }\end{array}$ & $\begin{array}{l}\text { Strontium-87 / } \\
\text { Strontium-86, } \\
\text { filtered (atom } \\
\text { ratio) }\end{array}$ & $\begin{array}{l}\text { Chemical } \\
\text { facies }\end{array}$ & $\begin{array}{l}\text { Dissolved- } \\
\text { solids } \\
\text { classification }\end{array}$ & $\begin{array}{l}\text { Sediment } \\
\text { source }\end{array}$ & $\begin{array}{l}\text { Sediment } \\
\text { facies }\end{array}$ & $\begin{array}{l}\text { Groundwater } \\
\text { recharge source }\end{array}$ \\
\hline \multicolumn{10}{|c|}{ West Coast Basin-Continued } \\
\hline $3 \mathrm{~S} / 14 \mathrm{~W}-4 \mathrm{R} 2$ & Inglewood3_2 & -60.0 & -9.11 & 0.7095 & $\mathrm{Na}-\mathrm{HCO}_{3}$ & Slightly saline & LAR, SGR & deep marine & $\begin{array}{l}\text { Montebello paleowater } \\
\text { (slightly saline) }\end{array}$ \\
\hline 3S/14W-4R3 & Inglewood3_3 & -58.4 & -8.59 & 0.7089 & $\mathrm{Na}-\mathrm{HCO}_{3}$ & Fresh & LAR, SGR & deep marine & Montebello paleowater \\
\hline $3 \mathrm{~S} / 14 \mathrm{~W}-4 \mathrm{R} 4$ & Inglewood3_4 & -54.4 & -8.31 & 0.7090 & $\mathrm{Na}-\mathrm{HCO}_{3}$ & Fresh & LAR, SGR & deep marine & Los Angeles paleowater \\
\hline $3 \mathrm{~S} / 14 \mathrm{~W}-4 \mathrm{R} 5$ & Inglewood3_5 & -40.8 & -6.45 & 0.7082 & $\mathrm{Na} / \mathrm{Ca}-\mathrm{HCO}_{3}$ & Fresh & LAR & non-marine & Local \\
\hline 3S/14W-4R6 & Inglewood3_6 & -44.4 & -7.03 & 0.7084 & $\mathrm{Ca} / \mathrm{Na}-\mathrm{HCO}_{3} / \mathrm{Cl}$ & Fresh & LAR & non-marine & Mixed \\
\hline $3 \mathrm{~S} / 14 \mathrm{~W}-4 \mathrm{R} 7$ & Inglewood3_7 & -40.3 & -6.44 & 0.7082 & mixed-Cl & Fresh & LAR & n.a. & Local \\
\hline $3 \mathrm{~S} / 14 \mathrm{~W}-13 \mathrm{~J} 5$ & Gardena1_1 & -53.3 & -7.75 & - & $\mathrm{Na}-\mathrm{HCO}_{3}$ & Fresh & n.a. & deep marine & Los Angeles paleowater \\
\hline $3 \mathrm{~S} / 14 \mathrm{~W}-13 \mathrm{~J} 6$ & Gardena1_2 & -49.0 & -7.29 & - & $\mathrm{Ca} / \mathrm{Na}-\mathrm{HCO}_{3}$ & Fresh & n.a. & shallow marine & Los Angeles \\
\hline $3 \mathrm{~S} / 14 \mathrm{~W}-13 \mathrm{~J} 7$ & Gardena1_3 & -48.0 & -7.29 & - & $\mathrm{Ca} / \mathrm{Na}-\mathrm{HCO}_{3}$ & Fresh & n.a. & shallow marine & Los Angeles \\
\hline $3 \mathrm{~S} / 14 \mathrm{~W}-13 \mathrm{~J} 8$ & Gardena1_4 & -42.4 & -6.49 & - & $\mathrm{Ca}-\mathrm{Cl}$ & Fresh & n.a. & n.a. & Local \\
\hline $3 \mathrm{~S} / 14 \mathrm{~W}-17 \mathrm{G} 3$ & Hawthorne1_1 & -50.5 & -7.70 & - & $\mathrm{Na}-\mathrm{HCO}_{3}$ & Fresh & n.a. & deep marine & Los Angeles paleowater \\
\hline $3 \mathrm{~S} / 14 \mathrm{~W}-17 \mathrm{G} 4$ & Hawthorne1_2 & -49.3 & -7.59 & - & $\mathrm{Na}-\mathrm{HCO}_{3}$ & Fresh & n.a. & deep marine & Los Angeles paleowater \\
\hline $3 \mathrm{~S} / 14 \mathrm{~W}-17 \mathrm{G} 5$ & Hawthorne1_3 & -46.1 & -7.06 & - & $\mathrm{Na}-\mathrm{HCO}_{3}$ & Fresh & n.a. & shallow marine & Local paleowater \\
\hline $3 \mathrm{~S} / 14 \mathrm{~W}-17 \mathrm{G} 6$ & Hawthorne1_4 & -45.6 & -7.03 & - & $\mathrm{Na}-\mathrm{HCO}_{3}$ & Fresh & n.a. & shallow marine & Mixed \\
\hline $3 \mathrm{~S} / 14 \mathrm{~W}-17 \mathrm{G} 7$ & Hawthorne1_5 & -45.5 & -6.92 & - & $\mathrm{Ca} / \mathrm{Na}-\mathrm{Cl}$ & Fresh & n.a. & non-marine & Mixed \\
\hline $3 \mathrm{~S} / 14 \mathrm{~W}-17 \mathrm{G} 8$ & Hawthorne1_6 & -50.6 & -6.85 & - & $\mathrm{Ca} / \mathrm{Na}$-mixed & Slightly saline & n.a. & $*$ & $\begin{array}{l}\text { Los Angeles/injection/ } \\
\text { seawater }(3 \%)\end{array}$ \\
\hline $3 \mathrm{~S} / 14 \mathrm{~W}-25 \mathrm{~K} 7$ & Gardena2_1 & -55.6 & -8.18 & - & $\mathrm{Na}-\mathrm{HCO}_{3}$ & Fresh & n.a. & deep marine & Los Angeles paleowater \\
\hline $3 \mathrm{~S} / 14 \mathrm{~W}-25 \mathrm{~K} 8$ & Gardena2_2 & -48.6 & -7.34 & 0.7084 & $\mathrm{Na} / \mathrm{Ca}-\mathrm{HCO}_{3}$ & Fresh & LAR & shallow marine & Los Angeles \\
\hline $3 \mathrm{~S} / 14 \mathrm{~W}-25 \mathrm{~K} 9$ & Gardena2_3 & -47.6 & -7.32 & - & $\mathrm{Ca} / \mathrm{Na}-\mathrm{HCO}_{3}$ & Fresh & n.a. & shallow marine & Los Angeles \\
\hline $3 \mathrm{~S} / 14 \mathrm{~W}-25 \mathrm{~K} 10$ & Gardena2_4 & -46.8 & -7.22 & - & $\mathrm{Na} / \mathrm{Ca}-\mathrm{HCO}_{3}$ & Fresh & n.a. & shallow marine & Los Angeles \\
\hline $3 \mathrm{~S} / 14 \mathrm{~W}-25 \mathrm{~K} 11$ & Gardena2_5 & -47.1 & -7.30 & 0.7084 & $\mathrm{Ca} / \mathrm{Na}-\mathrm{HCO}_{3}$ & Fresh & LAR & shallow marine & Los Angeles \\
\hline $3 \mathrm{~S} / 14 \mathrm{~W}-27 \mathrm{C} 2$ & Lawndale1_1 & -60.9 & -8.99 & 0.7090 & $\mathrm{Na}-\mathrm{HCO}_{3}$ & Fresh & LAR, SGR & deep marine & Montebello paleowater \\
\hline $3 \mathrm{~S} / 14 \mathrm{~W}-27 \mathrm{C} 3$ & Lawndale1_2 & -53.2 & -7.96 & 0.7091 & $\mathrm{Na}-\mathrm{HCO}_{3}$ & Fresh & LAR, SGR & deep marine & Los Angeles paleowater \\
\hline $3 \mathrm{~S} / 14 \mathrm{~W}-27 \mathrm{C} 4$ & Lawndale1_3 & -48.0 & -7.45 & 0.7088 & $\mathrm{Na}-\mathrm{HCO}_{3}$ & Fresh & LAR, SGR & shallow marine & Los Angeles \\
\hline $3 \mathrm{~S} / 14 \mathrm{~W}-27 \mathrm{C} 5$ & Lawndale1_4 & -45.2 & -7.10 & 0.7084 & $\mathrm{Ca} / \mathrm{Na}-\mathrm{HCO}_{3}$ & Fresh & LAR & non-marine & Mixed \\
\hline $3 \mathrm{~S} / 14 \mathrm{~W}-27 \mathrm{C} 6$ & Lawndale1_5 & -45.5 & -7.03 & 0.7084 & $\mathrm{Ca} / \mathrm{Na}-\mathrm{HCO}_{3}$ & Fresh & LAR & non-marine & Mixed \\
\hline $3 \mathrm{~S} / 14 \mathrm{~W}-27 \mathrm{C} 7$ & Lawndale1_6 & -41.9 & -6.28 & 0.7084 & $\mathrm{Ca} / \mathrm{Na}-\mathrm{Cl}$ & Slightly saline & LAR & $*$ & Local (slightly saline) \\
\hline
\end{tabular}


Table 1.2. Groundwater-quality data used for this study from multiple-well monitoring sites, and selected production and observation wells, Los Angeles and Orange Counties, California.-Continued

[See appendix 1 for explanation. Abbreviations: ft, foot; mg/L, milligrams per liter; mm/dd/yyyy, month/day/year; ug/L, micrograms per liter; CaCO 3 , calcium carbonate; \%, percent; <, less than; —, no data. Sediment source/facies: LAR, Los Angeles River; n.a., not assigned; SGR, San Gabriel River; SAR, Santa Ana River, *, potentially affected by mixing with anthropogenic sources of water or seawater]

\begin{tabular}{|c|c|c|c|c|c|c|c|c|c|}
\hline State well number & Local well name & $\begin{array}{c}\delta^{2} \text { Hydrogen, } \\
\text { unfiltered } \\
\text { (per mil) }\end{array}$ & $\begin{array}{c}\delta^{18} 0 x y g e n, \\
\text { unfiltered } \\
\text { (per mil) }\end{array}$ & $\begin{array}{l}\text { Strontium-87 / } \\
\text { Strontium-86, } \\
\text { filtered (atom } \\
\text { ratio) }\end{array}$ & $\begin{array}{l}\text { Chemical } \\
\text { facies }\end{array}$ & $\begin{array}{l}\text { Dissolved- } \\
\text { solids } \\
\text { classification }\end{array}$ & $\begin{array}{l}\text { Sediment } \\
\text { source }\end{array}$ & $\begin{array}{l}\text { Sediment } \\
\text { facies }\end{array}$ & $\begin{array}{l}\text { Groundwater } \\
\text { recharge source }\end{array}$ \\
\hline \multicolumn{10}{|c|}{ West Coast Basin-Continued } \\
\hline 3S/14W-30L2 & $\begin{array}{l}\text { Manhattan } \\
\text { Beach1_1 }\end{array}$ & -42.3 & -6.72 & 0.7099 & $\mathrm{Na}-\mathrm{Cl}$ & $\begin{array}{l}\text { Moderately } \\
\text { saline }\end{array}$ & SGR & n.a. & $\begin{array}{l}\text { Los Angeles paleowater } \\
\text { (moderately saline) }\end{array}$ \\
\hline $3 \mathrm{~S} / 14 \mathrm{~W}-30 \mathrm{~L} 3$ & $\begin{array}{l}\text { Manhattan } \\
\text { Beach1_2 }\end{array}$ & -56.5 & -8.49 & 0.7102 & $\mathrm{Na}-\mathrm{Cl}$ & Slightly saline & SGR & n.a. & $\begin{array}{l}\text { Montebello paleowater } \\
\quad \text { (slightly saline) }\end{array}$ \\
\hline 3S/14W-30L4 & $\begin{array}{l}\text { Manhattan } \\
\text { Beach1_3 }\end{array}$ & -61.9 & -9.05 & 0.7091 & $\mathrm{Na}-\mathrm{HCO}_{3}$ & Slightly saline & LAR, SGR & deep marine & $\begin{array}{l}\text { Montebello paleowater } \\
\quad \text { (slightly saline) }\end{array}$ \\
\hline $3 \mathrm{~S} / 14 \mathrm{~W}-30 \mathrm{~L} 5$ & $\begin{array}{l}\text { Manhattan } \\
\text { Beach1_4 }\end{array}$ & -51.9 & -7.86 & 0.7085 & $\mathrm{Na}-\mathrm{HCO}_{3}$ & Fresh & LAR & deep marine & Los Angeles paleowater \\
\hline 3S/14W-30L6 & $\begin{array}{l}\text { Manhattan } \\
\text { Beach1_5 }\end{array}$ & -23.3 & -3.79 & 0.7087 & $\mathrm{Na}-\mathrm{Cl}$ & Highly saline & LAR & $*$ & $\begin{array}{l}\text { Montebello paleowater } \\
\text { (highly saline) }\end{array}$ \\
\hline $3 \mathrm{~S} / 14 \mathrm{~W}-30 \mathrm{~L} 7$ & $\begin{array}{l}\text { Manhattan } \\
\text { Beach1_6 }\end{array}$ & -37.8 & -5.81 & 0.7084 & $\mathrm{Na} / \mathrm{Ca}-\mathrm{Cl}$ & $\begin{array}{l}\text { Moderately } \\
\text { saline }\end{array}$ & LAR & $*$ & $\begin{array}{l}\text { Los Angeles/seawater } \\
\quad(21 \%)\end{array}$ \\
\hline $3 \mathrm{~S} / 14 \mathrm{~W}-30 \mathrm{~L} 8$ & $\begin{array}{l}\text { Manhattan } \\
\text { Beach1_7 }\end{array}$ & -63.3 & -8.61 & 0.7085 & Na-mixed & Fresh & LAR & non-marine & Injection \\
\hline 3S/14W-33R5 & Torrance1_1 & -61.4 & -8.96 & 0.7093 & $\mathrm{Na}-\mathrm{HCO}_{3}$ & Fresh & LAR, SGR & deep marine & Montebello paleowater \\
\hline $3 \mathrm{~S} / 14 \mathrm{~W}-33 \mathrm{R} 6$ & Torrance1_2 & -62.8 & -9.01 & 0.7092 & $\mathrm{Na}-\mathrm{HCO}_{3}$ & Slightly saline & LAR, SGR & deep marine & $\begin{array}{l}\text { Montebello paleowater } \\
\quad \text { (slightly saline) }\end{array}$ \\
\hline $3 \mathrm{~S} / 14 \mathrm{~W}-33 \mathrm{R} 7$ & Torrance1_3 & -57.5 & -8.39 & 0.7092 & $\mathrm{Na}-\mathrm{HCO}_{3}$ & Fresh & LAR, SGR & deep marine & Montebello paleowater \\
\hline $3 \mathrm{~S} / 14 \mathrm{~W}-33 \mathrm{R} 8$ & Torrance1_4 & -50.2 & -7.80 & 0.7085 & $\mathrm{Na}-\mathrm{HCO}_{3}$ & Fresh & LAR & shallow marine & Los Angeles paleowater \\
\hline 3S/14W-33R9 & Torrance1_5 & -64.0 & -8.62 & 0.7084 & $\mathrm{Ca} / \mathrm{Na}-\mathrm{Cl}$ & $\begin{array}{l}\text { Moderately } \\
\text { saline }\end{array}$ & LAR & $*$ & Injection/seawater $(8 \%)$ \\
\hline $3 \mathrm{~S} / 14 \mathrm{~W}-33 \mathrm{R} 10$ & Torrance1_6 & -58.6 & -7.94 & 0.7085 & $\mathrm{Na} / \mathrm{Ca}$-mixed & Fresh & LAR & non-marine & Injection \\
\hline 4S/12W-30J1 & Long Beach8_1 & -61.9 & -9.19 & - & $\mathrm{Na}-\mathrm{HCO}_{3}$ & Fresh & n.a. & deep marine & Montebello paleowater \\
\hline $4 \mathrm{~S} / 12 \mathrm{~W}-30 \mathrm{~J} 2$ & Long Beach8_2 & -62.3 & -9.17 & - & $\mathrm{Na}-\mathrm{HCO}_{3}$ & Fresh & n.a. & shallow marine & Montebello paleowater \\
\hline $4 \mathrm{~S} / 12 \mathrm{~W}-30 \mathrm{~J} 3$ & Long Beach8_3 & -63.6 & -9.29 & - & $\mathrm{Na}-\mathrm{HCO}_{3}$ & Fresh & n.a. & shallow marine & Montebello paleowater \\
\hline $4 \mathrm{~S} / 12 \mathrm{~W}-30 \mathrm{~J} 4$ & Long Beach8_4 & -60.9 & -9.04 & - & $\mathrm{Na}-\mathrm{Cl}$ & Slightly saline & n.a. & n.a. & $\begin{array}{l}\text { Montebello paleowater } \\
\text { (slightly saline) }\end{array}$ \\
\hline $4 \mathrm{~S} / 12 \mathrm{~W}-30 \mathrm{~J} 5$ & Long Beach8_5 & -60.5 & -8.99 & - & $\mathrm{Na}-\mathrm{Cl}$ & Slightly saline & n.a. & n.a. & $\begin{array}{l}\text { Montebello paleowater } \\
\quad \text { (slightly saline) }\end{array}$ \\
\hline 4S/12W-30J6 & Long Beach8_6 & -56.1 & -8.39 & - & $\mathrm{Na}-\mathrm{Cl}$ & Fresh & n.a. & n.a. & Montebello \\
\hline $4 \mathrm{~S} / 13 \mathrm{~W}-5 \mathrm{~F} 1$ & Carson3_1 & -62.4 & -9.17 & 0.7090 & $\mathrm{Na}-\mathrm{HCO}_{3}$ & Fresh & LAR, SGR & deep marine & Montebello paleowater \\
\hline
\end{tabular}


Table 1.2. Groundwater-quality data used for this study from multiple-well monitoring sites, and selected production and observation wells, Los Angeles and Orange Counties, California.-Continued

[See appendix 1 for explanation. Abbreviations: ft, foot; mg/L, milligrams per liter; mm/dd/yyyy, month/day/year; ug/L, micrograms per liter; CaCO ${ }_{3}$, calcium carbonate; $\%$, percent; <, less than; - , no data.

Sediment source/facies: LAR, Los Angeles River; n.a., not assigned; SGR, San Gabriel River; SAR, Santa Ana River, *, potentially affected by mixing with anthropogenic sources of water or seawater]

\begin{tabular}{|c|c|c|c|c|c|c|c|c|c|}
\hline State well number & Local well name & $\begin{array}{c}\delta^{2} \text { Hydrogen, } \\
\text { unfiltered } \\
\text { (per mil) }\end{array}$ & $\begin{array}{c}\delta^{18} \text { Oxygen, } \\
\text { unfiltered } \\
\text { (per mil) }\end{array}$ & $\begin{array}{l}\text { Strontium-87 / } \\
\text { Strontium-86, } \\
\text { filtered (atom } \\
\text { ratio) }\end{array}$ & $\begin{array}{l}\text { Chemical } \\
\text { facies }\end{array}$ & $\begin{array}{l}\text { Dissolved- } \\
\text { solids } \\
\text { classification }\end{array}$ & $\begin{array}{l}\text { Sediment } \\
\text { source }\end{array}$ & $\begin{array}{l}\text { Sediment } \\
\text { facies }\end{array}$ & $\begin{array}{l}\text { Groundwater } \\
\text { recharge source }\end{array}$ \\
\hline \multicolumn{10}{|c|}{ West Coast Basin-Continued } \\
\hline $4 \mathrm{~S} / 13 \mathrm{~W}-5 \mathrm{~F} 2$ & Carson3_2 & -48.5 & -7.44 & 0.7090 & $\mathrm{Na}-\mathrm{HCO}_{3}$ & Fresh & LAR, SGR & shallow marine & Los Angeles \\
\hline $4 \mathrm{~S} / 13 \mathrm{~W}-5 \mathrm{~F} 3$ & Carson3_3 & -48.3 & -7.32 & 0.7089 & $\mathrm{Na}-\mathrm{HCO}_{3}$ & Fresh & LAR, SGR & shallow marine & Los Angeles \\
\hline 4S/13W-5F4 & Carson3_4 & -48.5 & -7.23 & 0.7087 & $\mathrm{Na}-\mathrm{HCO}_{3}$ & Fresh & LAR & shallow marine & Los Angeles \\
\hline 4S/13W-5F5 & Carson3_5 & -47.3 & -7.29 & 0.7086 & $\mathrm{Na} / \mathrm{Ca}-\mathrm{HCO}_{3}$ & Fresh & LAR & shallow marine & Los Angeles \\
\hline 4S/13W-5F6 & Carson3_6 & -47.1 & -7.27 & 0.7085 & $\mathrm{Na} / \mathrm{Ca}-\mathrm{HCO}_{3}$ & Fresh & LAR & shallow marine & Los Angeles \\
\hline 4S/13W-9H9 & Carson1_1 & -48.4 & -7.33 & 0.7090 & $\mathrm{Na}-\mathrm{HCO}_{3}$ & Fresh & LAR, SGR & shallow marine & Los Angeles \\
\hline 4S/13W-9H10 & Carson1_2 & -46.6 & -7.27 & 0.7090 & $\mathrm{Na} / \mathrm{Ca}-\mathrm{HCO}_{3}$ & Fresh & LAR, SGR & shallow marine & Los Angeles \\
\hline 4S/13W-9H11 & Carson1_3 & -47.3 & -7.30 & 0.7089 & $\mathrm{Ca} / \mathrm{Na}-\mathrm{HCO}_{3}$ & Fresh & LAR, SGR & shallow marine & Los Angeles \\
\hline 4S/13W-9H12 & Carson1_4 & -47.0 & -7.12 & 0.7094 & $\mathrm{Ca} / \mathrm{Na}-\mathrm{HCO}_{3}$ & Fresh & LAR, SGR & non-marine & Los Angeles \\
\hline 4S/13W-18K1 & Carson2_1 & -50.4 & -7.51 & - & $\mathrm{Na}-\mathrm{HCO}_{3}$ & Fresh & n.a. & shallow marine & Los Angeles \\
\hline 4S/13W-18K2 & Carson2_2 & -49.5 & -7.33 & - & $\mathrm{Na}-\mathrm{HCO}_{3}$ & Fresh & n.a. & shallow marine & Los Angeles \\
\hline 4S/13W-18K3 & Carson2_3 & -48.2 & -7.27 & - & $\mathrm{Na}-\mathrm{HCO}_{3}$ & Fresh & n.a. & shallow marine & Los Angeles \\
\hline $4 \mathrm{~S} / 13 \mathrm{~W}-18 \mathrm{~K} 4$ & Carson2_4 & -49.5 & -7.54 & - & $\mathrm{Na} / \mathrm{Ca}-\mathrm{HCO}_{3}$ & Fresh & n.a. & shallow marine & Los Angeles \\
\hline $4 \mathrm{~S} / 13 \mathrm{~W}-18 \mathrm{~K} 5$ & Carson2_5 & -48.3 & -7.24 & - & $\mathrm{Ca} / \mathrm{Na}-\mathrm{HCO}_{3}$ & Fresh & n.a. & shallow marine & Los Angeles \\
\hline 4S/13W-23D3 & Long Beach3_1 & -62.7 & -9.17 & 0.7089 & $\mathrm{Na}-\mathrm{HCO}_{3}$ & Fresh & LAR, SGR & deep marine & Montebello paleowater \\
\hline 4S/13W-23D4 & Long Beach3_2 & -51.1 & -7.72 & 0.7095 & $\mathrm{Na}-\mathrm{HCO}_{3}$ & Fresh & LAR, SGR & shallow marine & Mixed \\
\hline 4S/13W-23D5 & Long Beach3_3 & -53.2 & -8.07 & 0.7094 & $\mathrm{Na}-\mathrm{HCO}_{3}$ & Fresh & LAR, SGR & shallow marine & Montebello \\
\hline 4S/13W-23D6 & Long Beach3_4 & -48.4 & -7.32 & 0.7093 & $\mathrm{Ca}-\mathrm{Cl}$ & Fresh & LAR, SGR & n.a. & Los Angeles \\
\hline 4S/13W-23D7 & Long Beach3_5 & -47.4 & -7.10 & 0.7092 & $\mathrm{Ca}-\mathrm{Cl}$ & Slightly saline & LAR, SGR & $*$ & Los Angeles/seawater (3\%) \\
\hline 4S/13W-23N3 & $889 \mathrm{P}$ & -56.6 & -8.48 & 0.7094 & $\mathrm{Na}-\mathrm{HCO}_{3} / \mathrm{Cl}$ & Fresh & LAR, SGR & non-marine & Montebello \\
\hline $4 \mathrm{~S} / 13 \mathrm{~W}-26 \mathrm{~F} 5$ & $380 \mathrm{P}$ & -53.3 & -7.85 & 0.7094 & $\mathrm{Na}-\mathrm{HCO}_{3}$ & Fresh & LAR, SGR & shallow marine & Montebello \\
\hline $4 \mathrm{~S} / 13 \mathrm{~W}-27 \mathrm{H} 4$ & Long Beach7_1 & -64.0 & -9.39 & 0.7092 & $\mathrm{Na}-\mathrm{HCO}_{3}$ & Fresh & LAR, SGR & deep marine & Montebello paleowater \\
\hline $4 \mathrm{~S} / 13 \mathrm{~W}-27 \mathrm{H} 5$ & Long Beach7_2 & -55.1 & -8.37 & 0.7090 & $\mathrm{Na}-\mathrm{HCO}_{3}$ & Fresh & LAR, SGR & non-marine & Montebello paleowater \\
\hline $4 \mathrm{~S} / 13 \mathrm{~W}-27 \mathrm{H} 6$ & Long Beach7_3 & -53.6 & -8.15 & 0.7089 & $\mathrm{Na}-\mathrm{HCO}_{3}$ & Fresh & LAR, SGR & non-marine & Los Angeles paleowater \\
\hline 4S/13W-27H7 & Long Beach7_4 & -45.9 & -6.86 & 0.7092 & $\mathrm{Na} / \mathrm{Ca}-\mathrm{Cl}$ & $\begin{array}{l}\text { Moderately } \\
\text { saline }\end{array}$ & LAR, SGR & $*$ & Montebello/seawater (11\%) \\
\hline $4 \mathrm{~S} / 13 \mathrm{~W}-28 \mathrm{~A} 3$ & Wilmington1_1 & -46.8 & -7.29 & 0.7091 & $\mathrm{Na}-\mathrm{Cl}$ & Fresh & LAR, SGR & n.a. & Los Angeles \\
\hline $4 \mathrm{~S} / 13 \mathrm{~W}-28 \mathrm{~A} 4$ & Wilmington1_2 & -46.0 & -7.13 & 0.7093 & $\mathrm{Ca} / \mathrm{Na}-\mathrm{Cl}$ & Fresh & LAR, SGR & n.a. & Los Angeles \\
\hline
\end{tabular}

$4 \mathrm{~S} / 13 \mathrm{~W}-23 \mathrm{~N} 3$

$380 \mathrm{P}$

Long Beach7

West Coast Basin-Continued 
Table 1.2. Groundwater-quality data used for this study from multiple-well monitoring sites, and selected production and observation wells, Los Angeles and Orange Counties, California.-Continued

[See appendix 1 for explanation. Abbreviations: $\mathrm{ft}$, foot; mg/L, milligrams per liter; mm/dd/yyyy, month/day/year; ug/L, micrograms per liter; CaCO ${ }_{3}$, calcium carbonate; \%, percent; <, less than; -, no data Sediment source/facies: LAR, Los Angeles River; n.a., not assigned; SGR, San Gabriel River; SAR, Santa Ana River, *, potentially affected by mixing with anthropogenic sources of water or seawater]

\begin{tabular}{|c|c|c|c|c|c|c|c|c|c|}
\hline State well number & Local well name & $\begin{array}{c}\delta^{2} \text { Hydrogen, } \\
\text { unfiltered } \\
\text { (per mil) }\end{array}$ & $\begin{array}{c}\delta^{18} 0 x y g e n, \\
\text { unfiltered } \\
\text { (per mil) }\end{array}$ & $\begin{array}{l}\text { Strontium-87 / } \\
\text { Strontium-86, } \\
\text { filtered (atom } \\
\text { ratio) }\end{array}$ & $\begin{array}{l}\text { Chemical } \\
\text { facies }\end{array}$ & $\begin{array}{l}\text { Dissolved- } \\
\text { solids } \\
\text { classification }\end{array}$ & $\begin{array}{l}\text { Sediment } \\
\text { source }\end{array}$ & $\begin{array}{l}\text { Sediment } \\
\text { facies }\end{array}$ & $\begin{array}{l}\text { Groundwater } \\
\text { recharge source }\end{array}$ \\
\hline \multicolumn{10}{|c|}{ West Coast Basin-Continued } \\
\hline $4 \mathrm{~S} / 13 \mathrm{~W}-28 \mathrm{~A} 5$ & Wilmington1_3 & -49.4 & -7.34 & 0.7093 & $\mathrm{Na} / \mathrm{Ca}-\mathrm{Cl}$ & Slightly saline & LAR, SGR & $*$ & Mixed/seawater (5\%) \\
\hline $4 \mathrm{~S} / 13 \mathrm{~W}-28 \mathrm{~A} 6$ & Wilmington1_4 & -77.5 & -9.77 & 0.7088 & $\mathrm{Na}-\mathrm{Cl}$ & Slightly saline & LAR, SGR & $*$ & Injection/seawater $(6 \%)$ \\
\hline $4 \mathrm{~S} / 13 \mathrm{~W}-28 \mathrm{~A} 7$ & Wilmington1_5 & -73.3 & -9.58 & 0.7088 & $\mathrm{Ca} / \mathrm{Na}-\mathrm{Cl}$ & Fresh & LAR & n.a. & Injection \\
\hline $4 \mathrm{~S} / 13 \mathrm{~W}-29 \mathrm{H} 5$ & $340 \mathrm{~L}$ & -42.3 & -6.46 & 0.7089 & $\mathrm{Na}-\mathrm{Cl}$ & Slightly saline & LAR, SGR & n.a. & Local/seawater (7\%) \\
\hline 4S/13W-29H6 & $340 \mathrm{M}$ & -45.9 & -6.84 & 0.7089 & $\mathrm{Na} / \mathrm{Ca}-\mathrm{Cl}$ & Slightly saline & LAR, SGR & $*$ & Los Angeles/seawater (3\%) \\
\hline $4 \mathrm{~S} / 13 \mathrm{~W}-29 \mathrm{H} 7$ & $340 \mathrm{~N}$ & -46.3 & -7.21 & 0.7090 & $\mathrm{Na} / \mathrm{Ca}-\mathrm{Cl} / \mathrm{HCO}_{3}$ & Slightly saline & LAR, SGR & non-marine & Los Angeles \\
\hline $4 \mathrm{~S} / 13 \mathrm{~W}-31 \mathrm{~J} 1$ & $321 \mathrm{~A}$ & -50.5 & -7.88 & 0.7090 & $\mathrm{Na}-\mathrm{Cl}$ & $\begin{array}{l}\text { Moderately } \\
\text { saline }\end{array}$ & LAR, SGR & $*$ & Montebello/seawater (11\%) \\
\hline $4 \mathrm{~S} / 13 \mathrm{~W}-32 \mathrm{~F} 1$ & Wilmington2_1 & -59.7 & -8.73 & 0.7093 & $\mathrm{Na}-\mathrm{HCO}_{3}$ & Fresh & LAR, SGR & deep marine & Montebello paleowater \\
\hline $4 \mathrm{~S} / 13 \mathrm{~W}-32 \mathrm{~F} 2$ & Wilmington2_2 & -55.8 & -8.63 & 0.7091 & $\mathrm{Na}-\mathrm{Cl}$ & Slightly saline & LAR, SGR & n.a. & $\begin{array}{l}\text { Montebello paleowater } \\
\text { (slightly saline) }\end{array}$ \\
\hline $4 \mathrm{~S} / 13 \mathrm{~W}-32 \mathrm{~F} 3$ & Wilmington2_3 & -50.6 & -7.84 & 0.7090 & $\mathrm{Na}-\mathrm{Cl} / \mathrm{HCO}_{3}$ & Fresh & LAR, SGR & shallow marine & Mixed \\
\hline $4 \mathrm{~S} / 13 \mathrm{~W}-32 \mathrm{~F} 4$ & Wilmington2_4 & -51.3 & -7.96 & 0.7090 & $\mathrm{Na}-\mathrm{Cl}$ & Slightly saline & LAR, SGR & $*$ & Mixed/seawater (5\%) \\
\hline $4 \mathrm{~S} / 13 \mathrm{~W}-32 \mathrm{~F} 5$ & Wilmington2_5 & -57.7 & -7.57 & 0.7091 & $\mathrm{Na}-\mathrm{Cl}$ & $\begin{array}{l}\text { Moderately } \\
\text { saline }\end{array}$ & LAR, SGR & $*$ & Injection/seawater (28\%) \\
\hline 4S/13W-34A1 & $371 \mathrm{D}$ & -61.2 & -8.76 & 0.7095 & $\mathrm{Na}-\mathrm{HCO}_{3}$ & Fresh & LAR, SGR & shallow marine & Montebello \\
\hline 4S/13W-34M1 & $361 \mathrm{H}$ & -54.6 & -8.27 & 0.7092 & $\mathrm{Na}-\mathrm{HCO}_{3}$ & Fresh & LAR, SGR & shallow marine & Montebello \\
\hline $4 \mathrm{~S} / 13 \mathrm{~W}-35 \mathrm{~B} 2$ & $381 \mathrm{~J}$ & -61.5 & -9.05 & 0.7096 & $\mathrm{Na}-\mathrm{HCO}_{3}$ & Fresh & LAR, SGR & deep marine & Montebello \\
\hline $4 \mathrm{~S} / 13 \mathrm{~W}-35 \mathrm{~B} 3$ & $381 \mathrm{~K}$ & -44.9 & -6.64 & 0.7097 & $\mathrm{Na}-\mathrm{Cl}$ & $\begin{array}{l}\text { Moderately } \\
\text { saline }\end{array}$ & SGR & $*$ & Montebello/seawater (16\%) \\
\hline $4 \mathrm{~S} / 14 \mathrm{~W}-2 \mathrm{~N} 1$ & PM-3 Madrid_1 & -48.4 & -7.76 & - & $\mathrm{Na}-\mathrm{HCO}_{3}$ & Fresh & n.a. & deep marine & Los Angeles paleowater \\
\hline $4 \mathrm{~S} / 14 \mathrm{~W}-2 \mathrm{~N} 2$ & PM-3 Madrid_2 & -48.5 & -6.88 & - & $\mathrm{Na} / \mathrm{Ca}-\mathrm{HCO}_{3}$ & Fresh & n.a. & shallow marine & Los Angeles \\
\hline $4 \mathrm{~S} / 14 \mathrm{~W}-2 \mathrm{~N} 3$ & PM-3 Madrid_3 & -44.3 & -6.88 & - & $\operatorname{mixed}-\mathrm{Cl} / \mathrm{HCO}_{3}$ & Fresh & n.a. & non-marine & Los Angeles \\
\hline $4 \mathrm{~S} / 14 \mathrm{~W}-2 \mathrm{~N} 4$ & PM-3 Madrid_4 & -47.1 & -6.91 & - & $\mathrm{Na} / \mathrm{Ca}-\mathrm{Cl} / \mathrm{HCO}_{3}$ & Slightly saline & n.a. & n.a. & Los Angeles (slightly saline) \\
\hline 4S/14W-4Q1 & PM-4 Mariner_1 & -50.7 & -7.79 & - & $\mathrm{Na}-\mathrm{HCO}_{3}$ & Fresh & n.a. & shallow marine & Los Angeles paleowater \\
\hline 4S/14W-4Q2 & PM-4 Mariner_2 & -33.7 & -5.12 & - & $\mathrm{Na} / \mathrm{Ca}-\mathrm{Cl}$ & Highly saline & n.a. & $*$ & $\begin{array}{l}\text { Los Angeles/seawater } \\
\qquad(35 \%)\end{array}$ \\
\hline 4S/14W-4Q3 & PM-4 Mariner_3 & -83.1 & -10.54 & - & $\mathrm{Na}-\mathrm{SO}_{4} / \mathrm{Cl}$ & Fresh & n.a. & non-marine & Injection \\
\hline 4S/14W-4Q4 & PM-4 Mariner_4 & -65.9 & -8.65 & - & $\mathrm{Na} / \mathrm{Ca}-\mathrm{HCO}_{3} / \mathrm{SO}_{4}$ & Fresh & n.a. & non-marine & Los Angeles/injection \\
\hline
\end{tabular}


Table 1.2. Groundwater-quality data used for this study from multiple-well monitoring sites, and selected production and observation wells, Los Angeles and Orange Counties, California.-Continued

[See appendix 1 for explanation. Abbreviations: ft, foot; mg/L, milligrams per liter; mm/dd/yyyy, month/day/year; ug/L, micrograms per liter; $\mathrm{CaCO}_{3}$, calcium carbonate; \%, percent; <, less than; - , no data. Sediment source/facies: LAR, Los Angeles River; n.a., not assigned; SGR, San Gabriel River; SAR, Santa Ana River, *, potentially affected by mixing with anthropogenic sources of water or seawater]

\begin{tabular}{|c|c|c|c|c|c|c|c|c|c|}
\hline State well number & Local well name & $\begin{array}{c}\delta^{2} \text { Hydrogen, } \\
\text { unfiltered } \\
\text { (per mil) }\end{array}$ & $\begin{array}{c}\delta^{18} \text { Oxygen, } \\
\text { unfiltered } \\
\text { (per mil) }\end{array}$ & $\begin{array}{l}\text { Strontium-87 / } \\
\text { Strontium-86, } \\
\text { filtered (atom } \\
\text { ratio) }\end{array}$ & $\begin{array}{l}\text { Chemical } \\
\text { facies }\end{array}$ & $\begin{array}{l}\text { Dissolved- } \\
\text { solids } \\
\text { classification }\end{array}$ & $\begin{array}{l}\text { Sediment } \\
\text { source }\end{array}$ & $\begin{array}{l}\text { Sediment } \\
\text { facies }\end{array}$ & $\begin{array}{l}\text { Groundwater } \\
\text { recharge source }\end{array}$ \\
\hline \multicolumn{10}{|c|}{ West Coast Basin-Continued } \\
\hline $4 \mathrm{~S} / 14 \mathrm{~W}-10 \mathrm{C} 1$ & PM-1 Columbia_1 & -49.2 & -7.46 & - & $\mathrm{Na} / \mathrm{Ca}-\mathrm{HCO}_{3}$ & Fresh & n.a. & shallow marine & Los Angeles \\
\hline $4 \mathrm{~S} / 14 \mathrm{~W}-10 \mathrm{C} 2$ & PM-1 Columbia_2 & -59.6 & -8.40 & - & $\mathrm{Ca} / \mathrm{Na}-\mathrm{Cl}$ & Slightly saline & n.a. & $*$ & $\begin{array}{l}\text { Los Angeles/injection/ } \\
\text { seawater }(5 \%)\end{array}$ \\
\hline $4 \mathrm{~S} / 14 \mathrm{~W}-15 \mathrm{E} 1$ & Torrance2_1 & -60.2 & -8.86 & 0.7089 & $\mathrm{Na}-\mathrm{HCO}_{3}$ & Slightly saline & LAR, SGR & n.a. & $\begin{array}{l}\text { Montebello paleowater } \\
\quad \text { (slightly saline) }\end{array}$ \\
\hline $4 \mathrm{~S} / 14 \mathrm{~W}-15 \mathrm{E} 2$ & Torrance2_2 & -56.1 & -8.18 & 0.7090 & $\mathrm{Na}-\mathrm{Cl}$ & $\begin{array}{l}\text { Moderately } \\
\text { saline }\end{array}$ & LAR, SGR & $*$ & $\begin{array}{l}\text { Montebello paleowater } \\
\text { (moderately saline) }\end{array}$ \\
\hline $4 \mathrm{~S} / 14 \mathrm{~W}-15 \mathrm{E} 3$ & Torrance2_3 & -43.2 & -6.49 & 0.7089 & mixed-Cl & Highly saline & LAR, SGR & $*$ & $\begin{array}{l}\text { Montebello paleowater } \\
\text { (highly saline) }\end{array}$ \\
\hline $4 \mathrm{~S} / 14 \mathrm{~W}-15 \mathrm{E} 4$ & Torrance2_4 & -50.7 & -7.66 & 0.7089 & $\mathrm{Na}-\mathrm{HCO}_{3}$ & Fresh & LAR, SGR & shallow marine & Mixed \\
\hline $4 \mathrm{~S} / 14 \mathrm{~W}-15 \mathrm{E} 5$ & Torrance2_5 & -69.0 & -9.23 & 0.7083 & $\mathrm{Ca} / \mathrm{Na}-\mathrm{Cl}$ & $\begin{array}{l}\text { Moderately } \\
\text { saline }\end{array}$ & LAR & $*$ & Injection/seawater (9\%) \\
\hline 4S/14W-15E6 & Torrance2_6 & -56.7 & -7.97 & 0.7084 & $\mathrm{Na} / \mathrm{Ca}-\mathrm{Cl}$ & Fresh & LAR & n.a. & Los Angeles/Injection \\
\hline $4 \mathrm{~S} / 14 \mathrm{~W}-26 \mathrm{~A} 2$ & Lomita1_1 & -41.7 & -6.37 & 0.7086 & $\mathrm{Na} / \mathrm{Ca}-\mathrm{Cl}$ & Slightly saline & Local & n.a. & Local (slightly saline) \\
\hline $4 \mathrm{~S} / 14 \mathrm{~W}-26 \mathrm{~A} 3$ & Lomita1_2 & -43.3 & -6.57 & 0.7086 & $\mathrm{Na}-\mathrm{Cl}$ & Fresh & Local & n.a. & Local \\
\hline $4 \mathrm{~S} / 14 \mathrm{~W}-26 \mathrm{~A} 4$ & Lomita1_3 & -50.3 & -7.73 & 0.7087 & $\mathrm{Na}-\mathrm{Cl}$ & Fresh & LAR & n.a. & Los Angeles \\
\hline $4 \mathrm{~S} / 14 \mathrm{~W}-26 \mathrm{~A} 5$ & Lomita1_4 & -52.6 & -7.75 & 0.7087 & $\mathrm{Na}-\mathrm{Cl}$ & Fresh & Local & n.a. & Local paleowater \\
\hline $4 \mathrm{~S} / 14 \mathrm{~W}-26 \mathrm{~A} 6$ & Lomita1_5 & -41.1 & -6.22 & 0.7086 & $\mathrm{Na} / \mathrm{Ca}-\mathrm{Cl}$ & Slightly saline & Local & n.a. & Local (slightly saline) \\
\hline $4 \mathrm{~S} / 14 \mathrm{~W}-35 \mathrm{D} 10$ & Chandler3_1 & -37.0 & -5.90 & - & $\mathrm{Na} / \mathrm{Ca}-\mathrm{HCO}_{3}$ & Fresh & n.a. & non-marine & Local \\
\hline 4S/14W-35D11 & Chandler3_2 & -39.0 & -6.20 & - & $\mathrm{Ca} / \mathrm{Na}-\mathrm{HCO}_{3} / \mathrm{Cl}$ & Slightly saline & n.a. & non-marine & Local \\
\hline $5 \mathrm{~S} / 13 \mathrm{~W}-2 \mathrm{E} 1$ & Long Beach4_1 & -61.1 & -9.23 & 0.7094 & $\mathrm{Na}-\mathrm{HCO}_{3}$ & Fresh & LAR, SGR & deep marine & Montebello paleowater \\
\hline $5 \mathrm{~S} / 13 \mathrm{~W}-2 \mathrm{E} 2$ & Long Beach4_2 & -49.2 & -7.54 & 0.7096 & $\mathrm{Na}-\mathrm{HCO}_{3} / \mathrm{Cl}$ & Slightly saline & LAR, SGR & n.a. & $\begin{array}{l}\text { Los Angeles paleowater } \\
\text { (slightly saline) }\end{array}$ \\
\hline $5 \mathrm{~S} / 13 \mathrm{~W}-11 \mathrm{P} 1$ & Long Beach5_1 & -47.1 & -7.47 & 0.7096 & $\mathrm{Na}-\mathrm{Cl}$ & $\begin{array}{l}\text { Moderately } \\
\text { saline }\end{array}$ & LAR, SGR & n.a. & $\begin{array}{l}\text { Los Angeles paleowater } \\
\text { (moderately saline) }\end{array}$ \\
\hline $5 \mathrm{~S} / 13 \mathrm{~W}-11 \mathrm{P} 2$ & Long Beach5_2 & -3.7 & -0.42 & 0.7092 & $\mathrm{Na}-\mathrm{Cl}$ & Brine & LAR, SGR & $*$ & Seawater \\
\hline \multicolumn{10}{|c|}{ Santa Monica Basin } \\
\hline $1 \mathrm{~S} / 15 \mathrm{~W}-31 \mathrm{E} 1$ & SM 1 (2505) & -57.0 & -8.03 & 0.7088 & mixed- $\mathrm{SO}_{4} / \mathrm{Cl}$ & Fresh & Local & non-marine & Los Angeles/artificial \\
\hline $1 \mathrm{~S} / 15 \mathrm{~W}-33 \mathrm{~A} 1$ & SM Arcadia_5 & -54.5 & -7.80 & 0.7088 & mixed-mixed & Fresh & Local & non-marine & Los Angeles/artificial \\
\hline $2 \mathrm{~S} / 15 \mathrm{~W}-4 \mathrm{C} 2$ & SM 3 (2646K) & -49.8 & -7.26 & 0.7087 & mixed- $\mathrm{HCO}_{3} / \mathrm{SO}_{4}$ & Fresh & LAR, Local & non-marine & Los Angeles \\
\hline
\end{tabular}


Table 1.2. Groundwater-quality data used for this study from multiple-well monitoring sites, and selected production and observation wells, Los Angeles and Orange Counties, California.-Continued

[See appendix 1 for explanation. Abbreviations: ft, foot; mg/L, milligrams per liter; mm/dd/yyyy, month/day/year; ug/L, micrograms per liter; CaCO 3 , calcium carbonate; \%, percent; <, less than; - , no data. Sediment source/facies: LAR, Los Angeles River; n.a., not assigned; SGR, San Gabriel River; SAR, Santa Ana River, *, potentially affected by mixing with anthropogenic sources of water or seawater]

\begin{tabular}{|c|c|c|c|c|c|c|c|c|c|}
\hline State well number & Local well name & $\begin{array}{c}\delta^{2} \text { Hydrogen, } \\
\text { unfiltered } \\
\text { (per mil) }\end{array}$ & $\begin{array}{c}\delta^{180 x y g e n,} \\
\text { unfiltered } \\
\text { (per mil) }\end{array}$ & $\begin{array}{c}\text { Strontium-87 / } \\
\text { Strontium-86, } \\
\text { filtered (atom } \\
\text { ratio) }\end{array}$ & $\begin{array}{l}\text { Chemical } \\
\text { facies }\end{array}$ & $\begin{array}{l}\text { Dissolved- } \\
\text { solids } \\
\text { classification }\end{array}$ & $\begin{array}{l}\text { Sediment } \\
\text { source }\end{array}$ & $\begin{array}{l}\text { Sediment } \\
\text { facies }\end{array}$ & $\begin{array}{l}\text { Groundwater } \\
\text { recharge source }\end{array}$ \\
\hline \multicolumn{10}{|c|}{ Hollywood Basin } \\
\hline 1S/14W-18L1 & BH_2 & -39.4 & -6.31 & 0.7080 & $\mathrm{Na}-\mathrm{HCO}_{3} / \mathrm{Cl}$ & Fresh & Local & n.a. & Local \\
\hline $1 \mathrm{~S} / 15 \mathrm{~W}-24 \mathrm{~B} 1$ & BH_5 & -36.8 & -5.96 & 0.7081 & mixed- $\mathrm{HCO}_{3} / \mathrm{SO}_{4}$ & Fresh & Local & shallow marine & Local \\
\hline \multicolumn{10}{|c|}{ San Fernando Valley } \\
\hline $1 \mathrm{~N} / 13 \mathrm{~W}-35 \mathrm{P} 1$ & DS_WATERS & -54.5 & -7.72 & 0.7094 & $\mathrm{Ca} / \mathrm{Mg}$-mixed & Fresh & LAR, SGR & non-marine & n.a. \\
\hline \multicolumn{10}{|c|}{ San Gabriel Valley } \\
\hline $2 \mathrm{~S} / 11 \mathrm{~W}-5 \mathrm{P} 6$ & $\begin{array}{l}\text { Whittier Nar- } \\
\text { rows1_1 }\end{array}$ & -48.6 & -7.35 & - & $\mathrm{Na}-\mathrm{Cl}$ & Slightly saline & n.a. & n.a. & Local (slightly saline) \\
\hline $2 \mathrm{~S} / 11 \mathrm{~W}-5 \mathrm{P} 7$ & $\begin{array}{c}\text { Whittier Nar- } \\
\text { rows1_2 }\end{array}$ & -54.4 & -8.29 & - & $\mathrm{Na}-\mathrm{HCO}_{3}$ & Fresh & n.a. & shallow marine & Montebello \\
\hline 2S/11W-5P8 & $\begin{array}{c}\text { Whittier Nar- } \\
\text { rows1_3 }\end{array}$ & -60.6 & -8.48 & - & Ca-mixed & Fresh & n.a. & non-marine & Montebello/spreading \\
\hline $2 \mathrm{~S} / 11 \mathrm{~W}-5 \mathrm{P} 9$ & $\begin{array}{c}\text { Whittier Nar- } \\
\text { rows1_4 }\end{array}$ & -60.3 & -8.14 & - & Ca-mixed & Fresh & n.a. & non-marine & Montebello/spreading \\
\hline $2 \mathrm{~S} / 11 \mathrm{~W}-5 \mathrm{P} 10$ & $\begin{array}{l}\text { Whittier Nar- } \\
\text { rows1_5 }\end{array}$ & -59.9 & -8.53 & - & $\mathrm{Ca}-\mathrm{HCO}_{3} / \mathrm{SO}_{4}$ & Fresh & n.a. & non-marine & Montebello/spreading \\
\hline 2S/11W-5P11 & $\begin{array}{l}\text { Whittier Nar- } \\
\text { rows1_6 }\end{array}$ & -58.5 & -7.93 & - & $\mathrm{Ca} / \mathrm{Na}$-mixed & Fresh & n.a. & non-marine & Montebello/spreading \\
\hline $2 \mathrm{~S} / 11 \mathrm{~W}-5 \mathrm{P} 12$ & $\begin{array}{c}\text { Whittier Nar- } \\
\text { rows1_7 }\end{array}$ & -56.5 & -7.79 & - & $\mathrm{Na} / \mathrm{Ca}$-mixed & Fresh & n.a. & non-marine & Montebello/spreading \\
\hline $2 \mathrm{~S} / 11 \mathrm{~W}-5 \mathrm{P} 13$ & $\begin{array}{c}\text { Whittier Nar- } \\
\text { rows1_8 }\end{array}$ & -57.7 & -7.88 & - & $\mathrm{Na} / \mathrm{Ca}$-mixed & Fresh & n.a. & non-marine & Montebello/spreading \\
\hline 2S/11W-5P14 & $\begin{array}{c}\text { Whittier Nar- } \\
\text { rows1_9 }\end{array}$ & -57.7 & -7.92 & - & $\mathrm{Na} / \mathrm{Ca}$-mixed & Fresh & n.a. & non-marine & Montebello/spreading \\
\hline
\end{tabular}




\section{Background on Water-Quality Data Analyzed}

Water-quality data analyzed for this report include major-ion compositions; dissolved-solids, chloride ( $\mathrm{Cl})$, and boron (B) concentations; stable-isotope ratios for hydrogen $(\mathrm{H})$, oxygen $(\mathrm{O})$, strontium $(\mathrm{Sr})$, and carbon $\left({ }^{13} \mathrm{C} /{ }^{12} \mathrm{C}\right)$; and the radioactive isotopes, tritium $\left({ }^{3} \mathrm{H}\right)$ and carbon-14 $\left({ }^{14} \mathrm{C}\right)$. A brief description of each of these constituents and how they were used in this study is included below.

\section{Major-Ion Composition and Dissolved-Solids Concentration}

The major-ion compositions and dissolved-solids concentrations of groundwater samples from multiple-well monitoring sites were used to help define chronostratigraphic unit boundaries and model zones. The major-ion composition of groundwater is controlled by the natural chemistry of the recharge water and geochemical reactions, primarily dissolution and precipitation of minerals, in the subsurface (Hem, 1985). Reactions that affect major-ion concentrations include aluminosilicate dissolution, calcite dissolution and precipitation, cation exchange on clays, and microbial sulfate reduction. The aqueous concentration of major ions is controlled by kinetics (rate of dissolution of minerals) and equilibrium (saturation with respect to minerals). The major-ion composition was characterized for this report by using trilinear Piper diagrams (Piper, 1944). Dissolved-solids concentrations of the samples also were used to help characterize the water quality.

Piper diagrams (Piper, 1944) can be used to display the relative contribution of major cations and anions, on a charge-equivalent basis, to the total ionic content of the water. Piper diagram percentage scales show cation concentrations on a triangle to the left and anion concentrations on a triangle to the right, while a central diamond integrates the data (fig. 1.2). Piper diagrams provide a useful visual depiction for comparing or contrasting differences in major-ion composition at multiple locations and can be related to causal geochemical reactions and mixing of groundwater from multiple sources where sufficient data exist. In this report, the dominant cation and anion species are used to describe the water type (chemical facies) of a water sample when a single cation or anion composes more than 60 percent of the total cations or anions, respectively (table 1.2). When a single cation or anion does not exceed 60 percent, the sample is described as mixed, and the first and second most abundant cations or anions are given for description purposes.
Total dissolved solids (or dissolved solids) are a measure of the quantity of all dissolved chemicals in water (Hem, 1985). Dissolved solids can be measured or calculated in several ways; most commonly, a summation of dissolved ions is used if a complete analysis is available, or the residue that remains after evaporation at a specific temperature is weighed (residue-on-evaporation, or ROE). The computed dissolved solids can differ from the ROE value by $10-20 \mathrm{mg} / \mathrm{L}$ in either the positive or negative direction when the solids concentration is $100-500 \mathrm{mg} / \mathrm{L}$ (Hem, 1985); thus, a direct comparison of dissolved-solids concentrations from different labs is difficult unless the method used by the analyzing laboratory is known. For this report, the total dissolved-solids concentrations were calculated as the summation of the reported major cations (calcium, magnesium, sodium, and potassium) and anions (chloride, sulfate, bicarbonate, fluoride, silica, and nitrate, if available).

Dissolved solids are commonly used to classify waters. For the purposes of this report, water containing less than $1,000 \mathrm{mg} / \mathrm{L}$ is classified as fresh; 1,000 to $3,000 \mathrm{mg} / \mathrm{L}$ is classified as slightly saline; 3,000 to $10,000 \mathrm{mg} / \mathrm{L}$ is classified as moderately saline; 10,000 to 35,000 is classified as highly saline; and more than 35,000 is classified as brine. Samples from 301 wells were classified as fresh, 46 as slightly saline, 11 as moderately saline, 5 as highly saline, and 1 as brine (table 1.2).

\section{Dissolved Chloride and Boron}

Chloride ( $\mathrm{Cl}$ ) and boron (B) were used in this study to help determine chronostratigraphic unit boundaries and sediment facies. Chloride a negatively charged ion and is considered a conservative (unreactive) element. Sources of $\mathrm{Cl}$ include both natural and anthropogenic processes. Chloride is present in all natural waters, but the concentrations usually are low (Hem, 1985). Chloride concentrations in chemical analyses compiled for this study range from about $4 \mathrm{mg} / \mathrm{L}$ in well 8L14 (2S/11W-8L14; Whittier Narrows2_6) to $19,900 \mathrm{mg} / \mathrm{L}$ in well 11P2 (5S/13W-11P2; Long Beach5_2; table 1.2). Sources of high $\mathrm{Cl}$ concentrations in the LACP include seawater, which contains $\mathrm{Cl}$ concentrations of about $19,000 \mathrm{mg} / \mathrm{L}$, and oil-field brine water, which is reported to contain $\mathrm{Cl}$ concentrations ranging from 6,000 to $23,400 \mathrm{mg} / \mathrm{L}$ in the Long Beach-Santa Ana area (Piper and Garrett, 1953). Another source of high $\mathrm{Cl}$ concentrations in the study area is the dissolution of soluble salts found in fine-grained marine deposits. When porous rocks are submerged by the sea at any time after their formation, they become intruded with soluble salts, in which $\mathrm{Cl}$ is the major constituent (Hem, 1985). Fine-grained marine sediments may retain this chloride for a very long time (Hem, 1985). 


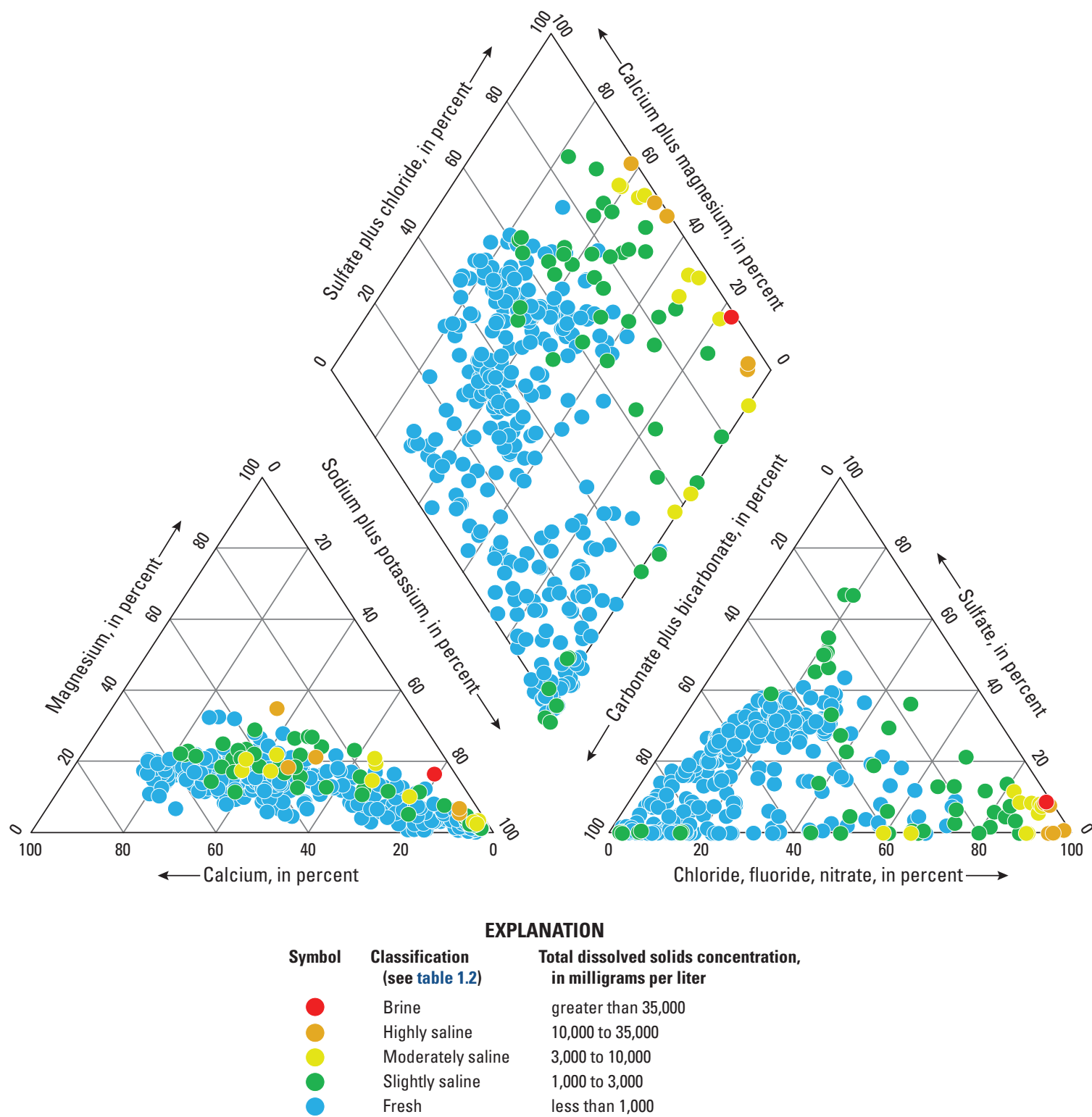

Figure 1.2. Major-ion composition in samples from monitoring wells in the Los Angeles Coastal Plain, Los Angeles and Orange Counties, California. 
Boron generally is soluble and unaffected by evaporation, oxidation/reduction reactions, and precipitation or dissolution reactions (Bassett and others, 1995). Dissolved B may be affected by adsorption onto the surface of minerals, especially clay, in the aquifer system (Hem, 1985). This process is dependent on the concentration of $\mathrm{B}, \mathrm{pH}$, and salinity, as well as on aquifer mineralogy. Water analyses normally report boron concentrations in terms of elemental $\mathrm{B}$, and the uncharged ion is the most likely form in most natural water (Hem, 1985). Boron concentrations in chemical analyses compiled for this study range from $40 \mu \mathrm{g} / \mathrm{L}$ in well $11 \mathrm{~A} 9$ (3S/12W-11A9; Norwalk2_3) to $14,200 \mu \mathrm{g} / \mathrm{L}$ in well 30L2 (3S/14W-30L2; Manhattan Beach1_1; table 1.2). Sources of high $\mathrm{B}$ concentrations in the LAC $\bar{C}$ include seawater, which contains boron concentrations of about $4,500 \mu \mathrm{g} / \mathrm{L}$, and oil-field brine water, which is reported to contain $\mathrm{B}$ concentrations of as high as $70,000 \mu \mathrm{g} / \mathrm{L}$ in coastal oil fields (Piper and Garrett, 1953). Similar to Cl, another source of elevated B concentrations is the dissolution of B from fine-grained marine deposits. Water sampled from these deposits often contains B concentrations higher than what would be inferred from the $\mathrm{Cl}$ concentration if seawater was the source. Data from the literature indicate that B is concentrated by algae (Manley, 1983; Carrano and others, 2009; Miller and others, 2016). Manley (1983) reported that the concentration of $\mathrm{B}$ in the sieve tube sap from the brown algae Macrocystis was about 75-times the concentration of B in seawater. Boron concentrations in marine algae are typically in the range of 100,000 $\mu \mathrm{g} / \mathrm{L}$ (Carrano and others, 2009), more than 20 times its concentration in seawater. Fine-grained organic sediments associated with deep marine deposits would be expected to have higher B concentrations than non-marine and shallow marine deposits because deep marine deposits often contain high concentrations of algae and other plankton.

Because $\mathrm{Cl}$ and $\mathrm{B}$ are relatively unreactive in groundwater, chloride-to-boron ratios have been used to help determine the source of high $\mathrm{Cl}$ and/or B concentrations in groundwater (Piper and Garrett, 1953; Martin, 1984; Dotsika and others, 2006). The $\mathrm{Cl} / \mathrm{B}$ mass ratio in seawater is 4,222, whereas it is much lower in oil-field brines (Piper and Garrett, 1953). Piper and Garrett (1953) stated that high-chloride water with a $\mathrm{Cl} / \mathrm{B}$ ratio less than 140 may be evidence for mixing with a brine source. The $\mathrm{Cl} / \mathrm{B}$ ratios in rainwater range from 200 to 5,000 (Dotsika and others, 2006). The $\mathrm{Cl} / \mathrm{B}$ ratios of a single rain event are highly variable, with a scatter of about 2 orders of magnitude (Rose and others, 2000). Rose and others (2000) determined that $\mathrm{Cl}$ and $\mathrm{B}$ data collected from lichens can be used to approximate atmospheric deposition of $\mathrm{Cl}$ and
B at a particular location. A study in Quebec found that lichens had $\mathrm{Cl} / \mathrm{B}$ ratios ranging from 88 to 545 , with an average of $270(\mathrm{n}=6)$. The highest $\mathrm{Cl} / \mathrm{B}$ ratios were analyzed in lichens sampled closest to the coast (Rose and others, 2000). Native groundwater in non-marine sediments derived primarily from granitic rocks will have $\mathrm{Cl} / \mathrm{B}$ ratios higher than present in local precipitation because $\mathrm{Cl}$ is more common in granitic rocks than B (Hem, 1985). Native groundwater in marine sediments would be expected to have lower $\mathrm{Cl} / \mathrm{B}$ ratios than non-marine sediments as a result of the enriched $\mathrm{B}$ concentrations, relative to $\mathrm{Cl}$ concentrations, in the marine sediments.

\section{Stable Isotopes}

Elements exist as multiple isotopes (same number of protons but differing numbers of neutrons), and many elements have more than one stable (nonradioactive) isotope. In this study, the stable-isotope ratios for hydrogen $(\mathrm{H})$, oxygen $(\mathrm{O})$, and strontium $(\mathrm{Sr})$ were used to help define chronostratigraphic unit boundaries, sediment source, water source, and model zones. The stable-isotope ratio for carbon $\left({ }^{13} \mathrm{C} / 12 \mathrm{C}\right)$ was used in conjunction with radiogenic carbon- 14 $\left({ }^{14} \mathrm{C}\right)$ to make inferences about the extent to which this exchange has caused the calculated ${ }^{14} \mathrm{C}$ age to overestimate the actual time elapsed since recharge (Mazor, 1991).

The isotopic composition for $\mathrm{H}, \mathrm{O}$, and $\mathrm{C}$ are expressed in the standard delta $(\delta)$ notation (Gonfiantini, 1978), in units of per mil (parts per thousand), as differences relative to a standard, by:

$$
(\delta E)=\left[\left(R_{\text {sample }}-R_{\text {standard }}\right) / R_{\text {standard }}\right] \times 10^{3}
$$

where

$$
\begin{aligned}
& R \quad \text { is the ratio of the heavier to the lighter isotope } \\
& \text { for a given element }(E) \text {. }
\end{aligned}
$$

Deuterium $\left(\mathrm{D}\right.$ or $\left.{ }^{2} \mathrm{H}\right)$ and protium $\left({ }^{1} \mathrm{H}\right)$ are naturally occurring stable isotopes of $\mathrm{H}$, and oxygen-18 $\left({ }^{18} \mathrm{O}\right)$ and oxygen-16 $\left({ }^{16} \mathrm{O}\right)$ are naturally occurring stable isotopes of $\mathrm{O}$. The standards for these isotopes $\left({ }^{2} \mathrm{H} /{ }^{1} \mathrm{H}\right.$ and $\left.{ }^{18} \mathrm{O} /{ }^{16} \mathrm{O}\right)$ are Vienna Standard Mean Ocean Water (VSMOW) and Standard Light Antarctic Precipitation (SLAP); by convention, the VSMOW value for $\delta$ is 0 per mil for both elements (Craig, 1961b), and the SLAP value is -428 per mil for deuterium ratios $(\delta \mathrm{D})$. Analytical precision is plus or minus $( \pm) 1.5$ per mil for $\delta \mathrm{D}$, and about \pm 0.5 per mil for ${ }^{18} \mathrm{O} /{ }^{16} \mathrm{O}$ ratios $\left(\delta^{18} \mathrm{O}\right.$; Coplen, 1994; Izbicki, 1996). 
The $\delta \mathrm{D}$ and $\delta^{18} \mathrm{O}$ composition of a groundwater sample can provide a record of the source water and its evaporative history. The isotopic composition of coastal precipitation throughout the world is correlated linearly and plots along a line known as the global meteoric water line (MWL; Craig, 1961a). Differences in the isotopic composition of precipitation occur along this line in response to trends dictated by latitude, altitude, and the temperature of condensation (Dansgaard, 1964). More negative values (depletion in the heavier relative to the lighter isotope) result when condensation takes place at colder temperatures and higher altitudes. The temperature effect, based on measurements in North America and Europe, is -0.7 per $\mathrm{mil} /{ }^{\circ} \mathrm{C}$ for $\delta^{18} \mathrm{O}$, which is equivalent to -5.6 per mil $/{ }^{\circ} \mathrm{C}$ for $\delta \mathrm{D}$ (Dansgaard, 1964). The altitude effect, based on measurements made on the western flank of the Sierra Nevada (not shown), is -2.3 per mil/km for $\delta^{18} \mathrm{O}$ (Ingraham and Taylor, 1991; Rose and others, 1996). This is equivalent to -18.4 per $\mathrm{mil} / \mathrm{km}$ for $\delta \mathrm{D}$ if isotope data fall on the global MWL or on a local MWL that is parallel to the global MWL. Water that has been partly evaporated is enriched in heavier isotopes relative to its original composition (Mazor, 1991); these values plot to the right of the MWL (for $\delta \mathrm{D}$ as the vertical and $\delta^{18} \mathrm{O}$ as the horizontal axis). If the isotopic compositions of two sources are known, mixtures between these two sources will plot on a line connecting the two sources. The isotopic composition of groundwater in the study area commonly is the result of mixing processes between multiple sources.

Carbon-13 $\left({ }^{13} \mathrm{C}\right)$ and carbon-12 $\left({ }^{12} \mathrm{C}\right)$ are naturally occurring stable isotopes of $\mathrm{C}$. The ratio of these isotopes is expressed as differences relative to the standard Vienna Pee Dee Belemnite (VPDB; Friedman and O’Neil, 1977; Coplen, 1994). Analytical precision is about \pm 0.5 per mil for the carbon-13/carbon-12 ratio $\left(\delta^{13} \mathrm{C}\right)$. Some representative $\delta^{13} \mathrm{C}$ values are about 0 per mil in carbonates, about -8 per mil in atmospheric $\mathrm{CO}_{2}$ at present (2018), and about -25 per mil for organic carbon in freshwater sediments (Degens, 1969) and aquifer materials (Clark and Fritz, 1999), for which the range is about $\pm 2-3$ per mil. The isotopic composition of dissolved inorganic carbon (DIC), carbonate, and bicarbonate in groundwater is usually derived from a mixture of atmospheric $\mathrm{CO}_{2}$, oxidation (degradation or mineralization) of organic carbon, and dissolution of carbonate minerals. Because an exchange of $\mathrm{C}$ isotopes (equilibration) between carbonate minerals and DIC occurs, albeit slowly, groundwater could acquire less negative $\delta^{13} \mathrm{C}$ values as it moves along a flow path from infiltration to where it is sampled in a well.

Strontium has two stable isotopes (strontium-87 [ $\left.{ }^{87} \mathrm{Sr}\right]$ and strontium-86 [ $\left.{ }^{86} \mathrm{Sr}\right]$ ) that are measured and reported directly as atom ratios $\left({ }^{87} \mathrm{Sr} /{ }^{86} \mathrm{Sr}\right)$ to 4 or 5 significant digits. Strontium- 87 in rocks and minerals is produced by decay of the radioactive isotope of rubidium (rubidium-87; ${ }^{87} \mathrm{Rb}$ ), which has a half-life of $5 \times 10^{10}$ years (Aldrich and others, 1956). Ratios of $\mathrm{Sr}$ depend on age and ${ }^{87} \mathrm{Rb}$ content of rocks and minerals; therefore, there can be large differences related to composition and age (Turekian and Wedepohl, 1961). The decay of ${ }^{87} \mathrm{Rb}$ isotope has increased the ${ }^{87} \mathrm{Sr} /{ }^{86} \mathrm{Sr}$ ratios of the Earth's crust from the initial value of 0.6989 (Wierzbowski, 2013). Because the continental crust is enriched in rubidium, its ${ }^{87} \mathrm{Sr} /{ }^{86} \mathrm{Sr}$ ratios become increasingly higher and more dissimilar from the ratios of the oceanic crust and mantle (Wierzbowski, 2013). The modern seawater ${ }^{87} \mathrm{Sr} /{ }^{86} \mathrm{Sr}$ ratio is 0.7092 , but this value has ranged from 0.7068 to 0.7092 during the Phanerozoic, owing to changing inputs of strontium (Wierzbowski, 2013). Sediments from the continental crust, such as granites, will have high ${ }^{87} \mathrm{Sr} /{ }^{86} \mathrm{Sr}$ ratios $(>0.7100)$, whereas sediments from marine sedimentary deposits will have low ${ }^{87} \mathrm{Sr} /{ }^{86} \mathrm{Sr}$ ratios (0.708; Wierzbowski, 2013). The dissolution and exchange of strontium between solid and aqueous phases is fairly rapid, so groundwater commonly acquires a $\mathrm{Sr}$ isotopic signature that matches the rock type with which it was most recently in contact (Turekian and Wedepohl, 1961).

\section{Radioactive Isotopes}

Tritium $\left({ }^{3} \mathrm{H}\right)$ and ${ }^{14} \mathrm{C}$ were the two radioactive isotopes used in this study to determine water age; that is, the time needed for recharging (infiltrating) water to move through the subsurface until it is sampled at a well. The water age was used in this report to help define chronostratigraphic unit boundaries, water source, and model zones. For the simplest case (plug flow and no mixing), water age can be calculated from the radioactive decay equation:

$$
\begin{aligned}
& A=A_{0}{ }^{-\lambda t}, \text { or its equivalent } \\
& 2.303\left(\log [A]-\log \left[A_{0}\right]\right)=-\lambda t
\end{aligned}
$$

where

$$
\begin{aligned}
& A \text { is the current activity, } \\
& A_{\mathrm{o}} \quad \text { is the activity in the water at its time of } \\
& \text { recharge, } \\
& \lambda \quad \text { is the decay constant, and } \\
& t \quad \text { is time, in years. }
\end{aligned}
$$

The half-life (time for activity of the nuclide to decay by half) is given by $t_{1 / 2}=0.693 / \lambda$. The half-life is 12.32 years for ${ }^{3} \mathrm{H}$ (Lucas and Unterweger, 2000) and 5,730 years for ${ }^{14} \mathrm{C}$ (Godwin, 1962). 
Tritium is a naturally occurring radioactive isotope produced by the interaction of high-energy cosmic rays with the upper atmosphere (Mazor, 1991). For this study, tritium activity in samples was measured and reported in tritium units (TUs); $1 \mathrm{TU}$ is equivalent to $1^{3} \mathrm{H}$ atom per $10^{18}$ hydrogen atoms (Taylor and Roether, 1982). Activity also is commonly reported in units of picocuries per liter $(\mathrm{pCi} / \mathrm{L}) ; 1 \mathrm{TU}$ is approximately $3.19 \mathrm{pCi} / \mathrm{L}$. Relatively high amounts of ${ }^{3} \mathrm{H}$ were introduced into the environment during the atmospheric detonation of thermonuclear bombs beginning in the early 1950s. This raised the ${ }^{3} \mathrm{H}$ concentration in precipitation several-hundredfold by the time testing was halted in 1963; however, ${ }^{3} \mathrm{H}$ concentrations in precipitation subsequently declined and are currently (2018) near natural background levels in many locations. Harms and others (2016) reported an activity of $2.5 \mathrm{TU}$ in a rainfall sample collected near downtown Los Angeles in 2014. Activities ranging from 1.3 to $2.6 \mathrm{TU}$ were measured in 7 of 8 rainfall samples collected during 2006 at an author's residence (R.A. Schroeder) on the coast in San Diego County. Activities in the Sierra Nevada snowpack were 3-4 TU during the winter of 2006-07 (R.L. Michel, USGS, written commun., 2007).

Absence of ${ }^{3} \mathrm{H}$ indicates water that recharged the aquifer earlier than about 1950; very high activity indicates water that infiltrated near the time of the "bomb peak" in the early 1960s; and low activity indicates either very recent recharge or a mixture of water with different ages if the simplifying assumptions are not valid (Mazor, 1991). For this study, water with a tritium content less than $1 \mathrm{TU}$ is interpreted as "older" water recharged prior to 1952 , while water with tritium content greater than or equal to $1 \mathrm{TU}$ is interpreted as "modern" water recharged after 1952.

A naturally occurring radioactive isotope of carbon, ${ }^{14} \mathrm{C}$, is produced by cosmic-ray spallation from nitrogen in the atmosphere (Mazor, 1991). Because of its long half-life, ${ }^{14} \mathrm{C}$ can be used to date water that is much older than is possible with ${ }^{3} \mathrm{H}$. Carbon-14 is measured from the DIC in water and reported as percent modern carbon (pmc) by comparing ${ }^{14} \mathrm{C}$ activities to the specific activity of National Bureau of Standards oxalic acid; 12.88 disintegrations per minute per gram (g) of C in the year 1950 equals 100 pmc (Mazor, 1991). Activity of ${ }^{14} \mathrm{C}$ has varied in the past in response to fluctuations in its natural production rate; activity has been decreased by injection of $\mathrm{CO}_{2}$ containing no ${ }^{14} \mathrm{C}$ into the atmosphere from burning of fossil fuel since the beginning of the Industrial Age approximately 200 years ago, and activity recently has increased with the nuclear era (Mazor, 1991). These factors are not important in the calculation of ${ }^{14} \mathrm{C}$ water ages for old water in this study as any effect is much less notable than is the exchange of aqueous DIC with carbonate minerals. The carbonate minerals have little or no ${ }^{14} \mathrm{C}$ resulting in a decrease in activity and corresponding increase in calculated "apparent" age of the DIC (Brinkmann and others, 1959; Vogel and Ehhalt, 1963).

\section{Application of Water-Quality Data}

Major-ion composition, boron concentrations, chloride-to-boron ratios, age of the water, and the stable-isotope ratios for $\mathrm{H}, \mathrm{O}$, and $\mathrm{Sr}$ were used in this study to help define the chronostratigraphic unit boundaries, sediment source, sediment facies, water source, and model zones. The following sections of the report describe how these different water-quality data or parameters were applied in this study.

\section{Chronostratigraphic Boundaries}

Following the initial identification of chronostratigraphic unit boundaries (see Chapter B), the boundary locations were refined using water-quality data from samples from the multiple-well monitoring sites (table 1.2). The principal water-quality data used were major-ion composition, dissolved-solids concentration, $\mathrm{Cl} / \mathrm{B}$ ratio, stable isotopes of water, Sr isotope ratio, and water age. Samples from wells screened in the same chronostratigraphic unit along a flow path were compared to determine if they had similar water-quality characteristics. If the characteristics were similar, no adjustment was made; however, if the characteristics differed, then the boundary locations were re-evaluated. Maps were prepared showing selected water-quality parameters to help identify where differences occur in a selected parameter in each chronostratigraphic unit (figs. 1.3-1.8). These maps often show spatial patterns of gradual change in the values of water-quality parameters across the LACP within individual chronostratigraphic units, but local deviations from the regional spatial trends were carefully evaluated as supporting evidence to assign chronostratigraphic units to the wells in question (figs. 1.3-1.8).

\section{Sediment Source}

In this study, strontium isotope ratios were used as geochemical tracers of sediment source. As stated in the "Stable Isotopes" section of this appendix, the dissolution and exchange of strontium between solid and aqueous phases is fairly rapid, so groundwater commonly acquires a $\mathrm{Sr}$ isotopic signature that matches the rock type with which it was most recently in contact (Turekian and Wedepohl, 1961). In this context, it was assumed that the ${ }^{87} \mathrm{Sr} /{ }^{86} \mathrm{Sr}$ ratio of a groundwater sample can be used to determine the origin of the sediment. The ${ }^{87} \mathrm{Sr} /{ }^{86} \mathrm{Sr}$ ratios in samples collected from wells within and adjacent to the LACP ranged from 0.7080 to $0.7116(\mathrm{n}=184$; table 1.2). Major sources of sediment to LACP include the Los Angeles River, San Gabriel River, Santa Ana River, and the low-lying hills that border the LACP (fig. 1.1). 


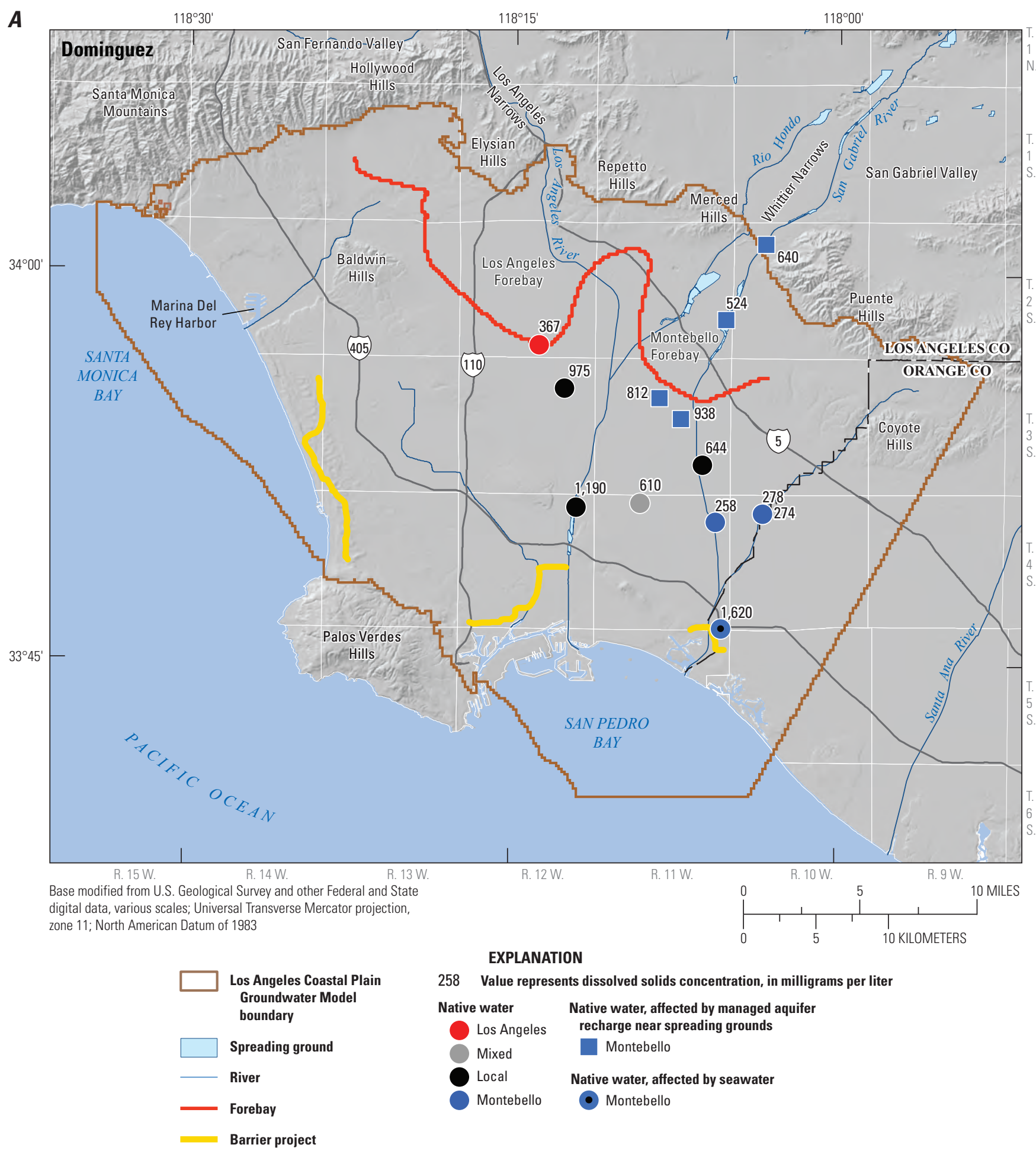

Figure 1.3. Dissolved-solids concentrations in samples from monitoring wells screened in chronostratigraphic units in the Los Angeles Coastal Plain, Los Angeles and Orange Counties, California: $A$, Dominguez; $B$, Mesa; $C$, Pacific A; $D$, Pacific; $E$, Harbor; $F$, Bent Spring; $G$, Upper Wilmington $A ; H$, Upper Wilmington $B$; I, Lower Wilmington; J, Long Beach $A$; $K$, Long Beach $B$; L, Long Beach BC; $M$, Long Beach C; and $N$, Tertiary. 


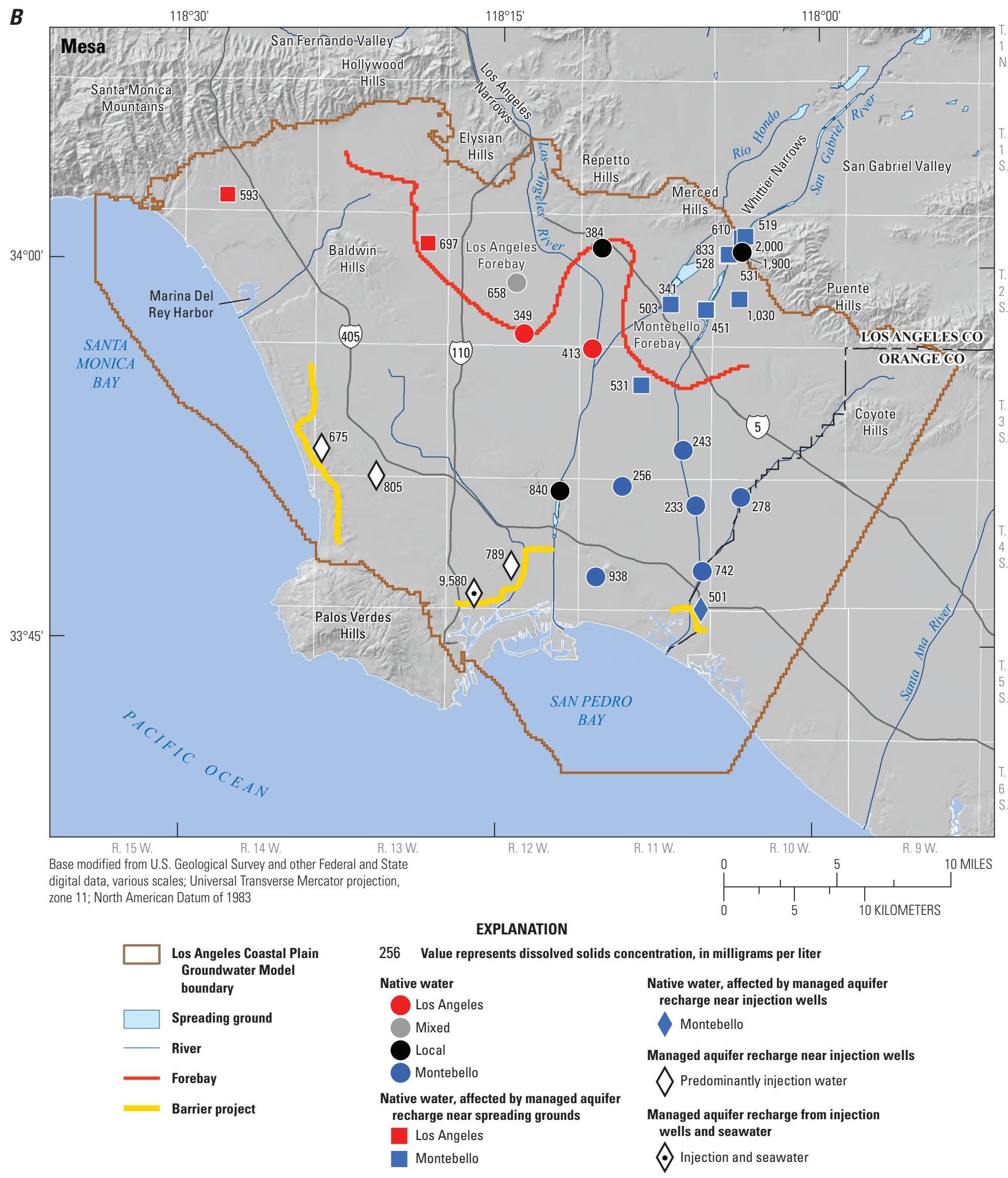

Figure 1.3.-Continued 


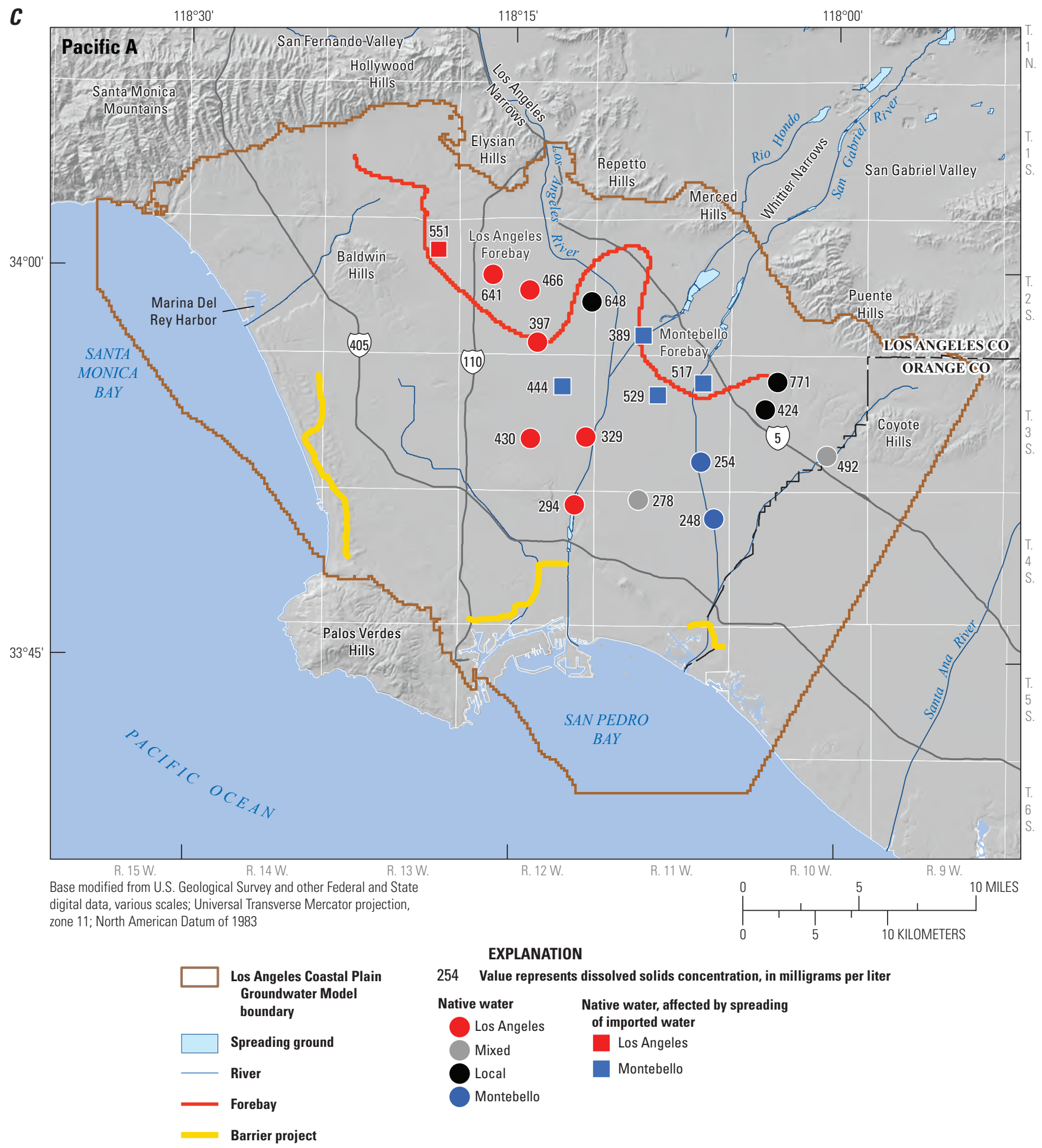

Figure 1.3.-Continued 


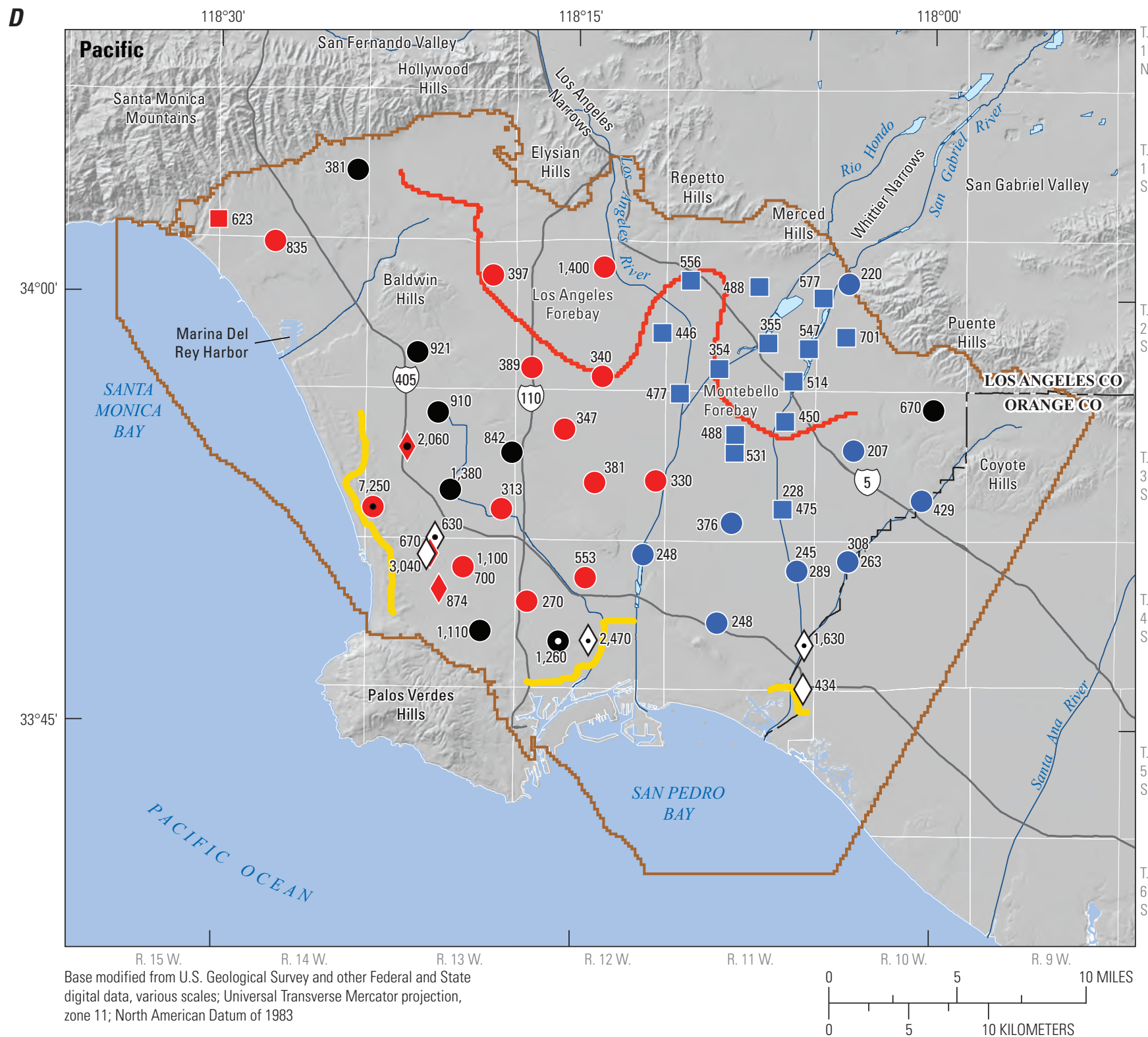

EXPLANATION

Los Angeles Coastal Plain Groundwater Model boundary

Spreading ground

River

Forebay

Barrier project
228

Native water
Los Angeles
Local
Montebello
Native water, affected by managed aquifer
recharge near spreading grounds
Los Angeles
Montebello

Native water, affected by seawater

Losal
Native water, affected by managed aquifer recharge near injection wells

$\checkmark$ Los Angeles

Native water, affected by managed aquifer recharge near injection wells and seawater

- Los Angeles

Managed aquifer recharge near injection wells $\checkmark$ Predominantly injection water

Managed aquifer recharge from injection wells and seawater $\diamond$ Injection and seawater

Figure 1.3.-Continued 
$\boldsymbol{E}$

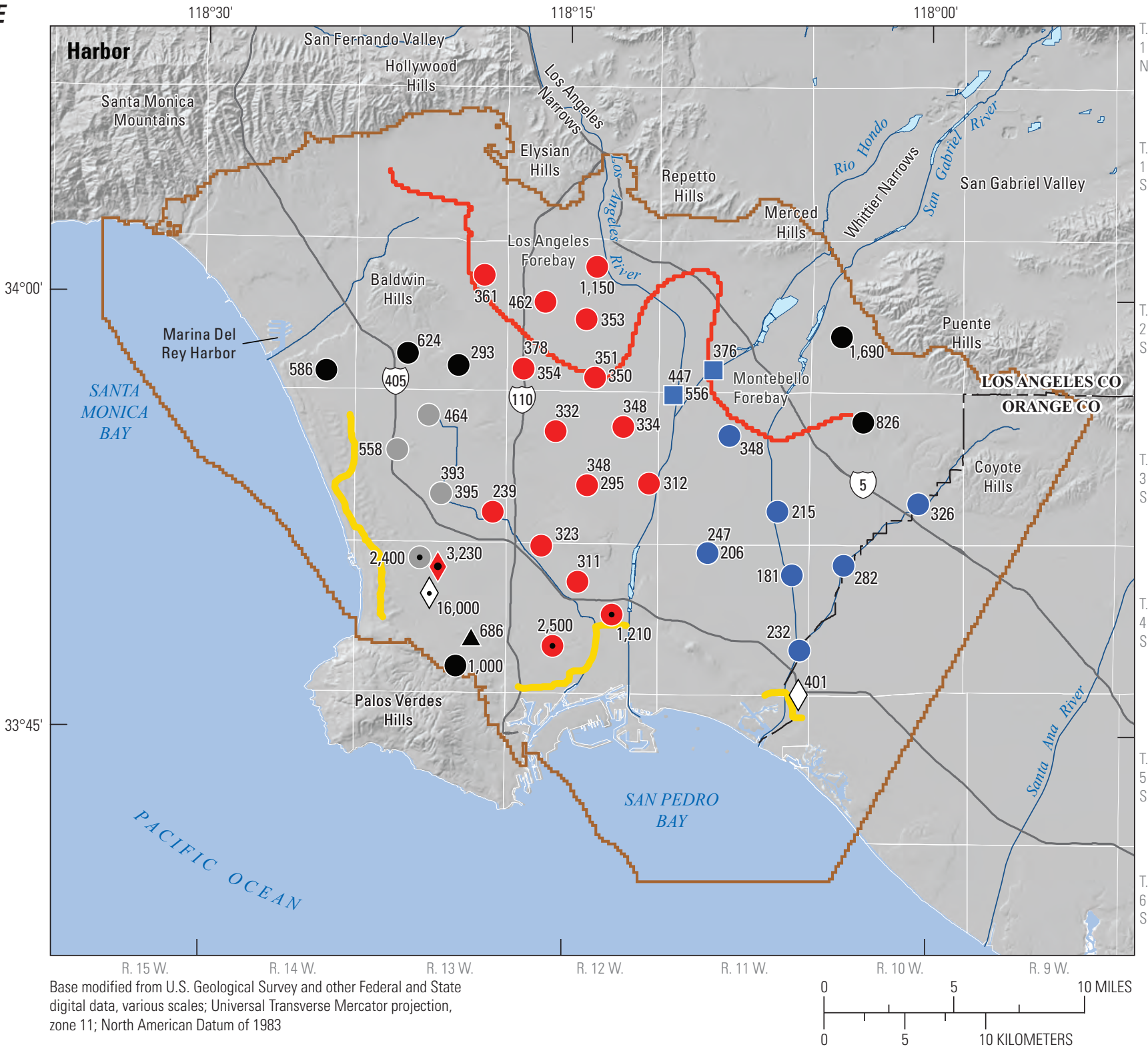

EXPLANATION

Los Angeles Coastal Plain 282 Value represents dissolved solids concentration, in milligrams per liter

Groundwater Model Native water Native water, affected by seawate boundary

Spreading ground

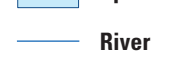

Forebay

Barrier project
Los Angeles

Mixed

Local

Montebello

Native water, affected by managed aquifer recharge near spreading grounds Montebello
Los Angeles

- Mixed

Native water, affected by managed aquifer recharge near injection wells and seawater

- Los Angeles
Managed aquifer recharge near injection wells $\diamond$ Predominantly injection water

Managed aquifer recharge from injection wells and seawater

$\checkmark$ Injection and seawater

Paleowater

$\Delta$ Local

Figure 1.3.-Continued 


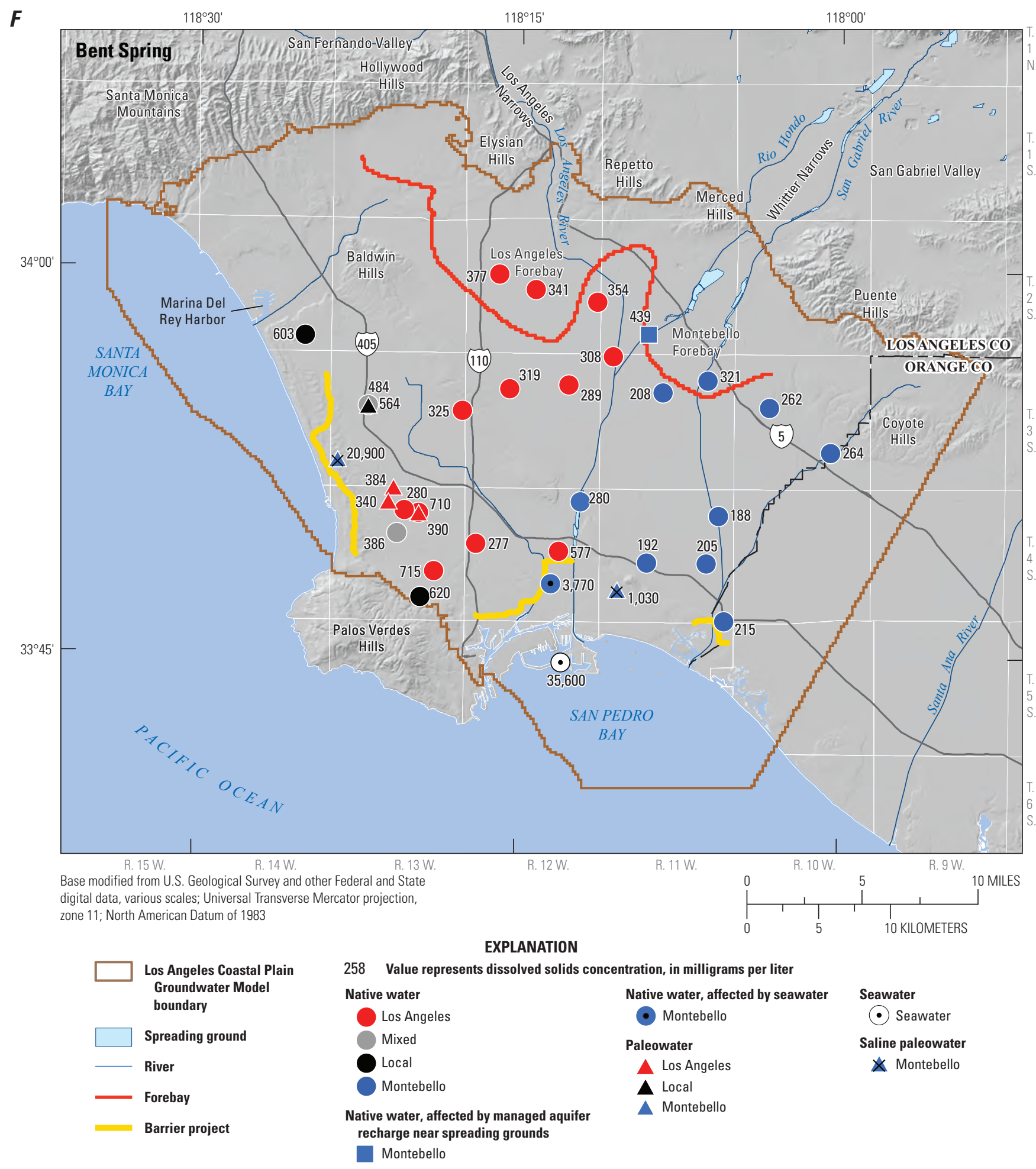

Figure 1.3.-Continued 
G

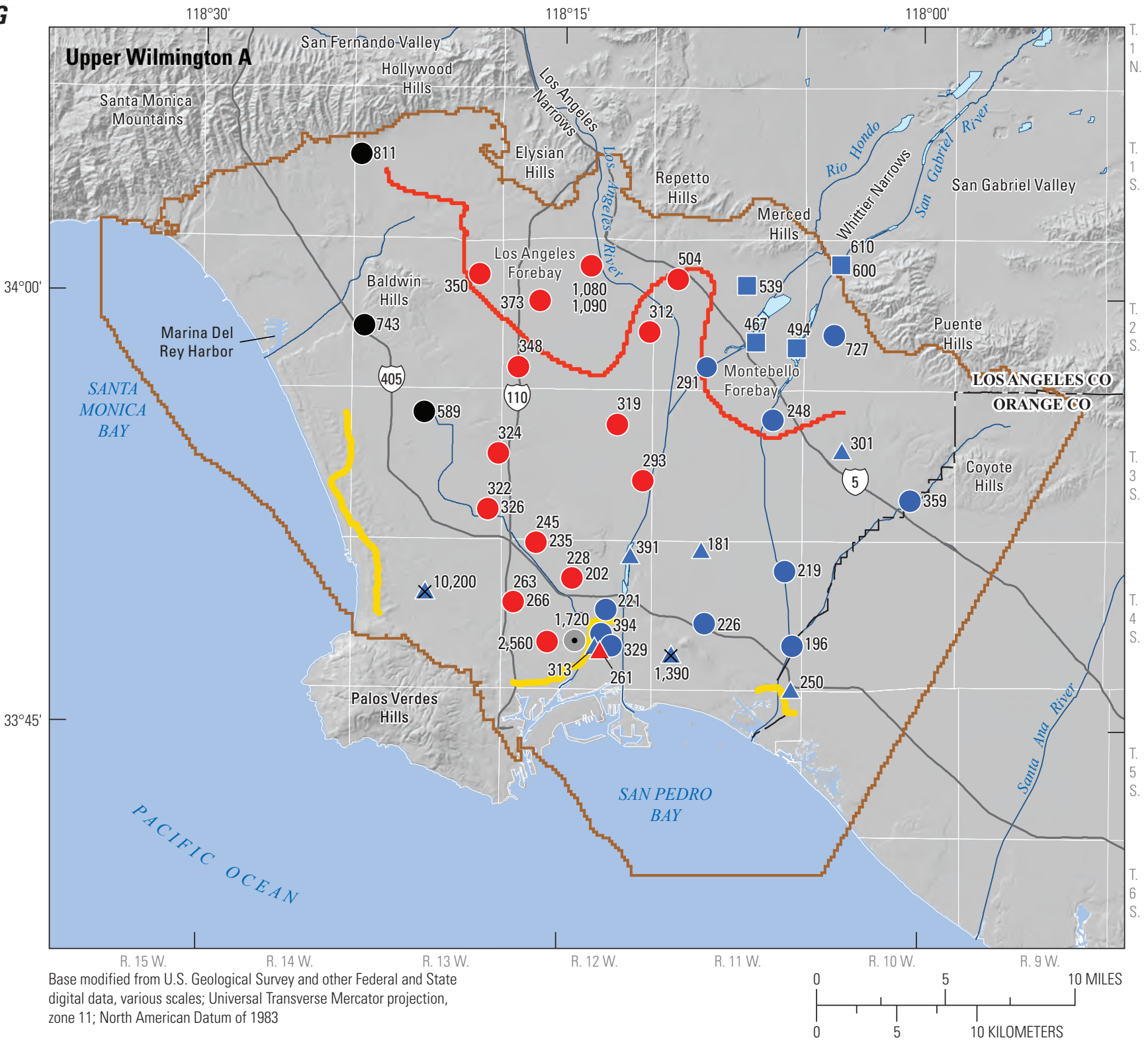

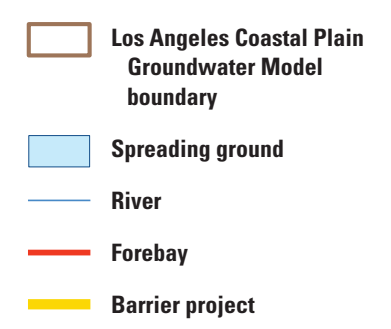

EXPLANATION

Value represents dissolved solids concentration, in milligrams per liter

Native water

Los Angeles

Local

Montebello

Native water, affected by managed aquifer recharge near spreading grounds

Montebello
Native water, affected

by seawater

- Mixed

Paleowater

- Los Angeles

$\Delta$ Montebello

Saline paleowater

* Montebello

Figure 1.3.-Continued 


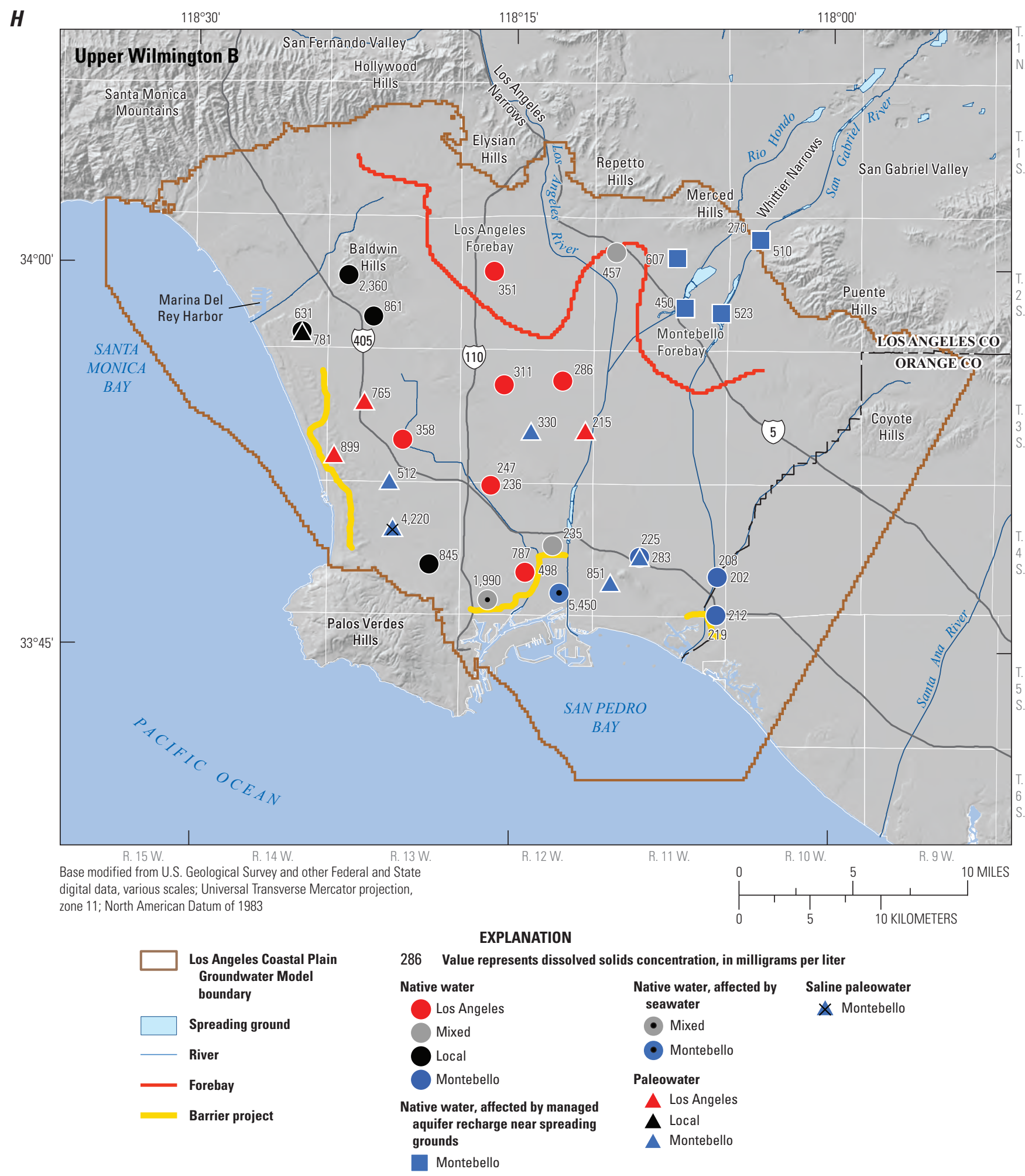

Figure 1.3.-Continued 


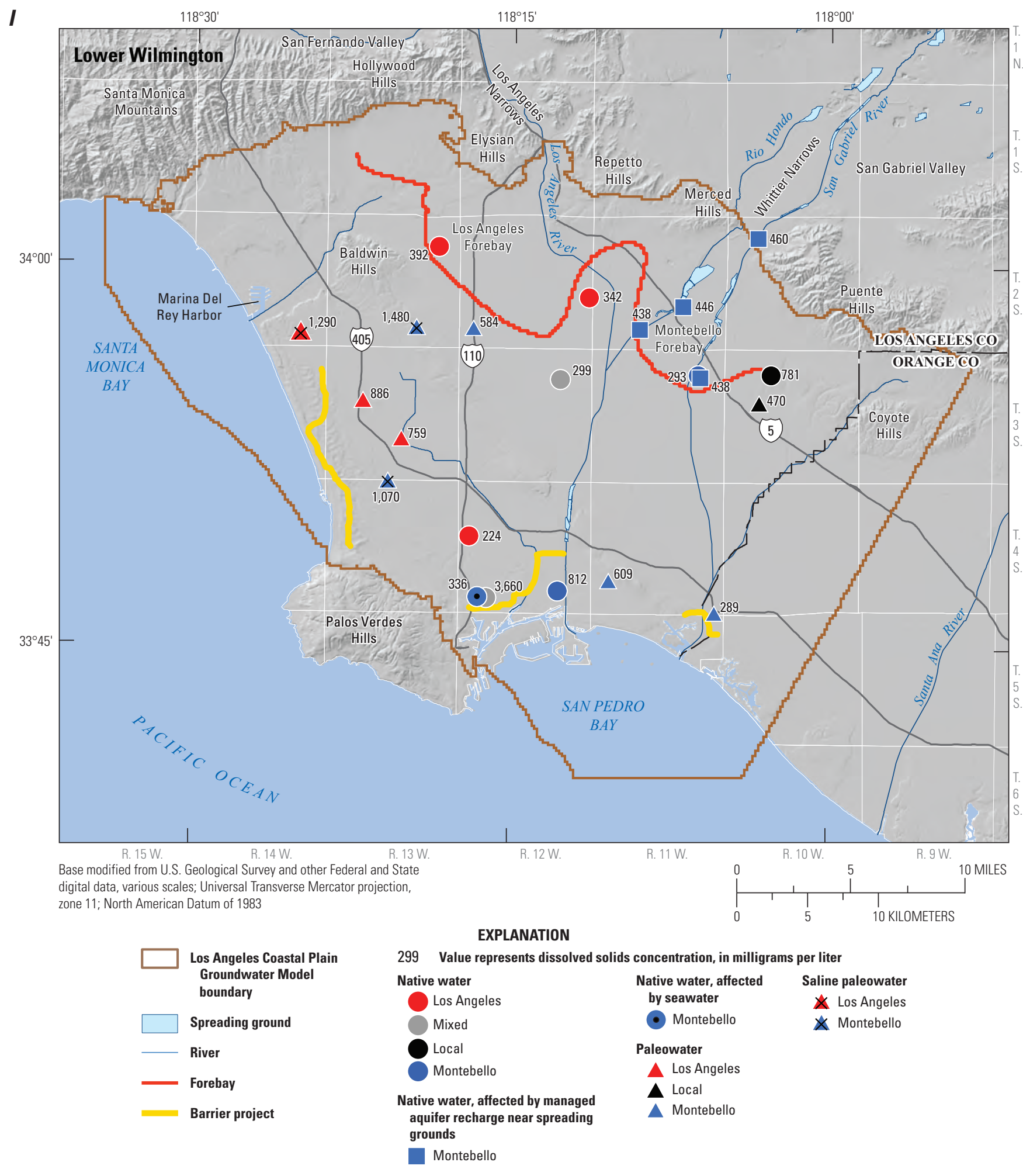

Figure 1.3.-Continued 


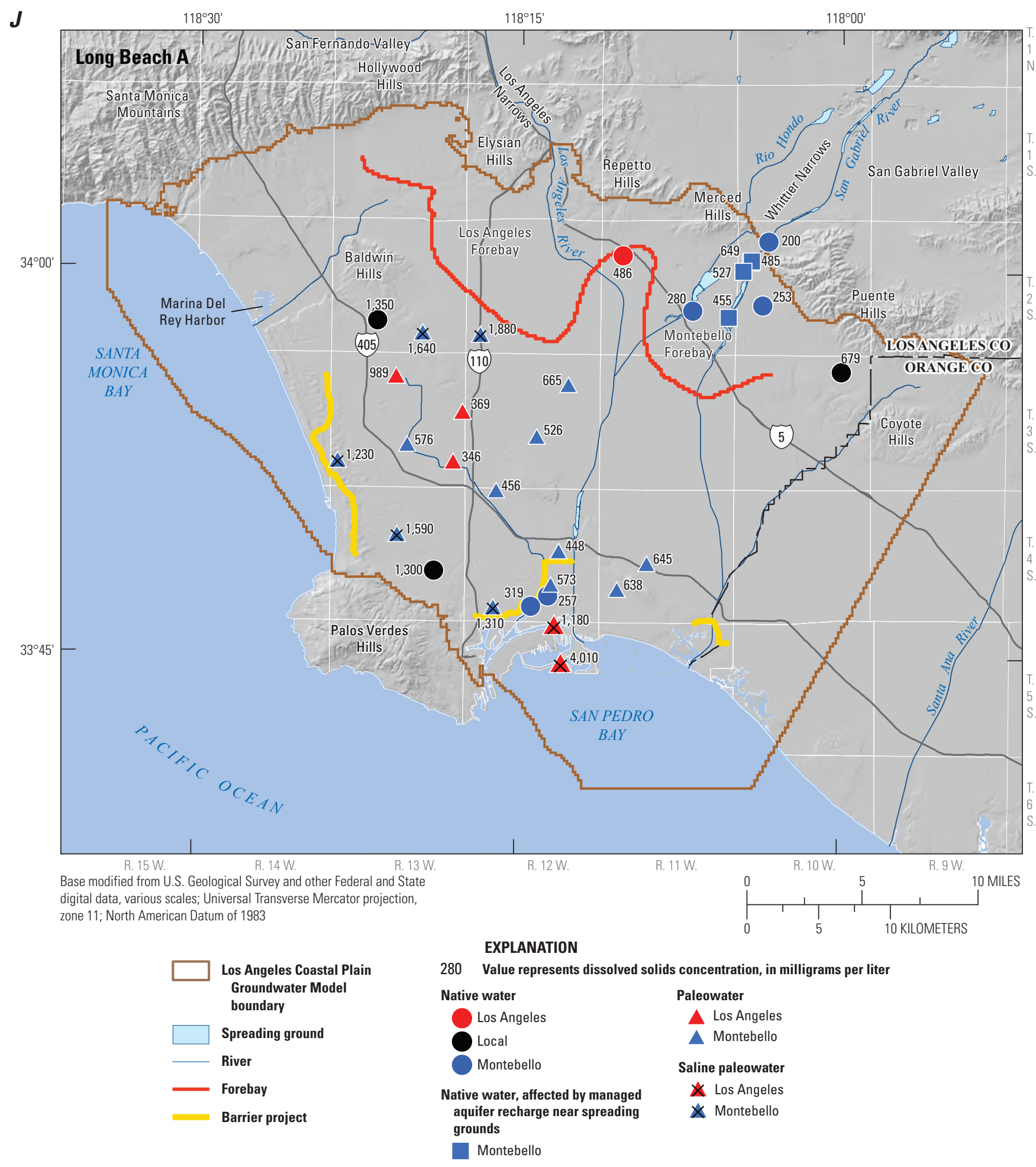

Figure 1.3.-Continued 


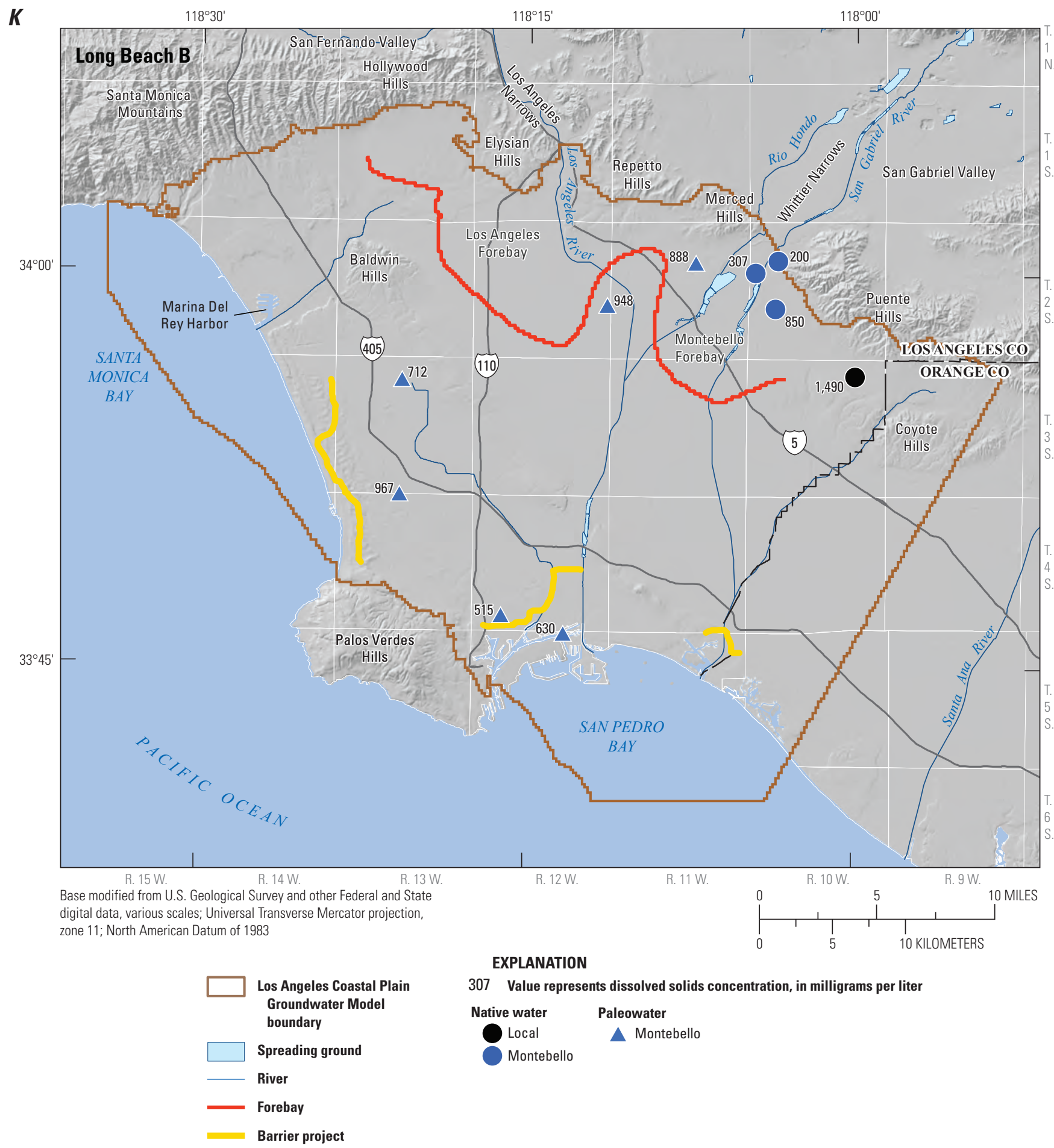

Figure 1.3.-Continued 


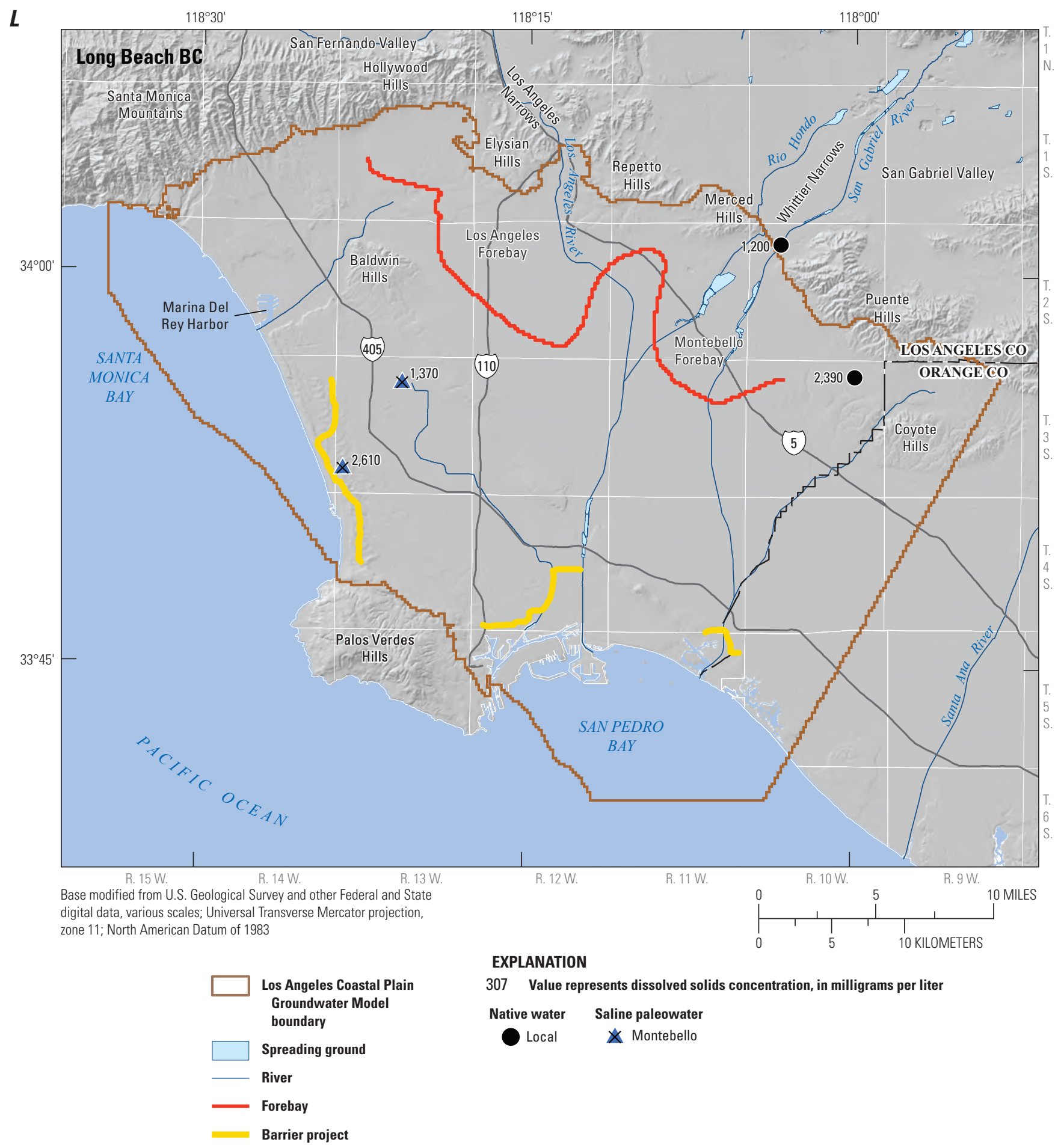

Figure 1.3.-Continued 


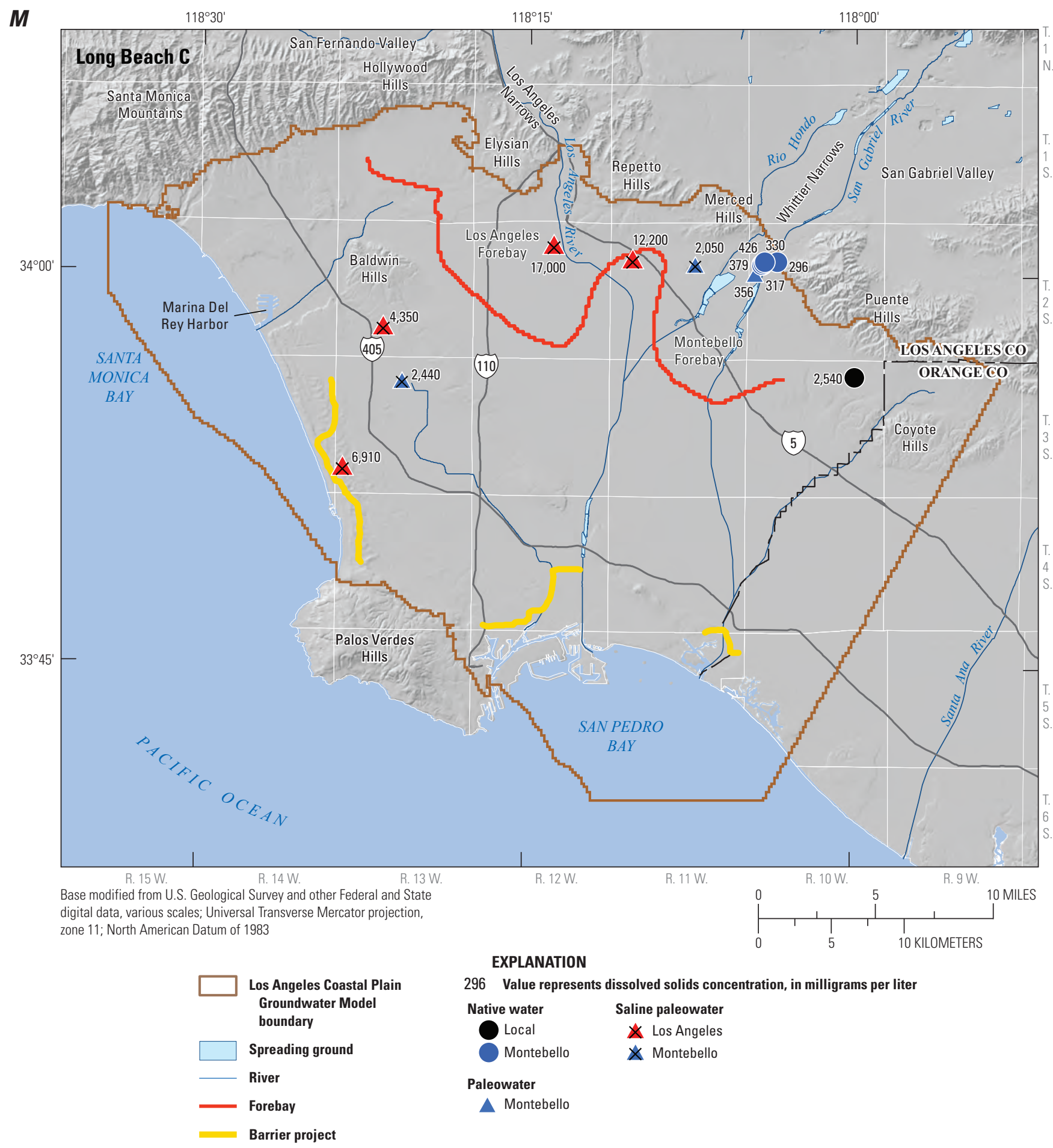

Figure 1.3.-Continued 


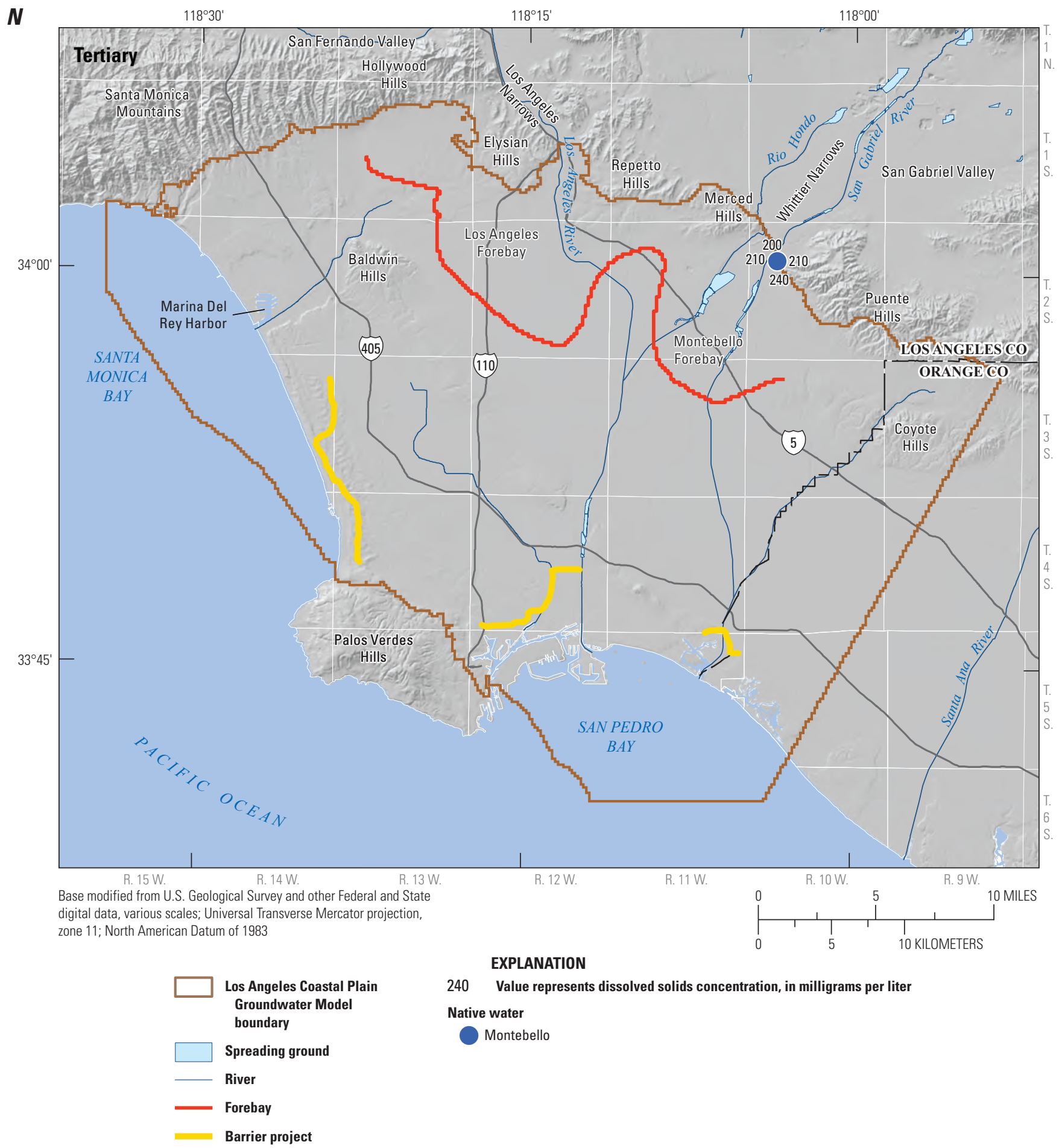

Figure 1.3.-Continued 
$\boldsymbol{A}$

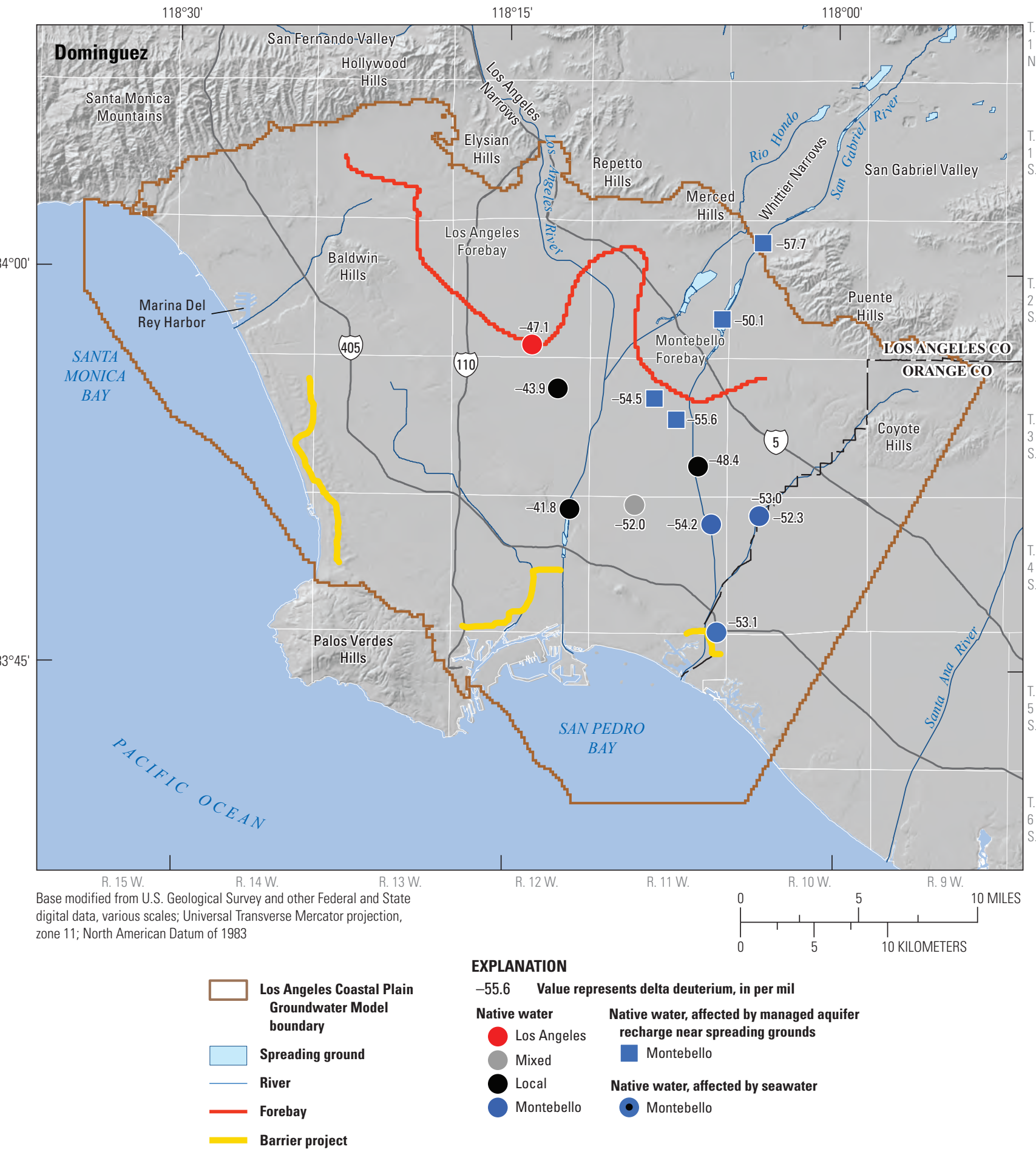

Figure 1.4. Delta deuterium values in samples from monitoring wells screened in chronostratigraphic units in the Los Angeles Coastal Plain, Los Angeles and Orange Counties, California: $A$, Dominguez; $B$, Mesa; $C$, Pacific A; $D$, Pacific; $E$, Harbor; $F$, Bent Spring; $G$, Upper Wilmington $\mathrm{A} ; H$, Upper Wilmington $\mathrm{B}$; I, Lower Wilmington; J, Long Beach $\mathrm{A}$; $K$, Long Beach $\mathrm{B}$; L, Long Beach BC; $M$, Long Beach $C$; and $N$, Tertiary. 
B

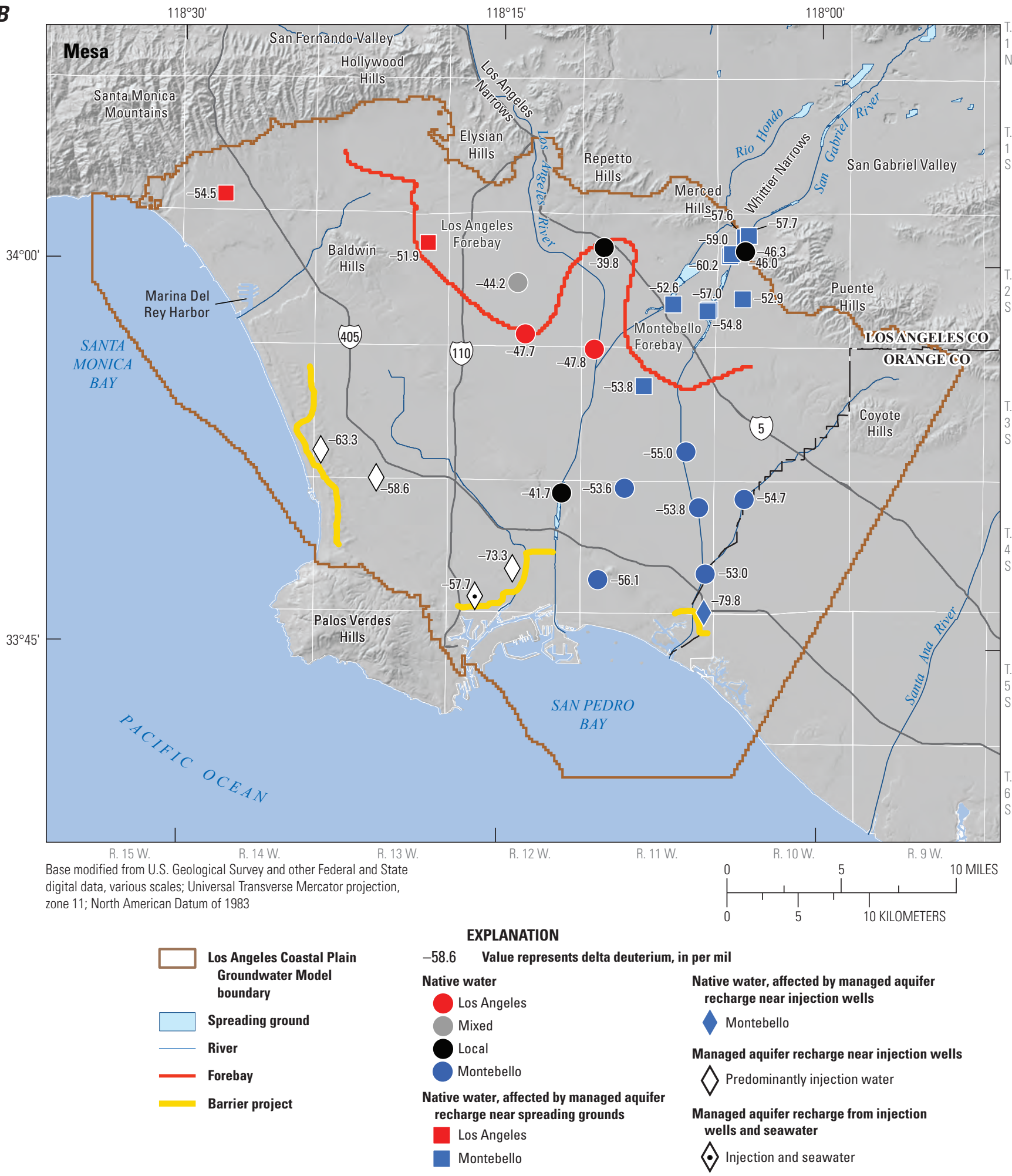

Figure 1.4.-Continued 


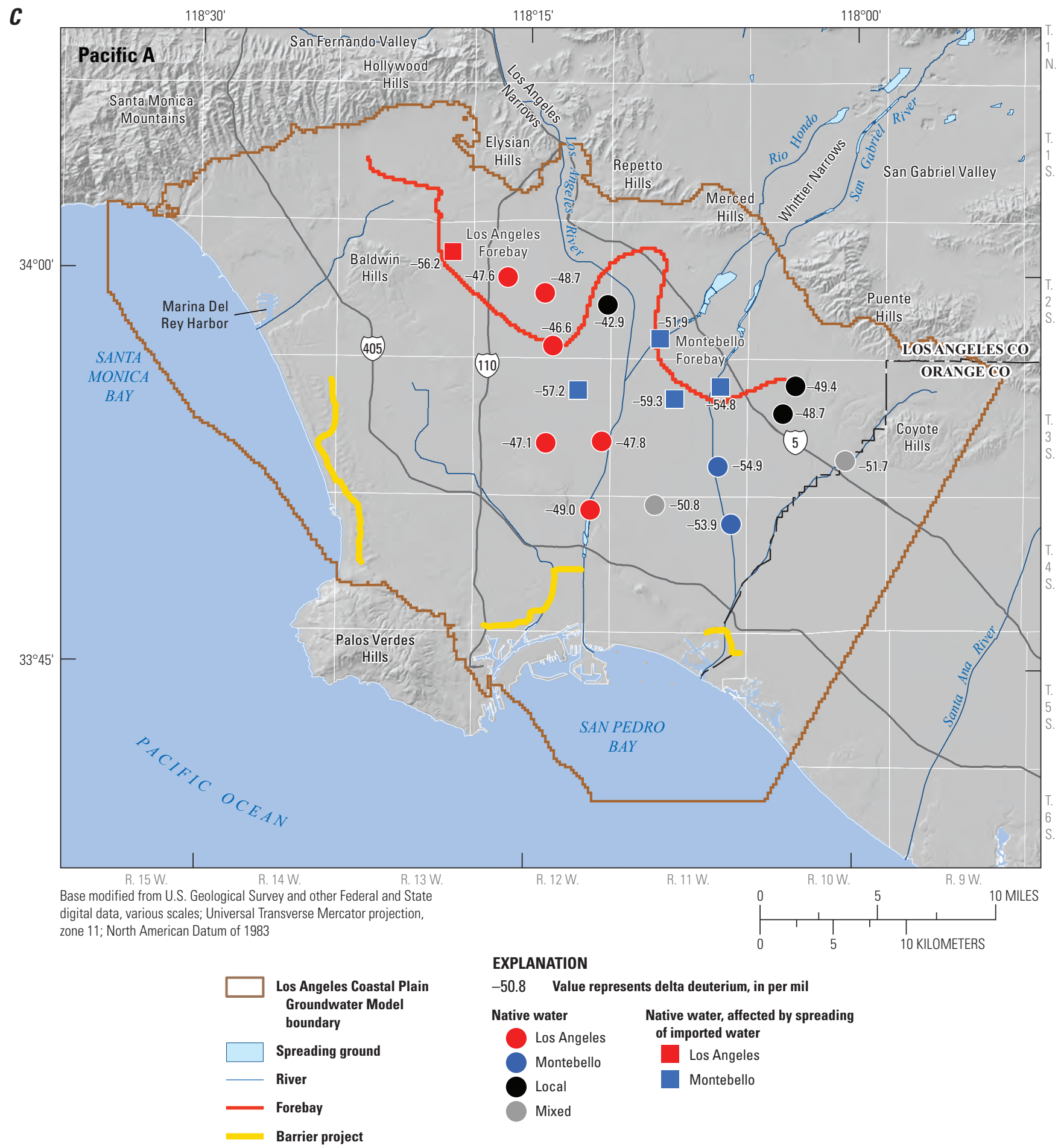

Figure 1.4.-Continued 
D

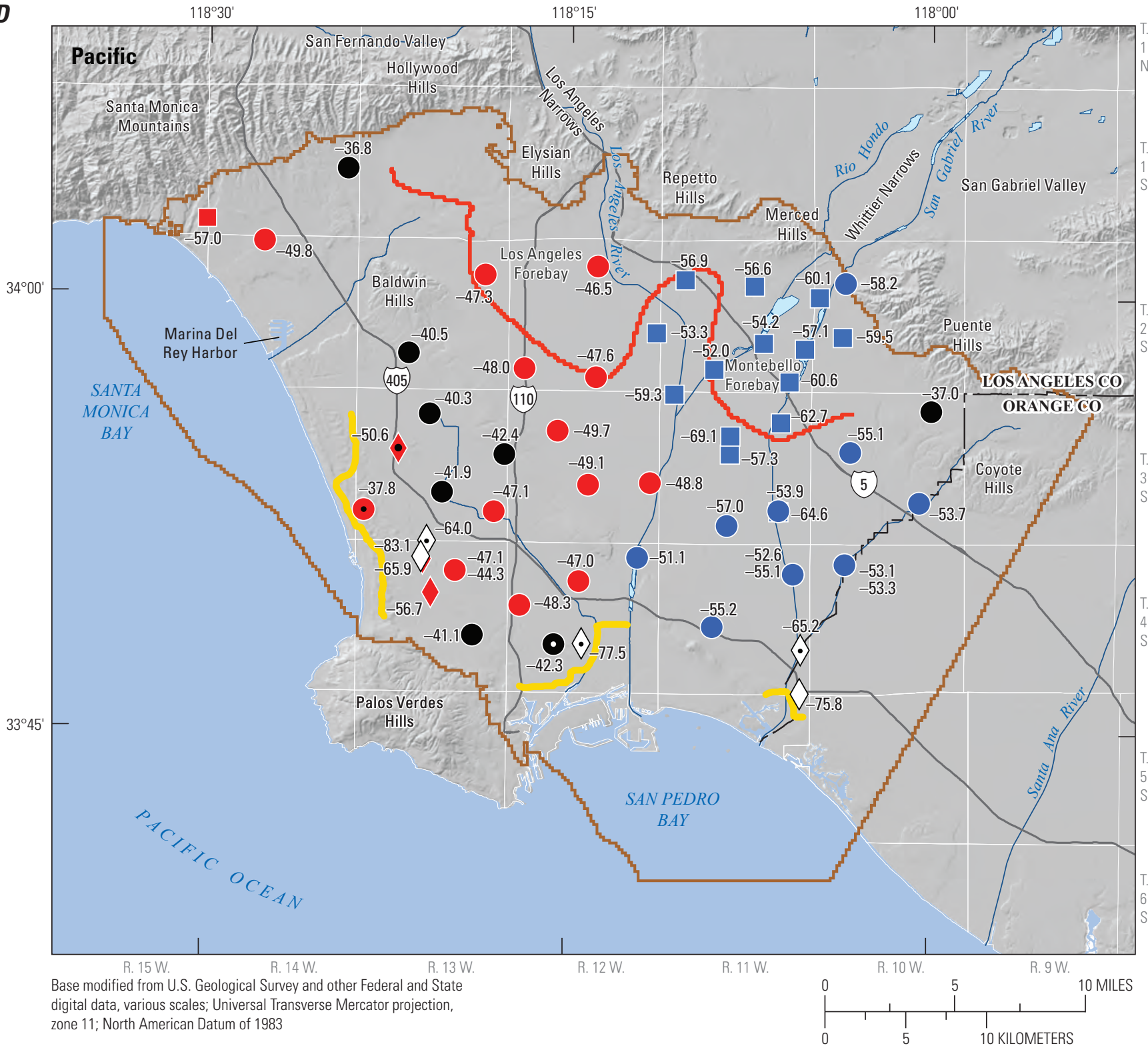

EXPLANATION

Los Angeles Coastal Plain Groundwater Model boundary

Spreading ground

River

Forebay

Barrier project
-56.6 Value represents delta deuterium, in per mil

Lostive water
Local
Montebello
Native water, affected by managed aquifer
recharge near spreading grounds
Los Angeles
Montebello
Native water, affected by seawater
Los Angeles
Local

Native water, affected by managed aquifer recharge near injection wells

$\checkmark$ Los Angeles

Native water, affected by managed aquifer recharge near injection wells and seawater

- Los Angeles

Managed aquifer recharge near injection wells $\checkmark$ Predominantly injection water

Managed aquifer recharge from injection wells and seawater $\diamond$ Injection and seawater

Figure 1.4.-Continued 
$\boldsymbol{E}$

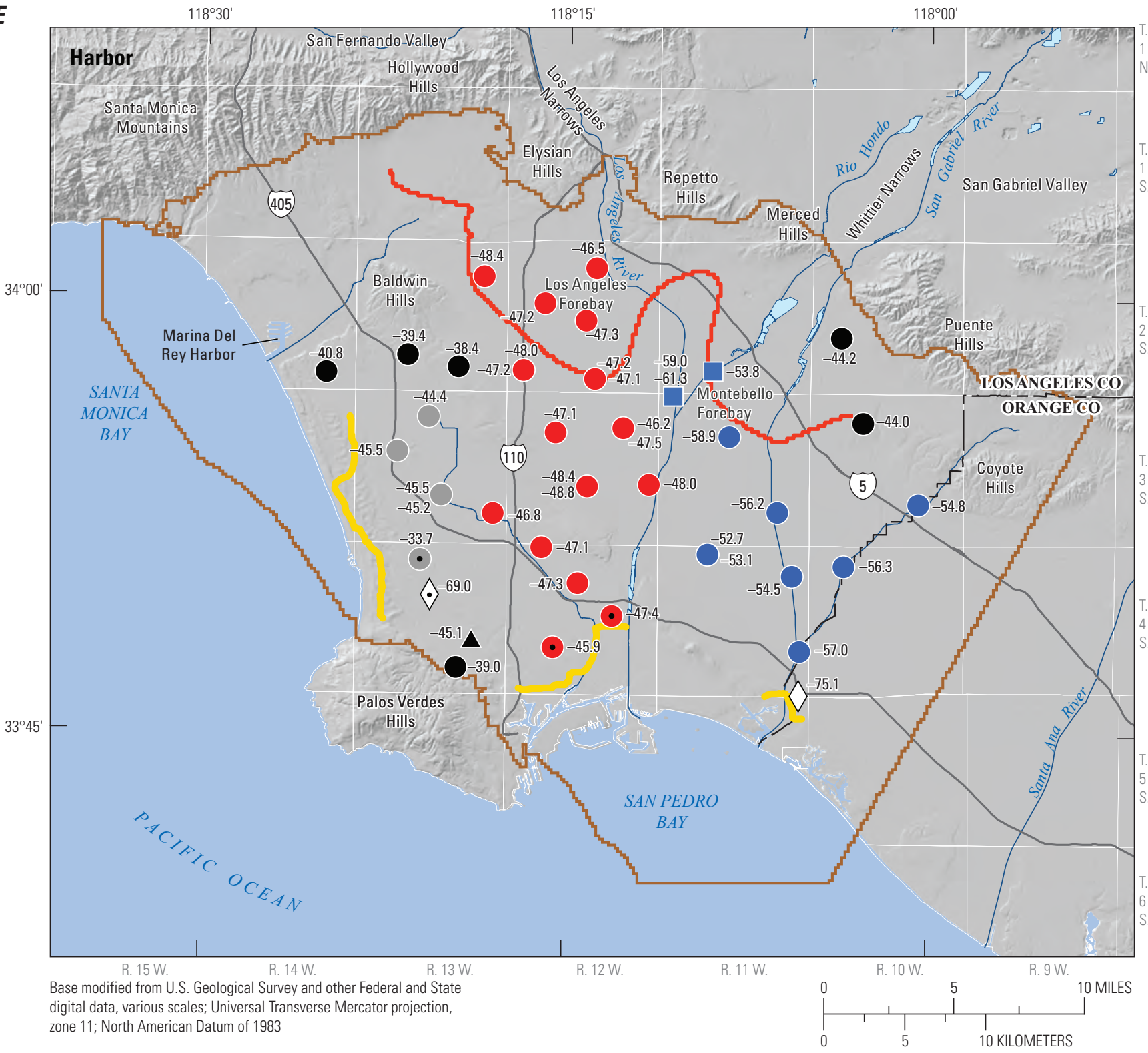

EXPLANATION

Los Angeles Coastal Plain Groundwater Model boundary

Spreading ground

River

Forebay

Barrier project

\section{-54.5 Value represents delta deuterium, in per mil}

Native water

$$
\text { Los Angeles }
$$

Mixed

Local

Montebello

Native water, affected by managed aquifer recharge near spreading grounds Montebello
Managed aquifer recharge from injection wells and seawater

$\diamond$ Injection and seawater

Managed aquifer recharge near injection wells $\diamond$ Predominantly injection water

\section{Paleowater}

$\Delta$ Local

Figure 1.4.-Continued 


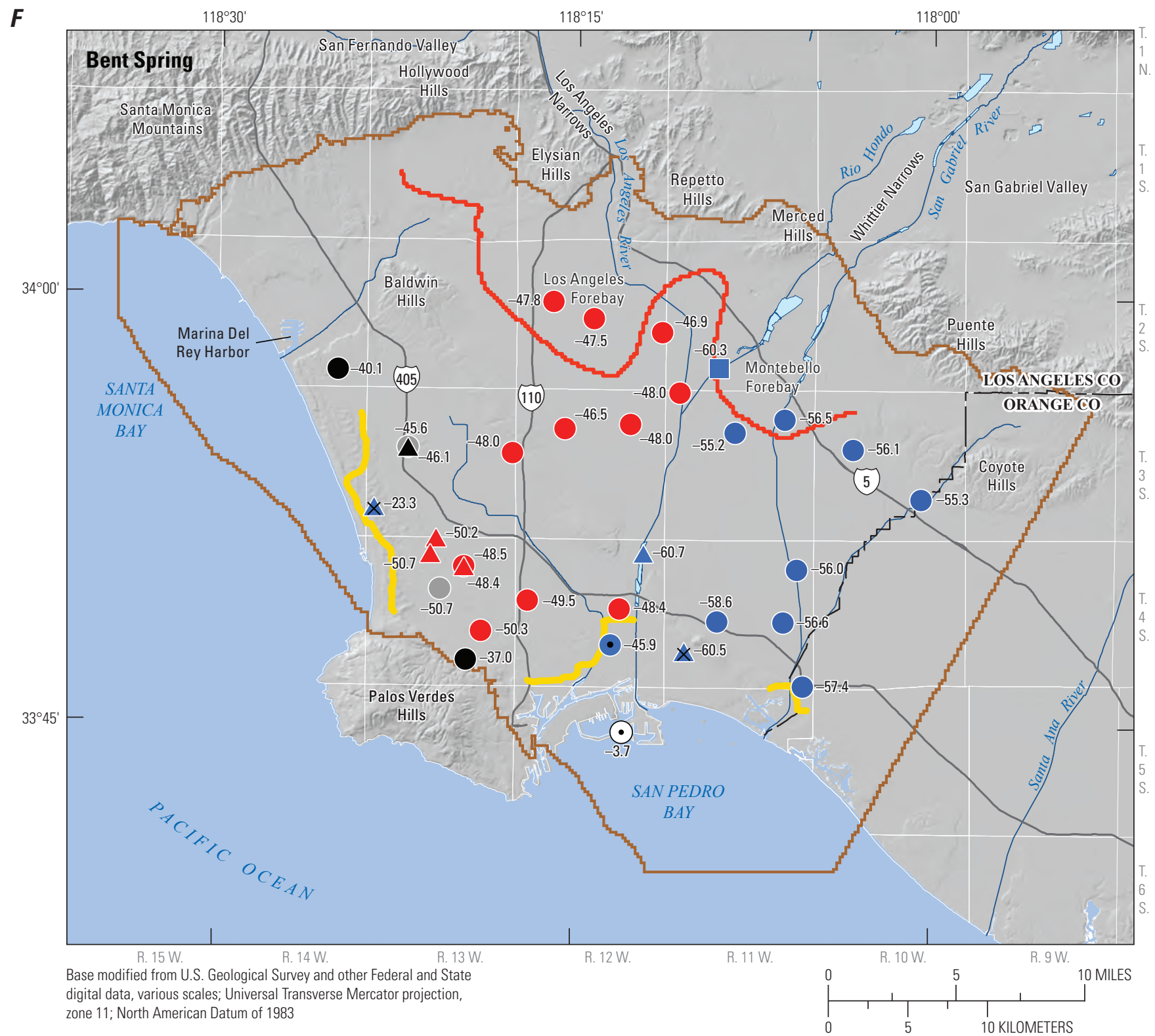
zone 11; North American Datum of 1983

\begin{tabular}{|l|l}
\hline & $\begin{array}{l}\text { Los Angeles Coastal Plain } \\
\text { Groundwater Model } \\
\text { boundary }\end{array}$ \\
\hline & Spreading ground \\
\hline$\quad$ River \\
\hline$\quad$ Forebay \\
Barrier project
\end{tabular}

\section{EXPLANATION}

-58.6 Value represents delta deuterium, in per mil

Native water
Los Angeles
Mixed
Local
Montebello

Native water, affected by managed aquifer recharge near spreading grounds

\section{Native water, affe
- Montebello \\ Paleowater \\ - Los Angeles \\ $\Delta$ Local \\ A Montebello}

Seawater

- Seawater

Saline paleowater

× Montebello

Figure 1.4.-Continued 
G

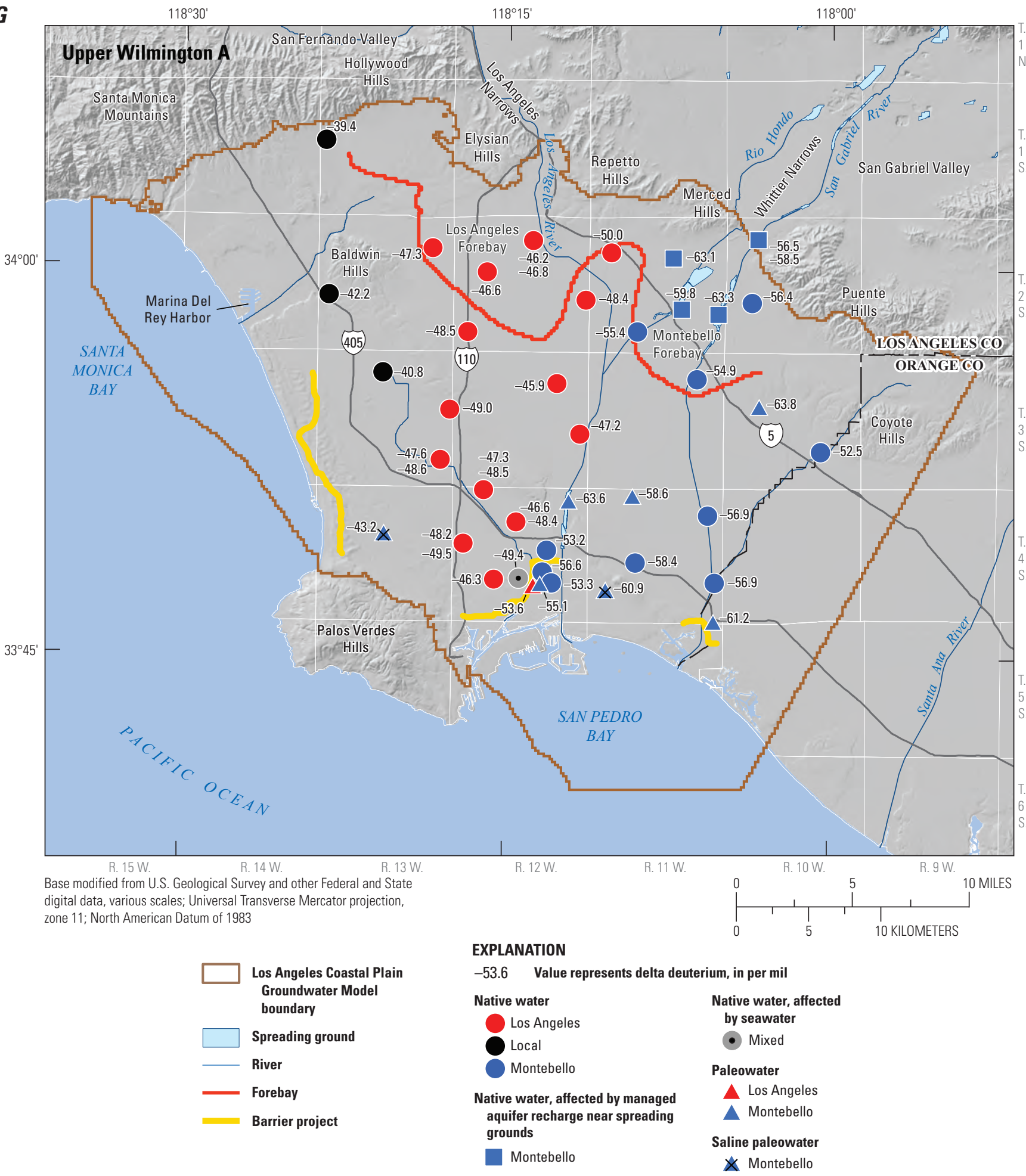

Figure 1.4.-Continued 


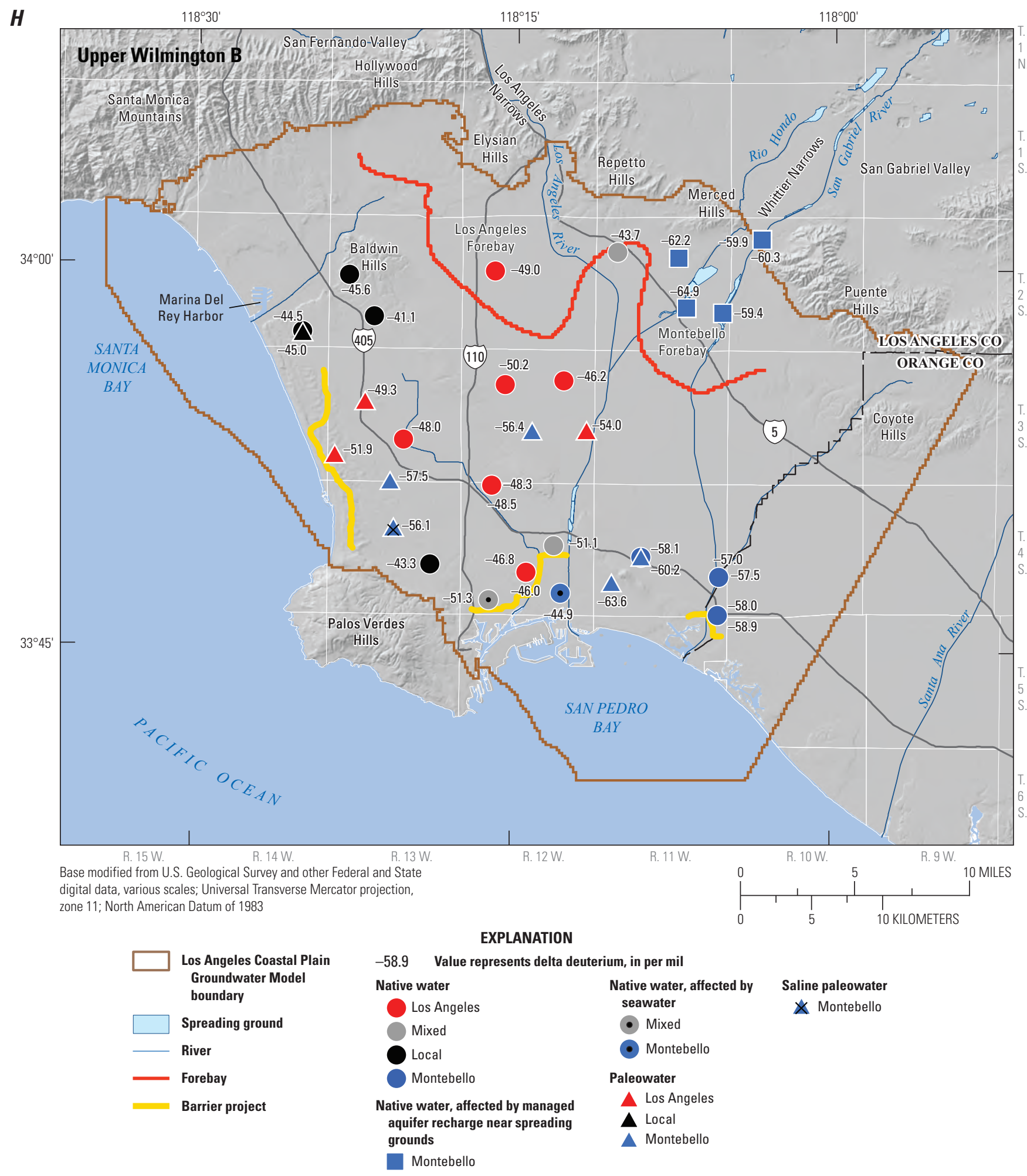

Figure 1.4.-Continued 


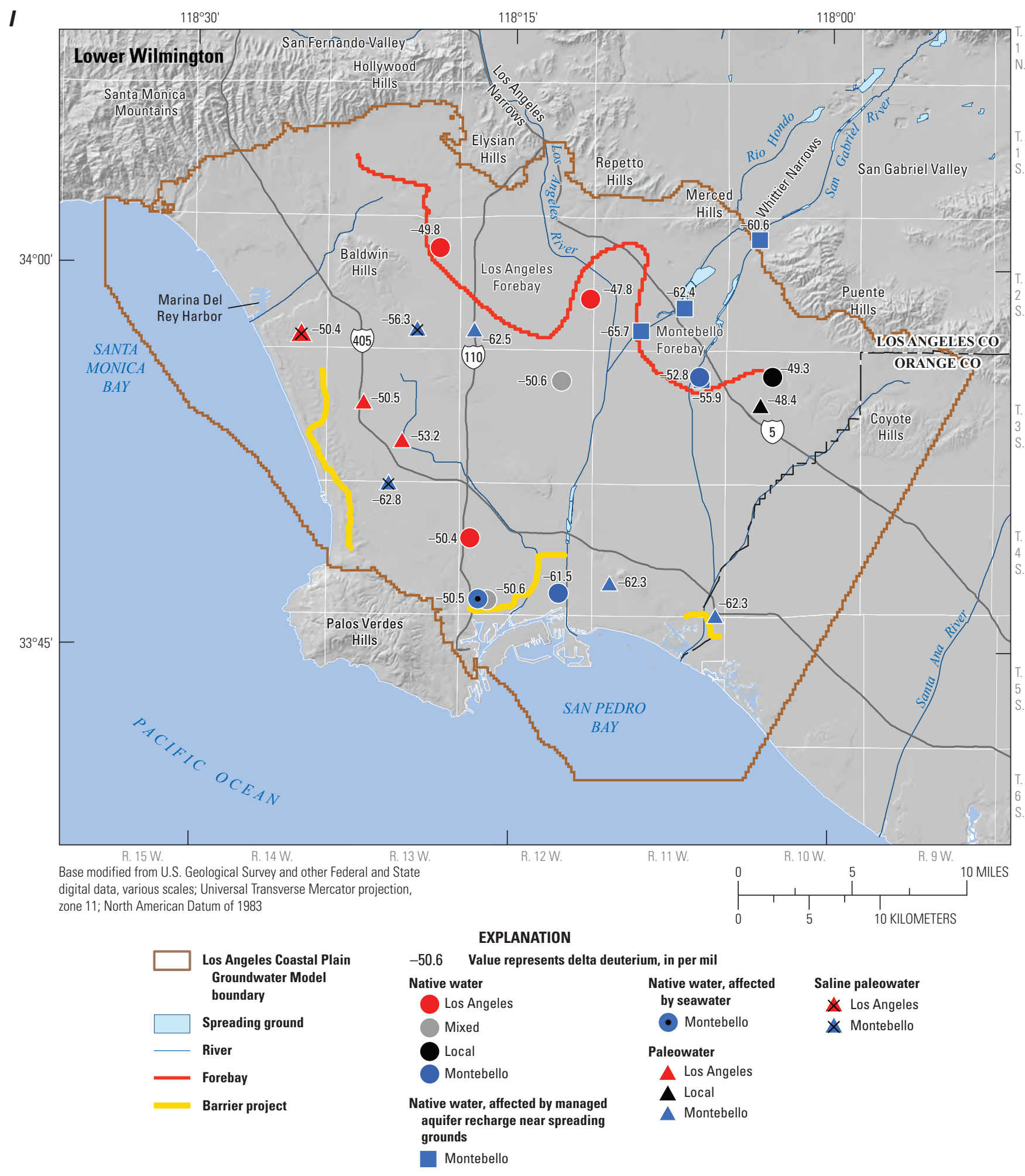

Figure 1.4.-Continued 


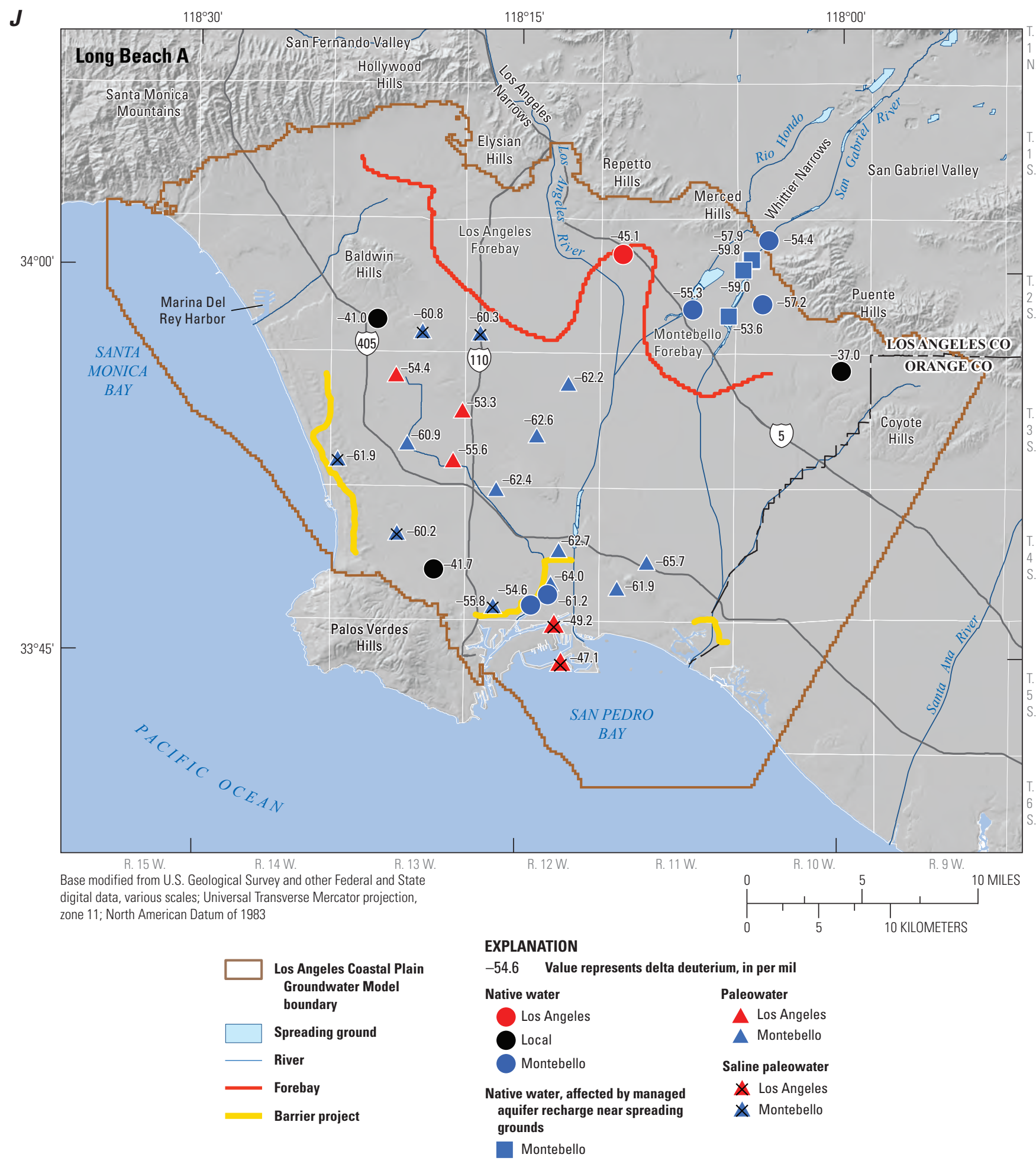

Figure 1.4.-Continued 


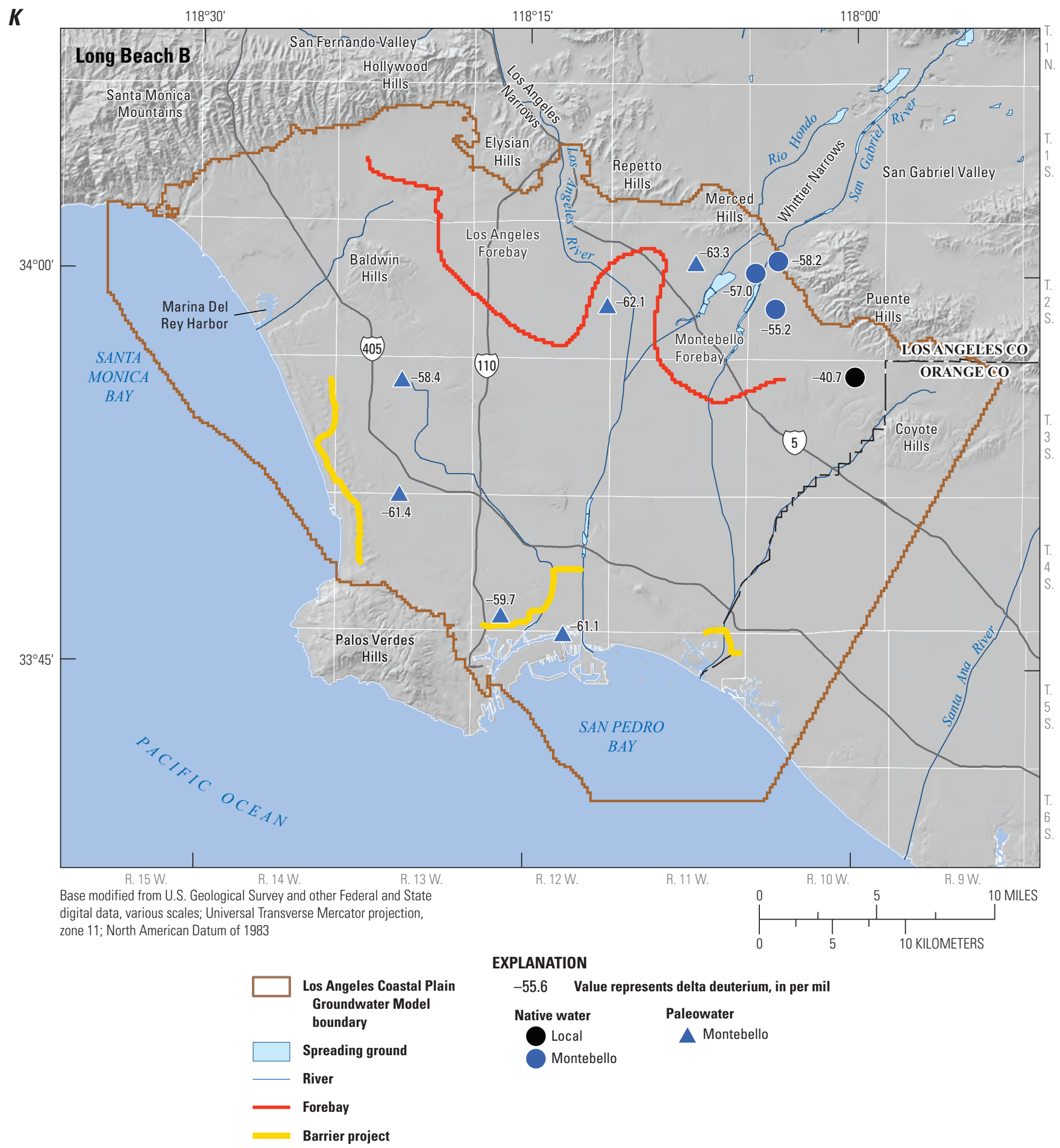

Figure 1.4.-Continued 


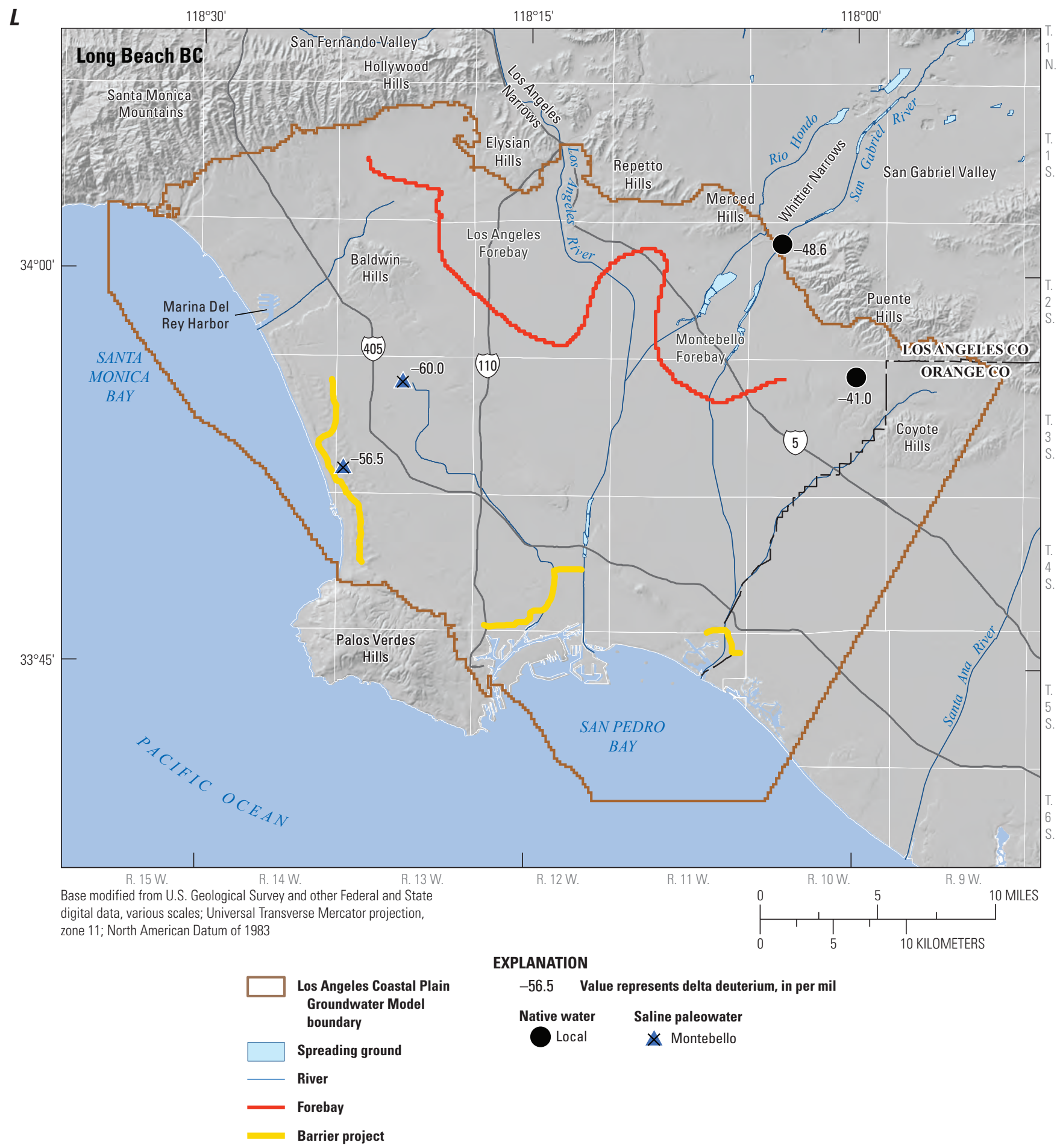

Figure 1.4.-Continued 
M

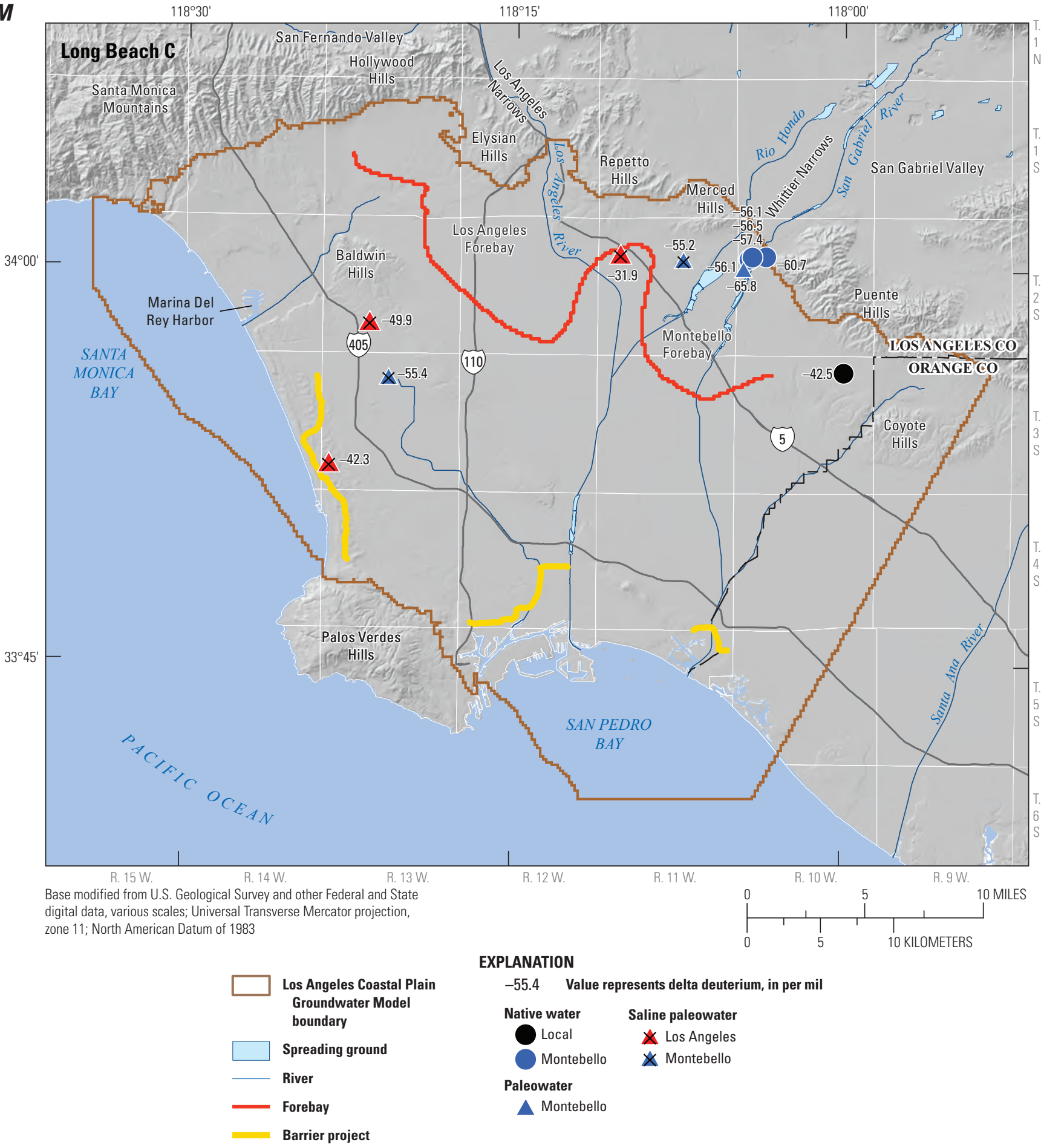

Figure 1.4.-Continued 


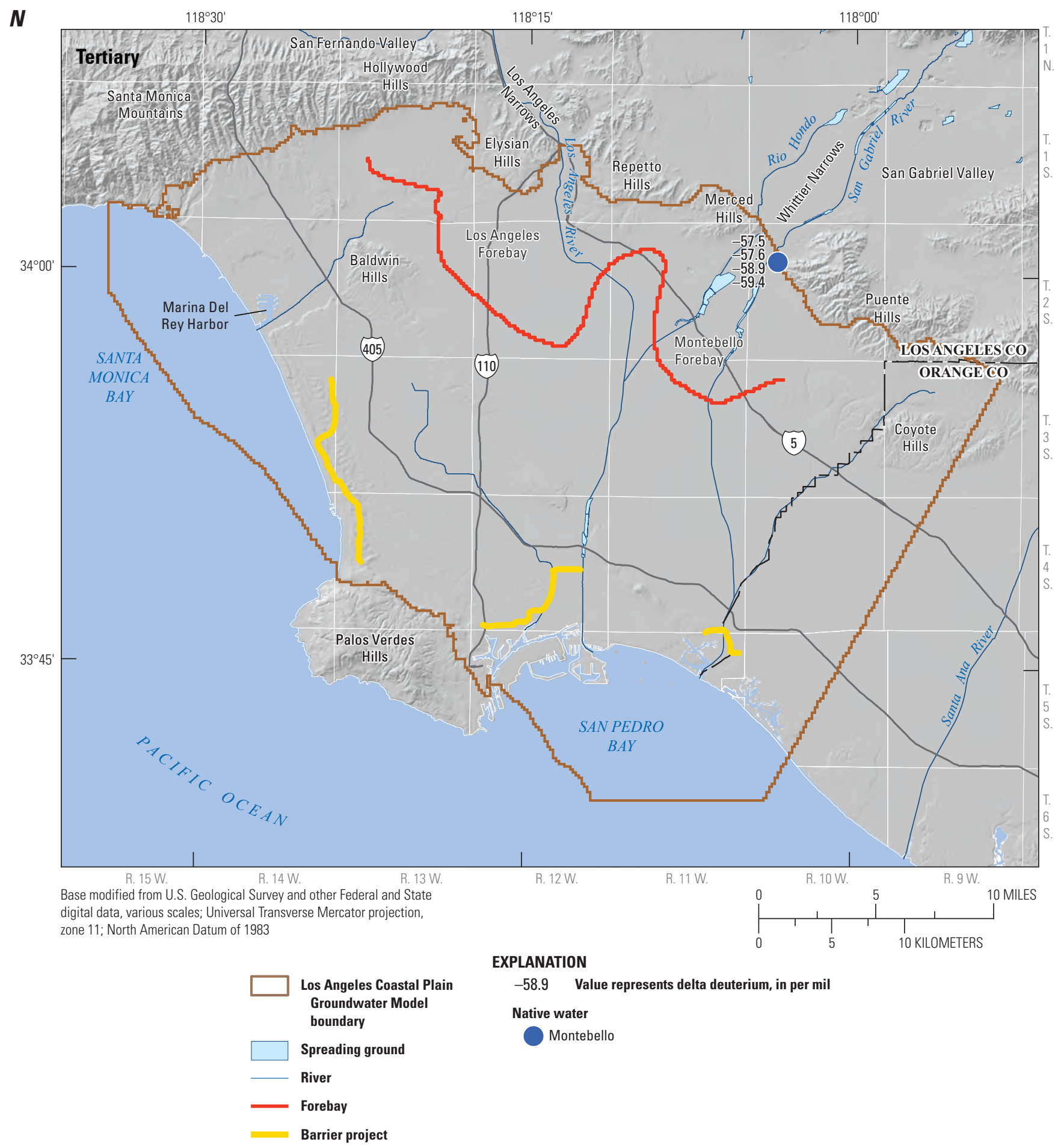

Figure 1.4.-Continued 
$\boldsymbol{A}$

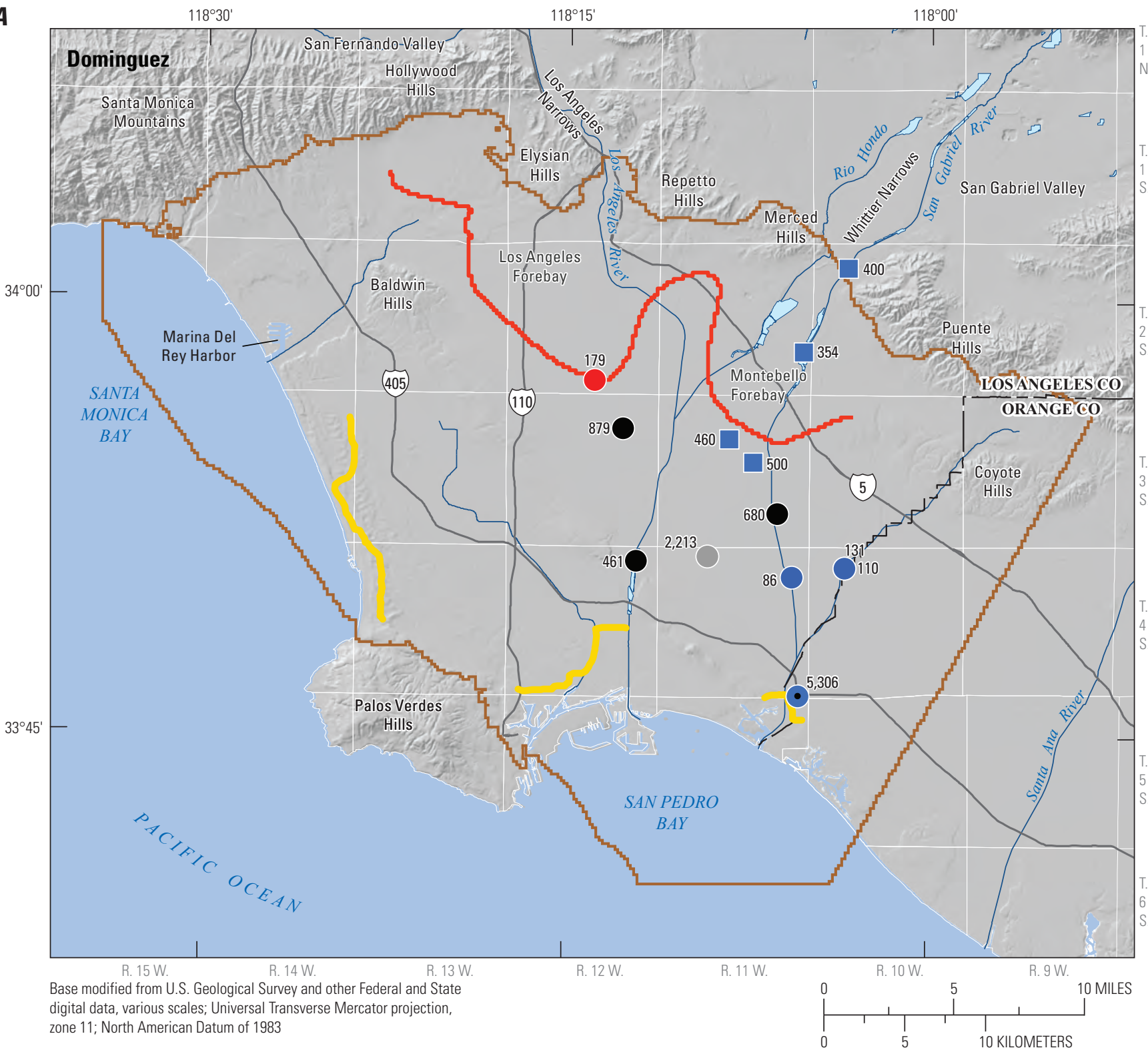

EXPLANATION

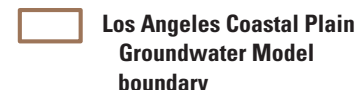
boundary

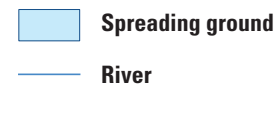

Forebay
354 Value represents dissolved chloride-to-boron ratio, in milligrams per milligram

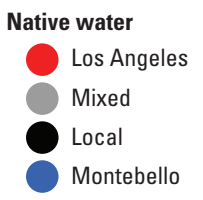

Native water, affected by managed aquifer

recharge near spreading grounds

Montebello

Native water, affected by seawater

- Montebello

Barrier project

Figure 1.5. Chloride-to-boron ratios in samples from monitoring wells screened in chronostratigraphic units in the Los Angeles Coastal Plain, Los Angeles and Orange Counties, California: $A$, Dominguez; $B$, Mesa; $C$, Pacific $A ; D$, Pacific; $E$, Harbor; $F$, Bent Spring; $G$, Upper Wilmington $\mathrm{A} ; H$, Upper Wilmington $\mathrm{B}$; I, Lower Wilmington; J, Long Beach $\mathrm{A} ; \mathrm{K}$, Long Beach $\mathrm{B}$; L, Long Beach BC; $M$, Long Beach $\mathrm{C}$; and $N$, Tertiary. 
B

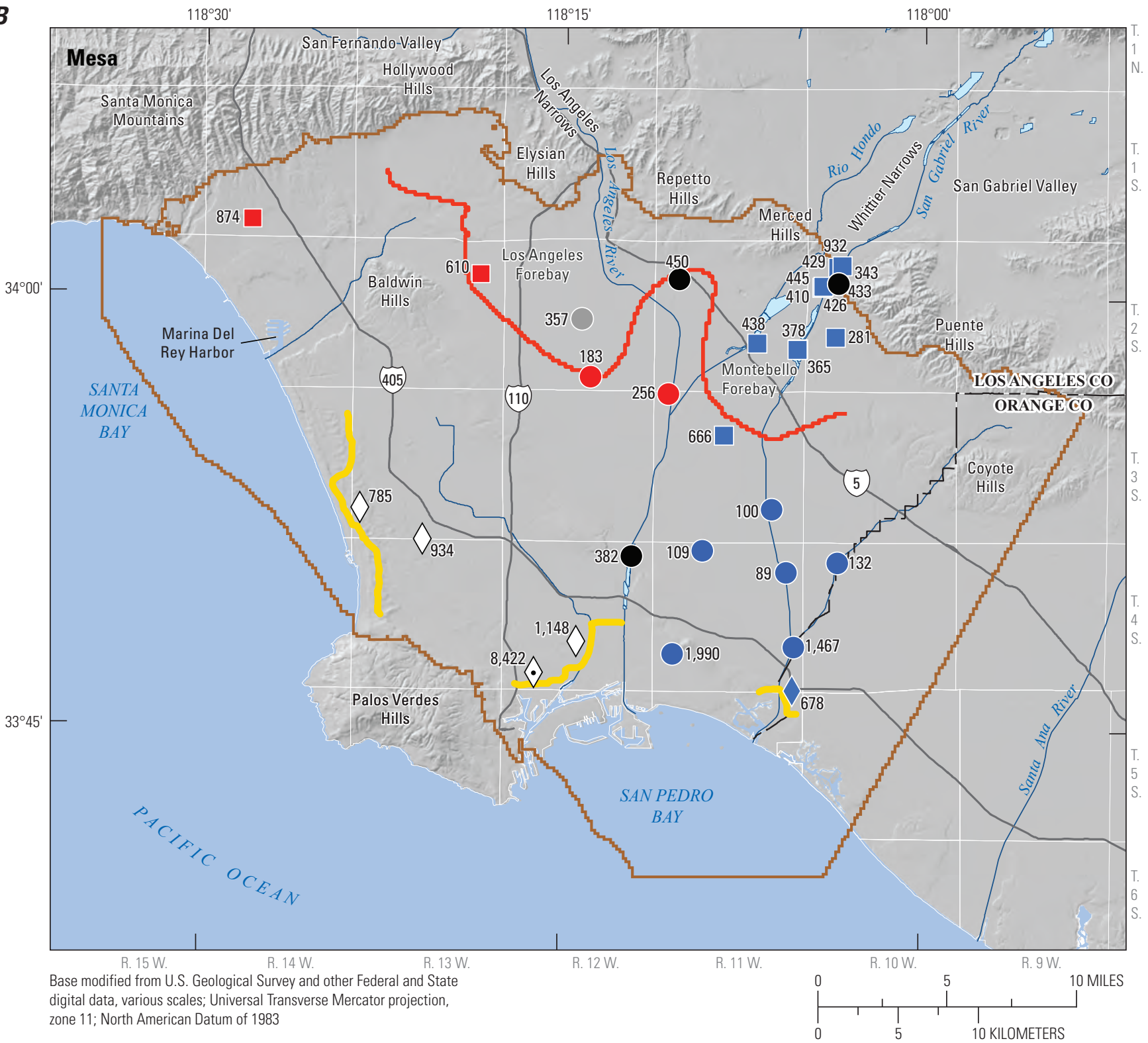
zone 11; North American Datum of 1983

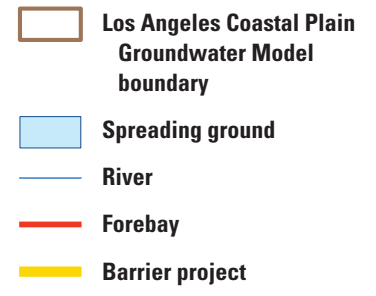

\section{Value represents dissolved chloride-to-boron ratio, in milligrams per milligram Native water \\ Los Angeles \\ Mixed \\ Native water, affected by managed aquifer recharge near injection wells \\ Montebello}

Local

Montebello

Native water, affected by managed aquifer recharge near spreading grounds

Los Angeles

Montebello
Managed aquifer recharge near injection wells

$\checkmark$ Predominantly injection water

Managed aquifer recharge from injection wells and seawater

- Injection and seawater

Figure 1.5.-Continued 


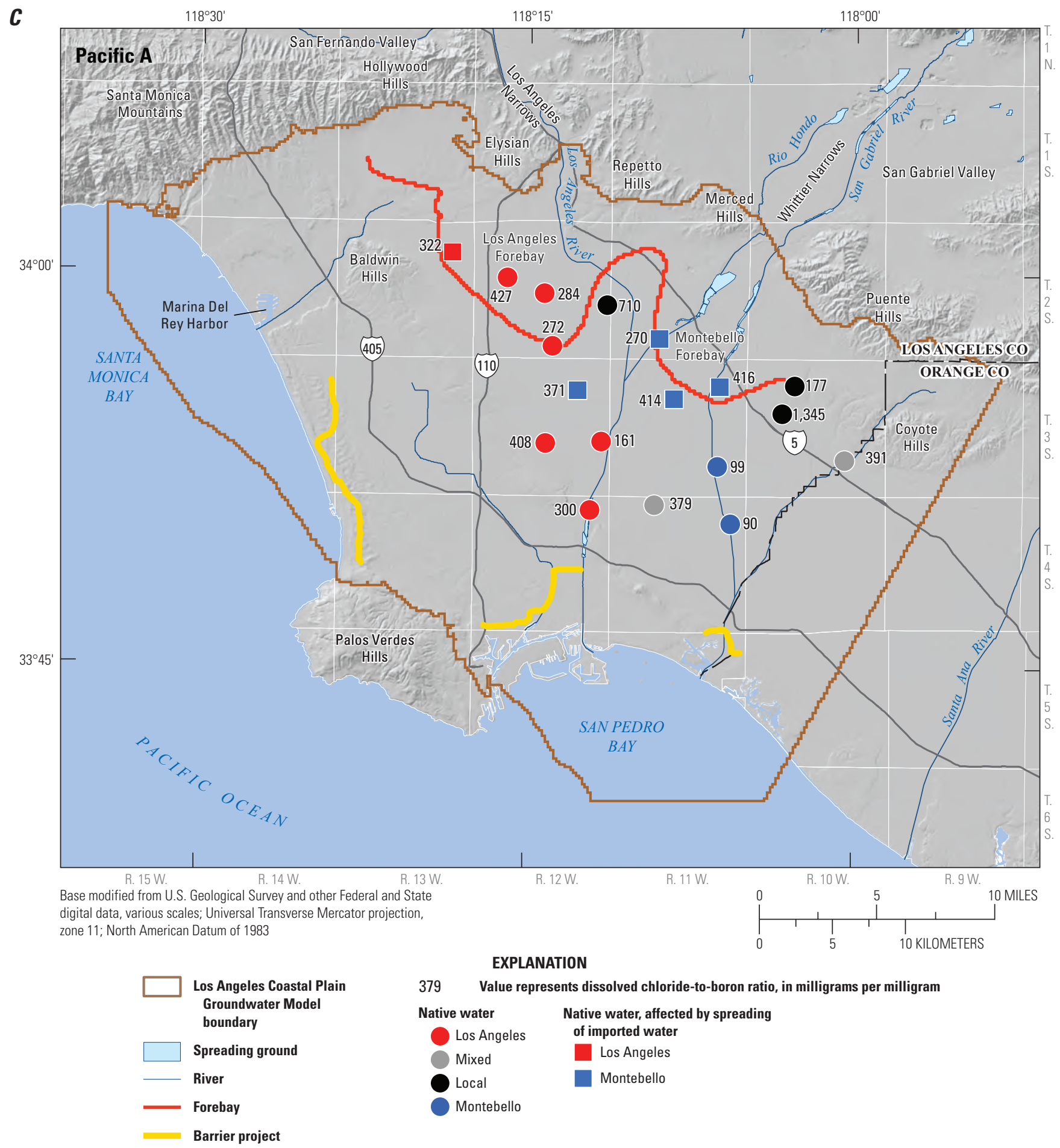

Figure 1.5.-Continued 
D

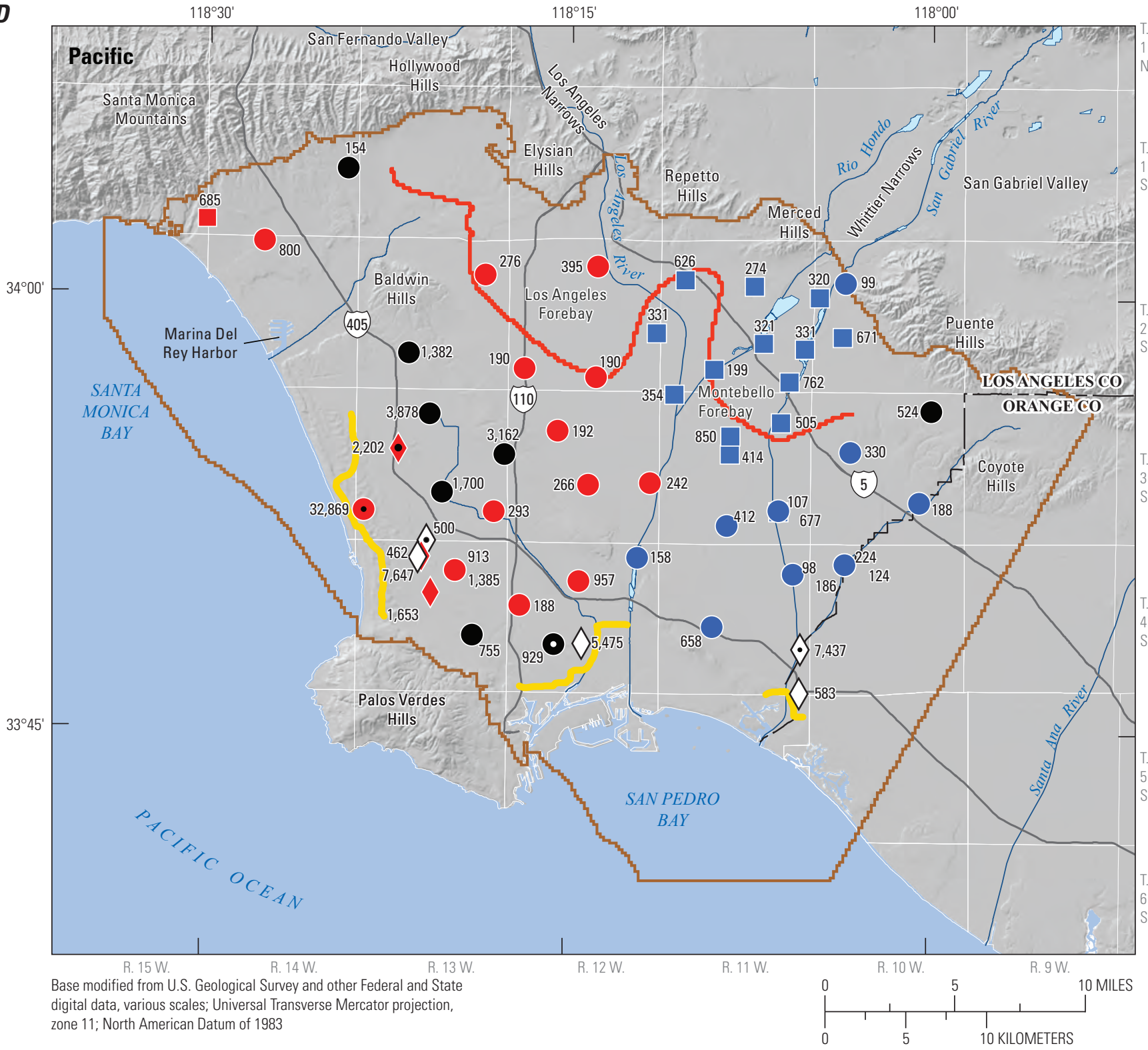

zone 11; North American Datum of 1983

\begin{tabular}{|l}
$\square \begin{array}{l}\text { Los Angeles Coastal Plain } \\
\text { Groundwater Model } \\
\text { boundary }\end{array}$ \\
\begin{tabular}{|l} 
Spreading ground \\
$\square$ \\
$\square$
\end{tabular} \\
\hline$\quad$ Fiver \\
Barriebay project
\end{tabular}

\section{EXPLANATION}

658 Value represents dissolved chloride-to-boron ratio, in milligrams per milligram

\section{Native water \\ Los Angeles \\ Local \\ Montebello}

Native water, affected by managed aquifer recharge near spreading grounds Los Angeles

Montebello

Native water, affected by seawater

Los Angeles

- Local
Native water, affected by managed aquifer recharge near injection wells

$\checkmark$ Los Angeles

Native water, affected by managed aquifer recharge near injection wells and seawater

- Los Angeles

Managed aquifer recharge near injection wells $\checkmark$ Predominantly injection water

Managed aquifer recharge from injection wells and seawater $\checkmark$ Injection and seawater

Figure 1.5.-Continued 
$\boldsymbol{E}$

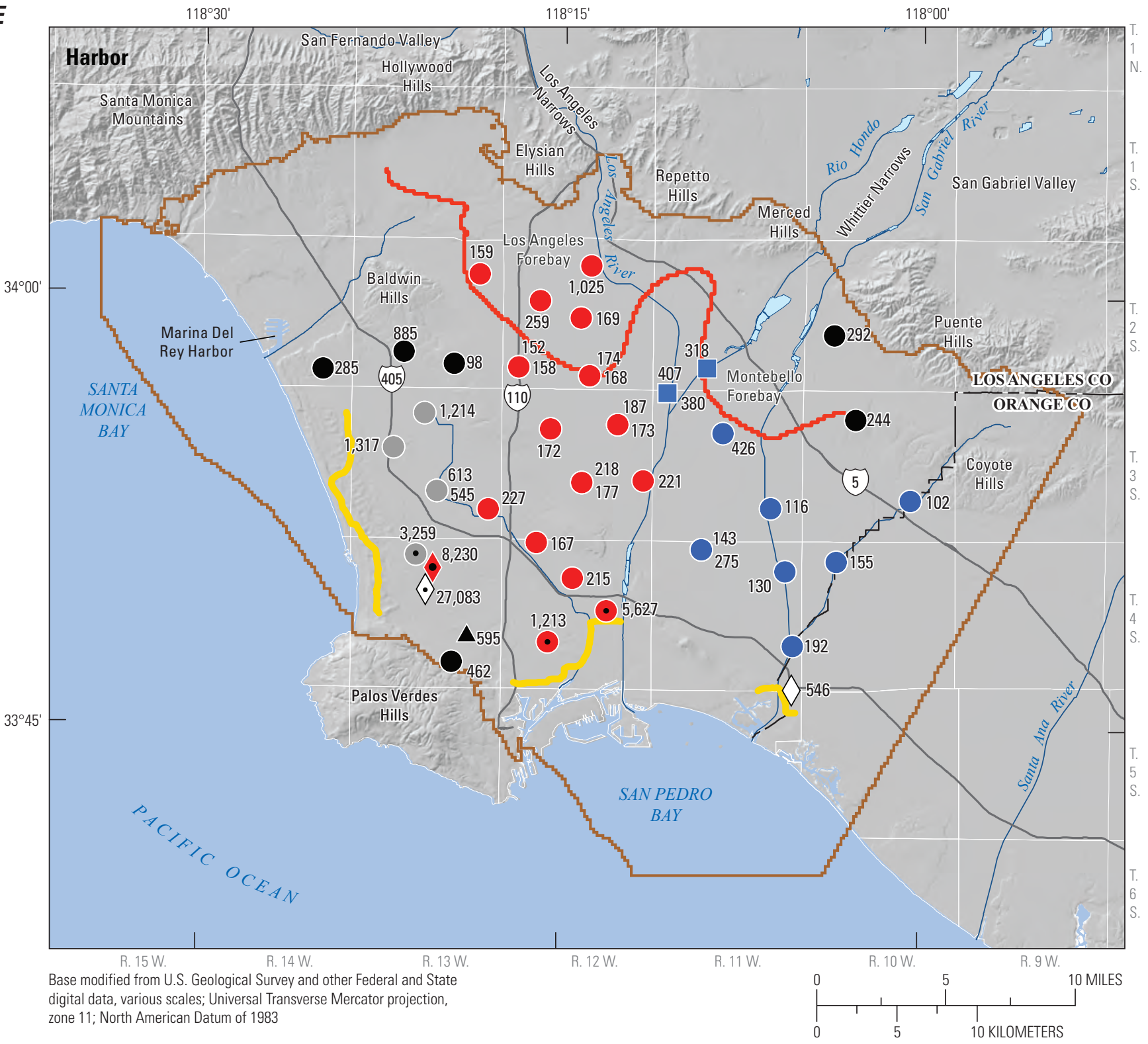

EXPLANATION

Los Angeles Coastal Plain Groundwater Model boundary

Spreading ground

River

Forebay

Barrier project
546 Value represents dissolved chloride-to-boron ratio, in milligrams per milligram Native water
Los Angeles
Mixed
Local
Montebello

Native water, affected by managed aquifer recharge near spreading grounds

Montebello
Native water, affected by seawater

- Los Angeles

- Mixed

Native water, affected by managed aquifer recharge near injection wells and seawater

Los Angeles
Managed aquifer recharge near injection wells $\diamond$ Predominantly injection water

Managed aquifer recharge from injection wells and seawater

$\diamond$ Injection and seawater

Paleowater

$\Delta$ Local

Figure 1.5.-Continued 
$\boldsymbol{F}$

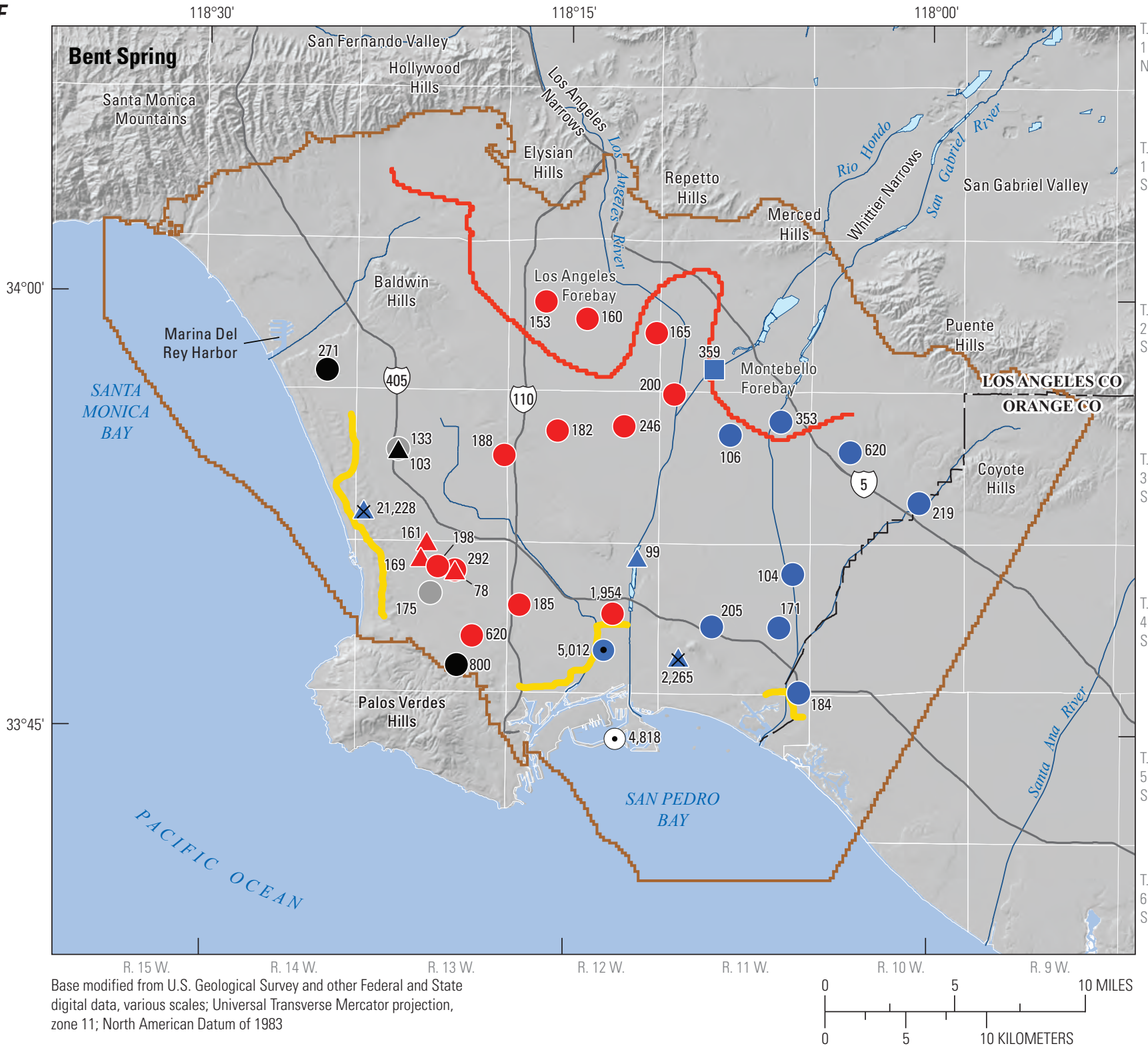
ne 11; North American Datum of 1983

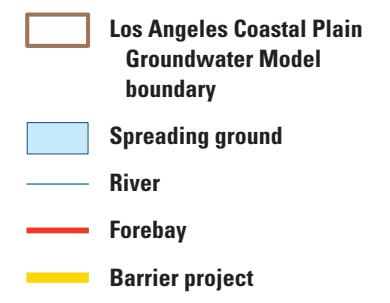

359 Value represents dissolved chloride-to-boron ratio, in milligrams per milligram

Native water
Los Angeles
Mixed
Local
Montebello

Native water, affected by managed aquifer recharge near spreading grounds Montebello
Native water, affected by seawater - Montebello

Paleowater

L Los Angeles

$\triangle$ Local

- Montebello
Seawater

- Seawater

Saline paleowater

× Montebello

Figure 1.5.-Continued 
G

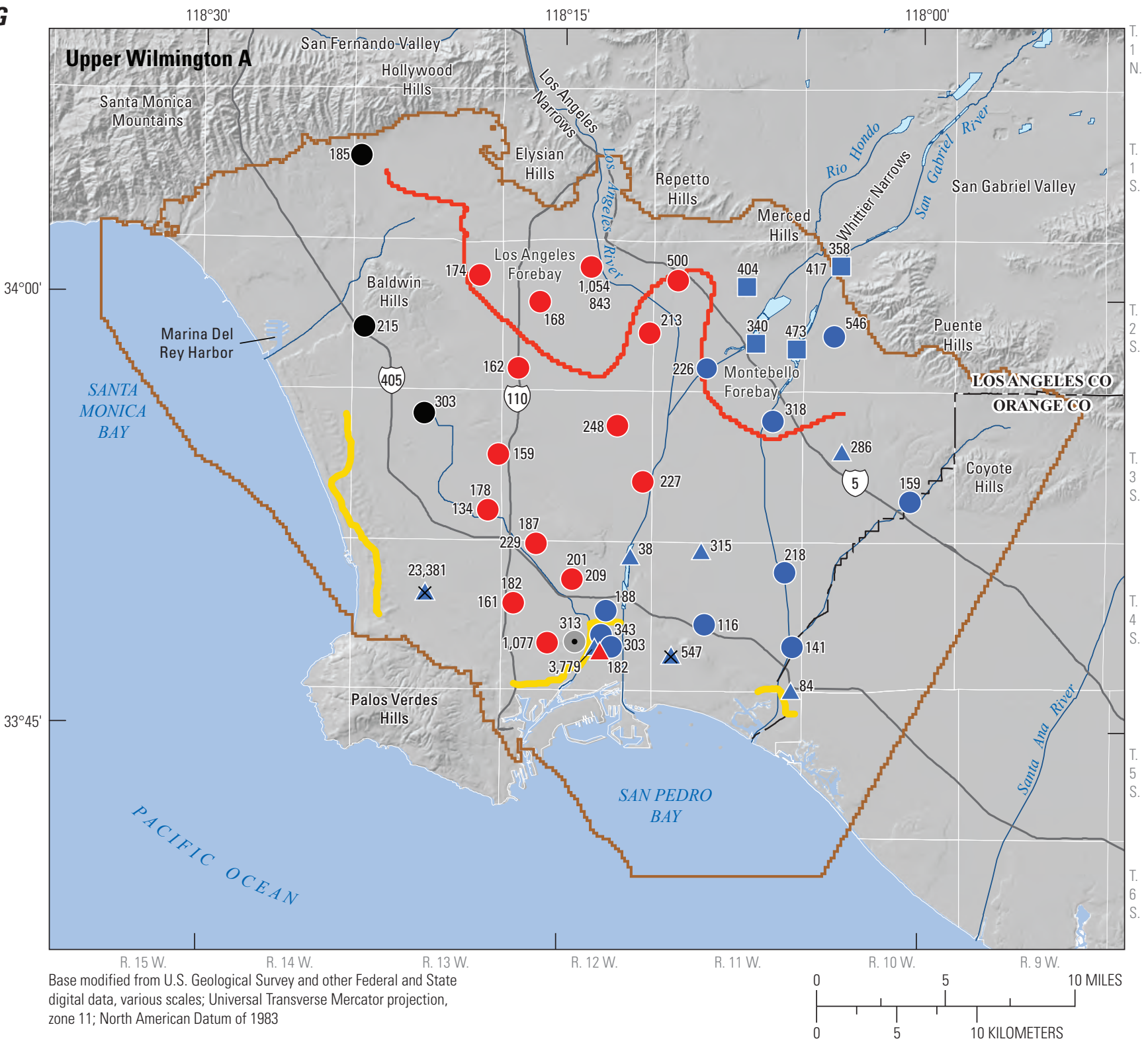

digital data, various scales; Universal Transwe
zone 11; North American Datum of 1983

\begin{tabular}{|l}
\hline $\begin{array}{l}\text { Los Angeles Coastal Plain } \\
\text { Groundwater Model } \\
\text { boundary }\end{array}$ \\
\begin{tabular}{|l} 
Spreading ground \\
$\square$ \\
\hline
\end{tabular} River \\
\hline$\quad$ Forebay \\
Barrier project
\end{tabular}
358 Value represents dissolved chloride-to-boron ratio, in milligrams per milligram
Native water
Los Angeles

\author{
Native water, affected \\ by seawater \\ - Mixed
}

Local

Montebello

Native water, affected by managed aquifer recharge near spreading grounds

Montebello
Paleowater

$\triangle$ Los Angeles

$\Delta$ Montebello

Saline paleowater

X Montebello

Figure 1.5.-Continued 


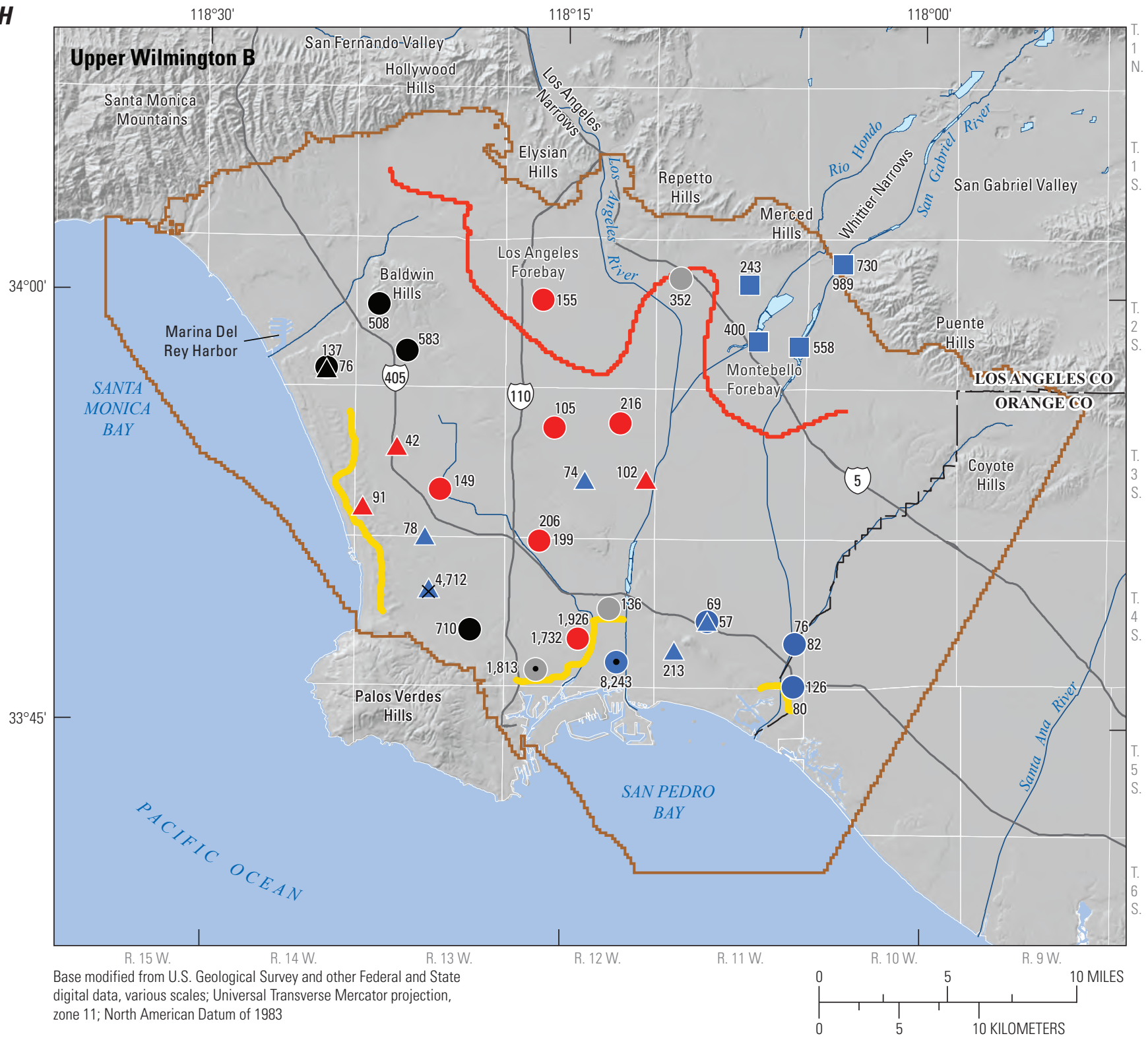

digital data, various scales; Universal Transverse Mercator projection zone 11; North American Datum of 1983

\section{EXPLANATION}

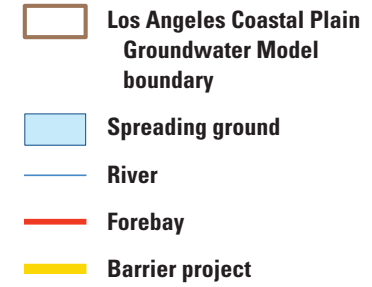

354 Value represents dissolved chloride-to-boron ratio, in milligrams per milligram

\section{Native water \\ Los Angeles \\ Mixed \\ Local \\ Montebello}

Native water, affected by managed aquifer recharge near spreading grounds

Montebello

$\begin{aligned} & \text { Native water, affected by } \\ & \text { seawater }\end{aligned}$
Saline paleowater
$\times$ Mixed

Paleowater

- Los Angeles

$\Delta$ Local

Montebello

Figure 1.5.-Continued 


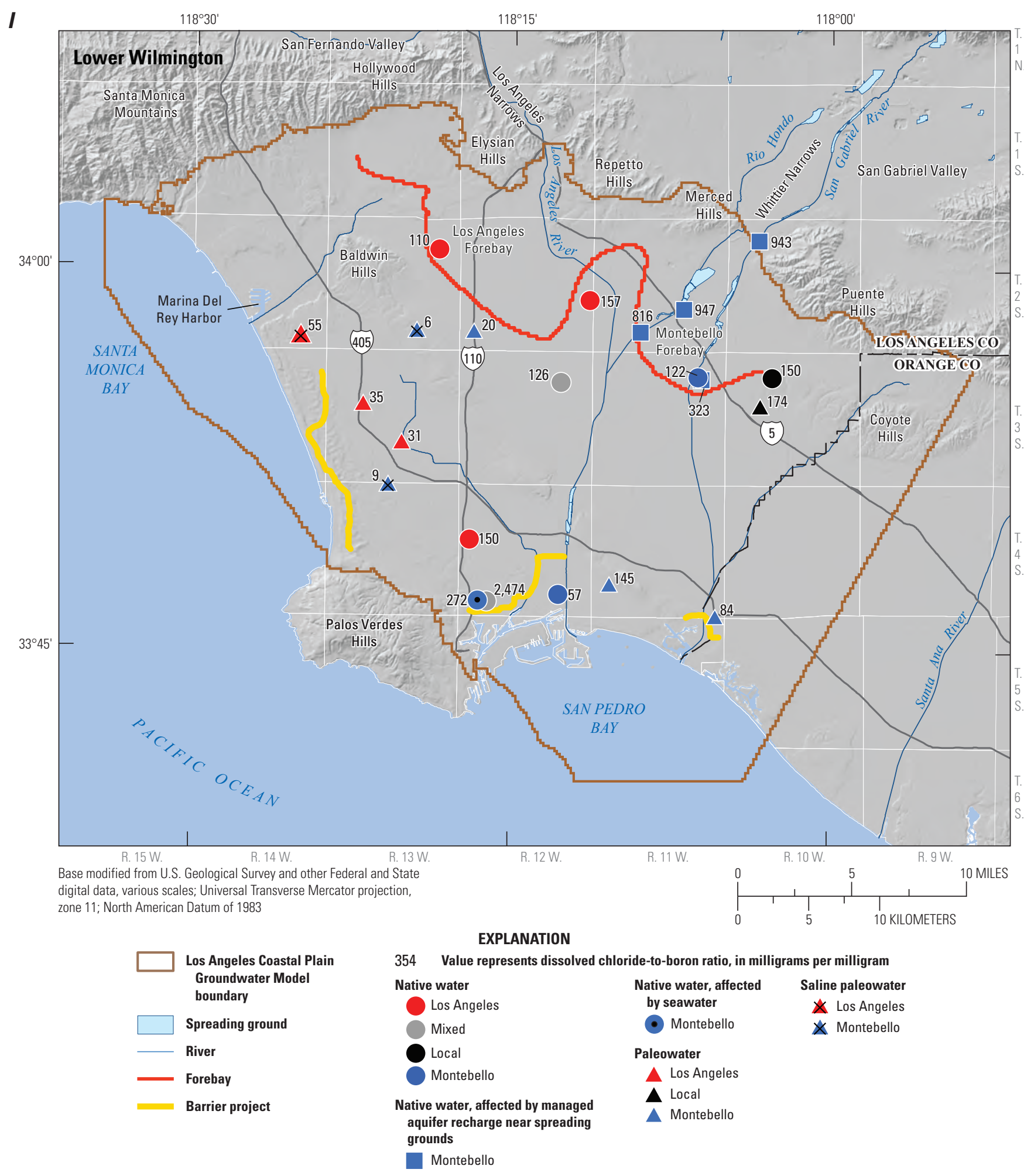

Figure 1.5.-Continued 


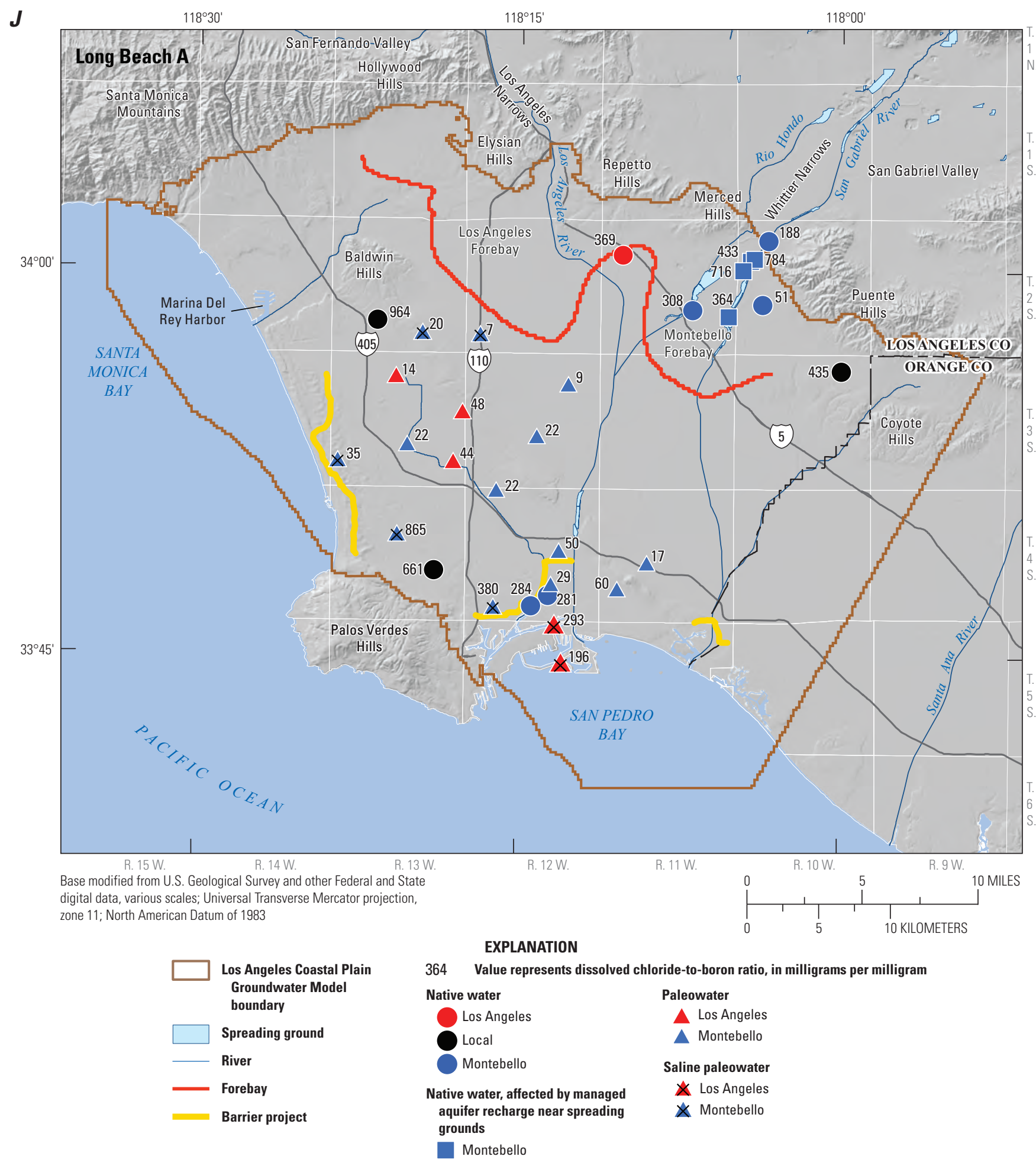

Figure 1.5.-Continued 


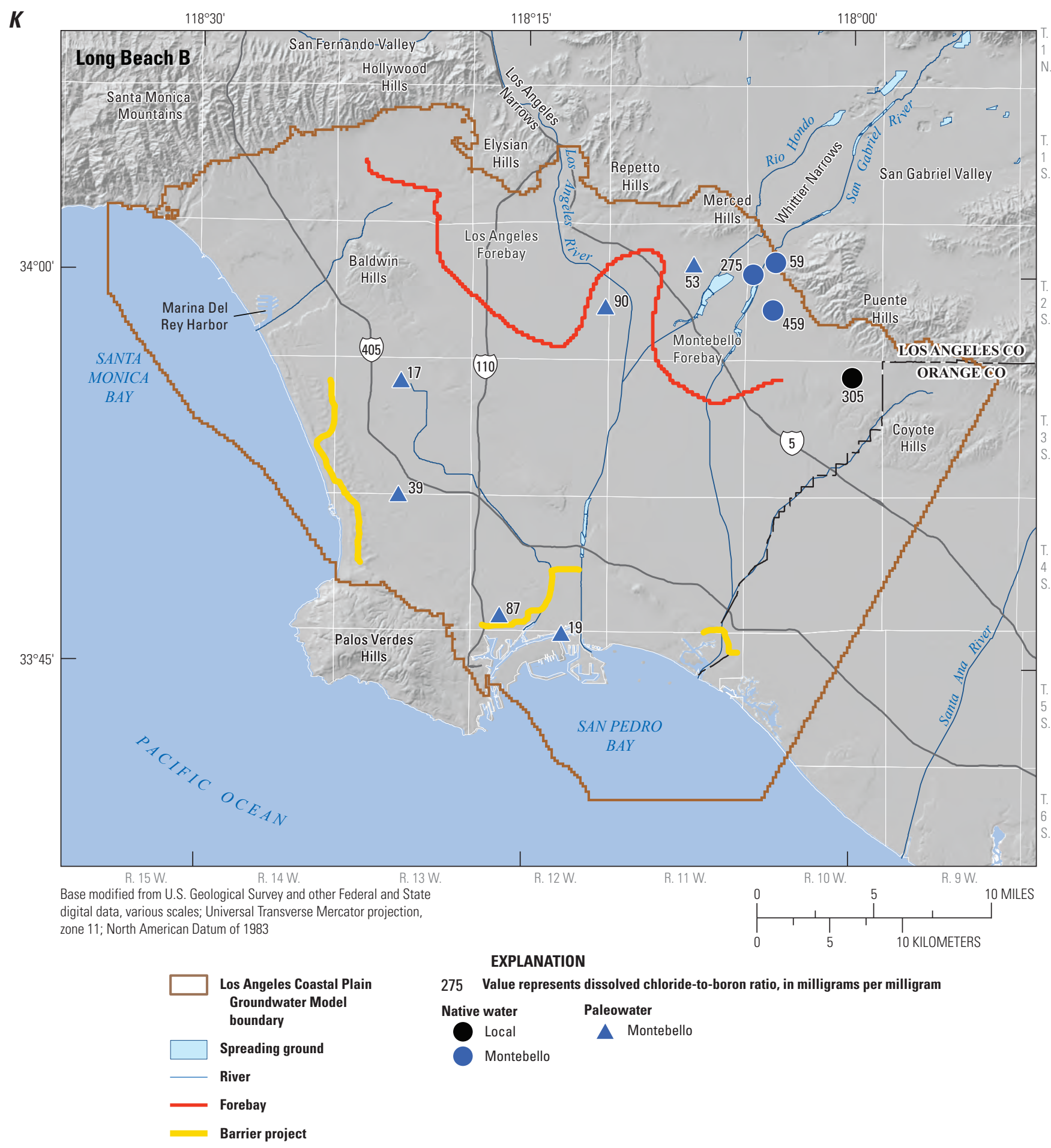

Figure 1.5.-Continued 
$\boldsymbol{L}$

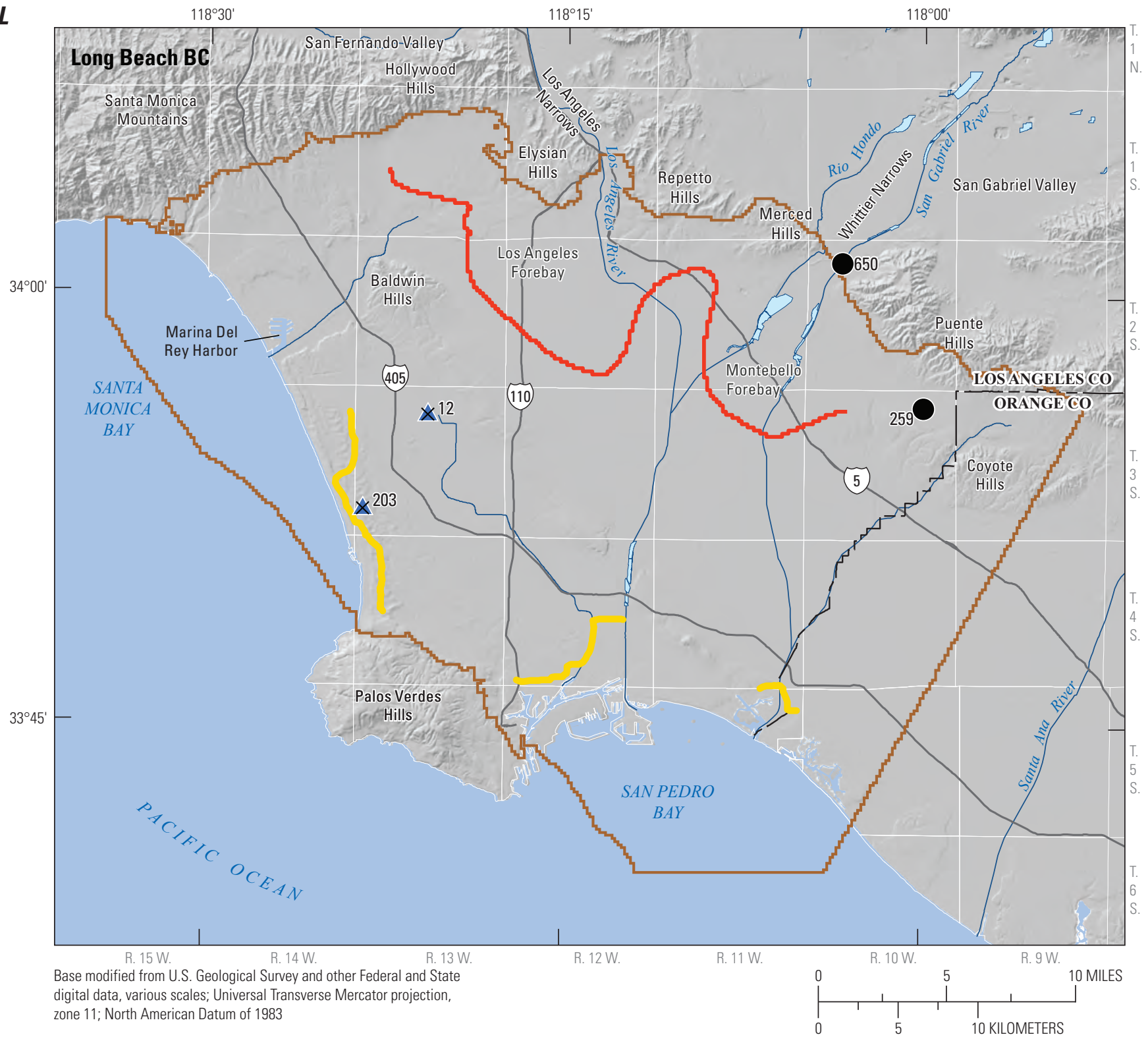
zone 11; North American Datum of 1983

\begin{tabular}{|l|l}
\hline & $\begin{array}{l}\text { Los Angeles Coastal Plain } \\
\text { Groundwater Model } \\
\text { boundary }\end{array}$ \\
$\square$ & Spreading ground \\
$\square$ & River \\
\hline$\quad$ Forebay \\
Barrier project
\end{tabular}

275 Value represents dissolved chloride-to-boron ratio, in milligrams per milligram

Native water Saline paleowater

Native water
Local
L Montebello

Figure 1.5.-Continued 


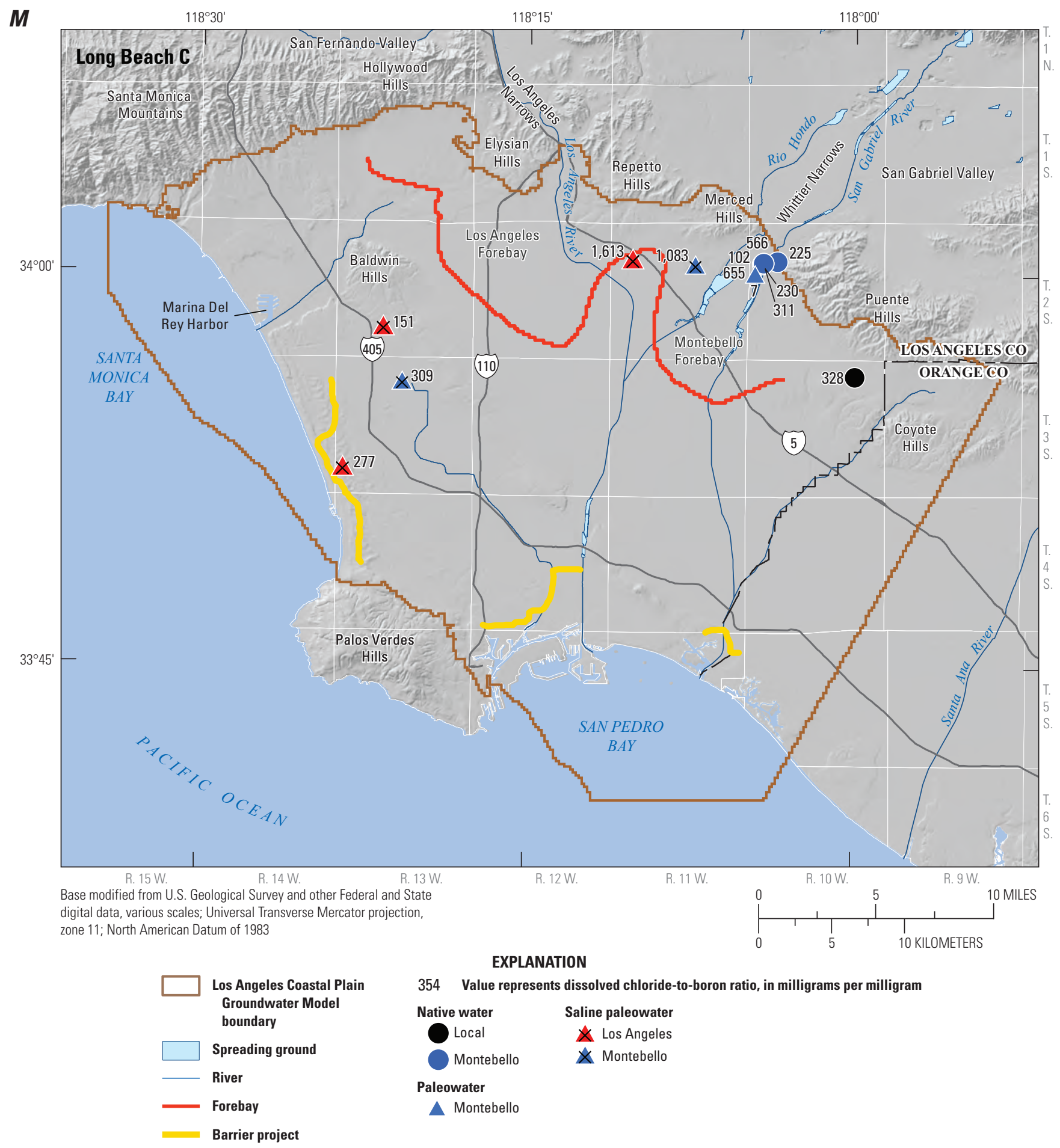

Figure 1.5.-Continued 


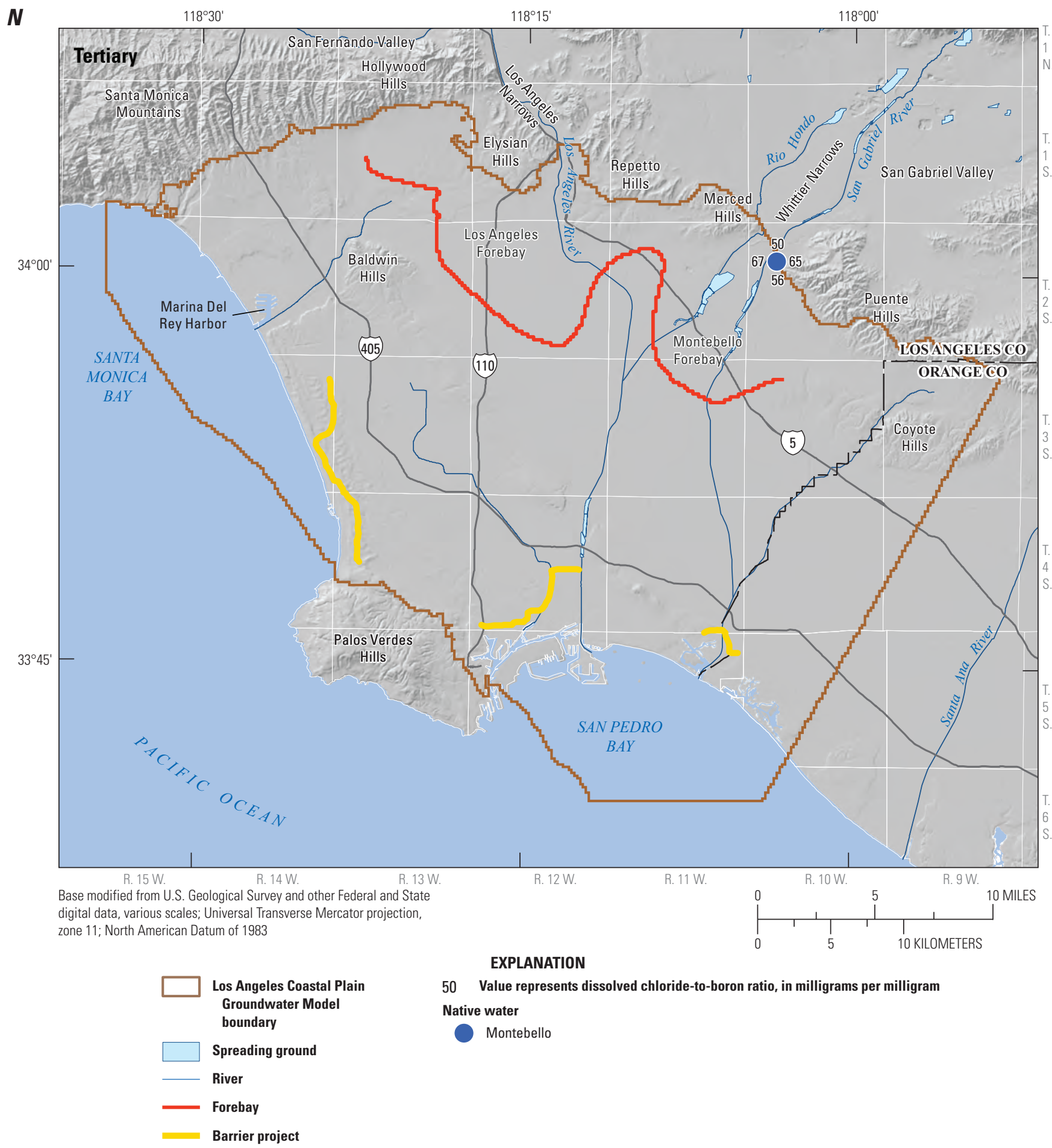

Figure 1.5.-Continued 
$\boldsymbol{A}$

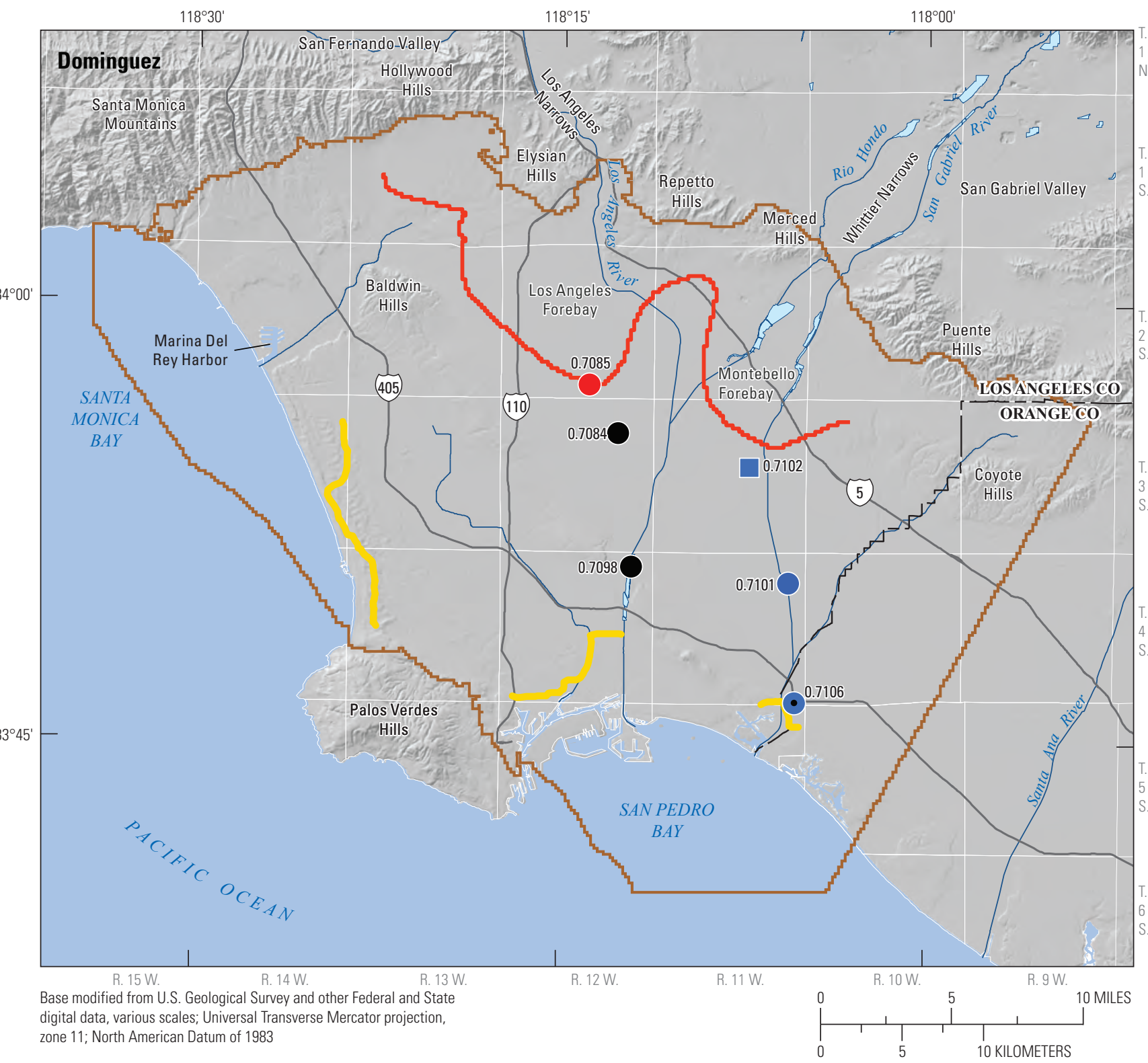

Los Angeles Coastal Plain Groundwater Model

EXPLANATION

boundary

Spreading ground

River

Forebay

Barrier project
0.7101 Value represents strontium-87 to strontium-86, atom ratio

Native water
Los Angeles
Local
Montebello

Native water, affected by managed aquifer

recharge near spreading grounds

Montebello

Native water, affected by seawater

- Montebello

Figure 1.6. Strontium-isotope ratios in samples from monitoring wells screened in chronostratigraphic units in the Los Angeles Coastal Plain, Los Angeles and Orange Counties, California: $A$, Dominguez; $B$, Mesa; $C$, Pacific A; $D$, Pacific; $E$, Harbor; $F$, Bent Spring; G, Upper Wilmington $A ; H$, Upper Wilmington $B$; I, Lower Wilmington; J, Long Beach $A ; K$, Long Beach $B$; L, Long Beach $B C$; and $M$, Long Beach $C$. 
B

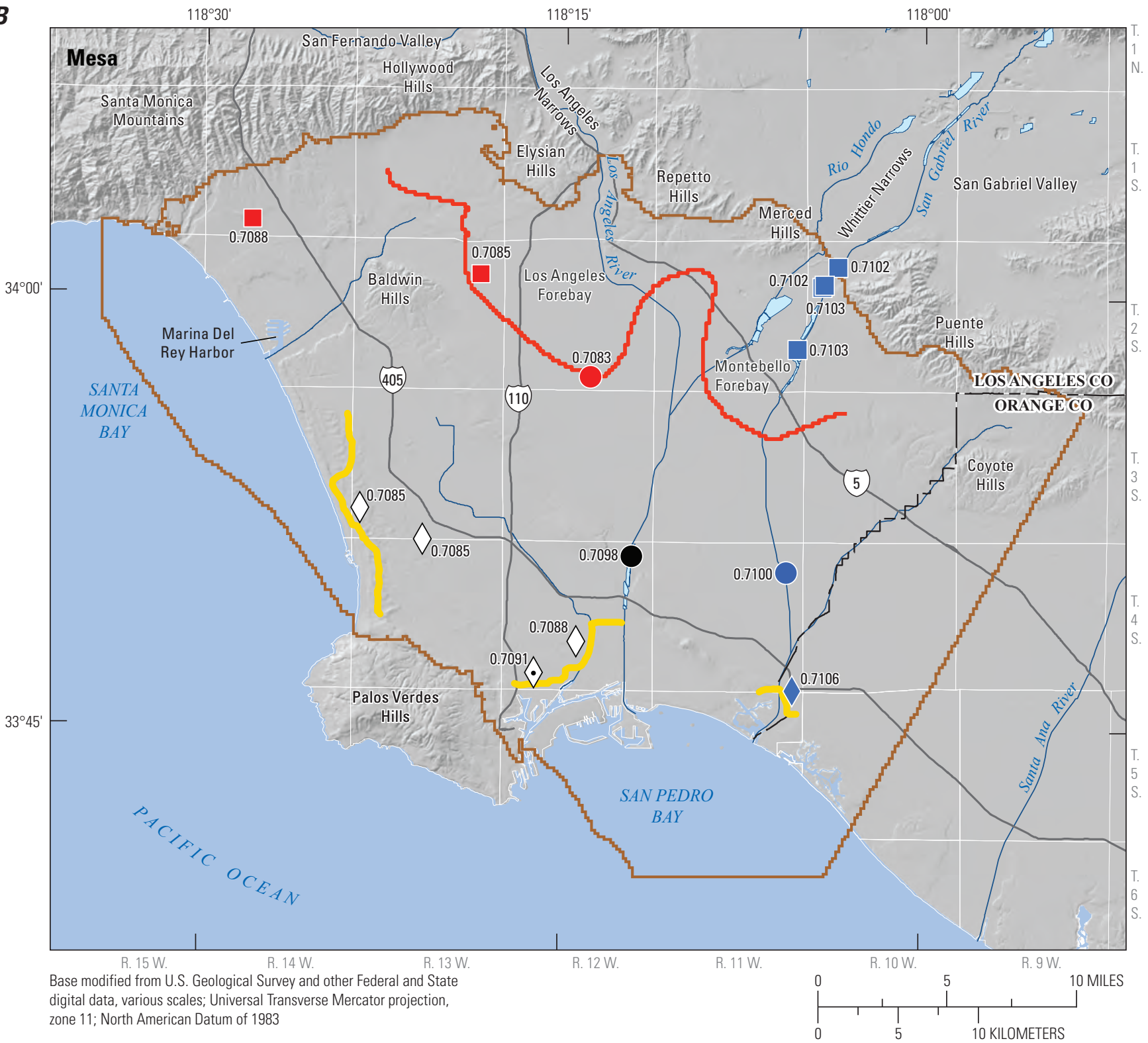
zone 11; North American Datum of 1983

\begin{tabular}{|l|l}
\hline & $\begin{array}{l}\text { Los Angeles Coastal Plain } \\
\text { Groundwater Model } \\
\text { boundary }\end{array}$ \\
\hline & $\begin{array}{l}\text { Spreading ground } \\
\square\end{array}$ \\
\hline$\quad$ River \\
\hline Forebay \\
Barrier project
\end{tabular}

0.7102 Value represents strontium-87 to strontium-86, atom ratio
Native water
Los Angeles
Local
Native water, affected by managed aquifer recharge near injection wells
Montebello

Montebello

Native water, affected by managed aquifer recharge near spreading grounds

Los Angeles

Montebello
Managed aquifer recharge near injection wells

$\measuredangle$ Predominantly injection water

Managed aquifer recharge from injection wells and seawater

- Injection and seawater

Figure 1.6.-Continued 


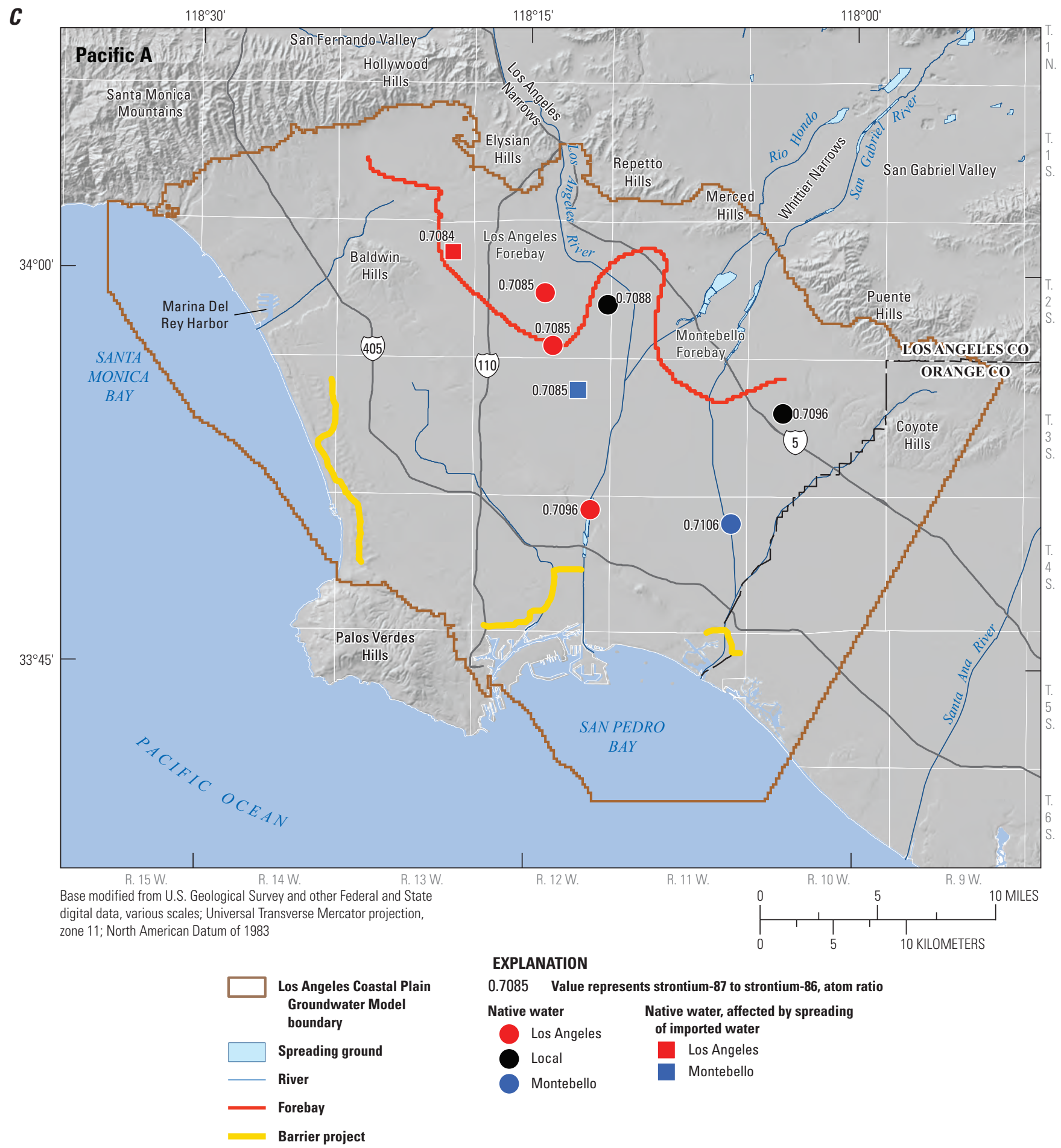

Figure 1.6.-Continued 
$\boldsymbol{D}$

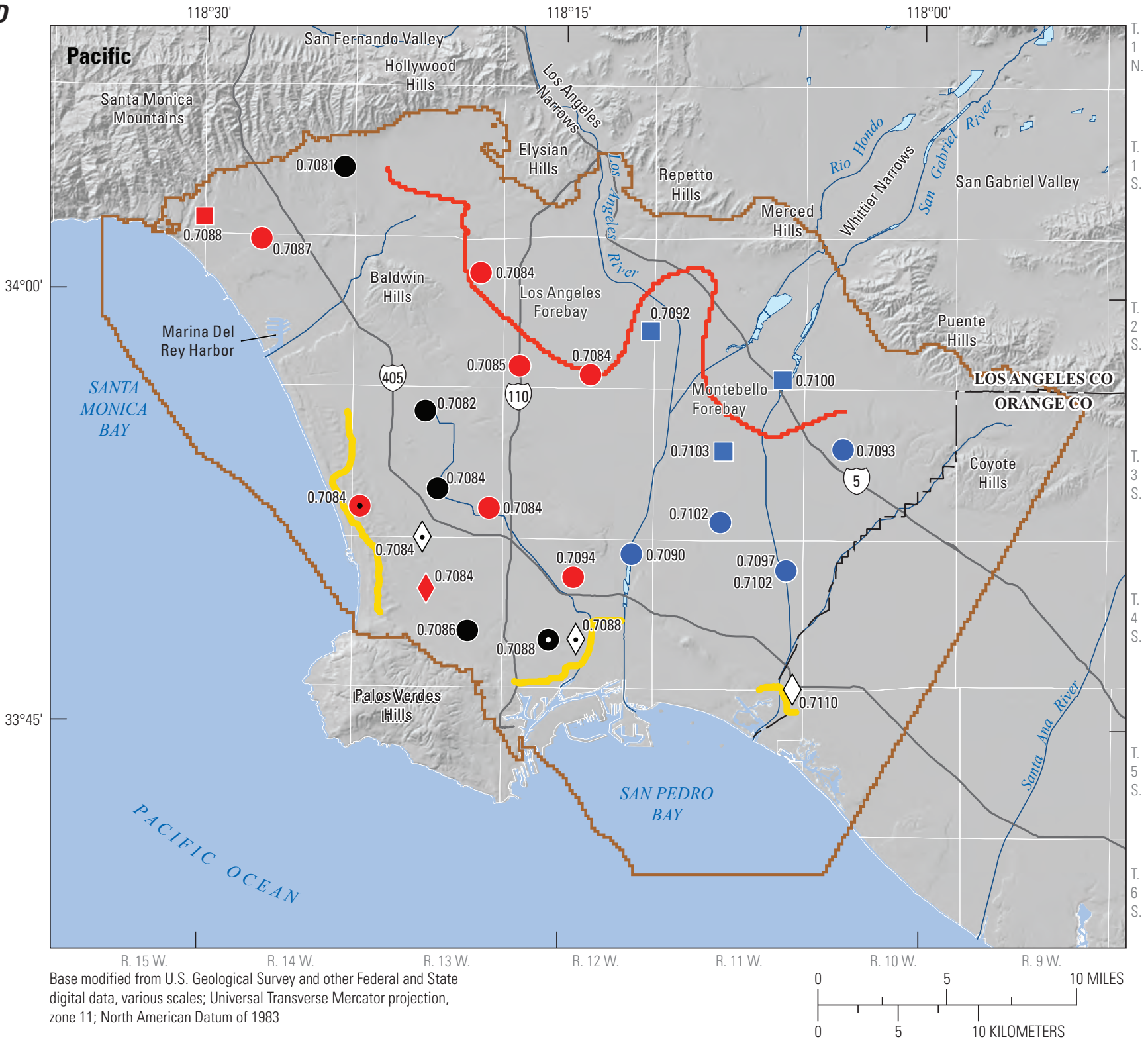

zone 11; North American Datum of 1983

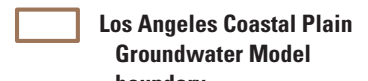
Groundwater Model boundary

Spreading ground

River

Forebay

Barrier project

EXPLANATION

0.7102 Value represents strontium-87 to strontium-86, atom ratio

Native water Native water, affected by managed aquifer recharge near

Los Angeles

Local

Montebello injection wells

$\checkmark$ Los Angeles

Managed aquifer recharge near injection wells

Native water, affected by managed aquifer recharge near spreading grounds

Los Angeles

Montebello

Native water, affected by seawater

- Los Angeles

- Local

Managed aquifer recharge from injection wells and seawater

$\checkmark$ Injection and seawater

Figure 1.6.-Continued 
$\boldsymbol{E}$

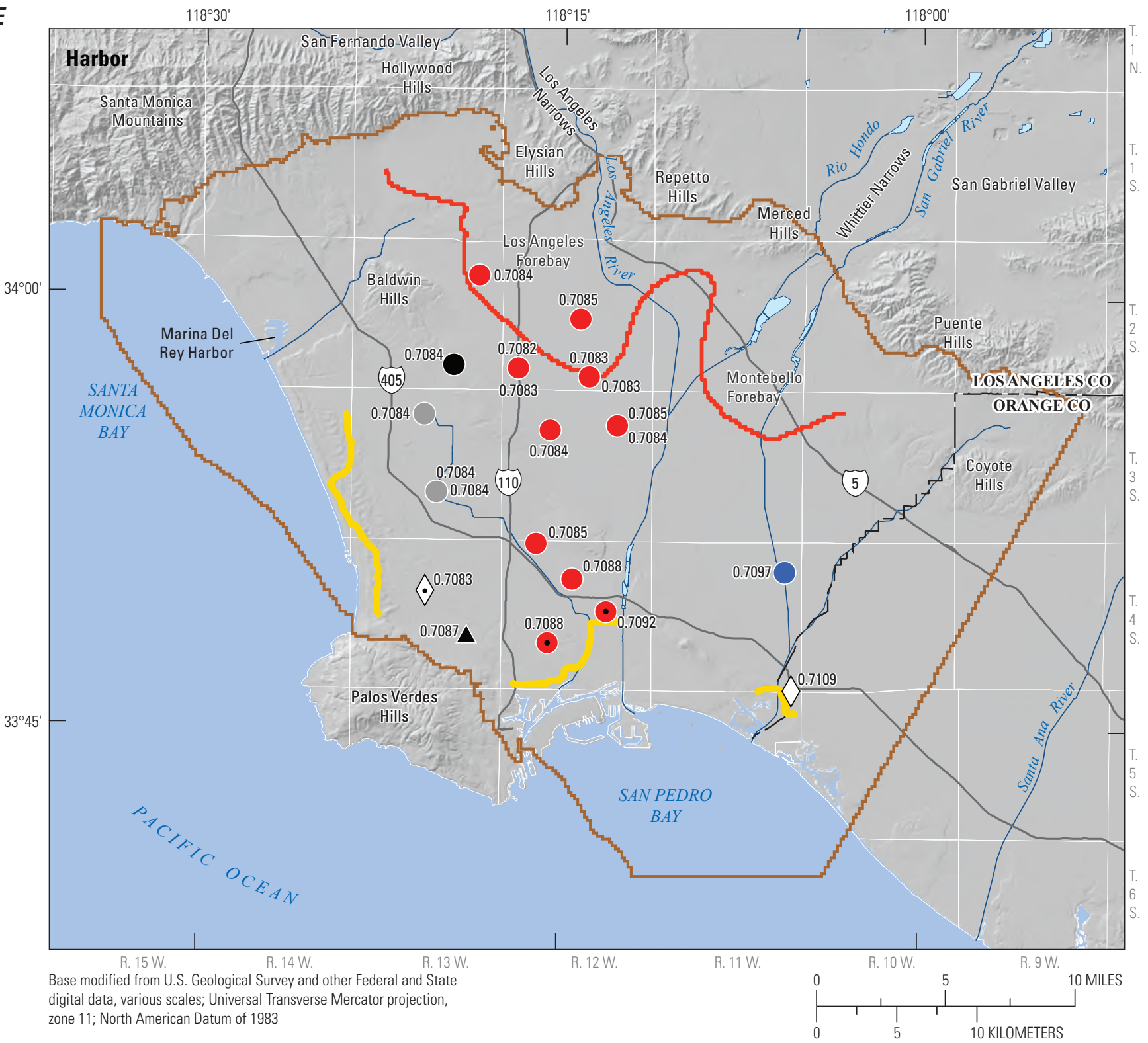

EXPLANATION

Los Angeles Coastal Plain Groundwater Model boundary

Spreading ground

River

Forebay

Barrier project

0.7109 Value represents strontium-87 to strontium-86, atom ratio

Native water

Los Angeles

Mixed

Local

Montebello

Native water, affected by seawater

- Los Angeles
Paleowater

$\Delta$ Local

Managed aquifer recharge from injection wells and seawater

$\diamond$ Injection and seawater

Managed aquifer recharge near injection wells $\checkmark$ Predominantly injection water

Figure 1.6.-Continued 


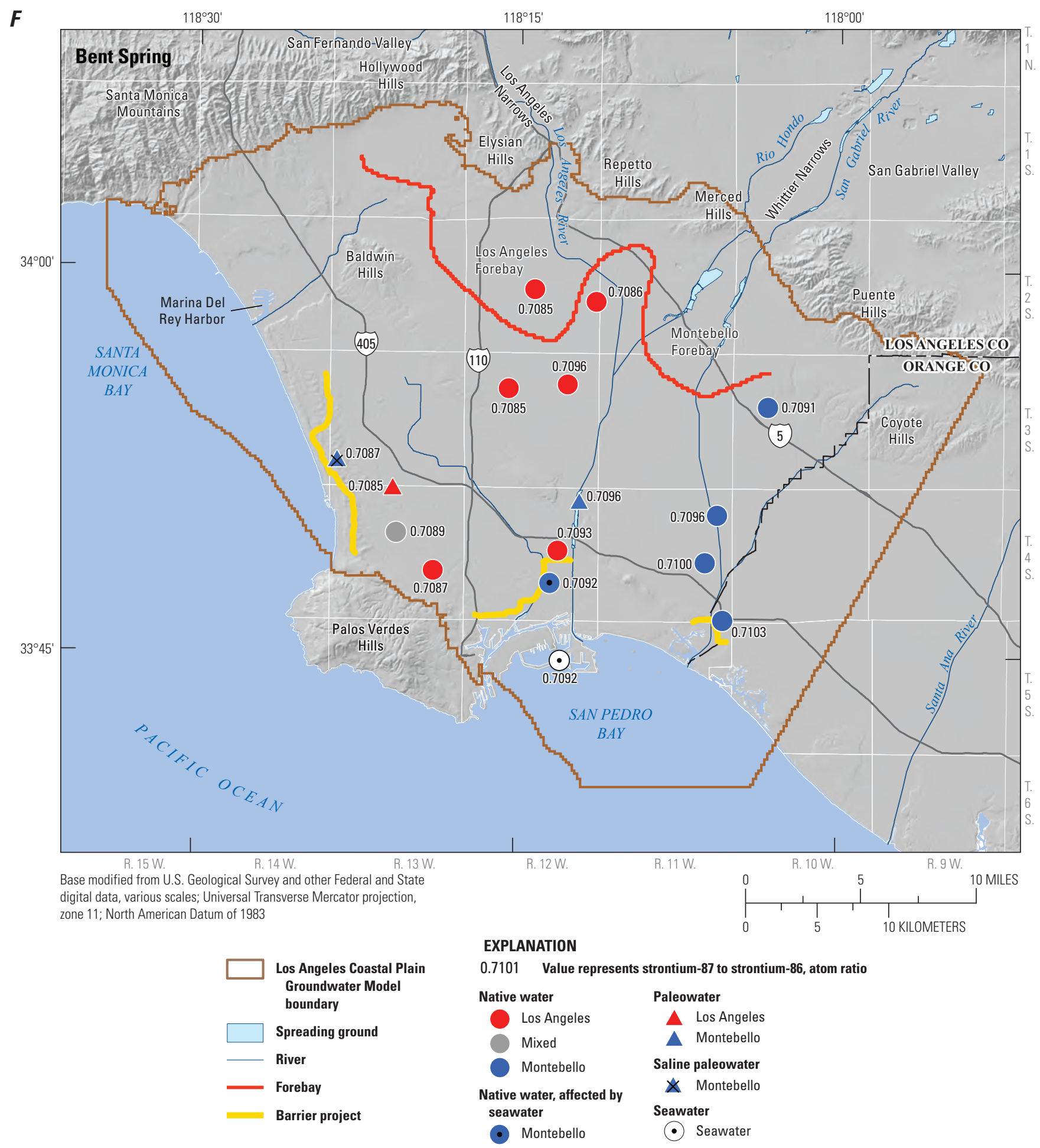

Figure 1.6.-Continued 
G

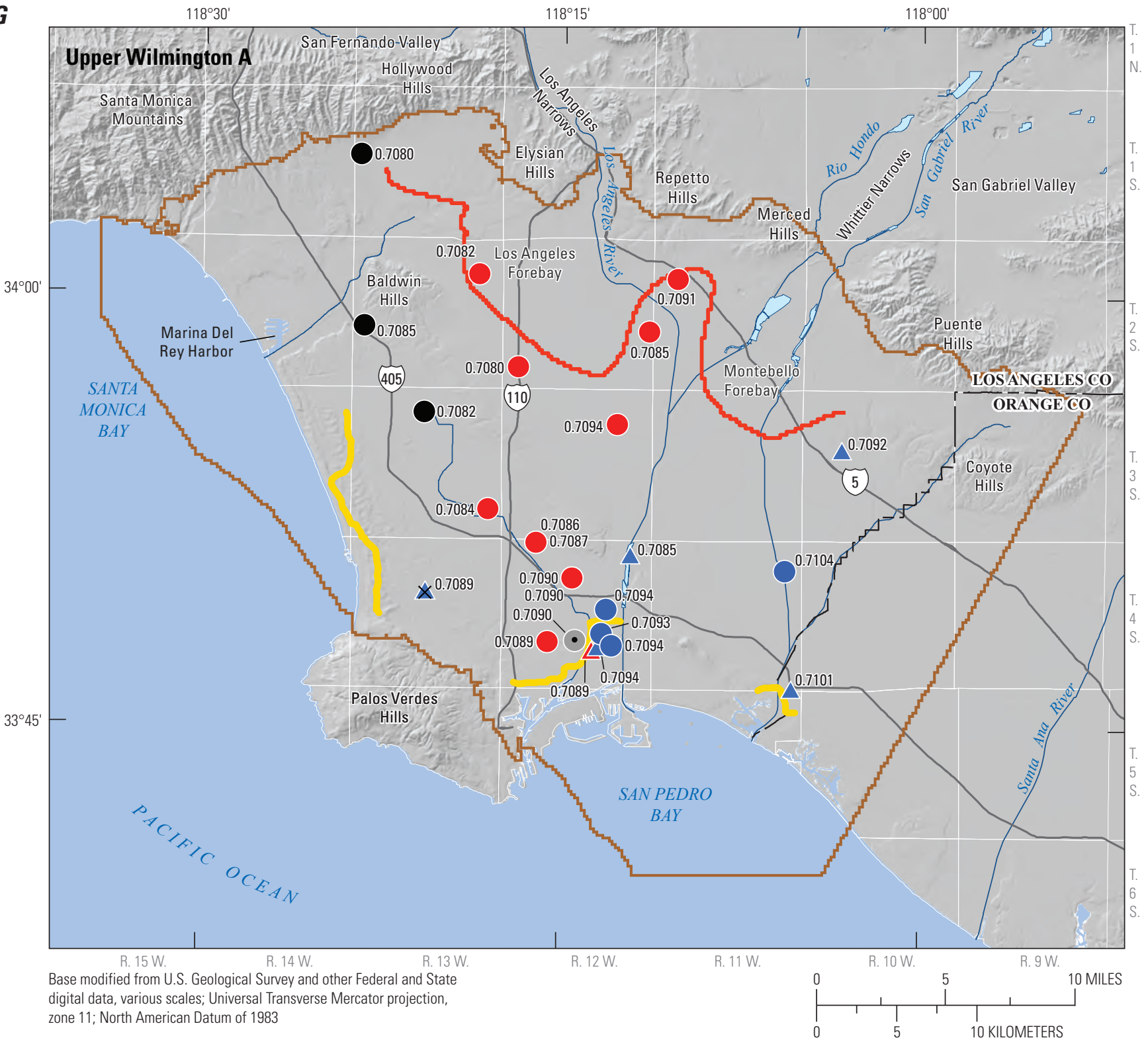

EXPLANATION

Los Angeles Coastal Plain Groundwater Model boundary

Spreading ground

River

Forebay

Barrier project
0.7101 Value represents strontium-87 to strontium-86, atom ratio
Native water

Los Angeles

Local

Montebello

Native water, affected by seawater
Paleowater

$\Delta$ Los Angeles

$\Delta$ Montebello

Saline paleowater

× Montebello

Figure 1.6.-Continued 


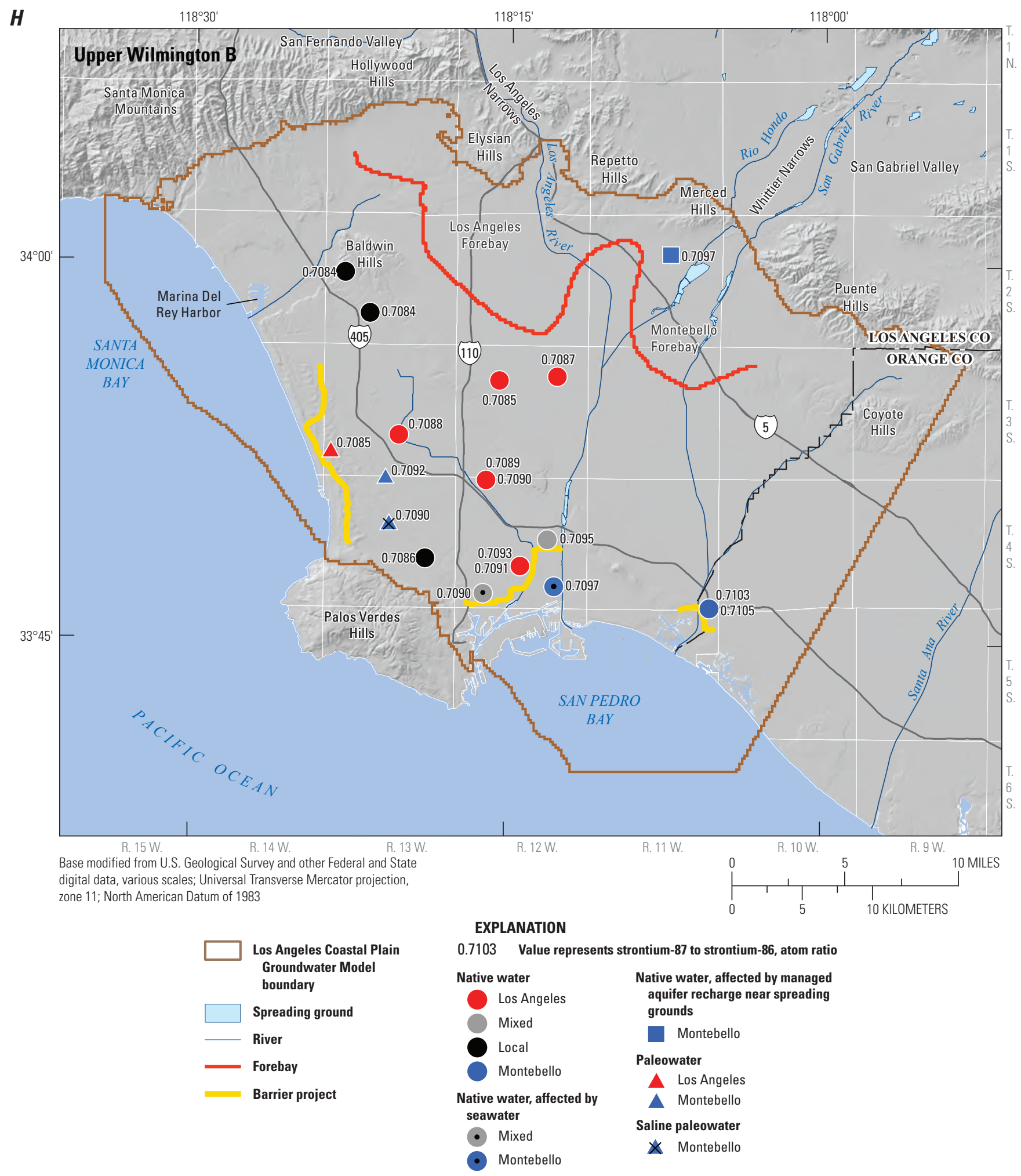

Figure 1.6.-Continued 


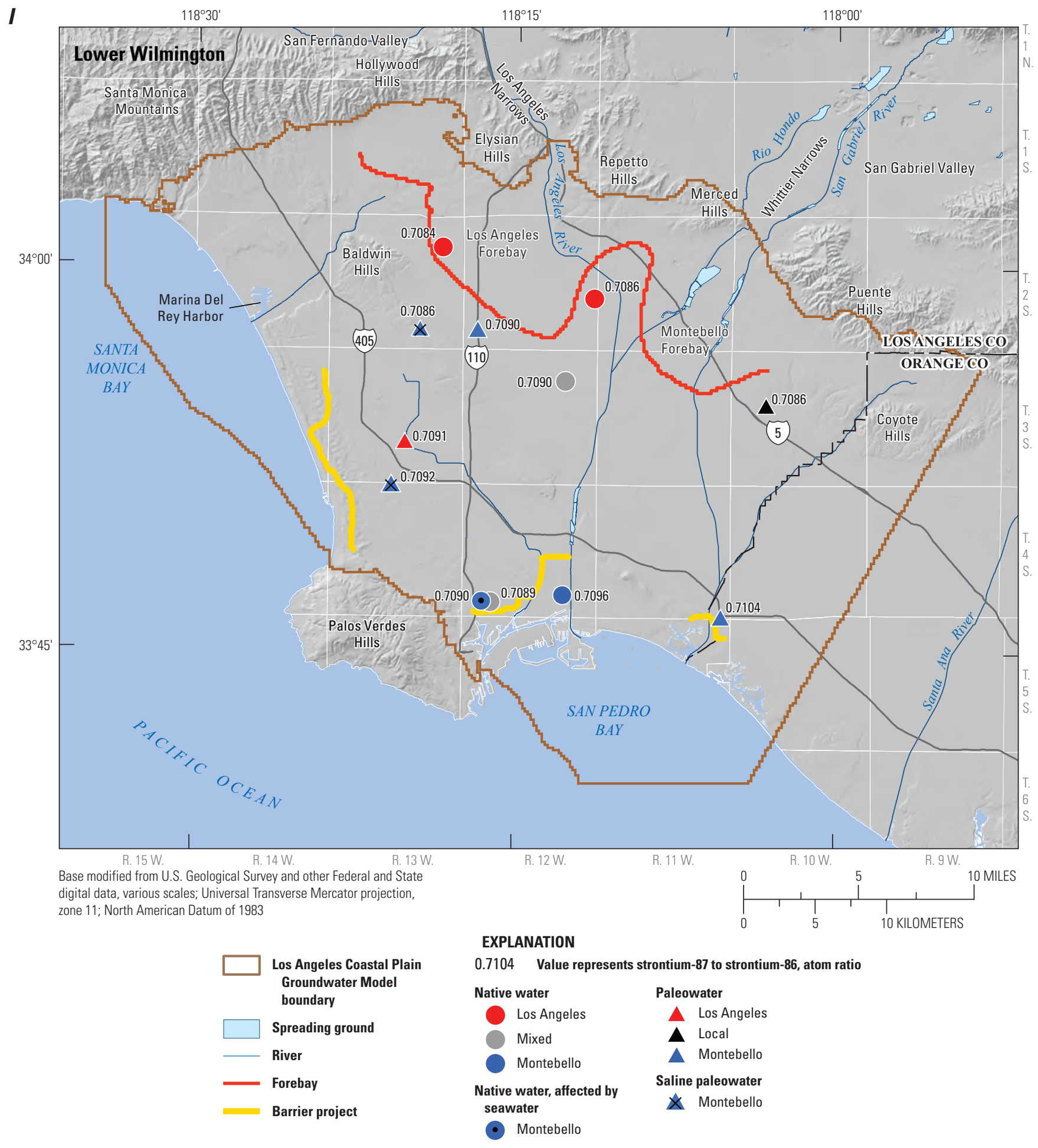

Figure 1.6.-Continued 


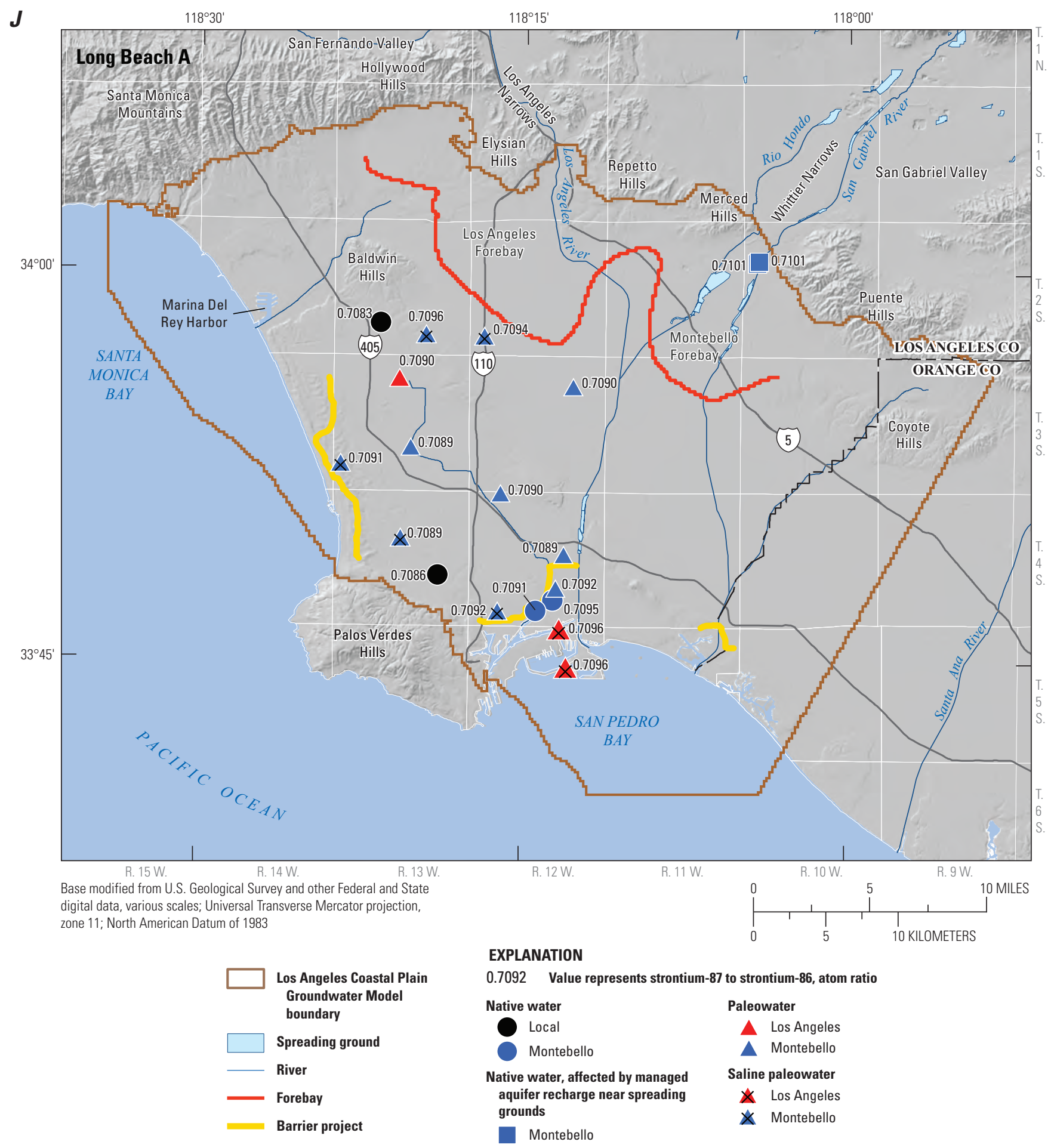

Figure 1.6. - Continued 


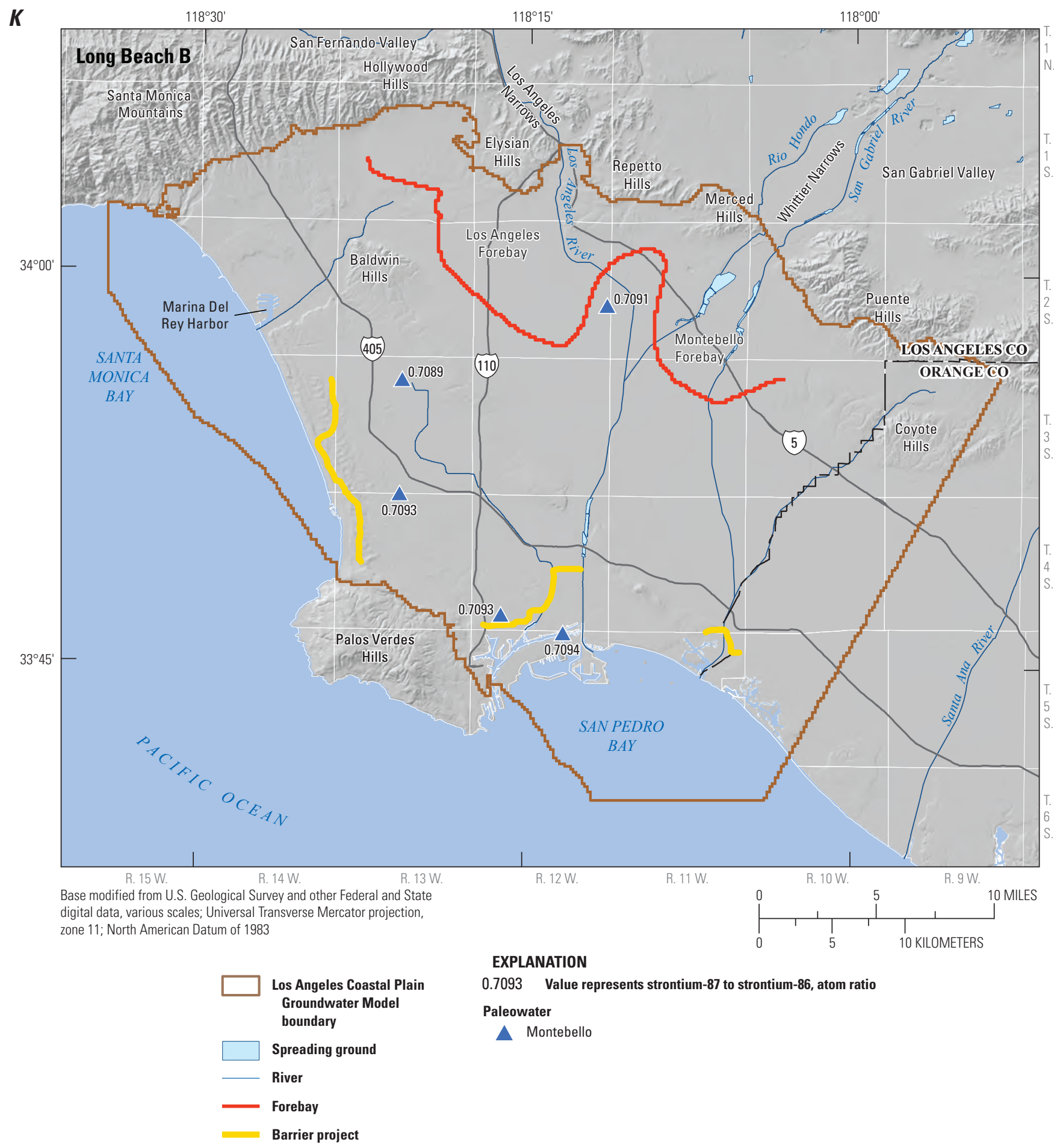

Figure 1.6.-Continued 


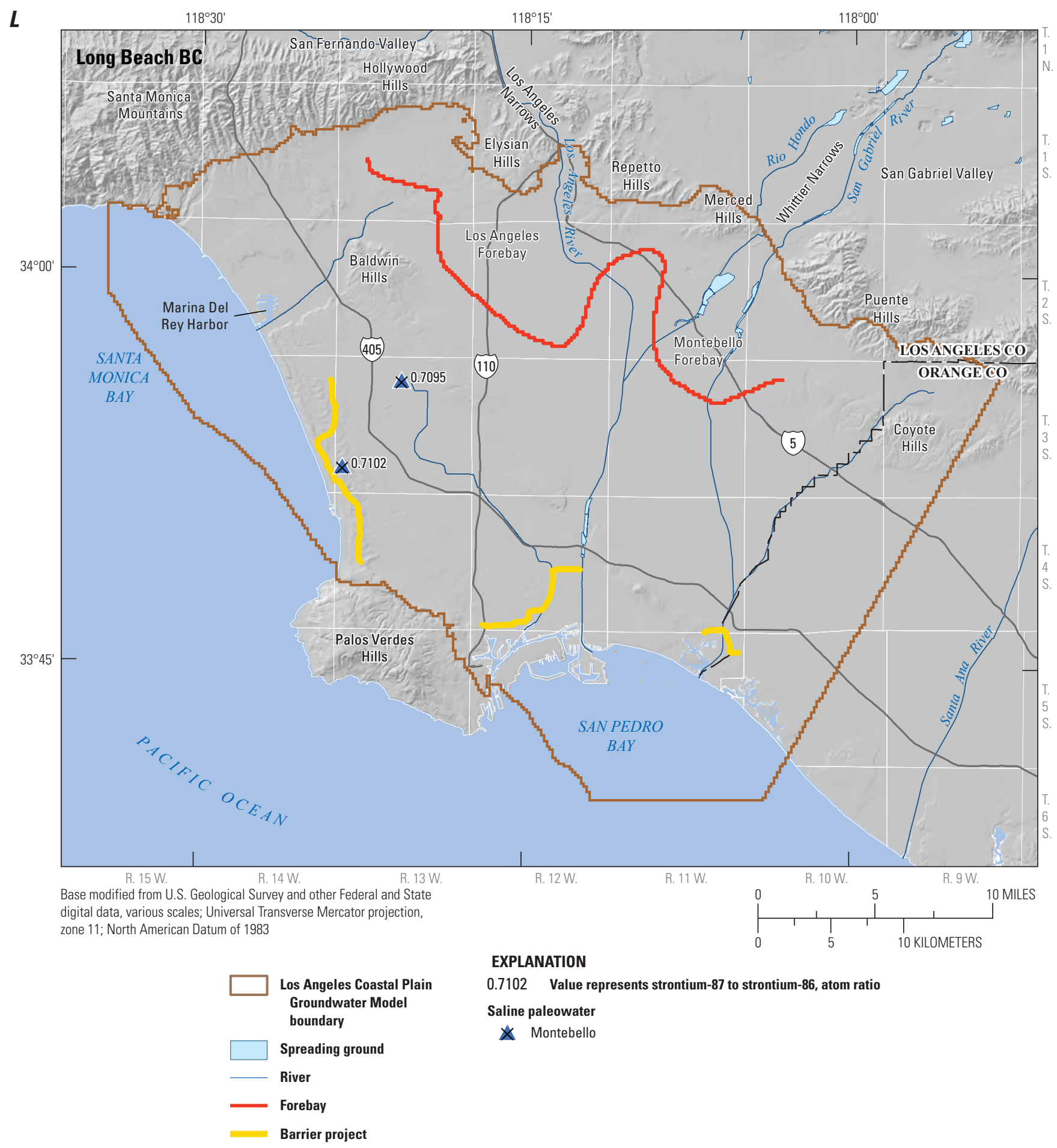

Figure 1.6.-Continued 


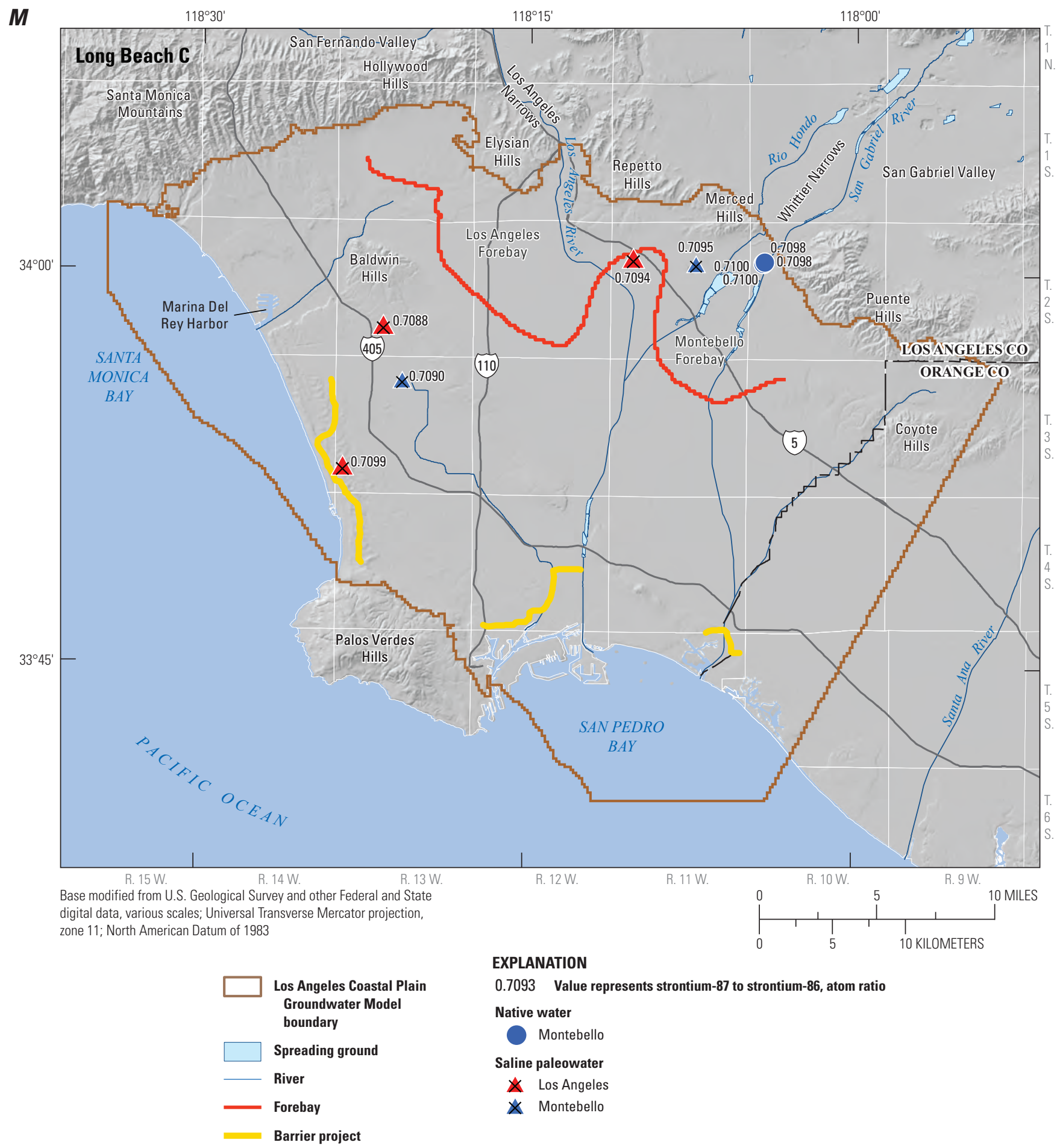

Figure 1.6.-Continued 


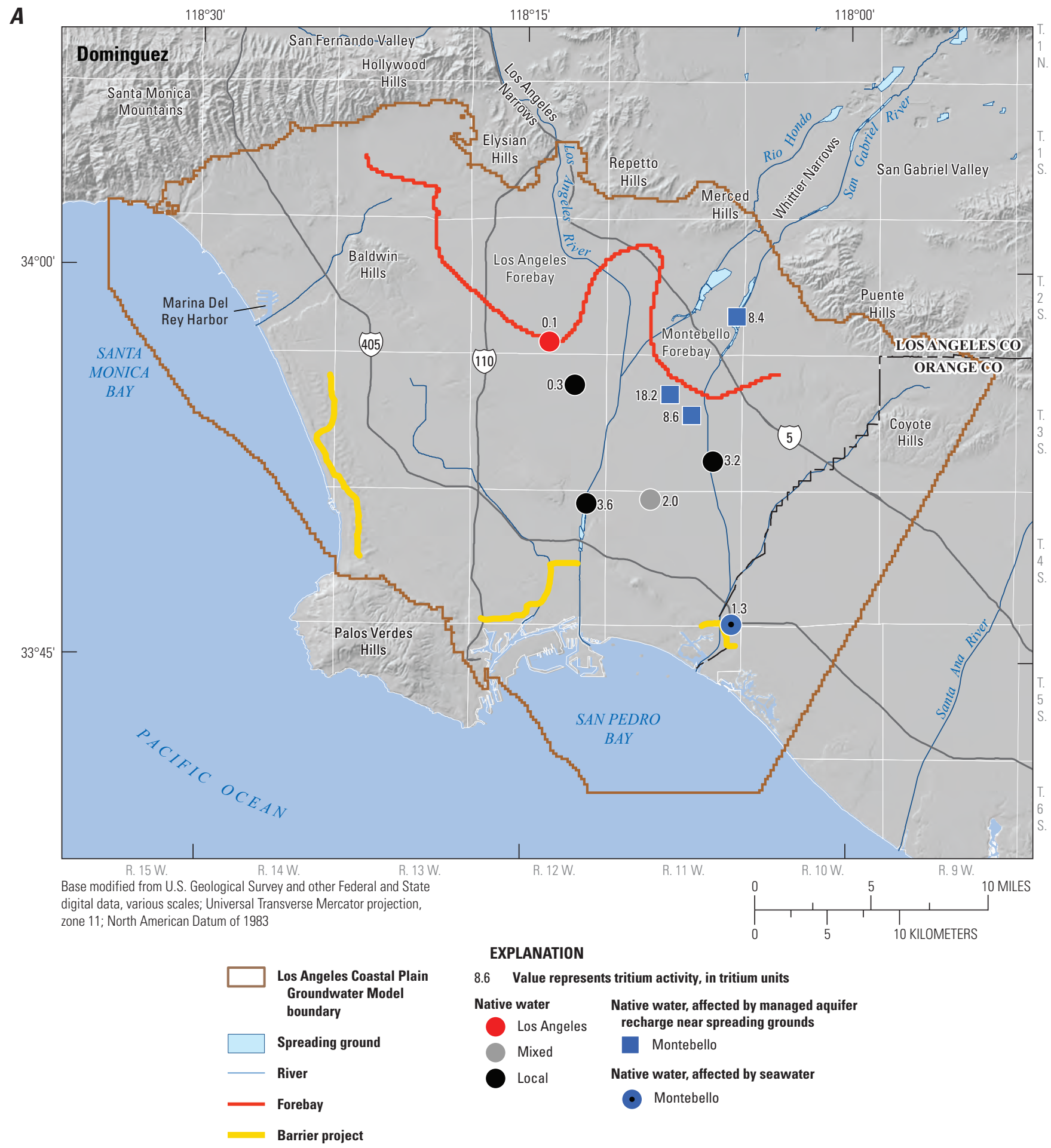

Figure 1.7. Tritium activity in samples from monitoring wells screened in chronostratigraphic units in the Los Angeles Coastal Plain, Los Angeles and Orange Counties, California: $A$, Dominguez; $B$, Mesa; $C$, Pacific A; $D$, Pacific; $E$, Harbor; $F$, Bent Spring; G, Upper Wilmington $A ; H$, Upper Wilmington $B$; I, Lower Wilmington; J, Long Beach $A ; K$, Long Beach $B$; and $L$, Long Beach $C$. 
$\boldsymbol{B}$

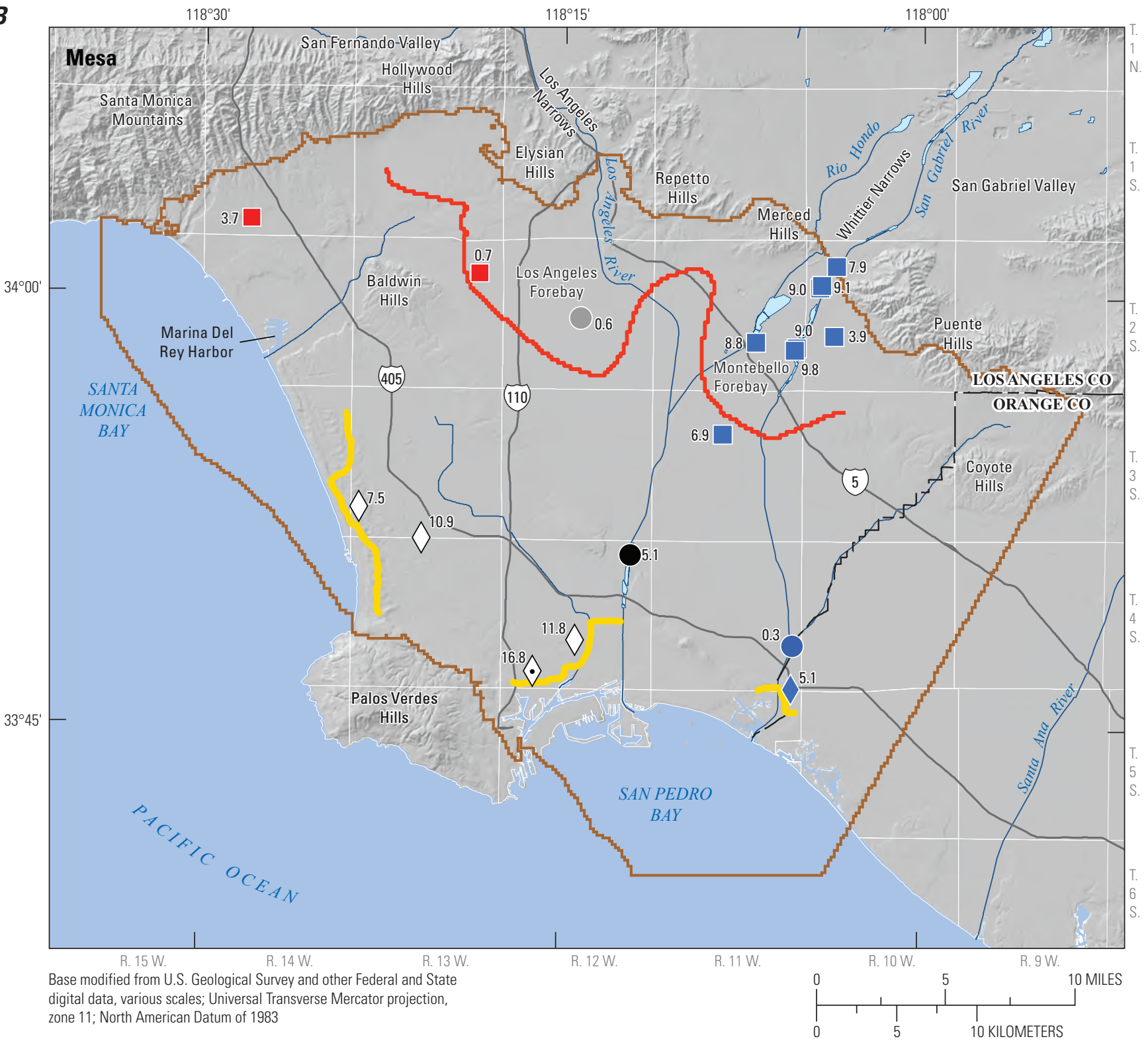

\section{EXPLANATION}

\begin{tabular}{|lc}
\hline $\begin{array}{l}\text { Los Angeles Coastal Plain } \\
\text { Groundwater Model } \\
\text { boundary }\end{array}$ & $\begin{array}{l}\text { Nolue represents tritium activity, in triti } \\
\text { Native water }\end{array}$ \\
$\begin{array}{l}\text { Spreading ground } \\
\text { River }\end{array}$ & Mixed \\
\hline Forebay & Montebello \\
Barrier project & $\begin{array}{c}\text { Native water, affected by managed aquifer } \\
\text { recharge near spreading grounds }\end{array}$ \\
& Los Angeles \\
& Montebello
\end{tabular}

\section{Native water, affected by managed aquifer recharge near injection wells \\ Montebello}

Managed aquifer recharge near injection wells

$\checkmark$ Predominantly injection water

Managed aquifer recharge from injection wells and seawater

-. Injection and seawater

Figure 1.7.-Continued 


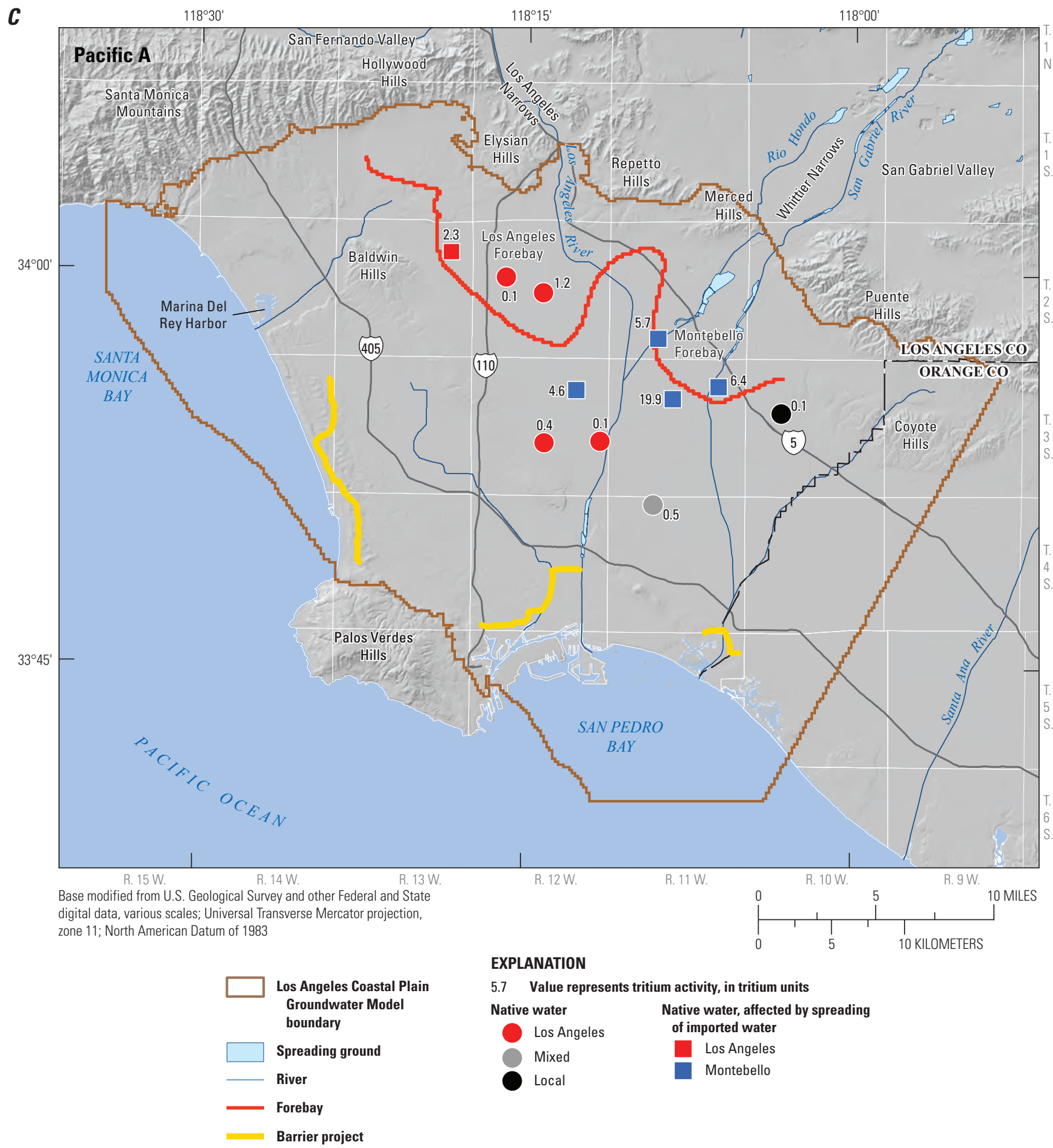

Figure 1.7.-Continued 
D

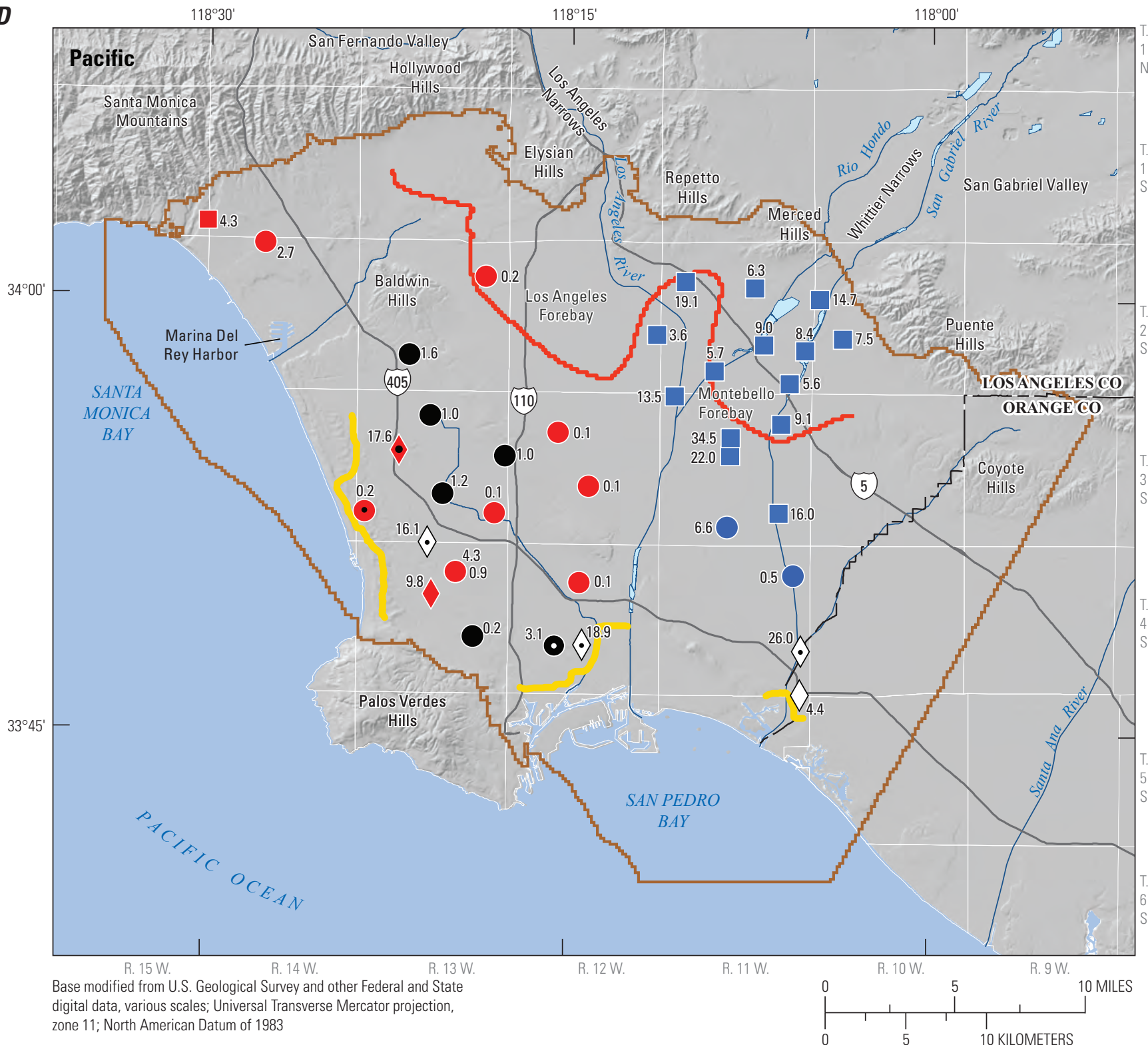

EXPLANATION

\begin{tabular}{|c|c|}
\hline \multirow{2}{*}{$\begin{array}{l}\text { Los Angeles Coastal Plain } \\
\text { Groundwater Model } \\
\text { boundary }\end{array}$} & 8.4 Value represents tritium activity, in tri \\
\hline & Native water \\
\hline Spreading ground & Local \\
\hline River & Montebello \\
\hline & $\begin{array}{l}\text { Native water, affected by managed aquifer } \\
\text { recharge near spreading grounds }\end{array}$ \\
\hline Barrier project & Los Angeles \\
\hline & Montebello \\
\hline & Native water, affected by seawater \\
\hline & Los Angeles \\
\hline
\end{tabular}
Native water, affected by managed aquifer recharge near injection wells
$\checkmark$ Los Angeles

Native water, affected by managed aquifer recharge near injection wells and seawater

- Los Angeles

Managed aquifer recharge near injection wells $\triangle$ Predominantly injection water

Managed aquifer recharge from injection wells and seawater $\checkmark$ Injection and seawater

Figure 1.7.-Continued 


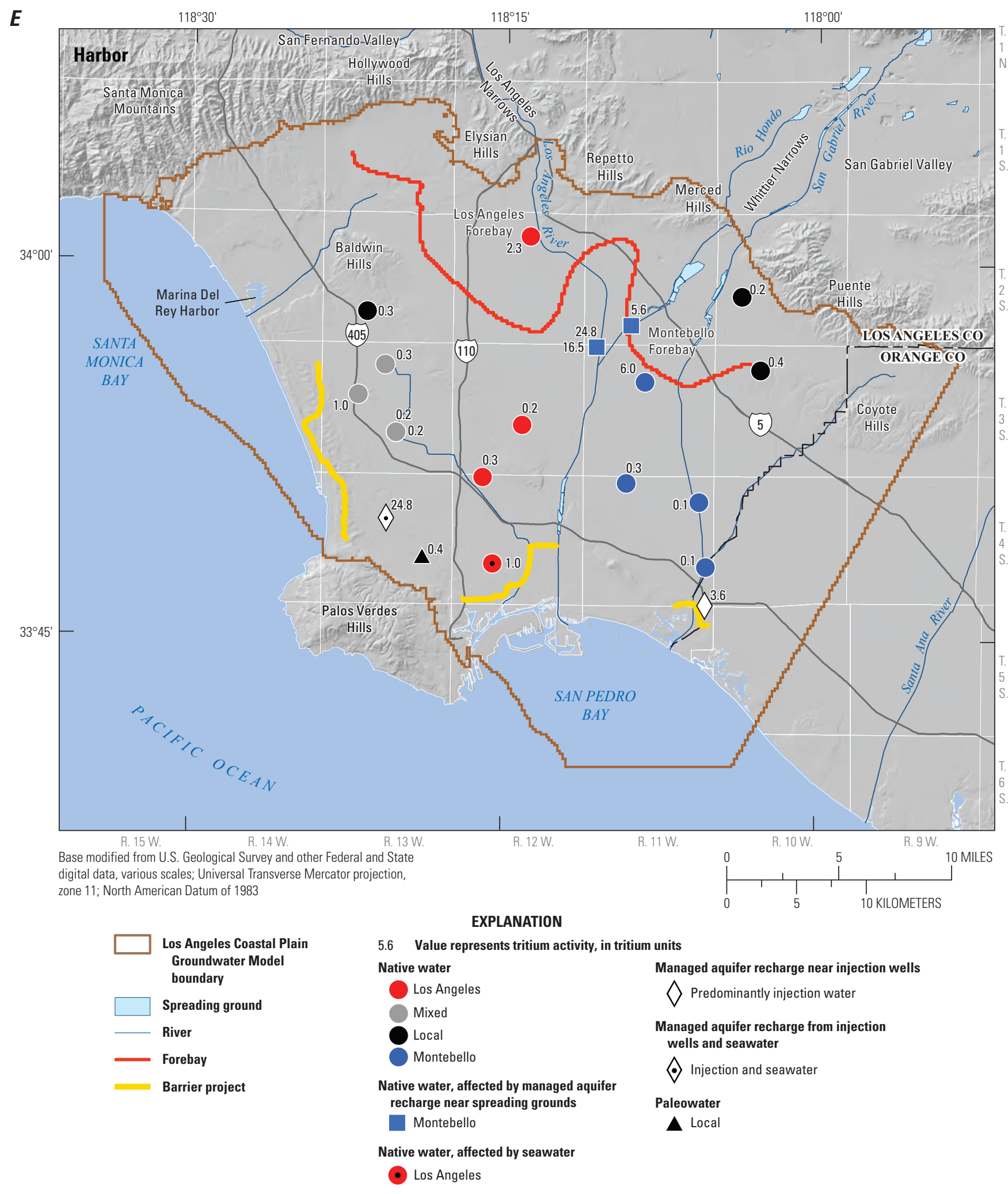

Figure 1.7.-Continued 


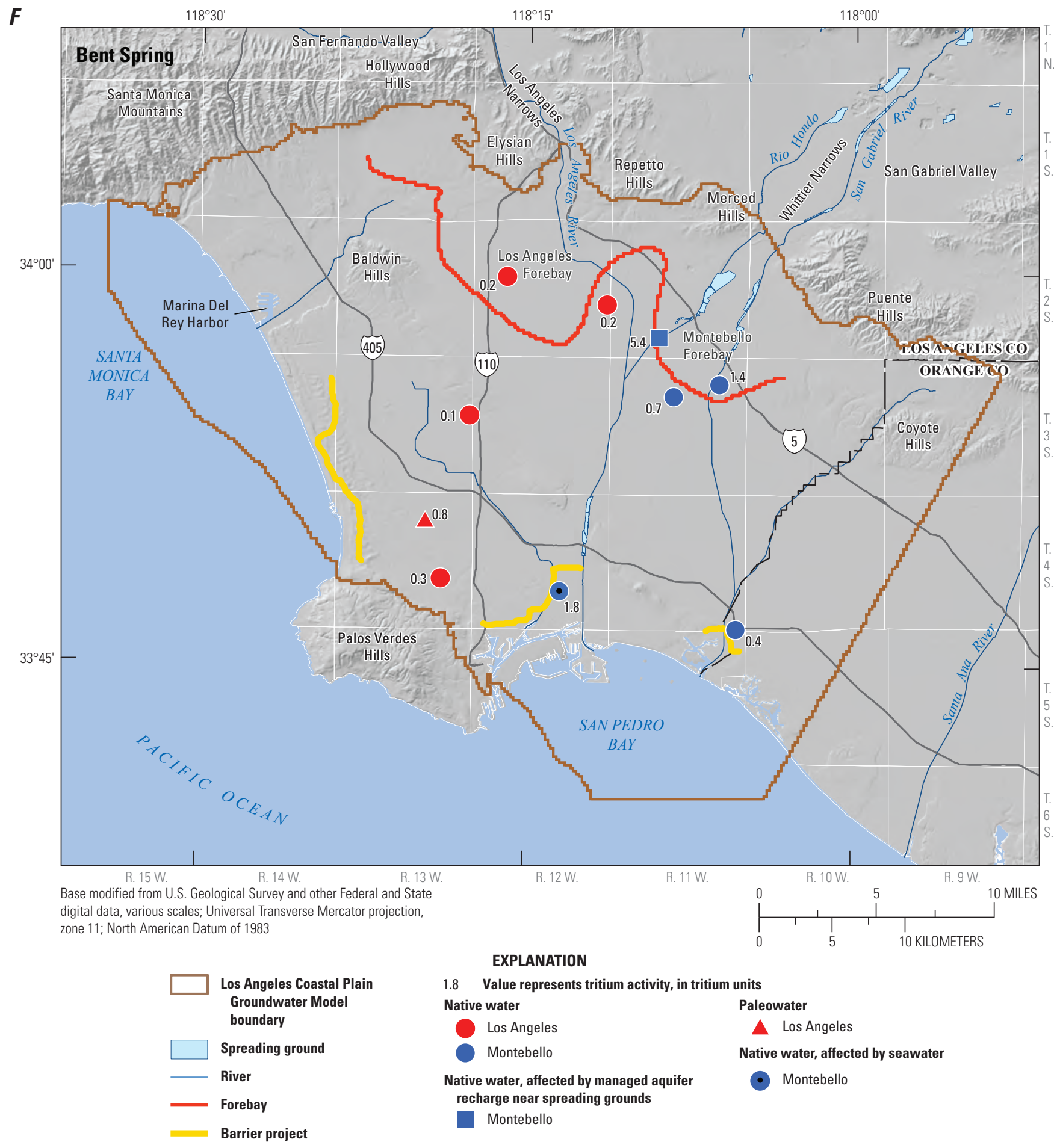

Figure 1.7.-Continued 


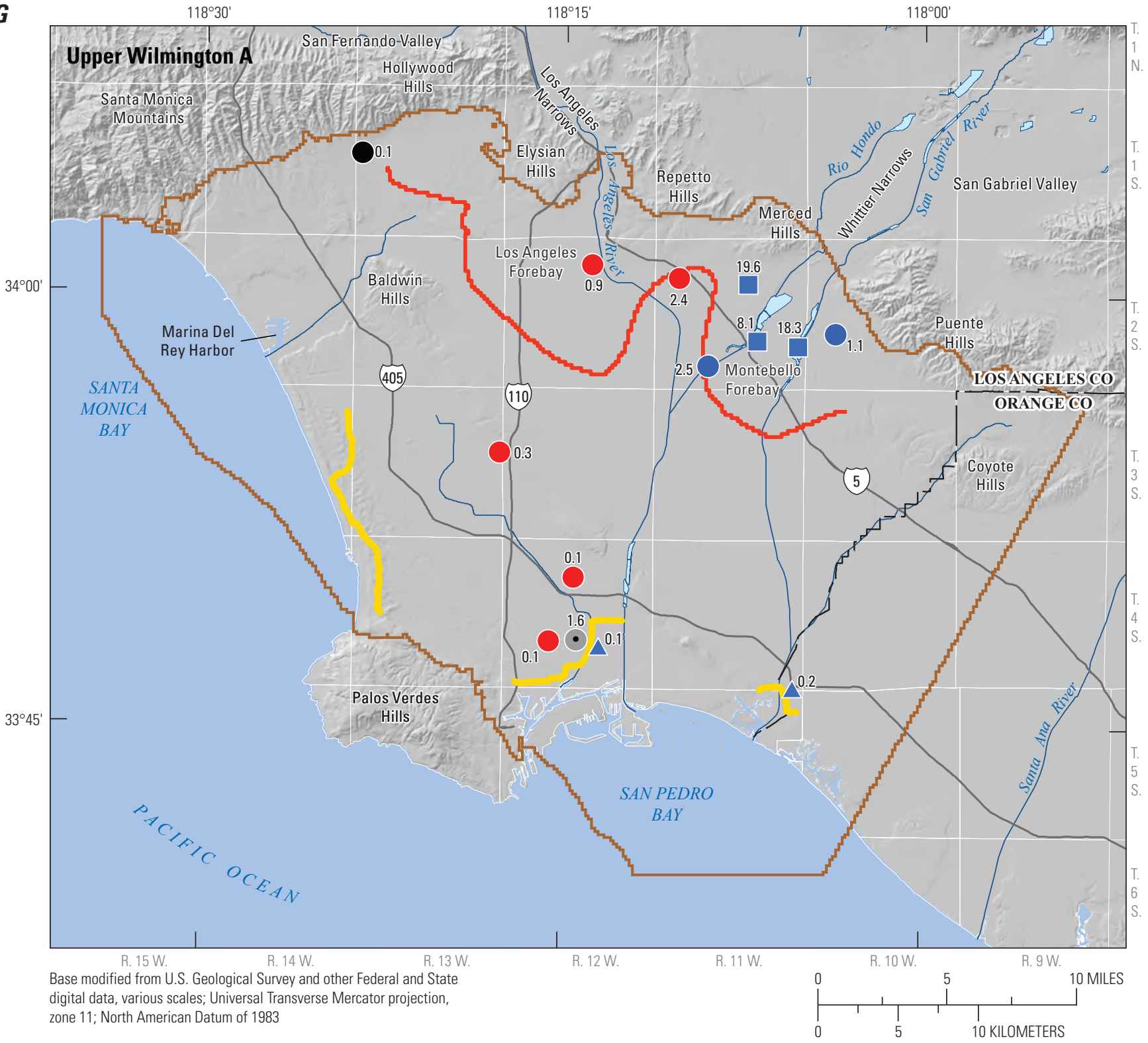

EXPLANATION

8.1 Value represents tritium activity, in tritium units

Los Angeles Coastal Plain Groundwater Model boundary

Spreading ground

River

Forebay

Barrier project

\section{Native water}

Los Angeles

Local

Montebello

Native water, affected by managed aquifer recharge near spreading grounds
Paleowater

A Montebello

Native water, affected by seawater

- Montebello

Figure 1.7.-Continued 


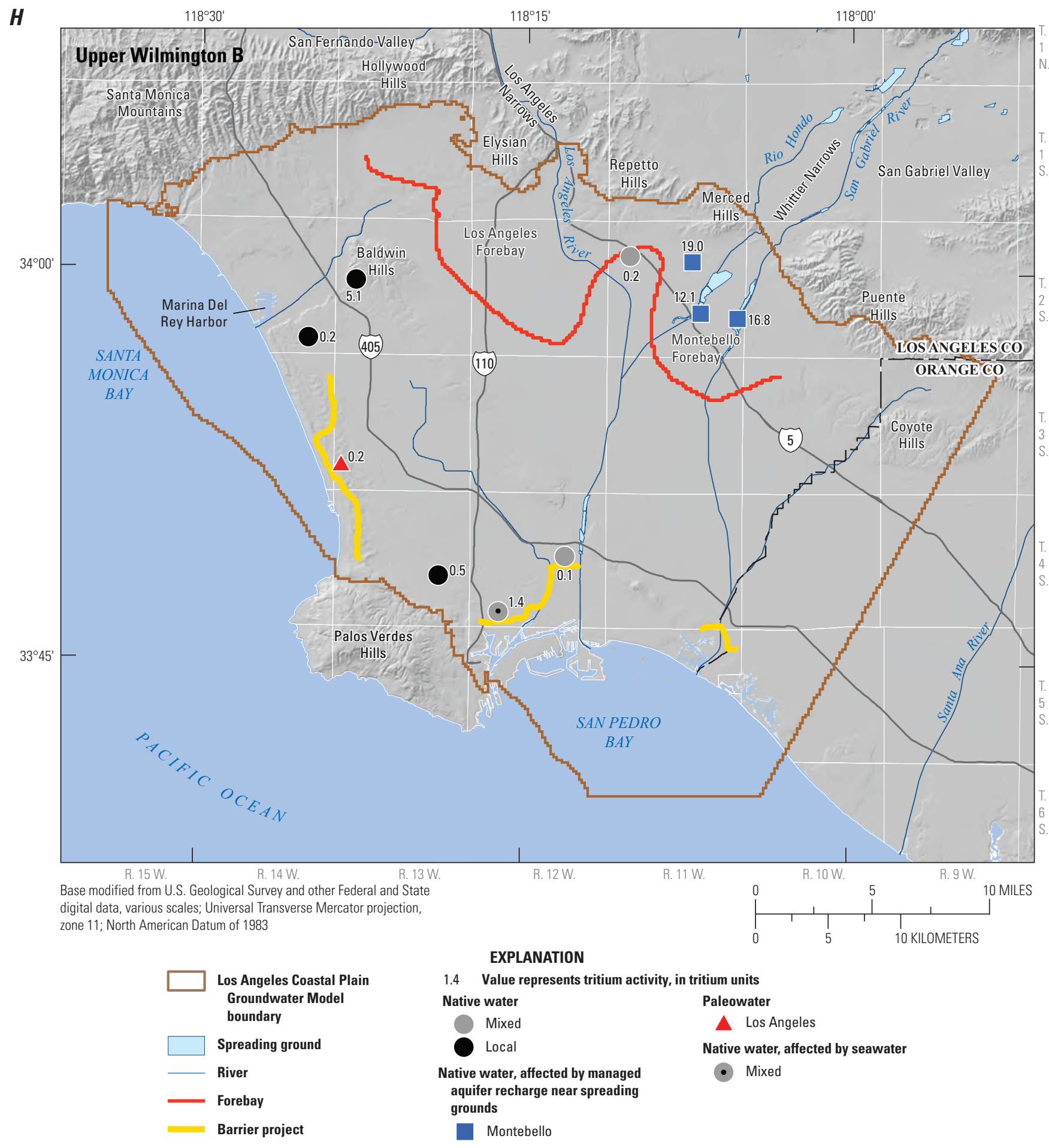

Figure 1.7.-Continued 


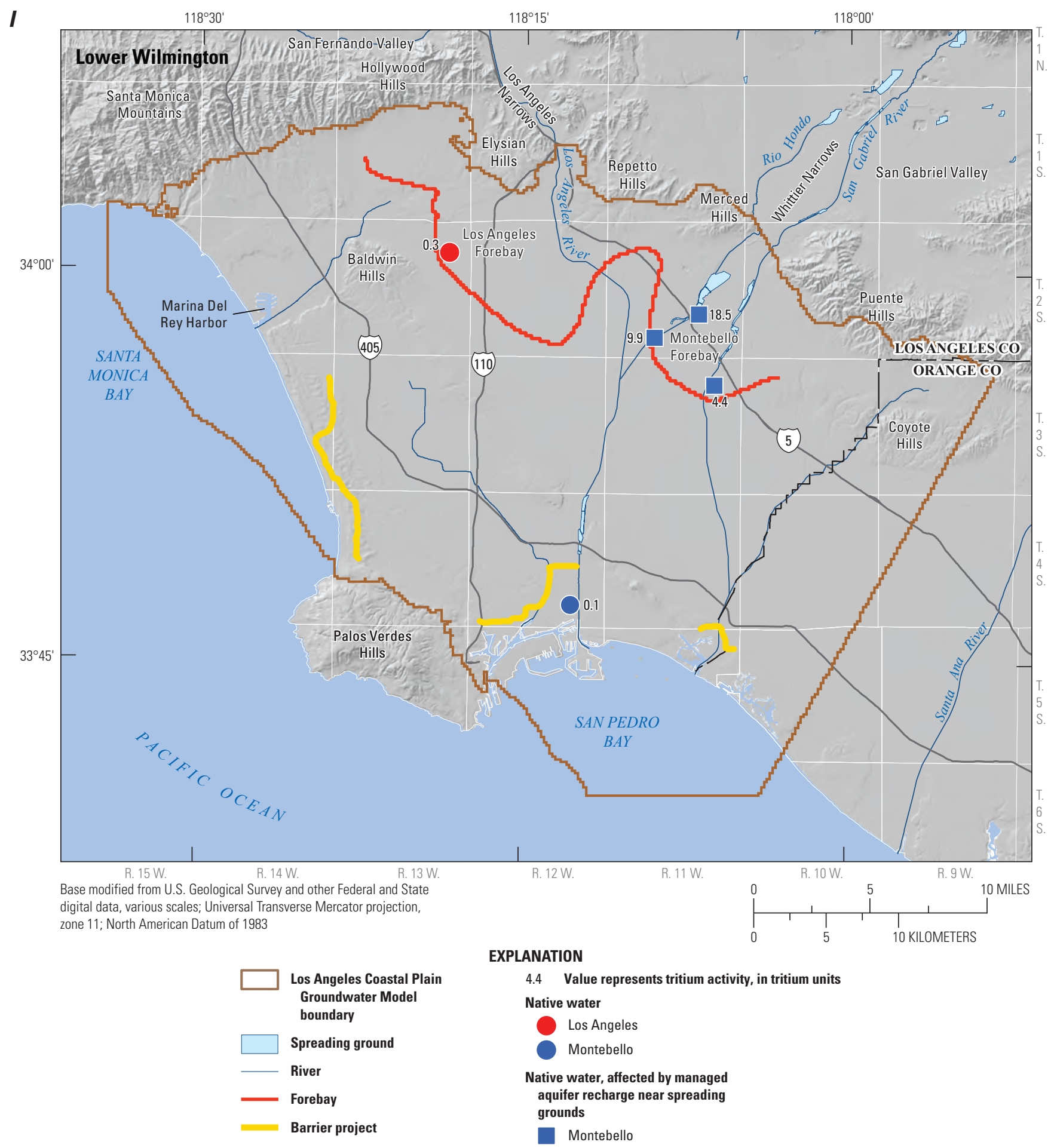

Figure 1.7.-Continued 


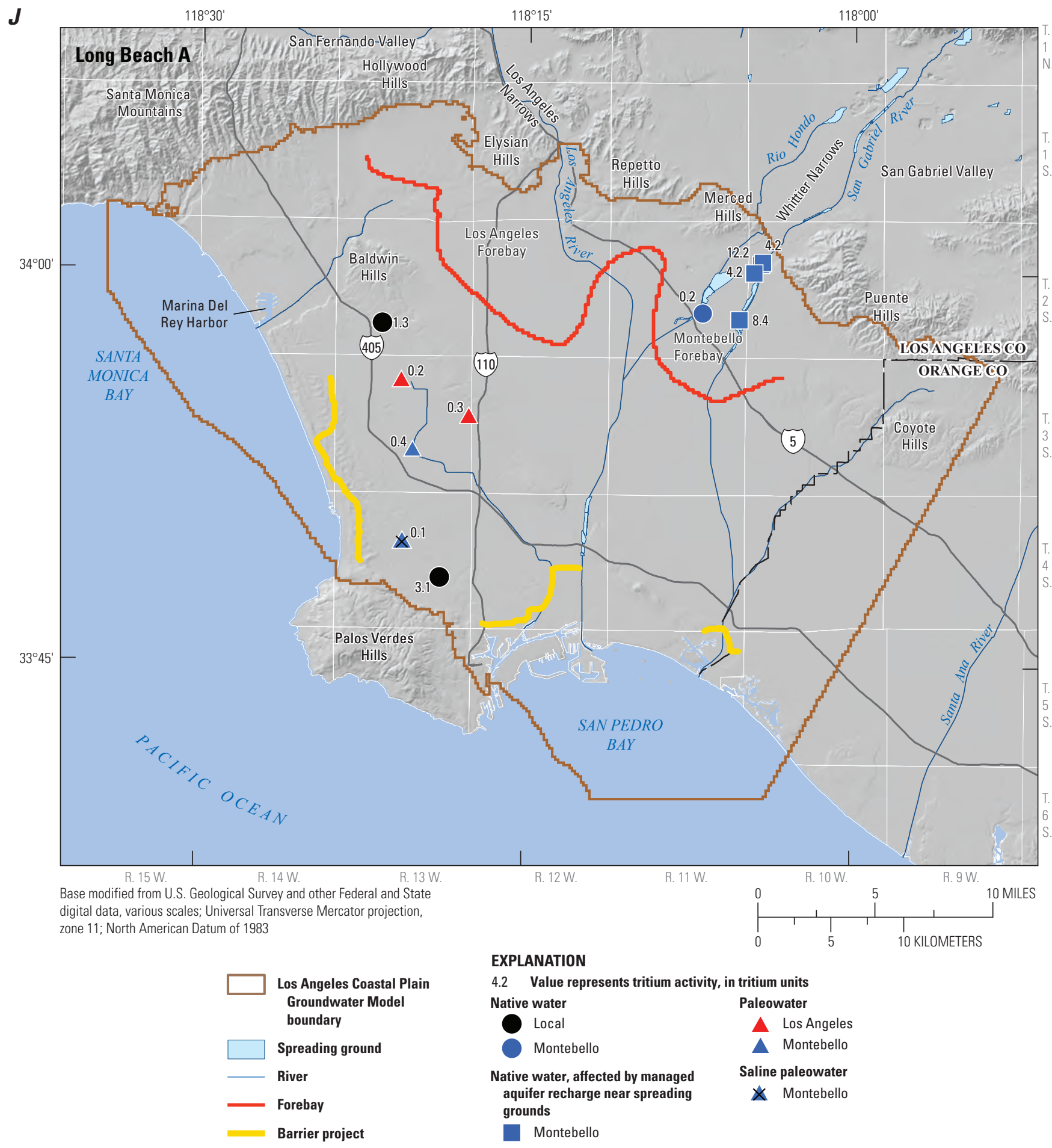

Figure 1.7.-Continued 


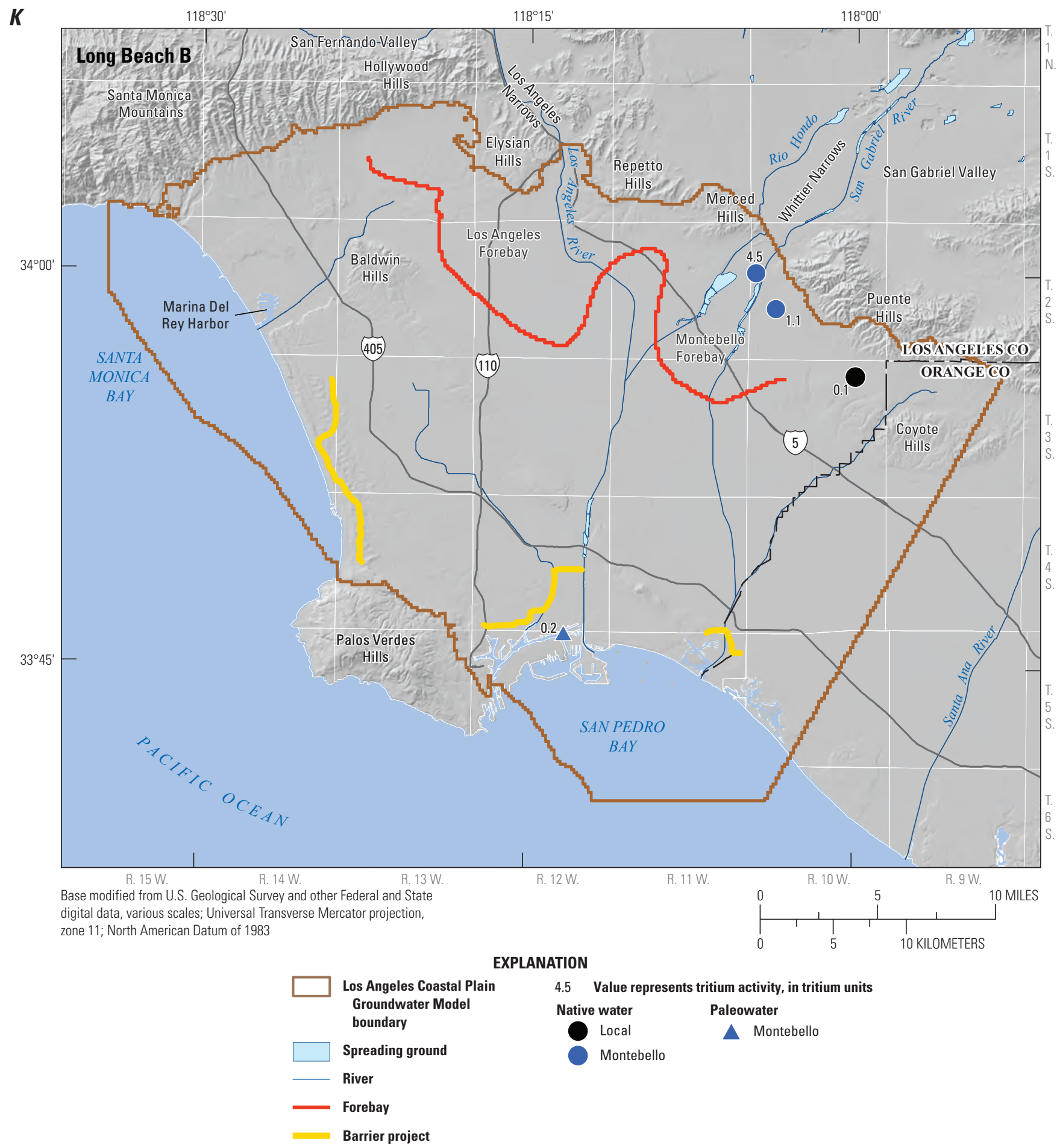

Figure 1.7.-Continued 


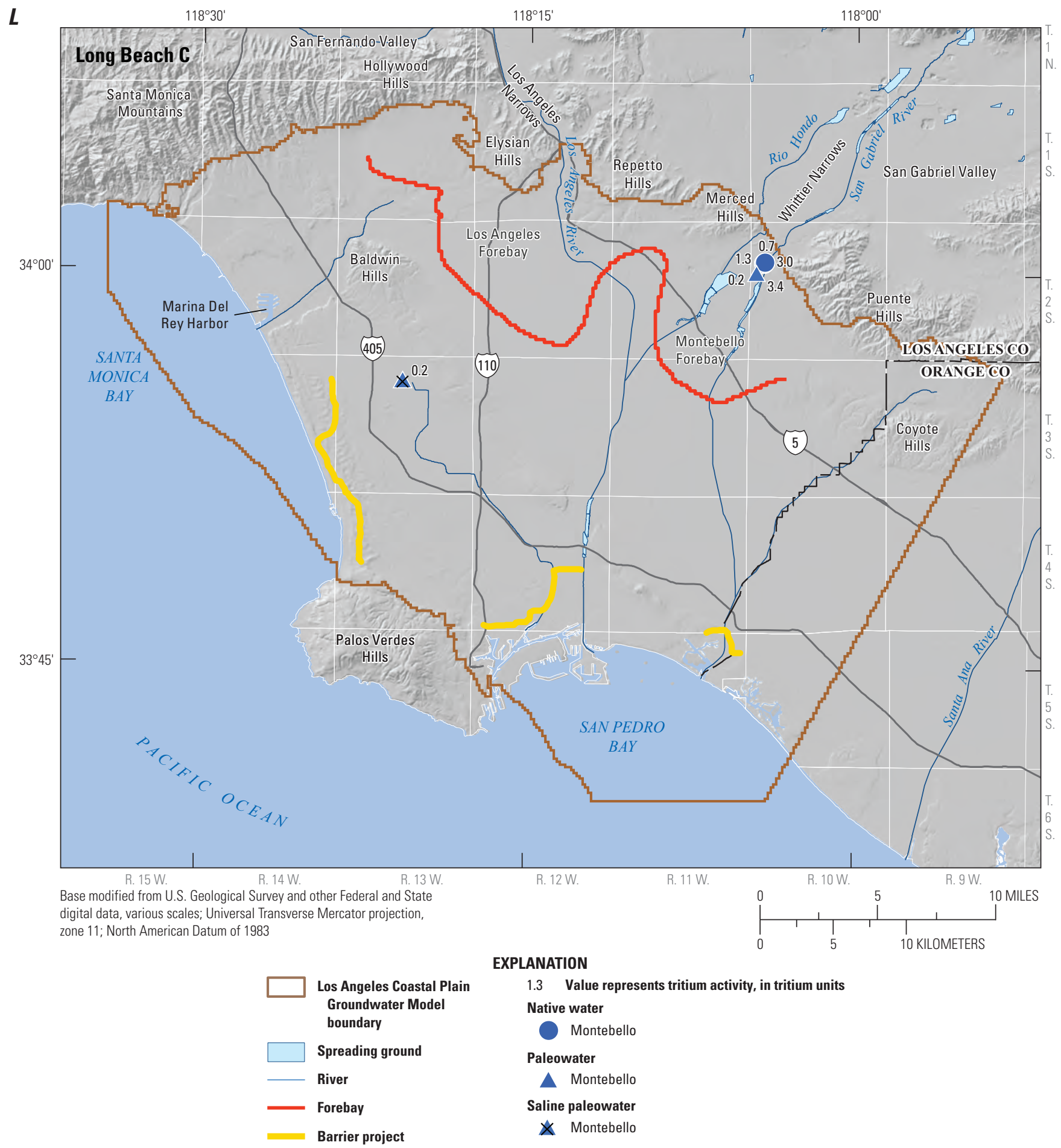

Figure 1.7.-Continued 
$\boldsymbol{A}$

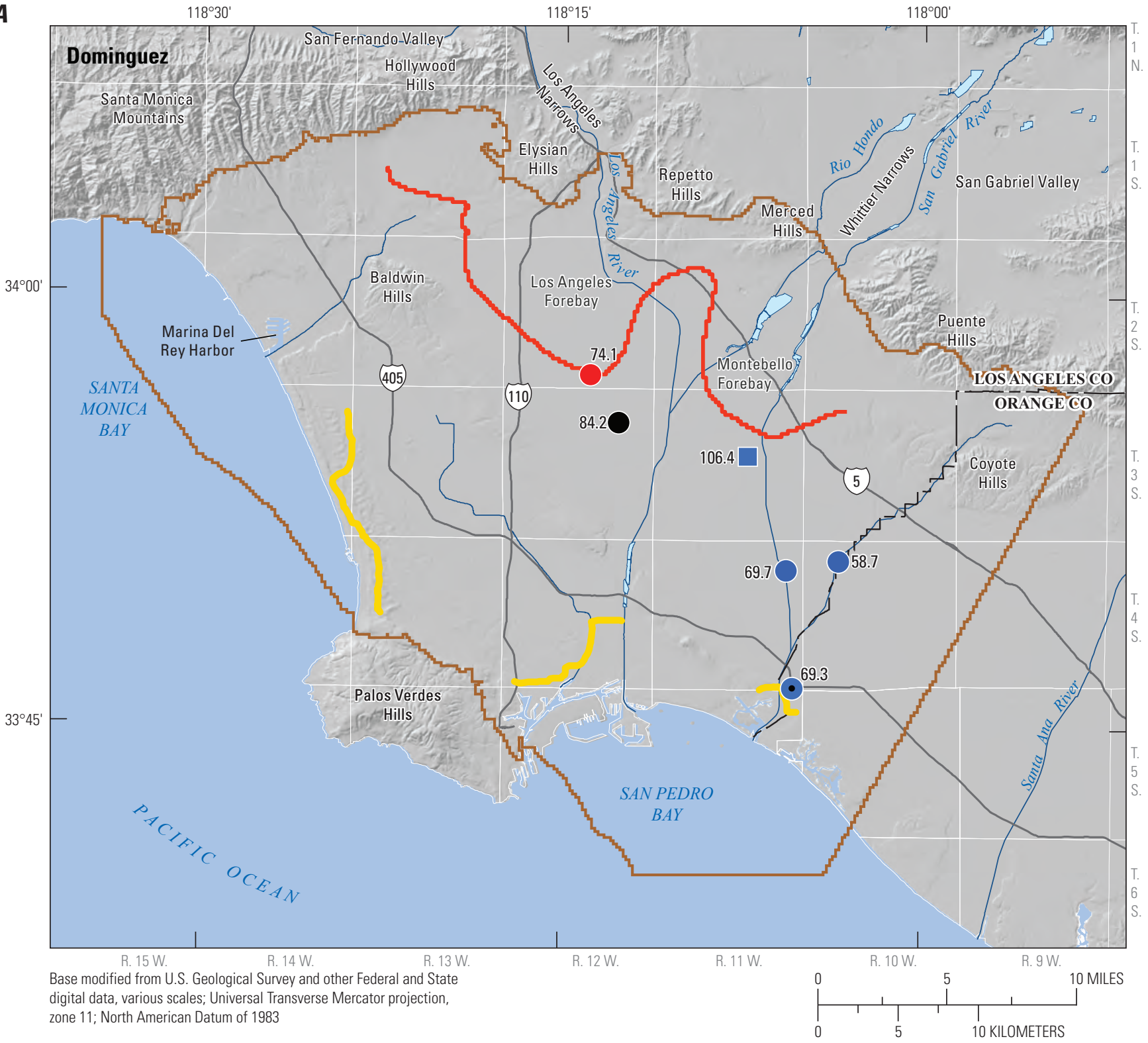

zone 11; North American Datum of 1983

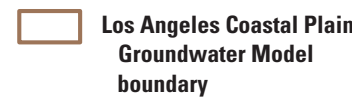

boundary

Spreading ground

River

Forebay

\section{EXPLANATION}

69.3 Value represents carbon-14 activity, in percent modern carbon

Native water

Los Angeles

Montebello

Local
Native water, affected by managed aquifer

recharge near spreading grounds

Montebello

Native water, seawater

- Montebello

Barrier project

Figure 1.8. Carbon-14 activity in samples from monitoring wells screened in chronostratigraphic units in the Los Angeles Coastal Plain, Los Angeles and Orange Counties, California: $A$, Dominguez; $B$, Mesa; $C$, Pacific $A ; D$, Pacific; $E$, Harbor; $F$, Bent Spring; $G$, Upper Wilmington $A ; H$, Upper Wilmington B; I, Lower Wilmington; J, Long Beach A; $K$, Long Beach B; L, Long Beach BC; and $M$, Long Beach C. 
B

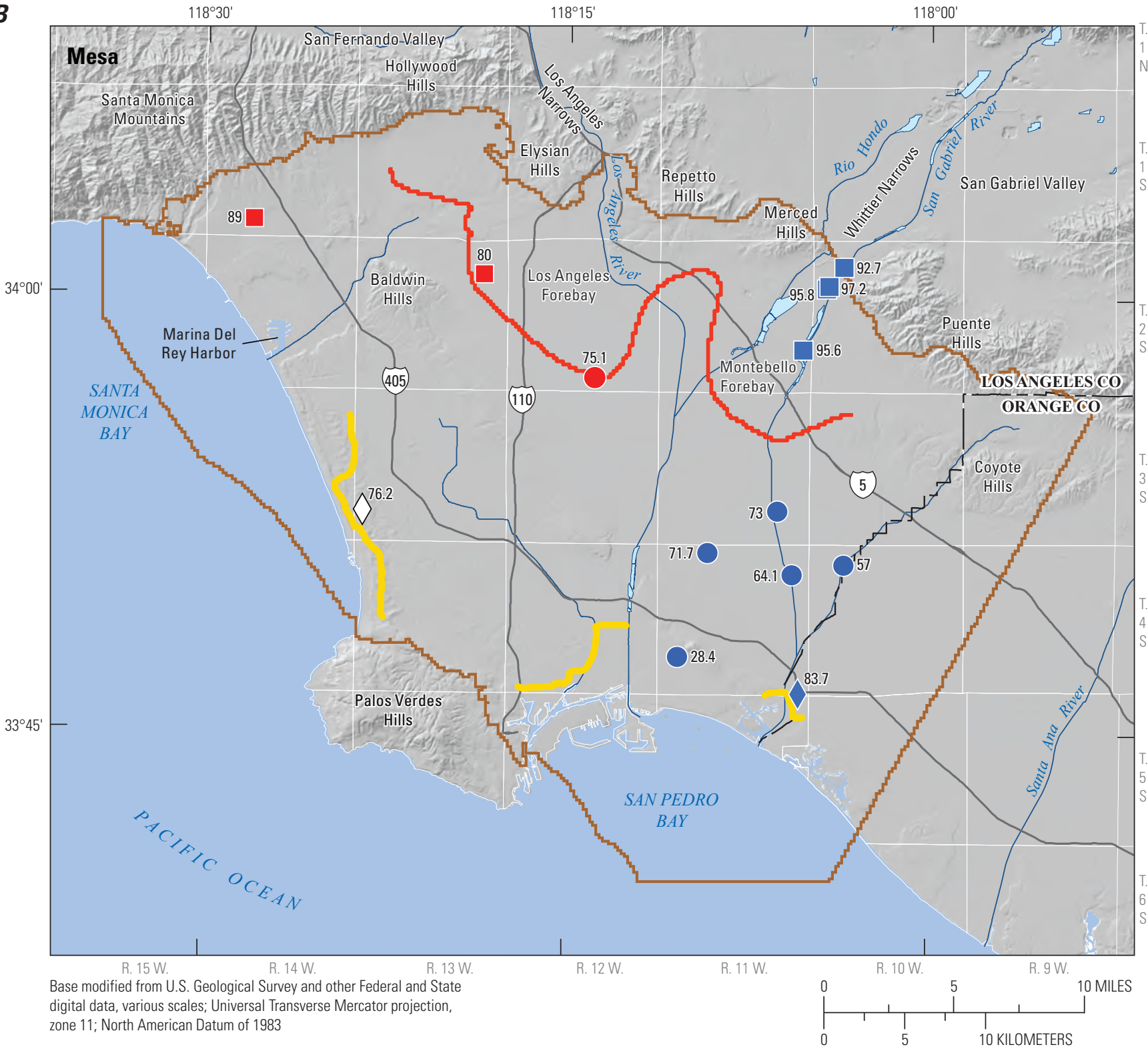

EXPLANATION

64.1 Value represents carbon-14 activity, in percent modern carbon

Groundwater Model boundary

Spreading ground

River

Forebay

Barrier project
Native water

Los Angeles

Montebello

Native water, affected by managed aquifer recharge near spreading grounds

Los Angeles

Montebello
Native water, affected by managed aquifer recharge near injection wells

Montebello

Managed aquifer recharge near injection wells

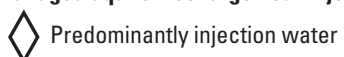

Figure 1.8.-Continued 
C

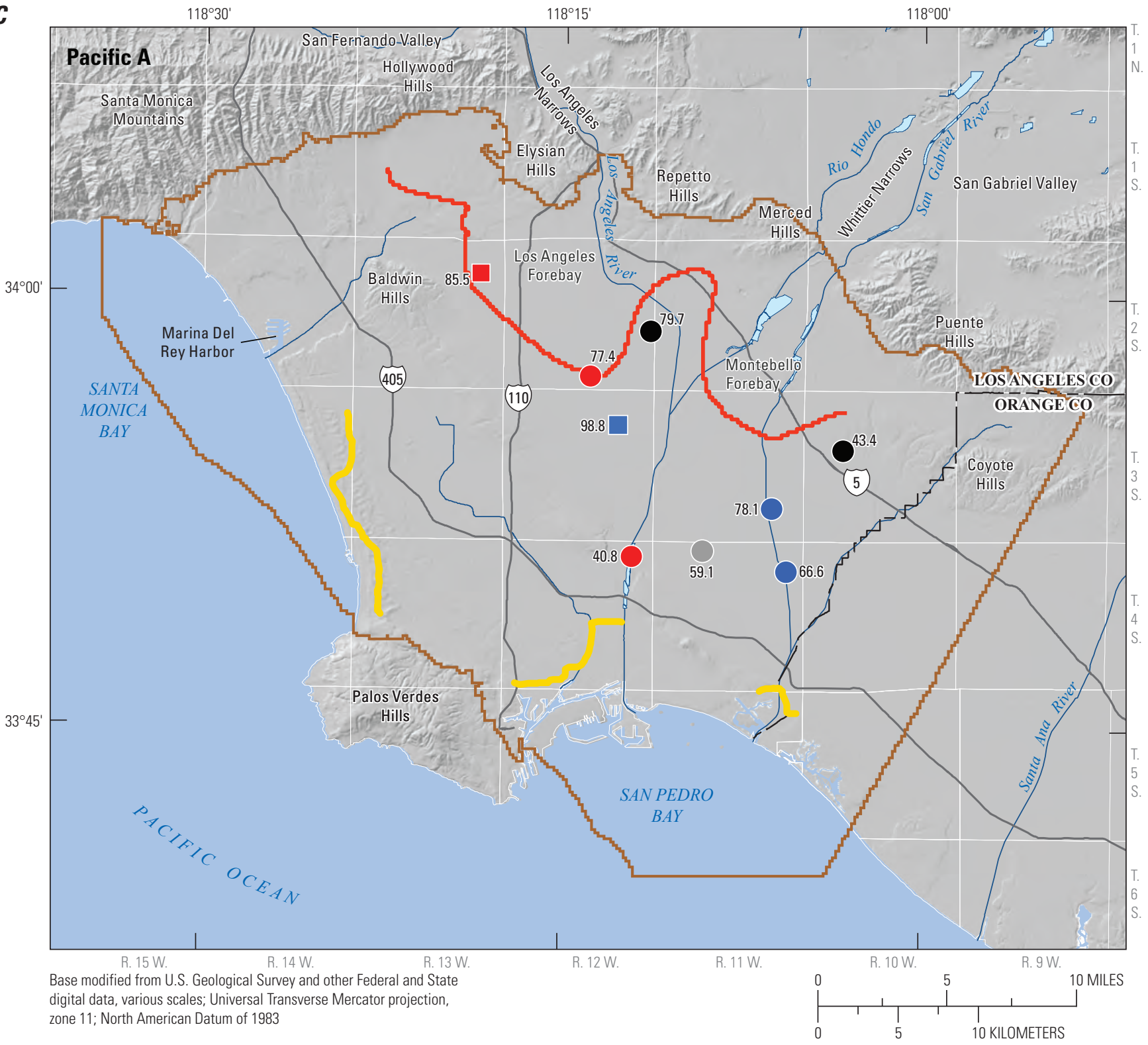
zone 11; North American Datum of 1983

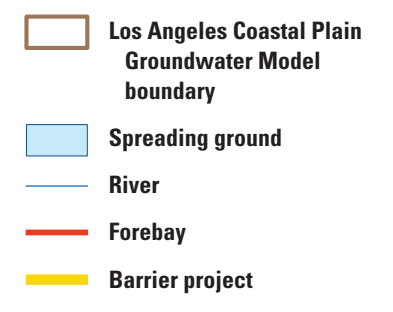

\section{EXPLANATION}

43.4 Value represents carbon-14 activity, in percent modern carbon

Native water Native water, affected by spreading

Los Angeles of imported water

Montebello Los Angeles

Local Montebello 
D

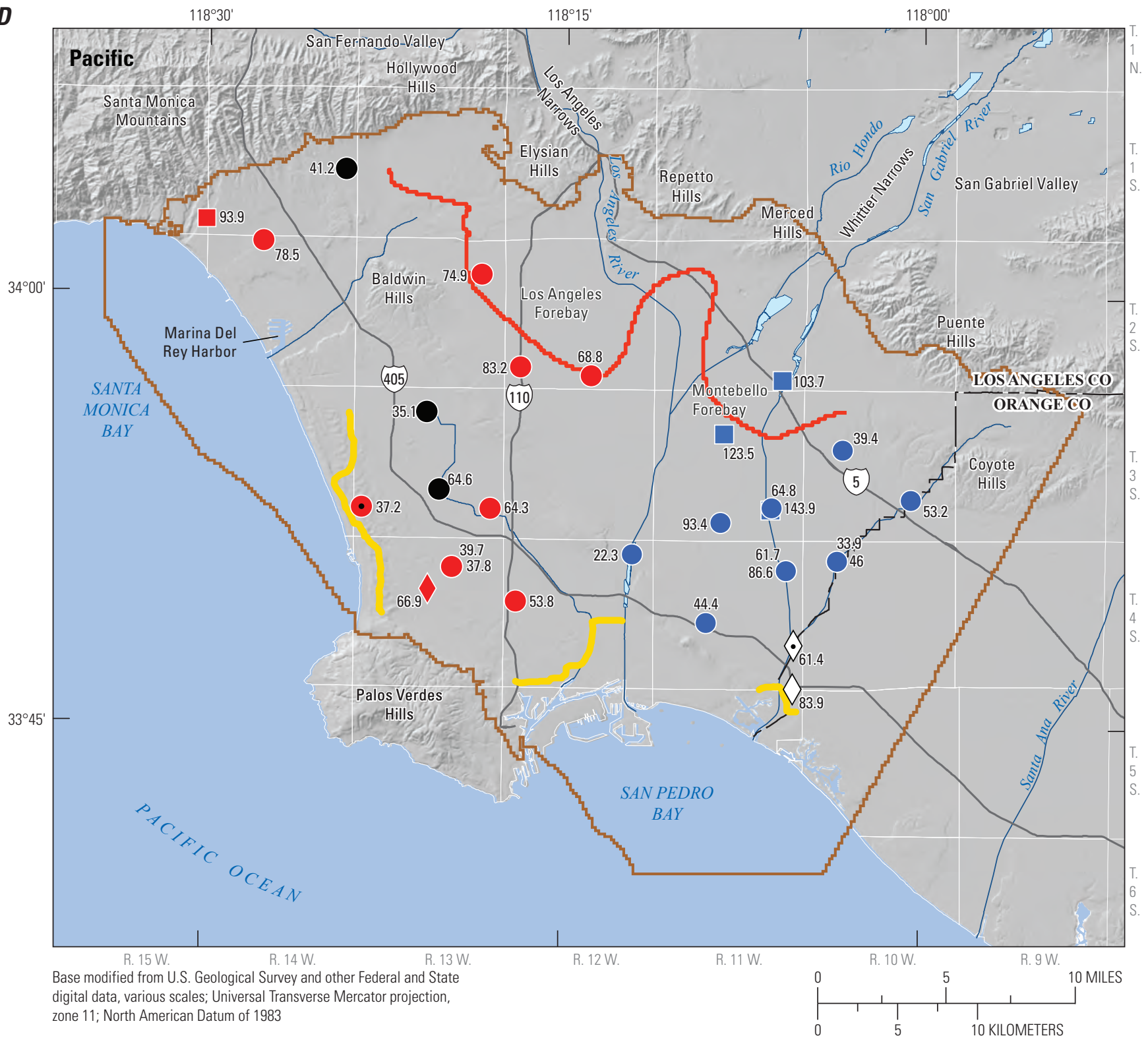

EXPLANATION

64.3 Value represents carbon-14 activity, in percent modern carbon

Los Angeles Coastal Plain Groundwater Model boundary

Spreading ground

River

Forebay

Barrier project

\section{Native water}

Los Angeles

Local

Montebello

Native water, affected by managed aquifer recharge near spreading grounds

Los Angeles
Montebello

Native water, affected by seawate

- Los Angeles
Native water, affected by managed aquifer recharge near injection wells

Los Angeles

Managed aquifer recharge near injection wells

$\checkmark$ Predominantly injection water

Managed aquifer recharge from injection wells and seawater

$\diamond$ Injection and seawater

Figure 1.8.-Continued 
$\boldsymbol{E}$

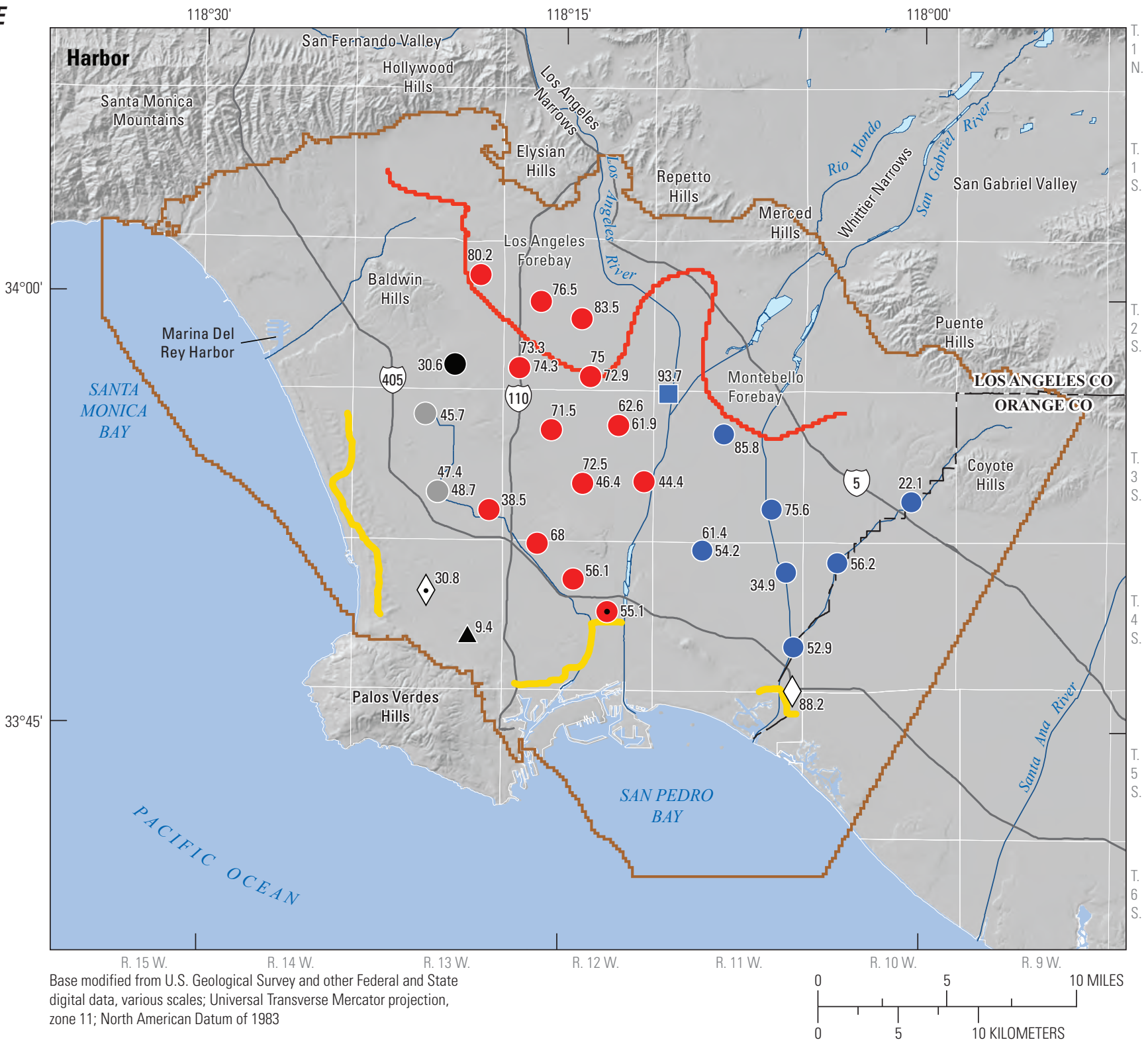

zone 11; North American Datum of 1983

\begin{tabular}{|l}
$\square \quad \begin{array}{l}\text { Los Angeles Coastal Plain } \\
\text { Groundwater Model } \\
\text { boundary }\end{array}$ \\
\begin{tabular}{|l} 
Spreading ground \\
$\square$
\end{tabular} \\
\hline River \\
Forebay \\
Barrier project
\end{tabular}

62.6 Value represents carbon-14 activity, in percent modern carbon

\section{Native water \\ Los Angeles \\ Mixed \\ Local \\ Montebello}

Native water, affected by managed aquifer recharge near spreading grounds

Montebello
Native water, affected by seawater

- Los Angeles

Managed aquifer recharge near injection wells $\checkmark$ Predominantly injection water

Managed aquifer recharge from injection wells and seawater

$\langle$ Injection and seawater

Paleowater

- Local

Figure 1.8.-Continued 
$\boldsymbol{F}$

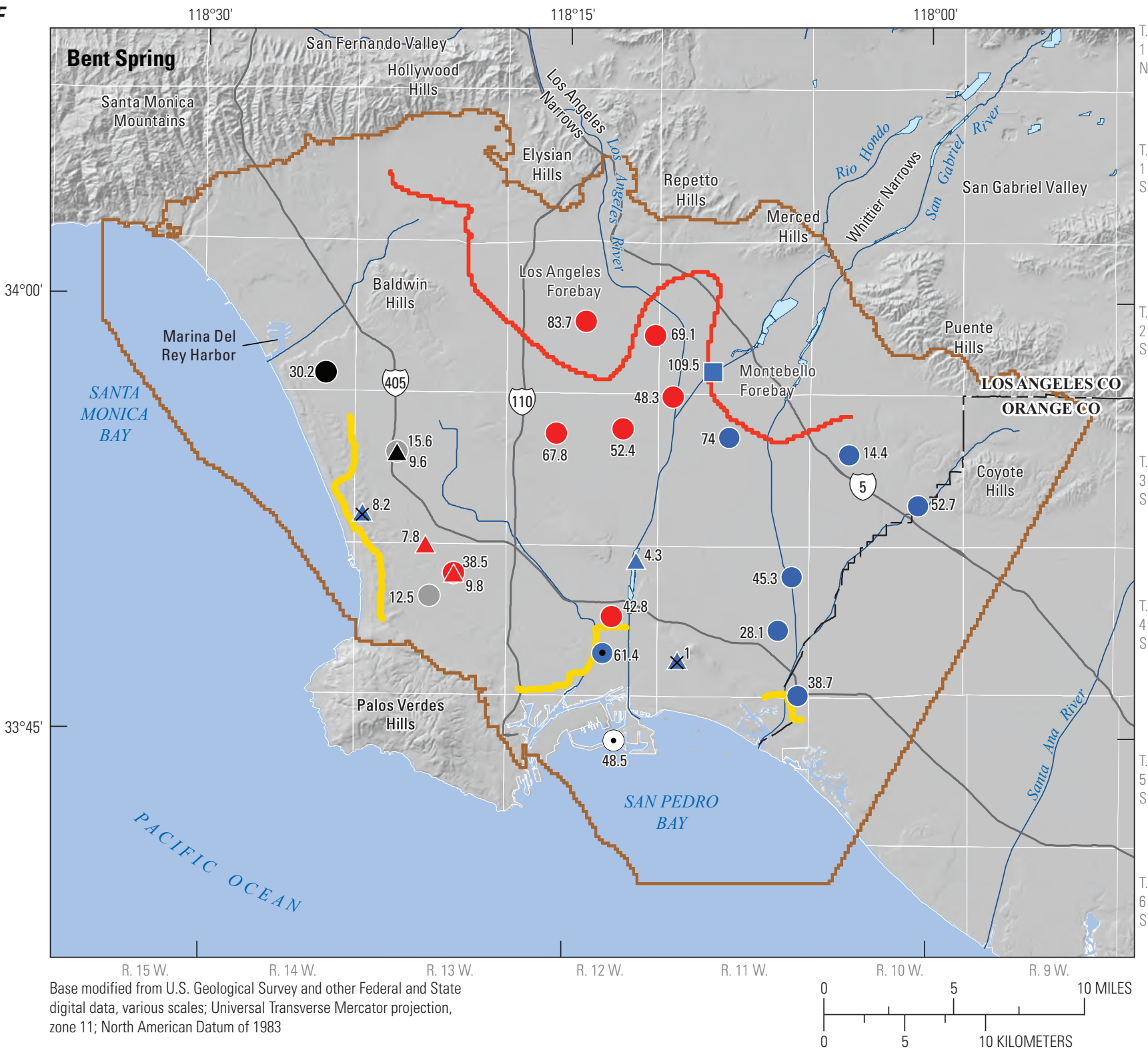

EXPLANATION

Los Angeles Coastal Plain Groundwater Model boundary

Spreading ground

River

Forebay

Barrier project

\section{Native water \\ Los Angeles \\ Mixed \\ Local \\ Montebello}

Native water, affected by managed aquifer recharge near spreading grounds

Montebello

ts carbon-14 activity, in percent modern carbon

\section{Native water, affected by seawater \\ - Los Angeles \\ Montebello}

Paleowater

- Los Angeles

$\triangle$ Local

A Montebello
Seawater

- Seawater

Saline paleowater

× Montebello

Figure 1.8.-Continued 
G

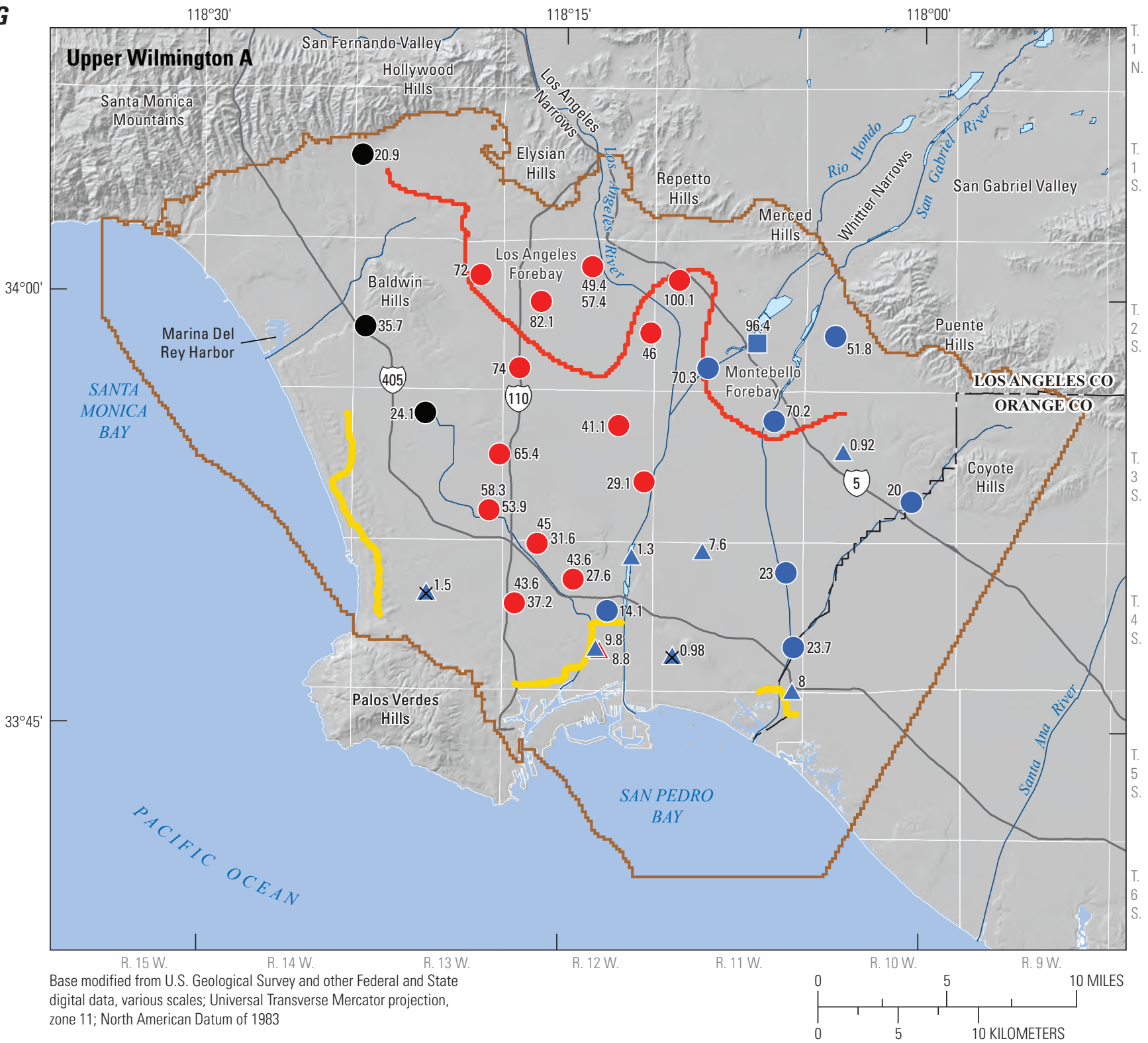
digital data various scales: Universal Transverse Mercator projection,

\begin{tabular}{|l|l}
\hline $\begin{array}{l}\text { Los Angeles Coastal Plain } \\
\text { Groundwater Model } \\
\text { boundary }\end{array}$ \\
\begin{tabular}{|l} 
Spreading ground \\
$\square$ \\
\hline
\end{tabular} River \\
\hline Forebay \\
Barrier project
\end{tabular}

\section{EXPLANATION}

43.6 Value represents carbon-14 activity, in percent modern carbon

Native water

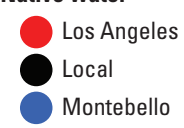

Native water, affected by managed aquifer recharge near spreading grounds

\section{Paleowater \\ A Los Angeles \\ Montebello}

Saline paleowater

× Montebello

Montebello

Figure 1.8.-Continued 


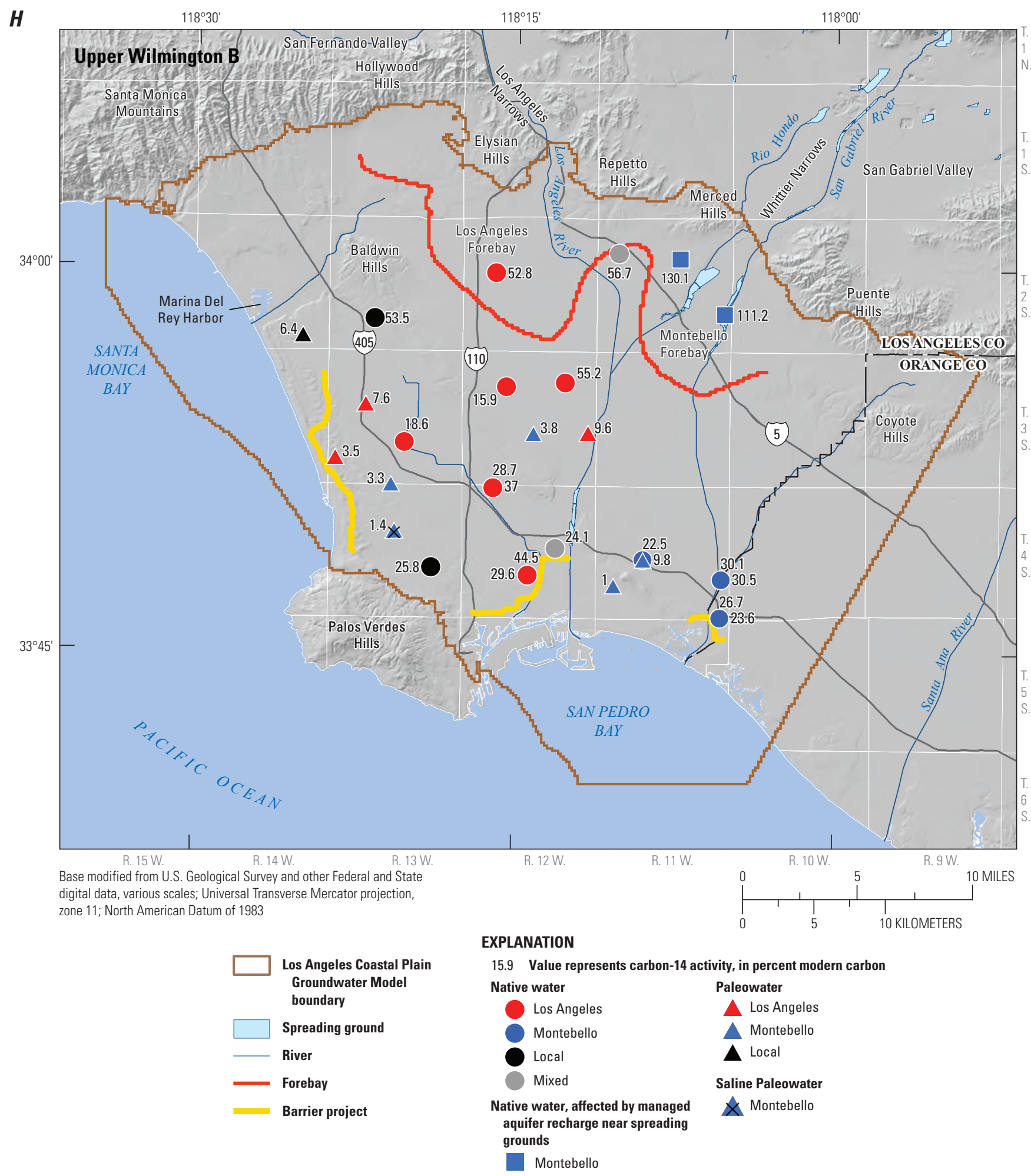

Figure 1.8.-Continued 
I

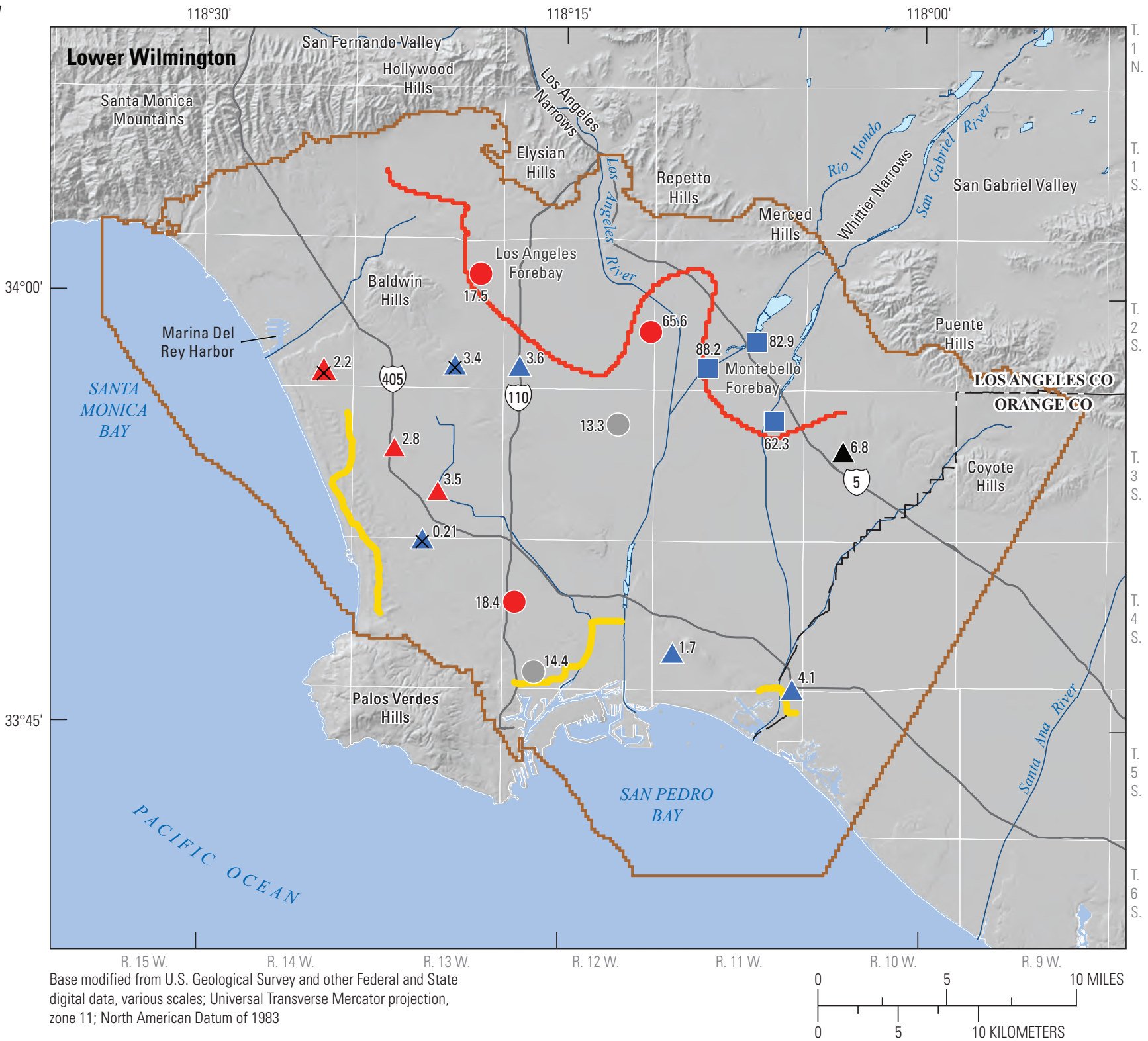

zone 11; North American Datum of 1983

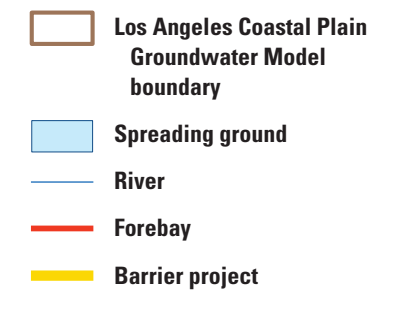

\section{EXPLANATION}

65.6 Value represents carbon-14 activity, in percent modern carbon

$\begin{array}{cc}\begin{array}{c}\text { Native water } \\ \text { Los Angeles } \\ \text { Mixed }\end{array} & \begin{array}{c}\text { Native water, affecte } \\ \text { aquifer recharge n } \\ \text { grounds }\end{array} \\ \text { Paleowater } & \text { Montebello } \\ \Delta \text { Los Angeles } & \text { Saline Paleowater } \\ \Delta \text { Montebello } & \searrow \text { Los Angeles }\end{array}$

Figure 1.8.-Continued 


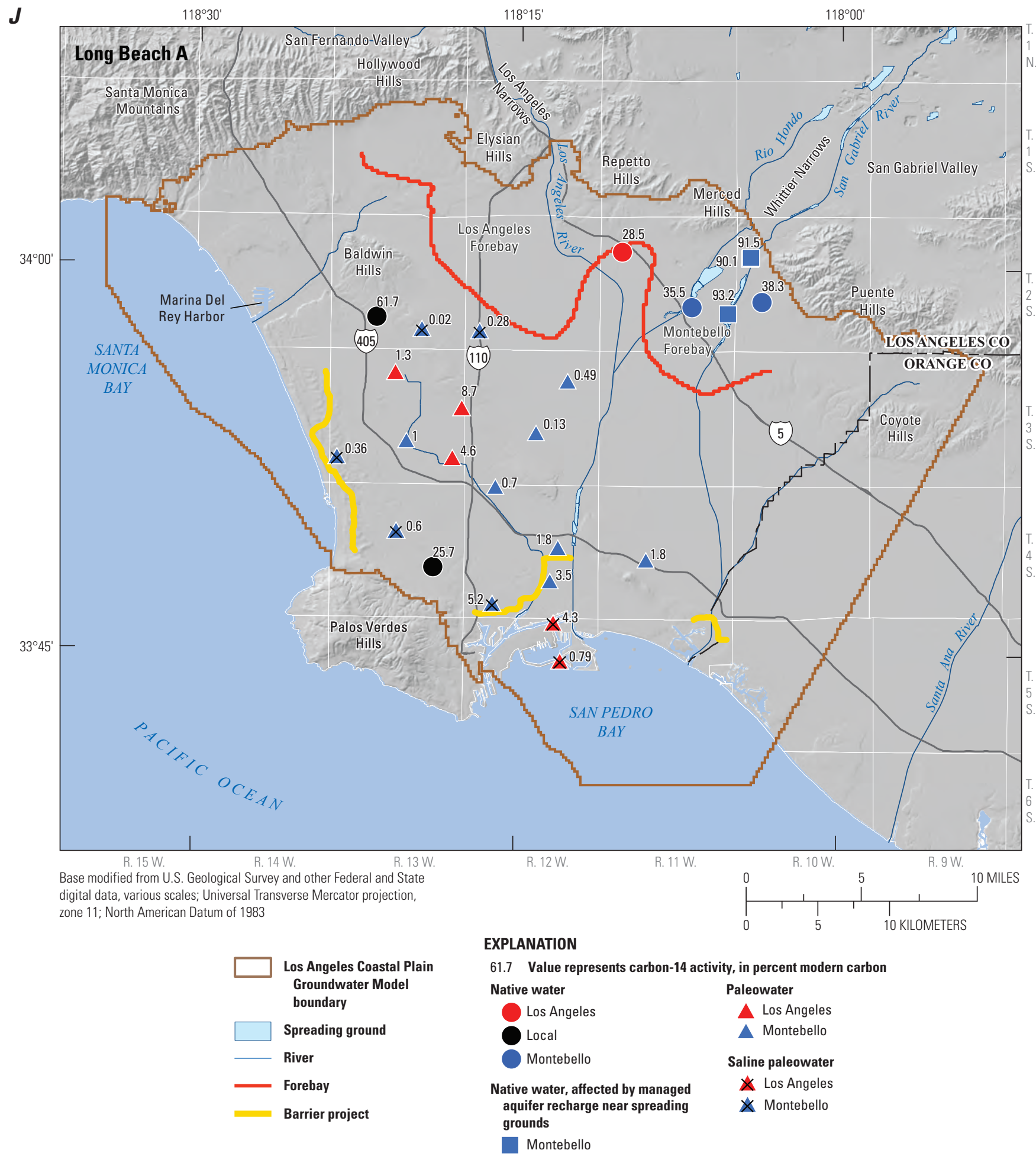

Figure 1.8.-Continued 


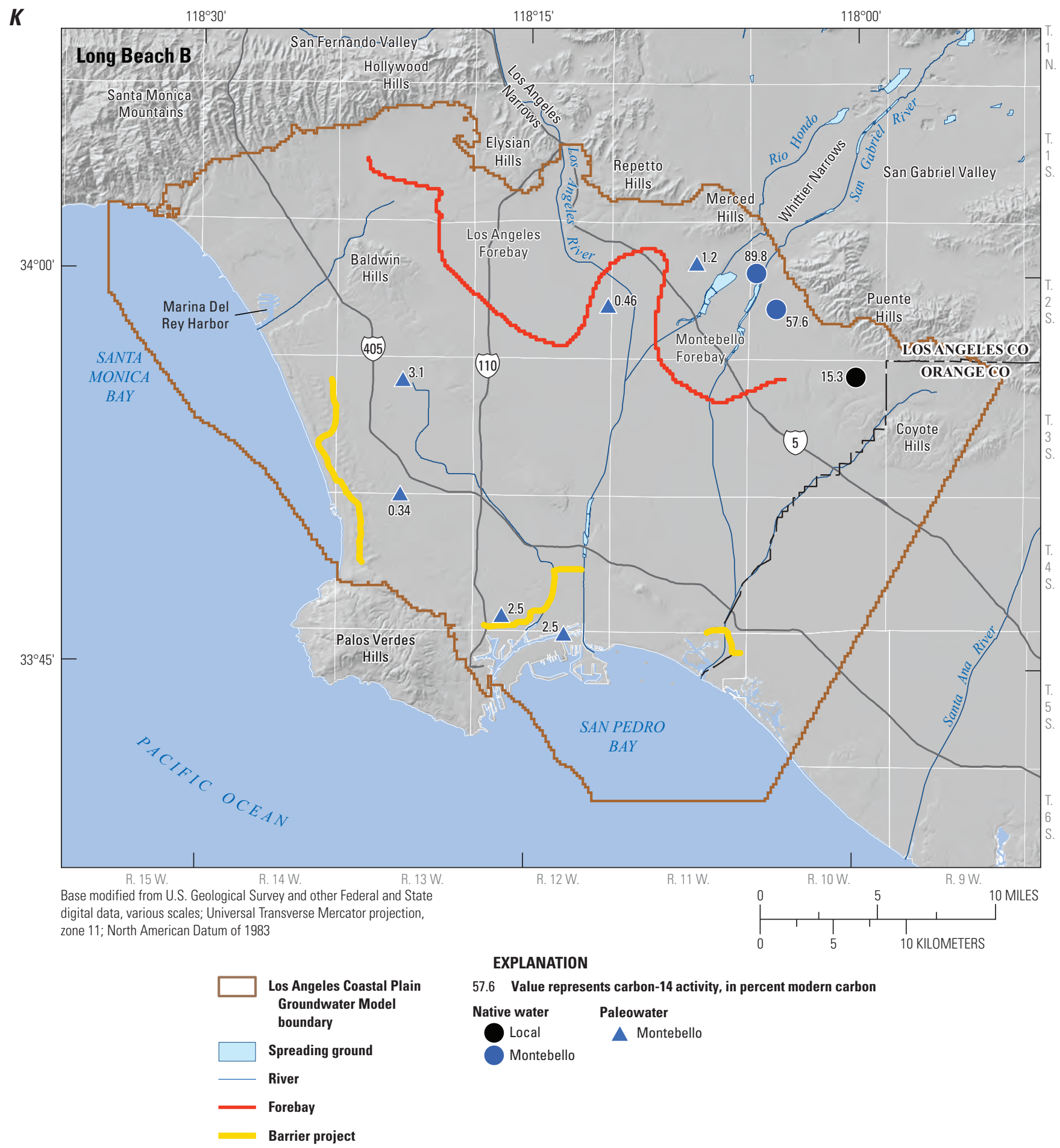

Figure 1.8.-Continued 


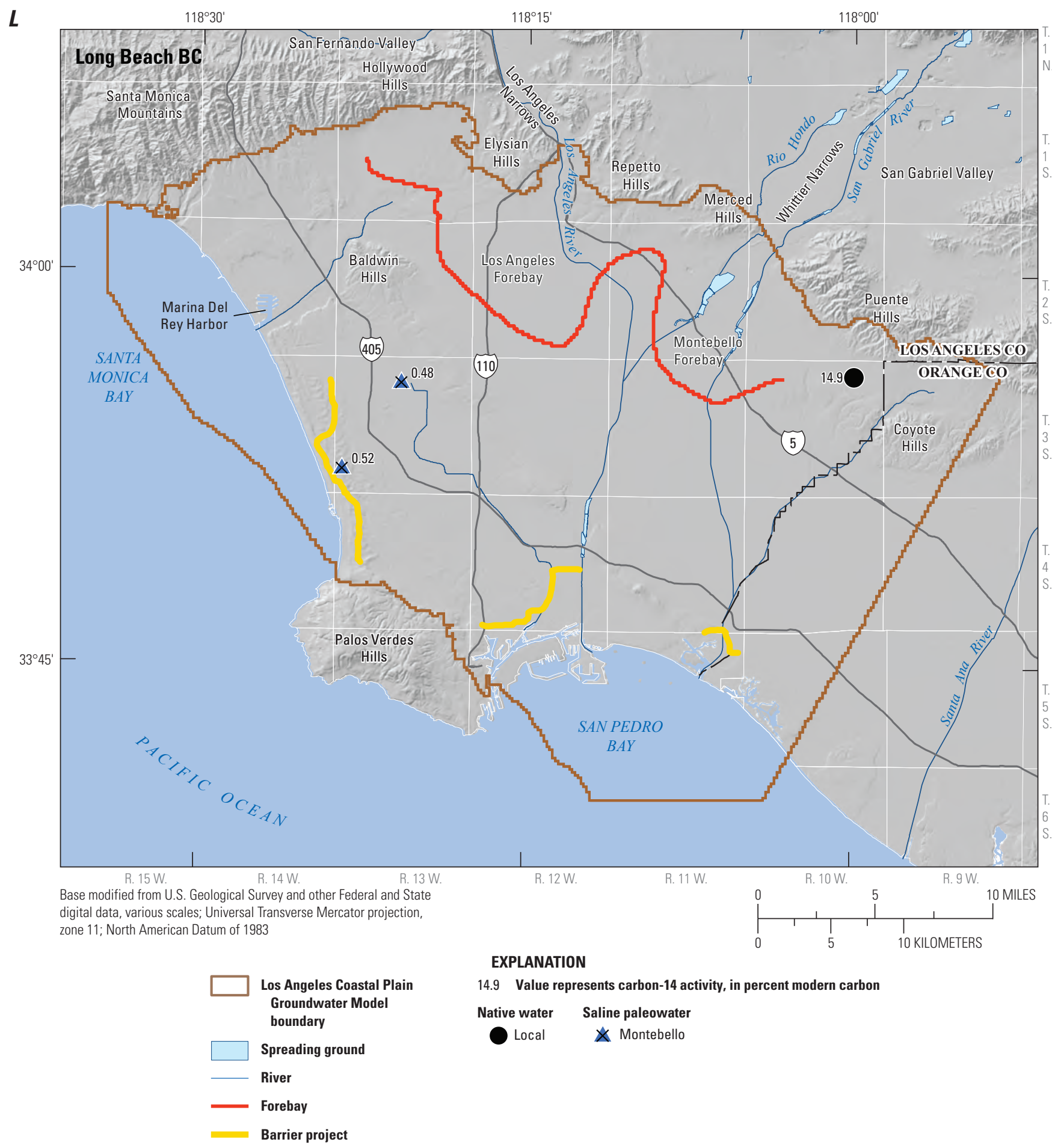

Figure 1.8.-Continued 


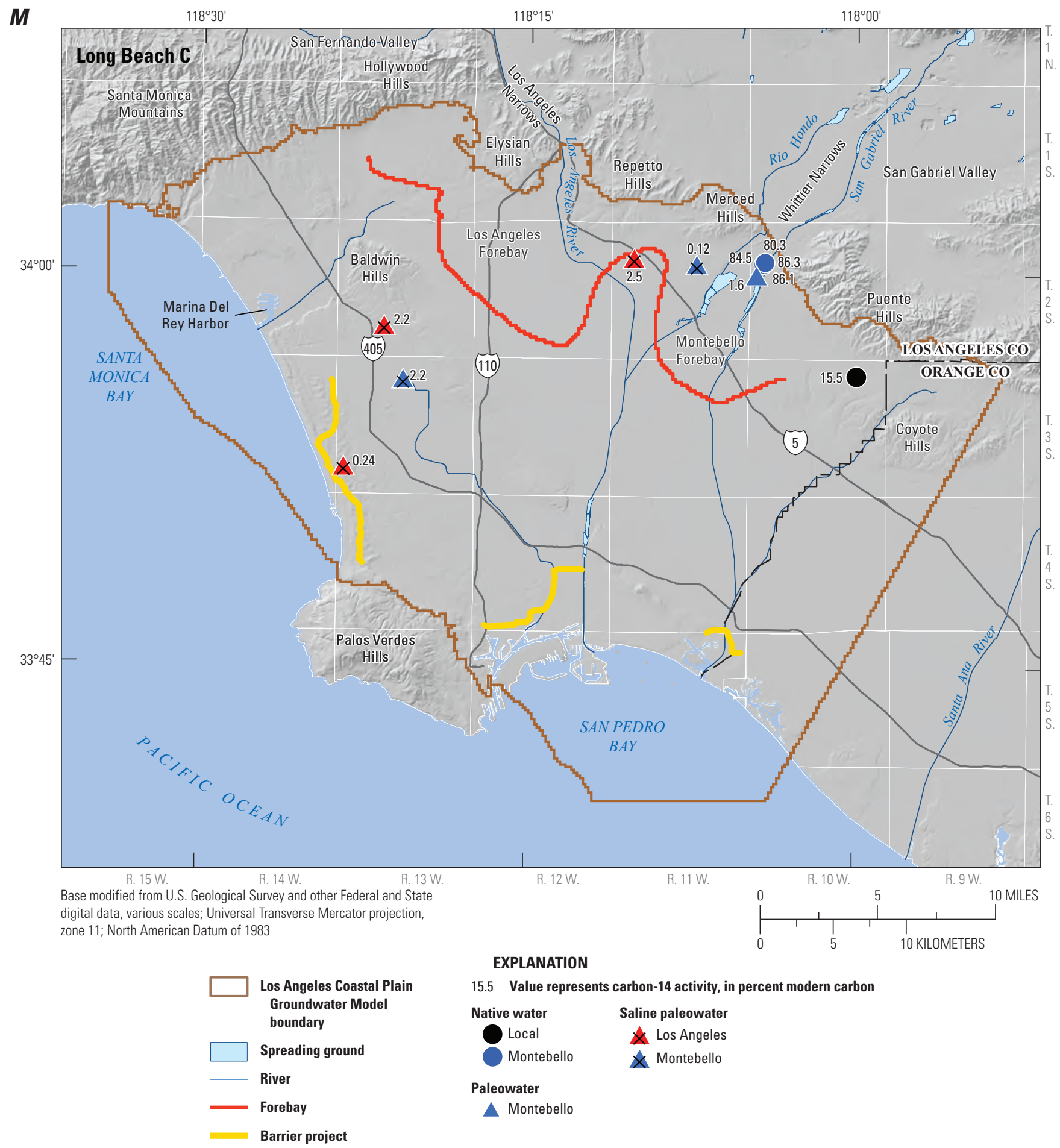

Figure 1.8.-Continued 
The lowest ${ }^{87} \mathrm{Sr} /{ }^{86} \mathrm{Sr}$ value was observed in a sample from a monitoring well in the northwestern part of the Central Basin, near the Los Angeles Forebay (2S/13W-31B5; Los Angeles4_3; fig. 1.1, table 1.2). The Los Angeles Forebay receives sediment from the Los Angeles River, which drains the San Fernando Valley, which is surrounded predominantly by marine sedimentary rocks (Jennings, 1977). Marine sedimentary rocks have ${ }^{87} \mathrm{Sr} /{ }^{86} \mathrm{Sr}$ ratios as low as 0.708 (Wierzbowski, 2013). Strontium-isotope ratios of samples from wells in the Los Angeles Forebay range from 0.7082 to 0.7085 ( $n=15$; figs. 1.6, 1.9, table 1.2). The samples in the Los Angeles Forebay were collected from wells screened solely in 8 of the 13 identified chronostratigraphic units in the LACP, and there is no substantial difference in isotopic values between units (table 1.2). For this study, ${ }^{87} \mathrm{Sr} /{ }^{86} \mathrm{Sr}$ ratios in the range of 0.7080 to 0.7088 indicated predominantly Los Angeles River sediment, unless affected by local sediment, as described below (fig. 1.9, table 1.2).

The San Gabriel River is another major source of sediment to the LACP (fig. 1.1). The headwaters of the San Gabriel River are in the San Gabriel Mountains (not shown), which are dominated by granitic rocks (Jennings, 1977). Sediments derived from the granitic rocks would be expected to have ${ }^{87} \mathrm{Sr} /{ }^{86} \mathrm{Sr}$ ratios greater than 0.7100 (Wierzbowski, 2013). The San Gabriel River enters the LACP through Whitter Narrows and then is a major source of sediment to the Montebello Forebay (fig. 1.1). Strontium-isotope ratios of samples from wells in the Montebello Forebay range from 0.7095 to $0.7103(\mathrm{n}=13$; table 1.2, figs. 1.6, 1.9). The samples in the Montebello Forebay were collected from wells screened in 5 of the 13 chronostratigraphic units identified for this study, with samples from older chronostratigraphic units having slightly lower ${ }^{87} \mathrm{Sr} /{ }^{86} \mathrm{Sr}$ ratios than samples from the younger units (table 1.2). However, even the lowest ${ }^{87} \mathrm{Sr} /{ }^{86} \mathrm{Sr}$ ratios sampled from wells in the Montebello Forebay are considerably higher than values sampled from wells in the Los Angeles Forebay (figs. 1.6, 1.9, table 1.2). The greater range of ${ }^{87} \mathrm{Sr} /{ }^{86} \mathrm{Sr}$ ratios in samples from the Montebello Forebay compared to the Los Angeles Forebay probably is the result of mixing of granitic sediments from the upper part of the San Gabriel watershed (Jennings, 1977) with sediments originating from the marine sedimentary rocks in the hills surrounding the lower San Gabriel Valley (fig. B2). For this study, ${ }^{87} \mathrm{Sr} /{ }^{86} \mathrm{Sr}$ ratios in the range of 0.7097 to 0.7104 indicated predominantly San Gabriel River sediment (fig. 1.9, table 1.2).

The lowest ${ }^{87} \mathrm{Sr} /{ }^{86} \mathrm{Sr}$ ratio measured in the Montebello Forebay (0.7095; well 2S/12W-10Q5; table 1.2) was not used to define the range of ${ }^{87} \mathrm{Sr} /{ }^{86} \mathrm{Sr}$ ratios in San Gabriel River sediment (fig. 1.9). The water from well 2S/12W-10Q5 was slightly saline and had a ${ }^{14} \mathrm{C}$ value indicating that it was paleowater (table 1.2). The slightly saline water sampled by this well probably is the result of old seawater that has not been completely flushed from the sediments. The ${ }^{87} \mathrm{Sr} /{ }^{86} \mathrm{Sr}$ ratio of Pleistocene age seawater is less than the ${ }^{87} \mathrm{Sr} /{ }^{86} \mathrm{Sr}$ ratio in present day seawater (0.7092; Wierzbowski, 2013). Consequently, recent exchange with old seawater would cause the ${ }^{87} \mathrm{Sr} /{ }^{86} \mathrm{Sr}$ ratio of native water in contact with San Gabriel River sediment to be lower than expected. Therefore, the ${ }^{87} \mathrm{Sr} /{ }^{86} \mathrm{Sr}$ ratio from well $10 \mathrm{Q} 5$ was not included in the San Gabriel River ${ }^{87} \mathrm{Sr} /{ }^{86} \mathrm{Sr}$ ratio range (0.7097 to 0.7104; fig. 1.9).

The highest ${ }^{87} \mathrm{Sr} /{ }^{86} \mathrm{Sr}$ ratio $(0.7116)$ was analyzed in a sample from a production well along the Santa Ana River in Orange County (4S/10W-14H3; Anaheim_46; fig. 1.1, table 1.2). The Santa Ana River has its headwaters in the San Bernardino Mountains (not shown), which are dominated by granitic rocks (Matti and others, 1992) and would be expected to have ${ }^{87} \mathrm{Sr} /{ }^{86} \mathrm{Sr}$ ratios greater than 0.7100 (Wierzbowski, 2013). Production well 3S/8W-34G2 (Canyon_RV_1

EAST) also is near the Santa Ana River, but the ${ }^{87} \overline{\mathrm{Sr}} /{ }^{86} \mathrm{Sr}$ ratio (0.7106) in the sample from this well was substantially lower than the ${ }^{87} \mathrm{Sr} /{ }^{86} \mathrm{Sr}$ ratio in the sample from well $4 \mathrm{~S} / 10 \mathrm{~W}-14 \mathrm{H} 3$ (0.7116; table 1.2). Well 3S/8W-34G2 is adjacent to the Santa Ana Mountains (fig. 1.1), where marine sedimentary rocks are exposed (Morton and Miller, 2006). The lower ${ }^{87} \mathrm{Sr} /{ }^{86} \mathrm{Sr}$ ratio in the sample from this well could be the result of mixing of sediment from the marine sedimentary rocks in the Santa Ana Mountains with granitic sediments from the San Bernardino Mountains. More strontium-isotope ratios along the Santa Ana River would better define the isotopic range of this source of sediment. For this study, 0.7114 indicated Santa Ana River sediments and ${ }^{87} \mathrm{Sr} /{ }^{86} \mathrm{Sr}$ ratios in the range of 0.7105 to 0.7114 indicated a mixture of San Gabriel River and Santa Ana River sediments (fig. 1.9, table 1.2). 


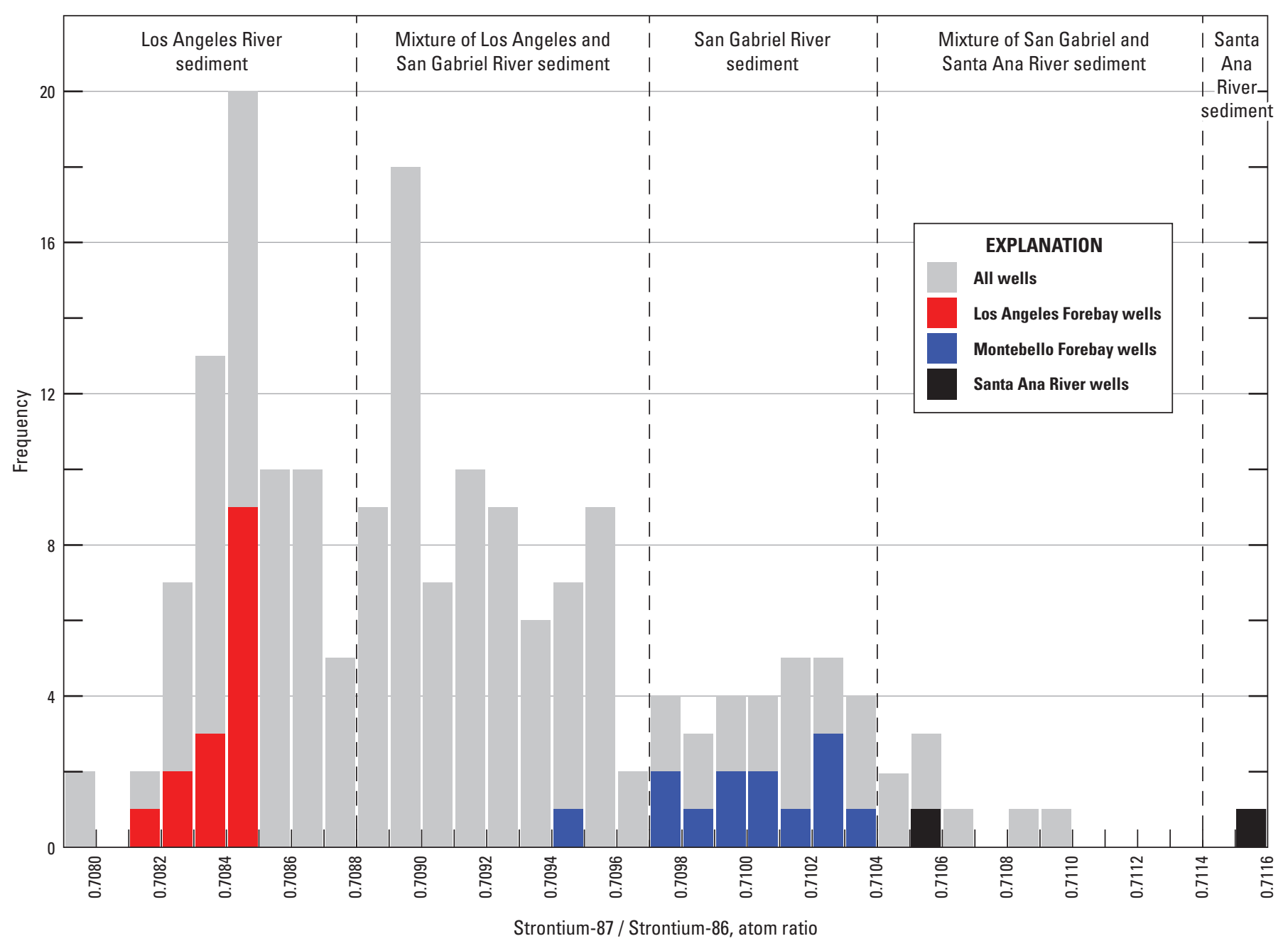

Figure 1.9. Strontium-isotope ratios in samples from monitoring wells and selected production wells in the Los Angeles Coastal Plain and surrounding area, Los Angeles and Orange Counties, California.

Another source of sediment to the LACP is erosion from the low-lying hills that border the LACP, referred to as local sediment in this report. These hills are predominantly marine sedimentary rocks (fig. B2); therefore, the ${ }^{87} \mathrm{Sr} /{ }^{86} \mathrm{Sr}$ ratios would be expected to be similar to those of Los Angeles River sediment. The ${ }^{87} \mathrm{Sr} /{ }^{86} \mathrm{Sr}$ ratios in samples from two wells adjacent to the Hollywood Hills (1S/14W-18L1, BH_2; and $1 \mathrm{~S} / 15 \mathrm{~W}-24 \mathrm{~B} 1, \mathrm{BH} 5$ ) were 0.7080 and 0.7081 and three wells adjacent to the Santa Monica Mountains (1S/15W-31E1, SM 1; 1S/15W-33A1, SM Arcadia_5; and 2S/15W-4C2, SM 3) ranged from 0.7087 to 0.7088 (fig. 1.6, table 1.2). The ${ }^{87} \mathrm{Sr} /{ }^{86} \mathrm{Sr}$ ratios of these samples are within the range of Los Angeles River sediment; however, these wells are not in the Los Angeles River drainage basin and likely do not encounter sediment from the Los Angeles River. Rather, these wells probably are encountering sediment from the Santa Monica
Mountains and Hollywood Hills. Likewise, the ${ }^{87} \mathrm{Sr} / 86 \mathrm{Sr}$ ratio in a sample from well 3S/11W-17F1 (17F1; Norwalk1_1), in the southeastern part of the Central Basin, was $0.70 \overline{8} 6$ (fig. 1.6, table 1.2). The ${ }^{87} \mathrm{Sr} / 86 \mathrm{Sr}$ ratio of this sample is within the range of Los Angeles River sediment; however, this well is not in the Los Angeles River drainage basin and likely does not encounter sediment from the Los Angeles River. Well 17F1 is near the Montebello Forebay (fig. 1.1); however, the ${ }^{87} \mathrm{Sr} /{ }^{86} \mathrm{Sr}$ ratio for well $17 \mathrm{~F} 1$ is noticeably different than ${ }^{87} \mathrm{Sr} /{ }^{86} \mathrm{Sr}$ ratios measured in samples from wells in the Montebello Forebay (fig. 1.6, table 1.2). This well probably encounters sediment from the Puente Hills. For this study, ${ }^{87} \mathrm{Sr} /{ }^{86} \mathrm{Sr}$ ratios in the range assigned to Los Angeles River sediment (0.7080 to 0.7088), but outside of the Los Angeles River drainage area, were considered to be predominantly local sediment (table 1.2). 
Some of the samples compiled for this study have isotopic values that do not fall into any of the groups identified for this study. These samples probably are a mixture of two or more sources of sediment. Strontium isotope ratios in the range of 0.7089 to 0.7096 were considered to be a mixture between Los Angeles River and San Gabriel River sediments (fig. 1.9, table 1.2). The ${ }^{87} \mathrm{Sr} /{ }^{86} \mathrm{Sr}$ ratios of samples from wells 3S/11W-17F3-5 (Norwalk1_3-5) fall within this range (table 1.2). However, these wells are near the Puente Hills and not within the Los Angeles River drainage area (fig. 1.1). Therefore, these wells probably encounter a mixture of San Gabriel River and local sediments (table 1.2).

Some of the samples analyzed for ${ }^{87} \mathrm{Sr} /{ }^{86} \mathrm{Sr}$ ratios were characterized as being affected by seawater $(*$ in Sediment facies column; table 1.2). The isotopic values of these samples could be affected by mixing with seawater. The ${ }^{87} \mathrm{Sr} /{ }^{86} \mathrm{Sr}$ ratio of modern seawater is 0.7092 (Wierzbowski, 2013); consequently, recent exchange with modern seawater would cause the ${ }^{87} \mathrm{Sr} /{ }^{86} \mathrm{Sr}$ ratio of native water in contact with Los Angeles River sediment to be higher than expected and the ${ }^{87} \mathrm{Sr} /{ }^{86} \mathrm{Sr}$ ratio of native water in contact with San Gabriel River sediment to be lower than expected.

\section{Sediment Facies}

Sediment facies were inferred for each chronostratigraphic unit by inspecting the grain size on available geologic logs, geophysical log signatures, microfossil data, and water-quality data ( $\mathrm{Cl} / \mathrm{B}$ ratios) compiled from multiple-well monitoring sites. The facies were generalized into non-marine sediments (alluvium and colluvium), shallow marine sediments (paralic and neritic deposits), and deep marine, or bathyal, sediments (slope and basin deposits; figs. B7-B19).

Chloride-to-boron ratios can be used to help differentiate non-marine from marine sediments because groundwater interacting with marine facies has lower $\mathrm{Cl} / \mathrm{B}$ ratios than groundwater interacting with non-marine sediments as a result of the enrichment of B by algae, as discussed in the "Dissolved Chloride and Boron" section of this appendix.

$\mathrm{The} \mathrm{Cl} / \mathrm{B}$ ratio for water in non-marine sediments will vary depending on the native source water, the type of sediment or rocks the water is flowing through, and anthropogenic sources of $\mathrm{Cl}$ and $\mathrm{B}$ (for example irrigation return flows, wastewater, artificial recharge, and seawater intrusion). Chloride concentrations in native water range from 10 to $65 \mathrm{mg} / \mathrm{L}$ in the LACP (Poland and others, 1959; Reichard and others, 2003, Land and others 2004). In this report, samples with $\mathrm{Cl}$ concentrations greater than $200 \mathrm{mg} / \mathrm{L}$ were assumed to be affected by mixing with anthropogenic sources of water or seawater and were not used to delineate the sediment facies. Granitic rocks in the San Gabriel Mountains are a major source of sediment to the LACP. As presented in the "Dissolved Chloride and Boron" section of this appendix, native groundwater in non-marine sediments derived primarily from granitic rocks will have $\mathrm{Cl} / \mathrm{B}$ ratios higher than local precipitation because $\mathrm{Cl}$ is more common than $\mathrm{B}$ in granitic rocks.

Long-term $\mathrm{Cl} / \mathrm{B}$ ratios in precipitation are not available for the LACP; however, annual means for $\mathrm{Cl}$ and $\mathrm{B}$ analyzed from the San Gabriel River from 1995 through 2005 indicate that the $\mathrm{Cl} / \mathrm{B}$ ratio of the San Gabriel River ranged from 185 to 517, with an average of 337 (Weston Solutions, Inc., 2005). Although the San Gabriel River drainage includes some marine rocks in lower altitude portions of the drainage, the river $\mathrm{Cl} / \mathrm{B}$ ratio is likely to be dominated by larger water fluxes from higher altitude granitic rock areas. For the purposes of this report, water samples with $\mathrm{Cl} / \mathrm{B}$ ratios greater than 300 indicated non-marine sediments if the samples are not affected by anthropogenic sources (fig. 1.10, table 1.2). For the purposes of this report, samples with $\mathrm{Cl} / \mathrm{B}$ ratios from 300 to 100 indicated shallow marine sediments, and ratios less than 100 indicated deep marine deposits (fig. 1.10, table 1.2). The threshold $\mathrm{Cl} / \mathrm{B}$ ratio used to distinguish shallow from deep marine sediments was determined by checking the ratio from wells that had microfossil or other collaborating data, indicating that the wells were sampling deep marine sediments. Because the categorization of $\mathrm{Cl} / \mathrm{B}$ ratios is somewhat subjective, these ratios were used as a secondary method of inferring sediment facies. Microfossils and interpretations from core samples were the primary datasets used to determine the final sediment facies (figs. B7-B19).

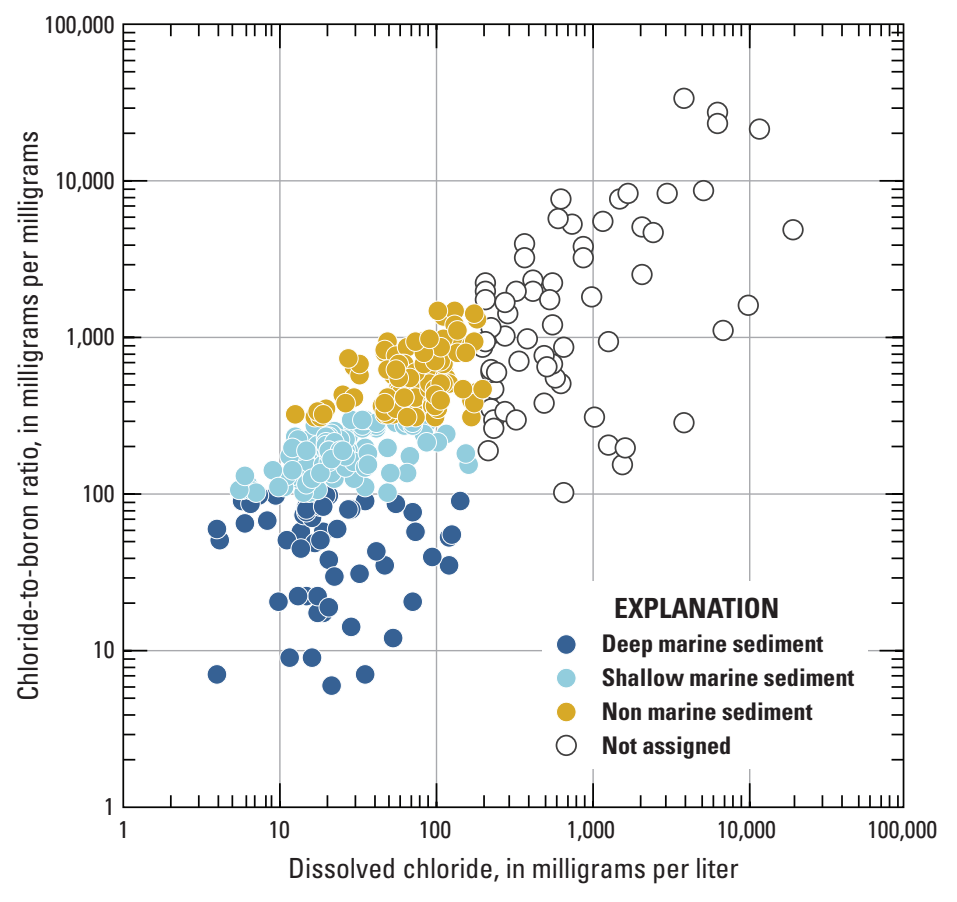

Figure 1.10. Chloride-to-boron ratio as a function of chloride in water from monitoring wells in the Los Angeles Coastal Plain, Los Angeles and Orange Counties, California. 


\section{Water Source}

Previous work by the USGS (Reichard and others, 2003, Land and others, 2004) indicated that the stable isotopes of water $\left(\mathrm{D}\right.$ and $\left.{ }^{18} \mathrm{O}\right)$ could be used to help determine the source of groundwater in the LACP. Seven main isotopic groups correspond with sources of water or activities/processes affecting groundwater: (1) native Los Angeles Forebay water, (2) native Montebello Forebay water, (3) water originating from local precipitation falling on the LACP and surrounding low lying hills, referred to as local water, (4) water that was recharged during the Pleistocene, referred to as paleowater, (5) water affected by managed aquifer recharge in spreading grounds, (6) water affected by seawater intrusion, and (7) water affected by managed aquifer recharge near injection wells. These isotopic groups were reviewed and refined for this study using the data compiled from multiple-well monitoring sites in the LACP (table 1.2).

\section{Los Angeles Forebay Water}

Previous studies by the USGS in the LACP found that native water in the Los Angeles Forebay plotted along or above the meteoric water line with a $\delta \mathrm{D}$ range of -44 to -50 per mil and $\delta^{18} \mathrm{O}$ range of -6.7 to -7.5 per mil (Reichard and others, 2003, Land and others, 2004). Infiltration of the Los Angeles River is the major source of recharge in the Los Angeles Forebay. Natural flow in the Los Angeles River originates as precipitation falling on the San Fernando Valley and surrounding mountains and hills (fig. 1.1). The elevation of the San Fernando Valley ranges from about $6,000 \mathrm{ft}$ in the San Gabriel Mountains to the northeast to about $650 \mathrm{ft}$ on the valley floor.

In this study, only stable-isotope data compiled from monitoring wells in the Los Angeles Forebay were used to define the isotopic range of native Los Angeles Forebay water (fig. 1.1). Stable-isotope data for this study were compiled from 25 wells in the Los Angeles Forebay, and had a $\delta \mathrm{D}$ ranged of -44.2 to -56.2 per mil and a $\delta^{18} \mathrm{O}$ range of -6.78 to -7.99 per mil (table 1.2 ), which is larger than $\delta \mathrm{D}$ ranges presented by previous investigators (Reichard and others, 2003; Land and others, 2004). Anthropogenic sources of runoff to the Los Angeles River that infiltrate the Los Angeles Forebay, including wastewater recharge and irrigation return flows, affect the isotopic signature of samples receiving modern recharge. Samples with tritium activity greater than or equal to $0.1 \mathrm{TU}$ were assumed to be affected by some anthropogenic sources of water. When samples believed to be affected with anthropogenic sources of water were removed, the remaining 13 samples had a $\delta \mathrm{D}$ range of -46.6 to -49.0 per mil and a $\delta^{18} \mathrm{O}$ range of -6.94 to -7.44 per mil (see 'older water', fig. 1.11A). Samples from wells in the LACP with isotopic ratios within or close to this range that plotted near the MWL probably originated as recharge by the Los Angeles River in the Los Angeles Forebay prior to anthropogenic runoff and are referred to as "Los Angeles Forebay water" for the purposes of this report (fig. 1.11A, table 1.2).

\section{Montebello Forebay Water}

Previous studies by the USGS in the LACP indicated that native groundwater in the Montebello Forebay was isotopically lighter than native Los Angeles Forebay water (Reichard and others, 2003, Land and others, 2004). These previous studies found that native water in the Montebello Forebay plotted along or above the meteoric water line with a $\delta$ D range of -54.0 to -66.0 per mil (and a $\delta^{18} \mathrm{O}$ range of -8.0 to -9.5 per mil). Infiltration of the San Gabriel River and Rio Hondo are the major sources of recharge in the Montebello Forebay. Natural flow in the San Gabriel River and Rio Hondo originates as precipitation falling on the San Gabriel Valley and the San Gabriel Mountains to the northeast (fig. 1.1). Elevation of the San Gabriel Valley and Mountains ranges from about 10,000 $\mathrm{ft}$ in the peaks of the San Gabriel Mountains to about $200 \mathrm{ft}$ at Whittier Narrows. Overall, the elevations of the mountains surrounding the San Gabriel Valley are considerably higher than the low mountains and hills surrounding the San Fernando Valley. 

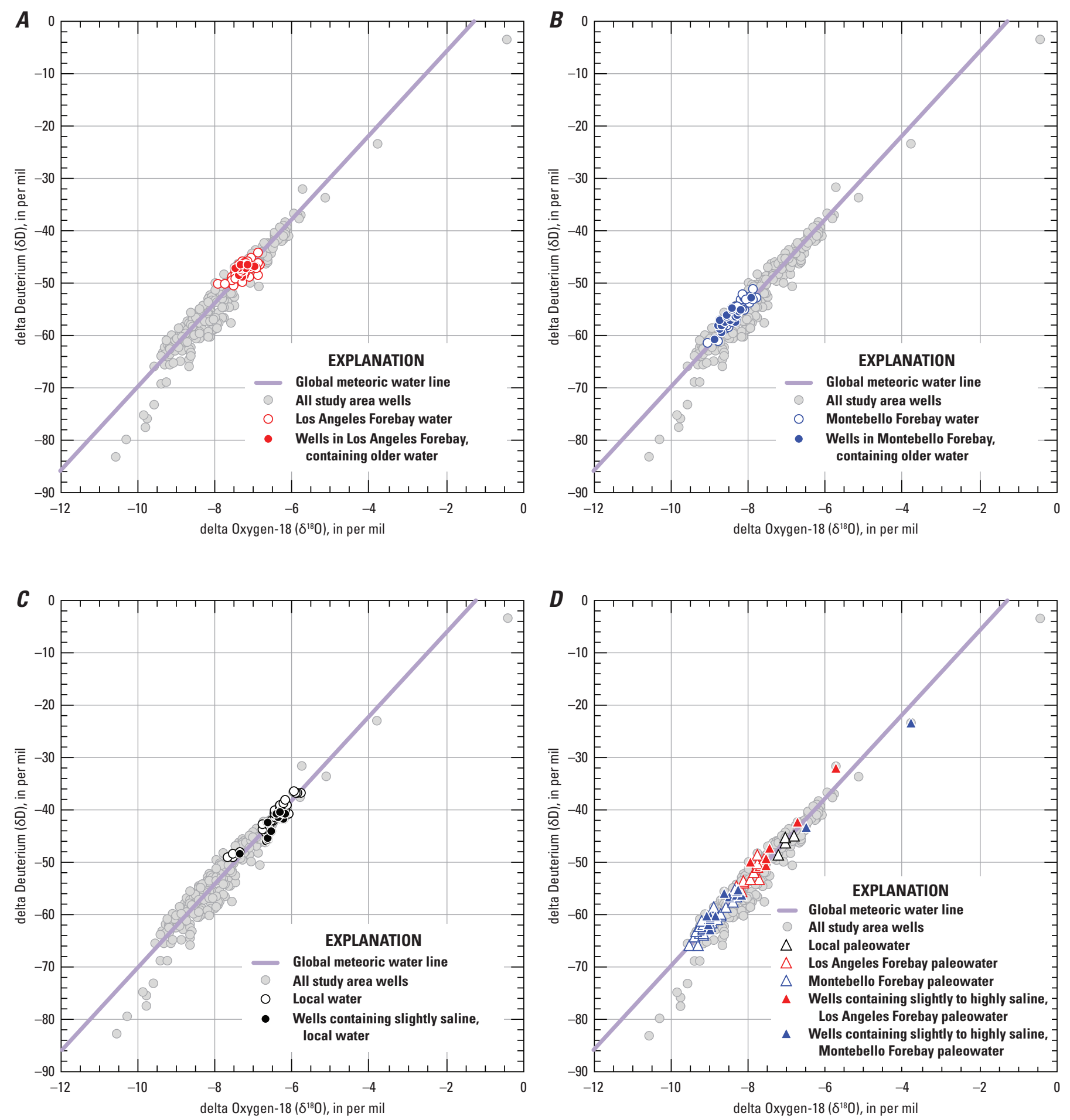

Figure 1.11. Relation between deuterium and oxygen-18 isotopic ratios for water samples from multiple-well monitoring sites in the Los Angeles Coastal Plain, Los Angeles and Orange Counties, California: $A$, Los Angeles Forebay water; $B$, Montebello Forebay water; $C$, local water; $D$, paleowater; $E$, water affected by managed aquifer recharge in spreading grounds or urban recharge; $F$, water affected by seawater intrusion; $G$, water affected by managed aquifer recharge near injection wells; and $H$, mixed water. 

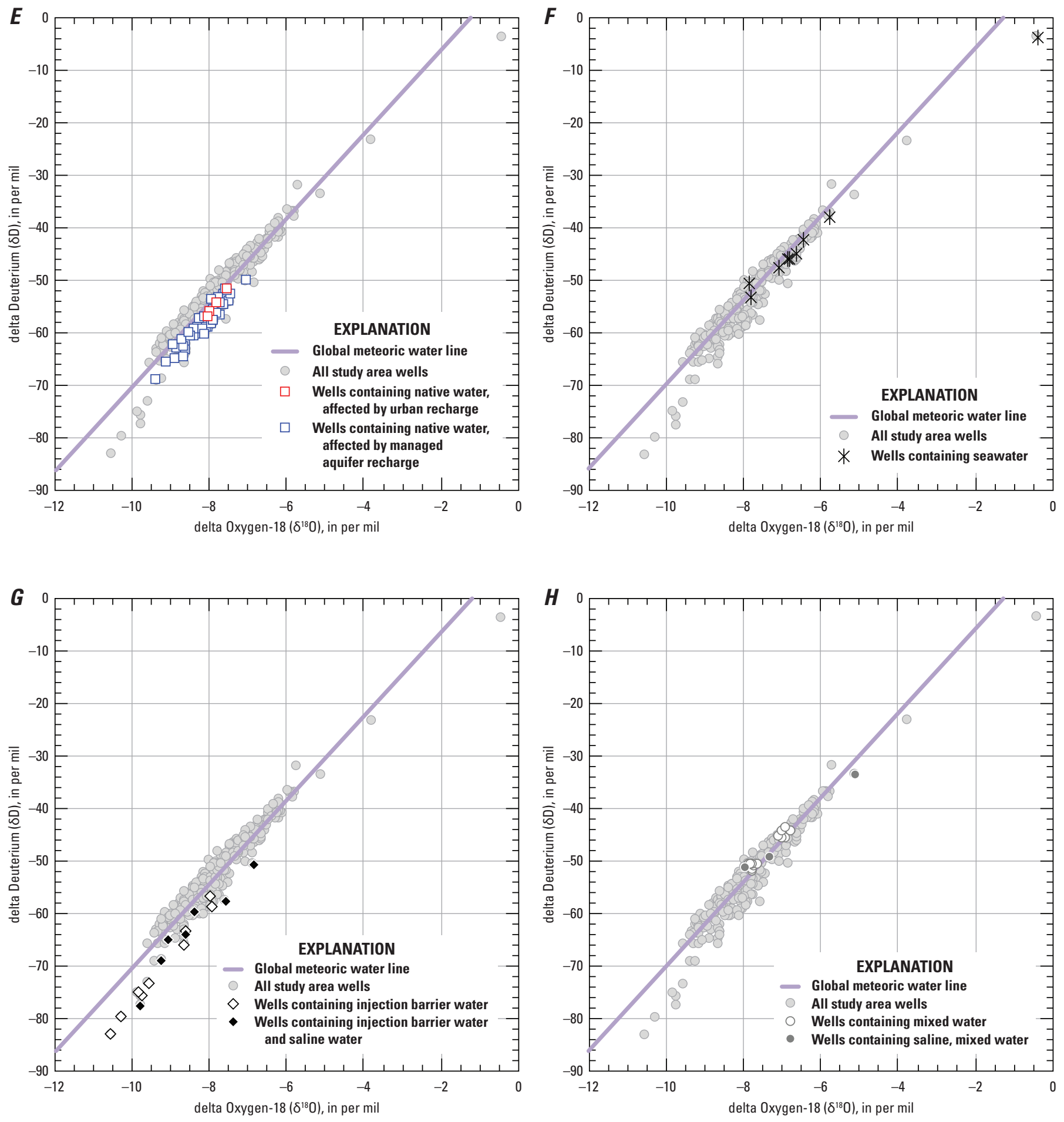

Figure 1.11.-Continued 
Stable-isotope data for this study were compiled from 58 monitoring wells located in the Montebello Forebay and had a $\delta \mathrm{D}$ range of -44.2 to -65.8 per mil (and a $\delta^{18} \mathrm{O}$ range of -6.55 to -9.56 per mil; table 1.2 ), which is larger than $\delta \mathrm{D}$ and $\delta^{18} \mathrm{O}$ ranges presented by previous investigators (Reichard and others, 2003, Land and others, 2004). Spreading of imported water (Colorado River or California State Water Project [SWP]) in the Montebello Forebay has occurred since the 1950s to supplement natural recharge. Colorado River and SWP water is isotopically lighter than native groundwater in the Montebello Forebay and plots below the MWL due to extensive evaporation (Reichard and others, 2003; Williams and Rodini, 1997; fig. 1.11). Samples affected by mixing with the imported water (managed aquifer recharge in spreading grounds or injection barriers) had isotopic compositions that plotted below the MWL (fig. 1.11). To more accurately estimate the isotopic range of native groundwater in the Montebello Forebay, 33 samples that plotted below the MWL, indicating that they were affected by mixing with imported water, were excluded (table 1.2). Of the remaining 25 samples, the isotopically heaviest (less negative) samples in the Montebello Forebay were from wells $2 \mathrm{~S} / 11 \mathrm{~W}-20 \mathrm{~N} 4$ (Whittier2 4; $\delta \mathrm{D}=-44.2$ ), 2S/11W-8L16 (Whittier Narrows2_9; $\delta \mathrm{D}=-46.0$ ), and 2S/11W-8L15 (Whittier Narrows2_8; $\delta \mathrm{D}=-46.3$; table 1.2). These wells are adjacent to the Puente Hills (fig. 1.1), and runoff from the Puente Hills probably is the source of recharge to these wells (see "Local Water" section). The isotopically lightest (more negative) samples in the Montebello Forebay, not affected by mixing with imported water, are from wells $2 \mathrm{~S} / 11 \mathrm{~W}-18 \mathrm{C} 4$ (Pico Rivera1_1; $\delta \mathrm{D}=-65.8$ ) and 2S/12W-10Q6 (Montebello1_2; $\delta \mathrm{D}=-63.3)$. These samples had ${ }^{14} \mathrm{C}$ activities of $1.6 \mathrm{pmc}$ or less (table 1.2), which corresponded to uncorrected ages (residence time) of more than 34,000 years before present. These lighter isotopic values were consistent with recharge during cooler conditions during the late Pleistocene (Clark and Fritz, 1997) and were classified as paleowaters (see "Paleowater" section).

After removing samples classified as local or paleowater, the remaining 20 samples in the Montebello Forebay had a $\delta \mathrm{D}$ range of -52.8 to -60.7 per mil and a $\delta^{18} \mathrm{O}$ range of -7.9 to -8.87 per mil (see "older water," fig. 1.11B). Samples from wells in the LACP with isotopic ratios within or close to this range that plotted near the MWL probably originated as recharge in the Montebello Forebay prior to the initiation of spreading of imported water and are referred to as "Montebello Forebay water" in this report (fig. 1.11B; table 1.2). The isotopic range of the Montebello Forebay water was lighter than Los Angeles Forebay water due to the higher elevation of the San Gabriel Mountains in the San Gabriel River watershed relative to the crest of the Los Angeles watershed. The isotopic range of the Montebello Forebay water was larger than the range of Los Angeles Forebay water because the Montebello Forebay receives natural recharge from the higher elevations of the San Gabriel Mountains and the lower hills that border the San Gabriel Valley.

\section{Local Water}

Isotopic data compiled for this study included multiple samples with $\delta \mathrm{D}$ and $\delta^{18} \mathrm{O}$ values heavier (less negative) than the range of Los Angeles Forebay water (table 1.2). Previous studies by the USGS in the LACP identified water with a $\delta \mathrm{D}$ range of -36 to -43 per mil and a $\delta^{18} \mathrm{O}$ range of -5.8 to -6.6 per mil as "local water" (Reichard and others, 2003; Land and others, 2004). Isotopically heavier water was attributed to local precipitation falling on the LACP and surrounding low lying hills, which are considerably lower in elevation than the hills and mountains that surround the San Fernando and San Gabriel Valleys. Samples within this range that plot on or near the MWL and are not affected by seawater intrusion are referred to as "local water" in this report (fig. 1.11C; table 1.2).

Samples from seven wells in or near the Whitter area [3S/11W-17F5 (17F5), 2S/11W-5P6 (5P6; Whittier Narrows1_1), 2S/11W-8L15-16 (8L15-16; Whittier Narrows2_8 and 9), 3S/11W-9D2, -9D4 (9D2, 9D4), and $3 \mathrm{~S} / 12 \mathrm{~W}-26 \mathrm{~K} 7$ (26K7); fig. 1.1] had $\delta \mathrm{D}$ values ranging from -46.0 to -49.4 per mil, which were isotopically lighter than the range previously reported for local water (table 1.2). The lighter samples were within the range of Los Angeles Forebay water; however, these wells are not in the Los Angeles River drainage basin and likely are not receiving water from the Los Angeles Forebay. These wells are near the Montebello Forebay; however, their isotopic ranges were substantially heavier than isotopic ranges measured in Montebello Forebay water (table 1.2). Therefore, these wells probably are receiving local runoff from the Puente Hills, and samples from these wells were classified as "local water," for the purposes of this report (fig. 1.11C; table 1.2). 


\section{Paleowater}

In this report, samples with ${ }^{14} \mathrm{C}$ activity of $10 \mathrm{pmc}$ or less were designated as paleowater (64 of the 249 samples with ${ }^{14} \mathrm{C}$ activity data compiled for this study; table 1.2). Samples with ${ }^{14} \mathrm{C}$ activities of 10 pmc or less correspond to uncorrected groundwater ages (residence times) of more than 18,000 years before present (table 1.2). These uncorrected ${ }^{14} \mathrm{C}$ ages indicated recharge occurred near the end of the last North American glaciation, when it likely was colder, wetter, or both in the surrounding mountains (Clark and Fritz, 1997). However, a recent (2017) study of beetle remains in the $\mathrm{La}$ Brea Tar Pits indicated that the climate in the Los Angeles Basin has been relatively stable over the past 50,000 years and was warmer and drier than inferred in previous studies (Holden and others, 2017). Consequently, paleowater that originated in the San Gabriel Mountains should be isotopically lighter than modern native Montebello Forebay water, but paleowater that originated in the Los Angeles Basins and surrounding low lying hills should be isotopically similar to native Los Angeles Forebay water. For this study, samples of paleowater with $\delta \mathrm{D}$ values lighter (more negative) than -55 per mil were considered to be "Montebello Forebay paleowater," values between -49 to -55 per mil were considered to be "Los Angeles Forebay paleowater," and values greater (less negative) than -49 per mil were generally considered to be "local paleowater" (fig. 1.11D; table 1.2).

\section{Water Affected by Managed Aquifer Recharge in Spreading Grounds}

Isotopic data compiled for this study showed that samples from many wells in the Montebello Forebay plotted below the MWL (fig. 1.11), indicating that the samples had been affected by evaporation. As stated previously, imported Colorado River and (later) SWP water has been spread in the Montebello Forebay since the 1950s to supplement local recharge, and isotopic values from these sources plotted below the MWL due to extensive evaporation (Reichard and others, 2003). Samples from wells in or near the Montebello Forebay with isotopic values that plotted below the MWL line and had $\delta \mathrm{D}$ values of less than -50 per mil probably were affected by the spreading of imported Colorado River or SWP water and are referred to as "water affected by managed aquifer recharge in spreading grounds" (or "spreading" [in table 1.2]) in this report (fig. 1.11E, table 1.2). Samples from two wells (2S/14W-12E5, -12E6 (12E5-6); fig. 1.1) had $\delta D$ values $(-51.9$ to -56.2 ; table 1.2$)$ that also plotted within this range; however, these wells are not located near the Montebello Forebay and likely are not receiving imported water from spreading grounds. These wells are probably receiving some imported water from applied irrigation or leaking underground pipes (Hevesi and Johnson, 2016). Samples from these wells are distinguished as "urban recharge" in fig. $1.11 E$ for the purposes of this report.

\section{Water Affected by Seawater Intrusion}

Comprehensive monitoring in the West Coast Basin indicated that seawater intrusion was affecting the water quality of the West Coast Basin in the early 1930s (Piper and Garrett, 1953). Seawater intrusion has affected samples from 19 of the wells compiled for this report, as evidenced by higher than background $\mathrm{Cl}$ concentrations (greater than $500 \mathrm{mg} / \mathrm{L}$ ) and high $\mathrm{Cl} / \mathrm{B}$ ratios (greater than 1,000; fig. 1.10, table 1.2). The occurrence of older seawater also affected samples from seven wells with moderate to high salinity identified as paleowater (fig. 1.11D, table 1.2). The $\delta \mathrm{D}$ and $\delta^{18} \mathrm{O}$ of seawater are both equal to 0.0 per mil and would plot below the MWL (fig. 1.11).

The isotopic composition of samples affected by seawater intrusion will plot along a mixing line between seawater and native water. If a simple two-member mixing is assumed, the chloride concentration of a sample can be used to estimate the isotopic composition of the sample prior to seawater intrusion because the isotopic composition and chloride concentration of seawater are known. In this study, $\mathrm{Cl}$ concentrations were used to estimate the $\delta \mathrm{D}$ of the native water prior to mixing with seawater to infer the source of the native water (table 1.2). Samples inferred to be affected by seawater intrusion are referred to as "water affected by seawater intrusion (seawater)" for the purposes of this report (fig. 1.11F, table 1.2). 


\section{Water Affected by Managed Aquifer Recharge near Injection Wells}

Injection of water along the West Coast Basin and Dominguez Gap Barrier Project is an important source of recharge to the West Coast Basin (Reichard and others, 2003). Samples affected by the injection of imported water ${ }^{2}$ are isotopically light, plot below and nearly parallel to the meteoric water line, and trend toward the isotopic composition of imported water (fig. 1.11G). The isotopic signature of imported water that has been spread in the Montebello Forebay or injected in the West Coast Basin are the same; therefore, the differentiation between the two sources was determined by location of the isotopic sample in the LACP. As of 2018, imported water spread at the Montebello Forebay had not yet reached the interior of the West Coast Basin; therefore, samples with isotopic signatures similar to imported water in the West Coast Basin were assumed to be the result of injection of imported water along the seawater barrier projects. Many of the samples affected by water from the injection barriers were also affected by seawater intrusion, which resulted in the samples being isotopically heavier than a simple mixture of native and imported water. Samples that were inferred to be affected by water from the seawater barrier projects are referred to as "managed aquifer recharge near injection wells" (or "injection" [in table 1.2]) for the purposes of this report (fig. 1.11G; table 1.2).

\section{Mixed Water}

Some of the samples compiled for this study have chemical compositions and isotopic values that do not classify predominantly into any of the other groups identified for this study. These samples probably are a mixture of two or more sources of water and are referred to as "mixed water" for the purposes of this report (fig. 1.11H; table 1.2).

\section{Model Zones}

Model parameters (horizontal and vertical hydraulic conductivity, specific storage, and specific yield) were initially estimated by dividing each layer into zones and estimating each zone's value based on an analysis of well log data, regional depositional patterns, and local variations of groundwater basin sediments reported in previous investigations (see "Calibration Results" section in Chapter D). Water-quality data collected from multiple-well monitoring sites (table 1.2) were used to help refine the

\footnotetext{
${ }^{2}$ Since 1994 and 2005, increasing proportions of tertiary-treated recycled water are utilized for injection into the West Coast Basin Barrier Project and Dominguez Gap Barrier Project, respectively, with the goal of providing the barriers with 100 percent recycled water (Water Replenishment District of Southern California, 2013). Detailed isotopic characterization of this water is beyond the scope of this study
}

model zones during model calibration. Major changes in water quality in samples from monitoring wells in the same model zone of a particular chronostratigraphic unit indicate that model zone is receiving water from multiple sources or includes sediment from different sources. Model zones were refined such that monitoring wells in the same chronostratigraphic unit and model zone had similar water quality. In general, each model zone had similar major-ion composition and dissolved-solids concentrations, the same sediment source (similar ${ }^{87} \mathrm{Sr} /{ }^{86} \mathrm{Sr}$ ratios), the same sediment facies (similar $\mathrm{Cl} / \mathrm{B}$ ratios), similar water age as indicated by tritium and ${ }^{14} \mathrm{C}$ activities, and the same water source (similar $\delta \mathrm{D}$ and $\delta^{18} \mathrm{O}$ isotopic ratios). Model zone maps with final calibrated values are shown and discussed in the "Model Calibration" section of this report (figs. D7, D8).

\section{References Cited}

Aldrich, L.T., Wetherill, G.W., Tilton, G.R., and Davis, G.L., 1956, The half-life of ${ }^{87} \mathrm{Rb}$ : Physical Review, v. 103, no. 4, p. 1045-1047, https://doi.org/10.1103/PhysRev.103.1045.

Bassett, R.L., Buszka, P.M., Davidson, G.R., and Chong-Diaz, D., 1995, Identification of groundwater solute sources using boron isotopic composition: Environmental Science \& Technology, v. 29, no. 12, p. 2915-2922, https://doi.org/10.1021/es00012a005.

Brinkmann, R., Münnich, K.O., and Vogel, J.C., 1959, ${ }^{14} \mathrm{C}$ Altersbestimmung von grundwasser: Naturwissenschaften, v. 46, p. 10-12, https://doi.org/10.1007/BF00621357.

Carrano, C.J., Schellenberg, S., Amin, S.A., Green, D.H., and Kupper, F.C., 2009, Boron and marine life-A new look at an enigmatic bioelement: Marine Biotechnology, v. 11, no. 4, p. 431-440, https://doi.org/10.1007/s10126-009-9191-4.

Clark, I.D., and Fritz, P., 1997, Environmental isotopes in hydrology: New York, Lewis Publishers, 328 p.

Clark, I.D., and Fritz, P., 1999, Environmental isotopes in hydrogeology - Tracing the carbon cycle ( $2 \mathrm{~d}$ ed.): Boca Raton, Fla., CRC Press, p. 111-136.

Coplen, T.B., 1994, Reporting of stable hydrogen, carbon, and oxygen isotopic abundances: Pure and Applied Chemistry, v. 66, no. 2, p. 273-276, https://doi.org/10.1351/pac199466020273.

Craig, H., 1961a, Isotopic variation in meteoric waters: Science, v. 133, no. 3465, p. 1702-1703, https://doi.org/10.1126/science.133.3465.1702. 
Craig, H., 1961b, Standard for reporting concentrations of deuterium and oxygen-18 in natural waters: Science, v. 133, no. 3467, p. 1833-1834, https://doi.org/10.1126/science.133.3467.1833.

Dansgaard, W., 1964, Stable isotopes in precipitation: Tellus, v. 16 , no. 4, p. 436-468, https://doi.org/10.3402/tellusa.v16i4.8993.

Degens, E.T., 1969, Biogeochemistry of stable carbon isotopes, chap. 12 of Eglinton, G., and Murphy, M.T.J., eds., Organic geochemistry-Methods and results: New York., Springer-Verlag, p. 304-329, https://doi.org/10.1007/978-3-642-87734-6_14.

Dotsika, E., Poutoukis, D., Michelot, J.L., and Kloppmann, W., 2006, Stable isotope and chloride, boron study for tracing sources of boron contamination in groundwater-Boron contents in fresh and thermal water in different areas in Greece: Water, Air, and Soil Pollution, v. 174, no. 1-4, p. 19-32, https://doi.org/10.1007/s11270-005-9015-8.

Friedman, I., and O'Neil, J.R., 1977, Compilation of stable isotope fractionation factors of geochemical interest, chap. KK of Fleischer, M., ed., Data of geochemistry (6th ed.): U.S. Geological Survey Professional Paper 440-KK, 12 p., https://doi.org/10.3133/pp440KK.

Godwin, H., 1962, Half-life of radiocarbon: Nature, v. 195, no. 4845, p. 984, https://doi.org/10.1038/195984a0.

Gonfiantini, R., 1978, Standards for stable isotope measurements in natural compounds: Nature, v. 271, no. 5645, p. 534-536, https://doi.org/10.1038/271534a0.

Harms, P.A., Visser, A., Moran, J.E., and Esser, B.K., 2016, Distribution of tritium in precipitation and surface water in California: Journal of Hydrology, v. 534, p. 63-72, https://doi.org/10.1016/j.jhydrol.2015.12.046.

Hem, J.D., 1985, Study and interpretation of the chemical characteristics of natural water ( $3 \mathrm{~d}$ ed.): U.S. Geological Survey Water-Supply Paper 2254, 263 p., https://doi.org/10.3133/wsp2254.

Hevesi, J.A., and Johnson, T.D., 2016, Estimating spatially and temporally varying recharge and runoff from precipitation and urban irrigation in the Los Angeles Basin, California: U.S. Geological Survey Scientific Investigations Report 2016-5068, 192 p., https://doi.org/10.3133/sir20165068.

Holden, A.R., Southon, J.R., Will, K., Kirby, M.E., Aalbu, R.L., and Markey, M.J., 2017, A 50,000 year insect record from Rancho La Brea, Southern CaliforniaInsights into past climate and fossil deposition: Quaternary Science Reviews, v. 168, p. 123-136, https://doi.org/10.1016/j.quascirev.2017.05.001.
Ingraham, N.L., and Taylor, B.E., 1991, Light stable isotope systematics of large-scale hydrologic regimes in California and Nevada: Water Resources Research, v. 27, no. 1, p. 77-90, https://doi.org/10.1029/90WR01708.

Izbicki, J.A., 1996, Seawater intrusion in a California coastal aquifer: U.S. Geological Survey Fact Sheet 125-96, 4 p., https://doi.org/10.3133/fs12596.

Jennings, C.W., 1977, Geologic map of California: California Division of Mines and Geology Geologic Data Map no. 2, scale 1:750,000.

Land, M., Everett, R.R., and Crawford, S.M., 2002, Geologic, hydrologic, and water-quality data from multiple-well monitoring sites in the Central and West Coast Basins, Los Angeles County, California, 1995-2000: U.S. Geological Survey Open-File Report 2001-277, 178 p., https://doi.org/10.3133/ofr01277.

Land, M., Reichard, E.G., Crawford, S.M., Everett, R.R., Newhouse, M.W., and Williams, C.F., 2004, Ground-water quality of coastal aquifer systems in the West Coast Basin, Los Angeles County, California, 1999-2002: U.S. Geological Survey Scientific Investigations Report 2004-5067, 80 p., https://doi.org/10.3133/sir20045067.

Lucas, L.L., and Unterweger, M.P., 2000, Comprehensive review and critical evaluation of the half-life of tritium: Journal of Research of the National Institute of Standards and Technology, v. 105 , no. 4, p. 541-549, https://doi.org/10.6028/jres.105.043.

Manley, S.L., 1983, Composition of sieve tube sap from Macrocystis pyrifera (phaeophyta) with emphasis on the inorganic constituents: Journal of Phycology, v. 19, no. 1, p. 118-121, https://doi.org/10.1111/j.0022-3646.1983.00118.x.

Martin, P., 1984, Ground-water monitoring at Santa Barbara, California-Phase 2, effects of pumping on water levels and on water quality in the Santa Barbara ground-water basin: U.S. Geological Survey Water Supply Paper 2197, 31 p., https://doi.org/10.3133/wsp2197.

Mathany, T.M., Land, M., and Belitz, K., 2008, Ground-water quality data in the coastal Los Angeles Basin Study Unit, 2006-Results from the California GAMA Program: U.S. Geological Survey Data Series 387, 98 p., https://pubs.usgs.gov/ds/387/.

Matti, J.C., Morton, D.M., and Cox, B.F., 1992, The San Andreas fault system in the vicinity of the central Transverse Ranges province, southern California: U.S. Geological Survey Open-File Report 92-354, 40 p., https://doi.org/10.3133/ofr92354. 
Mazor, E., 1991, Applied chemical and isotopic groundwater hydrology: Buckingham, England, Open University Press, $274 \mathrm{p}$.

Miller, E.P., Wu, Y., and Carrano, C.J., 2016, Boron uptake, localization, and speciation in marine brown algae: Metallomics, v. 8, no. 2, p. 161-169, https://doi.org/10.1039/C5MT00238A.

Morton, D.M., and Miller, F.K., 2006, Geologic map of the San Bernardino and Santa Ana 30' x 60' quadrangles, California, with digital data preparation by Cossette, P.M., and Bovard, K.R.: U.S. Geological Survey Open-File Report 2006-1217, scale 1:100,000, https://doi.org/10.3133/ofr20061217.

Piper, A.M., 1944, A graphic procedure in the geochemical interpretation of water analyses: American Geophysical Union Transactions, v. 25, no. 6, p. 914-928, https://doi.org/10.1029/TR025i006p00914.

Piper, A.M., and Garrett, A.A., 1953, Native and contaminated ground waters in the Long Beach-Santa Ana area, California: U.S. Geological Survey Water Supply Paper 1136, 320 p., https://doi.org/10.3133/wsp1136.

Poland, J.F., Garrett, A.A., and Sinnot, A., 1959, Geology, hydrology, and chemical character of ground waters in the Torrance-Santa Monica area, California: U.S. Geological Survey Water Supply Paper 1461, 425 p., https://doi.org/10.3133/wsp1461.

Reichard, E.G., Land, M., Crawford, S.M., Johnson, T., Everett, R.R., Kulshan, T.V., Ponti, D.J., Halford, K.J., Johnson, T.A., Paybins, K.S., and Nishikawa, T., 2003, Geohydrology, geochemistry, and ground-water simulation-optimization of the Central and West Coast Basins, Los Angeles County, California: U.S. Geological Survey Water Resources Investigations Report 03-4065, 184 p., https://doi.org/10.3133/wri034065.

Rose, E.F., Carignan, J., and Chaussidon, M., 2000, Transfer of atmospheric boron from the oceans to the continentsAn investigation using precipitation waters and epiphytic lichens: Geochemistry, Geophysics, Geosystems, v. 1, no. 11, 15 p., https://doi.org/10.1029/2000GC000077.

Rose, T.P., Davisson, M., and Criss, R.E., 1996, Isotope hydrology of voluminous cold springs in fractured rock from an active volcanic region, northeastern California: Journal of Hydrology, v. 179, no. 1-4, p. 207-236, https://doi.org/10.1016/0022-1694(95)02832-3.
Taylor, C.B., and Roether, W., 1982, A uniform scale for reporting low-level tritium in water: Vienna, International Journal of Applied Radiation and Isotopes, v. 33, no. 5, p. 377-382, https://doi.org/10.1016/0020-708X(82)90152-1.

Turekian, K.K., and Wedepohl, K.H., 1961, Distribution of the elements in some major units of the Earth's crust: Geological Society of America Bulletin, v. 72, no. 2, p. 175-192, https://doi.org/10.1130/0016-7606(1961)7 2[175:DOTEIS]2.0.CO;2.

Vogel, J.C., and Ehhalt, D.H., 1963, The use of carbon isotopes in groundwater studies, in Radioisotopes in hydrology-Proceedings of a symposium, Tokyo, March 1963: Vienna, International Atomic Energy Agency, p. 383-395.

U.S. Geological Survey, 2016, National Water Information System data available on the World Wide Web (USGS Water Data for the Nation), accessed 2016 at https://doi.org/10.5066/F7P55KJN.

Water Replenishment District of Southern California, 2013, Moving towards 100\% recycled water at the seawater intrusion barrier wells, Central Basin and West Coast: Technical Bulletin \#25, 2 p., available at https://www.wrd.org/content/technical-bulletins (https://www.wrd.org/sites/pr/files/TB25\%20-\%20 Moving\%20Towards\%20100\%25\%20Recycled\%20W ater $\% 20$ at $\% 20$ the $\% 20$ Seawater $\% 20$ Intrusion $\% 20$ Barrier $\% 2$ 0Wells\%20-\%20WRD\%20Service\%20Area.pdf).

Water Replenishment District of Southern California, 2017, Well search: Water Replenishment District of Southern California website, accessed 2017, at https://gis-apps.wrd.org/Html5Viewer/Index.html?viewer= Well_Search.Well_Search.

Weston Solutions, Inc., 2005, Final report, Los Angeles River watershed management area plan, Chapter 4: San Gabriel River watershed management area: Carlsbad, Calif., Los Angeles Regional WQCB, 36 p., https://www.waterboards.ca.gov/water_issues/programs/ tmdl/records/region_4/2009/ref3247.pdf.

Wierzbowski, H., 2013, Strontium isotope composition of sedimentary rocks and its application to chemostratigraphy and palaeoenvironmental reconstructions: Annales Universitatis Mariae Curie-Sklodowska, Sectio AAA, Physica, v. 68, no. 1, p. 23-37, https://journals.umcs.pl/aaa/article/download/805/648.

Williams, A.E., and Rodini, D.P., 1997, Regional isotopic effects and application to hydrologic investigations in southwestern California: Water Resources Research, v. 33, no. 7, p. 1721-1729. 


\title{
Appendix 2. Utilization of Downhole Geophysical Logs to Determine Sediment Grain Size
}

\author{
By Rhett Everett, Nicole Fenton, Whitney Seymour, and Scott Paulinski
}

The grain sizes of the sediments encountered at each of the multiple-well monitoring sites constructed by the USGS were estimated for this study by analysis of nuclear magnetic resonance (NMR), array induction 2 -foot resistivity (AIT), long-normal resistivity, short-normal resistivity, and gamma $\log$ data collected during the drilling of the sites. The sites were constructed using the direct mud-rotary technique; therefore, the drill cuttings often were a mixture of different depths, making the task of determining the thickness and grain size of the sediment layers difficult from visual observations alone. Analysis of the downhole geophysical logs was used to delineate the thickness of sediment layers and infer the grain sizes of the sediments (fig. 2.1).

Natural gamma logs were collected at all (57) of the USGS multiple-well monitoring sites. Natural gamma logs measure the intensities of gamma-ray emissions resulting from the natural decay of potassium- 40 and the daughter products of uranium and thorium (Schlumberger Limited, 1972). Gamma logs are used primarily to define lithology indicators and for geologic correlation. Clay, feldspar-rich gravel, and granite generally emit high-intensity gamma rays.

Digital NMR logs were collected at 24 sites. NMR logs can be used to make assessments of porosity, water content, mobile and immobile water fractions, and estimates of permeability (Coates and others, 1999). Low NMR values were interpreted as fine-grained sediments (silt and clay), intermediate NMR values were interpreted as medium-grained sediments (fine to medium sand), and high NMR values were interpreted as coarse-grained sediments (coarse sand and gravel). The thresholds between low, intermediate, and high NMR values were determined for each log based on an analysis of the NMR log values with respect to the geology, resistivity, and gamma logs. Thresholds were determined for the NMR and AIT logs to maximize the correlation between these logs so that high resistivity values and reported coarse-grained lithologies on the geologic log (coarse sand and gravel) corresponded to coarse-grained NMR log interpretations, while low resistivity values and reported fine-grained lithologies (silt and clay) corresponded to fine-grained NMR log interpretations.

Digital AIT resistivity logs were collected at 24 multiple-well monitoring sites. AIT logs measure formation conductivity as a function of borehole depth and distance from the borehole that can be converted to resistivity. The
AIT logs were analyzed in conjunction with gamma logs collected at each site to estimate the bulk grain size. In general, low-resistivity values were interpreted as fine-grained sediment, intermediate-resistivity values were interpreted as medium-grained sediment, and high-resistivity values were interpreted as coarse-grained sediment. Gamma values were interpreted in a similar fashion, with low-gamma values interpreted as coarse-grained sediment and high-gamma values interpreted as fine-grained sediment. The thresholds between the low-, intermediate-, and high-resistivity and gamma values were determined separately for each layer in each borehole to reduce the error associated with changes in water quality (Keys and MacCary, 1983).

Digital short-normal and long-normal resistivity logs were collected at 30 multiple-well monitoring sites. The depth of penetration of a resistivity logging tool is related to the distance between the current electrode and the potential electrode on the resistivity sonde (Keys and MacCary, 1983). The short-normal or 16-inch resistivity curve may be influenced by invasion of the drilling fluid into the formation (Keys and MacCary, 1983). The long-normal or 64-inch resistivity curve shows the resistivity of the same area as the short-normal (16-inch resistivity) curve but farther away from the borehole and beyond the invaded zone. In permeable soil or rock, porosity affects the depth of invasion, and the dissolved ion content of water in the pores determines the resistivity of the material. For this analysis, if the resistivity of the short-normal log was greater than the long-normal log in an interval, the interval's dissolved ion content was assumed to not be from the local sediment. Where available, total dissolved solids (TDS) measurements were used to verify poor water quality, defined as greater than $900 \mathrm{mg} / \mathrm{L}$. Poor-quality water reduces resistivity, which, if unrecognized, can lead to the potentially incorrect interpretation that low-resistivity values indicated fine-grained sediments. Spontaneous-potential logs also can be used to determine changes in water quality; however, natural variations in water type and quality compounded by the movement of water resulting from widespread pumping and induced recharge in the Los Angeles Basin do not allow for a straightforward interpretation of spontaneous-potential logs. For the intervals with poor water quality, the next best available log for interpreting grain size is the gamma log. Therefore, for zones with poor water quality, the gamma ray log was used to estimate grain size. 
$\boldsymbol{A}$
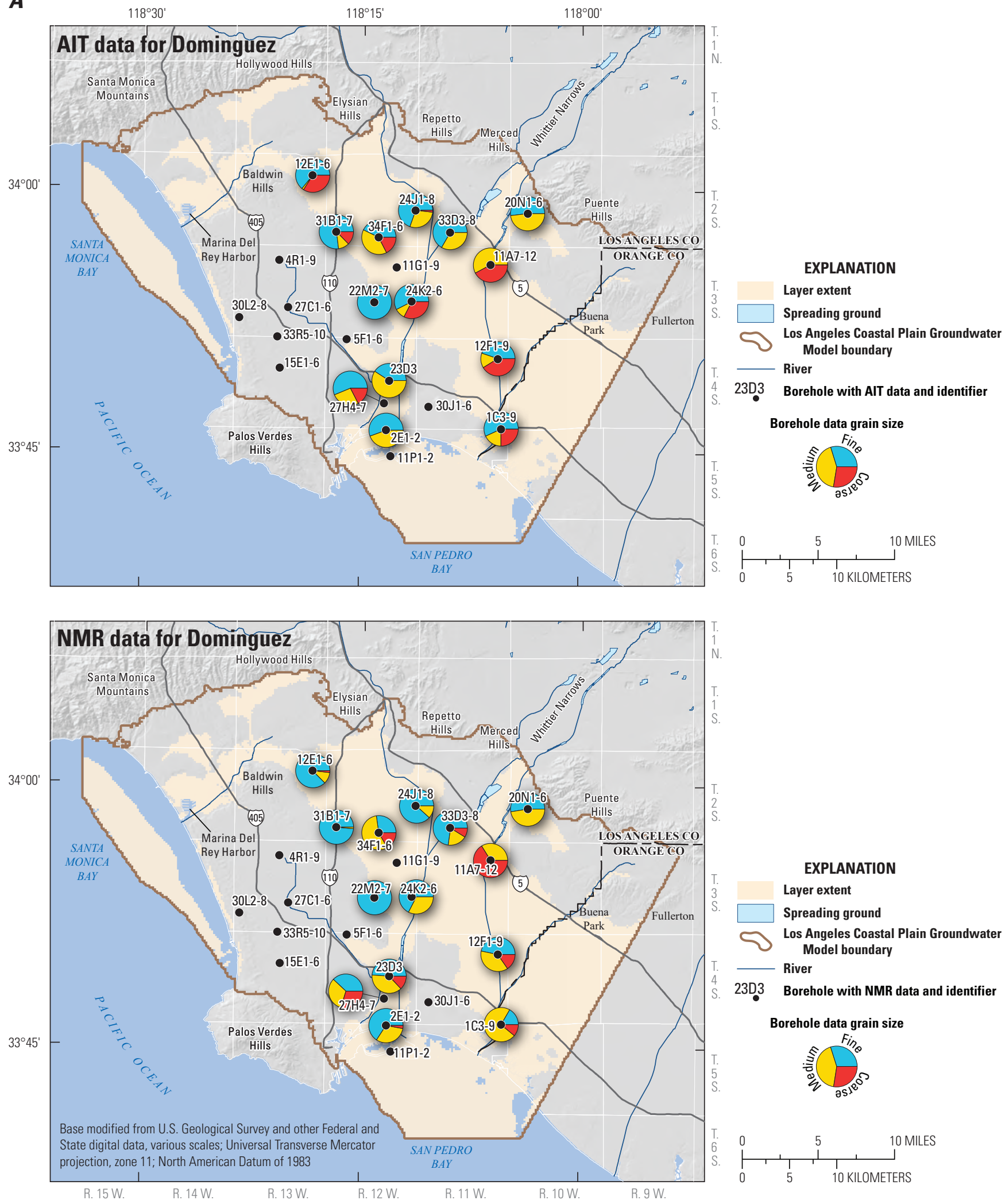

Borehole data grain size
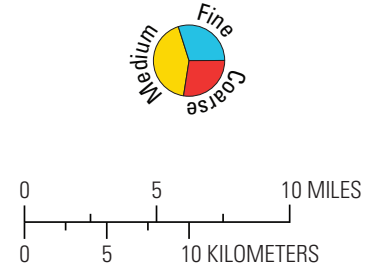

Figure 2.1. Results of grain-size analysis using array induction 2-foot resistivity (AIT), gamma, lithology, and nuclear magnetic resonance (NMR) logs for the $A$, Dominguez; $B$, Mesa; $C$, Pacific A; $D$, Pacific; $E$, Harbor; $F$, Bent Spring; $G$, Upper Wilmington A; $H$, Upper Wilmington $B ;$ I, Lower Wilmington; J, Long Beach $A ; K$, Long Beach $B$; and $L$, Long Beach $C$ aquifer systems in the Los Angeles Coastal Plain, California. 
$\boldsymbol{B}$

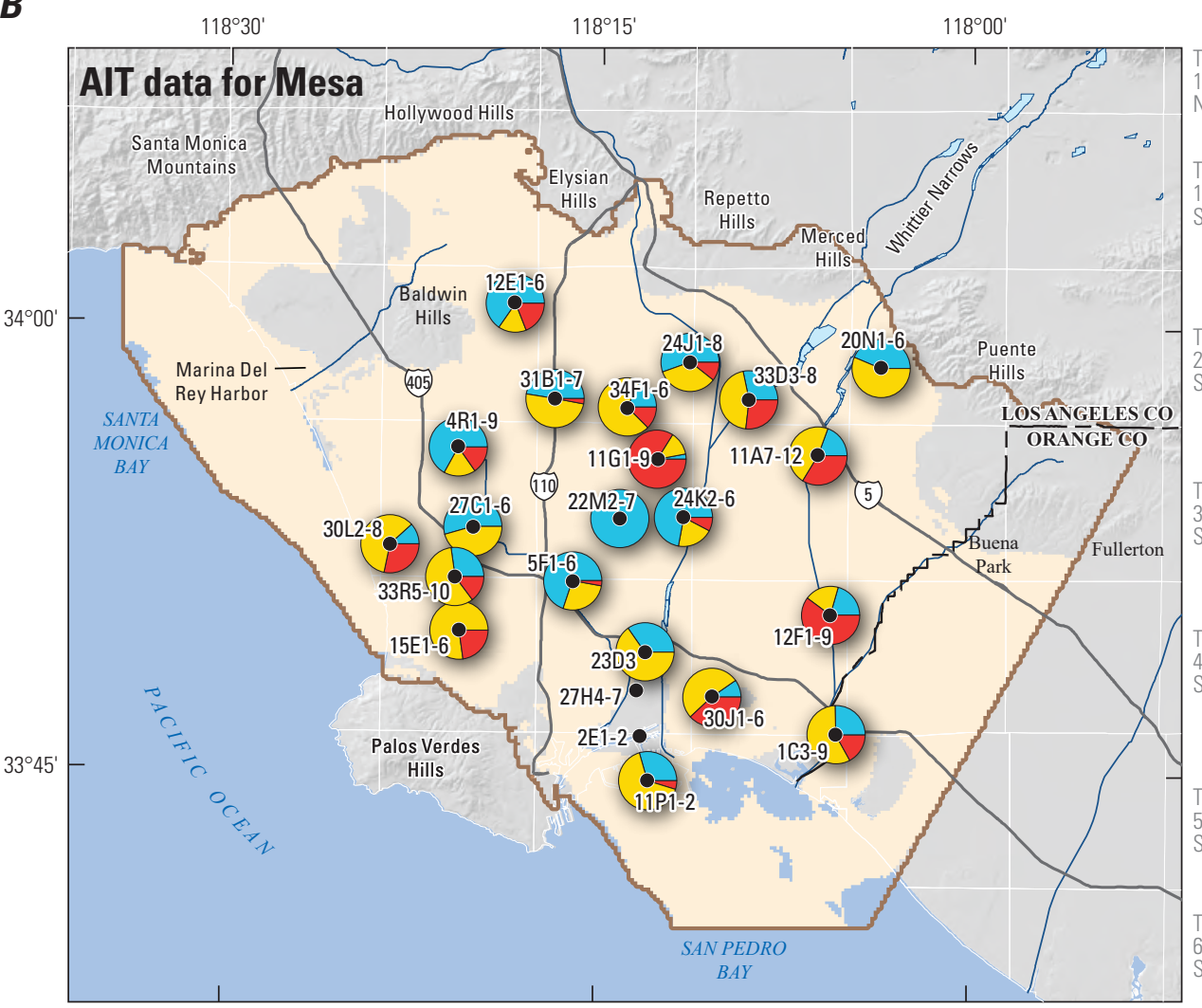

\section{EXPLANATION \\ Layer extent \\ Spreading ground \\ Los Angeles Coastal Plain Groundwater Model boundary \\ River \\ 23D3 Borehole with AIT data and identifier}

Borehole data grain size
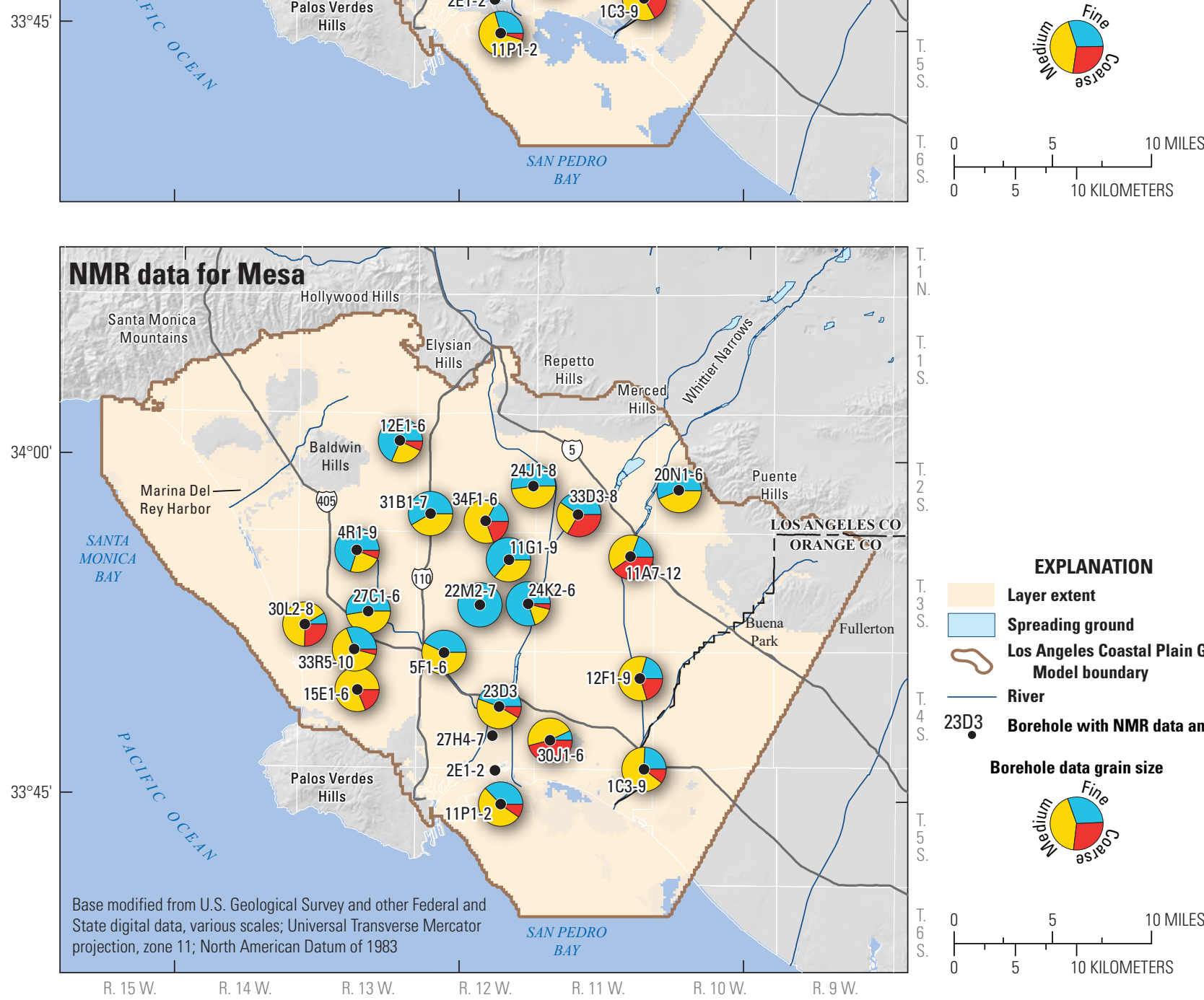

EXPLANATION

Layer extent

Spreading ground

Los Angeles Coastal Plain Groundwater

Model boundary

River

23D3 Borehole with NMR data and identifier

Borehole data grain size
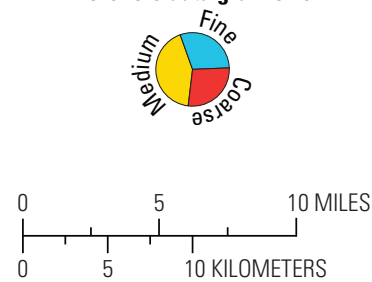

Figure 2.1.-Continued 
C
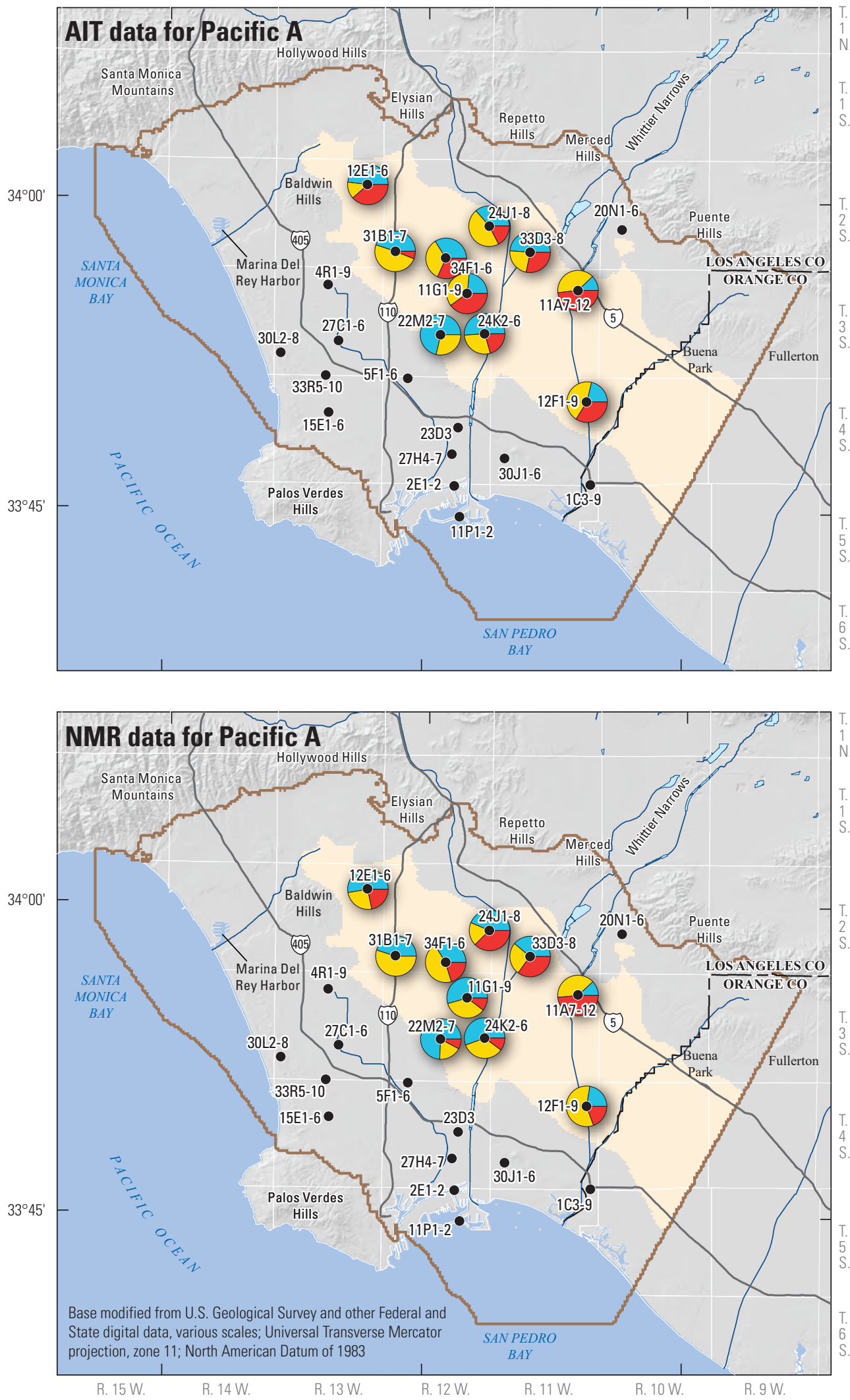

\section{EXPLANATION}

Layer extent

Spreading ground

Los Angeles Coastal Plain Groundwate Model boundary

River

23D3 Borehole with AIT data and identifier

Borehole data grain size<smiles>C1=CC2CC3CC1CC(C2)C3</smiles>

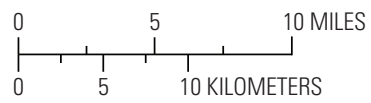

\section{EXPLANATION}

Layer extent

Spreading ground

Los Angeles Coastal Plain Groundwater

Model boundary

River

23D3 Borehole with NMR data and identifier

Borehole data grain size

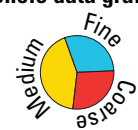

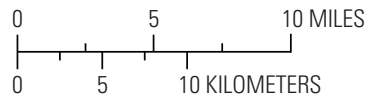

Figure 2.1.-Continued 
D
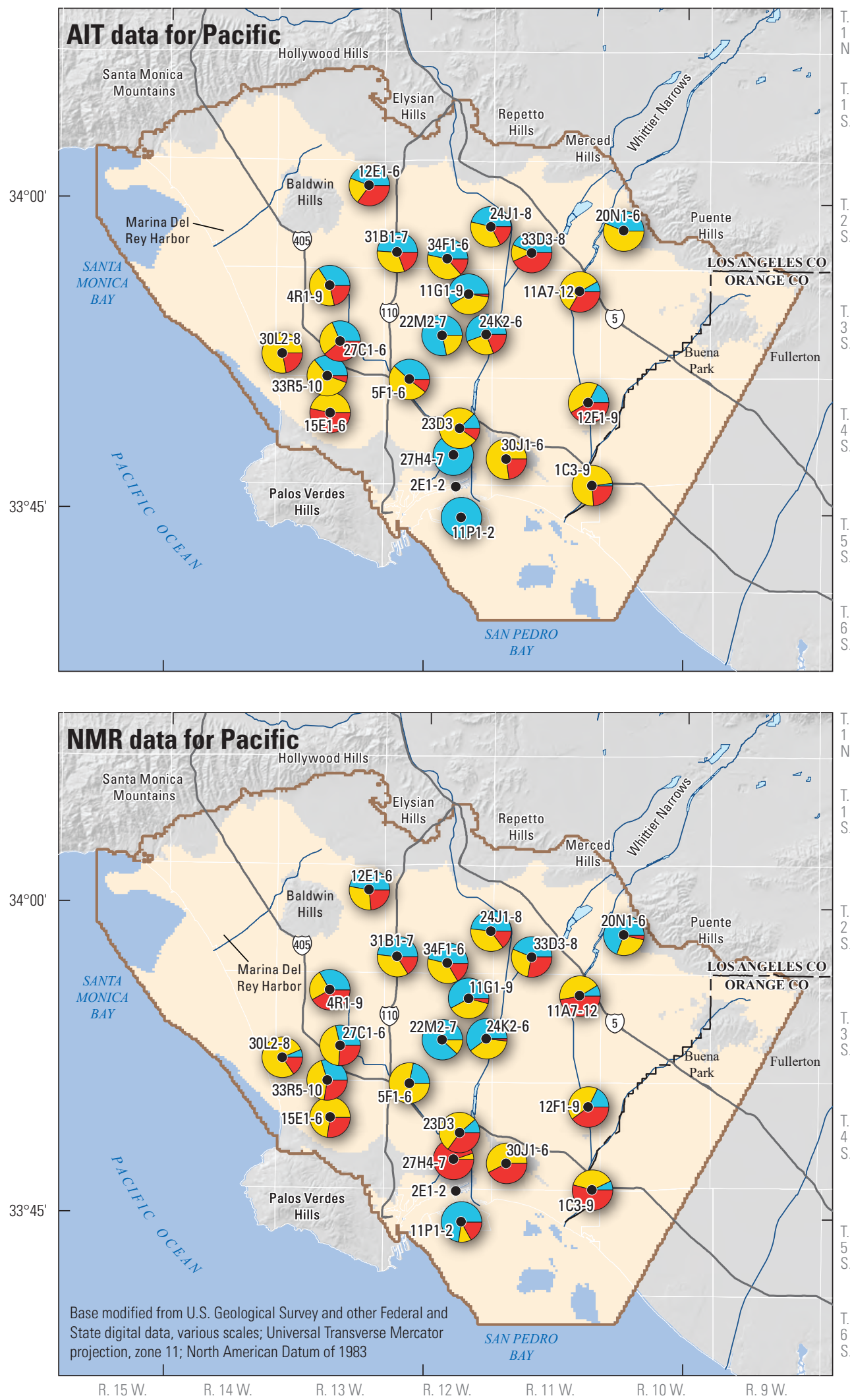

\section{EXPLANATION}

Layer extent

Spreading ground

Los Angeles Coastal Plain Groundwater Model boundary

River

23D3 Borehole with AIT data and identifier

Borehole data grain size<smiles>C1=CC2CC3CC1CC(C2)C3</smiles>

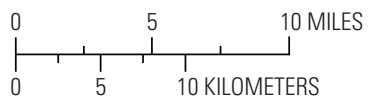

\section{EXPLANATION}

Layer extent

Spreading ground

Los Angeles Coastal Plain Groundwater

Model boundary

River

23D3 Borehole with NMR data and identifier

Borehole data grain size
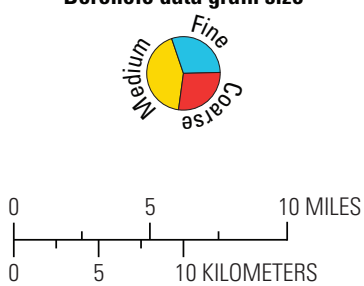

Figure 2.1.-Continued 
$\boldsymbol{E}$
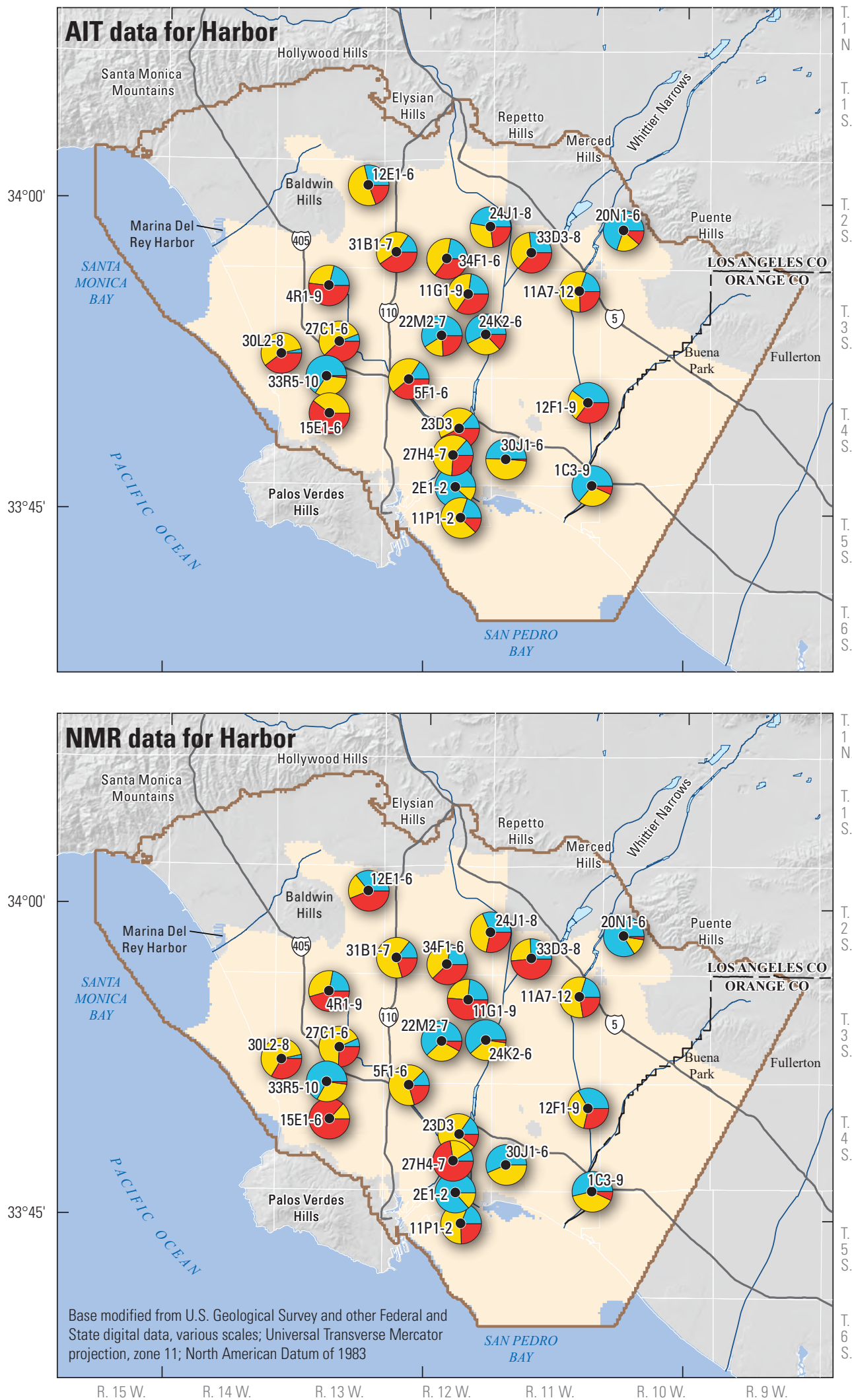

\section{EXPLANATION}

Layer extent

Spreading ground

Los Angeles Coastal Plain Groundwate Model boundary

River

23D3 Borehole with AIT data and identifier

Borehole data grain size<smiles>C1=CC2CC3CC1CC(C2)C3</smiles>

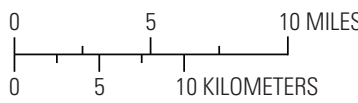

\section{EXPLANATION}

Layer extent

Spreading ground

Los Angeles Coastal Plain Groundwater

Model boundary

River

23D3 Borehole with NMR data and identifier

Borehole data grain size

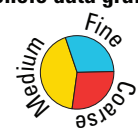

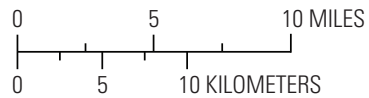

Figure 2.1.-Continued 
$\boldsymbol{F}$

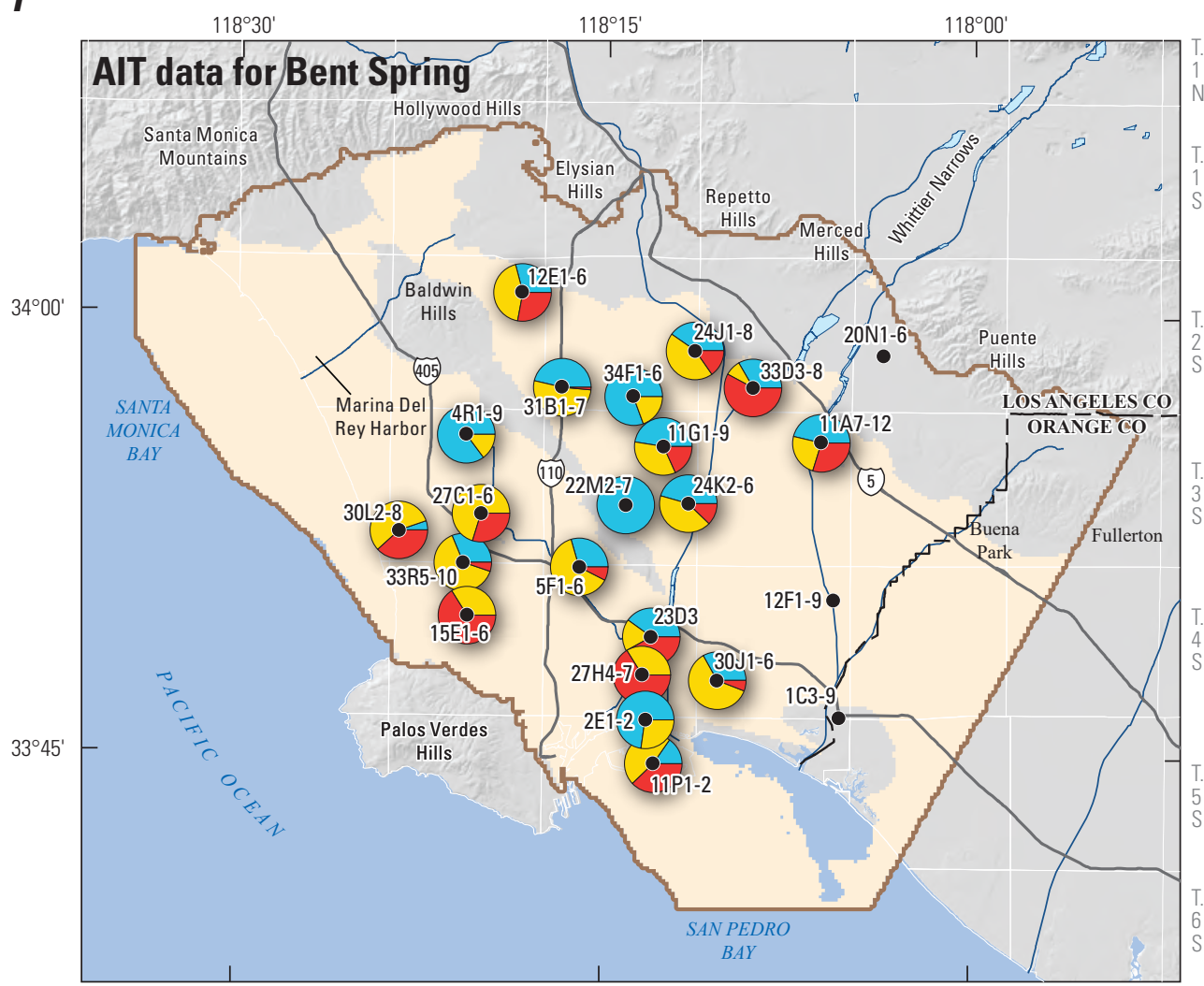

EXPLANATION

Layer extent

Spreading ground

Los Angeles Coastal Plain Groundwater Model boundary

River

23D3 Borehole with AIT data and identifier

Borehole data grain size
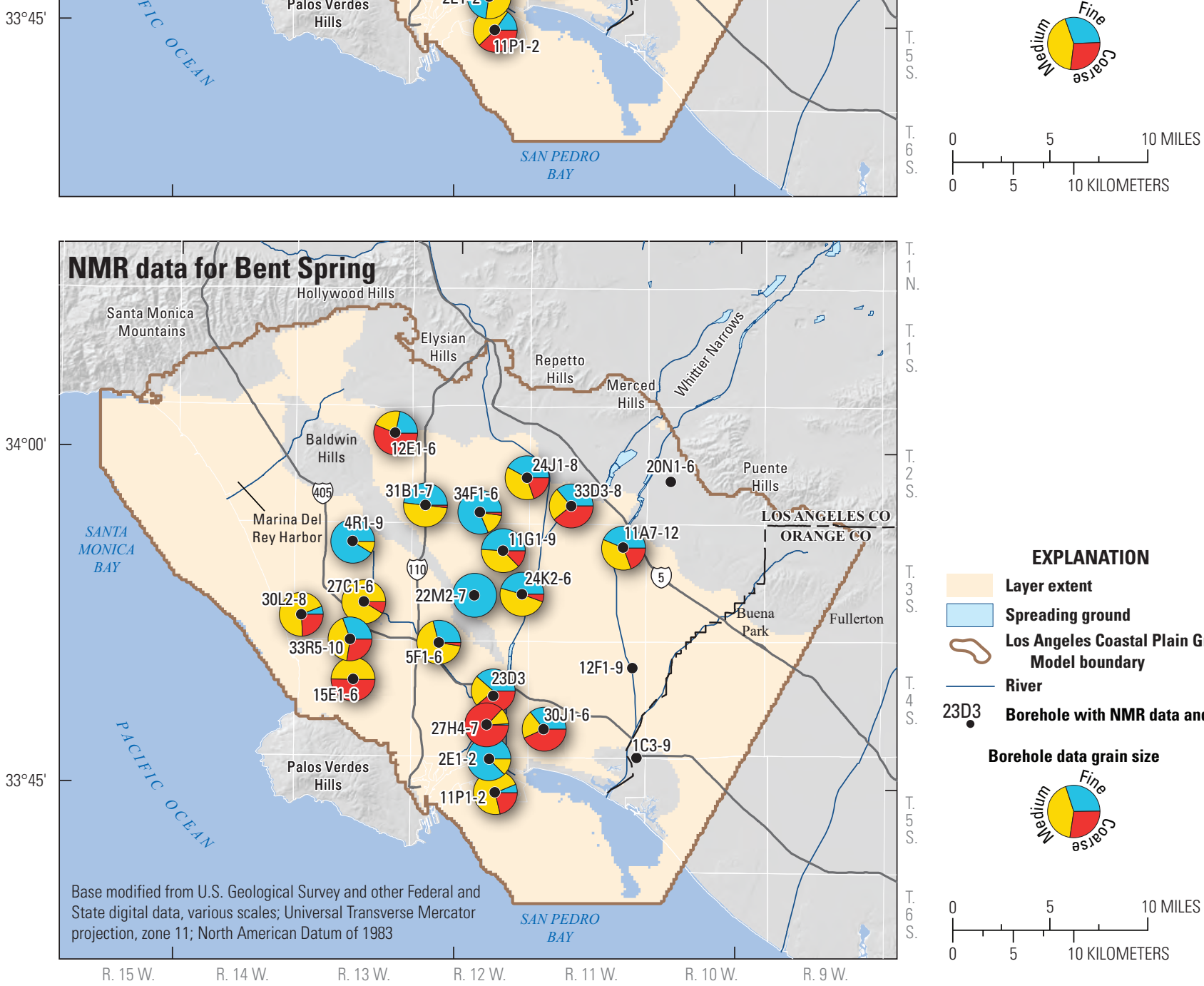

EXPLANATION

Layer extent

Spreading ground

Los Angeles Coastal Plain Groundwater

Model boundary

River

23D3 Borehole with NMR data and identifier

Borehole data grain size
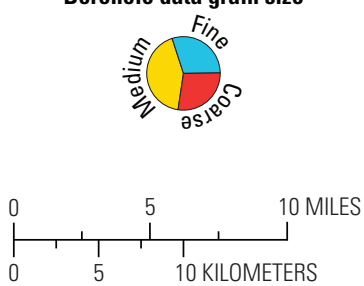

Figure 2.1.-Continued 

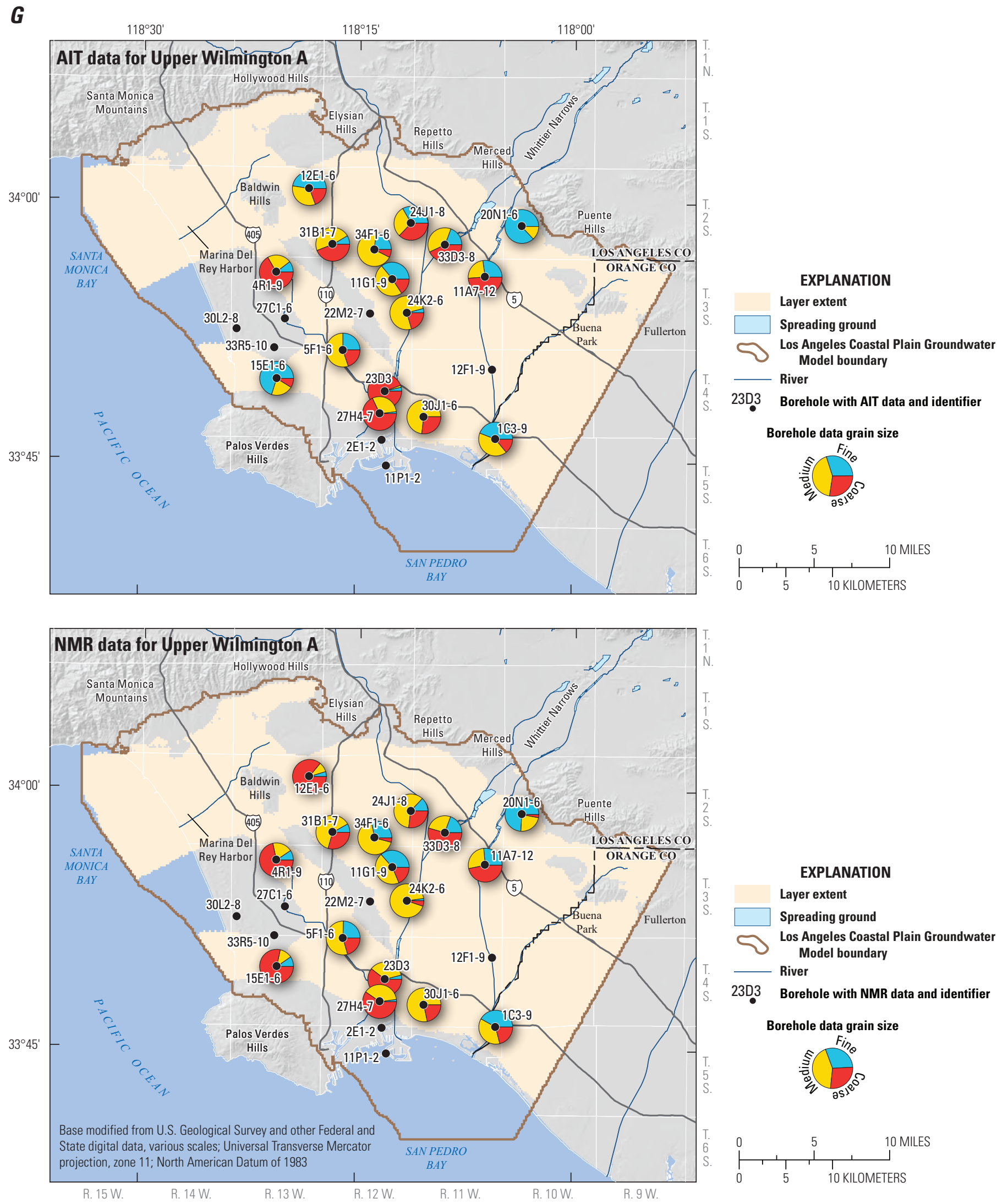

\section{EXPLANATION}

Layer extent

Spreading ground

Los Angeles Coastal Plain Groundwater Model boundary

River

23D3 Borehole with NMR data and identifier

Borehole data grain size

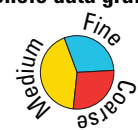

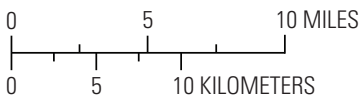

Figure 2.1.-Continued 
$\boldsymbol{H}$
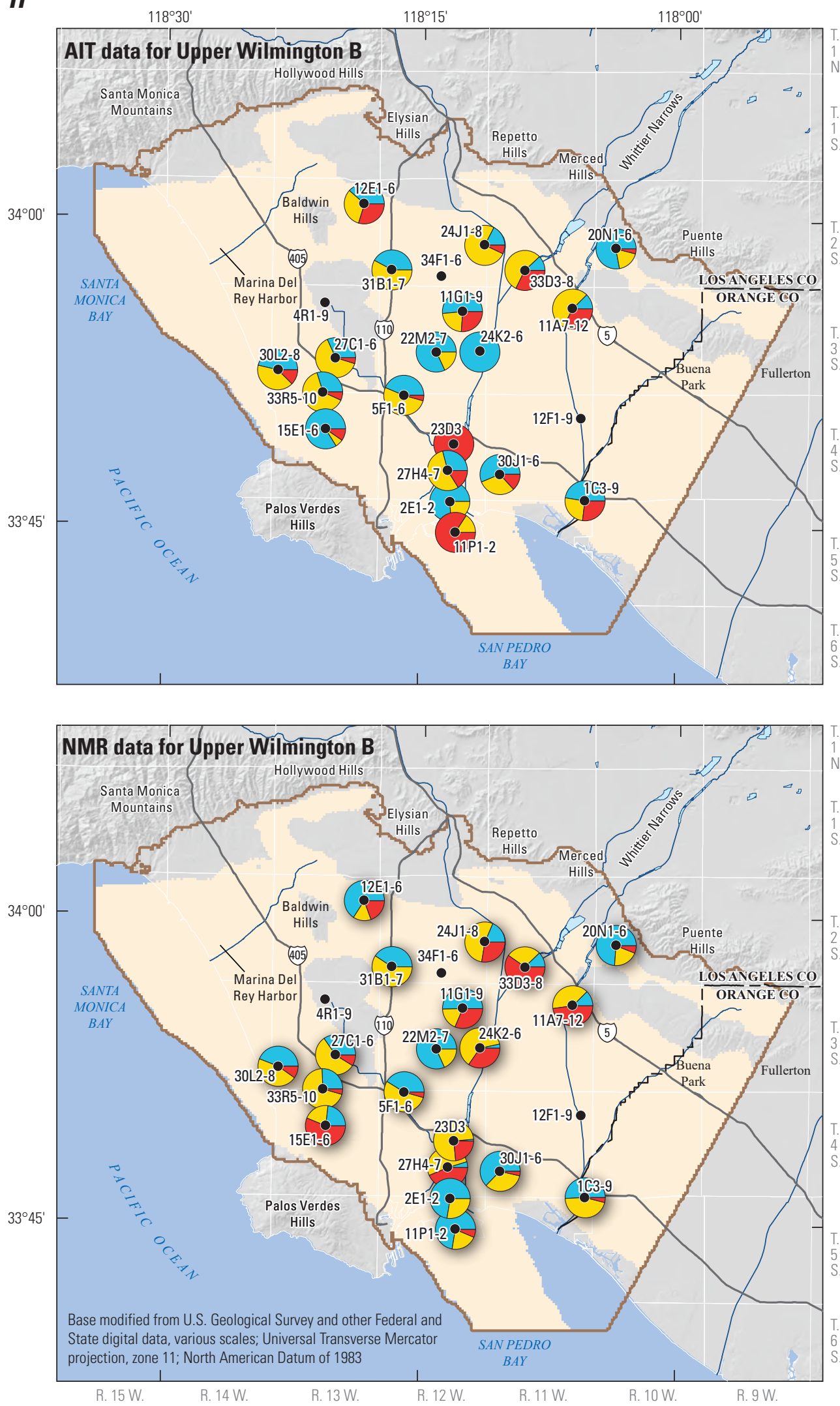

\section{EXPLANATION}

Layer extent

Spreading ground

Los Angeles Coastal Plain Groundwate Model boundary

River

23D3 Borehole with AIT data and identifier

Borehole data grain size<smiles>C1=CC2CC3CC(C1)C(C2)C3</smiles>

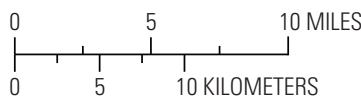

\section{EXPLANATION}

Layer extent

Spreading ground

Los Angeles Coastal Plain Groundwater

Model boundary

River

23D3 Borehole with NMR data and identifier

Borehole data grain size
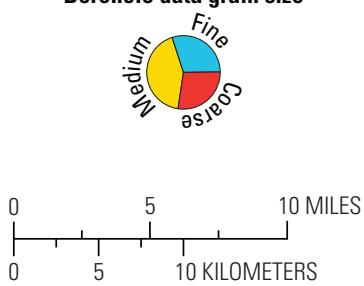

Figure 2.1.-Continued 
I
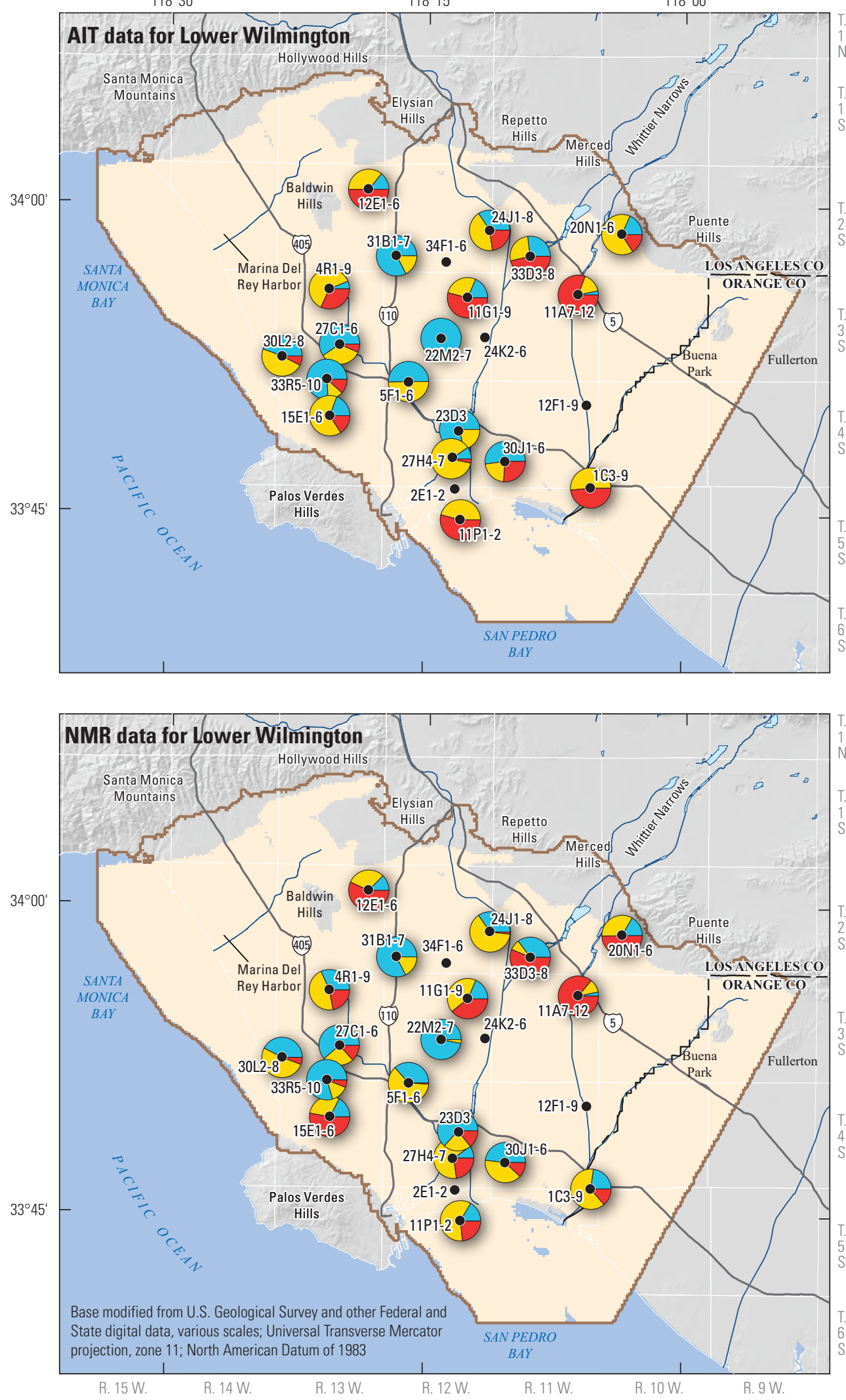

EXPLANATION

Layer extent

Spreading ground

Los Angeles Coastal Plain Groundwater Model boundary

\section{River}

23D3 Borehole with AIT data and identifier

Borehole data grain size

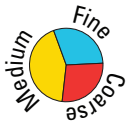

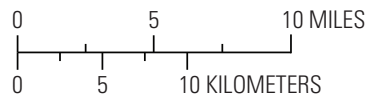

EXPLANATION

Layer extent

Spreading ground

Los Angeles Coastal Plain Groundwater

Model boundary

- River

23D3 Borehole with NMR data and identifier

Borehole data grain size<smiles>C1=CC2CC3CC1CC(C2)C3</smiles>

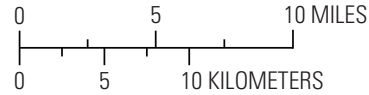

Figure 2.1.-Continued 

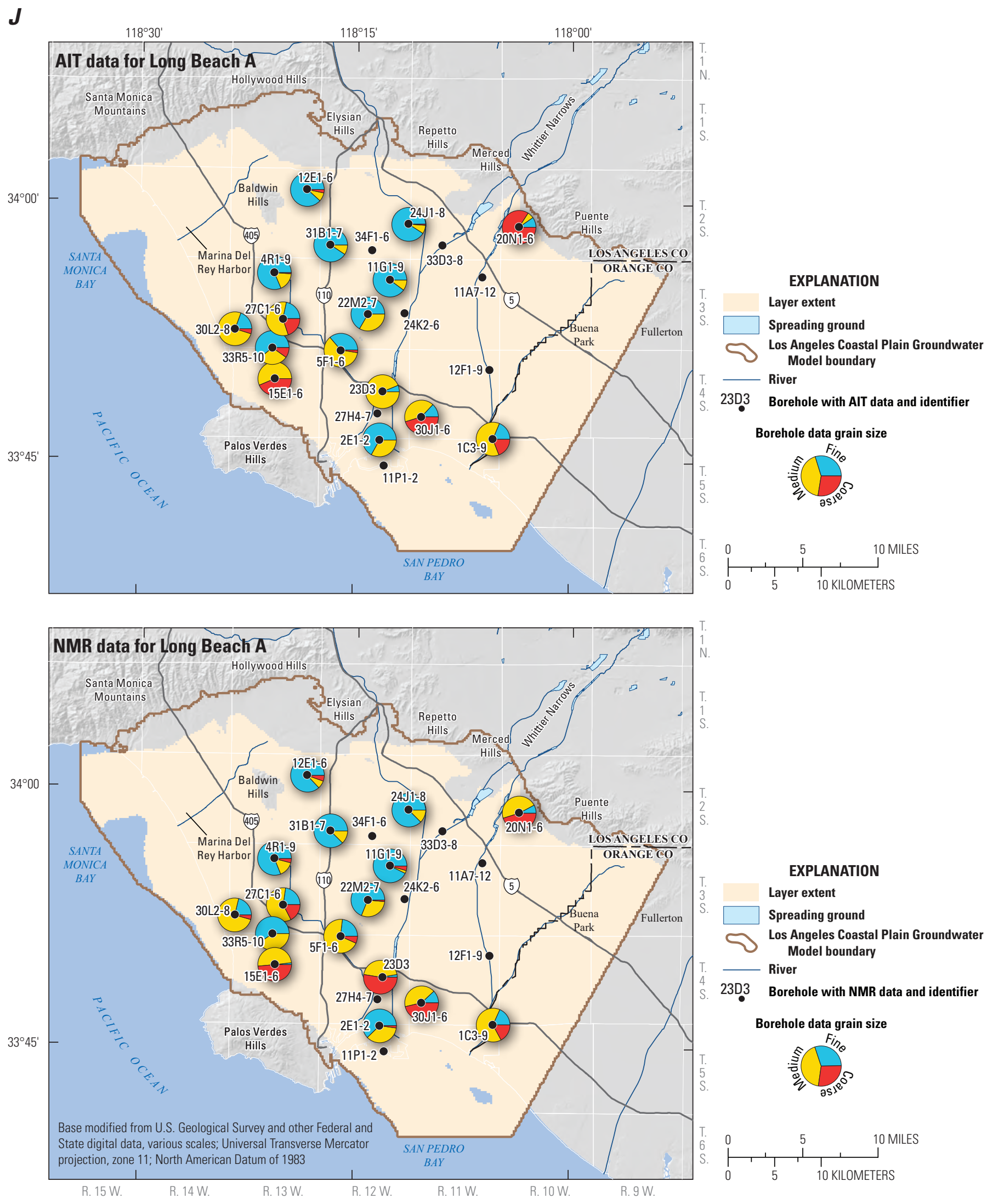

Figure 2.1.-Continued 


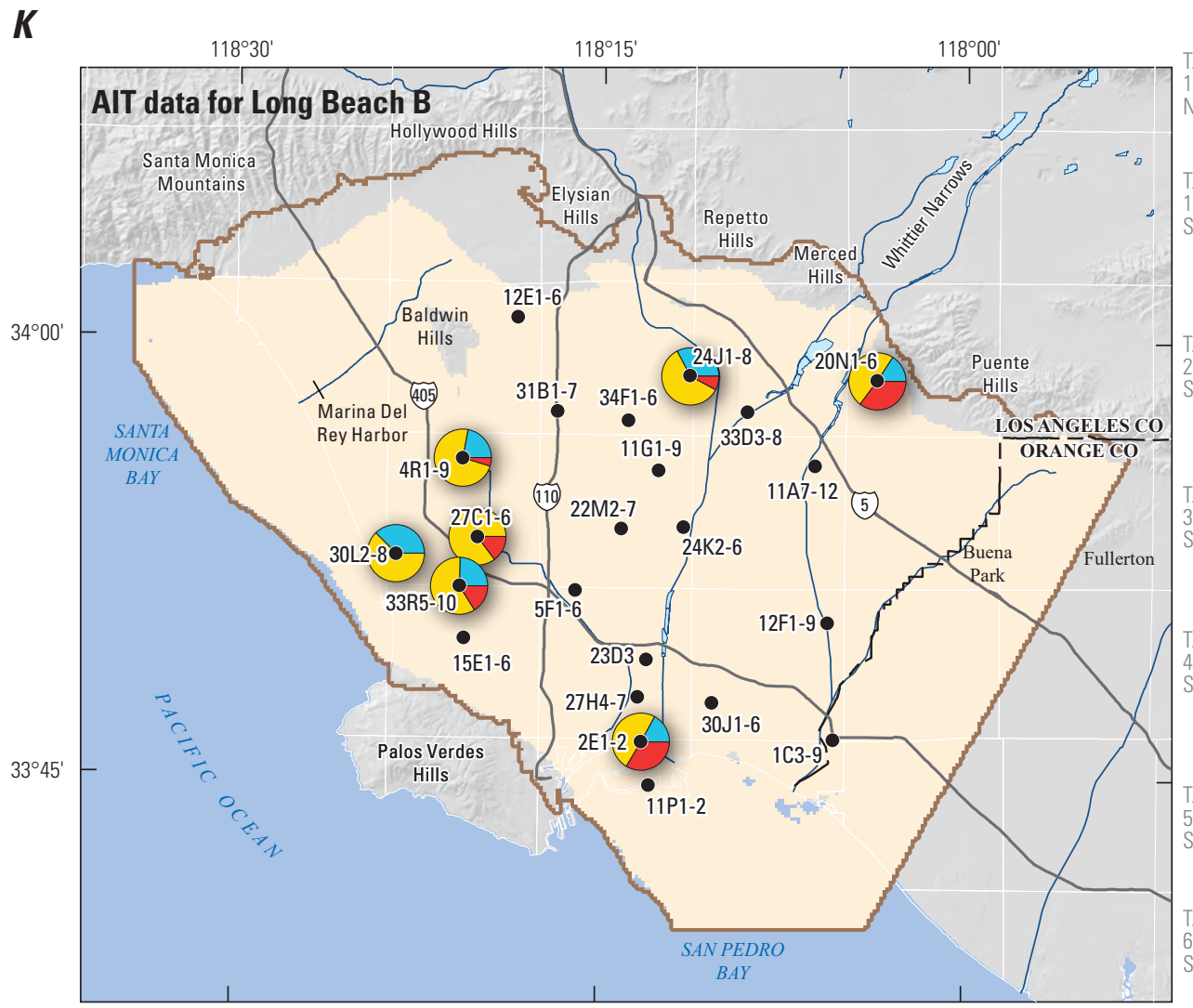

\section{EXPLANATION \\ Layer extent \\ Spreading ground \\ Los Angeles Coastal Plain Groundwater Model boundary \\ - River \\ 23D3 Borehole with AIT data and identifier}

Borehole data grain size<smiles>C1=CC2CC3CC1CC(C2)C3</smiles>
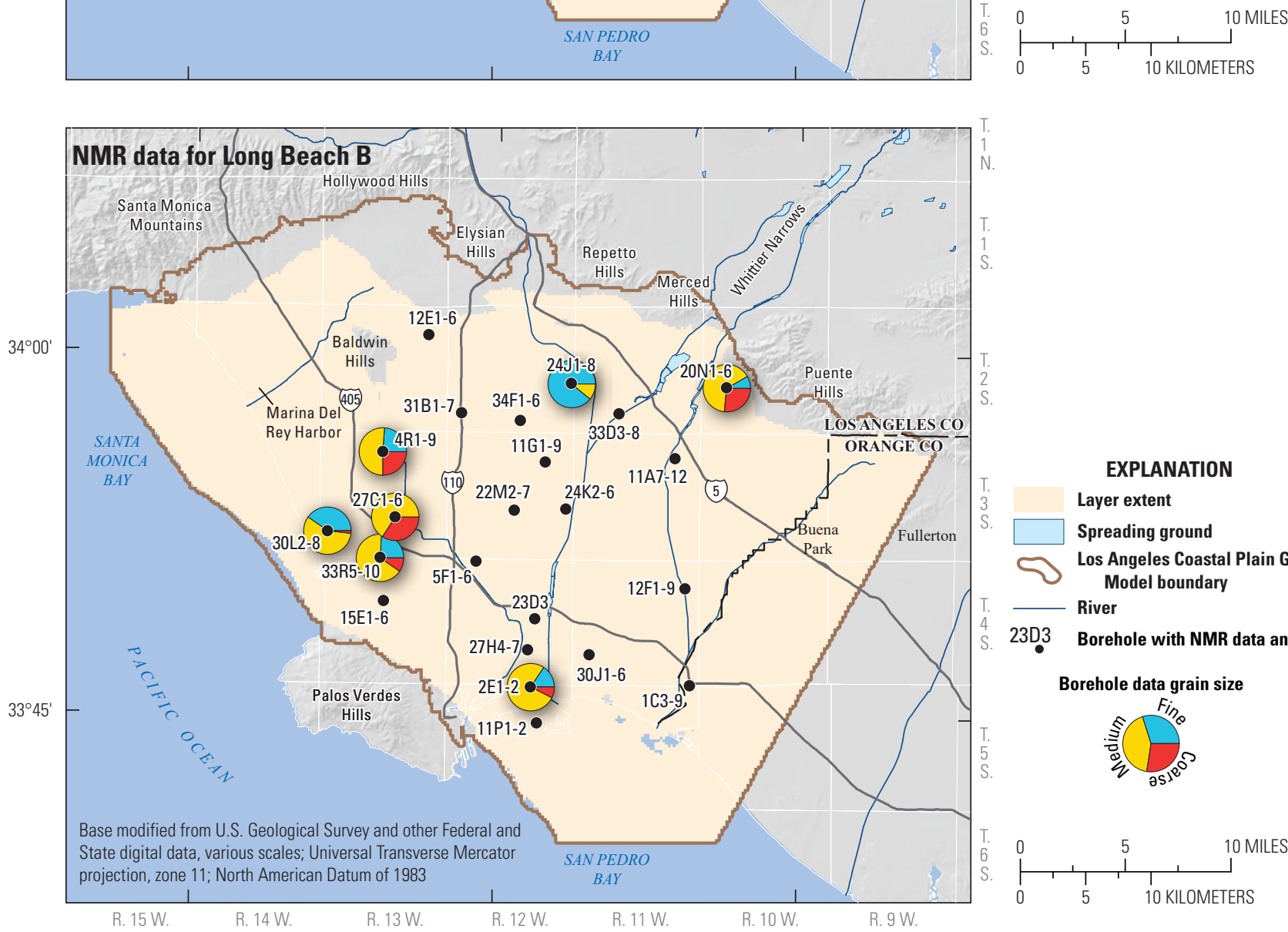

EXPLANATION

\section{Layer extent}

Spreading ground

Los Angeles Coastal Plain Groundwater

Model boundary

\section{River}

23D3 Borehole with NMR data and identifier

Borehole data grain size
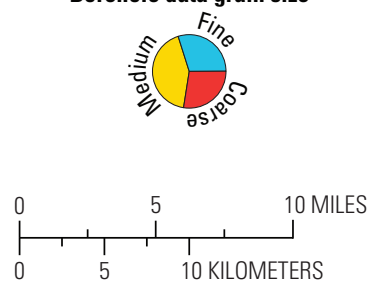

Figure 2.1.-Continued 

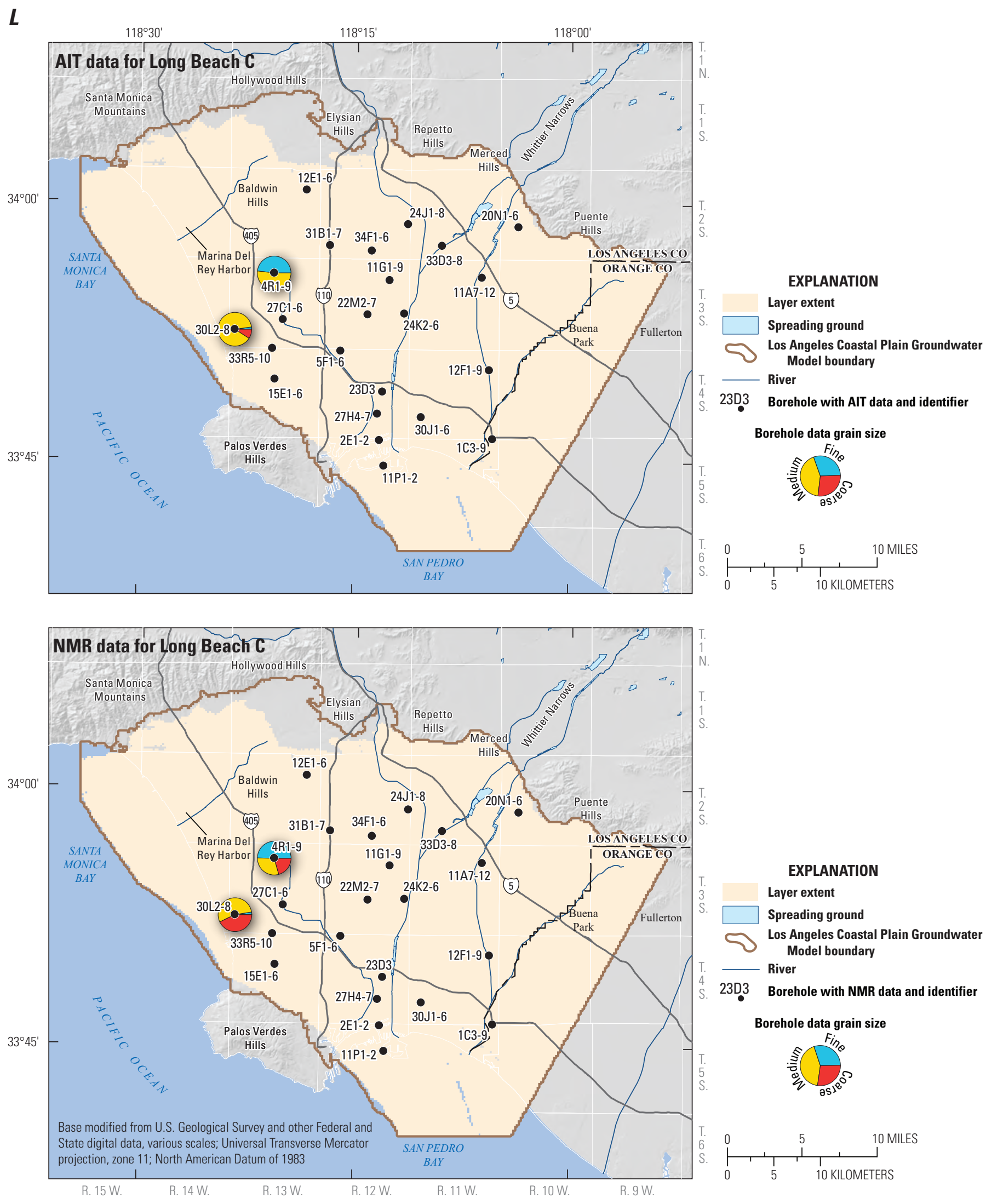

Figure 2.1.-Continued 
Tool calibration changes over time, and borehole and formation-fluid properties greatly vary between sites; therefore, interpretations of the resistivity and gamma logs were done on a site by site basis. Thresholds for the logs were manually adjusted for each chronostratigraphic unit in each borehole based on several criteria. First, all available logs were reviewed for quality, and a simple interpretation was performed to understand the general depositional setting. Anomalies and sections that would not be suitable for interpretation were noted during this process. Second, the descriptions of the geologic logs were reviewed along with the site hydrologist's field notes. During this process, any abrupt changes in lithology, intervals of well sorted material, and thick sequences of identical lithology were noted. The third and final step involved selecting the threshold values while comparing the logs to the noted lithology.

The process of setting the threshold values was completed in three steps. These steps were done visually, simultaneously using plots of the resistivity and gamma ray logs alongside the graphic of the lithology summary, with vertical bars representing the threshold values and a graphic of the interpreted grain size. First, starting at the top and working down the log, the abrupt changes in lithology noted in the review process were identified. At these depths, the thresholds for each chronostratigraphic unit were adjusted until the log values were bracketed by the appropriate thresholds. For example, in the case of gravel overlying clay, the thresholds were set for resistivity logs so the log values for the gravel were above the high threshold and the log values for the clay were below the low threshold. For accuracy, the graph of the interpreted lithology was compared to the graphic of the lithology summary throughout the process. After the abrupt lithology changes were addressed, the intervals of well-sorted material were examined. During this step, the threshold values were slightly adjusted as needed to ensure that log values of a given material were bracketed by the appropriate threshold. If large changes in the thresholds (approximately 10 percent of the log scale) were made during this step in the process, the abrupt changes in lithology were reviewed. Again, the graph of the interpreted lithology was compared to the graphic of the lithology summary for accuracy. The third step in setting the thresholds was completed as a check to ensure that subtle changes in lithology were interpreted properly. For this step, the hydrologist's notes were reviewed for thin beds of varying lithology that may not have been included in the lithology summary; for example, a 3-foot thick coarse sand layer in the middle of a 50 -foot thick clayey sand or a noted change in sand percentage. If the lithology at these depths was not interpreted correctly, all data were re-examined to determine a possible cause for the discrepancy. If the thresholds needed to be adjusted for proper interpretation, the entire process was repeated. Thresholds were fine tuned to increase agreement between the NMR and resistivity (AIT and long-normal resistivity) interpretations. The final interpreted lithology was then compared to the summary lithology and hydrologist's notes to ensure a reasonable match.

\section{References Cited}

\author{
Coates, G.R., Xiao, L., and Prammer, M.G., 1999, NMR \\ logging principles and applications: Halliburton \\ Energy Services, accessed May 21, 2018, at \\ https://www.halliburton.com/public/lp/contents/Books_and \\ Catalogs/web/NMR-Logging-Principles-and-Applications. \\ pdf. \\ Keys, W.S., and MacCary, L.M., 1983, Application \\ of borehole geophysics to water-resources \\ investigations: U.S. Geological Survey Techniques of \\ Water-Resources Investigations, book 2, chap. E1, 126 p., \\ https://doi.org/10.3133/twri02E1.
}

Schlumberger Limited, 1972, Log interpretation, volume IPrinciples: New York, Schlumberger, 113 p. 


\title{
Appendix 3. Los Angeles Coastal Plain Groundwater-flow Model Setup Including Wells Used to Constrain Boundary Conditions
}

\author{
By Daniel Culling and Scott Paulinski
}

Groundwater underflow (inflows and outflows) at the eastern boundary of the Los Angeles Coastal Plain Groundwater-flow Model (LACPGM) was simulated for all layers using the General Head Boundary Package (GHB) of MODFLOW-USG (Panday and others, 2013). Monthly water-level data were provided by Orange County Water District (OCWD) and the Water Replenishment District of Southern California (WRD) from selected wells on both sides of the boundary (fig. 3.1) and were used to estimate the temporally and spatially varying water levels along the Orange County General Head Boundary (GHB). Wells were chosen based on proximity to eastern boundary GHB model cells, temporal data coverage, and proximity to pumping. Production well water-level data were used only if the data were collected during static (non-pumping) conditions. Monthly water-level data from wells near the LACPGM's eastern boundary were averaged quarterly to match the modeled stress periods and used to estimate water levels at the nearest eastern boundary model cell of the LACPGM. GHB model cells based directly on water-level data from nearby wells are referred to as primary data GHB cells. Water-level data were interpolated between two primary data GHB cells if the long-term estimated water-levels of the two cells had a moderately strong linear correlation (coefficient of determination $\left(\mathrm{R}^{2}\right)>0.50$ ). This process filled in most (approximately 80 percent) data gaps within the GHB.

Due to sparse water-level data near the northern and southern end of the Orange County GHB, a few wells farther from the Orange County GHB were used to help estimate water levels along the GHB for some layers. These more distant wells include 12P2, 8A1, 18C1, and 9G1 (fig. 3.1). Although gaps in data do also exist along the middle section of the Orange County GHB, these gaps are generally smaller, and GHB water-levels in these gaps can be interpolated from nearby data. The data gaps along the northern and southern end of the Orange County GHB are generally larger and lack data to the north or south of the GHB. Data from more distant wells around the north and south ends of the GHB were used to limit extrapolation error. Many of the primary data GHB cells are based on water-level data that are not continuous for the entire model period (1971-2015). The OCWD has installed a series of multi-completion wells in the Orange County Basin to monitor water levels and water quality, including several wells near the eastern boundary of the LACPGM. These wells were not constructed until the early 1990s; consequently, many of the water-level periods of record in this area generally start around 1992. Few wells have water-level measurements extending back to the model start date (1971).

Water levels for wells missing earlier water-level data were extrapolated back in time using temporally overlapping water-level data from nearby wells with more complete records. To do this, a linear correlation plot was produced between the temporally overlapping data from the two wells, and a best-fit line was defined. Where a moderately strong linear correlation was found $\left(\mathrm{R}^{2}>0.50\right)$, the equation of the line relating the water levels of the primary data GHB cell to the water levels of the well with complete water-level data was used to compute estimated values for missing periods. The most critical well used for this purpose is well 8C2 (A-9), which has water-level data that span the model period. Small temporal gaps ( $<3$ stress periods) in data from a single well were filled by linearly interpolating between existing data points. Water-table slopes approaching the northern and southern boundary were linearly extrapolated to the boundary. In some rare cases, the calculated water level of a GHB cell was lower than the elevation of the bottom of the layer for that cell; in these instances, the water level was changed to match the bottom elevation of the layer.

In some cases, GHB water-levels were estimated based on data from other layers. Before doing this, a linear correlation plot was produced between hydrographs of different layers, and a best-fit line was defined. The equation of the best-fit line was then used to estimate the water-levels of an undefined GHB cell in one layer from the known water-levels of a GHB cell in another layer. Generally, the highest correlations were between adjacent layers, and correlations were lower for layers that were farther apart. The hydraulic heads in four groups of model layers were found that tended to be highly correlated: Dominguez and Mesa; Pacific A, Pacific, and Harbor; Bent Spring, Upper Wilmington A, Upper Wilmington B, and Lower Wilmington; and Long Beach A, Long Beach B, and Long Beach C. Where data were unavailable for estimates based on correlation, water levels were copied from the nearest model cell with a comparable value (for example, heads were copied between the Long Beach B and C aquifer systems, and so forth). 

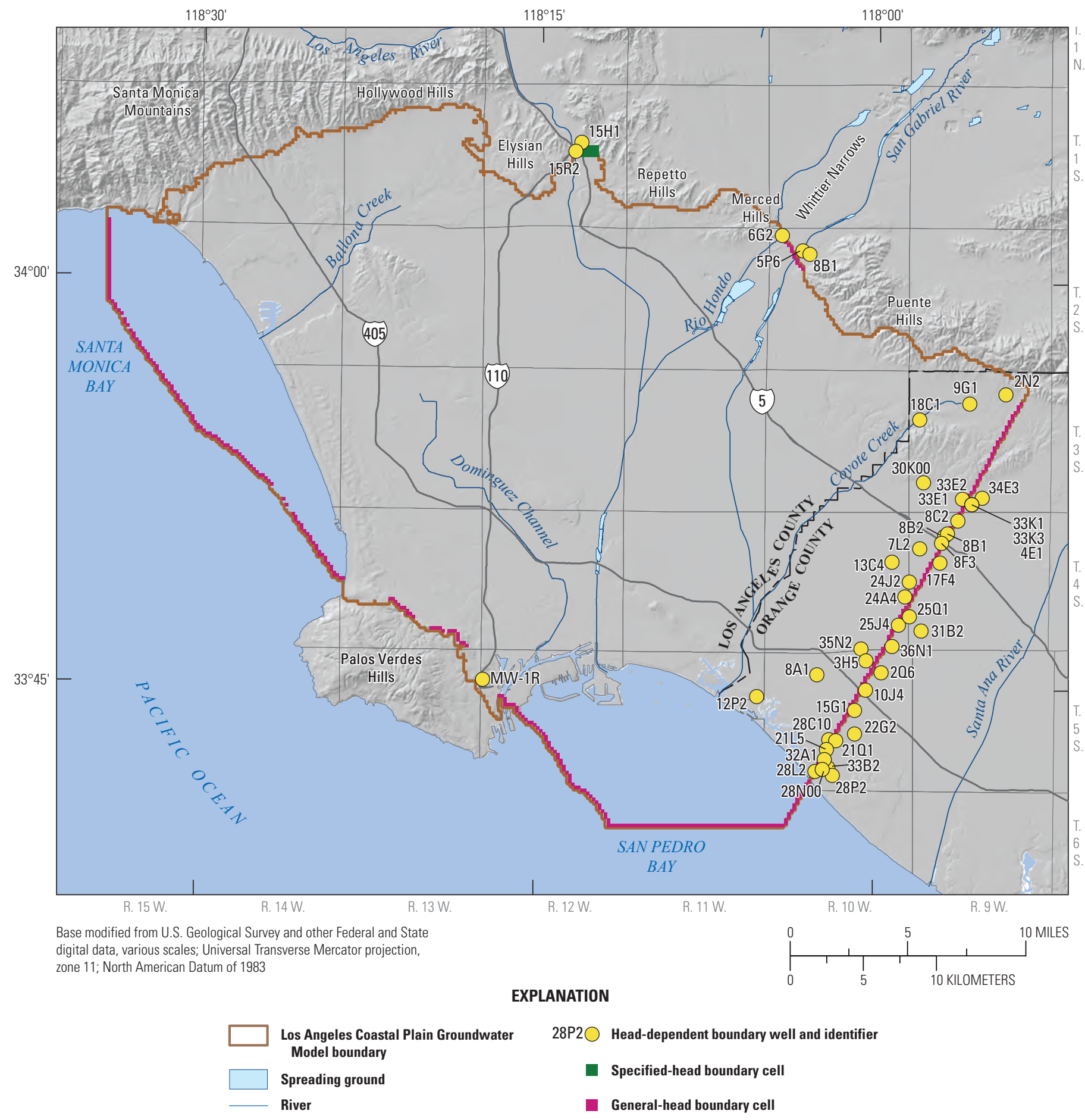

Figure 3.1. Wells used to constrain boundary conditions of the Los Angeles Coastal Plain Groundwater-flow Model. Common names are listed in table 3.1. 
Figure 3.1 shows and labels the wells used to estimate GHB water-levels by state well number. For readers more familiar with common names, a lookup table is provided (table 3.1). Observed heads for wells used to estimate the Los Angeles Narrows time-variant specified head along with estimated boundary heads are shown in table 3.2.

Table 3.1. Wells used to constrain boundary conditions.

\begin{tabular}{|c|c|}
\hline State well number & Common name \\
\hline 1S/13W-15H1 & $2771 \mathrm{I}$ \\
\hline $1 \mathrm{~S} / 13 \mathrm{~W}-15 \mathrm{R} 2$ & $2772 \mathrm{E}$ \\
\hline $2 \mathrm{~S} / 11 \mathrm{~W}-6 \mathrm{G} 2$ & $2927 \mathrm{~A}$ \\
\hline $2 \mathrm{~S} / 11 \mathrm{~W}-8 \mathrm{~B} 1$ & $2948 \mathrm{C}$ \\
\hline 4S/10W-7L2 & A-48 \\
\hline $4 \mathrm{~S} / 11 \mathrm{~W}-24 \mathrm{~A} 4$ & A-53 \\
\hline $4 \mathrm{~S} / 10 \mathrm{~W}-8 \mathrm{C} 2$ & A-9 \\
\hline $4 \mathrm{~S} / 10 \mathrm{~W}-8 \mathrm{~B} 1$ & AM-30 \\
\hline $4 \mathrm{~S} / 11 \mathrm{~W}-13 \mathrm{C} 4$ & AMD-8 \\
\hline 4S/10W-8F3 & CB-1 \\
\hline $3 \mathrm{~S} / 10 \mathrm{~W}-2 \mathrm{~N} 2$ & CREST-BR \\
\hline 3S/10W-33E1 & FM-18 \\
\hline $3 \mathrm{~S} / 10 \mathrm{~W}-33 \mathrm{~K} 1$ & FM-19A \\
\hline 3S/10W-34E3 & FM-20 \\
\hline $3 \mathrm{~S} / 10 \mathrm{~W}-21 \mathrm{H} 2$ & FM-6 \\
\hline $4 \mathrm{~S} / 11 \mathrm{~W}-35 \mathrm{~N} 2$ & GGM-2 \\
\hline $4 \mathrm{~S} / 11 \mathrm{~W}-25 \mathrm{~J} 4$ & GGM-3 \\
\hline 3S/10W-9G1 & LH-FS192 \\
\hline- & MW-1R \\
\hline $5 \mathrm{~S} / 11 \mathrm{~W}-32 \mathrm{~A} 1$ & OCWD-BSO4 \\
\hline $5 \mathrm{~S} / 11 \mathrm{~W}-22 \mathrm{G} 2$ & OCWD-BS106 \\
\hline $5 \mathrm{~S} / 11 \mathrm{~W}-15 \mathrm{G} 1$ & OCWD-BS107 \\
\hline $5 \mathrm{~S} / 11 \mathrm{~W}-28 \mathrm{P} 2$ & OCWD-BS19 \\
\hline $5 \mathrm{~S} / 11 \mathrm{~W}-28 \mathrm{C} 10$ & OCWD-BS20B \\
\hline $5 \mathrm{~S} / 11 \mathrm{~W}-21 \mathrm{~L} 5$ & PRT-HB \\
\hline $3 \mathrm{~S} / 10 \mathrm{~W}-30 \mathrm{~K}$ & RAY-MW31 \\
\hline $5 \mathrm{~S} / 12 \mathrm{~W}-1 \mathrm{C} 3$ & SB-1 \\
\hline $5 \mathrm{~S} / 11 \mathrm{~W}-8 \mathrm{~A} 1$ & SBM-1 \\
\hline 4S/11W-25Q1 & SCWC-SDAL \\
\hline $4 \mathrm{~S} / 11 \mathrm{~W}-36 \mathrm{~N} 1$ & SCWC-SSYC \\
\hline $5 \mathrm{~S} / 11 \mathrm{~W}-28 \mathrm{P}$ & SLC-P6 \\
\hline 2S/11W-5P6 & Whittier Narrows1_1 \\
\hline $2 \mathrm{~S} / 11 \mathrm{~W}-5 \mathrm{P} 13$ & Whittier Narrows $1 \_8$ \\
\hline $4 \mathrm{~S} / 10 \mathrm{~W}-31 \mathrm{~B} 2$ & $\mathrm{~W}-7040$ \\
\hline $5 \mathrm{~S} / 11 \mathrm{~W}-3 \mathrm{H} 5$ & WM-75A \\
\hline $5 \mathrm{~S} / 11 \mathrm{~W}-10 \mathrm{~J} 4$ & WM-99 \\
\hline 5S/11W-2Q6 & WM-OC2 \\
\hline
\end{tabular}

Table 3.2. Observed heads used to simulate boundary conditions at the Los Angeles Narrows.

$[\mathrm{mm} / \mathrm{dd} / \mathrm{yyyy}$, month/day/year; NAVD 88, North American Vertical Datum of 1988]

\begin{tabular}{|c|c|c|c|c|}
\hline $\begin{array}{c}\text { Date (mm/ } \\
\text { dd/yyyy) }\end{array}$ & Well used & $\begin{array}{c}\text { Common } \\
\text { name }\end{array}$ & $\begin{array}{c}\text { Observed } \\
\text { water level, in } \\
\text { feet relative to } \\
\text { NAVD } 88\end{array}$ & $\begin{array}{l}\text { Los Angeles } \\
\text { Narrows } \\
\text { boundary } \\
\text { head, in feet } \\
\text { relative to } \\
\text { NAVD } 88\end{array}$ \\
\hline $01 / 27 / 1971$ & $1 \mathrm{~S} / 13 \mathrm{~W}-15 \mathrm{R} 2$ & $2772 \mathrm{E}$ & 289.5 & 289.5 \\
\hline $02 / 24 / 1971$ & $1 \mathrm{~S} / 13 \mathrm{~W}-15 \mathrm{R} 2$ & $2772 \mathrm{E}$ & 289.4 & 289.4 \\
\hline 03/24/1971 & $1 \mathrm{~S} / 13 \mathrm{~W}-15 \mathrm{R} 2$ & $2772 \mathrm{E}$ & 289.4 & 289.4 \\
\hline 04/29/1971 & $1 \mathrm{~S} / 13 \mathrm{~W}-15 \mathrm{R} 2$ & $2772 \mathrm{E}$ & 289.6 & 289.6 \\
\hline 05/26/1971 & $1 \mathrm{~S} / 13 \mathrm{~W}-15 \mathrm{R} 2$ & $2772 \mathrm{E}$ & 289.6 & 289.6 \\
\hline 06/30/1971 & $1 \mathrm{~S} / 13 \mathrm{~W}-15 \mathrm{R} 2$ & $2772 \mathrm{E}$ & 289.6 & 289.6 \\
\hline $07 / 29 / 1971$ & 1S/13W-15R2 & $2772 \mathrm{E}$ & 289.5 & 289.5 \\
\hline $08 / 26 / 1971$ & $1 \mathrm{~S} / 13 \mathrm{~W}-15 \mathrm{R} 2$ & $2772 \mathrm{E}$ & 289.6 & 289.6 \\
\hline $09 / 22 / 1971$ & $1 \mathrm{~S} / 13 \mathrm{~W}-15 \mathrm{R} 2$ & $2772 \mathrm{E}$ & 289.6 & 289.6 \\
\hline $10 / 27 / 1971$ & $1 \mathrm{~S} / 13 \mathrm{~W}-15 \mathrm{R} 2$ & $2772 \mathrm{E}$ & 289.6 & 289.6 \\
\hline $11 / 04 / 1971$ & $1 \mathrm{~S} / 13 \mathrm{~W}-15 \mathrm{R} 2$ & $2772 \mathrm{E}$ & 289.6 & 289.6 \\
\hline $12 / 30 / 1971$ & 1S/13W-15R2 & $2772 \mathrm{E}$ & 289.8 & 289.8 \\
\hline $01 / 26 / 1972$ & $1 \mathrm{~S} / 13 \mathrm{~W}-15 \mathrm{R} 2$ & $2772 \mathrm{E}$ & 289.6 & 289.6 \\
\hline $02 / 25 / 1972$ & $1 \mathrm{~S} / 13 \mathrm{~W}-15 \mathrm{R} 2$ & $2772 \mathrm{E}$ & 289.6 & 289.6 \\
\hline $03 / 29 / 1972$ & $1 \mathrm{~S} / 13 \mathrm{~W}-15 \mathrm{R} 2$ & $2772 \mathrm{E}$ & 289.5 & 289.5 \\
\hline $04 / 26 / 1972$ & $1 \mathrm{~S} / 13 \mathrm{~W}-15 \mathrm{R} 2$ & $2772 \mathrm{E}$ & 289.5 & 289.5 \\
\hline $05 / 26 / 1972$ & $1 \mathrm{~S} / 13 \mathrm{~W}-15 \mathrm{R} 2$ & $2772 \mathrm{E}$ & 289.4 & 289.4 \\
\hline $06 / 28 / 1972$ & $1 \mathrm{~S} / 13 \mathrm{~W}-15 \mathrm{R} 2$ & $2772 \mathrm{E}$ & 289.4 & 289.4 \\
\hline $07 / 26 / 1972$ & $1 \mathrm{~S} / 13 \mathrm{~W}-15 \mathrm{R} 2$ & $2772 \mathrm{E}$ & 289.4 & 289.4 \\
\hline 08/29/1972 & $1 \mathrm{~S} / 13 \mathrm{~W}-15 \mathrm{R} 2$ & $2772 \mathrm{E}$ & 289.3 & 289.3 \\
\hline $09 / 28 / 1972$ & $1 \mathrm{~S} / 13 \mathrm{~W}-15 \mathrm{R} 2$ & $2772 \mathrm{E}$ & 289.2 & 289.2 \\
\hline $10 / 26 / 1972$ & $1 \mathrm{~S} / 13 \mathrm{~W}-15 \mathrm{R} 2$ & $2772 \mathrm{E}$ & 289.1 & 289.1 \\
\hline $11 / 28 / 1972$ & $1 \mathrm{~S} / 13 \mathrm{~W}-15 \mathrm{R} 2$ & $2772 \mathrm{E}$ & 289.1 & 289.1 \\
\hline $12 / 27 / 1972$ & $1 \mathrm{~S} / 13 \mathrm{~W}-15 \mathrm{R} 2$ & $2772 \mathrm{E}$ & 290 & 290 \\
\hline $01 / 31 / 1973$ & $1 \mathrm{~S} / 13 \mathrm{~W}-15 \mathrm{R} 2$ & $2772 \mathrm{E}$ & 289.5 & 289.5 \\
\hline $02 / 21 / 1973$ & $1 \mathrm{~S} / 13 \mathrm{~W}-15 \mathrm{R} 2$ & $2772 \mathrm{E}$ & 289.8 & 289.8 \\
\hline $03 / 29 / 1973$ & $1 \mathrm{~S} / 13 \mathrm{~W}-15 \mathrm{R} 2$ & $2772 \mathrm{E}$ & 290 & 290 \\
\hline $04 / 27 / 1973$ & $1 \mathrm{~S} / 13 \mathrm{~W}-15 \mathrm{R} 2$ & $2772 \mathrm{E}$ & 290.1 & 290.1 \\
\hline $05 / 24 / 1973$ & $1 \mathrm{~S} / 13 \mathrm{~W}-15 \mathrm{R} 2$ & $2772 \mathrm{E}$ & 290 & 290 \\
\hline 05/30/1974 & $1 \mathrm{~S} / 13 \mathrm{~W}-15 \mathrm{R} 2$ & $2772 \mathrm{E}$ & 289 & 289 \\
\hline 06/26/1974 & $1 \mathrm{~S} / 13 \mathrm{~W}-15 \mathrm{R} 2$ & $2772 \mathrm{E}$ & 288.8 & 288.8 \\
\hline 07/24/1974 & 1S/13W-15R2 & $2772 \mathrm{E}$ & 290 & 290 \\
\hline 08/30/1974 & $1 \mathrm{~S} / 13 \mathrm{~W}-15 \mathrm{R} 2$ & $2772 \mathrm{E}$ & 290.1 & 290.1 \\
\hline 09/27/1974 & $1 \mathrm{~S} / 13 \mathrm{~W}-15 \mathrm{R} 2$ & $2772 \mathrm{E}$ & 289.9 & 289.9 \\
\hline $10 / 30 / 1974$ & $1 \mathrm{~S} / 13 \mathrm{~W}-15 \mathrm{R} 2$ & $2772 \mathrm{E}$ & 289.9 & 289.9 \\
\hline $11 / 21 / 1974$ & $1 \mathrm{~S} / 13 \mathrm{~W}-15 \mathrm{R} 2$ & $2772 \mathrm{E}$ & 289.9 & 289.9 \\
\hline $12 / 26 / 1974$ & $1 \mathrm{~S} / 13 \mathrm{~W}-15 \mathrm{R} 2$ & $2772 \mathrm{E}$ & 289.8 & 289.8 \\
\hline $04 / 24 / 1975$ & $1 \mathrm{~S} / 13 \mathrm{~W}-15 \mathrm{R} 2$ & $2772 \mathrm{E}$ & 290 & 290 \\
\hline
\end{tabular}


Table 3.2. Observed heads used to simulate boundary conditions at the Los Angeles Narrows.-Continued

[mm/dd/yyyy, month/day/year; NAVD 88, North American Vertical Datum of 1988]

\begin{tabular}{|c|c|c|c|c|c|c|c|c|c|}
\hline $\begin{array}{l}\text { Date (mm/ } \\
\text { dd/yyyy) }\end{array}$ & Well used & $\begin{array}{c}\text { Common } \\
\text { name }\end{array}$ & $\begin{array}{c}\text { Observed } \\
\text { water level, in } \\
\text { feet relative to } \\
\text { NAVD } 88\end{array}$ & $\begin{array}{l}\text { Los Angeles } \\
\text { Narrows } \\
\text { boundary } \\
\text { head, in feet } \\
\text { relative to } \\
\text { NAVD } 88\end{array}$ & $\begin{array}{c}\text { Date (mm/ } \\
\text { dd/yyyy) }\end{array}$ & Well used & $\begin{array}{c}\text { Common } \\
\text { name }\end{array}$ & $\begin{array}{c}\text { Observed } \\
\text { water level, in } \\
\text { feet relative to } \\
\text { NAVD } 88\end{array}$ & $\begin{array}{l}\text { Los Angeles } \\
\text { Narrows } \\
\text { boundary } \\
\text { o head, in feet } \\
\text { relative to } \\
\text { NAVD } 88\end{array}$ \\
\hline $06 / 25 / 1975$ & $1 \mathrm{~S} / 13 \mathrm{~W}-15 \mathrm{R} 2$ & $2772 \mathrm{E}$ & 290.1 & 290.1 & $09 / 21 / 1978$ & $1 \mathrm{~S} / 13 \mathrm{~W}-15 \mathrm{R} 2$ & $2772 \mathrm{E}$ & 289.2 & 289.2 \\
\hline 07/23/1975 & $1 \mathrm{~S} / 13 \mathrm{~W}-15 \mathrm{R} 2$ & $2772 \mathrm{E}$ & 290 & 290 & $10 / 19 / 1978$ & $1 \mathrm{~S} / 13 \mathrm{~W}-15 \mathrm{R} 2$ & $2772 \mathrm{E}$ & 289.1 & 289.1 \\
\hline 08/27/1975 & $1 \mathrm{~S} / 13 \mathrm{~W}-15 \mathrm{R} 2$ & $2772 \mathrm{E}$ & 289.1 & 289.1 & $11 / 16 / 1978$ & $1 \mathrm{~S} / 13 \mathrm{~W}-15 \mathrm{R} 2$ & $2772 \mathrm{E}$ & 289.2 & 289.2 \\
\hline 09/24/1975 & 1S/13W-15R2 & $2772 \mathrm{E}$ & 289.1 & 289.1 & $12 / 27 / 1978$ & $1 \mathrm{~S} / 13 \mathrm{~W}-15 \mathrm{R} 2$ & $2772 \mathrm{E}$ & 289.1 & 289.1 \\
\hline $10 / 23 / 1975$ & 1S/13W-15R2 & $2772 \mathrm{E}$ & 285.8 & 285.8 & $01 / 18 / 1979$ & $1 \mathrm{~S} / 13 \mathrm{~W}-15 \mathrm{R} 2$ & $2772 \mathrm{E}$ & 288.8 & 288.8 \\
\hline $11 / 25 / 1975$ & $1 \mathrm{~S} / 13 \mathrm{~W}-15 \mathrm{R} 2$ & $2772 \mathrm{E}$ & 289.4 & 289.4 & $03 / 22 / 1979$ & $1 \mathrm{~S} / 13 \mathrm{~W}-15 \mathrm{R} 2$ & $2772 \mathrm{E}$ & 289 & 289 \\
\hline $12 / 17 / 1975$ & $1 \mathrm{~S} / 13 \mathrm{~W}-15 \mathrm{R} 2$ & $2772 \mathrm{E}$ & 289.2 & 289.2 & $04 / 19 / 1979$ & $1 \mathrm{~S} / 13 \mathrm{~W}-15 \mathrm{R} 2$ & $2772 \mathrm{E}$ & 289.4 & 289.4 \\
\hline $01 / 22 / 1976$ & 1S/13W-15R2 & $2772 \mathrm{E}$ & 289 & 289 & 05/30/1979 & $1 \mathrm{~S} / 13 \mathrm{~W}-15 \mathrm{R} 2$ & $2772 \mathrm{E}$ & 289.3 & 289.3 \\
\hline 02/19/1976 & $1 \mathrm{~S} / 13 \mathrm{~W}-15 \mathrm{R} 2$ & $2772 \mathrm{E}$ & 289.1 & 289.1 & $11 / 29 / 1979$ & $1 \mathrm{~S} / 13 \mathrm{~W}-15 \mathrm{R} 2$ & $2772 \mathrm{E}$ & 289.2 & 289.2 \\
\hline 03/18/1976 & $1 \mathrm{~S} / 13 \mathrm{~W}-15 \mathrm{R} 2$ & $2772 \mathrm{E}$ & 289 & 289 & $11 / 19 / 1980$ & $1 \mathrm{~S} / 13 \mathrm{~W}-15 \mathrm{R} 2$ & $2772 \mathrm{E}$ & 289.3 & 289.3 \\
\hline 04/21/1976 & 1S/13W-15R2 & $2772 \mathrm{E}$ & 289 & 289 & $11 / 24 / 1981$ & $1 \mathrm{~S} / 13 \mathrm{~W}-15 \mathrm{R} 2$ & $2772 \mathrm{E}$ & 288.7 & 288.7 \\
\hline 05/19/1976 & $1 \mathrm{~S} / 13 \mathrm{~W}-15 \mathrm{R} 2$ & $2772 \mathrm{E}$ & 289 & 289 & $04 / 21 / 1982$ & $1 \mathrm{~S} / 13 \mathrm{~W}-15 \mathrm{R} 2$ & $2772 \mathrm{E}$ & 289.1 & 289.1 \\
\hline 06/23/1976 & 1S/13W-15R2 & $2772 \mathrm{E}$ & 288.9 & 288.9 & $11 / 18 / 1982$ & $1 \mathrm{~S} / 13 \mathrm{~W}-15 \mathrm{R} 2$ & $2772 \mathrm{E}$ & 288.8 & 288.8 \\
\hline 07/22/1976 & $1 \mathrm{~S} / 13 \mathrm{~W}-15 \mathrm{R} 2$ & $2772 \mathrm{E}$ & 288.9 & 288.9 & $04 / 21 / 1983$ & $1 \mathrm{~S} / 13 \mathrm{~W}-15 \mathrm{R} 2$ & $2772 \mathrm{E}$ & 287.9 & 287.9 \\
\hline 08/25/1976 & 1S/13W-15R2 & $2772 \mathrm{E}$ & 288.9 & 288.9 & $10 / 19 / 1983$ & $1 \mathrm{~S} / 13 \mathrm{~W}-15 \mathrm{R} 2$ & $2772 \mathrm{E}$ & 288.5 & 288.5 \\
\hline 09/23/1976 & 1S/13W-15R2 & $2772 \mathrm{E}$ & 290.4 & 290.4 & $04 / 27 / 1984$ & $1 \mathrm{~S} / 13 \mathrm{~W}-15 \mathrm{R} 2$ & $2772 \mathrm{E}$ & 289.7 & 289.7 \\
\hline $10 / 20 / 1976$ & 1S/13W-15R2 & $2772 \mathrm{E}$ & 288.9 & 288.9 & $10 / 18 / 1984$ & $1 \mathrm{~S} / 13 \mathrm{~W}-15 \mathrm{R} 2$ & $2772 \mathrm{E}$ & 289.3 & 289.3 \\
\hline $11 / 17 / 1976$ & $1 \mathrm{~S} / 13 \mathrm{~W}-15 \mathrm{R} 2$ & $2772 \mathrm{E}$ & 289 & 289 & $04 / 18 / 1985$ & $1 \mathrm{~S} / 13 \mathrm{~W}-15 \mathrm{R} 2$ & $2772 \mathrm{E}$ & 289.3 & 289.3 \\
\hline $12 / 16 / 1976$ & 1S/13W-15R2 & $2772 \mathrm{E}$ & 289 & 289 & $10 / 31 / 1985$ & $1 \mathrm{~S} / 13 \mathrm{~W}-15 \mathrm{R} 2$ & $2772 \mathrm{E}$ & 281.3 & 281.3 \\
\hline 01/20/1977 & $1 \mathrm{~S} / 13 \mathrm{~W}-15 \mathrm{R} 2$ & $2772 \mathrm{E}$ & 288.9 & 288.9 & $01 / 31 / 1986$ & $1 \mathrm{~S} / 13 \mathrm{~W}-15 \mathrm{R} 2$ & $2772 \mathrm{E}$ & 289.2 & 289.2 \\
\hline 02/23/1977 & $1 \mathrm{~S} / 13 \mathrm{~W}-15 \mathrm{R} 2$ & $2772 \mathrm{E}$ & 288.9 & 288.9 & $03 / 27 / 1986$ & $1 \mathrm{~S} / 13 \mathrm{~W}-15 \mathrm{R} 2$ & $2772 \mathrm{E}$ & 289.5 & 289.5 \\
\hline 03/24/1977 & 1S/13W-15R2 & $2772 \mathrm{E}$ & 288.7 & 288.7 & $04 / 24 / 1986$ & $1 \mathrm{~S} / 13 \mathrm{~W}-15 \mathrm{R} 2$ & $2772 \mathrm{E}$ & 289.5 & 289.5 \\
\hline 04/21/1977 & 1S/13W-15R2 & $2772 \mathrm{E}$ & 288.4 & 288.4 & $05 / 23 / 1986$ & $1 \mathrm{~S} / 13 \mathrm{~W}-15 \mathrm{R} 2$ & $2772 \mathrm{E}$ & 289.5 & 289.5 \\
\hline 05/25/1977 & $1 \mathrm{~S} / 13 \mathrm{~W}-15 \mathrm{R} 2$ & $2772 \mathrm{E}$ & 288.8 & 288.8 & $10 / 27 / 1986$ & $1 \mathrm{~S} / 13 \mathrm{~W}-15 \mathrm{R} 2$ & $2772 \mathrm{E}$ & 289.7 & 289.7 \\
\hline 06/16/1977 & $1 \mathrm{~S} / 13 \mathrm{~W}-15 \mathrm{R} 2$ & $2772 \mathrm{E}$ & 288.1 & 288.1 & $11 / 25 / 1986$ & $1 \mathrm{~S} / 13 \mathrm{~W}-15 \mathrm{R} 2$ & $2772 \mathrm{E}$ & 289.7 & 289.7 \\
\hline 07/29/1977 & $1 \mathrm{~S} / 13 \mathrm{~W}-15 \mathrm{R} 2$ & $2772 \mathrm{E}$ & 288.7 & 288.7 & $01 / 30 / 1987$ & $1 \mathrm{~S} / 13 \mathrm{~W}-15 \mathrm{R} 2$ & $2772 \mathrm{E}$ & 289.7 & 289.7 \\
\hline 08/30/1977 & 1S/13W-15R2 & $2772 \mathrm{E}$ & 288.7 & 288.7 & $04 / 29 / 1987$ & $1 \mathrm{~S} / 13 \mathrm{~W}-15 \mathrm{R} 2$ & $2772 \mathrm{E}$ & 289.4 & 289.4 \\
\hline 09/22/1977 & $1 \mathrm{~S} / 13 \mathrm{~W}-15 \mathrm{R} 2$ & $2772 \mathrm{E}$ & 288.6 & 288.6 & $05 / 20 / 1987$ & $1 \mathrm{~S} / 13 \mathrm{~W}-15 \mathrm{R} 2$ & $2772 \mathrm{E}$ & 289.3 & 289.3 \\
\hline 10/27/1977 & 1S/13W-15R2 & $2772 \mathrm{E}$ & 288.7 & 288.7 & $06 / 23 / 1987$ & $1 \mathrm{~S} / 13 \mathrm{~W}-15 \mathrm{R} 2$ & $2772 \mathrm{E}$ & 289.3 & 289.3 \\
\hline 11/18/1977 & 1S/13W-15R2 & $2772 \mathrm{E}$ & 288.7 & 288.7 & $07 / 23 / 1987$ & $1 \mathrm{~S} / 13 \mathrm{~W}-15 \mathrm{R} 2$ & $2772 \mathrm{E}$ & 289.2 & 289.2 \\
\hline $12 / 29 / 1977$ & $1 \mathrm{~S} / 13 \mathrm{~W}-15 \mathrm{R} 2$ & $2772 \mathrm{E}$ & 289.1 & 289.1 & 08/28/1987 & $1 \mathrm{~S} / 13 \mathrm{~W}-15 \mathrm{R} 2$ & $2772 \mathrm{E}$ & 289.2 & 289.2 \\
\hline 01/26/1978 & 1S/13W-15R2 & $2772 \mathrm{E}$ & 288.9 & 288.9 & 09/30/1987 & $1 \mathrm{~S} / 13 \mathrm{~W}-15 \mathrm{R} 2$ & $2772 \mathrm{E}$ & 289.2 & 289.2 \\
\hline 02/23/1978 & $1 \mathrm{~S} / 13 \mathrm{~W}-15 \mathrm{R} 2$ & $2772 \mathrm{E}$ & 289.2 & 289.2 & $10 / 27 / 1987$ & $1 \mathrm{~S} / 13 \mathrm{~W}-15 \mathrm{R} 2$ & $2772 E$ & 289.4 & 289.4 \\
\hline 03/24/1978 & 1S/13W-15R2 & $2772 \mathrm{E}$ & 289.7 & 289.7 & $11 / 23 / 1987$ & $1 \mathrm{~S} / 13 \mathrm{~W}-15 \mathrm{R} 2$ & $2772 \mathrm{E}$ & 289.2 & 289.2 \\
\hline 04/20/1978 & 1S/13W-15R2 & $2772 \mathrm{E}$ & 288.9 & 288.9 & $12 / 21 / 1987$ & $1 \mathrm{~S} / 13 \mathrm{~W}-15 \mathrm{R} 2$ & $2772 \mathrm{E}$ & 289.4 & 289.4 \\
\hline $05 / 25 / 1978$ & $1 \mathrm{~S} / 13 \mathrm{~W}-15 \mathrm{R} 2$ & $2772 \mathrm{E}$ & 289.4 & 289.4 & $01 / 29 / 1988$ & $1 \mathrm{~S} / 13 \mathrm{~W}-15 \mathrm{R} 2$ & $2772 \mathrm{E}$ & 290.2 & 290.2 \\
\hline $06 / 22 / 1978$ & $1 \mathrm{~S} / 13 \mathrm{~W}-15 \mathrm{R} 2$ & $2772 \mathrm{E}$ & 289.3 & 289.3 & $02 / 18 / 1988$ & $1 \mathrm{~S} / 13 \mathrm{~W}-15 \mathrm{R} 2$ & $2772 E$ & 289.4 & 289.4 \\
\hline 07/26/1978 & $1 \mathrm{~S} / 13 \mathrm{~W}-15 \mathrm{R} 2$ & $2772 \mathrm{E}$ & 289.4 & 289.4 & $03 / 29 / 1988$ & $1 \mathrm{~S} / 13 \mathrm{~W}-15 \mathrm{R} 2$ & $2772 \mathrm{E}$ & 289.3 & 289.3 \\
\hline 08/30/1978 & $1 \mathrm{~S} / 13 \mathrm{~W}-15 \mathrm{R} 2$ & $2772 \mathrm{E}$ & 289.3 & 289.3 & $04 / 22 / 1988$ & $1 \mathrm{~S} / 13 \mathrm{~W}-15 \mathrm{R} 2$ & $2772 \mathrm{E}$ & 289.5 & 289.5 \\
\hline
\end{tabular}


Table 3.2. Observed heads used to simulate boundary conditions at the Los Angeles Narrows. - Continued [mm/dd/yyyy, month/day/year; NAVD 88, North American Vertical Datum of 1988]

\begin{tabular}{|c|c|c|c|c|c|c|c|c|c|}
\hline $\begin{array}{c}\text { Date (mm/ } \\
\text { dd/yyyy) }\end{array}$ & Well used & $\begin{array}{c}\text { Common } \\
\text { name }\end{array}$ & $\begin{array}{c}\text { Observed } \\
\text { water level, in } \\
\text { feet relative to } \\
\text { NAVD } 88\end{array}$ & $\begin{array}{l}\text { Los Angeles } \\
\text { Narrows } \\
\text { boundary } \\
\text { head, in feet } \\
\text { relative to } \\
\text { NAVD } 88\end{array}$ & $\begin{array}{l}\text { Date (mm/ } \\
\text { dd/yyyy) }\end{array}$ & Well used & $\begin{array}{c}\text { Common } \\
\text { name }\end{array}$ & $\begin{array}{c}\text { Observed } \\
\text { water level, in } \\
\text { feet relative to } \\
\text { NAVD } 88\end{array}$ & $\begin{array}{l}\text { Los Angeles } \\
\text { Narrows } \\
\text { boundary } \\
\text { head, in feet } \\
\text { relative to } \\
\text { NAVD } 88\end{array}$ \\
\hline $05 / 24 / 1988$ & $1 \mathrm{~S} / 13 \mathrm{~W}-15 \mathrm{R} 2$ & $2772 \mathrm{E}$ & 289.5 & 289.5 & $04 / 06 / 2001$ & $1 \mathrm{~S} / 13 \mathrm{~W}-15 \mathrm{R} 2$ & $2772 \mathrm{E}$ & 289.5 & 289.5 \\
\hline $06 / 28 / 1988$ & $1 \mathrm{~S} / 13 \mathrm{~W}-15 \mathrm{R} 2$ & $2772 \mathrm{E}$ & 289.5 & 289.5 & $01 / 20 / 2007$ & 1S/13W-15R2 & $2772 \mathrm{E}$ & 288.5 & 288.5 \\
\hline 07/28/1988 & $1 \mathrm{~S} / 13 \mathrm{~W}-15 \mathrm{R} 2$ & $2772 \mathrm{E}$ & 289.5 & 289.5 & $04 / 07 / 2007$ & $1 \mathrm{~S} / 13 \mathrm{~W}-15 \mathrm{R} 2$ & $2772 \mathrm{E}$ & 288.5 & 288.5 \\
\hline 08/19/1988 & $1 \mathrm{~S} / 13 \mathrm{~W}-15 \mathrm{R} 2$ & $2772 \mathrm{E}$ & 289.6 & 289.6 & $09 / 15 / 2007$ & $1 \mathrm{~S} / 13 \mathrm{~W}-15 \mathrm{R} 2$ & $2772 \mathrm{E}$ & 288.5 & 288.5 \\
\hline 09/16/1988 & $1 \mathrm{~S} / 13 \mathrm{~W}-15 \mathrm{R} 2$ & $2772 \mathrm{E}$ & 289.7 & 289.7 & $11 / 29 / 2007$ & $1 \mathrm{~S} / 13 \mathrm{~W}-15 \mathrm{R} 2$ & $2772 \mathrm{E}$ & 288.2 & 288.2 \\
\hline $10 / 21 / 1988$ & $1 \mathrm{~S} / 13 \mathrm{~W}-15 \mathrm{R} 2$ & $2772 \mathrm{E}$ & 289.7 & 289.7 & $12 / 21 / 2007$ & 1S/13W-15R2 & $2772 \mathrm{E}$ & 288.6 & 288.6 \\
\hline $11 / 23 / 1988$ & $1 \mathrm{~S} / 13 \mathrm{~W}-15 \mathrm{R} 2$ & $2772 \mathrm{E}$ & 289.7 & 289.7 & $03 / 17 / 2008$ & $1 \mathrm{~S} / 13 \mathrm{~W}-15 \mathrm{R} 2$ & $2772 \mathrm{E}$ & 288.3 & 288.3 \\
\hline $12 / 15 / 1988$ & $1 \mathrm{~S} / 13 \mathrm{~W}-15 \mathrm{R} 2$ & $2772 \mathrm{E}$ & 289.6 & 289.6 & $06 / 02 / 2008$ & $1 \mathrm{~S} / 13 \mathrm{~W}-15 \mathrm{R} 2$ & $2772 \mathrm{E}$ & 288.3 & 288.3 \\
\hline $02 / 28 / 1989$ & $1 \mathrm{~S} / 13 \mathrm{~W}-15 \mathrm{R} 2$ & $2772 \mathrm{E}$ & 289.5 & 289.5 & $07 / 07 / 2008$ & 1S/13W-15R2 & $2772 \mathrm{E}$ & 288.3 & 288.3 \\
\hline $03 / 24 / 1989$ & $1 \mathrm{~S} / 13 \mathrm{~W}-15 \mathrm{R} 2$ & $2772 \mathrm{E}$ & 289.4 & 289.4 & $08 / 11 / 2008$ & $1 \mathrm{~S} / 13 \mathrm{~W}-15 \mathrm{R} 2$ & $2772 \mathrm{E}$ & 288 & 288 \\
\hline $04 / 24 / 1989$ & $1 \mathrm{~S} / 13 \mathrm{~W}-15 \mathrm{R} 2$ & $2772 \mathrm{E}$ & 289.3 & 289.3 & 09/08/2008 & $1 \mathrm{~S} / 13 \mathrm{~W}-15 \mathrm{R} 2$ & $2772 \mathrm{E}$ & 287.5 & 287.5 \\
\hline 09/22/1989 & $1 \mathrm{~S} / 13 \mathrm{~W}-15 \mathrm{R} 2$ & $2772 \mathrm{E}$ & 289.5 & 289.5 & $12 / 02 / 2008$ & 1S/13W-15R2 & $2772 \mathrm{E}$ & 289 & 289 \\
\hline $10 / 25 / 1989$ & $1 \mathrm{~S} / 13 \mathrm{~W}-15 \mathrm{R} 2$ & $2772 \mathrm{E}$ & 289.5 & 289.5 & $07 / 06 / 2009$ & $1 \mathrm{~S} / 13 \mathrm{~W}-15 \mathrm{R} 2$ & $2772 \mathrm{E}$ & 288.9 & 288.9 \\
\hline $11 / 29 / 1989$ & $1 \mathrm{~S} / 13 \mathrm{~W}-15 \mathrm{R} 2$ & $2772 \mathrm{E}$ & 268 & 268 & 08/03/2009 & $1 \mathrm{~S} / 13 \mathrm{~W}-15 \mathrm{R} 2$ & $2772 \mathrm{E}$ & 288.8 & 288.8 \\
\hline $12 / 18 / 1989$ & $1 \mathrm{~S} / 13 \mathrm{~W}-15 \mathrm{R} 2$ & $2772 \mathrm{E}$ & 289.2 & 289.2 & 09/14/2009 & $1 \mathrm{~S} / 13 \mathrm{~W}-15 \mathrm{R} 2$ & $2772 \mathrm{E}$ & 288.7 & 288.7 \\
\hline 01/18/1990 & $1 \mathrm{~S} / 13 \mathrm{~W}-15 \mathrm{R} 2$ & $2772 \mathrm{E}$ & 289.3 & 289.3 & $12 / 10 / 2009$ & $1 \mathrm{~S} / 13 \mathrm{~W}-15 \mathrm{R} 2$ & $2772 \mathrm{E}$ & 288.7 & 288.7 \\
\hline $02 / 28 / 1990$ & $1 \mathrm{~S} / 13 \mathrm{~W}-15 \mathrm{R} 2$ & $2772 \mathrm{E}$ & 289.5 & 289.5 & $01 / 04 / 2010$ & $1 \mathrm{~S} / 13 \mathrm{~W}-15 \mathrm{R} 2$ & $2772 \mathrm{E}$ & 288.6 & 288.6 \\
\hline 03/17/1990 & $1 \mathrm{~S} / 13 \mathrm{~W}-15 \mathrm{R} 2$ & $2772 \mathrm{E}$ & 289.5 & 289.5 & $10 / 15 / 2011$ & $1 \mathrm{~S} / 13 \mathrm{~W}-15 \mathrm{H} 1$ & $2771 \mathrm{I}$ & 299.7 & 290.5 \\
\hline $04 / 21 / 1990$ & $1 \mathrm{~S} / 13 \mathrm{~W}-15 \mathrm{R} 2$ & $2772 \mathrm{E}$ & 289.6 & 289.6 & $08 / 10 / 2012$ & $1 \mathrm{~S} / 13 \mathrm{~W}-15 \mathrm{H} 1$ & $2771 \mathrm{I}$ & 299 & 289.3 \\
\hline 05/17/1990 & $1 \mathrm{~S} / 13 \mathrm{~W}-15 \mathrm{R} 2$ & $2772 \mathrm{E}$ & 289.3 & 289.3 & $10 / 15 / 2012$ & 1S/13W-15H1 & $2771 \mathrm{I}$ & 298.5 & 288.4 \\
\hline $07 / 27 / 1990$ & $1 \mathrm{~S} / 13 \mathrm{~W}-15 \mathrm{R} 2$ & $2772 \mathrm{E}$ & 289.4 & 289.4 & $09 / 11 / 2013$ & 1S/13W-15H1 & $2771 \mathrm{I}$ & 297.55 & 286.7 \\
\hline $10 / 11 / 1990$ & $1 \mathrm{~S} / 13 \mathrm{~W}-15 \mathrm{R} 2$ & $2772 \mathrm{E}$ & 289.2 & 289.2 & $03 / 12 / 2014$ & $1 \mathrm{~S} / 13 \mathrm{~W}-15 \mathrm{H} 1$ & $2771 \mathrm{I}$ & 298.03 & 287.6 \\
\hline $11 / 02 / 1990$ & $1 \mathrm{~S} / 13 \mathrm{~W}-15 \mathrm{R} 2$ & $2772 \mathrm{E}$ & 289.2 & 289.2 & $10 / 16 / 2014$ & $1 \mathrm{~S} / 13 \mathrm{~W}-15 \mathrm{H} 1$ & $2771 \mathrm{I}$ & 297.08 & 285.9 \\
\hline 01/10/1991 & $1 \mathrm{~S} / 13 \mathrm{~W}-15 \mathrm{R} 2$ & $2772 \mathrm{E}$ & 289.4 & 289.4 & $03 / 18 / 2015$ & 1S/13W-15H1 & $2771 \mathrm{I}$ & 297 & 285.7 \\
\hline 02/06/1991 & $1 \mathrm{~S} / 13 \mathrm{~W}-15 \mathrm{R} 2$ & $2772 \mathrm{E}$ & 289.1 & 289.1 & $10 / 08 / 2015$ & $1 \mathrm{~S} / 13 \mathrm{~W}-15 \mathrm{H} 1$ & $2771 \mathrm{I}$ & 295.65 & 283.4 \\
\hline
\end{tabular}

03/08/1991 1S/13W-15R2 2772E

04/09/1991 1S/13W-15R2 2772E

05/03/1991 1S/13W-15R2 2772E

06/07/1991 1S/13W-15R2 2772E

07/02/1991 1S/13W-15R2 2772E

08/08/1991 1S/13W-15R2 2772E

10/04/1991 1S/13W-15R2 2772E

11/05/1991 1S/13W-15R2 2772E

12/17/1991 1S/13W-15R2 2772E

01/14/1992 1S/13W-15R2 2772E

02/14/1992 1S/13W-15R2 2772E

03/06/1992 1S/13W-15R2 2772E

05/13/2000 1S/13W-15R2 2772E

$10 / 17 / 2000 \quad 1 \mathrm{~S} / 13 \mathrm{~W}-15 \mathrm{R} 2 \quad 2772 \mathrm{E}$
$289.2 \quad 289.2$

$289.2 \quad 289.2$

$289.2 \quad 289.2$

$289.2 \quad 289.2$

$289.2 \quad 289.2$

$289.3 \quad 289.3$

$289.5 \quad 289.5$

$290 \quad 290$

$289.4 \quad 289.4$

$289.5 \quad 289.5$

$289.7 \quad 289.7$

$289.7 \quad 289.7$

$289.7 \quad 289.7$

$289.5 \quad 289.5$

\section{References Cited}

Panday, S., Langevin, C.D., Niswonger, R.G., Ibaraki, M., and Hughes, J.D., 2013, MODFLOW-USG version 1-An unstructured grid version of MODFLOW for simulating groundwater flow and tightly coupled processes using a control volume finite-difference formulation: U.S. Geological Survey Techniques and Methods 6-A45, 66 p., https://doi.org/10.3133/tm6A45. 


\section{Appendix 4. Results for Los Angeles Coastal Plain Groundwater-flow Model and Management Scenario Simulations}

Appendix 4 figures contain detailed groundwater-flow budgets by subarea and groundwater-flow maps by layer of the Los Angeles Coastal Plain Groundwater Model (LACPGM).
Appendix 4 tables contain detailed groundwater-flow budgets by subarea of the LACPGM and detailed groundwater-flow budgets of the future water-management scenarios. 

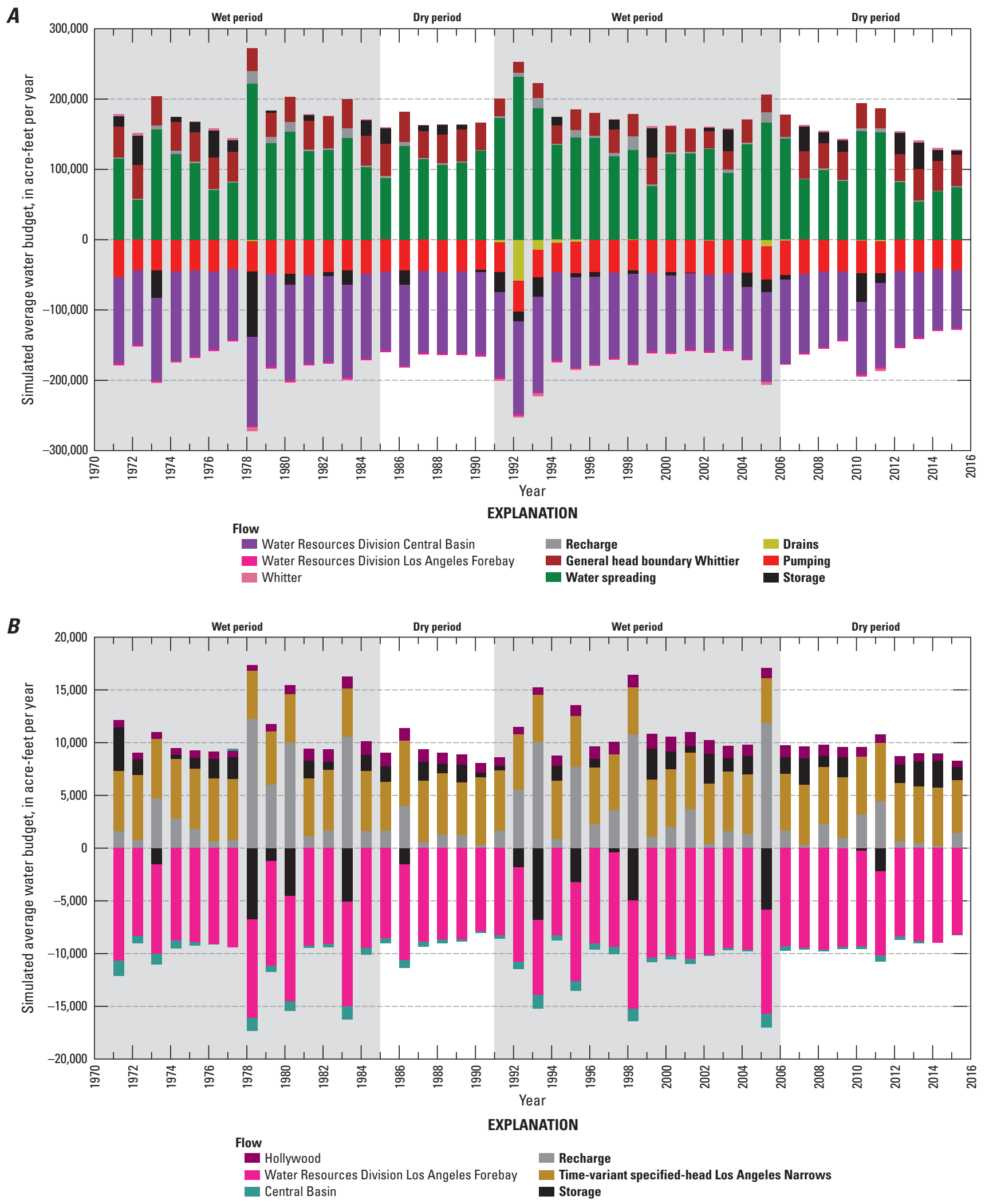

Figure 4.1. Simulated average annual groundwater-flow budgets by subarea of the Los Angeles Coastal Plain Groundwater-flow Model, Los Angeles and Orange Counties, California, 1971 to 2015: A, Montebello Forebay; $B$, Los Angeles Forebay, non-Water Replenishment District of Southern California (WRD); C, Los Angeles Forebay, WRD; D, Hollywood Basin; E, Central Basin Pressure Area, non-WRD; F, Central Basin Pressure Area, WRD; G, Orange County, North; H, Orange County, Central; I, Orange County, South; J, Santa Monica Basin; $K$, Whittier area; and $L$, West Coast Basin. 

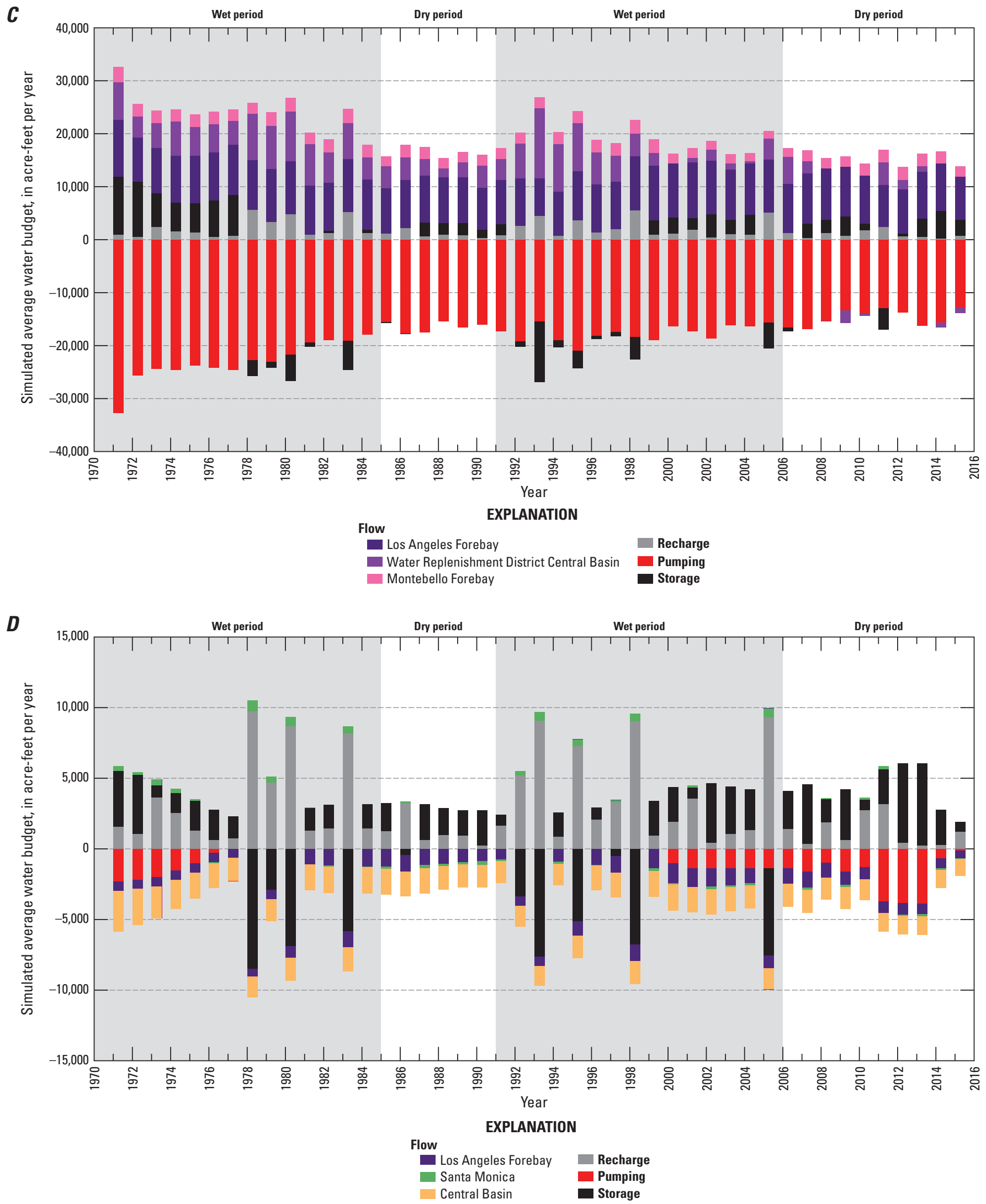

Figure 4.1.-Continued 

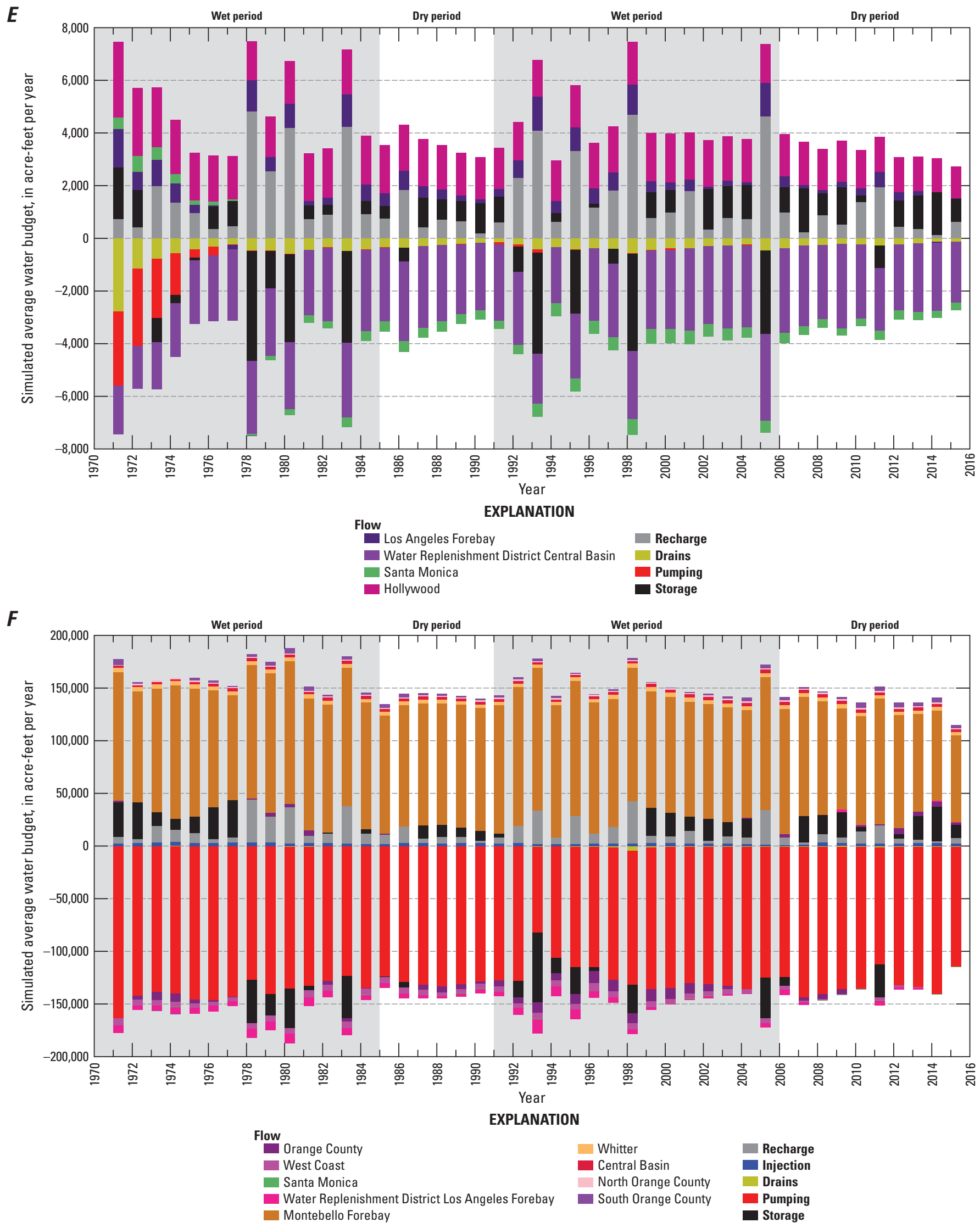

Figure 4.1.-Continued 

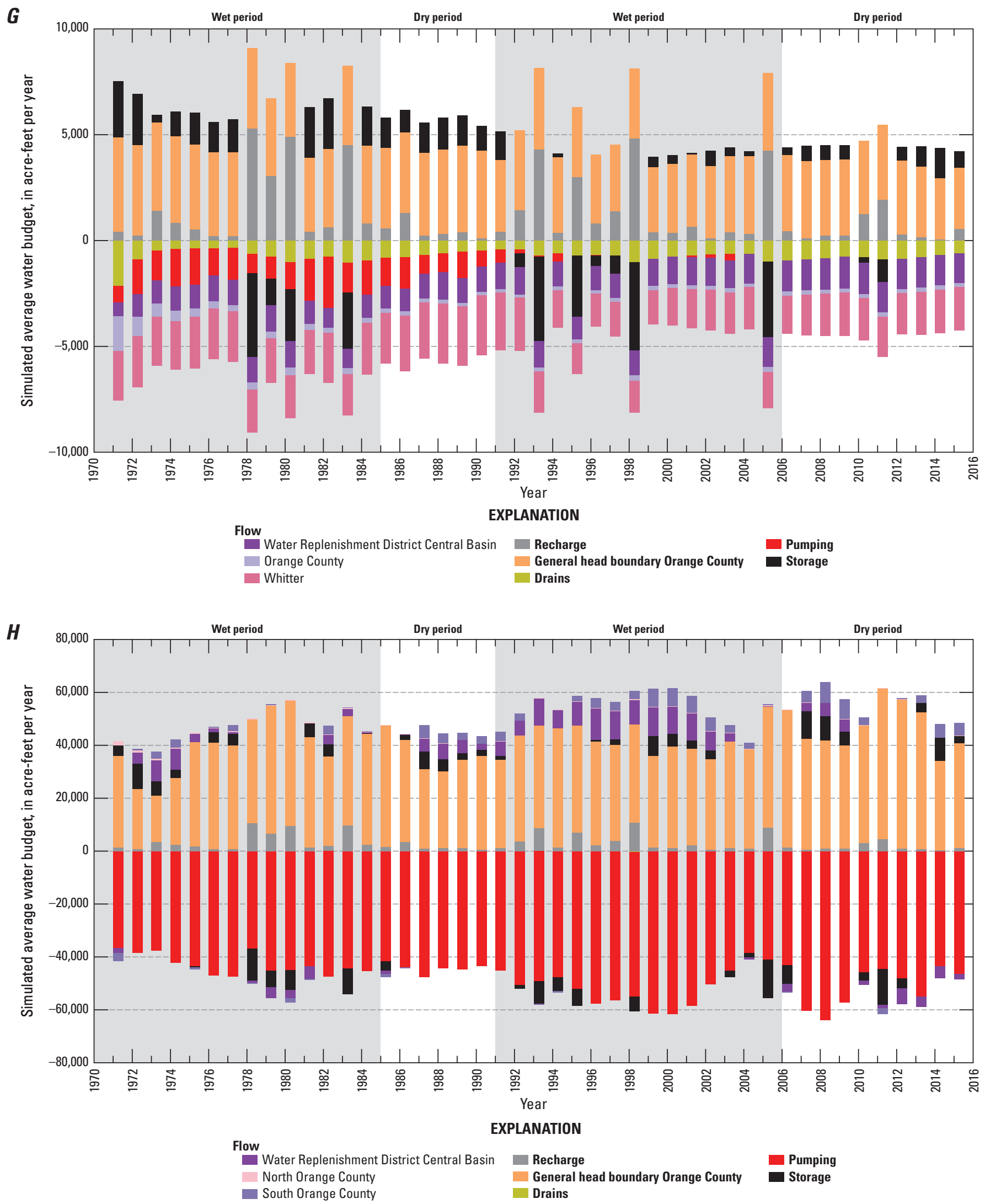

Figure 4.1.-Continued 

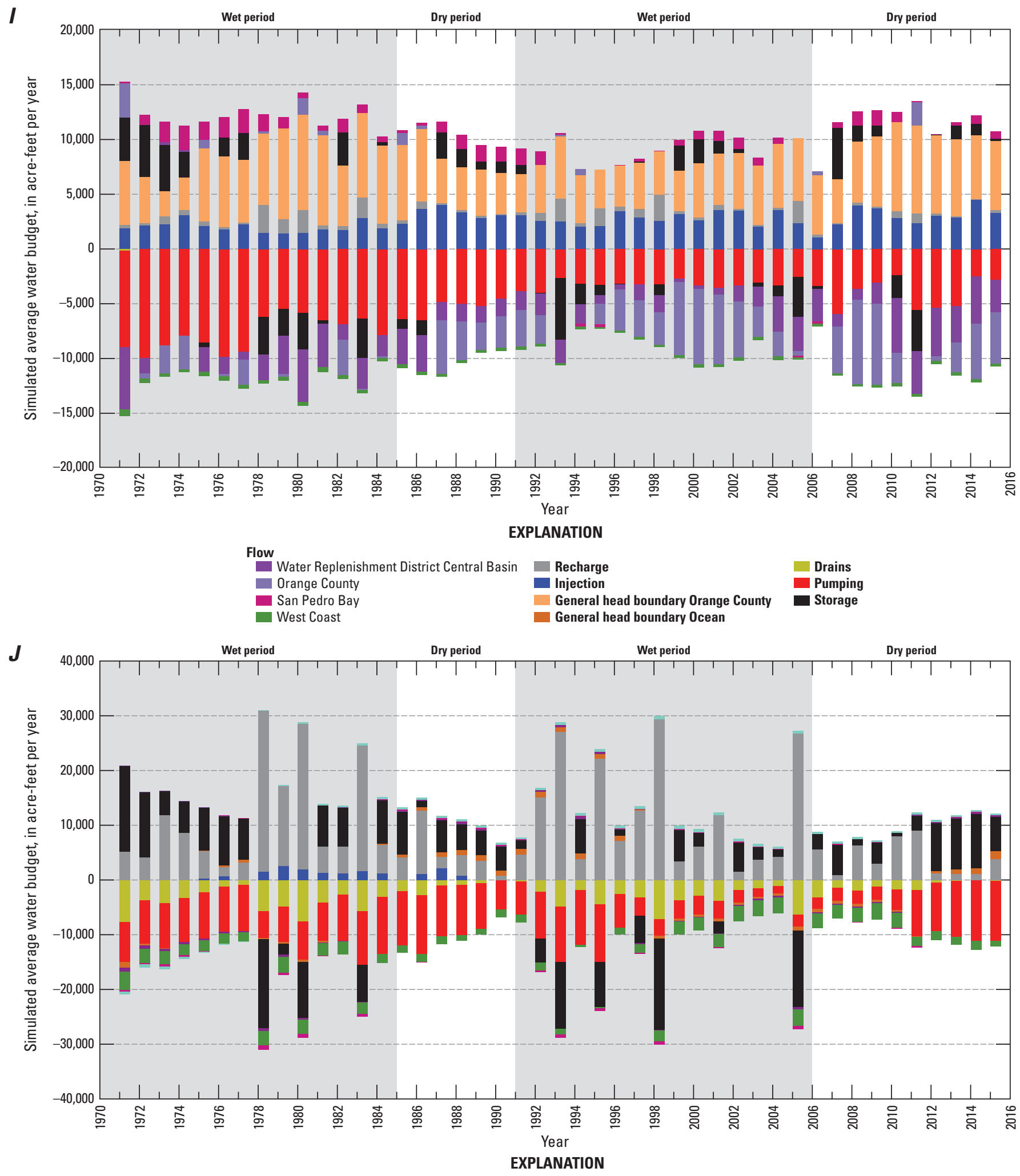

Flow

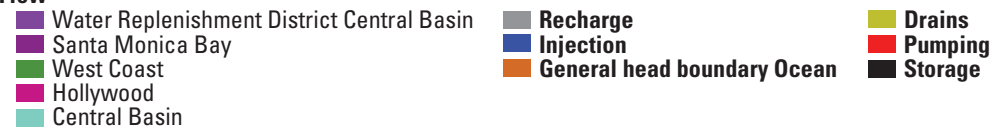

Figure 4.1.-Continued 

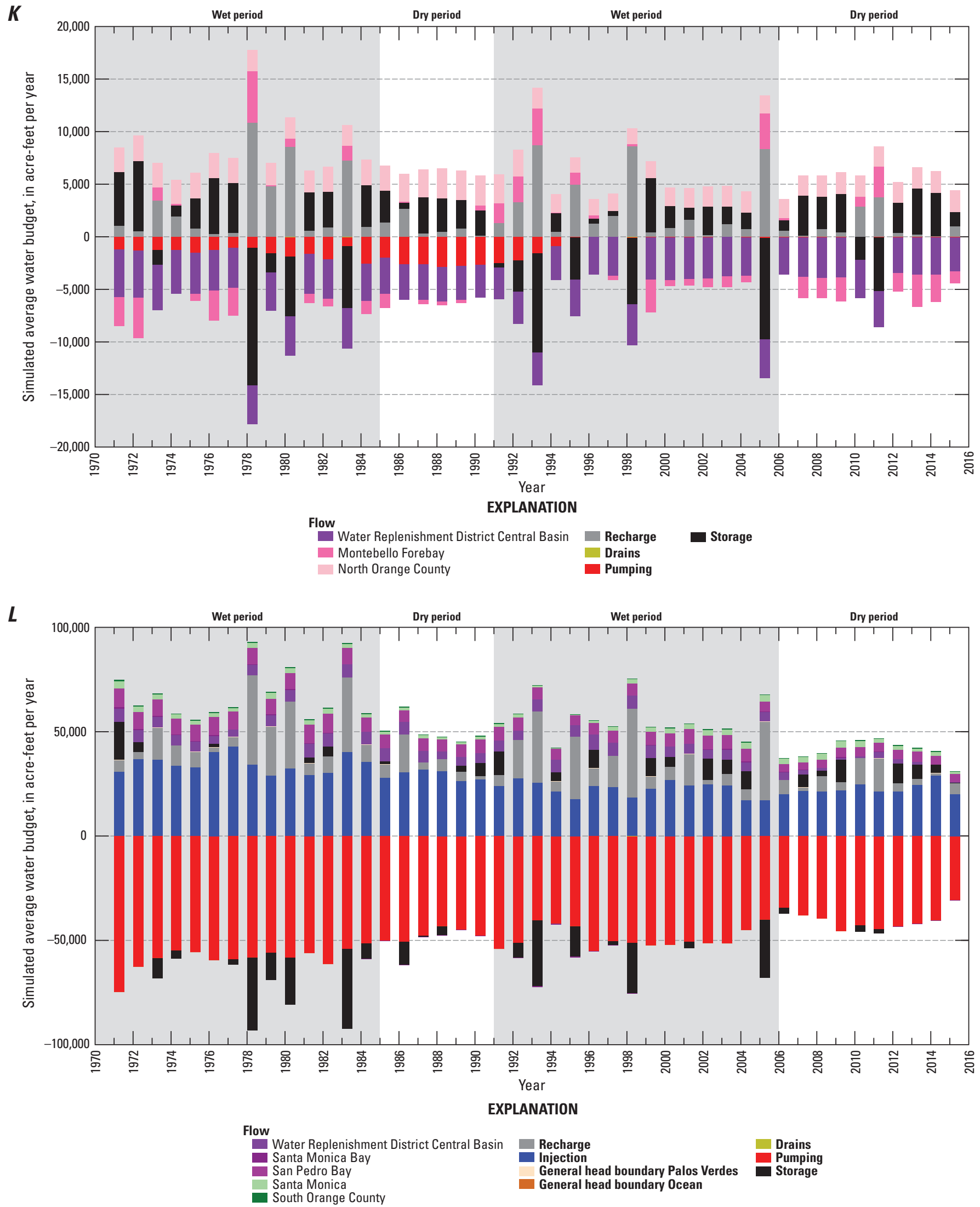

Figure 4.1.-Continued 


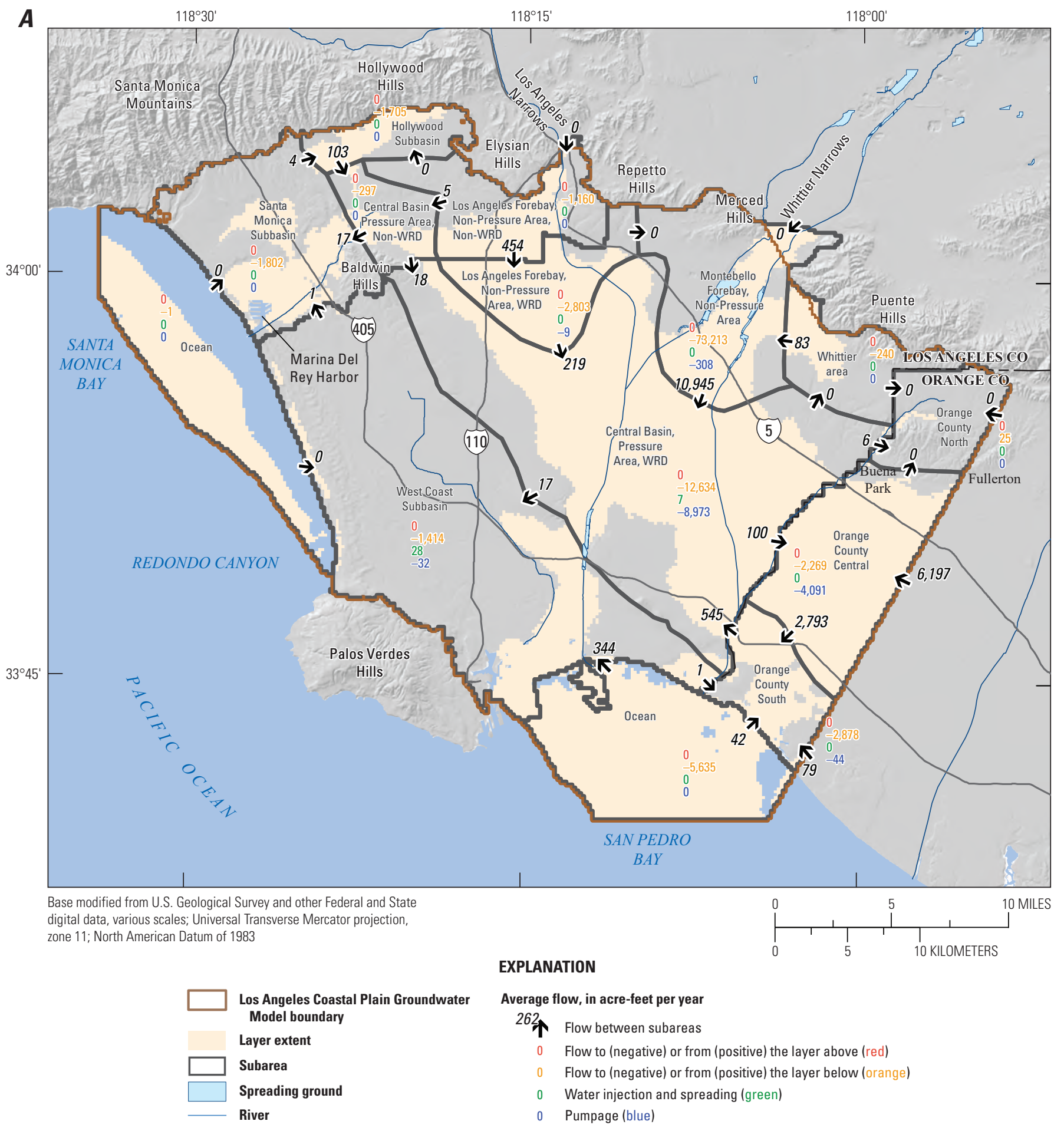

Figure 4.2. Average groundwater flow between subareas, underflow, recharge, spreading, injection, and pumping for $A$, Dominguez; $B$, Mesa; $C$, Pacific A; $D$, Pacific; $E$, Harbor; $F$, Bent Spring; G, Upper Wilmington $A ; H$, Upper Wilmington $B ; I$, Lower Wilmington; $J$, Long Beach $A ; K$, Long Beach $B$; and $L$, Long Beach $C$ layers of the Los Angeles Coastal Plain Groundwater-flow Model, Los Angeles and Orange Counties, California,1971 to 2015. All flows are in acre-feet/year. 


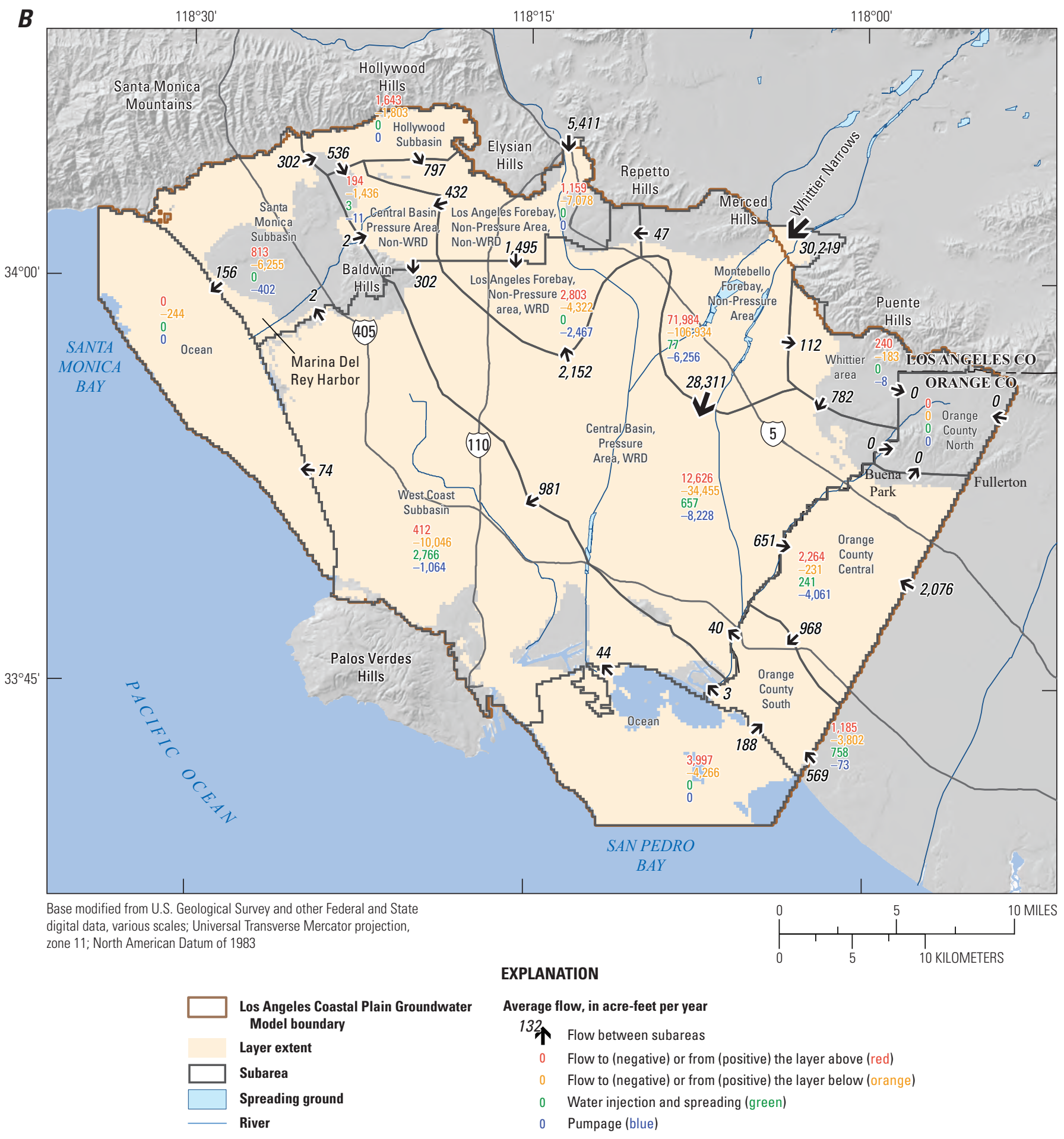

Figure 4.2.-Continued 
C

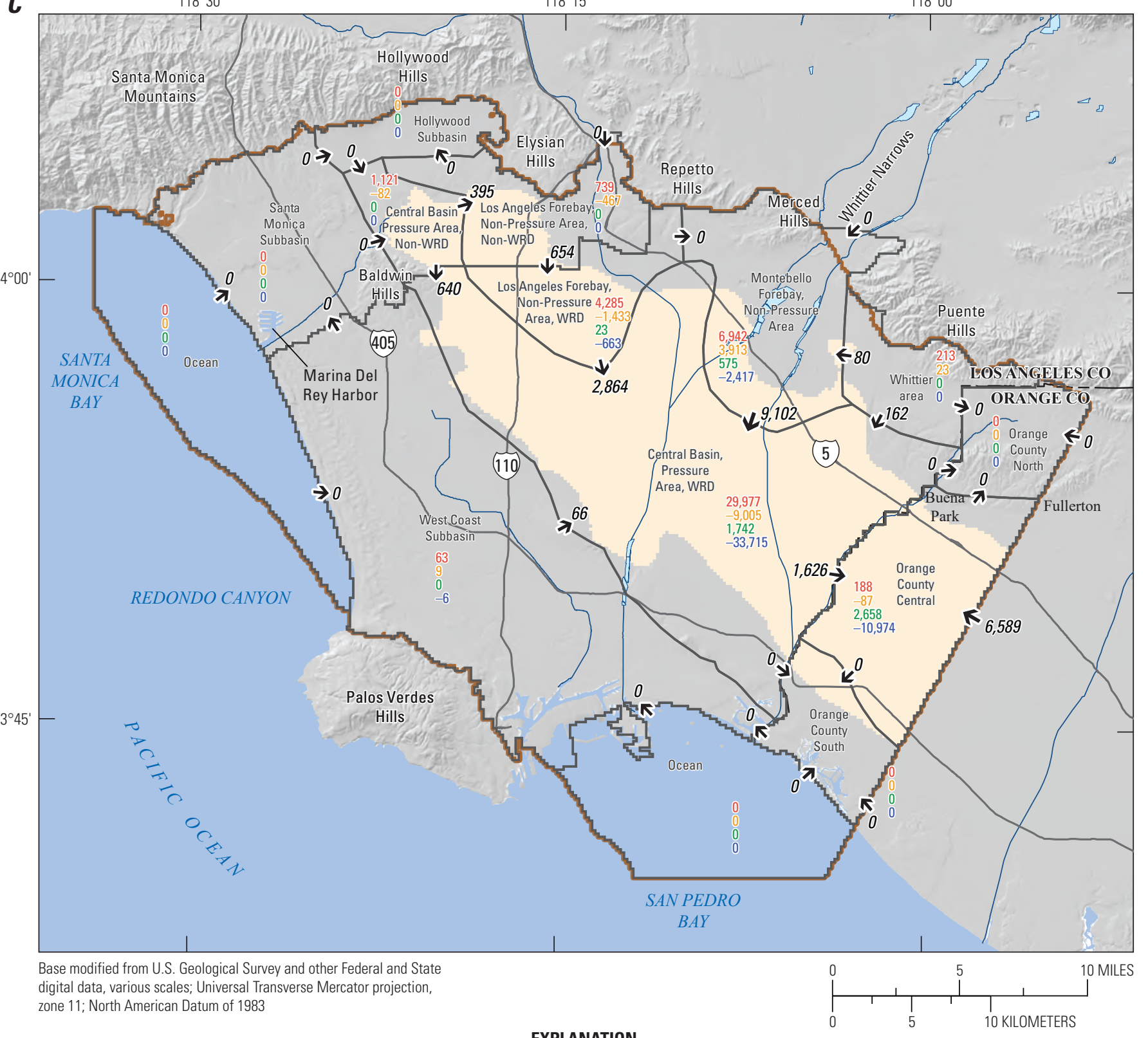

EXPLANATION

Los Angeles Coastal Plain Groundwater Model boundary

Layer extent

Subarea

Spreading ground

River
Average flow, in acre-feet per year

62 Flow between subareas

0 Flow to (negative) or from (positive) the layer above (red)

Flow to (negative) or from (positive) the layer below (orange)

Water injection and spreading (green)

Pumpage (blue)

Figure 4.2.-Continued 


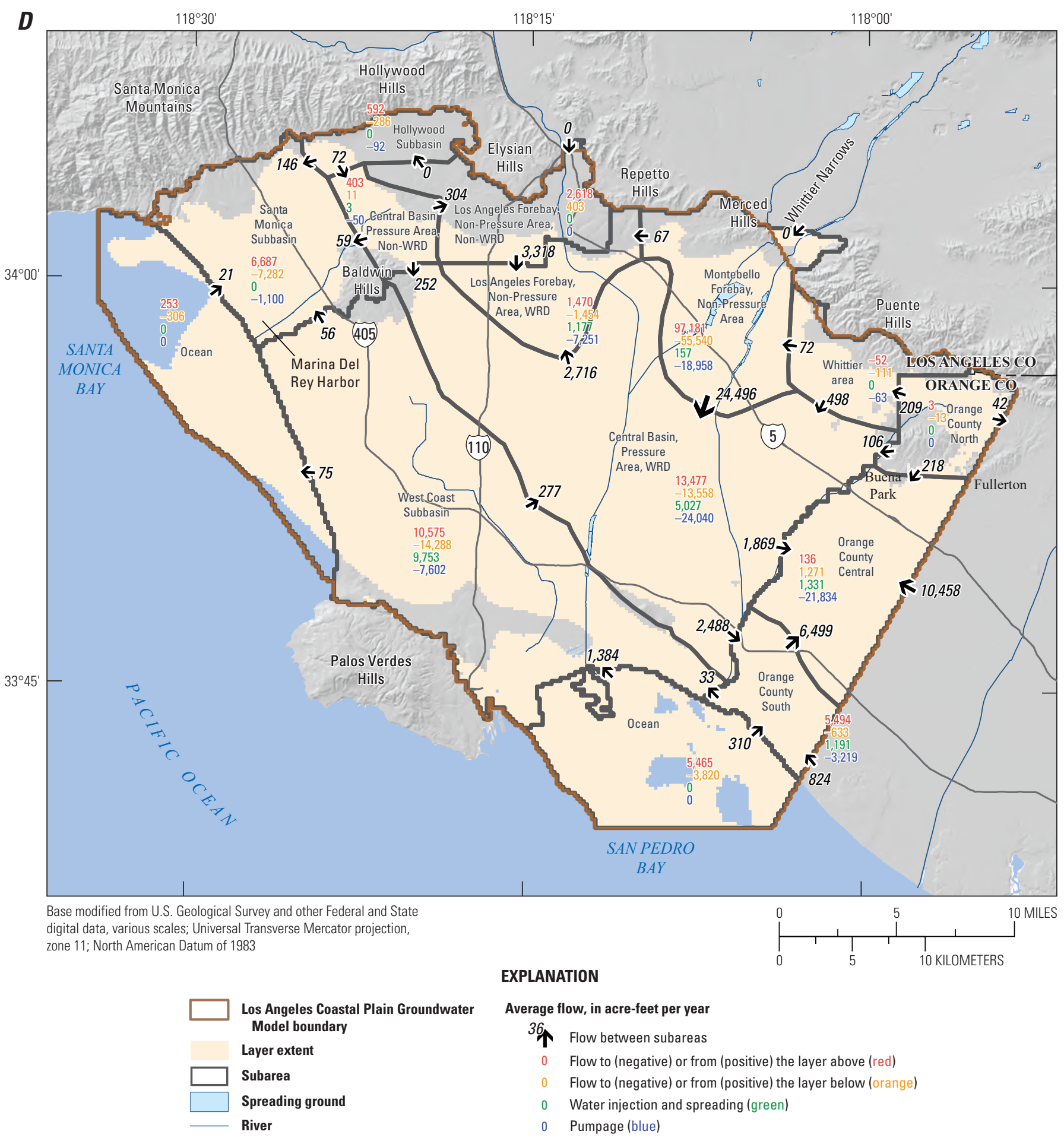

Figure 4.2.-Continued 


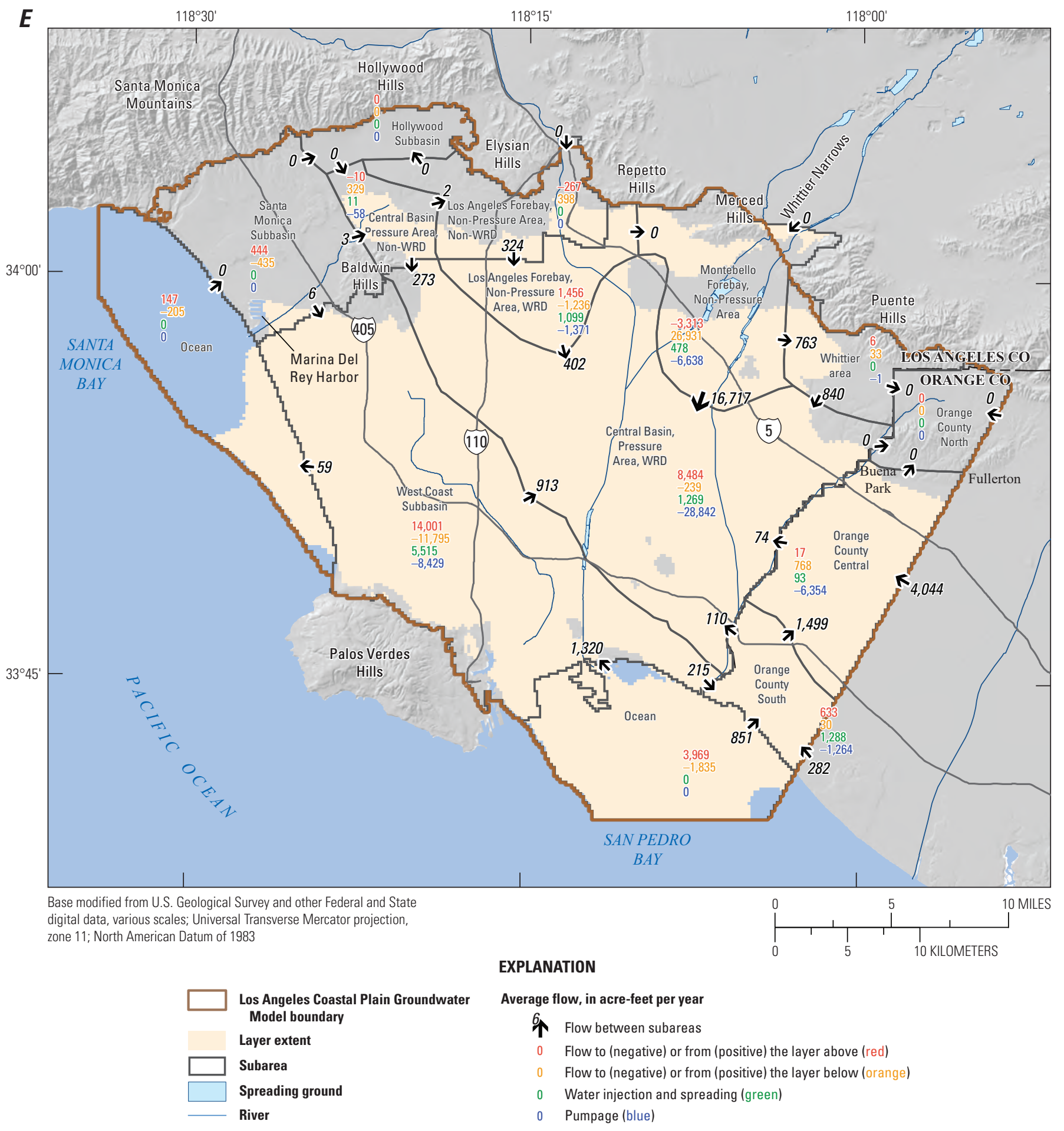

Figure 4.2.-Continued 
$\boldsymbol{F}$

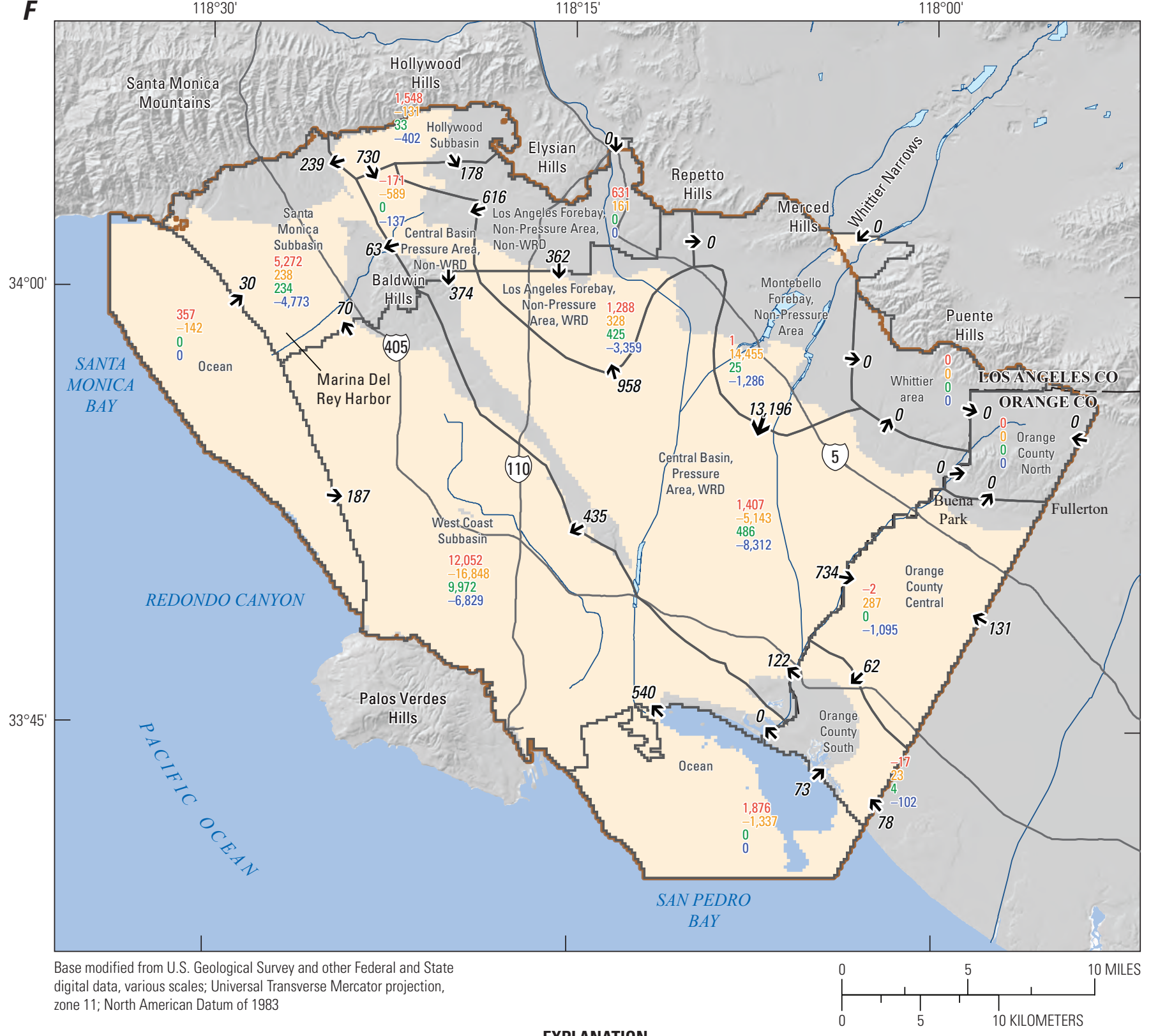

EXPLANATION

Average flow, in acre-feet per year

Los Angeles Coastal Plain Groundwater Model boundary

Layer extent

Subarea

Spreading ground

River
16 Flow between subareas

Flow to (negative) or from (positive) the layer above (red)

Flow to (negative) or from (positive) the layer below (orange)

Water injection and spreading (green)

Pumpage (blue)

Figure 4.2.-Continued 


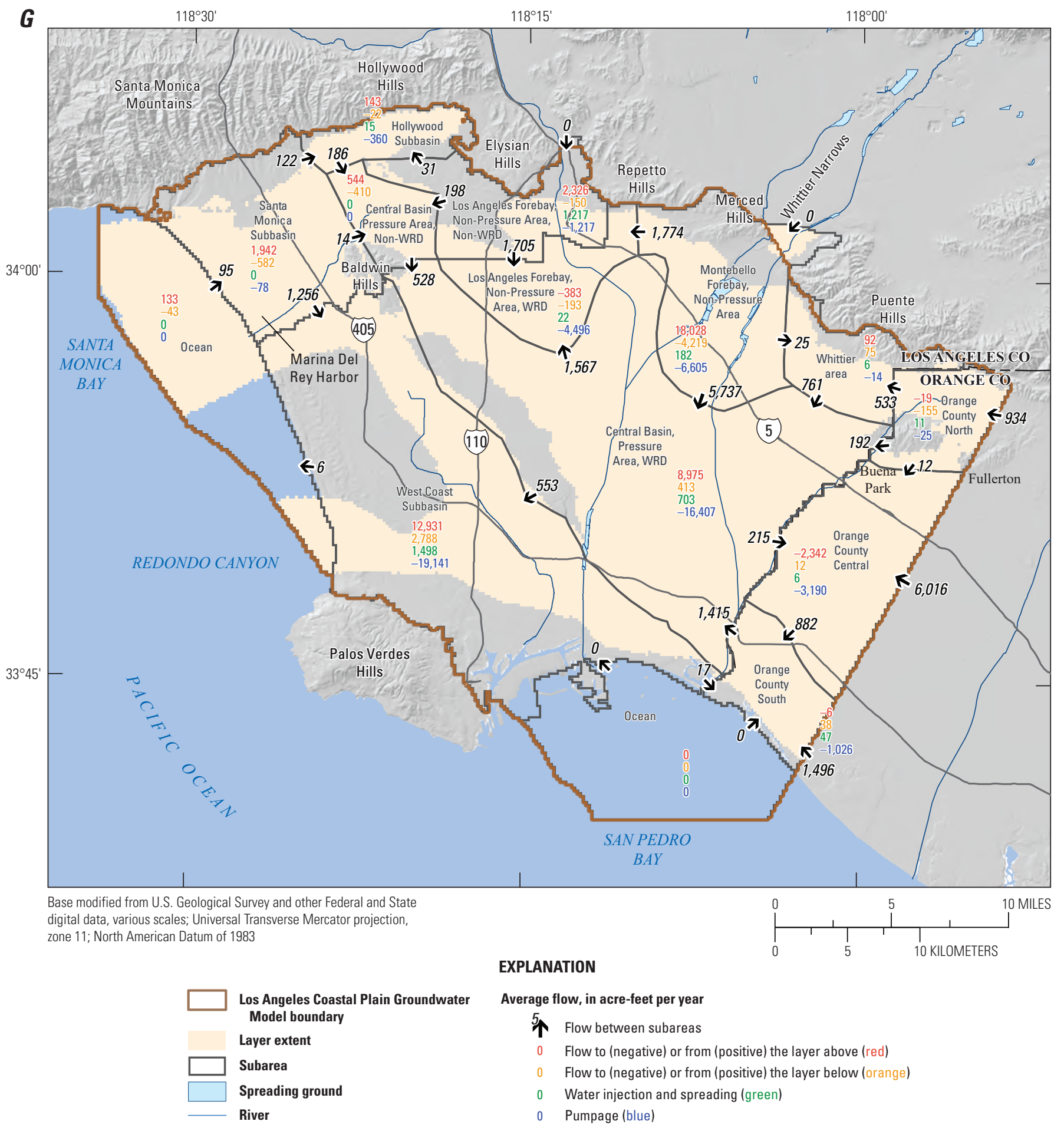

Figure 4.2.-Continued 


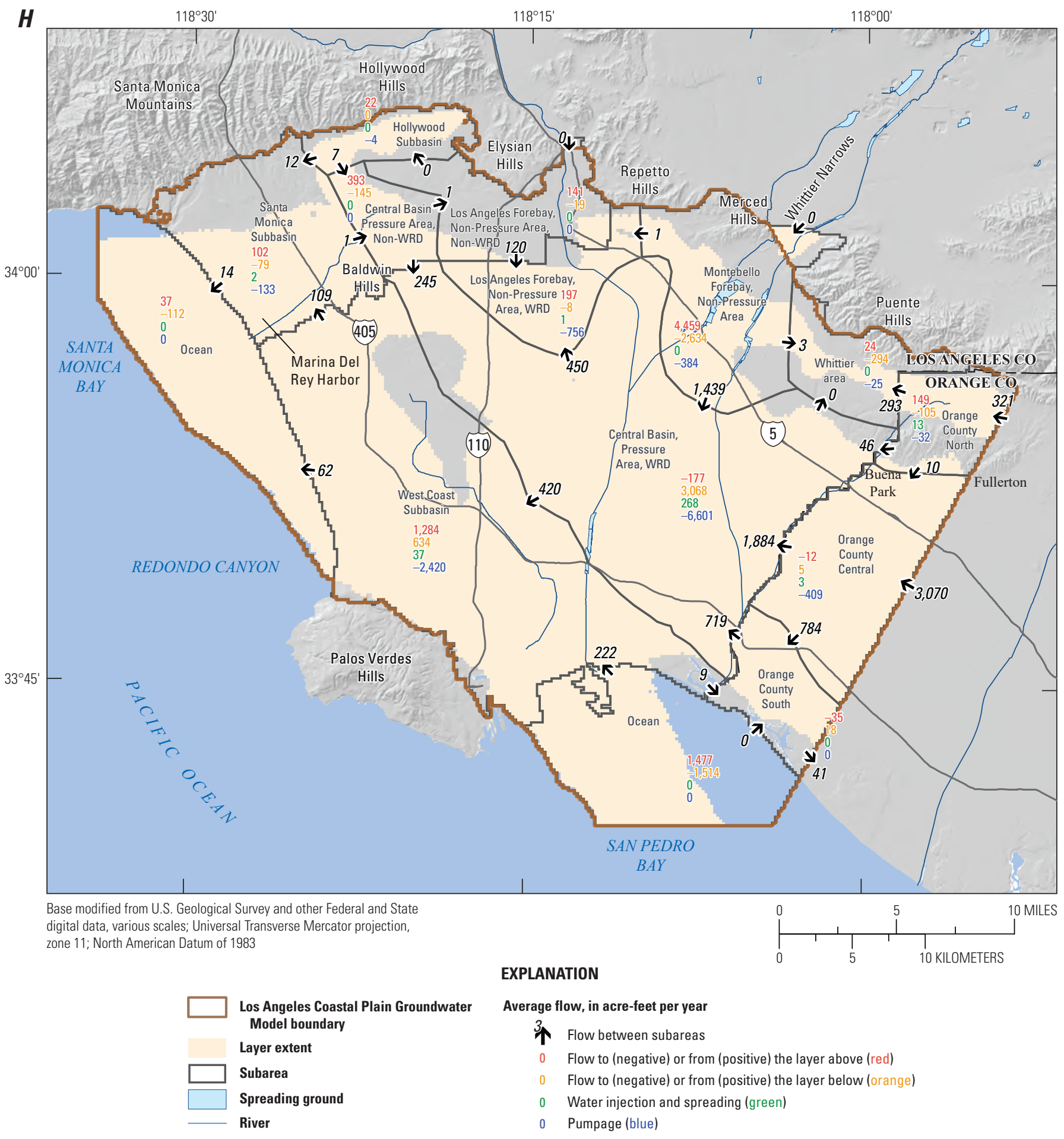

Figure 4.2.-Continued 


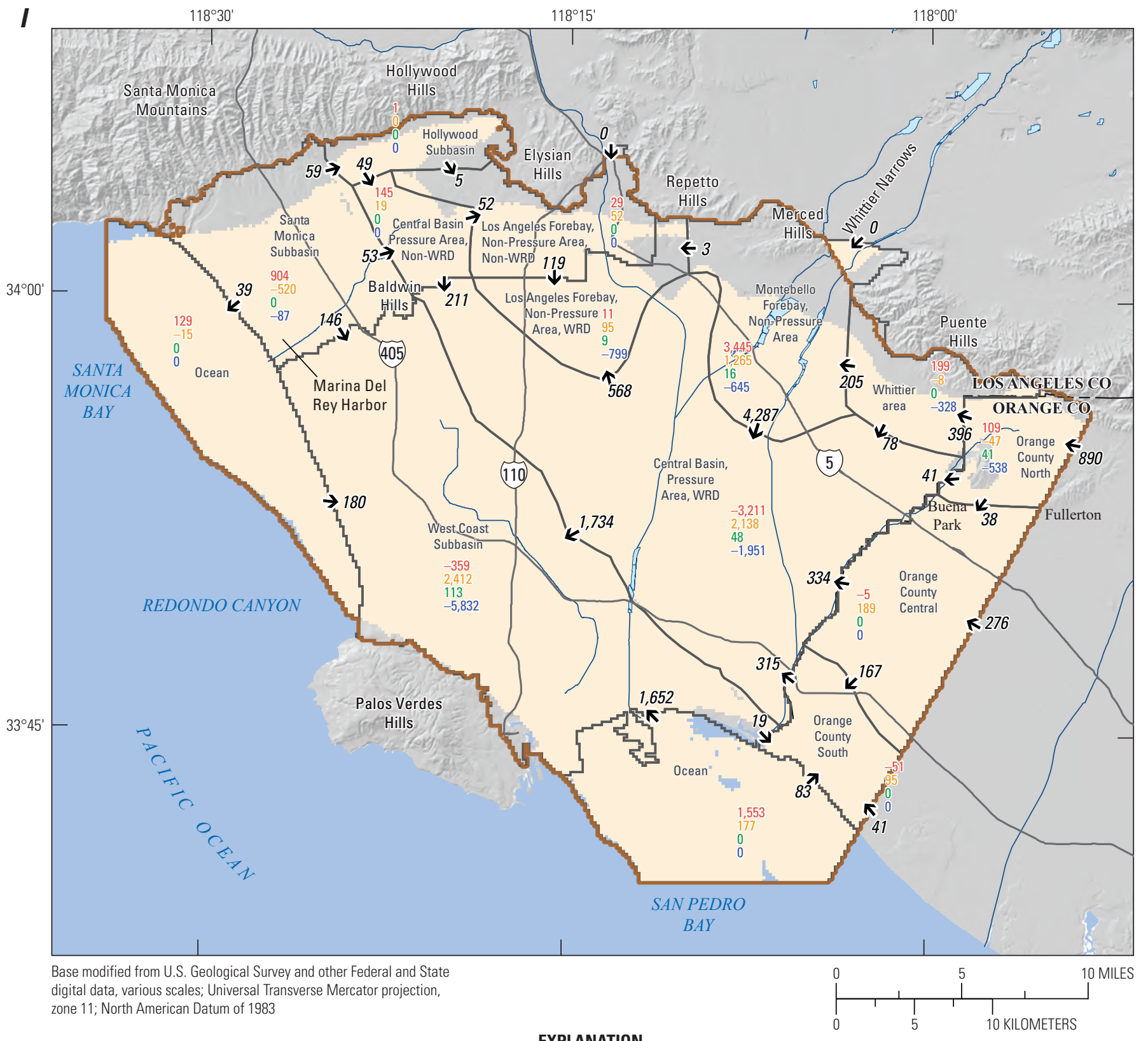

EXPLANATION

Los Angeles Coastal Plain Groundwater Model boundary

Layer extent

Subarea

Spreading ground

River
Average flow, in acre-feet per year

41 Flow between subareas

Flow to (negative) or from (positive) the layer above (red)

Flow to (negative) or from (positive) the layer below (orange)

Water injection and spreading (green)

Pumpage (blue)

Figure 4.2.-Continued 


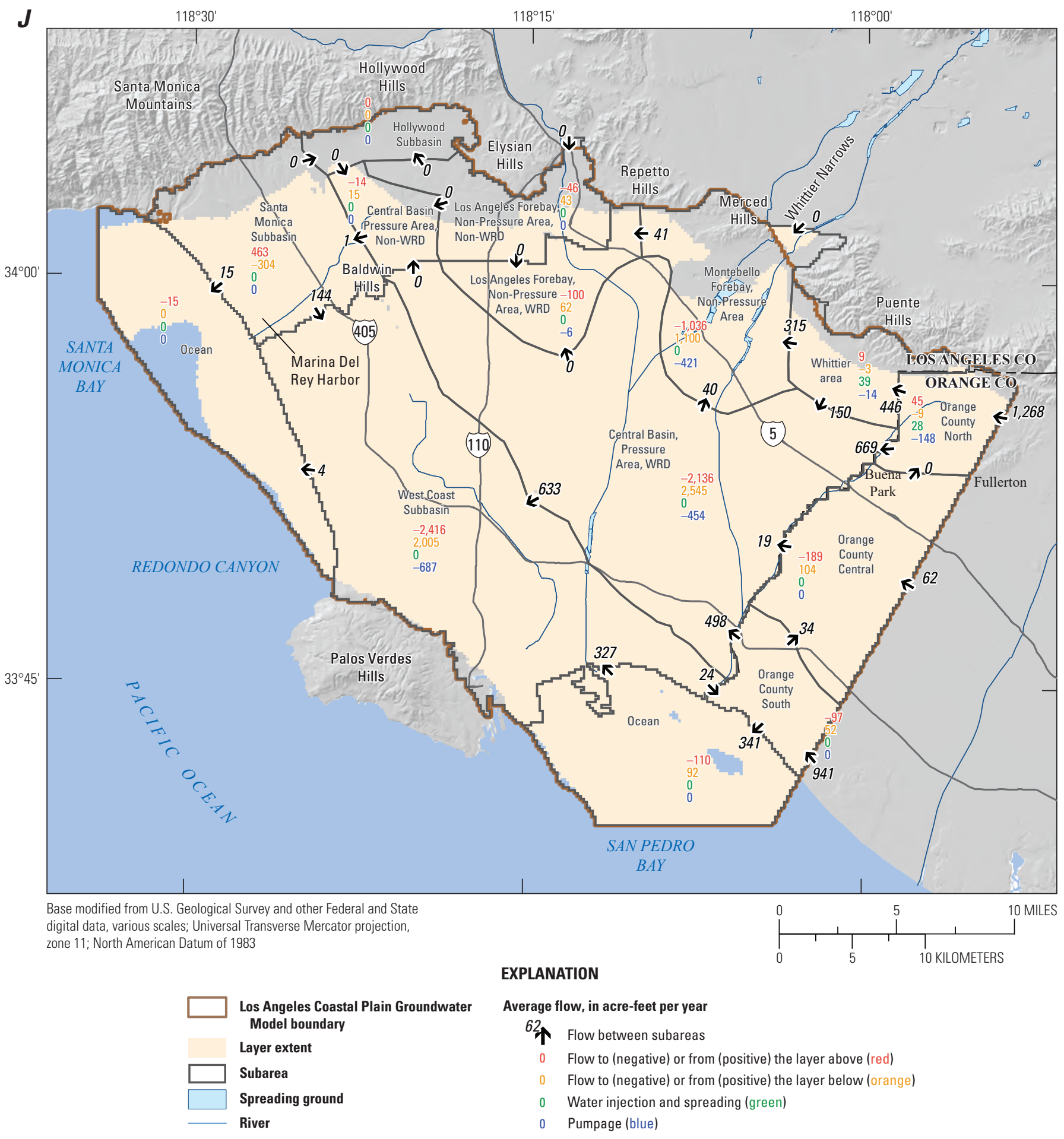

Figure 4.2.-Continued 


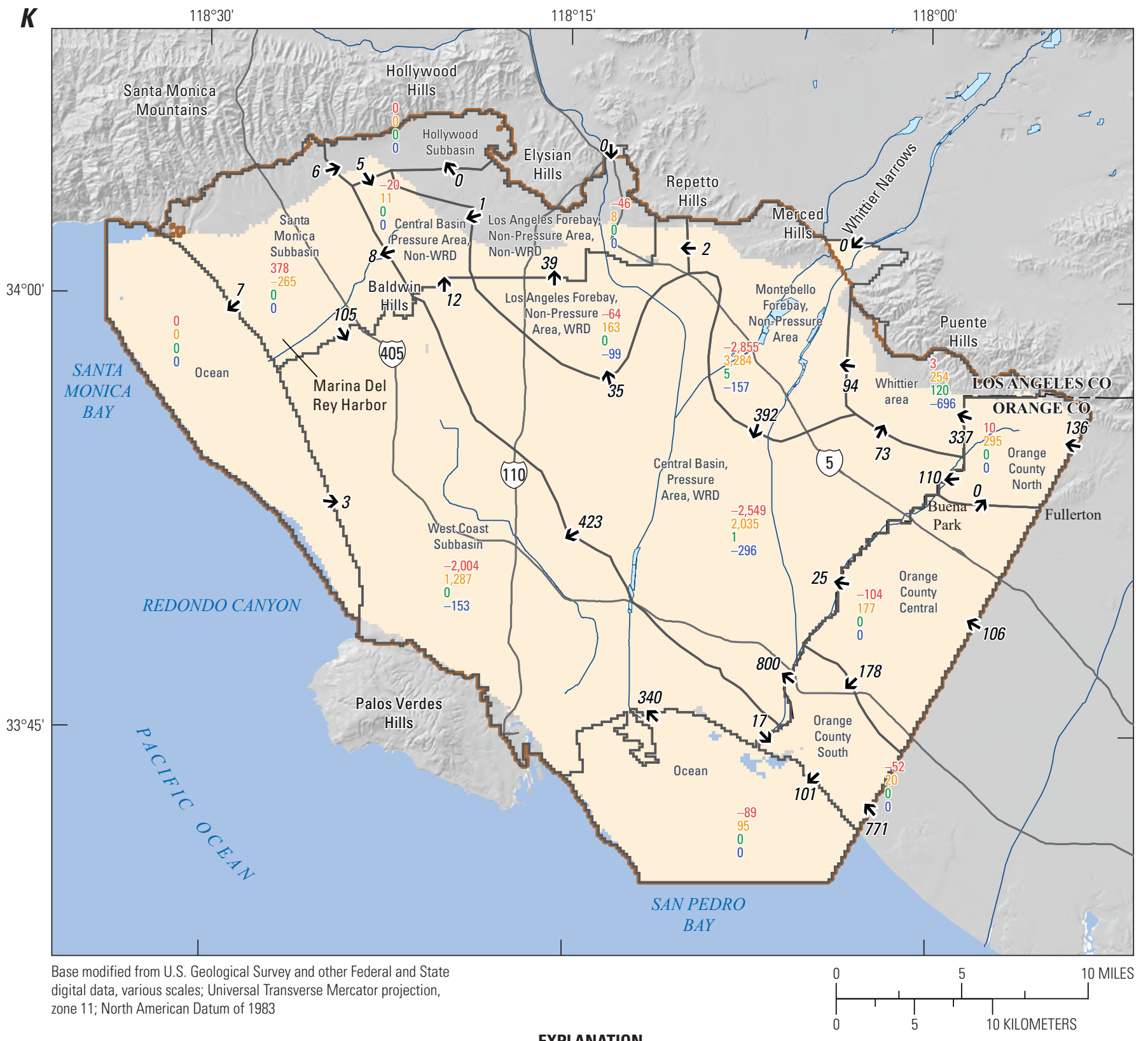

EXPLANATION

Los Angeles Coastal Plain Groundwater Average flow, in acre-feet per year

Model boundary

Layer extent

Subarea

Spreading ground

River
17 Flow between subareas

Flow to (negative) or from (positive) the layer above (red)

Flow to (negative) or from (positive) the layer below (orange)

Water injection and spreading (green)

Pumpage (blue)

Figure 4.2.-Continued 


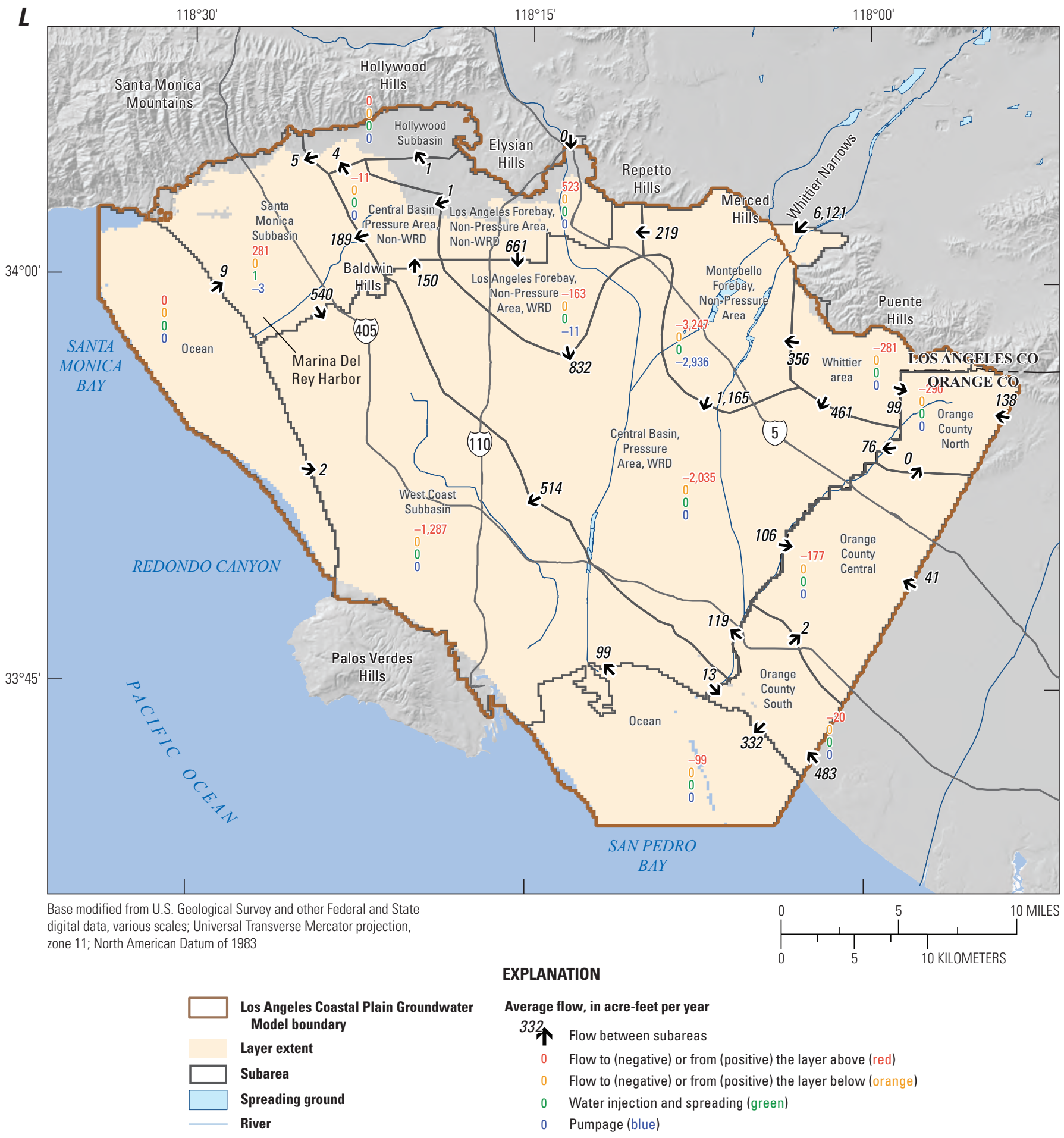

Figure 4.2.-Continued 
Table 4.1. Overall annual groundwater flow budget and individual annual groundwater flow budgets by subarea of the Los Angeles Coastal Plain Groundwater-flow Model, Los Angeles and Orange Counties, California, 1971 to 2015.

[GHB, general head boundary; OC, Orange County; WHT, Whittier; PV, Palos Verdes; CHD, time-variant specified-head; LA Narrows, Los Angeles Narrows]

\begin{tabular}{|c|c|c|c|c|c|c|c|c|c|c|c|c|c|}
\hline Year & $\begin{array}{c}\text { Water } \\
\text { spreading }\end{array}$ & Injection & Pumping & Recharge & Storage & Drains & $\begin{array}{l}\text { GHB } \\
\text { Ocean }\end{array}$ & $\begin{array}{c}\text { GHB } \\
\text { OC }\end{array}$ & $\begin{array}{l}\text { GHB } \\
\text { WHT }\end{array}$ & $\begin{array}{l}\text { GHB } \\
\text { PV }\end{array}$ & $\begin{array}{c}\text { CHD LA } \\
\text { Narrows }\end{array}$ & $\begin{array}{l}\text { Flow from Santa } \\
\text { Monica Bay }\end{array}$ & $\begin{array}{c}\text { Flow from San } \\
\text { Pedro Bay }\end{array}$ \\
\hline 1971 & 115,000 & 35,200 & $-385,000$ & 27,200 & 118,000 & $-13,000$ & 7,950 & 44,900 & 43,300 & 31.3 & 5,650 & -41.6 & 9,070 \\
\hline 1972 & 57,000 & 41,900 & $-339,000$ & 17,400 & 134,000 & $-5,820$ & 8,670 & 31,100 & 48,500 & 30.5 & 6,150 & -18 & 9,220 \\
\hline 1973 & 157,000 & 42,300 & $-326,000$ & 71,400 & $-18,400$ & $-5,920$ & 9,450 & 24,000 & 41,000 & 30.4 & 5,670 & -30.3 & 9,790 \\
\hline 1974 & 122,000 & 41,000 & $-330,000$ & 48,200 & 34,000 & $-4,680$ & 9,780 & 32,100 & 41,200 & 30.2 & 5,670 & -4.49 & 9,910 \\
\hline 1975 & 109,000 & 38,200 & $-334,000$ & 34,000 & 49,900 & $-3,480$ & 9,450 & 50,000 & 41,800 & 29.7 & 5,720 & 40.6 & 9,440 \\
\hline 1976 & 71,000 & 45,700 & $-343,000$ & 12,600 & 104,000 & $-2,260$ & 10,600 & 50,600 & 44,800 & 29.8 & 5,940 & 0.522 & 10,600 \\
\hline 1977 & 81,300 & 48,700 & $-336,000$ & 18,300 & 82,600 & $-2,840$ & 11,000 & 48,700 & 42,400 & 29.9 & 5,860 & 73.1 & 10,700 \\
\hline 1978 & 222,000 & 40,700 & $-300,000$ & 193,000 & $-241,000$ & $-9,310$ & 9,030 & 49,400 & 32,500 & 29.9 & 4,570 & -119 & 9,220 \\
\hline 1979 & 137,000 & 36,300 & $-327,000$ & 104,000 & $-50,800$ & $-7,270$ & 7,920 & 60,300 & 34,000 & 29.9 & 5,050 & 80.6 & 8,310 \\
\hline 1980 & 154,000 & 38,600 & $-323,000$ & 159,000 & $-124,000$ & $-11,000$ & 7,240 & 59,600 & 35,600 & 30.4 & 4,610 & -102 & 8,090 \\
\hline 1981 & 126,000 & 35,200 & $-319,000$ & 26,800 & 28,800 & $-6,100$ & 8,540 & 53,300 & 40,600 & 31.1 & 5,460 & 124 & 9,140 \\
\hline 1982 & 127,000 & 36,200 & $-321,000$ & 34,400 & 23,800 & $-4,450$ & 10,100 & 42,900 & 44,900 & 31.7 & 5,710 & 268 & 10,300 \\
\hline 1983 & 145,000 & 47,100 & $-302,000$ & 160,000 & $-149,000$ & $-8,040$ & 8,640 & 53,000 & 41,300 & 31.9 & 4,560 & -68.6 & 8,440 \\
\hline 1984 & 103,000 & 40,700 & $-321,000$ & 36,100 & 38,000 & $-5,130$ & 7,700 & 52,800 & 42,100 & 31.6 & 5,660 & 27.0 & 7,430 \\
\hline 1985 & 88,000 & 32,500 & $-296,000$ & 30,800 & 34,900 & $-3,770$ & 7,340 & 56,400 & 45,400 & 31.2 & 4,620 & 153 & 6,850 \\
\hline 1986 & 134,000 & 38,300 & $-306,000$ & 70,200 & $-36,100$ & $-4,660$ & 6,700 & 49,000 & 42,800 & 30.4 & 6,220 & 81.1 & 5,830 \\
\hline 1987 & 115,000 & 40,900 & $-307,000$ & 15,400 & 48,500 & $-2,710$ & 7,580 & 38,000 & 38,100 & 30.4 & 5,790 & -44.5 & 7,130 \\
\hline 1988 & 107,000 & 37,800 & $-300,000$ & 23,800 & 41,900 & $-2,280$ & 8,070 & 36,900 & 41,300 & 30.7 & 5,860 & 56.6 & 7,150 \\
\hline 1989 & 110,000 & 32,000 & $-300,000$ & 22,300 & 37,200 & $-1,900$ & 8,470 & 41,800 & 44,900 & 30.4 & 5,020 & 103 & 7,600 \\
\hline 1990 & 127,000 & 33,400 & $-292,000$ & 7,120 & 28,500 & $-1,360$ & 8,860 & 43,400 & 38,900 & 30.6 & 6,380 & -75.1 & 8,010 \\
\hline 1991 & 173,000 & 29,800 & $-299,000$ & 26,000 & $-4,120$ & $-5,530$ & 9,000 & 40,200 & 25,100 & 30.7 & 5,730 & 116 & 8,100 \\
\hline 1992 & 232,000 & 33,500 & $-308,000$ & 80,400 & $-53,700$ & $-61,600$ & 8,600 & 48,300 & 14,900 & 30.7 & 5,240 & 167 & 7,550 \\
\hline 1993 & 187,000 & 30,200 & $-241,000$ & 159,000 & $-195,000$ & $-20,900$ & 6,640 & 48,300 & 20,900 & 30.6 & 4,440 & -104 & 5,700 \\
\hline 1994 & 135,000 & 25,400 & $-270,000$ & 22,100 & 4,760 & $-8,270$ & 6,040 & 53,000 & 25,900 & 30 & 5,560 & 11.0 & 5,020 \\
\hline 1995 & 146,000 & 21,800 & $-289,000$ & 128,000 & $-83,100$ & $-9,630$ & 5,250 & 47,200 & 28,800 & 29.6 & 4,850 & -22.3 & 4,430 \\
\hline 1996 & 145,000 & 29,900 & $-302,000$ & 40,000 & 1,960 & $-4,570$ & 5,960 & 46,000 & 32,000 & 29.5 & 5,420 & -179 & 5,290 \\
\hline 1997 & 118,000 & 28,900 & $-303,000$ & 67,400 & 5,930 & $-5,950$ & 6,270 & 43,800 & 33,100 & 30 & 5,350 & -229 & 6,220 \\
\hline 1998 & 128,000 & 23,600 & $-301,000$ & 188,000 & $-109,000$ & $-14,500$ & 5,430 & 44,500 & 31,700 & 30.6 & 4,490 & -212 & 6,010 \\
\hline 1999 & 76,400 & 28,500 & $-321,000$ & 25,100 & 106,000 & $-6,870$ & 6,160 & 41,300 & 38,900 & 30.6 & 5,450 & 22.3 & 6,760 \\
\hline 2000 & 122,000 & 32,100 & $-318,000$ & 30,300 & 42,500 & $-4,910$ & 6,640 & 46,500 & 37,800 & 30.9 & 5,520 & -16.3 & 7,160 \\
\hline
\end{tabular}


Table 4.1. Overall annual groundwater flow budget and individual annual groundwater flow budgets by subarea of the Los Angeles Coastal Plain Groundwater-flow Model, Los Angeles and Orange Counties, California, 1971 to 2015.-Continued

[GHB, general head boundary; OC, Orange County; WHT, Whittier; PV, Palos Verdes; CHD, time-variant specified-head; LA Narrows, Los Angeles Narrows]

\begin{tabular}{|c|c|c|c|c|c|c|c|c|c|c|c|c|c|}
\hline Year & $\begin{array}{c}\text { Water } \\
\text { spreading }\end{array}$ & Injection & Pumping & Recharge & Storage & Drains & $\begin{array}{l}\text { GHB } \\
\text { Ocean }\end{array}$ & $\begin{array}{c}\text { GHB } \\
\text { OC }\end{array}$ & $\begin{array}{l}\text { GHB } \\
\text { WHT }\end{array}$ & $\begin{array}{l}\text { GHB } \\
\text { PV }\end{array}$ & $\begin{array}{c}\text { CHD LA } \\
\text { Narrows }\end{array}$ & $\begin{array}{l}\text { Flow from Santa } \\
\text { Monica Bay }\end{array}$ & $\begin{array}{c}\text { Flow from San } \\
\text { Pedro Bay }\end{array}$ \\
\hline 2001 & 123,000 & 30,500 & $-311,000$ & 57,400 & 17,300 & $-6,240$ & 7,240 & 44,600 & 32,100 & 31.2 & 5,390 & -39.2 & 7,920 \\
\hline 2002 & 129,000 & 30,800 & $-307,000$ & 9,670 & 61,200 & $-4,740$ & 7,160 & 42,700 & 24,800 & 31.2 & 5,680 & 67.3 & 7,570 \\
\hline 2003 & 95,100 & 29,000 & $-298,000$ & 27,500 & 61,800 & $-4,500$ & 6,690 & 49,300 & 26,900 & 31.5 & 5,600 & -1.19 & 7,200 \\
\hline 2004 & 136,000 & 22,800 & $-288,000$ & 24,400 & 16,600 & $-3,730$ & 6,330 & 46,900 & 32,600 & 31.2 & 5,660 & 59.7 & 6,790 \\
\hline 2005 & 167,000 & 21,400 & $-274,000$ & 166,000 & $-150,000$ & $-18,500$ & 4,230 & 55,200 & 24,600 & 30.8 & 4,230 & -116 & 4,750 \\
\hline 2006 & 144,000 & 21,700 & $-274,000$ & 30,400 & $-17,000$ & $-6,600$ & 3,020 & 60,800 & 31,700 & 29.8 & 5,350 & -107 & 3,450 \\
\hline 2007 & 86,300 & 25,200 & $-316,000$ & 7,490 & 103,000 & $-3,600$ & 3,380 & 49,800 & 39,100 & 29.5 & 5,670 & -55.7 & 4,110 \\
\hline 2008 & 98,700 & 28,600 & $-310,000$ & 32,700 & 58,800 & $-4,570$ & 4,660 & 50,000 & 35,700 & 29.9 & 5,470 & -1.42 & 5,200 \\
\hline 2009 & 83,600 & 28,600 & $-304,000$ & 18,300 & 76,200 & $-3,660$ & 5,390 & 49,000 & 40,700 & 30.1 & 5,710 & 111 & 6,030 \\
\hline 2010 & 155,000 & 30,100 & $-290,000$ & 53,200 & $-44,500$ & $-5,490$ & 5,150 & 56,100 & 35,600 & 30.3 & 5,530 & 50.4 & 5,460 \\
\hline 2011 & 152,000 & 26,200 & $-277,000$ & 71,600 & $-72,800$ & $-6,700$ & 4,350 & 68,500 & 27,800 & 29.8 & 5,540 & 253 & 4,480 \\
\hline 2012 & 82,200 & 26,700 & $-299,000$ & 15,800 & 62,000 & $-2,740$ & 4,860 & 66,800 & 38,000 & 29.9 & 5,550 & 149 & 4,690 \\
\hline 2013 & 54,900 & 30,200 & $-312,000$ & 11,200 & 99,500 & $-2,110$ & 6,100 & 62,300 & 44,800 & 30.4 & 5,350 & 116 & 5,360 \\
\hline 2014 & 69,300 & 36,600 & $-296,000$ & 5,500 & 89,700 & $-1,780$ & 6,230 & 42,400 & 42,300 & 30.1 & 5,510 & 180 & 5,010 \\
\hline 2015 & 74,700 & 25,900 & $-262,000$ & 23,900 & 35,400 & $-1,670$ & 5,910 & 48,600 & 44,200 & 29.7 & 5,040 & 115 & 4,520 \\
\hline
\end{tabular}


Table 4.2. Overall annual groundwater flow budget and individual annual groundwater flow budgets by subarea of the Los Angeles Coastal Plain Groundwater-flow Model for Montebello Forebay, Los Angeles and Orange Counties, California.

[GHB, general head boundary; OC, Orange County; WHT, Whittier; PV, Palos Verdes; CHD, time-variant specified-head; LA Narrows, Los Angeles Narrows; WRD, Water Replenishment District of Southern California]

\begin{tabular}{|c|c|c|c|c|c|c|c|c|c|c|c|c|c|c|}
\hline Year & $\begin{array}{c}\text { Water } \\
\text { spreading }\end{array}$ & Injection & Pumping & Recharge & Storage & Drains & $\begin{array}{c}\text { GHB } \\
\text { Ocean }\end{array}$ & $\begin{array}{c}\text { GHB } \\
\text { OC }\end{array}$ & $\begin{array}{l}\text { GHB } \\
\text { WHT }\end{array}$ & $\begin{array}{l}\text { GHB } \\
\text { VPV }\end{array}$ & $\begin{array}{c}\text { CHD LA } \\
\text { Narrows }\end{array}$ & $\begin{array}{c}\text { Flow from WRD } \\
\text { Central Basin }\end{array}$ & $\begin{array}{l}\text { Flow from WRD Los } \\
\text { Angeles Forebay }\end{array}$ & $\begin{array}{l}\text { Flow from } \\
\text { Whitter }\end{array}$ \\
\hline 1971 & 115,000 & 0.00 & $-54,000$ & 2,120 & $-15,100$ & -29.1 & - & - & 43,300 & - & 0.00 & $-122,000$ & $-2,870$ & 2,760 \\
\hline 1972 & 57,000 & 0.00 & $-44,100$ & 1,160 & $-41,400$ & -8.44 & - & - & 48,500 & - & 0.00 & $-105,000$ & $-2,350$ & 3,810 \\
\hline 1973 & 157,000 & 0.00 & $-43,500$ & 6,340 & 39,000 & -338 & - & - & 41,000 & - & 0.00 & $-118,000$ & $-2,310$ & $-1,210$ \\
\hline 1974 & 122,000 & 0.00 & $-45,900$ & 4,200 & $-6,770$ & -24.4 & - & - & 41,200 & - & 0.00 & $-126,000$ & $-2,200$ & -135 \\
\hline 1975 & 109,000 & 0.00 & $-44,300$ & 2,820 & $-14,200$ & -14.2 & - & - & 41,800 & - & 0.00 & $-122,000$ & $-2,400$ & 661 \\
\hline 1976 & 71,000 & 0.00 & $-45,200$ & 1,140 & $-38,500$ & 0.00 & - & - & 44,800 & - & 0.00 & $-111,000$ & $-2,380$ & 2,830 \\
\hline 1977 & 81,300 & 0.00 & $-41,400$ & 1,450 & $-16,600$ & -932 & - & - & 42,400 & - & 0.00 & $-99,900$ & $-2,170$ & 2,640 \\
\hline 1978 & 222,000 & 0.00 & $-43,000$ & 18,000 & 93,500 & $-1,960$ & - & - & 32,500 & - & 0.00 & $-127,000$ & $-2,040$ & $-4,900$ \\
\hline 1979 & 137,000 & 0.00 & $-48,000$ & 8,820 & $-3,230$ & -538 & - & - & 34,000 & - & 0.00 & $-132,000$ & $-2,600$ & -126 \\
\hline 1980 & 154,000 & 0.00 & $-47,400$ & 13,800 & 16,000 & -964 & - & - & 35,600 & - & 0.00 & $-135,000$ & $-2,510$ & -773 \\
\hline 1981 & 126,000 & 0.00 & $-50,700$ & 2,120 & $-8,440$ & -34.8 & - & - & 40,600 & - & 0.00 & $-125,000$ & $-2,170$ & 874 \\
\hline 1982 & 127,000 & 0.00 & $-46,100$ & 3,110 & 5,810 & -107 & - & - & 44,900 & - & 0.00 & $-122,000$ & $-2,400$ & 712 \\
\hline 1983 & 145,000 & 0.00 & $-43,200$ & 14,100 & 21,100 & -165 & - & - & 41,300 & - & 0.00 & $-132,000$ & $-2,690$ & $-1,430$ \\
\hline 1984 & 103,000 & 0.00 & $-49,100$ & 2,840 & $-22,200$ & -36.0 & - & - & 42,100 & - & 0.00 & $-120,000$ & $-2,300$ & 1,230 \\
\hline 1985 & 88,000 & 0.00 & $-45,700$ & 3,030 & $-22,000$ & -18.2 & - & - & 45,400 & - & 0.00 & $-112,000$ & $-1,830$ & 1,330 \\
\hline 1986 & 134,000 & 0.00 & $-43,500$ & 5,600 & 20,300 & -122 & - & - & 42,800 & - & 0.00 & $-116,000$ & $-2,300$ & -118 \\
\hline 1987 & 115,000 & 0.00 & $-44,900$ & 1,070 & $-8,890$ & -183 & - & - & 38,100 & - & 0.00 & $-116,000$ & $-2,270$ & 414 \\
\hline 1988 & 107,000 & 0.00 & $-46,500$ & 1,720 & $-13,600$ & -5.99 & - & - & 41,300 & - & 0.00 & $-115,000$ & $-1,910$ & 365 \\
\hline 1989 & 110,000 & 0.00 & $-45,300$ & 1,980 & $-7,000$ & -0.177 & - & - & 44,900 & - & 0.00 & $-117,000$ & $-1,980$ & 309 \\
\hline 1990 & 127,000 & 0.00 & $-43,200$ & 615 & 3,450 & 0.00 & - & - & 38,900 & - & 0.00 & $-117,000$ & $-2,070$ & -418 \\
\hline 1991 & 173,000 & 0.00 & $-42,300$ & 2,320 & 28,000 & $-4,090$ & - & - & 25,100 & - & 0.00 & $-122,000$ & $-2,010$ & $-1,890$ \\
\hline 1992 & 232,000 & 0.00 & $-43,800$ & 6,330 & 14,400 & $-58,200$ & - & - & 14,900 & - & 0.00 & $-132,000$ & $-2,090$ & $-2,410$ \\
\hline 1993 & 187,000 & 0.00 & $-39,500$ & 14,500 & 27,700 & $-14,100$ & - & - & 20,900 & - & 0.00 & $-136,000$ & $-1,980$ & $-3,490$ \\
\hline 1994 & 135,000 & 0.00 & $-41,100$ & 1,610 & $-11,500$ & $-4,740$ & - & - & 25,900 & - & 0.00 & $-126,000$ & $-2,270$ & -45.0 \\
\hline 1995 & 146,000 & 0.00 & $-44,400$ & 10,700 & 6,100 & $-3,120$ & - & - & 28,800 & - & 0.00 & $-128,000$ & $-2,260$ & $-1,180$ \\
\hline 1996 & 145,000 & 0.00 & $-46,400$ & 3,000 & 6,330 & -105 & - & - & 32,000 & - & 0.00 & $-124,000$ & $-2,300$ & -345 \\
\hline 1997 & 118,000 & 0.00 & $-46,600$ & 5,560 & $-13,500$ & -41.6 & - & - & 33,100 & - & 0.00 & $-122,000$ & $-2,360$ & 375 \\
\hline 1998 & 128,000 & 0.00 & $-43,200$ & 18,900 & 5,300 & -659 & - & - & 31,700 & - & 0.00 & $-126,000$ & $-2,520$ & -248 \\
\hline 1999 & 76,400 & 0.00 & $-48,200$ & 2,120 & $-40,800$ & -15.0 & - & - & 38,900 & - & 0.00 & $-111,000$ & $-2,540$ & 3,100 \\
\hline 2000 & 122,000 & 0.00 & $-46,200$ & 2,320 & 4,750 & -6.07 & - & - & 37,800 & - & 0.00 & $-110,000$ & $-1,820$ & 565 \\
\hline
\end{tabular}


Table 4.2. Overall annual groundwater flow budget and individual annual groundwater flow budgets by subarea of the Los Angeles Coastal Plain Groundwater-flow Model for Montebello Forebay, Los Angeles and Orange Counties, California.-Continued

[GHB, general head boundary; OC, Orange County; WHT, Whittier; PV, Palos Verdes; CHD, time-variant specified-head; LA Narrows, Los Angeles Narrows; WRD, Water Replenishment District of Southern California]

\begin{tabular}{|c|c|c|c|c|c|c|c|c|c|c|c|c|c|c|}
\hline Year & $\begin{array}{c}\text { Water } \\
\text { spreading }\end{array}$ & Injection & Pumping & Recharge & Storage & Drains & $\begin{array}{c}\text { GHB } \\
\text { Ocean }\end{array}$ & $\begin{array}{l}\text { GHB } \\
\text { OC }\end{array}$ & $\begin{array}{l}\text { GHB } \\
\text { WHT }\end{array}$ & $\begin{array}{l}\text { GHB } \\
\text { PVV }\end{array}$ & $\begin{array}{l}\text { CHD LA } \\
\text { Narrows }\end{array}$ & $\begin{array}{c}\text { Flow from WRD } \\
\text { Central Basin }\end{array}$ & $\begin{array}{l}\text { Flow from WRD Los } \\
\text { Angeles Forebay }\end{array}$ & $\begin{array}{c}\text { Flow from } \\
\text { Whitter }\end{array}$ \\
\hline 2001 & 123,000 & 0.00 & $-46,300$ & 2,960 & 623 & -526 & - & - & 32,100 & - & 0.00 & $-109,000$ & $-1,810$ & 584 \\
\hline 2002 & 129,000 & 0.00 & $-48,600$ & 703 & $-4,760$ & $-1,160$ & - & - & 24,800 & - & 0.00 & $-109,000$ & $-1,640$ & 818 \\
\hline 2003 & 95,100 & 0.00 & $-46,500$ & 4,340 & $-31,100$ & $-1,170$ & - & - & 26,900 & - & 0.00 & $-109,000$ & $-1,710$ & 1,010 \\
\hline 2004 & 136,000 & 0.00 & $-46,500$ & 1,990 & 20,100 & -808 & - & - & 32,600 & - & 0.00 & $-102,000$ & $-1,490$ & 597 \\
\hline 2005 & 167,000 & 0.00 & $-47,300$ & 15,000 & 18,000 & $-9,580$ & - & - & 24,600 & - & 0.00 & $-127,000$ & $-1,410$ & $-3,340$ \\
\hline 2006 & 144,000 & 0.00 & $-48,700$ & 2,080 & 7,250 & $-1,120$ & - & - & 31,700 & - & 0.00 & $-119,000$ & $-1,600$ & -218 \\
\hline 2007 & 86,300 & 0.00 & $-48,300$ & 534 & $-35,400$ & -7.99 & - & - & 39,100 & - & 0.00 & $-113,000$ & $-2,000$ & 2,020 \\
\hline 2008 & 98,700 & 0.00 & $-44,800$ & 2,440 & $-16,200$ & -453 & - & - & 35,700 & - & 0.00 & $-108,000$ & $-1,970$ & 1,910 \\
\hline 2009 & 83,600 & 0.00 & $-45,200$ & 1,160 & $-16,300$ & -574 & - & - & 40,700 & - & 0.00 & $-96,300$ & $-1,970$ & 2,290 \\
\hline 2010 & 155,000 & 0.00 & $-45,800$ & 4,380 & 40,700 & $-1,770$ & - & - & 35,600 & - & 0.00 & $-103,000$ & $-2,220$ & -908 \\
\hline 2011 & 152,000 & 0.00 & $-45,400$ & 6,390 & 14,500 & $-2,390$ & - & - & 27,800 & - & 0.00 & $-119,000$ & $-2,330$ & $-2,940$ \\
\hline 2012 & 82,200 & 0.00 & $-44,600$ & 1,390 & $-30,900$ & -37.7 & - & - & 38,000 & - & 0.00 & $-107,000$ & $-2,440$ & 1,720 \\
\hline 2013 & 54,900 & 0.00 & $-46,400$ & 939 & $-37,800$ & 0.00 & - & - & 44,800 & - & 0.00 & $-92,700$ & $-2,320$ & 3,030 \\
\hline 2014 & 69,300 & 0.00 & $-42,200$ & 377 & $-15,600$ & 0.00 & - & - & 42,300 & - & 0.00 & $-85,800$ & $-2,190$ & 2,610 \\
\hline 2015 & 74,700 & 0.00 & $-44,000$ & 2,060 & $-5,920$ & 0.00 & - & - & 44,200 & - & 0.00 & $-82,100$ & $-1,920$ & 1,110 \\
\hline
\end{tabular}


Table 4.3. Overall annual groundwater flow budget and individual annual groundwater flow budgets by subarea of the Los Angeles Coastal Plain Groundwater-flow Model for Los Angeles Forebay, non-Water Replenishment District of Southern California (WRD), Los Angeles and Orange Counties, California.

[GHB, general head boundary; OC, Orange County; WHT, Whittier; PV, Palos Verdes; CHD, time-variant specified-head; LA Narrows, Los Angeles Narrows; WRD, Water Replenishment District of Southern California]

\begin{tabular}{|c|c|c|c|c|c|c|c|c|c|c|c|c|c|c|}
\hline Year & $\begin{array}{c}\text { Water } \\
\text { spreading }\end{array}$ & Injection & Pumping & Recharge & Storage & Drains & $\begin{array}{c}\text { GHB } \\
\text { Ocean }\end{array}$ & $\begin{array}{c}\text { GHB } \\
\text { OC }\end{array}$ & $\begin{array}{l}\text { GHB } \\
\text { WHT }\end{array}$ & $\begin{array}{l}\text { GHB } \\
\text { PV }\end{array}$ & $\begin{array}{l}\text { CHD LA } \\
\text { Narrows }\end{array}$ & $\begin{array}{l}\text { Flow from } \\
\text { Hollywood }\end{array}$ & $\begin{array}{c}\text { Flow from WRD Los } \\
\text { Angeles Forebay }\end{array}$ & $\begin{array}{l}\text { Flow from } \\
\text { Central Basin }\end{array}$ \\
\hline 1971 & 0.00 & 0.00 & 0.00 & 1,640 & $-4,180$ & 0.00 & - & - & - & - & 5,650 & 673 & $-10,700$ & $-1,450$ \\
\hline 1972 & 0.00 & 0.00 & 0.00 & 773 & $-1,450$ & 0.00 & - & - & - & - & 6,150 & 651 & $-8,350$ & -671 \\
\hline 1973 & 0.00 & 0.00 & 0.00 & 4,720 & 1,550 & 0.00 & - & - & - & - & 5,670 & 630 & $-8,470$ & $-1,000$ \\
\hline 1974 & 0.00 & 0.00 & 0.00 & 2,800 & -394 & 0.00 & - & - & - & - & 5,670 & 640 & $-8,770$ & -731 \\
\hline 1975 & 0.00 & 0.00 & 0.00 & 1,850 & -995 & 0.00 & - & - & - & - & 5,720 & 664 & $-8,920$ & -310 \\
\hline 1976 & 0.00 & 0.00 & 0.00 & 665 & $-1,890$ & 0.00 & - & - & - & - & 5,940 & 665 & $-9,120$ & -42.9 \\
\hline 1977 & 0.00 & 0.00 & 0.00 & 731 & $-2,030$ & 0.00 & - & - & - & - & 5,860 & 623 & $-9,400$ & 164 \\
\hline 1978 & 0.00 & 0.00 & 0.00 & 12,300 & 6,770 & 0.00 & - & - & - & - & 4,570 & 519 & $-9,370$ & $-1,210$ \\
\hline 1979 & 0.00 & 0.00 & 0.00 & 6,000 & 1,250 & 0.00 & - & - & - & - & 5,050 & 680 & $-9,940$ & -545 \\
\hline 1980 & 0.00 & 0.00 & 0.00 & 10,000 & 4,530 & 0.00 & - & - & - & - & 4,610 & 854 & $-10,000$ & -916 \\
\hline 1981 & 0.00 & 0.00 & 0.00 & 1,150 & $-1,690$ & 0.00 & - & - & - & - & 5,460 & 1,130 & $-9,270$ & -164 \\
\hline 1982 & 0.00 & 0.00 & 0.00 & 1,700 & -789 & 0.00 & - & - & - & - & 5,710 & 1,190 & $-9,120$ & -273 \\
\hline 1983 & 0.00 & 0.00 & 0.00 & 10,600 & 5,100 & 0.00 & - & - & - & - & 4,560 & 1,120 & $-9,910$ & $-1,240$ \\
\hline 1984 & 0.00 & 0.00 & 0.00 & 1,650 & $-1,540$ & 0.00 & - & - & - & - & 5,660 & 1,260 & $-9,490$ & -616 \\
\hline 1985 & 0.00 & 0.00 & 0.00 & 1,680 & $-1,440$ & 0.00 & - & - & - & - & 4,620 & 1,260 & $-8,540$ & -473 \\
\hline 1986 & 0.00 & 0.00 & 0.00 & 3,990 & 1,540 & 0.00 & - & - & - & - & 6,220 & 1,180 & $-9,130$ & -712 \\
\hline 1987 & 0.00 & 0.00 & 0.00 & 605 & $-1,790$ & 0.00 & - & - & - & - & 5,790 & 1,140 & $-8,890$ & -443 \\
\hline 1988 & 0.00 & 0.00 & 0.00 & 1,280 & -836 & 0.00 & - & - & - & - & 5,860 & 1,050 & $-8,660$ & -367 \\
\hline 1989 & 0.00 & 0.00 & 0.00 & 1,230 & $-1,680$ & 0.00 & - & - & - & - & 5,020 & 959 & $-8,670$ & -210 \\
\hline 1990 & 0.00 & 0.00 & 0.00 & 315 & -488 & 0.00 & - & - & - & - & 6,380 & 873 & $-7,900$ & -159 \\
\hline 1991 & 0.00 & 0.00 & 0.00 & 1,660 & -460 & 0.00 & - & - & - & - & 5,730 & 769 & $-8,320$ & -300 \\
\hline 1992 & 0.00 & 0.00 & 0.00 & 5,560 & 1,840 & 0.00 & - & - & - & - & 5,240 & 672 & $-8,970$ & -662 \\
\hline 1993 & 0.00 & 0.00 & 0.00 & 10,100 & 6,830 & 0.00 & - & - & - & - & 4,440 & 683 & $-7,100$ & $-1,300$ \\
\hline 1994 & 0.00 & 0.00 & 0.00 & 856 & $-1,410$ & 0.00 & - & - & - & - & 5,560 & 928 & $-8,280$ & -473 \\
\hline 1995 & 0.00 & 0.00 & 0.00 & 7,690 & 3,280 & 0.00 & - & - & - & - & 4,850 & 999 & $-9,350$ & -917 \\
\hline 1996 & 0.00 & 0.00 & 0.00 & 2,250 & -818 & 0.00 & - & - & - & - & 5,420 & 1,140 & $-9,050$ & -575 \\
\hline 1997 & 0.00 & 0.00 & 0.00 & 3,570 & 427 & 0.00 & - & - & - & - & 5,350 & 1,180 & $-8,980$ & -686 \\
\hline 1998 & 0.00 & 0.00 & 0.00 & 10,800 & 4,960 & 0.00 & - & - & - & - & 4,490 & 1,170 & $-10,300$ & $-1,160$ \\
\hline 1999 & 0.00 & 0.00 & 0.00 & 1,060 & $-2,920$ & 0.00 & - & - & - & - & 5,450 & 1,390 & $-10,400$ & -409 \\
\hline 2000 & 0.00 & 0.00 & 0.00 & 1,990 & $-1,640$ & 0.00 & - & - & - & - & 5,520 & 1,400 & $-10,300$ & -305 \\
\hline
\end{tabular}


Table 4.3. Overall annual groundwater flow budget and individual annual groundwater flow budgets by subarea of the Los Angeles Coastal Plain Groundwater-flow Model for Los Angeles Forebay, non-Water Replenishment District of Southern California (WRD), Los Angeles and Orange Counties, California.-Continued

[GHB, general head boundary; OC, Orange County; WHT, Whittier; PV, Palos Verdes; CHD, time-variant specified-head; LA Narrows, Los Angeles Narrows; WRD, Water Replenishment District of Southern California]

\begin{tabular}{|c|c|c|c|c|c|c|c|c|c|c|c|c|c|c|}
\hline Year & $\begin{array}{c}\text { Water } \\
\text { spreading }\end{array}$ & Injection & Pumping & Recharge & Storage & Drains & $\begin{array}{c}\text { GHB } \\
\text { Ocean }\end{array}$ & $\begin{array}{l}\text { GHB } \\
\text { OC }\end{array}$ & $\begin{array}{l}\text { GHB } \\
\text { WHT }\end{array}$ & $\begin{array}{l}\text { GHB } \\
\text { PV }\end{array}$ & $\begin{array}{l}\text { CHD LA } \\
\text { Narrows }\end{array}$ & $\begin{array}{l}\text { Flow from } \\
\text { Hollywood }\end{array}$ & $\begin{array}{c}\text { Flow from WRD Los } \\
\text { Angeles Forebay }\end{array}$ & $\begin{array}{c}\text { Flow from } \\
\text { Central Basin }\end{array}$ \\
\hline 2001 & 0.00 & 0.00 & 0.00 & 3,690 & -583 & 0.00 & - & - & - & - & 5,390 & 1,330 & $-10,500$ & -443 \\
\hline 2002 & 0.00 & 0.00 & 0.00 & 437 & $-2,820$ & 0.00 & - & - & - & - & 5,680 & 1,290 & $-10,200$ & -77.1 \\
\hline 2003 & 0.00 & 0.00 & 0.00 & 1,640 & $-1,250$ & 0.00 & - & - & - & - & 5,600 & 1,190 & $-9,480$ & -205 \\
\hline 2004 & 0.00 & 0.00 & 0.00 & 1,340 & $-1,730$ & 0.00 & - & - & - & - & 5,660 & 1,080 & $-9,680$ & -123 \\
\hline 2005 & 0.00 & 0.00 & 0.00 & 11,900 & 5,840 & 0.00 & - & - & - & - & 4,230 & 938 & $-9,920$ & $-1,280$ \\
\hline 2006 & 0.00 & 0.00 & 0.00 & 1,670 & $-1,620$ & 0.00 & - & - & - & - & 5,350 & 1,100 & $-9,320$ & -423 \\
\hline 2007 & 0.00 & 0.00 & 0.00 & 337 & $-2,510$ & 0.00 & - & - & - & - & 5,670 & 1,130 & $-9,520$ & -131 \\
\hline 2008 & 0.00 & 0.00 & 0.00 & 2,270 & -999 & 0.00 & - & - & - & - & 5,470 & 1,040 & $-9,660$ & -109 \\
\hline 2009 & 0.00 & 0.00 & 0.00 & 991 & $-1,930$ & 0.00 & - & - & - & - & 5,710 & 965 & $-9,400$ & -201 \\
\hline 2010 & 0.00 & 0.00 & 0.00 & 3,180 & 244 & 0.00 & - & - & - & - & 5,530 & 870 & $-9,070$ & -266 \\
\hline 2011 & 0.00 & 0.00 & 0.00 & 4,430 & 2,250 & 0.00 & - & - & - & - & 5,540 & 805 & $-7,940$ & -587 \\
\hline 2012 & 0.00 & 0.00 & 0.00 & 647 & $-1,700$ & 0.00 & - & - & - & - & 5,550 & 812 & $-8,410$ & -297 \\
\hline 2013 & 0.00 & 0.00 & 0.00 & 503 & $-2,380$ & 0.00 & - & - & - & - & 5,350 & 758 & $-8,830$ & -169 \\
\hline 2014 & 0.00 & 0.00 & 0.00 & 224 & $-2,560$ & 0.00 & - & - & - & - & 5,510 & 674 & $-8,990$ & 28.4 \\
\hline 2015 & 0.00 & 0.00 & 0.00 & 1,430 & $-1,210$ & 0.00 & - & - & - & - & 5,040 & 576 & $-8,230$ & -27.8 \\
\hline
\end{tabular}


Table 4.4. Overall annual groundwater flow budget and individual annual groundwater flow budgets by subarea of the Los Angeles Coastal Plain Groundwater-flow Model for Los Angeles Forebay, Water Replenishment District of Southern California (WRD), Los Angeles and Orange Counties, California.

[GHB, general head boundary; OC, Orange County; WHT, Whittier; PV, Palos Verdes; CHD, time-variant specified-head; LA Narrows, Los Angeles Narrows; WRD, Water Replenishment District of Southern California]

\begin{tabular}{|c|c|c|c|c|c|c|c|c|c|c|c|c|c|c|}
\hline Year & $\begin{array}{c}\text { Water } \\
\text { spreading }\end{array}$ & Injection & Pumping & Recharge & Storage & Drains & $\begin{array}{l}\text { GHB } \\
\text { Ocean }\end{array}$ & $\begin{array}{c}\text { GHB } \\
\text { OC }\end{array}$ & $\begin{array}{l}\text { GHB } \\
\text { WHT }\end{array}$ & $\begin{array}{l}\text { GHB } \\
\text { PV }\end{array}$ & $\begin{array}{l}\text { CHD LA } \\
\text { Narrows }\end{array}$ & $\begin{array}{l}\text { Flow from Los } \\
\text { Angeles Forebay }\end{array}$ & $\begin{array}{l}\text { Flow from WRD } \\
\text { Central Basin }\end{array}$ & $\begin{array}{c}\text { Flow from } \\
\text { Montebello Forebay }\end{array}$ \\
\hline 1971 & 0.00 & 0.00 & $-32,700$ & 946 & $-11,000$ & 0.00 & - & - & - & - & 0.00 & 10,700 & 7,180 & 2,870 \\
\hline 1972 & 0.00 & 0.00 & $-25,600$ & 560 & $-10,400$ & 0.00 & - & - & - & - & 0.00 & 8,350 & 3,880 & 2,350 \\
\hline 1973 & 0.00 & 0.00 & $-24,400$ & 2,420 & $-6,410$ & 0.00 & - & - & - & - & 0.00 & 8,470 & 4,750 & 2,310 \\
\hline 1974 & 0.00 & 0.00 & $-24,600$ & 1,590 & $-5,440$ & 0.00 & - & - & - & - & 0.00 & 8,770 & 6,570 & 2,200 \\
\hline 1975 & 0.00 & 0.00 & $-23,700$ & 1,340 & $-5,570$ & 0.00 & - & - & - & - & 0.00 & 8,920 & 5,480 & 2,400 \\
\hline 1976 & 0.00 & 0.00 & $-24,200$ & 571 & $-6,850$ & 0.00 & - & - & - & - & 0.00 & 9,120 & 5,280 & 2,380 \\
\hline 1977 & 0.00 & 0.00 & $-24,600$ & 749 & $-7,770$ & 0.00 & - & - & - & - & 0.00 & 9,400 & 4,460 & 2,170 \\
\hline 1978 & 0.00 & 0.00 & $-22,800$ & 5,660 & 3,000 & 0.00 & - & - & - & - & 0.00 & 9,370 & 8,730 & 2,040 \\
\hline 1979 & 0.00 & 0.00 & $-23,100$ & 3,390 & 1,050 & 0.00 & - & - & - & - & 0.00 & 9,940 & 8,190 & 2,600 \\
\hline 1980 & 0.00 & 0.00 & $-21,700$ & 4,850 & 4,980 & 0.00 & - & - & - & - & 0.00 & 10,000 & 9,360 & 2,510 \\
\hline 1981 & 0.00 & 0.00 & $-19,500$ & 989 & 811 & 0.00 & - & - & - & - & 0.00 & 9,270 & 7,830 & 2,170 \\
\hline 1982 & 0.00 & 0.00 & $-19,000$ & 1,270 & -374 & 0.00 & - & - & - & - & 0.00 & 9,120 & 5,810 & 2,400 \\
\hline 1983 & 0.00 & 0.00 & $-19,100$ & 5,280 & 5,500 & 0.00 & - & - & - & - & 0.00 & 9,910 & 6,780 & 2,690 \\
\hline 1984 & 0.00 & 0.00 & $-17,900$ & 1,310 & -569 & 0.00 & - & - & - & - & 0.00 & 9,490 & 4,240 & 2,300 \\
\hline 1985 & 0.00 & 0.00 & $-15,500$ & 1,160 & 208 & 0.00 & - & - & - & - & 0.00 & 8,540 & 4,220 & 1,830 \\
\hline 1986 & 0.00 & 0.00 & $-17,800$ & 2,230 & 11.0 & 0.00 & - & - & - & - & 0.00 & 9,130 & 4,180 & 2,300 \\
\hline 1987 & 0.00 & 0.00 & $-17,500$ & 622 & $-2,640$ & 0.00 & - & - & - & - & 0.00 & 8,890 & 3,040 & 2,270 \\
\hline 1988 & 0.00 & 0.00 & $-15,400$ & 977 & $-2,230$ & 0.00 & - & - & - & - & 0.00 & 8,660 & 1,600 & 1,910 \\
\hline 1989 & 0.00 & 0.00 & $-16,500$ & 899 & $-2,220$ & 0.00 & - & - & - & - & 0.00 & 8,670 & 2,760 & 1,980 \\
\hline 1990 & 0.00 & 0.00 & $-16,000$ & 327 & $-1,600$ & 0.00 & - & - & - & - & 0.00 & 7,900 & 4,110 & 2,070 \\
\hline 1991 & 0.00 & 0.00 & $-17,300$ & 844 & $-2,120$ & 0.00 & - & - & - & - & 0.00 & 8,320 & 4,010 & 2,010 \\
\hline 1992 & 0.00 & 0.00 & $-19,200$ & 2,570 & 959 & 0.00 & - & - & - & - & 0.00 & 8,970 & 6,550 & 2,090 \\
\hline 1993 & 0.00 & 0.00 & $-15,400$ & 4,510 & 11,400 & 0.00 & - & - & - & - & 0.00 & 7,100 & 13,200 & 1,980 \\
\hline 1994 & 0.00 & 0.00 & $-19,000$ & 805 & 1,310 & 0.00 & - & - & - & - & 0.00 & 8,280 & 9,010 & 2,270 \\
\hline 1995 & 0.00 & 0.00 & $-20,900$ & 3,640 & 3,330 & 0.00 & - & - & - & - & 0.00 & 9,350 & 9,010 & 2,260 \\
\hline 1996 & 0.00 & 0.00 & $-18,200$ & 1,410 & 561 & 0.00 & - & - & - & - & 0.00 & 9,050 & 6,040 & 2,300 \\
\hline 1997 & 0.00 & 0.00 & $-17,400$ & 2,050 & 783 & 0.00 & - & - & - & - & 0.00 & 8,980 & 4,800 & 2,360 \\
\hline 1998 & 0.00 & 0.00 & $-18,400$ & 5,490 & 4,250 & 0.00 & - & - & - & - & 0.00 & 10,300 & 4,300 & 2,520 \\
\hline 1999 & 0.00 & 0.00 & $-18,900$ & 1,000 & $-2,640$ & 0.00 & - & - & - & - & 0.00 & 10,400 & 2,310 & 2,540 \\
\hline 2000 & 0.00 & 0.00 & $-16,300$ & 1,170 & $-3,010$ & 0.00 & - & - & - & - & 0.00 & 10,300 & 34.0 & 1,820 \\
\hline
\end{tabular}


Table 4.4. Overall annual groundwater flow budget and individual annual groundwater flow budgets by subarea of the Los Angeles Coastal Plain Groundwater-flow Model for Los Angeles Forebay, Water Replenishment District of Southern California (WRD), Los Angeles and Orange Counties, California.-Continued

[GHB, general head boundary; OC, Orange County; WHT, Whittier; PV, Palos Verdes; CHD, time-variant specified-head; LA Narrows, Los Angeles Narrows; WRD, Water Replenishment District of Southern California]

\begin{tabular}{|c|c|c|c|c|c|c|c|c|c|c|c|c|c|c|}
\hline Year & $\begin{array}{c}\text { Water } \\
\text { spreading }\end{array}$ & Injection & Pumping & Recharge & Storage & Drains & $\begin{array}{c}\text { GHB } \\
\text { Ocean }\end{array}$ & $\begin{array}{c}\text { GHB } \\
\text { OC }\end{array}$ & $\begin{array}{l}\text { GHB } \\
\text { WHT }\end{array}$ & $\begin{array}{l}\text { GHB } \\
\text { PV }\end{array}$ & $\begin{array}{c}\text { CHD LA } \\
\text { Narrows }\end{array}$ & $\begin{array}{l}\text { Flow from Los } \\
\text { Angeles Forebay }\end{array}$ & $\begin{array}{l}\text { Flow from WRD } \\
\text { Central Basin }\end{array}$ & $\begin{array}{c}\text { Flow from } \\
\text { Montebello Forebay }\end{array}$ \\
\hline 2001 & 0.00 & 0.00 & $-17,300$ & 1,900 & $-2,190$ & 0.00 & - & - & - & - & 0.00 & 10,500 & 862 & 1,810 \\
\hline 2002 & 0.00 & 0.00 & $-18,600$ & 424 & $-4,410$ & 0.00 & - & - & - & - & 0.00 & 10,200 & 1,990 & 1,640 \\
\hline 2003 & 0.00 & 0.00 & $-16,100$ & 1,090 & $-2,710$ & 0.00 & - & - & - & - & 0.00 & 9,480 & 1,110 & 1,710 \\
\hline 2004 & 0.00 & 0.00 & $-16,300$ & 966 & $-3,750$ & 0.00 & - & - & - & - & 0.00 & 9,680 & 407 & 1,490 \\
\hline 2005 & 0.00 & 0.00 & $-15,600$ & 5,180 & 4,890 & 0.00 & - & - & - & - & 0.00 & 9,920 & 4,000 & 1,410 \\
\hline 2006 & 0.00 & 0.00 & $-16,600$ & 1,280 & 674 & 0.00 & - & - & - & - & 0.00 & 9,320 & 5,050 & 1,600 \\
\hline 2007 & 0.00 & 0.00 & $-16,900$ & 337 & $-2,670$ & 0.00 & - & - & - & - & 0.00 & 9,520 & 2,370 & 2,000 \\
\hline 2008 & 0.00 & 0.00 & $-15,400$ & 1,210 & $-2,590$ & 0.00 & - & - & - & - & 0.00 & 9,660 & -44.0 & 1,970 \\
\hline 2009 & 0.00 & 0.00 & $-13,400$ & 724 & $-3,680$ & 0.00 & - & - & - & - & 0.00 & 9,400 & $-2,380$ & 1,970 \\
\hline 2010 & 0.00 & 0.00 & $-13,900$ & 1,740 & $-1,320$ & 0.00 & - & - & - & - & 0.00 & 9,070 & -462 & 2,220 \\
\hline 2011 & 0.00 & 0.00 & $-13,000$ & 2,390 & 3,970 & 0.00 & - & - & - & - & 0.00 & 7,940 & 4,330 & 2,330 \\
\hline 2012 & 0.00 & 0.00 & $-13,700$ & 675 & -484 & 0.00 & - & - & - & - & 0.00 & 8,410 & 1,670 & 2,440 \\
\hline 2013 & 0.00 & 0.00 & $-16,200$ & 493 & $-3,510$ & 0.00 & - & - & - & - & 0.00 & 8,830 & 1,080 & 2,320 \\
\hline 2014 & 0.00 & 0.00 & $-15,700$ & 224 & $-5,220$ & 0.00 & - & - & - & - & 0.00 & 8,990 & -919 & 2,190 \\
\hline 2015 & 0.00 & 0.00 & $-12,900$ & 785 & $-2,940$ & 0.00 & - & - & - & - & 0.00 & 8,230 & -997 & 1,920 \\
\hline
\end{tabular}


Table 4.5. Overall annual groundwater flow budget and individual annual groundwater flow budgets by subarea of the Los Angeles Coastal Plain Groundwater-flow Model for Hollywood Basin, Los Angeles and Orange Counties, California.

[GHB, general head boundary; OC, Orange County; WHT, Whittier; PV, Palos Verdes; CHD, time-variant specified-head; LA Narrows, Los Angeles Narrows]

\begin{tabular}{|c|c|c|c|c|c|c|c|c|c|c|c|c|c|c|}
\hline Year & $\begin{array}{c}\text { Water } \\
\text { spreading }\end{array}$ & Injection & Pumping & Recharge & Storage & Drains & $\begin{array}{c}\text { GHB } \\
\text { Ocean }\end{array}$ & $\begin{array}{c}\text { GHB } \\
\text { OC }\end{array}$ & $\begin{array}{l}\text { GHB } \\
\text { WHT }\end{array}$ & $\begin{array}{l}\text { GHB } \\
\text { PV }\end{array}$ & $\begin{array}{c}\text { CHD LA } \\
\text { Narrows }\end{array}$ & $\begin{array}{l}\text { Flow from Los } \\
\text { Angeles Forebay }\end{array}$ & $\begin{array}{c}\text { Flow from } \\
\text { Santa Monica }\end{array}$ & $\begin{array}{c}\text { Flow from } \\
\text { Central Basin }\end{array}$ \\
\hline 1971 & 0.00 & 0.00 & $-2,320$ & 1,570 & $-3,980$ & 0.00 & - & - & - & - & 0.00 & -673 & 322 & $-2,880$ \\
\hline 1972 & 0.00 & 0.00 & $-2,190$ & 1,050 & $-4,190$ & 0.00 & - & - & - & - & 0.00 & -651 & 161 & $-2,570$ \\
\hline 1973 & 0.00 & 0.00 & $-2,020$ & 3,640 & -873 & 0.00 & - & - & - & - & 0.00 & -630 & 399 & $-2,260$ \\
\hline 1974 & 0.00 & 0.00 & $-1,550$ & 2,570 & $-1,370$ & 0.00 & - & - & - & - & 0.00 & -640 & 298 & $-2,060$ \\
\hline 1975 & 0.00 & 0.00 & $-1,040$ & 1,300 & $-2,110$ & 0.00 & - & - & - & - & 0.00 & -664 & 102 & $-1,810$ \\
\hline 1976 & 0.00 & 0.00 & -292 & 614 & $-2,140$ & 0.00 & - & - & - & - & 0.00 & -665 & -49.4 & $-1,750$ \\
\hline 1977 & 0.00 & 0.00 & 0.00 & 747 & $-1,530$ & 0.00 & - & - & - & - & 0.00 & -623 & -10.9 & $-1,640$ \\
\hline 1978 & 0.00 & 0.00 & 0.00 & 9,730 & 8,510 & 0.00 & - & - & - & - & 0.00 & -519 & 760 & $-1,460$ \\
\hline 1979 & 0.00 & 0.00 & 0.00 & 4,720 & 2,900 & 0.00 & - & - & - & - & 0.00 & -680 & 400 & $-1,530$ \\
\hline 1980 & 0.00 & 0.00 & 0.00 & 8,720 & 6,880 & 0.00 & - & - & - & - & 0.00 & -854 & 631 & $-1,620$ \\
\hline 1981 & 0.00 & 0.00 & 0.00 & 1,310 & $-1,610$ & 0.00 & - & - & - & - & 0.00 & $-1,130$ & 9.29 & $-1,800$ \\
\hline 1982 & 0.00 & 0.00 & 0.00 & 1,470 & $-1,650$ & 0.00 & - & - & - & - & 0.00 & $-1,190$ & -62.5 & $-1,860$ \\
\hline 1983 & 0.00 & 0.00 & 0.00 & 8,170 & 5,850 & 0.00 & - & - & - & - & 0.00 & $-1,120$ & 505 & $-1,710$ \\
\hline 1984 & 0.00 & 0.00 & 0.00 & 1,450 & $-1,710$ & 0.00 & - & - & - & - & 0.00 & $-1,260$ & -51.2 & $-1,850$ \\
\hline 1985 & 0.00 & 0.00 & 0.00 & 1,240 & $-1,980$ & 0.00 & - & - & - & - & 0.00 & $-1,260$ & -133 & $-1,830$ \\
\hline 1986 & 0.00 & 0.00 & 0.00 & 3,270 & 442 & 0.00 & - & - & - & - & 0.00 & $-1,180$ & 96.6 & $-1,750$ \\
\hline 1987 & 0.00 & 0.00 & 0.00 & 637 & $-2,520$ & 0.00 & - & - & - & - & 0.00 & $-1,140$ & -235 & $-1,780$ \\
\hline 1988 & 0.00 & 0.00 & 0.00 & 1,000 & $-1,890$ & 0.00 & - & - & - & - & 0.00 & $-1,050$ & -155 & $-1,680$ \\
\hline 1989 & 0.00 & 0.00 & 0.00 & 952 & $-1,790$ & 0.00 & - & - & - & - & 0.00 & -959 & -170 & $-1,610$ \\
\hline 1990 & 0.00 & 0.00 & 0.00 & 262 & $-2,480$ & 0.00 & - & - & - & - & 0.00 & -873 & -284 & $-1,590$ \\
\hline 1991 & 0.00 & 0.00 & 0.00 & 1,650 & -752 & 0.00 & - & - & - & - & 0.00 & -769 & -87.3 & $-1,550$ \\
\hline 1992 & 0.00 & 0.00 & 0.00 & 5,190 & 3,360 & 0.00 & - & - & - & - & 0.00 & -672 & 297 & $-1,460$ \\
\hline 1993 & 0.00 & 0.00 & 0.00 & 9,080 & 7,630 & 0.00 & - & - & - & - & 0.00 & -683 & 618 & $-1,380$ \\
\hline 1994 & 0.00 & 0.00 & 0.00 & 887 & $-1,680$ & 0.00 & - & - & - & - & 0.00 & -928 & -119 & $-1,530$ \\
\hline 1995 & 0.00 & 0.00 & 0.00 & 7,310 & 5,140 & 0.00 & - & - & - & - & 0.00 & -999 & 431 & $-1,600$ \\
\hline 1996 & 0.00 & 0.00 & 0.00 & 2,070 & -828 & 0.00 & - & - & - & - & 0.00 & $-1,140$ & -33.1 & $-1,730$ \\
\hline 1997 & 0.00 & 0.00 & 0.00 & 3,320 & 518 & 0.00 & - & - & - & - & 0.00 & $-1,180$ & 126 & $-1,750$ \\
\hline 1998 & 0.00 & 0.00 & 0.00 & 9,030 & 6,780 & 0.00 & - & - & - & - & 0.00 & $-1,170$ & 541 & $-1,620$ \\
\hline 1999 & 0.00 & 0.00 & 0.00 & 952 & $-2,440$ & 0.00 & - & - & - & - & 0.00 & $-1,390$ & -180 & $-1,830$ \\
\hline 2000 & 0.00 & 0.00 & $-1,030$ & 1,910 & $-2,450$ & 0.00 & - & - & - & - & 0.00 & $-1,400$ & -83 & $-1,840$ \\
\hline
\end{tabular}


Table 4.5. Overall annual groundwater flow budget and individual annual groundwater flow budgets by subarea of the Los Angeles Coastal Plain Groundwater-flow Model for Hollywood Basin, Los Angeles and Orange Counties, California.-Continued

[GHB, general head boundary; OC, Orange County; WHT, Whittier; PV, Palos Verdes; CHD, time-variant specified-head; LA Narrows, Los Angeles Narrows]

\begin{tabular}{|c|c|c|c|c|c|c|c|c|c|c|c|c|c|c|}
\hline Year & $\begin{array}{c}\text { Water } \\
\text { spreading }\end{array}$ & Injection & Pumping & Recharge & Storage & Drains & $\begin{array}{c}\text { GHB } \\
\text { Ocean }\end{array}$ & $\begin{array}{c}\text { GHB } \\
\text { OC }\end{array}$ & $\begin{array}{l}\text { GHB } \\
\text { WHT }\end{array}$ & $\begin{array}{l}\text { GHB } \\
\text { PV }\end{array}$ & $\begin{array}{c}\text { CHD LA } \\
\text { Narrows }\end{array}$ & $\begin{array}{l}\text { Flow from Los } \\
\text { Angeles Forebay }\end{array}$ & $\begin{array}{c}\text { Flow from } \\
\text { Santa Monica }\end{array}$ & $\begin{array}{l}\text { Flow from } \\
\text { Central Basin }\end{array}$ \\
\hline 2001 & 0.00 & 0.00 & $-1,370$ & 3,570 & -767 & 0.00 & - & - & - & - & 0.00 & $-1,330$ & 136 & $-1,780$ \\
\hline 2002 & 0.00 & 0.00 & $-1,370$ & 453 & $-4,200$ & 0.00 & - & - & - & - & 0.00 & $-1,290$ & -221 & $-1,770$ \\
\hline 2003 & 0.00 & 0.00 & $-1,370$ & 1,070 & $-3,340$ & 0.00 & - & - & - & - & 0.00 & $-1,190$ & -156 & $-1,690$ \\
\hline 2004 & 0.00 & 0.00 & $-1,370$ & 1,330 & $-2,880$ & 0.00 & - & - & - & - & 0.00 & $-1,080$ & -118 & $-1,640$ \\
\hline 2005 & 0.00 & 0.00 & $-1,370$ & 9,330 & 6,160 & 0.00 & - & - & - & - & 0.00 & -938 & 610 & $-1,460$ \\
\hline 2006 & 0.00 & 0.00 & $-1,370$ & 1,410 & $-2,670$ & 0.00 & - & - & - & - & 0.00 & $-1,100$ & -6.22 & $-1,600$ \\
\hline 2007 & 0.00 & 0.00 & $-1,610$ & 348 & $-4,200$ & 0.00 & - & - & - & - & 0.00 & $-1,130$ & -174 & $-1,630$ \\
\hline 2008 & 0.00 & 0.00 & -995 & 1,890 & $-1,660$ & 0.00 & - & - & - & - & 0.00 & $-1,040$ & 53.5 & $-1,560$ \\
\hline 2009 & 0.00 & 0.00 & $-1,600$ & 643 & $-3,590$ & 0.00 & - & - & - & - & 0.00 & -965 & -119 & $-1,550$ \\
\hline 2010 & 0.00 & 0.00 & $-1,290$ & 2,750 & -721 & 0.00 & - & - & - & - & 0.00 & -870 & 135 & $-1,450$ \\
\hline 2011 & 0.00 & 0.00 & $-3,730$ & 3,180 & $-2,450$ & 0.00 & - & - & - & - & 0.00 & -805 & 234 & $-1,320$ \\
\hline 2012 & 0.00 & 0.00 & $-3,840$ & 440 & $-5,610$ & 0.00 & - & - & - & - & 0.00 & -812 & -71.7 & $-1,320$ \\
\hline 2013 & 0.00 & 0.00 & $-3,890$ & 249 & $-5,820$ & 0.00 & - & - & - & - & 0.00 & -758 & -118 & $-1,300$ \\
\hline 2014 & 0.00 & 0.00 & -688 & 278 & $-2,500$ & 0.00 & - & - & - & - & 0.00 & -674 & -134 & $-1,280$ \\
\hline 2015 & 0.00 & 0.00 & -107 & 1,220 & -699 & 0.00 & - & - & - & - & 0.00 & -576 & -36.5 & $-1,200$ \\
\hline
\end{tabular}


Table 4.6. Overall annual groundwater flow budget and individual annual groundwater flow budgets by subarea of the Los Angeles Coastal Plain Groundwater-flow Model for Central Basin Pressure Area, non- Water Replenishment District of Southern California (WRD), Los Angeles and Orange Counties, California.

[GHB, general head boundary; OC, Orange County; WHT, Whittier; PV, Palos Verdes; CHD, time-variant specified-head; LA Narrows, Los Angeles Narrows; WRD, Water Replenishment District of Southern California]

\begin{tabular}{|c|c|c|c|c|c|c|c|c|c|c|c|c|c|c|c|}
\hline Year & $\begin{array}{c}\text { Water } \\
\text { spreading }\end{array}$ & Injection & Pumping & Recharge & Storage & Drains & $\begin{array}{c}\text { GHB } \\
\text { Ocean }\end{array}$ & $\begin{array}{l}\text { GHB } \\
\text { OC }\end{array}$ & $\begin{array}{l}\text { GHB } \\
\text { WHT }\end{array}$ & $\begin{array}{l}\text { GHB } \\
\text { PV }\end{array}$ & $\begin{array}{l}\text { CHD LA } \\
\text { Narrows }\end{array}$ & $\begin{array}{l}\text { Flow from Los } \\
\text { Angeles Forebay }\end{array}$ & $\begin{array}{l}\text { Flow from WRD } \\
\text { Central Basin }\end{array}$ & $\begin{array}{c}\text { Flow from } \\
\text { Santa Monica }\end{array}$ & $\begin{array}{l}\text { Flow from } \\
\text { Hollywood }\end{array}$ \\
\hline 1971 & 0.00 & 0.00 & $-2,820$ & 740 & $-1,950$ & $-2,780$ & - & - & - & - & 0.00 & 1,450 & $-1,850$ & 436 & 2,880 \\
\hline 1972 & 0.00 & 0.00 & $-2,940$ & 421 & $-1,420$ & $-1,140$ & - & - & - & - & 0.00 & 671 & $-1,620$ & 621 & 2,570 \\
\hline 1973 & 0.00 & 0.00 & $-2,250$ & 1,990 & 917 & -780 & - & - & - & - & 0.00 & 1,000 & $-1,780$ & 470 & 2,260 \\
\hline 1974 & 0.00 & 0.00 & $-1,580$ & 1,360 & 319 & -568 & - & - & - & - & 0.00 & 731 & $-2,030$ & 353 & 2,060 \\
\hline 1975 & 0.00 & 0.00 & -321 & 965 & 87 & -424 & - & - & - & - & 0.00 & 310 & $-2,410$ & 159 & 1,810 \\
\hline 1976 & 0.00 & 0.00 & -334 & 352 & -874 & -316 & - & - & - & - & 0.00 & 43.0 & $-2,500$ & 131 & 1,750 \\
\hline 1977 & 0.00 & 0.00 & -5.74 & 475 & -943 & -247 & - & - & - & - & 0.00 & -164 & $-2,710$ & 67.6 & 1,640 \\
\hline 1978 & 0.00 & 0.00 & -19.0 & 4,820 & 4,180 & -457 & - & - & - & - & 0.00 & 1,210 & $-2,770$ & -55.5 & 1,460 \\
\hline 1979 & 0.00 & 0.00 & -14.0 & 2,550 & 1,410 & -468 & - & - & - & - & 0.00 & 545 & $-2,580$ & -149 & 1,530 \\
\hline 1980 & 0.00 & 0.00 & -8.98 & 4,190 & 3,340 & -596 & - & - & - & - & 0.00 & 916 & $-2,550$ & -228 & 1,620 \\
\hline 1981 & 0.00 & 0.00 & -2.75 & 739 & -513 & -440 & - & - & - & - & 0.00 & 164 & $-2,490$ & -279 & 1,800 \\
\hline 1982 & 0.00 & 0.00 & -4.49 & 903 & -373 & -352 & - & - & - & - & 0.00 & 273 & $-2,790$ & -263 & 1,860 \\
\hline 1983 & 0.00 & 0.00 & -7.01 & 4,240 & 3,470 & -491 & - & - & - & - & 0.00 & 1,240 & $-2,840$ & -373 & 1,710 \\
\hline 1984 & 0.00 & 0.00 & -12.0 & 928 & -497 & -421 & - & - & - & - & 0.00 & 616 & $-3,100$ & -356 & 1,850 \\
\hline 1985 & 0.00 & 0.00 & -8.01 & 752 & -488 & -343 & - & - & - & - & 0.00 & 473 & $-2,810$ & -383 & 1,830 \\
\hline 1986 & 0.00 & 0.00 & -8.01 & 1,850 & 505 & -361 & - & - & - & - & 0.00 & 712 & $-3,030$ & -403 & 1,750 \\
\hline 1987 & 0.00 & 0.00 & -8.01 & 421 & $-1,130$ & -294 & - & - & - & - & 0.00 & 443 & $-3,100$ & -368 & 1,780 \\
\hline 1988 & 0.00 & 0.00 & -7.98 & 711 & -782 & -254 & - & - & - & - & 0.00 & 367 & $-2,900$ & -376 & 1,680 \\
\hline 1989 & 0.00 & 0.00 & -7.01 & 643 & -790 & -225 & - & - & - & - & 0.00 & 210 & $-2,650$ & -370 & 1,610 \\
\hline 1990 & 0.00 & 0.00 & -7.01 & 193 & $-1,150$ & -175 & - & - & - & - & 0.00 & 159 & $-2,560$ & -348 & 1,590 \\
\hline 1991 & 0.00 & 0.00 & -69.8 & 608 & -983 & -161 & - & - & - & - & 0.00 & 300 & $-2,900$ & -308 & 1,550 \\
\hline 1992 & 0.00 & 0.00 & -85.8 & 2,290 & 943 & -242 & - & - & - & - & 0.00 & 662 & $-2,780$ & -354 & 1,460 \\
\hline 1993 & 0.00 & 0.00 & -114 & 4,100 & 3,840 & -434 & - & - & - & - & 0.00 & 1,300 & $-1,900$ & -486 & 1,380 \\
\hline 1994 & 0.00 & 0.00 & -2.19 & 630 & -329 & -337 & - & - & - & - & 0.00 & 473 & $-2,120$ & -497 & 1,530 \\
\hline 1995 & 0.00 & 0.00 & -3.06 & 3,310 & 2,420 & -434 & - & - & - & - & 0.00 & 917 & $-2,470$ & -487 & 1,600 \\
\hline 1996 & 0.00 & 0.00 & -3.23 & 1,180 & -136 & -379 & - & - & - & - & 0.00 & 575 & $-2,750$ & -487 & 1,730 \\
\hline 1997 & 0.00 & 0.00 & -3.84 & 1,810 & 556 & -397 & - & - & - & - & 0.00 & 686 & $-2,800$ & -485 & 1,750 \\
\hline 1998 & 0.00 & 0.00 & -3.00 & 4,690 & 3,710 & -583 & - & - & - & - & 0.00 & 1,160 & $-2,590$ & -588 & 1,620 \\
\hline 1999 & 0.00 & 0.00 & -1.12 & 775 & -986 & -457 & - & - & - & - & 0.00 & 409 & $-2,980$ & -555 & 1,830 \\
\hline 2000 & 0.00 & 0.00 & -62.1 & 988 & -841 & -379 & - & - & - & - & 0.00 & 305 & $-3,010$ & -530 & 1,840 \\
\hline
\end{tabular}


Table 4.6. Overall annual groundwater flow budget and individual annual groundwater flow budgets by subarea of the Los Angeles Coastal Plain Groundwater-flow Model for Central Basin Pressure Area, non- Water Replenishment District of Southern California (WRD), Los Angeles and Orange Counties, California.-Continued

[GHB, general head boundary; OC, Orange County; WHT, Whittier; PV, Palos Verdes; CHD, time-variant specified-head; LA Narrows, Los Angeles Narrows; WRD, Water Replenishment District of Southern California]

\begin{tabular}{|c|c|c|c|c|c|c|c|c|c|c|c|c|c|c|c|}
\hline Year & $\begin{array}{c}\text { Water } \\
\text { spreading }\end{array}$ & Injection & Pumping & Recharge & Storage & Drains & $\begin{array}{c}\text { GHB } \\
\text { Ocean }\end{array}$ & $\begin{array}{c}\text { GHB } \\
\text { OC }\end{array}$ & $\begin{array}{l}\text { GHB } \\
\text { WHT }\end{array}$ & $\begin{array}{l}\text { GHB } \\
\text { PV }\end{array}$ & $\begin{array}{l}\text { CHD LA } \\
\text { Narrows }\end{array}$ & $\begin{array}{l}\text { Flow from Los } \\
\text { Angeles Forebay }\end{array}$ & $\begin{array}{l}\text { Flow from WRD } \\
\text { Central Basin }\end{array}$ & $\begin{array}{c}\text { Flow from } \\
\text { Santa Monica }\end{array}$ & $\begin{array}{l}\text { Flow from } \\
\text { Hollywood }\end{array}$ \\
\hline 2001 & 0.00 & 0.00 & -1.16 & 1,790 & -18.0 & -386 & - & - & - & - & 0.00 & 443 & $-3,120$ & -511 & 1,780 \\
\hline 2002 & 0.00 & 0.00 & -0.308 & 327 & $-1,560$ & -310 & - & - & - & - & 0.00 & 77.0 & $-2,940$ & -476 & 1,770 \\
\hline 2003 & 0.00 & 0.00 & -0.0344 & 773 & $-1,210$ & -273 & - & - & - & - & 0.00 & 205 & $-3,170$ & -441 & 1,690 \\
\hline 2004 & 0.00 & 0.00 & -23.2 & 723 & $-1,290$ & -247 & - & - & - & - & 0.00 & 123 & $-3,130$ & -379 & 1,640 \\
\hline 2005 & 0.00 & 0.00 & -0.156 & 4,630 & 3,180 & -463 & - & - & - & - & 0.00 & 1,280 & $-3,280$ & -441 & 1,460 \\
\hline 2006 & 0.00 & 0.00 & -0.056 & 987 & -954 & -384 & - & - & - & - & 0.00 & 423 & $-3,210$ & -377 & 1,600 \\
\hline 2007 & 0.00 & 0.00 & -0.64 & 241 & $-1,660$ & -284 & - & - & - & - & 0.00 & 131 & $-3,050$ & -331 & 1,630 \\
\hline 2008 & 0.00 & 0.00 & -0.212 & 884 & -834 & -254 & - & - & - & - & 0.00 & 109 & $-2,810$ & -322 & 1,560 \\
\hline 2009 & 0.00 & 0.00 & -0.801 & 528 & $-1,410$ & -213 & - & - & - & - & 0.00 & 201 & $-3,220$ & -262 & 1,550 \\
\hline 2010 & 0.00 & 0.00 & -0.248 & 1,390 & -245 & -230 & - & - & - & - & 0.00 & 266 & $-2,830$ & -286 & 1,450 \\
\hline 2011 & 0.00 & 0.00 & -0.0881 & 1,940 & 864 & -280 & - & - & - & - & 0.00 & 587 & $-2,360$ & -351 & 1,320 \\
\hline 2012 & 0.00 & 0.00 & -9.48 & 451 & $-1,010$ & -230 & - & - & - & - & 0.00 & 297 & $-2,500$ & -338 & 1,320 \\
\hline 2013 & 0.00 & 0.00 & 0.00 & 353 & $-1,280$ & -186 & - & - & - & - & 0.00 & 169 & $-2,620$ & -302 & 1,300 \\
\hline 2014 & 0.00 & 0.00 & 0.00 & 135 & $-1,610$ & -138 & - & - & - & - & 0.00 & -28.0 & $-2,600$ & -269 & 1,280 \\
\hline 2015 & 0.00 & 0.00 & 0.00 & 642 & -861 & -128 & - & - & - & - & 0.00 & 28.0 & $-2,310$ & -288 & 1,200 \\
\hline
\end{tabular}


Table 4.7. Overall annual groundwater flow budget and individual annual groundwater flow budgets by subarea of the Los Angeles Coastal Plain Grol Counties, California.

[GHB, general head boundary; OC, Orange County; WHT, Whittier; PV, Palos Verdes; CHD, time-variant specified-head; LA Narrows, Los Angeles Narrows; WRD, Water Reple

\begin{tabular}{|c|c|c|c|c|c|c|c|c|c|c|c|c|}
\hline Year & $\begin{array}{c}\text { Water } \\
\text { spreading }\end{array}$ & Injection & Pumping & Recharge & Storage & Drains & $\begin{array}{c}\text { GHB } \\
\text { Ocean }\end{array}$ & $\begin{array}{c}\text { GHB } \\
\text { OC }\end{array}$ & $\begin{array}{l}\text { GHB } \\
\text { WHT }\end{array}$ & $\begin{array}{c}\text { GHB } \\
\text { PV }\end{array}$ & $\begin{array}{c}\text { CHD LA } \\
\text { Narrows }\end{array}$ & $\begin{array}{c}\text { Flow from } \\
\text { Orange County }\end{array}$ \\
\hline 1971 & 0.00 & 2,400 & $-164,000$ & 6,240 & $-32,800$ & -257 & - & - & - & - & 0.00 & 1,750 \\
\hline 1972 & 0.00 & 3,050 & $-142,000$ & 3,790 & $-34,600$ & -90.0 & - & - & - & - & 0.00 & $-3,980$ \\
\hline 1973 & 0.00 & 3,220 & $-138,000$ & 16,000 & $-12,600$ & -89.0 & - & - & - & - & 0.00 & $-7,980$ \\
\hline 1974 & 0.00 & 4,160 & $-140,000$ & 11,300 & $-10,600$ & -356 & - & - & - & - & 0.00 & $-7,910$ \\
\hline 1975 & 0.00 & 2,760 & $-146,000$ & 9,650 & $-15,800$ & -343 & - & - & - & - & 0.00 & $-3,200$ \\
\hline 1976 & 0.00 & 2,910 & $-146,000$ & 3,680 & $-30,500$ & -398 & - & - & - & - & 0.00 & $-1,510$ \\
\hline 1977 & 0.00 & 3,450 & $-143,000$ & 4,740 & $-35,300$ & -424 & - & - & - & - & 0.00 & -634 \\
\hline 1978 & 0.00 & 3,420 & $-126,000$ & 40,600 & 41,700 & -554 & - & - & - & - & 0.00 & 969 \\
\hline 1979 & 0.00 & 3,320 & $-140,000$ & 24,400 & 20,800 & -627 & - & - & - & - & 0.00 & 4,150 \\
\hline 1980 & 0.00 & 2,750 & $-135,000$ & 34,100 & 37,200 & -737 & - & - & - & - & 0.00 & 3,160 \\
\hline 1981 & 0.00 & 2,820 & $-132,000$ & 7,140 & 4,220 & -612 & - & - & - & - & 0.00 & 4,720 \\
\hline 1982 & 0.00 & 2,770 & $-127,000$ & 9,290 & -719 & -515 & - & - & - & - & 0.00 & $-3,610$ \\
\hline 1983 & 0.00 & 2,270 & $-123,000$ & 35,400 & 40,500 & -543 & - & - & - & - & 0.00 & $-2,760$ \\
\hline 1984 & 0.00 & 1,930 & $-135,000$ & 9,940 & $-4,240$ & -546 & - & - & - & - & 0.00 & -311 \\
\hline 1985 & 0.00 & 2,170 & $-123,000$ & 8,380 & 326 & -546 & - & - & - & - & 0.00 & 1,300 \\
\hline 1986 & 0.00 & 2,770 & $-129,000$ & 15,600 & 5,250 & -569 & - & - & - & - & 0.00 & -136 \\
\hline 1987 & 0.00 & 2,780 & $-131,000$ & 4,600 & $-12,300$ & -559 & - & - & - & - & 0.00 & $-4,860$ \\
\hline 1988 & 0.00 & 2,560 & $-133,000$ & 6,340 & $-11,200$ & -549 & - & - & - & - & 0.00 & $-5,930$ \\
\hline 1989 & 0.00 & 2,830 & $-131,000$ & 5,910 & $-8,800$ & -551 & - & - & - & - & 0.00 & $-4,820$ \\
\hline 1990 & 0.00 & 3,040 & $-128,000$ & 2,170 & $-9,060$ & -636 & - & - & - & - & 0.00 & $-2,270$ \\
\hline 1991 & 0.00 & 2,640 & $-127,000$ & 5,760 & $-3,370$ & -556 & - & - & - & - & 0.00 & $-5,440$ \\
\hline 1992 & 0.00 & 3,100 & $-127,000$ & 16,100 & 15,700 & -584 & - & - & - & - & 0.00 & $-5,550$ \\
\hline 1993 & 0.00 & 2,040 & $-81,700$ & 31,400 & 66,000 & -726 & - & - & - & - & 0.00 & $-10,200$ \\
\hline 1994 & 0.00 & 2,010 & $-106,000$ & 6,070 & 14,400 & -691 & - & - & - & - & 0.00 & $-6,780$ \\
\hline 1995 & 0.00 & 1,940 & $-114,000$ & 26,500 & 25,600 & -836 & - & - & - & - & 0.00 & $-9,080$ \\
\hline 1996 & 0.00 & 2,350 & $-114,000$ & 9,440 & 3,310 & -853 & - & - & - & - & 0.00 & $-11,800$ \\
\hline 1997 & 0.00 & 2,650 & $-126,000$ & 15,300 & 26.7 & $-1,500$ & - & - & - & - & 0.00 & $-10,500$ \\
\hline 1998 & 0.00 & 2,490 & $-128,000$ & 40,300 & 26,600 & $-4,440$ & - & - & - & - & 0.00 & $-9,210$ \\
\hline 1999 & 0.00 & 2,720 & $-135,000$ & 7,160 & $-26,600$ & $-1,650$ & - & - & - & - & 0.00 & $-11,000$ \\
\hline 2000 & 0.00 & 2,630 & $-134,000$ & 6,760 & $-22,600$ & -884 & - & - & - & - & 0.00 & $-10,200$ \\
\hline 2001 & 0.00 & 2,510 & $-130,000$ & 11,700 & $-13,900$ & -812 & - & - & - & - & 0.00 & $-10,100$ \\
\hline 2002 & 0.00 & 2,530 & $-130,000$ & 2,620 & $-20,800$ & -806 & - & - & - & - & 0.00 & $-7,090$ \\
\hline 2003 & 0.00 & 2,730 & $-132,000$ & 6,280 & $-13,800$ & -923 & - & - & - & - & 0.00 & $-3,020$ \\
\hline 2004 & 0.00 & 2,180 & $-135,000$ & 6,040 & $-17,800$ & -863 & - & - & - & - & 0.00 & 753 \\
\hline 2005 & 0.00 & 1,800 & $-124,000$ & 32,300 & 38,300 & $-1,050$ & - & - & - & - & 0.00 & -245 \\
\hline 2006 & 0.00 & 606 & $-124,000$ & 7,790 & 7,840 & -983 & - & - & - & - & 0.00 & 2,980 \\
\hline 2007 & 0.00 & 1,340 & $-143,000$ & 2,170 & $-24,900$ & -982 & - & - & - & - & 0.00 & $-2,950$ \\
\hline 2008 & 0.00 & 3,390 & $-139,000$ & 7,880 & $-18,400$ & $-1,080$ & - & - & - & - & 0.00 & $-4,830$ \\
\hline 2009 & 0.00 & 3,110 & $-135,000$ & 5,280 & $-23,800$ & -926 & - & - & - & - & 0.00 & $-4,390$ \\
\hline 2010 & 0.00 & 2,310 & $-134,000$ & 11,500 & $-4,150$ & -933 & - & - & - & - & 0.00 & 1,590 \\
\hline 2011 & 0.00 & 2,520 & $-111,000$ & 17,200 & 31,200 & $-1,260$ & - & - & - & - & 0.00 & 1,250 \\
\hline 2012 & 0.00 & 2,370 & $-131,000$ & 4,890 & $-3,870$ & $-1,110$ & - & - & - & - & 0.00 & 5,980 \\
\hline 2013 & 0.00 & 2,770 & $-133,000$ & 3,510 & $-22,500$ & -985 & - & - & - & - & 0.00 & 3,860 \\
\hline 2014 & 0.00 & 3,040 & $-140,000$ & 1,470 & $-33,000$ & -909 & - & - & - & - & 0.00 & 4,470 \\
\hline 2015 & 0.00 & 2,520 & $-114,000$ & 5,400 & $-12,100$ & -796 & - & - & - & - & 0.00 & 1,920 \\
\hline
\end{tabular}


Indwater-flow Model for Central Basin Pressure Area, Water Replenishment District of Southern California (WRD), Los Angeles and Orange

nishment District of Southern California]

\begin{tabular}{|c|c|c|c|c|c|c|c|}
\hline $\begin{array}{l}\text { Flow from } \\
\text { West Coast }\end{array}$ & $\begin{array}{c}\text { Flow from } \\
\text { Santa Monica }\end{array}$ & $\begin{array}{l}\text { Flow from WRD Los } \\
\text { Angeles Forebay }\end{array}$ & $\begin{array}{c}\text { Flow from } \\
\text { Montebello Forebay }\end{array}$ & $\begin{array}{l}\text { Flow from } \\
\text { Whitter }\end{array}$ & $\begin{array}{l}\text { Flow from } \\
\text { Central Basin }\end{array}$ & $\begin{array}{l}\text { Flow from North } \\
\text { Orange County }\end{array}$ & $\begin{array}{l}\text { Flow from South } \\
\text { Orange County }\end{array}$ \\
\hline$-6,550$ & -4.21 & $-7,180$ & 122,000 & 4,540 & 1,850 & 654 & 5,690 \\
\hline$-5,540$ & -3.72 & $-3,880$ & 105,000 & 4,480 & 1,620 & 1,050 & 1,440 \\
\hline$-5,160$ & -5.70 & $-4,750$ & 118,000 & 4,310 & 1,780 & 1,080 & -312 \\
\hline$-4,740$ & -4.82 & $-6,570$ & 126,000 & 4,150 & 2,030 & 1,130 & -170 \\
\hline$-4,660$ & -3.94 & $-5,480$ & 122,000 & 3,920 & 2,410 & 1,130 & 2,290 \\
\hline$-3,790$ & -3.15 & $-5,280$ & 111,000 & 3,860 & 2,500 & 1,210 & 1,580 \\
\hline$-3,380$ & -3.06 & $-4,460$ & 99,900 & 3,760 & 2,710 & 1,210 & 773 \\
\hline$-4,860$ & -10.2 & $-8,730$ & 127,000 & 3,680 & 2,770 & 1,210 & 2,380 \\
\hline$-5,490$ & -7.60 & $-8,190$ & 132,000 & 3,640 & 2,580 & 1,260 & 3,520 \\
\hline$-5,630$ & -11.3 & $-9,360$ & 135,000 & 3,730 & 2,550 & 1,260 & 4,750 \\
\hline$-6,560$ & -4.15 & $-7,830$ & 125,000 & 3,800 & 2,490 & 1,100 & 3,980 \\
\hline$-6,160$ & -4.31 & $-5,810$ & 122,000 & 3,780 & 2,790 & 943 & 1,440 \\
\hline$-6,370$ & -10.6 & $-6,780$ & 132,000 & 3,840 & 2,840 & 924 & 2,870 \\
\hline$-6,090$ & -5.11 & $-4,240$ & 120,000 & 3,570 & 3,100 & 1,100 & 1,890 \\
\hline$-6,190$ & -4.22 & $-4,220$ & 112,000 & 3,450 & 2,810 & 1,060 & 3,240 \\
\hline$-5,950$ & -6.27 & $-4,180$ & 116,000 & 3,340 & 3,030 & 1,090 & 3,310 \\
\hline$-5,290$ & -3.95 & $-3,040$ & 116,000 & 3,410 & 3,100 & 1,150 & 1,630 \\
\hline$-3,720$ & -3.84 & $-1,600$ & 115,000 & 3,280 & 2,900 & 1,290 & 1,630 \\
\hline$-3,950$ & -3.73 & $-2,760$ & 117,000 & 3,220 & 2,650 & 1,170 & 1,490 \\
\hline$-4,750$ & -3.36 & $-4,110$ & 117,000 & 3,110 & 2,560 & 1,210 & 1,560 \\
\hline$-5,400$ & -3.4 & $-4,010$ & 122,000 & 2,990 & 2,900 & 1,260 & 1,680 \\
\hline$-4,450$ & -6.24 & $-6,550$ & 132,000 & 3,040 & 2,780 & 1,280 & 1,950 \\
\hline$-5,880$ & -10.0 & $-13,200$ & 136,000 & 3,110 & 1,900 & 1,250 & 2,130 \\
\hline$-5,930$ & -3.98 & $-9,010$ & 126,000 & 3,200 & 2,120 & 1,190 & 1,780 \\
\hline$-5,530$ & -8.74 & $-9,010$ & 128,000 & 3,470 & 2,470 & 1,060 & 799 \\
\hline$-7,520$ & -4.99 & $-6,040$ & 124,000 & 3,560 & 2,750 & 1,130 & 468 \\
\hline$-6,130$ & -6.37 & $-4,800$ & 122,000 & 3,680 & 2,800 & 1,150 & 1,420 \\
\hline$-6,240$ & -11.8 & $-4,300$ & 126,000 & 3,910 & 2,590 & 1,170 & 1,580 \\
\hline$-5,980$ & -4.69 & $-2,310$ & 111,000 & 4,050 & 2,980 & 1,260 & 271 \\
\hline$-5,050$ & -4.85 & -34.1 & 110,000 & 4,040 & 3,010 & 1,300 & 354 \\
\hline$-4,710$ & -6.33 & -862 & 109,000 & 3,960 & 3,120 & 1,320 & 655 \\
\hline$-4,230$ & -3.98 & $-1,990$ & 109,000 & 3,890 & 2,940 & 1,320 & 1,490 \\
\hline$-4,800$ & -4.00 & $-1,110$ & 109,000 & 3,760 & 3,170 & 1,310 & 1,790 \\
\hline$-4,070$ & -4.25 & -407 & 102,000 & 3,650 & 3,130 & 1,400 & 3,240 \\
\hline$-4,470$ & -11.0 & $-4,000$ & 127,000 & 3,660 & 3,280 & 1,390 & 3,150 \\
\hline$-3,780$ & -4.72 & $-5,050$ & 119,000 & 3,530 & 3,210 & 1,440 & 2,970 \\
\hline$-2,020$ & -3.66 & $-2,370$ & 113,000 & 3,750 & 3,050 & 1,470 & 1,140 \\
\hline$-1,300$ & -3.65 & 43.5 & 108,000 & 3,880 & 2,810 & 1,490 & 987 \\
\hline-921 & -3.52 & 2,380 & 96,300 & 3,800 & 3,220 & 1,490 & 1,890 \\
\hline-648 & -4.56 & 462 & 103,000 & 3,610 & 2,830 & 1,470 & 5,030 \\
\hline$-3,010$ & -6.29 & $-4,330$ & 119,000 & 3,410 & 2,360 & 1,430 & 3,910 \\
\hline$-2,060$ & -3.66 & $-1,670$ & 107,000 & 3,420 & 2,500 & 1,440 & 4,410 \\
\hline$-1,140$ & -3.45 & $-1,080$ & 92,700 & 3,540 & 2,620 & 1,450 & 3,320 \\
\hline-81 & -3.22 & 919 & 85,800 & 3,570 & 2,600 & 1,440 & 4,350 \\
\hline-218 & -3.94 & 997 & 82,100 & 3,270 & 2,310 & 1,390 & 2,950 \\
\hline
\end{tabular}


Table 4.8. Overall annual groundwater flow budget and individual annual groundwater flow budgets by subarea of the Los Angeles Coastal Plain Groundwater-flow Model for Orange County North, Los Angeles and Orange Counties, California.

[GHB, general head boundary; OC, Orange County; WHT, Whittier; PV, Palos Verdes; CHD, time-variant specified-head; LA Narrows, Los Angeles Narrows; WRD, Water Replenishment District of Southern California]

\begin{tabular}{|c|c|c|c|c|c|c|c|c|c|c|c|c|c|c|}
\hline Year & $\begin{array}{c}\text { Water } \\
\text { spreading }\end{array}$ & Injection & Pumping & Recharge & Storage & Drains & $\begin{array}{c}\text { GHB } \\
\text { Ocean }\end{array}$ & GHB OC & $\begin{array}{l}\text { GHB } \\
\text { WHT }\end{array}$ & $\begin{array}{l}\text { GHB } \\
\text { PV }\end{array}$ & $\begin{array}{c}\text { CHD LA } \\
\text { Narrows }\end{array}$ & $\begin{array}{c}\text { Flow from WRD } \\
\text { Central Basin }\end{array}$ & $\begin{array}{c}\text { Flow from } \\
\text { Orange County }\end{array}$ & $\begin{array}{c}\text { Flow from } \\
\text { Whitter }\end{array}$ \\
\hline 1971 & 0.00 & 0.00 & -808 & 431 & $-2,650$ & $-2,130$ & - & 4,460 & - & - & 0.00 & -654 & $-1,630$ & $-2,320$ \\
\hline 1972 & 0.00 & 0.00 & $-1,670$ & 246 & $-2,400$ & -885 & - & 4,270 & - & - & 0.00 & $-1,050$ & -908 & $-2,410$ \\
\hline 1973 & 0.00 & 0.00 & $-1,410$ & 1,420 & -343 & -490 & - & 4,170 & - & - & 0.00 & $-1,080$ & -638 & $-2,310$ \\
\hline 1974 & 0.00 & 0.00 & $-1,800$ & 850 & $-1,160$ & -388 & - & 4,080 & - & - & 0.00 & $-1,130$ & -487 & $-2,290$ \\
\hline 1975 & 0.00 & 0.00 & $-1,710$ & 536 & $-1,510$ & -376 & - & 4,010 & - & - & 0.00 & $-1,130$ & -390 & $-2,440$ \\
\hline 1976 & 0.00 & 0.00 & $-1,300$ & 218 & $-1,420$ & -364 & - & 3,960 & - & - & 0.00 & $-1,210$ & -328 & $-2,400$ \\
\hline 1977 & 0.00 & 0.00 & $-1,500$ & 221 & $-1,540$ & -347 & - & 3,960 & - & - & 0.00 & $-1,210$ & -282 & $-2,380$ \\
\hline 1978 & 0.00 & 0.00 & -914 & 5,290 & 3,960 & -630 & - & 3,790 & - & - & 0.00 & $-1,210$ & -331 & $-2,030$ \\
\hline 1979 & 0.00 & 0.00 & $-1,060$ & 3,070 & 1,230 & -761 & - & 3,660 & - & - & 0.00 & $-1,260$ & -325 & $-2,100$ \\
\hline 1980 & 0.00 & 0.00 & $-1,260$ & 4,920 & 2,450 & $-1,040$ & - & 3,470 & - & - & 0.00 & $-1,260$ & -370 & $-2,010$ \\
\hline 1981 & 0.00 & 0.00 & $-1,960$ & 407 & $-2,390$ & -881 & - & 3,510 & - & - & 0.00 & $-1,100$ & -282 & $-2,080$ \\
\hline 1982 & 0.00 & 0.00 & $-2,410$ & 639 & $-2,400$ & -774 & - & 3,700 & - & - & 0.00 & -943 & -238 & $-2,370$ \\
\hline 1983 & 0.00 & 0.00 & $-1,420$ & 4,500 & 2,650 & $-1,040$ & - & 3,750 & - & - & 0.00 & -924 & -283 & $-1,930$ \\
\hline 1984 & 0.00 & 0.00 & $-1,600$ & 811 & $-1,840$ & -958 & - & 3,660 & - & - & 0.00 & $-1,100$ & -238 & $-2,430$ \\
\hline 1985 & 0.00 & 0.00 & $-1,320$ & 585 & $-1,410$ & -821 & - & 3,810 & - & - & 0.00 & $-1,060$ & -203 & $-2,400$ \\
\hline 1986 & 0.00 & 0.00 & $-1,480$ & 1,310 & $-1,060$ & -783 & - & 3,790 & - & - & 0.00 & $-1,090$ & -198 & $-2,620$ \\
\hline 1987 & 0.00 & 0.00 & -892 & 236 & $-1,410$ & -694 & - & 3,930 & - & - & 0.00 & $-1,150$ & -185 & $-2,650$ \\
\hline 1988 & 0.00 & 0.00 & -905 & 315 & $-1,490$ & -600 & - & 4,000 & - & - & 0.00 & $-1,290$ & -174 & $-2,830$ \\
\hline 1989 & 0.00 & 0.00 & $-1,240$ & 407 & $-1,420$ & -536 & - & 4,080 & - & - & 0.00 & $-1,170$ & -159 & $-2,800$ \\
\hline 1990 & 0.00 & 0.00 & -761 & 114 & $-1,160$ & -470 & - & 4,130 & - & - & 0.00 & $-1,210$ & -149 & $-2,820$ \\
\hline 1991 & 0.00 & 0.00 & -625 & 415 & $-1,350$ & -418 & - & 3,400 & - & - & 0.00 & $-1,260$ & -144 & $-2,720$ \\
\hline 1992 & 0.00 & 0.00 & -160 & 1,440 & 677 & -436 & - & 3,780 & - & - & 0.00 & $-1,280$ & -140 & $-2,520$ \\
\hline 1993 & 0.00 & 0.00 & -55.7 & 4,290 & 3,990 & -706 & - & 3,850 & - & - & 0.00 & $-1,250$ & -200 & $-1,940$ \\
\hline 1994 & 0.00 & 0.00 & -388 & 363 & -171 & -604 & - & 3,580 & - & - & 0.00 & $-1,190$ & -160 & $-1,770$ \\
\hline 1995 & 0.00 & 0.00 & -3.57 & 3,010 & 2,880 & -719 & - & 3,290 & - & - & 0.00 & $-1,060$ & -189 & $-1,440$ \\
\hline 1996 & 0.00 & 0.00 & -2.28 & 816 & 521 & -693 & - & 3,250 & - & - & 0.00 & $-1,130$ & -175 & $-1,550$ \\
\hline 1997 & 0.00 & 0.00 & -8.01 & 1,380 & 853 & -710 & - & 3,140 & - & - & 0.00 & $-1,150$ & -181 & $-1,620$ \\
\hline 1998 & 0.00 & 0.00 & 0.00 & 4,830 & 4,190 & $-1,010$ & - & 3,290 & - & - & 0.00 & $-1,170$ & -255 & $-1,490$ \\
\hline 1999 & 0.00 & 0.00 & 0.00 & 382 & -484 & -876 & - & 3,100 & - & - & 0.00 & $-1,260$ & -215 & $-1,620$ \\
\hline 2000 & 0.00 & 0.00 & 0.00 & 380 & -408 & -756 & - & 3,240 & - & - & 0.00 & $-1,300$ & -199 & $-1,770$ \\
\hline
\end{tabular}


Table 4.8. Overall annual groundwater flow budget and individual annual groundwater flow budgets by subarea of the Los Angeles Coastal Plain Groundwater-flow Model for Orange County North, Los Angeles and Orange Counties, California.-Continued

[GHB, general head boundary; OC, Orange County; WHT, Whittier; PV, Palos Verdes; CHD, time-variant specified-head; LA Narrows, Los Angeles Narrows; WRD, Water Replenishment District of Southern California]

\begin{tabular}{|c|c|c|c|c|c|c|c|c|c|c|c|c|c|c|}
\hline Year & $\begin{array}{c}\text { Water } \\
\text { spreading }\end{array}$ & Injection & Pumping & Recharge & Storage & Drains & $\begin{array}{c}\text { GHB } \\
\text { Ocean }\end{array}$ & GHB OC & $\begin{array}{l}\text { GHB } \\
\text { WHT }\end{array}$ & $\begin{array}{c}\text { GHB } \\
\text { PV }\end{array}$ & $\begin{array}{c}\text { CHD LA } \\
\text { Narrows }\end{array}$ & $\begin{array}{l}\text { Flow from WRD } \\
\text { Central Basin }\end{array}$ & $\begin{array}{c}\text { Flow from } \\
\text { Orange County }\end{array}$ & $\begin{array}{c}\text { Flow from } \\
\text { Whitter }\end{array}$ \\
\hline 2001 & 0.00 & 0.00 & -78.2 & 666 & -62.0 & -715 & - & 3,410 & - & - & 0.00 & $-1,320$ & -194 & $-1,830$ \\
\hline 2002 & 0.00 & 0.00 & -157 & 122 & -721 & -669 & - & 3,400 & - & - & 0.00 & $-1,320$ & -190 & $-1,910$ \\
\hline 2003 & 0.00 & 0.00 & -332 & 386 & -392 & -623 & - & 3,610 & - & - & 0.00 & $-1,310$ & -185 & $-1,950$ \\
\hline 2004 & 0.00 & 0.00 & 0.00 & 318 & -211 & -622 & - & 3,670 & - & - & 0.00 & $-1,400$ & -181 & $-2,000$ \\
\hline 2005 & 0.00 & 0.00 & 0.00 & 4,250 & 3,600 & -986 & - & 3,670 & - & - & 0.00 & $-1,390$ & -231 & $-1,710$ \\
\hline 2006 & 0.00 & 0.00 & 0.00 & 441 & -350 & -961 & - & 3,600 & - & - & 0.00 & $-1,440$ & -202 & $-1,790$ \\
\hline 2007 & 0.00 & 0.00 & 0.00 & 110 & -721 & -896 & - & 3,650 & - & - & 0.00 & $-1,470$ & -196 & $-1,930$ \\
\hline 2008 & 0.00 & 0.00 & 0.00 & 245 & -684 & -834 & - & 3,580 & - & - & 0.00 & $-1,490$ & -197 & $-1,990$ \\
\hline 2009 & 0.00 & 0.00 & 0.00 & 225 & -661 & -777 & - & 3,620 & - & - & 0.00 & $-1,490$ & -194 & $-2,040$ \\
\hline 2010 & 0.00 & 0.00 & 0.00 & 1,260 & 281 & -778 & - & 3,460 & - & - & 0.00 & $-1,470$ & -189 & $-2,000$ \\
\hline 2011 & 0.00 & 0.00 & 0.00 & 1,940 & 1,070 & -896 & - & 3,540 & - & - & 0.00 & $-1,430$ & -202 & $-1,880$ \\
\hline 2012 & 0.00 & 0.00 & 0.00 & 288 & -631 & -862 & - & 3,510 & - & - & 0.00 & $-1,440$ & -190 & $-1,940$ \\
\hline 2013 & 0.00 & 0.00 & 0.00 & 167 & -943 & -788 & - & 3,340 & - & - & 0.00 & $-1,450$ & -187 & $-2,020$ \\
\hline 2014 & 0.00 & 0.00 & 0.00 & 58.0 & $-1,420$ & -694 & - & 2,880 & - & - & 0.00 & $-1,440$ & -188 & $-2,050$ \\
\hline 2015 & 0.00 & 0.00 & 0.00 & 538 & -782 & -619 & - & 2,910 & - & - & 0.00 & $-1,390$ & -189 & $-2,040$ \\
\hline
\end{tabular}


Table 4.9. Overall annual groundwater flow budget and individual annual groundwater flow budgets by subarea of the Los Angeles Coastal Plain Groundwater-flow Model for Orange County Central, Los Angeles and Orange Counties, California.

[GHB, general head boundary; OC, Orange County; WHT, Whittier; PV, Palos Verdes; CHD, time-variant specified-head; LA Narrows, Los Angeles Narrows; WRD, Water Replenishment District of Southern California]

\begin{tabular}{|c|c|c|c|c|c|c|c|c|c|c|c|c|c|c|}
\hline Year & $\begin{array}{c}\text { Water } \\
\text { spreading }\end{array}$ & Injection & Pumping & Recharge & Storage & Drains & $\begin{array}{c}\text { GHB } \\
\text { Ocean }\end{array}$ & GHB OC & $\begin{array}{l}\text { GHB } \\
\text { WHT }\end{array}$ & $\begin{array}{l}\text { GHB } \\
\text { PV }\end{array}$ & $\begin{array}{l}\text { CHD LA } \\
\text { Narrows }\end{array}$ & $\begin{array}{l}\text { Flow from WRD } \\
\text { Central Basin }\end{array}$ & $\begin{array}{l}\text { Flow from North } \\
\text { Orange County }\end{array}$ & $\begin{array}{c}\text { Flow from South } \\
\text { Orange County }\end{array}$ \\
\hline 1971 & 0.00 & 0.00 & $-36,700$ & 1,370 & $-3,940$ & 0.00 & - & 34,600 & - & - & 0.00 & $-1,750$ & 1,630 & $-3,100$ \\
\hline 1972 & 0.00 & 0.00 & $-38,600$ & 865 & $-9,720$ & 0.00 & - & 22,600 & - & - & 0.00 & 3,980 & 908 & 476 \\
\hline 1973 & 0.00 & 0.00 & $-37,700$ & 3,520 & $-5,380$ & 0.00 & - & 17,600 & - & - & 0.00 & 7,980 & 638 & 2,590 \\
\hline 1974 & 0.00 & 0.00 & $-42,300$ & 2,550 & $-3,200$ & 0.00 & - & 25,100 & - & - & 0.00 & 7,910 & 487 & 3,070 \\
\hline 1975 & 0.00 & 0.00 & $-43,400$ & 1,930 & 575 & 0.00 & - & 39,300 & - & - & 0.00 & 3,200 & 390 & -745 \\
\hline 1976 & 0.00 & 0.00 & $-47,000$ & 862 & $-3,920$ & 0.00 & - & 40,200 & - & - & 0.00 & 1,510 & 328 & 222 \\
\hline 1977 & 0.00 & 0.00 & $-47,500$ & 892 & $-4,400$ & 0.00 & - & 39,100 & - & - & 0.00 & 634 & 282 & 2,290 \\
\hline 1978 & 0.00 & 0.00 & $-36,900$ & 10,600 & 12,000 & 0.00 & - & 39,100 & - & - & 0.00 & -969 & 331 & -224 \\
\hline 1979 & 0.00 & 0.00 & $-45,200$ & 6,620 & 6,250 & 0.00 & - & 48,300 & - & - & 0.00 & $-4,150$ & 325 & 261 \\
\hline 1980 & 0.00 & 0.00 & $-45,000$ & 9,480 & 7,500 & 0.00 & - & 47,400 & - & - & 0.00 & $-3,160$ & 370 & $-1,560$ \\
\hline 1981 & 0.00 & 0.00 & $-43,500$ & 1,520 & $-5,300$ & 0.00 & - & 41,600 & - & - & 0.00 & $-4,720$ & 282 & -397 \\
\hline 1982 & 0.00 & 0.00 & $-47,500$ & 2,080 & $-4,610$ & 0.00 & - & 33,700 & - & - & 0.00 & 3,610 & 238 & 3,240 \\
\hline 1983 & 0.00 & 0.00 & $-44,400$ & 9,620 & 9,780 & 0.00 & - & 41,400 & - & - & 0.00 & 2,760 & 283 & 112 \\
\hline 1984 & 0.00 & 0.00 & $-45,400$ & 2,380 & -315 & 0.00 & - & 42,000 & - & - & 0.00 & 311 & 238 & 182 \\
\hline 1985 & 0.00 & 0.00 & $-41,800$ & 1,730 & 3,430 & 0.00 & - & 45,700 & - & - & 0.00 & $-1,300$ & 203 & $-1,140$ \\
\hline 1986 & 0.00 & 0.00 & $-44,000$ & 3,520 & $-1,910$ & 0.00 & - & 38,600 & - & - & 0.00 & 136 & 198 & -306 \\
\hline 1987 & 0.00 & 0.00 & $-47,600$ & 1,020 & $-6,540$ & 0.00 & - & 30,100 & - & - & 0.00 & 4,860 & 185 & 4,900 \\
\hline 1988 & 0.00 & 0.00 & $-44,400$ & 1,200 & $-4,500$ & 0.00 & - & 29,000 & - & - & 0.00 & 5,930 & 174 & 3,550 \\
\hline 1989 & 0.00 & 0.00 & $-44,700$ & 1,160 & $-2,530$ & 0.00 & - & 33,500 & - & - & 0.00 & 4,820 & 159 & 2,550 \\
\hline 1990 & 0.00 & 0.00 & $-43,600$ & 524 & $-2,230$ & 0.00 & - & 35,500 & - & - & 0.00 & 2,270 & 149 & 2,910 \\
\hline 1991 & 0.00 & 0.00 & $-45,100$ & 1,230 & $-1,600$ & 0.00 & - & 33,300 & - & - & 0.00 & 5,440 & 144 & 3,380 \\
\hline 1992 & 0.00 & 0.00 & $-50,600$ & 3,590 & 1,440 & 0.00 & - & 40,200 & - & - & 0.00 & 5,550 & 140 & 2,580 \\
\hline 1993 & 0.00 & 0.00 & $-49,100$ & 8,750 & 8,690 & 0.00 & - & 38,700 & - & - & 0.00 & 10,200 & 200 & -177 \\
\hline 1994 & 0.00 & 0.00 & $-47,700$ & 1,420 & 5,090 & 0.00 & - & 45,000 & - & - & 0.00 & 6,780 & 160 & -560 \\
\hline 1995 & 0.00 & 0.00 & $-52,100$ & 7,060 & 6,440 & 0.00 & - & 40,300 & - & - & 0.00 & 9,080 & 189 & 1,880 \\
\hline 1996 & 0.00 & 0.00 & $-57,800$ & 2,360 & -640 & 0.00 & - & 39,000 & - & - & 0.00 & 11,800 & 175 & 3,720 \\
\hline 1997 & 0.00 & 0.00 & $-56,400$ & 3,790 & $-2,110$ & -24.2 & - & 36,500 & - & - & 0.00 & 10,500 & 181 & 3,340 \\
\hline 1998 & 0.00 & 0.00 & $-54,500$ & 10,700 & 5,530 & -434 & - & 37,300 & - & - & 0.00 & 9,210 & 255 & 2,990 \\
\hline 1999 & 0.00 & 0.00 & $-61,300$ & 1,480 & $-7,440$ & -92.9 & - & 34,500 & - & - & 0.00 & 11,000 & 215 & 6,720 \\
\hline 2000 & 0.00 & 0.00 & $-61,700$ & 1,210 & $-4,970$ & 0.00 & - & 38,300 & - & - & 0.00 & 10,200 & 199 & 6,870 \\
\hline
\end{tabular}


Table 4.9. Overall annual groundwater flow budget and individual annual groundwater flow budgets by subarea of the Los Angeles Coastal Plain Groundwater-flow Model for Orange County Central, Los Angeles and Orange Counties, California.-Continued

[GHB, general head boundary; OC, Orange County; WHT, Whittier; PV, Palos Verdes; CHD, time-variant specified-head; LA Narrows, Los Angeles Narrows; WRD, Water Replenishment District of Southern California]

\begin{tabular}{|c|c|c|c|c|c|c|c|c|c|c|c|c|c|c|}
\hline Year & $\begin{array}{c}\text { Water } \\
\text { spreading }\end{array}$ & Injection & Pumping & Recharge & Storage & Drains & $\begin{array}{c}\text { GHB } \\
\text { Ocean }\end{array}$ & GHB OC & $\begin{array}{l}\text { GHB } \\
\text { WHT }\end{array}$ & $\begin{array}{l}\text { GHB } \\
\text { PV }\end{array}$ & $\begin{array}{c}\text { CHD LA } \\
\text { Narrows }\end{array}$ & $\begin{array}{c}\text { Flow from WRD } \\
\text { Central Basin }\end{array}$ & $\begin{array}{l}\text { Flow from North } \\
\text { Orange County }\end{array}$ & $\begin{array}{c}\text { Flow from South } \\
\text { Orange County }\end{array}$ \\
\hline 2001 & 0.00 & 0.00 & $-58,600$ & 2,180 & $-3,290$ & 0.00 & - & 36,500 & - & - & 0.00 & 10,100 & 194 & 6,340 \\
\hline 2002 & 0.00 & 0.00 & $-50,500$ & 610 & $-3,370$ & 0.00 & - & 34,100 & - & - & 0.00 & 7,090 & 190 & 5,070 \\
\hline 2003 & 0.00 & 0.00 & $-45,100$ & 1,220 & 2,400 & 0.00 & - & 40,300 & - & - & 0.00 & 3,020 & 185 & 2,790 \\
\hline 2004 & 0.00 & 0.00 & $-38,500$ & 1,080 & 1,620 & 0.00 & - & 37,400 & - & - & 0.00 & -753 & 181 & 2,260 \\
\hline 2005 & 0.00 & 0.00 & $-41,100$ & 8,810 & 14,500 & 0.00 & - & 45,900 & - & - & 0.00 & 245 & 231 & 385 \\
\hline 2006 & 0.00 & 0.00 & $-43,100$ & 1,480 & 7,120 & 0.00 & - & 51,800 & - & - & 0.00 & $-2,980$ & 202 & -330 \\
\hline 2007 & 0.00 & 0.00 & $-60,500$ & 547 & $-10,400$ & 0.00 & - & 42,100 & - & - & 0.00 & 2,950 & 196 & 4,260 \\
\hline 2008 & 0.00 & 0.00 & $-63,900$ & 989 & $-9,300$ & 0.00 & - & 40,800 & - & - & 0.00 & 4,830 & 197 & 7,720 \\
\hline 2009 & 0.00 & 0.00 & $-57,400$ & 969 & $-5,370$ & 0.00 & - & 39,000 & - & - & 0.00 & 4,390 & 194 & 7,410 \\
\hline 2010 & 0.00 & 0.00 & $-45,800$ & 2,980 & 3,080 & 0.00 & - & 44,500 & - & - & 0.00 & $-1,590$ & 189 & 2,740 \\
\hline 2011 & 0.00 & 0.00 & $-44,600$ & 4,470 & 13,500 & 0.00 & - & 56,900 & - & - & 0.00 & $-1,250$ & 202 & $-2,130$ \\
\hline 2012 & 0.00 & 0.00 & $-48,200$ & 1,070 & 3,630 & 0.00 & - & 56,100 & - & - & 0.00 & $-5,980$ & 190 & 412 \\
\hline 2013 & 0.00 & 0.00 & $-55,000$ & 664 & $-3,390$ & 0.00 & - & 51,900 & - & - & 0.00 & $-3,860$ & 187 & 2,720 \\
\hline 2014 & 0.00 & 0.00 & $-43,600$ & 322 & $-8,750$ & 0.00 & - & 33,700 & - & - & 0.00 & $-4,470$ & 188 & 5,070 \\
\hline 2015 & 0.00 & 0.00 & $-46,500$ & 1,310 & $-2,750$ & 0.00 & - & 39,500 & - & - & 0.00 & $-1,920$ & 189 & 4,720 \\
\hline
\end{tabular}


Table 4.10. Overall annual groundwater flow budget and individual annual groundwater flow budgets by subarea of the Los Angeles Coastal Plain Groundwater-flow Model for Orange County South, Los Angeles and Orange Counties, California.

[GHB, general head boundary; OC, Orange County; WHT, Whittier; PV, Palos Verdes; CHD, time-variant specified-head; LA Narrows, Los Angeles Narrows; WRD, Water Replenishment District of Southern California]

\begin{tabular}{|c|c|c|c|c|c|c|c|c|c|c|c|c|c|c|c|}
\hline Year & $\begin{array}{c}\text { Water } \\
\text { spreading }\end{array}$ & Injection & Pumping & Recharge & Storage & Drains & $\begin{array}{c}\text { GHB } \\
\text { Ocean }\end{array}$ & GHB OC & $\begin{array}{l}\text { GHB } \\
\text { WHT }\end{array}$ & $\begin{array}{c}\text { GHB } \\
\text { PV }\end{array}$ & $\begin{array}{l}\text { CHD LA } \\
\text { Narrows }\end{array}$ & $\begin{array}{c}\text { Flow from WRD } \\
\text { Central Basin }\end{array}$ & $\begin{array}{c}\text { Flow from } \\
\text { Orange County }\end{array}$ & $\begin{array}{l}\text { Flow from San } \\
\text { Pedro Bay }\end{array}$ & $\begin{array}{l}\text { Flow from } \\
\text { West Coast }\end{array}$ \\
\hline 1971 & 0.00 & 1,920 & $-8,860$ & 290 & $-3,970$ & -132 & 4.37 & 5,850 & - & - & 0.00 & $-5,690$ & 3,100 & 143 & -584 \\
\hline 1972 & 0.00 & 2,160 & $-9,940$ & 193 & $-4,790$ & 0.00 & 7.36 & 4,230 & - & - & 0.00 & $-1,440$ & -476 & 890 & -410 \\
\hline 1973 & 0.00 & 2,280 & $-8,790$ & 694 & $-4,190$ & 0.00 & 11.7 & 2,320 & - & - & 0.00 & 312 & $-2,590$ & 1,860 & -270 \\
\hline 1974 & 0.00 & 3,070 & $-7,930$ & 519 & $-2,360$ & 0.00 & 13.3 & 2,940 & - & - & 0.00 & 170 & $-3,070$ & 2,190 & -250 \\
\hline 1975 & 0.00 & 2,110 & $-8,570$ & 392 & 374 & 0.00 & 11.0 & 6,720 & - & - & 0.00 & $-2,290$ & 745 & 1,650 & -373 \\
\hline 1976 & 0.00 & 1,830 & $-9,840$ & 159 & $-1,680$ & 0.00 & 11.8 & 6,510 & - & - & 0.00 & $-1,580$ & -222 & 1,860 & -395 \\
\hline 1977 & 0.00 & 2,260 & $-9,360$ & 164 & $-2,460$ & 0.00 & 13.1 & 5,720 & - & - & 0.00 & -773 & $-2,290$ & 2,170 & -350 \\
\hline 1978 & 0.00 & 1,470 & $-6,240$ & 2,600 & 3,400 & 0.00 & 10.6 & 6,470 & - & - & 0.00 & $-2,380$ & 224 & 1,520 & -274 \\
\hline 1979 & 0.00 & 1,440 & $-5,480$ & 1,310 & 2,440 & 0.00 & 7.76 & 8,310 & - & - & 0.00 & $-3,520$ & -261 & 991 & -348 \\
\hline 1980 & 0.00 & 1,460 & $-5,840$ & 2,110 & 3,350 & 0.00 & 5.51 & 8,670 & - & - & 0.00 & $-4,750$ & 1,560 & 497 & -355 \\
\hline 1981 & 0.00 & 1,830 & $-6,510$ & 315 & 306 & 0.00 & 5.43 & 8,260 & - & - & 0.00 & $-3,980$ & 397 & 424 & -426 \\
\hline 1982 & 0.00 & 1,760 & $-6,870$ & 380 & $-2,980$ & 0.00 & 9.26 & 5,530 & - & - & 0.00 & $-1,440$ & $-3,240$ & 1,240 & -339 \\
\hline 1983 & 0.00 & 2,810 & $-6,340$ & 1,870 & 3,590 & 0.00 & 7.65 & 7,750 & - & - & 0.00 & $-2,870$ & -112 & 749 & -279 \\
\hline 1984 & 0.00 & 1,890 & $-7,900$ & 420 & -327 & 0.00 & 5.80 & 7,170 & - & - & 0.00 & $-1,890$ & -182 & 473 & -305 \\
\hline 1985 & 0.00 & 2,320 & $-6,440$ & 326 & 869 & 0.00 & 4.81 & 6,840 & - & - & 0.00 & $-3,240$ & 1,140 & 242 & -319 \\
\hline 1986 & 0.00 & 3,660 & $-6,500$ & 671 & 1,380 & 0.00 & 4.44 & 6,640 & - & - & 0.00 & $-3,310$ & 306 & 211 & -302 \\
\hline 1987 & 0.00 & 4,030 & $-4,870$ & 197 & $-2,420$ & 0.00 & 7.66 & 4,020 & - & - & 0.00 & $-1,630$ & $-4,900$ & 978 & -238 \\
\hline 1988 & 0.00 & 3,380 & $-4,990$ & 223 & $-1,650$ & 0.00 & 9.35 & 3,870 & - & - & 0.00 & $-1,630$ & $-3,550$ & 1,290 & -234 \\
\hline 1989 & 0.00 & 2,830 & $-5,210$ & 196 & -731 & 0.00 & 10.3 & 4,260 & - & - & 0.00 & $-1,490$ & $-2,550$ & 1,480 & -245 \\
\hline 1990 & 0.00 & 3,080 & $-4,560$ & 92.6 & $-1,010$ & 0.00 & 9.91 & 3,800 & - & - & 0.00 & $-1,560$ & $-2,910$ & 1,340 & -281 \\
\hline 1991 & 0.00 & 3,100 & $-3,870$ & 255 & -832 & 0.00 & 10.8 & 3,500 & - & - & 0.00 & $-1,680$ & $-3,380$ & 1,510 & -266 \\
\hline 1992 & 0.00 & 2,580 & $-4,020$ & 726 & 74.0 & 0.00 & 9.54 & 4,370 & - & - & 0.00 & $-1,950$ & $-2,580$ & 1,210 & -248 \\
\hline 1993 & 0.00 & 2,520 & $-2,670$ & 2,060 & 5,630 & 0.00 & 4.70 & 5,720 & - & - & 0.00 & $-2,130$ & 177 & 121 & -170 \\
\hline 1994 & 0.00 & 2,070 & $-3,160$ & 296 & 1,920 & 0.00 & 2.77 & 4,370 & - & - & 0.00 & $-1,780$ & 560 & -216 & -215 \\
\hline 1995 & 0.00 & 2,140 & $-3,280$ & 1,580 & 951 & 0.00 & 2.32 & 3,540 & - & - & 0.00 & -799 & $-1,880$ & -212 & -130 \\
\hline 1996 & 0.00 & 3,440 & $-3,160$ & 453 & 84.2 & 0.00 & 3.41 & 3,730 & - & - & 0.00 & -468 & $-3,720$ & 19.6 & -198 \\
\hline 1997 & 0.00 & 2,890 & $-3,270$ & 802 & -119 & 0.00 & 4.44 & 4,190 & - & - & 0.00 & $-1,420$ & $-3,340$ & 254 & -236 \\
\hline 1998 & 0.00 & 2,560 & $-3,230$ & 2,440 & 951 & -31.1 & 3.36 & 3,930 & - & - & 0.00 & $-1,580$ & $-2,990$ & 31.8 & -182 \\
\hline 1999 & 0.00 & 3,180 & $-2,730$ & 305 & $-2,290$ & 0.00 & 5.39 & 3,680 & - & - & 0.00 & -271 & $-6,720$ & 515 & -229 \\
\hline 2000 & 0.00 & 2,640 & $-3,310$ & 249 & $-2,160$ & 0.00 & 6.64 & 4,970 & - & - & 0.00 & -354 & $-6,870$ & 778 & -266 \\
\hline
\end{tabular}


Table 4.10. Overall annual groundwater flow budget and individual annual groundwater flow budgets by subarea of the Los Angeles Coastal Plain Groundwater-flow Model for Orange County South, Los Angeles and Orange Counties, California.-Continued

[GHB, general head boundary; OC, Orange County; WHT, Whittier; PV, Palos Verdes; CHD, time-variant specified-head; LA Narrows, Los Angeles Narrows; WRD, Water Replenishment District of Southern California]

\begin{tabular}{|c|c|c|c|c|c|c|c|c|c|c|c|c|c|c|c|}
\hline Year & $\begin{array}{c}\text { Water } \\
\text { spreading }\end{array}$ & Injection & Pumping & Recharge & Storage & Drains & $\begin{array}{c}\text { GHB } \\
\text { Ocean }\end{array}$ & GHB OC & $\begin{array}{l}\text { GHB } \\
\text { WHT }\end{array}$ & $\begin{array}{l}\text { GHB } \\
\text { PV }\end{array}$ & $\begin{array}{c}\text { CHD LA } \\
\text { Narrows }\end{array}$ & $\begin{array}{c}\text { Flow from WRD } \\
\text { Central Basin }\end{array}$ & $\begin{array}{c}\text { Flow from } \\
\text { Orange County }\end{array}$ & $\begin{array}{l}\text { Flow from San } \\
\text { Pedro Bay }\end{array}$ & $\begin{array}{l}\text { Flow from } \\
\text { West Coast }\end{array}$ \\
\hline 2001 & 0.00 & 3,550 & $-3,520$ & 466 & $-1,110$ & -7.27 & 7.32 & 4,720 & - & - & 0.00 & -655 & $-6,340$ & 936 & -260 \\
\hline 2002 & 0.00 & 3,540 & $-3,350$ & 121 & -372 & 0.00 & 7.86 & 5,150 & - & - & 0.00 & $-1,490$ & $-5,070$ & 1,000 & -279 \\
\hline 2003 & 0.00 & 2,040 & $-3,060$ & 198 & 408 & 0.00 & 6.70 & 5,390 & - & - & 0.00 & $-1,790$ & $-2,790$ & 721 & -302 \\
\hline 2004 & 0.00 & 3,580 & $-3,350$ & 200 & 1,000 & 0.00 & 5.77 & 5,850 & - & - & 0.00 & $-3,240$ & $-2,260$ & 536 & -323 \\
\hline 2005 & 0.00 & 2,380 & $-2,540$ & 2,020 & 3,670 & 0.00 & 2.65 & 5,680 & - & - & 0.00 & $-3,150$ & -385 & -149 & -195 \\
\hline 2006 & 0.00 & 1,050 & $-3,370$ & 304 & 291 & 0.00 & 1.94 & 5,400 & - & - & 0.00 & $-2,970$ & 330 & -210 & -229 \\
\hline 2007 & 0.00 & 2,250 & $-5,940$ & 109 & $-4,660$ & 0.00 & 3.90 & 4,040 & - & - & 0.00 & $-1,140$ & $-4,260$ & 479 & -193 \\
\hline 2008 & 0.00 & 3,970 & $-3,650$ & 260 & $-1,490$ & 0.00 & 7.59 & 5,580 & - & - & 0.00 & -987 & $-7,720$ & 1,260 & -195 \\
\hline 2009 & 0.00 & 3,700 & $-3,100$ & 206 & -952 & 0.00 & 8.35 & 6,410 & - & - & 0.00 & $-1,890$ & $-7,410$ & 1,370 & -236 \\
\hline 2010 & 0.00 & 2,850 & $-2,420$ & 604 & 2,060 & 0.00 & 6.97 & 8,140 & - & - & 0.00 & $-5,030$ & $-2,740$ & 936 & -295 \\
\hline 2011 & 0.00 & 2,370 & $-5,580$ & 901 & 3,770 & 0.00 & 3.13 & 8,030 & - & - & 0.00 & $-3,910$ & 2,130 & 79.2 & -248 \\
\hline 2012 & 0.00 & 3,060 & $-5,400$ & 213 & -56.1 & 0.00 & 2.60 & 7,150 & - & - & 0.00 & $-4,410$ & -412 & 9.84 & -277 \\
\hline 2013 & 0.00 & 2,870 & $-5,240$ & 133 & $-1,210$ & 0.00 & 4.08 & 7,050 & - & - & 0.00 & $-3,320$ & $-2,720$ & 303 & -292 \\
\hline 2014 & 0.00 & 4,500 & $-2,480$ & 68.3 & $-1,050$ & 0.00 & 5.88 & 5,830 & - & - & 0.00 & $-4,350$ & $-5,070$ & 753 & -289 \\
\hline 2015 & 0.00 & 3,320 & $-2,840$ & 278 & -228 & 0.00 & 5.29 & 6,260 & - & - & 0.00 & $-2,950$ & $-4,720$ & 639 & -227 \\
\hline
\end{tabular}


Table 4.11. Overall annual groundwater flow budget and individual annual groundwater flow budgets by subarea of the Los Angeles Coastal Plain Groundwater-flow Model for Santa Monica Basin, Los Angeles and Orange Counties, California.

[GHB, general head boundary; OC, Orange County; WHT, Whittier; PV, Palos Verdes; CHD, time-variant specified-head; LA Narrows, Los Angeles Narrows; WRD, Water Replenishment District of Southern California]

\begin{tabular}{|c|c|c|c|c|c|c|c|c|c|c|c|c|c|c|c|c|}
\hline Year & $\begin{array}{c}\text { Water } \\
\text { spreading }\end{array}$ & Injection & Pumping & Recharge & Storage & Drains & $\begin{array}{c}\text { GHB } \\
\text { Ocean }\end{array}$ & $\begin{array}{c}\text { GHB } \\
\text { OC }\end{array}$ & $\begin{array}{l}\text { GHB } \\
\text { WHT }\end{array}$ & $\begin{array}{c}\text { GHB } \\
\text { PV }\end{array}$ & $\begin{array}{c}\text { CHD LA } \\
\text { Narrows }\end{array}$ & $\begin{array}{c}\text { Flow from } \\
\text { WRD Central } \\
\text { Basin }\end{array}$ & $\begin{array}{c}\text { Flow from } \\
\text { Santa Monica } \\
\text { Bay }\end{array}$ & $\begin{array}{l}\text { Flow from } \\
\text { West Coast }\end{array}$ & $\begin{array}{l}\text { Flow from } \\
\text { Hollywood }\end{array}$ & $\begin{array}{c}\text { Flow from } \\
\text { Central } \\
\text { Basin }\end{array}$ \\
\hline 1971 & 0.00 & 0.00 & $-7,360$ & 5,160 & $-15,700$ & $-7,660$ & $-1,050$ & - & - & - & 0.00 & 4.21 & -645 & $-3,380$ & -322 & -436 \\
\hline 1972 & 0.00 & 0.00 & $-7,900$ & 4,200 & $-11,800$ & $-3,700$ & -413 & - & - & - & 0.00 & 3.72 & -529 & $-2,690$ & -161 & -621 \\
\hline 1973 & 0.00 & 0.00 & $-8,200$ & 11,900 & $-4,340$ & $-4,230$ & -199 & - & - & - & 0.00 & 5.70 & -447 & $-2,310$ & -399 & -470 \\
\hline 1974 & 0.00 & 0.00 & $-7,970$ & 8,630 & $-5,770$ & $-3,350$ & -50.3 & - & - & - & 0.00 & 4.82 & -376 & $-2,010$ & -298 & -353 \\
\hline 1975 & 0.00 & 298 & $-8,450$ & 5,010 & $-7,810$ & $-2,320$ & 114 & - & - & - & 0.00 & 3.94 & -314 & $-1,890$ & -102 & -159 \\
\hline 1976 & 0.00 & 718 & $-8,340$ & 1,700 & $-8,970$ & $-1,180$ & 329 & - & - & - & 0.00 & 3.15 & -270 & $-1,860$ & 49.4 & -131 \\
\hline 1977 & 0.00 & 0.00 & $-8,510$ & 3,260 & $-7,590$ & -886 & 453 & - & - & - & 0.00 & 3.06 & -167 & $-1,680$ & 10.9 & -67.6 \\
\hline 1978 & 0.00 & 1,550 & $-4,910$ & 29,400 & 16,300 & $-5,700$ & -220 & - & - & - & 0.00 & 10.2 & -526 & $-2,580$ & -760 & 55.5 \\
\hline 1979 & 0.00 & 2,530 & $-6,490$ & 14,700 & 1,960 & $-4,880$ & -316 & - & - & - & 0.00 & 7.60 & -425 & $-2,910$ & -400 & 149 \\
\hline 1980 & 0.00 & 1,930 & $-6,900$ & 26,600 & 10,100 & $-7,630$ & -511 & - & - & - & 0.00 & 11.3 & -394 & $-2,570$ & -631 & 228 \\
\hline 1981 & 0.00 & 1,270 & $-6,960$ & 4,870 & $-7,490$ & $-4,130$ & -295 & - & - & - & 0.00 & 4.15 & -179 & $-2,340$ & -9.29 & 279 \\
\hline 1982 & 0.00 & 1,260 & $-8,430$ & 4,830 & $-7,140$ & $-2,700$ & 54.8 & - & - & - & 0.00 & 4.31 & -106 & $-2,380$ & 62.5 & 263 \\
\hline 1983 & 0.00 & 1,650 & $-9,720$ & 22,900 & 6,850 & $-5,750$ & 18.6 & - & - & - & 0.00 & 10.6 & -125 & $-2,010$ & -505 & 373 \\
\hline 1984 & 0.00 & 1,180 & $-10,300$ & 5,200 & $-7,910$ & $-3,150$ & 299 & - & - & - & 0.00 & 5.11 & 113 & $-1,620$ & 51.2 & 356 \\
\hline 1985 & 0.00 & 0.00 & $-9,890$ & 4,180 & $-7,830$ & $-2,040$ & 534 & - & - & - & 0.00 & 4.22 & 188 & $-1,310$ & 133 & 383 \\
\hline 1986 & 0.00 & 1,150 & $-10,800$ & 11,600 & $-1,150$ & $-2,820$ & 622 & - & - & - & 0.00 & 6.27 & 191 & $-1,400$ & -96.6 & 403 \\
\hline 1987 & 0.00 & 2,150 & $-9,330$ & 2,150 & $-5,930$ & -975 & 738 & - & - & - & 0.00 & 3.95 & 126 & $-1,390$ & 235 & 368 \\
\hline 1988 & 0.00 & 773 & $-9,280$ & 3,810 & $-4,770$ & -866 & 914 & - & - & - & 0.00 & 3.84 & 317 & -972 & 155 & 376 \\
\hline 1989 & 0.00 & 0.00 & $-8,340$ & 3,550 & $-4,410$ & -585 & 1,070 & - & - & - & 0.00 & 3.73 & 346 & -995 & 170 & 370 \\
\hline 1990 & 0.00 & 0.00 & $-5,370$ & 740 & $-4,350$ & -79.2 & 1,030 & - & - & - & 0.00 & 3.36 & 57.9 & $-1,360$ & 284 & 348 \\
\hline 1991 & 0.00 & 0.00 & $-6,060$ & 4,700 & $-1,590$ & -304 & 979 & - & - & - & 0.00 & 3.40 & 88.8 & $-1,390$ & 87.3 & 308 \\
\hline 1992 & 0.00 & 0.00 & $-8,600$ & 15,100 & 4,310 & $-2,140$ & 1,070 & - & - & - & 0.00 & 6.24 & 315 & $-1,460$ & -297 & 354 \\
\hline 1993 & 0.00 & 0.00 & $-10,000$ & 27,000 & 12,300 & $-4,920$ & 879 & - & - & - & 0.00 & 10.0 & 389 & -961 & -618 & 486 \\
\hline 1994 & 0.00 & 0.00 & $-9,960$ & 3,790 & $-6,340$ & $-1,900$ & 1,020 & - & - & - & 0.00 & 3.98 & 478 & -397 & 119 & 497 \\
\hline 1995 & 0.00 & 0.00 & $-10,600$ & 22,200 & 8,150 & $-4,470$ & 842 & - & - & - & 0.00 & 8.74 & 404 & -296 & -431 & 487 \\
\hline 1996 & 0.00 & 0.00 & $-6,210$ & 7,230 & $-1,250$ & $-2,540$ & 838 & - & - & - & 0.00 & 4.99 & 64.2 & $-1,160$ & 33.1 & 487 \\
\hline 1997 & 0.00 & 0.00 & $-3,240$ & 12,700 & 5,050 & $-3,270$ & 285 & - & - & - & 0.00 & 6.37 & -151 & $-1,630$ & -126 & 485 \\
\hline 1998 & 0.00 & 0.00 & $-3,120$ & 29,400 & 16,700 & $-7,150$ & -425 & - & - & - & 0.00 & 11.8 & -203 & $-1,900$ & -541 & 588 \\
\hline 1999 & 0.00 & 0.00 & $-3,330$ & 3,450 & $-5,740$ & $-3,760$ & -397 & - & - & - & 0.00 & 4.69 & -96.8 & $-2,340$ & 180 & 555 \\
\hline
\end{tabular}


Table 4.11. Overall annual groundwater flow budget and individual annual groundwater flow budgets by subarea of the Los Angeles Coastal Plain Groundwater-flow Model for Santa Monica Basin, Los Angeles and Orange Counties, California.

[GHB, general head boundary; OC, Orange County; WHT, Whittier; PV, Palos Verdes; CHD, time-variant specified-head; LA Narrows, Los Angeles Narrows; WRD, Water Replenishment District of Southern California]

\begin{tabular}{|c|c|c|c|c|c|c|c|c|c|c|c|c|c|c|c|c|}
\hline Year & $\begin{array}{c}\text { Water } \\
\text { spreading }\end{array}$ & Injection & Pumping & Recharge & Storage & Drains & $\begin{array}{c}\text { GHB } \\
\text { Ocean }\end{array}$ & $\begin{array}{c}\text { GHB } \\
\text { OC }\end{array}$ & $\begin{array}{l}\text { GHB } \\
\text { WHT }\end{array}$ & $\begin{array}{c}\text { GHB } \\
\text { PV }\end{array}$ & $\begin{array}{c}\text { CHD LA } \\
\text { Narrows }\end{array}$ & $\begin{array}{c}\text { Flow from } \\
\text { WRD Central } \\
\text { Basin }\end{array}$ & $\begin{array}{c}\text { Flow from } \\
\text { Santa Monica } \\
\text { Bay }\end{array}$ & $\begin{array}{l}\text { Flow from } \\
\text { West Coast }\end{array}$ & $\begin{array}{l}\text { Flow from } \\
\text { Hollywood }\end{array}$ & $\begin{array}{c}\text { Flow from } \\
\text { Central } \\
\text { Basin }\end{array}$ \\
\hline 2000 & 0.00 & 0.00 & $-3,500$ & 6,160 & $-2,450$ & $-2,870$ & -360 & - & - & - & 0.00 & 4.85 & -127 & $-2,380$ & 83 & 530 \\
\hline 2001 & 0.00 & 0.00 & $-3,310$ & 11,900 & 2,200 & $-3,790$ & -465 & - & - & - & 0.00 & 6.33 & -156 & $-2,330$ & -136 & 511 \\
\hline 2002 & 0.00 & 0.00 & $-2,390$ & 1,460 & $-5,420$ & $-1,790$ & -402 & - & - & - & 0.00 & 3.98 & -201 & $-2,800$ & 221 & 476 \\
\hline 2003 & 0.00 & 0.00 & $-1,530$ & 3,680 & $-2,340$ & $-1,500$ & -410 & - & - & - & 0.00 & 4.00 & -322 & $-2,860$ & 156 & 441 \\
\hline 2004 & 0.00 & 0.00 & $-1,280$ & 4,190 & $-1,430$ & $-1,190$ & -461 & - & - & - & 0.00 & 4.25 & -336 & $-2,860$ & 118 & 379 \\
\hline 2005 & 0.00 & 0.00 & $-2,250$ & 26,800 & 14,000 & $-6,290$ & -745 & - & - & - & 0.00 & 11.0 & -357 & $-3,020$ & -610 & 441 \\
\hline 2006 & 0.00 & 0.00 & $-2,180$ & 5,610 & $-2,800$ & $-3,150$ & -564 & - & - & - & 0.00 & 4.72 & -273 & $-2,630$ & 6.22 & 377 \\
\hline 2007 & 0.00 & 0.00 & $-2,390$ & 878 & $-5,590$ & $-1,430$ & -499 & - & - & - & 0.00 & 3.66 & -199 & $-2,460$ & 174 & 331 \\
\hline 2008 & 0.00 & 0.00 & $-2,440$ & 6,330 & $-1,150$ & $-1,940$ & -486 & - & - & - & 0.00 & 3.65 & -208 & $-2,670$ & -53.5 & 322 \\
\hline 2009 & 0.00 & 0.00 & $-2,460$ & 2,980 & $-3,850$ & $-1,170$ & -402 & - & - & - & 0.00 & 3.52 & -235 & $-2,940$ & 119 & 262 \\
\hline 2010 & 0.00 & 0.00 & $-3,700$ & 8,060 & -543 & $-1,780$ & -354 & - & - & - & 0.00 & 4.56 & -174 & $-2,760$ & -135 & 286 \\
\hline 2011 & 0.00 & 0.00 & $-8,410$ & 9,030 & $-2,780$ & $-1,870$ & -88.8 & - & - & - & 0.00 & 6.29 & 170 & $-1,730$ & -234 & 351 \\
\hline 2012 & 0.00 & 0.00 & $-8,860$ & 1,200 & $-8,840$ & -501 & 398 & - & - & - & 0.00 & 3.66 & 149 & $-1,630$ & 71.7 & 338 \\
\hline 2013 & 0.00 & 0.00 & $-10,300$ & 1,180 & $-9,320$ & -151 & 740 & - & - & - & 0.00 & 3.45 & 169 & $-1,410$ & 118 & 302 \\
\hline 2014 & 0.00 & 0.00 & $-11,100$ & 1,090 & $-9,850$ & -38.4 & 1,110 & - & - & - & 0.00 & 3.22 & 299 & $-1,590$ & 134 & 269 \\
\hline 2015 & 0.00 & 0.00 & $-11,000$ & 3,870 & $-6,250$ & -130 & 1,400 & - & - & - & 0.00 & 3.94 & 308 & -994 & 36.5 & 288 \\
\hline
\end{tabular}


Table 4.12. Overall annual groundwater flow budget and individual annual groundwater flow budgets by subarea of the Los Angeles Coastal Plain Groundwater-flow Model for Whittier area, Los Angeles and Orange Counties, California

[GHB, general head boundary; OC, Orange County; WHT, Whittier; PV, Palos Verdes; CHD, time-variant specified-head; LA Narrows, Los Angeles Narrows; WRD, Water Replenishment District of Southern California]

\begin{tabular}{|c|c|c|c|c|c|c|c|c|c|c|c|c|c|c|}
\hline Year & $\begin{array}{c}\text { Water } \\
\text { spreading }\end{array}$ & Injection & Pumping & Recharge & Storage & Drains & $\begin{array}{l}\text { GHB } \\
\text { Ocean }\end{array}$ & $\begin{array}{c}\text { GHB } \\
\text { OC }\end{array}$ & $\begin{array}{l}\text { GHB } \\
\text { WHT }\end{array}$ & $\begin{array}{l}\text { GHB } \\
\text { PV }\end{array}$ & $\begin{array}{l}\text { CHD LA } \\
\text { Narrows }\end{array}$ & $\begin{array}{l}\text { Flow from WRD } \\
\text { Central Basin }\end{array}$ & $\begin{array}{c}\text { Flow from Montebello } \\
\text { Forebay }\end{array}$ & $\begin{array}{c}\text { Flow from North } \\
\text { Orange County }\end{array}$ \\
\hline 1971 & 0.00 & 0.00 & $-1,210$ & 1,030 & $-5,160$ & 0.00 & - & - & - & - & 0.00 & $-4,540$ & $-2,760$ & 2,320 \\
\hline 1972 & 0.00 & 0.00 & $-1,320$ & 520 & $-6,680$ & 0.00 & - & - & - & - & 0.00 & $-4,480$ & $-3,810$ & 2,410 \\
\hline 1973 & 0.00 & 0.00 & $-1,240$ & 3,470 & 1,440 & 0.00 & - & - & - & - & 0.00 & $-4,310$ & 1,210 & 2,310 \\
\hline 1974 & 0.00 & 0.00 & $-1,270$ & 1,910 & $-1,080$ & 0.00 & - & - & - & - & 0.00 & $-4,150$ & 135 & 2,290 \\
\hline 1975 & 0.00 & 0.00 & $-1,540$ & 767 & $-2,910$ & 0.00 & - & - & - & - & 0.00 & $-3,920$ & -661 & 2,440 \\
\hline 1976 & 0.00 & 0.00 & $-1,260$ & 286 & $-5,270$ & 0.00 & - & - & - & - & 0.00 & $-3,860$ & $-2,830$ & 2,400 \\
\hline 1977 & 0.00 & 0.00 & $-1,080$ & 364 & $-4,740$ & 0.00 & - & - & - & - & 0.00 & $-3,760$ & $-2,640$ & 2,380 \\
\hline 1978 & 0.00 & 0.00 & $-1,050$ & 10,900 & 13,100 & -1.17 & - & - & - & - & 0.00 & $-3,680$ & 4,900 & 2,030 \\
\hline 1979 & 0.00 & 0.00 & $-1,580$ & 4,790 & 1,800 & 0.00 & - & - & - & - & 0.00 & $-3,640$ & 126 & 2,100 \\
\hline 1980 & 0.00 & 0.00 & $-1,850$ & 8,540 & 5,710 & -43.7 & - & - & - & - & 0.00 & $-3,730$ & 773 & 2,010 \\
\hline 1981 & 0.00 & 0.00 & $-1,630$ & 602 & $-3,630$ & 0.848 & - & - & - & - & 0.00 & $-3,800$ & -874 & 2,080 \\
\hline 1982 & 0.00 & 0.00 & $-2,150$ & 906 & $-3,360$ & 0.237 & - & - & - & - & 0.00 & $-3,780$ & -712 & 2,370 \\
\hline 1983 & 0.00 & 0.00 & -868 & 7,250 & 5,860 & -54.7 & - & - & - & - & 0.00 & $-3,840$ & 1,430 & 1,930 \\
\hline 1984 & 0.00 & 0.00 & $-2,540$ & 941 & $-3,990$ & -20.8 & - & - & - & - & 0.00 & $-3,570$ & $-1,230$ & 2,430 \\
\hline 1985 & 0.00 & 0.00 & $-1,990$ & 1,380 & $-3,000$ & -4.42 & - & - & - & - & 0.00 & $-3,450$ & $-1,330$ & 2,400 \\
\hline 1986 & 0.00 & 0.00 & $-2,630$ & 2,660 & -579 & -2.08 & - & - & - & - & 0.00 & $-3,340$ & 118 & 2,620 \\
\hline 1987 & 0.00 & 0.00 & $-2,610$ & 301 & $-3,480$ & 0.00 & - & - & - & - & 0.00 & $-3,410$ & -414 & 2,650 \\
\hline 1988 & 0.00 & 0.00 & $-2,880$ & 484 & $-3,200$ & 0.00 & - & - & - & - & 0.00 & $-3,280$ & -365 & 2,830 \\
\hline 1989 & 0.00 & 0.00 & $-2,770$ & 822 & $-2,670$ & 0.00 & - & - & - & - & 0.00 & $-3,220$ & -309 & 2,800 \\
\hline 1990 & 0.00 & 0.00 & $-2,680$ & 150 & $-2,400$ & 0.00 & - & - & - & - & 0.00 & $-3,110$ & 418 & 2,820 \\
\hline 1991 & 0.00 & 0.00 & $-2,540$ & 1,320 & 401 & 0.00 & - & - & - & - & 0.00 & $-2,990$ & 1,890 & 2,720 \\
\hline 1992 & 0.00 & 0.00 & $-2,260$ & 3,320 & 2,960 & 0.00 & - & - & - & - & 0.00 & $-3,040$ & 2,410 & 2,520 \\
\hline 1993 & 0.00 & 0.00 & $-1,550$ & 8,710 & 9,490 & -1.17 & - & - & - & - & 0.00 & $-3,110$ & 3,490 & 1,940 \\
\hline 1994 & 0.00 & 0.00 & -885 & 494 & $-1,770$ & 0.00 & - & - & - & - & 0.00 & $-3,200$ & 45.0 & 1,770 \\
\hline 1995 & 0.00 & 0.00 & -41.8 & 4,950 & 4,060 & 0.00 & - & - & - & - & 0.00 & $-3,470$ & 1,180 & 1,440 \\
\hline 1996 & 0.00 & 0.00 & -37.4 & 1,250 & -457 & 0.00 & - & - & - & - & 0.00 & $-3,560$ & 345 & 1,550 \\
\hline 1997 & 0.00 & 0.00 & -36.1 & 1,980 & -495 & 0.313 & - & - & - & - & 0.00 & $-3,680$ & -375 & 1,620 \\
\hline 1998 & 0.00 & 0.00 & -25.2 & 8,590 & 6,310 & -86.5 & - & - & - & - & 0.00 & $-3,910$ & 248 & 1,490 \\
\hline 1999 & 0.00 & 0.00 & -22.8 & 430 & $-5,150$ & -21.7 & - & - & - & - & 0.00 & $-4,050$ & $-3,100$ & 1,620 \\
\hline 2000 & 0.00 & 0.00 & -54.7 & 843 & $-2,060$ & -12.0 & - & - & - & - & 0.00 & $-4,040$ & -565 & 1,770 \\
\hline
\end{tabular}


Table 4.12. Overall annual groundwater flow budget and individual annual groundwater flow budgets by subarea of the Los Angeles Coastal Plain Groundwater-flow Model for Whittier area, Los Angeles and Orange Counties, California

[GHB, general head boundary; OC, Orange County; WHT, Whittier; PV, Palos Verdes; CHD, time-variant specified-head; LA Narrows, Los Angeles Narrows; WRD, Water Replenishment District of Southern California]

\begin{tabular}{|c|c|c|c|c|c|c|c|c|c|c|c|c|c|c|}
\hline Year & $\begin{array}{c}\text { Water } \\
\text { spreading }\end{array}$ & Injection & Pumping & Recharge & Storage & Drains & $\begin{array}{c}\text { GHB } \\
\text { Ocean }\end{array}$ & $\begin{array}{c}\text { GHB } \\
\text { OC }\end{array}$ & $\begin{array}{l}\text { GHB } \\
\text { WHT }\end{array}$ & $\begin{array}{l}\text { GHB } \\
\text { PV }\end{array}$ & $\begin{array}{l}\text { CHD LA } \\
\text { Narrows }\end{array}$ & $\begin{array}{c}\text { Flow from WRD } \\
\text { Central Basin }\end{array}$ & $\begin{array}{c}\text { Flow from Montebello } \\
\text { Forebay }\end{array}$ & $\begin{array}{c}\text { Flow from North } \\
\text { Orange County }\end{array}$ \\
\hline 2001 & 0.00 & 0.00 & -51.2 & 1,600 & $-1,180$ & -9.93 & - & - & - & - & 0.00 & $-3,960$ & -584 & 1,830 \\
\hline 2002 & 0.00 & 0.00 & -84.5 & 175 & $-2,710$ & 0.00 & - & - & - & - & 0.00 & $-3,890$ & -818 & 1,910 \\
\hline 2003 & 0.00 & 0.00 & -34.8 & 1,230 & $-1,630$ & 0.00 & - & - & - & - & 0.00 & $-3,760$ & $-1,010$ & 1,950 \\
\hline 2004 & 0.00 & 0.00 & -58.5 & 743 & $-1,560$ & 0.00 & - & - & - & - & 0.00 & $-3,650$ & -597 & 2,000 \\
\hline 2005 & 0.00 & 0.00 & -66.6 & 8,380 & 9,660 & -42.4 & - & - & - & - & 0.00 & $-3,660$ & 3,340 & 1,710 \\
\hline 2006 & 0.00 & 0.00 & -44.6 & 585 & -985 & -6.24 & - & - & - & - & 0.00 & $-3,530$ & 218 & 1,790 \\
\hline 2007 & 0.00 & 0.00 & -52.8 & 145 & $-3,760$ & 0.00 & - & - & - & - & 0.00 & $-3,750$ & $-2,020$ & 1,930 \\
\hline 2008 & 0.00 & 0.00 & -53.5 & 759 & $-3,090$ & 0.00 & - & - & - & - & 0.00 & $-3,880$ & $-1,910$ & 1,990 \\
\hline 2009 & 0.00 & 0.00 & -52.9 & 417 & $-3,690$ & 0.00 & - & - & - & - & 0.00 & $-3,800$ & $-2,290$ & 2,040 \\
\hline 2010 & 0.00 & 0.00 & -49.0 & 2,900 & 2,150 & 0.00 & - & - & - & - & 0.00 & $-3,610$ & 908 & 2,000 \\
\hline 2011 & 0.00 & 0.00 & -46.7 & 3,760 & 5,130 & 0.00 & - & - & - & - & 0.00 & $-3,410$ & 2,940 & 1,880 \\
\hline 2012 & 0.00 & 0.00 & -56.4 & 367 & $-2,890$ & 0.00 & - & - & - & - & 0.00 & $-3,420$ & $-1,720$ & 1,940 \\
\hline 2013 & 0.00 & 0.00 & -68.0 & 217 & $-4,400$ & 0.00 & - & - & - & - & 0.00 & $-3,540$ & $-3,030$ & 2,020 \\
\hline 2014 & 0.00 & 0.00 & -47.4 & 88.6 & $-4,090$ & 0.00 & - & - & - & - & 0.00 & $-3,570$ & $-2,610$ & 2,050 \\
\hline 2015 & 0.00 & 0.00 & -39.3 & 1,000 & $-1,390$ & 0.00 & - & - & - & - & 0.00 & $-3,270$ & $-1,110$ & 2,040 \\
\hline
\end{tabular}


Table 4.13. Overall annual groundwater flow budget and individual annual groundwater flow budgets by subarea of the Los Angeles Coastal Plain Groundwater-flow Model for West Coast Basin, Los Angeles and Orange Counties, California.

[GHB, general head boundary; OC, Orange County; WHT, Whittier; PV, Palos Verdes; CHD, time-variant specified-head; LA Narrows, Los Angeles Narrows; WRD, Water Replenishment District of Southern California]

\begin{tabular}{|c|c|c|c|c|c|c|c|c|c|c|c|c|c|c|c|c|}
\hline Year & $\begin{array}{c}\text { Water } \\
\text { spreading }\end{array}$ & Injection & Pumping & Recharge & Storage & Drains & $\begin{array}{c}\text { GHB } \\
\text { Ocean }\end{array}$ & $\begin{array}{c}\text { GHB } \\
\text { OC }\end{array}$ & $\begin{array}{l}\text { GHB } \\
\text { WHT }\end{array}$ & $\begin{array}{c}\text { GHB } \\
\text { PV }\end{array}$ & $\begin{array}{c}\text { CHD LA } \\
\text { Narrows }\end{array}$ & $\begin{array}{c}\text { Flow from } \\
\text { WRD Central } \\
\text { Basin }\end{array}$ & $\begin{array}{c}\text { Flow from } \\
\text { Santa Monica } \\
\text { Bay }\end{array}$ & $\begin{array}{c}\text { Flow from } \\
\text { San Pedro } \\
\text { Bay }\end{array}$ & $\begin{array}{c}\text { Flow from } \\
\text { Santa } \\
\text { Monica }\end{array}$ & $\begin{array}{c}\text { Flow from } \\
\text { South Orange } \\
\text { County }\end{array}$ \\
\hline 1971 & 0.00 & 30,800 & $-74,700$ & 5,650 & $-18,100$ & -6.85 & 0.00 & - & - & 31.3 & 0.00 & 6,550 & 603 & 8,930 & 3,380 & 584 \\
\hline 1972 & 0.00 & 36,700 & $-62,600$ & 3,620 & $-4,770$ & 0.00 & 0.00 & - & - & 30.5 & 0.00 & 5,540 & 511 & 8,330 & 2,690 & 410 \\
\hline 1973 & 0.00 & 36,800 & $-58,400$ & 15,200 & 9,710 & 0.00 & 0.00 & - & - & 30.4 & 0.00 & 5,160 & 417 & 7,930 & 2,310 & 270 \\
\hline 1974 & 0.00 & 33,800 & $-55,000$ & 9,810 & 3,700 & 0.00 & 0.00 & - & - & 30.2 & 0.00 & 4,740 & 371 & 7,720 & 2,010 & 250 \\
\hline 1975 & 0.00 & 33,000 & $-55,700$ & 7,470 & -105 & 0.00 & 0.00 & - & - & 29.7 & 0.00 & 4,660 & 355 & 7,790 & 1,890 & 373 \\
\hline 1976 & 0.00 & 40,200 & $-59,400$ & 2,350 & $-1,720$ & 0.00 & 0.00 & - & - & 29.8 & 0.00 & 3,790 & 271 & 8,770 & 1,860 & 395 \\
\hline 1977 & 0.00 & 43,000 & $-59,300$ & 4,530 & 2,370 & 0.00 & 0.00 & - & - & 29.9 & 0.00 & 3,380 & 241 & 8,520 & 1,680 & 350 \\
\hline 1978 & 0.00 & 34,300 & $-58,200$ & 42,900 & 34,700 & -6.06 & 0.00 & - & - & 29.9 & 0.00 & 4,860 & 407 & 7,690 & 2,580 & 274 \\
\hline 1979 & 0.00 & 29,000 & $-56,100$ & 23,500 & 13,000 & 0.00 & 0.00 & - & - & 29.9 & 0.00 & 5,490 & 506 & 7,320 & 2,910 & 348 \\
\hline 1980 & 0.00 & 32,400 & $-58,400$ & 32,000 & 22,400 & -35.5 & 0.00 & - & - & 30.4 & 0.00 & 5,630 & 293 & 7,590 & 2,570 & 355 \\
\hline 1981 & 0.00 & 29,200 & $-56,100$ & 5,670 & $-2,790$ & 0.00 & 0.00 & - & - & 31.1 & 0.00 & 6,560 & 303 & 8,720 & 2,340 & 426 \\
\hline 1982 & 0.00 & 30,400 & $-61,400$ & 7,800 & $-4,780$ & 0.00 & 0.00 & - & - & 31.7 & 0.00 & 6,160 & 373 & 9,080 & 2,380 & 339 \\
\hline 1983 & 0.00 & 40,300 & $-54,200$ & 35,700 & 38,200 & 0.00 & 0.00 & - & - & 31.9 & 0.00 & 6,370 & 56.1 & 7,690 & 2,010 & 279 \\
\hline 1984 & 0.00 & 35,700 & $-51,700$ & 8,190 & 7,100 & 0.00 & 0.00 & - & - & 31.6 & 0.00 & 6,090 & -86.5 & 6,960 & 1,620 & 305 \\
\hline 1985 & 0.00 & 28,000 & $-50,300$ & 6,370 & $-1,530$ & 0.00 & 0.00 & - & - & 31.2 & 0.00 & 6,190 & -35.8 & 6,600 & 1,310 & 319 \\
\hline 1986 & 0.00 & 30,700 & $-50,800$ & 18,000 & 11,100 & 0.00 & 0.00 & - & - & 30.4 & 0.00 & 5,950 & -110 & 5,620 & 1,400 & 302 \\
\hline 1987 & 0.00 & 31,900 & $-47,800$ & 3,550 & 620 & 0.00 & 0.00 & - & - & 30.4 & 0.00 & 5,290 & -171 & 6,160 & 1,390 & 238 \\
\hline 1988 & 0.00 & 31,100 & $-43,200$ & 5,770 & 4,160 & 0.00 & 0.00 & - & - & 30.7 & 0.00 & 3,720 & -260 & 5,860 & 972 & 234 \\
\hline 1989 & 0.00 & 26,400 & $-45,000$ & 4,520 & $-2,980$ & 0.00 & 0.00 & - & - & 30.4 & 0.00 & 3,950 & -243 & 6,130 & 995 & 245 \\
\hline 1990 & 0.00 & 27,300 & $-47,900$ & 1,610 & $-6,060$ & 0.00 & 0.00 & - & - & 30.6 & 0.00 & 4,750 & -133 & 6,670 & 1,360 & 281 \\
\hline 1991 & 0.00 & 24,100 & $-54,100$ & 5,200 & $-11,100$ & 0.00 & 0.00 & - & - & 30.7 & 0.00 & 5,400 & 27.4 & 6,590 & 1,390 & 266 \\
\hline 1992 & 0.00 & 27,800 & $-51,300$ & 18,200 & 7,080 & 0.00 & 0.00 & - & - & 30.7 & 0.00 & 4,450 & -148 & 6,340 & 1,460 & 248 \\
\hline 1993 & 0.00 & 25,600 & $-40,600$ & 34,100 & 31,300 & -24.6 & 0.00 & - & - & 30.6 & 0.00 & 5,880 & -493 & 5,580 & 961 & 170 \\
\hline 1994 & 0.00 & 21,400 & $-42,000$ & 4,890 & $-4,380$ & 0.00 & 0.00 & - & - & 30.0 & 0.00 & 5,930 & -467 & 5,240 & 397 & 215 \\
\hline 1995 & 0.00 & 17,700 & $-43,200$ & 30,000 & 14,600 & -52.2 & 0.00 & - & - & 29.6 & 0.00 & 5,530 & -426 & 4,640 & 296 & 130 \\
\hline 1996 & 0.00 & 24,100 & $-55,200$ & 8,540 & $-8,710$ & 0.00 & 0.00 & - & - & 29.5 & 0.00 & 7,520 & -243 & 5,270 & 1,160 & 198 \\
\hline 1997 & 0.00 & 23,400 & $-50,400$ & 15,200 & 1,980 & -4.29 & 0.00 & - & - & 30.0 & 0.00 & 6,130 & -78.4 & 5,970 & 1,630 & 236 \\
\hline 1998 & 0.00 & 18,500 & $-51,200$ & 42,500 & 24,000 & -152 & 0.00 & - & - & 30.6 & 0.00 & 6,240 & -9.60 & 5,970 & 1,900 & 182 \\
\hline 1999 & 0.00 & 22,600 & $-52,400$ & 5,990 & $-8,880$ & -2.64 & 0.00 & - & - & 30.6 & 0.00 & 5,980 & 119 & 6,240 & 2,340 & 229 \\
\hline
\end{tabular}


Table 4.13. Overall annual groundwater flow budget and individual annual groundwater flow budgets by subarea of the Los Angeles Coastal Plain Groundwater-flow Model for West Coast Basin, Los Angeles and Orange Counties, California.-Continued

[GHB, general head boundary; OC, Orange County; WHT, Whittier; PV, Palos Verdes; CHD, time-variant specified-head; LA Narrows, Los Angeles Narrows; WRD, Water Replenishment District of Southern California]

\begin{tabular}{|c|c|c|c|c|c|c|c|c|c|c|c|c|c|c|c|c|}
\hline Year & $\begin{array}{c}\text { Water } \\
\text { spreading }\end{array}$ & Injection & Pumping & Recharge & Storage & Drains & $\begin{array}{c}\text { GHB } \\
\text { Ocean }\end{array}$ & $\begin{array}{c}\text { GHB } \\
\text { OC }\end{array}$ & $\begin{array}{l}\text { GHB } \\
\text { WHT }\end{array}$ & $\begin{array}{l}\text { GHB } \\
\text { PV }\end{array}$ & $\begin{array}{c}\text { CHD LA } \\
\text { Narrows }\end{array}$ & $\begin{array}{c}\text { Flow from } \\
\text { WRD Central } \\
\text { Basin }\end{array}$ & $\begin{array}{c}\text { Flow from } \\
\text { Santa Monica } \\
\text { Bay }\end{array}$ & $\begin{array}{c}\text { Flow from } \\
\text { San Pedro } \\
\text { Bay }\end{array}$ & $\begin{array}{l}\text { Flow from } \\
\text { Santa } \\
\text { Monica }\end{array}$ & $\begin{array}{c}\text { Flow from } \\
\text { South Orange } \\
\text { County }\end{array}$ \\
\hline 2000 & 0.00 & 26,900 & $-52,000$ & 6,300 & $-4,660$ & 0.00 & 0.00 & - & - & 30.9 & 0.00 & 5,050 & 111 & 6,380 & 2,380 & 266 \\
\hline 2001 & 0.00 & 24,400 & $-50,800$ & 15,000 & 3,000 & 0.00 & 0.00 & - & - & 31.2 & 0.00 & 4,710 & 117 & 6,990 & 2,330 & 260 \\
\hline 2002 & 0.00 & 24,700 & $-51,300$ & 2,220 & $-10,100$ & 0.00 & 0.00 & - & - & 31.2 & 0.00 & 4,230 & 268 & 6,570 & 2,800 & 279 \\
\hline 2003 & 0.00 & 24,200 & $-51,500$ & 5,620 & $-6,850$ & 0.00 & 0.00 & - & - & 31.5 & 0.00 & 4,800 & 320 & 6,480 & 2,860 & 302 \\
\hline 2004 & 0.00 & 17,000 & $-45,100$ & 5,460 & $-8,680$ & 0.00 & 0.00 & - & - & 31.2 & 0.00 & 4,070 & 395 & 6,260 & 2,860 & 323 \\
\hline 2005 & 0.00 & 17,200 & $-40,100$ & 37,700 & 27,700 & -44.6 & 0.00 & - & - & 30.8 & 0.00 & 4,470 & 241 & 4,900 & 3,020 & 195 \\
\hline 2006 & 0.00 & 20,100 & $-34,500$ & 6,790 & 2,870 & 0.00 & 0.00 & - & - & 29.8 & 0.00 & 3,780 & 166 & 3,660 & 2,630 & 229 \\
\hline 2007 & 0.00 & 21,700 & $-38,100$ & 1,730 & $-6,210$ & 0.00 & 0.00 & - & - & 29.5 & 0.00 & 2,020 & 143 & 3,630 & 2,460 & 193 \\
\hline 2008 & 0.00 & 21,200 & $-39,500$ & 7,560 & $-2,410$ & 0.00 & 0.00 & - & - & 29.9 & 0.00 & 1,300 & 206 & 3,950 & 2,670 & 195 \\
\hline 2009 & 0.00 & 21,800 & $-45,600$ & 4,140 & $-10,600$ & 0.00 & 0.00 & - & - & 30.1 & 0.00 & 921 & 347 & 4,660 & 2,940 & 236 \\
\hline 2010 & 0.00 & 24,900 & $-42,900$ & 12,400 & 2,900 & 0.00 & 0.00 & - & - & 30.3 & 0.00 & 648 & 224 & 4,520 & 2,760 & 295 \\
\hline 2011 & 0.00 & 21,300 & $-44,800$ & 16,000 & 1,980 & 0.00 & 0.00 & - & - & 29.8 & 0.00 & 3,010 & 83.2 & 4,400 & 1,730 & 248 \\
\hline 2012 & 0.00 & 21,200 & $-43,400$ & 4,140 & $-9,370$ & 0.00 & 0.00 & - & - & 29.9 & 0.00 & 2,060 & -0.806 & 4,680 & 1,630 & 277 \\
\hline 2013 & 0.00 & 24,600 & $-42,200$ & 2,810 & $-6,950$ & 0.00 & 0.00 & - & - & 30.4 & 0.00 & 1,140 & -52.6 & 5,050 & 1,410 & 292 \\
\hline 2014 & 0.00 & 29,000 & $-40,400$ & 1,150 & $-4,080$ & 0.00 & 0.00 & - & - & 30.1 & 0.00 & 81.0 & -119 & 4,260 & 1,590 & 289 \\
\hline 2015 & 0.00 & 20,000 & $-30,700$ & 5,330 & -217 & 0.00 & 0.00 & - & - & 29.7 & 0.00 & 218 & -193 & 3,880 & 994 & 227 \\
\hline
\end{tabular}


Table 4.14. Average annual 25 -year water budget in acre-feet for base-case scenario with wet climatic conditions, Los Angeles Coastal Plain Ground [WRD, Water Replenishment District of Southern California]

\begin{tabular}{|c|c|c|c|c|c|c|c|c|}
\hline $\begin{array}{c}\text { Chronostratigraphic } \\
\text { unit name }\end{array}$ & $\begin{array}{l}\text { Model } \\
\text { layer }\end{array}$ & $\begin{array}{l}\text { Los } \\
\text { Angeles } \\
\text { Forebay }\end{array}$ & $\begin{array}{c}\text { WRD } \\
\text { Central Basin }\end{array}$ & $\begin{array}{l}\text { Orange } \\
\text { County }\end{array}$ & $\begin{array}{l}\text { West } \\
\text { Coast }\end{array}$ & $\begin{array}{l}\text { Santa } \\
\text { Monica }\end{array}$ & Hollywood & $\begin{array}{l}\text { WRD Los } \\
\text { Angeles } \\
\text { Forebay }\end{array}$ \\
\hline \multicolumn{9}{|c|}{ Pumping and net interborehole flow ou } \\
\hline Dominguez & 2 & 0.00 & $-8,130$ & $-3,020$ & -31.1 & 0.00 & 0.00 & -1.00 \\
\hline Mesa & 3 & 0.00 & $-8,420$ & $-3,340$ & $-1,190$ & -301 & 0.00 & $-2,650$ \\
\hline Pacific A & 4 & 0.00 & $-28,100$ & $-7,660$ & -0.0004 & 0.00 & 0.00 & -830 \\
\hline Pacific & 5 & 0.00 & $-26,700$ & $-26,600$ & $-5,250$ & -628 & -299 & $-4,620$ \\
\hline Harbor & 6 & 0.00 & $-34,700$ & $-10,000$ & $-11,100$ & 0.00 & 0.00 & $-1,020$ \\
\hline Bent Spring & 7 & 0.00 & $-11,300$ & $-2,270$ & $-4,420$ & $-7,370$ & $-1,250$ & $-3,710$ \\
\hline Upper Wilmington A & 8 & $-1,180$ & $-18,700$ & $-3,970$ & $-14,600$ & -133 & $-1,550$ & $-4,520$ \\
\hline Upper Wilmington B & 9 & 0.00 & $-7,240$ & -545 & $-1,840$ & -318 & -25.2 & -652 \\
\hline Lower Wilmington & 10 & 0.00 & $-2,390$ & 0.00 & $-5,810$ & -205 & 0.00 & -647 \\
\hline Long Beach A & 11 & 0.00 & -535 & 0.00 & -707 & 0.00 & 0.00 & -6.48 \\
\hline Long Beach B & 12 & 0.00 & -236 & 0.00 & -115 & 0.00 & 0.00 & -97.8 \\
\hline Long Beach C & 13 & 0.00 & 0.00 & 0.00 & 0.00 & -1.29 & 0.00 & -11.6 \\
\hline \multirow[t]{2}{*}{ Total } & & $-1,180$ & $-146,000$ & $-57,500$ & $-45,100$ & $-8,950$ & $-3,130$ & $-18,800$ \\
\hline & & & & & & & \multicolumn{2}{|c|}{ Net flow from adjacent inland zones } \\
\hline Dominguez & 2 & -618 & 12,900 & $-2,050$ & 46.8 & 19.7 & -112 & 152 \\
\hline Mesa & 3 & $-1,180$ & 27,600 & -247 & 1,200 & -371 & $-1,050$ & 3,740 \\
\hline Pacific A & 4 & -96.2 & 7,830 & 2,230 & -41.9 & 0.00 & 0.00 & -924 \\
\hline Pacific & 5 & $-3,090$ & 21,100 & 10,000 & -427 & 230 & -81.5 & 3,350 \\
\hline Harbor & 6 & -362 & 20,900 & 2,220 & -730 & -12.0 & 0.00 & -860 \\
\hline Bent Spring & 7 & -804 & 12,700 & 931 & -13.6 & 301 & -895 & 1,030 \\
\hline Upper Wilmington A & 8 & $-1,830$ & 7,670 & -423 & 1,340 & $-1,400$ & 107 & 5,160 \\
\hline Upper Wilmington B & 9 & -167 & 3,770 & $-2,200$ & -183 & 224 & -3.09 & 236 \\
\hline Lower Wilmington & 10 & -39.4 & 3,660 & -337 & 1,420 & -195 & 2.41 & 481 \\
\hline Long Beach A & 11 & -0.365 & 720 & 12.7 & 798 & -139 & -0.0166 & 44.0 \\
\hline Long Beach B & 12 & 37.2 & 889 & -223 & 536 & -81.3 & 3.52 & -10.1 \\
\hline Long Beach C & 13 & -608 & 1,930 & 130 & 1,040 & -290 & 1.95 & 52.6 \\
\hline \multirow[t]{2}{*}{ Total } & & $-8,760$ & 122,000 & 10,000 & 4,990 & $-1,710$ & $-2,030$ & 12,400 \\
\hline & & & & & & & \multicolumn{2}{|r|}{ Water spreading } \\
\hline Dominguez & 2 & 0.00 & 0.00 & 0.00 & 0.00 & 0.00 & 0.00 & 0.00 \\
\hline Mesa & 3 & 0.00 & 0.00 & 0.00 & 0.00 & 0.00 & 0.00 & 0.00 \\
\hline Pacific A & 4 & 0.00 & 0.00 & 0.00 & 0.00 & 0.00 & 0.00 & 0.00 \\
\hline Pacific & 5 & 0.00 & 0.00 & 0.00 & 0.00 & 0.00 & 0.00 & 0.00 \\
\hline Harbor & 6 & 0.00 & 0.00 & 0.00 & 0.00 & 0.00 & 0.00 & 0.00 \\
\hline Bent Spring & 7 & 0.00 & 0.00 & 0.00 & 0.00 & 0.00 & 0.00 & 0.00 \\
\hline Upper Wilmington A & 8 & 0.00 & 0.00 & 0.00 & 0.00 & 0.00 & 0.00 & 0.00 \\
\hline Upper Wilmington B & 9 & 0.00 & 0.00 & 0.00 & 0.00 & 0.00 & 0.00 & 0.00 \\
\hline Lower Wilmington & 10 & 0.00 & 0.00 & 0.00 & 0.00 & 0.00 & 0.00 & 0.00 \\
\hline Long Beach A & 11 & 0.00 & 0.00 & 0.00 & 0.00 & 0.00 & 0.00 & 0.00 \\
\hline Long Beach B & 12 & 0.00 & 0.00 & 0.00 & 0.00 & 0.00 & 0.00 & 0.00 \\
\hline Long Beach C & 13 & 0.00 & 0.00 & 0.00 & 0.00 & 0.00 & 0.00 & 0.00 \\
\hline Total & & 0.00 & 0.00 & 0.00 & 0.00 & 0.00 & 0.00 & 0.00 \\
\hline
\end{tabular}


water-flow Model.

\begin{tabular}{|c|c|c|c|c|c|}
\hline $\begin{array}{c}\text { Montebello } \\
\text { Forebay }\end{array}$ & Whitter & Central Basin & $\begin{array}{c}\text { North Orange } \\
\text { County }\end{array}$ & $\begin{array}{l}\text { South Orange } \\
\text { County }\end{array}$ & Total \\
\hline-431 & 0.00 & 0.00 & 0.00 & -36.2 & $-11,700$ \\
\hline$-5,600$ & -29.9 & 0.00 & 0.00 & -207 & $-21,700$ \\
\hline$-2,870$ & 0.00 & 0.00 & 0.00 & 0.00 & $-39,500$ \\
\hline$-17,300$ & -17.3 & -2.44 & 0.00 & $-3,820$ & $-85,200$ \\
\hline$-8,050$ & 0.00 & 0.00 & 0.00 & $-1,090$ & $-66,000$ \\
\hline$-2,650$ & 0.00 & -16.1 & 0.00 & -108 & $-33,100$ \\
\hline$-4,590$ & 0.00 & 0.00 & 0.00 & -380 & $-49,600$ \\
\hline-392 & -0.746 & 0.00 & 0.00 & 0.00 & $-11,000$ \\
\hline-446 & -161 & 0.00 & -137 & 0.00 & $-9,800$ \\
\hline-229 & 0.00 & 0.00 & 0.00 & 0.00 & $-1,480$ \\
\hline-192 & 0.00 & 0.00 & 0.00 & 0.00 & -640 \\
\hline$-4,080$ & 0.00 & 0.00 & 0.00 & 0.00 & $-4,100$ \\
\hline$-46,800$ & -209 & -18.5 & -137 & $-5,640$ & $-334,000$ \\
\hline$-12,900$ & -81.6 & 112 & 7.19 & 2,550 & $-2.82 \mathrm{E}-11$ \\
\hline$-31,000$ & -599 & 946 & 0.00 & 979 & $1.01 \mathrm{E}-11$ \\
\hline$-7,840$ & -304 & -854 & 0.00 & 0.00 & $-5.26 \mathrm{E}-11$ \\
\hline$-25,500$ & -456 & -622 & -702 & $-3,740$ & $-4.91 \mathrm{E}-11$ \\
\hline$-18,600$ & -59.7 & -255 & 0.00 & $-2,270$ & $-6.28 \mathrm{E}-11$ \\
\hline$-14,000$ & 0.00 & 846 & 0.00 & -33.2 & $4.12 \mathrm{E}-11$ \\
\hline$-8,340$ & -308 & -278 & -696 & $-1,010$ & $-1.10 \mathrm{E}-11$ \\
\hline$-1,480$ & 255 & -191 & -315 & 60.4 & $5.63 \mathrm{E}-12$ \\
\hline$-4,250$ & 53.8 & -243 & -438 & -111 & $-2.87 \mathrm{E}-11$ \\
\hline 229 & -70.4 & -1.49 & $-1,100$ & -488 & $3.41 \mathrm{E}-13$ \\
\hline-324 & -201 & -0.143 & -167 & -459 & $-1.08 \mathrm{E}-12$ \\
\hline$-1,090$ & $-1,060$ & -40.4 & -34.3 & -28.9 & $3.69 \mathrm{E}-13$ \\
\hline$-125,000$ & $-2,830$ & -580 & $-3,450$ & $-4,560$ & $-1.88 \mathrm{E}-10$ \\
\hline 85,300 & 0.00 & 0.00 & 0.00 & 0.00 & 85,300 \\
\hline 43,700 & 0.00 & 0.00 & 0.00 & 0.00 & 43,700 \\
\hline 0.00 & 0.00 & 0.00 & 0.00 & 0.00 & 0.00 \\
\hline 2,010 & 0.00 & 0.00 & 0.00 & 0.00 & 2,010 \\
\hline 0.00 & 0.00 & 0.00 & 0.00 & 0.00 & 0.00 \\
\hline 0.00 & 0.00 & 0.00 & 0.00 & 0.00 & 0.00 \\
\hline 0.00 & 0.00 & 0.00 & 0.00 & 0.00 & 0.00 \\
\hline 0.00 & 0.00 & 0.00 & 0.00 & 0.00 & 0.00 \\
\hline 0.00 & 0.00 & 0.00 & 0.00 & 0.00 & 0.00 \\
\hline 0.00 & 0.00 & 0.00 & 0.00 & 0.00 & 0.00 \\
\hline 0.00 & 0.00 & 0.00 & 0.00 & 0.00 & 0.00 \\
\hline 0.00 & 0.00 & 0.00 & 0.00 & 0.00 & 0.00 \\
\hline 131,000 & 0.00 & 0.00 & 0.00 & 0.00 & 131,000 \\
\hline
\end{tabular}


Table 4.14. Average annual 25-year water budget in acre-feet for base-case scenario with wet climatic conditions, Los Angeles Coastal Plain Ground [WRD, Water Replenishment District of Southern California]

\begin{tabular}{|c|c|c|c|c|c|c|c|c|}
\hline $\begin{array}{c}\text { Chronostratigraphic } \\
\text { unit name }\end{array}$ & $\begin{array}{l}\text { Model } \\
\text { layer }\end{array}$ & $\begin{array}{l}\text { Los } \\
\text { Angeles } \\
\text { Forebay }\end{array}$ & $\begin{array}{c}\text { WRD } \\
\text { Central Basin }\end{array}$ & $\begin{array}{l}\text { Orange } \\
\text { County }\end{array}$ & $\begin{array}{l}\text { West } \\
\text { Coast }\end{array}$ & $\begin{array}{l}\text { Santa } \\
\text { Monica }\end{array}$ & Hollywood & $\begin{array}{l}\text { WRD Los } \\
\text { Angeles } \\
\text { Forebay }\end{array}$ \\
\hline & & & & & & & \multicolumn{2}{|c|}{ Injection and net interborehole flow in } \\
\hline Dominguez & 2 & 0.00 & 5.85 & 0.00262 & 35.5 & 0.00 & 0.00 & 0.000225 \\
\hline Mesa & 3 & 0.00 & 743 & 232 & 1,690 & $9.15 \mathrm{E}-05$ & 0.00 & 0.00 \\
\hline Pacific A & 4 & 0.00 & 2,210 & 2,530 & 0.00 & 0.00 & 0.00 & 28.2 \\
\hline Pacific & 5 & 0.00 & 7,530 & 2,020 & 8,060 & 0.0316 & 0.00 & 1,210 \\
\hline Harbor & 6 & 0.00 & 2,040 & 79.6 & 5,250 & 0.00 & 0.00 & 1,410 \\
\hline Bent Spring & 7 & 0.00 & 983 & 0.00 & 9,500 & 241 & 48.3 & 724 \\
\hline Upper Wilmington A & 8 & 1,180 & 980 & 0.894 & 1,200 & 0.00 & 14.4 & 50.1 \\
\hline Upper Wilmington B & 9 & 0.00 & 444 & 1.89 & 96.2 & 1.34 & 0.00 & 15.3 \\
\hline Lower Wilmington & 10 & 0.00 & 66.6 & 0.00 & 94.1 & 0.00 & 0.00 & 34.1 \\
\hline Long Beach A & 11 & 0.00 & 2.96 & 0.00 & 0.00 & 0.00 & 0.00 & 0.00482 \\
\hline Long Beach B & 12 & 0.00 & 0.455 & 0.00 & 0.00 & 0.00 & 0.00 & 0.0408 \\
\hline Long Beach C & 13 & 0.00 & 0.00 & 0.00 & 0.00 & 0.919 & 0.00 & 0.00 \\
\hline \multirow[t]{2}{*}{ Total } & & 1,180 & 15,000 & 4,870 & 25,900 & 243 & 62.7 & 3,470 \\
\hline & & & & & & & & Areal recharge \\
\hline Dominguez & 2 & 1,450 & 10,400 & 3,740 & 1,430 & 1,780 & 2,210 & 1,720 \\
\hline Mesa & 3 & 2,100 & 4,390 & 34.4 & 11,400 & 8,160 & 1,330 & 51.5 \\
\hline Pacific A & 4 & 0.00 & 0.00 & 0.00 & 0.00 & 0.00 & 0.00 & 0.00 \\
\hline Pacific & 5 & 0.00 & 399 & 60.0 & 923 & 1,180 & 0.0782 & 0.00 \\
\hline Harbor & 6 & 254 & 4.88 & 0.00 & 309 & 0.00 & 0.00 & 224 \\
\hline Bent Spring & 7 & 19.0 & 0.00 & 0.00 & 1,030 & 9.73 & 0.00 & 0.00 \\
\hline Upper Wilmington A & 8 & 0.00 & 36.1 & 11.8 & 170 & 82.7 & 0.00 & 44.4 \\
\hline Upper Wilmington B & 9 & 0.00 & 0.00 & 0.00 & 21.5 & 12.2 & 0.00 & 0.00 \\
\hline Lower Wilmington & 10 & 0.00 & 26.4 & 0.00 & 0.00 & 0.00 & 0.00 & 0.00 \\
\hline Long Beach A & 11 & 0.00 & 8.83 & 0.00 & 0.00 & 0.00 & 0.00 & 0.00 \\
\hline Long Beach B & 12 & 0.00 & 0.00 & 0.00 & 0.00 & 0.00 & 0.00 & 0.00 \\
\hline Long Beach C & 13 & 265 & 126 & 0.00 & 121 & 4.04 & 0.00 & 159 \\
\hline \multirow[t]{2}{*}{ Total } & & 4,090 & 15,400 & 3,840 & 15,400 & 11,200 & 3,540 & 2,200 \\
\hline & & & & & & & \multicolumn{2}{|c|}{ Flow from Santa Monica Bay } \\
\hline Dominguez & 2 & 0.00 & 0.00 & 0.00 & 0.00 & 0.00113 & 0.00 & 0.00 \\
\hline Mesa & 3 & 0.00 & 0.00 & 0.00 & -46.8 & -222 & 0.00 & 0.00 \\
\hline Pacific A & 4 & 0.00 & 0.00 & 0.00 & 0.00 & 0.00 & 0.00 & 0.00 \\
\hline Pacific & 5 & 0.00 & 0.00 & 0.00 & -19.0 & -21.4 & 0.00 & 0.00 \\
\hline Harbor & 6 & 0.00 & 0.00 & 0.00 & -19.3 & 0.00 & 0.00 & 0.00 \\
\hline Bent Spring & 7 & 0.00 & 0.00 & 0.00 & 72.4 & 69.2 & 0.00 & 0.00 \\
\hline Upper Wilmington A & 8 & 0.00 & 0.00 & 0.00 & -16.7 & 193 & 0.00 & 0.00 \\
\hline Upper Wilmington B & 9 & 0.00 & 0.00 & 0.00 & -53.4 & -4.86 & 0.00 & 0.00 \\
\hline Lower Wilmington & 10 & 0.00 & 0.00 & 0.00 & 144 & -30.4 & 0.00 & 0.00 \\
\hline Long Beach A & 11 & 0.00 & 0.00 & 0.00 & -3.75 & -17.2 & 0.00 & 0.00 \\
\hline Long Beach B & 12 & 0.00 & 0.00 & 0.00 & 0.684 & -10.0 & 0.00 & 0.00 \\
\hline Long Beach C & 13 & 0.00 & 0.00 & 0.00 & 3.24 & 9.98 & 0.00 & 0.00 \\
\hline Total & & 0.00 & 0.00 & 0.00 & 61.6 & -33.6 & 0.00 & 0.00 \\
\hline
\end{tabular}


water-flow Model._-Continued

\begin{tabular}{|c|c|c|c|c|c|}
\hline $\begin{array}{l}\text { Montebello } \\
\text { Forebay }\end{array}$ & Whitter & Central Basin & $\begin{array}{l}\text { North Orange } \\
\text { County }\end{array}$ & $\begin{array}{l}\text { South Orange } \\
\text { County }\end{array}$ & Total \\
\hline $5.76 \mathrm{E}-05$ & 0.00 & 0.00 & 0.00 & 0.00 & 41.4 \\
\hline 123 & 0.00 & 1.73 & 0.00 & 1,130 & 3,920 \\
\hline 708 & 0.00 & 0.00 & 0.00 & 0.00 & 5,480 \\
\hline 234 & 0.00 & 0.407 & 0.00 & 1,200 & 20,300 \\
\hline 679 & 2.01 & 12.6 & 0.00 & 1,660 & 11,100 \\
\hline 37.6 & 0.00 & 0.55 & 0.00 & 0.137 & 11,500 \\
\hline 260 & 10.6 & 0.00 & 14.4 & 34.9 & 3,750 \\
\hline 3.58 & 0.824 & 0.00 & 16.5 & 0.00 & 580 \\
\hline 28.2 & 0.724 & 0.00 & 0.00 & 0.00 & 224 \\
\hline 0.0143 & 64.7 & 0.00 & 107 & 0.00 & 174 \\
\hline 21.5 & 71.6 & 0.00 & 0.00 & 0.00 & 93.6 \\
\hline 5,000 & 0.00 & 0.00 & 0.00 & 0.00 & 5,000 \\
\hline 7,100 & 150 & 15.3 & 137 & 4,020 & 62,200 \\
\hline 2,620 & 353 & 540 & 33.5 & 547 & 26,800 \\
\hline 1,300 & 465 & 989 & 0.00 & 273 & 30,500 \\
\hline 0.00 & 0.00 & 0.00 & 0.00 & 0.00 & 0.00 \\
\hline 251 & 594 & 218 & 999 & 0.00219 & 4,620 \\
\hline 2.13 & 0.00 & 0.00 & 0.00 & 0.00 & 793 \\
\hline 0.00 & 0.00 & 0.00 & 0.00 & 0.00 & 1,060 \\
\hline 220 & 65.7 & 0.00 & 270 & 0.00 & 901 \\
\hline 0.00 & 0.00 & 0.00 & 0.00 & 0.00 & 33.7 \\
\hline 0.00 & 30.8 & 0.00 & 95.4 & 0.00 & 153 \\
\hline 30.6 & 2.19 & 0.00 & 85.6 & 0.00 & 127 \\
\hline 7.98 & 0.00 & 0.00 & 0.00 & 0.00 & 7.98 \\
\hline 1,510 & 1,430 & 73.8 & 147 & 0.00 & 3,830 \\
\hline 5,940 & 2,940 & 1,820 & 1,630 & 820 & 68,900 \\
\hline 0.00 & 0.00 & 0.00 & 0.00 & 0.00 & 0.00113 \\
\hline 0.00 & 0.00 & 0.00 & 0.00 & 0.00 & -269 \\
\hline 0.00 & 0.00 & 0.00 & 0.00 & 0.00 & 0.00 \\
\hline 0.00 & 0.00 & 0.00 & 0.00 & 0.00 & -40.4 \\
\hline 0.00 & 0.00 & 0.00 & 0.00 & 0.00 & -19.3 \\
\hline 0.00 & 0.00 & 0.00 & 0.00 & 0.00 & 142 \\
\hline 0.00 & 0.00 & 0.00 & 0.00 & 0.00 & 176 \\
\hline 0.00 & 0.00 & 0.00 & 0.00 & 0.00 & -58.3 \\
\hline 0.00 & 0.00 & 0.00 & 0.00 & 0.00 & 114 \\
\hline 0.00 & 0.00 & 0.00 & 0.00 & 0.00 & -21.0 \\
\hline 0.00 & 0.00 & 0.00 & 0.00 & 0.00 & -9.35 \\
\hline 0.00 & 0.00 & 0.00 & 0.00 & 0.00 & 13.2 \\
\hline 0.00 & 0.00 & 0.00 & 0.00 & 0.00 & 28.0 \\
\hline
\end{tabular}


Table 4.14. Average annual 25 -year water budget in acre-feet for base-case scenario with wet climatic conditions, Los Angeles Coastal Plain Ground [WRD, Water Replenishment District of Southern California]

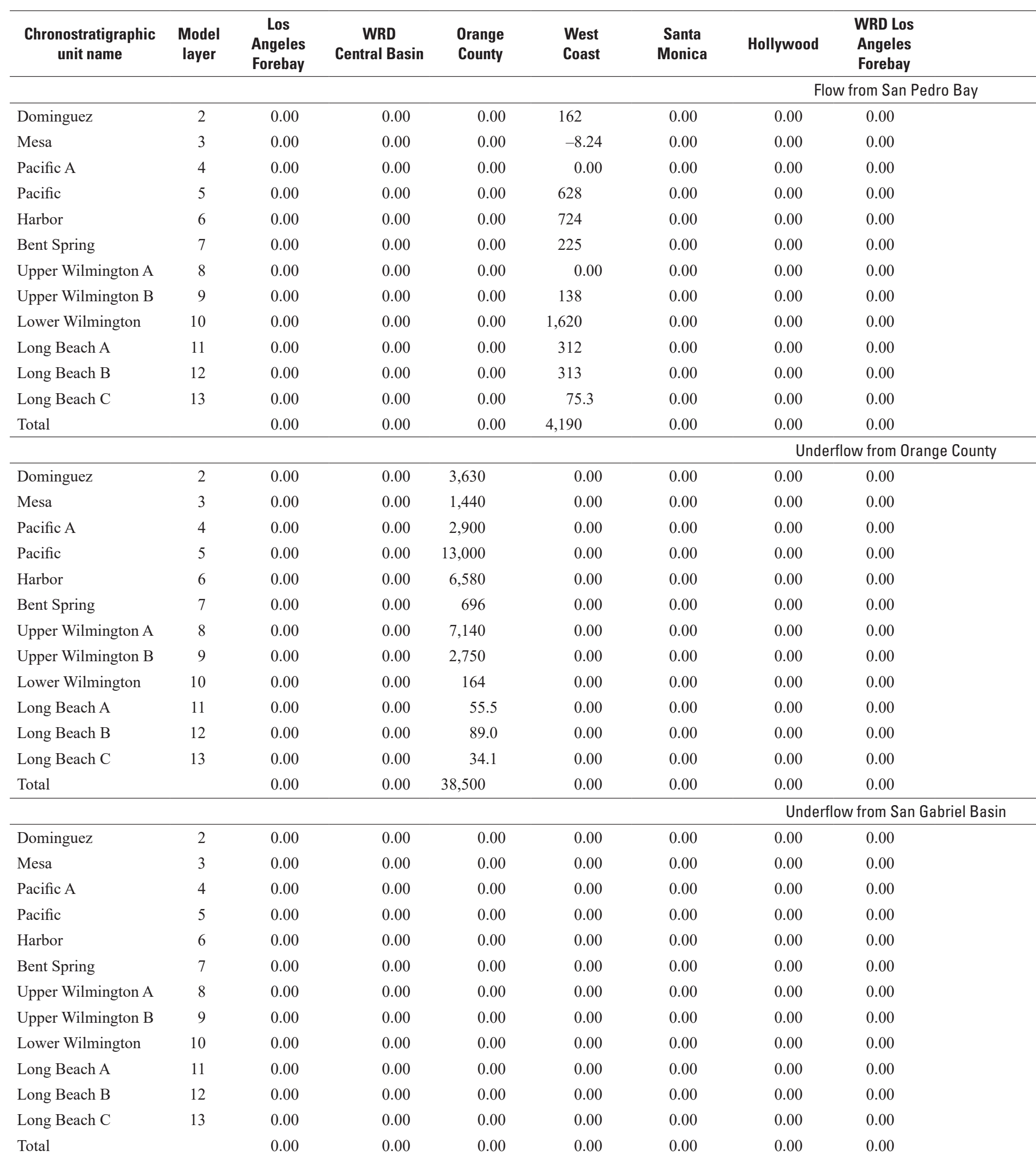


water-flow Model.-Continued

\begin{tabular}{|c|c|c|c|c|c|}
\hline $\begin{array}{c}\text { Montebello } \\
\text { Forebay }\end{array}$ & Whitter & Central Basin & $\begin{array}{l}\text { North Orange } \\
\text { County }\end{array}$ & $\begin{array}{l}\text { South Orange } \\
\text { County }\end{array}$ & Total \\
\hline 0.00 & 0.00 & 0.00 & 0.00 & 28.0 & 190 \\
\hline 0.00 & 0.00 & 0.00 & 0.00 & 141 & 133 \\
\hline 0.00 & 0.00 & 0.00 & 0.00 & 0.00 & 0.00 \\
\hline 0.00 & 0.00 & 0.00 & 0.00 & 281 & 909 \\
\hline 0.00 & 0.00 & 0.00 & 0.00 & 765 & 1,490 \\
\hline 0.00 & 0.00 & 0.00 & 0.00 & 66.2 & 291 \\
\hline 0.00 & 0.00 & 0.00 & 0.00 & 0.00 & 0.00 \\
\hline 0.00 & 0.00 & 0.00 & 0.00 & 0.00 & 138 \\
\hline 0.00 & 0.00 & 0.00 & 0.00 & 30.0 & 1,650 \\
\hline 0.00 & 0.00 & 0.00 & 0.00 & -366 & -54.3 \\
\hline 0.00 & 0.00 & 0.00 & 0.00 & -105 & 207 \\
\hline 0.00 & 0.00 & 0.00 & 0.00 & -342 & -267 \\
\hline 0.00 & 0.00 & 0.00 & 0.00 & 499 & 4,690 \\
\hline 0.00 & 0.00 & 0.00 & 0.00 & 82.7 & 3,710 \\
\hline 0.00 & 0.00 & 0.00 & 0.00 & 544 & 1,980 \\
\hline 0.00 & 0.00 & 0.00 & 0.00 & 0.00 & 2,900 \\
\hline 0.00 & 0.00 & 0.00 & -74.8 & 340 & 13,300 \\
\hline 0.00 & 0.00 & 0.00 & 0.00 & 233 & 6,820 \\
\hline 0.00 & 0.00 & 0.00 & 0.00 & 50.9 & 747 \\
\hline 0.00 & 0.00 & 0.00 & 856 & 1,350 & 9,340 \\
\hline 0.00 & 0.00 & 0.00 & 271 & -42.1 & 2,980 \\
\hline 0.00 & 0.00 & 0.00 & 736 & 39.6 & 939 \\
\hline 0.00 & 0.00 & 0.00 & 1,100 & 880 & 2,040 \\
\hline 0.00 & 0.00 & 0.00 & 58.3 & 610 & 757 \\
\hline 0.00 & 0.00 & 0.00 & 61.9 & 388 & 484 \\
\hline 0.00 & 0.00 & 0.00 & 3,010 & 4,470 & 45,900 \\
\hline 0.00 & 0.00 & 0.00 & 0.00 & 0.00 & 0.00 \\
\hline 26,000 & 0.00 & 0.00 & 0.00 & 0.00 & 26,000 \\
\hline 0.00 & 0.00 & 0.00 & 0.00 & 0.00 & 0.00 \\
\hline 0.00 & 0.00 & 0.00 & 0.00 & 0.00 & 0.00 \\
\hline 0.00 & 0.00 & 0.00 & 0.00 & 0.00 & 0.00 \\
\hline 0.00 & 0.00 & 0.00 & 0.00 & 0.00 & 0.00 \\
\hline 0.00 & 0.00 & 0.00 & 0.00 & 0.00 & 0.00 \\
\hline 0.00 & 0.00 & 0.00 & 0.00 & 0.00 & 0.00 \\
\hline 0.00 & 0.00 & 0.00 & 0.00 & 0.00 & 0.00 \\
\hline 0.00 & 0.00 & 0.00 & 0.00 & 0.00 & 0.00 \\
\hline 0.00 & 0.00 & 0.00 & 0.00 & 0.00 & 0.00 \\
\hline 3,460 & 0.00 & 0.00 & 0.00 & 0.00 & 3,460 \\
\hline 29,400 & 0.00 & 0.00 & 0.00 & 0.00 & 29,400 \\
\hline
\end{tabular}


Table 4.14. Average annual 25 -year water budget in acre-feet for base-case scenario with wet climatic conditions, Los Angeles Coastal Plain Ground [WRD, Water Replenishment District of Southern California]

\begin{tabular}{|c|c|c|c|c|c|c|c|c|}
\hline $\begin{array}{c}\text { Chronostratigraphic } \\
\text { unit name }\end{array}$ & $\begin{array}{l}\text { Model } \\
\text { layer }\end{array}$ & $\begin{array}{c}\text { Los } \\
\text { Angeles } \\
\text { Forebay }\end{array}$ & $\begin{array}{c}\text { WRD } \\
\text { Central Basin }\end{array}$ & $\begin{array}{l}\text { Orange } \\
\text { County }\end{array}$ & $\begin{array}{l}\text { West } \\
\text { Coast }\end{array}$ & $\begin{array}{c}\text { Santa } \\
\text { Monica }\end{array}$ & Hollywood & $\begin{array}{l}\text { WRD Los } \\
\text { Angeles } \\
\text { Forebay }\end{array}$ \\
\hline & & & & & & & \multicolumn{2}{|c|}{ Underflow from Palos Verdes Hills } \\
\hline Dominguez & 2 & 0.00 & 0.00 & 0.00 & 0.00 & 0.00 & 0.00 & 0.00 \\
\hline Mesa & 3 & 0.00 & 0.00 & 0.00 & 0.00 & 0.00 & 0.00 & 0.00 \\
\hline Pacific A & 4 & 0.00 & 0.00 & 0.00 & 0.00 & 0.00 & 0.00 & 0.00 \\
\hline Pacific & 5 & 0.00 & 0.00 & 0.00 & 0.00 & 0.00 & 0.00 & 0.00 \\
\hline Harbor & 6 & 0.00 & 0.00 & 0.00 & 0.00 & 0.00 & 0.00 & 0.00 \\
\hline Bent Spring & 7 & 0.00 & 0.00 & 0.00 & 0.00 & 0.00 & 0.00 & 0.00 \\
\hline Upper Wilmington A & 8 & 0.00 & 0.00 & 0.00 & 0.00 & 0.00 & 0.00 & 0.00 \\
\hline Upper Wilmington B & 9 & 0.00 & 0.00 & 0.00 & 0.00 & 0.00 & 0.00 & 0.00 \\
\hline Lower Wilmington & 10 & 0.00 & 0.00 & 0.00 & 3.10 & 0.00 & 0.00 & 0.00 \\
\hline Long Beach A & 11 & 0.00 & 0.00 & 0.00 & 0.934 & 0.00 & 0.00 & 0.00 \\
\hline Long Beach B & 12 & 0.00 & 0.00 & 0.00 & 0.488 & 0.00 & 0.00 & 0.00 \\
\hline Long Beach C & 13 & 0.00 & 0.00 & 0.00 & 25.6 & 0.00 & 0.00 & 0.00 \\
\hline \multirow[t]{2}{*}{ Total } & & 0.00 & 0.00 & 0.00 & 30.2 & 0.00 & 0.00 & 0.00 \\
\hline & & & & & & & \multicolumn{2}{|c|}{ Flow from Marina Del Rey } \\
\hline Dominguez & 2 & 0.00 & 0.00 & 0.00 & 0.00 & 0.00 & 0.00 & 0.00 \\
\hline Mesa & 3 & 0.00 & 0.00 & 0.00 & 0.00 & 567 & 0.00 & 0.00 \\
\hline Pacific A & 4 & 0.00 & 0.00 & 0.00 & 0.00 & 0.00 & 0.00 & 0.00 \\
\hline Pacific & 5 & 0.00 & 0.00 & 0.00 & 0.00 & 0.00 & 0.00 & 0.00 \\
\hline Harbor & 6 & 0.00 & 0.00 & 0.00 & 0.00 & 0.00 & 0.00 & 0.00 \\
\hline Bent Spring & 7 & 0.00 & 0.00 & 0.00 & 0.00 & 0.00 & 0.00 & 0.00 \\
\hline Upper Wilmington A & 8 & 0.00 & 0.00 & 0.00 & 0.00 & 0.00 & 0.00 & 0.00 \\
\hline Upper Wilmington B & 9 & 0.00 & 0.00 & 0.00 & 0.00 & 0.00 & 0.00 & 0.00 \\
\hline Lower Wilmington & 10 & 0.00 & 0.00 & 0.00 & 0.00 & 0.00 & 0.00 & 0.00 \\
\hline Long Beach A & 11 & 0.00 & 0.00 & 0.00 & 0.00 & 0.00 & 0.00 & 0.00 \\
\hline Long Beach B & 12 & 0.00 & 0.00 & 0.00 & 0.00 & 0.00 & 0.00 & 0.00 \\
\hline Long Beach C & 13 & 0.00 & 0.00 & 0.00 & 0.00 & 0.00 & 0.00 & 0.00 \\
\hline \multirow[t]{2}{*}{ Total } & & 0.00 & 0.00 & 0.00 & 0.00 & 567 & 0.00 & 0.00 \\
\hline & & & & & & & \multicolumn{2}{|c|}{ Flow from Port of Long Beach } \\
\hline Dominguez & 2 & 0.00 & 0.00 & 0.00 & 0.00 & 0.00 & 0.00 & 0.00 \\
\hline Mesa & 3 & 0.00 & 0.00 & 0.00 & -0.00022 & 0.00 & 0.00 & 0.00 \\
\hline Pacific A & 4 & 0.00 & 0.00 & 0.00 & 0.00 & 0.00 & 0.00 & 0.00 \\
\hline Pacific & 5 & 0.00 & 0.00 & 0.00 & 0.00 & 0.00 & 0.00 & 0.00 \\
\hline Harbor & 6 & 0.00 & 0.00 & 0.00 & 0.00 & 0.00 & 0.00 & 0.00 \\
\hline Bent Spring & 7 & 0.00 & 0.00 & 0.00 & 0.00 & 0.00 & 0.00 & 0.00 \\
\hline Upper Wilmington A & 8 & 0.00 & 0.00 & 0.00 & 0.00 & 0.00 & 0.00 & 0.00 \\
\hline Upper Wilmington B & 9 & 0.00 & 0.00 & 0.00 & 0.00 & 0.00 & 0.00 & 0.00 \\
\hline Lower Wilmington & 10 & 0.00 & 0.00 & 0.00 & 0.00 & 0.00 & 0.00 & 0.00 \\
\hline Long Beach A & 11 & 0.00 & 0.00 & 0.00 & 0.00 & 0.00 & 0.00 & 0.00 \\
\hline Long Beach B & 12 & 0.00 & 0.00 & 0.00 & 0.00 & 0.00 & 0.00 & 0.00 \\
\hline Long Beach C & 13 & 0.00 & 0.00 & 0.00 & 0.00 & 0.00 & 0.00 & 0.00 \\
\hline Total & & 0.00 & 0.00 & 0.00 & -0.00022 & 0.00 & 0.00 & 0.00 \\
\hline
\end{tabular}


water-flow Model._-Continued

\begin{tabular}{|c|c|c|c|c|c|}
\hline $\begin{array}{l}\text { Montebello } \\
\text { Forebay }\end{array}$ & Whitter & Central Basin & $\begin{array}{l}\text { North Orange } \\
\text { County }\end{array}$ & $\begin{array}{l}\text { South Orange } \\
\text { County }\end{array}$ & Total \\
\hline 0.00 & 0.00 & 0.00 & 0.00 & 0.00 & 0.00 \\
\hline 0.00 & 0.00 & 0.00 & 0.00 & 0.00 & 0.00 \\
\hline 0.00 & 0.00 & 0.00 & 0.00 & 0.00 & 0.00 \\
\hline 0.00 & 0.00 & 0.00 & 0.00 & 0.00 & 0.00 \\
\hline 0.00 & 0.00 & 0.00 & 0.00 & 0.00 & 0.00 \\
\hline 0.00 & 0.00 & 0.00 & 0.00 & 0.00 & 0.00 \\
\hline 0.00 & 0.00 & 0.00 & 0.00 & 0.00 & 0.00 \\
\hline 0.00 & 0.00 & 0.00 & 0.00 & 0.00 & 0.00 \\
\hline 0.00 & 0.00 & 0.00 & 0.00 & 0.00 & 3.10 \\
\hline 0.00 & 0.00 & 0.00 & 0.00 & 0.00 & 0.934 \\
\hline 0.00 & 0.00 & 0.00 & 0.00 & 0.00 & 0.488 \\
\hline 0.00 & 0.00 & 0.00 & 0.00 & 0.00 & 25.6 \\
\hline 0.00 & 0.00 & 0.00 & 0.00 & 0.00 & 30.2 \\
\hline 0.00 & 0.00 & 0.00 & 0.00 & 0.00 & 0.00 \\
\hline 0.00 & 0.00 & 0.00 & 0.00 & 0.00 & 567 \\
\hline 0.00 & 0.00 & 0.00 & 0.00 & 0.00 & 0.00 \\
\hline 0.00 & 0.00 & 0.00 & 0.00 & 0.00 & 0.00 \\
\hline 0.00 & 0.00 & 0.00 & 0.00 & 0.00 & 0.00 \\
\hline 0.00 & 0.00 & 0.00 & 0.00 & 0.00 & 0.00 \\
\hline 0.00 & 0.00 & 0.00 & 0.00 & 0.00 & 0.00 \\
\hline 0.00 & 0.00 & 0.00 & 0.00 & 0.00 & 0.00 \\
\hline 0.00 & 0.00 & 0.00 & 0.00 & 0.00 & 0.00 \\
\hline 0.00 & 0.00 & 0.00 & 0.00 & 0.00 & 0.00 \\
\hline 0.00 & 0.00 & 0.00 & 0.00 & 0.00 & 0.00 \\
\hline 0.00 & 0.00 & 0.00 & 0.00 & 0.00 & 0.00 \\
\hline 0.00 & 0.00 & 0.00 & 0.00 & 0.00 & 567 \\
\hline 0.00 & 0.00 & 0.00 & 0.00 & 0.00 & 0.00 \\
\hline 0.00 & 0.00 & 0.00 & 0.00 & 0.00 & -0.00022 \\
\hline 0.00 & 0.00 & 0.00 & 0.00 & 0.00 & 0.00 \\
\hline 0.00 & 0.00 & 0.00 & 0.00 & 0.00 & 0.00 \\
\hline 0.00 & 0.00 & 0.00 & 0.00 & 0.00 & 0.00 \\
\hline 0.00 & 0.00 & 0.00 & 0.00 & 0.00 & 0.00 \\
\hline 0.00 & 0.00 & 0.00 & 0.00 & 0.00 & 0.00 \\
\hline 0.00 & 0.00 & 0.00 & 0.00 & 0.00 & 0.00 \\
\hline 0.00 & 0.00 & 0.00 & 0.00 & 0.00 & 0.00 \\
\hline 0.00 & 0.00 & 0.00 & 0.00 & 0.00 & 0.00 \\
\hline 0.00 & 0.00 & 0.00 & 0.00 & 0.00 & 0.00 \\
\hline 0.00 & 0.00 & 0.00 & 0.00 & 0.00 & 0.00 \\
\hline 0.00 & 0.00 & 0.00 & 0.00 & 0.00 & -0.00022 \\
\hline
\end{tabular}


Table 4.14. Average annual 25-year water budget in acre-feet for base-case scenario with wet climatic conditions, Los Angeles Coastal Plain Ground [WRD, Water Replenishment District of Southern California]

\begin{tabular}{|c|c|c|c|c|c|c|c|c|}
\hline $\begin{array}{c}\text { Chronostratigraphic } \\
\text { unit name }\end{array}$ & $\begin{array}{l}\text { Model } \\
\text { layer }\end{array}$ & $\begin{array}{l}\text { Los } \\
\text { Angeles } \\
\text { Forebay }\end{array}$ & $\begin{array}{c}\text { WRD } \\
\text { Central Basin }\end{array}$ & $\begin{array}{l}\text { Orange } \\
\text { County }\end{array}$ & $\begin{array}{l}\text { West } \\
\text { Coast }\end{array}$ & $\begin{array}{l}\text { Santa } \\
\text { Monica }\end{array}$ & Hollywood & $\begin{array}{l}\text { WRD Los } \\
\text { Angeles } \\
\text { Forebay }\end{array}$ \\
\hline & & & & & & & \multicolumn{2}{|c|}{ Underflow from San Fernando Basin } \\
\hline Dominguez & 2 & 0.00 & 0.00 & 0.00 & 0.00 & 0.00 & 0.00 & 0.00 \\
\hline Mesa & 3 & 5,250 & 0.00 & 0.00 & 0.00 & 0.00 & 0.00 & 0.00 \\
\hline Pacific A & 4 & 0.00 & 0.00 & 0.00 & 0.00 & 0.00 & 0.00 & 0.00 \\
\hline Pacific & 5 & 0.00 & 0.00 & 0.00 & 0.00 & 0.00 & 0.00 & 0.00 \\
\hline Harbor & 6 & 0.00 & 0.00 & 0.00 & 0.00 & 0.00 & 0.00 & 0.00 \\
\hline Bent Spring & 7 & 0.00 & 0.00 & 0.00 & 0.00 & 0.00 & 0.00 & 0.00 \\
\hline Upper Wilmington A & 8 & 0.00 & 0.00 & 0.00 & 0.00 & 0.00 & 0.00 & 0.00 \\
\hline Upper Wilmington B & 9 & 0.00 & 0.00 & 0.00 & 0.00 & 0.00 & 0.00 & 0.00 \\
\hline Lower Wilmington & 10 & 0.00 & 0.00 & 0.00 & 0.00 & 0.00 & 0.00 & 0.00 \\
\hline Long Beach A & 11 & 0.00 & 0.00 & 0.00 & 0.00 & 0.00 & 0.00 & 0.00 \\
\hline Long Beach B & 12 & 0.00 & 0.00 & 0.00 & 0.00 & 0.00 & 0.00 & 0.00 \\
\hline Long Beach C & 13 & 0.00 & 0.00 & 0.00 & 0.00 & 0.00 & 0.00 & 0.00 \\
\hline \multirow[t]{2}{*}{ Total } & & 5,250 & 0.00 & 0.00 & 0.00 & 0.00 & 0.00 & 0.00 \\
\hline & & & & & & & & Drains \\
\hline Dominguez & 2 & 0.00 & $-1,170$ & -95.0 & -18.9 & -342 & 0.00 & 0.00 \\
\hline Mesa & 3 & 0.00 & -169 & 0.00 & 0.00 & $-1,270$ & 0.00 & 0.00 \\
\hline Pacific A & 4 & 0.00 & 0.00 & 0.00 & 0.00 & 0.00 & 0.00 & 0.00 \\
\hline Pacific & 5 & 0.00 & 0.00 & 0.00 & 0.00 & -240 & 0.00 & 0.00 \\
\hline Harbor & 6 & 0.00 & 0.00 & 0.00 & 0.00 & 0.00 & 0.00 & 0.00 \\
\hline Bent Spring & 7 & 0.00 & 0.00 & 0.00 & 0.00 & $-1,980$ & 0.00 & 0.00 \\
\hline Upper Wilmington A & 8 & 0.00 & 0.00 & 0.00 & 0.00 & 0.00 & 0.00 & 0.00 \\
\hline Upper Wilmington B & 9 & 0.00 & 0.00 & 0.00 & 0.00 & 0.00 & 0.00 & 0.00 \\
\hline Lower Wilmington & 10 & 0.00 & 0.00 & 0.00 & 0.00 & 0.00 & 0.00 & 0.00 \\
\hline Long Beach A & 11 & 0.00 & -743 & 0.00 & 0.00 & 0.00 & 0.00 & 0.00 \\
\hline Long Beach B & 12 & 0.00 & 0.00 & 0.00 & 0.00 & 0.00 & 0.00 & 0.00 \\
\hline Long Beach C & 13 & 0.00 & 0.00 & 0.00 & 0.00 & 0.00 & 0.00 & 0.00 \\
\hline Total & & 0.00 & $-2,080$ & -95 & -18.9 & $-3,830$ & 0.00 & 0.00 \\
\hline \multirow[t]{2}{*}{ Total net flow } & & 577 & 3,600 & -341 & 5,510 & $-2,490$ & $-1,560$ & -652 \\
\hline & & & & & & & \multicolumn{2}{|r|}{ Change in storage } \\
\hline Dominguez & 2 & -608 & 706 & 92.1 & 213 & $-1,100$ & -49.5 & $-1,330$ \\
\hline Mesa & 3 & 233 & 2,530 & -9.49 & 4140 & -664 & 262 & 171 \\
\hline Pacific A & 4 & 30.1 & 512 & -4.80 & 1.24 & 0.00 & 0.00 & 3.20 \\
\hline Pacific & 5 & 28.1 & -298 & -23.9 & 242 & -767 & -6.98 & 156 \\
\hline Harbor & 6 & 49.8 & 6.64 & -15.1 & 205 & -0.0106 & 0.00 & 189 \\
\hline Bent Spring & 7 & 30.2 & 12.3 & -16.9 & 460 & -14.2 & -477 & 5.37 \\
\hline Upper Wilmington A & 8 & 545 & 39.6 & -277 & 51.2 & 100 & $-1,290$ & 88.0 \\
\hline Upper Wilmington B & 9 & 5.51 & 60.6 & -5.89 & 37.1 & -22.9 & -9.20 & 10.8 \\
\hline Lower Wilmington & 10 & 74.5 & 36.4 & -1.60 & 87.8 & 8.75 & 6.77 & 15.7 \\
\hline Long Beach A & 11 & -2.40 & 36.9 & -9.29 & 36.0 & 3.57 & 0.0106 & -0.799 \\
\hline Long Beach B & 12 & 0.195 & -3.81 & -32.7 & 25.8 & 7.49 & 0.0575 & 4.21 \\
\hline Long Beach C & 13 & 191 & -34.6 & -36.4 & 9.17 & -46.9 & 1.74 & 31.8 \\
\hline Total & & 577 & 3,600 & -341 & 5,500 & $-2,490$ & $-1,560$ & -653 \\
\hline
\end{tabular}


water-flow Model._Continued

\begin{tabular}{|c|c|c|c|c|c|}
\hline $\begin{array}{c}\text { Montebello } \\
\text { Forebay }\end{array}$ & Whitter & Central Basin & $\begin{array}{l}\text { North Orange } \\
\text { County }\end{array}$ & $\begin{array}{l}\text { South Orange } \\
\text { County }\end{array}$ & Total \\
\hline 0.00 & 0.00 & 0.00 & 0.00 & 0.00 & 0.00 \\
\hline 0.00 & 0.00 & 0.00 & 0.00 & 0.00 & 5,250 \\
\hline 0.00 & 0.00 & 0.00 & 0.00 & 0.00 & 0.00 \\
\hline 0.00 & 0.00 & 0.00 & 0.00 & 0.00 & 0.00 \\
\hline 0.00 & 0.00 & 0.00 & 0.00 & 0.00 & 0.00 \\
\hline 0.00 & 0.00 & 0.00 & 0.00 & 0.00 & 0.00 \\
\hline 0.00 & 0.00 & 0.00 & 0.00 & 0.00 & 0.00 \\
\hline 0.00 & 0.00 & 0.00 & 0.00 & 0.00 & 0.00 \\
\hline 0.00 & 0.00 & 0.00 & 0.00 & 0.00 & 0.00 \\
\hline 0.00 & 0.00 & 0.00 & 0.00 & 0.00 & 0.00 \\
\hline 0.00 & 0.00 & 0.00 & 0.00 & 0.00 & 0.00 \\
\hline 0.00 & 0.00 & 0.00 & 0.00 & 0.00 & 0.00 \\
\hline 0.00 & 0.00 & 0.00 & 0.00 & 0.00 & 5,250 \\
\hline-142 & 0.00 & -595 & -30.3 & -1.98 & $-2,390$ \\
\hline 0.00 & 0.00 & 0.00 & 0.00 & -8.90 & $-1,450$ \\
\hline 0.00 & 0.00 & 0.00 & 0.00 & 0.00 & 0.00 \\
\hline-480 & -59.6 & 0.00 & -387 & 0.00 & $-1,170$ \\
\hline 0.00 & 0.00 & 0.00 & 0.00 & 0.00 & 0.00 \\
\hline 0.00 & 0.00 & 0.00 & 0.00 & 0.00 & $-1,980$ \\
\hline 0.00 & 0.00 & 0.00 & -494 & 0.00 & -494 \\
\hline 0.00 & 0.00 & 0.00 & 0.00 & 0.00 & 0.00 \\
\hline 0.00 & 0.00 & 0.00 & -241 & 0.00 & -241 \\
\hline 0.00 & 0.00 & 0.00 & -22.8 & 0.00 & -766 \\
\hline 0.00 & 0.00 & 0.00 & 0.00 & 0.00 & 0.00 \\
\hline 0.00 & 0.00 & 0.00 & 0.00 & 0.00 & 0.00 \\
\hline-623 & -59.6 & -595 & $-1,180$ & -10.9 & $-8,490$ \\
\hline 775 & -6.28 & 642 & 13.4 & -397 & 5,670 \\
\hline-94.6 & -51.5 & -301 & 47.0 & -249 & $-2,720$ \\
\hline-67.9 & -80.7 & 828 & 0.00 & -99.5 & 7,240 \\
\hline 7.61 & 6.39 & 9.53 & 0.00 & 0.00 & 565 \\
\hline-5.23 & -116 & 14.3 & -89.0 & -32.0 & -897 \\
\hline-3.31 & -9.05 & 1.09 & 0.00 & -3.91 & 420 \\
\hline 0.191 & 0.00 & 30.7 & 0.00 & -0.602 & 30.7 \\
\hline 300 & 29.7 & 10.3 & -250 & -1.91 & -650 \\
\hline 0.547 & 1.92 & 29.6 & -3.76 & -1.69 & 103 \\
\hline 0.598 & 3.55 & 8.10 & 13.2 & -0.507 & 253 \\
\hline-2.39 & 23.9 & 1.60 & 220 & -1.81 & 305 \\
\hline 1.15 & 6.17 & 4.68 & 17.9 & -3.14 & 28.0 \\
\hline 639 & 179 & 5.03 & 58.5 & -4.68 & 992 \\
\hline 776 & -6.42 & 642 & 13.7 & -398 & 5,660 \\
\hline
\end{tabular}


Table 4.15. Average annual 25-year water budget in acre-feet for base-case scenario with dry climatic conditions, Los Angeles Coastal Plain Ground [WRD, Water Replenishment District of Southern California]

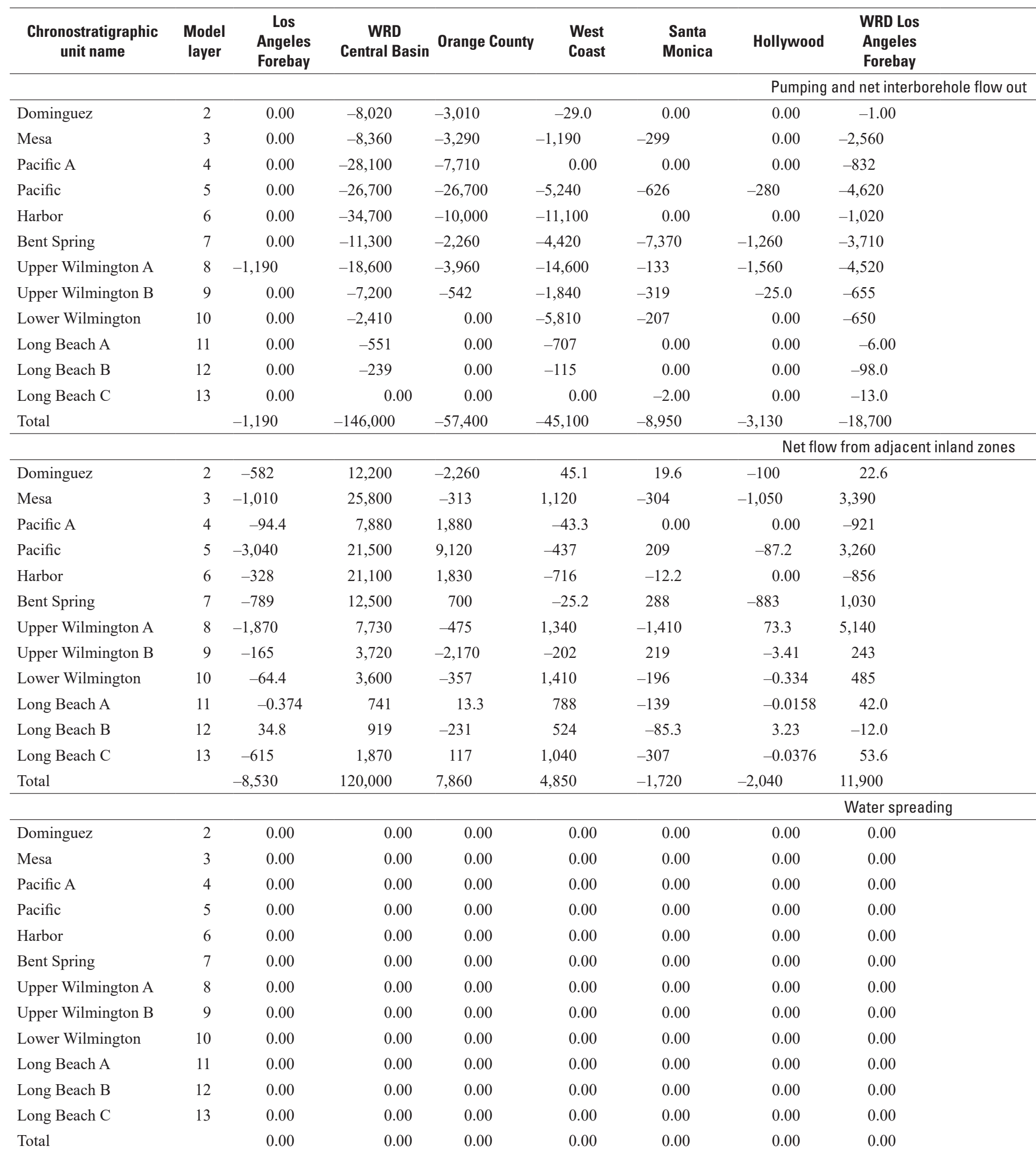


Nater-flow Model.

\begin{tabular}{|c|c|c|c|c|c|}
\hline $\begin{array}{c}\text { Montebello } \\
\text { Forebay }\end{array}$ & Whitter & Central Basin & $\begin{array}{l}\text { North Orange } \\
\text { County }\end{array}$ & $\begin{array}{l}\text { South Orange } \\
\text { County }\end{array}$ & Total \\
\hline-397 & 0.00 & 0.00 & 0.00 & -36.8 & $-11,500$ \\
\hline$-5,560$ & -22.0 & 0.00 & 0.00 & -205 & $-21,500$ \\
\hline$-2,870$ & 0.00 & 0.00 & 0.00 & 0.00 & $-39,500$ \\
\hline$-17,300$ & -14.2 & -1.99 & 0.00 & $-3,870$ & $-85,300$ \\
\hline$-8,050$ & -5.83 & 0.00 & 0.00 & $-1,120$ & $-66,000$ \\
\hline$-2,650$ & 0.00 & -16.3 & 0.00 & -96.3 & $-33,100$ \\
\hline$-4,590$ & 0.00 & 0.00 & 0.00 & -322 & $-49,500$ \\
\hline-392 & -0.777 & 0.00 & 0.00 & 0.00 & $-11,000$ \\
\hline-446 & -163 & 0.00 & -135 & 0.00 & $-9,820$ \\
\hline-230 & 0.00 & 0.00 & 0.00 & 0.00 & $-1,490$ \\
\hline-193 & 0.00 & 0.00 & 0.00 & 0.00 & -645 \\
\hline$-4,080$ & 0.00 & 0.00 & 0.00 & 0.00 & $-4,090$ \\
\hline$-46,700$ & -206 & -18.3 & -135 & $-5,660$ & $-333,000$ \\
\hline$-11,800$ & -78.3 & 92.2 & 6.05 & 2,460 & $-2.05 \mathrm{E}-11$ \\
\hline$-28,700$ & -715 & 799 & 0.00 & 928 & $2.80 \mathrm{E}-11$ \\
\hline$-7,570$ & -289 & -845 & 0.00 & 0.00 & $-2.59 \mathrm{E}-11$ \\
\hline$-24,900$ & -448 & -591 & -660 & $-3,890$ & $4.23 \mathrm{E}-11$ \\
\hline$-18,100$ & -97.8 & -257 & 0.00 & $-2,590$ & $-5.37 \mathrm{E}-11$ \\
\hline$-13,700$ & 0.00 & 827 & 0.00 & -34.6 & $1.72 \mathrm{E}-11$ \\
\hline$-8,130$ & -292 & -259 & -719 & $-1,120$ & $7.05 \mathrm{E}-12$ \\
\hline$-1,440$ & 261 & -195 & -322 & 61.6 & $5.68 \mathrm{E}-14$ \\
\hline$-4,120$ & 60.8 & -238 & -456 & -125 & $-1.49 \mathrm{E}-11$ \\
\hline 258 & -65.0 & -1.36 & $-1,140$ & -502 & $1.25 \mathrm{E}-12$ \\
\hline-311 & -194 & 4.22 & -167 & -486 & $-4.83 \mathrm{E}-12$ \\
\hline$-1,050$ & -941 & -36.8 & -94.0 & -42.0 & $-1.05 \mathrm{E}-11$ \\
\hline$-120,000$ & $-2,800$ & -701 & $-3,550$ & $-5,340$ & $-6.55 \mathrm{E}-11$ \\
\hline 80,100 & 0.00 & 0.00 & 0.00 & 0.00 & 80,100 \\
\hline 40,700 & 0.00 & 0.00 & 0.00 & 0.00 & 40,700 \\
\hline 0.00 & 0.00 & 0.00 & 0.00 & 0.00 & 0.00 \\
\hline 1,850 & 0.00 & 0.00 & 0.00 & 0.00 & 1,850 \\
\hline 0.00 & 0.00 & 0.00 & 0.00 & 0.00 & 0.00 \\
\hline 0.00 & 0.00 & 0.00 & 0.00 & 0.00 & 0.00 \\
\hline 0.00 & 0.00 & 0.00 & 0.00 & 0.00 & 0.00 \\
\hline 0.00 & 0.00 & 0.00 & 0.00 & 0.00 & 0.00 \\
\hline 0.00 & 0.00 & 0.00 & 0.00 & 0.00 & 0.00 \\
\hline 0.00 & 0.00 & 0.00 & 0.00 & 0.00 & 0.00 \\
\hline 0.00 & 0.00 & 0.00 & 0.00 & 0.00 & 0.00 \\
\hline 0.00 & 0.00 & 0.00 & 0.00 & 0.00 & 0.00 \\
\hline 123,000 & 0.00 & 0.00 & 0.00 & 0.00 & 123,000 \\
\hline
\end{tabular}


Table 4.15. Average annual 25-year water budget in acre-feet for base-case scenario with dry climatic conditions, Los Angeles Coastal Plain Ground [WRD, Water Replenishment District of Southern California]

\begin{tabular}{|c|c|c|c|c|c|c|c|c|}
\hline $\begin{array}{l}\text { Chronostratigraphic } \\
\text { unit name }\end{array}$ & $\begin{array}{l}\text { Model } \\
\text { layer }\end{array}$ & $\begin{array}{l}\text { Los } \\
\text { Angeles } \\
\text { Forebay }\end{array}$ & $\begin{array}{c}\text { WRD } \\
\text { Central Basin }\end{array}$ & Orange County & $\begin{array}{l}\text { West } \\
\text { Coast }\end{array}$ & $\begin{array}{l}\text { Santa } \\
\text { Monica }\end{array}$ & Hollywood & $\begin{array}{l}\text { WRD Los } \\
\text { Angeles } \\
\text { Forebay }\end{array}$ \\
\hline & & & & & & & \multicolumn{2}{|c|}{ Injection and net interborehole flow in } \\
\hline Dominguez & 2 & 0.00 & 4.13 & 0.00252 & 35.5 & 0.00 & 0.00 & 0.000261 \\
\hline Mesa & 3 & 0.00 & 742 & 238 & 1,690 & 0.000164 & 0.00 & 0.00 \\
\hline Pacific A & 4 & 0.00 & 2,190 & 2,480 & 0.00 & 0.00 & 0.00 & 29.0 \\
\hline Pacific & 5 & 0.00 & 7,390 & 2,030 & 8,060 & 0.0247 & 0.00 & 1,170 \\
\hline Harbor & 6 & 0.00 & 2,000 & 81.5 & 5,250 & 0.00 & 0.00 & 1,370 \\
\hline Bent Spring & 7 & 0.00 & 979 & 0.00 & 9,500 & 241 & 44.1 & 724 \\
\hline Upper Wilmington A & 8 & 1,190 & 980 & 0.844 & 1,190 & 0.00 & 14.1 & 50.4 \\
\hline Upper Wilmington B & 9 & 0.00 & 444 & 4.44 & 95.1 & 0.610 & 0.00 & 14.8 \\
\hline Lower Wilmington & 10 & 0.00 & 63.0 & 0.00 & 93.0 & 0.00 & 0.00 & 32.3 \\
\hline Long Beach A & 11 & 0.00 & 2.82 & 0.00 & 0.00 & 0.00 & 0.00 & 0.00126 \\
\hline Long Beach B & 12 & 0.00 & 0.380 & 0.00 & 0.00 & 0.00 & 0.00 & 0.0128 \\
\hline Long Beach C & 13 & 0.00 & 0.00 & 0.00 & 0.00 & 0.112 & 0.00 & 0.00 \\
\hline \multirow[t]{2}{*}{ Total } & & 1,190 & 14,800 & 4,830 & 25,900 & 241 & 58.2 & 3,390 \\
\hline & & & & & & & & Areal recharge \\
\hline Dominguez & 2 & 1,130 & 7,810 & 2,740 & 1,070 & 1,470 & 1,760 & 1,340 \\
\hline Mesa & 3 & 1,650 & 3,350 & 19.9 & 8,840 & 6,290 & 1,010 & 38.1 \\
\hline Pacific A & 4 & 0.00 & 0.00 & 0.00 & 0.00 & 0.00 & 0.00 & 0.00 \\
\hline Pacific & 5 & 0.00 & 294 & 34.2 & 709 & 925 & 0.0392 & 0.00 \\
\hline Harbor & 6 & 189 & 2.99 & 0.00 & 240 & 0.00 & 0.00 & 177 \\
\hline Bent Spring & 7 & 14.7 & 0.00 & 0.00 & 815 & 6.40 & 0.00 & 0.00 \\
\hline Upper Wilmington A & 8 & 0.00 & 25.2 & 7.05 & 139 & 64.2 & 0.00 & 31.7 \\
\hline Upper Wilmington B & 9 & 0.00 & 0.00 & 0.00 & 16.6 & 8.94 & 0.00 & 0.00 \\
\hline Lower Wilmington & 10 & 0.00 & 19.3 & 0.00 & 0.00 & 0.00 & 0.00 & 0.00 \\
\hline Long Beach A & 11 & 0.00 & 4.99 & 0.00 & 0.00 & 0.00 & 0.00 & 0.00 \\
\hline Long Beach B & 12 & 0.00 & 0.00 & 0.00 & 0.00 & 0.00 & 0.00 & 0.00 \\
\hline Long Beach C & 13 & 211 & 94.8 & 0.00 & 93.8 & 3.08 & 0.00 & 126 \\
\hline \multirow[t]{2}{*}{ Total } & & 3,200 & 11.600 & 2.800 & 11,900 & 8,760 & 2,770 & 1,710 \\
\hline & & & & & & & \multicolumn{2}{|c|}{ Flow from Santa Monica Bay } \\
\hline Dominguez & 2 & 0.00 & 0.00 & 0.00 & 0.00 & 0.00114 & 0.00 & 0.00 \\
\hline Mesa & 3 & 0.00 & 0.00 & 0.00 & -48.8 & -220 & 0.00 & 0.00 \\
\hline Pacific A & 4 & 0.00 & 0.00 & 0.00 & 0.00 & 0.00 & 0.00 & 0.00 \\
\hline Pacific & 5 & 0.00 & 0.00 & 0.00 & -15.8 & -21.7 & 0.00 & 0.00 \\
\hline Harbor & 6 & 0.00 & 0.00 & 0.00 & -17.4 & 0.00 & 0.00 & 0.00 \\
\hline Bent Spring & 7 & 0.00 & 0.00 & 0.00 & 95.3 & 66.9 & 0.00 & 0.00 \\
\hline Upper Wilmington A & 8 & 0.00 & 0.00 & 0.00 & -16.3 & 194 & 0.00 & 0.00 \\
\hline Upper Wilmington B & 9 & 0.00 & 0.00 & 0.00 & -51.7 & -4.75 & 0.00 & 0.00 \\
\hline Lower Wilmington & 10 & 0.00 & 0.00 & 0.00 & 145 & -30.4 & 0.00 & 0.00 \\
\hline Long Beach A & 11 & 0.00 & 0.00 & 0.00 & -3.36 & -16.1 & 0.00 & 0.00 \\
\hline Long Beach B & 12 & 0.00 & 0.00 & 0.00 & 1.62 & -9.02 & 0.00 & 0.00 \\
\hline Long Beach C & 13 & 0.00 & 0.00 & 0.00 & 4.90 & 12 & 0.00 & 0.00 \\
\hline Total & & 0.00 & 0.00 & 0.00 & 93.8 & -28.6 & 0.00 & 0.00 \\
\hline
\end{tabular}


vater-flow Model._Continued

\begin{tabular}{|c|c|c|c|c|c|}
\hline $\begin{array}{c}\text { Montebello } \\
\text { Forebay }\end{array}$ & Whitter & Central Basin & $\begin{array}{c}\text { North Orange } \\
\text { County }\end{array}$ & $\begin{array}{l}\text { South Orange } \\
\text { County }\end{array}$ & Total \\
\hline $8.23 \mathrm{E}-05$ & 0.00 & 0.00 & 0.00 & 0.00 & 39.6 \\
\hline 113 & 0.00 & 1.14 & 0.00 & 1,130 & 3,910 \\
\hline 686 & 0.00 & 0.00 & 0.00 & 0.00 & 5,380 \\
\hline 226 & 0.00 & 0.558 & 0.00 & 1,190 & 20,100 \\
\hline 656 & 0.00126 & 12.7 & 0.00 & 1,640 & 11,000 \\
\hline 35.9 & 0.00 & 0.764 & 0.00 & 1.34 & 11,500 \\
\hline 250 & 10.7 & 0.00 & 15.6 & 69.1 & 3,770 \\
\hline 3.45 & 0.849 & 0.00 & 17.0 & 0.00 & 580 \\
\hline 27.9 & 0.747 & 0.00 & 0.00 & 0.00 & 217 \\
\hline 0.014 & 62.2 & 0.00 & 102 & 0.00 & 167 \\
\hline 21.0 & 73.5 & 0.00 & 0.00 & 0.00 & 94.9 \\
\hline 5,000 & 0.00 & 0.00 & 0.00 & 0.00 & 5,000 \\
\hline 7,020 & 148 & 15.1 & 135 & 4,040 & 61,800 \\
\hline 1,960 & 258 & 431 & 23.5 & 410 & 20,400 \\
\hline 969 & 336 & 778 & 0.00 & 198 & 23,500 \\
\hline 0.00 & 0.00 & 0.00 & 0.00 & 0.00 & 0.00 \\
\hline 198 & 428 & 178 & 696 & 0.000584 & 3,460 \\
\hline 1.35 & 0.00 & 0.00 & 0.00 & 0.00 & 610 \\
\hline 0.00 & 0.00 & 0.00 & 0.00 & 0.00 & 837 \\
\hline 172 & 39.5 & 0.00 & 176 & 0.00 & 654 \\
\hline 0.00 & 0.00 & 0.00 & 0.00 & 0.00 & 25.5 \\
\hline 0.00 & 21.4 & 0.00 & 60.5 & 0.00 & 101 \\
\hline 24.3 & 1.09 & 0.00 & 56.4 & 0.00 & 86.8 \\
\hline 6.05 & 0.00 & 0.00 & 0.00 & 0.00 & 6.05 \\
\hline 1,220 & 1,080 & 55.3 & 116 & 0.00 & 3,000 \\
\hline 4,550 & 2,160 & 1,440 & 1,130 & 608 & 52,700 \\
\hline 0.00 & 0.00 & 0.00 & 0.00 & 0.00 & 0.00114 \\
\hline 0.00 & 0.00 & 0.00 & 0.00 & 0.00 & -268 \\
\hline 0.00 & 0.00 & 0.00 & 0.00 & 0.00 & 0.00 \\
\hline 0.00 & 0.00 & 0.00 & 0.00 & 0.00 & -37.6 \\
\hline 0.00 & 0.00 & 0.00 & 0.00 & 0.00 & -17.4 \\
\hline 0.00 & 0.00 & 0.00 & 0.00 & 0.00 & 162 \\
\hline 0.00 & 0.00 & 0.00 & 0.00 & 0.00 & 178 \\
\hline 0.00 & 0.00 & 0.00 & 0.00 & 0.00 & -56.4 \\
\hline 0.00 & 0.00 & 0.00 & 0.00 & 0.00 & 115 \\
\hline 0.00 & 0.00 & 0.00 & 0.00 & 0.00 & -19.5 \\
\hline 0.00 & 0.00 & 0.00 & 0.00 & 0.00 & -7.41 \\
\hline 0.00 & 0.00 & 0.00 & 0.00 & 0.00 & 16.8 \\
\hline 0.00 & 0.00 & 0.00 & 0.00 & 0.00 & 65.2 \\
\hline
\end{tabular}


Table 4.15. Average annual 25-year water budget in acre-feet for base-case scenario with dry climatic conditions, Los Angeles Coastal Plain Ground [WRD, Water Replenishment District of Southern California]

\begin{tabular}{|c|c|c|c|c|c|c|c|c|}
\hline $\begin{array}{c}\text { Chronostratigraphic } \\
\text { unit name }\end{array}$ & $\begin{array}{l}\text { Model } \\
\text { layer }\end{array}$ & $\begin{array}{c}\text { Los } \\
\text { Angeles } \\
\text { Forebay }\end{array}$ & $\begin{array}{c}\text { WRD } \\
\text { Central Basin }\end{array}$ & Orange County & $\begin{array}{l}\text { West } \\
\text { Coast }\end{array}$ & $\begin{array}{c}\text { Santa } \\
\text { Monica }\end{array}$ & Hollywood & $\begin{array}{l}\text { WRD Los } \\
\text { Angeles } \\
\text { Forebay }\end{array}$ \\
\hline & & & & & & & \multicolumn{2}{|c|}{ Flow from San Pedro Bay } \\
\hline Dominguez & 2 & 0.00 & 0.00 & 0.00 & 200 & 0.00 & 0.00 & 0.00 \\
\hline Mesa & 3 & 0.00 & 0.00 & 0.00 & 7.92 & 0.00 & 0.00 & 0.00 \\
\hline Pacific A & 4 & 0.00 & 0.00 & 0.00 & 0.00 & 0.00 & 0.00 & 0.00 \\
\hline Pacific & 5 & 0.00 & 0.00 & 0.00 & 772 & 0.00 & 0.00 & 0.00 \\
\hline Harbor & 6 & 0.00 & 0.00 & 0.00 & 823 & 0.00 & 0.00 & 0.00 \\
\hline Bent Spring & 7 & 0.00 & 0.00 & 0.00 & 293 & 0.00 & 0.00 & 0.00 \\
\hline Upper Wilmington A & 8 & 0.00 & 0.00 & 0.00 & 0.00 & 0.00 & 0.00 & 0.00 \\
\hline Upper Wilmington B & 9 & 0.00 & 0.00 & 0.00 & 150 & 0.00 & 0.00 & 0.00 \\
\hline Lower Wilmington & 10 & 0.00 & 0.00 & 0.00 & 1,650 & 0.00 & 0.00 & 0.00 \\
\hline Long Beach A & 11 & 0.00 & 0.00 & 0.00 & 316 & 0.00 & 0.00 & 0.00 \\
\hline Long Beach B & 12 & 0.00 & 0.00 & 0.00 & 319 & 0.00 & 0.00 & 0.00 \\
\hline Long Beach C & 13 & 0.00 & 0.00 & 0.00 & 80.9 & 0.00 & 0.00 & 0.00 \\
\hline \multirow[t]{2}{*}{ Total } & & 0.00 & 0.00 & 0.00 & 4,610 & 0.00 & 0.00 & 0.00 \\
\hline & & & & & & & \multicolumn{2}{|c|}{ Underflow from Orange County } \\
\hline Dominguez & 2 & 0.00 & 0.00 & 4,910 & 0.00 & 0.00 & 0.00 & 0.00 \\
\hline Mesa & 3 & 0.00 & 0.00 & 1,380 & 0.00 & 0.00 & 0.00 & 0.00 \\
\hline Pacific A & 4 & 0.00 & 0.00 & 3,360 & 0.00 & 0.00 & 0.00 & 0.00 \\
\hline Pacific & 5 & 0.00 & 0.00 & 14,000 & 0.00 & 0.00 & 0.00 & 0.00 \\
\hline Harbor & 6 & 0.00 & 0.00 & 6,970 & 0.00 & 0.00 & 0.00 & 0.00 \\
\hline Bent Spring & 7 & 0.00 & 0.00 & 970 & 0.00 & 0.00 & 0.00 & 0.00 \\
\hline Upper Wilmington A & 8 & 0.00 & 0.00 & 7,000 & 0.00 & 0.00 & 0.00 & 0.00 \\
\hline Upper Wilmington B & 9 & 0.00 & 0.00 & 2,710 & 0.00 & 0.00 & 0.00 & 0.00 \\
\hline Lower Wilmington & 10 & 0.00 & 0.00 & 179 & 0.00 & 0.00 & 0.00 & 0.00 \\
\hline Long Beach A & 11 & 0.00 & 0.00 & 56.4 & 0.00 & 0.00 & 0.00 & 0.00 \\
\hline Long Beach B & 12 & 0.00 & 0.00 & 91.5 & 0.00 & 0.00 & 0.00 & 0.00 \\
\hline Long Beach C & 13 & 0.00 & 0.00 & 35.2 & 0.00 & 0.00 & 0.00 & 0.00 \\
\hline \multirow[t]{2}{*}{ Total } & & 0.00 & 0.00 & 41,700 & 0.00 & 0.00 & 0.00 & 0.00 \\
\hline & & & & & & & \multicolumn{2}{|c|}{ Underflow from San Gabriel Basin } \\
\hline Dominguez & 2 & 0.00 & 0.00 & 0.00 & 0.00 & 0.00 & 0.00 & 0.00 \\
\hline Mesa & 3 & 0.00 & 0.00 & 0.00 & 0.00 & 0.00 & 0.00 & 0.00 \\
\hline Pacific A & 4 & 0.00 & 0.00 & 0.00 & 0.00 & 0.00 & 0.00 & 0.00 \\
\hline Pacific & 5 & 0.00 & 0.00 & 0.00 & 0.00 & 0.00 & 0.00 & 0.00 \\
\hline Harbor & 6 & 0.00 & 0.00 & 0.00 & 0.00 & 0.00 & 0.00 & 0.00 \\
\hline Bent Spring & 7 & 0.00 & 0.00 & 0.00 & 0.00 & 0.00 & 0.00 & 0.00 \\
\hline Upper Wilmington A & 8 & 0.00 & 0.00 & 0.00 & 0.00 & 0.00 & 0.00 & 0.00 \\
\hline Upper Wilmington B & 9 & 0.00 & 0.00 & 0.00 & 0.00 & 0.00 & 0.00 & 0.00 \\
\hline Lower Wilmington & 10 & 0.00 & 0.00 & 0.00 & 0.00 & 0.00 & 0.00 & 0.00 \\
\hline Long Beach A & 11 & 0.00 & 0.00 & 0.00 & 0.00 & 0.00 & 0.00 & 0.00 \\
\hline Long Beach B & 12 & 0.00 & 0.00 & 0.00 & 0.00 & 0.00 & 0.00 & 0.00 \\
\hline Long Beach C & 13 & 0.00 & 0.00 & 0.00 & 0.00 & 0.00 & 0.00 & 0.00 \\
\hline Total & & 0.00 & 0.00 & 0.00 & 0.00 & 0.00 & 0.00 & 0.00 \\
\hline
\end{tabular}


Nater-flow Model.—Continued

\begin{tabular}{|c|c|c|c|c|c|}
\hline $\begin{array}{c}\text { Montebello } \\
\text { Forebay }\end{array}$ & Whitter & Central Basin & $\begin{array}{l}\text { North Orange } \\
\text { County }\end{array}$ & $\begin{array}{l}\text { South Orange } \\
\text { County }\end{array}$ & Total \\
\hline 0.00 & 0.00 & 0.00 & 0.00 & 26.4 & 227 \\
\hline 0.00 & 0.00 & 0.00 & 0.00 & 125 & 133 \\
\hline 0.00 & 0.00 & 0.00 & 0.00 & 0.00 & 0.00 \\
\hline 0.00 & 0.00 & 0.00 & 0.00 & 219 & 991 \\
\hline 0.00 & 0.00 & 0.00 & 0.00 & 690 & 1,510 \\
\hline 0.00 & 0.00 & 0.00 & 0.00 & 60.5 & 354 \\
\hline 0.00 & 0.00 & 0.00 & 0.00 & 0.00 & 0.00 \\
\hline 0.00 & 0.00 & 0.00 & 0.00 & 0.00 & 150 \\
\hline 0.00 & 0.00 & 0.00 & 0.00 & 47.3 & 1,690 \\
\hline 0.00 & 0.00 & 0.00 & 0.00 & -353 & -36.9 \\
\hline 0.00 & 0.00 & 0.00 & 0.00 & -102 & 217 \\
\hline 0.00 & 0.00 & 0.00 & 0.00 & -329 & -248 \\
\hline 0.00 & 0.00 & 0.00 & 0.00 & 384 & 4,990 \\
\hline 0.00 & 0.00 & 0.00 & 0.00 & 72.7 & 4,980 \\
\hline 0.00 & 0.00 & 0.00 & 0.00 & 399 & 1,780 \\
\hline 0.00 & 0.00 & 0.00 & 0.00 & 0.00 & 3,360 \\
\hline 0.00 & 0.00 & 0.00 & -46.8 & 1,180 & 15,200 \\
\hline 0.00 & 0.00 & 0.00 & 0.00 & 671 & 7,640 \\
\hline 0.00 & 0.00 & 0.00 & 0.00 & 77.9 & 1,050 \\
\hline 0.00 & 0.00 & 0.00 & 899 & 1,320 & 9,220 \\
\hline 0.00 & 0.00 & 0.00 & 284 & -51.6 & 2,950 \\
\hline 0.00 & 0.00 & 0.00 & 751 & 36.6 & 967 \\
\hline 0.00 & 0.00 & 0.00 & 1,180 & 882 & 2,110 \\
\hline 0.00 & 0.00 & 0.00 & 68.5 & 630 & 790 \\
\hline 0.00 & 0.00 & 0.00 & 79.2 & 389 & 503 \\
\hline 0.00 & 0.00 & 0.00 & 3,210 & 5,610 & 50,500 \\
\hline 0.00 & 0.00 & 0.00 & 0.00 & 0.00 & 0.00 \\
\hline 27,000 & 0.00 & 0.00 & 0.00 & 0.00 & 27,000 \\
\hline 0.00 & 0.00 & 0.00 & 0.00 & 0.00 & 0.00 \\
\hline 0.00 & 0.00 & 0.00 & 0.00 & 0.00 & 0.00 \\
\hline 0.00 & 0.00 & 0.00 & 0.00 & 0.00 & 0.00 \\
\hline 0.00 & 0.00 & 0.00 & 0.00 & 0.00 & 0.00 \\
\hline 0.00 & 0.00 & 0.00 & 0.00 & 0.00 & 0.00 \\
\hline 0.00 & 0.00 & 0.00 & 0.00 & 0.00 & 0.00 \\
\hline 0.00 & 0.00 & 0.00 & 0.00 & 0.00 & 0.00 \\
\hline 0.00 & 0.00 & 0.00 & 0.00 & 0.00 & 0.00 \\
\hline 0.00 & 0.00 & 0.00 & 0.00 & 0.00 & 0.00 \\
\hline 3,200 & 0.00 & 0.00 & 0.00 & 0.00 & 3,200 \\
\hline 30,200 & 0.00 & 0.00 & 0.00 & 0.00 & 30,200 \\
\hline
\end{tabular}


Table 4.15. Average annual 25-year water budget in acre-feet for base-case scenario with dry climatic conditions, Los Angeles Coastal Plain Ground [WRD, Water Replenishment District of Southern California]

\begin{tabular}{|c|c|c|c|c|c|c|c|c|}
\hline $\begin{array}{c}\text { Chronostratigraphic } \\
\text { unit name }\end{array}$ & $\begin{array}{l}\text { Model } \\
\text { layer }\end{array}$ & $\begin{array}{c}\text { Los } \\
\text { Angeles } \\
\text { Forebay }\end{array}$ & $\begin{array}{c}\text { WRD } \\
\text { Central Basin }\end{array}$ & Orange County & $\begin{array}{l}\text { West } \\
\text { Coast }\end{array}$ & $\begin{array}{c}\text { Santa } \\
\text { Monica }\end{array}$ & Hollywood & $\begin{array}{l}\text { WRD Los } \\
\text { Angeles } \\
\text { Forebay }\end{array}$ \\
\hline & & & & & & & \multicolumn{2}{|c|}{ Underflow from Palos Verdes Hills } \\
\hline Dominguez & 2 & 0.00 & 0.00 & 0.00 & 0.00 & 0.00 & 0.00 & 0.00 \\
\hline Mesa & 3 & 0.00 & 0.00 & 0.00 & 0.00 & 0.00 & 0.00 & 0.00 \\
\hline Pacific A & 4 & 0.00 & 0.00 & 0.00 & 0.00 & 0.00 & 0.00 & 0.00 \\
\hline Pacific & 5 & 0.00 & 0.00 & 0.00 & 0.00 & 0.00 & 0.00 & 0.00 \\
\hline Harbor & 6 & 0.00 & 0.00 & 0.00 & 0.00 & 0.00 & 0.00 & 0.00 \\
\hline Bent Spring & 7 & 0.00 & 0.00 & 0.00 & 0.00 & 0.00 & 0.00 & 0.00 \\
\hline Upper Wilmington A & 8 & 0.00 & 0.00 & 0.00 & 0.00 & 0.00 & 0.00 & 0.00 \\
\hline Upper Wilmington B & 9 & 0.00 & 0.00 & 0.00 & 0.00 & 0.00 & 0.00 & 0.00 \\
\hline Lower Wilmington & 10 & 0.00 & 0.00 & 0.00 & 3.15 & 0.00 & 0.00 & 0.00 \\
\hline Long Beach A & 11 & 0.00 & 0.00 & 0.00 & 0.947 & 0.00 & 0.00 & 0.00 \\
\hline Long Beach B & 12 & 0.00 & 0.00 & 0.00 & 0.494 & 0.00 & 0.00 & 0.00 \\
\hline Long Beach C & 13 & 0.00 & 0.00 & 0.00 & 25.8 & 0.00 & 0.00 & 0.00 \\
\hline \multirow[t]{2}{*}{ Total } & & 0.00 & 0.00 & 0.00 & 30.4 & 0.00 & 0.00 & 0.00 \\
\hline & & & & & & & \multicolumn{2}{|c|}{ Flow from Marina Del Rey } \\
\hline Dominguez & 2 & 0.00 & 0.00 & 0.00 & 0.00 & 0.00 & 0.00 & 0.00 \\
\hline Mesa & 3 & 0.00 & 0.00 & 0.00 & 0.00 & 659 & 0.00 & 0.00 \\
\hline Pacific A & 4 & 0.00 & 0.00 & 0.00 & 0.00 & 0.00 & 0.00 & 0.00 \\
\hline Pacific & 5 & 0.00 & 0.00 & 0.00 & 0.00 & 0.00 & 0.00 & 0.00 \\
\hline Harbor & 6 & 0.00 & 0.00 & 0.00 & 0.00 & 0.00 & 0.00 & 0.00 \\
\hline Bent Spring & 7 & 0.00 & 0.00 & 0.00 & 0.00 & 0.00 & 0.00 & 0.00 \\
\hline Upper Wilmington A & 8 & 0.00 & 0.00 & 0.00 & 0.00 & 0.00 & 0.00 & 0.00 \\
\hline Upper Wilmington B & 9 & 0.00 & 0.00 & 0.00 & 0.00 & 0.00 & 0.00 & 0.00 \\
\hline Lower Wilmington & 10 & 0.00 & 0.00 & 0.00 & 0.00 & 0.00 & 0.00 & 0.00 \\
\hline Long Beach A & 11 & 0.00 & 0.00 & 0.00 & 0.00 & 0.00 & 0.00 & 0.00 \\
\hline Long Beach B & 12 & 0.00 & 0.00 & 0.00 & 0.00 & 0.00 & 0.00 & 0.00 \\
\hline Long Beach C & 13 & 0.00 & 0.00 & 0.00 & 0.00 & 0.00 & 0.00 & 0.00 \\
\hline \multirow[t]{2}{*}{ Total } & & 0.00 & 0.00 & 0.00 & 0.00 & 659 & 0.00 & 0.00 \\
\hline & & & & & & & \multicolumn{2}{|c|}{ Flow from Port of Long Beach } \\
\hline Dominguez & 2 & 0.00 & 0.00 & 0.00 & 0.00 & 0.00 & 0.00 & 0.00 \\
\hline Mesa & 3 & 0.00 & 0.00 & 0.00 & -0.00017 & 0.00 & 0.00 & 0.00 \\
\hline Pacific A & 4 & 0.00 & 0.00 & 0.00 & 0.00 & 0.00 & 0.00 & 0.00 \\
\hline Pacific & 5 & 0.00 & 0.00 & 0.00 & 0.00 & 0.00 & 0.00 & 0.00 \\
\hline Harbor & 6 & 0.00 & 0.00 & 0.00 & 0.00 & 0.00 & 0.00 & 0.00 \\
\hline Bent Spring & 7 & 0.00 & 0.00 & 0.00 & 0.00 & 0.00 & 0.00 & 0.00 \\
\hline Upper Wilmington A & 8 & 0.00 & 0.00 & 0.00 & 0.00 & 0.00 & 0.00 & 0.00 \\
\hline Upper Wilmington B & 9 & 0.00 & 0.00 & 0.00 & 0.00 & 0.00 & 0.00 & 0.00 \\
\hline Lower Wilmington & 10 & 0.00 & 0.00 & 0.00 & 0.00 & 0.00 & 0.00 & 0.00 \\
\hline Long Beach A & 11 & 0.00 & 0.00 & 0.00 & 0.00 & 0.00 & 0.00 & 0.00 \\
\hline Long Beach B & 12 & 0.00 & 0.00 & 0.00 & 0.00 & 0.00 & 0.00 & 0.00 \\
\hline Long Beach C & 13 & 0.00 & 0.00 & 0.00 & 0.00 & 0.00 & 0.00 & 0.00 \\
\hline Total & & 0.00 & 0.00 & 0.00 & -0.00017 & 0.00 & 0.00 & 0.00 \\
\hline
\end{tabular}


vater-flow Model._Continued

Montebello Forebay

Whitter Central Basin

North Orange South Orange

County

County

0.00

0.00

0.00

0.00

0.00

0.00

0.00

0.00

0.00

0.00

0.00

0.00

0.00

0.00

0.00

0.00

0.00

0.00

0.00

0.00

0.00

0.00

0.00

0.00

0.00

0.00

\subsection{0}

0.00

0.00

0.00

0.00

0.00

0.00

0.00

0.00

0.00

0.00

0.00

0.00

0.00

0.00

0.00

0.00

0.00

0.00

0.00

0.00

0.00

0.00

0.00

0.00

0.00

0.00

0.00

0.00

0.00

0.00

0.00

0.00

0.00

0.00

0.00

0.00

0.00

0.00

0.00

0.00

0.00

0.00

0.00

0.00

0.00

0.00

0.00

0.00

0.00

0.00

0.00

0.00

0.00

0.00

0.00

0.00

0.00

0.00

0.00

0.00

0.00

0.00

0.00

0.00

0.00

0.00

0.00

0.00

0.00

$$
0.00
$$

$$
0.00
$$

0.00

0.00

0.00

0.00

0.00

0.00

0.00

0.00

$$
0.00
$$

0.00

$$
0.00
$$

$$
0.00
$$

0.00

0.00

0.00

0.00

0.00

0.00

0.00

$\begin{array}{lll}0.00 & 0.00 & 0.00 \\ 0.00 & 0.00 & 0.00 \\ 0.00 & 0.00 & 0.00\end{array}$

$\begin{array}{lll}0.00 & 0.00 & 0.00\end{array}$

$\begin{array}{lll}0.00 & 0.00 & 0.00\end{array}$

$\begin{array}{lll}0.00 & 0.00 & 0.00\end{array}$

$\begin{array}{lll}0.00 & 0.00 & 0.00\end{array}$

$\begin{array}{lll}0.00 & 0.00 & 0.00\end{array}$

$\begin{array}{lll}0.00 & 0.00 & 0.00\end{array}$

$\begin{array}{lll}0.00 & 0.00 & 3.15\end{array}$

$\begin{array}{lll}0.00 & 0.00 & 0.947\end{array}$

$\begin{array}{lll}0.00 & 0.00 & 0.947 \\ 0.00 & 0.00 & 0.494\end{array}$

$\begin{array}{lll}0.00 & 0.00 & 25.8\end{array}$

$\begin{array}{lll}0.00 & 0.00 & 30.4\end{array}$


Table 4.15. Average annual 25-year water budget in acre-feet for base-case scenario with dry climatic conditions, Los Angeles Coastal Plain Ground [WRD, Water Replenishment District of Southern California]

\begin{tabular}{|c|c|c|c|c|c|c|c|c|}
\hline $\begin{array}{l}\text { Chronostratigraphic } \\
\text { unit name }\end{array}$ & $\begin{array}{l}\text { Model } \\
\text { layer }\end{array}$ & $\begin{array}{l}\text { Los } \\
\text { Angeles } \\
\text { Forebay }\end{array}$ & $\begin{array}{c}\text { WRD } \\
\text { Central Basin }\end{array}$ & Orange County & $\begin{array}{l}\text { West } \\
\text { Coast }\end{array}$ & $\begin{array}{l}\text { Santa } \\
\text { Monica }\end{array}$ & Hollywood & $\begin{array}{l}\text { WRD Los } \\
\text { Angeles } \\
\text { Forebay }\end{array}$ \\
\hline \multicolumn{9}{|c|}{ Underflow from San Fernando Basin } \\
\hline Dominguez & 2 & 0.00 & 0.00 & 0.00 & 0.00 & 0.00 & 0.00 & 0.00 \\
\hline Mesa & 3 & 5,330 & 0.00 & 0.00 & 0.00 & 0.00 & 0.00 & 0.00 \\
\hline Pacific A & 4 & 0.00 & 0.00 & 0.00 & 0.00 & 0.00 & 0.00 & 0.00 \\
\hline Pacific & 5 & 0.00 & 0.00 & 0.00 & 0.00 & 0.00 & 0.00 & 0.00 \\
\hline Harbor & 6 & 0.00 & 0.00 & 0.00 & 0.00 & 0.00 & 0.00 & 0.00 \\
\hline Bent Spring & 7 & 0.00 & 0.00 & 0.00 & 0.00 & 0.00 & 0.00 & 0.00 \\
\hline Upper Wilmington A & 8 & 0.00 & 0.00 & 0.00 & 0.00 & 0.00 & 0.00 & 0.00 \\
\hline Upper Wilmington B & 9 & 0.00 & 0.00 & 0.00 & 0.00 & 0.00 & 0.00 & 0.00 \\
\hline Lower Wilmington & 10 & 0.00 & 0.00 & 0.00 & 0.00 & 0.00 & 0.00 & 0.00 \\
\hline Long Beach A & 11 & 0.00 & 0.00 & 0.00 & 0.00 & 0.00 & 0.00 & 0.00 \\
\hline Long Beach B & 12 & 0.00 & 0.00 & 0.00 & 0.00 & 0.00 & 0.00 & 0.00 \\
\hline Long Beach C & 13 & 0.00 & 0.00 & 0.00 & 0.00 & 0.00 & 0.00 & 0.00 \\
\hline \multirow[t]{2}{*}{ Total } & & 5,330 & 0.00 & 0.00 & 0.00 & 0.00 & 0.00 & 0.00 \\
\hline & & & & & & & & Drains \\
\hline Dominguez & 2 & 0.00 & -666 & -55.8 & -9.70 & -333 & 0.00 & 0.00 \\
\hline Mesa & 3 & 0.00 & -168 & 0.00 & 0.00 & -957 & 0.00 & 0.00 \\
\hline Pacific A & 4 & 0.00 & 0.00 & 0.00 & 0.00 & 0.00 & 0.00 & 0.00 \\
\hline Pacific & 5 & 0.00 & 0.00 & 0.00 & 0.00 & -267 & 0.00 & 0.00 \\
\hline Harbor & 6 & 0.00 & 0.00 & 0.00 & 0.00 & 0.00 & 0.00 & 0.00 \\
\hline Bent Spring & 7 & 0.00 & 0.00 & 0.00 & 0.00 & $-1,550$ & 0.00 & 0.00 \\
\hline Upper Wilmington A & 8 & 0.00 & 0.00 & 0.00 & 0.00 & 0.00 & 0.00 & 0.00 \\
\hline Upper Wilmington B & 9 & 0.00 & 0.00 & 0.00 & 0.00 & 0.00 & 0.00 & 0.00 \\
\hline Lower Wilmington & 10 & 0.00 & 0.00 & 0.00 & 0.00 & 0.00 & 0.00 & 0.00 \\
\hline Long Beach A & 11 & 0.00 & -737 & 0.00 & 0.00 & 0.00 & 0.00 & 0.00 \\
\hline Long Beach B & 12 & 0.00 & 0.00 & 0.00 & 0.00 & 0.00 & 0.00 & 0.00 \\
\hline Long Beach C & 13 & 0.00 & 0.00 & 0.00 & 0.00 & 0.00 & 0.00 & 0.00 \\
\hline Total & & 0.00 & $-1,570$ & -55.8 & -9.70 & $-3,110$ & 0.00 & 0.00 \\
\hline \multirow[t]{2}{*}{ Total net flow } & & -3.05 & $-1,760$ & -308 & 2,320 & $-4,140$ & $-2,340$ & $-1,710$ \\
\hline & & & & & & & & Change in storage \\
\hline Dominguez & 2 & -788 & $-2,050$ & 150 & 1.12 & $-1,350$ & -138 & $-1,790$ \\
\hline Mesa & 3 & 72.6 & 431 & -7.85 & 1,780 & $-1,210$ & -310 & -201 \\
\hline Pacific A & 4 & 25.7 & 416 & -3.01 & 1.23 & 0.00 & 0.00 & 1.57 \\
\hline Pacific & 5 & 16.0 & -428 & -20.4 & -39.8 & $-1,510$ & -15.7 & 87.5 \\
\hline Harbor & 6 & 16.2 & -18.7 & -14.3 & 119 & -0.0193 & 0.00 & 115 \\
\hline Bent Spring & 7 & 10.2 & -10.5 & -15.1 & 322 & -32.2 & -534 & 3.61 \\
\hline Upper Wilmington A & 8 & 467 & -0.84 & -290 & 24.9 & 68.5 & $-1,340$ & 62.5 \\
\hline Upper Wilmington B & 9 & 5.17 & 11.3 & -6.05 & 17.2 & -32.6 & -9.52 & 7.03 \\
\hline Lower Wilmington & 10 & 44.8 & 12.5 & -3.25 & 71.5 & -5.42 & 3.78 & 11.2 \\
\hline Long Beach A & 11 & -3.72 & 16.5 & -13.3 & 21.0 & 0.508 & 0.00574 & -4.09 \\
\hline Long Beach B & 12 & -0.590 & -41.7 & -40.3 & 15.9 & 2.18 & 0.00989 & -2.04 \\
\hline Long Beach C & 13 & 131 & -95.9 & -45.2 & -16.8 & -68.6 & -0.238 & 0.746 \\
\hline Total & & -3.20 & $-1,760$ & -308 & 2,320 & $-4,140$ & $-2,340$ & $-1,710$ \\
\hline
\end{tabular}


vater-flow Model._Continued

\begin{tabular}{|c|c|c|c|c|c|}
\hline $\begin{array}{c}\text { Montebello } \\
\text { Forebay }\end{array}$ & Whitter & Central Basin & $\begin{array}{l}\text { North Orange } \\
\text { County }\end{array}$ & $\begin{array}{l}\text { South Orange } \\
\text { County }\end{array}$ & Total \\
\hline 0.00 & 0.00 & 0.00 & 0.00 & 0.00 & 0.00 \\
\hline 0.00 & 0.00 & 0.00 & 0.00 & 0.00 & 5,330 \\
\hline 0.00 & 0.00 & 0.00 & 0.00 & 0.00 & 0.00 \\
\hline 0.00 & 0.00 & 0.00 & 0.00 & 0.00 & 0.00 \\
\hline 0.00 & 0.00 & 0.00 & 0.00 & 0.00 & 0.00 \\
\hline 0.00 & 0.00 & 0.00 & 0.00 & 0.00 & 0.00 \\
\hline 0.00 & 0.00 & 0.00 & 0.00 & 0.00 & 0.00 \\
\hline 0.00 & 0.00 & 0.00 & 0.00 & 0.00 & 0.00 \\
\hline 0.00 & 0.00 & 0.00 & 0.00 & 0.00 & 0.00 \\
\hline 0.00 & 0.00 & 0.00 & 0.00 & 0.00 & 0.00 \\
\hline 0.00 & 0.00 & 0.00 & 0.00 & 0.00 & 0.00 \\
\hline 0.00 & 0.00 & 0.00 & 0.00 & 0.00 & 0.00 \\
\hline 0.00 & 0.00 & 0.00 & 0.00 & 0.00 & 5,330 \\
\hline-146 & 0.00 & -541 & -20.9 & -2.26 & $-1,780$ \\
\hline 0.00 & 0.00 & 0.00 & 0.00 & -10.7 & $-1,140$ \\
\hline 0.00 & 0.00 & 0.00 & 0.00 & 0.00 & 0.00 \\
\hline-356 & -19.7 & 0.00 & -275 & 0.00 & -918 \\
\hline 0.00 & 0.00 & 0.00 & 0.00 & 0.00 & 0.00 \\
\hline 0.00 & 0.00 & 0.00 & 0.00 & 0.00 & $-1,550$ \\
\hline 0.00 & 0.00 & 0.00 & -445 & 0.00 & -445 \\
\hline 0.00 & 0.00 & 0.00 & 0.00 & 0.00 & 0.00 \\
\hline 0.00 & 0.00 & 0.00 & -224 & 0.00 & -224 \\
\hline 0.00 & 0.00 & 0.00 & -37 & 0.00 & -774 \\
\hline 0.00 & 0.00 & 0.00 & 0.00 & 0.00 & 0.00 \\
\hline 0.00 & 0.00 & 0.00 & 0.00 & 0.00 & 0.00 \\
\hline-502 & -19.7 & -541 & $-1,000$ & -12.9 & $-6,820$ \\
\hline$-2,330$ & -714 & 196 & -208 & -370 & $-11,400$ \\
\hline$-1,410$ & -74.6 & -362 & 45.6 & -257 & $-8,030$ \\
\hline$-1,100$ & -368 & 490 & 0.00 & -73.6 & -495 \\
\hline-10.4 & -6.09 & 7.67 & 0.00 & 0.00 & 433 \\
\hline-95.2 & -211 & 3.83 & -172 & -23.0 & $-2,410$ \\
\hline-30.6 & -55.3 & 0.746 & 0.00 & -3.16 & 129 \\
\hline-0.958 & 0.00 & 20.5 & 0.00 & -0.362 & -237 \\
\hline 131 & 13.2 & 8.94 & -305 & -1.33 & $-1,160$ \\
\hline-1.98 & 1.78 & 19.4 & -5.72 & -1.77 & 4.19 \\
\hline-3.15 & 0.101 & 6.19 & 1.80 & -1.15 & 139 \\
\hline-23.0 & 23.2 & 0.0887 & 215 & -1.37 & 231 \\
\hline-19.7 & 1.12 & 1.50 & 6.03 & -3.26 & -80.8 \\
\hline 240 & -39.4 & -0.629 & 7.16 & -5.05 & 107 \\
\hline$-2,330$ & -714 & 196 & -208 & -371 & $-11,400$ \\
\hline
\end{tabular}


Table 4.16. Average annual 25-year water budget in acre-feet for increased-pumpage scenario with wet climatic conditions, Los Angeles Coastal Pla [WRD, Water Replenishment District of Southern California]

\begin{tabular}{|c|c|c|c|c|c|c|c|c|}
\hline $\begin{array}{c}\text { Chronostratigraphic } \\
\text { unit name }\end{array}$ & $\begin{array}{l}\text { Model } \\
\text { layer }\end{array}$ & $\begin{array}{l}\text { Los } \\
\text { Angeles } \\
\text { Forebay }\end{array}$ & $\begin{array}{c}\text { WRD } \\
\text { Central Basin }\end{array}$ & Orange County & $\begin{array}{l}\text { West } \\
\text { Coast }\end{array}$ & $\begin{array}{l}\text { Santa } \\
\text { Monica }\end{array}$ & Hollywood & $\begin{array}{l}\text { WRD Los } \\
\text { Angeles } \\
\text { Forebay }\end{array}$ \\
\hline \multicolumn{9}{|c|}{ Pumping and net interborehole flow out } \\
\hline Dominguez & 2 & 0.00 & $-8,360$ & $-3,060$ & -41.0 & 0.00 & 0.00 & -1.00 \\
\hline Mesa & 3 & 0.00 & $-8,990$ & $-3,380$ & $-1,270$ & -301 & 0.00 & $-2,710$ \\
\hline Pacific A & 4 & 0.00 & $-31,800$ & $-7,660$ & 0.00 & 0.00 & 0.00 & -844 \\
\hline Pacific & 5 & 0.00 & $-28,700$ & $-26,700$ & $-8,720$ & -631 & -298 & $-4,730$ \\
\hline Harbor & 6 & 0.00 & $-37,800$ & $-9,940$ & $-15,000$ & 0.00 & 0.00 & $-1,010$ \\
\hline Bent Spring & 7 & 0.00 & $-15,100$ & $-2,270$ & $-6,490$ & $-7,360$ & $-1,250$ & $-3,710$ \\
\hline Upper Wilmington A & 8 & $-1,240$ & $-20,600$ & $-3,960$ & $-21,800$ & -132 & $-1,550$ & $-5,390$ \\
\hline Upper Wilmington B & 9 & 0.00 & $-7,950$ & -547 & $-1,870$ & -320 & -25.0 & -655 \\
\hline Lower Wilmington & 10 & 0.00 & $-2,990$ & 0.00 & $-6,570$ & -210 & 0.00 & -654 \\
\hline Long Beach A & 11 & 0.00 & -722 & 0.00 & -724 & 0.00 & 0.00 & -8.00 \\
\hline Long Beach B & 12 & 0.00 & -253 & 0.00 & -116 & 0.00 & 0.00 & -99.0 \\
\hline Long Beach C & 13 & 0.00 & 0.00 & 0.00 & 0.00 & -1.00 & 0.00 & -21.0 \\
\hline Total & \multicolumn{2}{|r|}{$-1,240$} & $-163,000$ & $-57,500$ & $-62,600$ & $-8,960$ & $-3,130$ & $-19,800$ \\
\hline \multicolumn{9}{|c|}{ Net flow from adjacent inland zones } \\
\hline Dominguez & 2 & -592 & 12,600 & $-2,510$ & 10.7 & 19.2 & -110 & 68.7 \\
\hline Mesa & 3 & $-1,230$ & 27,000 & -382 & 1,340 & -377 & $-1,030$ & 3,740 \\
\hline Pacific A & 4 & -181 & 9,750 & 1,830 & -69.4 & 0.00 & 0.00 & $-1,760$ \\
\hline Pacific & 5 & $-3,080$ & 23,200 & 8,930 & -583 & 147 & -76.9 & 4,160 \\
\hline Harbor & 6 & -404 & 23,600 & 1,320 & -763 & -18.1 & 0.00 & $-1,480$ \\
\hline Bent Spring & 7 & -886 & 14,600 & 360 & 261 & 301 & -978 & 823 \\
\hline Upper Wilmington A & 8 & $-1,990$ & 8,180 & $-1,060$ & 2,770 & $-2,290$ & 29.1 & 6,000 \\
\hline Upper Wilmington B & 9 & -170 & 4,450 & $-2,990$ & 74.5 & 202 & -6.43 & 253 \\
\hline Lower Wilmington & 10 & -122 & 3,760 & -443 & 1,980 & -267 & -4.08 & 478 \\
\hline Long Beach A & 11 & -0.459 & 787 & 14.9 & 942 & -178 & -0.0199 & 45.4 \\
\hline Long Beach B & 12 & 35.8 & 1,280 & -264 & 572 & -114 & 4.00 & -24.9 \\
\hline Long Beach C & 13 & -659 & 2,150 & 115 & 1,250 & -445 & -1.71 & 52.6 \\
\hline \multirow[t]{2}{*}{ Total } & & $-9,280$ & 131,000 & 4,920 & 7,780 & $-3,020$ & $-2,180$ & 12,300 \\
\hline & & & & & & & \multicolumn{2}{|r|}{ Water spreading } \\
\hline Dominguez & 2 & 0.00 & 0.00 & 0.00 & 0.00 & 0.00 & 0.00 & 0.00 \\
\hline Mesa & 3 & 0.00 & 0.00 & 0.00 & 0.00 & 0.00 & 0.00 & 0.00 \\
\hline Pacific A & 4 & 0.00 & 0.00 & 0.00 & 0.00 & 0.00 & 0.00 & 0.00 \\
\hline Pacific & 5 & 0.00 & 0.00 & 0.00 & 0.00 & 0.00 & 0.00 & 0.00 \\
\hline Harbor & 6 & 0.00 & 0.00 & 0.00 & 0.00 & 0.00 & 0.00 & 0.00 \\
\hline Bent Spring & 7 & 0.00 & 0.00 & 0.00 & 0.00 & 0.00 & 0.00 & 0.00 \\
\hline Upper Wilmington A & 8 & 0.00 & 0.00 & 0.00 & 0.00 & 0.00 & 0.00 & 0.00 \\
\hline Upper Wilmington B & 9 & 0.00 & 0.00 & 0.00 & 0.00 & 0.00 & 0.00 & 0.00 \\
\hline Lower Wilmington & 10 & 0.00 & 0.00 & 0.00 & 0.00 & 0.00 & 0.00 & 0.00 \\
\hline Long Beach A & 11 & 0.00 & 0.00 & 0.00 & 0.00 & 0.00 & 0.00 & 0.00 \\
\hline Long Beach B & 12 & 0.00 & 0.00 & 0.00 & 0.00 & 0.00 & 0.00 & 0.00 \\
\hline Long Beach C & 13 & 0.00 & 0.00 & 0.00 & 0.00 & 0.00 & 0.00 & 0.00 \\
\hline Total & & 0.00 & 0.00 & 0.00 & 0.00 & 0.00 & 0.00 & 0.00 \\
\hline
\end{tabular}


in Groundwater-flow Model.

\begin{tabular}{|c|c|c|c|c|c|}
\hline $\begin{array}{c}\text { Montebello } \\
\text { Forebay }\end{array}$ & Whitter & Central Basin & $\begin{array}{c}\text { North Orange } \\
\text { County }\end{array}$ & $\begin{array}{l}\text { South Orange } \\
\text { County }\end{array}$ & Total \\
\hline-424 & 0.00 & 0.00 & 0.00 & -39.0 & $-11,900$ \\
\hline$-5,640$ & -22.0 & 0.00 & 0.00 & -209 & $-22,500$ \\
\hline$-2,880$ & 0.00 & 0.00 & 0.00 & 0.00 & $-43,100$ \\
\hline$-18,000$ & -20.0 & -4.00 & 0.00 & $-3,970$ & $-91,700$ \\
\hline$-8,080$ & -6.00 & 0.00 & 0.00 & $-1,090$ & $-72,900$ \\
\hline$-2,630$ & 0.00 & -18.0 & 0.00 & -107 & $-39,000$ \\
\hline$-5,340$ & 0.00 & 0.00 & 0.00 & -337 & $-60,400$ \\
\hline-392 & -1.00 & 0.00 & 0.00 & 0.00 & $-11,800$ \\
\hline-447 & -161 & 0.00 & -137 & 0.00 & $-11,200$ \\
\hline-233 & 0.00 & 0.00 & 0.00 & 0.00 & $-1,690$ \\
\hline-194 & 0.00 & 0.00 & 0.00 & 0.00 & -661 \\
\hline$-4,100$ & 0.00 & 0.00 & 0.00 & 0.00 & $-4,120$ \\
\hline$-48,300$ & -210 & -22.0 & -137 & $-5,750$ & $-371,000$ \\
\hline$-12,000$ & -103 & 105 & 7.28 & 2,550 & $-1.41 \mathrm{E}-11$ \\
\hline$-30,200$ & -733 & 876 & 0.00 & 1,000 & $-3.51 \mathrm{E}-11$ \\
\hline$-8,230$ & -299 & $-1,040$ & 0.00 & 0.00 & $2.71 \mathrm{E}-11$ \\
\hline$-27,000$ & -473 & -606 & -701 & $-3,830$ & $-3.00 \mathrm{E}-11$ \\
\hline$-19,100$ & -78.7 & -342 & 0.00 & $-2,730$ & $-1.46 \mathrm{E}-11$ \\
\hline$-15,300$ & 0.00 & 852 & 0.00 & -43.3 & $1.98 \mathrm{E}-12$ \\
\hline$-9,020$ & -321 & -234 & -716 & $-1,340$ & $-2.80 \mathrm{E}-11$ \\
\hline$-1,580$ & 260 & -223 & -321 & 55.0 & $-1.26 \mathrm{E}-11$ \\
\hline$-4,520$ & 44.6 & -267 & -445 & -200 & $3.81 \mathrm{E}-12$ \\
\hline 257 & -71.6 & -1.07 & $-1,120$ & -675 & $-1.14 \mathrm{E}-12$ \\
\hline-338 & -208 & 2.92 & -175 & -768 & $-4.66 \mathrm{E}-12$ \\
\hline$-1,130$ & $-1,090$ & -50.9 & -43.9 & -152 & $-4.09 \mathrm{E}-12$ \\
\hline$-128,000$ & $-3,070$ & -925 & $-3,510$ & $-6,140$ & $-1.47 \mathrm{E}-10$ \\
\hline 85,300 & 0.00 & 0.00 & 0.00 & 0.00 & 85,300 \\
\hline 43,700 & 0.00 & 0.00 & 0.00 & 0.00 & 43,700 \\
\hline 0.00 & 0.00 & 0.00 & 0.00 & 0.00 & 0.00 \\
\hline 2,010 & 0.00 & 0.00 & 0.00 & 0.00 & 2,010 \\
\hline 0.00 & 0.00 & 0.00 & 0.00 & 0.00 & 0.00 \\
\hline 0.00 & 0.00 & 0.00 & 0.00 & 0.00 & 0.00 \\
\hline 0.00 & 0.00 & 0.00 & 0.00 & 0.00 & 0.00 \\
\hline 0.00 & 0.00 & 0.00 & 0.00 & 0.00 & 0.00 \\
\hline 0.00 & 0.00 & 0.00 & 0.00 & 0.00 & 0.00 \\
\hline 0.00 & 0.00 & 0.00 & 0.00 & 0.00 & 0.00 \\
\hline 0.00 & 0.00 & 0.00 & 0.00 & 0.00 & 0.00 \\
\hline 0.00 & 0.00 & 0.00 & 0.00 & 0.00 & 0.00 \\
\hline 131,000 & 0.00 & 0.00 & 0.00 & 0.00 & 131,000 \\
\hline
\end{tabular}


Table 4.16. Average annual 25-year water budget in acre-feet for increased-pumpage scenario with wet climatic conditions, Los Angeles Coastal Pla [WRD, Water Replenishment District of Southern California]

\begin{tabular}{|c|c|c|c|c|c|c|c|c|}
\hline $\begin{array}{c}\text { Chronostratigraphic } \\
\text { unit name }\end{array}$ & $\begin{array}{l}\text { Model } \\
\text { layer }\end{array}$ & $\begin{array}{c}\text { Los } \\
\text { Angeles } \\
\text { Forebay }\end{array}$ & $\begin{array}{c}\text { WRD } \\
\text { Central Basin }\end{array}$ & Orange County & $\begin{array}{l}\text { West } \\
\text { Coast }\end{array}$ & $\begin{array}{l}\text { Santa } \\
\text { Monica }\end{array}$ & Hollywood & $\begin{array}{l}\text { WRD Los } \\
\text { Angeles } \\
\text { Forebay }\end{array}$ \\
\hline & & & & & & & \multicolumn{2}{|c|}{ Injection and net interborehole flow in } \\
\hline Dominguez & 2 & 0.00 & 1.18 & 0.00268 & 33.1 & 0.00 & 0.00 & 0.000259 \\
\hline Mesa & 3 & 0.00 & 759 & 238 & 1,630 & $9.51 \mathrm{E}-05$ & 0.00 & 0.00 \\
\hline Pacific A & 4 & 0.00 & 2,400 & 2,560 & 0.00 & 0.00 & 0.00 & 33.3 \\
\hline Pacific & 5 & 0.00 & 7,760 & 2,030 & 8,080 & 0.0343 & 0.00 & 1,260 \\
\hline Harbor & 6 & 0.00 & 2,160 & 97.6 & 5,340 & 0.00 & 0.00 & 1,370 \\
\hline Bent Spring & 7 & 0.00 & 1,310 & 0.00 & 9,760 & 245 & 48.0 & 758 \\
\hline Upper Wilmington A & 8 & 1,240 & 1,120 & 0.968 & 1,790 & 0.00 & 14.3 & 62.9 \\
\hline Upper Wilmington B & 9 & 0.00 & 502 & 0.0913 & 95.2 & 0.00 & 0.00 & 15.7 \\
\hline Lower Wilmington & 10 & 0.00 & 47.9 & 0.00 & 107 & 0.00 & 0.00 & 30.7 \\
\hline Long Beach A & 11 & 0.00 & 2.96 & 0.00 & 0.00 & 0.00 & 0.00 & 0.00 \\
\hline Long Beach B & 12 & 0.00 & 0.254 & 0.00 & 0.00 & 0.00 & 0.00 & 0.00 \\
\hline Long Beach C & 13 & 0.00 & 0.00 & 0.00 & 0.00 & 1.06 & 0.00 & 0.00 \\
\hline \multirow[t]{2}{*}{ Total } & & 1,240 & 16,100 & 4,930 & 26,800 & 246 & 62.3 & 3,530 \\
\hline & & & & & & & & Areal recharge \\
\hline Dominguez & 2 & 1,450 & 10,400 & 3,740 & 1,430 & 1,780 & 2,210 & 1,720 \\
\hline Mesa & 3 & 2,100 & 4,390 & 34.4 & 11,400 & 8,160 & 1,330 & 51.5 \\
\hline Pacific A & 4 & 0.00 & 0.00 & 0.00 & 0.00 & 0.00 & 0.00 & 0.00 \\
\hline Pacific & 5 & 0.00 & 399 & 60.0 & 923 & 1,180 & 0.0782 & 0.00 \\
\hline Harbor & 6 & 254 & 4.88 & 0.00 & 309 & 0.00 & 0.00 & 224 \\
\hline Bent Spring & 7 & 19.0 & 0.00 & 0.00 & 1,030 & 9.73 & 0.00 & 0.00 \\
\hline Upper Wilmington A & 8 & 0.00 & 36.1 & 11.8 & 170 & 82.7 & 0.00 & 44.4 \\
\hline Upper Wilmington B & 9 & 0.00 & 0.00 & 0.00 & 21.5 & 12.2 & 0.00 & 0.00 \\
\hline Lower Wilmington & 10 & 0.00 & 26.4 & 0.00 & 0.00 & 0.00 & 0.00 & 0.00 \\
\hline Long Beach A & 11 & 0.00 & 8.83 & 0.00 & 0.00 & 0.00 & 0.00 & 0.00 \\
\hline Long Beach B & 12 & 0.00 & 0.00 & 0.00 & 0.00 & 0.00 & 0.00 & 0.00 \\
\hline Long Beach C & 13 & 265 & 126 & 0.00 & 121 & 4.04 & 0.00 & 159 \\
\hline \multirow[t]{2}{*}{ Total } & & 4,090 & 15,400 & 3,840 & 15,400 & 11,200 & 3,540 & 2,200 \\
\hline & & & & & & & \multicolumn{2}{|c|}{ Flow from Santa Monica Bay } \\
\hline Dominguez & 2 & 0.00 & 0.00 & 0.00 & 0.00 & 0.00115 & 0.00 & 0.00 \\
\hline Mesa & 3 & 0.00 & 0.00 & 0.00 & -75.3 & -291 & 0.00 & 0.00 \\
\hline Pacific A & 4 & 0.00 & 0.00 & 0.00 & 0.00 & 0.00 & 0.00 & 0.00 \\
\hline Pacific & 5 & 0.00 & 0.00 & 0.00 & 73.8 & -33.7 & 0.00 & 0.00 \\
\hline Harbor & 6 & 0.00 & 0.00 & 0.00 & -2.31 & 0.00 & 0.00 & 0.00 \\
\hline Bent Spring & 7 & 0.00 & 0.00 & 0.00 & 395 & -89.8 & 0.00 & 0.00 \\
\hline Upper Wilmington A & 8 & 0.00 & 0.00 & 0.00 & -1.51 & 128 & 0.00 & 0.00 \\
\hline Upper Wilmington B & 9 & 0.00 & 0.00 & 0.00 & -51.8 & -13.2 & 0.00 & 0.00 \\
\hline Lower Wilmington & 10 & 0.00 & 0.00 & 0.00 & 188 & -42.4 & 0.00 & 0.00 \\
\hline Long Beach A & 11 & 0.00 & 0.00 & 0.00 & -2.89 & -16.6 & 0.00 & 0.00 \\
\hline Long Beach B & 12 & 0.00 & 0.00 & 0.00 & 6.94 & -7.74 & 0.00 & 0.00 \\
\hline Long Beach C & 13 & 0.00 & 0.00 & 0.00 & 15.6 & 26.8 & 0.00 & 0.00 \\
\hline Total & & 0.00 & 0.00 & 0.00 & 545 & -340 & 0.00 & 0.00 \\
\hline
\end{tabular}


in Groundwater-flow Model._-Continued

\begin{tabular}{|c|c|c|c|c|c|}
\hline $\begin{array}{c}\text { Montebello } \\
\text { Forebay }\end{array}$ & Whitter & Central Basin & $\begin{array}{l}\text { North Orange } \\
\text { County }\end{array}$ & $\begin{array}{l}\text { South Orange } \\
\text { County }\end{array}$ & Total \\
\hline $7.29 \mathrm{E}-05$ & 0.00 & 0.00 & 0.00 & 0.00 & 34.2 \\
\hline 121 & 0.00 & 1.27 & 0.00 & 1,130 & 3,880 \\
\hline 719 & 0.00 & 0.00 & 0.00 & 0.00 & 5,720 \\
\hline 236 & 0.00 & 0.0582 & 0.00 & 1,180 & 20,500 \\
\hline 703 & 0.00132 & 16.7 & 0.00 & 1,750 & 11,400 \\
\hline 38.6 & 0.00 & 0.925 & 0.00 & 2.66 & 12,200 \\
\hline 266 & 11.7 & 0.00 & 14.5 & 56.2 & 4,570 \\
\hline 3.76 & 0.926 & 0.00 & 16.6 & 0.00 & 634 \\
\hline 29.2 & 0.815 & 0.00 & 0.00 & 0.00 & 215 \\
\hline 0.0153 & 65.1 & 0.00 & 106 & 0.00 & 174 \\
\hline 21.4 & 73.1 & 0.00 & 0.00 & 0.00 & 94.8 \\
\hline 5,000 & 0.00 & 0.00 & 0.00 & 0.00 & 5,000 \\
\hline 7,140 & 152 & 18.9 & 137 & 4,120 & 64,500 \\
\hline 2,620 & 353 & 540 & 33.5 & 547 & 26,800 \\
\hline 1,300 & 465 & 989 & 0.00 & 273 & 30,500 \\
\hline 0.00 & 0.00 & 0.00 & 0.00 & 0.00 & 0.00 \\
\hline 251 & 594 & 218 & 999 & 0.00219 & 4,620 \\
\hline 2.13 & 0.00 & 0.00 & 0.00 & 0.00 & 793 \\
\hline 0.00 & 0.00 & 0.00 & 0.00 & 0.00 & 1,060 \\
\hline 220 & 65.7 & 0.00 & 270 & 0.00 & 901 \\
\hline 0.00 & 0.00 & 0.00 & 0.00 & 0.00 & 33.7 \\
\hline 0.00 & 30.8 & 0.00 & 95.4 & 0.00 & 153 \\
\hline 30.6 & 2.19 & 0.00 & 85.6 & 0.00 & 127 \\
\hline 7.98 & 0.00 & 0.00 & 0.00 & 0.00 & 7.98 \\
\hline 1,510 & 1,430 & 73.8 & 147 & 0.00 & 3,830 \\
\hline 5,940 & 2,940 & 1,820 & 1,630 & 820 & 68,900 \\
\hline 0.00 & 0.00 & 0.00 & 0.00 & 0.00 & 0.00115 \\
\hline 0.00 & 0.00 & 0.00 & 0.00 & 0.00 & -367 \\
\hline 0.00 & 0.00 & 0.00 & 0.00 & 0.00 & 0.00 \\
\hline 0.00 & 0.00 & 0.00 & 0.00 & 0.00 & 40.2 \\
\hline 0.00 & 0.00 & 0.00 & 0.00 & 0.00 & -2.31 \\
\hline 0.00 & 0.00 & 0.00 & 0.00 & 0.00 & 305 \\
\hline 0.00 & 0.00 & 0.00 & 0.00 & 0.00 & 127 \\
\hline 0.00 & 0.00 & 0.00 & 0.00 & 0.00 & -65 \\
\hline 0.00 & 0.00 & 0.00 & 0.00 & 0.00 & 146 \\
\hline 0.00 & 0.00 & 0.00 & 0.00 & 0.00 & -19.5 \\
\hline 0.00 & 0.00 & 0.00 & 0.00 & 0.00 & -0.797 \\
\hline 0.00 & 0.00 & 0.00 & 0.00 & 0.00 & 42.4 \\
\hline 0.00 & 0.00 & 0.00 & 0.00 & 0.00 & 206 \\
\hline
\end{tabular}


Table 4.16. Average annual 25-year water budget in acre-feet for increased-pumpage scenario with wet climatic conditions, Los Angeles Coastal Pla [WRD, Water Replenishment District of Southern California]

\begin{tabular}{|c|c|c|c|c|c|c|c|c|}
\hline $\begin{array}{c}\text { Chronostratigraphic } \\
\text { unit name }\end{array}$ & $\begin{array}{l}\text { Model } \\
\text { layer }\end{array}$ & $\begin{array}{c}\text { Los } \\
\text { Angeles } \\
\text { Forebay }\end{array}$ & $\begin{array}{c}\text { WRD } \\
\text { Central Basin }\end{array}$ & Orange County & $\begin{array}{l}\text { West } \\
\text { Coast }\end{array}$ & $\begin{array}{l}\text { Santa } \\
\text { Monica }\end{array}$ & Hollywood & $\begin{array}{l}\text { WRD Los } \\
\text { Angeles } \\
\text { Forebay }\end{array}$ \\
\hline & & & & & & & \multicolumn{2}{|c|}{ Flow from San Pedro Bay } \\
\hline Dominguez & 2 & 0.00 & 0.00 & 0.00 & 330 & 0.00 & 0.00 & 0.00 \\
\hline Mesa & 3 & 0.00 & 0.00 & 0.00 & 21.4 & 0.00 & 0.00 & 0.00 \\
\hline Pacific A & 4 & 0.00 & 0.00 & 0.00 & 0.00 & 0.00 & 0.00 & 0.00 \\
\hline Pacific & 5 & 0.00 & 0.00 & 0.00 & 1,420 & 0.00 & 0.00 & 0.00 \\
\hline Harbor & 6 & 0.00 & 0.00 & 0.00 & 1,430 & 0.00 & 0.00 & 0.00 \\
\hline Bent Spring & 7 & 0.00 & 0.00 & 0.00 & 606 & 0.00 & 0.00 & 0.00 \\
\hline Upper Wilmington A & 8 & 0.00 & 0.00 & 0.00 & 0.00 & 0.00 & 0.00 & 0.00 \\
\hline Upper Wilmington B & 9 & 0.00 & 0.00 & 0.00 & 241 & 0.00 & 0.00 & 0.00 \\
\hline Lower Wilmington & 10 & 0.00 & 0.00 & 0.00 & 1,880 & 0.00 & 0.00 & 0.00 \\
\hline Long Beach A & 11 & 0.00 & 0.00 & 0.00 & 368 & 0.00 & 0.00 & 0.00 \\
\hline Long Beach B & 12 & 0.00 & 0.00 & 0.00 & 395 & 0.00 & 0.00 & 0.00 \\
\hline Long Beach C & 13 & 0.00 & 0.00 & 0.00 & 139 & 0.00 & 0.00 & 0.00 \\
\hline \multirow[t]{2}{*}{ Total } & & 0.00 & 0.00 & 0.00 & 6,830 & 0.00 & 0.00 & 0.00 \\
\hline & & & & & & & \multicolumn{2}{|c|}{ Underflow from Orange County } \\
\hline Dominguez & 2 & 0.00 & 0.00 & 3,990 & 0.00 & 0.00 & 0.00 & 0.00 \\
\hline Mesa & 3 & 0.00 & 0.00 & 1,540 & 0.00 & 0.00 & 0.00 & 0.00 \\
\hline Pacific A & 4 & 0.00 & 0.00 & 3,270 & 0.00 & 0.00 & 0.00 & 0.00 \\
\hline Pacific & 5 & 0.00 & 0.00 & 14,200 & 0.00 & 0.00 & 0.00 & 0.00 \\
\hline Harbor & 6 & 0.00 & 0.00 & 7,340 & 0.00 & 0.00 & 0.00 & 0.00 \\
\hline Bent Spring & 7 & 0.00 & 0.00 & 1,200 & 0.00 & 0.00 & 0.00 & 0.00 \\
\hline Upper Wilmington A & 8 & 0.00 & 0.00 & 7,810 & 0.00 & 0.00 & 0.00 & 0.00 \\
\hline Upper Wilmington B & 9 & 0.00 & 0.00 & 3,550 & 0.00 & 0.00 & 0.00 & 0.00 \\
\hline Lower Wilmington & 10 & 0.00 & 0.00 & 255 & 0.00 & 0.00 & 0.00 & 0.00 \\
\hline Long Beach A & 11 & 0.00 & 0.00 & 60.7 & 0.00 & 0.00 & 0.00 & 0.00 \\
\hline Long Beach B & 12 & 0.00 & 0.00 & 103 & 0.00 & 0.00 & 0.00 & 0.00 \\
\hline Long Beach C & 13 & 0.00 & 0.00 & 39.5 & 0.00 & 0.00 & 0.00 & 0.00 \\
\hline \multirow[t]{2}{*}{ Total } & & 0.00 & 0.00 & 43,300 & 0.00 & 0.00 & 0.00 & 0.00 \\
\hline & & & & & & & \multicolumn{2}{|c|}{ Underflow from San Gabriel Basin } \\
\hline Dominguez & 2 & 0.00 & 0.00 & 0.00 & 0.00 & 0.00 & 0.00 & 0.00 \\
\hline Mesa & 3 & 0.00 & 0.00 & 0.00 & 0.00 & 0.00 & 0.00 & 0.00 \\
\hline Pacific A & 4 & 0.00 & 0.00 & 0.00 & 0.00 & 0.00 & 0.00 & 0.00 \\
\hline Pacific & 5 & 0.00 & 0.00 & 0.00 & 0.00 & 0.00 & 0.00 & 0.00 \\
\hline Harbor & 6 & 0.00 & 0.00 & 0.00 & 0.00 & 0.00 & 0.00 & 0.00 \\
\hline Bent Spring & 7 & 0.00 & 0.00 & 0.00 & 0.00 & 0.00 & 0.00 & 0.00 \\
\hline Upper Wilmington A & 8 & 0.00 & 0.00 & 0.00 & 0.00 & 0.00 & 0.00 & 0.00 \\
\hline Upper Wilmington B & 9 & 0.00 & 0.00 & 0.00 & 0.00 & 0.00 & 0.00 & 0.00 \\
\hline Lower Wilmington & 10 & 0.00 & 0.00 & 0.00 & 0.00 & 0.00 & 0.00 & 0.00 \\
\hline Long Beach A & 11 & 0.00 & 0.00 & 0.00 & 0.00 & 0.00 & 0.00 & 0.00 \\
\hline Long Beach B & 12 & 0.00 & 0.00 & 0.00 & 0.00 & 0.00 & 0.00 & 0.00 \\
\hline Long Beach C & 13 & 0.00 & 0.00 & 0.00 & 0.00 & 0.00 & 0.00 & 0.00 \\
\hline Total & & 0.00 & 0.00 & 0.00 & 0.00 & 0.00 & 0.00 & 0.00 \\
\hline
\end{tabular}


in Groundwater-flow Model.-Continued

\begin{tabular}{|c|c|c|c|c|c|}
\hline $\begin{array}{c}\text { Montebello } \\
\text { Forebay }\end{array}$ & Whitter & Central Basin & $\begin{array}{l}\text { North Orange } \\
\text { County }\end{array}$ & $\begin{array}{l}\text { South Orange } \\
\text { County }\end{array}$ & Total \\
\hline 0.00 & 0.00 & 0.00 & 0.00 & 27.1 & 357 \\
\hline 0.00 & 0.00 & 0.00 & 0.00 & 147 & 168 \\
\hline 0.00 & 0.00 & 0.00 & 0.00 & 0.00 & 0.00 \\
\hline 0.00 & 0.00 & 0.00 & 0.00 & 279 & 1,700 \\
\hline 0.00 & 0.00 & 0.00 & 0.00 & 856 & 2,290 \\
\hline 0.00 & 0.00 & 0.00 & 0.00 & 64.0 & 670 \\
\hline 0.00 & 0.00 & 0.00 & 0.00 & 0.00 & 0.00 \\
\hline 0.00 & 0.00 & 0.00 & 0.00 & 0.00 & 241 \\
\hline 0.00 & 0.00 & 0.00 & 0.00 & 87.3 & 1,970 \\
\hline 0.00 & 0.00 & 0.00 & 0.00 & -372 & -3.98 \\
\hline 0.00 & 0.00 & 0.00 & 0.00 & -111 & 284 \\
\hline 0.00 & 0.00 & 0.00 & 0.00 & -347 & -208 \\
\hline 0.00 & 0.00 & 0.00 & 0.00 & 631 & 7,460 \\
\hline 0.00 & 0.00 & 0.00 & 0.00 & 94.2 & 4,080 \\
\hline 0.00 & 0.00 & 0.00 & 0.00 & 584 & 2,130 \\
\hline 0.00 & 0.00 & 0.00 & 0.00 & 0.00 & 3,270 \\
\hline 0.00 & 0.00 & 0.00 & -74.7 & 542 & 14,600 \\
\hline 0.00 & 0.00 & 0.00 & 0.00 & 404 & 7,740 \\
\hline 0.00 & 0.00 & 0.00 & 0.00 & 84.1 & 1,280 \\
\hline 0.00 & 0.00 & 0.00 & 861 & 1,590 & 10,300 \\
\hline 0.00 & 0.00 & 0.00 & 275 & -25.4 & 3,790 \\
\hline 0.00 & 0.00 & 0.00 & 739 & 49.7 & 1,040 \\
\hline 0.00 & 0.00 & 0.00 & 1,110 & 1,090 & 2,260 \\
\hline 0.00 & 0.00 & 0.00 & 60.6 & 907 & 1,070 \\
\hline 0.00 & 0.00 & 0.00 & 64.6 & 518 & 622 \\
\hline 0.00 & 0.00 & 0.00 & 3,030 & 5,840 & 52,200 \\
\hline 0.00 & 0.00 & 0.00 & 0.00 & 0.00 & 0.00 \\
\hline 28,300 & 0.00 & 0.00 & 0.00 & 0.00 & 28,300 \\
\hline 0.00 & 0.00 & 0.00 & 0.00 & 0.00 & 0.00 \\
\hline 0.00 & 0.00 & 0.00 & 0.00 & 0.00 & 0.00 \\
\hline 0.00 & 0.00 & 0.00 & 0.00 & 0.00 & 0.00 \\
\hline 0.00 & 0.00 & 0.00 & 0.00 & 0.00 & 0.00 \\
\hline 0.00 & 0.00 & 0.00 & 0.00 & 0.00 & 0.00 \\
\hline 0.00 & 0.00 & 0.00 & 0.00 & 0.00 & 0.00 \\
\hline 0.00 & 0.00 & 0.00 & 0.00 & 0.00 & 0.00 \\
\hline 0.00 & 0.00 & 0.00 & 0.00 & 0.00 & 0.00 \\
\hline 0.00 & 0.00 & 0.00 & 0.00 & 0.00 & 0.00 \\
\hline 3,820 & 0.00 & 0.00 & 0.00 & 0.00 & 3,820 \\
\hline 32,100 & 0.00 & 0.00 & 0.00 & 0.00 & 32,100 \\
\hline
\end{tabular}


Table 4.16. Average annual 25-year water budget in acre-feet for increased-pumpage scenario with wet climatic conditions, Los Angeles Coastal Pla [WRD, Water Replenishment District of Southern California]

\begin{tabular}{|c|c|c|c|c|c|c|c|c|}
\hline $\begin{array}{c}\text { Chronostratigraphic } \\
\text { unit name }\end{array}$ & $\begin{array}{l}\text { Model } \\
\text { layer }\end{array}$ & $\begin{array}{l}\text { Los } \\
\text { Angeles } \\
\text { Forebay }\end{array}$ & $\begin{array}{c}\text { WRD } \\
\text { Central Basin }\end{array}$ & Orange County & $\begin{array}{l}\text { West } \\
\text { Coast }\end{array}$ & $\begin{array}{c}\text { Santa } \\
\text { Monica }\end{array}$ & Hollywood & $\begin{array}{l}\text { WRD Los } \\
\text { Angeles } \\
\text { Forebay }\end{array}$ \\
\hline & & & & & & & \multicolumn{2}{|c|}{ Underflow from Palos Verdes Hills } \\
\hline Dominguez & 2 & 0.00 & 0.00 & 0.00 & 0.00 & 0.00 & 0.00 & 0.00 \\
\hline Mesa & 3 & 0.00 & 0.00 & 0.00 & 0.00 & 0.00 & 0.00 & 0.00 \\
\hline Pacific A & 4 & 0.00 & 0.00 & 0.00 & 0.00 & 0.00 & 0.00 & 0.00 \\
\hline Pacific & 5 & 0.00 & 0.00 & 0.00 & 0.00 & 0.00 & 0.00 & 0.00 \\
\hline Harbor & 6 & 0.00 & 0.00 & 0.00 & 0.00 & 0.00 & 0.00 & 0.00 \\
\hline Bent Spring & 7 & 0.00 & 0.00 & 0.00 & 0.00 & 0.00 & 0.00 & 0.00 \\
\hline Upper Wilmington A & 8 & 0.00 & 0.00 & 0.00 & 0.00 & 0.00 & 0.00 & 0.00 \\
\hline Upper Wilmington B & 9 & 0.00 & 0.00 & 0.00 & 0.00 & 0.00 & 0.00 & 0.00 \\
\hline Lower Wilmington & 10 & 0.00 & 0.00 & 0.00 & 3.63 & 0.00 & 0.00 & 0.00 \\
\hline Long Beach A & 11 & 0.00 & 0.00 & 0.00 & 1.10 & 0.00 & 0.00 & 0.00 \\
\hline Long Beach B & 12 & 0.00 & 0.00 & 0.00 & 0.583 & 0.00 & 0.00 & 0.00 \\
\hline Long Beach C & 13 & 0.00 & 0.00 & 0.00 & 27.0 & 0.00 & 0.00 & 0.00 \\
\hline \multirow[t]{2}{*}{ Total } & & 0.00 & 0.00 & 0.00 & 32.3 & 0.00 & 0.00 & 0.00 \\
\hline & & & & & & & \multicolumn{2}{|c|}{ Flow from Marina Del Rey } \\
\hline Dominguez & 2 & 0.00 & 0.00 & 0.00 & 0.00 & 0.00 & 0.00 & 0.00 \\
\hline Mesa & 3 & 0.00 & 0.00 & 0.00 & 0.00 & 1,210 & 0.00 & 0.00 \\
\hline Pacific A & 4 & 0.00 & 0.00 & 0.00 & 0.00 & 0.00 & 0.00 & 0.00 \\
\hline Pacific & 5 & 0.00 & 0.00 & 0.00 & 0.00 & 0.00 & 0.00 & 0.00 \\
\hline Harbor & 6 & 0.00 & 0.00 & 0.00 & 0.00 & 0.00 & 0.00 & 0.00 \\
\hline Bent Spring & 7 & 0.00 & 0.00 & 0.00 & 0.00 & 0.00 & 0.00 & 0.00 \\
\hline Upper Wilmington A & 8 & 0.00 & 0.00 & 0.00 & 0.00 & 0.00 & 0.00 & 0.00 \\
\hline Upper Wilmington B & 9 & 0.00 & 0.00 & 0.00 & 0.00 & 0.00 & 0.00 & 0.00 \\
\hline Lower Wilmington & 10 & 0.00 & 0.00 & 0.00 & 0.00 & 0.00 & 0.00 & 0.00 \\
\hline Long Beach A & 11 & 0.00 & 0.00 & 0.00 & 0.00 & 0.00 & 0.00 & 0.00 \\
\hline Long Beach B & 12 & 0.00 & 0.00 & 0.00 & 0.00 & 0.00 & 0.00 & 0.00 \\
\hline Long Beach C & 13 & 0.00 & 0.00 & 0.00 & 0.00 & 0.00 & 0.00 & 0.00 \\
\hline \multirow[t]{2}{*}{ Total } & & 0.00 & 0.00 & 0.00 & 0.00 & 1,210 & 0.00 & 0.00 \\
\hline & & & & & & & \multicolumn{2}{|c|}{ Flow from Port of Long Beach } \\
\hline Dominguez & 2 & 0.00 & 0.00 & 0.00 & 0.00 & 0.00 & 0.00 & 0.00 \\
\hline Mesa & 3 & 0.00 & 0.00 & 0.00 & 0.000212 & 0.00 & 0.00 & 0.00 \\
\hline Pacific A & 4 & 0.00 & 0.00 & 0.00 & 0.00 & 0.00 & 0.00 & 0.00 \\
\hline Pacific & 5 & 0.00 & 0.00 & 0.00 & 0.00 & 0.00 & 0.00 & 0.00 \\
\hline Harbor & 6 & 0.00 & 0.00 & 0.00 & 0.00 & 0.00 & 0.00 & 0.00 \\
\hline Bent Spring & 7 & 0.00 & 0.00 & 0.00 & 0.00 & 0.00 & 0.00 & 0.00 \\
\hline Upper Wilmington A & 8 & 0.00 & 0.00 & 0.00 & 0.00 & 0.00 & 0.00 & 0.00 \\
\hline Upper Wilmington B & 9 & 0.00 & 0.00 & 0.00 & 0.00 & 0.00 & 0.00 & 0.00 \\
\hline Lower Wilmington & 10 & 0.00 & 0.00 & 0.00 & 0.00 & 0.00 & 0.00 & 0.00 \\
\hline Long Beach A & 11 & 0.00 & 0.00 & 0.00 & 0.00 & 0.00 & 0.00 & 0.00 \\
\hline Long Beach B & 12 & 0.00 & 0.00 & 0.00 & 0.00 & 0.00 & 0.00 & 0.00 \\
\hline Long Beach C & 13 & 0.00 & 0.00 & 0.00 & 0.00 & 0.00 & 0.00 & 0.00 \\
\hline Total & & 0.00 & 0.00 & 0.00 & 0.000212 & 0.00 & 0.00 & 0.00 \\
\hline
\end{tabular}


in Groundwater-flow Model._-Continued

\begin{tabular}{|c|c|c|c|c|c|}
\hline $\begin{array}{c}\text { Montebello } \\
\text { Forebay }\end{array}$ & Whitter & Central Basin & $\begin{array}{l}\text { North Orange } \\
\text { County }\end{array}$ & $\begin{array}{l}\text { South Orange } \\
\text { County }\end{array}$ & Total \\
\hline 0.00 & 0.00 & 0.00 & 0.00 & 0.00 & 0.00 \\
\hline 0.00 & 0.00 & 0.00 & 0.00 & 0.00 & 0.00 \\
\hline 0.00 & 0.00 & 0.00 & 0.00 & 0.00 & 0.00 \\
\hline 0.00 & 0.00 & 0.00 & 0.00 & 0.00 & 0.00 \\
\hline 0.00 & 0.00 & 0.00 & 0.00 & 0.00 & 0.00 \\
\hline 0.00 & 0.00 & 0.00 & 0.00 & 0.00 & 0.00 \\
\hline 0.00 & 0.00 & 0.00 & 0.00 & 0.00 & 0.00 \\
\hline 0.00 & 0.00 & 0.00 & 0.00 & 0.00 & 0.00 \\
\hline 0.00 & 0.00 & 0.00 & 0.00 & 0.00 & 3.63 \\
\hline 0.00 & 0.00 & 0.00 & 0.00 & 0.00 & 1.10 \\
\hline 0.00 & 0.00 & 0.00 & 0.00 & 0.00 & 0.583 \\
\hline 0.00 & 0.00 & 0.00 & 0.00 & 0.00 & 27.0 \\
\hline 0.00 & 0.00 & 0.00 & 0.00 & 0.00 & 32.3 \\
\hline 0.00 & 0.00 & 0.00 & 0.00 & 0.00 & 0.00 \\
\hline 0.00 & 0.00 & 0.00 & 0.00 & 0.00 & 1,210 \\
\hline 0.00 & 0.00 & 0.00 & 0.00 & 0.00 & 0.00 \\
\hline 0.00 & 0.00 & 0.00 & 0.00 & 0.00 & 0.00 \\
\hline 0.00 & 0.00 & 0.00 & 0.00 & 0.00 & 0.00 \\
\hline 0.00 & 0.00 & 0.00 & 0.00 & 0.00 & 0.00 \\
\hline 0.00 & 0.00 & 0.00 & 0.00 & 0.00 & 0.00 \\
\hline 0.00 & 0.00 & 0.00 & 0.00 & 0.00 & 0.00 \\
\hline 0.00 & 0.00 & 0.00 & 0.00 & 0.00 & 0.00 \\
\hline 0.00 & 0.00 & 0.00 & 0.00 & 0.00 & 0.00 \\
\hline 0.00 & 0.00 & 0.00 & 0.00 & 0.00 & 0.00 \\
\hline 0.00 & 0.00 & 0.00 & 0.00 & 0.00 & 0.00 \\
\hline 0.00 & 0.00 & 0.00 & 0.00 & 0.00 & 1,210 \\
\hline 0.00 & 0.00 & 0.00 & 0.00 & 0.00 & 0.00 \\
\hline 0.00 & 0.00 & 0.00 & 0.00 & 0.00 & 0.000212 \\
\hline 0.00 & 0.00 & 0.00 & 0.00 & 0.00 & 0.00 \\
\hline 0.00 & 0.00 & 0.00 & 0.00 & 0.00 & 0.00 \\
\hline 0.00 & 0.00 & 0.00 & 0.00 & 0.00 & 0.00 \\
\hline 0.00 & 0.00 & 0.00 & 0.00 & 0.00 & 0.00 \\
\hline 0.00 & 0.00 & 0.00 & 0.00 & 0.00 & 0.00 \\
\hline 0.00 & 0.00 & 0.00 & 0.00 & 0.00 & 0.00 \\
\hline 0.00 & 0.00 & 0.00 & 0.00 & 0.00 & 0.00 \\
\hline 0.00 & 0.00 & 0.00 & 0.00 & 0.00 & 0.00 \\
\hline 0.00 & 0.00 & 0.00 & 0.00 & 0.00 & 0.00 \\
\hline 0.00 & 0.00 & 0.00 & 0.00 & 0.00 & 0.00 \\
\hline 0.00 & 0.00 & 0.00 & 0.00 & 0.00 & 0.000212 \\
\hline
\end{tabular}


Table 4.16. Average annual 25-year water budget in acre-feet for increased-pumpage scenario with wet climatic conditions, Los Angeles Coastal Pla [WRD, Water Replenishment District of Southern California]

\begin{tabular}{|c|c|c|c|c|c|c|c|c|}
\hline $\begin{array}{c}\text { Chronostratigraphic } \\
\text { unit name }\end{array}$ & $\begin{array}{l}\text { Model } \\
\text { layer }\end{array}$ & $\begin{array}{c}\text { Los } \\
\text { Angeles } \\
\text { Forebay }\end{array}$ & $\begin{array}{c}\text { WRD } \\
\text { Central Basin }\end{array}$ & Orange County & $\begin{array}{l}\text { West } \\
\text { Coast }\end{array}$ & $\begin{array}{l}\text { Santa } \\
\text { Monica }\end{array}$ & Hollywood & $\begin{array}{l}\text { WRD Los } \\
\text { Angeles } \\
\text { Forebay }\end{array}$ \\
\hline \multicolumn{9}{|c|}{ Underflow from San Fernando Basin } \\
\hline Dominguez & 2 & 0.00 & 0.00 & 0.00 & 0.00 & 0.00 & 0.00 & 0.00 \\
\hline Mesa & 3 & 5,330 & 0.00 & 0.00 & 0.00 & 0.00 & 0.00 & 0.00 \\
\hline Pacific A & 4 & 0.00 & 0.00 & 0.00 & 0.00 & 0.00 & 0.00 & 0.00 \\
\hline Pacific & 5 & 0.00 & 0.00 & 0.00 & 0.00 & 0.00 & 0.00 & 0.00 \\
\hline Harbor & 6 & 0.00 & 0.00 & 0.00 & 0.00 & 0.00 & 0.00 & 0.00 \\
\hline Bent Spring & 7 & 0.00 & 0.00 & 0.00 & 0.00 & 0.00 & 0.00 & 0.00 \\
\hline Upper Wilmington A & 8 & 0.00 & 0.00 & 0.00 & 0.00 & 0.00 & 0.00 & 0.00 \\
\hline Upper Wilmington B & 9 & 0.00 & 0.00 & 0.00 & 0.00 & 0.00 & 0.00 & 0.00 \\
\hline Lower Wilmington & 10 & 0.00 & 0.00 & 0.00 & 0.00 & 0.00 & 0.00 & 0.00 \\
\hline Long Beach A & 11 & 0.00 & 0.00 & 0.00 & 0.00 & 0.00 & 0.00 & 0.00 \\
\hline Long Beach B & 12 & 0.00 & 0.00 & 0.00 & 0.00 & 0.00 & 0.00 & 0.00 \\
\hline Long Beach C & 13 & 0.00 & 0.00 & 0.00 & 0.00 & 0.00 & 0.00 & 0.00 \\
\hline \multirow[t]{2}{*}{ Total } & & 5,330 & 0.00 & 0.00 & 0.00 & 0.00 & 0.00 & 0.00 \\
\hline & & & & & & & & Drains \\
\hline Dominguez & 2 & 0.00 & -425 & -34.9 & -6.39 & -329 & 0.00 & 0.00 \\
\hline Mesa & 3 & 0.00 & -136 & 0.00 & 0.00 & $-1,260$ & 0.00 & 0.00 \\
\hline Pacific A & 4 & 0.00 & 0.00 & 0.00 & 0.00 & 0.00 & 0.00 & 0.00 \\
\hline Pacific & 5 & 0.00 & 0.00 & 0.00 & 0.00 & -203 & 0.00 & 0.00 \\
\hline Harbor & 6 & 0.00 & 0.00 & 0.00 & 0.00 & 0.00 & 0.00 & 0.00 \\
\hline Bent Spring & 7 & 0.00 & 0.00 & 0.00 & 0.00 & $-1,960$ & 0.00 & 0.00 \\
\hline Upper Wilmington A & 8 & 0.00 & 0.00 & 0.00 & 0.00 & 0.00 & 0.00 & 0.00 \\
\hline Upper Wilmington B & 9 & 0.00 & 0.00 & 0.00 & 0.00 & 0.00 & 0.00 & 0.00 \\
\hline Lower Wilmington & 10 & 0.00 & 0.00 & 0.00 & 0.00 & 0.00 & 0.00 & 0.00 \\
\hline Long Beach A & 11 & 0.00 & -723 & 0.00 & 0.00 & 0.00 & 0.00 & 0.00 \\
\hline Long Beach B & 12 & 0.00 & 0.00 & 0.00 & 0.00 & 0.00 & 0.00 & 0.00 \\
\hline Long Beach C & 13 & 0.00 & 0.00 & 0.00 & 0.00 & 0.00 & 0.00 & 0.00 \\
\hline Total & & 0.00 & $-1,280$ & -34.9 & -6.39 & $-3,760$ & 0.00 & 0.00 \\
\hline \multirow[t]{2}{*}{ Total net flow } & & 136 & $-1,760$ & -558 & $-5,170$ & $-3,400$ & $-1,710$ & $-1,750$ \\
\hline & & & & & & & & Change in storage \\
\hline Dominguez & 2 & -653 & $-1,380$ & -41.5 & -303 & $-1,320$ & -53.8 & $-1,720$ \\
\hline Mesa & 3 & 158 & 321 & -12.1 & $-3,780$ & -785 & 243 & -235 \\
\hline Pacific A & 4 & 22.0 & 283 & -5.38 & 1.13 & 0.00 & 0.00 & 1.06 \\
\hline Pacific & 5 & 11.5 & -588 & -25.8 & -840 & $-1,120$ & -8.72 & 53.1 \\
\hline Harbor & 6 & 18.2 & -41.3 & -17.9 & -96.2 & -0.0238 & 0.00 & 100 \\
\hline Bent Spring & 7 & 20.2 & -31.8 & -21.7 & 130 & -25.5 & -503 & 2.72 \\
\hline Upper Wilmington A & 8 & 426 & -39.9 & -301 & -49.8 & 61.9 & $-1,370$ & 45.6 \\
\hline Upper Wilmington B & 9 & 4.53 & -46.9 & -7.59 & -62.5 & -66.4 & -9.73 & 5.02 \\
\hline Lower Wilmington & 10 & -12.0 & -5.61 & -5.06 & -7.63 & -23.7 & 0.931 & 7.50 \\
\hline Long Beach A & 11 & -5.69 & -8.09 & -15.9 & -39.6 & -1.93 & 0.00312 & -7.77 \\
\hline Long Beach B & 12 & -1.36 & -79.9 & -49.2 & -22.4 & -2.75 & -0.0125 & -8.11 \\
\hline Long Beach C & 13 & 147 & -134 & -53.9 & -105 & -108 & -1.89 & 6.64 \\
\hline Total & & 136 & $-1,750$ & -557 & $-5,170$ & $-3,400$ & $-1,710$ & $-1,750$ \\
\hline
\end{tabular}


in Groundwater-flow Model._-Continued

\begin{tabular}{|c|c|c|c|c|c|}
\hline $\begin{array}{c}\text { Montebello } \\
\text { Forebay }\end{array}$ & Whitter & Central Basin & $\begin{array}{l}\text { North Orange } \\
\text { County }\end{array}$ & $\begin{array}{c}\text { South Orange } \\
\text { County }\end{array}$ & Total \\
\hline 0.00 & 0.00 & 0.00 & 0.00 & 0.00 & 0.00 \\
\hline 0.00 & 0.00 & 0.00 & 0.00 & 0.00 & 5,330 \\
\hline 0.00 & 0.00 & 0.00 & 0.00 & 0.00 & 0.00 \\
\hline 0.00 & 0.00 & 0.00 & 0.00 & 0.00 & 0.00 \\
\hline 0.00 & 0.00 & 0.00 & 0.00 & 0.00 & 0.00 \\
\hline 0.00 & 0.00 & 0.00 & 0.00 & 0.00 & 0.00 \\
\hline 0.00 & 0.00 & 0.00 & 0.00 & 0.00 & 0.00 \\
\hline 0.00 & 0.00 & 0.00 & 0.00 & 0.00 & 0.00 \\
\hline 0.00 & 0.00 & 0.00 & 0.00 & 0.00 & 0.00 \\
\hline 0.00 & 0.00 & 0.00 & 0.00 & 0.00 & 0.00 \\
\hline 0.00 & 0.00 & 0.00 & 0.00 & 0.00 & 0.00 \\
\hline 0.00 & 0.00 & 0.00 & 0.00 & 0.00 & 0.00 \\
\hline 0.00 & 0.00 & 0.00 & 0.00 & 0.00 & 5,330 \\
\hline-73.6 & 0.00 & -581 & -30.1 & -1.98 & $-1,480$ \\
\hline 0.00 & 0.00 & 0.00 & 0.00 & -3.16 & $-1,400$ \\
\hline 0.00 & 0.00 & 0.00 & 0.00 & 0.00 & 0.00 \\
\hline-350 & -51.4 & 0.00 & -385 & 0.00 & -990 \\
\hline 0.00 & 0.00 & 0.00 & 0.00 & 0.00 & 0.00 \\
\hline 0.00 & 0.00 & 0.00 & 0.00 & 0.00 & $-1,960$ \\
\hline 0.00 & 0.00 & 0.00 & -488 & 0.00 & -488 \\
\hline 0.00 & 0.00 & 0.00 & 0.00 & 0.00 & 0.00 \\
\hline 0.00 & 0.00 & 0.00 & -239 & 0.00 & -239 \\
\hline 0.00 & 0.00 & 0.00 & -18.0 & 0.00 & -741 \\
\hline 0.00 & 0.00 & 0.00 & 0.00 & 0.00 & 0.00 \\
\hline 0.00 & 0.00 & 0.00 & 0.00 & 0.00 & 0.00 \\
\hline-423 & -51.4 & -581 & $-1,160$ & -5.14 & $-7,300$ \\
\hline-825 & -242 & 311 & -9.13 & -483 & $-15,400$ \\
\hline-740 & -60.9 & -318 & 46.9 & -305 & $-6,850$ \\
\hline-646 & -207 & 564 & 0.00 & -114 & $-4,490$ \\
\hline-5.13 & -1.72 & 6.75 & 0.00 & 0.00 & 302 \\
\hline-58.1 & -135 & 8.66 & -90.5 & -35.0 & $-2,830$ \\
\hline-18.9 & -33.5 & 0.692 & 0.00 & -4.65 & -93.5 \\
\hline-0.845 & 0.00 & 24.9 & 0.00 & -0.772 & -406 \\
\hline 106 & 24.2 & 9.06 & -256 & -2.7 & $-1,350$ \\
\hline-1.34 & 1.85 & 16.7 & -3.94 & -2.09 & -172 \\
\hline-2.14 & 2.91 & 4.20 & 12.4 & -2.18 & -30.5 \\
\hline-18.4 & 23.3 & -1.09 & 217 & -3.59 & 139 \\
\hline-9.81 & 4.32 & -0.499 & 14.7 & -5.89 & -161 \\
\hline 573 & 139 & -4.18 & 49.9 & -7.49 & 501 \\
\hline-823 & -242 & 311 & -8.80 & -484 & $-15,400$ \\
\hline
\end{tabular}


Table 4.17. Average annual 25 -year water budget in acre-feet for increased-pumpage scenario with dry climatic conditions, Los Angeles Coastal Plai [WRD, Water Replenishment District of Southern California]

\begin{tabular}{|c|c|c|c|c|c|c|c|c|}
\hline $\begin{array}{c}\text { Chronostratigraphic } \\
\text { unit name }\end{array}$ & $\begin{array}{l}\text { Model } \\
\text { layer }\end{array}$ & $\begin{array}{l}\text { Los } \\
\text { Angeles } \\
\text { Forebay }\end{array}$ & $\begin{array}{c}\text { WRD } \\
\text { Central } \\
\text { Basin }\end{array}$ & $\begin{array}{l}\text { Orange } \\
\text { County }\end{array}$ & $\begin{array}{l}\text { West } \\
\text { Coast }\end{array}$ & $\begin{array}{l}\text { Santa } \\
\text { Monica }\end{array}$ & Hollywood & $\begin{array}{l}\text { WRD Los } \\
\text { Angeles } \\
\text { Forebay }\end{array}$ \\
\hline \multicolumn{9}{|c|}{ Pumping and net interborehole flow out } \\
\hline Dominguez & 2 & 0.00 & $-8,200$ & $-3,040$ & -38.0 & 0.00 & 0.00 & -0.987 \\
\hline Mesa & 3 & 0.00 & $-8,920$ & $-3,310$ & $-1,260$ & -300 & 0.00 & $-2,600$ \\
\hline Pacific A & 4 & 0.00 & $-31,700$ & $-7,710$ & 0.00 & 0.00 & 0.00 & -846 \\
\hline Pacific & 5 & 0.00 & $-28,700$ & $-26,700$ & $-8,710$ & -629 & -279 & $-4,730$ \\
\hline Harbor & 6 & 0.00 & $-37,800$ & $-9,930$ & $-15,000$ & 0.00 & 0.00 & $-1,010$ \\
\hline Bent Spring & 7 & 0.00 & $-15,100$ & $-2,260$ & $-6,490$ & $-7,360$ & $-1,260$ & $-3,700$ \\
\hline Upper Wilmington A & 8 & $-1,250$ & $-20,600$ & $-3,950$ & $-21,800$ & -132 & $-1,560$ & $-5,400$ \\
\hline Upper Wilmington B & 9 & 0.00 & $-7,910$ & -544 & $-1,870$ & -320 & -25.2 & -658 \\
\hline Lower Wilmington & 10 & 0.00 & $-3,000$ & 0.00 & $-6,570$ & -212 & 0.00 & -657 \\
\hline Long Beach A & 11 & 0.00 & -738 & 0.00 & -724 & 0.00 & 0.00 & -7.81 \\
\hline Long Beach B & 12 & 0.00 & -255 & 0.00 & -116 & 0.00 & 0.00 & -99.4 \\
\hline Long Beach C & 13 & 0.00 & 0.00 & 0.00 & 0.00 & -2.00 & 0.00 & -22.5 \\
\hline \multirow[t]{2}{*}{ Total } & & $-1,250$ & $-163,000$ & $-57,500$ & $-62,600$ & $-8,960$ & $-3,130$ & $-19,700$ \\
\hline & & & & & & & \multicolumn{2}{|c|}{ Net flow from adjacent inland zones } \\
\hline Dominguez & 2 & -560 & 12,000 & $-2,780$ & 14.6 & 19.2 & -98.6 & -53.8 \\
\hline Mesa & 3 & $-1,050$ & 25,200 & -458 & 1,260 & -306 & $-1,030$ & 3,330 \\
\hline Pacific A & 4 & -176 & 9,800 & 1,460 & -69.7 & 0.00 & 0.00 & $-1,750$ \\
\hline Pacific & 5 & $-3,020$ & 23,500 & 8,030 & -580 & 126 & -81.2 & 4,060 \\
\hline Harbor & 6 & -362 & 23,800 & 914 & -748 & -18.4 & 0.00 & $-1,480$ \\
\hline Bent Spring & 7 & -867 & 14,500 & 122 & 248 & 287 & -962 & 821 \\
\hline Upper Wilmington A & 8 & $-2,050$ & 8,240 & $-1,120$ & 2,770 & $-2,300$ & -2.71 & 5,980 \\
\hline Upper Wilmington B & 9 & -169 & 4,400 & $-2,970$ & 55.4 & 197 & -6.66 & 261 \\
\hline Lower Wilmington & 10 & -150 & 3,700 & -464 & 1,970 & -267 & -7.65 & 481 \\
\hline Long Beach A & 11 & -0.472 & 809 & 15.5 & 932 & -179 & -0.0191 & 43.3 \\
\hline Long Beach B & 12 & 33.1 & 1,310 & -272 & 560 & -119 & 3.67 & -26.8 \\
\hline Long Beach C & 13 & -667 & 2,100 & 101 & 1,250 & -462 & -3.93 & 53.7 \\
\hline \multirow[t]{2}{*}{ Total } & & $-9,030$ & 129,000 & 2,580 & 7,660 & $-3,030$ & $-2,190$ & 11,700 \\
\hline & & & & & & & \multicolumn{2}{|r|}{ Water spreading } \\
\hline Dominguez & 2 & 0.00 & 0.00 & 0.00 & 0.00 & 0.00 & 0.00 & 0.00 \\
\hline Mesa & 3 & 0.00 & 0.00 & 0.00 & 0.00 & 0.00 & 0.00 & 0.00 \\
\hline Pacific A & 4 & 0.00 & 0.00 & 0.00 & 0.00 & 0.00 & 0.00 & 0.00 \\
\hline Pacific & 5 & 0.00 & 0.00 & 0.00 & 0.00 & 0.00 & 0.00 & 0.00 \\
\hline Harbor & 6 & 0.00 & 0.00 & 0.00 & 0.00 & 0.00 & 0.00 & 0.00 \\
\hline Bent Spring & 7 & 0.00 & 0.00 & 0.00 & 0.00 & 0.00 & 0.00 & 0.00 \\
\hline Upper Wilmington A & 8 & 0.00 & 0.00 & 0.00 & 0.00 & 0.00 & 0.00 & 0.00 \\
\hline Upper Wilmington B & 9 & 0.00 & 0.00 & 0.00 & 0.00 & 0.00 & 0.00 & 0.00 \\
\hline Lower Wilmington & 10 & 0.00 & 0.00 & 0.00 & 0.00 & 0.00 & 0.00 & 0.00 \\
\hline Long Beach A & 11 & 0.00 & 0.00 & 0.00 & 0.00 & 0.00 & 0.00 & 0.00 \\
\hline Long Beach B & 12 & 0.00 & 0.00 & 0.00 & 0.00 & 0.00 & 0.00 & 0.00 \\
\hline Long Beach C & 13 & 0.00 & 0.00 & 0.00 & 0.00 & 0.00 & 0.00 & 0.00 \\
\hline Total & & 0.00 & 0.00 & 0.00 & 0.00 & 0.00 & 0.00 & 0.00 \\
\hline
\end{tabular}


n Groundwater-flow Model.

\begin{tabular}{|c|c|c|c|c|c|}
\hline $\begin{array}{c}\text { Montebello } \\
\text { Forebay }\end{array}$ & Whitter & Central Basin & $\begin{array}{c}\text { North Orange } \\
\text { County }\end{array}$ & $\begin{array}{l}\text { South Orange } \\
\text { County }\end{array}$ & Total \\
\hline-389 & 0.00 & 0.00 & 0.00 & -39.1 & $-11,700$ \\
\hline$-5,590$ & -20.4 & 0.00 & 0.00 & -207 & $-22,200$ \\
\hline$-2,880$ & 0.00 & 0.00 & 0.00 & 0.00 & $-43,100$ \\
\hline$-18,000$ & -16.8 & -3.54 & 0.00 & $-4,010$ & $-91,800$ \\
\hline$-8,080$ & -7.54 & 0.00 & 0.00 & $-1,130$ & $-73,000$ \\
\hline$-2,630$ & 0.00 & -17.8 & 0.00 & -96.2 & $-39,000$ \\
\hline$-5,350$ & 0.00 & 0.00 & 0.00 & -281 & $-60,300$ \\
\hline-392 & -0.557 & 0.00 & 0.00 & 0.00 & $-11,700$ \\
\hline-447 & -164 & 0.00 & -135 & 0.00 & $-11,200$ \\
\hline-234 & 0.00 & 0.00 & 0.00 & 0.00 & $-1,700$ \\
\hline-196 & 0.00 & 0.00 & 0.00 & 0.00 & -667 \\
\hline$-4,100$ & 0.00 & 0.00 & 0.00 & 0.00 & $-4,120$ \\
\hline$-48,300$ & -209 & -21.4 & -135 & $-5,760$ & $-371,000$ \\
\hline$-11,000$ & -85.2 & 86.7 & 6.12 & 2,430 & $2.96 \mathrm{E}-11$ \\
\hline$-27,800$ & -832 & 730 & 0.00 & 949 & $-7.17 \mathrm{E}-11$ \\
\hline$-7,960$ & -284 & $-1,030$ & 0.00 & 0.00 & $9.78 \mathrm{E}-12$ \\
\hline$-26,400$ & -464 & -576 & -658 & $-3,980$ & $-7.96 \mathrm{E}-11$ \\
\hline$-18,500$ & -128 & -343 & 0.00 & $-3,050$ & $9.64 \mathrm{E}-11$ \\
\hline$-14,900$ & 0.00 & 826 & 0.00 & -44.5 & $-4.55 \mathrm{E}-11$ \\
\hline$-8,810$ & -305 & -214 & -739 & $-1,450$ & $7.28 \mathrm{E}-12$ \\
\hline$-1,540$ & 266 & -228 & -329 & 56.1 & $-2.19 \mathrm{E}-11$ \\
\hline$-4,370$ & 51.9 & -262 & -463 & -213 & $1.02 \mathrm{E}-11$ \\
\hline 286 & -66.2 & -0.950 & $-1,150$ & -689 & $-9.09 \mathrm{E}-13$ \\
\hline-324 & -201 & 7.14 & -175 & -795 & $-2.05 \mathrm{E}-12$ \\
\hline$-1,080$ & -973 & -47.4 & -104 & -165 & $-1.99 \mathrm{E}-12$ \\
\hline$-122,000$ & $-3,020$ & $-1,050$ & $-3,610$ & $-6,950$ & $-4.91 \mathrm{E}-11$ \\
\hline 80,100 & 0.00 & 0.00 & 0.00 & 0.00 & 80,100 \\
\hline 40,700 & 0.00 & 0.00 & 0.00 & 0.00 & 40,700 \\
\hline 0.00 & 0.00 & 0.00 & 0.00 & 0.00 & 0.00 \\
\hline 1,850 & 0.00 & 0.00 & 0.00 & 0.00 & 1,850 \\
\hline 0.00 & 0.00 & 0.00 & 0.00 & 0.00 & 0.00 \\
\hline 0.00 & 0.00 & 0.00 & 0.00 & 0.00 & 0.00 \\
\hline 0.00 & 0.00 & 0.00 & 0.00 & 0.00 & 0.00 \\
\hline 0.00 & 0.00 & 0.00 & 0.00 & 0.00 & 0.00 \\
\hline 0.00 & 0.00 & 0.00 & 0.00 & 0.00 & 0.00 \\
\hline 0.00 & 0.00 & 0.00 & 0.00 & 0.00 & 0.00 \\
\hline 0.00 & 0.00 & 0.00 & 0.00 & 0.00 & 0.00 \\
\hline 0.00 & 0.00 & 0.00 & 0.00 & 0.00 & 0.00 \\
\hline 123,000 & 0.00 & 0.00 & 0.00 & 0.00 & 123,000 \\
\hline
\end{tabular}


Table 4.17. Average annual 25 -year water budget in acre-feet for increased-pumpage scenario with dry climatic conditions, Los Angeles Coastal Plai [WRD, Water Replenishment District of Southern California]

\begin{tabular}{|c|c|c|c|c|c|c|c|c|}
\hline $\begin{array}{c}\text { Chronostratigraphic } \\
\text { unit name }\end{array}$ & $\begin{array}{l}\text { Model } \\
\text { layer }\end{array}$ & $\begin{array}{c}\text { Los } \\
\text { Angeles } \\
\text { Forebay }\end{array}$ & $\begin{array}{l}\text { WRD } \\
\text { Central } \\
\text { Basin }\end{array}$ & $\begin{array}{l}\text { Orange } \\
\text { County }\end{array}$ & $\begin{array}{l}\text { West } \\
\text { Coast }\end{array}$ & $\begin{array}{l}\text { Santa } \\
\text { Monica }\end{array}$ & Hollywood & $\begin{array}{l}\text { WRD Los } \\
\text { Angeles } \\
\text { Forebay }\end{array}$ \\
\hline \multicolumn{9}{|c|}{ Injection and net interborehole flow in } \\
\hline Dominguez & 2 & 0.00 & 0.178 & 0.00265 & 33.1 & 0.00 & 0.00 & 0.000297 \\
\hline Mesa & 3 & 0.00 & 757 & 243 & 1,630 & 0.000162 & 0.00 & 0.00 \\
\hline Pacific A & 4 & 0.00 & 2,370 & 2,510 & 0.00 & 0.00 & 0.00 & 34 \\
\hline Pacific & 5 & 0.00 & 7,600 & 2,030 & 8,080 & 0.0275 & 0.00 & 1,210 \\
\hline Harbor & 6 & 0.00 & 2,120 & 100 & 5,340 & 0.00 & 0.00 & 1,320 \\
\hline Bent Spring & 7 & 0.00 & 1,310 & 0.00 & 9,760 & 244 & 43.8 & 758 \\
\hline Upper Wilmington A & 8 & 1,250 & 1,120 & 0.922 & 1,780 & 0.00 & 14.1 & 63.3 \\
\hline Upper Wilmington B & 9 & 0.00 & 501 & 0.261 & 94 & 0.00 & 0.00 & 15.3 \\
\hline Lower Wilmington & 10 & 0.00 & 45.3 & 0.00 & 106 & 0.00 & 0.00 & 28.8 \\
\hline Long Beach A & 11 & 0.00 & 2.82 & 0.00 & 0.00 & 0.00 & 0.00 & 0.00 \\
\hline Long Beach B & 12 & 0.00 & 0.295 & 0.00 & 0.00 & 0.00 & 0.00 & 0.00 \\
\hline Long Beach C & 13 & 0.00 & 0.00 & 0.00 & 0.00 & 0.248 & 0.00 & 0.00 \\
\hline \multirow[t]{2}{*}{ Total } & & 1,250 & 15,800 & 4,880 & 26,800 & 245 & 58 & 3,430 \\
\hline & & & & & & & & Areal recharge \\
\hline Dominguez & 2 & 1,130 & 7,810 & 2,740 & 1,070 & 1,470 & 1,760 & 1,340 \\
\hline Mesa & 3 & 1,650 & 3,350 & 19.9 & 8,840 & 6,290 & 1,010 & 38.1 \\
\hline Pacific A & 4 & 0.00 & 0.00 & 0.00 & 0.00 & 0.00 & 0.00 & 0.00 \\
\hline Pacific & 5 & 0.00 & 294 & 34.2 & 709 & 925 & 0.0392 & 0.00 \\
\hline Harbor & 6 & 189 & 2.99 & 0.00 & 240 & 0.00 & 0.00 & 177 \\
\hline Bent Spring & 7 & 14.7 & 0.00 & 0.00 & 815 & 6.40 & 0.00 & 0.00 \\
\hline Upper Wilmington A & 8 & 0.00 & 25.2 & 7.05 & 139 & 64.2 & 0.00 & 31.7 \\
\hline Upper Wilmington B & 9 & 0.00 & 0.00 & 0.00 & 16.6 & 8.94 & 0.00 & 0.00 \\
\hline Lower Wilmington & 10 & 0.00 & 19.3 & 0.00 & 0.00 & 0.00 & 0.00 & 0.00 \\
\hline Long Beach A & 11 & 0.00 & 4.99 & 0.00 & 0.00 & 0.00 & 0.00 & 0.00 \\
\hline Long Beach B & 12 & 0.00 & 0.00 & 0.00 & 0.00 & 0.00 & 0.00 & 0.00 \\
\hline Long Beach C & 13 & 211 & 94.8 & 0.00 & 93.8 & 3.08 & 0.00 & 126 \\
\hline \multirow[t]{2}{*}{ Total } & & 3,200 & 11,600 & 2,800 & 11,900 & 8,760 & 2,770 & 1,710 \\
\hline & & & & & & & \multicolumn{2}{|c|}{ Flow from Santa Monica Bay } \\
\hline Dominguez & 2 & 0.00 & 0.00 & 0.00 & 0.00 & 0.00115 & 0.00 & 0.00 \\
\hline Mesa & 3 & 0.00 & 0.00 & 0.00 & -52.4 & -284 & 0.00 & 0.00 \\
\hline Pacific A & 4 & 0.00 & 0.00 & 0.00 & 0.00 & 0.00 & 0.00 & 0.00 \\
\hline Pacific & 5 & 0.00 & 0.00 & 0.00 & 80.0 & -33.5 & 0.00 & 0.00 \\
\hline Harbor & 6 & 0.00 & 0.00 & 0.00 & 0.941 & 0.00 & 0.00 & 0.00 \\
\hline Bent Spring & 7 & 0.00 & 0.00 & 0.00 & 421 & -90.5 & 0.00 & 0.00 \\
\hline Upper Wilmington A & 8 & 0.00 & 0.00 & 0.00 & -0.93 & 130 & 0.00 & 0.00 \\
\hline Upper Wilmington B & 9 & 0.00 & 0.00 & 0.00 & -50.1 & -13.1 & 0.00 & 0.00 \\
\hline Lower Wilmington & 10 & 0.00 & 0.00 & 0.00 & 190 & -42.4 & 0.00 & 0.00 \\
\hline Long Beach A & 11 & 0.00 & 0.00 & 0.00 & -2.49 & -15.5 & 0.00 & 0.00 \\
\hline Long Beach B & 12 & 0.00 & 0.00 & 0.00 & 7.89 & -6.72 & 0.00 & 0.00 \\
\hline Long Beach C & 13 & 0.00 & 0.00 & 0.00 & 17.2 & 28.8 & 0.00 & 0.00 \\
\hline Total & & 0.00 & 0.00 & 0.00 & 611 & -327 & 0.00 & 0.00 \\
\hline
\end{tabular}


n Groundwater-flow Model.-Continued

\begin{tabular}{|c|c|c|c|c|c|}
\hline $\begin{array}{l}\text { Montebello } \\
\text { Forebay }\end{array}$ & Whitter & Central Basin & $\begin{array}{c}\text { North Orange } \\
\text { County }\end{array}$ & $\begin{array}{l}\text { South Orange } \\
\text { County }\end{array}$ & Total \\
\hline $9.81 \mathrm{E}-05$ & 0.00 & 0.00 & 0.00 & 0.00 & 33.3 \\
\hline 109 & 0.00 & 0.587 & 0.00 & 1,130 & 3,860 \\
\hline 696 & 0.00 & 0.00 & 0.00 & 0.00 & 5,600 \\
\hline 227 & 0.00 & 0.137 & 0.00 & 1,180 & 20,300 \\
\hline 679 & 0.00134 & 16.6 & 0.00 & 1,740 & 11,300 \\
\hline 36.7 & 0.00 & 0.887 & 0.00 & 4.43 & 12,200 \\
\hline 255 & 11.8 & 0.00 & 15.6 & 90.4 & 4,600 \\
\hline 3.63 & 0.952 & 0.00 & 17.1 & 0.00 & 632 \\
\hline 28.9 & 0.839 & 0.00 & 0.00 & 0.00 & 210 \\
\hline 0.0151 & 62.4 & 0.00 & 102 & 0.00 & 168 \\
\hline 21 & 74.9 & 0.00 & 0.00 & 0.00 & 96.2 \\
\hline 5,000 & 0.00 & 0.00 & 0.00 & 0.00 & 5,000 \\
\hline 7,060 & 151 & 18 & 135 & 4,140 & 64,000 \\
\hline 1,960 & 258 & 431 & 23.5 & 410 & 20,400 \\
\hline 969 & 336 & 778 & 0.00 & 198 & 23,500 \\
\hline 0.00 & 0.00 & 0.00 & 0.00 & 0.00 & 0.00 \\
\hline 198 & 428 & 178 & 696 & 0.000584 & 3,460 \\
\hline 1.35 & 0.00 & 0.00 & 0.00 & 0.00 & 610 \\
\hline 0.00 & 0.00 & 0.00 & 0.00 & 0.00 & 837 \\
\hline 172 & 39.5 & 0.00 & 176 & 0.00 & 654 \\
\hline 0.00 & 0.00 & 0.00 & 0.00 & 0.00 & 25.5 \\
\hline 0.00 & 21.4 & 0.00 & 60.5 & 0.00 & 101 \\
\hline 24.3 & 1.09 & 0.00 & 56.4 & 0.00 & 86.8 \\
\hline 6.05 & 0.00 & 0.00 & 0.00 & 0.00 & 6.05 \\
\hline 1,220 & 1,080 & 55.3 & 116 & 0.00 & 3,000 \\
\hline 4,550 & 2,160 & 1,440 & 1,130 & 608 & 52,700 \\
\hline 0.00 & 0.00 & 0.00 & 0.00 & 0.00 & 0.00115 \\
\hline 0.00 & 0.00 & 0.00 & 0.00 & 0.00 & -336 \\
\hline 0.00 & 0.00 & 0.00 & 0.00 & 0.00 & 0.00 \\
\hline 0.00 & 0.00 & 0.00 & 0.00 & 0.00 & 46.5 \\
\hline 0.00 & 0.00 & 0.00 & 0.00 & 0.00 & 0.941 \\
\hline 0.00 & 0.00 & 0.00 & 0.00 & 0.00 & 331 \\
\hline 0.00 & 0.00 & 0.00 & 0.00 & 0.00 & 129 \\
\hline 0.00 & 0.00 & 0.00 & 0.00 & 0.00 & -63.2 \\
\hline 0.00 & 0.00 & 0.00 & 0.00 & 0.00 & 147 \\
\hline 0.00 & 0.00 & 0.00 & 0.00 & 0.00 & -18.0 \\
\hline 0.00 & 0.00 & 0.00 & 0.00 & 0.00 & 1.16 \\
\hline 0.00 & 0.00 & 0.00 & 0.00 & 0.00 & 46.0 \\
\hline 0.00 & 0.00 & 0.00 & 0.00 & 0.00 & 284 \\
\hline
\end{tabular}


Table 4.17. Average annual 25 -year water budget in acre-feet for increased-pumpage scenario with dry climatic conditions, Los Angeles Coastal Plai [WRD, Water Replenishment District of Southern California]

\begin{tabular}{|c|c|c|c|c|c|c|c|c|}
\hline $\begin{array}{c}\text { Chronostratigraphic } \\
\text { unit name }\end{array}$ & $\begin{array}{l}\text { Model } \\
\text { layer }\end{array}$ & $\begin{array}{c}\text { Los } \\
\text { Angeles } \\
\text { Forebay }\end{array}$ & $\begin{array}{c}\text { WRD } \\
\text { Central } \\
\text { Basin }\end{array}$ & $\begin{array}{l}\text { Orange } \\
\text { County }\end{array}$ & $\begin{array}{l}\text { West } \\
\text { Coast }\end{array}$ & $\begin{array}{c}\text { Santa } \\
\text { Monica }\end{array}$ & Hollywood & $\begin{array}{l}\text { WRD Los } \\
\text { Angeles } \\
\text { Forebay }\end{array}$ \\
\hline & & & & & & & \multicolumn{2}{|c|}{ Flow from San Pedro Bay } \\
\hline Dominguez & 2 & 0.00 & 0.00 & 0.00 & 362 & 0.00 & 0.00 & 0.00 \\
\hline Mesa & 3 & 0.00 & 0.00 & 0.00 & 35.7 & 0.00 & 0.00 & 0.00 \\
\hline Pacific A & 4 & 0.00 & 0.00 & 0.00 & 0.00 & 0.00 & 0.00 & 0.00 \\
\hline Pacific & 5 & 0.00 & 0.00 & 0.00 & 1,560 & 0.00 & 0.00 & 0.00 \\
\hline Harbor & 6 & 0.00 & 0.00 & 0.00 & 1,530 & 0.00 & 0.00 & 0.00 \\
\hline Bent Spring & 7 & 0.00 & 0.00 & 0.00 & 672 & 0.00 & 0.00 & 0.00 \\
\hline Upper Wilmington A & 8 & 0.00 & 0.00 & 0.00 & 0.00 & 0.00 & 0.00 & 0.00 \\
\hline Upper Wilmington B & 9 & 0.00 & 0.00 & 0.00 & 253 & 0.00 & 0.00 & 0.00 \\
\hline Lower Wilmington & 10 & 0.00 & 0.00 & 0.00 & 1,910 & 0.00 & 0.00 & 0.00 \\
\hline Long Beach A & 11 & 0.00 & 0.00 & 0.00 & 372 & 0.00 & 0.00 & 0.00 \\
\hline Long Beach B & 12 & 0.00 & 0.00 & 0.00 & 401 & 0.00 & 0.00 & 0.00 \\
\hline Long Beach C & 13 & 0.00 & 0.00 & 0.00 & 144 & 0.00 & 0.00 & 0.00 \\
\hline \multirow[t]{2}{*}{ Total } & & 0.00 & 0.00 & 0.00 & 7,230 & 0.00 & 0.00 & 0.00 \\
\hline & & & & & & & \multicolumn{2}{|c|}{ Underflow from Orange County } \\
\hline Dominguez & 2 & 0.00 & 0.00 & 5,320 & 0.00 & 0.00 & 0.00 & 0.00 \\
\hline Mesa & 3 & 0.00 & 0.00 & 1,500 & 0.00 & 0.00 & 0.00 & 0.00 \\
\hline Pacific A & 4 & 0.00 & 0.00 & 3,740 & 0.00 & 0.00 & 0.00 & 0.00 \\
\hline Pacific & 5 & 0.00 & 0.00 & 15,200 & 0.00 & 0.00 & 0.00 & 0.00 \\
\hline Harbor & 6 & 0.00 & 0.00 & 7,740 & 0.00 & 0.00 & 0.00 & 0.00 \\
\hline Bent Spring & 7 & 0.00 & 0.00 & 1,480 & 0.00 & 0.00 & 0.00 & 0.00 \\
\hline Upper Wilmington A & 8 & 0.00 & 0.00 & 7,680 & 0.00 & 0.00 & 0.00 & 0.00 \\
\hline Upper Wilmington B & 9 & 0.00 & 0.00 & 3,510 & 0.00 & 0.00 & 0.00 & 0.00 \\
\hline Lower Wilmington & 10 & 0.00 & 0.00 & 270 & 0.00 & 0.00 & 0.00 & 0.00 \\
\hline Long Beach A & 11 & 0.00 & 0.00 & 61.5 & 0.00 & 0.00 & 0.00 & 0.00 \\
\hline Long Beach B & 12 & 0.00 & 0.00 & 105 & 0.00 & 0.00 & 0.00 & 0.00 \\
\hline Long Beach C & 13 & 0.00 & 0.00 & 40.6 & 0.00 & 0.00 & 0.00 & 0.00 \\
\hline \multirow[t]{2}{*}{ Total } & & 0.00 & 0.00 & 46,700 & 0.00 & 0.00 & 0.00 & 0.00 \\
\hline & & & & & & & \multicolumn{2}{|c|}{ Underflow from San Gabriel Basin } \\
\hline Dominguez & 2 & 0.00 & 0.00 & 0.00 & 0.00 & 0.00 & 0.00 & 0.00 \\
\hline Mesa & 3 & 0.00 & 0.00 & 0.00 & 0.00 & 0.00 & 0.00 & 0.00 \\
\hline Pacific A & 4 & 0.00 & 0.00 & 0.00 & 0.00 & 0.00 & 0.00 & 0.00 \\
\hline Pacific & 5 & 0.00 & 0.00 & 0.00 & 0.00 & 0.00 & 0.00 & 0.00 \\
\hline Harbor & 6 & 0.00 & 0.00 & 0.00 & 0.00 & 0.00 & 0.00 & 0.00 \\
\hline Bent Spring & 7 & 0.00 & 0.00 & 0.00 & 0.00 & 0.00 & 0.00 & 0.00 \\
\hline Upper Wilmington A & 8 & 0.00 & 0.00 & 0.00 & 0.00 & 0.00 & 0.00 & 0.00 \\
\hline Upper Wilmington B & 9 & 0.00 & 0.00 & 0.00 & 0.00 & 0.00 & 0.00 & 0.00 \\
\hline Lower Wilmington & 10 & 0.00 & 0.00 & 0.00 & 0.00 & 0.00 & 0.00 & 0.00 \\
\hline Long Beach A & 11 & 0.00 & 0.00 & 0.00 & 0.00 & 0.00 & 0.00 & 0.00 \\
\hline Long Beach B & 12 & 0.00 & 0.00 & 0.00 & 0.00 & 0.00 & 0.00 & 0.00 \\
\hline Long Beach C & 13 & 0.00 & 0.00 & 0.00 & 0.00 & 0.00 & 0.00 & 0.00 \\
\hline Total & & 0.00 & 0.00 & 0.00 & 0.00 & 0.00 & 0.00 & 0.00 \\
\hline
\end{tabular}


n Groundwater-flow Model.-Continued

\begin{tabular}{|c|c|c|c|c|c|}
\hline $\begin{array}{c}\text { Montebello } \\
\text { Forebay }\end{array}$ & Whitter & Central Basin & $\begin{array}{l}\text { North Orange } \\
\text { County }\end{array}$ & $\begin{array}{l}\text { South Orange } \\
\text { County }\end{array}$ & Total \\
\hline 0.00 & 0.00 & 0.00 & 0.00 & 25.8 & 388 \\
\hline 0.00 & 0.00 & 0.00 & 0.00 & 131 & 167 \\
\hline 0.00 & 0.00 & 0.00 & 0.00 & 0.00 & 0.00 \\
\hline 0.00 & 0.00 & 0.00 & 0.00 & 218 & 1,770 \\
\hline 0.00 & 0.00 & 0.00 & 0.00 & 782 & 2,310 \\
\hline 0.00 & 0.00 & 0.00 & 0.00 & 58.3 & 730 \\
\hline 0.00 & 0.00 & 0.00 & 0.00 & 0.00 & 0.00 \\
\hline 0.00 & 0.00 & 0.00 & 0.00 & 0.00 & 253 \\
\hline 0.00 & 0.00 & 0.00 & 0.00 & 105 & 2,010 \\
\hline 0.00 & 0.00 & 0.00 & 0.00 & -359 & 13.5 \\
\hline 0.00 & 0.00 & 0.00 & 0.00 & -107 & 294 \\
\hline 0.00 & 0.00 & 0.00 & 0.00 & -334 & -190 \\
\hline 0.00 & 0.00 & 0.00 & 0.00 & 519 & 7,750 \\
\hline 0.00 & 0.00 & 0.00 & 0.00 & 84.8 & 5,400 \\
\hline 0.00 & 0.00 & 0.00 & 0.00 & 441 & 1,940 \\
\hline 0.00 & 0.00 & 0.00 & 0.00 & 0.00 & 3,740 \\
\hline 0.00 & 0.00 & 0.00 & -46.7 & 1,390 & 16,600 \\
\hline 0.00 & 0.00 & 0.00 & 0.00 & 844 & 8,580 \\
\hline 0.00 & 0.00 & 0.00 & 0.00 & 111 & 1,590 \\
\hline 0.00 & 0.00 & 0.00 & 903 & 1,570 & 10,200 \\
\hline 0.00 & 0.00 & 0.00 & 288 & -34.9 & 3,770 \\
\hline 0.00 & 0.00 & 0.00 & 754 & 46.7 & 1,070 \\
\hline 0.00 & 0.00 & 0.00 & 1,180 & 1,090 & 2,340 \\
\hline 0.00 & 0.00 & 0.00 & 70.8 & 927 & 1,100 \\
\hline 0.00 & 0.00 & 0.00 & 82 & 518 & 640 \\
\hline 0.00 & 0.00 & 0.00 & 3,240 & 6,990 & 56,900 \\
\hline 0.00 & 0.00 & 0.00 & 0.00 & 0.00 & 0.00 \\
\hline 29,300 & 0.00 & 0.00 & 0.00 & 0.00 & 29,300 \\
\hline 0.00 & 0.00 & 0.00 & 0.00 & 0.00 & 0.00 \\
\hline 0.00 & 0.00 & 0.00 & 0.00 & 0.00 & 0.00 \\
\hline 0.00 & 0.00 & 0.00 & 0.00 & 0.00 & 0.00 \\
\hline 0.00 & 0.00 & 0.00 & 0.00 & 0.00 & 0.00 \\
\hline 0.00 & 0.00 & 0.00 & 0.00 & 0.00 & 0.00 \\
\hline 0.00 & 0.00 & 0.00 & 0.00 & 0.00 & 0.00 \\
\hline 0.00 & 0.00 & 0.00 & 0.00 & 0.00 & 0.00 \\
\hline 0.00 & 0.00 & 0.00 & 0.00 & 0.00 & 0.00 \\
\hline 0.00 & 0.00 & 0.00 & 0.00 & 0.00 & 0.00 \\
\hline 3,570 & 0.00 & 0.00 & 0.00 & 0.00 & 3,570 \\
\hline 32,900 & 0.00 & 0.00 & 0.00 & 0.00 & 32,900 \\
\hline
\end{tabular}


Table 4.17. Average annual 25 -year water budget in acre-feet for increased-pumpage scenario with dry climatic conditions, Los Angeles Coastal Plai [WRD, Water Replenishment District of Southern California]

\begin{tabular}{|c|c|c|c|c|c|c|c|c|}
\hline $\begin{array}{c}\text { Chronostratigraphic } \\
\text { unit name }\end{array}$ & $\begin{array}{l}\text { Model } \\
\text { layer }\end{array}$ & $\begin{array}{c}\text { Los } \\
\text { Angeles } \\
\text { Forebay }\end{array}$ & $\begin{array}{c}\text { WRD } \\
\text { Central } \\
\text { Basin }\end{array}$ & $\begin{array}{l}\text { Orange } \\
\text { County }\end{array}$ & $\begin{array}{l}\text { West } \\
\text { Coast }\end{array}$ & $\begin{array}{l}\text { Santa } \\
\text { Monica }\end{array}$ & Hollywood & $\begin{array}{l}\text { WRD Los } \\
\text { Angeles } \\
\text { Forebay }\end{array}$ \\
\hline & & & & & & & \multicolumn{2}{|c|}{ Underflow from Palos Verdes Hills } \\
\hline Dominguez & 2 & 0.00 & 0.00 & 0.00 & 0.00 & 0.00 & 0.00 & 0.00 \\
\hline Mesa & 3 & 0.00 & 0.00 & 0.00 & 0.00 & 0.00 & 0.00 & 0.00 \\
\hline Pacific A & 4 & 0.00 & 0.00 & 0.00 & 0.00 & 0.00 & 0.00 & 0.00 \\
\hline Pacific & 5 & 0.00 & 0.00 & 0.00 & 0.00 & 0.00 & 0.00 & 0.00 \\
\hline Harbor & 6 & 0.00 & 0.00 & 0.00 & 0.00 & 0.00 & 0.00 & 0.00 \\
\hline Bent Spring & 7 & 0.00 & 0.00 & 0.00 & 0.00 & 0.00 & 0.00 & 0.00 \\
\hline Upper Wilmington A & 8 & 0.00 & 0.00 & 0.00 & 0.00 & 0.00 & 0.00 & 0.00 \\
\hline Upper Wilmington B & 9 & 0.00 & 0.00 & 0.00 & 0.00 & 0.00 & 0.00 & 0.00 \\
\hline Lower Wilmington & 10 & 0.00 & 0.00 & 0.00 & 3.68 & 0.00 & 0.00 & 0.00 \\
\hline Long Beach A & 11 & 0.00 & 0.00 & 0.00 & 1.12 & 0.00 & 0.00 & 0.00 \\
\hline Long Beach B & 12 & 0.00 & 0.00 & 0.00 & 0.589 & 0.00 & 0.00 & 0.00 \\
\hline Long Beach C & 13 & 0.00 & 0.00 & 0.00 & 27.2 & 0.00 & 0.00 & 0.00 \\
\hline \multirow[t]{2}{*}{ Total } & & 0.00 & 0.00 & 0.00 & 32.5 & 0.00 & 0.00 & 0.00 \\
\hline & & & & & & & \multicolumn{2}{|c|}{ Flow from Marina Del Rey } \\
\hline Dominguez & 2 & 0.00 & 0.00 & 0.00 & 0.00 & 0.00 & 0.00 & 0.00 \\
\hline Mesa & 3 & 0.00 & 0.00 & 0.00 & 0.00 & 1,280 & 0.00 & 0.00 \\
\hline Pacific A & 4 & 0.00 & 0.00 & 0.00 & 0.00 & 0.00 & 0.00 & 0.00 \\
\hline Pacific & 5 & 0.00 & 0.00 & 0.00 & 0.00 & 0.00 & 0.00 & 0.00 \\
\hline Harbor & 6 & 0.00 & 0.00 & 0.00 & 0.00 & 0.00 & 0.00 & 0.00 \\
\hline Bent Spring & 7 & 0.00 & 0.00 & 0.00 & 0.00 & 0.00 & 0.00 & 0.00 \\
\hline Upper Wilmington A & 8 & 0.00 & 0.00 & 0.00 & 0.00 & 0.00 & 0.00 & 0.00 \\
\hline Upper Wilmington B & 9 & 0.00 & 0.00 & 0.00 & 0.00 & 0.00 & 0.00 & 0.00 \\
\hline Lower Wilmington & 10 & 0.00 & 0.00 & 0.00 & 0.00 & 0.00 & 0.00 & 0.00 \\
\hline Long Beach A & 11 & 0.00 & 0.00 & 0.00 & 0.00 & 0.00 & 0.00 & 0.00 \\
\hline Long Beach B & 12 & 0.00 & 0.00 & 0.00 & 0.00 & 0.00 & 0.00 & 0.00 \\
\hline Long Beach C & 13 & 0.00 & 0.00 & 0.00 & 0.00 & 0.00 & 0.00 & 0.00 \\
\hline \multirow[t]{2}{*}{ Total } & & 0.00 & 0.00 & 0.00 & 0.00 & 1,280 & 0.00 & 0.00 \\
\hline & & & & & & & \multicolumn{2}{|c|}{ Flow from Port of Long Beach } \\
\hline Dominguez & 2 & 0.00 & 0.00 & 0.00 & 0.00 & 0.00 & 0.00 & 0.00 \\
\hline Mesa & 3 & 0.00 & 0.00 & 0.00 & 0.000254 & 0.00 & 0.00 & 0.00 \\
\hline Pacific A & 4 & 0.00 & 0.00 & 0.00 & 0.00 & 0.00 & 0.00 & 0.00 \\
\hline Pacific & 5 & 0.00 & 0.00 & 0.00 & 0.00 & 0.00 & 0.00 & 0.00 \\
\hline Harbor & 6 & 0.00 & 0.00 & 0.00 & 0.00 & 0.00 & 0.00 & 0.00 \\
\hline Bent Spring & 7 & 0.00 & 0.00 & 0.00 & 0.00 & 0.00 & 0.00 & 0.00 \\
\hline Upper Wilmington A & 8 & 0.00 & 0.00 & 0.00 & 0.00 & 0.00 & 0.00 & 0.00 \\
\hline Upper Wilmington B & 9 & 0.00 & 0.00 & 0.00 & 0.00 & 0.00 & 0.00 & 0.00 \\
\hline Lower Wilmington & 10 & 0.00 & 0.00 & 0.00 & 0.00 & 0.00 & 0.00 & 0.00 \\
\hline Long Beach A & 11 & 0.00 & 0.00 & 0.00 & 0.00 & 0.00 & 0.00 & 0.00 \\
\hline Long Beach B & 12 & 0.00 & 0.00 & 0.00 & 0.00 & 0.00 & 0.00 & 0.00 \\
\hline Long Beach C & 13 & 0.00 & 0.00 & 0.00 & 0.00 & 0.00 & 0.00 & 0.00 \\
\hline Total & & 0.00 & 0.00 & 0.00 & 0.000254 & 0.00 & 0.00 & 0.00 \\
\hline
\end{tabular}


n Groundwater-flow Model.-Continued

\begin{tabular}{|c|c|c|c|c|c|}
\hline $\begin{array}{c}\text { Montebello } \\
\text { Forebay }\end{array}$ & Whitter & Central Basin & $\begin{array}{l}\text { North Orange } \\
\text { County }\end{array}$ & $\begin{array}{c}\text { South Orange } \\
\text { County }\end{array}$ & Total \\
\hline 0.00 & 0.00 & 0.00 & 0.00 & 0.00 & 0.00 \\
\hline 0.00 & 0.00 & 0.00 & 0.00 & 0.00 & 0.00 \\
\hline 0.00 & 0.00 & 0.00 & 0.00 & 0.00 & 0.00 \\
\hline 0.00 & 0.00 & 0.00 & 0.00 & 0.00 & 0.00 \\
\hline 0.00 & 0.00 & 0.00 & 0.00 & 0.00 & 0.00 \\
\hline 0.00 & 0.00 & 0.00 & 0.00 & 0.00 & 0.00 \\
\hline 0.00 & 0.00 & 0.00 & 0.00 & 0.00 & 0.00 \\
\hline 0.00 & 0.00 & 0.00 & 0.00 & 0.00 & 0.00 \\
\hline 0.00 & 0.00 & 0.00 & 0.00 & 0.00 & 3.68 \\
\hline 0.00 & 0.00 & 0.00 & 0.00 & 0.00 & 1.12 \\
\hline 0.00 & 0.00 & 0.00 & 0.00 & 0.00 & 0.589 \\
\hline 0.00 & 0.00 & 0.00 & 0.00 & 0.00 & 27.2 \\
\hline 0.00 & 0.00 & 0.00 & 0.00 & 0.00 & 32.5 \\
\hline 0.00 & 0.00 & 0.00 & 0.00 & 0.00 & 0.00 \\
\hline 0.00 & 0.00 & 0.00 & 0.00 & 0.00 & 1,280 \\
\hline 0.00 & 0.00 & 0.00 & 0.00 & 0.00 & 0.00 \\
\hline 0.00 & 0.00 & 0.00 & 0.00 & 0.00 & 0.00 \\
\hline 0.00 & 0.00 & 0.00 & 0.00 & 0.00 & 0.00 \\
\hline 0.00 & 0.00 & 0.00 & 0.00 & 0.00 & 0.00 \\
\hline 0.00 & 0.00 & 0.00 & 0.00 & 0.00 & 0.00 \\
\hline 0.00 & 0.00 & 0.00 & 0.00 & 0.00 & 0.00 \\
\hline 0.00 & 0.00 & 0.00 & 0.00 & 0.00 & 0.00 \\
\hline 0.00 & 0.00 & 0.00 & 0.00 & 0.00 & 0.00 \\
\hline 0.00 & 0.00 & 0.00 & 0.00 & 0.00 & 0.00 \\
\hline 0.00 & 0.00 & 0.00 & 0.00 & 0.00 & 0.00 \\
\hline 0.00 & 0.00 & 0.00 & 0.00 & 0.00 & 1,280 \\
\hline 0.00 & 0.00 & 0.00 & 0.00 & 0.00 & 0.00 \\
\hline 0.00 & 0.00 & 0.00 & 0.00 & 0.00 & 0.000254 \\
\hline 0.00 & 0.00 & 0.00 & 0.00 & 0.00 & 0.00 \\
\hline 0.00 & 0.00 & 0.00 & 0.00 & 0.00 & 0.00 \\
\hline 0.00 & 0.00 & 0.00 & 0.00 & 0.00 & 0.00 \\
\hline 0.00 & 0.00 & 0.00 & 0.00 & 0.00 & 0.00 \\
\hline 0.00 & 0.00 & 0.00 & 0.00 & 0.00 & 0.00 \\
\hline 0.00 & 0.00 & 0.00 & 0.00 & 0.00 & 0.00 \\
\hline 0.00 & 0.00 & 0.00 & 0.00 & 0.00 & 0.00 \\
\hline 0.00 & 0.00 & 0.00 & 0.00 & 0.00 & 0.00 \\
\hline 0.00 & 0.00 & 0.00 & 0.00 & 0.00 & 0.00 \\
\hline 0.00 & 0.00 & 0.00 & 0.00 & 0.00 & 0.00 \\
\hline 0.00 & 0.00 & 0.00 & 0.00 & 0.00 & 0.000254 \\
\hline
\end{tabular}


Table 4.17. Average annual 25 -year water budget in acre-feet for increased-pumpage scenario with dry climatic conditions, Los Angeles Coastal Plai [WRD, Water Replenishment District of Southern California]

\begin{tabular}{|c|c|c|c|c|c|c|c|c|}
\hline $\begin{array}{c}\text { Chronostratigraphic } \\
\text { unit name }\end{array}$ & $\begin{array}{l}\text { Model } \\
\text { layer }\end{array}$ & $\begin{array}{c}\text { Los } \\
\text { Angeles } \\
\text { Forebay }\end{array}$ & $\begin{array}{l}\text { WRD } \\
\text { Central } \\
\text { Basin }\end{array}$ & $\begin{array}{l}\text { Orange } \\
\text { County }\end{array}$ & $\begin{array}{l}\text { West } \\
\text { Coast }\end{array}$ & $\begin{array}{l}\text { Santa } \\
\text { Monica }\end{array}$ & Hollywood & $\begin{array}{l}\text { WRD Los } \\
\text { Angeles } \\
\text { Forebay }\end{array}$ \\
\hline \multicolumn{9}{|c|}{ Underflow from San Fernando Basin } \\
\hline Dominguez & 2 & 0.00 & 0.00 & 0.00 & 0.00 & 0.00 & 0.00 & 0.00 \\
\hline Mesa & 3 & 5,400 & 0.00 & 0.00 & 0.00 & 0.00 & 0.00 & 0.00 \\
\hline Pacific A & 4 & 0.00 & 0.00 & 0.00 & 0.00 & 0.00 & 0.00 & 0.00 \\
\hline Pacific & 5 & 0.00 & 0.00 & 0.00 & 0.00 & 0.00 & 0.00 & 0.00 \\
\hline Harbor & 6 & 0.00 & 0.00 & 0.00 & 0.00 & 0.00 & 0.00 & 0.00 \\
\hline Bent Spring & 7 & 0.00 & 0.00 & 0.00 & 0.00 & 0.00 & 0.00 & 0.00 \\
\hline Upper Wilmington A & 8 & 0.00 & 0.00 & 0.00 & 0.00 & 0.00 & 0.00 & 0.00 \\
\hline Upper Wilmington B & 9 & 0.00 & 0.00 & 0.00 & 0.00 & 0.00 & 0.00 & 0.00 \\
\hline Lower Wilmington & 10 & 0.00 & 0.00 & 0.00 & 0.00 & 0.00 & 0.00 & 0.00 \\
\hline Long Beach A & 11 & 0.00 & 0.00 & 0.00 & 0.00 & 0.00 & 0.00 & 0.00 \\
\hline Long Beach B & 12 & 0.00 & 0.00 & 0.00 & 0.00 & 0.00 & 0.00 & 0.00 \\
\hline Long Beach C & 13 & 0.00 & 0.00 & 0.00 & 0.00 & 0.00 & 0.00 & 0.00 \\
\hline \multirow[t]{2}{*}{ Total } & & 5,400 & 0.00 & 0.00 & 0.00 & 0.00 & 0.00 & 0.00 \\
\hline & & & & & & & & Drains \\
\hline Dominguez & 2 & 0.00 & -411 & -36.9 & -5.53 & -308 & 0.00 & 0.00 \\
\hline Mesa & 3 & 0.00 & -131 & 0.00 & 0.00 & -955 & 0.00 & 0.00 \\
\hline Pacific A & 4 & 0.00 & 0.00 & 0.00 & 0.00 & 0.00 & 0.00 & 0.00 \\
\hline Pacific & 5 & 0.00 & 0.00 & 0.00 & 0.00 & -232 & 0.00 & 0.00 \\
\hline Harbor & 6 & 0.00 & 0.00 & 0.00 & 0.00 & 0.00 & 0.00 & 0.00 \\
\hline Bent Spring & 7 & 0.00 & 0.00 & 0.00 & 0.00 & $-1,540$ & 0.00 & 0.00 \\
\hline Upper Wilmington A & 8 & 0.00 & 0.00 & 0.00 & 0.00 & 0.00 & 0.00 & 0.00 \\
\hline Upper Wilmington B & 9 & 0.00 & 0.00 & 0.00 & 0.00 & 0.00 & 0.00 & 0.00 \\
\hline Lower Wilmington & 10 & 0.00 & 0.00 & 0.00 & 0.00 & 0.00 & 0.00 & 0.00 \\
\hline Long Beach A & 11 & 0.00 & -717 & 0.00 & 0.00 & 0.00 & 0.00 & 0.00 \\
\hline Long Beach B & 12 & 0.00 & 0.00 & 0.00 & 0.00 & 0.00 & 0.00 & 0.00 \\
\hline Long Beach C & 13 & 0.00 & 0.00 & 0.00 & 0.00 & 0.00 & 0.00 & 0.00 \\
\hline Total & & 0.00 & $-1,260$ & -36.9 & -5.53 & $-3,030$ & 0.00 & 0.00 \\
\hline \multirow[t]{2}{*}{ Total net flow } & & -436 & $-7,490$ & -563 & $-8,320$ & $-5,060$ & $-2,480$ & $-2,860$ \\
\hline & & & & & & & & Change in storage \\
\hline Dominguez & 2 & -819 & $-4,130$ & -18.6 & -492 & $-1,550$ & -140 & $-2,130$ \\
\hline Mesa & 3 & 7.46 & $-1,950$ & -10.9 & $-5,840$ & $-1,330$ & -327 & -700 \\
\hline Pacific A & 4 & 3.07 & 40.9 & -3.63 & 0.690 & 0.00 & 0.00 & -0.583 \\
\hline Pacific & 5 & -4.61 & -770 & -22.3 & $-1,340$ & $-1,900$ & -17.9 & -27.5 \\
\hline Harbor & 6 & -6.98 & -68.8 & -17.2 & -210 & -0.0327 & 0.00 & 25.0 \\
\hline Bent Spring & 7 & 3.00 & -56.5 & -20.0 & -27.7 & -47.9 & -560 & 0.888 \\
\hline Upper Wilmington A & 8 & 344 & -84.4 & -315 & -77.4 & 24.3 & $-1,420$ & 14.7 \\
\hline Upper Wilmington B & 9 & 4.20 & -99.1 & -7.79 & -83.0 & -75.8 & -10.0 & 1.11 \\
\hline Lower Wilmington & 10 & -45.1 & -30.0 & -6.76 & -24.2 & -37.9 & -2.94 & 2.83 \\
\hline Long Beach A & 11 & -7.03 & -28.9 & -20.0 & -54.8 & -5.01 & -0.00182 & -11.1 \\
\hline Long Beach B & 12 & -2.13 & -118 & -56.9 & -32.5 & -8.10 & -0.0607 & -14.4 \\
\hline Long Beach C & 13 & 87.0 & -196 & -62.8 & -131 & -130 & -4.09 & -24.4 \\
\hline Total & & -436 & $-7,490$ & -562 & $-8,320$ & $-5,060$ & $-2,480$ & $-2,860$ \\
\hline
\end{tabular}


n Groundwater-flow Model.-Continued

\begin{tabular}{|c|c|c|c|c|c|}
\hline $\begin{array}{c}\text { Montebello } \\
\text { Forebay }\end{array}$ & Whitter & Central Basin & $\begin{array}{l}\text { North Orange } \\
\text { County }\end{array}$ & $\begin{array}{l}\text { South Orange } \\
\text { County }\end{array}$ & Total \\
\hline 0.00 & 0.00 & 0.00 & 0.00 & 0.00 & 0.00 \\
\hline 0.00 & 0.00 & 0.00 & 0.00 & 0.00 & 5,400 \\
\hline 0.00 & 0.00 & 0.00 & 0.00 & 0.00 & 0.00 \\
\hline 0.00 & 0.00 & 0.00 & 0.00 & 0.00 & 0.00 \\
\hline 0.00 & 0.00 & 0.00 & 0.00 & 0.00 & 0.00 \\
\hline 0.00 & 0.00 & 0.00 & 0.00 & 0.00 & 0.00 \\
\hline 0.00 & 0.00 & 0.00 & 0.00 & 0.00 & 0.00 \\
\hline 0.00 & 0.00 & 0.00 & 0.00 & 0.00 & 0.00 \\
\hline 0.00 & 0.00 & 0.00 & 0.00 & 0.00 & 0.00 \\
\hline 0.00 & 0.00 & 0.00 & 0.00 & 0.00 & 0.00 \\
\hline 0.00 & 0.00 & 0.00 & 0.00 & 0.00 & 0.00 \\
\hline 0.00 & 0.00 & 0.00 & 0.00 & 0.00 & 0.00 \\
\hline 0.00 & 0.00 & 0.00 & 0.00 & 0.00 & 5,400 \\
\hline-109 & 0.00 & -528 & -20.7 & -2.26 & $-1,420$ \\
\hline 0.00 & 0.00 & 0.00 & 0.00 & -7.48 & $-1,090$ \\
\hline 0.00 & 0.00 & 0.00 & 0.00 & 0.00 & 0.00 \\
\hline-307 & -16.8 & 0.00 & -273 & 0.00 & -829 \\
\hline 0.00 & 0.00 & 0.00 & 0.00 & 0.00 & 0.00 \\
\hline 0.00 & 0.00 & 0.00 & 0.00 & 0.00 & $-1,540$ \\
\hline 0.00 & 0.00 & 0.00 & -439 & 0.00 & -439 \\
\hline 0.00 & 0.00 & 0.00 & 0.00 & 0.00 & 0.00 \\
\hline 0.00 & 0.00 & 0.00 & -222 & 0.00 & -222 \\
\hline 0.00 & 0.00 & 0.00 & -30.1 & 0.00 & -748 \\
\hline 0.00 & 0.00 & 0.00 & 0.00 & 0.00 & 0.00 \\
\hline 0.00 & 0.00 & 0.00 & 0.00 & 0.00 & 0.00 \\
\hline-417 & -16.8 & -528 & -985 & -9.74 & $-6,290$ \\
\hline$-3,980$ & -936 & -139 & -232 & -471 & $-33,000$ \\
\hline$-1,970$ & -76.7 & -375 & 45.5 & -327 & $-12,000$ \\
\hline$-1,790$ & -476 & 231 & 0.00 & -90 & $-12,300$ \\
\hline-23.0 & -14.9 & 1.41 & 0.00 & 0.00 & 3.87 \\
\hline-150 & -233 & -3.56 & -174 & -25.9 & $-4,670$ \\
\hline-54.3 & -85.1 & 0.319 & 0.00 & -3.94 & -421 \\
\hline-2.03 & 0.00 & 8.93 & 0.00 & -0.536 & -702 \\
\hline-79.6 & 7.04 & 7.59 & -312 & -2.14 & $-1,890$ \\
\hline-3.93 & 1.71 & 5.72 & -5.98 & -2.18 & -275 \\
\hline-5.99 & -0.601 & 0.943 & 0.833 & -2.83 & -152 \\
\hline-39.5 & 22.6 & -2.61 & 213 & -3.16 & 63.2 \\
\hline-31.6 & -0.58 & -3.69 & 2.80 & -6.02 & -271 \\
\hline 172 & -79.8 & -9.85 & -1.55 & -7.86 & -389 \\
\hline$-3,980$ & -935 & -139 & -232 & -472 & $-33,000$ \\
\hline
\end{tabular}


Table 4.18. Average annual 25 -year water budget in acre-feet for optimized increased-pumpage scenario with wet conditions, Los Angeles Coastal P [WRD, Water Replenishment District of Southern California]

\begin{tabular}{|c|c|c|c|c|c|c|c|c|}
\hline $\begin{array}{l}\text { Chronostratigraphic } \\
\text { unit name }\end{array}$ & $\begin{array}{l}\text { Model } \\
\text { layer }\end{array}$ & $\begin{array}{l}\text { Los Angeles } \\
\text { Forebay }\end{array}$ & $\begin{array}{c}\text { WRD } \\
\text { Central } \\
\text { Basin }\end{array}$ & $\begin{array}{l}\text { Orange } \\
\text { County }\end{array}$ & $\begin{array}{l}\text { West } \\
\text { Coast }\end{array}$ & $\begin{array}{c}\text { Santa } \\
\text { Monica }\end{array}$ & Hollywood & $\begin{array}{l}\text { WRD Los } \\
\text { Angeles } \\
\text { Forebay }\end{array}$ \\
\hline \multicolumn{9}{|c|}{ Pumping and net interborehole flow out } \\
\hline Dominguez & 2 & 0.00 & $-8,430$ & $-3,030$ & -35.0 & 0.00 & 0.00 & -1.01 \\
\hline Mesa & 3 & 0.00 & $-9,000$ & $-3,350$ & $-1,210$ & -301 & 0.00 & $-2,940$ \\
\hline Pacific A & 4 & 0.00 & $-31,800$ & $-7,660$ & 0.00 & 0.00 & 0.00 & -843 \\
\hline Pacific & 5 & 0.00 & $-28,600$ & $-26,700$ & $-9,150$ & -625 & -299 & $-4,710$ \\
\hline Harbor & 6 & 0.00 & $-37,900$ & $-9,980$ & $-15,200$ & 0.00 & 0.00 & $-1,010$ \\
\hline Bent Spring & 7 & 0.00 & $-15,200$ & $-2,270$ & $-6,500$ & $-7,370$ & $-1,250$ & $-3,720$ \\
\hline Upper Wilmington A & 8 & $-1,230$ & $-20,600$ & $-3,960$ & $-21,800$ & -134 & $-1,550$ & $-5,400$ \\
\hline Upper Wilmington B & 9 & 0.00 & $-7,870$ & -543 & $-1,880$ & -320 & -25.2 & -654 \\
\hline Lower Wilmington & 10 & 0.00 & $-2,980$ & 0.00 & $-6,490$ & -205 & 0.00 & -651 \\
\hline Long Beach A & 11 & 0.00 & -709 & 0.00 & -717 & 0.00 & 0.00 & -7.97 \\
\hline Long Beach B & 12 & 0.00 & -246 & 0.00 & -113 & 0.00 & 0.00 & -98.7 \\
\hline Long Beach C & 13 & 0.00 & 0.00 & 0.00 & 0.00 & -1.00 & 0.00 & -17.8 \\
\hline \multirow[t]{2}{*}{ Total } & \multirow{2}{*}{\multicolumn{8}{|c|}{$30 \quad-20,100$}} \\
\hline & & & & & & & & \\
\hline Dominguez & 2 & -601 & 14,100 & $-1,880$ & -21.7 & 19.4 & -111 & 202 \\
\hline Mesa & 3 & $-1,200$ & 30,500 & -189 & 817 & -371 & $-1,040$ & 4,170 \\
\hline Pacific A & 4 & -213 & 9,710 & 2,280 & -69.7 & 0.00 & 0.00 & $-1,800$ \\
\hline Pacific & 5 & $-3,010$ & 23,000 & 10,500 & $-1,270$ & 159 & -70.7 & 4,250 \\
\hline Harbor & 6 & -388 & 24,000 & 2,180 & $-1,510$ & -4.15 & 0.00 & $-1,500$ \\
\hline Bent Spring & 7 & -867 & 14,700 & 783 & 36.0 & 336 & -953 & 833 \\
\hline Upper Wilmington A & 8 & $-1,920$ & 8,020 & -633 & 1,500 & $-1,320$ & 58.2 & 6,030 \\
\hline Upper Wilmington B & 9 & -167 & 4,150 & $-2,550$ & -70.5 & 223 & -4.83 & 260 \\
\hline Lower Wilmington & 10 & -84.5 & 4,080 & -376 & 1,630 & -223 & -1.55 & 474 \\
\hline Long Beach A & 11 & -0.432 & 821 & 13.7 & 801 & -157 & -0.0204 & 48.5 \\
\hline Long Beach B & 12 & 39.9 & 1,120 & -242 & 495 & -98.5 & 4.56 & -16.0 \\
\hline Long Beach C & 13 & -626 & 2,070 & 128 & 1,090 & -355 & 0.796 & 60.9 \\
\hline Total & & $-9,030$ & 136,000 & 9,980 & 3,430 & $-1,790$ & $-2,120$ & 13,000 \\
\hline
\end{tabular}

\begin{tabular}{|c|c|c|c|c|c|c|c|c|}
\hline & & & & & & & \multicolumn{2}{|c|}{ Water spreading } \\
\hline Dominguez & 2 & 0.00 & 0.00 & 0.00 & 0.00 & 0.00 & 0.00 & 0.00 \\
\hline Mesa & 3 & 0.00 & 0.00 & 0.00 & 0.00 & 0.00 & 0.00 & 0.00 \\
\hline Pacific A & 4 & 0.00 & 0.00 & 0.00 & 0.00 & 0.00 & 0.00 & 0.00 \\
\hline Pacific & 5 & 0.00 & 0.00 & 0.00 & 0.00 & 0.00 & 0.00 & 0.00 \\
\hline Harbor & 6 & 0.00 & 0.00 & 0.00 & 0.00 & 0.00 & 0.00 & 0.00 \\
\hline Bent Spring & 7 & 0.00 & 0.00 & 0.00 & 0.00 & 0.00 & 0.00 & 0.00 \\
\hline Upper Wilmington A & 8 & 0.00 & 0.00 & 0.00 & 0.00 & 0.00 & 0.00 & 0.00 \\
\hline Upper Wilmington B & 9 & 0.00 & 0.00 & 0.00 & 0.00 & 0.00 & 0.00 & 0.00 \\
\hline Lower Wilmington & 10 & 0.00 & 0.00 & 0.00 & 0.00 & 0.00 & 0.00 & 0.00 \\
\hline Long Beach A & 11 & 0.00 & 0.00 & 0.00 & 0.00 & 0.00 & 0.00 & 0.00 \\
\hline Long Beach B & 12 & 0.00 & 0.00 & 0.00 & 0.00 & 0.00 & 0.00 & 0.00 \\
\hline Long Beach C & 13 & 0.00 & 0.00 & 0.00 & 0.00 & 0.00 & 0.00 & 0.00 \\
\hline Total & & 0.00 & 0.00 & 0.00 & 0.00 & 0.00 & 0.00 & 0.00 \\
\hline
\end{tabular}


lain Groundwater-flow Model.

\begin{tabular}{|c|c|c|c|c|c|}
\hline $\begin{array}{c}\text { Montebello } \\
\text { Forebay }\end{array}$ & Whitter & Central Basin & $\begin{array}{l}\text { North Orange } \\
\text { County }\end{array}$ & $\begin{array}{c}\text { South Orange } \\
\text { County }\end{array}$ & Total \\
\hline-479 & 0.00 & 0.00 & 0.00 & -38.5 & $-12,000$ \\
\hline$-5,720$ & -39.9 & 0.00 & 0.00 & -209 & $-22,800$ \\
\hline$-2,880$ & 0.00 & 0.00 & 0.00 & 0.00 & $-43,200$ \\
\hline$-18,000$ & -16.9 & -4.56 & 0.00 & $-3,940$ & $-92,000$ \\
\hline$-8,080$ & 0.00 & 0.00 & 0.00 & $-1,110$ & $-73,200$ \\
\hline$-2,630$ & 0.00 & -17.2 & 0.00 & -102 & $-39,000$ \\
\hline$-5,340$ & 0.00 & 0.00 & 0.00 & -323 & $-60,400$ \\
\hline-392 & -0.853 & 0.00 & 0.00 & 0.00 & $-11,700$ \\
\hline-448 & -161 & 0.00 & -137 & 0.00 & $-11,100$ \\
\hline-230 & 0.00 & 0.00 & 0.00 & 0.00 & $-1,660$ \\
\hline-191 & 0.00 & 0.00 & 0.00 & 0.00 & -648 \\
\hline$-4,090$ & 0.00 & 0.00 & 0.00 & 0.00 & $-4,110$ \\
\hline$-48,500$ & -219 & -21.7 & -137 & $-5,720$ & $-372,000$ \\
\hline$-14,200$ & -54.4 & 108 & 7.18 & 2,450 & $9.55 \mathrm{E}-12$ \\
\hline$-33,900$ & -539 & 913 & 0.00 & 850 & $-4.38 \mathrm{E}-11$ \\
\hline$-8,590$ & -331 & -984 & 0.00 & 0.00 & $-4.49 \mathrm{E}-11$ \\
\hline$-27,700$ & -454 & -577 & -702 & $-4,040$ & $-7.96 \mathrm{E}-11$ \\
\hline$-19,700$ & -63.0 & -332 & 0.00 & $-2,660$ & $-9.64 \mathrm{E}-11$ \\
\hline$-15,700$ & 0.00 & 834 & 0.00 & -42.0 & $2.98 \mathrm{E}-11$ \\
\hline$-9,300$ & -306 & -236 & -691 & $-1,210$ & $-1.86 \mathrm{E}-11$ \\
\hline$-1,630$ & 255 & -208 & -313 & 56.6 & $-2.88 \mathrm{E}-12$ \\
\hline$-4,700$ & 55.2 & -259 & -437 & -154 & $4.35 \mathrm{E}-12$ \\
\hline 206 & -68.1 & -0.681 & $-1,100$ & -565 & $2.61 \mathrm{E}-12$ \\
\hline-345 & -205 & 2.37 & -169 & -589 & $4.66 \mathrm{E}-12$ \\
\hline$-1,160$ & $-1,070$ & -38.7 & -35.2 & -75.3 & $1.68 \mathrm{E}-12$ \\
\hline$-137,000$ & $-2,780$ & -778 & $-3,440$ & $-5,980$ & $-2.66 \mathrm{E}-10$ \\
\hline 95,300 & 0.00 & 0.00 & 0.00 & 0.00 & 95,300 \\
\hline 50,600 & 0.00 & 0.00 & 0.00 & 0.00 & 50,600 \\
\hline 0.00 & 0.00 & 0.00 & 0.00 & 0.00 & 0.00 \\
\hline 2,160 & 0.00 & 0.00 & 0.00 & 0.00 & 2,160 \\
\hline 0.00 & 0.00 & 0.00 & 0.00 & 0.00 & 0.00 \\
\hline 0.00 & 0.00 & 0.00 & 0.00 & 0.00 & 0.00 \\
\hline 0.00 & 0.00 & 0.00 & 0.00 & 0.00 & 0.00 \\
\hline 0.00 & 0.00 & 0.00 & 0.00 & 0.00 & 0.00 \\
\hline 0.00 & 0.00 & 0.00 & 0.00 & 0.00 & 0.00 \\
\hline 0.00 & 0.00 & 0.00 & 0.00 & 0.00 & 0.00 \\
\hline 0.00 & 0.00 & 0.00 & 0.00 & 0.00 & 0.00 \\
\hline 0.00 & 0.00 & 0.00 & 0.00 & 0.00 & 0.00 \\
\hline 148,000 & 0.00 & 0.00 & 0.00 & 0.00 & 148,000 \\
\hline
\end{tabular}


Table 4.18. Average annual 25 -year water budget in acre-feet for optimized increased-pumpage scenario with wet conditions, Los Angeles Coastal P [WRD, Water Replenishment District of Southern California]

\begin{tabular}{|c|c|c|c|c|c|c|c|c|}
\hline $\begin{array}{c}\text { Chronostratigraphic } \\
\text { unit name }\end{array}$ & $\begin{array}{l}\text { Model } \\
\text { layer }\end{array}$ & $\begin{array}{l}\text { Los Angeles } \\
\text { Forebay }\end{array}$ & $\begin{array}{l}\text { WRD } \\
\text { Central } \\
\text { Basin }\end{array}$ & $\begin{array}{l}\text { Orange } \\
\text { County }\end{array}$ & $\begin{array}{l}\text { West } \\
\text { Coast }\end{array}$ & $\begin{array}{l}\text { Santa } \\
\text { Monica }\end{array}$ & Hollywood & $\begin{array}{l}\text { WRD Los } \\
\text { Angeles } \\
\text { Forebay }\end{array}$ \\
\hline \multicolumn{9}{|c|}{ Injection and net interborehole flow in } \\
\hline Dominguez & 2 & 0.00 & 4.90 & 0.0026 & 85 & 0.00 & 0.00 & 0.000235 \\
\hline Mesa & 3 & 0.00 & 1,120 & 231 & 4,680 & $8.54 \mathrm{E}-05$ & 0.00 & 0.00 \\
\hline Pacific A & 4 & 0.00 & 2,400 & 2,530 & 0.00 & 0.00 & 0.00 & 31.7 \\
\hline Pacific & 5 & 0.00 & 8,280 & 2,020 & 20,800 & 0.0305 & 0.00 & 1,380 \\
\hline Harbor & 6 & 0.00 & 2,220 & 87.3 & 13,300 & 0.00 & 0.00 & 1,470 \\
\hline Bent Spring & 7 & 0.00 & 1,300 & 0.00 & 17,500 & 237 & 48.3 & 761 \\
\hline Upper Wilmington A & 8 & 1,230 & 1,100 & 0.840 & 2,000 & 0.00 & 14.3 & 59 \\
\hline Upper Wilmington B & 9 & 0.00 & 503 & 6.05 & 133 & 1.18 & 0.00 & 15.5 \\
\hline Lower Wilmington & 10 & 0.00 & 52.3 & 0.00 & 139 & 0.00 & 0.00 & 32.5 \\
\hline Long Beach A & 11 & 0.00 & 2.95 & 0.00 & 0.362 & 0.00 & 0.00 & 0.00 \\
\hline Long Beach B & 12 & 0.00 & 0.371 & 0.00 & 0.00 & 0.00 & 0.00 & 0.00 \\
\hline Long Beach C & 13 & 0.00 & 0.00 & 0.00 & 0.00 & 0.979 & 0.00 & 0.00 \\
\hline \multirow[t]{2}{*}{ Total } & & 1,230 & 17,000 & 4,880 & 58,600 & 240 & 62.6 & 3,750 \\
\hline & & & & & & & & Areal recharge \\
\hline Dominguez & 2 & 1,450 & 10,400 & 3,740 & 1,430 & 1,780 & 2,210 & 1,720 \\
\hline Mesa & 3 & 2,100 & 4,390 & 34.4 & 11,400 & 8,160 & 1,330 & 51.5 \\
\hline Pacific A & 4 & 0.00 & 0.00 & 0.00 & 0.00 & 0.00 & 0.00 & 0.00 \\
\hline Pacific & 5 & 0.00 & 399 & 60.0 & 923 & 1,180 & 0.0782 & 0.00 \\
\hline Harbor & 6 & 254 & 4.88 & 0.00 & 309 & 0.00 & 0.00 & 224 \\
\hline Bent Spring & 7 & 19.0 & 0.00 & 0.00 & 1,030 & 9.73 & 0.00 & 0.00 \\
\hline Upper Wilmington A & 8 & 0.00 & 36.1 & 11.8 & 170 & 82.7 & 0.00 & 44.4 \\
\hline Upper Wilmington B & 9 & 0.00 & 0.00 & 0.00 & 21.5 & 12.2 & 0.00 & 0.00 \\
\hline Lower Wilmington & 10 & 0.00 & 26.4 & 0.00 & 0.00 & 0.00 & 0.00 & 0.00 \\
\hline Long Beach A & 11 & 0.00 & 8.83 & 0.00 & 0.00 & 0.00 & 0.00 & 0.00 \\
\hline Long Beach B & 12 & 0.00 & 0.00 & 0.00 & 0.00 & 0.00 & 0.00 & 0.00 \\
\hline Long Beach C & 13 & 265 & 126 & 0.00 & 121 & 4.04 & 0.00 & 159 \\
\hline \multirow[t]{2}{*}{ Total } & & 4,090 & 15,400 & 3,840 & 15,400 & 11,200 & 3,540 & 2,200 \\
\hline & & & & & & & \multicolumn{2}{|c|}{ Flow from Santa Monica Bay } \\
\hline Dominguez & 2 & 0.00 & 0.00 & 0.00 & 0.00 & 0.00111 & 0.00 & 0.00 \\
\hline Mesa & 3 & 0.00 & 0.00 & 0.00 & 17.3 & -122 & 0.00 & 0.00 \\
\hline Pacific A & 4 & 0.00 & 0.00 & 0.00 & 0.00 & 0.00 & 0.00 & 0.00 \\
\hline Pacific & 5 & 0.00 & 0.00 & 0.00 & -322 & -0.902 & 0.00 & 0.00 \\
\hline Harbor & 6 & 0.00 & 0.00 & 0.00 & -137 & 0.00 & 0.00 & 0.00 \\
\hline Bent Spring & 7 & 0.00 & 0.00 & 0.00 & -418 & 512 & 0.00 & 0.00 \\
\hline Upper Wilmington A & 8 & 0.00 & 0.00 & 0.00 & -49.6 & 431 & 0.00 & 0.00 \\
\hline Upper Wilmington B & 9 & 0.00 & 0.00 & 0.00 & -104 & 5.71 & 0.00 & 0.00 \\
\hline Lower Wilmington & 10 & 0.00 & 0.00 & 0.00 & 204 & -28.5 & 0.00 & 0.00 \\
\hline Long Beach A & 11 & 0.00 & 0.00 & 0.00 & -1.69 & -15.7 & 0.00 & 0.00 \\
\hline Long Beach B & 12 & 0.00 & 0.00 & 0.00 & 3.14 & -8.39 & 0.00 & 0.00 \\
\hline Long Beach C & 13 & 0.00 & 0.00 & 0.00 & 7.27 & 15.5 & 0.00 & 0.00 \\
\hline Total & & 0.00 & 0.00 & 0.00 & -801 & 789 & 0.00 & 0.00 \\
\hline
\end{tabular}


lain Groundwater-flow Model.-Continued

\begin{tabular}{|c|c|c|c|c|c|}
\hline $\begin{array}{c}\text { Montebello } \\
\text { Forebay }\end{array}$ & Whitter & Central Basin & $\begin{array}{l}\text { North Orange } \\
\text { County }\end{array}$ & $\begin{array}{l}\text { South Orange } \\
\text { County }\end{array}$ & Total \\
\hline $5.66 \mathrm{E}-05$ & 0.00 & 0.00 & 0.00 & 0.00 & 89.9 \\
\hline 138 & 0.00 & 1.54 & 0.00 & 1,640 & 7,810 \\
\hline 756 & 0.00 & 0.00 & 0.00 & 0.00 & 5,720 \\
\hline 248 & 0.00 & 0.0311 & 0.00 & 1,660 & 34,400 \\
\hline 735 & 12.0 & 16.1 & 0.00 & 2,040 & 19,900 \\
\hline 42.1 & 0.00 & 0.901 & 0.00 & 3.15 & 19,900 \\
\hline 283 & 10.4 & 0.00 & 14.4 & 63.9 & 4,770 \\
\hline 3.93 & 0.803 & 0.00 & 16.5 & 0.00 & 680 \\
\hline 29.3 & 0.705 & 0.00 & 0.00 & 0.00 & 254 \\
\hline 0.0123 & 64.4 & 0.00 & 106 & 0.00 & 174 \\
\hline 22.4 & 72.4 & 0.00 & 0.00 & 0.00 & 95.1 \\
\hline 5,000 & 0.00 & 0.00 & 0.00 & 0.00 & 5,000 \\
\hline 7,260 & 161 & 18.6 & 137 & 5,420 & 98,800 \\
\hline 2,620 & 353 & 540 & 33.5 & 547 & 26,800 \\
\hline 1,300 & 465 & 989 & 0.00 & 273 & 30,500 \\
\hline 0.00 & 0.00 & 0.00 & 0.00 & 0.00 & 0.00 \\
\hline 251 & 594 & 218 & 999 & 0.00219 & 4,620 \\
\hline 2.13 & 0.00 & 0.00 & 0.00 & 0.00 & 793 \\
\hline 0.00 & 0.00 & 0.00 & 0.00 & 0.00 & 1,060 \\
\hline 220 & 65.7 & 0.00 & 270 & 0.00 & 901 \\
\hline 0.00 & 0.00 & 0.00 & 0.00 & 0.00 & 33.7 \\
\hline 0.00 & 30.8 & 0.00 & 95.4 & 0.00 & 153 \\
\hline 30.6 & 2.19 & 0.00 & 85.6 & 0.00 & 127 \\
\hline 7.98 & 0.00 & 0.00 & 0.00 & 0.00 & 7.98 \\
\hline 1,510 & 1,430 & 73.8 & 147 & 0.00 & 3,830 \\
\hline 5,940 & 2,940 & 1,820 & 1,630 & 820 & 68,900 \\
\hline 0.00 & 0.00 & 0.00 & 0.00 & 0.00 & 0.00111 \\
\hline 0.00 & 0.00 & 0.00 & 0.00 & 0.00 & -105 \\
\hline 0.00 & 0.00 & 0.00 & 0.00 & 0.00 & 0.00 \\
\hline 0.00 & 0.00 & 0.00 & 0.00 & 0.00 & -323 \\
\hline 0.00 & 0.00 & 0.00 & 0.00 & 0.00 & -137 \\
\hline 0.00 & 0.00 & 0.00 & 0.00 & 0.00 & 94.0 \\
\hline 0.00 & 0.00 & 0.00 & 0.00 & 0.00 & 382 \\
\hline 0.00 & 0.00 & 0.00 & 0.00 & 0.00 & -97.9 \\
\hline 0.00 & 0.00 & 0.00 & 0.00 & 0.00 & 175 \\
\hline 0.00 & 0.00 & 0.00 & 0.00 & 0.00 & -17.4 \\
\hline 0.00 & 0.00 & 0.00 & 0.00 & 0.00 & -5.25 \\
\hline 0.00 & 0.00 & 0.00 & 0.00 & 0.00 & 22.8 \\
\hline 0.00 & 0.00 & 0.00 & 0.00 & 0.00 & -12.2 \\
\hline
\end{tabular}


Table 4.18. Average annual 25-year water budget in acre-feet for optimized increased-pumpage scenario with wet conditions, Los Angeles Coastal P [WRD, Water Replenishment District of Southern California]

\begin{tabular}{|c|c|c|c|c|c|c|c|c|}
\hline $\begin{array}{c}\text { Chronostratigraphic } \\
\text { unit name }\end{array}$ & $\begin{array}{l}\text { Model } \\
\text { layer }\end{array}$ & $\begin{array}{l}\text { Los Angeles } \\
\text { Forebay }\end{array}$ & $\begin{array}{c}\text { WRD } \\
\text { Central } \\
\text { Basin }\end{array}$ & $\begin{array}{l}\text { Orange } \\
\text { County }\end{array}$ & $\begin{array}{l}\text { West } \\
\text { Coast }\end{array}$ & $\begin{array}{c}\text { Santa } \\
\text { Monica }\end{array}$ & Hollywood & $\begin{array}{l}\text { WRD Los } \\
\text { Angeles } \\
\text { Forebay }\end{array}$ \\
\hline & & & & & & & \multicolumn{2}{|c|}{ Flow from San Pedro Bay } \\
\hline Dominguez & 2 & 0.00 & 0.00 & 0.00 & 9.99 & 0.00 & 0.00 & 0.00 \\
\hline Mesa & 3 & 0.00 & 0.00 & 0.00 & -21.4 & 0.00 & 0.00 & 0.00 \\
\hline Pacific A & 4 & 0.00 & 0.00 & 0.00 & 0.00 & 0.00 & 0.00 & 0.00 \\
\hline Pacific & 5 & 0.00 & 0.00 & 0.00 & 288 & 0.00 & 0.00 & 0.00 \\
\hline Harbor & 6 & 0.00 & 0.00 & 0.00 & 388 & 0.00 & 0.00 & 0.00 \\
\hline Bent Spring & 7 & 0.00 & 0.00 & 0.00 & -109 & 0.00 & 0.00 & 0.00 \\
\hline Upper Wilmington A & 8 & 0.00 & 0.00 & 0.00 & 0.00 & 0.00 & 0.00 & 0.00 \\
\hline Upper Wilmington B & 9 & 0.00 & 0.00 & 0.00 & 89.4 & 0.00 & 0.00 & 0.00 \\
\hline Lower Wilmington & 10 & 0.00 & 0.00 & 0.00 & 1,530 & 0.00 & 0.00 & 0.00 \\
\hline Long Beach A & 11 & 0.00 & 0.00 & 0.00 & 318 & 0.00 & 0.00 & 0.00 \\
\hline Long Beach B & 12 & 0.00 & 0.00 & 0.00 & 313 & 0.00 & 0.00 & 0.00 \\
\hline Long Beach C & 13 & 0.00 & 0.00 & 0.00 & 86.1 & 0.00 & 0.00 & 0.00 \\
\hline \multirow[t]{2}{*}{ Total } & & 0.00 & 0.00 & 0.00 & 2,890 & 0.00 & 0.00 & 0.00 \\
\hline & & & & & & & \multicolumn{2}{|c|}{ Underflow from Orange County } \\
\hline Dominguez & 2 & 0.00 & 0.00 & 3,510 & 0.00 & 0.00 & 0.00 & 0.00 \\
\hline Mesa & 3 & 0.00 & 0.00 & 1,400 & 0.00 & 0.00 & 0.00 & 0.00 \\
\hline Pacific A & 4 & 0.00 & 0.00 & 2,840 & 0.00 & 0.00 & 0.00 & 0.00 \\
\hline Pacific & 5 & 0.00 & 0.00 & 12,600 & 0.00 & 0.00 & 0.00 & 0.00 \\
\hline Harbor & 6 & 0.00 & 0.00 & 6,600 & 0.00 & 0.00 & 0.00 & 0.00 \\
\hline Bent Spring & 7 & 0.00 & 0.00 & 806 & 0.00 & 0.00 & 0.00 & 0.00 \\
\hline Upper Wilmington A & 8 & 0.00 & 0.00 & 7,310 & 0.00 & 0.00 & 0.00 & 0.00 \\
\hline Upper Wilmington B & 9 & 0.00 & 0.00 & 3,090 & 0.00 & 0.00 & 0.00 & 0.00 \\
\hline Lower Wilmington & 10 & 0.00 & 0.00 & 198 & 0.00 & 0.00 & 0.00 & 0.00 \\
\hline Long Beach A & 11 & 0.00 & 0.00 & 57.5 & 0.00 & 0.00 & 0.00 & 0.00 \\
\hline Long Beach B & 12 & 0.00 & 0.00 & 94.3 & 0.00 & 0.00 & 0.00 & 0.00 \\
\hline Long Beach C & 13 & 0.00 & 0.00 & 36.1 & 0.00 & 0.00 & 0.00 & 0.00 \\
\hline \multirow[t]{2}{*}{ Total } & & 0.00 & 0.00 & 38,600 & 0.00 & 0.00 & 0.00 & 0.00 \\
\hline & & & & & & & \multicolumn{2}{|c|}{ Underflow from San Gabriel Basi } \\
\hline Dominguez & 2 & 0.00 & 0.00 & 0.00 & 0.00 & 0.00 & 0.00 & 0.00 \\
\hline Mesa & 3 & 0.00 & 0.00 & 0.00 & 0.00 & 0.00 & 0.00 & 0.00 \\
\hline Pacific A & 4 & 0.00 & 0.00 & 0.00 & 0.00 & 0.00 & 0.00 & 0.00 \\
\hline Pacific & 5 & 0.00 & 0.00 & 0.00 & 0.00 & 0.00 & 0.00 & 0.00 \\
\hline Harbor & 6 & 0.00 & 0.00 & 0.00 & 0.00 & 0.00 & 0.00 & 0.00 \\
\hline Bent Spring & 7 & 0.00 & 0.00 & 0.00 & 0.00 & 0.00 & 0.00 & 0.00 \\
\hline Upper Wilmington A & 8 & 0.00 & 0.00 & 0.00 & 0.00 & 0.00 & 0.00 & 0.00 \\
\hline Upper Wilmington B & 9 & 0.00 & 0.00 & 0.00 & 0.00 & 0.00 & 0.00 & 0.00 \\
\hline Lower Wilmington & 10 & 0.00 & 0.00 & 0.00 & 0.00 & 0.00 & 0.00 & 0.00 \\
\hline Long Beach A & 11 & 0.00 & 0.00 & 0.00 & 0.00 & 0.00 & 0.00 & 0.00 \\
\hline Long Beach B & 12 & 0.00 & 0.00 & 0.00 & 0.00 & 0.00 & 0.00 & 0.00 \\
\hline Long Beach C & 13 & 0.00 & 0.00 & 0.00 & 0.00 & 0.00 & 0.00 & 0.00 \\
\hline Total & & 0.00 & 0.00 & 0.00 & 0.00 & 0.00 & 0.00 & 0.00 \\
\hline
\end{tabular}


lain Groundwater-flow Model._Continued

\begin{tabular}{|c|c|c|c|c|c|}
\hline $\begin{array}{c}\text { Montebello } \\
\text { Forebay }\end{array}$ & Whitter & Central Basin & $\begin{array}{l}\text { North Orange } \\
\text { County }\end{array}$ & $\begin{array}{c}\text { South Orange } \\
\text { County }\end{array}$ & Total \\
\hline 0.00 & 0.00 & 0.00 & 0.00 & 26.5 & 36.5 \\
\hline 0.00 & 0.00 & 0.00 & 0.00 & 136 & 114 \\
\hline 0.00 & 0.00 & 0.00 & 0.00 & 0.00 & 0.00 \\
\hline 0.00 & 0.00 & 0.00 & 0.00 & 278 & 566 \\
\hline 0.00 & 0.00 & 0.00 & 0.00 & 771 & 1,160 \\
\hline 0.00 & 0.00 & 0.00 & 0.00 & 67.2 & -42.0 \\
\hline 0.00 & 0.00 & 0.00 & 0.00 & 0.00 & 0.00 \\
\hline 0.00 & 0.00 & 0.00 & 0.00 & 0.00 & 89.4 \\
\hline 0.00 & 0.00 & 0.00 & 0.00 & 61.4 & 1,590 \\
\hline 0.00 & 0.00 & 0.00 & 0.00 & -354 & -36.2 \\
\hline 0.00 & 0.00 & 0.00 & 0.00 & -104 & 209 \\
\hline 0.00 & 0.00 & 0.00 & 0.00 & -341 & -255 \\
\hline 0.00 & 0.00 & 0.00 & 0.00 & 540 & 3,430 \\
\hline 0.00 & 0.00 & 0.00 & 0.00 & 79.4 & 3,590 \\
\hline 0.00 & 0.00 & 0.00 & 0.00 & 515 & 1,910 \\
\hline 0.00 & 0.00 & 0.00 & 0.00 & 0.00 & 2,840 \\
\hline 0.00 & 0.00 & 0.00 & -74.8 & 205 & 12,800 \\
\hline 0.00 & 0.00 & 0.00 & 0.00 & 208 & 6,810 \\
\hline 0.00 & 0.00 & 0.00 & 0.00 & 58.9 & 865 \\
\hline 0.00 & 0.00 & 0.00 & 854 & 1,440 & 9,600 \\
\hline 0.00 & 0.00 & 0.00 & 270 & -34.7 & 3,320 \\
\hline 0.00 & 0.00 & 0.00 & 735 & 43.1 & 976 \\
\hline 0.00 & 0.00 & 0.00 & 1,100 & 952 & 2,110 \\
\hline 0.00 & 0.00 & 0.00 & 58.5 & 730 & 883 \\
\hline 0.00 & 0.00 & 0.00 & 62.0 & 434 & 533 \\
\hline 0.00 & 0.00 & 0.00 & 3,000 & 4,630 & 46,200 \\
\hline 0.00 & 0.00 & 0.00 & 0.00 & 0.00 & 0.00 \\
\hline 23,100 & 0.00 & 0.00 & 0.00 & 0.00 & 23,100 \\
\hline 0.00 & 0.00 & 0.00 & 0.00 & 0.00 & 0.00 \\
\hline 0.00 & 0.00 & 0.00 & 0.00 & 0.00 & 0.00 \\
\hline 0.00 & 0.00 & 0.00 & 0.00 & 0.00 & 0.00 \\
\hline 0.00 & 0.00 & 0.00 & 0.00 & 0.00 & 0.00 \\
\hline 0.00 & 0.00 & 0.00 & 0.00 & 0.00 & 0.00 \\
\hline 0.00 & 0.00 & 0.00 & 0.00 & 0.00 & 0.00 \\
\hline 0.00 & 0.00 & 0.00 & 0.00 & 0.00 & 0.00 \\
\hline 0.00 & 0.00 & 0.00 & 0.00 & 0.00 & 0.00 \\
\hline 0.00 & 0.00 & 0.00 & 0.00 & 0.00 & 0.00 \\
\hline 3,140 & 0.00 & 0.00 & 0.00 & 0.00 & 3,140 \\
\hline 26,300 & 0.00 & 0.00 & 0.00 & 0.00 & 26,300 \\
\hline
\end{tabular}


Table 4.18. Average annual 25 -year water budget in acre-feet for optimized increased-pumpage scenario with wet conditions, Los Angeles Coastal $P$ [WRD, Water Replenishment District of Southern California]

\begin{tabular}{|c|c|c|c|c|c|c|c|c|}
\hline $\begin{array}{c}\text { Chronostratigraphic } \\
\text { unit name }\end{array}$ & $\begin{array}{l}\text { Model } \\
\text { layer }\end{array}$ & $\begin{array}{l}\text { Los Angeles } \\
\text { Forebay }\end{array}$ & $\begin{array}{c}\text { WRD } \\
\text { Central } \\
\text { Basin }\end{array}$ & $\begin{array}{l}\text { Orange } \\
\text { County }\end{array}$ & $\begin{array}{l}\text { West } \\
\text { Coast }\end{array}$ & $\begin{array}{l}\text { Santa } \\
\text { Monica }\end{array}$ & Hollywood & $\begin{array}{l}\text { WRD Los } \\
\text { Angeles } \\
\text { Forebay }\end{array}$ \\
\hline & & & & & & & \multicolumn{2}{|c|}{ Underflow from Palos Verdes Hills } \\
\hline Dominguez & 2 & 0.00 & 0.00 & 0.00 & 0.00 & 0.00 & 0.00 & 0.00 \\
\hline Mesa & 3 & 0.00 & 0.00 & 0.00 & 0.00 & 0.00 & 0.00 & 0.00 \\
\hline Pacific A & 4 & 0.00 & 0.00 & 0.00 & 0.00 & 0.00 & 0.00 & 0.00 \\
\hline Pacific & 5 & 0.00 & 0.00 & 0.00 & 0.00 & 0.00 & 0.00 & 0.00 \\
\hline Harbor & 6 & 0.00 & 0.00 & 0.00 & 0.00 & 0.00 & 0.00 & 0.00 \\
\hline Bent Spring & 7 & 0.00 & 0.00 & 0.00 & 0.00 & 0.00 & 0.00 & 0.00 \\
\hline Upper Wilmington A & 8 & 0.00 & 0.00 & 0.00 & 0.00 & 0.00 & 0.00 & 0.00 \\
\hline Upper Wilmington B & 9 & 0.00 & 0.00 & 0.00 & 0.00 & 0.00 & 0.00 & 0.00 \\
\hline Lower Wilmington & 10 & 0.00 & 0.00 & 0.00 & 2.92 & 0.00 & 0.00 & 0.00 \\
\hline Long Beach A & 11 & 0.00 & 0.00 & 0.00 & 0.902 & 0.00 & 0.00 & 0.00 \\
\hline Long Beach B & 12 & 0.00 & 0.00 & 0.00 & 0.486 & 0.00 & 0.00 & 0.00 \\
\hline Long Beach C & 13 & 0.00 & 0.00 & 0.00 & 25.7 & 0.00 & 0.00 & 0.00 \\
\hline \multirow[t]{2}{*}{ Total } & & 0.00 & 0.00 & 0.00 & 30.0 & 0.00 & 0.00 & 0.00 \\
\hline & & & & & & & \multicolumn{2}{|c|}{ Flow from Marina Del Rey } \\
\hline Dominguez & 2 & 0.00 & 0.00 & 0.00 & 0.00 & 0.00 & 0.00 & 0.00 \\
\hline Mesa & 3 & 0.00 & 0.00 & 0.00 & 0.00 & 137 & 0.00 & 0.00 \\
\hline Pacific A & 4 & 0.00 & 0.00 & 0.00 & 0.00 & 0.00 & 0.00 & 0.00 \\
\hline Pacific & 5 & 0.00 & 0.00 & 0.00 & 0.00 & 0.00 & 0.00 & 0.00 \\
\hline Harbor & 6 & 0.00 & 0.00 & 0.00 & 0.00 & 0.00 & 0.00 & 0.00 \\
\hline Bent Spring & 7 & 0.00 & 0.00 & 0.00 & 0.00 & 0.00 & 0.00 & 0.00 \\
\hline Upper Wilmington A & 8 & 0.00 & 0.00 & 0.00 & 0.00 & 0.00 & 0.00 & 0.00 \\
\hline Upper Wilmington B & 9 & 0.00 & 0.00 & 0.00 & 0.00 & 0.00 & 0.00 & 0.00 \\
\hline Lower Wilmington & 10 & 0.00 & 0.00 & 0.00 & 0.00 & 0.00 & 0.00 & 0.00 \\
\hline Long Beach A & 11 & 0.00 & 0.00 & 0.00 & 0.00 & 0.00 & 0.00 & 0.00 \\
\hline Long Beach B & 12 & 0.00 & 0.00 & 0.00 & 0.00 & 0.00 & 0.00 & 0.00 \\
\hline Long Beach C & 13 & 0.00 & 0.00 & 0.00 & 0.00 & 0.00 & 0.00 & 0.00 \\
\hline \multirow[t]{2}{*}{ Total } & & 0.00 & 0.00 & 0.00 & 0.00 & 137 & 0.00 & 0.00 \\
\hline & & & & & & & \multicolumn{2}{|c|}{ Flow from Port of Long Beach } \\
\hline Dominguez & 2 & 0.00 & 0.00 & 0.00 & 0.00 & 0.00 & 0.00 & 0.00 \\
\hline Mesa & 3 & 0.00 & 0.00 & 0.00 & -0.00156 & 0.00 & 0.00 & 0.00 \\
\hline Pacific A & 4 & 0.00 & 0.00 & 0.00 & 0.00 & 0.00 & 0.00 & 0.00 \\
\hline Pacific & 5 & 0.00 & 0.00 & 0.00 & 0.00 & 0.00 & 0.00 & 0.00 \\
\hline Harbor & 6 & 0.00 & 0.00 & 0.00 & 0.00 & 0.00 & 0.00 & 0.00 \\
\hline Bent Spring & 7 & 0.00 & 0.00 & 0.00 & 0.00 & 0.00 & 0.00 & 0.00 \\
\hline Upper Wilmington A & 8 & 0.00 & 0.00 & 0.00 & 0.00 & 0.00 & 0.00 & 0.00 \\
\hline Upper Wilmington B & 9 & 0.00 & 0.00 & 0.00 & 0.00 & 0.00 & 0.00 & 0.00 \\
\hline Lower Wilmington & 10 & 0.00 & 0.00 & 0.00 & 0.00 & 0.00 & 0.00 & 0.00 \\
\hline Long Beach A & 11 & 0.00 & 0.00 & 0.00 & 0.00 & 0.00 & 0.00 & 0.00 \\
\hline Long Beach B & 12 & 0.00 & 0.00 & 0.00 & 0.00 & 0.00 & 0.00 & 0.00 \\
\hline Long Beach C & 13 & 0.00 & 0.00 & 0.00 & 0.00 & 0.00 & 0.00 & 0.00 \\
\hline Total & & 0.00 & 0.00 & 0.00 & -0.00156 & 0.00 & 0.00 & 0.00 \\
\hline
\end{tabular}


lain Groundwater-flow Model.-Continued

\begin{tabular}{|c|c|c|c|c|c|}
\hline $\begin{array}{c}\text { Montebello } \\
\text { Forebay }\end{array}$ & Whitter & Central Basin & $\begin{array}{l}\text { North Orange } \\
\text { County }\end{array}$ & $\begin{array}{c}\text { South Orange } \\
\text { County }\end{array}$ & Total \\
\hline 0.00 & 0.00 & 0.00 & 0.00 & 0.00 & 0.00 \\
\hline 0.00 & 0.00 & 0.00 & 0.00 & 0.00 & 0.00 \\
\hline 0.00 & 0.00 & 0.00 & 0.00 & 0.00 & 0.00 \\
\hline 0.00 & 0.00 & 0.00 & 0.00 & 0.00 & 0.00 \\
\hline 0.00 & 0.00 & 0.00 & 0.00 & 0.00 & 0.00 \\
\hline 0.00 & 0.00 & 0.00 & 0.00 & 0.00 & 0.00 \\
\hline 0.00 & 0.00 & 0.00 & 0.00 & 0.00 & 0.00 \\
\hline 0.00 & 0.00 & 0.00 & 0.00 & 0.00 & 0.00 \\
\hline 0.00 & 0.00 & 0.00 & 0.00 & 0.00 & 2.92 \\
\hline 0.00 & 0.00 & 0.00 & 0.00 & 0.00 & 0.902 \\
\hline 0.00 & 0.00 & 0.00 & 0.00 & 0.00 & 0.486 \\
\hline 0.00 & 0.00 & 0.00 & 0.00 & 0.00 & 25.7 \\
\hline 0.00 & 0.00 & 0.00 & 0.00 & 0.00 & 30.0 \\
\hline 0.00 & 0.00 & 0.00 & 0.00 & 0.00 & 0.00 \\
\hline 0.00 & 0.00 & 0.00 & 0.00 & 0.00 & 137 \\
\hline 0.00 & 0.00 & 0.00 & 0.00 & 0.00 & 0.00 \\
\hline 0.00 & 0.00 & 0.00 & 0.00 & 0.00 & 0.00 \\
\hline 0.00 & 0.00 & 0.00 & 0.00 & 0.00 & 0.00 \\
\hline 0.00 & 0.00 & 0.00 & 0.00 & 0.00 & 0.00 \\
\hline 0.00 & 0.00 & 0.00 & 0.00 & 0.00 & 0.00 \\
\hline 0.00 & 0.00 & 0.00 & 0.00 & 0.00 & 0.00 \\
\hline 0.00 & 0.00 & 0.00 & 0.00 & 0.00 & 0.00 \\
\hline 0.00 & 0.00 & 0.00 & 0.00 & 0.00 & 0.00 \\
\hline 0.00 & 0.00 & 0.00 & 0.00 & 0.00 & 0.00 \\
\hline 0.00 & 0.00 & 0.00 & 0.00 & 0.00 & 0.00 \\
\hline 0.00 & 0.00 & 0.00 & 0.00 & 0.00 & 137 \\
\hline 0.00 & 0.00 & 0.00 & 0.00 & 0.00 & 0.00 \\
\hline 0.00 & 0.00 & 0.00 & 0.00 & 0.00 & -0.00156 \\
\hline 0.00 & 0.00 & 0.00 & 0.00 & 0.00 & 0.00 \\
\hline 0.00 & 0.00 & 0.00 & 0.00 & 0.00 & 0.00 \\
\hline 0.00 & 0.00 & 0.00 & 0.00 & 0.00 & 0.00 \\
\hline 0.00 & 0.00 & 0.00 & 0.00 & 0.00 & 0.00 \\
\hline 0.00 & 0.00 & 0.00 & 0.00 & 0.00 & 0.00 \\
\hline 0.00 & 0.00 & 0.00 & 0.00 & 0.00 & 0.00 \\
\hline 0.00 & 0.00 & 0.00 & 0.00 & 0.00 & 0.00 \\
\hline 0.00 & 0.00 & 0.00 & 0.00 & 0.00 & 0.00 \\
\hline 0.00 & 0.00 & 0.00 & 0.00 & 0.00 & 0.00 \\
\hline 0.00 & 0.00 & 0.00 & 0.00 & 0.00 & 0.00 \\
\hline 0.00 & 0.00 & 0.00 & 0.00 & 0.00 & -0.00156 \\
\hline
\end{tabular}


Table 4.18. Average annual 25-year water budget in acre-feet for optimized increased-pumpage scenario with wet conditions, Los Angeles Coastal P [WRD, Water Replenishment District of Southern California]

\begin{tabular}{|c|c|c|c|c|c|c|c|c|}
\hline $\begin{array}{c}\text { Chronostratigraphic } \\
\text { unit name }\end{array}$ & $\begin{array}{l}\text { Model } \\
\text { layer }\end{array}$ & $\begin{array}{l}\text { Los Angeles } \\
\text { Forebay }\end{array}$ & $\begin{array}{c}\text { WRD } \\
\text { Central } \\
\text { Basin }\end{array}$ & $\begin{array}{l}\text { Orange } \\
\text { County }\end{array}$ & $\begin{array}{l}\text { West } \\
\text { Coast }\end{array}$ & $\begin{array}{l}\text { Santa } \\
\text { Monica }\end{array}$ & Hollywood & $\begin{array}{l}\text { WRD Los } \\
\text { Angeles } \\
\text { Forebay }\end{array}$ \\
\hline & & & & & & & \multicolumn{2}{|c|}{ Underflow from San Fernando Basir } \\
\hline Dominguez & 2 & 0.00 & 0.00 & 0.00 & 0.00 & 0.00 & 0.00 & 0.00 \\
\hline Mesa & 3 & 5,290 & 0.00 & 0.00 & 0.00 & 0.00 & 0.00 & 0.00 \\
\hline Pacific A & 4 & 0.00 & 0.00 & 0.00 & 0.00 & 0.00 & 0.00 & 0.00 \\
\hline Pacific & 5 & 0.00 & 0.00 & 0.00 & 0.00 & 0.00 & 0.00 & 0.00 \\
\hline Harbor & 6 & 0.00 & 0.00 & 0.00 & 0.00 & 0.00 & 0.00 & 0.00 \\
\hline Bent Spring & 7 & 0.00 & 0.00 & 0.00 & 0.00 & 0.00 & 0.00 & 0.00 \\
\hline Upper Wilmington A & 8 & 0.00 & 0.00 & 0.00 & 0.00 & 0.00 & 0.00 & 0.00 \\
\hline Upper Wilmington B & 9 & 0.00 & 0.00 & 0.00 & 0.00 & 0.00 & 0.00 & 0.00 \\
\hline Lower Wilmington & 10 & 0.00 & 0.00 & 0.00 & 0.00 & 0.00 & 0.00 & 0.00 \\
\hline Long Beach A & 11 & 0.00 & 0.00 & 0.00 & 0.00 & 0.00 & 0.00 & 0.00 \\
\hline Long Beach B & 12 & 0.00 & 0.00 & 0.00 & 0.00 & 0.00 & 0.00 & 0.00 \\
\hline Long Beach C & 13 & 0.00 & 0.00 & 0.00 & 0.00 & 0.00 & 0.00 & 0.00 \\
\hline \multirow[t]{2}{*}{ Total } & & 5,290 & 0.00 & 0.00 & 0.00 & 0.00 & 0.00 & 0.00 \\
\hline & & & & & & & & Drains \\
\hline Dominguez & 2 & 0.00 & $-1,560$ & -147 & -32.0 & -416 & 0.00 & 0.00 \\
\hline Mesa & 3 & 0.00 & -426 & 0.00 & $-1,500$ & $-1,280$ & 0.00 & 0.00 \\
\hline Pacific A & 4 & 0.00 & 0.00 & 0.00 & 0.00 & 0.00 & 0.00 & 0.00 \\
\hline Pacific & 5 & 0.00 & 0.00 & 0.00 & 0.00 & -299 & 0.00 & 0.00 \\
\hline Harbor & 6 & 0.00 & 0.00 & 0.00 & 0.00 & 0.00 & 0.00 & 0.00 \\
\hline Bent Spring & 7 & 0.00 & 0.00 & 0.00 & 0.00 & $-1,980$ & 0.00 & 0.00 \\
\hline Upper Wilmington A & 8 & 0.00 & 0.00 & 0.00 & 0.00 & 0.00 & 0.00 & 0.00 \\
\hline Upper Wilmington B & 9 & 0.00 & 0.00 & 0.00 & 0.00 & 0.00 & 0.00 & 0.00 \\
\hline Lower Wilmington & 10 & 0.00 & 0.00 & 0.00 & 0.00 & 0.00 & 0.00 & 0.00 \\
\hline Long Beach A & 11 & 0.00 & -750 & 0.00 & 0.00 & 0.00 & 0.00 & 0.00 \\
\hline Long Beach B & 12 & 0.00 & 0.00 & 0.00 & 0.00 & 0.00 & 0.00 & 0.00 \\
\hline Long Beach C & 13 & 0.00 & 0.00 & 0.00 & 0.00 & 0.00 & 0.00 & 0.00 \\
\hline Total & & 0.00 & $-2,740$ & -147 & $-1,540$ & $-3,970$ & 0.00 & 0.00 \\
\hline \multirow[t]{2}{*}{ Total net flow } & & 348 & 2,640 & -354 & 14,900 & $-2,320$ & $-1,650$ & $-1,090$ \\
\hline & & & & & & & & Change in storage \\
\hline Dominguez & 2 & -635 & 503 & 103 & 389 & $-1,030$ & -52.0 & $-1,480$ \\
\hline Mesa & 3 & 191 & 2,040 & -9.44 & 12,700 & -628 & 251 & 35.1 \\
\hline Pacific A & 4 & 27.8 & 468 & -4.83 & 1.24 & 0.00 & 0.00 & 2.14 \\
\hline Pacific & 5 & 19.9 & -297 & -23.9 & 656 & -685 & -7.80 & 102 \\
\hline Harbor & 6 & 32.6 & -5.95 & -15.7 & 319 & -0.00627 & 0.00 & 145 \\
\hline Bent Spring & 7 & 24.6 & -5.45 & -18.3 & 719 & -12.2 & -493 & 3.92 \\
\hline Upper Wilmington A & 8 & 482 & 0.0495 & -282 & 33.6 & 106 & $-1,340$ & 64.4 \\
\hline Upper Wilmington B & 9 & 4.97 & 7.33 & -6.61 & 32.5 & -21 & -9.53 & 7.81 \\
\hline Lower Wilmington & 10 & 29.8 & 18.6 & -2.89 & 68.3 & 9.17 & 3.96 & 11.5 \\
\hline Long Beach A & 11 & -3.94 & 18.4 & -11.8 & 16.3 & 2.91 & 0.00725 & -4.04 \\
\hline Long Beach B & 12 & -0.505 & -32.9 & -38.8 & 15.4 & 5.78 & 0.0274 & -0.923 \\
\hline Long Beach C & 13 & 175 & -70.2 & -42.8 & -24.1 & -64.9 & 0.577 & 22.5 \\
\hline Total & & 348 & 2,640 & -354 & 14,900 & $-2,320$ & $-1,650$ & $-1,090$ \\
\hline
\end{tabular}


lain Groundwater-flow Model.-Continued

\begin{tabular}{|c|c|c|c|c|c|}
\hline $\begin{array}{c}\text { Montebello } \\
\text { Forebay }\end{array}$ & Whitter & Central Basin & $\begin{array}{c}\text { North Orange } \\
\text { County }\end{array}$ & $\begin{array}{l}\text { South Orange } \\
\text { County }\end{array}$ & Total \\
\hline 0.00 & 0.00 & 0.00 & 0.00 & 0.00 & 0.00 \\
\hline 0.00 & 0.00 & 0.00 & 0.00 & 0.00 & 5,290 \\
\hline 0.00 & 0.00 & 0.00 & 0.00 & 0.00 & 0.00 \\
\hline 0.00 & 0.00 & 0.00 & 0.00 & 0.00 & 0.00 \\
\hline 0.00 & 0.00 & 0.00 & 0.00 & 0.00 & 0.00 \\
\hline 0.00 & 0.00 & 0.00 & 0.00 & 0.00 & 0.00 \\
\hline 0.00 & 0.00 & 0.00 & 0.00 & 0.00 & 0.00 \\
\hline 0.00 & 0.00 & 0.00 & 0.00 & 0.00 & 0.00 \\
\hline 0.00 & 0.00 & 0.00 & 0.00 & 0.00 & 0.00 \\
\hline 0.00 & 0.00 & 0.00 & 0.00 & 0.00 & 0.00 \\
\hline 0.00 & 0.00 & 0.00 & 0.00 & 0.00 & 0.00 \\
\hline 0.00 & 0.00 & 0.00 & 0.00 & 0.00 & 0.00 \\
\hline 0.00 & 0.00 & 0.00 & 0.00 & 0.00 & 5,290 \\
\hline-504 & 0.00 & -585 & -30.4 & -3.57 & $-3,280$ \\
\hline 0.00 & 0.00 & 0.00 & 0.00 & -77.7 & $-3,280$ \\
\hline 0.00 & 0.00 & 0.00 & 0.00 & 0.00 & 0.00 \\
\hline-812 & -64.1 & 0.00 & -388 & 0.00 & $-1,560$ \\
\hline 0.00 & 0.00 & 0.00 & 0.00 & 0.00 & 0.00 \\
\hline 0.00 & 0.00 & 0.00 & 0.00 & 0.00 & $-1,980$ \\
\hline 0.00 & 0.00 & 0.00 & -497 & 0.00 & -497 \\
\hline 0.00 & 0.00 & 0.00 & 0.00 & 0.00 & 0.00 \\
\hline 0.00 & 0.00 & 0.00 & -241 & 0.00 & -241 \\
\hline 0.00 & 0.00 & 0.00 & -24.9 & 0.00 & -775 \\
\hline 0.00 & 0.00 & 0.00 & 0.00 & 0.00 & 0.00 \\
\hline 0.00 & 0.00 & 0.00 & 0.00 & 0.00 & 0.00 \\
\hline$-1,320$ & -64.1 & -585 & $-1,180$ & -81.2 & $-11,600$ \\
\hline 960 & 40.0 & 454 & 12.0 & -373 & 13,600 \\
\hline 96.7 & -46.2 & -311 & 47.0 & -227 & $-2,640$ \\
\hline 2.15 & -37.0 & 674 & 0.00 & -93.6 & 15,100 \\
\hline 7.60 & 6.65 & 8.13 & 0.00 & 0.00 & 517 \\
\hline-7.13 & -115 & 11.5 & -88.8 & -31.2 & -466 \\
\hline-2.54 & -4.88 & 0.833 & 0.00 & -3.97 & 464 \\
\hline-0.0136 & 0.00 & 27.6 & 0.00 & -0.659 & 245 \\
\hline 217 & 30.0 & 9.60 & -250 & -2.26 & -931 \\
\hline 0.377 & 1.93 & 22.6 & -3.76 & -1.88 & 34.7 \\
\hline 0.424 & 3.57 & 6.35 & 13.2 & -1.06 & 161 \\
\hline-5.82 & 23.9 & 0.332 & 220 & -2.43 & 254 \\
\hline 0.974 & 5.77 & 2.69 & 17.2 & -4.18 & -29.4 \\
\hline 652 & 171 & 1.71 & 56.9 & -5.70 & 872 \\
\hline 962 & 40.0 & 454 & 11.9 & -374 & 13,600 \\
\hline
\end{tabular}


Table 4.19. Average annual 25 -year water budget in acre-feet for optimized increased-pumpage scenario with dry conditions, Los Angeles Coastal PI [WRD, Water Replenishment District of Southern California]

\begin{tabular}{|c|c|c|c|c|c|c|c|c|}
\hline $\begin{array}{c}\text { Chronostratigraphic } \\
\text { unit name }\end{array}$ & $\begin{array}{l}\text { Model } \\
\text { layer }\end{array}$ & $\begin{array}{l}\text { Los Angeles } \\
\text { Forebay }\end{array}$ & $\begin{array}{l}\text { WRD } \\
\text { Central Basin }\end{array}$ & Orange County & $\begin{array}{l}\text { West } \\
\text { Coast }\end{array}$ & Santa Monica & Hollywood & $\begin{array}{l}\text { WRD Los } \\
\text { Angeles } \\
\text { Forebay }\end{array}$ \\
\hline \multicolumn{9}{|c|}{ Pumping and net interborehole flow out } \\
\hline Dominguez & 2 & 0.00 & $-8,320$ & $-3,010$ & -33.2 & 0.00 & 0.00 & -0.985 \\
\hline Mesa & 3 & 0.00 & $-8,930$ & $-3,290$ & $-1,210$ & -299 & 0.00 & $-2,850$ \\
\hline Pacific A & 4 & 0.00 & $-31,700$ & $-7,700$ & -0.000369 & 0.00 & 0.00 & -845 \\
\hline Pacific & 5 & 0.00 & $-28,600$ & $-26,700$ & $-9,140$ & -623 & -280 & $-4,710$ \\
\hline Harbor & 6 & 0.00 & $-37,900$ & $-9,970$ & $-15,200$ & 0.00 & 0.00 & $-1,010$ \\
\hline Bent Spring & 7 & 0.00 & $-15,200$ & $-2,260$ & $-6,500$ & $-7,370$ & $-1,260$ & $-3,710$ \\
\hline Upper Wilmington A & 8 & $-1,240$ & $-20,600$ & $-3,950$ & $-21,800$ & -134 & $-1,560$ & $-5,400$ \\
\hline Upper Wilmington B & 9 & 0.00 & $-7,830$ & -540 & $-1,880$ & -320 & -25.2 & -657 \\
\hline Lower Wilmington & 10 & 0.00 & $-3,000$ & 0.00 & $-6,490$ & -206 & 0.00 & -654 \\
\hline Long Beach A & 11 & 0.00 & -724 & 0.00 & -717 & 0.00 & 0.00 & -7.95 \\
\hline Long Beach B & 12 & 0.00 & -248 & 0.00 & -113 & 0.00 & 0.00 & -99.1 \\
\hline Long Beach C & 13 & 0.00 & 0.00 & 0.00 & 0.00 & -1.78 & 0.00 & -19.2 \\
\hline \multirow[t]{2}{*}{ Total } & \multirow{2}{*}{\multicolumn{8}{|c|}{$\frac{0}{\text { Net flow from adjacent inland zones }}$}} \\
\hline & & & & & & & & \\
\hline Dominguez & 2 & -567 & 13,400 & $-2,090$ & -17.9 & 19.3 & -99.1 & 73.4 \\
\hline Mesa & 3 & $-1,030$ & 28,700 & -254 & 737 & -301 & $-1,030$ & 3,790 \\
\hline Pacific A & 4 & -211 & 9,770 & 1,930 & -70.5 & 0.00 & 0.00 & $-1,800$ \\
\hline Pacific & 5 & $-2,950$ & 23,400 & 9,590 & $-1,290$ & 139 & -75.9 & 4,170 \\
\hline Harbor & 6 & -350 & 24,100 & 1,790 & $-1,490$ & -4.42 & 0.00 & $-1,490$ \\
\hline Bent Spring & 7 & -850 & 14,600 & 554 & 25.3 & 322 & -939 & 834 \\
\hline Upper Wilmington A & 8 & $-1,970$ & 8,080 & -684 & 1,500 & $-1,340$ & 25 & 6,010 \\
\hline Upper Wilmington B & 9 & -165 & 4,100 & $-2,510$ & -88.7 & 219 & -5.11 & 268 \\
\hline Lower Wilmington & 10 & -111 & 4,020 & -396 & 1,620 & -223 & -4.74 & 478 \\
\hline Long Beach A & 11 & -0.444 & 842 & 14.2 & 791 & -157 & -0.0196 & 46.5 \\
\hline Long Beach B & 12 & 37.4 & 1,150 & -249 & 483 & -102 & 4.25 & -17.8 \\
\hline Long Beach C & 13 & -633 & 2,020 & 115 & 1,100 & -372 & -1.42 & 62.1 \\
\hline \multirow[t]{2}{*}{ Total } & & $-8,790$ & 134,000 & 7,810 & 3,300 & $-1,800$ & $-2,130$ & 12,400 \\
\hline & & & & & & & \multicolumn{2}{|r|}{ Water spreading } \\
\hline Dominguez & 2 & 0.00 & 0.00 & 0.00 & 0.00 & 0.00 & 0.00 & 0.00 \\
\hline Mesa & 3 & 0.00 & 0.00 & 0.00 & 0.00 & 0.00 & 0.00 & 0.00 \\
\hline Pacific A & 4 & 0.00 & 0.00 & 0.00 & 0.00 & 0.00 & 0.00 & 0.00 \\
\hline Pacific & 5 & 0.00 & 0.00 & 0.00 & 0.00 & 0.00 & 0.00 & 0.00 \\
\hline Harbor & 6 & 0.00 & 0.00 & 0.00 & 0.00 & 0.00 & 0.00 & 0.00 \\
\hline Bent Spring & 7 & 0.00 & 0.00 & 0.00 & 0.00 & 0.00 & 0.00 & 0.00 \\
\hline Upper Wilmington A & 8 & 0.00 & 0.00 & 0.00 & 0.00 & 0.00 & 0.00 & 0.00 \\
\hline Upper Wilmington B & 9 & 0.00 & 0.00 & 0.00 & 0.00 & 0.00 & 0.00 & 0.00 \\
\hline Lower Wilmington & 10 & 0.00 & 0.00 & 0.00 & 0.00 & 0.00 & 0.00 & 0.00 \\
\hline Long Beach A & 11 & 0.00 & 0.00 & 0.00 & 0.00 & 0.00 & 0.00 & 0.00 \\
\hline Long Beach B & 12 & 0.00 & 0.00 & 0.00 & 0.00 & 0.00 & 0.00 & 0.00 \\
\hline Long Beach C & 13 & 0.00 & 0.00 & 0.00 & 0.00 & 0.00 & 0.00 & 0.00 \\
\hline Total & & 0.00 & 0.00 & 0.00 & 0.00 & 0.00 & 0.00 & 0.00 \\
\hline
\end{tabular}


ain Groundwater-flow Model.

\begin{tabular}{|c|c|c|c|c|c|}
\hline $\begin{array}{c}\text { Montebello } \\
\text { Forebay }\end{array}$ & Whitter & Central Basin & $\begin{array}{c}\text { North Orange } \\
\text { County }\end{array}$ & $\begin{array}{c}\text { South } \\
\text { Orange County }\end{array}$ & Total \\
\hline-443 & 0.00 & 0.00 & 0.00 & -39 & $-11,800$ \\
\hline$-5,680$ & -28.3 & 0.00 & 0.00 & -207 & $-22,500$ \\
\hline$-2,880$ & 0.00 & 0.00 & 0.00 & 0.00 & $-43,200$ \\
\hline$-18,000$ & -14.0 & -3.63 & 0.00 & $-3,990$ & $-92,100$ \\
\hline$-8,080$ & 0.00 & 0.00 & 0.00 & $-1,150$ & $-73,300$ \\
\hline$-2,630$ & 0.00 & -17.5 & 0.00 & -90.7 & $-39,000$ \\
\hline$-5,340$ & 0.00 & 0.00 & 0.00 & -267 & $-60,400$ \\
\hline-392 & -0.884 & 0.00 & 0.00 & 0.00 & $-11,600$ \\
\hline-448 & -164 & 0.00 & -135 & 0.00 & $-11,100$ \\
\hline-231 & 0.00 & 0.00 & 0.00 & 0.00 & $-1,680$ \\
\hline-192 & 0.00 & 0.00 & 0.00 & 0.00 & -653 \\
\hline$-4,090$ & 0.00 & 0.00 & 0.00 & 0.00 & $-4,110$ \\
\hline$-48,400$ & -207 & -21.1 & -135 & $-5,740$ & $-371,000$ \\
\hline$-13,100$ & -59.8 & 88.5 & 6.04 & 2,360 & $-4.87 \mathrm{E}-11$ \\
\hline$-31,600$ & -654 & 764 & 0.00 & 797 & $1.32 \mathrm{E}-11$ \\
\hline$-8,330$ & -314 & -973 & 0.00 & 0.00 & $-1.93 \mathrm{E}-12$ \\
\hline$-27,100$ & -445 & -546 & -660 & $-4,190$ & $1.33 \mathrm{E}-10$ \\
\hline$-19,200$ & -95.7 & -333 & 0.00 & $-2,980$ & $-6.50 \mathrm{E}-11$ \\
\hline$-15,300$ & 0.00 & 812 & 0.00 & -43.3 & $-1.22 \mathrm{E}-11$ \\
\hline$-9,100$ & -290 & -216 & -714 & $-1,310$ & $-1.36 \mathrm{E}-11$ \\
\hline$-1,600$ & 261 & -213 & -320 & 57.8 & $-9.48 \mathrm{E}-12$ \\
\hline$-4,570$ & 62.1 & -254 & -454 & -167 & $6.85 \mathrm{E}-12$ \\
\hline 235 & -62.7 & -0.559 & $-1,130$ & -578 & $-3.07 \mathrm{E}-12$ \\
\hline-332 & -198 & 6.63 & -169 & -615 & $-6.82 \mathrm{E}-13$ \\
\hline$-1,120$ & -950 & -35.1 & -94.8 & -88.4 & $7.35 \mathrm{E}-12$ \\
\hline$-131,000$ & $-2,750$ & -900 & $-3,540$ & $-6,760$ & $-1.46 \mathrm{E}-11$ \\
\hline 90,100 & 0.00 & 0.00 & 0.00 & 0.00 & 90,100 \\
\hline 47,600 & 0.00 & 0.00 & 0.00 & 0.00 & 47,600 \\
\hline 0.00 & 0.00 & 0.00 & 0.00 & 0.00 & 0.00 \\
\hline 1,990 & 0.00 & 0.00 & 0.00 & 0.00 & 1,990 \\
\hline 0.00 & 0.00 & 0.00 & 0.00 & 0.00 & 0.00 \\
\hline 0.00 & 0.00 & 0.00 & 0.00 & 0.00 & 0.00 \\
\hline 0.00 & 0.00 & 0.00 & 0.00 & 0.00 & 0.00 \\
\hline 0.00 & 0.00 & 0.00 & 0.00 & 0.00 & 0.00 \\
\hline 0.00 & 0.00 & 0.00 & 0.00 & 0.00 & 0.00 \\
\hline 0.00 & 0.00 & 0.00 & 0.00 & 0.00 & 0.00 \\
\hline 0.00 & 0.00 & 0.00 & 0.00 & 0.00 & 0.00 \\
\hline 0.00 & 0.00 & 0.00 & 0.00 & 0.00 & 0.00 \\
\hline 140,000 & 0.00 & 0.00 & 0.00 & 0.00 & 140,000 \\
\hline
\end{tabular}


Table 4.19. Average annual 25 -year water budget in acre-feet for optimized increased-pumpage scenario with dry conditions, Los Angeles Coastal PI [WRD, Water Replenishment District of Southern California]

\begin{tabular}{|c|c|c|c|c|c|c|c|c|}
\hline $\begin{array}{c}\text { Chronostratigraphic } \\
\text { unit name }\end{array}$ & $\begin{array}{l}\text { Model } \\
\text { layer }\end{array}$ & $\begin{array}{l}\text { Los Angeles } \\
\text { Forebay }\end{array}$ & $\begin{array}{c}\text { WRD } \\
\text { Central Basin }\end{array}$ & Orange County & $\begin{array}{l}\text { West } \\
\text { Coast }\end{array}$ & Santa Monica & Hollywood & $\begin{array}{l}\text { WRD Los } \\
\text { Angeles } \\
\text { Forebay }\end{array}$ \\
\hline \multicolumn{9}{|c|}{ Injection and net interborehole flow in } \\
\hline Dominguez & 2 & 0.00 & 3.33 & 0.00247 & 85.1 & 0.00 & 0.00 & 0.00027 \\
\hline Mesa & 3 & 0.00 & 1,120 & 237 & 4,670 & 0.000164 & 0.00 & 0.00 \\
\hline Pacific A & 4 & 0.00 & 2,370 & 2,490 & 0.00 & 0.00 & 0.00 & 32.4 \\
\hline Pacific & 5 & 0.00 & 8,140 & 2,020 & 20,800 & 0.0238 & 0.00 & 1,330 \\
\hline Harbor & 6 & 0.00 & 2,190 & 89.6 & 13,300 & 0.00 & 0.00 & 1,430 \\
\hline Bent Spring & 7 & 0.00 & 1,300 & 0.00 & 17,500 & 237 & 44.0 & 761 \\
\hline Upper Wilmington A & 8 & 1,240 & 1,100 & 0.791 & 1,990 & 0.00 & 14.1 & 59.2 \\
\hline Upper Wilmington B & 9 & 0.00 & 503 & 9.66 & 132 & 0.986 & 0.00 & 15.0 \\
\hline Lower Wilmington & 10 & 0.00 & 48.8 & 0.00 & 138 & 0.00 & 0.00 & 30.7 \\
\hline Long Beach A & 11 & 0.00 & 2.81 & 0.00 & 0.335 & 0.00 & 0.00 & 0.00 \\
\hline Long Beach B & 12 & 0.00 & 0.334 & 0.00 & 0.00 & 0.00 & 0.00 & 0.00 \\
\hline Long Beach C & 13 & 0.00 & 0.00 & 0.00 & 0.00 & 0.172 & 0.00 & 0.00 \\
\hline \multirow[t]{2}{*}{ Total } & & 1,240 & 16,800 & 4,850 & 58,600 & 238 & 58.1 & 3,660 \\
\hline & & & & & & & & Areal recharge \\
\hline Dominguez & 2 & 1,130 & 7,810 & 2,740 & 1,070 & 1,470 & 1,760 & 1,340 \\
\hline Mesa & 3 & 1,650 & 3,350 & 19.9 & 8,840 & 6,290 & 1,010 & 38.1 \\
\hline Pacific A & 4 & 0.00 & 0.00 & 0.00 & 0.00 & 0.00 & 0.00 & 0.00 \\
\hline Pacific & 5 & 0.00 & 294 & 34.2 & 709 & 925 & 0.0392 & 0.00 \\
\hline Harbor & 6 & 189 & 2.99 & 0.00 & 240 & 0.00 & 0.00 & 177 \\
\hline Bent Spring & 7 & 14.7 & 0.00 & 0.00 & 815 & 6.4 & 0.00 & 0.00 \\
\hline Upper Wilmington A & 8 & 0.00 & 25.2 & 7.05 & 139 & 64.2 & 0.00 & 31.7 \\
\hline Upper Wilmington B & 9 & 0.00 & 0.00 & 0.00 & 16.6 & 8.94 & 0.00 & 0.00 \\
\hline Lower Wilmington & 10 & 0.00 & 19.3 & 0.00 & 0.00 & 0.00 & 0.00 & 0.00 \\
\hline Long Beach A & 11 & 0.00 & 4.99 & 0.00 & 0.00 & 0.00 & 0.00 & 0.00 \\
\hline Long Beach B & 12 & 0.00 & 0.00 & 0.00 & 0.00 & 0.00 & 0.00 & 0.00 \\
\hline Long Beach C & 13 & 211 & 94.8 & 0.00 & 93.8 & 3.08 & 0.00 & 126 \\
\hline \multirow[t]{2}{*}{ Total } & & 3,200 & 11,600 & 2,800 & 11,900 & 8,760 & 2,770 & 1,710 \\
\hline & & & & & & & \multicolumn{2}{|c|}{ Flow from Santa Monica Bay } \\
\hline Dominguez & 2 & 0.00 & 0.00 & 0.00 & 0.00 & 0.00112 & 0.00 & 0.00 \\
\hline Mesa & 3 & 0.00 & 0.00 & 0.00 & 13.1 & -123 & 0.00 & 0.00 \\
\hline Pacific A & 4 & 0.00 & 0.00 & 0.00 & 0.00 & 0.00 & 0.00 & 0.00 \\
\hline Pacific & 5 & 0.00 & 0.00 & 0.00 & -319 & -1.35 & 0.00 & 0.00 \\
\hline Harbor & 6 & 0.00 & 0.00 & 0.00 & -136 & 0.00 & 0.00 & 0.00 \\
\hline Bent Spring & 7 & 0.00 & 0.00 & 0.00 & -396 & 510 & 0.00 & 0.00 \\
\hline Upper Wilmington A & 8 & 0.00 & 0.00 & 0.00 & -49.1 & 432 & 0.00 & 0.00 \\
\hline Upper Wilmington B & 9 & 0.00 & 0.00 & 0.00 & -102 & 5.82 & 0.00 & 0.00 \\
\hline Lower Wilmington & 10 & 0.00 & 0.00 & 0.00 & 205 & -28.4 & 0.00 & 0.00 \\
\hline Long Beach A & 11 & 0.00 & 0.00 & 0.00 & -1.31 & -14.6 & 0.00 & 0.00 \\
\hline Long Beach B & 12 & 0.00 & 0.00 & 0.00 & 4.05 & -7.39 & 0.00 & 0.00 \\
\hline Long Beach C & 13 & 0.00 & 0.00 & 0.00 & 8.90 & 17.4 & 0.00 & 0.00 \\
\hline Total & & 0.00 & 0.00 & 0.00 & -773 & 791 & 0.00 & 0.00 \\
\hline
\end{tabular}


ain Groundwater-flow Model._-Continued

\begin{tabular}{|c|c|c|c|c|c|}
\hline $\begin{array}{c}\text { Montebello } \\
\text { Forebay }\end{array}$ & Whitter & Central Basin & $\begin{array}{l}\text { North Orange } \\
\text { County }\end{array}$ & $\begin{array}{c}\text { South } \\
\text { Orange County }\end{array}$ & Total \\
\hline $8.08 \mathrm{E}-05$ & 0.00 & 0.00 & 0.00 & 0.00 & 88.4 \\
\hline 128 & 0.00 & 0.925 & 0.00 & 1,640 & 7,800 \\
\hline 732 & 0.00 & 0.00 & 0.00 & 0.00 & 5,620 \\
\hline 239 & 0.00 & 0.0791 & 0.00 & 1,660 & 34,200 \\
\hline 712 & 0.375 & 16.1 & 0.00 & 2,030 & 19,800 \\
\hline 40.2 & 0.00 & 0.863 & 0.00 & 4.97 & 19,900 \\
\hline 273 & 10.5 & 0.00 & 15.6 & 98.6 & 4,800 \\
\hline 3.80 & 0.828 & 0.00 & 17.0 & 0.00 & 681 \\
\hline 29.1 & 0.728 & 0.00 & 0.00 & 0.00 & 247 \\
\hline 0.0120 & 61.9 & 0.00 & 102 & 0.00 & 167 \\
\hline 21.9 & 74.3 & 0.00 & 0.00 & 0.00 & 96.6 \\
\hline 5,000 & 0.00 & 0.00 & 0.00 & 0.00 & 5,000 \\
\hline 7,180 & 149 & 17.9 & 135 & 5,430 & 98,300 \\
\hline 1,960 & 258 & 431 & 23.5 & 410 & 20,400 \\
\hline 969 & 336 & 778 & 0.00 & 198 & 23,500 \\
\hline 0.00 & 0.00 & 0.00 & 0.00 & 0.00 & 0.00 \\
\hline 198 & 428 & 178 & 696 & 0.000584 & 3,460 \\
\hline 1.35 & 0.00 & 0.00 & 0.00 & 0.00 & 610 \\
\hline 0.00 & 0.00 & 0.00 & 0.00 & 0.00 & 837 \\
\hline 172 & 39.5 & 0.00 & 176 & 0.00 & 654 \\
\hline 0.00 & 0.00 & 0.00 & 0.00 & 0.00 & 25.5 \\
\hline 0.00 & 21.4 & 0.00 & 60.5 & 0.00 & 101 \\
\hline 24.3 & 1.09 & 0.00 & 56.4 & 0.00 & 86.8 \\
\hline 6.05 & 0.00 & 0.00 & 0.00 & 0.00 & 6.05 \\
\hline 1,220 & 1,080 & 55.3 & 116 & 0.00 & 3,000 \\
\hline 4,550 & 2,160 & 1,440 & 1,130 & 608 & 52,700 \\
\hline 0.00 & 0.00 & 0.00 & 0.00 & 0.00 & 0.00112 \\
\hline 0.00 & 0.00 & 0.00 & 0.00 & 0.00 & -110 \\
\hline 0.00 & 0.00 & 0.00 & 0.00 & 0.00 & 0.00 \\
\hline 0.00 & 0.00 & 0.00 & 0.00 & 0.00 & -320 \\
\hline 0.00 & 0.00 & 0.00 & 0.00 & 0.00 & -136 \\
\hline 0.00 & 0.00 & 0.00 & 0.00 & 0.00 & 114 \\
\hline 0.00 & 0.00 & 0.00 & 0.00 & 0.00 & 383 \\
\hline 0.00 & 0.00 & 0.00 & 0.00 & 0.00 & -96.0 \\
\hline 0.00 & 0.00 & 0.00 & 0.00 & 0.00 & 176 \\
\hline 0.00 & 0.00 & 0.00 & 0.00 & 0.00 & -15.9 \\
\hline 0.00 & 0.00 & 0.00 & 0.00 & 0.00 & -3.34 \\
\hline 0.00 & 0.00 & 0.00 & 0.00 & 0.00 & 26.3 \\
\hline 0.00 & 0.00 & 0.00 & 0.00 & 0.00 & 17.9 \\
\hline
\end{tabular}


Table 4.19. Average annual 25-year water budget in acre-feet for optimized increased-pumpage scenario with dry conditions, Los Angeles Coastal PI [WRD, Water Replenishment District of Southern California]

\begin{tabular}{|c|c|c|c|c|c|c|c|c|}
\hline $\begin{array}{c}\text { Chronostratigraphic } \\
\text { unit name }\end{array}$ & $\begin{array}{l}\text { Model } \\
\text { layer }\end{array}$ & $\begin{array}{l}\text { Los Angeles } \\
\text { Forebay }\end{array}$ & $\begin{array}{c}\text { WRD } \\
\text { Central Basin }\end{array}$ & Orange County & $\begin{array}{l}\text { West } \\
\text { Coast }\end{array}$ & Santa Monica & Hollywood & $\begin{array}{l}\text { WRD Los } \\
\text { Angeles } \\
\text { Forebay }\end{array}$ \\
\hline & & & & & & & \multicolumn{2}{|c|}{ Flow from San Pedro Bay } \\
\hline Dominguez & 2 & 0.00 & 0.00 & 0.00 & 50.3 & 0.00 & 0.00 & 0.00 \\
\hline Mesa & 3 & 0.00 & 0.00 & 0.00 & -5.26 & 0.00 & 0.00 & 0.00 \\
\hline Pacific A & 4 & 0.00 & 0.00 & 0.00 & 0.00 & 0.00 & 0.00 & 0.00 \\
\hline Pacific & 5 & 0.00 & 0.00 & 0.00 & 430 & 0.00 & 0.00 & 0.00 \\
\hline Harbor & 6 & 0.00 & 0.00 & 0.00 & 486 & 0.00 & 0.00 & 0.00 \\
\hline Bent Spring & 7 & 0.00 & 0.00 & 0.00 & -41.5 & 0.00 & 0.00 & 0.00 \\
\hline Upper Wilmington A & 8 & 0.00 & 0.00 & 0.00 & 0.00 & 0.00 & 0.00 & 0.00 \\
\hline Upper Wilmington B & 9 & 0.00 & 0.00 & 0.00 & 102 & 0.00 & 0.00 & 0.00 \\
\hline Lower Wilmington & 10 & 0.00 & 0.00 & 0.00 & 1,550 & 0.00 & 0.00 & 0.00 \\
\hline Long Beach A & 11 & 0.00 & 0.00 & 0.00 & 322 & 0.00 & 0.00 & 0.00 \\
\hline Long Beach B & 12 & 0.00 & 0.00 & 0.00 & 319 & 0.00 & 0.00 & 0.00 \\
\hline Long Beach C & 13 & 0.00 & 0.00 & 0.00 & 91.7 & 0.00 & 0.00 & 0.00 \\
\hline \multirow[t]{2}{*}{ Total } & & 0.00 & 0.00 & 0.00 & 3,310 & 0.00 & 0.00 & 0.00 \\
\hline & & & & & & & \multicolumn{2}{|c|}{ Underflow from Orange County } \\
\hline Dominguez & 2 & 0.00 & 0.00 & 4,780 & 0.00 & 0.00 & 0.00 & 0.00 \\
\hline Mesa & 3 & 0.00 & 0.00 & 1,340 & 0.00 & 0.00 & 0.00 & 0.00 \\
\hline Pacific A & 4 & 0.00 & 0.00 & 3,290 & 0.00 & 0.00 & 0.00 & 0.00 \\
\hline Pacific & 5 & 0.00 & 0.00 & 13,700 & 0.00 & 0.00 & 0.00 & 0.00 \\
\hline Harbor & 6 & 0.00 & 0.00 & 6,980 & 0.00 & 0.00 & 0.00 & 0.00 \\
\hline Bent Spring & 7 & 0.00 & 0.00 & 1,080 & 0.00 & 0.00 & 0.00 & 0.00 \\
\hline Upper Wilmington A & 8 & 0.00 & 0.00 & 7,170 & 0.00 & 0.00 & 0.00 & 0.00 \\
\hline Upper Wilmington B & 9 & 0.00 & 0.00 & 3,050 & 0.00 & 0.00 & 0.00 & 0.00 \\
\hline Lower Wilmington & 10 & 0.00 & 0.00 & 212 & 0.00 & 0.00 & 0.00 & 0.00 \\
\hline Long Beach A & 11 & 0.00 & 0.00 & 58.3 & 0.00 & 0.00 & 0.00 & 0.00 \\
\hline Long Beach B & 12 & 0.00 & 0.00 & 96.8 & 0.00 & 0.00 & 0.00 & 0.00 \\
\hline Long Beach C & 13 & 0.00 & 0.00 & 37.2 & 0.00 & 0.00 & 0.00 & 0.00 \\
\hline \multirow[t]{2}{*}{ Total } & & 0.00 & 0.00 & 41,700 & 0.00 & 0.00 & 0.00 & 0.00 \\
\hline & & & & & & & \multicolumn{2}{|c|}{ Underflow from San Gabriel Basin } \\
\hline Dominguez & 2 & 0.00 & 0.00 & 0.00 & 0.00 & 0.00 & 0.00 & 0.00 \\
\hline Mesa & 3 & 0.00 & 0.00 & 0.00 & 0.00 & 0.00 & 0.00 & 0.00 \\
\hline Pacific A & 4 & 0.00 & 0.00 & 0.00 & 0.00 & 0.00 & 0.00 & 0.00 \\
\hline Pacific & 5 & 0.00 & 0.00 & 0.00 & 0.00 & 0.00 & 0.00 & 0.00 \\
\hline Harbor & 6 & 0.00 & 0.00 & 0.00 & 0.00 & 0.00 & 0.00 & 0.00 \\
\hline Bent Spring & 7 & 0.00 & 0.00 & 0.00 & 0.00 & 0.00 & 0.00 & 0.00 \\
\hline Upper Wilmington A & 8 & 0.00 & 0.00 & 0.00 & 0.00 & 0.00 & 0.00 & 0.00 \\
\hline Upper Wilmington B & 9 & 0.00 & 0.00 & 0.00 & 0.00 & 0.00 & 0.00 & 0.00 \\
\hline Lower Wilmington & 10 & 0.00 & 0.00 & 0.00 & 0.00 & 0.00 & 0.00 & 0.00 \\
\hline Long Beach A & 11 & 0.00 & 0.00 & 0.00 & 0.00 & 0.00 & 0.00 & 0.00 \\
\hline Long Beach B & 12 & 0.00 & 0.00 & 0.00 & 0.00 & 0.00 & 0.00 & 0.00 \\
\hline Long Beach C & 13 & 0.00 & 0.00 & 0.00 & 0.00 & 0.00 & 0.00 & 0.00 \\
\hline Total & & 0.00 & 0.00 & 0.00 & 0.00 & 0.00 & 0.00 & 0.00 \\
\hline
\end{tabular}


ain Groundwater-flow Model._Continued

\begin{tabular}{|c|c|c|c|c|c|}
\hline $\begin{array}{c}\text { Montebello } \\
\text { Forebay }\end{array}$ & Whitter & Central Basin & $\begin{array}{l}\text { North Orange } \\
\text { County }\end{array}$ & $\begin{array}{c}\text { South } \\
\text { Orange County }\end{array}$ & Total \\
\hline 0.00 & 0.00 & 0.00 & 0.00 & 24.9 & 75.1 \\
\hline 0.00 & 0.00 & 0.00 & 0.00 & 119 & 114 \\
\hline 0.00 & 0.00 & 0.00 & 0.00 & 0.00 & 0.00 \\
\hline 0.00 & 0.00 & 0.00 & 0.00 & 216 & 646 \\
\hline 0.00 & 0.00 & 0.00 & 0.00 & 695 & 1,180 \\
\hline 0.00 & 0.00 & 0.00 & 0.00 & 61.5 & 20.1 \\
\hline 0.00 & 0.00 & 0.00 & 0.00 & 0.00 & 0.00 \\
\hline 0.00 & 0.00 & 0.00 & 0.00 & 0.00 & 102 \\
\hline 0.00 & 0.00 & 0.00 & 0.00 & 78.6 & 1,630 \\
\hline 0.00 & 0.00 & 0.00 & 0.00 & -341 & -18.9 \\
\hline 0.00 & 0.00 & 0.00 & 0.00 & -100 & 219 \\
\hline 0.00 & 0.00 & 0.00 & 0.00 & -329 & -237 \\
\hline 0.00 & 0.00 & 0.00 & 0.00 & 426 & 3,730 \\
\hline 0.00 & 0.00 & 0.00 & 0.00 & 69.2 & 4,850 \\
\hline 0.00 & 0.00 & 0.00 & 0.00 & 368 & 1,710 \\
\hline 0.00 & 0.00 & 0.00 & 0.00 & 0.00 & 3,290 \\
\hline 0.00 & 0.00 & 0.00 & -46.8 & 1,050 & 14,700 \\
\hline 0.00 & 0.00 & 0.00 & 0.00 & 645 & 7,630 \\
\hline 0.00 & 0.00 & 0.00 & 0.00 & 85.9 & 1,160 \\
\hline 0.00 & 0.00 & 0.00 & 897 & 1,420 & 9,480 \\
\hline 0.00 & 0.00 & 0.00 & 283 & -44.3 & 3,290 \\
\hline 0.00 & 0.00 & 0.00 & 750 & 40.1 & 1,000 \\
\hline 0.00 & 0.00 & 0.00 & 1,170 & 953 & 2,190 \\
\hline 0.00 & 0.00 & 0.00 & 68.7 & 750 & 915 \\
\hline 0.00 & 0.00 & 0.00 & 79.4 & 435 & 551 \\
\hline 0.00 & 0.00 & 0.00 & 3,210 & 5,770 & 50,700 \\
\hline 0.00 & 0.00 & 0.00 & 0.00 & 0.00 & 0.00 \\
\hline 24,100 & 0.00 & 0.00 & 0.00 & 0.00 & 24,100 \\
\hline 0.00 & 0.00 & 0.00 & 0.00 & 0.00 & 0.00 \\
\hline 0.00 & 0.00 & 0.00 & 0.00 & 0.00 & 0.00 \\
\hline 0.00 & 0.00 & 0.00 & 0.00 & 0.00 & 0.00 \\
\hline 0.00 & 0.00 & 0.00 & 0.00 & 0.00 & 0.00 \\
\hline 0.00 & 0.00 & 0.00 & 0.00 & 0.00 & 0.00 \\
\hline 0.00 & 0.00 & 0.00 & 0.00 & 0.00 & 0.00 \\
\hline 0.00 & 0.00 & 0.00 & 0.00 & 0.00 & 0.00 \\
\hline 0.00 & 0.00 & 0.00 & 0.00 & 0.00 & 0.00 \\
\hline 0.00 & 0.00 & 0.00 & 0.00 & 0.00 & 0.00 \\
\hline 2,880 & 0.00 & 0.00 & 0.00 & 0.00 & 2,880 \\
\hline 27,000 & 0.00 & 0.00 & 0.00 & 0.00 & 27,000 \\
\hline
\end{tabular}


Table 4.19. Average annual 25-year water budget in acre-feet for optimized increased-pumpage scenario with dry conditions, Los Angeles Coastal PI [WRD, Water Replenishment District of Southern California]

\begin{tabular}{|c|c|c|c|c|c|c|c|c|}
\hline $\begin{array}{c}\text { Chronostratigraphic } \\
\text { unit name }\end{array}$ & $\begin{array}{l}\text { Model } \\
\text { layer }\end{array}$ & $\begin{array}{l}\text { Los Angeles } \\
\text { Forebay }\end{array}$ & $\begin{array}{c}\text { WRD } \\
\text { Central Basin }\end{array}$ & Orange County & $\begin{array}{l}\text { West } \\
\text { Coast }\end{array}$ & Santa Monica & Hollywood & $\begin{array}{l}\text { WRD Los } \\
\text { Angeles } \\
\text { Forebay }\end{array}$ \\
\hline & & & & & & & \multicolumn{2}{|c|}{ Underflow from Palos Verdes Hills } \\
\hline Dominguez & 2 & 0.00 & 0.00 & 0.00 & 0.00 & 0.00 & 0.00 & 0.00 \\
\hline Mesa & 3 & 0.00 & 0.00 & 0.00 & 0.00 & 0.00 & 0.00 & 0.00 \\
\hline Pacific A & 4 & 0.00 & 0.00 & 0.00 & 0.00 & 0.00 & 0.00 & 0.00 \\
\hline Pacific & 5 & 0.00 & 0.00 & 0.00 & 0.00 & 0.00 & 0.00 & 0.00 \\
\hline Harbor & 6 & 0.00 & 0.00 & 0.00 & 0.00 & 0.00 & 0.00 & 0.00 \\
\hline Bent Spring & 7 & 0.00 & 0.00 & 0.00 & 0.00 & 0.00 & 0.00 & 0.00 \\
\hline Upper Wilmington A & 8 & 0.00 & 0.00 & 0.00 & 0.00 & 0.00 & 0.00 & 0.00 \\
\hline Upper Wilmington B & 9 & 0.00 & 0.00 & 0.00 & 0.00 & 0.00 & 0.00 & 0.00 \\
\hline Lower Wilmington & 10 & 0.00 & 0.00 & 0.00 & 2.96 & 0.00 & 0.00 & 0.00 \\
\hline Long Beach A & 11 & 0.00 & 0.00 & 0.00 & 0.916 & 0.00 & 0.00 & 0.00 \\
\hline Long Beach B & 12 & 0.00 & 0.00 & 0.00 & 0.492 & 0.00 & 0.00 & 0.00 \\
\hline Long Beach C & 13 & 0.00 & 0.00 & 0.00 & 25.9 & 0.00 & 0.00 & 0.00 \\
\hline \multirow[t]{2}{*}{ Total } & & 0.00 & 0.00 & 0.00 & 30.3 & 0.00 & 0.00 & 0.00 \\
\hline & & & & & & & \multicolumn{2}{|c|}{ Flow from Marina Del Rey } \\
\hline Dominguez & 2 & 0.00 & 0.00 & 0.00 & 0.00 & 0.00 & 0.00 & 0.00 \\
\hline Mesa & 3 & 0.00 & 0.00 & 0.00 & 0.00 & 241 & 0.00 & 0.00 \\
\hline Pacific A & 4 & 0.00 & 0.00 & 0.00 & 0.00 & 0.00 & 0.00 & 0.00 \\
\hline Pacific & 5 & 0.00 & 0.00 & 0.00 & 0.00 & 0.00 & 0.00 & 0.00 \\
\hline Harbor & 6 & 0.00 & 0.00 & 0.00 & 0.00 & 0.00 & 0.00 & 0.00 \\
\hline Bent Spring & 7 & 0.00 & 0.00 & 0.00 & 0.00 & 0.00 & 0.00 & 0.00 \\
\hline Upper Wilmington A & 8 & 0.00 & 0.00 & 0.00 & 0.00 & 0.00 & 0.00 & 0.00 \\
\hline Upper Wilmington B & 9 & 0.00 & 0.00 & 0.00 & 0.00 & 0.00 & 0.00 & 0.00 \\
\hline Lower Wilmington & 10 & 0.00 & 0.00 & 0.00 & 0.00 & 0.00 & 0.00 & 0.00 \\
\hline Long Beach A & 11 & 0.00 & 0.00 & 0.00 & 0.00 & 0.00 & 0.00 & 0.00 \\
\hline Long Beach B & 12 & 0.00 & 0.00 & 0.00 & 0.00 & 0.00 & 0.00 & 0.00 \\
\hline Long Beach C & 13 & 0.00 & 0.00 & 0.00 & 0.00 & 0.00 & 0.00 & 0.00 \\
\hline \multirow[t]{2}{*}{ Total } & & 0.00 & 0.00 & 0.00 & 0.00 & 241 & 0.00 & 0.00 \\
\hline & & & & & & & \multicolumn{2}{|c|}{ Flow from Port of Long Beach } \\
\hline Dominguez & 2 & 0.00 & 0.00 & 0.00 & 0.00 & 0.00 & 0.00 & 0.00 \\
\hline Mesa & 3 & 0.00 & 0.00 & 0.00 & -0.00152 & 0.00 & 0.00 & 0.00 \\
\hline Pacific A & 4 & 0.00 & 0.00 & 0.00 & 0.00 & 0.00 & 0.00 & 0.00 \\
\hline Pacific & 5 & 0.00 & 0.00 & 0.00 & 0.00 & 0.00 & 0.00 & 0.00 \\
\hline Harbor & 6 & 0.00 & 0.00 & 0.00 & 0.00 & 0.00 & 0.00 & 0.00 \\
\hline Bent Spring & 7 & 0.00 & 0.00 & 0.00 & 0.00 & 0.00 & 0.00 & 0.00 \\
\hline Upper Wilmington A & 8 & 0.00 & 0.00 & 0.00 & 0.00 & 0.00 & 0.00 & 0.00 \\
\hline Upper Wilmington B & 9 & 0.00 & 0.00 & 0.00 & 0.00 & 0.00 & 0.00 & 0.00 \\
\hline Lower Wilmington & 10 & 0.00 & 0.00 & 0.00 & 0.00 & 0.00 & 0.00 & 0.00 \\
\hline Long Beach A & 11 & 0.00 & 0.00 & 0.00 & 0.00 & 0.00 & 0.00 & 0.00 \\
\hline Long Beach B & 12 & 0.00 & 0.00 & 0.00 & 0.00 & 0.00 & 0.00 & 0.00 \\
\hline Long Beach C & 13 & 0.00 & 0.00 & 0.00 & 0.00 & 0.00 & 0.00 & 0.00 \\
\hline Total & & 0.00 & 0.00 & 0.00 & -0.00152 & 0.00 & 0.00 & 0.00 \\
\hline
\end{tabular}


ain Groundwater-flow Model._-Continued

\begin{tabular}{|c|c|c|c|c|c|}
\hline $\begin{array}{c}\text { Montebello } \\
\text { Forebay }\end{array}$ & Whitter & Central Basin & $\begin{array}{l}\text { North Orange } \\
\text { County }\end{array}$ & $\begin{array}{c}\text { South } \\
\text { Orange County }\end{array}$ & Total \\
\hline 0.00 & 0.00 & 0.00 & 0.00 & 0.00 & 0.00 \\
\hline 0.00 & 0.00 & 0.00 & 0.00 & 0.00 & 0.00 \\
\hline 0.00 & 0.00 & 0.00 & 0.00 & 0.00 & 0.00 \\
\hline 0.00 & 0.00 & 0.00 & 0.00 & 0.00 & 0.00 \\
\hline 0.00 & 0.00 & 0.00 & 0.00 & 0.00 & 0.00 \\
\hline 0.00 & 0.00 & 0.00 & 0.00 & 0.00 & 0.00 \\
\hline 0.00 & 0.00 & 0.00 & 0.00 & 0.00 & 0.00 \\
\hline 0.00 & 0.00 & 0.00 & 0.00 & 0.00 & 0.00 \\
\hline 0.00 & 0.00 & 0.00 & 0.00 & 0.00 & 2.96 \\
\hline 0.00 & 0.00 & 0.00 & 0.00 & 0.00 & 0.916 \\
\hline 0.00 & 0.00 & 0.00 & 0.00 & 0.00 & 0.492 \\
\hline 0.00 & 0.00 & 0.00 & 0.00 & 0.00 & 25.9 \\
\hline 0.00 & 0.00 & 0.00 & 0.00 & 0.00 & 30.3 \\
\hline 0.00 & 0.00 & 0.00 & 0.00 & 0.00 & 0.00 \\
\hline 0.00 & 0.00 & 0.00 & 0.00 & 0.00 & 241 \\
\hline 0.00 & 0.00 & 0.00 & 0.00 & 0.00 & 0.00 \\
\hline 0.00 & 0.00 & 0.00 & 0.00 & 0.00 & 0.00 \\
\hline 0.00 & 0.00 & 0.00 & 0.00 & 0.00 & 0.00 \\
\hline 0.00 & 0.00 & 0.00 & 0.00 & 0.00 & 0.00 \\
\hline 0.00 & 0.00 & 0.00 & 0.00 & 0.00 & 0.00 \\
\hline 0.00 & 0.00 & 0.00 & 0.00 & 0.00 & 0.00 \\
\hline 0.00 & 0.00 & 0.00 & 0.00 & 0.00 & 0.00 \\
\hline 0.00 & 0.00 & 0.00 & 0.00 & 0.00 & 0.00 \\
\hline 0.00 & 0.00 & 0.00 & 0.00 & 0.00 & 0.00 \\
\hline 0.00 & 0.00 & 0.00 & 0.00 & 0.00 & 0.00 \\
\hline 0.00 & 0.00 & 0.00 & 0.00 & 0.00 & 241 \\
\hline 0.00 & 0.00 & 0.00 & 0.00 & 0.00 & 0.00 \\
\hline 0.00 & 0.00 & 0.00 & 0.00 & 0.00 & -0.00152 \\
\hline 0.00 & 0.00 & 0.00 & 0.00 & 0.00 & 0.00 \\
\hline 0.00 & 0.00 & 0.00 & 0.00 & 0.00 & 0.00 \\
\hline 0.00 & 0.00 & 0.00 & 0.00 & 0.00 & 0.00 \\
\hline 0.00 & 0.00 & 0.00 & 0.00 & 0.00 & 0.00 \\
\hline 0.00 & 0.00 & 0.00 & 0.00 & 0.00 & 0.00 \\
\hline 0.00 & 0.00 & 0.00 & 0.00 & 0.00 & 0.00 \\
\hline 0.00 & 0.00 & 0.00 & 0.00 & 0.00 & 0.00 \\
\hline 0.00 & 0.00 & 0.00 & 0.00 & 0.00 & 0.00 \\
\hline 0.00 & 0.00 & 0.00 & 0.00 & 0.00 & 0.00 \\
\hline 0.00 & 0.00 & 0.00 & 0.00 & 0.00 & 0.00 \\
\hline 0.00 & 0.00 & 0.00 & 0.00 & 0.00 & -0.00152 \\
\hline
\end{tabular}


Table 4.19. Average annual 25 -year water budget in acre-feet for optimized increased-pumpage scenario with dry conditions, Los Angeles Coastal PI [WRD, Water Replenishment District of Southern California]

\begin{tabular}{|c|c|c|c|c|c|c|c|c|}
\hline $\begin{array}{c}\text { Chronostratigraphic } \\
\text { unit name }\end{array}$ & $\begin{array}{c}\text { Model } \\
\text { layer }\end{array}$ & $\begin{array}{l}\text { Los Angeles } \\
\text { Forebay }\end{array}$ & $\begin{array}{c}\text { WRD } \\
\text { Central Basin }\end{array}$ & Orange County & $\begin{array}{l}\text { West } \\
\text { Coast }\end{array}$ & Santa Monica & Hollywood & $\begin{array}{l}\text { WRD Los } \\
\text { Angeles } \\
\text { Forebay }\end{array}$ \\
\hline \multicolumn{9}{|c|}{ Underflow from San Fernando Basir } \\
\hline Dominguez & 2 & 0.00 & 0.00 & 0.00 & 0.00 & 0.00 & 0.00 & 0.00 \\
\hline Mesa & 3 & 5,370 & 0.00 & 0.00 & 0.00 & 0.00 & 0.00 & 0.00 \\
\hline Pacific A & 4 & 0.00 & 0.00 & 0.00 & 0.00 & 0.00 & 0.00 & 0.00 \\
\hline Pacific & 5 & 0.00 & 0.00 & 0.00 & 0.00 & 0.00 & 0.00 & 0.00 \\
\hline Harbor & 6 & 0.00 & 0.00 & 0.00 & 0.00 & 0.00 & 0.00 & 0.00 \\
\hline Bent Spring & 7 & 0.00 & 0.00 & 0.00 & 0.00 & 0.00 & 0.00 & 0.00 \\
\hline Upper Wilmington A & 8 & 0.00 & 0.00 & 0.00 & 0.00 & 0.00 & 0.00 & 0.00 \\
\hline Upper Wilmington B & 9 & 0.00 & 0.00 & 0.00 & 0.00 & 0.00 & 0.00 & 0.00 \\
\hline Lower Wilmington & 10 & 0.00 & 0.00 & 0.00 & 0.00 & 0.00 & 0.00 & 0.00 \\
\hline Long Beach A & 11 & 0.00 & 0.00 & 0.00 & 0.00 & 0.00 & 0.00 & 0.00 \\
\hline Long Beach B & 12 & 0.00 & 0.00 & 0.00 & 0.00 & 0.00 & 0.00 & 0.00 \\
\hline Long Beach C & 13 & 0.00 & 0.00 & 0.00 & 0.00 & 0.00 & 0.00 & 0.00 \\
\hline \multirow[t]{2}{*}{ Total } & & 5,370 & 0.00 & 0.00 & 0.00 & 0.00 & 0.00 & 0.00 \\
\hline & & & & & & & & Drains \\
\hline Dominguez & 2 & 0.00 & $-1,040$ & -84.6 & -16.6 & -427 & 0.00 & 0.00 \\
\hline Mesa & 3 & 0.00 & -428 & 0.00 & $-1,290$ & -959 & 0.00 & 0.00 \\
\hline Pacific A & 4 & 0.00 & 0.00 & 0.00 & 0.00 & 0.00 & 0.00 & 0.00 \\
\hline Pacific & 5 & 0.00 & 0.00 & 0.00 & 0.00 & -297 & 0.00 & 0.00 \\
\hline Harbor & 6 & 0.00 & 0.00 & 0.00 & 0.00 & 0.00 & 0.00 & 0.00 \\
\hline Bent Spring & 7 & 0.00 & 0.00 & 0.00 & 0.00 & $-1,550$ & 0.00 & 0.00 \\
\hline Upper Wilmington A & 8 & 0.00 & 0.00 & 0.00 & 0.00 & 0.00 & 0.00 & 0.00 \\
\hline Upper Wilmington B & 9 & 0.00 & 0.00 & 0.00 & 0.00 & 0.00 & 0.00 & 0.00 \\
\hline Lower Wilmington & 10 & 0.00 & 0.00 & 0.00 & 0.00 & 0.00 & 0.00 & 0.00 \\
\hline Long Beach A & 11 & 0.00 & -744 & 0.00 & 0.00 & 0.00 & 0.00 & 0.00 \\
\hline Long Beach B & 12 & 0.00 & 0.00 & 0.00 & 0.00 & 0.00 & 0.00 & 0.00 \\
\hline Long Beach C & 13 & 0.00 & 0.00 & 0.00 & 0.00 & 0.00 & 0.00 & 0.00 \\
\hline Total & & 0.00 & $-2,210$ & -84.6 & $-1,310$ & $-3,230$ & 0.00 & 0.00 \\
\hline \multirow[t]{2}{*}{ Total net flow } & & -224 & $-2,720$ & -312 & 12,000 & $-3,950$ & $-2,420$ & $-2,160$ \\
\hline & & & & & & & & Change in storage \\
\hline Dominguez & 2 & -806 & $-2,190$ & 170 & 182 & $-1,280$ & -139 & $-1,910$ \\
\hline Mesa & 3 & 35.8 & -54.1 & -7.7 & 10,400 & $-1,170$ & -320 & -372 \\
\hline Pacific A & 4 & 15.7 & 312 & -3.02 & 1.23 & 0.00 & 0.00 & 0.534 \\
\hline Pacific & 5 & 6.50 & -430 & -20.3 & 476 & $-1,420$ & -16.7 & 28.2 \\
\hline Harbor & 6 & 4.16 & -30.7 & -14.8 & 248 & -0.0147 & 0.00 & 71.5 \\
\hline Bent Spring & 7 & 6.01 & -28.6 & -16.4 & 602 & -28.1 & -550 & 2.17 \\
\hline Upper Wilmington A & 8 & 402 & -40.2 & -294 & 8.38 & 72.8 & -1390 & 36.6 \\
\hline Upper Wilmington B & 9 & 4.64 & -41.9 & -6.75 & 12.4 & -30.6 & -9.84 & 4.05 \\
\hline Lower Wilmington & 10 & -1.24 & -4.90 & -4.51 & 52.6 & -4.90 & 0.491 & 7.10 \\
\hline Long Beach A & 11 & -5.24 & -1.68 & -15.7 & 1.82 & -0.132 & 0.00241 & -7.31 \\
\hline Long Beach B & 12 & -1.27 & -70.2 & -46.3 & 5.75 & 0.51 & -0.0199 & -7.07 \\
\hline Long Beach C & 13 & 115 & -131 & -51.5 & -49.6 & -86.4 & -1.62 & -8.34 \\
\hline Total & & -224 & $-2,720$ & -311 & 12,000 & $-3,950$ & $-2,420$ & $-2,160$ \\
\hline
\end{tabular}


ain Groundwater-flow Model._-Continued

\begin{tabular}{|c|c|c|c|c|c|}
\hline $\begin{array}{c}\text { Montebello } \\
\text { Forebay }\end{array}$ & Whitter & Central Basin & $\begin{array}{c}\text { North Orange } \\
\text { County }\end{array}$ & $\begin{array}{c}\text { South } \\
\text { Orange County }\end{array}$ & Total \\
\hline 0.00 & 0.00 & 0.00 & 0.00 & 0.00 & 0.00 \\
\hline 0.00 & 0.00 & 0.00 & 0.00 & 0.00 & 5,370 \\
\hline 0.00 & 0.00 & 0.00 & 0.00 & 0.00 & 0.00 \\
\hline 0.00 & 0.00 & 0.00 & 0.00 & 0.00 & 0.00 \\
\hline 0.00 & 0.00 & 0.00 & 0.00 & 0.00 & 0.00 \\
\hline 0.00 & 0.00 & 0.00 & 0.00 & 0.00 & 0.00 \\
\hline 0.00 & 0.00 & 0.00 & 0.00 & 0.00 & 0.00 \\
\hline 0.00 & 0.00 & 0.00 & 0.00 & 0.00 & 0.00 \\
\hline 0.00 & 0.00 & 0.00 & 0.00 & 0.00 & 0.00 \\
\hline 0.00 & 0.00 & 0.00 & 0.00 & 0.00 & 0.00 \\
\hline 0.00 & 0.00 & 0.00 & 0.00 & 0.00 & 0.00 \\
\hline 0.00 & 0.00 & 0.00 & 0.00 & 0.00 & 0.00 \\
\hline 0.00 & 0.00 & 0.00 & 0.00 & 0.00 & 5,370 \\
\hline-462 & 0.00 & -532 & -21.1 & -7.95 & $-2,590$ \\
\hline 0.00 & 0.00 & 0.00 & 0.00 & -72.6 & $-2,750$ \\
\hline 0.00 & 0.00 & 0.00 & 0.00 & 0.00 & 0.00 \\
\hline-614 & -22.4 & 0.00 & -276 & 0.00 & $-1,210$ \\
\hline 0.00 & 0.00 & 0.00 & 0.00 & 0.00 & 0.00 \\
\hline 0.00 & 0.00 & 0.00 & 0.00 & 0.00 & $-1,550$ \\
\hline 0.00 & 0.00 & 0.00 & -448 & 0.00 & -448 \\
\hline 0.00 & 0.00 & 0.00 & 0.00 & 0.00 & 0.00 \\
\hline 0.00 & 0.00 & 0.00 & -224 & 0.00 & -224 \\
\hline 0.00 & 0.00 & 0.00 & -39 & 0.00 & -783 \\
\hline 0.00 & 0.00 & 0.00 & 0.00 & 0.00 & 0.00 \\
\hline 0.00 & 0.00 & 0.00 & 0.00 & 0.00 & 0.00 \\
\hline$-1,080$ & -22.4 & -532 & $-1,010$ & -80.5 & $-9,560$ \\
\hline$-2,100$ & -666 & 6.64 & -210 & -342 & $-3,130$ \\
\hline$-1,200$ & -73.0 & -370 & 45.6 & -232 & $-7,810$ \\
\hline$-1,010$ & -322 & 338 & 0.00 & -67.4 & 7,470 \\
\hline-10.3 & -5.73 & 5.12 & 0.00 & 0.00 & 316 \\
\hline-92.8 & -209 & 0.177 & -172 & -22.2 & $-1,870$ \\
\hline-28.6 & -49.6 & 0.477 & 0.00 & -3.21 & 197 \\
\hline-1.14 & 0.00 & 14.6 & 0.00 & -0.416 & -0.109 \\
\hline 45.3 & 13.8 & 8.20 & -305 & -1.68 & $-1,440$ \\
\hline-2.1 & 1.79 & 12.1 & -5.71 & -1.96 & -64.0 \\
\hline-3.25 & 0.152 & 3.78 & 1.83 & -1.68 & 45.5 \\
\hline-26.1 & 23.2 & -1.16 & 215 & -1.98 & 181 \\
\hline-19.3 & 0.785 & -0.459 & 5.38 & -4.28 & -137 \\
\hline 256 & -46.7 & -3.90 & 5.61 & -6.05 & -8.24 \\
\hline$-2,100$ & -666 & 6.40 & -209 & -342 & $-3,130$ \\
\hline
\end{tabular}




\section{Appendix 5. Rainfall-Recharge Analysis}

\section{By Scott Paulinski}

Future temporal extension (updating) of the Los Angeles Coastal Plain Groundwater Model (LACPGM) would require additional data, including areal recharge, pumpage, water spreading, injection, and water-level data near boundaries. In the LACPGM, areal recharge is based on estimates from a model developed by Hevesi and Johnson (2016). To enable updating LACPGM without further updates to the Hevesi and Johnson (2016) model, a rainfall versus recharge analysis was done to establish a simple relation between recharge in each model cell and recent rainfall amounts. In this analysis, recharge derived from Hevesi and Johnson's (2016) model was compared to precipitation data from downtown Los Angeles from calendar year 1971 to 2014 (Los Angeles Almanac, 2018) to develop the relation between precipitation and recharge.

Quarterly recharge data derived from Hevesi and Johnson's (2016) model and used in the LACPGM (Paulinski and others, 2021) were plotted against average (mean) current and antecedent precipitation data ranging from one quarter of a year of antecedent data to four continuous quarters of a year of antecedent data. The best fit was found at the current quarter of a year and two quarters of a year of antecedent data. The fit was improved upon by weighting the influence of each of the three antecedent quarters differently. Weights were determined by manual adjustment. Weights of 1.0 for the current quarter, 0.59 for the first antecedent quarter, and 0.35
$(0.59 \times 0.59)$ for the second antecedent quarter were assigned. Upon examination of the antecedent-precipitation index versus recharge plot (fig. 5.1), we noted that the data followed two different curves, one for antecedent-precipitation index values below 15.5 inches and one for precipitation index values of 15.5 inches and above. Therefore, piecewise regression using two curves achieved the best fit to the data (fig. 5.1). The lower precipitation values were fit with a second order polynomial curve, which had an $\mathrm{R}^{2}$ of 0.57 . For the higher precipitation values, a linear fit had an $\mathrm{R}^{2}$ of 0.86 (fig. 5.1).

Quarterly recharges for the future water management scenarios presented in Chapter D were estimated for each model cell using the average recharge for the model cell and the relation shown in figure 5.1. To estimate recharge for each quarter beyond 2014, a weighted-average precipitation index for the current quarter and the antecedent two-quarters was first calculated. Model-area recharge for each quarter was approximated using the relation between antecedent-precipitation index and recharge shown in figure 5.1. A recharge multiplier was then calculated by dividing the model area recharge for the quarter by the model area recharge averaged over 1971 through 2014. Recharge for each quarter in each model cell was estimated using the equations shown in figure 5.1 and multiplying that model cell's average recharge by the corresponding recharge and zone multipliers described in Chapter D. 


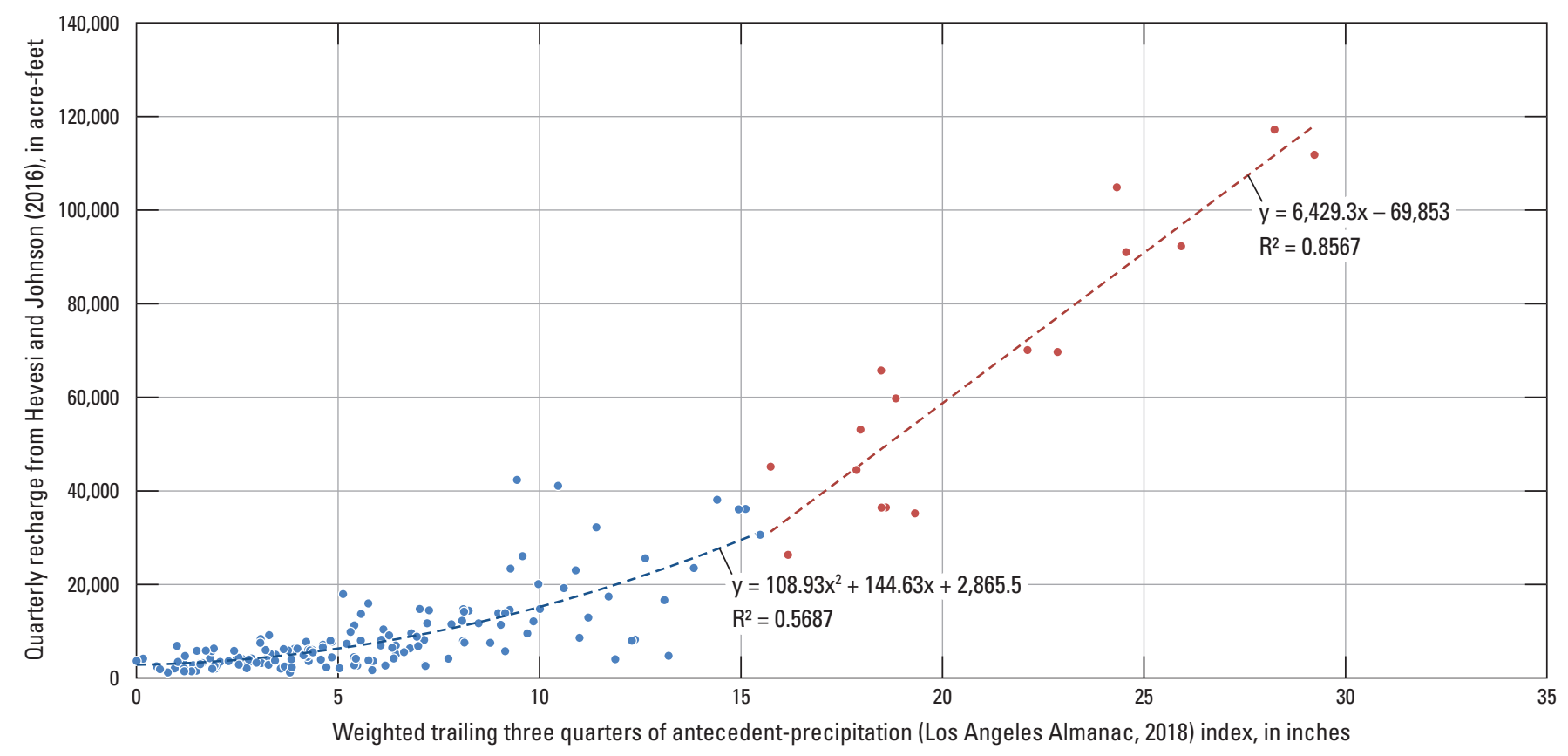

Figure 5.1. Weighted trailing three quarters index of antecedent precipitation (Los Angeles Almanac, 2018) versus quarterly recharge from Hevesi and Johnson (2016) from 1971 to 2014, for the Los Angeles Coastal Plain, California. Two separate curves fitted to data, one for the lower precipitation values and one for the higher precipitation values.

\section{References Cited}

Hevesi, J.A., and Johnson, T.D., 2016, Estimating spatially and temporally varying recharge and runoff from precipitation and urban irrigation in the Los Angeles Basin, California: U.S. Geological Survey Scientific Investigations Report 2016-5068, 192 p., https://doi.org/10.3133/sir20165068.
Los Angeles Almanac, 2018, Monthly rainfall by season downtown Los Angeles (USC Campus) 1877-2017, accessed on June 2018 at http://www.laalmanac.com/weather/we08aa.php.

Paulinski, S.R., Martin, P., Martin, D.J., Johnson, T.A., and Faunt, C.C., 2021, MODFLOW-USG model used to evaluate water management issues in the Los Angeles Coastal Plain, California: U.S. Geological Survey Data Release, https://doi.org/10.5066/P9H15ZAX. 

For more information concerning the research in this report, contact the

Director, California Water Science Center

U.S. Geological Survey

6000 J Street, Placer Hall

Sacramento, California 95819

https://ca.water.usgs.gov

Publishing support provided by the

U.S. Geological Survey Science Publishing Network,

Sacramento Publishing Service Center 


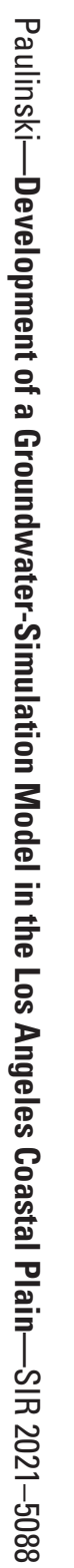

